\author{
UNIVERSIDAD DE LEÓN \\ DEPARTAMENTO DE HISTORIA
}

TESIS DOCTORAL

\title{
LA SIDERURGIA TRADICIONAL EN EL NOROESTE DE ESPAÑA (SIGLOS XVI -XIX)
}

JOSÉ A. BALBOA DE PAZ

-AÑO 2014- 


\section{ÍNDICE}

INTRODUCCIÓN.

I. LA SIDERURGIA TRADICIONAL: LA TECNOLOGÍA

Introducción....................................................................................

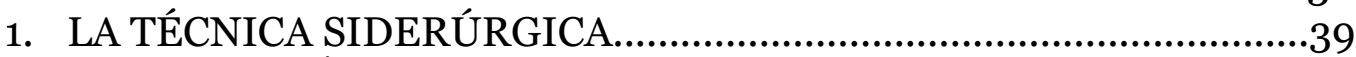

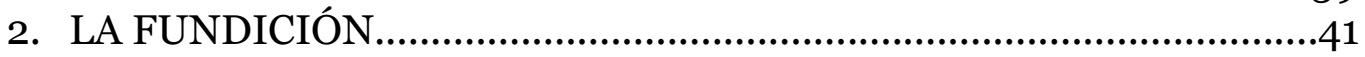

2.1. Los hornos primitivos..................................................................41

2.2. Las ferrerías.............................................................................43

3. LAS FERRERÍAS DEL NOROESTE................................................ 46

3.1. Chapacuñas y bazados..................................................................53

3.2. La rueda hidráulica....................................................................57

3.3. Los barquines y trompas...........................................................60

3.4. El horno....................................................................................65

3.5. El mazo...................................................................................

3.6. Las herramientas........................................................................74

3.7. La carbonera y bodega............................................................... 75

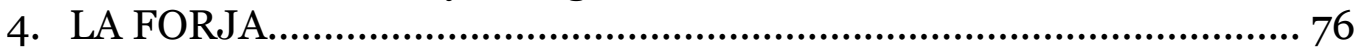

4.1. Los mazos, machucos o martinetes............................................. 76

4.2. Las fraguas..............................................................................

II. LAS CONDICIONES GEOGRÁFICAS DE LAS FERRERÍAS DEL NOROESTE DE ESPAÑA: AGUA Y COMBUSTIBLE.

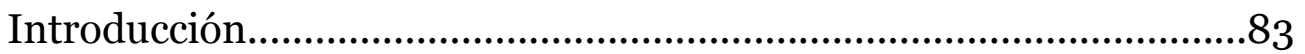

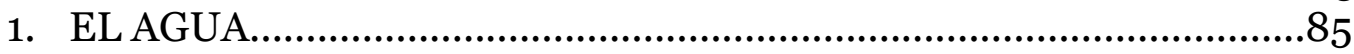

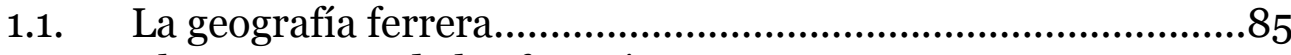

1.2. El agua motor de las ferrerías..................................................99

2. EL COMBUSTIBLE........................................................................104

2.1. La leña para el raguado del mineral........................................104

2.2. La reducción en el horno..........................................................107

2.3. El bosque eurosiberiano del noroeste.......................................112

2.4. El bosque del noroeste en la Edad Moderna.............................117

2.5. El bosque en el siglo XIX.......................................................131

2.6. El carbón vegetal..........................................................................137

2.7. El carbón mineral .....................................................................145 


\section{LAS CONDICIONES MATERIALES DE LAS FERRERÍAS DE NOROESTE DE ESPAÑA: EL MINERAL DE HIERRO.}

Introducción.................................................................................... 149

1. EL MINERAL AUTÓCTONO.......................................................151

1.1. Yacimientos gallegos......................................................... 154

1.1.1. Criaderos del Caurel. La Mina de Formigueiros........................................................155

1.1.2. Minas de Folgoso y Paradela..........................161

1.1.3. Criaderos de Incio.......................................... 161

1.1.4. Minas de Loureiro.........................................165

1.1.5. Minas de Freijo...............................................166

1.1.6. Minas de Lousadela y Piedrafita ...................168

1.1.7. Criaderos de Fonsagrada...............................168

1.1.8. Veneras de Lorenzana..................................170

1.1.9. Yacimientos costeros......................................171

1.1.10. Yacimientos orensanos...............................172

1.2. Yacimientos leoneses...........................................................173

1.2.1. Yacimientos del arco interno..........................173

1.2.2. Los hierros de Gestoso................................... 173

1.2.3. Mina de La Chana............................................174

1.2.4. Mina de Pombriego........................................ 177

1.2.5. Yacimientos del arco externo........................177

1.2.6. Mina de Paradasolana....................................178

1.2.7. Minas de La Somoza.......................................179

1.2.8. Mina de Ancares.............................................179

1.3. Yacimientos asturianos.....................................................181

1.3.1. Mina de Brueba.............................................183

1.3.2. Mina de Camaior...........................................183

1.3.3. Mina de Castañedo del Monte........................184

1.3.4. Mina de Caso....................................................185

2. EL MINERAL VASCO..................................................................186

3. LA EXPLOTACIÓN DEL MINERAL................................................191

3.1. La minería del hierro........................................................192

3.2. El transporte del mineral.....................................................198

4. LOS RENDIMIENTOS DEL MINERAL........................................203

IV. LAS CONDICIONES HUMANAS: PROPIETARIOS, ARRENDATARIOS Y TRABAJADORES

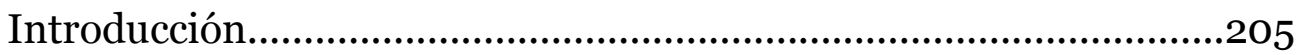

1. LA CONSTRUCCIÓN DE LAS FERRERÍAS................................206

1.1. Licencias de Construcción.................................................207

1.2. Oposición a la construcción de ferrerías............................212

1.3. El valor de las ferrerías.......................................................219 
2. LA PROPIEDAD DE LAS FERRERÍAS....................................226

2.1. El papel de los vascos en el origen de las ferrerías del noroeste......................................................................226

2.2. La nobleza y la Iglesia como promotoras en la construcción de las ferrerías en los siglos XVI y XVII..........................231

2.3. Continuidad y diversificación en la propiedad de las ferrerías durante el siglo XVIII.......................................239

2.4. La burguesía industrial como promotora de ferrerías en el siglo XIX.

242

3. LA EXPLOTACIÓN DE LAS FERRERÍAS: ARRENDATARIOS Y FOREROS .246

3.1. Los foros................................................................248

3.2. Los arrendamientos...................................................256

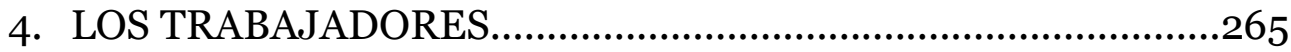

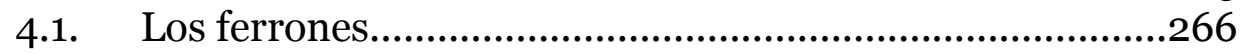

4.2. Otros oficios relacionados con las ferrerías....................275

V. LA PRODUCIÓN DE HIERRO. COSTES DE PRODUCCIÓN Y RENTABILIDAD DE LAS FERRERÍAS

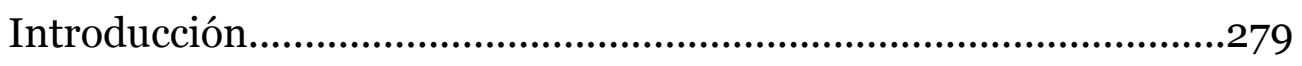

1. LA CAPACIDAD PRODUCTIVA DE LAS FERRERÍAS..............280

2. LA EVOLUCIÓN DE LA PRODUCCIÓN...................................291

3. LOS COSTES DE PRODUCCIÓN..............................................306

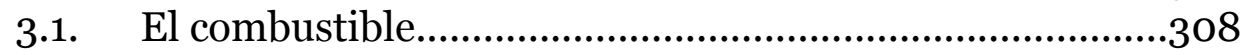

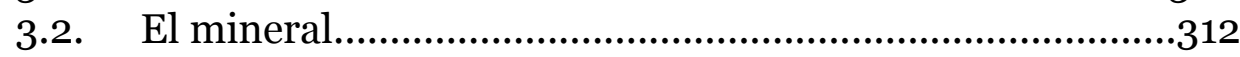

3.3. Los salarios.............................................................319

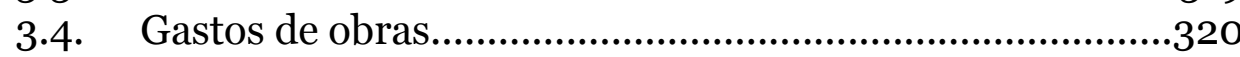

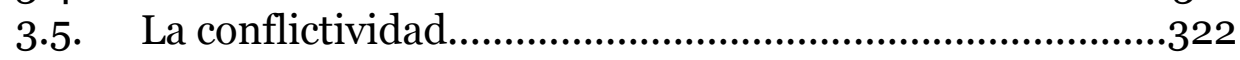

4. LA RENTABILIDAD DE LAS FERRERÍAS.............................326

VI. LA COMERCIALIZACIÓN DE HIERRO. MAZOS Y HERREROS

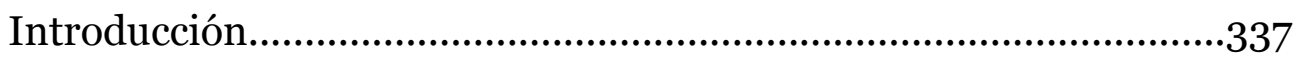

1. EL COMERCIO DEL HIERRO............................................... 339

2. LOS PRECIOSDEL HIERRO..............................................350

3. MAZOS Y MARTINETES.....................................................356

4. LAS FRAGUAS Y LOS ARTESANOS DEL HIERRO...................366 


\section{APÉNDICES, FUENTES Y BIBLIOGRAFÍA}

APÉNDICE I: Medidas ponderales en la siderurgia del noroeste.........389

APÉNDICE II: Cuadros sobre ferrerías, producciones y mazos..............392

APÉNDICE III: Pleitos de la Real Audiencia de La Coruña relativos a montes y ferrerías.........................................................................421

APÉNDICE IV: Selección de documentos sobre siderurgia del

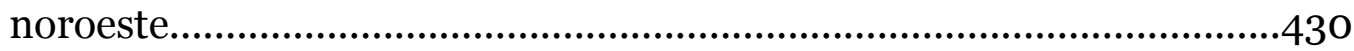

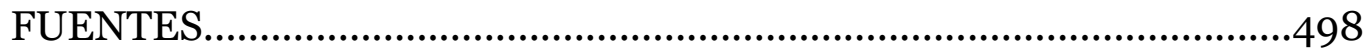

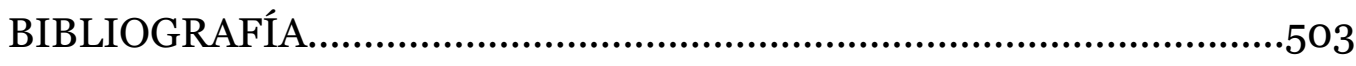

\section{CATÁLOGO DE FERRERÍAS (TOMO II)}

\section{LAS FERRERÍAS DE LEÓN.........................................9}

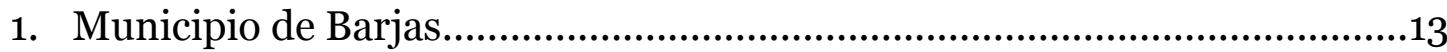

1. Ferrería de Barjas.........................................................................13

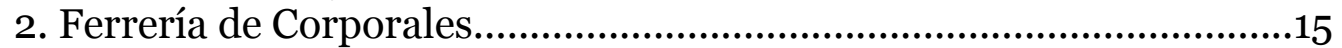

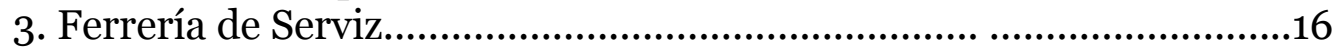

2. Municipio de Benuza......................................................................19

4. Ferrería de Llamas......................................................................19

3. Municipio de Candín.............................................................................22

5. Ferrería de Tejedo...................................................................22

4. Municipio de Folgoso......................................................................28

6. Ferrerías de Marciel.......................................................................28

5. Municipio de Oencia........................................................................ 30

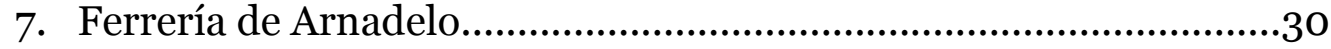

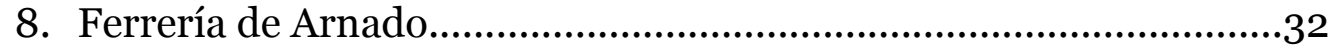

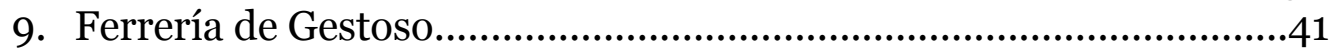

10. Ferrería de Lusío.........................................................................41

11. Ferrería de Pontepetre...............................................................43

12. Ferrerías de Río Cabo..............................................................51

13. Ferrería de San Vitul................................................................59

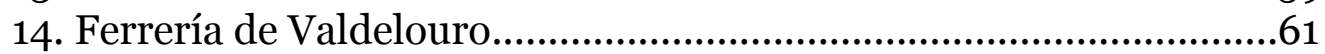

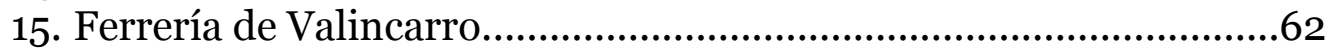




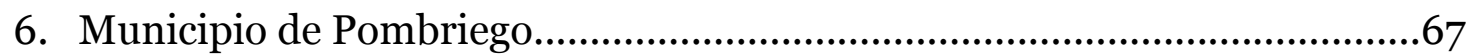

16. Ferrería de Pombriego......................................................................67

7. Municipio de Ponferrada..........................................................................

17. Ferrería de Compludo......................................................................71

18. Ferrería de Montes...................................................................................75

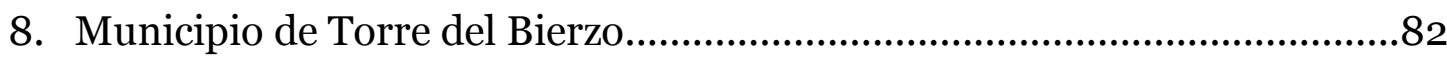

19. Ferrería de Torre del Bierzo..........................................................82

20.Ferrería de Navaleo...........................................................................86

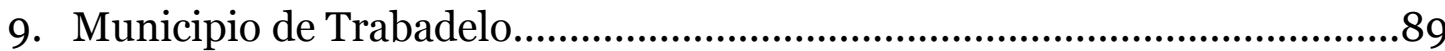

21. Ferrería de San Fiz do Seo..............................................................89

10. Municipio de Vega de Valcarce..................................................................90

22. Ferrería de Herrerías.......................................................................90

23. Ferrería de La Portela.............................................................................97

11. Municipio de Villafranca del Bierzo.................................................................99

24. Ferrería de La Somoza.....................................................................99

2. LAS FERRERÍAS DE LUGO.

1. Municipio de Baralla...............................................................................117

1. Ferrería de Neira de Rey.......................................................................117

2. Ferrería de Piago.................................................................................121

2. Municipio de Bóveda...............................................................................123

3. Ferrería de Penacova...............................................................................123

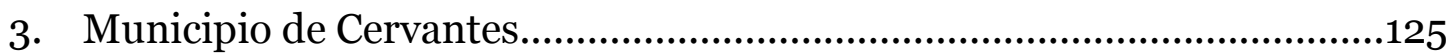

4. Ferrería de Fonquente.....................................................................125

5. Ferrería de San Martín de Ribera........................................................126

4. Municipio de Courel..............................................................................128

6. Ferrería de Ferreirós.........................................................................128

7. Ferrería de Folgoso............................................................................139

8. Ferrería de Lousadela...........................................................................145

9. Ferrería de Seoane............................................................................155

10. Ferrería de Valdomir..........................................................................161

11. Ferrería de Vilasibil...........................................................................170

12. Ferrería de Visuña.............................................................................171

5. Municipio de Fonsagrada..........................................................................181

13. Ferrería de Pereyrúa.........................................................................181

14. Ferrerías de Vilar de Cuiña..................................................................183

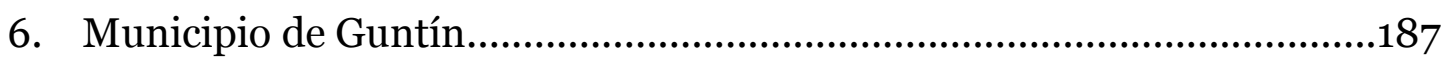

15. Ferrería de Pallares...............................................................................187 


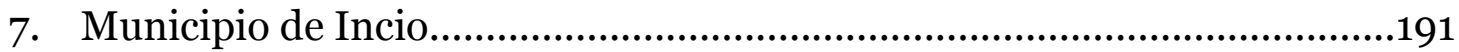

16Ferrería do Barreiro............................................................................191

17. Ferrería do Incio......................................................................................193

8. Municipio de Lugo.............................................................................198

18. Ferrería de Ombreiro...................................................................... 198

9. Municipio de Mondoñedo.........................................................................199

19. Ferrería de Viloalle...........................................................................199

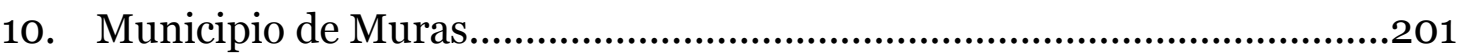

20.Ferrería de Silán.................................................................................201

11. Municipio de Navia de Suarna...............................................................203

21. Ferrería de Rao..................................................................................203

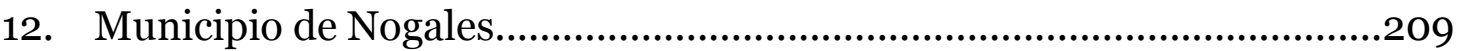

22. Ferrería de Bueyes (Bois)...................................................................209

13. Municipio de Ourol..........................................................................216

23. Ferrería de Bravos...............................................................................216

14. Municipio de A Pontenova.......................................................................221

24. Ferrería de Bogo................................................................................221

16. Municipio de Portomarín.........................................................................226

25. Ferrería de Gonzar............................................................................226

17. Municipio de La Puebla (A Pobra) de Brollón..........................................228

26. Ferrería de Biduedo....................................................................228

27. Ferrería de Lor..................................................................................231

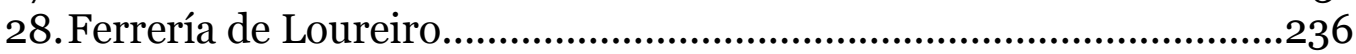

18. Municipio de Quiroga......................................................................242

29. Ferrería de Gorgueira.......................................................................242

30.Ferrería de Outeiro.........................................................................24

31. Ferrería de Paleiras...............................................................................247

32. Ferrería de Quintá..............................................................................254

33. Ferrería de La Rodela..........................................................................260

34. Ferrería de Rugando...........................................................................270

35. Ferrería de Soldón...............................................................................273

36. Ferrería de Vilarcabú........................................................................287

19. Municipio de Ríotorto........................................................................290

37. Ferrería de Vilaseca...........................................................................290

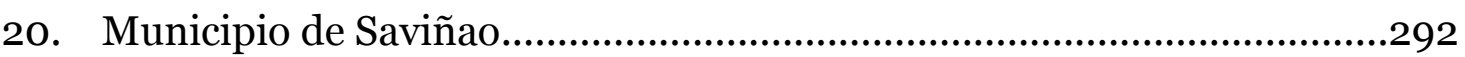

38.Ferrería de Sardiñeira........................................................................292

21. Municipio de Samos.................................................................................294 
39. Ferrería de Carqueixeda............................................................294

40.Ferrería de Gundriz......................................................................295

41. Ferrería de Lusío (Rial)................................................................ 300

42. Ferrería de Santalla......................................................................304

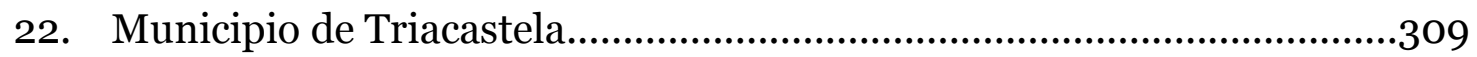

43. Ferrería de Furco....................................................................... 309

23. Municipio de Valadouro.......................................................................310

44. Ferrería de Pesqueira...................................................................310

24. Municipio de Villanueva de Lorenzana.................................................316

45. Ferrería de Lorenzana..................................................................316

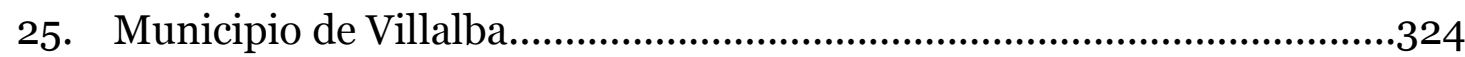

46. Ferrería de Saramugo....................................................................324

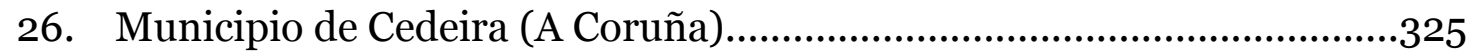

47. Ferrería de Montoxo...................................................................325

3. LAS FERRERÍAS DE ORENSE........................................329

1. Municipio del Barco de Valdeorras......................................................333

1. Ferrería de A Fervenza..................................................................333

2. Municipio de Carballeda......................................................................334

2. Ferrería da Pontenova........................................................................334

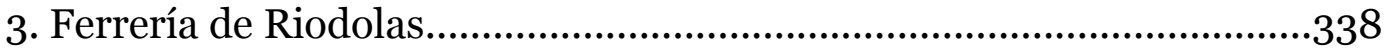

4. Ferrería de Robledo de Domiz..........................................................339

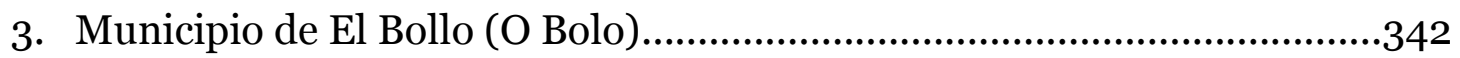

5. Ferrería de Mondón.......................................................................342

6. Ferrería de Vegas de Camba..........................................................348

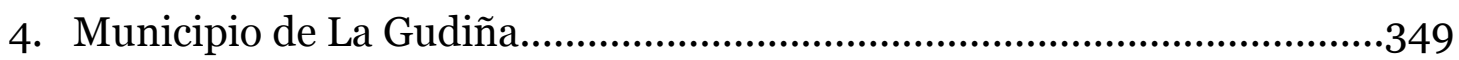

7. Ferrería de Moas...........................................................................349

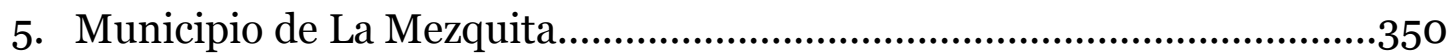

8. Ferrería de La Mezquita.................................................................350

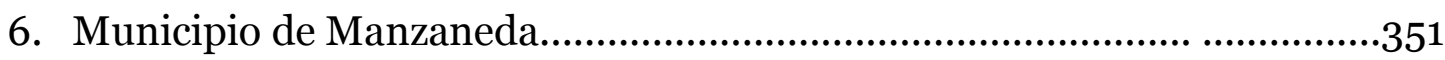

9. Ferrería de San Miguel de Vidueira.................................................351

7. Municipio de Villamartín de Valdeorras..............................................351

10. Ferrería de Cernego.......................................................................351

11. Ferrería de San Vicente de Leira...................................................353

12. Ferrería de Valdeorras................................................................359 
1. Municipio de Allande. 369

1. Ferrería de Armenade.

2. Ferrería de Penaseita 371

3. Ferrería de Villarín.... 372

2. Municipio de Amieva .373

4. Ferrería de La Ceneya..............................................................................373

3. Municipio de Belmonte.............................................................................. 375

5. Ferrería de Agüerina...........................................................................375

6. Ferrería de Belmonte...........................................................................377

4. Municipio de Boal............................................................................. 381

7. Ferrería de Froseira......................................................................... 381

5. Municipio de Cangas de Onís...................................................................384

8. Ferrería de Coviella.............................................................................384

9. Ferrería de Riera................................................................................385

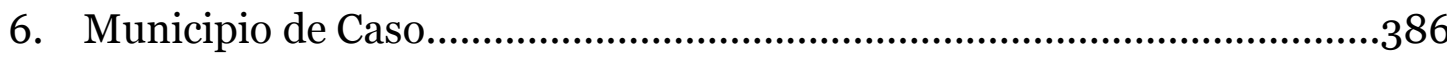

10. Ferrería de Abantro........................................................................386

7. Municipio de Castropol...........................................................................388

11. Ferrería de La Cabanada................................................................388

12. Ferrería de la Corredoira....................................................................391

13. Ferrería de Lagar.................................................................................391

14. Ferrería de Montealegre.......................................................................393

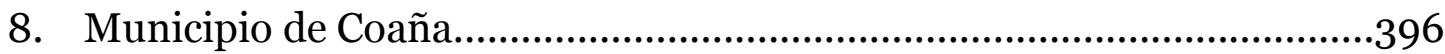

15. Ferrería de Coaña...............................................................................396

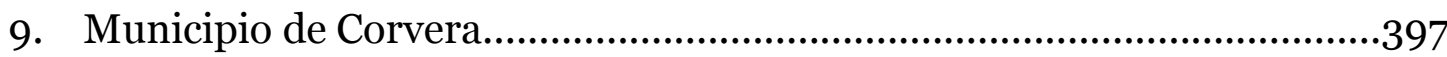

16. Ferrería de Trasona...............................................................................397

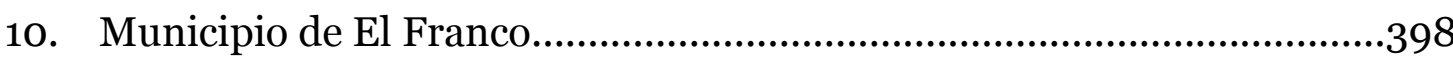

17. Ferrería de Boimouro.....................................................................398

18. Ferrería del Franco............................................................................401

19. Ferrería de Sueiro de Arriba...............................................................402

20.Ferrería de Sueiro de Abajo.................................................................404

11. Municipio de Gijón................................................................................405

21. Ferrería de Deva..................................................................................405

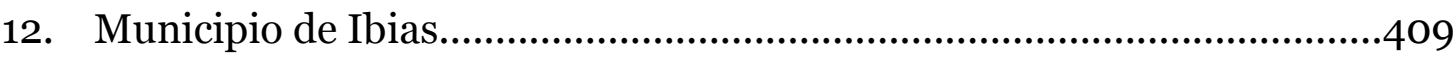

22.Ferrería de Vionga...............................................................................409

13. Municipio de La Nava.............................................................................410

23. Ferrería de La Nava.................................................................................410 
14. Municipio de Penamellera...................................................................... 411

24. Ferrería de Penamellera...................................................................... 411

15. Municipio de Pola de Lena........................................................................413

25. Ferrería de Renueva............................................................................ 413

16. Municipio de Ponga.................................................................................414

26. Ferrería de Soto Rodrigo....................................................................414

17. Municipio de Santalla de Oscos................................................................ 417

27. Ferrería de Ferreirela........................................................................417

28. Ferrería del Pontigón........................................................................419

18. Municipio de Somiedo............................................................................421

29. Ferrería de Somiedo..........................................................................421

19. Municipio de Soto del Barco....................................................................423

30.Ferrería de Labayos..........................................................................423

20. Municipio de Tapia de Casariego............................................................426

31. Ferrería de La Veguiña................................................................426

21. Municipio de Tineo............................................................................. 430

32. Ferrería de Arganza............................................................................430

33. Ferrería de Besullo..............................................................................431

34. Ferrería de la Fanosa.........................................................................432

22. Municipio de Valdés.............................................................................434

35. Ferrería de Brieves.............................................................................434

36. Ferrería de Carcedo.............................................................................437

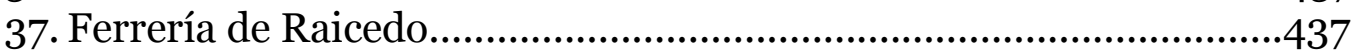

38. Ferrería de Salientes........................................................................... 441

39. Ferrería de Setienes...............................................................................442

23. Municipio de Vegadeo...........................................................................444

40.Ferrería de Abres...........................................................................444

41. Ferrería de Meredo................................................................................ 446

42. Ferrería de Nafarea.................................................................................448

24. Municipio de Villanueva de Oscos............................................................449

43. Ferrería de Villanueva de Oscos..........................................................449

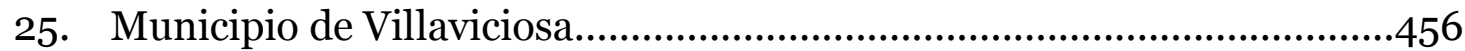

44. Ferrería de Amandi...........................................................................456

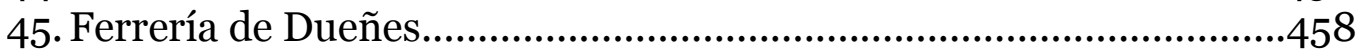

46. Ferrería de Peón...................................................................................... 464

26. Municipio de Navia............................................................................... 465

47. Ferrería de Arbón............................................................................... 465

48.Ferrería de Bullimeiro............................................................................466 


\section{INTRODUCCIÓN}

En el año 1989 leí en la Universidad de León mi tesina de licenciatura "Hierro y herrerías en el Bierzo preindustrial", dirigida por el profesor Joaquín González Vecín, posteriormente publicada por la Diputación Provincial de León, con el mismo título. En ella estudié la siderurgia berciana desde la Edad Media hasta el siglo XIX, esclareciendo una actividad prácticamente desconocida en León, pese a conservar aún los restos ruinosos de varias ferrerías, a excepción de la de Compludo que había sido declarada Monumento Histórico en 1968 y, parcialmente, restaurada. Las 24 ferrerías estudiadas, cuyos orígenes se remontaban, en algún caso, a la Edad Media, estaban localizadas fundamentalmente en el oeste del Bierzo, muy cerca de los yacimientos de hierro de Gestoso y Formigueiros, este último en la provincia de Lugo.

Las ferrerías bercianas, que fabricaron hierro mediante un método de reducción directo en hornos bajos, formaron parte de un tipo de industria rural, que aprovechaba los abundantes cursos de agua y la existencia de masas forestales y veneras de hierro para elaborarlo. Pero a diferencia de la industria textil rural, que emplea el tiempo muerto de los campesinos; la siderurgia no fue una actividad a tiempo parcial, excepto para algunos suministradores de carbón, sino una actividad compleja que movía a un número considerable de personas e intereses: propietarios, renderos o arrendatarios, oficiales, venaqueros $\mathrm{y}$ comerciantes; y que afectaba igualmente a otros muchos sectores y personas: machuqueros, herreros, cerrajeros, armeros.

Las ferrerías forman vastos conjuntos en los que alrededor de la fábrica se arraciman la vivienda del propietario o arrendatario, la capilla, los inmuebles de los operarios, las caballerizas, el molino y los campos de cultivo. Aunque de origen medieval, los siglos en los que esta actividad alcanzó su mayor desarrollo fueron los que se extienden del XVI al XIX; pues fue entonces cuando se consolida un tipo de siderurgia hidráulica, en la que enormes ruedas movidas por agua permitirían accionar los barquines y martinetes con los que reducir el mineral de hierro. En las postrimerías del siglo XV los condes de Lemos construyen en el Bierzo las ferrerías de Herrerías en el Valcarce, Arnado y Ponte 
Petre a orillas del Selmo, y probablemente las de Marciel en la zona de Bembibre. Todos estos establecimientos cobraron gran impulso en el siglo XVI al compás del crecimiento demográfico, la expansión agrícola y la presencia en el noroeste de numerosos ferrones vascos.

Después de la crisis del XVII, el siglo XVIII se mostró como un tiempo de efervescencia constructiva, en la línea del reformismo borbónico y la buena coyuntura de su primera mitad; pues a las anteriores ferrerías se añadieron las de Linares (1729) y Pombriego (1750), construidas por los benedictinos de San Pedro de Montes; las de Torre y San Andrés de las Puentes levantadas hacia 1764 por Carlos Lemaur, el ingeniero de la nueva carretera de Madrid-Galicia; y por último, la de Tejedo de Ancares (1788), obra de varios comerciantes ancareses residentes en Ferrol. Pero fue el siglo XIX, pese a los negros presagios que anunciaba la Revolución Industrial para aquella industria, cuando esta zona alejada y mal comunicada vio incrementar su número en 15 nuevas ferrerías: Serviz (1823), Portela de Valcarce (1834/35), Corporales (1835/40) Valdelouro (1835), Arnadelo (1840), Valincarro (1840), Lusío (1840), San Vitul (1844), Gestoso (1845), las dos de Río Cabo (h. 1840), Llamas (1859), Barjas (h. 1860) y Compludo (h.1860).

De las Respuestas del Catastro de Ensenada y los informes de Cornide (1780), Datoli (1797) y Munárriz (1807) se deduce que las ferrerías bercianas trabajaban entre 200 y 250 días al año, con una producción por ferrería en torno a los 1.200 y 1.500 quintales (de 5 arrobas) anuales, es decir entre 70 y 90 toneladas de hierro, aunque la media en periodos largos no superase probablemente las 40 toneladas anuales. El total de producción en el siglo XVIII alcanzó unas 500 toneladas anuales, cantidad significativa para aquella época. La mayor parte de este hierro, fundido en barras o pletinas, era exportado hacia Castilla, León, Galicia e incluso Portugal. Solo una pequeña parte era transformado directamente en el Bierzo para hacer clavazón, aperos de labranza y utensilios del ajuar doméstico, ya en las propias ferrerías o más frecuentemente en los mazos o martinetes y en fraguas de los alrededores; el resto era comercializado por arrieros maragatos y comerciantes de Ponferrada, Villafranca, La Bañeza y León. 
Las ferrerías solían estar arrendadas normalmente por varios años o a más generalmente a largo plazo (foros), siendo los renteros los verdaderos organizadores de la producción. Muchos de estos renteros, en los siglos XVI y XVII, fueron de origen vasco. Ellos contrataban a los oficiales o ferrones y adquirían la vena y el carbón. Eran los que más exponían, pero al mismo tiempo obtenían grandes beneficios. Constituían un pequeño grupo de hidalgos rurales, que tuvieron en estos artefactos una parte considerable de sus recursos económicos. Por ejemplo, según el Catastro de Ensenada, frente a los 7.089 R.v. del mayor hacendado de Villafranca o los 7.159 del de Ponferrada, el propietario de la ferrería de Valcarce contaba con una renta anual de 78.546 R.v, de los cuales 74.550 provenían directamente de beneficios de la ferrería, lo que le permitía una vida muy holgada.

Muchas de las ferrerías construidas en el siglo XIX lo fueron por antiguos arrendatarios. Frente a la vieja hidalguía de siglos pasados, estos nuevos propietarios constituyen una incipiente burguesía de ideas liberales y, en muchos casos, relacionada con la política como alcaldes, diputados y senadores. En todo caso, gente enriquecida que fue capaz de costear estos artefactos, los cuales convirtieron a algunos de sus propietarios en los hombres más ricos de la comarca, como el ponferradino Nemesio Fernández, propietario de las ferrerías de Serviz, Corporales, Portela de Valcarce, Llamas y San Pedro de Montes, esta adquirida en la Desamortización. Al morir en 1859, este antiguo arrendatario hecho a sí mismo, dejó una fortuna valorada en 2.839.221 reales, de los cuales el valor de las ferrerías y el carbón superaba el millón, siendo al mismo tiempo el mayor contribuyente del Partido de Ponferrada.

El estudio en mi tesina de la siderurgia berciana vino a completar un vacío en la historia de la provincia de León; pero sobre todo estaba enmarcado en un contexto de investigaciones sobre la siderurgia española, que estaba dando importantes frutos para el conocimiento de la siderurgia tradicional; es decir, la que utiliza el método directo de reducción del hierro, como las fargas catalanas y las ferrerías vascas y cántabras. Hasta los años setenta del siglo XX, la investigación sobre la siderurgia tradicional había interesado sobre todo a eruditos locales, ingenieros y etnógrafos. Los estudios sobre la farga catalana de 
Gallardo y Rubio (1930), las ferrerías cántabras de Barreda y Ferrer (1948), las vascas de Laborde (1952) y Garmendia (1976) e incluso algunos posteriores como los de Pere Molera (1980), Molera y Barrueco (1983), eran descripciones del funcionamiento de dicho método, sin profundizar en el proceso histórico, solo parcialmente conocido.

El trabajo de síntesis publicado por J. Alcalá-Zamora (1976), autor que ese mismo año publicaba un exhaustivo estudio sobre las fábricas santanderinas de Liérganes y la Cavada, preludió el interés por la historia de la siderurgia en general y la de la tradicional en particular. Tal síntesis era un estado de la cuestión sobre dicha materia, al tiempo que planteaba las líneas de estudio que habría que emprender para lograr un conocimiento más cabal de aquella realidad económica que, con mayor o menor importancia, se había desarrollado en varias regiones españolas, aunque sin acertar a valorar la importancia de alguna de ellas. Ese trabajo, así como los dos anteriores de Vázquez de Prada sobre las ferrerías vascas (1973) y las fargas catalanas (1975), y el de González Echegaray sobre las cántabras $(1972,1974)$, fueron los alicientes que permitieron que en la década de los ochenta comenzaran a ver la luz los importantes estudios, muchos de ellos tesis doctorales, sobre la materia: los de Arbide Elorza (1980), Bilbao y Pinedo (1982), Bilbao (1984 y 1989), Díaz de Salazar (1983), Maluquer de Motes (1984), etc.

A estos trabajos siguieron, en los años noventa, otro buen número de publicaciones sobre la siderurgia vasca: los de Carrión Arregui sobre la siderurgia Guipuzcoana en el siglo XVIII (1991) y Uriarte Ayo sobre la siderurgia tradicional vizcaína (1988); las ferrerías cántabras: los interesantes trabajos de Arroyo Valiente y Corbera Millán (1993) y Ma Carmen Ceballos (2001); las ferrerías del norte de Burgos y sierra de la Demanda: los de Ortega Valcarce (1974) y González Bueno (1997). Sobre las fargas catalanas, sobre las que existían muchos estudios técnicos -incluso en 1991 se celebró en Ripoll un I ${ }^{\circ}$ Simposi Internacional, cuyas ponencias se editaron en 1993-, se publicaron entonces varios trabajos de gran interés histórico, como los de Simó y Arias (1992) Mascarella i Rovira (1993), Mas I Canals (1993) y Mas Arredondo (2000). En estos últimos años Priotti (2005) y Aragón Ruano (2011 y 2012) han 
profundizado en la proyección económica nacional e internacional de la siderurgia vasca en los siglos XVI y XVII.

En nuestra zona de estudio, al margen de algunas notas de ingenieros de minas en Revistas Mineras del siglo XIX, el trabajo más temprano sobre la siderurgia fue el publicado en 1926 por el general Severo Gómez Núñez, en el que incluyó el informe del teniente coronel Munárriz sobre la fábrica de hierro de la Somoza, en el Bierzo, del primer decenio del siglo XIX. Pero el estudio más completo sobre una ferrería lo realizó P. Saavedra (1982) sobre la asturiana de Villanueva de Oscos, a partir del libro de cuentas que conserva el A.H.N., sección clero, $\mathrm{n}^{0}$ 9.437, porque nos ofreció la contabilidad de 155 años, desde 1670 a 1835, con series numéricas de producciones, precios, costes de vena y carbón. También es de gran interés el capítulo que este autor dedicó en su tesis a la industria metalúrgica en la antigua provincia de Mondoñedo (1985). No se ha publicado desde entonces ninguna contabilidad con tal riqueza; solo el Libro de Cuentas de la ferrería lucense de Quinta ofrece datos semejantes pero para un periodo de medio siglo (1745 a 1792), libro sobre el que Mingués Rodríguez publicó un breve artículo (1996) y que he revisado íntegramente de nuevo por algunos errores y erratas que he constatado. También es de gran interés el artículo de García Tato sobre las ferrerías de Río Cabo y Pombriego en el siglo XIX (2000), tanto por el estudio de estas forjas, como por los documentos que aporta sobre la mina de Formigueiros.

Los libros publicados sobre la siderurgia del noroeste, además de los que he publicado yo mismo sobre las ferrerías del Bierzo (1990, 1991, 2008) son pocos y con numerosas lagunas. Sobre las grandes ferrerías de Lugo, como titula su libro, publicó un buen estudio el etnógrafo Clodio González (1994), más interesante por sus descripciones y valor arqueológico (Arqueología Industrial) que por los datos históricos. Aunque enumera buena parte de las que hubo, sin embargo la mayoría están mal datadas y desconoce su evolución histórica. Ricardo Gurriarán dedicó un breve capítulo, en una historia de la minería en Valdeorras (2000), a las ferrerías de esa comarca, no a todas las de Orense, pero con escaso aparato documental. A la siderurgia tradicional asturiana dedicó Ocampo Suárez-Valdés un capítulo de su tesis que repitió en varios libros (1987, 
1990), con datos casi exclusivamente del Catastro de Ensenada. Más interesante es el libro de J. López y A. Graña sobre las ferrerías y mazos de Asturias (1998) porque se trata de un trabajo de campo con descripciones y planos de los edificios de 11 ferrerías y 4 mazos de esa comunidad, con algunas breves referencias históricas.

Esta tesis, por tanto, responde a ese mismo intento de conocer la historia siderúrgica española, aunque con un cierto retraso, porque razones personales me llevaron a posponer este trabajo de investigación que pretendía completar el que había emprendido en la tesina. Una de sus conclusiones, que me llevó en la tesis a ampliar el ámbito de estudio al noroeste, fue comprobar las intensas relaciones existentes entre ferrones, renteros y propietarios, las cuales trascendían la comarca del Bierzo. Era frecuente que ferrones que habían trabajado en fábricas bercianas lo hubieran hecho anteriormente en ferrerías gallegas y viceversa; también descubrí que con frecuencia los mismos arrendatarios regentaban ferrerías bercianas y gallegas, a veces al mismo tiempo, e incluso que tales arrendatarios estaban unidos por lazos familiares. Lo mismo podríamos decir de los propietarios, pequeña nobleza e hidalgos casados entre si, verdaderas sagas familiares vinculadas al mundo del hierro. En ese sentido, las montañas no fueron nunca un factor de aislamiento sino de unión, y Villafranca del Bierzo, Monforte y Lugo aparecían como lugares de residencia de aquellos propietarios.

Fueron estas relaciones las que me llevaron a interesarme por el estudio de la siderurgia en Galicia, porque me pareció que había no solo grandes semejanzas en la tecnología de estos artefactos, sino una estrecha relación entre todas las del Bierzo, Orense y Lugo, relaciones que en gran parte tenían que ver no sólo con las mismas, o muy parecidas, características geográficas, sino con la abundancia de agua y bosques y la existencia de ricos yacimientos de hierro en el punto de contacto de las tres provincias, en la zona del monte Formigueiros, en el Caurel y en Rocas, en Puebla de Brollón. Buena parte de las ferrerías leonesas, orensanas y lucenses se abastecían de ese mineral, cuyas características se adecuaban perfectamente para poder reducirlo en los hornos bajos. 
Más tarde averigüé que había otras ferrerías, las cercanas a la costa lucense, que no habían usado ese mineral sino vena vasca, lo que me puso en contacto con otra realidad, el de las ferrerías asturianas. En un principio no pretendía estudiar ese nuevo espacio, pero luego me di cuenta que muchas ferrerías del occidente de Asturias, tanto del interior como de la costa estaban relacionadas con las ferrerías gallegas (por ejemplo, en los protocolos del archivo provincial de Lugo aparecían con mucha frecuencia datos de ferrerías asturianas), no solo en los aspectos técnicos, como era lógico, sino en las relaciones entre ferrones y arrendatarios. De este modo decidí integrarlas en el estudio, incluso pensé que sería bueno hacer lo mismo con las del oriente de Asturias, ya que en general se trataba de ferrerías cronológicamente más tempranas y que con la deforestación de las zonas costeras, la actividad se había desplazado, aunque no completamente, hacia el oeste.

Por tanto, el ámbito geográfico de mi estudio abarca León, Galicia y Asturias, aunque no cubra todo el territorio de esas regiones, porque en León solo han existido ferrerías en el Bierzo, y en Galicia solo en Orense y Lugo, y no en todo el territorio de estas provincias sino en dos ámbitos: las zonas más cercanas a los yacimientos de Formigueiros y Rocas, por tanto en Valdeorras, Quiroga y el Caurel, con alguna ampliación cercana hacia O Bolo, en Orense, y hacia Cervantes en Lugo, y en la costa. Más amplitud encontramos en Asturias, porque las 48 ferrerías que hemos documentado se encuentran distribuidas por 26 municipios, aunque la mayoría se localizan en la zona oeste, en una línea que va desde la costa hasta Grandas de Salime y Somiedo, pasando por los Oscos; también es en esta zona, y en la limítrofe gallega, en la que se encuentran la mayoría de los mazos o machucos.

El noroeste así delimitado presenta unas características muy semejantes, que la hacen sumamente atractiva para la actividad siderúrgica. En primer lugar el mineral de hierro, bien porque cuenta con yacimientos locales susceptibles de ser explotados, como los de Formigueiros, Rocas, la Chana de Borrenes y otros de menor importancia; bien porque la comunicación con mar hizo posible la importación de mineral de hierro de Vizcaya, que en general consumirían todas las ferrerías de la costa, a veces mezclado con alguna vena local. Por esa razón, 
he dedicado un capítulo al estudio de estos yacimientos, así como al trabajo minero realizado en los mismos, casi siempre a cielo abierto, aunque en algún caso hubo una minería subterránea poco profunda. También he dedicado un apartado al transporte de la vena por los llamados "caminos de la vena", la ragua del mineral y los rendimientos del mismo, que normalmente fue de un 33 por ciento aproximadamente, aunque su riqueza superara con creces el 50\% e incluso más.

La vena, por eso, no fue lo más importante para explicar el número de ferrerías del noroeste, porque como hemos dicho esta pudo importarse sin excesivas dificultades, aunque a un coste mayor, del País Vasco. Sí lo fue la existencia de numerosos cursos de agua, ya que las ferrerías y mazos de los que vamos a hablar son ingenios movidos por la fuerza hidráulica. En ese sentido, fueron necesarios permisos para su uso porque frecuentemente su construcción entraba en conflicto con otros artefactos (otras ferrerías, molinos, batanes) o con los campesinos que usaban el agua para el regadío de sus campos. La conflictividad fue causa de muchos retrasos en la construcción de ferrerías y mazos, pero también añadió costes a la producción por los frecuentes y largos pleitos. En esta conflictividad jugó un papel muy importante el bosque, por el extraordinario consumo de leña y carbón que necesitan las ferrerías. No hay que olvidar que el carbón vino a representar, según la época, entre un 40 y un 60\% del coste total de la producción de hierro.

Una segunda cuestión que me planteé, una vez acotado el marco geográfico de estudio, fue determinar el ámbito cronológico. Desechada la Edad Media por las razones históricas que diré, me centré en el estudio de la siderurgia desde el siglo XVI hasta su desaparición a finales del siglo XIX, a la que en puridad se le suele llamar etapa clásica o preindustrial. Se trataba de un proyecto muy ambicioso, porque era un espacio muy extenso y demasiados siglos, lo que me obligaría a consultar mucha documentación, con el peligro de dispersarme y no profundizar suficientemente, como se supone que debe de ser una tesis doctoral. Pero la cronología señalada me parecía evidente. El siglo XVI era un buen comienzo, pues aunque las ferrerías hidráulicas se conocen desde la Edad Media, los investigadores están de acuerdo en que fue en ese siglo cuando 
se desarrolló una técnica más avanzada y sofisticada, lo que algunos llaman "ferrerías a la genovesa", pero que otros creen que no fue más que una especialización entre ferrerías mayores y menores, lo que en nuestra zona se llamarán ferrerías y mazos o machucos. Por otro lado, fue en ese comienzo de la modernidad cuando se construyen un buen número de artefactos, como veremos. Luego, nada en los siglos XVI al XIX, al margen del mayor número de ferrerías que se van construyendo y, por tanto, el aumento de la producción, permite pensar en diferencias técnicas o de otro tipo. La siderurgia tradicional, como señala Alcalá-Zamora, abarca tales siglos y por eso, pese a los inconvenientes, preferí lograr una imagen de conjunto aún a costa de una menor profundidad.

Desde el punto de vista metodológico, lo primero que me planteé fue estudiar de forma monográfica todas las ferrerías que se habían construido en la zona, porque solo sabiendo cuántas había habido y cuándo fueron construidas podía valorarse su importancia económica e histórica. No es lo mismo un pequeño número de ferrerías, sin apenas proyección sobre la economía y marginales en el territorio, que más de un centenar como fueron las que se construyeron, que con los mazos superaron los 200 artefactos (ferrerías mayores y menores), porque tal cantidad tiene consecuencias cualitativas evidentes. Para ello revisé toda la bibliografía que se había escrito sobre el tema, aunque la mayoría, con alguna excepción, se trataba de trabajos eruditos no siempre bien documentados; pues como dije anteriormente, en general estos buscaron más describir la técnica que valorar su importancia histórica. Sin conocer el número de ferrerías y su evolución a lo largo de los siglos es imposible conocer cuál fue realmente su importancia económica y su influencia social.

Las fuentes de información que había manejado en la tesina sobre las ferrerías bercianas fueron fundamentalmente, además del Catastro de Ensenada, los protocolos notariales del Archivo Histórico Provincial de León y algunos informes del Archivo Militar de Segovia, como los de los militares Francisco J. Datoli y Juan Manuel Munárriz. Los protocolos fueron una fuente que me permitió conocer el origen de muchas ferrerías, por la costumbre de 
protocolarizar los permisos de construcción concedidos por los pueblos a promotores y propietarios; también por que en ellos aparecen muchos contratos de arrendamiento, foros, obras por descalabros provocados por las avenidas de las aguas, arreglos de barquines y mazos; obligaciones para acarretar la vena desde los yacimientos a la ferrería, venta de hierro; poderes para pleitear por problemas con el bosque y el carbón. En ese sentido, el vaciado de otros archivos provinciales, como el de Lugo, en el que trabajé de forma sistemática durante meses fue realmente muy productivo y hallé numerosas noticias sobre ferrerías lucenses, orensanas, leonesas y asturianas.

Sin embargo, la fuente que más metódicamente consulté fueron los pleitos, tanto del Archivo Histórico del Reino de Galicia, que conserva la documentación de la Audiencia de La Coruña desde el siglo XVI, como el de la Chancillería de Valladolid. En ellos, a través de largos sumarios sumamente ricos en información, aunque engorrosos, pude rastrear las vicisitudes históricas y familiares de numerosas ferrerías; porque en los pleitos, con mucha frecuencia, se aportan documentos, normalmente en copias legalizadas por los notarios, para defender una causa que puede remontarse a varios siglos antes. El trabajo fue realmente arduo porque no existe un catálogo de juicios por ferrerías sino por personas. El conocimiento del nombre de algunos propietarios de ferrerías me permitió consultar en los ficheros los juicios de esos propietarios, algunos de los cuales afectaban a sus ferrerías; así conociendo cada vez mejor a estos pude poco a poco desvelar la historia de las mismas. En general esta fuente es más cualitativa que cuantitativa, aunque en algún caso se ofrecen datos contables y relaciones de producción, aunque para periodos muy cortos, nada que ver con los libros de cuentas como los de Villanueva de Oscos o Quintá, por cierto este último en el Archivo Histórico del Reino de Galicia.

Además de esta fuente, trabajé en el Archivo Histórico Nacional, tanto en libros del clero (monasterios de Samos, Lorenzana y Villanueva de Oscos), como en la sección de Estado y Hacienda, en los que aparecen permisos para la construcción de ferrerías; en el de Simancas, concretamente el fondo Marina, con datos sobre algunas ferrerías asturianas; en los archivos militares, como el de Madrid y Segovia, y el de la Marina en Madrid; en el de la Real Academia de 
la Historias, en el del monasterio de Silos, donde se conservan documentos de la Congregación de Valladolid, con las contabilidades de varios años de las ferrerías de San Julián de Samos y San Pedro de Montes. Pude contar también con algunos datos dispersos de archivos familiares, que amablemente me proporcionaron sus propietarios, como los libros del Guarda Mayor de Montes, de la familia Rodríguez de Cacabelos, los de la familia de Llano y Ovalle de Villafranca del Bierzo sobre las ferrerías de Ramón Ovalle, cuentas de la ferrería de Llamas de uno de sus arrendatarios en el siglo XIX que conservaba un descendiente, el maestro de Toral de los Vados Manuel Rodríguez. El vaciado de Los Boletines Provinciales y las Revistas Mineras fueron también una importante fuente de información, por ejemplo para conocer los permisos de construcción de ferrerías en el siglo XIX.

Toda esta documentación me permitió, en primer lugar, realizar el estudio monográfico de las ferrerías. En total son 131 las ferrerías que documenté en la zona, así como unos 80 mazos. El estudio de todas esas ferrerías se anexan en el Catálogo de Ferrerías, que como apéndice incluyo al final de la tesis, lo que por otro lado me ahorra el tener que realizar un apéndice documental más exhaustivo. No he hecho lo mismo con los mazos, aunque la mayoría están referenciados en ese estudio monográfico de las ferrerías, con datos que aclaran su propiedad y su cronología. Entre la documentación estudiada hallé igualmente numerosas noticias sobre artesanos herreros por lo que, aunque no era esa mi intención, las utilicé para analizar someramente, en el capítulo sobre la distribución y venta del hierro, el alcance de esta actividad por la región estudiada y su hinterland.

Las ferrerías, desde el punto de vista cronológico, se construyen a lo largo de los siglos XVI al XIX. En los siglos XV y XVI se erigieron el 31,2\%, en una época de crecimiento económico y demográfico en la Corona de Castilla bien atestiguado en las fuentes; el 9,1\% en el siglo XVII, probablemente por la crisis; el 23,6\% en el siglo XVIII, en relación con el reformismo borbónico y algunas medidas legales que favorecieron esa industria; y por último el 35,8\% en el siglo XIX, probablemente, entre otras causas, debido al aislamiento de la zona respecto a los nuevos centros siderúrgicos españoles. También hubo algunos 
cierres, un $10 \%$ aproximadamente, sobre todo en la segunda mitad del siglo XVIII, especialmente en la zona oriental y central de Asturias y en la costa gallega, por problemas en el abastecimiento de carbón y por el precio excesivo de la vena vasca. Pero una gran parte continuó hasta bien entrado el siglo XIX, dejando de funcionar la mayoría hacia los años sesenta y el resto en los años ochenta.

Territorialmente en la provincia de Lugo se construyeron en los siglos XV-XVI el $56 \%$ de todas las ferrerías del noroeste en dichos dos siglos, probablemente por la cercanía de los yacimientos de Rocas y Formigueiros respecto de las del interior y por el uso de vena vasca en las de la costa; por otro lado, las 23 ferrerías de esos dos siglos significan el 50\% del total de esta provincia, que en el siglo XVIII construye otras 11, es decir, un 23,9\% más, pero sólo el 17,3\% en el siguiente. Por el contrario, en el resto de las provincias la mayoría de sus ferrerías se levantan en el siglo XIX, especialmente en el Bierzo y Orense, con un 56\% y un 66\% respectivamente; en el Bierzo hay también un $24 \%$ de ferrerías de los siglos XV-XVI. En Oviedo, el XIX es el siglo de mayor número, pero este sólo representa el 35,4\%; pues igualmente se erigieron muchas en el siglo XVIII, un 24,48\%, y sobre todo en los siglos XV al XVII, que juntos superan el $38 \%$.

Si a las 131 ferrerías añadimos, como hemos dicho, unos 80 mazos la cantidad de artefactos superan los 210. Hasta ahora la actividad siderúrgica en el noroeste de España se consideraba si no marginal, sí de escasa entidad frente a la siderurgia vasca, cántabra o catalana; sin embargo, el estudio demuestra lo contrario, porque dejando a un lado la siderurgia vasca, cuya importancia es indudable al menos hasta la mitad del siglo XVIII, con un número entre ferrerías mayores y menores que superó los 300 artefactos; tanto en Cantabria como en Cataluña su número fue muy inferior al que hubo en nuestra zona de estudio, ya que en ningún caso superaron el medio centenar de ferrerías cada una de esas regiones, e incluso en Cataluña bastantes menos. Pero si del número total descendemos a su análisis por siglos, vemos cómo desde la segunda mitad del siglo XVIII y en el siglo XIX, los problemas de la siderurgia vasca, convierten al noroeste en el núcleo ferrero más importante de la península, en gran parte 
debido a los arsenales del Ferrol y La Coruña grandes consumidores de hierro y clavazón.

Con pequeñas variantes, la técnica de todas estas ferrerías fue muy semejante. ¿Cómo, cuándo y quién la introdujo en el noroeste? Aunque hubo ferrerías en la Edad Media, incluso algunas hidráulicas como documenté en mi tesina, lo que llama la atención es su número a partir de finales del siglo XV y sobre todo en el XVI. Las fuentes lo dejan bien claro. Las nuevas ferrerías, técnicamente más avanzadas y perfeccionadas, son de influencia vasca, como lo pone de manifiesto la terminología de sus partes; pero sobre todo lo demuestra la enorme cantidad de ferrones y arrendatarios vascos durante los siglos XVI y XVII. ¿Por qué emigraron? ¿Cuál fue su papel en la siderurgia del noroeste? Estas fueron preguntas obligadas ante tantos nombres vascos como aparecían en la documentación. Creo que, además del crecimiento demográfico, la nueva tecnología expulsó de las ferrerías vascas a muchos ferrones, los cuales buscaron alternativas en otras regiones españolas, entre ellas en Asturias, Galicia y el Bierzo.

En el noreste hallaron unas condiciones geográficas, materiales y humanas muy propicias para su expansión. En primer lugar, como ya hemos dicho, por la existencia de numerosos cursos de agua susceptibles de ser utilizados para mover los mazos y barquines de las ferrerías, cursos de agua que, normalmente en zonas de montaña poco pobladas, no suscitaron en aquel siglo muchos problemas por su uso. Además Galicia, Asturias y el Bierzo contaban con una importante masa arbórea, que podía proporcionar la madera y el carbón necesarios para raguar el mineral y reducirlo en el horno. Por último, encontraron a unos señores bien dispuestos para acogerlos, dado que muchas de las ferrerías las construirían los vascos en territorios que pertenecían a la nobleza o a las órdenes militares y religiosas. Los vascos, por tanto, no sólo fueron los ferrones que trabajaron en las ferrerías como oficiales, fueron también en muchas ocasiones los promotores y arrendatarios de las mismas.

Algunos de estos vascos se convertirían, a través de foros de larga duración, en poseedores de ferrerías de las que obtuvieron pingües beneficios, 
lo que les llevó a entroncar con la hidalguía local, propietaria también de ferrerías o simplemente de tierras. Se formaron así verdaderas sagas familiares vinculadas al mundo del hierro, aunque igualmente propietarias de otros bienes, tierras vinculadas en mayorazgos en los que incluyeron a las ferrerías. De este modo, desde la segunda mitad del siglo XVII el número de apellidos vascos va desapareciendo de la documentación, en muchos casos porque, con excepción de algunas ferrerías costeras, ya no emigran desde el País Vasco, pero en otros casos porque han perdido sus apellidos como consecuencia de matrimonios con esa hidalguía local. Incluso en los siglos XVIII y XIX algunos alcanzan títulos nobiliarios.

También el mineral vasco de Somorrostro pudo ser un aliciente en la construcción de ferrerías en el noroeste. Así como el agua y el carbón eran recursos necesarios in situ, no lo fue de igual modo el mineral de hierro, porque este podía importarse de Vizcaya. Por esa razón muchas de las ferrerías más madrugadoras se encuentran en las cercanías de la costa. El hallazgo de minerales autóctonos, sobre todo los de Formigueiros y Rocas, en la provincia de Lugo, probablemente descubiertos por venaqueros vascos, ya que son de esa procedencia los que trabajaron en ellos en los primeros siglos de la Edad Moderna, fue un poderoso aliciente para la construcción de otras ferrerías en el interior de Lugo y el Bierzo.

En los siglos XVIII y XIX, la construcción de nuevos artefactos ya no dependió de la iniciativa vasca ni tampoco de la vena vizcaína, aunque todavía se utilizó profusamente en las ferrerías cercanas a la costa. Sin embargo, la mayoría en esos siglos se construyen en el interior, en zonas aún no deforestadas y con venas locales susceptibles de ser explotadas, y sus promotores fueron miembros de la hidalguía rural; pero sobre todo, a partir de la segunda mitad del siglo XVIII y en el XIX, de algunas compañías, como la de Ribadeo, y especialmente antiguos arrendatarios buenos conocedores del negocio del hierro, que consiguieron los permisos y contaron con el dinero para levantar estos artilugios en ese siglo XIX o adquirirlos en la desamortización, tras la nacionalización de los que poseían los monasterios benedictinos y cistercienses. 
Con la excepción de los datos seriados de las dos ferrerías mencionadas, la documentación que hallé fue muy exigua desde el punto de vista cuantitativo. No me fue difícil seguir la evolución histórica y familiar de las ferrerías, pero sí conocer con exactitud el volumen de la producción, tanto de las ferrerías una a una como el montante total en los diferentes siglos. Las fuentes nos permiten conocer, con cierta fiabilidad, la producción teórica por ferrería, pues aunque variaban mucho de unas a otras, una media de $700 \mathrm{qq} . /$ año, es decir, unas 40 toneladas, puede aceptarse sin grandes visos de error. Hay ferrerías que no trabajan más que un par de meses, las llamadas regateras; pero también las hay que trabajan la mayor parte del año, con las interrupciones propias de estos artefactos para algunas reparaciones y en las festividades. Por ello hay ferrerías cuya producción evalúan las fuentes en 1500 qq./año, mientras que otras apenas superan los 350 qq./años; pero en general una media de 700 qq. ó 40 toneladas puede ser perfectamente aceptada.

Si esto es así, la producción total hay que relacionarla con el número de las ferrerías en funcionamiento, lo que varió considerablemente de unos siglos a otros; pero esto lógicamente no es completamente fiable, porque a causa de los escalabros o las dificultades para abastecerse de vena y carbón, la producción fue muy irregular. Por eso, este capítulo ha sido sin duda el más difícil de abordar en la tesis, porque no hemos hallado no ya contabilidades de ferrerías, tampoco datos estadísticos seriados, excepto para algún momento de los siglos XVIII y XIX. Aunque parezca extraño en una actividad de esta magnitud, no hubo datos oficiales de producción, al margen de los que proporciona el Catastro de Ensenada o, ahora más abundantes y precisos, los que incluyen anualmente los inspectores en sus respectivos distritos mineros en el siglo XIX, que anualmente recogen La Revista Minera. En total, la producción de hierro en el noroeste se puede estimar entre las 1.500 toneladas del siglo XVI y las 3.000/4.000 toneladas del siglo XIX, lo que supone entre un 3\% y un 15\% de la producción nacional, hasta alcanzar en el siglo XIX el 26\% respecto al hierro forjado. 
Los costes de producción de una ferrería incluyen numerosos conceptos: carbón, mineral de hierro, salarios de los oficiales, descalabros, amortización de los capitales y gastos generales (depende de si las ferrerías tenían o no administrador, pero incluían alimentos, salarios del administrador, ama de casa y criados). Aunque es difícil de conocer la evolución a lo largo de los siglos de estos costes, contamos con datos en diversos momentos que nos ofrecen un cuadro bastante claro, al menos de los siglos XVIII y XIX. En general, con las matizaciones que veremos en su momento, de todos estos conceptos el carbón fue el más gravoso porque suponía de media en el tiempo computado (finales del siglo XVII hasta el siglo XIX) casi el $43 \%$ del total frente al 29,8\% de la vena, $12,7 \%$ del trabajo de los operarios y $16 \%$ de los arreglos y otros conceptos. Tales porcentajes, con sus fluctuaciones a lo largo del tiempo, se mueven en parámetros muy parecidos a los de otras ferrerías españolas, quizá con la excepción del carbón, que suele ser algo inferior en las del noroeste.

Una última cuestión que hemos abordado en la tesis es la comercialización de ese hierro, sus precios, hinterland y los usos que se hicieron con él. En general, solo una parte muy pequeña de la producción, menos del $10 \%$, se transformaba directamente en las ferrerías en clavazón y herrage; el resto se vendía fuera. Unas veces los propietarios o arrendatarios contaban con lonjas o almacenes en algunas villas, otras sencillamente vendían la producción al por mayor a comerciantes y tratantes, los cuales a su vez lo revendían a los mazos y herreros de la zona. Su hinterland abarcó Galicia, Asturias y Castilla y León; pero incluso en algunos momentos, por ejemplo en el siglo XVI, el hierro del noroeste llegó a Andalucía, Portugal y Francia. Por esta razón, ciñéndonos al noroeste, el hierro dio ocupación a varios miles de machuqueros y artesanos (herreros, cerrajeros, armeros) distribuidos por el medio rural pero también por villas y ciudades, aspecto que hemos abordado de forma somera.

En definitiva, el trabajo aborda todos estos aspectos en seis capítulos, además de los apéndices y el catálogo de las ferrerías. En el primero analizamos y describimos la técnica siderúrgica por entender que sin ella no sería posible la existencia de ferrerías, técnica que, como hemos dicho, llega al occidente desde el País Vasco, de ahí las semejanzas entre las ferrerías de todo el norte de 
España. Los capítulos segundo y tercero explican las condiciones geográficas y materiales de las ferrerías, con el estudio del medio geográfico, el agua, el bosque, la fabricación de carbón y la minería del hierro. El capítulo cuarto analiza las condiciones humanas de esta actividad ¿quién la promueve?, ¿quién construye las ferrerías y mazos?, las relaciones entre propietarios y arrendatarios, el mundo de los trabajadores directos e indirectos que trabajan en las ferrerías o para las ferrerías. Por último, los capítulos quinto y sexto abordan el complejo tema de la producción, su evolución secular y los factores que la explican, los costes de producción, la comercialización del hierro y su uso por machuqueros y herreros. 


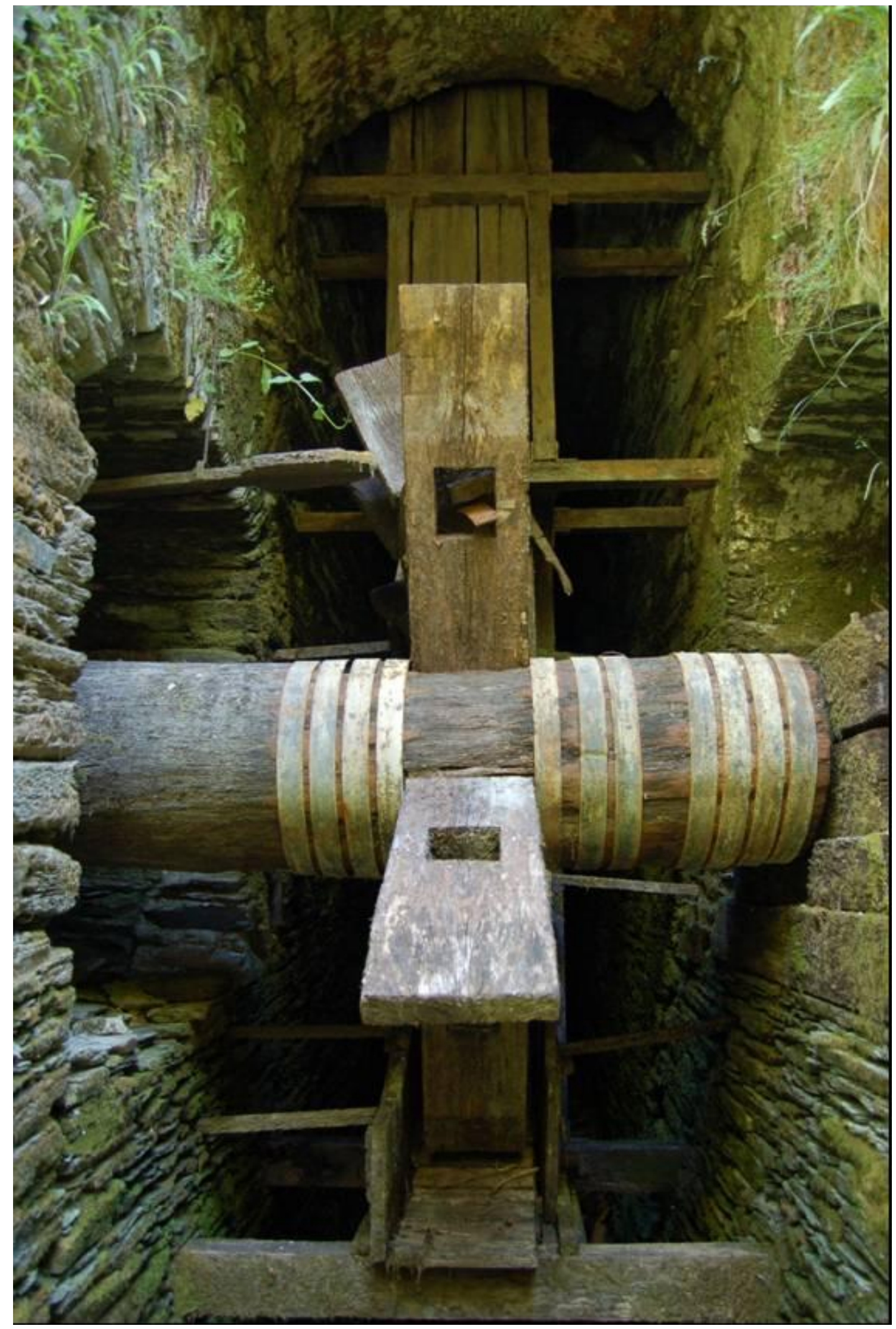

Rueda de la ferrería de Seoane del Caurel 


\section{LA SIDERURGIA TRADICIONAL. LA TECNOLOGÍA}

La siderurgia, cuyos orígenes se remontan a los últimos siglos del segundo milenio antes de nuestra era ${ }^{1}$, se introduce en el noroeste de España prácticamente con la dominación romana, a partir del siglo I, en relación con las explotaciones auríferas del noroeste. Esta hipótesis la confirman tanto la escasa o nula presencia de útiles de hierro en los castros prerromanos, como los numerosos restos de escorias de hierro en las cercanías de los yacimientos auríferos explotados por los romanos, como ocurre en el castro de Orellán al lado de Las Médulas² y en yacimientos asturianos en los que además de escorias se han hallado vestigios de hornos 3 . Por la localización de estas escorias, deducimos que sus métodos siderúrgicos eran primitivos y elementales: pequeños hornos situados en las laderas de las montañas para aprovechar el tiro natural y lograr una mejor inyección de aire a los mismos.

Un paso adelante en el desarrollo de los procesos siderúrgicos se produce en la Edad Media, época en la que se documentan actividades metalúrgicas en diversas zonas del noroeste, con mención expresa de un temprano tipo de ferrería hidráulica, precedente directo de aquellas que alcanzarán su auge en los siglos de la etapa clásica. En el Bierzo leonés se pueden constatar diversos ámbitos mineros en Ancares, Valcarce, Ribas de Sil y Valdueza, con actividades siderúrgicas desde finales del siglo XII4. De Galicia conocemos varios ejemplos relacionados con monasterios: el de Sobrado (La Coruña) poseía en el siglo XII una mina de hierro en las cercanías de Piedrafita, en el actual municipio de Guitiriz, y un complejo sideromelalúrgico, una ferraria, en su granja de

\footnotetext{
1 J.COLLIS (1989): La Edad del Hierro en Europa. Barcelona, p. 36 y ss.

2 F. J. SÁNCHEZ PALENCIA (Ed.) (2000): Las Médulas (León). Un paisaje cultural en la Asturia Augustana. León, p. 264-265.

3 L. ADARO (1916): Criaderos de hierro de España, tomo II ${ }^{o}$. Criaderos de Asturias. Memorias del Instituto Geológico de España. Madird, p. 46-47; J. L. GUTIÉRREZ et alii (1993): "Minería y metalurgia en torno a la Cordillera Cantábrica. Primeras evidencias arqueológicas y propuesta de estudio". IV Came, tomo III, p. 907-908.

4 J. A. BALBOA DE PAZ (1990): Hierro y herrerías en el Bierzo preindustrial. León, p. 65-83.
} 
Constantín5; el de Lorenzana (Lugo) fue propietaria de las ferrerías medievales del Saltejo y Vilaseca ${ }^{6}$. En Asturias, por último, se citan minas de hierro, forjas y escoriales en varios lugares del concejo de Valdés: en Muñás y Carceu7.

Un dato precoz sobre la existencia de ferrerías hidráulicas en la Edad Media ${ }^{8}$, además de una toponimia de datación incierta pero relativamente temprana, como Molinaferrera o Ferramulín (que aluden probablemente a molinos de hierro o ferrerías), es el documento sobre el "ferri de Ysorga", en las cercanías de la Chana de Borrenes, en el Bierzo. En 1245 el monasterio cisterciense de Carracedo vende una heredad en Chana "in quo invenitur venam ad faciendum ferrum"9; pero de ella los monjes se reservan el derecho a extraer hierro, utilizar madera y carbón y elaborarlo en una ferrería -"molineras"- en el río Isurga ${ }^{10}$. En el contexto en el que aparece ese término no puede referirse sino a molinos de hierro, es decir ferrerías, aunque se nos escape el uso del agua: probablemente mover las ruedas de los mazos o de los barquines. Todos los elementos necesarios "ad faciendum ferrum" quedan claramente expresados en el documento: vena de hierro, madera, carbón y agua.

La vitalidad y el esplendor de los numerosos monasterios, la acción repobladora emprendida por monjes, señores y campesinos, y el desarrollo económico que alcanzan algunas villas que nacen a lo largo del Camino de Santiago fueron, sin duda, poderosos alicientes en el surgimiento y posterior desarrollo de este tipo de actividad siderúrgica, que probablemente llega del otro lado de los Pirineos; motor, a su vez, de la notable política roturadora y

\footnotetext{
5 E. PORTELA y $\mathrm{M}^{\mathrm{a}}$ C. PALLARÉS (2000): "El complejo siderometalúrgico de la granja cisterciense de Constantín. Bases para el desarrollo de una investigación en arqueología medieval”. Arqueología y territorio medieval, 7, p. 81-91.

${ }^{6}$ M. X. RODRÍGUEZ GALDO (1976): Señores y campesinos en Galicia. Siglos XIV-XVI. Santiago de Compostela, p. 82-83.

7 J. J. ARGUELLO (1996). “Minería y metalurgia en Muñás y Carcéu (Valdés-Asturies)”. Actas de las I jornadas sobre minería y tecnología en la Edad Media peninsular. León, p. 134 y ss.

${ }^{8}$ E. Portela y $\mathrm{M}^{\mathrm{a}}$ Pallares en la obra mencionada anteriormente creen que la ferrería de Constantín, que datan a finales del siglo XII, era probablemente hidráulica. No quedan restos arqueológicos pero algunos textos hacen pensar en ello, como el que habla de una presa.

9 M. MARTíNEZ (1997): Cartulario de Santa María de Carracedo (992-150o). Ponferrada, t. Io, p. $298, \mathrm{n}^{0} 428$.

${ }^{10}$ IBIDEM, $\mathrm{n}^{\circ}$ 428. El documento sigue diciendo: “quem terminus retenimus nobis liberum ad extraendam venam, et faciendum inde ferram, et omnia necesaria ad faciendum ferrum, videlicet ligna, et carbonem et molineras possimus facere in rivo Issorga".
} 
constructiva que se observa a lo largo de esos siglos ${ }^{11}$. Pero esta labor no se circunscribe al Camino de Santiago o a sus aledaños, sino que ya en la Edad Media comienzan a materializarse los ámbitos en los que se desarrollará la siderurgia en los siglos posteriores, lo que significa que desde muy pronto hay en ellos actividades de este tipo, probablemente por la existencia de pequeñas veneras de hierro, agua y carbón; también por un aumento en la demanda de hierro ${ }^{12}$ por causas diversas, entre ellas el crecimiento de la población.

Además de lo reseñado, desde el siglo XV podemos constatarlo en el entorno de la mina de Formigueiros y de la costa atlántica, ya por la utilización de venas locales o por un temprano comercio de mineral vizcaíno. La existencia de una actividad siderúrgica en el Bierzo, en el curso alto de los ríos Valcarce y Selmo, parece evidente en la Baja Edad Media; pues las primeras referencias a ferrerías datan, en el caso de la ferrería de Valcarce, a esos años, probablemente al siglo XIV13, y las de Arnado y Pontepetre son sin ninguna duda del siglo XV14. Lo mismo ocurre con la zona de Quiroga en la que conocemos por esa época una forja o ferrería denominada del Vieiro ${ }^{15}$, probablemente en los alrededores de La Seara, donde hay un topónimo con ese nombre y una cascada de agua o fervenza. Por último, en la zona más cercana a la costa, el monasterio de Villanueva de Lorenzana usaba vena local y vizcaína también desde ese siglo o

${ }^{11}$ E. PORTELA y Ma C. PALLARÉS (1979): "Os mosteiros, protagonistas da colonización e do proceso de señorialización na Galicia medieval: o exemplo do mosterio de Sobrado". Estudis d'historia agraria, 2, p. 63.

${ }^{12}$ Un indicio de ello son los numerosos topónimos medievales referidos a hierro: Venera, Veneira, Ferraria, Ferreira, Ferreiravella, que encontramos en Galicia y Asturias; y cuya localización coincide con zonas en las que en la Edad Moderna hay ferrerías.

${ }_{13}$ BALBOA DE PAZ, J.A. (1990): Hierro y herrerías en el Bierzo preindustrial. Diputación Provincial. León, p. 73

14 IBIDEM, p. 73-77 y 89

15 P. OTERO PIÑEYRO (2007): Colección documental del archivo de la casa de Otero de Quiroga (siglos XIII-XVIII). Lugo: Una sentencia de 1425 a favor de Diego García de Chan de Pena ante el juez de la tierra de Quiroga y el alcalde de la villa de Novais, sobre una fianza de once masas de hierro que deberá pagarle Lopo Gómez de Santalla, como fiador que fue de Alfonso Pérez de la Seara, habla "de un verbo e renda que lle el fecera da sua metade da forga de Vieyros, que el paratia (sic) -¿poseía?- con o dito Afonso Peres, o qual vervo fesera con o dicto Afonso Peres, en que lle avia de dar cad'anno onse masas de ferro e que lle dera por fiadores a o dito Lope Peres a a Afonso Martinez de Visuña" (doc. 24, p. 73). Otro documento de esos años ( $\mathrm{n}^{0}$ 51, p. 123), sin fecha pero posterior (quizá de 1432, pues habla de 77 masas que, a once cada año desde la sentencia de 1425, coinciden con ese año) en el que Diego García expresa sus últimas voluntades, menciona que Afonso Peres, "o charro" le debe "setenta y sete masas da mina forga que me avia de dar de sete annos que me non comprio, e mays ago a fargo (cargo?) en boo paramento da metade da ferramenta ben adereçada a vista dos fondedores", y antes ha dicho que le deben "Juan do Forno duas masas" y "Lope da Seara seys masas" de hierro. 
tal vez antes ${ }^{16}$, y probablemente varias ferrerías asturianas hacían lo mismo ya en el siglo $\mathrm{XV}^{17}$.

Respecto a la forja del Vieiro debo resaltar dos hechos que me parecen significativos respecto a la caracterización de esta siderurgia anterior al año 1500, fecha a partir de la cual se mencionan vascos como ferrones y arrendatarios de ferrerías del noroeste. El primero es que en esta, aunque ignoramos qué tipo de ferrería era, es revelador que el término que emplea para nombrar el hierro que sale del horno no sea el de ágoa o goa ${ }^{18}$, sino el de "masa de ferro", término que conocemos en otros casos de ferrerías medievales anteriores a la presencia de ferrones vascos, por ejemplo en Molinaseca (León), donde igualmente se menciona en 1210 una "massam de ferro"19. El segundo es que del estudio prosopográfico de varias relaciones de vecinos del siglo XV en pueblos de Quiroga no aparece ningún nombre vasco ${ }^{20}$, tan frecuentes a partir del siglo XVI en toda esta zona.

Los siglos XVI al XIX abarcan la etapa que denominamos tradicional, clásica o preindustrial, objeto de nuestro estudio. La historia de la siderurgia española desde 1500 hasta nuestros días, se suele dividir en dos épocas: la primera, a la que habría que llamar moderna, preindustrial, clásica o tradicional, llegaría hasta 1847 y lustros inmediatos, cuando comienza a generalizarse el coque en los hornos altos. La segunda, a partir de esa fecha, sería ya la plenamente industrial o contemporánea ${ }^{21}$. En nuestro caso, en el noroeste, lo que llamamos siderurgia tradicional se extiende hasta los años finales del siglo XIX, los ochenta aproximadamente; porque es entonces cuando desaparecen definitivamente las ferrerías, aunque ya desde los años cincuenta

\footnotetext{
16 P. SAAVEDRA (1985): Economía, política, y sociedad en Galicia: la provincia de Mondoñedo, 1480-183o. Xunta de Galicia. Santiago, p. 329.

${ }^{17}$ Por ejemplo las ferrerías de Peón, Dueñes, Penamellera, Raicedo, entre otras, se mencionan ya en el siglo XV.

${ }_{18}$ Término vasco que alude a la masa que sale del horno en cada hornada, y que luego se extenderá por toda la región con otros muchos: aroza, zamarra, etc.

${ }_{19}$ Escritura del monasterio de Sobrado del año 1210, en la que Miguel Peláez y su mujer han de dar al arcediano Gonzalo Fernández una "massam de ferro" por el hospital de Molinaseca. En P. LOSCERTALES, (1976): Tumbos del monasterio de Sobrado. Madrid, T. II, p, 220.

${ }^{20}$ P. OTERO PIÑEYRO (2007): Ob. cit.

${ }^{21}$ J. ALCALÁ-ZAMORA (1974): "Producción de hierro y altos hornos en la España anterior a 1850". Moneda y Crédito, 128, p. 118.
} 
encontremos hornos altos al coque en Sabero y Mieres ${ }^{22}$. Una etapa intermedia, a caballo entre lo preindustrial y lo industrial, la constituyen los hornos altos que consumen carbón vegetal como los de Sargadelos, Trubia, El Franco y Fornaza. A esta etapa quizá convenga el nombre de protoindustrial ${ }^{23}$, aunque no parece que exista una relación clara y directa con la industrialización posterior.

\section{CUADRO I.- FERRERÍAS CONSTRUIDAS POR SIGLOS Y PROVINCIAS}

\begin{tabular}{|l|c|c|c|l|c|c|c|l|c|}
\hline FERRERÍAS & XVI & $\%$ & XVII & $\%$ & XVIII & $\%$ & XIX & $\%$ & TOTAL \\
\hline ASTURIAS & 11 & 22,9 & 8 & 16,6 & 12 & 25 & 17 & 35,4 & 48 \\
\hline LEÓN & 6 & 24 & 0 & 0 & 5 & 20 & 14 & 56 & 25 \\
\hline LUGO & 23 & 50 & 4 & 8,6 & 11 & 23,9 & 8 & 17,3 & 46 \\
\hline ORENSE & 1 & 8,3 & 0 & 0 & 3 & 25 & 8 & 66,6 & 12 \\
\hline TOTAL & 41 & 31,2 & 12 & 9,1 & 31 & 23,6 & 47 & 35,8 & 131 \\
\hline
\end{tabular}

FUENTE: Elaboración propia a partir de los datos del Catálogo de ferrerías

A lo largo de esos siglos, el número de ferrerías que conocemos en el noroeste de España alcanza la cifra de 131, aunque nunca trabajando todas al mismo tiempo; pues mientras se construyen unas, otras se abandonan o cierran, a veces temporalmente. Pese al precedente medieval, cronológicamente las ferrerías, de acuerdo con el CUADRO I, fueron fundadas entre los siglos XV y XIX. Algunas, las menos, se remontaban a la Baja Edad Media; pero en general se erigieron unas en los siglos XV y XVI (31,2\%), en una época de crecimiento económico y demográfico en la Corona de Castilla perfectamente atestiguado; pocas en el siglo XVII (9,1\%), probablemente por la crisis; bastantes en el XVIII $(23,6 \%)$, en relación con el reformismo borbónico y algunas medidas legales que favorecieron esa industria; y por último, muchas en la primera mitad del siglo

\footnotetext{
${ }^{22}$ J. A. BALBOA (2001): "La ferrería de San Blas de Sabero". Rev. Bierzo (Ponferrada), p. 85-93. 23 Sobre protoindustrialización: R. ARACIL y M. GARCÍA BONAFÉ (1980): "La protoindustrialització: un nou concepte en la història econòmica". L'Avenç (Barcelona), $\mathrm{n}^{\circ} 32$; KRIEDTE, MEDICK Y SCHULUMBOHM (1986): Industrialización antes de la industrialización. Critica, Barcelona.
} 
XIX (35,8\%) debido al proceso desamortizador, el crecimiento demográfico, la roturación de tierras y el aislamiento de estas comarcas respecto a los nuevos centros siderúrgicos.

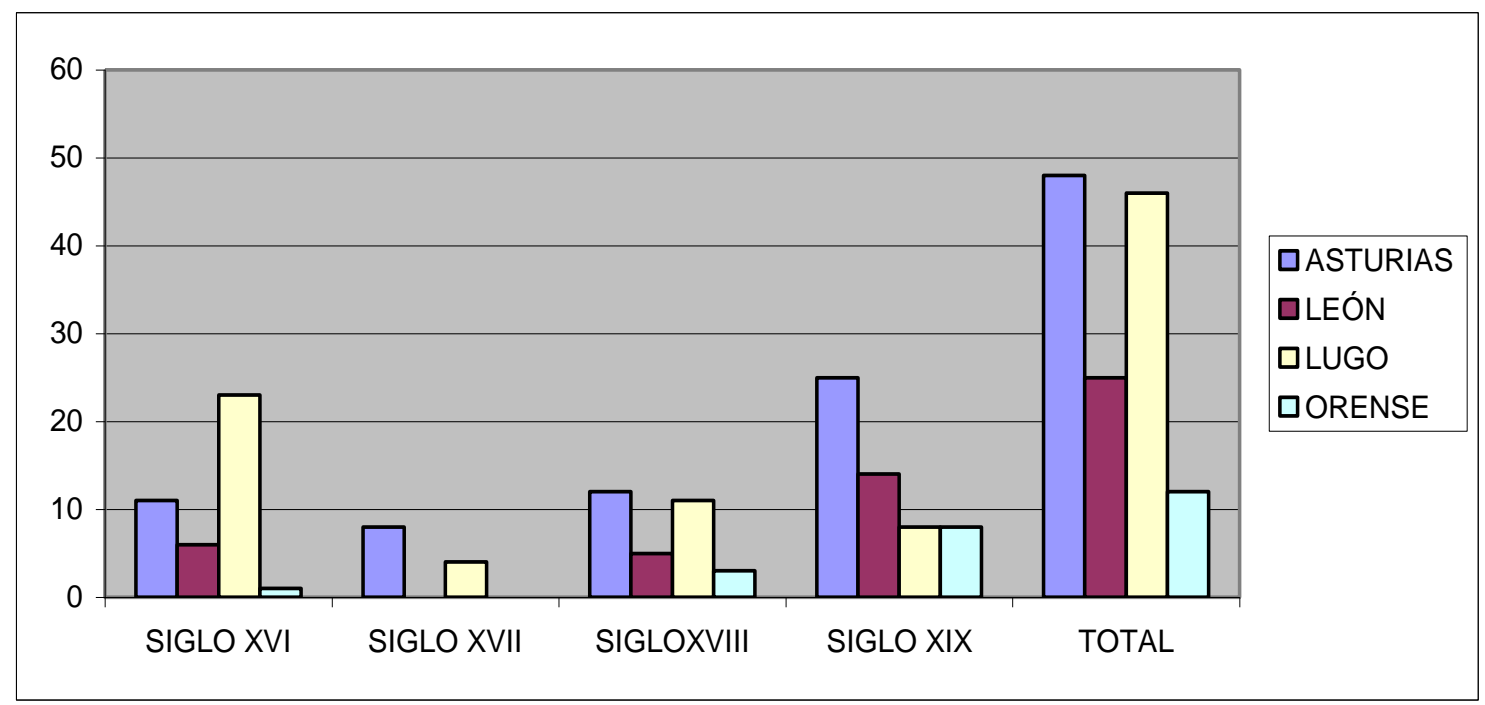

Gráfico 1. Ferrerías por siglos y provincias

También hubo algunos cierres entre los siglos XVI y XIX, un 10\% aproximadamente, sobre todo en la segunda mitad del siglo XVIII, especialmente en la zona oriental y central de Asturias (Penamellera, Dueñes, Peón, La Fanosa, Amandi, etc.) y en la costa gallega (Viloalle, Bravos, Silán, Villanueva de Lorenzana,), por problemas en el abastecimiento de carbón y por el precio excesivo de la vena vasca; incluso varias del interior, como las bercianas de San Fiz do Seo, Marciel o las que construyó Lemaur en el siglo XVIII en la zona de Torre del Bierzo. Pero una gran parte continuó hasta bien entrado el siglo XIX, dejando de funcionar la mayoría hacia la segunda mitad del mismo, años sesenta, y el resto en los años finales, hacia los ochenta. Por esa razón, el número de las que funcionaron por siglos fue elevado, pero especialmente significativo lo fue en los siglos XVIII y XIX: casi setenta a finales del siglo XVIII y aproximadamente unas noventa hacia la mitad del siglo XIX.

Una última observación respecto al cuadro $\mathrm{I}^{\mathrm{O}}$ se refiere el número de ferrerías por provincia y siglo. En la de Lugo se construyen en los siglos XV-XVI el $56 \%$ de todas las ferrerías del noroeste de esos dos siglos, probablemente por la cercanía de los yacimientos de Rocas y Formigueiros respecto de las del 
interior y por el uso de vena vasca en las de la costa; por otro lado, esas 23 ferrerías significan además el 50\% del total de esta provincia, que en el siglo XVIII construye otras 11, es decir, un 23,9\% más pero sólo el 17,3\% en el siguiente. Por el contrario, en el resto de las provincias la mayoría de sus ferrerías se construyen en el siglo XIX, especialmente en el Bierzo y Orense, con un 56\% y un 66\% respectivamente; en el Bierzo hay también un $24 \%$ de ferrerías de los siglos XV-XVI. En Oviedo el XIX es el siglo de mayor número, pero éste sólo representa el 35,4\%; pues igualmente se levantaron muchas en el siglo XVIII, un 24,48\%, y sobre todo en los siglos XV al XVII, que juntos representan el $38,77 \%$.

Si a estas ferrerías que, en le terminología vasca, podemos llamar mayores, porque su cometido era el de reducir el mineral para transformarlo en hierro forjado y acero, añadimos las ferrerías menores o ferrerías tiraderas, que en nuestra zona llamamos mazos, machucos o martinetes; ferrerías que no fundían sino que estiraban el hierro y elaboraban utillaje doméstico o agrícola a partir de aquel, su número aumenta de forma considerable. Por ejemplo, en el siglo XVIII conocemos la existencia de setenta mazos, a los que habría que añadir otra docena aproximadamente en el siglo XIX. Algunos de estos mazos se remontaban a los siglos XVI y XVII, en que aparecen unas veces asociados a ferrerías y otras solos. Por tanto entre ferrerías mayores y menores, el total supera los doscientos artefactos siderúrgicos 24 . Esta cifra es aún menor que la del País Vasco aunque no muy lejana ${ }^{25}$, y es claramente superior a la de Cantabria $^{26}$ y Cataluña ${ }^{27}$. Esto demuestra la importancia de la siderurgia del noroeste.

\footnotetext{
24 Incluso algunas más si añadiéramos las de la provincia de La Coruña. Ver J. FERNÁNDEZ (1991): Forxas hidráulicas, mazos ou machucos no norte galego. Sada (A Coruña). ${ }^{25}$ Suele hablarse de 300 ferrerías en el siglo XVI en todo el País Vasco. Para Guipúzcoa, Carrión Arregui menciona, entre mayores y menores, 124 en 1625, 103 en 1773 y 94 en 1802 y 1826 ( I. CARRIÓN ARREGUI (1991). La siderurgia guipuzcoana en el siglo XVIII. Bilbao, p. 124). Para Vizcaya se citan 177 en 1658 y 146 en 1792 (V. VÁZQUEZ DE PRADA (1973): Las antiguas ferrerías de Vizcaya (1450-1800). Melanges en l'honeur de Fernand Braudel, v. I, p. 667 y 671). L. $\mathrm{M}^{\mathrm{a}}$ Bilbao y E. Fernández de Pinedo, por su parte, mencionan para todo el País Vasco 238 ferrerías en 1752 y 220 (140/150 en Vizcaya y 75 en Guipúzcoa) entre 1770 y 1790 (L. M ${ }^{\mathrm{a}}$ BILBAO y E. FERNÁNDEZ DE PINEDO (1982): "Auge y crisis de la siderometalurgia tradicional en el País Vasco (1700-1850)". En La Economía española al final del Antiguo Régimen, t. II, p, 163).

${ }^{26}$ C. CEBALLOS (2001): Arozas y ferrones. Las ferrerías de Cantabria en el Antiguo Régimen. Santander, p. 58. La autora enumera en cantabaria 95 ferrerías en los siglos XV al XIX.
} 
El último proceso en el trabajo del hierro se hacía en las fraguas. Las hubo por todas partes, en las ciudades y villas pero también en la mayoría de los pueblos. En unos casos estaban asociadas a los mazos, porque en torno a estos, utilizándolos por días, solían encontrarse siempre varias fraguas; en otros, se trataba exclusivamente de pequeñas oficinas, normalmente en las afueras de los pueblos, en las que trabajaba un maestro herrero ayudado a veces por un aprendiz y, en ocasiones, por algún oficial, dado que en este oficio sí existió una cierta organización gremial, como ya veremos. Según el Catastro de Ensenada, el número de herreros en el siglo XVIII fue de 5.901, como podemos comprobar en el cuadro II. Todo esto muestra la importancia del sector siderúrgico y el número de los que se dedicaban a este oficio de forma directa, además de los que trabajaban en las minas, el acarreto de la vena y la fabricación del carbón. La importancia de este sector, sobre todo en el siglo XVIII, en relación con la maestranza de las Coruña y los arsenales del Ferrol, fue extraordinaria ${ }^{28}$.

CUADRO II. HERREROS EN EL NOROESTE

A MEDIADOS DEL SIGLO XVIII

\begin{tabular}{|l|c|l|}
\hline & NÚMERO & $\%$ \\
\hline ASTURIAS & 1.557 & 26,3 \\
\hline GALICIA & 2.238 & 37,9 \\
\hline LEÓN & 2.106 & 35,6 \\
\hline TOTAL & 5.901 & 100 \\
\hline
\end{tabular}

FUENTE: A.H.N.: Catastro de Ensenada. Mapas Generales, letra G

${ }^{27}$ C. MAS (2000): Historia de la farga catalana. Lérida, p. 60. El autor habla de 39 fargas en Cataluña, 48 contando con las de Andorra.

${ }^{28}$ J. CARMONA (1993): "Sargadelos en la historia de la siderurgia española". Revista de Historia Industrial, 3, p. 11. 


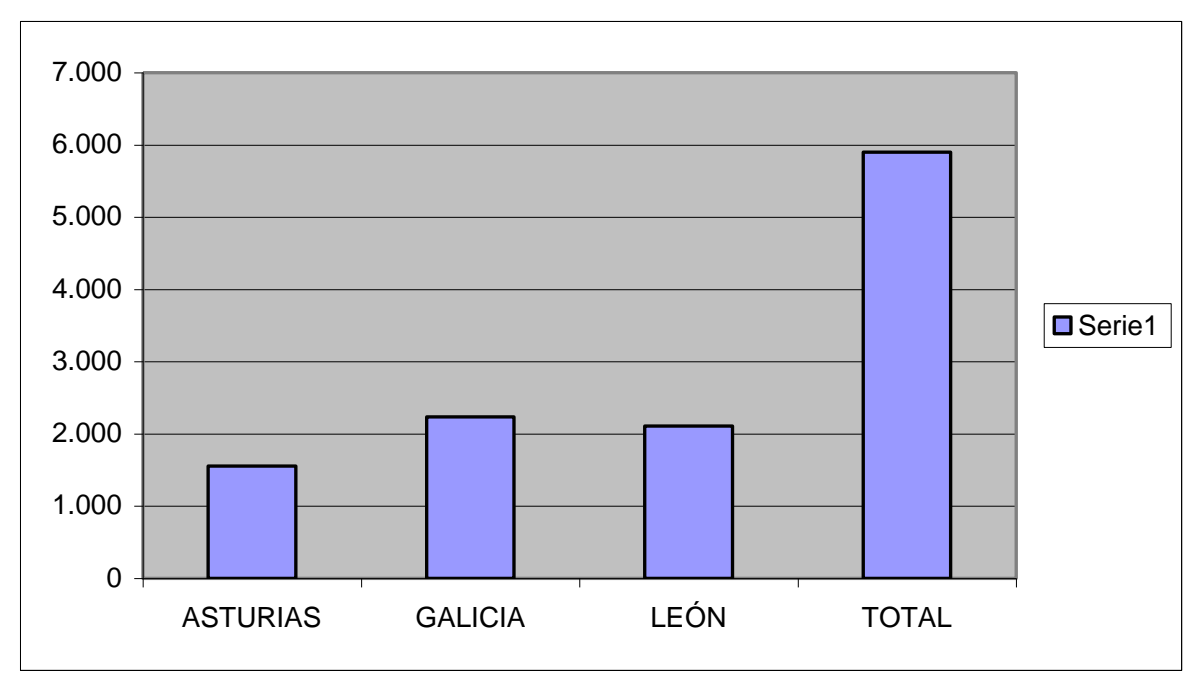

Gráfico 2. Número de herreros

\section{LA TÉCNICA SIDERÚRGICA}

Desde el Neolítico el hombre descubrió que ciertos materiales -los metales-, como el oro y el cobre, son maleables; es decir, que al golpearlos no se fracturan sino que se estiran y modifican su forma, permitiendo adoptar la que uno desee. Posteriormente averiguó que esa maleabilidad es mucho mayor cuando esos metales son sometidos al fuego, pues a determinada temperatura llegan a licuarse o fundirse y, en moldes, adoptan la forma necesaria para desempeñar una determinada función, siendo además más duros y resistentes que la piedra anteriormente utilizada para los mismos menesteres: armas, fíbulas, utensilios domésticos, herramientas. Nacía así, en la llamada Edad de los Metales -en el tercer milenio a C.-, la metalurgia.

La metalurgia es el conjunto de operaciones (físicas y químicas) a que es necesario someter un mineral para:

Separar la ganga de la mena: lo que se hace a través de operaciones de tipo físico: trituración del mineral, lavado, flotación.

Extraer el metal de la mena, proceso químico que varía con el tipo de mineral: calcinación o tostación, reducción, fusión. 
La siderurgia es el nombre que recibe la metalurgia del hierro (Fe). Por lo tanto, es el conjunto de operaciones (físicas y químicas) a que es necesario someter el mineral de hierro para separar la mena de la ganga y extraer el metal de la mena; porque el hierro no es un metal libre (como los cinco considerados nobles) sino combinado y mucho más difícil de reducir, pues requiere de grandes temperaturas. Los minerales de hierro son muy abundantes en la naturaleza y, en general, fácilmente asequibles; pero sólo algunos fueron explotados en la siderurgia primitiva y tradicional. Son estos:

- $\mathrm{Fe}_{2} \mathrm{O}_{3}+\mathrm{nH}_{2} \mathrm{O}$ : Hematites parda o Limonita: amarillento, ocre y blando; contiene un $60 \%$ de hierro y es fácil de reducir

- $\mathrm{Fe}_{2} \mathrm{O}_{3}$ : Hematites roja u Oligisto: rojo, gris, azul y negro; tiene un 69 '9\% de hierro y algo más difícil de reducir

- $\mathrm{Fe}_{3} \mathrm{O}_{4}$ : Magnetita: gris-negro, magnético; 72 '4\% de hierro y difícil de reducir

Estos minerales de hierro, en estado natural, apenas tienen aplicación útil. Hay que eliminar el oxígeno y dejar el hierro (Fe) libre, lo que sólo se consigue por medio de un proceso químico, llamado "reducción". Se logra rompiendo la unión del hierro ( $\mathrm{Fe}$ ) y el oxígeno $(\mathrm{O})$ por medio de temperaturas superiores a los 400-500 grados. Al tiempo hay que conseguir que el $\mathrm{O}$ reaccione con otro elemento y se una a él. Dicho elemento es el carbono (C) con el que forma $\mathrm{CO}_{2}$. La combustión del carbón vegetal o el coque con el hierro logra unir ambos procesos. Esto es la siderurgia.

El hierro es relativamente abundante en la naturaleza, lo que significa que se pueden beneficiar muchas venas locales. Sin embargo, el problema del hierro está en su tecnología, muy diferente a la de los metales primeramente conocidos (oro, plata, cobre), cuya temperatura de fusión es baja. El mineral de hierro no es tan fácil de fundir. Hay que molerlo, mezclarlo con el combustible y someterlo a elevadas temperaturas (entre $750^{\circ}$ y $1.530^{\circ}$ ). En las ferrerías la masa de hierro que queda en el fondo del horno es esponjosa -no es hierro fundido, como en el horno alto, y no se puede verter en un molde- y con muchas impurezas, pues la temperatura máxima alcanzada no supera los $1350^{\circ}$. Se 
precisa la forja para eliminar aquellas impurezas, compactar las fibras y darle forma. La siderurgia, por tanto, supone dos procesos diferentes: la fundición y la forja. En un principio ambos fueron realizados por el mismo operario -el ferrarius-, pero posteriormente la fundición la llevaron a cabo los ferrones, en las ferrerías y fargas, y la forja los herreros en los machucos o mazos y en las fraguas.

\section{LA FUNDICIÓN}

Consiste en la reducción del mineral por medio del calor proporcionado por la combustión -en contacto con el mineral de hierro- de leña, carbón vegetal o carbón mineral. Esta reducción se logra mediante dos procedimientos diferentes: directo o indirecto. El procedimiento indirecto, que no es objeto de este estudio, es el característico de la moderna siderurgia, la del horno alto. Se denomina indirecto porque la obtención del hierro (dulce, acero) se logra en dos fases: primero el arrabio o hierro colado en el horno alto, luego el hierro dulce o el acero pudelándolo, es decir eliminando una parte del carbono en un horno de pudelado. El procedimiento directo realiza ambas fases en un mismo proceso en el horno bajo, aunque la zamarra que sale del horno hay que forjarla posteriormente en el mazo. Es el propio de la siderurgia primitiva y tradicional. Este procedimiento directo se logra en hornos bajos, que históricamente han sido de varios tipos:

\subsection{Los hornos primitivos}

Desde la Antigüedad hasta los primeros siglos de la Edad Media, el hierro se obtuvo mediante un proceso de reducción a baja temperatura, del orden de $\operatorname{los} 750^{\circ}$ a $900^{\circ}$, en un pequeño horno cargado con capas alternativas de carbón vegetal y mineral de hierro ${ }^{29}$. La forma y tamaño de estos hornos fue cambiando a lo largo del tiempo. En un primer momento, el horno consistía en un simple hoyo que se abría en el suelo en forma de un gran tazón, por lo que se le da el nombre de horno de tazón. El aire se inyectaba bien por tiro natural al colocar el

29 J. COLLIS (1989): La Edad del Hierro en Europa. Barcelona, p. 36-41. 
horno en la ladera de una montaña, bien por medio de un fuelle, hecho de piel y accionado con la mano o con el pie.

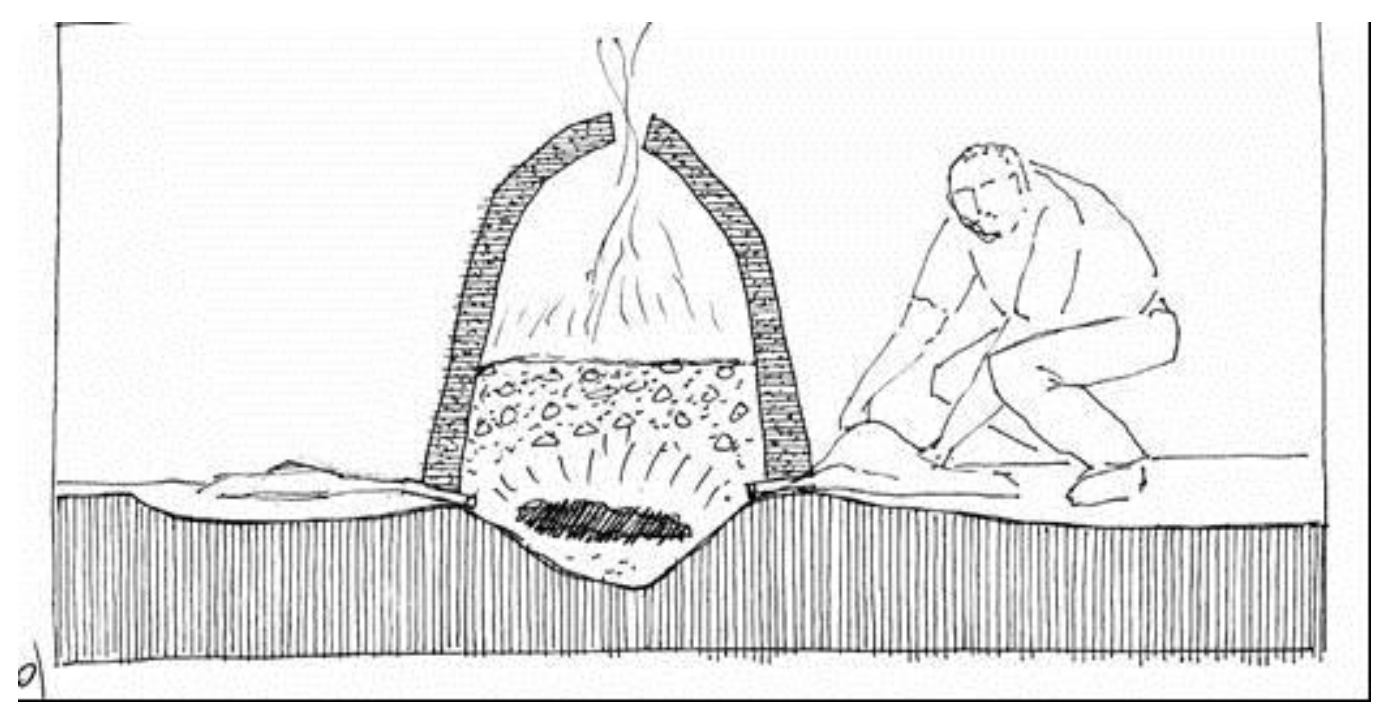

Horno de cuba baja (dib. Eloy Algorri)

Una evolución de este horno es el llamado de cuba baja al rodear con un muro el horno de tazón, lo que permite hacer hornadas mayores. De este tipo es el bowl-furnace de la tipología de H. F. Cleere, el horno de lobo alemán y la haizeola (ferrería de aire o de monte), agarrola (ferrería en seco) o gentilola (ferrería de gentiles) del País Vasco, que conocieron un gran florecimiento en los siglos XI al XIII. En este caso, el tazón se hundía en tierra entre 30 y 50 centímetros. El muro que lo rodea se elevaba del suelo entre 100 y 150 centímetros. El diámetro interior de la cuba podía ser de 50 a 70 centímetros. El mineral, la leña y el carbón se cargaban por la parte superior del horno30. Al final del proceso, el hierro quedaba en el fondo con aspecto de una pesada esponja, que luego se forjaba. La inyección del aire era semejante al anteriormente descrito ${ }^{31}$. En cada hornada, con una duración variable de ocho a doce horas, se obtenían de 80 a 120 kilogramos de hierro; pero el rendimiento era de apenas un $15 \%$ del hierro contenido en el mineral, de ahí que sus escorias

$3^{30}$ Según F. BAUDEL (1984): Civilización material, economía y capitalismo, siglos XV-XVIII. Las estructuras de lo cotidiano. Madrid, p. 263) hasta el siglo XI-XII no se generalizó la sustitución de la leña por carbón vegetal.

${ }^{31}$ J. GORROCHATEGUI et alii (1993): "Paleometalurgia del hierro de Bizkaia. Las ferrerías de monte altomedievales". Io simposi internacional sobre la farga catalana. Ripoll, p. 229 y ss.; I. ARBIDE ELORZA (1993): "Instalaciones primitivas utilizadas para la obtención del hierro en Legazpi”. I ${ }^{o}$ simposi internacional sobre la farga catalana. Ripoll, p. 289 y ss. 
sean negras y pesadas ya que aún pueden contener entre el 49 y el $59 \%$ de hierro32.

\subsection{Las ferrerías}

Una variante de este horno de cuba baja son las ferrerías, en sus dos modalidades: la farga catalana y la zeharrola (ferrerías de agua) del País Vasco, y sus variantes regionales en otros lugares de España, como las ferrerías del noroeste. Ambas surgen a partir del siglo XII (algunos autores, como Manuel Riu y Marta Sancho hablan de fargas hidráulicas en el siglo XI e incluso en el IX33). Se trata de ferrerías hidráulicas, que utilizan el agua para mover los mazos, los barquines y posteriormente las trompas ${ }^{34}$, logrando temperaturas que pueden alcanzar $\operatorname{los} 1350^{\circ}$. Desde entonces estarán en funcionamiento hasta finales del siglo XIX, aunque con importantes mejoras en el sistema hidráulico desde el siglo XVI.

Marta Sancho resume así la evolución de la industria siderúrgica en Cataluña que, con algunas matizaciones, especialmente en lo que se refiere a la utilización de la trompa de agua, también se puede extender al norte y noroeste de España. Habla de cuatro fases:

$1^{\text {a }}$ Hasta el siglo IX: hornos de reducción itinerantes, situados a pie de mina. Hornos bajos con tiro forzado manual y primera forja a fuerza de brazos.

\footnotetext{
${ }^{2}$ I. ARBIDE ELORZA (1993): Ob. cit., p. 289-303.

33 RIU RIU, M. (1996): "La metalurgia del hierro en la España cristiana medieval". Actas de las I jornadas sobre minería y tecnología en la Edad Media peninsular. León, p. 41-55: este autor señala que es difícil saber si en el País Vasco y Navarra hubo ferrerías de agua antes del siglo XIII, pero sí las hubo ya en este, por ejemplo la ferrería de Motrico en 1256 era hidráulica; SANCHO Y PLANAS, M. (1996): “Aportaciones de la arqueología para el estudio de la producción de hierro en la Cataluña medieval: Estado de la investigación y nuevas perspectivas". Actas de las I jornadas sobre minería y tecnología en la Edad Media peninsular. León, p. 436452.; SANCHO, M. (2000): "Minería y metalurgia en la Edad Media: relaciones socioeconómicas y evolución”. Primer simposio sobre la Minería y Metalurgia Antigua en el SW Europeo. Serós, p. 319-324.

34 En el País Vasco, de acuerdo con varios fueros de 1290 y 1335 a la villa de Legazpi, aparecen en el siglo XIII, aunque hay discrepancias sobre los términos que en ellos se mencionan: unos identifican ferrerías masuqueras con ferrerías de viento y las ferrerías de maço de agua con las hidráulicas (I. ARBIDE (1993): Ob. cit., p. 289 y ss.); otros, por el contrario, defienden que también las mazuqueras son, como las mazonas, hidráulicas, y se oponen a las llamadas de "omes", que serían las de monte (M. URTEAGA, M. (1996): "Siderurgia medieval en Gipuzkoa" $I^{a}$ Congreso de Mineria y metalurgia... León, p. 544.
} 
$2^{\text {a }}$ Siglos IX-XIII: Hornos de reducción estables situados al lado de cursos de agua y en cualquier zona donde exista un mínimo de yacimientos de óxidos de hierro y masa forestal susceptible de ser convertida en carbón. Hornos bajos con tiro forzado manual y primera forja con mazo hidráulico.

$3^{\text {a }}$ Siglos XIV-XV: Hornos de reducción estables, situados al lado de cursos de agua en zonas próximas a los grandes yacimientos de óxidos de hierro y a grandes masas forestales. Hornos bajos con tiro forzado mediante fuelles hidráulicos y primera forja con mazo hidráulico.

$4^{\text {a }}$ Siglos XVI-XIX: Hornos de reducción estables, situados al lado de cursos de agua en zonas próximas a grandes yacimientos de óxidos de hierro y a grandes masas forestales. Hornos bajos con tiro forzado mediante trompa de agua y primera forja con mazo hidráulico35.

En el siglo XVI, en el que aparecen las trompas, se habla de nuevas ferrerías a la "genovesa", término que algunos autores, como Caro Baroja, interpretaron como la utilización de energía hidráulica ${ }^{36}$; pero como ya sabemos esta tiene un origen anterior. Otros creyeron que debería tratarse de alguna mejora en el sistema hidráulico, pero sin concretar qué tipo, de la que habrían sido introductores en España el milanés Juan Tomás de Fabricario y el vasco Marcos de Zumalabe37. El término se aplicó igualmente a las forjas hidráulicas del país de Foix, en Ariége, donde en el siglo XVI se habla de "martinet à la génoise" o "moulines ferriéres à la genoise"; incluso Jean Cantelaube reseña que "il est intéressant de noter que, dans le pays catalan voisin, en Vallespir, deux génois exploitent, dans les premiéres annes du XVI ${ }^{\mathrm{e}}$ siecle, la forge du Tech et celle de Barrat d'amont" 38 .

\footnotetext{
35 M. SANCHO (s/f): “Tierra, aire, agua y fuego: Los cuatro elementos en la evolución técnica de la siderurgia medieval" en www.ub.edu/arqueologiamedieval/webmar2009/INASMET.pdf.

${ }^{36}$ Así lo afirma en trabajos antiguos, aunque en otros habla de ferrerías hidráulicas en el siglo XIII, pero es en el XVI cuando acaban difundiéndose por todo el País Vasco: J. CARO BAROJA (1986): Vasconiana. Estudios vascos, III, San Sebastián, p. 152-155.

${ }^{37}$ L. Ma BILBAO Ma (1987): "Introducción y aplicaciones de la energía hidráulica en la siderurgia vasca, siglos XIII-XVII”. Studia Histórica. Historia Moderna, vol. 5, p. 68 ${ }^{8}$ J. CANTALAUBE (1993): "Apparition et évololution de la forge à la catalane dans l'est des Pyrénées françaises”. I ${ }^{o}$ Simposi International sobre la farga catalana. Ripoll, p. 28
} 


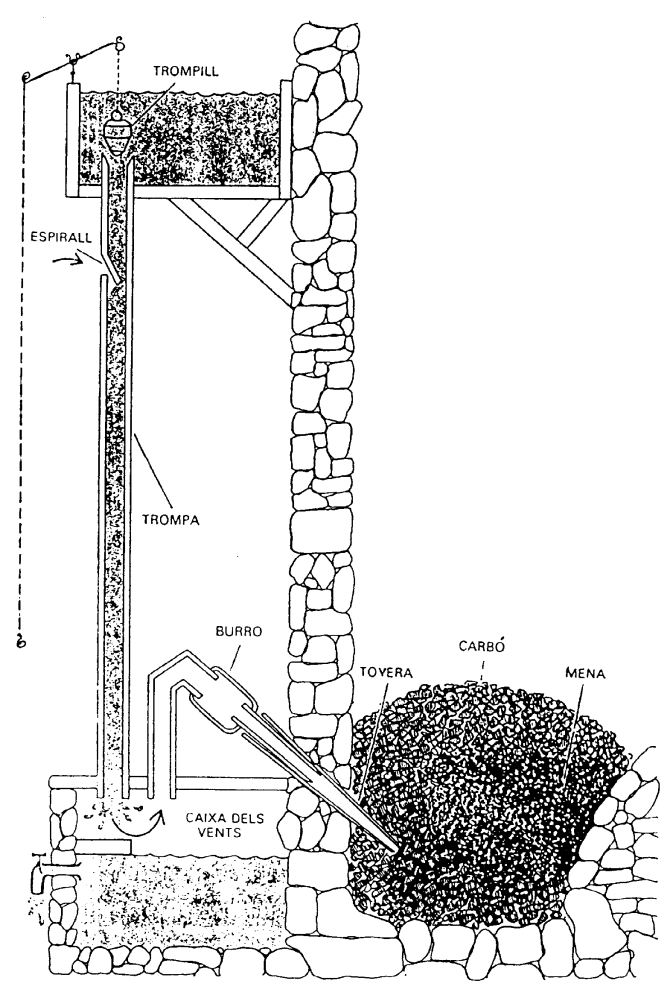

Farga con trompa (P. Molera, 1980)

Sin embargo, lo que se ha llamado "ferrería a la genovesa" en el siglo XVI no es una nueva ferrería hidráulica, sino los martinetes o ferrerías menores (también llamadas tiraderas), a veces al lado de las ferrerías mayores, a veces en lugares diferentes; su función no fue la de fundir hierro sino estirarlo, forjarlo o fabricar útiles domésticos 39 . Esta división del trabajo herrero tuvo una enorme importancia pues mejoró la productividad y racionalizó el trabajo al especializarlo. De la zama-

rra que se obtenía en la ferrería mayor salían cuatro tochos que después se adelgazaban en las ferrerías menores o martinetes. Algunos autores creen que en la segunda mitad del siglo XVII y principios del XVIII tuvo lugar en Vizcaya, como una adaptación a las nuevas necesidades, un cambio en esta doble tipología, con la aparición de las "cearrolas", unas ferrerías de menor tamaño que sin necesidad de recalentar el tocho producían barras de alta calidad, de menos peso y menor gasto de combustible, pero de gran rentabilidad. Esto no parece haberse propagado ni hacia Guipúzcoa ${ }^{\circ 0} \mathrm{ni}$, como ya veremos, en el noroeste, donde se mantuvo siempre la distinción entre ferrerías y mazos.

Las diferencias entre ambos tipos de ferrería (la farga y la ferrería vasca) eran muy pequeñas, pues ambas utilizaban el procedimiento directo para reducir el mineral, y en ese sentido, durante siglos, se pueden perfectamente confundir. Tales diferencias, sobre todo desde el siglo XVI, radican fundamentalmente en el sistema de inyección del aire al horno: la farga clásica 
utilizará el sistema de trompas, llamadas justamente "trompas catalanas"; la ferrería vasca moderna seguirá usando barquines o grandes fuelles, aunque hubo intentos por introducir el sistema catalán en el siglo XVII. También hay algunas diferencias respecto a los hornos, troncopiramidales en ambos casos, pero con esquinas redondeadas en el vasco, y más recto y sobre todo más grande en la farga catalana y, por ello, de una mayor producción en cada hornada ${ }^{41}$.

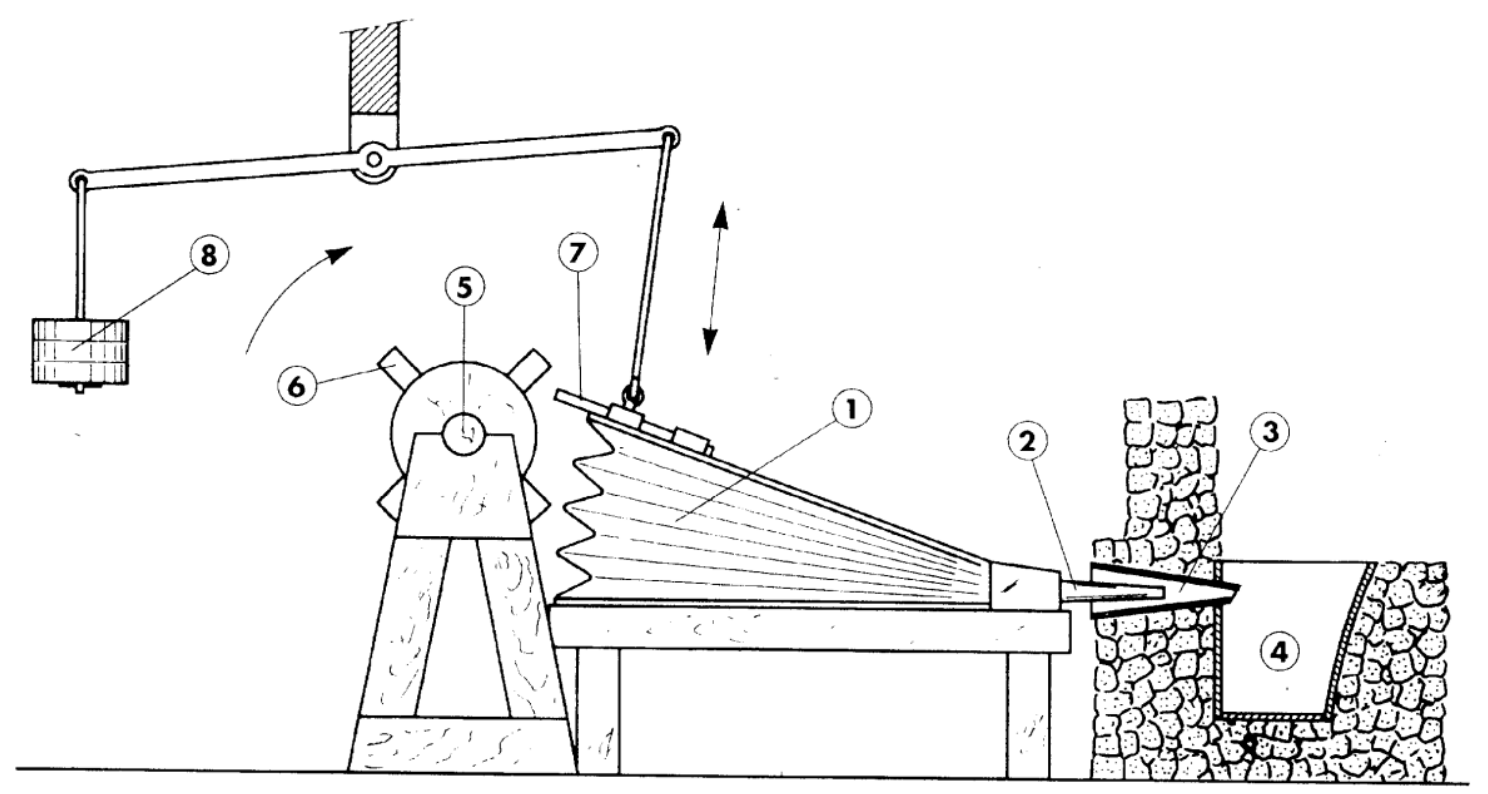

1) "Hauspon", barquín of fuelle. 2) Cañón. 3) Tobera. 4) "Sutegia" o fogal. 5) "Hatisponrdatza" o eje burquinero.

6) "Masukaria" o diente mazuquero. 7) Esgamel. 8) Contrapeso.

Ferrería vasca con barquines para inyectar aire al horno (P. Molera, 1980)

\section{LAS FERRERÍAS DEL NOROESTE}

Las ferrerías, ferrarias y en ocasiones castellanizado el nombre en herrerías ${ }^{42}$, fueron unas instalaciones, fábricas o artefactos destinados a la elaboración de hierro forjado que, más tarde, era transformado en clavazón, aperos de labranza o armas en mazos o martinetes y fraguas por artesanos herreros, armeros o cerrajeros. Localizadas en el ámbito rural, en zonas ricas en

${ }^{41}$ CANTALAUBE , J. (1993): Ob. cit., p. 27 y ss.

${ }^{4}$ En la documentación aparece indistintamente ferrerías y herrerías, pero este último término parece más una imposición de los escribanos; pues el vulgo las solía conocer con el nombre de ferrerías. Este es el término que vamos a utilizar en este estudio, dejando el de herrerías como sinónimo de fragua, en las que trabajan herreros que no elaboran hierro, sino útiles a partir de él. 
agua, madera y, en algunos casos, mineral de hierro, forman vastos conjuntos arquitectónicos en los que alrededor de la ferrería se arraciman la vivienda del propietario o arrendatario, la capilla, los inmuebles de los operarios, las caballerizas, el molino y los campos de cultivo.

La ferrería, en sentido estricto, constaba de dos partes: La primera el sistema hidráulico: la chapacuña, en donde se captaba el agua en el río, canal, banzado y banzadillo, donde estaban colocadas las ruedas que movían el mazo y los barquines, con la estolda y desagües nuevamente al río. La segunda la formaba el edificio adosado en paralelo al banzadillo, organizado en su interior normalmente por dos muros cruzados y cuatro estancias: las dos más cercanas a aquel, divididas por el muro llamado bergamazo, eran la sala de barquines y la sala del mazo, y a continuación las dos carboneras -a veces una sola-, comunicadas por un arco de medio punto con la sala del mazo.

Durante los siglos de la Edad Moderna hasta su desaparición en los años finales del siglo XIX, el sistema utilizado por las ferrerías del Noroeste de España sería el de las ferrerías vascas; es decir, la que utiliza barquines o fuelles movidos por ruedas hidráulicas para inyectar aire al horno en lugar de la "trompa" de agua, característica típica de la farga catalana, que sólo se introduciría en esta zona en el siglo XIX. Quizá por eso, los autores de informes en ese siglo, normalmente ingenieros de minas, utilizan el término de "forja a la catalana" cuando mencionan las ferrerías bercianas, gallegas y asturianas 43 . ¿Cuáles eran las diferencias entre una farga y una ferrería? Era común a ambos sistemas la reducción del óxido de hierro con carbón vegetal en una especie de horno de escasa altura en el que, a través de una tobera, se inyectaba aire. La diferencia principal se refería al sistema de producción de dicho aire44.

\footnotetext{
43 J.A. BALBOA (1992): El Bierzo en la obra de dos militares del siglo XVIII: Datoli y Munárriz. Ponferrada. Munárriz, en su informe, p. 129, al explicar el funcionamiento de las ferrerías bercianas, dice hacia 1805 que en éstas "se trabaja con el horno a la catalana". El BOPO, $1861, \mathrm{n}^{0} 11$ anuncia que se establecerán en el bosque de Muniellos "cuatro forjas catalanas"; la ESTADÍSTICA MINERA, 1864, p. 24, hablando de las ferrerías bercianas, dice que "cada día va siendo más difícil el beneficio de las menas en forjas catalanas"; respecto de las de Lugo, esta misma revista en 1879 , p. 52, señala que "la metalurgia de esta provincia está representada por las forjas a la catalana".

44 J. ALCALA-ZAMORA (1974): "Producción de hierro y altos hornos en la España anterior a 1850". Moneda y crédito, 128, p. 132.
} 


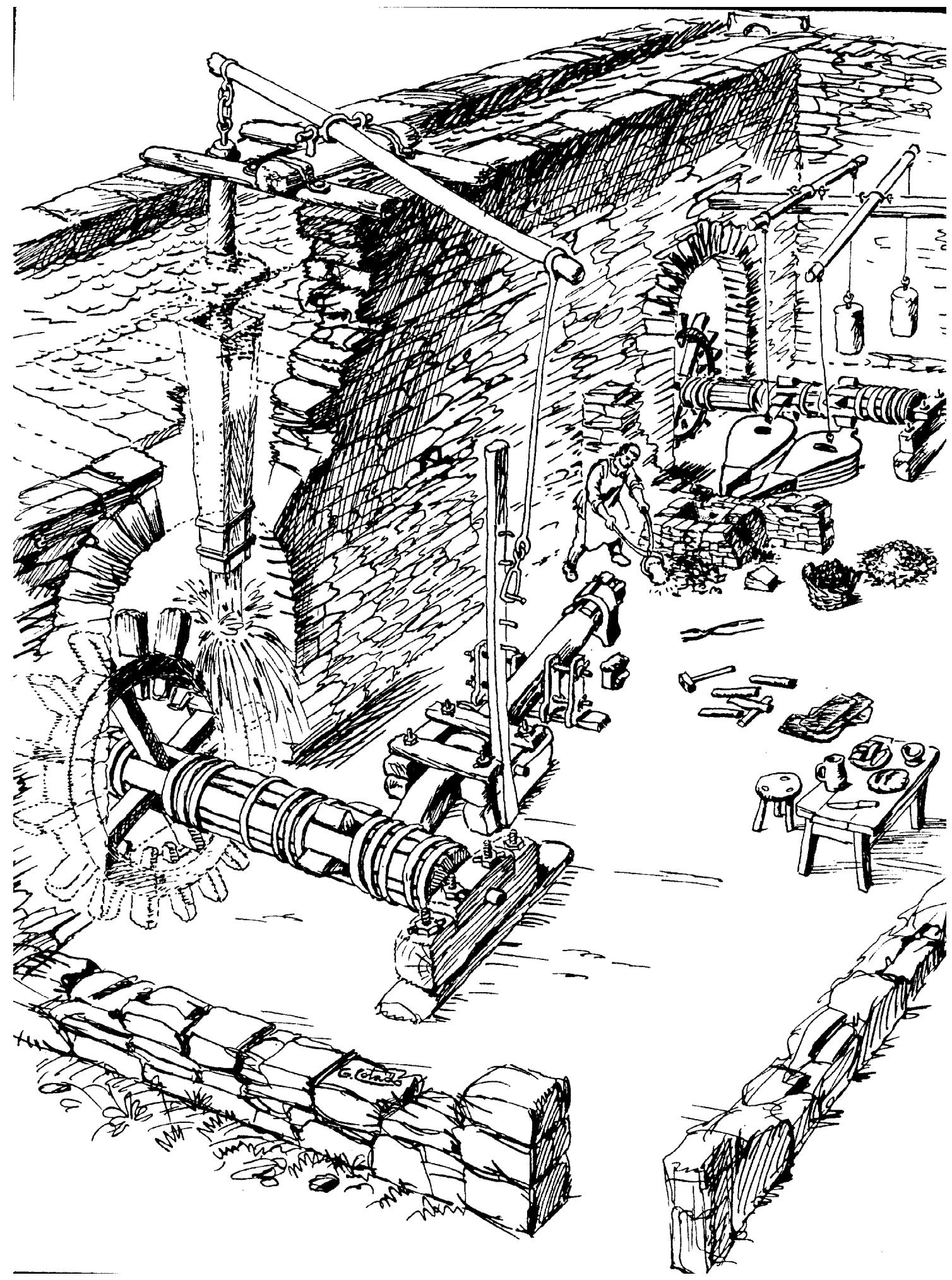

Recreación de una ferrería del noroeste de España (dib. P. G. Cotado) 
En la farga catalana el aire era generado por la caída del agua por una "trompa de agua"45. Con ella se conseguía una corriente de aire que aprovechaba el efecto Venturi, provocado por la caída brusca del agua desde un depósito, a través de un tubo estrangulado, a una caja de madera o arca de la que salía la tobera que inyectaba el aire al horno, mientras el agua desaguaba por la parte inferior hacia el rairo. El sistema requería un depósito de agua situado cuatro o cinco metros por encima del suelo de la ferrería, y un tubo, normalmente de madera, lo mismo que la caja de los vientos o arca, también de madera46.

Este procedimiento debió nacer en Cataluña en el siglo XVI y desde esa región se difundió hacia Francia y el norte de España en el siglo XVII, aunque aquí con poco éxito. Hubo algún intento para introducir el sistema de trompas en el País Vasco47, que no prosperó. Las ferrerías vascas utilizaron, para la inyección de aire a través de la tobera, unos "barquines” o enormes fuelles de madera, hierro y piel movidos por una rueda hidráulica. Unas veces, esta rueda movía exclusivamente los dos barquines, por lo que la ferrería necesitaba otra para el mazo; otras, una sola rueda -procedimiento "pujoi-makur"-servía para ambas finalidades ${ }^{48}$. Ambos sistemas producían una corriente continua de aire seco, pues disponían de dos fuelles; de manera que cuando uno soplaba, el otro aspiraba aire por una abertura o válvula.

Durante la Edad Moderna, el sistema vasco fue el utilizado por las ferrerías bercianas, según el informe del coronel Munárriz49, que las visitó y

45 P. MOLERA, LLibre de la farga, ob. cit. pág. 14. En opinión de este autor era "un enginyós sistema d'insuflar aire al forn" y que constituía "l'element més caracteristic del procedimet de la farga catalana".

${ }^{46}$ Una buena y actualizada descripción de la farga catalana puede verse en C. MAS (2000): Història de la farga catalana. Leida, p. 65 y ss.

47 J. ALMUNIA, "El ingenio de fundir sin fuelles de Pablo Antonio de Rivadeneira". Revista del Instituto del hierro y el acero, $\mathrm{n}^{0}$ 2. Madrid, 1957, pág. 153 y ss.

48 P. MOLERA, Ibidem, pág. 85.

49 El General Munárriz fue enviado al Bierzo, comisionado por el Gobierno, para emitir un informe sobre la posibilidad de instalar en él una fábrica de pólvora. Posteriormente dirigió las obras de la fábrica de hierro de la Somoza. Su informe, escrito hacia 1805, fue publicado, como ya hemos dicho, por el general Gómez Nuñez. En todas las ferrerías bercianas, dice Munárriz, "se trabaja con el horno a la catalana, esto es, en una fragua circular de 14 a 15 pulgadas de honda y otro tanto de ancha por arriba y algo menos en el fondo, forrada por todas partes con planchas de hierro. En un lado hay una canalita que se cubre por la parte de afuera con una pieza de quita y pón para sangrar la fragua cuando conviene; a su izquierda está la pared en que se apoya la fragua y se llama cadenarte, por la cual atraviesa la tobera, en cuya colocación consiste toda la ciencia de estos ferrones, sin que para ello usen de más observaciones ni instrumentos que un tanteo, y así suele suceder que a veces están seis u ocho 
estudió hacia los años 1804-1805; pero ese sistema era el mismo que se utilizaba en las ferrerías gallegas y asturianas, pues como en el Bierzo también en esas regiones fue introducido por ferrones vascos, como ponen de manifiesto los numerosos contratos de foro o arrendamiento de los siglos XVI y XVII, así como el vocabulario tan peculiar de estos ingenios: garandoa, agarrias, agoa o goa, zamarra, aldabarra, arragua o ragua, boga, chiflón, aroza, etc. ${ }^{\circ}$. Guillermo Schulz, en el primer tercio del siglo XIX, escribe que "todas las herrerías de Galicia son bastante uniformes entre si, parecidas á las de Asturias, y siguen un mismo método dirigiéndose las operaciones según la práctica antigua traída de Vizcaya, aunque en el día más ó menos esmerada"51.

En general, las ferrerías en sentido estricto (pues habría que añadir las casas -del dueño o arrendatario y de los trabajadores-, molino, capilla, plaza de la vena, etc. $5^{2}$ ) estaban formadas, como hemos indicado, por tres espacios unidos y dispuestos uno a continuación de otro o paralelamente: el banzado y banzadillo, en cuya parte interior se colocaban las ruedas verticales que mueven el mazo y los barquines; la zona de trabajo, con el horno y el mazo, frecuente-

días sin acertar en el punto crítico, poniéndolas unas veces inclinada hacia el fondo de la fragua y queman el hierro, $y$ otras con poca inclinación y no dan lugar a fundir el mineral, que se coloca en los bordes de ella y sobre el carbón. Hemos notado en todas las herrerías que la inclinación de la tobera era de 32 a 40 grados; dicha tobera es de cobre y en figura de un cono truncado, algo aplastado, de peso de 11 a 12 libras; la base menor, que es la que cae hacia la fragua, tiene un diámetro de pulgada y media, y la mayor 10; su eje o altura es de un pié, poco más o menos, y las hacen en los mazos de Soldón y Folgoso, en Galicia; pero son mejores las que traen de Asturias y Vizcaya. Por detrás del cadenarte entran en la tobera los cañones de los dos barquines, que los mueve una rueda hidráulica muy tosca, y al lado opuesto está el mazo en donde se adoba y estira la zamarra, o agoa, movido igualmente por otra rueda hidráulica de paletas, de tan mala construcción como la anterior. El mazo es de poco peso, y así las barras o bandas que salen de estas herrerías quedan mal adobadas y con una figura y grueso diferentes, por lo que es preciso llevarlas a estirar en algún mazo si se quieren hacer con ellas alguna obra algo delicada. De estos mazos hay dos en el Bierzo; pero bastante infelices, según nos han dicho" (MUNÁRRIZ, p. 129-130).

${ }^{\circ}$ E. ALARCOS (1980): "Elementos vascos en el léxico de las ferrerías asturianas", en Cajón de sastre asturiano, 2, p. 107-116.

${ }^{11}$ G. SCHULZ (1838): "Ojeada sobre el estado actual de la minería de Asturias y Galicia”. Anales de Minas. Madrid, t. I, p. 390

${ }^{52}$ La ferrería de Pallares, del monasterio de Samos, fue descrita así en 1821, con motivo de su tasación para desamortizarla: "La casa de la administración de la herrería que havita el $P$. Administrador compuesta de cocina...; la Capilla u Oratorio...; una sala al sur con puerta que baja a dicho oratorio; otra al lado del río...; otra emparejada al lado del naciente; y por debajo de la del naciente la panera y de la del poniente la bodega del fierro....; la bodega del vino y una caballeriza...; y la caseta que habitan los carboneros...; y el edificio destinado a caballerizas...”. En C. GONZÁLEZ (1994): A producción tradicional do ferro en Galicia: as grandes ferrerías da provincia de Lugo. Lugo., p. 238: AHPLugo: Desamortización, 1821, 5 (12). 

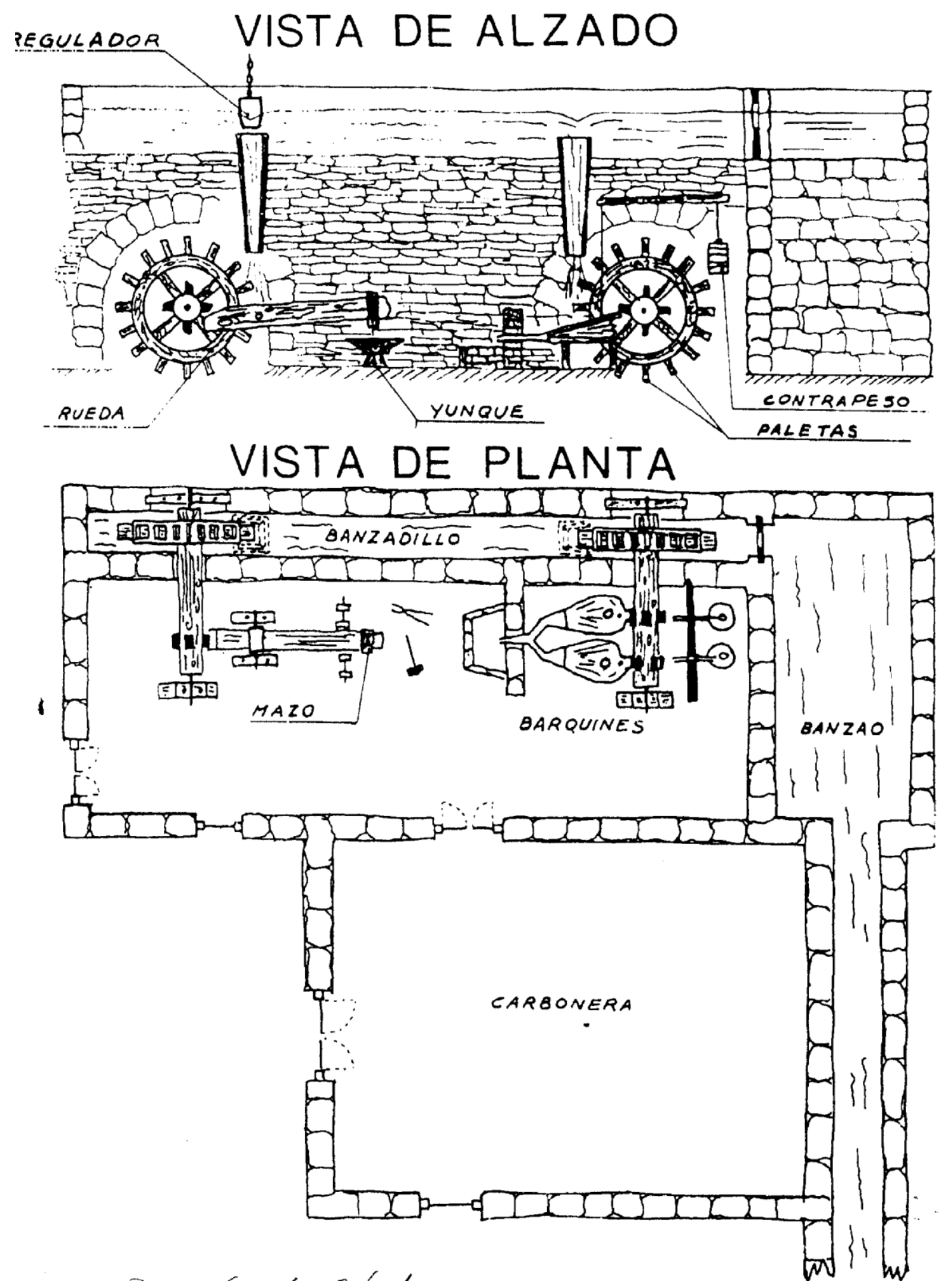

Planta y alzado de una ferrería del noroeste (dib. P. G. Cotado) 
mente separados por un muro (bergamazo) en dos salas diferente y por último las carboneras, bodega y cuarto de tazar la vena, que eran las de mayores dimensiones y aquellas cuyas paredes solían ser más elevadas tant para aumentar su capacidad como para prevenir los incendios53. Todas estas salas tenían dimensiones diferentes, tal como podemos ver en el cuadro III. La superficie media de estas edificaciones era aproximadamente de unos $350 \mathrm{~m}^{2}$, de los que las carboneras suponían casi el 60\%.

\section{CUADRO III.- DIMENSIONES DE LOS ESPACIOS DE FERRERÍAS}

$\left(\right.$ en $\left.\mathrm{m}^{2}\right)$

\begin{tabular}{|c|c|c|c|c|}
\hline FERRERÍA & MAZO & BARQUINES & CARBONERAS & TOTAL \\
\hline Froseira & 54,0 & 48,0 & 124,8 & 226,8 \\
\hline Lagar & 51,5 & 50,7 & 116,2 & 218,4 \\
\hline Cabanada & 47,5 & 45,0 & 167,5 & 260,0 \\
\hline Sotorrodrigo & 73,5 & 58,1 & 263,3 & 394,9 \\
\hline Vilar de Cuiña & \multicolumn{2}{|c|}{217} & 256,5 & 473,5 \\
\hline Bogo & 142,9 & 142,9 & 285,8 & 571,7 \\
\hline Bueyes & \multicolumn{2}{|c|}{118,6} & 202,8 & 321,4 \\
\hline Pombriego & 59,3 & 45,8 & 165,9 & 271 \\
\hline
\end{tabular}

FUENTE: A. Mato (2010): La sociedad rural en el concejo de Ponga (1750-1930). Oviedo, p. 115 (Froseira, Lagar, Cabanada y Sotorrodrigo);

http://www. guillenderohan.com/EXPOGRI/memoriamazos/: (Vilar de Cuiña, Bogo y Bueyes); Estadística Minera, año 1891, p. 190.195 (Pombriego).

\subsection{Chapacuñas y banzados}

\footnotetext{
53 Continúa la descripción de la ferrería de Pallares: "la fábrica del fierro con puerta al naciente, la fragua de lado del poniente provista de barquines y rueda con el buelo y cruces rompidos; más adelante la rueda del mazo y el banzado bastante deteriorado; la carbonera al lado del Norte con el techo muy desmejorado; la tazadera al sur con la puerta para entrar la vena junto a la de la fragua; pegada a ésta otra de manos con la puerta para la tazadera: un pajar a la esquina de la carbonera con puerta al sur, y pegada una cavalleriza para marranos". En C. GONZÁLEZ (1994): Ob. cit., p. 238.
} 
Las ferrerías que estamos estudiando son hidráulicas, necesitan el agua de un río, normalmente de pendiente acusada y caudal regular, o de un arroyo. A las situadas en estos, que no pueden trabajar más de dos o tres meses al año por falta de agua, se las denominaba "regateras" 54 o "aguacheras" 55 . Es frecuente el escalonamiento de las ferrerías a lo largo del curso del río o de sus afluentes. Así en el Bierzo, sobre el Selmo y sus afluentes se construyeron a lo largo de los siglos hasta diez ferrerías; el Lor lucense contó con cinco y en Asturias, en el Porcia -conocido como "río de las ferrerías"- se erigieron cinco, y en el Suarón tres.

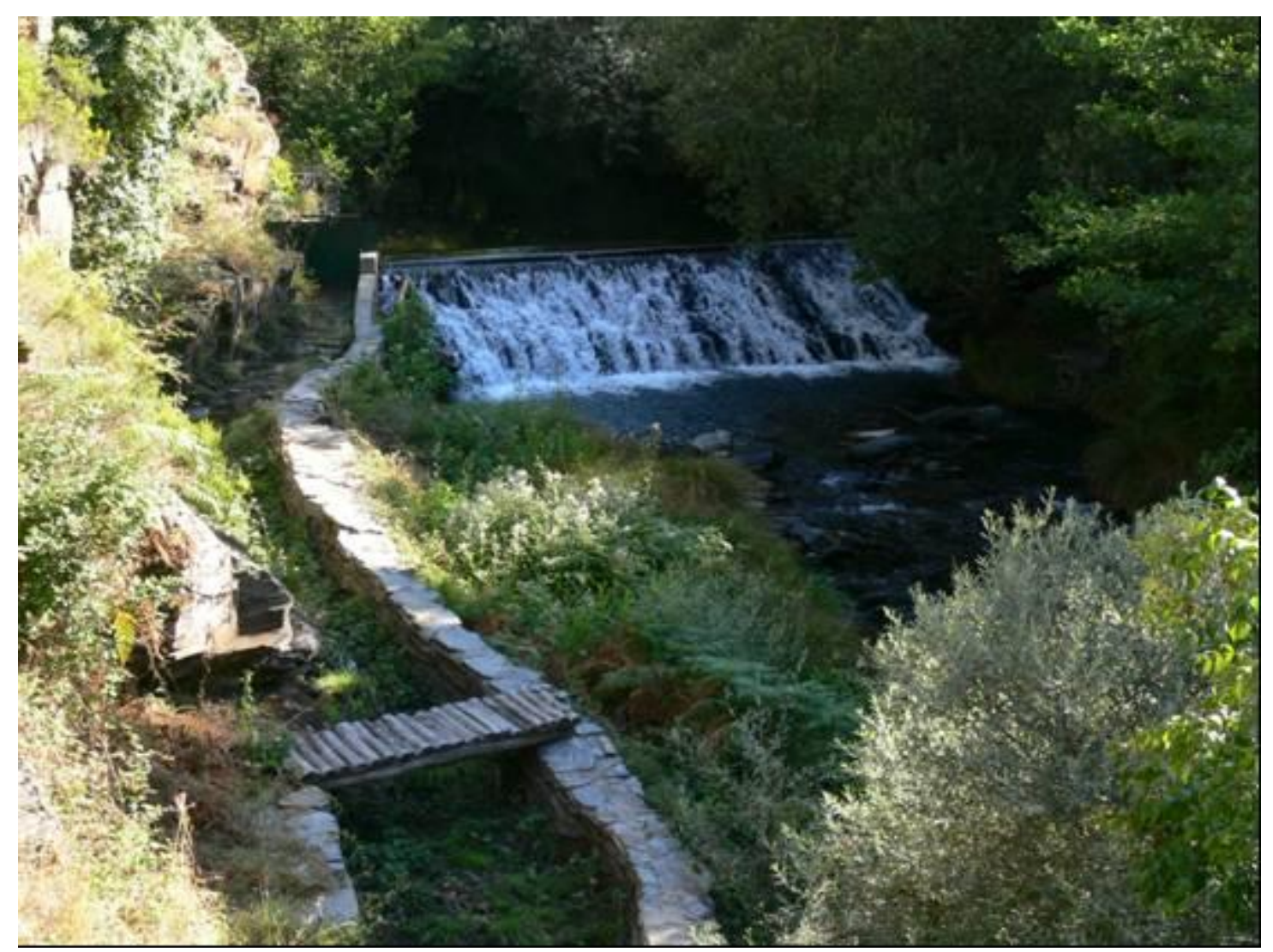

Chapacuña y presa de la ferrería de Rugando (Lugo)

54 MUNÁRRIZ, p. 132. Respecto de las ferrerías de Río Cabo, en el Bierzo, se habla de "fábrica regatera o que funciona la tercera parte del año por faltarle agua ocho meses". En I. GARCíA TATO (2000): "Las ferrerías de Río Cabo y Pombriego en el siglo XIX”. Revista Bierzo, p. 163. 55 I. GONZÁLEZ TASCÓN (1987): Fábricas hidráulicas españolas. Madrid, p. 82: dice que las que funcionan solo en época de lluvias se les llama aguacheras. 
El agua se toma del río en el que se ha practicado una presa, “chapacuña" o "torula" 56 , para elevar el nivel de la misma y aprovechar mejor su energía al crear un salto artificial, que hará caer el agua desde cuatro o cinco metros sobre las ruedas de la ferrería. La mayoría de estas presas están hechas de madera y piedra, aunque hay algunas, especialmente desde el siglo XVIII, verdaderas obras de cantería, como las de las ferrerías de San Vicente de Leira y Bogo57. Probablemente, por ser abundante y más barata, al principio las presas debieron de ser de madera, una simple empalizada de troncos, piedra y barro, cuyo objetivo era simplemente desviar el agua; posteriormente, en el siglo XVIII encontramos presas de piedra bien construidas, probablemente para evitar su destrucción por la avenida de las aguas y también porque la coyuntura permitió inversiones más cuantiosas.

El agua desviada corre luego por un cauce, canle o rairo (de unos 2x2 metros de sección aproximadamente) ${ }^{8}$, más o menos paralelo al río y longitud variable pero que supera frecuentemente los 300 y hasta los 700 y 1.000 metros 59 -con una pendiente en torno al 10\%-, embalsándose en un estanque, banzado, banzao o camarao $^{60}$ (antepara en el País Vasco) situado varios

\footnotetext{
${ }^{6}$ P. MADOZ: ob. cit. dice al hablar de Alguerdo (ayt. de Ibias): "las aguas del Ibias, por cauces que denominan torulas o chapacuñas, riegan algunos prados", p. 30; y en Armenade (ayt. de Allande): "por medio de cauces formados por empalizadas que llaman torulas o chapacuñas", p. 49 .

57 P. B. VILLARREAL DE BERRIZ (1736): Máquinas hidráulicas de molinos y herrerías y govierno de los árboles y montes de Vizcaya. Facsimil de la Sociedad Guipuzcoana de Publicaciones, 1973, cap. 1, p. 4 y ss. Escribe que en el País Vasco hay varios tipos de presas: las de gravedad y las de arco. Todas las que conocemos en el noroeste son de gravedad, algunas realizadas con empalizadas de troncos, ramas y piedras, aunque generalmente de piedra sillar o de mampostería.

${ }^{8}$ De la ferrería de San Miguel de Ribera se dice que la zanja tenía tres o cuatro varas de ancho y de dos a tres de profundidad, parte de la cual, unas 474 varas, estaba construida en terreno tan "escabroso, pendiente y peñascoso ... que parecía poco menos que imposible su consecución”(AHRG. R. A.: 11.837/11). La de Pombriego era de 1,85x2,20 m. (Estadística Minera, año 1891, p. 191).

59 El cauce de la ferrería de San Vicente de Leira, por ejemplo, tiene 300 metros, el de Froseira 600 , el de Armenande 700 metros, el de Soto Rodrigo unos 890 metros y el de la de Cuiña (Buen Retiro) tiene un kilómetro. En unos casos es de tierra pero también los hay de piedra labrada e incluso algunos fueron excavados en la propia roca, como los de Pombriego y Montealegre. En el juicio por la ferrería de Quintá, en 1692, un testigo dice que "desde el sitio donde a de empezar el banzado tiene el rayro o presa por donde se a de conduzir el agua asta llegar a la entrada del rio por donde a de subir a ella dicha agua quinientas y sesenta baras", es decir más de 460 metros (AHRG. R.A.: 16662/4)..

6o En el Bierzo y Galicia se denominan banzados y banzaos; en Asturias también banzau, camarón y camarado o camarao. En L. R. Castellanos (1954): "La industria popular del hierro: el mazo". BIDEA, XXII, p. 295. Jovellanos, hablando de la ferrería de Belmonte menciona que tenía "camarado de madera y barquines".
} 
metros por encima del nivel del suelo de la ferrería. Tanto a la entrada como en su recorrido y final solía contar con compuertas y aliviaderos ${ }^{61}$. El banzado, construido en piedra, mampostería o madera (esto es más corriente en los mazos que en las ferrerías), suele tener una capacidad entre 150 y 300 metros cúbicos $^{62}$. Su forma es muchas veces irregular, adaptándose al terreno, aunque también los hay regulares, normalmente rectangulares, y de dimensiones muy variables. El de Seoane del Caurel, en piedra, tiene 26 metros de largo por 6 de ancho, y el de Cuiña 32 metros de longitud.

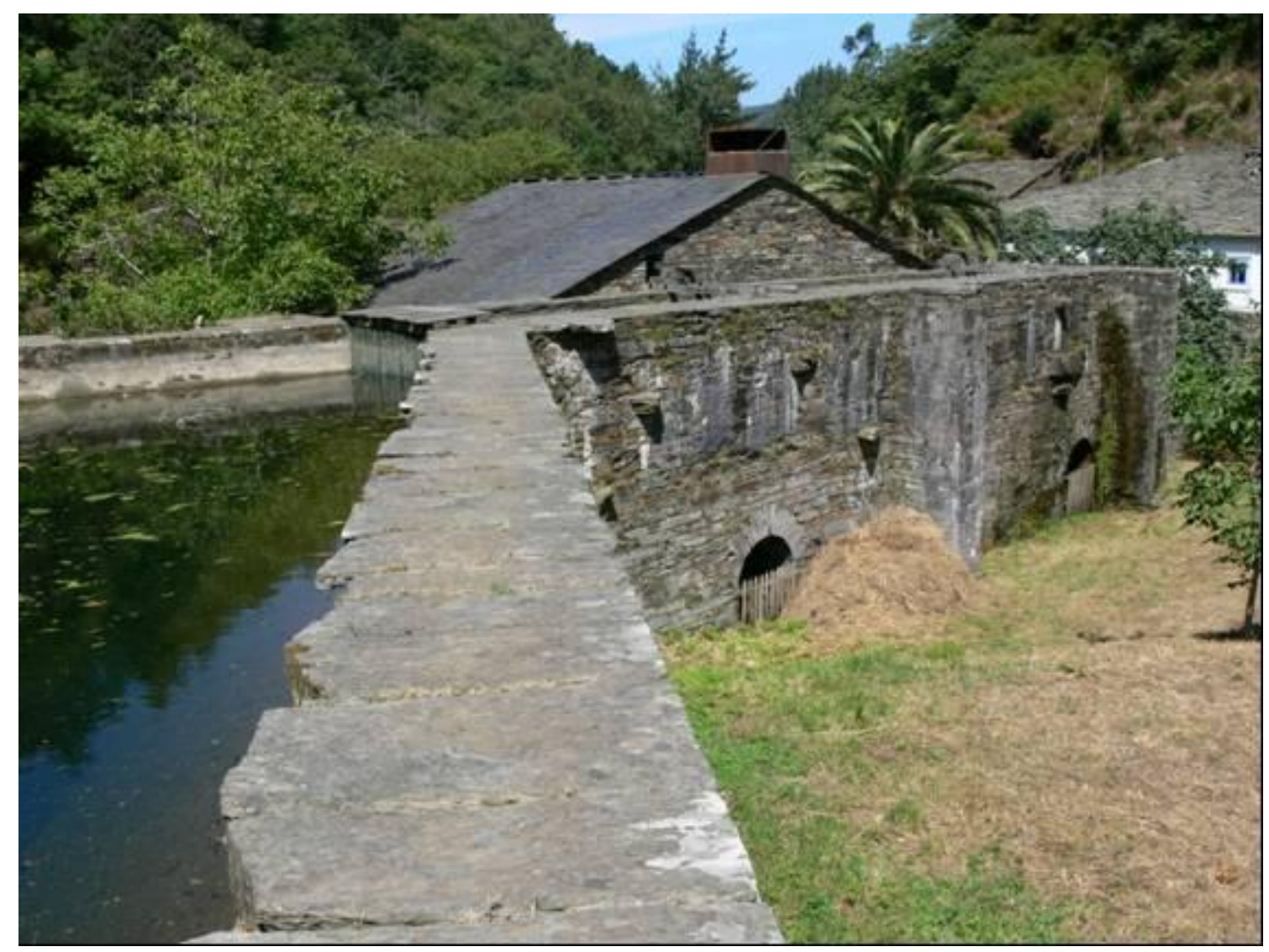

Banzado y banzadillo de la ferrería de Bogo (Lugo)

\footnotetext{
${ }^{61}$ Ferrería de Río Cabo (inventario de 1838): "Esta herrería se halla con una presa o cauce por donde se le echa el agua para hacerla trabajar, que su principio en el río tiene una chapacuña de piedra corriente y poco coste. Enseguida dos compuertas, la una para contener y templar el agua del río y la otra, a la parte de habajo con su cadena de fierro para subirla y bajarla y acabar de represar o cortar el agua que no jire para el banzado cuando hay algún descalabro que componer en él". I. GARCÍA TATO (2000): Ob. cit., p. 124.

62 B.O.P.L., 1868, 13 de enero, publica un informe sobre las características que han de tener las forjas a la catalana; en él dice: "el embalse debe tener 24,244 metros de longitud, contando en ellos el vanzadillo, para los ventiladores o trompas; tres metros de altura y 2,o9 de extensión. $\mathrm{Su}$ capacidad es de 152'9 metros cúbicos”. El banzado de la ferrería asturiana de Lagar embalsaba unos 300.000 litros de agua.
} 
El banzado se prolonga paralelo a la pared de la ferrería, en la que se encuentran el mazo y los barquines. A esta parte se la denomina también "banzadillo"63 y lo forman dos gruesas paredes de piedra (también los hubo de madera) paralelas, separadas una de otra entre 1 y 1'5 metros; y su altura sobrepasa frecuentemente los 6 metros. A los 4 ó 4'5 metros del suelo, depende de la altura de las ruedas, entre las dos paredes hay una solera o piso de madera o lajas de pizarra que sirve para retener y estancar el agua 64 . Este es el banzadillo en sentido estricto, que suele tener de 7 a 15 metros de longitud por 1 ó 1'5 de ancho y otros 2 de profundidad. En el piso de madera o pizarra hay practicadas dos pequeñas aberturas por las que el agua, a través de un tubo de madera denominado "chiflón" o "chifrón", se precipita sobre las palas o aspas de las ruedas 65 . Una trampilla o tapón, que se regula desde el interior de la ferrería, permite aumentar o disminuir el caudal de agua, para de este modo acelerar o retardar el movimiento de las ruedas de mazos y barquines. Para eliminar el agua sobrante cuenta con una salida lateral o frontal denominada aliviadero, rebasadoiro o aliviadoiro, mientras que el agua que cae sobre las ruedas vuelve al río por la estolda ${ }^{\mathbf{6 6}}$. Este término de estolda también se aplica a las paredes del banzado o banzadillo67.

\footnotetext{
63 Ibidem y A.H.P.L. P. N.: 9113 (1868): Hablando de la ferrería de Valdomir, en el Caurel, dice: "una herrería con banzadillo y banzado, con mazo y martinete para deshacer el hierro". En el País Vasco se denomina anteparas. Aquí primero fueron de madera y luego de piedra. Las trazas de la ferrería de Arsulondo (Cizurquil) tenían $19 \mathrm{~m}$. de longitud por 2,2 de ancho y una altura desde los cimientos de 8,2 m. La altura del depósito era de algo menos de 2,7 m, con una superficie de $40 \mathrm{~m}^{2} \mathrm{y}$ un volumen de $100 \mathrm{~m}^{3}$. Cit. en i. CARRIÓN ARREGUI (1986): "Aspectos técnicos de las ferrerías guipuzcoanas en el siglo XVIII". Actas del III congreso de la Sociedad Española de Historia de las Ciencias. San Sebastián, t. I, p. 153,

${ }^{64}$ La ferrería de Folgoso del Caurel tenía el banzadillo de madera, pues en la relación de bienes de su propietario, Rafael Armesto, de 1868 se dice: "como tambiém el banzado del cual solo ecsisten las vigas del piso". AHPL. P. N.: 9113. De la ferrería de La Rodela dice un testigo en un juicio de 1692: "tiene el vanzado de largo ocho baras (6,68 metros) y de alto asta llegar al fondo de la estolda donde están las ruedas seis baras (5 metros)” (AHRG. R.A.: 1662/4).

65 Normalmente era de sección prismática, hecho de cuatro tablones, más ancho por donde entra el agua que por donde sale. En el interrogatorio del juicio por la construcción de la ferrería de Quintá, en 1692, un testigo señala: "que la cayda del agua del alto de dicho bançado no es como canal de molino, sino que se descuelga por un chifrón o agujero que está en el suelo del bançado y baja con fuerça para açer andar las ruedas las quales no echan el agua con fuerza açia delante, sino açia atrás, dejandola descolgar los basos como los de una noria con que no le dan más fuerça por dicha raçon en la corriente" (AHRG. R.A.: 1662/4). En otro pleito de la ferrería de la Rodela, de 1759, otro testigo añade: "El agua que hace andar a las ruedas hes la que cae del banzado en los basos de ellas" (AHRG. R.A.: 6800/4).

${ }^{66}$ Cuando en 1664 se hace la ferrería asturiana de La Fanosa, su dueño ha de dar al carpintero todos los materiales a pie de obra: " $y$ açer la presa y las calçes, reples y estoldas y paredones $y$ cassa de la ferrería y el traer el agua a la boca del camarado asta dar en el yugo. En J. LÓPEZ y A. GRAÑA (1998): Ferrerías, mazos y fraguas en Asturias. Oviedo, p. 127-128.

${ }_{67}$ Ferrería de Río Cabo (inventario de 1838): El banzado "se halla sostenido de dos paredes maestras que llaman de la estolda, con sus pontones de madera para sostener igualmente
} 


\subsection{La rueda hidráulica}

El agua, como hemos dicho, cae desde el banzadillo, a través del chiflón, sobre las palas de unas ruedas motrices de tipo vertical ${ }^{68}$, colocadas en medio de las dos paredes del mismo ${ }^{69}$. Estas ruedas verticales pueden ser de dos tipos: de alimentación inferior o de alimentación superior. La primera no requería grandes obras pero sí un flujo suficiente de agua, y su potencia no superaba los tres caballos de vapor; la segunda no necesitaba tanta agua pero sí una presa y cauce elevado, con lo que la potencia aumentaba hasta alcanzar máximos de cuarenta caballos de vapor y medias normales de cinco a siete ${ }^{70}$. Las ruedas de las ferrerías eran de este tipo y solían ser dos, la del árbol mayor, que mueve el mazo o martinete, y la del árbol menor, que acciona los barquines y suele ser algo más pequeña. Tradicionalmente se creyó que las ruedas primero movieron los barquines ${ }^{71} \mathrm{y}$ posteriormente los mazos, pero hoy se piensa que fue al revés por la mayor complejidad de esta última. En algunas ferrerías había una tercera rueda para accionar el mazo del martinete o machuco.

Las ruedas hidráulicas fueron conocidas ya en la Antigüedad, aunque no de forma generalizada; se utilizaron para mover las piedras de molino, como recuerda el poeta Antipater de Tesalónica en el siglo I72. También los romanos las usaron tanto para molinos harineros 73 , como en la minería por medio de norias encadenadas 74; pero sería en la Edad Media cuando su uso se

como la parez las vigas que se llaman agullas del piso del banzado". En I. GARCÍA TATO (2000): Ob. cit., p. 124

${ }^{68}$ Según I. GONZÁLEZ TASCÓN (1987): Ob. cit., p. 84, estas ruedas son todas de tipo vertical, ya que esta disposición es la que permite mover el mazo sin emplear ningún tipo de engranajes, que resultarían muy débiles, al ser necesariamente de madera, para resistir el impacto de los mazos.

69 En 1763 en la ferrería de Villanueva de Oscos: "Hiciéronse de nuevo las dos ruedas, mayor y barquinera, y costó la madera para los curbatones, cruces y vasos ciento y veinte reales. Ocupóse el maestro en hazerlas treinta días, y llevó de su jornal doscientos y quarenta reales. $Y$ de jornal de tres carpinteros que le asistieron dichos días, a dos reales, ciento y ochenta reales". AHN. Sección Clero: Libro 9.437.

70 T. S. REYNOLDS (1994): "Raíces medievales de la Revolución Industrial". En N. GARCÍA TAPIA: Historia de la técnica. Barcelona, p. 29. De la de la ferrería de Pombriego, dice el informe de 1891, que el salto de agua produce sobre el motor de paletas una fuerza de 9,78 caballos de vapor.

${ }^{71}$ I. ARBIDE et allii (1980): Ferrerías en Legazpi. Guipúzcoa, p. 64.

${ }^{72}$ G. MORIS (1995): "Ingenios hidráulicos históricos. Molinos, batanes y ferrerías". Ingeniería del Agua, vol. 2, no 4, p. 26. 
generalizaría tanto en molinos harineros, de papel, batanes y, al menos desde el siglo XI, en las ferrerías, primero para mover los mazos y posteriormente los fuelles o barquines, como hemos dicho75. Quizá por esa razón, González Tascón denomina a esa época como la "edad del maquinismo hidráulico", nombre ajustado porque realmente supo sacar un gran rendimiento al agua 76 . Topónimos como Molinaferrera, Ferramulín en el noroeste de España, como hemos dicho, son referencias evidentes a este uso que, documentalmente, conocemos en nuestra tierra ya en el siglo XIII77.

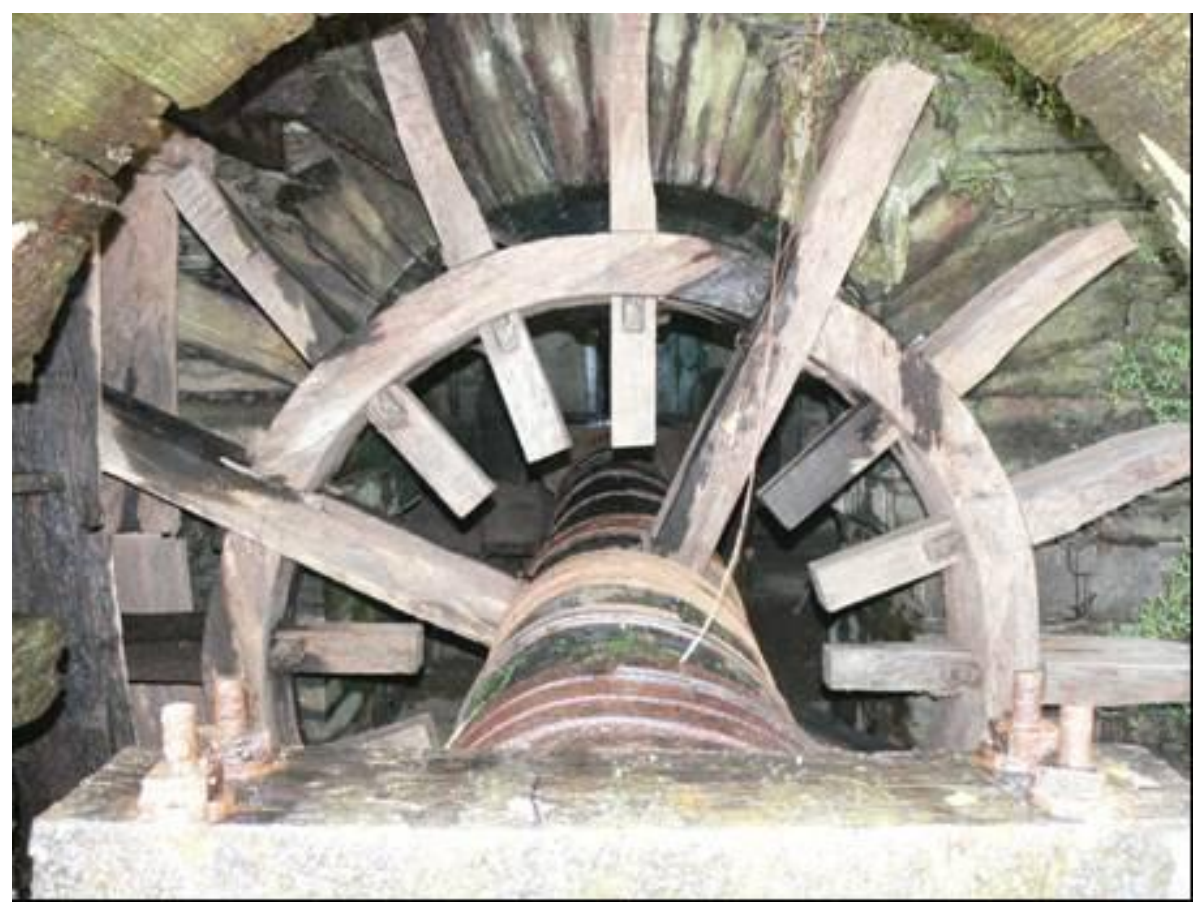

Rueda de la ferrería de Bogo (Lugo)

73 A. TREVOR HODGE (1994): "Una fábrica romana". En N. GARCÍA TAPIA: Historia de la técnica. Barcelona, p. 16 y ss. Esa fábrica romana es la de los molinos de Barbégal, cerca de Arlés (Francia), excavada en 1940 por Fernand Benoît.

74 J. M. LUZÓN (1970): “instrumentos mineros de la España Antigua”. En La Minería hispana e iberoamericana. VI Congreso Internacional de Minería. León, p. 229 y ss.

75 En Europa las primeras menciones a su uso en ferrerías se remonta al siglo XIII en Suecia y Hungría, y al XIV en Inglaterra; pero Marta Sancho, como hemos dicho, documenta ese uso en la primera mitad del siglo XI, como manifiesta en su trabajo arqueológico sobre la farga de Fabregada; también en el sur de Francia, en Issoudun, se menciona una en 1116. En R. CÓRDOBA (1996): "Innovación tecnológica y desarrollo industrial en la península Ibérica durante la Edad Media”. Actas de las I ${ }^{a}$ jornadas sobre minería y tecnología en la Edad Media peninsular. León, p. 328

${ }^{76}$ Cit. en R. CÓRDOBA (1996): Ob. cit. p. 319

77 BALBOA, J. A: (1990): Hierro y herrerías en el Bierzo preindustrial. León, p. 78. Un documento del monasterio de Carracedo (León) del año 1245, habla de la fabricación de hierro y menciona, con el mineral, todo lo necesario para hacerlo: "videlicet ligna, carbonem et molineras" en el río Isorga. 
Las paletas de las ruedas pueden ser rectas o labradas ${ }^{78}$, incluso algunas, como la de Compludo, están vaciadas a modo de cucharas, antecedente de la turbina Pelton79, que igualmente vemos en otras ferrerías ${ }^{80}$. Las ruedas suelen ser de 2,5 a 3,5 metros de diámetro. Por ejemplo la de Compludo mide poco más de 3 metros; la de Pombriego 2,86 con paletas de o,48 m. de alto por o,36 m. de ancho, que es también el ancho de la rueda ${ }^{81}$. Dichas ruedas alcanzan una velocidad, que puede regularse desde el interior por medio de una "vara" o palanca ${ }^{82}$, entre los 20 y los 30 giros por minuto, lo que supone entre 80 y 120 golpes de mazo. Desde el banzadillo el agua cae a las ruedas por un chiflón ${ }^{83}$, las cuales, a su vez, mueven los barquines, que inyectan aire al horno, y el mazo, a veces también el martinete ${ }^{84}$. Tales ruedas están construidas en madera y hierro, y constan de diferentes partes, con sus respectivos nombres: cruces, curbatones, $\operatorname{vasos}^{85}$.

Estas ruedas transmiten su empuje a los barquines y mazos por medio de un rodezno en el que se engastan unas levas que, al golpear sobre la parte posterior del mazo o de los barquines transforman el movimiento rotatorio en un movimiento hacia arriba y hacia abajo. En un documento sobre un pleito de la ferrería de Quintá de 1692, los peritos que actúan como testigos nos informa

\footnotetext{
${ }^{78}$ Sobre esta cuestión, con referencias a Villarreal de Berriz, medidas de las ruedas en ferrerías cántabras y vascas, ver: M. CORBERA (2000): La siderurgia tradicional en Cantabria. Oviedo, p. 95-96; I. CARRIÓN (1991): La siderurgia guipuzcoana en el siglo XVIII. Bilbao, p. 154 y ss. 79 I. GONZÁLEZ TASCÓN (1987): Ob. cit., p. 86

80 El testigo en un pleito de la ferrería de la Rodela recuerda en 1759 que "el agua que hace andar a las ruedas hes la que cae del banzado en los basos de ellas” (AHRG. R. A.: 6.800/4) ${ }^{81}$ ESTADÍSTICA MINERA, año 1891. Provincia de León, p. 193; sin embargo, el ingeniero José Arcieniega, que visitó esta ferrería en 1864, dice que "tiene un martillo movido por una rueda de diez y seis paletas, que llaman barrederas, siendo 1, $67 \mathrm{~m}$. el radio de cada una y su ancho 0,27 (...) son angostas, y no obra sobre ellas todo el peso de la columna de agua" (REVISTA MINERA, t. XVI, 1865, p. 113).

${ }^{82}$ En la inauguración de la ferrería de Quintá, en 1566, se dice "que tiraron sobre el palo de la tapadera del chifrón y dieron agua a la rueda del maço" (AHRG. Hombreiro: leg. 19)

${ }_{33}$ AHRG. R.A.: 1662/4: En el pleito por la construcción de la ferrería de Quintá, los maestros que peritan como testigos señalan en 1692: "que la cayda del agua del alto del dicho banzado no es como de canal de molino, sino que se descuelga por un chiflón o agujero que está en el suelo del banzado y baja con fuerza para azer andar las ruedas, las quales no echan la agua con fuerza acia adelante sino acia atrás, dejándola descolgar los basos como los de una noria con que no le dan más fuerça por dicha raçon en la corriente".

${ }^{84}$ Inventario de la ferrería de La Veguiña (Tapia) de 1852: "Enseguida han bisto las tres ruedas que lleban el nombre de árbol mayor de la herrería, el de la barquinera y el del martinete, las quales hallaron sin ningún defecto". En J. LÓPEZ y A. GRAÑA (1998): Ob. cit., p. 145.

85 Un documento dice respecto de la ferrería de Villanueva de Oscos: "Hiciéronse las dos ruedas, mayor y barquinera, y costó la madera para los curbatones, cruzes y vasos ciento y veinte reales”. En IBIDEM, p. 23
} 
de algunas características de estos rodeznos, cuyas dimensiones superan los cinco metros y medio de largo ${ }^{86}$.

\subsection{Los barquines y trompas}

Los barquines eran los grandes fuelles o foles (hauspoak en vasco) que inyectaban aire al horno para avivar el fuego y reducir el mineral. Normalmente eran dos y al conjunto se le conocía con el nombre de barquinera. Dichos barquines se movían alternativamente para producir una corriente de aire continua. Estaban construidos con madera y cuero, y constaban de tres partes: El "cuerpo", lugar en el que se produce el aire, fabricado de tablas de madera en su fondo y tapa, con los costados de piel para que fueran flexibles; la "valvula" o "ventana", pequeño orificio en uno de los lados del fuelle por el que el aire entra en su interior; y el "cañón", por el que éste es expulsado. El cañón, como ya hemos dicho, se introduce en la tobera metálica del horno. Tanto el cañón como la tobera solían ser de cobre y, con frecuencia había que repararla, por lo que las ferrerías contaban con varias de repuesto, como vemos en muchos inventarios 87. A su vez, el cuero había que engrasarlo frecuentemente con manteca o unto para que no se deteriorara y mantuviera su flexibilidad.

Los barquines los movía una rueda hidráulica diferente de la del mazo, que se accionaba desde dentro por medio de una vara ${ }^{88}$. Era una rueda de palas que movía un eje, en cuyo extremo llevaba una suerte de dientes o trinquetes, llamados malugreiros o malumbreiros, que en su giro presionaban sobre el barquín oprimiéndolo. Entre la acción de uno y otro diente, un contrapeso elevaba la parte superior del fuelle permitiendo su toma

\footnotetext{
86 AHRG. R.A.: 1662/4: "Medieronse los dos arboles de la eraria bieja y se alló tener de largo el arbol de la rueda de mazear siete baras menos una quarta, y el arbol de la rueda barquinera siete baras menos otra quarta. (...). Medieronse los dos arboles de la fabrica nueba y el que está puesto en ella dijeron era el de maçear y se alló tener seis baras de largo, y el otro arbol que está tendido en el soto que llaman de la Puente y dijeron ser para la rueda barquinera de dicha nueba fábrica se alló tener de largo siete baras y dos tercios de otra".

87 Ver nota 113

88 En 1829 en el juicio por las ágoas de la ferrería de Ferreirós un testigo menciona varias veces, cómo uno de los dueños "se apoderó de la bara de los barquines o fuelles", "echando don Benito mano... de la bara de dar agua a los fuelles y se la entregó al Gregorio", "porque quando... el Gregorio Martínez se apoderó de la bara de dar agua a la barquinera..." (AHRG. R.A.: 19.222/30)
} 
de aire. Estos malugreiros, por su gran desgaste, había que repararlos prácticamente todos los años.

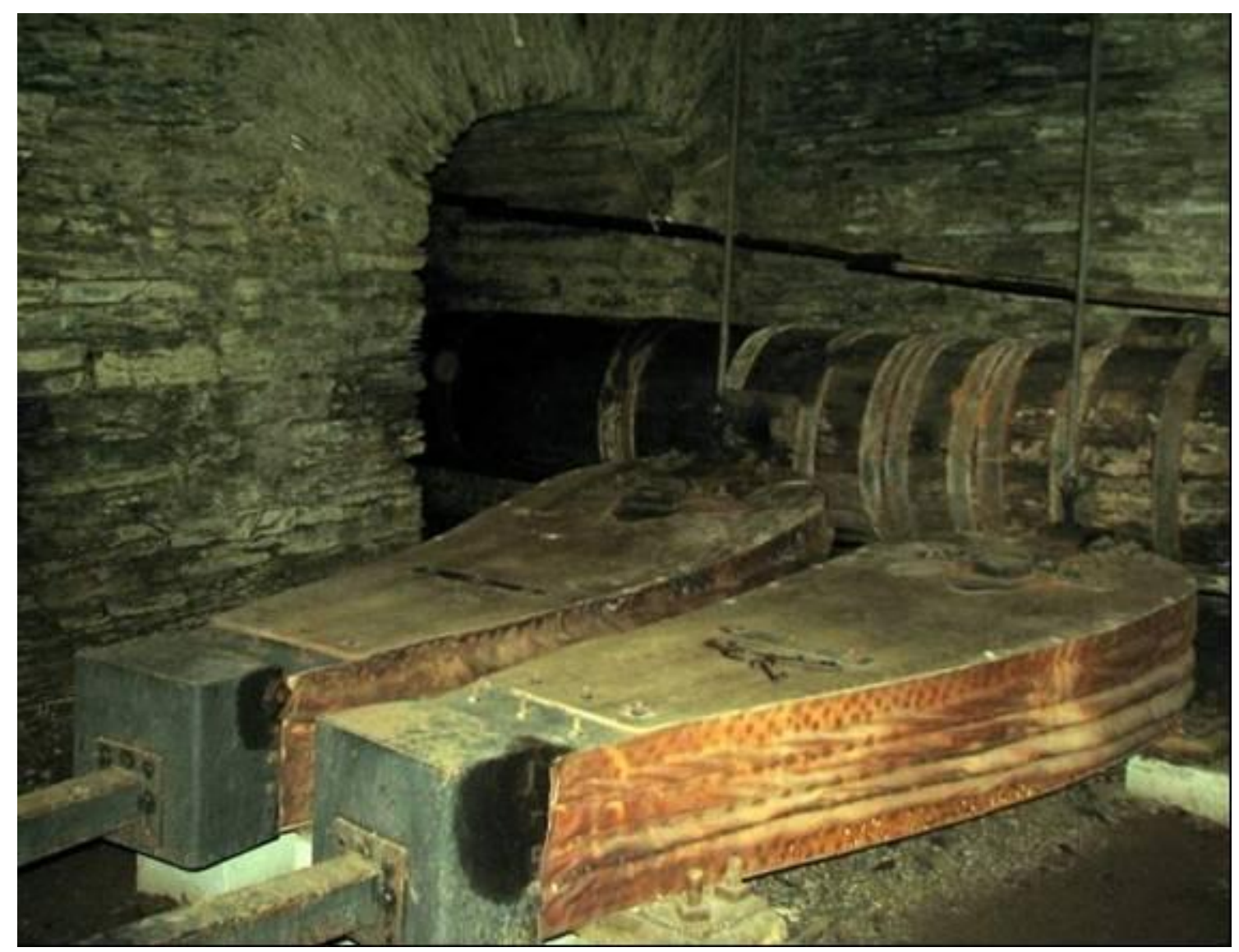

Barquines de la ferrería de Seoane del Caurel

Cuando el agua escaseaba, el ingenio hidráulico de la ferrería estaba montado de manera que una misma rueda hiciese funcionar el mazo y los barquines: del árbol o rodezno salía un cigüeñal que movía en vaivén una tabla situada en la parte de arriba. En el extremo contrario tenía un travesaño y este en cada punta una barra de hierro, sujeta a los barquines, de manera que cuando subía una, otra bajaba, obligando de este modo a subir y bajar igual y alternativamente a cada barquín, produciendo un chorro de aire de forma continua. Este sistema se conocía en el País Vasco como "pujoimakur"89; sin embargo, no hemos hallado en el noroeste referencias escritas al mismo, lo que no significa que no existiera.

89 P. MOLERA (1983): Llibre de la farga. Barcelona, p. 85 
Los primeros datos documentales sobre la utilización de barquines en el Noroeste son de los primeros años del siglo XVII, pero desde el XIV eran conocidos en otras regiones de España ${ }^{90}$; probablemente en esta zona fueron introducidos a finales del siglo XV o a principios del XVI por oficiales o arrendatarios vascos, de los que sí tenemos abundantes noticias, como ya veremos. La referencia más antigua que he visto a barquineros y barquines en la documentación estudiada es de 1606, en que un "Pedro de Alza barquinero" firma como testigo en la ferrería de Lousadela91. En 1634 Gerónimo González, en nombre del marqués de Villafranca, contrata con Juan de Zaúregui, maestro barquinero vecino de Villazuán, en la abadía de Samos, los barquines grandes de la fragua mayor de la ferrería de Pontepetre, por 365 reales de vellón, más todos los materiales necesarios y el trabajo de tres obreros. En el contrato se especifican los materiales utilizados en su construcción, lo que nos da una idea de las enormes dimensiones de los mismos: ocho cueros de bueyes grandes, cuarenta libras de unto, seis quintales de hierro para clavazón y planchas de hierro, cuatro tablas de humeiro (aliso) o abedul buenas y labradas al pie de la obra $^{92}$.

Algunos de los maestros barquineros tienen nombres vascos, lo que sin duda es una prueba más del origen de esta técnica introducida en el noroeste por ferrones de aquella región. Lo es el citado Juan de Záuregui en 1634, y lo es también en 1752 Manuel Zelaia, de Folgoso del Caurel, del que dice el Catastro de Ensenada que en "el ofizio de hacer varquines se ocupará dos meses" 93 . Más expresamente lo señalan Cristóbal Chavarría y Domingo Manterola, testigos en un juicio en Asturias hacia 1691, que se declaran vizcaínos y maestros de barquines de ferrerías y machucos 94 . Las fuentes mencionan igualmente a

\footnotetext{
9o L. M. DIEZ DE SALAZAR (1983): Ferrerías en Guipúzcoa (siglos XIV-XVI). San Sebastián, t. II, p. 83 .

91 AHPLu: 2555/1

92 AHPL. P. N.: 2126 (1834).

93 CATASTRO DE ENSENADA. R. G.. Folgoso del Caurel

94 A.Ch.V. Registro de Ejecutorias: caja 3052/35. Cristóbal Chavarría se declara vecino de Avilés y natural del Señorío de Vizcaya, del valle de Oyarzun, pero que lleva en "esta tierra" más de treinta años como "maestro de varquines de herrerías y machucos"; Domingo de Manterola, por su parte, afirma ser del mismo señorío de "un lugar que se llama Oya y ser maestro de varquines de herreríasy machucos y residente en este principado de asturias".
} 
maestros barquineros gallegos y asturiano, como Pedro de Alva y Blas López, de Visuña95.

Los barquines de madera y cuero fueron el sistema utilizado para la inyección de aire tanto en las ferrerías vascas como en las bercianas, gallegas y asturianas durante la Edad Moderna. Una variante, aunque poco utilizada, fueron los barquines de madera exclusivamente, pero como señala un informe de 1795 "la precisión que exigen los de madera para que produzcan su efecto parece que hace preferir los de cuero, cuyo establecimiento es casi conocido de todos"96. En el País Vasco hubo intentos para introducir el sistema de trompas catalán por Pablo Antonio de Ribadeneira, en la primera mitad del siglo XVII97; pero no prosperó por la oposición de los ferrones, pues aunque era necesaria menos agua debía caer desde una altura mayor lo que exigía presas más largas o más altas. Pese a ello, en 1754 Larramendi en su Coreografía ${ }^{98}$ señala la existencia de algunas ferrerías que lo han adoptado.

Sí prosperó, en cambio, en el noroeste durante el siglo XIX. Una de las ventajas de este sistema frente a los barquines, además de su menor coste, era que estos sufrían incendios con relativa frecuencia; tal vez fuera esta la razón que llevó a los ferrones de nuestra zona a su sustitución, aunque algunos no confiaban en ellos99. En el Bierzo, los barquines fueron sustituidos por trompas de agua en los años veinte del siglo XIX. En un Estado General de Cuentas del monasterio de Montes, del año 1824, se dice que en el cuatrienio precedente, el abad don Eladio Enríquez había hecho algunas mejoras en la ferrería de Linares, propia del monasterio, y "en lugar de barquines construyó trompas

95 CATASTRO DE ENSENADA. R. G.: Visuña: dice que son labradores pero "en el ejercicio de hacer barquines dos meses al año, y en cada día de ellos lucrará tres reales de vellón".

${ }_{96}$ AMN. Colección Guillén: ms. 2127, año 1795

97 J. ALMUNIA ((1953): "El ingenio para fundir sin fuelles de Pablo Antonio de Rivadeneira". Revista del Instituto del Hierro y del Acero (Madrid), $n^{\circ}$ 2, p. 153 y ss.

98 P. MOLERA (1980): La farga. Barcelona, p. 87.

99 Todavía en 1805 José Antonio Ojea, director de la ferrería de Iraeta, escribía a Munárriz, ocupado en aquellos años en la construcción por encargo del gobierno de una ferrería en el Bierzo, y preocupado por el tema: "He hablado y consultado a varios sujetos prácticos en herrerías, y casi todos están por los barquines de cuero, fundándose en que los de piedra consumen más carbón, dan un hierro de inferior calidad y disminuyen el producto diario de la herrería. Lo cierto es que se hallan establecidos los barquines de piedra en muy pocas herrerías, y aún alguno que otro los abandonó después de hechos, volviendo a los de cuero, bien que esto contemplo puede provenir en gran parte de las preocupaciones de los tiradores o arozas, que se resisten a cualquier cambio". Cit. en A. CARRASCO (1889): "Fábricas artilleras de Villafranca del Bierzo". Memorial de Artillería (Madrid), tomo XII, serie 4, p. 126. 
que pudieran hacer el oficio de aquellos"100. De este hecho se hace eco años más tarde Madoz, cuando al hablar de esta ferrería dice que "fue la primera del país en que se sustituyeron los barquines con unas máquinas que llaman bombas, generalizadas después a las demás"101, lo que sin duda es cierto.

En años posteriores vemos cómo se extiende el sistema por otras ferrerías de la región, por ejemplo en el inventario de las dos ferrerías de Río Cabo, del año $1838^{102}$. A partir de entonces en varios contratos de arriendo se especifica que "el árbol de macear, banzao y trompas, cuando sea necesario hacerlos de nuevo"103 correrá a cargo del dueño y no del arrendatario. Actualmente este sistema puede verse en funcionamiento en la ferrería de Compludo. Las ferrerías gallegas y asturianas, a su vez, también sustituyeron los barquines por trompas, llamadas a veces en Galicia foles de pedra para diferenciarlos de aquellos otros de cuero, aunque durante un tiempo convivieron diferentes sistemas ${ }^{104}$. En las ferrerías de Río Cabo, anteriormente con barquines, tenían en 1838 arcas o trompas como ya hemos dicho, y lo mismo la ferrería de Órreos en $1848^{105}$; sin embargo, la de la Veguiña en 1852 seguía usando barquines ${ }^{106}$.

\footnotetext{
100 A.M.S. Estado general de cuentas del monasterio de San Pedro de Montes, año 1824. ${ }^{101}$ P. MADOZ: ob. cit, pág. 198, término Linares.

${ }^{102}$ I. GARCÍA TATO (2000): ob cit., p. 100, nota 40. En la descripción de la ferrería de arriba se dice cómo "por detrás del paredón de la fragua se halla colocada el arca del ayre y su trompa toma el agua del banzado de los pistones"; y lo mismo dice de la de abajo: "se halla una pared que se llama paredón de la fragua y por detrás de éste el arca bien construida donde se toma el ayre para dicha fragua, descendiendo el agua para la indicada arca de un banzadillo, separado del mayor por dos trompas bien seguras y con los arcos necesarios de fierro" Del texto de ese inventario de 1838 se puede deducir que anteriormente tuvo barquines, sustituidos posteriormente por trompas: "los pistones se hallan colocados en el sitio mismo de cuando trabajaban y la reuda que los mobía lo mismo, ésta se halla corriente y aquellos imperfectos de los artículos o adminículos que le son necesarios para moberlos por hallarse rotos".

103 AHPL. P. N.: 3582 (1848): arriendo de la ferrería de San Pedro de Órreos: "todos los reparos de la casa, fábrica y bienes sean de cuenta del arrendatario, a escepción del árbol de macear, banzado y de las trompas, cuando sea necesario hacerlos de nuevo". AHPL. P. N.: 2724 (1860): arriendo de la ferrería de San Vicente de Leira: Todos los daños serán por cuenta del arrendatario, a excepción "del caso en que el árbol mayor se rompa o la chapacuña se destruya por entero".

104 G. SCHULZ (1838): "Ojeada sobre el estado actual de la minería de Asturias y Galicia”. Anales de Minas. Madrid, t. I, p. 390: "todas las herrerías de Galicia son bastante uniformes entre si, parecidas á las de Asturias, y siguen un mismo método dirigiéndose las operaciones según la práctica antigua traída de Vizcaya, aunque en el día más ó menos esmerada. El aparato neumático es de trompas comunes, ó trompas de arca, ó barquines de cuero; en algunas se usan barquines de madera, y en una sola pistones de madera”.

105 Ver nota 102, también AHPL. P. N.: 3.582 (1848): Escritura de arriendo de la ferrería de Órreos: "Que todos los reparos de la casa, fábrica y bienes sean de cuenta de la arrendataria, a escepción del árbol de macear, banzado y de las trompas cuando sea necesario hacerlos de пиеvo".
} 
El sistema de trompas, que utiliza el efecto Venturi, consiste en un tubo (chiflón) hecho de madera (a veces un simple árbol perforado) o de metal por el que se precipita con fuerza el agua desde el banzao o el banzadillo al abrir la trampilla que lo cierra por medio de una vara. Antes de llegar al arca o trova (caixa du vents), la corriente succiona el aire que entra por unos pequeños orificios u "oidos" (espiralls), y es expulsado por la tobera en dirección al hogar o regazal. El arca era estanca, completamente cerrada excepto por dos pequeños agujeros, uno en el fondo para facilitar la salida del agua y otro para conducir el aire por la tobera al horno. El aire era continuo y se podía aumentar o disminuir aumentando o reduciendo la cantidad de agua ${ }^{107 .}$

\subsection{El horno}

El horno, crisol o regazal es la parte de la ferrería en la que el mineral de hierro es reducido por medio del carbón vegetal; por tanto, se trata del centro de la ferrería y su parte más importante pues en ella se hace el trabajo principal. En los del noroeste, más que una forma circular ${ }^{108}$, tenía la de un tronco de pirámide invertido, con tres paredes rectas y una inclinada, y solía estar algo enterrado en el suelo de la ferrería ${ }^{109}$. Su altura, por lo regular, no sobrepasaba los o'50 metros, con una anchura cuyo diámetro podía alcanzar los o'85 metros, pero más estrecho en el fondo, en torno a los o’40 metros. Aunque la tipología era común, sin embargo las formas y dimensiones variaban de unos hornos a otros, pues como decía Villarreal de Berriz en 1736, hablando de los vascos, "los fogares u horno donde se hace la fundición no se sujetan a reglas de geometría:

\footnotetext{
106 Inventario de 1852: "Los barquines mayores hicieron dos labranzas y la que sigue... que se hicieron nuebos”. En J. LÓPEZ y A. GRAÑA (1998): Ob. cit., p. 146.

107 P. MOLERA (1983): Ob. cit., p. 85.

${ }^{108}$ Eso, al menos es lo que dice Munárriz, quizá por influencia vasca, pues en aquella región la ferrería vasca, aunque de forma trancopiramidal, tendía a redondear sus ángulos, lo que le daba una forma circular.

109 Así lo afirma el informe sobre la ferrería de Pombriego de 1891 (Estadística Minera, 1891, 190). Villarreal de Berriz aconsejaba en el siglo XVIII que "el fogal u horno sea baxo tanto, si fuese posible, se levantase solo un pie del suelo ó piso de la Herrería, y que lo profundo del horno, donde se pone el hierro, que llaman signilo, no reciba humedad: el conseguir uno y otro es muy difícil”. P. B. VILLARREAL DE BERRIZ (1736): Máquinas hidráulicas de molinos y herrerías y gobierno de los árboles y montes de Vizcaya. Madrid. Reeditado en San Sebastián, 1973, p. 110.
} 
los oficiales tienen sus medidas" ${ }^{110}$. Parece que las fargas catalanas y las de las de la región francesa de Ariége eran de mayor dimensión, y de ahí su mayor producción por ágoa ${ }^{111}$.

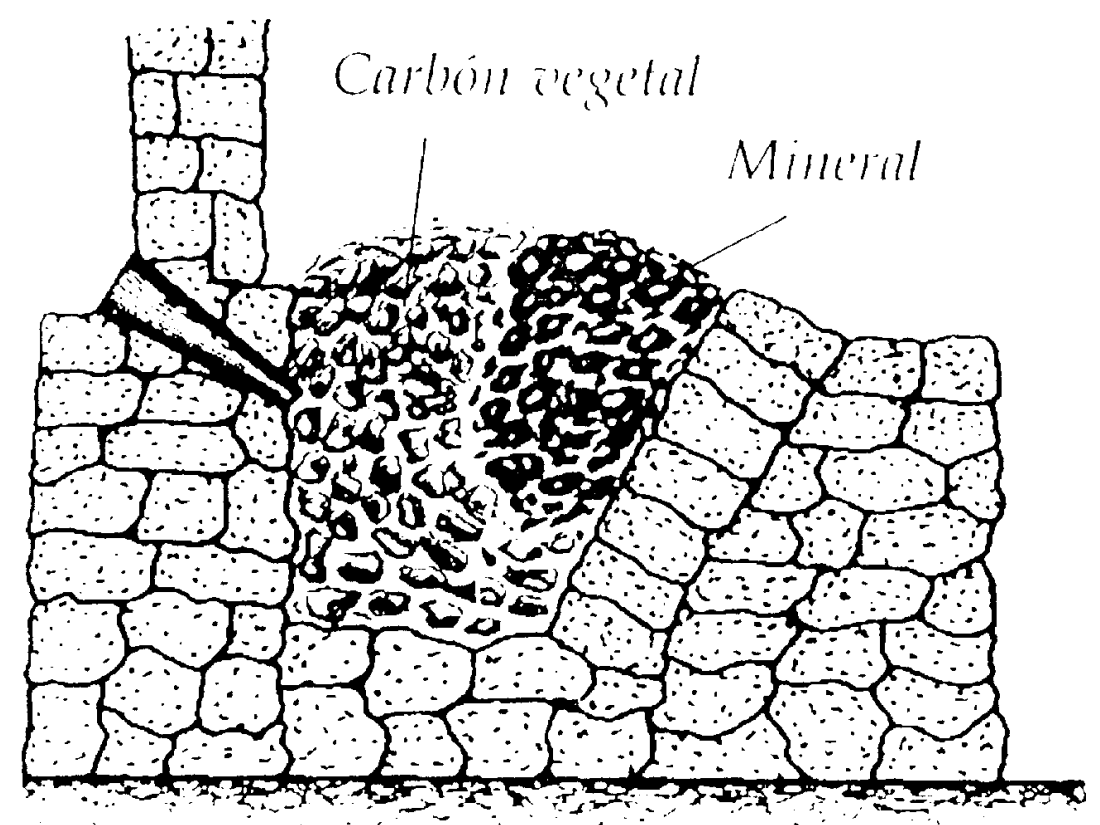

Horno bajo. Asociación de Amigos del Museo de Hierro de Legazpi

El horno estaba originariamente construido con muros de mampostería unidos con arcilla; posteriormente esos muros fueron recubiertos en su interior con planchas de hierro. La del fondo se llama ciguillo. Uno de los muros del horno es la pared sobre la que este se apoya y se la denomina cadenarte, bergamazo o pie del foc, recubierta por otra plancha de hierro llamada veterría. En otro de los muros laterales hay un agujero semicircular de nombre canalita o canillero, denominado en las fargas cagaferro, que permite sangrar el horno y extraer las escorias que caen a un cenicero llamado la cicatería112.

${ }^{110}$ IBIDEM, p. 109-110. I. CARRIÓN (1991). Ob. cit., p. 185 recoge datos de algunos libros de metalurgia, con medidas diferentes según las zonas, estimando unas dimensiones aproximadas de $70-80 \mathrm{~cm}$. de profundidad, por otros tantos de ancho, con una forma cuadrangular.

${ }^{111}$ J. MALUQUER, J. (1984): "La siderurgia tradicional: la farga catalana". L'Avenc, 72, p. 22; J. CANTELAUBE, J. (1993): Ob. cit., p. 31.

112 Inventario de las ferrerías de Río Cabo, de 1838: La fragua "se halla corriente de sus fierros necesarios, como son zapata, ciguillo, beterre, puerta de fragua, y todo lo demás restante bestida de fierro". En I. GARCÍA TATO (2000). Ob. cit., p. 123. 
A través del cadenarte penetra en el horno la tobera, con una inclinación de 32 a 40 grados, para así poder inyectar aire a todo el por igual. Esta inclinación de la tobera tenía en nuestro horno -aunque esto no significa que estuviera muy extendido este ejemplo- un mayor parecido con el sistema catalán ( $37^{\circ}$ de inclinación) que con el sistema vasco $\left(15^{\circ}\right.$ solamente) ${ }^{113}$; la altura a la que era colocada variaba en función de la profundidad y anchura del horno, aproximadamente unos $0,30 \mathrm{~m}$. por encima del crisol. La tobera estaba construida en cobre, con un peso entre los 5 y los 5'5 kilogramos; siendo muy frecuente su desgaste y su reparación. Normalmente, como ponen de manifiesto los inventarios, todas las ferrerías solían contar con varias de repuesto ${ }^{114}$.

En el horno se realizaba la parte química de la fundición que luego se completaba en el mazo. La dificultad de esta operación consistía en el control de la temperatura del horno, de la que dependían las reacciones químicas adecuadas para la obtención del hierro. No había que pasarse ni quedarse corto. Todo se hacía a ojo, de ahí el papel de los fundidores.

El horno se cargaba con capas alternativas de mineral y carbón vegetal, a las que se denominaba agoa. El mineral previamente había sido lavado ${ }^{115}$, raguado y tazado. La ragua, como ya veremos posteriormente, consistía en una primera calcinación del mineral al aire libre, en la que este al deshidratarse facilitaba su reducción; permitiendo, así mismo, al tazador romper el mineral en pequeños pedazos, del tamaño de una avellana, poco más o menos. Luego se

\footnotetext{
${ }^{113}$ L.M. DIEZ DE SALAZAR (1983): Ob. cit., p. 83.

114 En Tejedo de Ancares, año 1802, se inventarían "cinco toberas nuebas y quatro viejas". (AHPL. P. N.: 3783 (1802); en el de la ferrería de Quintá, en 1836, "cuatro tuberas, su peso 25 libras" (AHRG. Hombreiro 21/4). En la de Bueyes, dice el Catastro de Ensenada: "Las tuberas en que se se encaxan los cañones de los barquines son de cobre, estas a cada paso se derriten y consumen, tienen de coste cada una cien rs. vn., la composicion de cada una ymporta la que menos treinta y tres rs. y la que mas quarenta y quatro, y por que estas composicion son muchas en el discurso de el truaxo de dicha herraria y no poder con realidad asemptar su ymporte cierto regulan que en los tres meses lauorables se gastaran y consumiran, por quinqueneo, quatro tuberas, que a dicho precio ymportan quatrocientos rs. vn.”.

${ }^{115}$ La mena, señala el informe de la ESTADÍSTICA MINERA de 1891, "se somete a un lavado por medio de un arroyo inmediato a la fábrica, para purgarla de la tierra que contiene", lo que aumenta su rendimiento.
} 
echaba en el horno junto con el carbón vegetal y sin fundente alguno ${ }^{116}$, logrando, al avivar el fuego, temperaturas superiores a los $1000^{\circ}$.

Aprovechando el fuego de la ágoa anterior se ponían al rojo las caras metálicas del horno. Sobre un lecho de carbones encendidos se echaban paletadas de mineral hacia la parte opuesta de la tobera, alternando con otras de carbón en la proporción conveniente para que aquel no se licuara. El fundidor con un rodo de madera o de hierro acerca poco a poco la mena hacia la tobera, vertiendo encima más carbón y de vez en cuando rociaba con agua para concentrar el fuego abajo, y cuando ya se había derretido y descendido el mineral de la tobera se consideraba terminada la fundición y se procedía a sacar la lupa, goa o zamarra por medio de unas palancas y ganchos de hierro. Antes de esto se aviva el fuego durante una media hora echando mucho carbón y aire, rociando con agua para apagar los fuegos y reconcentrarlos abajo. Tras sacar la goa se abre el canillero, tapado con arcilla, para que salgan las escorias al cenicero o cicateria. Una vez sacada la escoria se tapaba otra vez con arcilla y se procedía nuevamente a cargar el horno con otra ágoa. El proceso de fundición de cada ágoa requería en torno a cuatro horas por lo que en 24 horas se realizaban seis ágoas ${ }^{117}$.

El término ágoa parece tener dos significados diferentes: uno, el de las fundiciones realizadas en un día; otro, el de cada una de las fundiciones que salen del horno cada cuatro o cinco horas. En el primer caso se trata del número total de ágoas o días que trabaja la ferrería; también en el número de ágoas en el que algunas ferrerías estaban divididas, siendo sus propietarios partes alicuotas de las mismas ${ }^{118}$. En este sentido, por tanto, ágoa es igual que fundición o el

\footnotetext{
${ }^{116}$ Nunca se mencionan fundentes, ya utilizados en las ferrerías vascas en el siglo XVIII. DATOLI, p. 55, asegura que "el mineral lo usan sin fundente alguno, aunque por su naturaleza convendría usar de la pìedra calcar".

117 MUNÁRRIZ, p. 131 y 132

${ }^{118}$ En un pleito del año 1829 por las ágoas de la ferrería de Ferreirós, cuyas 72 ágoas estaban divididas entre varios propietarios, 64 de las cuales las tenía arrendadas doña María Rivadeneira, se explican ambos términos. El arriendo de esas ágoas "se entienden desde el día veinte y cinco de julio de cada año, hasta igual fecha y mes del siguiente"; es decir, el arriendo era por un año (aunque probablemente el tiempo de trabajo era mucho menor), y el trabajo diario de veinticuatro horas "porque ordinariamente para sacar yguales fundiciones o agoas (que es lo que se funde en 24 horas) se empieza a trauajar de noche y concluye de noche" (AHRG. R.A.: 19.222/30).
} 
trabajo que la ferrería realiza en veinticuatro horas ${ }^{119}$. En estas ferrerías divididas en ágoas, el cómputo de las mismas lo llevaba el tirador, y los oficiales eran comunes para todos los propietarios, usando para ello las mismas herramientas pero no el carbón y la vena ${ }^{120}$. Como se trata de días completos, un testigo dice que para que no haya diferencias entre unas y otras el trabajo se realiza ininterrumpidamente desde el domingo por la noche hasta la misma hora del sábado ${ }^{121}$. En un texto de 1869 referido a la ferrería de Valdomir se habla además de primeras y segundas aguas o ágoas: unas desde septiembre hasta finales de enero, las otras desde esa fecha hasta finales de julio, probablemente por los diferentes caudales del río en esos dos tiempos ${ }^{122}$. Este concepto de ágoa como día de trabajo lo confirman otros varios testigos ${ }^{123}$.

Frente a esto concepto, ágoa también se entiende como cada una de las fundiciones que cada cuatro o cinco horas salen del horno, como reconocen algunos testigos en un juicio de $1829^{124}$ y antes el Catastro de Ensenada de mediados del siglo XVIII ${ }^{125}$ y Munárriz hacia $1805^{126}$. Según este autor, en cada

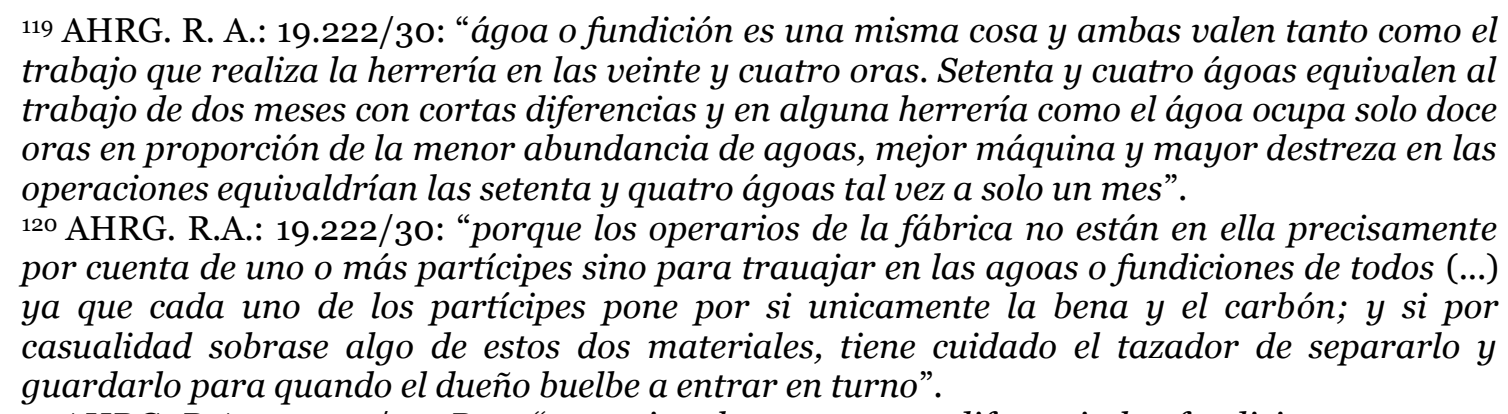
${ }^{121}$ AHRG. R.A.: 19.222/30: Para "sacar iguales o con poca diferencia las fundiciones o agoas, empieza a trauajar a cosa de las doce de la noche del domingo o dias festibos, y concluye en la misma ora sobre un poco mas o menos del sábado de cada semana"

122 AHPL. P.N., 9113: "Sin embargo de ser muy conocida la denominación de primeras y segundas aguas, se expresa para mayor claridad que las primeras aguas se entienden desde principios de septiembre de cada año hasta el veinticinco de enero siguiente; y las segundas aguas principian el veinte $y$ seis de dicho enero $y$ concluien en el veinticinco de julio inmediato".

123 AHRG. R.A.: 19.222/30

124 AHRG. R.A.: 19.222/30: "que el ágoa es la fundición o material que para ello se prepara, y al día con su noche que biene a ser cada veinte y cuatro oras, se hacen cuatro o cinco ágoas"; otro añade "que cada ágoa tarda cuatro horas y en veinte y cuatro horas se trabajan seis ágoas u hornadas", y otro que "la agoa o fundición de la bena o mineral que produce el fierro, tarda cuatro oras por lo común en derretirse y fundirse, por manera que en veinte y cuatro horas de que consta el día y la noche, se reputan trabajadas en cada herrería seis hornadas o ágoas poco más o menos, según se allan arreadas, ó abundantes de aguas y conocimiento de los operarios, cuyas circunstancias reune la de Ferreirós, como que es uno de los mejores hornos del país en calidad y abundancia".

125 El CATASTRO DE ENSENADA. R. G.: Barxa de Lor, dice de la ferrería de Lor: "solo travaxa echo el cómputo por un quinquenio, y sin hacerlo de los excalabros mayores, ducientos días en cada un año; en cuyas veinte y quatro horas fabrica cinco quintales por ser más rudo y recio 
una de estas ágoas entraban en el horno 13 arrobas de mineral y 12 ó 13 cargas de carbón, de las que se obtenían unas 5 ó 6 arrobas de hierro ya estirado en bandas ${ }^{127}$; es decir, entre 60 y 70 kilogramos (casi el 40 por ciento del mineral de hierro, lo que era una buena proporción, pues lo normal era entre el 30 y el 35 por ciento, como ya veremos). Esta cifra parece coincidir con las de los testigos del juicio por las ágoas de la ferrería de Ferreirós de 1829, que hablan que cada ágoa pesa sobre un quintal de cinco arrobas, es decir, unos 57,5 kilogramos ${ }^{128}$. Estas cifras son algo inferiores a las que se obtenían en los hornos del País Vasco o Cataluña, cercanas a los 90 y $100 \mathrm{kgs,}$, al ser hornos de dimensiones algo mayores, o a los $170 \mathrm{~kg}$. de las ferrerías de Ariège ${ }^{129}$.

\subsection{El mazo}

La masa de hierro -goa o zamarra- que sale del horno es una torta de hierro circular ligeramente cónica hacia abajo. Según un informe de 1891 se divide en dos paquetes que llaman: cabezón, cuando tiene rabo o apéndice, y cintas cuando no lo tiene. Cada uno de estos paquetes vuelve a meterse en el horno sucesivamente para ablandarlo aún más. Hecho esto se los somete al batido y tirage en el mazo ${ }^{130}$. Esta operación podía hacerse directamente en el propio mazo de la ferrería, lo más corriente, o en el de un machuco. Mediante ella se transformaba en "barras", también llamado "hierro banda", "bergallón"

\footnotetext{
el mineral y no sacar por esta causa más de cinco hagoas en ella"; de la de Quintá (Quiroga): "en cada uno de los quales se persuaden que fabrica cinco quintales y medio de hierro". ${ }^{126}$ MUNÁRRIZ, p. 131: "cada uno de los fundidores saca su ágoa en tres o cuatro horas y descansa mientras el otro saca la suya".

127 El informe citado de la ferrería de Pombriego, de 1891, dice que la proporción de carbón que se invierte en estas operaciones es de tres a cuatro por cada uno de mena; y de dos o tres de mena, según la calidad, por cada uno de hierro.

${ }_{128}$ AHRG. R.A.: 19.222/30: "Cada ágoa pesa (por lo común) un quintal de fierro"; otro añade que "cada una de ellas componen un quintal de cinco arrobas castellanas poco más o menos, con tal que dicha herrería tenga abundancia de aguas, conocimiento de ella los operarios y no se esperimente escalabro o ruina en alguna de las piezas de su compuesto".

129 I. CARRIÓN (1993): "El funcionamiento de la empresa siderúrgica vasca en el siglo XVIII: los ferrones guipuzcoanos". En Io simpisi sobre la farga catalana. Ripoll, p. 352. El autor afirma que producía en cada ágoa un quintal macho, para los que se necesitaban tres de mineral y cuatro cargas de carbón. J. CANTELAUBE (1993): Ob. cit., señala respecto de las fargas del sur de Francia que en cada ágoa entraban alrededor de $480 \mathrm{~kg}$. de mineral y $405 \mathrm{~kg}$. de carbón vegetal de la que se obtenían $170 \mathrm{~kg}$. de hierro, y que la fundición duraba seis horas, por lo que se hacían cuatro en 24 horas. Es decir, 680 diarios frente a $360 \mathrm{~kg}$. en las del noroeste, casi el doble.

${ }^{130}$ J. CANTELAUBE (1993): Ob. cit., p. 32 afirma que la masa, de unos $170 \mathrm{~kg}$., que salen del horno la dividen en dos "massoques", los cuales son a su vez subdivididos cada uno de ellos en otros dos "massouquettes", que sucesivamente son estirados en el mazo.
} 
(tiras largas y estrechas para clavazón), "planchas" (de forma rectangular y finas), "planchuela" (planchas pequeñas), "cuadradillo", "cortadillo", "varilla", etc.

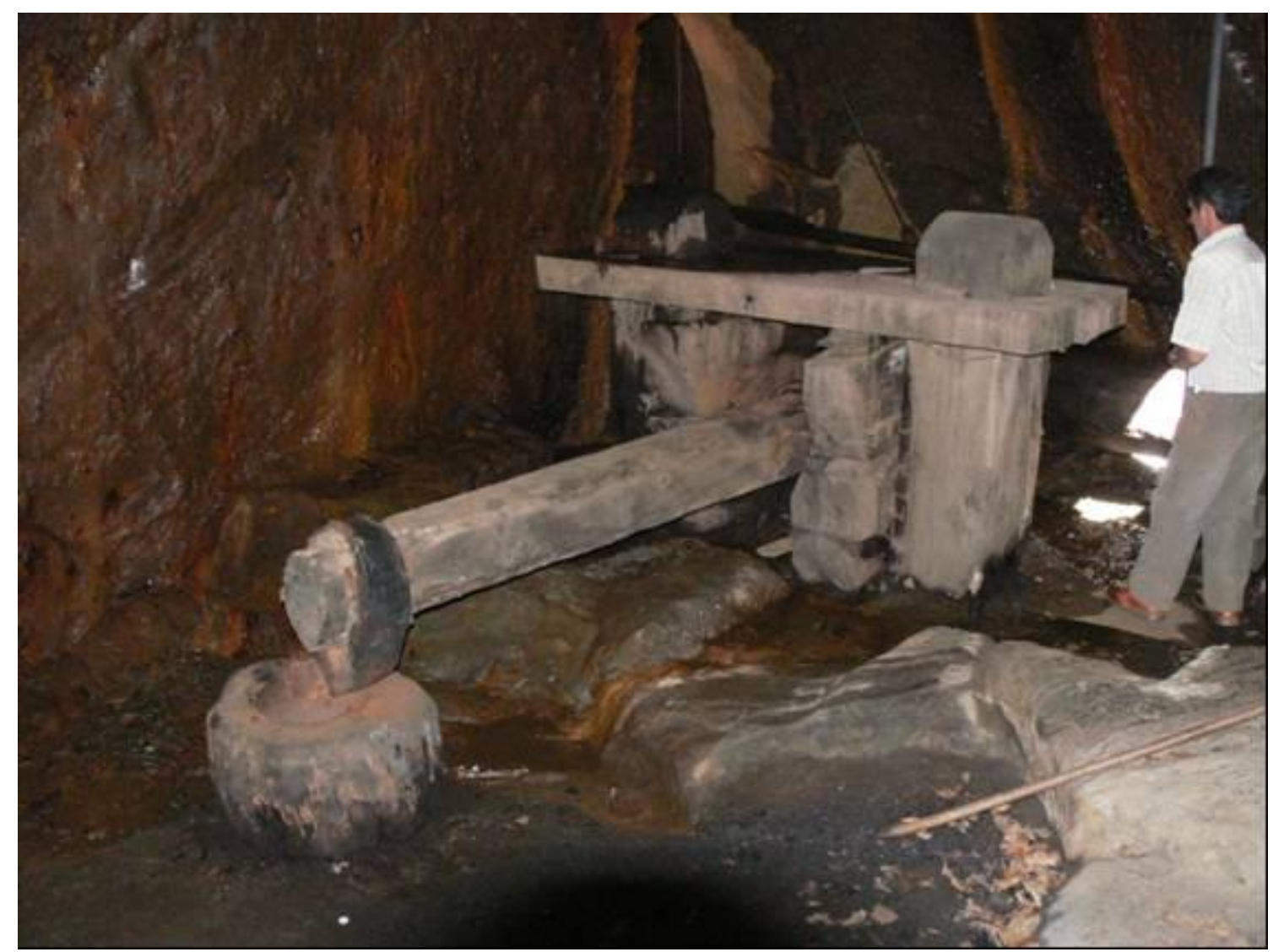

Mazo de la ferrería de Penacova (Lugo)

El mazo es una especie de martillo pilón de grandes dimensiones. Desde el interior de la ferrería, el ferrón manipula una vara o palanca (uraga en vasco) que permite la caída regulada del agua desde el banzadillo, por el chiflón, a las palas o álabes de una rueda hidráulica, poniéndola en movimiento ${ }^{131}$. El eje de la rueda o árbol mayor (al conjunto de rueda y árbol se le denomina rodezmo), de unos cuatro o cinco metros de largo por cincuenta o sesenta centímetros de diámetro -normalmente de roble reforzado con aros de hierro o sellos-, comienza a girar con una velocidad que varía de acuerdo con la cantidad de agua vertida sobre la rueda. Este eje pivota, por medio de una espiga de hierro o gorreón, sobre una zapata o cabezar amarrada a una pieza de

${ }^{131}$ Inventario de las ferrerías de Río Cabo (1838): "También se hallan corrientes las baras con sus argollas de fierro para tirar por estas cuando se bajan y suben las mazas de la trompa $y$ chifrán de la rueda de macear". En I. GARCÍA TATO. (2000): Ob. cit., p. 123. 
madera llamada durmiente, que un ingenioso y rústico sistema, la canal o canaleta, refrigera con agua para impedir su calentamiento ${ }^{132}$.

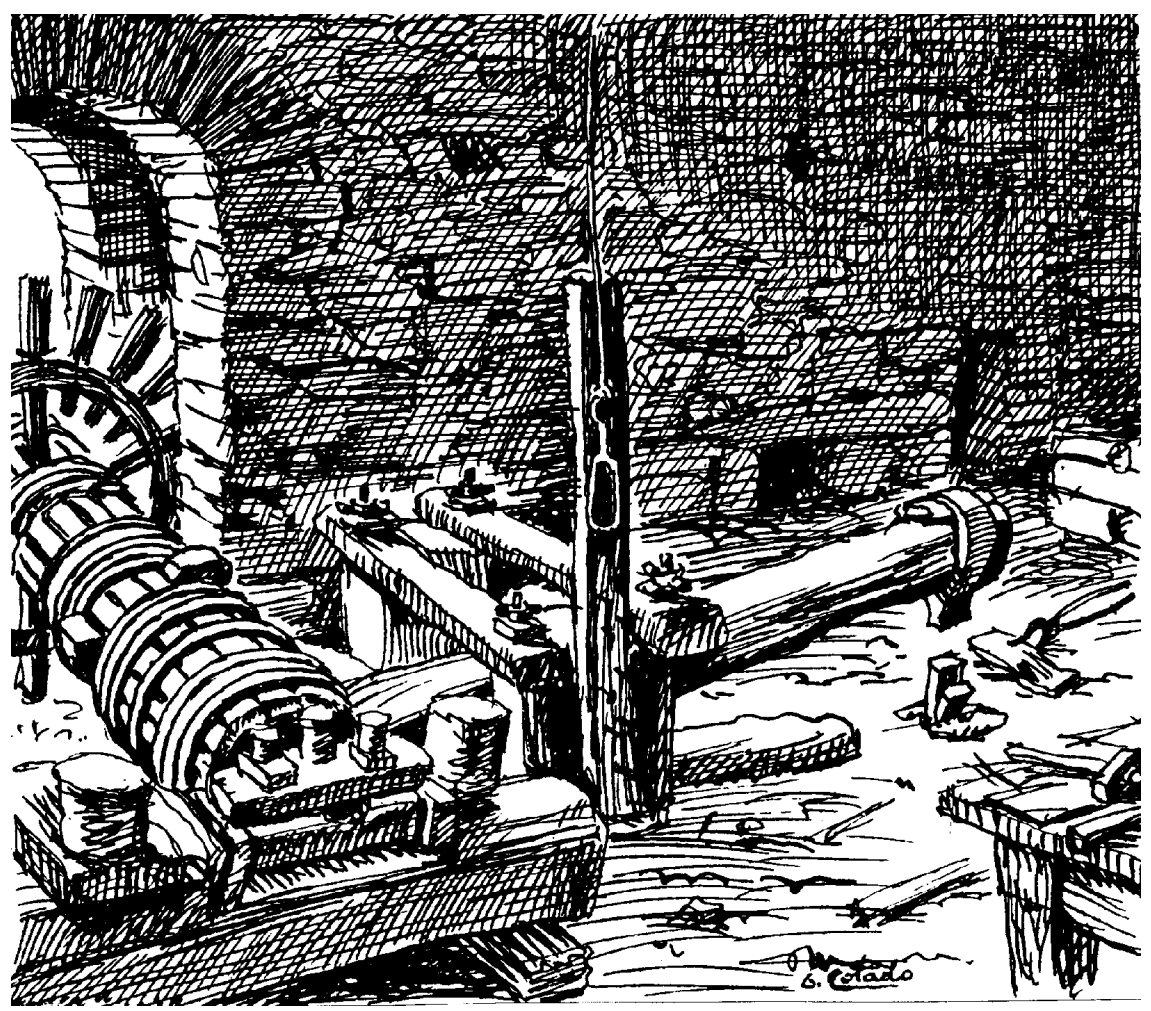

Mazo de Compludo, León (dib. P. G. Cotado)

El extremo del eje opuesto a la rueda está provisto de cuatro piñones, levas, trinquetes, manubreiros o malugreiros (mazuqueiros también; en vasco maisukariak), que en su giro golpean la parte posterior, reforzada con una plancha de hierro o dendala, del martillo pilón, palanca de unos cuatro a

${ }^{132}$ Foro de la ferrería de Montealegre del año 1571, entre las condiciones del propietario, lo señores de Presno, está el proporcionar madera para "el arbol mayor o menor, çepos $e$ dormientes, e puercas o maderas principales o mayores, ansi de la presa como de la herreria o camarado". Cit. en J. LÓPEZ y A. GRINDA (1998): Ob. cit., p. 127. En el inventario de las ferrerías de Río Cabo (1838): "En ésta (fábrica) se halla un palo nominado de árbol mayor con su rueda todo bien corriente y dicho palo bien cinchado con arcos de fierro y bandas de lo mismo por debajo de aquellos. Sus gurriones o eges buenos y para sostener el que se llama de las manos (...) dos cepos firmes y corrientes y casi sin intermedio otros dos que se llaman los mayores también corrientes, para sostener el fierro que llaman la boga, donde se introduce el mango y el mazo para elaborar el fierro, ambas dos piezas indicadas se hallan corrientes y lo mismo la semela, banda y sucello que se ponen en dicho mango también de fierro. También se hallan las cuñas de fierro necesarias en el topete del mango para apretar el mazo, cuando es necesario, lo mismo en dicha boga y las necesarias tambien en las aldabarras para llebar adelante o atrás dicho mazo, pues todo es indispensable para arreglar el macear. También se halla una yunque de fierro al parecer buena donde peta el mazo para tirar el fierro". En I. GARCÍA TATO, I. (2000): Ob. cit., p. 124. 
seis metros de longitud ${ }^{133}$, obligándole a ejercer un movimiento de arriba hacia abajo; movimiento que es posible porque hacia la mitad del mazo, éste juega sobre unos cojinetes de hierro, la boga, especie de anillo de hierro que abrazaba el mazo con dos extremos salientes, engastados sobre dos piezas de madera denominadas aldabarra, la inferior y gato, la superior. En el otro extremo, el mango va provisto de un mazo de acero que, rítmicamente, golpea sobre un yunque, ingre o bigornia también de acero, clavado en el suelo rocoso de la ferrería. Estos golpes se repiten cuatro veces en cada giro completo del rodezno. Dado que el mazo era una pieza muy costosa ${ }^{134}$ y de poca duración, con frecuencia se ponían aros, flejes o sellos de hierro para reforzar el árbol ${ }^{135}$.

La velocidad del mazo está en relación con el movimiento del rodezno y el número de piñones o malugreiros que, como hemos dicho, suelen ser cuatro; generalmente alcanza de 80 a 120 golpes por minuto ${ }^{136}$. Estos golpes someten el mango del mazo (árbol de macear se le llama a veces) a tal presión que su vida suele ser corta, no superando normalmente los dos o tres años ${ }^{137}$.

\footnotetext{
$133 \mathrm{El}$ mazo de la ferrería de Compludo tiene, desde la cola hasta el martillo, 3,92 metros, su punto de apoyo se encuentra a 2,67 m. del martillo, pero probablemente es pequeño respecto a la media de las ferrerías. Por ejemplo, en 1692 en el pleito por la construcción de la ferrería de Quintá: "medieronse los dos arboles de la eraria vieja y se alló tener de largo el arbol de la rueda de mazear siete varas menos una quarta y el arbol de la rueda barquinera siete baras menos otra cuarta. Medieronse el ancho del rio por junto por donde sale el agua de la estolda de la dicha eraria y de orilla a orilla, en ancho, se alló tener doze baras. Medieronse los dos arboles de las ruedas de la fabrica nueba y el que esta puesto en ella que dijeron era el de maçear se alló tener seis baras de largo y el otro arbol que está tendido en el soto que llaman de la Puente y dijeron ser para la rueda barquinera de dicha nueba fabrica se allo tener de largo siete baras y dos tercias de otra...” (AHRG. R.A.: 1662/4). Es decir que estos árboles superaban los cinco e incluso los cinco y medio de largo.

${ }^{134}$ En 1641 se colocó el árbol de la ferrería de Lousadela "que costó ponerse más de cien ducados" (AHRG. R.A.: 19.816/8

135 Jovellanos, que visitó la ferrería de Belmonte en 1792, habla de cómo en la fragua "se formaba la última sortija para el gran dedo", aludiendo a un aro para el árbol de macear. JOVELLANOS: Diarios (1792), p. 103.

${ }^{136}$ Carmen Ceballos, por el contrario, afirma que en las ferrerías de Cantabria el número de golpes por minuto era de sólo 60 a 65. En C. CEBALLOS (2001): Arozas y ferrones. Las ferrerías de Cantabria en el Antiguo Régimen. Santander, p. 145

137 Eso era lo normal pero había casos extraordinarios, por ejemplo hacia 1721-1724, quebró el árbol de la ferrería de Villanueva de Oscos en plena campaña, por lo que hubo que buscar otro nuevo, que se halló en lo más intrincado del bosque. Solo con ayuda de muchos campesinos pudo llevarse la ferrería: "es alaja verdaderamente que no se allará mejor en muchas leguas en contorno, tan firme y bueno, que aseguran los que entienden durará más de setenta años". En Fr. D. YAÑEZ (1973): "El monasterio de Villanueva de Oscos y sus abades". BIDEA, n 8o, p. 700 .
} 
El mazo tiene por finalidad golpear la zamarra para estirarla en bandas o barras, además de eliminar las escorias e impurezas del hierro. Tanto Munárriz como Datoli ${ }^{138}$ señalan que los mazos de las ferrerías bercianas eran de poco peso, en relación con la magnitud de la zamarra que sale del horno. Según este último, los martinetes de las ferrerías de Vizcaya tenían 14 ó 15 quintales de peso (entre 644 y $690 \mathrm{~kg}$.) "o seis veces más pesados que en las del Bierzo"139; que, de acuerdo con esto, tendrían menos de $200 \mathrm{~kg}$. de peso, cifra que tal vez habría que elevar en la mayoría de estas ferrerías, que suelen pesar de 300 a 500 kilos, como señalan algunos autores gallegos y asturianos ${ }^{140}$.

\subsection{Las herramientas}

En la ferrería, además de carboneras, ruedas, mazos y barquines ${ }^{141}$, se utilizaba un buen número de herramientas, de las que nos informan los inventarios que conocemos, cada una especializada en una tarea diferente. Así las tenazas, de las que se nombran los siguientes tipos: tenazas mayores, tenazas de gabear, tenazas de caldear, burras o burricas, tenazas de repillar, corbas mayores y menores, de cortar las ágoas, corbetas. Hay igualmente varios tipos de barras o palancas: la de levantar las ágoas, la de fundir y la palanqueta, ésta para limpiar la vena. Entre los mazos se citan el mayor y el menor, marras, marrotes para enderezar el hierro, el martillo de tazar la vena, martillo de dos gallos, tajaderas para partir las ágoas, palas para la vena, torna de carbón, subara, rodos de sacar las brasas de la fragua, etc. ${ }^{142}$.

${ }_{138}$ MUNARRIZ, p. 130.

139 DATOLI, 55. Por su parte, I. CARRIÓN (1991). Ob. cit., p. 196 menciona que los de Agariz y Olaberría, a finales del siglo XVIII pesaban entre 300 y $400 \mathrm{~kg}$. el mazo. Claro que si le añadimos la boga, con un peso en torno a los $170 \mathrm{~kg}$., el total daría un peso entre 470 y $570 \mathrm{~kg}$.; J. CANTELAUBE (1993): Ob. cit. p. 31, afirma que las ferrerías de la zona de Ariéges, en Francia, el martillo tenía unos 600 kilogramos de peso y golpeaba de 100 a 125 golpes/minuto.

${ }^{140}$ En Asturias la ferrería de Veiguiña (Tapia de Casariego) tenía en 1852 dos mazos, uno llamado "mayor", cuyo martillo de hierro pesaba 7 quintales o $490 \mathrm{~kg}$. La ferrería de Ceneya (Amieva) el mazo grande pesaba en 1866 cincuenta arrobas aproximadamente (550 kg.). En J. LÓPEZ y A. GRAÑA (1998): Ob. Cit., p. 22. En Cantabria, C. Ceballos (ob. cit.) habla de un peso medio de $350 \mathrm{~kg}$.

${ }^{141}$ AHPLu: 2478/4: acuerdo de uso de la ferrería de Ferreirós en 1788 por sus diversos propietarios al estar dividida en ágoas: "entendiéndose quanto al artefacto y casa de dicha ferraria, carbonera, rueda, banzado, barquines, tuberas, mangos, zepos, boga, yunque, mazo, canada, palancas, thenazas maiores y menores, marras, talladeras y picachos de la brasa, torna carbón y más herramientas".

${ }_{142}$ Inventarios de ferrerías: ferrería de Soldón (año 1574): AHRG. R.A.: 19.768/72; ferrería de Lor (año 1759): cit. en I. GARCÍA TATO (1999): Vilanova, Outarelo y San Francisco Blanco. Monografía histórica de una parroquia gallega. Instituto de Estudios Valdeorreses. Cuaderno 
Era muy frecuente, pues se hacía imprescindible, que en las ferrerías hubiera una fragua de mano para arreglar esas herramientas ${ }^{143}$.

\subsubsection{La carbonera y bodega}

Era un edificio diferente, frecuentemente a continuación del de forja pero también podía situarse paralelo a ella. Normalmente se hallaba dividido en dos partes: la mayor la ocupaba la carbonera, con un cuarto donde el tazador partía la vena en pequeños trozos semejantes a avellanas, que era como se introducía en el horno ${ }^{144}$; la otra la bodega (adega en gallego) donde se guardaba el hierro listo para la venta ${ }^{145}$. En el CUADRO III hemos visto las dimensiones de este espacio en algunas ferrerías del noroeste, con medias en muchos casos que superan los $200 \mathrm{~m}^{2}$. En algún caso había además un pequeño cuarto en el que dormían los trabajadores, como en la de Pombriego, en León. El peligro de incendio así como la necesidad de más volumen para acoger el carbón hacía que este edificio fuera normalmente más alto que el resto de la ferrería ${ }^{146}$.

monográfico $\mathrm{n}^{\circ}$ 30, p. 495-498; ferrería de Ferreirós (año 1788): AHPLU: 2478/4; ferrería de Tejedo (año 1802): AHPL. P.N.: 3.783; ferrería de Soldón ( año 1815). AHPLU: 2406/3; ferrería de Quintá (año 1836): AHRG. Hombreiro 21/4; ferrería de La Veguiña (año 1852): cit. J. LÓPEZ y A. GRINDA (1998), p. 145 y 146; ferrería de Valdomir (año 1868): AHPL. P.N.: 9.113.

${ }_{143}$ AHPLu: 2478/4. En 1788 los dueños de las diferentes ágoas de la ferrería de Ferreirós acuerdan el uso de la ferrería y herramientas. En el acuerdo, hablan de hacer una fragua de mano para el arreglo de éstas. En 1815 (AHPLu. 2406/3) se inventaría la fragua de manos corriente con su tobera de cobre, yunque, dos martillos y dos tenazas, una rueda de piedra de afilar,

144 AHPLu: 2406/3. Inventario de Soldón de 1815 se menciona la carbonera "con una yunque de fierro en que se taza la bena, el carro de traerla usado". En la carbonera propiamente se citan 9.600 rs. de carbón. En el inventario de la ferrería de Lor, de 1759, en la bodega reconocen unas existencias de carbón suficientes para tres meses y medio, cuyo carbón vale 6.268 rs. y $17 \mathrm{mrs}$. En I. GARCÍA TATO I. (1999): Vilanova, Outarelo y San Francisco Blanco. Monografía histórica de una parroquia gallega. Instituto de Estudios Valdeorreses. Cuaderno monográfico $\mathrm{n}^{\circ} 30, \mathrm{p} \ldots$

145 En el inventario de la ferrería de Soldón de 1815 (AHPLu: 2406/3) se menciona en la bodega "la valanza de pesar (el hierro) con su quintal de fierro de dos piezas, una pesa tambien de fierro de 40 libras, otra de 10, otra de 6, otra de 5, otra de 4, de 3, 31/2, la arroba y la media (arroba) todo de fierro". Además 39 quintales de hierro y 23 libras, 11 en tocho y el resto en rejas, picado, lampo y algunas repuntas.

${ }^{146}$ En la reforma de la ferrería de Villanueva de Oscos, de 1789 se dice: "se levantaron algunas paredes desde el cimiento, y otras se reformaron y se les dio mayor altura, como también a los postes interiores de las carboneras, que sustentan su tejado, afin de hazerla más capaz de recibir, como recibe duplicado carbón del que cabía antes de esta obra. Para echar, distribuir y llenarla de carbón hasta la inmediación de su cumbre, se hicieron escalres, un corredor y balaustrado" AHN. Sección clero: Libro 9437. 


\section{LA FORJA}

El hierro que salía del horno de la ferrería debía de ser forjado. Es este el proceso de conformación de los metales por el que, aprovechando su ductilidad y maleabilidad y sometiéndolos a esfuerzos violentos de comprensión a determinada temperatura, se modifica su estructura, se estiran, se hacen más resistentes; en definitiva se mejoran sus cualidades. Esta operación requiere calor y fuerza, lo que se logra por medio de hogares y mazos en los martinetes o machucos, y de mazas o martillos en las fraguas; en la moderna siderurgia se consigue mediante grandes martillos pilones y trenes de cilindros de laminación.

\subsection{Los mazos, machucos o martinetes.}

Los mazos o machucos son pequeños edificios, normalmente de tosca mampostería, sobre la falda de una montaña y al lado de un cauce de agua. Esta, conducida desde el río hasta un banzado, permitirá accionar el martillo pilón, llamado con más propiedad martinete, mazo o machuco (es esto lo que da nombre a estos ingenios, en los que se toma la parte por el todo). Su producción principal consistía en estirar y espalmar el hierro con objeto de prepararlo para un posterior uso (varilla, plancha, barras, pletinas, etc.); pero también elaboraban piezas domésticas y para el trabajo agrícola. Con frecuencia a su alrededor había varias fraguas que, por días de mazo, lo utilizaban; pues a diferencias de las ferrerías, normalmente de un solo propietario, aunque también hemos visto alguna que podían estar divididas en ágoas, los mazos solían ser de varios propietarios o, al menos, varios herreros como arrendatarios trabajaban juntos o independientemente unos de otros ${ }^{147}$.

\footnotetext{
147 AHPL. P.N.: caja 2.126 (1646): Venta en el mazo de Santigoso de "un día de mazo menos un quarto en cada semana de mazo que les corresponde con los más herederos en el mazo que se halla en este dicho lugar en la fragua del medio". El mazo de Melezna, como ya veremos, pertenecía a los herreros de varias fraguas que estaban en su alrededor.
} 


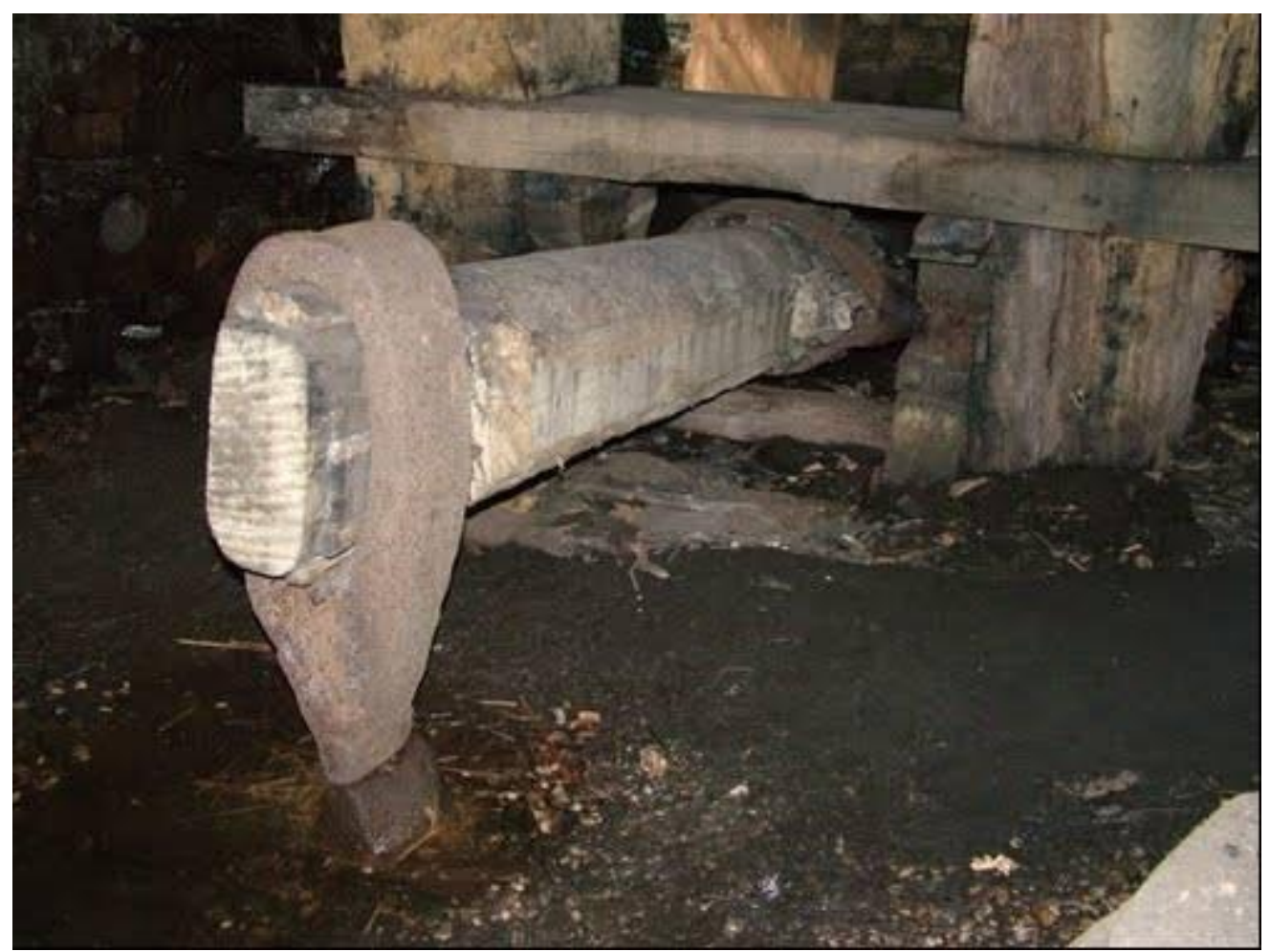

Mazo de Besullo (Asturias)

Los mazos son semejantes a las ferrerías pero se diferencian de estas en que no tienen horno para reducir el mineral de hierro, por lo que el hierro se lo suministran aquellas. En el País Vasco se las conocía como ferrerías menores para distinguirlas de las ferrerías mayores. También son más pequeñas sus edificaciones, pues generalmente no constan más que de un cuarto en el que se encuentra el mazo y un hogar, fogón o regazal para caldear el hierro, al que se inyecta aire por medio de un fuelle o barquín movido por una rueda hidráulica o por una trompa catalana ${ }^{148}$. Carecen de grandes carboneras porque el consumo de combustible es pequeño. Generalmente el martinete de los mazos suele ser mayor que el de las ferrerías; es decir, tiene más peso ya que el fin de los mismos es forjar el hierro a fuerza de golpes. Larramendi dice, por el contrario, que estos eran más pequeños que el de las ferrerías mayores, pero Datoli y Munárriz afirman lo contrario respecto de las bercianas ${ }^{149}$. Mediante la calda y la carburación se conseguían aceros de cierta calidad.

\footnotetext{
${ }^{148}$ Foro del mazo de Folgoso, año 1612: "la mytad enteramente de el dicho maçuco de Folgoso con su presa y banzado y mazo de macear con mas una fragua con sus varquines, yunque $y$ mas aderentes a ella necesarios" (AHPLU: 2408/2).

149 MUNÁRRIZ, p. 130; DATOLI, p. 55. En Un informe del siglo XVIII asturiano se habla de los mazos de los martinetes diciendo que "los martillos de 200 a 400 libras de peso dan por el mayor número de malobreros de que van guarnecidos los árboles, 120 ó 200 golpes por
} 
Los mazos suelen ser edificios exentos, aunque algunas ferrerías tuvieron al lado machucos que formaban parte, por tanto, del mismo proceso productivo. La ferrería de Valdomir, por ejemplo, tenía al lado uno150; en Portela de Valcarce, un documento de 1859, dice que hay "una herrería y a su lado un martinete surtido con las mismas aguas que la herrería". Las ferrerías asturianas de Lagar y A Cabanada igualmente contaban con un mazo propio, al lado o en las inmediaciones. También algunas ferrerías, en determinadas épocas del año, realizaban labores de mazo, como ocurría con la de Paleiras en el siglo XVIII y en la de Llamas en el XIX ${ }^{151}$. Algunos mazos se transformaron con el tiempo en ferrerías y algunas ferrerías en mazos ${ }^{152}$.

Con frecuencia los mazos pertenecían a varias personas que los utilizaban conjuntamente, pues solían dividirse en quiñones, quendas o calendas 153 . Generalmente cuando tocaba la vez o quenda, trabajaban dos personas: el maestro de mazo y un aprendiz o ayudante, pues las operaciones de calda, estirado y espalmado de las piezas eran operaciones complicadas, que un solo hombre no podía realizar o que lo hacía con mucho esfuerzo y pérdida de tiempo. La calda exigía tirar de la vara que abría el agua para mover la rueda de los barquines, si los tenía, o del arca o trompa, y lo mismo había que hacer para accionar el mazo, operaciones que solía realizar el aprendiz, mientras el maestro sometía al mazo las piezas que debía estirar o espalmar.

minuto; bastan para pulir una barra de 14 pies de largo de 7 a 8 minutos" (A.M.N. Col. Guillén, CMLXXIII. F. de Armas).

${ }^{150}$ AHRG. R. A.: 21.359/74. : En 1640 Diego de Prada vende la tercera parte de "la herraria de Valdomir, y el machuco, con todo lo a ella perteneciente en fauor de D. Venito Armesto y Valcarce y de $D^{a}$ María de Valcarce, su mujer" en precio de 8.100 reales.

${ }^{151}$ Durante el verano se utilizaba como machuco para fabricar rejas y batederas. Entre los gastos que anota el administrador menciona el del vino de "cuatro dias que ocuparon los oficiales antes de empezar a trabajar arreglando la Herrería que dejaron los mazuqueros descompuesta", y en sus cuentas antota que desde el 27 de agosto de 1880 hasta el 7 de septiembre del mismo año "se hicieron en la ferrería 14 quintales y 80 libras de rejas y un quintal y 30 libras de batederas". Documento privado en mi poder: cuentas de la ferrería de Llamas.

${ }^{152}$ AHPL. P. N.: 3581 (1846): ferrería de Outeiro. Acuerdo entre los dos hermanos que "construyeron un mazo o martinete de hacer rejas, batideras y otras herramientas en dicho lugar de Otero. Posteriormente, aunque separados y bajo la misma compañía lo elebaron a herrería de fundir y labrar hierro".

153 AHPL. P.N.: 2.126 (1646): Del mazo de Santigoso, en 1646, sabemos cómo uno de sus propietarios vende "un día de mazo menos un quarto en cada semana de mazo que les corresponde con los más herederos en el mazo que se halla en este dicho lugar en la fragua del medio". 
Como en la ferrería, también en el mazo eran precisas muchas herramientas especializadas, unas para los ajustes y el mantenimiento del artefacto, como el porrón o maza y la tenaza turquesa para calzar el mazo; otras para el manipulado y forja del hierro, para la que eran necesarios distintos tipos de martillos, tenazas, cizallas y tajaderas 154 .

\subsection{Las fraguas}

En las fraguas, a veces llamadas más simplemente forjas o herrerías, se realiza la última operación sobre el hierro, el trabajo sobre piezas pequeñas para la elaboración de utensilios domésticos (calderos, sartenes, ollas, tijeras, llaves), aperos de labranza (rejas de arado, azadas, azadones, palas), herramientas de corte (cuchillos, navajas, hachas, hoces, guadañas), herraduras, clavazón, etc.; también era el lugar al que los campesinos llevaban a arreglar sus aperos cuando estos se desgastaban: calzar la reja del arado, afilar los utensilios de corte, etc. En ese sentido eran imprescindibles en la economía campesina de otros tiempos y su localización asequible, pues al no ser hidráulicas se podían ubicar en cualquier parte. Igualmente las había en villas y ciudades, aunque en este caso solían situarse en lugares que no molestaran a los vecinos, pues frecuentemente suscitaban protestas ${ }^{155}$. En ambos casos, los trabajadores solían ser únicamente el maestro herrero y algún aprendiz.

Las fraguas son hogares abiertos provistos de inyección de aire para forzar la combustión, y aunque hay diferencias de acuerdo con la especialización del herrero (de clavos, de herradura, armero, etc.) solían tener todas ellas un gran parecido. La fragua tradicional suele ser un pequeño edificio de mampostería o adobe, muchas veces rehundido en la tierra y cubierto de losa o tejas, que consta generalmente de una sola habitación. Unas veces el edificio

\footnotetext{
154 AHRG. R. A.: 21.859/104, ferrería y machuco de Pesqueira, y AHRG. R. A.: 20.527/41, machco de Saviñao.

155 En 1593 varios vecinos se opusieron en Vivero a la construcción de una fragua en una calle "donde vive gente noble y principal", porque los golpes de los herreros "abastan para atronar todo el barryo", estropean el vino de las bodegas, y perturban a las personas nobles no acostumbradas a "semexantes hestruendos y golpes, lo qual no podía dexar de causarles mucho daño a su salud" (AHRG. R.A.: 25.922/25).
} 
está dentro de la población, otras a las afueras del poblado ${ }^{156}$ por el ruido. En Asturias hay fraguas debajo de los hórreos, como en Parlero (Villayón) ${ }^{157}$, también podían situarse en la parte baja de la casa vivienda del herrero, aunque esto era menos frecuente por miedo a los incendios y por el ruido.

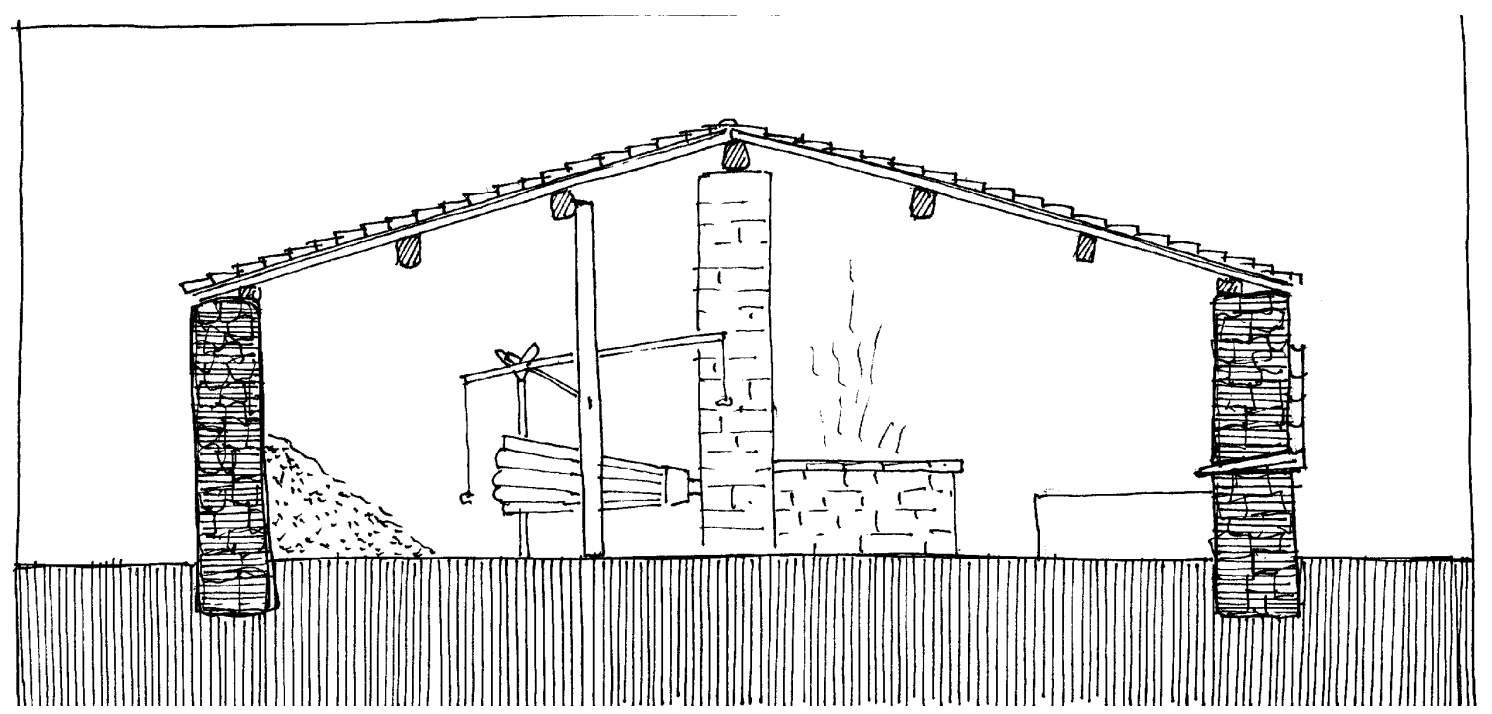

Fragua (dib. E. Algorri)

Generalmente la fragua costa de un hogar o regazar, que puede estar hecho en mampostería, arcilla u otro material, en el que se hace el fuego para caldear las piezas. El combustible solía ser carbón vegetal que produce pocas impurezas, y desde el siglo XIX hulla semigrasa y coque. Unas veces el hogar está pegado a la pared, otras separada de ella. El fuego se aviva mediante un pequeño barquín o fuelle movido a mano ${ }^{158}$. El hierro al rojo vivo se saca con

${ }^{156} \mathrm{El}$ inventario de bienes del herrero Francisco González, vecino de Burbia, en 1784 dice que le pertenece "un cuarto de casa cubierto de losa, que sirbió de fragua al sitio que llaman el rego, dentro de esta población" (AHPL. P. N.: 3398); en Pereje se vende en 1796 "una casa cubierta de losa que sirbe de fragua de hacer y adobar erraje" (AHPL. P. N.: 3398).

157 En 1858 Juan Ochoa y su mujer, vecinos de Colobredo, se obligan a pagar a José Antonio Lombardero 5.203 reales por hierro y para ello hipotecan la casa en que habitan, la panera y "la fragua con todos sus pertrechos debajo de la panera”. En J. LÓPEZ y A. GRAÑA (1998): Ob. cit., p. 73

${ }^{158}$ Los yunques y barquines son los elementos más citados en la documentación: año 1581 foro de una fragua al herrero Diego Dalba en Albariza (Asturias) "que tiene unas varquias con su tubera, una incla, una vigornia con tubo de gruesas y otros de fesorias, una clavera con dos punzones para hazer erraduras, dos vergas para clavos, unos muelles y cuatro martillos, tres tenazas, dos tajadoras" (AHN. Pap. Leg. 136, libro foral $1^{\circ}$, f. 128); año 1660 incendio de Villanueva de Valdueza, casas, lagares, "y los aderezos de la fragua que estaban dentro ... como era un yunque de hierro, los barquines...” (en J.D. RODRÍGUEZ CUBERO (1996): El señorío de Villanueva de Valdueza. Ponferrada, p. 49); año 1774: inventario de Domingo López, de Burbia: "Una casa fragua con sus barquines viexos, una yunque, bigornia y más herramientas. Vale todo trescientos reales" (AHPL. P.N.: 3395); año 1779: venta de una fragua en San Cristóbal de Montes: "con sus barquines, yunque, martillos y más pertrechos necesarios en dicha fragua" 
unas tenazas y se golpea sobre el yunque o incla, que suele apoyarse sobre un cepo o tocón de árbol, con un martillo de golpear o mandarria. El yunque de hierro o acero suele ser una pieza que el herrero compra; en sus agujeros normalmente dos- lleva otras más ligeras terminadas en pico, a las que se denomina bigornias, necesarias para ciertos trabajos, como doblar las piezas. A su lado solía haber un recipiente con agua (cocín, en Asturias) para templar el hierro, lo que se logra calentándolo y enfriándolo luego bruscamente, y una piedra de afilar. Entre los utensilios, además de mazas, martillos y tenazas, hay tajaderas, tijeras, claveras, etc ${ }^{159}$.

Las ferrerías solían contar con una fragua con barquín de mano donde se reparan las herramientas ${ }^{160}$; también había fraguas al lado de los mazos, de los que se servían en los llamados "días de mazo", como vemos en el caso de Santigoso, Melezna o Valdomir ${ }^{161}$; pero era más frecuente que éstas se encontraran diseminadas por pueblos y aldeas ${ }^{162}$. Los trabajos de forja más

en 545 rs. (AHPL. P.N.: 2571); 1789: venta en Santa Eufemia de Visuña: "una casa de fragua de herrero cubierta de losa con sus aderentes de yunque, barquines y más pertrechos..." (AHPLu: 2417/9). En Asturias estos barquines de fragua se denominan de campanilla: en 1838 se vende en Taramundi "una fragua o barquín de campanilla para trabajar su oficio de herrero" (AHPLu: 2072/8).

159 Muchas escrituras de venta o inventarios mencionan los útiles de las fraguas. La de Meixans, que se hipoteca en 1797, dice que lo hace "con sus fuelles, yunque, martillos, tenazas y demás aperos de ella necesarios al ejercicio y oficio, que este otorgante tiene de herrero". La fragua de Francisco González en Burbia tiene "dos barquines con su tobera, una yunque, una bigornia, dos martillos mayores, cinco menores, dos claberas, dos tufos o punteros, una sufridera de ojo, dos pares de tenazas de fragua, dos tixeras largas para cortar el yerro de calderos, un tornillo de hierro para limar, una yunque para componer los calderos, siete limas pequeñas y medianas, dos cortaderas de cortar yerros, una rueda o piedra grande para afilar y amolar los yerros" (AHPL. P. N.: 3398 (1784).

160 En un inventario de la ferrería de Tejedo, hecho en 1802, después de inventariar edificios y parte de la ferrería, añade los utensilios de la fragua aneja: tres tenazas, unas tijeras, dos martillos grandes y dos chicos, una bigornia, tres claveras de mano y dos de cepo, una cortadera, ocho tufos, una lima de media caña grande, tres cortaderas (AHPL. PN.: 3.783).

${ }^{161}$ En 1596 Juan de Zuluaga, rendero de las ferrerías de Loureiro y Valdomir, arrienda a Bastián da Ribera, ferramentero vecino de Valdomir, "una fragua con sus barquines, yunques y más aderentes nezesarios que ella tiene en el dicho maçuco en la que al presente labra y travaxa el dicho Bastián da Ribeira" por diez ducados de renta (AHPLu: 2407/9 (1596)

162 MUSEO NAVAL: Col. Guillén, ms. 2.175, p. 4, año 1795. Informe de Pedro Delgado sobre "Razón de las fraguas de las inmediaciones de Rivadeo": Concejo de Santa Eulalia de Oscos: 104, idem de Villanueva de Oscos: 19, idem de San Martín de Oscos: 12, idem de Yllano: 11, idem de Boal: 191, idem de Taramundi: 127, idem de castropol: 84. Total 548. Nota: "Pudiera nombrar los sitios y dueños de estas individualmente, dejo de hacerlo por no creerlo necesario pero se puede contar con muchas más, en el supuesto de lo dificil que es una indagación precisa que no ha sido mi obgeto". 
importantes son el martillado, el estirado, el recaldado, el plegado y la soldadura. El trabajo de los herreros dependía de su habilidad y del aprendizaje. A diferencia de los herreros de las aldeas, que hacían un poco de todo; los de las villas y ciudades -también en el ámbito comarcal- estaban más especializados: herreros propiamente dichos, cerrajeros, cuchilleros, de clavazón, armeros, etc., los cuales, además, tenían una estructura gremial, que comentaremos en el capítulo quinto. 


\section{LAS CONDICIONES GEOGRÁFICAS DE LAS FERRERÍAS: AGUA Y COMBUSTIBLE.}

La existencia en el Noroeste de España de una importante actividad siderúrgica durante los siglos XVI al XIX se explica, en parte, por la abundancia en esa región de aquellas materias primas imprescindibles para ponerla en marcha: agua, carbón vegetal y mineral de hierro. No es extraño, por esa razón, que los propietarios de la tierra y los concejos expliciten a menudo, en la concesión de permisos para la construcción de ferrerías en sus términos, que lo hacen atendiendo a "que tenemos superabundantes montes para coadyubar a la perpetua existencia de la propuesta fábrica"163; o por ser sus montes "tan abundantes en zepa de urz y fáciles de reproducirse, y otras maderas capaces por si solos de sostener y abastecer una ferrería o fábrica de hacer hierro"164. Pedro Díaz, rendero de la de Valdomir, denuncia en 1619 a vecinos de Santa Eufemia, en el Caurel, por abrir una presa para regar sus prados, alegando que tenía "en fuero real la dicha ferrería de Valdomill, aguas, montes y beneras a ella anejo y pertenecientes para el uso y exercicio della"165. En el texto aparecen explícitamente las condiciones necesarias para fabricar hierro: agua, carbón y mineral.

El agua y el bosque condicionan en gran manera la geografía ferrera, ya que estos artefactos se localizan siempre a orillas de ríos y arroyos, por ser el agua necesaria para accionar los mazos y barquines. La existencia de numerosos cursos fluviales que vierten sus aguas al Atlántico y al Cantábrico, jerarquizados en torno a algunos grandes ríos, fue un factor de primer orden en la construcción de ferrerías y mazos. Estos y aquellas no se localizan en los cursos de mayor caudal, como el Miño o el Sil, sino en sus afluentes, de los que, por medio de un canal, los propietarios extraían el agua que conducían hasta ellas para accionar sus ruedas. En muchos ríos sólo existe un artefacto pero fue frecuente construir varios sucesivamente, hasta convertirse en verdaderos "ríos

\footnotetext{
163 Así dicen en 1788 los vecinos de Tejedo de Ancares (AHPL. P.N.: 3492, año 1788). 164 Como afirman los vecinos de Lusío (Oencia) en 1840 (AHPL. P.N: 3580, año1840). 165 AHRG. R. A.: 5951/55. Derecho por el que, añade, pagaba "fuero y rrenta al rey nuestro señor y al comendador de la Varra en su nombre”.
} 
de las ferrerías"166, como también ocurría en el País Vasco y Cantabria. Pese a la abundancia de agua, en muchas ocasiones hubo problemas por su uso, no sólo entre ferrerías, sino entre estas y los dueños de molinos y batanes, o con campesinos y comunidades aldeanas que la utilizaban para el riego de sus campos.

Más problemas que el agua causó el combustible. Las ferrerías, además de leña para raguar el mineral, sólo utilizaban carbón vegetal para reducirlo; por lo que era necesaria la existencia de abundantes bosques para alimentarlas. Por sus condiciones físicas y climáticas, el área estudiada fue rica en ese recurso; pero la negligente política forestal seguida por arrendatarios y autoridades acabó arruinando el bosque. No fueron solo las ferrerías, sin duda grandes consumidoras de madera y carbón, o los astilleros de la Armada para los que se guardaban los mejores ejemplares de árboles bravos, las que despoblaron los montes, sino la ausencia durante siglos de una decidida política repobladora ${ }^{167}$. Francisco Javier Datoli se extrañaba, hacia 1797, que en una zona con ferrerías antiquísimas como el Bierzo no hubiera plantíos para raguar el mineral ni se arrancara el brezo de forma racional para fabricar carbón ${ }^{168}$. Esta negligente política y la desaparición del bosque subsiguiente se convertía, a fines del siglo XVIII, en un factor limitador para la expansión de las ferrerías, que momentáneamente se paliaría en el siglo XIX con la desamortización y un mayor control del bosque por las autoridades.

\footnotetext{
${ }^{166}$ Así se denominaba, por ejemplo, al Porcia, en Asturias. También hay ríos con el nombre de Ferreiros o de la Ferrería, como el Narón llamado Ferreiros, o el Ferreira afluente del Eo. Varios otros se conocieron igualmente como ríos do Mazo por accionar las ruedas de martinetes.

167 A. FLÓREZ ESTRADA (1852): Curso de economía política. Atlas. Madrid, 1958, p. 37, nota 1: "En España la mal entendida legislación de montes ha sido en mi concepto la principal causa de la mezquina producción que hemos obtenido de este importantísimo ramo (de producción de hierro)".

168 F.J. DATOLI, en J.A. BALBOA DE PAZ: El Bierzo en la obra de dos militares del siglo XVIII: Datoli y Munárriz. Ponferrada, 1992, p. 56. Se extrañaba este que en el Bierzo los dueños de las ferrerías "no hayan hecho hasta aquí ningún plantío que pueda asegurar el surtido de leñas para raguar el mineral, ni menos para las maderas indispensables para la conservación de las máquinas, ni tampoco establecido un método para cultivar y aún arrancar el brezo de que hacen carbón".
} 


\section{EL AGUA}

Las ferrerías son ingenios en los que, mediante un procedimiento directo, se reduce el mineral de hierro en hornos bajos. Para llevar a cabo tal reducción se precisa calor y agua, esta última para mover las ruedas que accionan los barquines que inyectan aire al horno, y el mazo donde se forja el hierro a fuerza de golpes. Agua, leña y carbón son, por ello, verdaderos condicionantes de la localización de las ferrerías, aunque también la facilidad de acceso y, por tanto, las vías de comunicación deben tenerse en cuenta, tanto para adquirir la vena como para comercializar el hierro.

\subsection{La geografía ferrera}

Las ferrerías y mazos del noroeste de España se localizan en las provincias de León, Lugo, Orense y Oviedo. Sin embargo, el espacio en que se sitúan es más restringido de lo que aquellas provincias ocupan. No hubo ferrerías en León, sino en el Bierzo, es decir en el ángulo noroeste de la provincia ${ }^{169}$; tampoco las hubo en Orense, solo en la comarca de Valdeorras y, en menor medida, en la del Bollo. En Oviedo esta actividad tuvo una extensión mayor a lo largo de su historia; pero agotados los bosques de la zona costera oriental antes del XIX, la mayoría de las ferrerías se situaron en el occidente, en la zona de los Oscos, Castropol, Valdés y en el curso del río Eo; aunque también hubo algunas en la zona del interior oriental de los concejos de Penamellera, Ponga, Onís y Amieva. Sólo Lugo resulta una excepción, pues hay ferrerías en muchas comarcas, aunque preferentemente se encuentran en el Caurel y en los valles de Lóuzara y Quiroga, afluentes del Sil; pero igualmente se construyeron otras en afluentes de los ríos Miño, Eo y Navia; e incluso en la costa, en el Valle del Oro (Valadouro), en los ríos Asma, Landro, Ourol y otros pequeños cursos de agua cantábricos.

${ }^{169}$ En el siglo XIX, Los Anales de Minas mencionan una ferrería en Boñar "que usa mena del país". 


\begin{tabular}{|c|c|c|c|c|c|}
\hline PROVINCIA & $\begin{array}{l}\text { PARTIDO } \\
\text { JUDICIAL }\end{array}$ & $\mathrm{N}^{\mathrm{O}} / \mathrm{PART}$ & $\%$ & $\begin{array}{l}\text { No/PR } \\
\text { OV. }\end{array}$ & $\%$ \\
\hline \multirow[t]{14}{*}{ ASTURIAS } & Avilés & 1 & 2 & & \\
\hline & Cangas de Narcea & 1 & 2 & & \\
\hline & Cangas de Onís & 4 & 8,3 & & \\
\hline & Castropol & 15 & 31,2 & & \\
\hline & Gijón & 1 & 2 & & \\
\hline & Grado & 3 & 6,2 & & \\
\hline & Laviana & 1 & 2 & & \\
\hline & Lena & 1 & 2 & & \\
\hline & Llanes & 1 & 2 & & \\
\hline & Piloña & 1 & 2 & & \\
\hline & Pravia & 1 & 2 & & \\
\hline & Tineo & 6 & 12,5 & & \\
\hline & Valdés & 9 & 18,7 & & \\
\hline & Villaviciosa & 3 & 6,2 & & \\
\hline TOTAL & & & & 48 & 36,6 \\
\hline LEÓN & Ponferrada & 25 & 100 & & \\
\hline TOTAL & & & & 25 & 19 \\
\hline \multirow[t]{9}{*}{ LUGO } & Becerreá & 6 & 13 & & \\
\hline & Chantada & 1 & 2,1 & & \\
\hline & Fonsagrada & 3 & 6,5 & & \\
\hline & Lugo & 2 & 4,3 & & \\
\hline & Mondoñedo & 5 & 10,8 & & \\
\hline & Monforte & 20 & 43,4 & & \\
\hline & Sarria & 6 & 13 & & \\
\hline & Villalba & 2 & 4,3 & & \\
\hline & Vivero & 1 & 2,1 & & \\
\hline TOTAL & & & & 46 & 35,1 \\
\hline \multirow[t]{3}{*}{ ORENSE } & Barco Valdeorras & 7 & 58,3 & & \\
\hline & Puebla de Trives & 3 & 25 & & \\
\hline & Verín & 2 & 16,6 & & \\
\hline TOTAL & & & & 12 & 9,1 \\
\hline TOTAL & & & & 131 & 100 \\
\hline
\end{tabular}

FUENTE: Elaboración propia con los datos del Catálogo de ferrerías

Si trazáramos con un compás un círculo con la punta en el monte de Formigueiros, de cuyas veneras se abastecieron muchas ferrerías gallegas y bercianas, y el extremo de los radios lo situáramos en Monforte de Lemos o en Ponferrada, el territorio abarcado por dicho círculo integraría a la mayor parte de las ferrerías gallegas y bercianas; si el radio lo ampliáramos hasta Lugo 
también incluiríamos a algunas ferrerías de Asturias. Sólo quedarían fuera de este ámbito las más cercanas a la costa gallega y asturiana, aquellas que se abastecieron bien con el hierro de algunas venas locales, bien con el mineral vizcaíno de Somorrostro. También con ese hierro se aprovisionaron las ferrerías del oriente asturiano. Sin duda, la vena vizcaína y las minas de Formigueiros, Venera de Roques y Chana de Borrenes tienen mucho que ver con la localización de tales artefactos; pero el agua y el bosque han sido condiciones aún más necesarias para permitir el funcionamiento de este tipo de instalaciones hidráulicas, grandes consumidoras de madera y carbón vegetal.

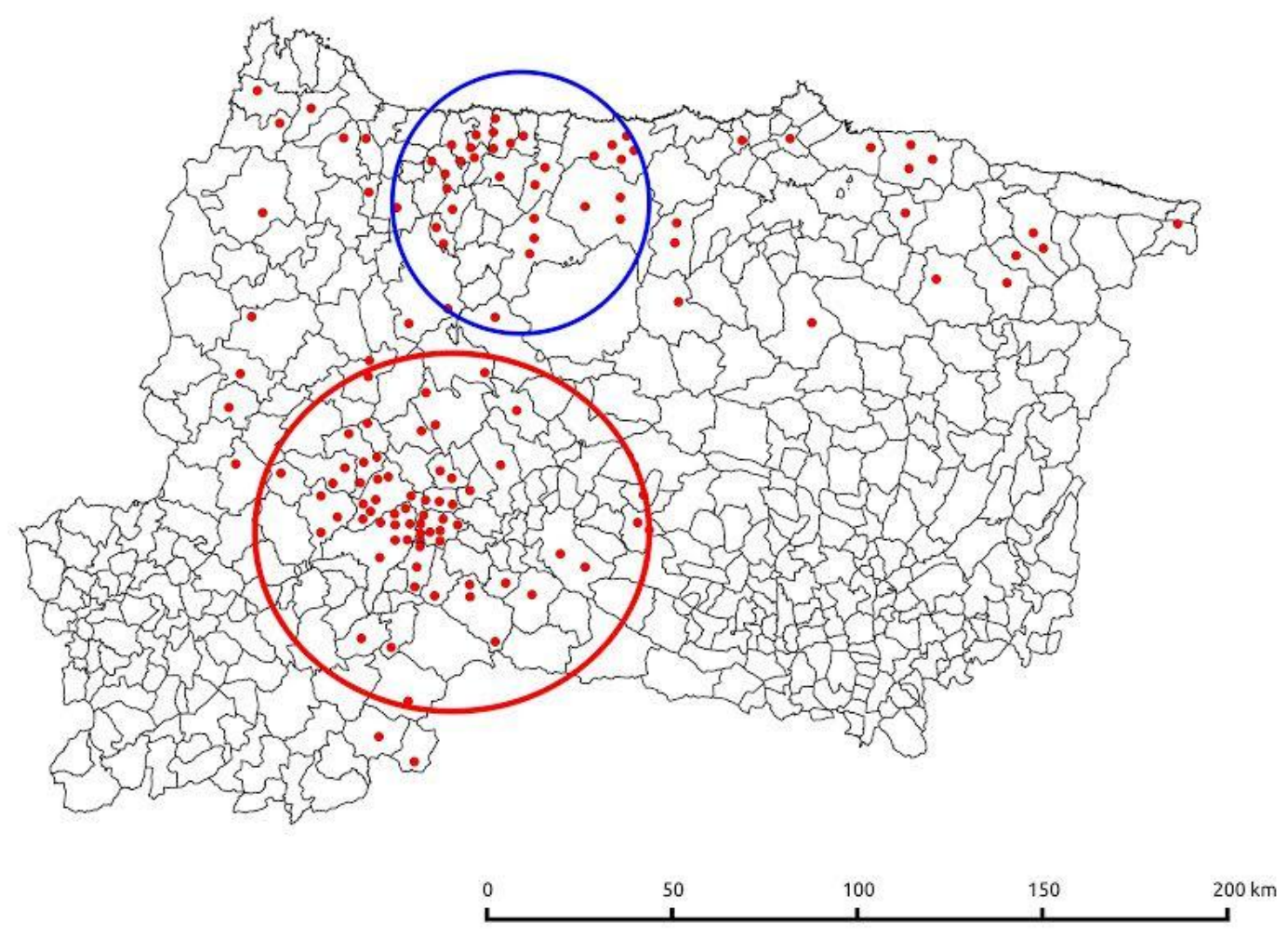

Localización de las ferrerías en el Noroeste de España, en las provincias de León, Lugo, Orense y Asturias

Si analizamos detenidamente el CUADRO IV, en que se recoge el número de ferrerías por provincias y partidos judiciales, nos encontramos con que el 36,6\% de las ferrerías se sitúan en Asturias, pero la mayoría de ellas se hallan en 
los partidos judiciales de la parte oeste de la provincia: Castropol (31,2\%), Valdés $(18,7 \%)$ y Tineo (12,5\%), que con el de Cangas de Narcea suponen casi el $65 \%$ del total. La provincia de Lugo cuenta con el 35,1\% del total pero aquí el $43,4 \%$ y el $13 \%$ se encuentran en los partidos de Monforte y Sarria respectivamente, es decir en torno a los yacimientos de Formigueiros y Rocas; otro tanto ocurre con León provincia en la que el 100\% de las ferrerías se encuentran en el partido judicial de Ponferrada, y Orense, en la que el $58,3 \%$ de sus ferrerías se localizan en Valdeorras, ambas comarcas en los aledaños del yacimiento citado de Formigueiros. Hubo también algunas ferrerías en el oriente de Asturias, en zonas de la costa y del interior, que se aprovecharon de la importante masa arbórea de concejos como Ponga, Amieva, Caso y Cangas de Onís, como hemos dicho.

En resumen, la mayoría de las ferrerías del noroeste se localizan en la confluencia de las provincias de Lugo, Orense, León y Asturias, en torno a la sierra de los Ancares y los montes del Caurel, y los ríos que descienden de esas montañas como afuentes del Sil, Navia y Eo, en lo que se conoce como macizo astur-occidental-leonés. Esta geografía siderúrgica conforma un espacio geográfico de rasgos geomorfológicos y climáticos muy semejantes. Toda ella, con pequeñas salvedades a oriente y occidente, se sitúa en la zona geológica conocida como Asturoccidental-Leonesa, que es una de las partes del viejo macizo Hespérico, encuadrada entre la zona Centro Ibérica (Galicia occidental) y la zona Cantábrica (Asturias oriental y Cantabria). Su límite oriental es el antiforme de Narcea, en Asturias; y el occidental el antiforme del Ollo de Sapo, en la provincia de Lugo. Fuera de este ámbito quedan algunas ferrerías del oriente asturiano que se localizan en la vertiente septentrional de la cordillera Cantábrica, en los Picos de Europa, zona caliza de ríos cortos pero caudalosos e impetuosos.

El macizo Asturoccidental-leonés es una zona montañosa de materiales antiguos que van desde el Precámbrico al Silúrico, fragmentados por la orogenia hercianiana o varisca, provocada por la convergencia y colisión de dos continentes (Laurassia y Gondwana), lo que dio lugar a una tectónica de bloques (horts) y cubetas (graben), posteriormente rejuvenecidos por la orogenia alpina 
como un relieve de rasgos apalachenses ${ }^{170}$. Todas estas tierras están formadas por materiales litológicos muy diversos, entre los que sobresalen las cuarcitas, pizarras (de Narcea, de Luarca), calizas y granitos, cuya erosión ofrece una morfología típica de crestas y valles resultado de la acción erosiva diferencial, combinada con la glaciar y periglaciar de las mayores alturas. Su aspecto es muy variado por combinar numerosas montañas y valles, al ser zonas disecadas por los innumerables arroyos, torrentes y riachuelos de las cabeceras del Eo y el Navia, que fluyen hacia el Norte; y del Selmo, Soldón, Quiroga y Lor, que vierten al Sil por su margen derecha.

En este límite entre Galicia y Asturias, en sentido meridiano, se suceden desde la rasa costera, primero una estrecha franja de perfil aplanado y escasa altitud; hacia el interior una serie de tierras altas que comienzan en el bajo valle del Eo, con ramales de 500 a 600 metros de altitud, las cuales continúan elevándose cada vez más en las sierras de Meira, Lorenzana y Fonsagrada, en Galicia; y en las de Bobia y Rañadoiro en Asturias, hasta alcanzar cotas superiores a los 1.600 metros en las sierras de Ancares y el Caurel (Courel). Por el sur de esas sierras se sitúa la cubeta tectónica del Bierzo, atravesada por el Sil y sus afluentes, rodeada a su vez de elevadas montañas; y al oeste y al sur de la misma por toda una serie de alineaciones montañosas, como el macizo de Manzaneda y la sierra de Queija, cuyas aguas corren hacia el Sil y hacia las tierras y cubetas del interior de Galicia. Por el norte de Galicia, como cerrando el espacio, se alinean otras sierras paralelas a la costa: las sierras de Faladoira, Carba y Gistral, que son el límite de aguas del Miño y los ríos que desaguan en el Cantábrico ${ }^{171}$.

\footnotetext{
170 A. MARTÍN SERRANO (1989): "Rasgos generales y problemática de las superficies de erosión en Galicia”. Cuaderno Laboratorio Xeológico de Laxe. Coruña, vol. 14, p. 8, señala que "los principales rasgos del actual paisaje gallego son tectónicos". J. R. VIDAL ROMANI et alii (1998): "Evolución geomorfológica del macizo Hespérico peninsular. Estudio del sector comprendido entre las provincias de Lugo y Orense (Galicia, NW de España): Cuadernos Laboratorio Xeolóxico de Laxe. Coruña, v. 23, p. 165-199.

${ }^{171}$ M. P. TORRES DE LUNA (1989): Galicia. En Atlas de España, t. I. Planeta Agostini. Barcelona, p. 8-9. También A. PÉREZ ALBERTI (1984): A xeografía. Vigo, p. 17 y ss.
} 


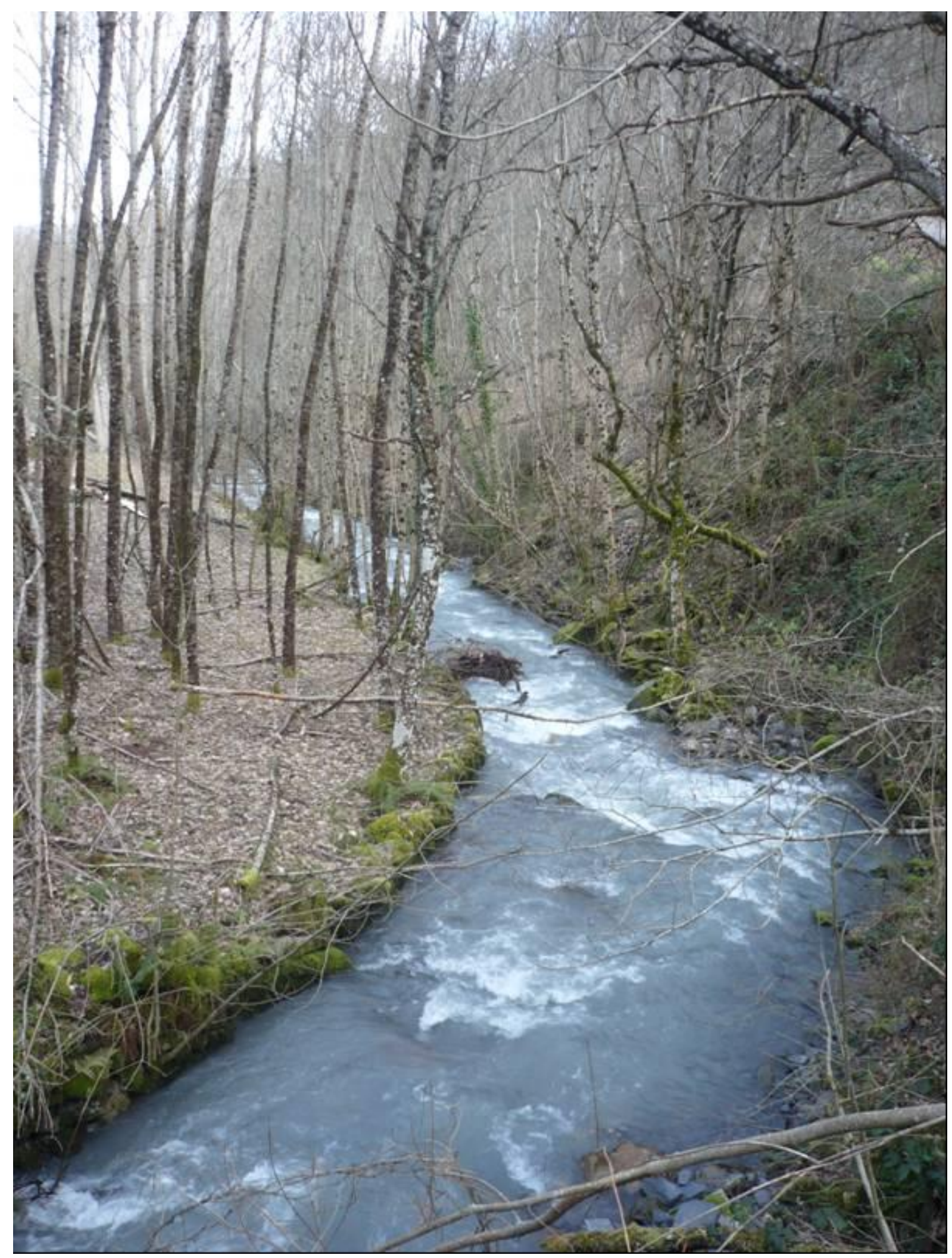

Río Selmo (León), cuyas aguas movieron numerosas ferrerías

Dichas sierras y montañas orientales y sudorientales (que son donde se alcanzan las mayores altitudes, en torno a los 2.000 metros) son además divisoria de aguas y origen de numerosos cursos fluviales que descienden hacia 
el Atlántico y el Cantábrico, después de abrir largos y profundos valles sobre los materiales más blandos, las pizarras. El Sil y el Miño drenan las aguas de todas esas montañas hacia el Atlántico; el Eo, Navia y el Narcea lo hacen hacia el Cantábrico al igual que los cursos que nacen en las sierras de Meira, Lorenzana, Carba, Gistral, Bobia y Rañadoiro'172. En todos los casos se trata de cursos de agua impetuosos, con un régimen muy parecido de tipo pluvial o pluvionival, que proporciona caudales suficientes para mover durante buena parte del año las ruedas que accionan los mazos y barquines ${ }^{173}$. Otro tanto podríamos decir de los ríos que descienden de la cordillera Cantábrica hacia el mar, cortos pero torrenciales, como el Deva, Sella o Piloña.

Sin embargo, las ferrerías y machucos no se asientan a orillas de los grandes cursos de agua, como el Miño y el Sil, sino en sus afluentes; y también en los arroyos de montaña de caudal más irregular, lo que no permitía trabajar a las ferrerías más que un reducido número de meses: son las ferrerías que se conocieron con el nombre de "regateras" o "aguacheras"174, pero son las menos. Por otro lado, a lo largo de los cuatro siglos que estudiamos, las variaciones climáticas fueron notables y diferentes al clima actual, más cálido; por ello también el agua de estos cursos fue más irregular en unas épocas que en otras. Los estudios sobre el clima revelan que la regla dominante entre 1300 y 1850 fue la inestabilidad y los cambios climáticos bruscos, con sucesión de épocas secas y periodos fríos y lluviosos; es lo que se ha llamado la Pequeña Edad del Hielo. Por lo que se refiere a nuestro periodo de estudio, el punto álgido de esa edad del hielo, unos doscientos años, se produjo entre $1540 \mathrm{y}$ 1730, en los que asistimos a momentos muy fríos entre 1590-1600 y 1680-1730, y también a épocas de abundantes lluvias entre 1540 y 1630, lo que aumentó el

\footnotetext{
${ }^{172}$ P. MEMBIELA et alii (1991): "Características hidroquímicas de los ríos de Galicia (NW Península Ibérica)”. Limnética, 7, p. 164.

173 Los caudales máximos son los de invierno y comienzos de la primavera, luego descienden bruscamente en verano para volver a recuperarse a partir de octubre. Por eso muchas ferrerías sólo trabajaban desde ese mes, o desde noviembre, hasta junio.

${ }^{174} \mathrm{El}$ informe de Munárriz en J. A. BALBOA (1992): Ob. Cit., p 132. "hay otras (ferrerías) que llaman regateras, que solo lo hacen seis o siete meses"; I. GONZÁLEZ TASCÓN (1987): Fábricas hidráulicas españolas. Madrid, p. 82: a las que funcionan sólo en época de lluvias se les llama aguacheras.
} 
caudal de los ríos, responsable de numerosos descalabros en las ferrerías, como tendremos ocasión de ver ${ }^{175}$.

Es decir, que en general las ferrerías contaron con más agua de lo que los datos actuales nos ilustran y, por tanto, el tiempo anual de funcionamiento dependió menos de ese factor que de la abundancia o carencia de combustible y de las dificultades en la comercialización del hierro. Además, el caudal específico, que es lo que realmente interesa para conocer si tal caudal es alto o bajo, es elevado, como vemos en el CUADRO V, pues prácticamente todos los ríos del cuadro superan los $15 \mathrm{l} / \mathrm{s} / \mathrm{km}^{2}$, límite a partir del cual podemos hablar de caudales elevados. Si eso es así ahora, en siglos pasados el problema de la cantidad de agua debió de ser, con excepciones, un problema menor; otra cosa distinta, que trataremos en otro capítulo, fueron los intereses en torno a ella y, por tanto, la conflictividad que su uso suscitó.

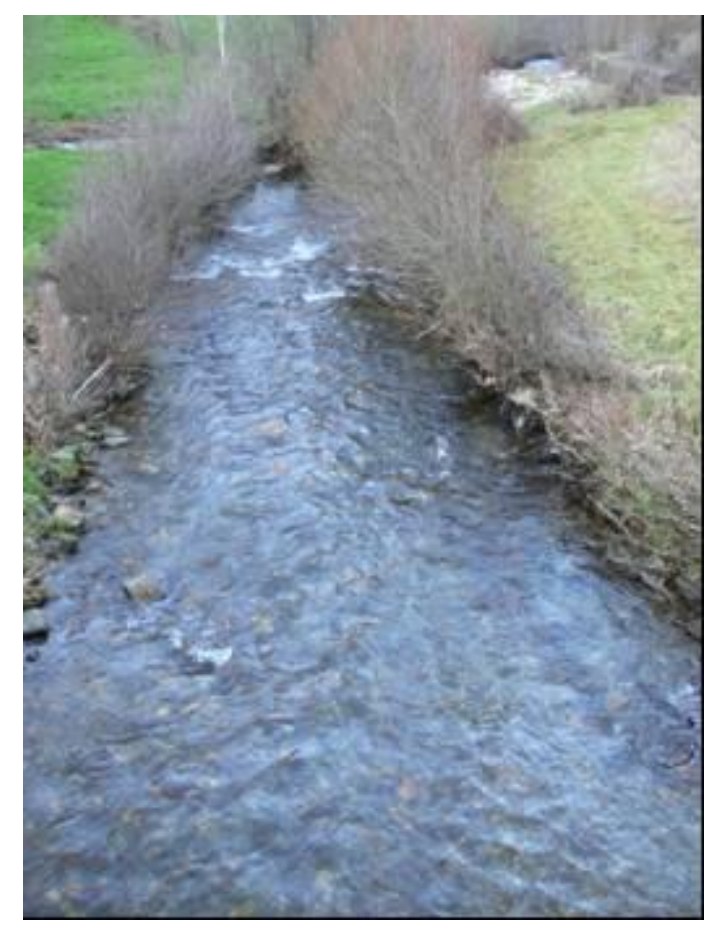

Río Barjas (León) cerca de la f. de Serviz

175 B. FAGAN (2008): La Pequeña Edad del Hielo. Cómo el clima afectó a la historia de Europa, 1300-185o. Barcelona, 91, 93, 150 y ss.; A. ARAGÓN (2011): "Cambio climático y transformaciones económicas en Gipuzkoa entre los siglos XVI y XVII. Los papeles de Pedro Morgan, I, p. 108 y 111. 
CUADRO V. CAUDAL DE ALGUNOS RÍOS DEL NOROESTE

\begin{tabular}{|l|c|c|c|c|}
\hline RÍO & $\begin{array}{c}\text { CUENCA } \\
\left(\mathrm{km}^{2}\right)\end{array}$ & $\begin{array}{c}\text { AFORO } \\
\left(\mathrm{km}^{2}\right)\end{array}$ & $\begin{array}{c}\text { CAUDAL } \\
\left(\mathrm{m}^{3} / \mathrm{seg} .\right)\end{array}$ & $\begin{array}{c}\text { C. ESPECÍCO } \\
\left(\mathrm{l} / \mathrm{s} / \mathrm{km}^{2}\right)\end{array}$ \\
\hline BOEZA & 867 & 855 & 13,5 & 15,7 \\
\hline BURBIA & 542 & 492 & 12,7 & 25,8 \\
\hline SELMO & 190 & 176 & 5,1 & 28,9 \\
\hline CABRERA & 561 & 560 & 9,5 & 16,9 \\
\hline BIBEY & 1.561 & 794 & 21 & 26,4 \\
\hline LOR & 370 & 337 & 13,2 & 39,2 \\
\hline CABE & 734 & 353 & 4,7 & 13,3 \\
\hline LADRA & 887 & 843 & 22,1 & 26,2 \\
\hline EO & 819 & 712 & 16,7 & 23,4 \\
\hline MASMA & 291 & 145 & 3,8 & 26,2 \\
\hline OURO & 188 & 163 & 4 & 24,5 \\
\hline LANDRO & 268 & 192 & 4,2 & 21,8 \\
\hline NAVIA & 2.572 & 1.776 & 55,1 & 31 \\
\hline IBIAS & 389 & 294 & 11,4 & 38,7 \\
\hline PORCIA & 144 & 132 & 3 & 22,7 \\
\hline NARCEA & 1.850 & 531 & 12,1 & 22,7 \\
\hline PIGÜEÑA & 405 & 403 & 5 & 12,4 \\
\hline DEVA & 1.184 & 643 & 14,6 & 22,7 \\
\hline
\end{tabular}

- Caudal medio anual

- Caudal específico: relación entre caudal absoluto y superficie de la cuenca medido en litros por segundo. Un caudal inferior a $5 \mathrm{l} / \mathrm{s} / \mathrm{km}^{2}$ indica que hay escasez de agua, entre 5 y 15 se trata de valores medios y por encima de 15 valores elevados.

FUENTE: Ministerio de medio Ambiente. Cedex: Anuario de aforos.

Los ríos son además articuladores de la geografía ferrera (APÉNDICE II, 1). El principal curso de agua que drena el noroeste es el Miño con su afluente el Sil ${ }^{176}$. Este último es el más estrechamente ligado a esta geografía, aunque no directamente en sus aguas, sino en las de sus afluentes. El Sil nace al pie de la Peña Orniz, en las barrancadas meridionales de las cumbres de Cuetos Albos, a 1.980 metros de altitud. Con dirección sur-suroeste cruza Babia Alta y Leitariegos, atraviesa la banda carbonífera de Laciana y por el desfiladero del Pedruño entra en el Bierzo177. Aquí, a la altura de Ponferrada, recibe por su

${ }^{176}$ C. VIDAL BOX (1941): "Contribución al conocimiento morfológico de las cuencas de los ríos Sil y Miño”. B.R.S.E.H.N., tomo XXXIX. Madrid, p. 121-153.

177 C. VIDAL BOX (1943): "Notas previas a un estudio morfológico y geológico de la alta cuenca del río Sil, cuencas de Laceana y Babia Alta (provincia de León). Revista de la Real Academia de Ciencias, t. XXXVII. Madrid, p. 97-117; P. y A. HERNÁNDEZ SAMPELAYO (1943): "Acerca de la morfología de los ríos de la cordillera Cantábrica hacia el Atlántico. El Bierzo". Estudios Geográficos, t. IV, $\mathrm{n}^{\circ}$ 13. Madrid, p. 695-725. 
izquierda las aguas del Boeza, que nace en el pico de la Rebeza a 2.020 metros y drena el Bierzo Oriental en el gran arco que describen los Montes de León y la Sierra de Gistredo. En el curso alto de este río, a orillas de un pequeño afluente, estuvieron las ferrerías de Marciel; en otro afluente, el Tremor, se levantó la primera que Lemaur construyó en Torre del Bierzo, y en un pequeño subafluente -el arroyo de San Andrés de las Puentes- la segunda. En otro afluente, el Miera, que baja de los Montes de León, se encuentra la ferrería de Compludo.

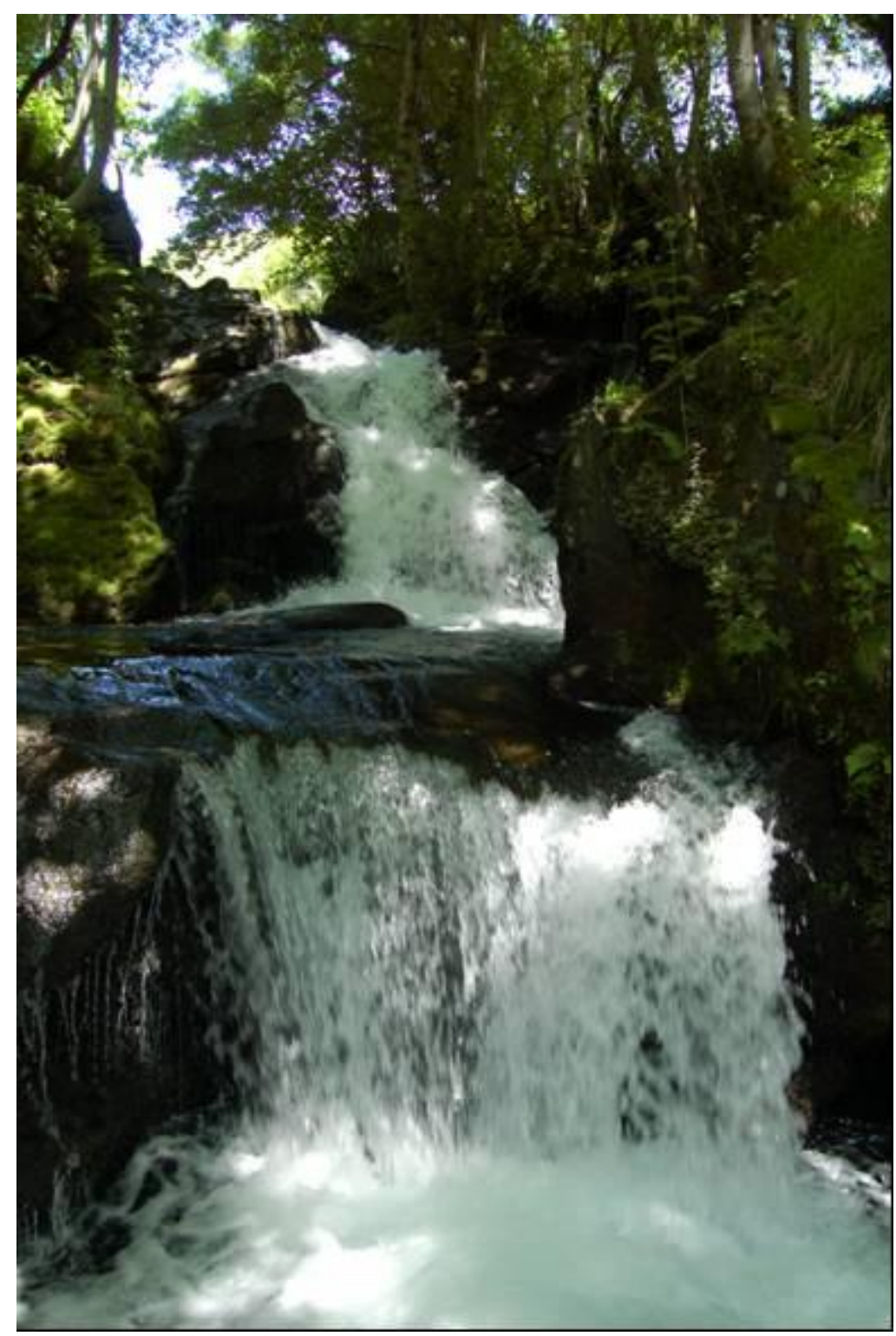

Río en las montañas del Caurel 

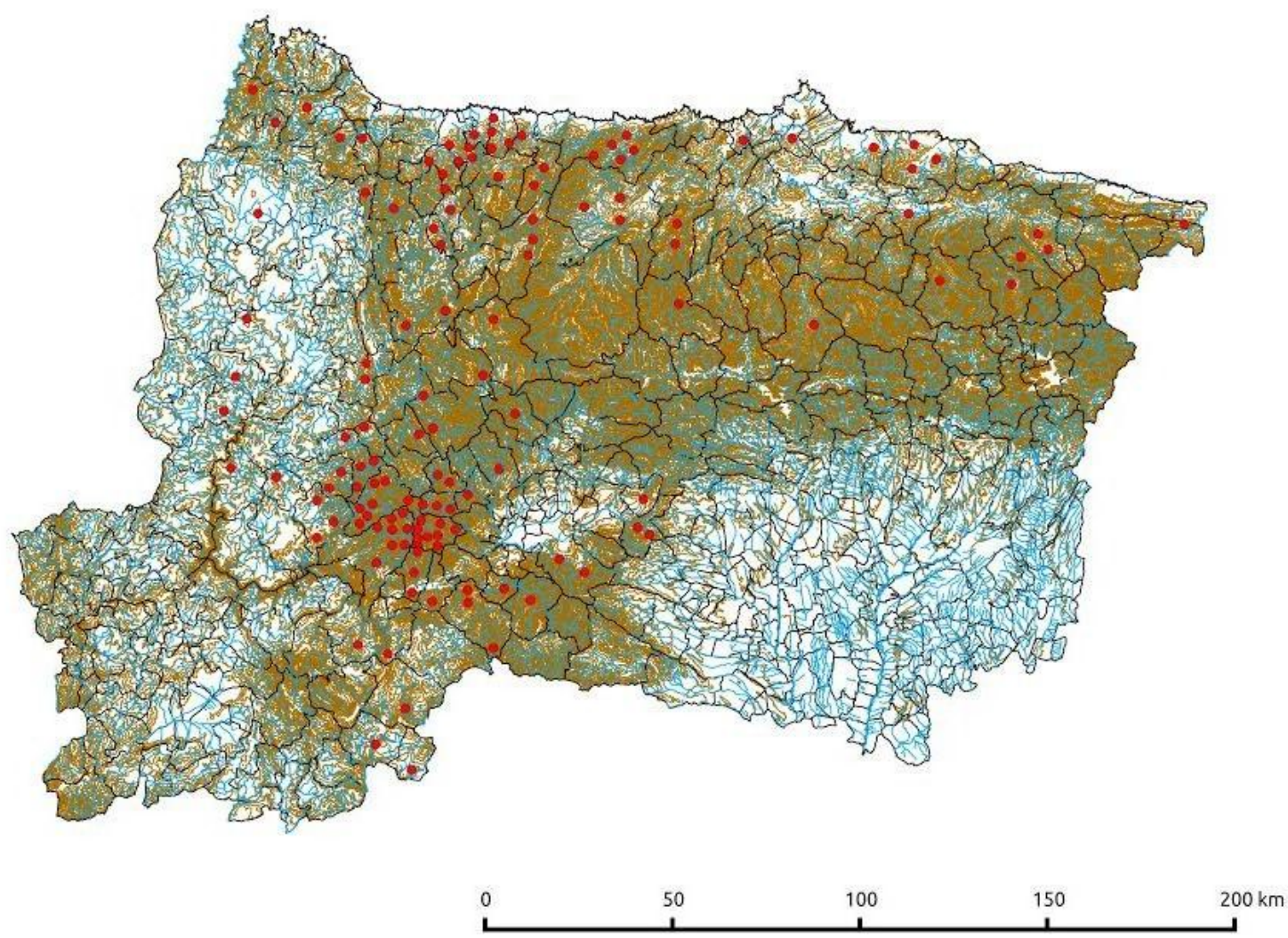

RÍOS Y FERRERÍAS EN EL NOROESTE DE ESPAÑA

(Provincias de León, Lugo, Orense y Asturias) 
Por la derecha entran en el Sil los ríos Cúa, Burbia y su afluente el Valcarce, que descienden de la sierra de Ancares y los montes de Piedrafita. En un afluente del Cúa, el Ancares, encontramos la ferrería de Tejedo; en el Burbia la de La Somoza; en el Valcarce las de Herrerías de Valcarce y La Portela; y en pequeños cursos que desaguan en este último las de Barjas, Corporales, Serviz y San Fiz do Seo. El curso de agua más importante por sus ferrerías en el Bierzo fue el Selmo, cuyo primer tramo gallego se conoce como Visuña. En este y en sus afluentes se construyeron las ferrerías de Órreos o Visuña (Galicia); Valincarro, San Vitul, Gestoso, las dos del Río Cabo, Arnado, Lusío, Pontepetre, Arnadelo y Valdelouro, en el Bierzo. Por la izquierda, poco después de Ponferrada desagua en el Sil el Oza, cuyas aguas movieron la ferrería de Montes o Linares; y ya a la salida de esta comarca, el Cabrera, en cuyas orillas hubo otras dos: las de Llamas y Pombriego.

En Galicia, el Sil abre el amplio valle de Valdeorras, comarca en la que recibe las aguas que bajan de la sierra del Caurel por la derecha, y las de los macizos de Trevinca y Manzaneda por la izquierda. El primer afluente por este lado es el río Casayo con los subafluentes de Riodolas y Forcadas. Hubo en ellos tres ferrerías: Pontenova, Riodolas y Robledo de Domiz. Pasado el Barco de Valdeorras, existió otra en el pequeño arroyo de la Fervenza; más adelante desagua en el Sil el Bibey, cuyos principales afluentes son el Camba y el Jares, con tres ferrerías: Mondón, Vegas de Camba y San Miguel de Vidueira. Por la derecha, recibe las aguas de la sierra del Caurel por medio del río Leira, en cuyo curso se erigieron las de San Vicente de Leira, Cernego y Valdeorras. Dos pequeñas ferrerías, la de Moas y la Mezquita, se hallan en sendos riachuelos al sureste de la provincia de Orense que no fluyen hacia el Sil.

Después de encajarse en los esquistos, el Sil abre una nueva depresión tectónica, el valle de Quiroga, y poco después la de Monforte de Lemos ${ }^{178}$. Las aguas principales bajan ahora por su derecha drenando las sierras del Caurel y de Lóuzara por medio de cuatro importantes cursos de agua: el Soldón, el

${ }_{178}$ J. R. VIDAL ROMANÍ et alii (1998): Ob. cit., p. 169, distinguen en Galicia tres tipos de fosas tectónicas: las asociadas a fallas direccionales (Maceda, Xinzo de Limia, Verín-Chaves), las que se forman como cobijaduras bajo fallas inversas (Quiroga, A Rúa) y las depresiones grabadas o de corrosión química, nunca afectadas por la tectónica, o si lo fueron en cualquier caso pasivamente (Monforte). 
Quiroga, el Lor y el Cabe, con algunos pequeños subafluentes. En estos ríos se encuentran la mayoría de las ferrerías lucenses. En el Soldón, que es el primero, las de Soldón, Outeiro, Rugando y Gorgueira; en el Quiroga, las de Quintá y la Rodela, y en dos pequeños subafluentes las de Vilarbacú y Paleiras; en el Lor las de Seoane, Vilasibil, Ferreirós, Folgoso, Valdomir, Loureiro y Lor; en su afluente el Lóuzara, las de Carqueixeda, Gondriz, Santalla y Losadela; por último en el Cabe y sus afluentes las de Incio, Barreiro, Biduedo y Penacova.

El Miño tiene sus fuentes en la sierra de Meira, aunque tradicionalmente se ha considerado su nacimiento en la laguna de Fonmiñá (Pastoriza) por fluir subterráneamente en su primer tramo. Recibe aguas de las sierras de Lorenzana (Lourenzá), Xistral y Carba. Este río, del que solo nos interesa la primera parte de su curso, careció, como hemos dicho, de ferrerías pero algunos de sus afluentes sí las tuvieron, como en el Narla la de Ombreiro, antes de Lugo; y después de esta ciudad hasta Los Peares, en el Ferreira, la de Pallares; en el Sardiñeira la de ese nombre; y en el Neira, que desciende de Baleira, las de Neira de Rey y Piago.

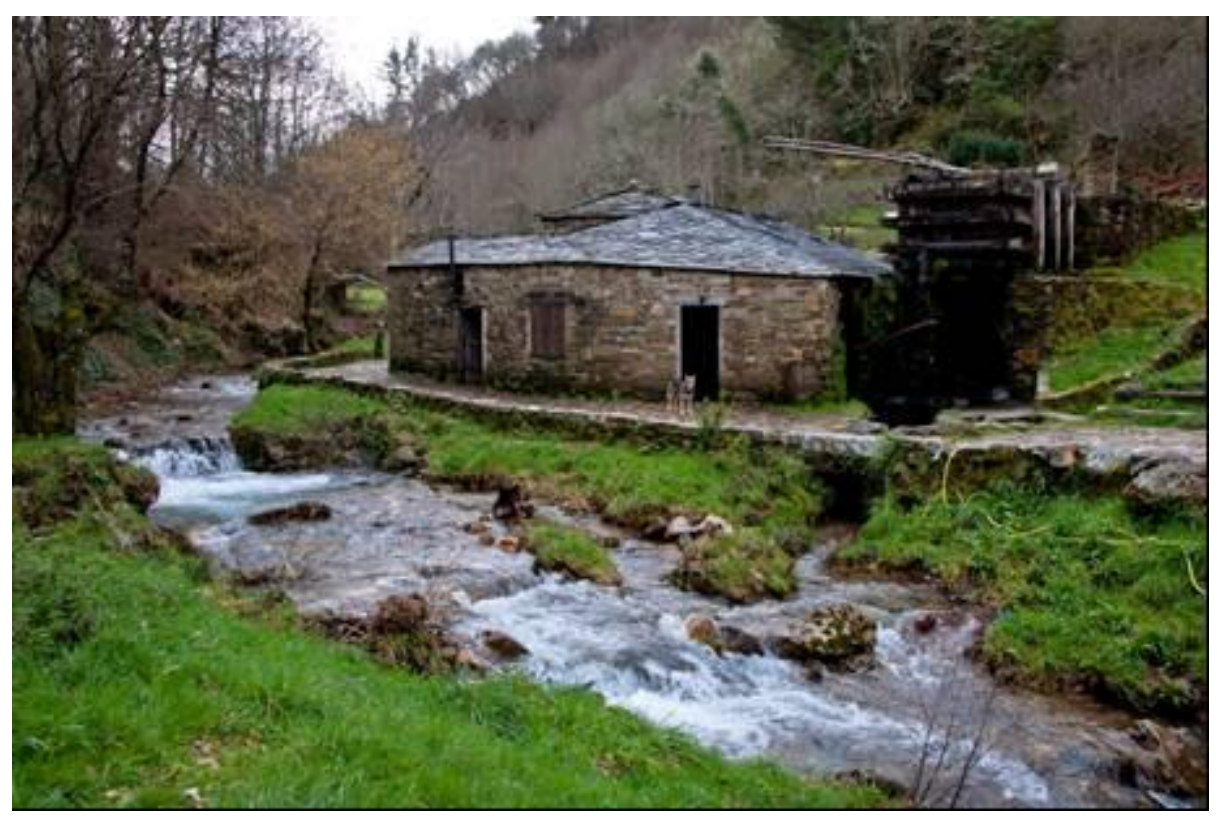

Mazonovo en Asturias sobre el río Mazonovo, afluente del Agüeira

Tampoco el Navia, que nace en las cercanías del Cebrero lucense, en Busnullán, movió ferrería alguna, excepto en su curso alto. Tras un breve recorrido como límite entre Galicia y Asturias penetra en esta Comunidad en la 
que desemboca en el lugar de Navia. Son numerosos los afluentes que jalonan su curso, tanto en el tramo gallego como en el asturiano. En el primero hay ferrerías en el río Bueyes o Bois, la de este nombre; en el Suarna, las dos de Vilar de Cuiña; y en el Balouta, la de Rao. En el Navia directamente solo conozco la de San Martín de la Ribera y quizá la de Pereyrúa. En el tramo asturiano hubo una en su curso alto, la de la Fornaza pero no utilizó sus aguas, pues en realidad fue un horno alto. Poco después de entrar en esa provincia recibe al Ibias y aguas abajo al río de Oro ó Ourua, en el que se asentaron las ferrerías de Armenade y Villarín. Después de Grandas de Salime desemboca el Agüeira, cuyas aguas movieron la de Pontigón; luego el Ourubio con la de Froseira; y más abajo el Arbón que tuvo una ferrería conocida con ese nombre. En un subafluente del Navia se levantó la de Bullimeiro.

El Eo nace en Galicia, en Pradela, a 780 metros de altitud, en el concejo de Baleira; el final de su curso delimita las comunidades de Galicia y Asturias. En la zona gallega, después de recoger las aguas de numerosos arroyos en su cabecera, el Eo, considerablemente aumentado su caudal, corre hacia el norte flanqueado por las sierras del Pozo, Meira y Cadeira por el oeste, y por las de Foncuberta y Bobia al este. Del lado gallego varios de sus afluentes moverían las ruedas de ferrerías como las de Vilaseca y Vilaboa. Del lado asturiano, ya en su desembocadura, en la ría del Eo, desagua el Suarón, que nace en la sierra de Bobia, y cuyas aguas accionaron las de Montealegre, Nafarea y Meredo.

Las sierras septentrionales de Galicia vierten sus aguas al Cantábrico por medio de cortos pero impetuosos ríos como el Masma y el Landro, en cuyas orillas o en las de sus afluentes, se levantaron ferrerías como las de Villanueva de Lorenzana y Viloalle (en el Masma), y Bravos, Silán y Muras (en el Landro). También en la zona asturiana, el río Porcia, que nace en la sierra de Bobia, en el concejo de Castropol, desemboca en ese mar tras un breve recorrido de apenas 25 kilómetros, después de atravesar una comarca caracterizada por una orografía de fuertes pendientes. En él y en sus afluentes, por ejemplo el del Mazo, se erigieron las ferrerías de La Cabanada, Sueiro I y II, Veguiña, Lagar y Boimoiro, las cuales dieron a aquel el nombre de río de las Ferrerías. Los ríos Nalón y Narcea bajan de la cordillera Cantábrica; el primero nace en 
Fuentenalona, en Tarna, y después de un recorrido de $129 \mathrm{~km}$. desemboca en la ría de Pravia. Poco antes, en Forcinas se une a él el río Narcea, que nace en las Fuentes del Narcea. En su recorrido ambos moverán las ruedas de las ferrerías de Renueva y Villallana (el Nalón), y las de Arganza, Belmonte, Agüerina, Somiedo y Penaseita, en el Narcea y sus afluentes.

Por último, en la zona central y oriental de Asturias, predominantemente calcárea, con ríos que presentan caudales intermitentes y variables, como los de Amandi, Cares, Deva, Piloña o Arroes hubo igualmente varias ferrerías, como las de Amandi, Penamellera, Peón, Dueñes, Riera, Piloña, etc.

Estos ríos y sus afluentes, además, accionaron los mazos de machucos y martinetes, en unos casos de forma más o menos aislada, como vemos en varios ríos de la cuenca del Sil: el mazo de la Portela, en el río Valcarce, el de Melezna en un arroyo afluente del Selmo; el de Robledo de Domiz en Valdeorras; el de Soldón en el río de este nombre y el de Outeiro. En otros casos con una enorme concentración, como vemos en las cuencas del Eo y del Navia. En la cuenca del Eo, el río Turía movió las ruedas de los mazos de As Veigas, Mazo Novo y el de la Vega de Zarza; el río de las Mestas, los de las Mestas y os Teixois; el Cabrera los de Aguillón y Vega de Llan, en el de las Valiñas el mazo de Bres, y en el Ouria el de las Tingas. Por su parte, en la cuenca del Navia, en el río Santalla o Agüeira encontramos los mazos de Pumares, A Pruida. Peizais, el Pontigón (luego convertido en ferrería), Os Penedois, As Barreiras y el de Parada; y en uno de sus afluentes, el Mazo Novo. En el río de Vilanova, los mazos de Santa Eufemia, Sanmamede, a Valía, Caraduxe y el Ángel, este en el afluente Fusqueirarubia; por último, en el río Ahío el mazo de Mon.

\subsection{El agua motor de las ferrerías}

En el noroeste de España son numerosos los ríos y los arroyos, pero no siempre fue posible utilizar el agua para mover las ruedas de las ferrerías y machucos. En unos casos porque los arroyos son temporales o porque los ríos sufren fuertes estiajes, lo que impide trabajar varios meses del año. Las ferrerías que laboraban todo el año fueron raras, no sólo por el problema del agua, a 
veces también faltaba el combustible e incluso el mineral de hierro. Además, todas solían descansar los domingos y días de fiesta, por lo que 250 días al año era una cifra considerada elevada en las mejores ferrerías. Refiriéndonos ahora al agua, y con la salvedad de las fiestas y "dominicas", el Catastro de Ensenada, por ejemplo, solo en algunas ferrerías, como las lucenses de Lor y Gondriz dice que no tienen problemas de agua ${ }^{179}$; de las bercianas de Arnado y Pontepetre señala igualmente que tienen agua todo el año pero que sólo trabajan 250 días. Lo media que hemos obtenido (CUADRO VI) es de unos cinco meses y medio, unos 166 días efectivos, pero sólo el 50\% superan esa media, la otra mitad están por debajo, incluso alguna no llega más a que a tres meses o noventa días, e incluso alguna menos.

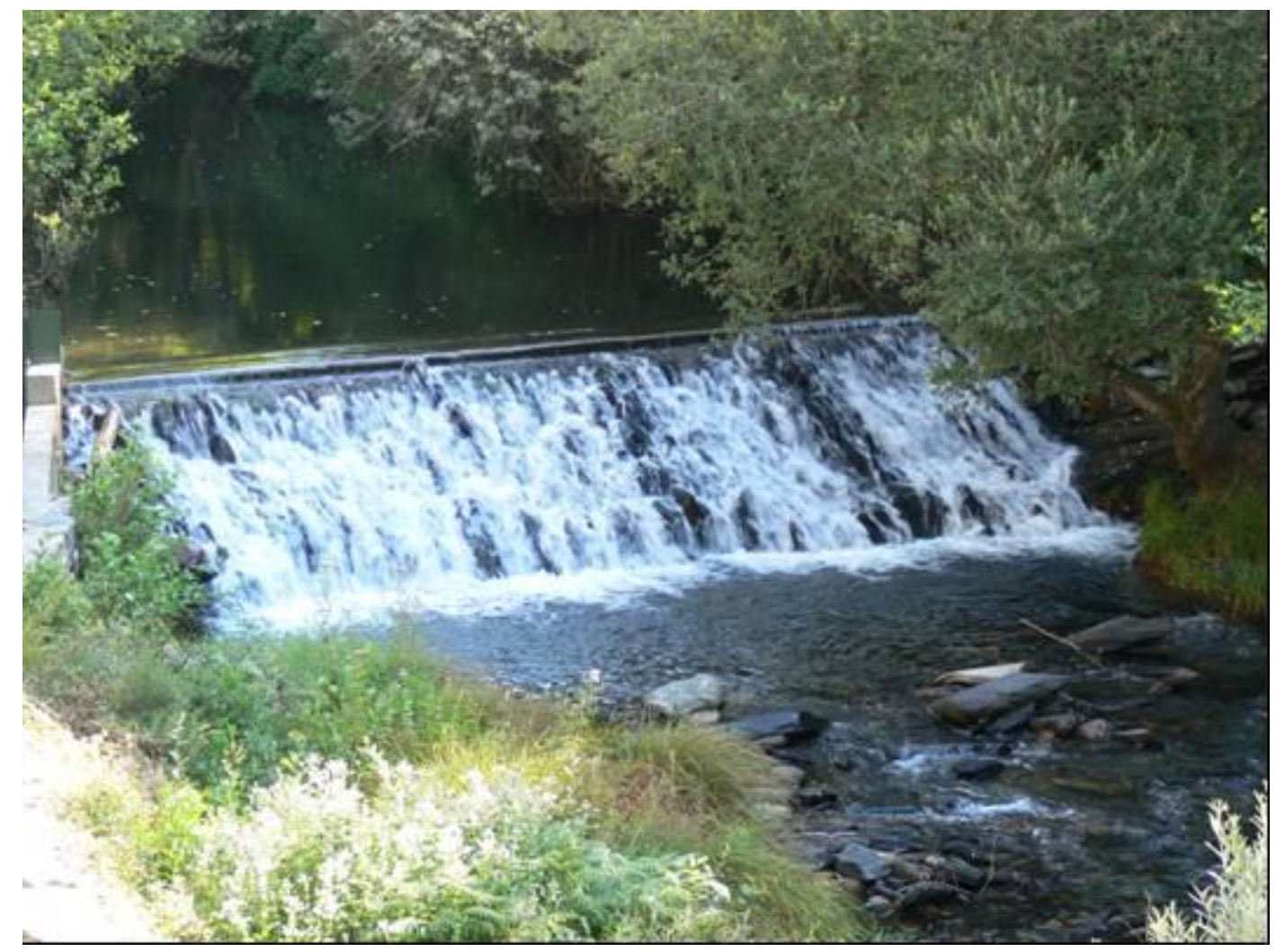

Chapacuña en el río Soldón (Lugo)

179 CATASTRO DE ENSENADA: Ferrería de Lor: "trabaxa con el agua del río Lor fabricando yerro... y por quanto tiene agua suficiente todo el año y trabaza todos los días de él, a excepción de los festivos"; Ferrería de Gondriz: "Y aunque esta se halla con agua suficiente para todo el año..” 
En algunos casos, el Catastro señala que sólo pueden trabajar con el agua de las avenidas: son las ferrerías regateras o aguacheras ${ }^{180}$. Los expertos se hacen eco de este problema ${ }^{181}$ y también algunos testigos en juicios ${ }^{182}$; pero ese tiempo medio relativamente pequeño no era solo por el problema del agua, sino por falta de combustible o vena. Incluso fue muy frecuente que, por las avenidas, se destruyeran partes del canal, banzado o las ruedas, lo que obligaba a parar durante días e incluso semanas para su reparación, como podemos ver en numerosos ejemplos en el Catálogo de Ferrerías.

\section{CUADRO VI. TIEMPO DE TRABAJO DE LAS FERRERÍAS EN 1752}

\begin{tabular}{|l|c|c|c|}
\hline FERRERÍA & PROVINCIA & DIAS* & $\begin{array}{c}\% \\
\text { (sobre media) }\end{array}$ \\
\hline Arnado & León & 250 & 150,6 \\
\hline Pontepetre & León & 250 & 150,6 \\
\hline Linares & León & 120 & 72,2 \\
\hline Valcarce & León & 200 & 120,4 \\
\hline Órreos & Lugo & 120 & 72,2 \\
\hline Valdomir & Lugo & 105 & 63,2 \\
\hline Quintá & Lugo & 180 & 108,4 \\
\hline Rodela & Lugo & 180 & 108,4 \\
\hline Rugando & Lugo & 150 & 90,3 \\
\hline
\end{tabular}

\footnotetext{
${ }^{180}$ J. A. BALBOA (1992): Ob. cit. p. 132. Respecto a la ferrería de Río Cabo, en el Bierzo, se habla de "fábrica regatera o que funciona la tercera parte del año por faltarle agua ocho meses". En I. GARCÍA TATO (2000): Ob. cit., p. 163.

${ }^{181}$ DATOLI: Ob. Cit., p. 57 y 58, por ejemplo dice: "La herrería de Valcarce dexa de andar por lo regular desde mediados de agosto hasta mediados de octubre... a causa de la falta de aguas"; "la de Bueyes escasea de agua en el verano en términos que solo anda ocho o nueve meses al año"; "la de Oencia tiene agua abundante en todo el año", "la de Arnado anda todo el año"; "la de Montes está parada uno o dos meses del verano.. por falta de agua, carbones y leñas"; "la de Ancares escasea en agua por lo que suele estar parada los meses de julio, agosto y septiembre". MUNÁRRIZ: Ob. Cit., p. 132, habla de las del Bierzo: "El trabajo de una herrería con otra puede regularse nueve meses anualmente, ya por falta de agua en el verano y ya por los continuos descalabros que padece, pues aunque las de Oencia y Arnado trabajan algún tiempo más, hay otras que llaman regateras, que solo lo hacen seis o siete meses".

${ }_{182}$ AHRG. Real Audiencia: 190/33. En el interrogatorio de Antonio Núñez, maestro de cantería, que hace un puente en el río Quiroga, cerca de la ferrería de la Rodela dijo, en 1756, "que oyó vulgarmente de que en los meses rigurosos del brano y estio suele no trabajar (aquella ferrería) por la poca abundanzia de agua”.
} 


\begin{tabular}{|l|l|r|r|}
\hline Paleiras & Lugo & 180 & 108,4 \\
\hline Bueyes & Lugo & 90 & 54,2 \\
\hline Pallares & Lugo & 120 & 72,2 \\
\hline Leira & Orense & 250 & 150,6 \\
\hline Meredo & Asturias & 240 & 144,5 \\
\hline Nafarea & Asturias & 180 & 108,4 \\
\hline Vill. Oscos & Asturias & 210 & 126,5 \\
\hline Boimouro & Asturias & 120 & 72,2 \\
\hline La Veguina & Asturias & 90 & 54,2 \\
\hline Montealegre & Asturias & 150 & 90,3 \\
\hline Setienes & Asturias & 150 & 90,3 \\
\hline MEDIA & & 166 & 100 \\
\hline
\end{tabular}

* El tiempo de trabajo de muchas ferrerías viene dado en meses, lo hemos reducido a días (un mes: 30 días). De algunas ferrerías no se especifica el tiempo. Así de las de Lugo: de Gundriz dice que trabaja todo el año; de la de Lor que tiene agua suficiente; y de las de Santalla y Lusío que solo trabajan con el agua de avenidas (no las incluimos en el cuadro).

FUENTE: PARES: Catastro de Ensenada. Respuesta 17 del Interrogatorio General. Se trata de una muestra de ferrerías, que se citan en las localidades que se indican en: Fuentes y Bibliografía.

Respecto de los machucos o martinetes ocurría algo semejante; incluso su situación era peor pues generalmente se hallaban en arroyos de agua escasa ${ }^{183}$, lo que explica que muy pocos trabajaran todo el año, y que la mayoría lo hiciera entre tres y seis meses, como comprobamos en el CUADRO VII. Habría que hacer la salvedad de que los machucos gallegos funcionaban una media de algo más de seis meses, mientras que los asturianos lo hacían poco más de cuatro, y que mientras sólo un mazo asturiano en Santalla de Oscos todo el año, en Lugo lo hacían cinco: tres en el municipio de Cervantes, y uno en los de Fonsagrada y Becerreá 184 .

${ }^{183} \mathrm{El}$ mazo de Viloalle (Mondoñedo) “...que por no andar sino seis meses en tiempo de ybierno por falta de agua...",

${ }^{184}$ De acuerdo con las Respuestas Generales del Catastro de Ensenada 
CUADRO VII. TIEMPO DE TRABAJO

DE LOS MAZOS EN 1752

\begin{tabular}{|c|c|c|}
\hline $\begin{array}{ll}\text { TIEMPO } & \text { DE } \\
\text { TRABAJO } & \end{array}$ & $\mathrm{N}^{0} \mathrm{MAZOS}$ & $\%$ \\
\hline TODO EL AÑO & 6 & 15,7 \\
\hline DE 7 A 9 MESES & 6 & 15,7 \\
\hline DE 5 A 6 MESES & 10 & 26,3 \\
\hline DE 3 A 4 MESES & 12 & 31,5 \\
\hline SOLO 2 MESES & 4 & 10,5 \\
\hline TOTAL MAZOS* & 38 & 100 \\
\hline TOTAL MAZOS** & 69 & \\
\hline
\end{tabular}

*Mazos de los que se cita el tiempo de trabajo

**Total de mazos hallados en el Catastro

FUENTE: PARES: Catastro de Ensenada. Respuesta 17

del interrogatorio Geneal. Se tratade una muestra

de los lugares que se citan en Fuentes y Bibliografía

En otros casos, los problemas derivaban de la pluralidad de intereses en torno al agua. No hay que olvidar que hasta mediados del siglo XIX la historia de la industria es la historia del agua, y mucho más la de la siderurgia ${ }^{185}$. El agua era la más importante de las energías pero, al mismo tiempo, era también una fuente de conflictos por los intereses que se suscitaban en torno a ella, tanto de los molinos, batanes, mazos y ferrerías instalados en un mismo río, como por otros usos, especialmente el riego. De ahí que no sólo se originaran pleitos entre ferrerías, que a veces lograron paralizar la construcción de otras nuevas, también los hubo con los otros artefactos: machucos, molinos y batanes; pero sobre todo con los campesinos y concejos por el riego de sus campos ${ }^{186}$. Las razones que se alegaban más frecuentemente eran la escasez de agua para los diferentes usos o que al embalsarla aguas abajo de una ferrería o de un molino

\footnotetext{
185 D. WORONOFF (1994): Histoire de l'industrie en France. E. Seuil. Paris, p. 106.

186 Según P. SAAVEDRA (1994): La vida cotidiana en la Galicia del Antiguo Régimen. Barcelona, p. 112 "en la zona interior de Lugo la extensión del cultivo de la patata en la $2^{\text {a }}$ mitad del siglo XVIII implicó profundos cambios en la rotación de cultivos y en la distribución anual del trabajo; porque además fue acompañado de un aumento de la superficie de prado, de ahí la abundancia de pleitos por las aguas".
} 
podía "encorar" e impedir que aquella pudiera mover sus ruedas. Por eso en muchos lugares fue necesario regular su uso mediante ordenanzas o fueros, aunque, a diferencia del País Vasco, en el noroeste no hemos hallado ningún Fuero de Ferrerías ${ }^{187}$.

\section{EL COMBUSTIBLE}

En la siderurgia preindustrial, la fabricación del hierro se llevaba a cabo con combustible vegetal, primero utilizado directamente como leña para raguar o calcinar el mineral y así eliminar el agua y ciertas impurezas que contiene. Más tarde, transformada la madera en carbón vegetal, se usaba este para reducirlo en el horno; pues las ferrerías sólo utilizaron carbón vegetal y nunca carbón mineral, combustible que desde el siglo XVIII se usaba a veces para caldear el hierro en los mazos y fraguas de herrero. El carbón vegetal proporcionaba tanto el agente reductor como la temperatura necesaria para fundir el hierro; por esa razón, su consumo era enorme, lo que hacía necesario contar con amplias zonas de bosque alrededor de cada ferrería. Por eso fue frecuente la oposición a la construcción de nuevas fábricas en las cercanías de antiguas ferrerías o conflictos entre ellas por las leñas y el carbón.

\subsection{La leña para el raguado del mineral}

La calcinación del mineral o raguado, al no existir hornos de cementación, se hacía con madera verde en pilas al aire libre, llamadas raguas. Esta operación solía hacerse una o dos veces en cada campaña, bien en el monte, bien en las "plazas" o "eras" que existían al lado de las ferrerías. Munárriz cuenta cómo hacia 1807 vio en el valle del Valcarce raguar de una sola vez tres mil quintales de mineral de hierro con doscientos carros de leña ${ }^{188}$. En los libros de cuentas de la ferrería de Villanueva de Oscos se menciona que en

187 M. K. CAMPOS y B. FERNÁNDEZ (1996): "Fuero de ferrerías del valle de Marquina de Suso". En Actas de las I Jornadas sobre minería y tecnología en la Edad Media peninsular. León, p. 625-637; J. A. LEMA PUEYO (1996): "Instituciones en el fuero de Ferrerías de Vizcaya (siglo XV)". En Actas de las I Jornadas sobre minería y tecnología en la Edad Media peninsular. León, p. 691-698; J. L. ORELLA ANZUÉ (1996): "El fuero de Ferrerías de Guipuzkoa (1338). Fijación crítica del texto y estudio de sus instituciones". En Actas de las I Jornadas sobre minería y tecnología en la Edad Media peninsular. León, p. 567-604.

188 J.M. MUNÁRRIZ: Ob. Cit., p. 131 
las raguas (una o dos veces al año) se utilizaban normalmente más de mil quintales de vena con doscientos o más carros de leña ${ }^{189}$. De forma más precisa, en un informe de 1785 se indica que para calcinar 1.200 quintales de vena se emplearon 200 carros de leña de 30 arrobas el carro, lo que significa un kilo de leña por cada kilo de vena (si el quintal de vena fuese de $57,5 \mathrm{~kg}$ ), ó o,8o kg. de leña por kilo de vena (si fuera un quintal macho de 71 '3 $\mathrm{kg}$., que era lo más frecuente) $)^{190}$.

Un informe del siglo XIX sobre la ferrería leonesa de Pombriego explica cómo se llevaban a cabo estas raguas. El fuego se hacía normalmente en una era o superficie plana, en la que se colocaba la leña, partida en troncos de aproximadamente medio metro de largo, en círculo sobre un hueco central que actuaba de chimenea. Sobre la leña se disponía el mineral de hierro, evitando que se cayera y arrojando carbones encendidos por aquel hueco central, controlando durante varios días su calcinación. Cada ragua, aunque variaba en sus dimensiones de unas a otras, solía contener 450 quintales métricos de mena y 300 de leña ${ }^{191}$. Por tanto, si 450 q.m. de mena necesitaron 300 q.m. de leña, un quintal de aquella requiere o,66 q. de leña, es decir 66 kilos o lo que es lo mismo o,66 kg. de carbón por cada kg. de vena, cantidad muy semejante a la que hemos visto en el informe asturiano de 1785 citado anteriormente.

\footnotetext{
${ }^{189}$ AHN. Clero: libro 9437. ; por ejemplo, en 1702, se dice que "hízose una que llevó mil y trescientos quintales de vena".

190 J. LÓPEZ. y A. GRAÑA (1998): Ferrerías, fraguas y mazos en Asturias. Oviedo, p. 137: "para cozer esta (vena) se ha de usar de leña, y está averiguado que en esta operación, por ejemplo con mil y doscientos quintales se gastan doscientos carros de leña, que por lo fragoso del país no se regulan más que a treinta arrobas".

${ }^{191}$ ESTADÍSTICA MINERA, año 1891. Provincia de León, p. 193: "Sobre una era ó superficie plana inmediata á la fábrica se coloca la leña, que es de chopo, humero, castaño. etc., y se tiene partida en troncos cilíndricos de 0,42 á $0,63 \mathrm{~m}$. con el grueso de la rama o tronco, de una manera radial y formando un cilindro de $5 \mathrm{~m}$. 30 de diámetro y un alto de $1 \mathrm{~m}$. 75, dejando en el centro un hueco, también cilíndrico, de $0,42 \mathrm{~m}$. de diámetro por la misma altura, y dos canales horizontales que se cruzan en ángulo recto, y sobre este montón de leña se va echando el mineral, empezando por la parte superior de la leña, conteniéndole con algunas estaquillas para que no se caiga fuera de ésta, para cuyo efecto se ponen algunos leños en sentido de la circunferencia hacia la parte exterior. Por el hueco central se echan carbones encendidos y se continúa el montón de mineral hacia la parte superior con $1 \mathrm{~m}$. 5o, de manera que parece un sombrero. El fuego se propaga á todo el montón de un modo paulatino que da tiempo á cargar el mineral, y se tiene calcinando veinticuatro horas para ser conducido á la fábrica. Cada ragua de estas dimensiones contiene 450 quintales métricos de mena y 300 de leña. Las dimensiones de estas raguas varían mucho entre los límites de 4 á 7 metros de diámetro y de un metro a $1 \mathrm{~m} 75$ de altura en la leña y $1 \mathrm{~m} .20$ a $2 \mathrm{~m}$. 40 de mineral".
} 
La ragua, por tanto, no sólo calcinaba el mineral sino que eliminaba el agua y muchas impurezas de su ganga, por lo que era lógico que redujera su peso, en este caso, según el informe de la ferrería de Pombriego, en un 42 por ciento. Otros informes realizados en el País Vasco por la Real Sociedad Vascongada de Amigos del País, en la segunda mitad el siglo XVIII, señalan que el método más antiguo consistía en una ragua realizada en hoyas u hornos de cal y canto, pero posteriormente se hicieron al aire libre, pues se observó que "la vena se cuece con más igualdad y menos merma, con algún ahorro de troncos y leña, à lo que se junta la ventaja de poderse cocer à un mismo tiempo mucha mayor cantidad". Sin embargo el dispendio en madera llevó a ensayos y pruebas, en 1772 y 1773, con hornos de calcinación, comprobándose que era más rentable por este medio, con lo que debieron de generalizarse ${ }^{192}$.

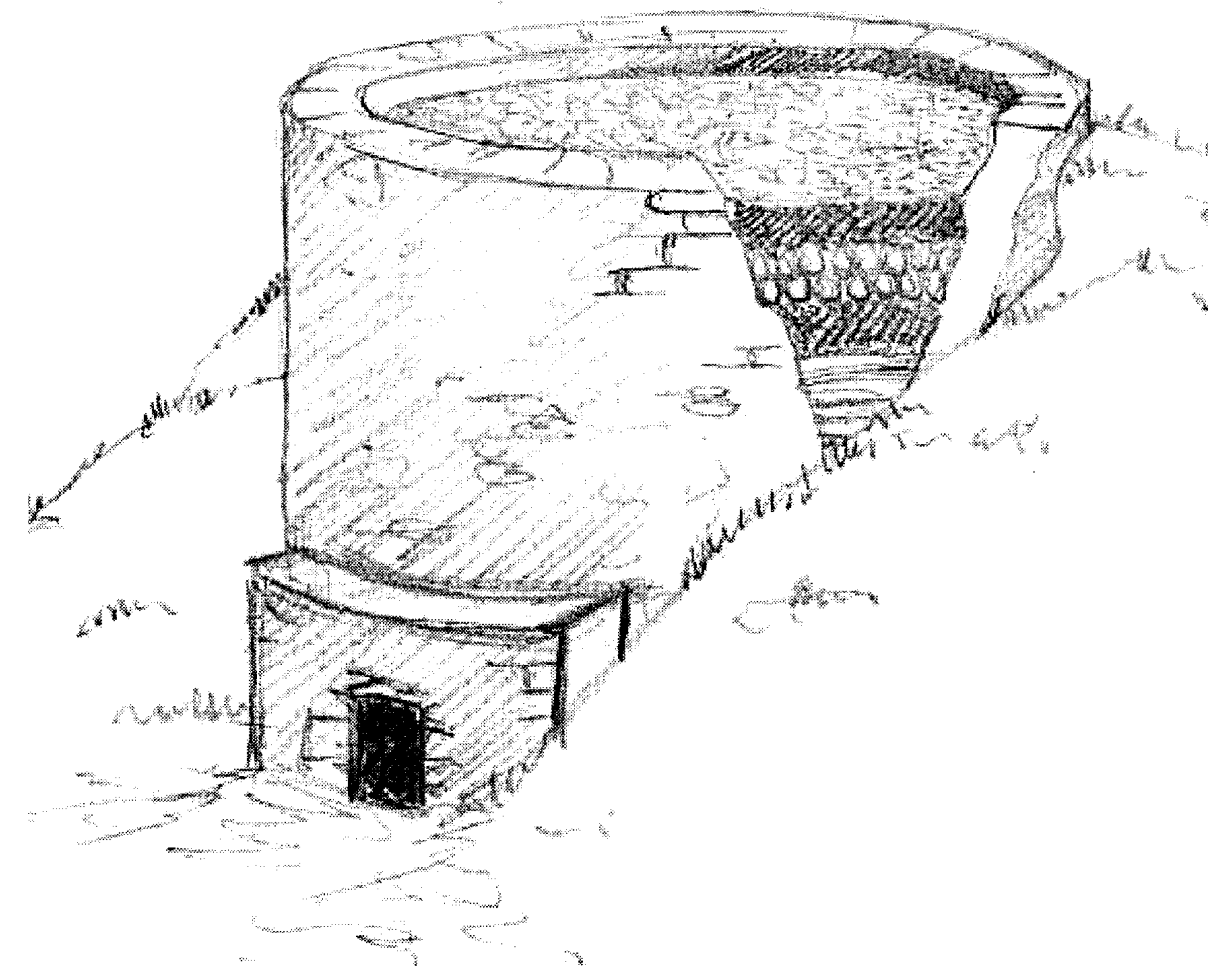

Horno de calcinación (Ferrería de La Somoza, León)

${ }^{192}$ J. ALMUNIA (1951): Contribución de la Real Sociedad Vascongada al progreso de la siderurgia española a fines del siglo XVIII. CSIC. Madrid, p. 17 y 18 
La calcinación al aire libre era un dispendio en madera que podría economizarse con la utilización de hornos de cementación'193; pero ni en ese siglo ni en el siguiente llegaron a usarse $\mathrm{o}$, al menos, a generalizarse en el noroeste; pues si bien en 1824 se dice del abad de San Pedro de Montes, Eladio Enríquez (1820-1824), que "hizo también un horno para cozer la vena en la herrería de Linares"194, otros autores señalan todavía a fines del siglo XIX que en el Bierzo su calcinación se realizaba en pilas al aire libre ${ }^{195}$. Conocemos, sin embargo, algún horno de este tipo, como el que se construyó en la Somoza berciana hacia 1805 , en la ferrería llamada de Godoy, que aún se conserva en muy buen estado. Está construido en la ladera de una colina por lo que es fácil acceder a su boca, que era por donde se cargaba. La fábrica era de piedra de pizarra unida con argamasa, de planta circular y cónica, con un diámetro más grande en la base -en la que había una especie de portezuela para descargar el mineral- que en la parte superior o boca.

\subsection{La reducción en el horno}

Las fases siguientes del proceso se efectuaban en el horno de la ferrería utilizando carbón vegetal. Antes de la Revolución Industrial, la producción de una tonelada de hierro en Europa precisaba de dos de carbón; y para lograr una de éstas, cuatro de madera ${ }^{196}$, lo que parece poco, al menos para el sistema de horno bajo utilizado por las ferrerías ${ }^{197}$; pues los datos que se conocen de las vascas la proporción es de uno a cinco, es decir, un quintal de hierro por cinco de carbón ${ }^{198}$. En Asturias, en 1838, se emplearon para producir 12.000

\footnotetext{
193 F. J. DATOLI: Ob. Cit., p. 55

194 AMS. Estado general de cuentas del monasterio de Montes, año 1824, ff. 247.

195 J. M. SOLER (1883): Reseña geológico minera y catálogo de minerales, rocas, etc.en la provincia de León. Madrid, p. 25: "la calcinación de la mena se hizo en pilas al aire libre, empleando leña y monte bajo"; también la ESTADÍSTICA MINERA, año 1884, p. 67.

196 Según Clive Day, citado en J. GARMENDÍA: Las ferrerías. San Sebastián, 1976, p. 138.

197 Creo que estas proporciones son más comunes en los hornos altos tradicionales, es decir, los que utilizan carbón vegetal, aunque algunos autores hablan de ferrerías francesas con consumos de 2 por 1 .

198 Labairu en 1895 señala que por cada quintal de hierro (de 144 libras o 70 kg.) eran necesarias de 4,5 a 5 cargas de carbón (de $80 \mathrm{~kg}$. la carga, lo que viene a ser $5 \mathrm{~kg}$, de carbón por un kilo de hierro); y lo mismo o parecido dicen Zuaznavar (1905) y Esparza (1930). En A. GARCÍA SANZ (1982): "El aprovisionamiento de carbón en las ferrerías navarras de Elcorri. Cálculo de su consumo y precios (1802-1867). Cuadernos de etnología y etnografía de Navarra. Pamplona, XIV, p. 396. Este autor, a su vez, señala que entre las condiciones para construir la ferrería de Elcorri había una cláusula por la que se le permitía a Martín de Jáuregui sacar de los montes
} 
quintales de hierro, 14.00o de leña y 70.00o quintales de carbón, lo que significa casi seis de carbón más uno de leña, es decir, siete quintales de combustible por cada quintal de hierro; en Galicia, en la misma fecha, para producir 25.000 quintales de hierro, se gastaron 25.000 quintales de leña y 130.00o quintales de carbón, por lo que para reducir un quintal de hierro hicieron falta algo más de seis de combustible, aunque sólo cinco de carbón ${ }^{199}$; otras fuentes aumentan esta proporción a seis e incluso a más ${ }^{200}$, por lo que seis puede ser una media aceptable ${ }^{201}$.

Para producir esos 200.000 quintales de carbón en 1838 en Asturias y Galicia, de acuerdo con esa media indicada de seis por uno, serían necesarios 1.200.00o quintales de madera. Esta cantidad era la que consumían las trece ferrerías asturianas y las treinta gallegas que cita Schultz ese año, es decir, una media de 18.604 quintales de carbón o un millón de kilos de madera por ferrería (con quintales de $57 \mathrm{~kg}$.). Pero a esa cantidad de leña habría que añadir las bercianas, en torno a quince por esa fecha. Madoz, poco después, dirá que tales ferrerías bercianas consumen más de un millón de arrobas de carbón de urz²02, es decir unos 200.00o quintales de carbón. Pero a lo largo de los siglos que aquí estudiamos el número de ferrerías superó las 130, aunque por siglos fuera bastante menor, en torno a cuarenta/cincuenta en los siglos XVI y XVII, unas

públicos de Echani-Aranaz 4.000 cargas con las que pensaba fabricar 700 quintales de hierro, lo que da una proporción de 6,5 a 1.

199 G. SCHULZ: "Ojeada sobre el estado actual de la minería en el distrito de Asturias y Galicia". Anales de Minas, t. I. Madrid, 1838, p. 385 y 391.

${ }^{200}$ La REVISTA MINERA de los años 1863, 1864 y 1866 proporciona datos bastante precisos. Así en 1863, 23 forjas de Lugo fundieron 10.953 q.m de vena que produjeron 3.805 q.m. de hierro con un consumo de 6 q. de carbón por cada quintal de hierro; las de Orense gastaron 6,14 quintales de carbón por quintal de hierro. En 1866, las forjas de Lugo produjeron 4.781 q.m. de hierro y consumieron 31.682 q.m. de carbón vegetal, con lo que el consumo de combustible fue de 6,67 q. por quintal de hierro; las de Orense consumieron 15.594 q.m. de carbón "lo que, observa el informante, es exagerado si se admite como exacta la cantidad de mena beneficiada (1.397 q.m.). No es exagerado sospechar que la producción de estas herrerías está representada por un número entre 2.300 y 2.600 q.m. suponiendo el consumo racional de seis a siete de carbón por uno de hierro obtenido". REVISTA MINERA, t. XVI (1866), p. 112, y t. XIX (1868), p. 759 y 760 .

${ }_{201}$ D. PAZ (1991): El monasterio de Santa María de Villanueva de Oscos. Oviedo, p. 154, señala que la ferrería de este monasterio en 155 años de funcionamiento produjo 91.546 quintales de hierro para los que fue necesario utilizar $15.753 .592 \mathrm{~kg}$. de vena y unos $36.997 .483 \mathrm{~kg}$. de carbón; por lo que para producir un kg. de hierro eran necesarios tres de vena y casi siete de carbón.

${ }^{202}$ P. MADOZ: (1845-1850): Diccionario geográfico-estadístico-histórico de España y sus posesiones de ultramar. Madrid, p. 138. 
setenta en el XVIII y casi ochenta en los años centrales del siglo XIX, como ya hemos dicho. El consumo de combustible fue extraordinario.

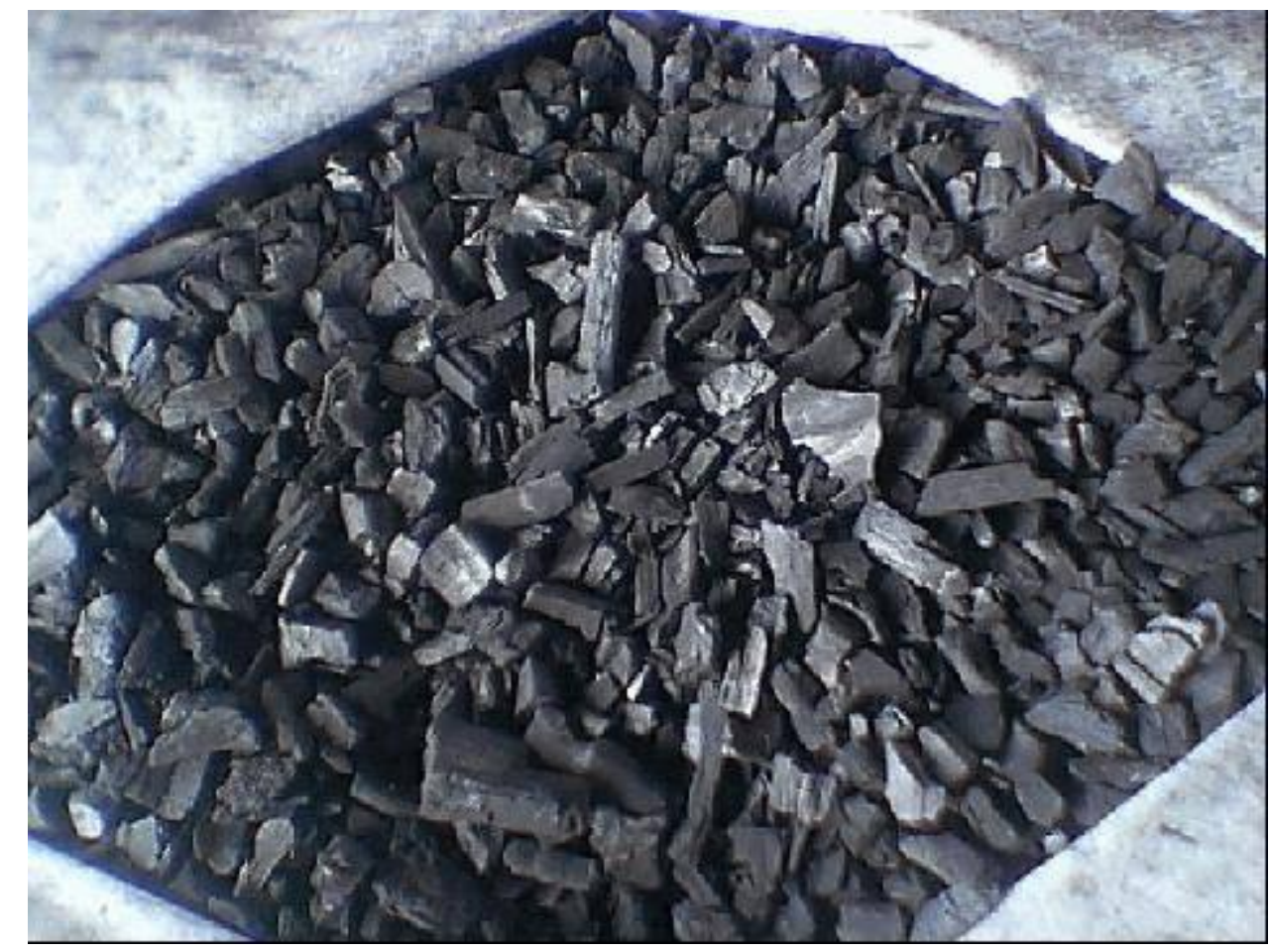

Carbón vegetal

La fabricación de carbón vegetal a partir de maderas de roble, haya, castaño o raíces de brezo producía en estas maderas una merma aproximada de $3 / 4$ del peso del producto, por lo cual para conseguir un kilogramo de carbón era necesario cuatro de madera aproximadamente, como ya hemos indicado anteriormente. Pero considerando que estas maderas incluían materiales no carbonizables como las cortezas, quemadas en su totalidad, habrá que pensar en una relación de 1 a 5 . Las cifras que se manejan habitualmente son variables en función del tipo de madera, del proceso de elaboración, etc., aunque siempre de ese orden ya que se citan rendimientos de solo el 15 al 23 por ciento ${ }^{203}$. En consecuencia, el proceso de fabricación de un kilogramo de hierro necesitaba en torno a $6 \mathrm{~kg}$. de carbón y por tanto 30 de madera, a los que habría que añadir casi otro kg. para la calcinación o ragua, es decir en total en torno a 31 kilogramos.

203 L. GUITIÁN (2001): "La destrucción histórica del bosque en Galicia". Semata. Ciencias sociales y Humanidades, vol. 13, p. 139, 
$\mathrm{Si}$ aceptamos una producción media de 40 toneladas de hierro por ferrería y año, el consumo de madera se situaría en torno a 1.240 tn de madera por ferrería/año, cantidad que dividida por cinco nos daría unas 250 tn de carbón ${ }^{204}$. Tomando como media de producción las citadas 40 toneladas de hierro por ferrería y año en el siglo XVIII, donde encontramos trabajando unas sesenta ferrerías en todo el noroeste, habría que hablar de unas 74.00o toneladas de madera. Luis Guitián escribe que, aceptando una producción de madera en torno a 40 o 50 tn/ha cada 20 años, en un año tipo del siglo XVIII las 25 ferrerías gallegas (esta cifra es la que el supone que existen) consumirían anualmente al menos unas 747 ha de bosque. Pero teniendo en cuenta que la tala no podía repetirse al menos hasta dos décadas más tarde, la supervivencia de esta industria solo estaría garantizada disponiendo de unas 15.000 ha de bosque en el entorno de las ferrerías, superficie que no sería muy diferente en el caso de bosques de 100 años de edad ${ }^{205}$. Si en lugar de 25 hablamos de 50 o 60 ferrerías esa cifra se dobla evidentemente. A lo largo de los siglos XVI-XIX, periodo en el que funcionan unas 130 ferrerías, el consumo de madera tuvo que causar un enorme impacto sobre el bosque.

Tan ingente cantidad de madera suponía la existencia de un frondoso y extenso bosque o de un bosque cubierto de brezo, como ocurría en muchas zonas de Galicia y el Bierzo. Sin bosque no hay ferrerías. Por eso, para lograr el permiso de construcción una ferrería debía de contar, además de con agua, con una zona de bosque con la que abastecerse de madera y carbón. Lo podemos ver en todas de las que conocemos su documento de fundación, de lo que daré algunos ejemplos:

* Ferrería de Lor: A comienzos del siglo XVIII, la encomienda de Quiroga permite su construcción atendiendo a que en el coto de Lor "auia muchos montes propios (de su) directo dominio, sin que estos sirviesen de utilidad alguna (para) el aprovechamiento de ellos" ${ }^{206}$. Por ello, se lo aforan en 1719 a

\footnotetext{
204 En la ferrería asturiana de Soto Rodrigo, entre 1849 y 1855, se consumieron una media de $314 \mathrm{tn} /$ año de carbón, para las que se utilizaron en torno a 1.370 hayas por año. Cit. en A. MATO (2010): La sociedad rural en el concejo de Ponga (1750-1930). Oviedo, p. 121 205 L. GUITIÁN (2001): Ob. Cit., p. 139,

${ }^{206}$ AHRG. R. A.: 3020/42
} 
don Joaquín Pardo Rivadeneira por la vida de tres reyes para haga en ese lugar una ferrería.

* Ferrería de Soto Rodrigo: En 1776 el Consejo de Estado concede a don Vicente Ignacio de Argüelles permiso para la construcción de esta ferrería en el concejo de Ponga, por ser un lugar ideal para ello por contar con agua " $y$ una porción de monte contiguo a los montes de la expresada parroquia" que tendría una gran utilidad para los vecinos "en la fábrica de carbón”"207.

* Ferrería de Tejedo: En 1788 los vecinos de Tejedo y Pereda de Ancares permiten la construcción de esta ferrería, porque "tenemos superabundantes montes para coadyuvar a la perpetua existencia de la propuesta fábrica sin ser necesario tocar, ni entrometerse a arrancar en los vedados y contados que abundantemente tenemos para edificios, como tampoco en los fructíferos" ${ }^{208}$.

* Ferrería de Piago: Los vecinos de varios lugares de la parroquia de Santiago de Fontaneira dan permiso, en 1797, para construir la ferrería "en atenzión a que el sitio referido da Retorta, su zircunferencia y a mucha distancia ay número crezido de montes poblados de brezo, zepa o coza para su surtido, consumo reproduzible a pocos años de su arranque que no sirven para frutificar ni tienen otra utilidad"209.

* Ferrería de Seoane: En febrero de 1815, los vecinos de las parroquias de San Juan de Seoane y San Pedro de Esperante, dan permiso para construirla, entre otras razones, porque a orillas del Lor "se miran montes de mucha

\footnotetext{
207 Añaden los vecinos que "por la espesura de sus montes no producen para sus fábricas beneficio alguno a que se añadía que los pocos robles que hay estaban sofocados de los más árboles de que se componía como hayas, avellanos, plátanos y otros", y que talando los inútiles se beneficiaría el bosque. Cit. en A. MATO (2010): La sociedad rural en el concejo de Ponga (1750-1930). Oviedo, p. 298

208 AHPL, P.N.: caja 3492 (1788)

209 AHPLU: 6792/2 (1797). Permiso que conceden "para que puedan hazer y fabricar la mencionada Erraria disfrutando de la leña o coza de los montes en que respectivamente son partizipes". Añaden que de no ser así tendrían que desplazarse muy lejos, por ejemplo llevando "a veneficiar (el carbón) semanalmente a la ziudad de Lugo distante más de zinco leguas, mazos de Orizón y otras partes".
} 
elevación de producción de leña de roble, cepa de ucedo y otros con bastante abundancia" ${ }^{210}$.

* Ferrería de Serviz: En 1823 los vecinos permiten a Nemesio Fernández su construcción atendiendo a la gran abundancia de urz existente en su término, "muy suficiente a dar surtido a una fábrica de yerro" y a las ventajas que la misma les iba a reportar, "para dar de esta forma salida a las producciones de sus montes que no la tienen" 211.

\subsection{El bosque eurosiberiano del noroeste}

La toponimia del noroeste es un reflejo fiel de la existencia en tiempos pasados de un bosque enormemente rico en variedades arbóreas y vegetales. Topónimos como Carballo, Carballal, Carballeira, Carbayu, Carbayón, Castañoso, Encinedo, Fabero, Fresnedo, Jardonal, Noceda, Nogales, Nogaledo, Pineda, Piorno, Rebollo, Rebollal, Requejo, Robledo, Robleu, Salgueiral, Sardonal, Souto, Soutelo, Tejedo, La Uz, etc., se repiten insistentemente por toda la geografía del noroeste ${ }^{212}$. Esta variedad era importante porque para la ragua se utilizaban todo tipo de leñas; sin embargo, para la fabricación de carbón lo normal era hacerlo con haya, roble y encina en Asturias; con roble, castaño y sobre todo urz en León y Galicia. De ahí la importancia del tipo de bosque eurosiberiano con algunos matices mediterráneos, tan rico y variado en especies arbóreas, propio de todo el noroeste de España.

La geomorfología de la zona con abundantes montañas elevadas y recónditos valles; el clima oceánico húmedo, con precipitaciones relativamente abundantes, entre los 800 y $1.500 \mathrm{~mm}$. anuales (aunque en algunas zonas meridionales con cierta tendencia a la aridez estival); y las aguas corrientes tan abundantes, festoneadas de árboles de ribera, han sido los factores que han propiciado la existencia de este tipo de bosque eurosiberiano. La vegetación arbórea originaria estaba formada por frondosas caducifolias, cuyas especies

\footnotetext{
${ }^{210}$ AHPLU: 2474/4 (1815).

${ }^{211}$ AHPL, PN.: caja 3577, año 1823

${ }^{212}$ Sobre toponimia: X. L. GARCÍA ARIAS: Pueblos asturianos: el porqué de sus nombres. Gijón, 1977; J. GARCÍA: Pueblos y ríos bercianos. Ponferrada, 1994.
} 
predominantes eran el roble (quercus robur), llamado carballo (en Galicia y el Bierzo) o carbayu (Asturias), el roble albar (quercus pyrenaica) y las hayas (fagus sylvatica), acompañados de castaños, abedules, avellanos, alisos y encinas, y en la zona de la costa pinos, al menos desde el siglo XVIII. El matorral lo constituían los brezos (carqueixa, urz o uz), tojos y retamas (xesta, árgoma).

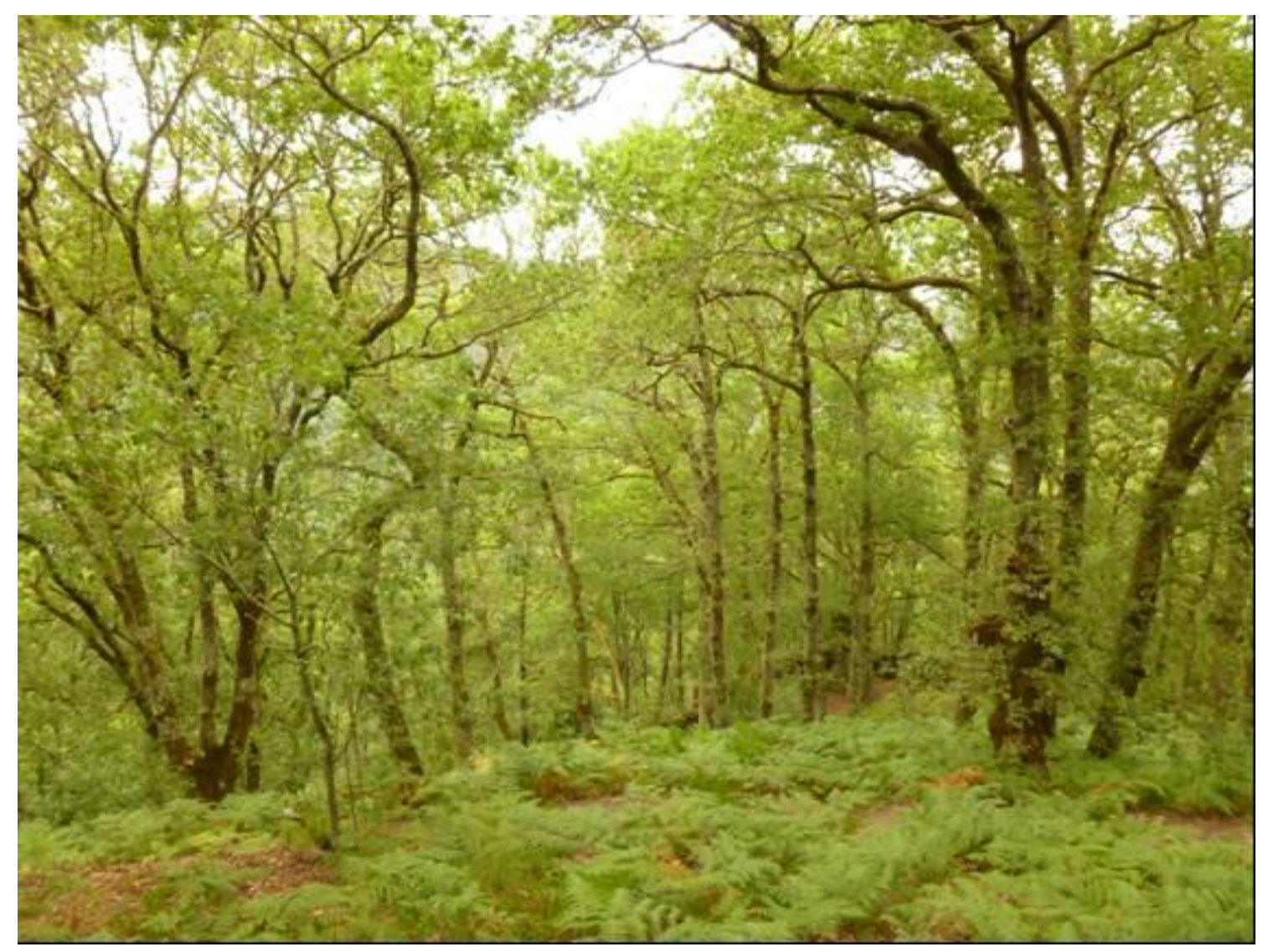

Bosque de robles en Orense

Aunque se trata de una fuente tardía y parcial, la Clasificación General de Montes Públicos de 1859 nos ofrece una imagen anterior a su definitiva transformación por la Desamortización, lo que nos permite saber qué especies eran predominantes en los bosques de la zona en los siglos de la modernidad. Tal clasificación se hizo en el marco de la ley general de Desamortización de 1855, que se proponía enajenar los montes públicos, conservando solo los que estuviesen poblados de abetos, pinos, hayas, castaños y robles, entre otras especies. No se trata, por tanto, de todos los montes españoles, sino de los públicos, es decir, los del Estado y los comunales o de vecinos. Estos montes 
constituían solo una parte -incluso la menor del sector forestal-, pues los montes de particulares ocupaban una extensión mucho mayor, pero sobre ellos disponemos de poca información ${ }^{213}$.

Según la Clasificación, España contaba en 1855, excluido el País Vasco, con 10.186.045 de hectáreas de montes públicos, de las que un 92,9\% eran patrimonio de los pueblos. Las provincias de León, Lugo, Orense y Oviedo representan el 9,49\% del total de España, cifra pequeña respecto de su extensión, pues con excepción de León y Oviedo, predominaban los montes de propiedad privada. Lo que nos muestra el CUADRO VIII es que si bien el número de bosques del Estado, con la excepción de León (o,4\% de la provincia), es relativamente alto, un 36,5\% (entre el 35,3 de Orense y el 63\% de Lugo) la mayoría de las hectáreas arboladas en todas las provincias, por encima del 99,4\%, corresponde a bosques de los pueblos, que suponen el 63,4\% del número total.

\section{CUADRO VIII. ENAJENABLES Y EXCEPTUADOS DE LA DESAMORTIZACIÓN}

\begin{tabular}{|c|c|c|c|c|c|c|c|c|c|c|c|c|}
\hline & \multicolumn{4}{|c|}{ DEL ESTADO } & \multicolumn{4}{|c|}{ DE LOS PUEBLOS } & \multicolumn{4}{|c|}{ TOTAL } \\
\hline & $\mathrm{N}^{0}$ & $\%$ & HECT. & $\%$ & $\mathrm{~N}^{\mathrm{O}}$ & $\%$ & HECT. & $\%$ & $\mathrm{~N}^{0}$ & $\%$ & HECT. & $\%$ \\
\hline LEÓN & 10 & 0,4 & 953 & 0,1 & 2.174 & 99,4 & 601.085 & 99,8 & 2.185 & 100 & 602.238 & 100 \\
\hline LUGO & 1.170 & 63,0 & 1.293 & 0,8 & 685 & 36,9 & 157.781 & 99,1 & 1.855 & 100 & 159.074 & 100 \\
\hline ORENSE & 541 & 35,3 & 204 & 0,3 & 990 & 64,6 & 52.760 & 99,6 & 1.532 & 100 & 52.965 & 100 \\
\hline ASTURIAS & 858 & 57,4 & 2.165 & 1,4 & 635 & 42,5 & 150.071 & 98,1 & 1.493 & 100 & 152.866 & 100 \\
\hline TOTAL & 2.579 & 36,5 & 4.615 & 0,4 & 4.484 & 63,4 & 961.697 & 99,4 & 7.065 & 100 & 967.143 & 100 \\
\hline
\end{tabular}

FUENTE: Clasificación General de Montes Públicos aprobado por R. O. de septiembre de 1859

A esto hay que añadir que, por la premura con que se hizo, en esta fuente no están todos los montes públicos; recuentos posteriores añadieron algunos miles de hectáreas más. En Asturias, por ejemplo afloraron después de la

${ }^{213}$ J. SANZ (1985): "La historia contemporánea de los montes públicos españoles, 1812-1930. Notas y reflexiones". En R. GARRABOU y J. SANZ: Historia agraria de la España contemporánea. Barcelona, t. II, p. 194. 
Clasificación, al menos doscientas cincuenta mil hectáreas más de montes públicos; también en León y Lugo, aunque en menor extensión ${ }^{214}$. Con todo, lo que pretendemos con esta fuente es conocer el tipo de bosque característico en las zonas en donde hubo ferrerías, o al menos, los árboles que predominaban. Para ello hemos tomado como muestra una serie de Partidos Judiciales ${ }^{215}$ de las citadas provincias y hemos recogido solo las especies dominantes en cada bosque, sabiendo que se trata de bosques mixtos en los que abundaban igualmente otras especies, aunque siempre dominando alguna, que es lo que recoge la citada fuente (CUADRO IX).

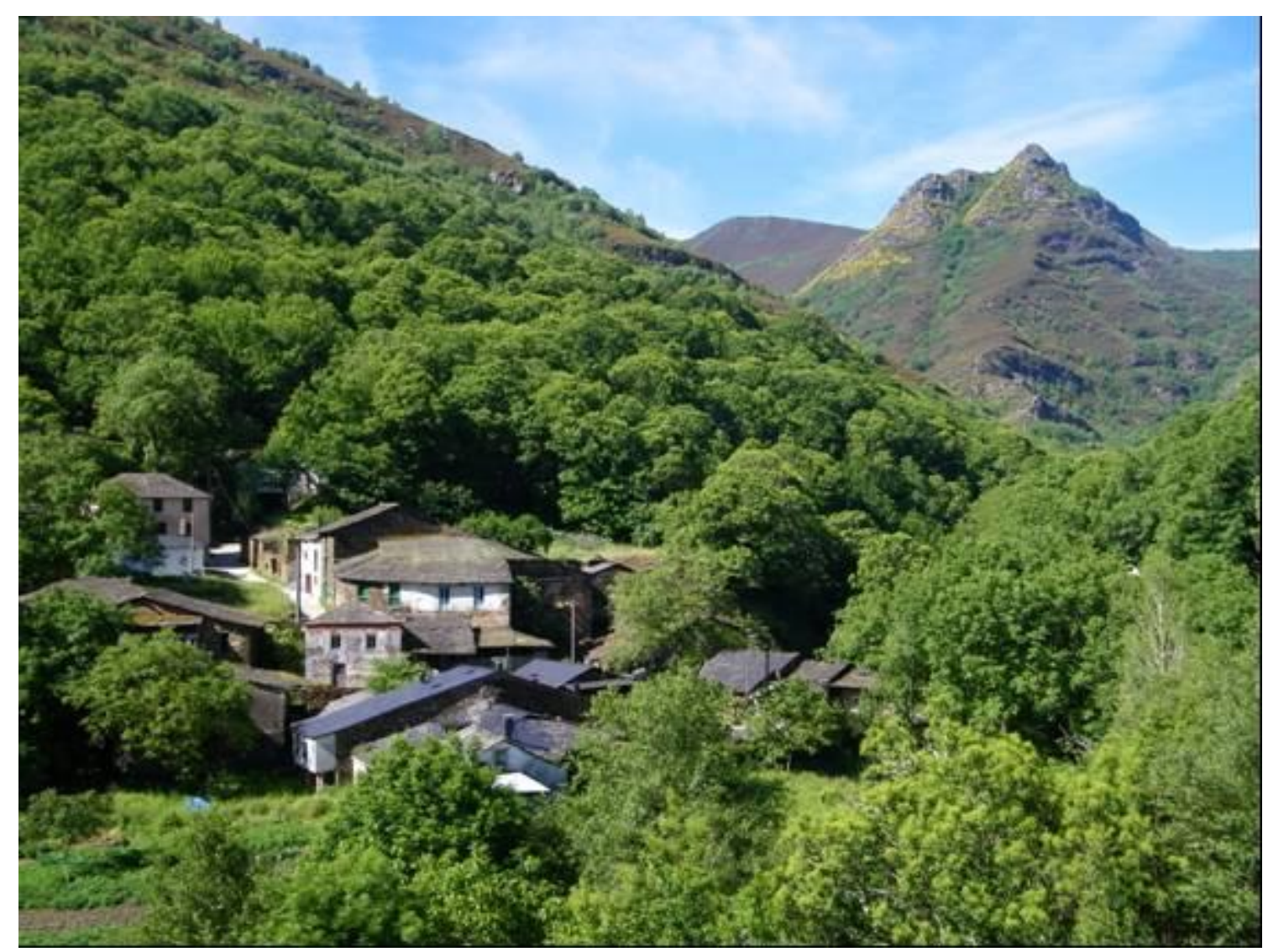

Bosque de castaños en el Caurel (Lugo)

Lo primero que llama la atención es la disparidad de hectáreas de montes públicos de unos partidos judiciales respecto de otros. Ponferrada y Villafranca del Bierzo son los que cuentan con una mayor cantidad de hectáreas de montes

${ }^{214}$ A. LÓPEZ ASTUDILLO (1992): “Los montes públicos y las diversas vías de privatización en el siglo XIX”. Agricultura y Sociedad, no 65, p. 74 y 75.

215 En este caso los partidos judiciales son los que existían en el siglo XIX cuando se confeccionó esa Calsificación. 
públicos, la mayoría de ellos de los pueblos, al igual que ocurre en la comarca limítrofe de Valdeorras, en Orense. Aquí incluso los bosques privados suelen estar aforados a los pueblos, que los disfrutan en común ${ }^{216}$. Este número es muy inferior en las provincias de Lugo y Oviedo, ya que en ellas predominaban los montes privados, aunque con algunas diferencias comarcales.

En segundo lugar reclama nuestra atención la diferencia entre el oriente y el occidente de Asturias, esta última zona con un menor número de hectáreas de montes públicos. Aunque probablemente no estén todos recogidos en esa Clasificación, como ya hemos dicho, algunos autores explican esta diferencia por la propiedad privada dominante en el occidente, especialmente de monasterios y señores, probablemente por donaciones en la Edad Media ${ }^{217}$. En todo caso existía un usufructo colectivo, por no hablar de montes vecinales, bien de varas, bien de mano común ${ }^{218}$. Lugo es un ejemplo de esto último, pues los partidos judiciales del interior como Fonsagrada, Monforte o Quiroga contaban con muchos montes, pero eran de titularidad privada en la mayoría de los casos: de órdenes religiosas y militares y de la hidalguía, aunque normalmente de usufructo colectivo (los de mano común), de los vecinos o de sólo algunos vecinos (los de varas).

Respecto a la especies dominantes en esos bosques es significativo que en Ponferrada, Villafranca y Valdeorras predominen los montes de roble y brezo, en los dos primeros, el roble supera el 75\% del total, mientras que en Asturias, sobre todo en la zona oriental, lo que domina es el haya (76\%) seguido del roble. Estas maderas serán las más frecuentemente utilizadas por las ferrerías, aunque como leñas se usaban las de otros muchos árboles, incluidos castaños, avellanos, encinas, chopos y abedules. En las zonas de costa, por el contrario, lo que hallamos es un monte raso o cubierto de árgoma, signo de que había sufrido, como denuncian muchas voces en el siglo XVIII, un intenso proceso de deforestación, no sólo por las ferrerías sino para abastecer la construcción de

\footnotetext{
${ }^{216}$ Es lo que ocurre con muchos bosques de la merindad de Aguiar, propios del marqués de Villafranca, pero aforados a los pueblos.

${ }_{217}^{21}$ J. Ma MORO (1979): "Los montes públicos en Asturias a mediados del siglo XIX". Agricultura y sociedad, 12, p. 236-237

${ }_{218}$ B. BARREIRO (1997): "Montes comunales y vida campesina en las regiones cantábricas". Studia Histórica, $H^{a}$ Moderna, 16, p. 34 y ss,
} 
barcos, especialmente en los astilleros del Ferrol, creados a principios de ese siglo. Los montes públicos del interior de Lugo, cubiertos en su mayor parte de árgoma, creo que no son representativos del bosque de esa provincia, en la que los bosques, la mayoría de titularidad privada, estaban poblados igualmente de roble, encina, castaños y urz.

\section{CUADRO IX. ESPECIES DOMINANTES EN LOS MONTES PÚBLICOS DE ALGUNOS PARTIDOS JUDICIALES DEL NOROESTE}

\begin{tabular}{|c|c|c|c|c|c|c|c|c|}
\hline \multirow[t]{2}{*}{$\begin{array}{l}\text { P. } \\
\text { JUDICIAL }\end{array}$} & \multirow[t]{2}{*}{ HECT. } & \multicolumn{7}{|c|}{$\begin{array}{c}\text { ESPECIES } \\
\text { (especies en tantos por cien) }\end{array}$} \\
\hline & & ROBLES & HAYAS & ENCINAS & CASTAÑO & BREZO & OTROS & TOTAL \\
\hline PONFERRADA & 108.905 & 79,50 & & 8,83 & 0,27 & 11,16 & 0,22 & 100 \\
\hline VILLAFRANCA & 80.571 & 73,65 & 0,91 & 7,34 & 0,10 & 12,84 & 3,38 & 100 \\
\hline FONSAGRADA & 78.102 & 3,41 & & & & 20,60 & 76,32 & 100 \\
\hline MONFORTE & 3.784 & 0,39 & & & 0,02 & 19,45 & 80,12 & 100 \\
\hline QUIROGA & 8.747 & 0,06 & & & & & 99,93 & 100 \\
\hline VIVERO & 4.621 & 2,01 & & & & & 97,98 & 100 \\
\hline VALDEORRAS & 12.657 & 33,64 & & 8,37 & & 52,61 & 5,36 & 100 \\
\hline BELMONTE & 12.542 & 17,40 & 62,32 & & & & 16,26 & 100 \\
\hline CANGAS ONÍS & 27.222 & 14,10 & 76,50 & & & & 9,54 & 100 \\
\hline CASTROPOL & 50 & 84,00 & & & & & 16,00 & 100 \\
\hline GIJÓN & 3.585 & 0,94 & & & & & 99,05 & 100 \\
\hline
\end{tabular}

FUENTE: Clasificación General de Montes Públicos aprobado por R. O. de septiembre de 1859

\subsection{El bosque del noroeste en la Edad Moderna}

El espacio forestal fue en la Edad Moderna menos extenso que en la actualidad y también más precario, porque estuvo sometido a un uso más intensivo y a numerosos intereses: caza, ganadería, recolección de frutos silvestres, leña, carboneo, madera para edificaciones y construcción naval, y 
como reserva de tierras en momentos de crecimiento demográfico o necesidades agrarias, por ejemplo mediante las bouzas, searas, senaras y estivadas ${ }^{219}$.

A lo largo de la Baja Edad Media, la superficie ocupada por el bosque disminuyó sensiblemente, tanto por el aumento del espacio cultivado (roturaciones) como por su explotación, lo que dio lugar a una mayor extensión de los brezales ${ }^{220}$. Es entonces, a comienzos de la Edad Moderna, cuando comienza tenerse conciencia de su valor, de que son necesarias algunas medidas públicas para protegerlo. Aunque el comienzo de la Pequeña Edad del Hielo, de la que ya hemos hablado, caracterizada por las fuertes precipitaciones y el frío invernal, fue favorable al bosque, su enorme consumo llevó a una disminución paulatina, que solo se detendría en los años centrales del siglo XIX, con medidas drásticas de protección y reforestación ${ }^{221}$.

La distribución de la tierra en la Edad Moderna (CUADRO X) supone que casi el 6o\% de Galicia era monte y bosque; en el caso de Asturias y León la proporción es menor por el peso de la Tierra de Campos, pero si dejamos la zona de la Meseta, el monte y bosque alcanzaría igualmente porcentajes cercanos al $60 \%$ e incluso el $75^{222}$. Las ordenanzas concejiles, en las que frecuentemente se regula el uso del monte, son expresión de esa complejidad de intereses 223. A lo largo de los siglos, la acción antrópica modificó sustancialmente este bosque, especialmente por el consumo ciudadano, naval, de las ferrerías, la sustitución de los carballos por sotos de castaños y más recientemente por pinos y eucaliptos; pero sobre todo el bosque ha retrocedido como efecto de las roturaciones para organizar los campos de cultivo, las praderías, tierras de labor y los incendios. Donde no ha ocurrido esto, se ha

${ }^{219}$ A fines del siglo XVIII, en un informe de 1785 contra las pretensiones de Andrés Bravo de construir algunas ferrerías y martinetes en el oeste de Asturias se dice que con su consumo "quedarían los vezinos de los pueblos privados del uso de las rozas o senaras, que reduze a romper el monte cavándolo o rozándolo y quemando la maleza, se siembra con el abono de las cenizas que suele produzir buenos frutos, y dejándolo discurrir 15 o más años ejecuntando en cada uno en diferentes sitios, aprovechando los montes de su término con esta alternativa que les faltaría si se quemasen para fabricar carbón". En J. LÓPEZ y A. GRAÑA (1998). Ob. cit., p. 123.

${ }^{220}$ L. GUITIÁN (2001): Ob. cit., p. 119 y ss.

221 IBIDEM.

222 B. BARREIRO (1997): Ob, cit., p. 18, señala que en la zona cantábrica, y por tanto en Asturias, el espacio inculto y comunal superaba el $75 \%$ del territorio.

${ }^{223}$ L. RUBIO (1993): El sistema político concejil en la Provincia de León. León; también B. BARREIRO (1997): Ob. cit., p. 47 y ss. 
degradado formando grandes extensiones de una landa de brezos, tojos y árgoma ${ }^{224 .}$

\section{CUADRO X. DISTRIBUCIÓN DE LA TIERRA PRODUCTIVA A MEDIADOS DEL SIGLO XVIII) \\ (en medidas de tierra)}

\begin{tabular}{|l|c|l|c|l|}
\hline & LABORABLE & $\%$ & MONTE Y BOSQUE & $\%$ \\
\hline GALICIA & 5.610 .701 & 40,52 & $8.235 \cdot 512$ & 59,47 \\
\hline LEÓN Y ASTURIAS & 4.914 .963 & 67,75 & 2.371 .131 & 32,54 \\
\hline
\end{tabular}

FUENTE: Catastro de Ensenada. Cf. Grupo 75 (1977): La economía del Antiguo Régimen. La renta nacional de la Corona de Castilla. Madrid, p. 85)

La situación del monte en la Edad Moderna era muy diferente de la actual. Aunque con grandes claros, ocupaba amplios espacios de la Galicia interior, el Bierzo y Asturias tanto en el interior como en la costa. Los montes constituían la parte más extensa de la superficie útil de Asturias. Abarcaban bastante más de la mitad de todo el territorio ${ }^{225}$, y en algunos concejos, sobre todo del interior, hasta más de un $75 \%$; aunque esto no significa que estuviera siempre arbolado. Tomando como muestra el $41 \%$ de las respuestas del Catastro de Ensenada, se estima que en el siglo XVIII en Asturias solo el 10,9\% de la superficie estaba arbolada, siendo los bosques de roble y haya los dominantes, con más del 60\% de esa superficie. No puede hablarse de que Asturias fuera un paraíso, si bien tampoco se puede hablar de una grave deforestación, aunque desde el siglo XVI varias pragmáticas reales venían advirtiendo contra los abusos que destruían el bosque ${ }^{226}$.

\footnotetext{
224 VV.AA.: Atlas de España (Galicia, Asturias, Cantabria). Barcelona, Planeta, 1989, p. 19 y 109.

225 J. GARCÍA FERNÁNDEZ: Sociedad y organización tradicional del espacio en Asturias. Gijón, 1988, p.127.

${ }^{226}$ Las autoridades del Principado se hacen eco de las mismas. Así la Junta General de 1595 reconoce que "en los montes de los que son concejiles y comunes, en los lugares y feligresías donde los ay, (se han realizado) muchas cortas de encinas y robres y otros frutos, de cuia causa viene la disminución y no se conservan". En B. BARREIRO (1994): "Masa arbórea y su producto en Asturias durante la Edad Moderna". En V. CABERO (ed.); El medio rural español. Cultura, paisaje y naturaleza. Salamanca, p. 243-248.
} 
Los datos no permiten discriminar la proporción de roble y haya de ese 60\% comentado, pero sí un informe anterior de José Colosia, de 1749, referido a algunos concejos cercanos a la costa. De acuerdo con sus datos el total de árboles útiles para la construcción naval era de 3.232.024 de ejemplares, de los cuales 2.094.265 correspondían a robles (64\%), 445.958 a haya, encinas, fresnos y similares $(13,7 \%)$ y 670.522 a castaños $(20,7 \%)^{227}$. Probablemente esta relativa abundancia de montes arbolados explica la percepción de algunos concejos y viajeros en los siglos de la Edad Moderna. En la zona de Villaviciosa se dice en 1549 que por los términos de esta villa "ay muchos montes de robles y ayas y otros árboles" ${ }^{228}$. Un informe de 1775, que emite el comisario don Julián de Ibarguen, se expresaba en parecidos términos. ${ }^{229}$. Quizá por eso, un tanto hiperbólicamente, en 1797 un testigo afirmaba que aún "se podría decir que todo (el Principado) es un bosque" ${ }^{230}$.

En Galicia, por su parte, el bosque era tan abundante y frondoso como el de Asturias. En los siglos XIV-XVI, el paisaje mindoniense se caracterizaba por la presencia de numerosas especies arbóreas, especialmente robles ${ }^{231}$. Las zonas del interior de las provincias de Lugo y Orense abundaban en bosques de roble, sobre todo en las comarcas de Quiroga y el Caurel232. Por el contrario, en la costa cantábrica gallega el bosque era un "bosque humanizado" que recibía cuidados periódicos y estaba amojonado ${ }^{233}$. En el siglo XVIII entre el 75 y el 80

\footnotetext{
227 IBIDEM, p. 244

${ }^{228}$ L. FERNÁNDEZ MARTÍN (1975): Ob. cit. p. 322

229 Dice el informe: "Según lo por mi visto y oído de la generalidad de este terreno toda su tierra inculta produce naturalmente robles, hayas, fresnos, alisos, álamos negros, pládanos, acebos, abedules, tejos, avellanos y otras muchas especies de árboles silvestres que indudablemente se hallan mezcladas en sus montes, si bien ningunas en tanta abundancia como las de roble y haya, particularmente a cierta distancia de las costas del mar, y más cuanto mayor es ésta". Citado en L. ADARO (1989): Datos para una historia minera e industrial de Asturias. Gijón, p. 192.

${ }^{230}$ Cit. En G. ANES: Historia de Asturias. Edad Moderna. Oviedo. Ayalga, 1977, t. II, p. 90

${ }^{231}$ Fernando Colón en su "Itinerario y Cosmografía de España" (1517-23) habla cómo desde Villalba "hasta Castro de Rey hay tres leguas de robledales y cascojos. Hasta Santa María hay una legua de robledales"; también se admira de la presencia de muchos castañares, y así anota "hasta Mondoñedo cinco leguas de castañares". Cit. en M. X. RODRÍGUEZ GALDO: Señores y campesinos en Galicia en los siglos XIV-XVI. Santiago, 1976, p. 29-30.

${ }_{232}$ En un juicio por la ferrería de Soldón de 1603 se recuerda que esta "tiene alrededor muy grandes y buenos montes para leñas de ragoas y carbón a quatro o cinco jornadas cada día y aún más”. AHRG. R. A.: 20441/70.

233 En ese bosque se criaban "castaños, abellanos, vedules, ameneros, prado, fresno, cerderas, nogales, mimbres, salgueros y otros géneros de árboles", pero no "roble y carvallo de lo cual
} 
por cien de su superficie gallega era monte proindiviso, alto o bajo, productivo o "inútil por naturaleza"234

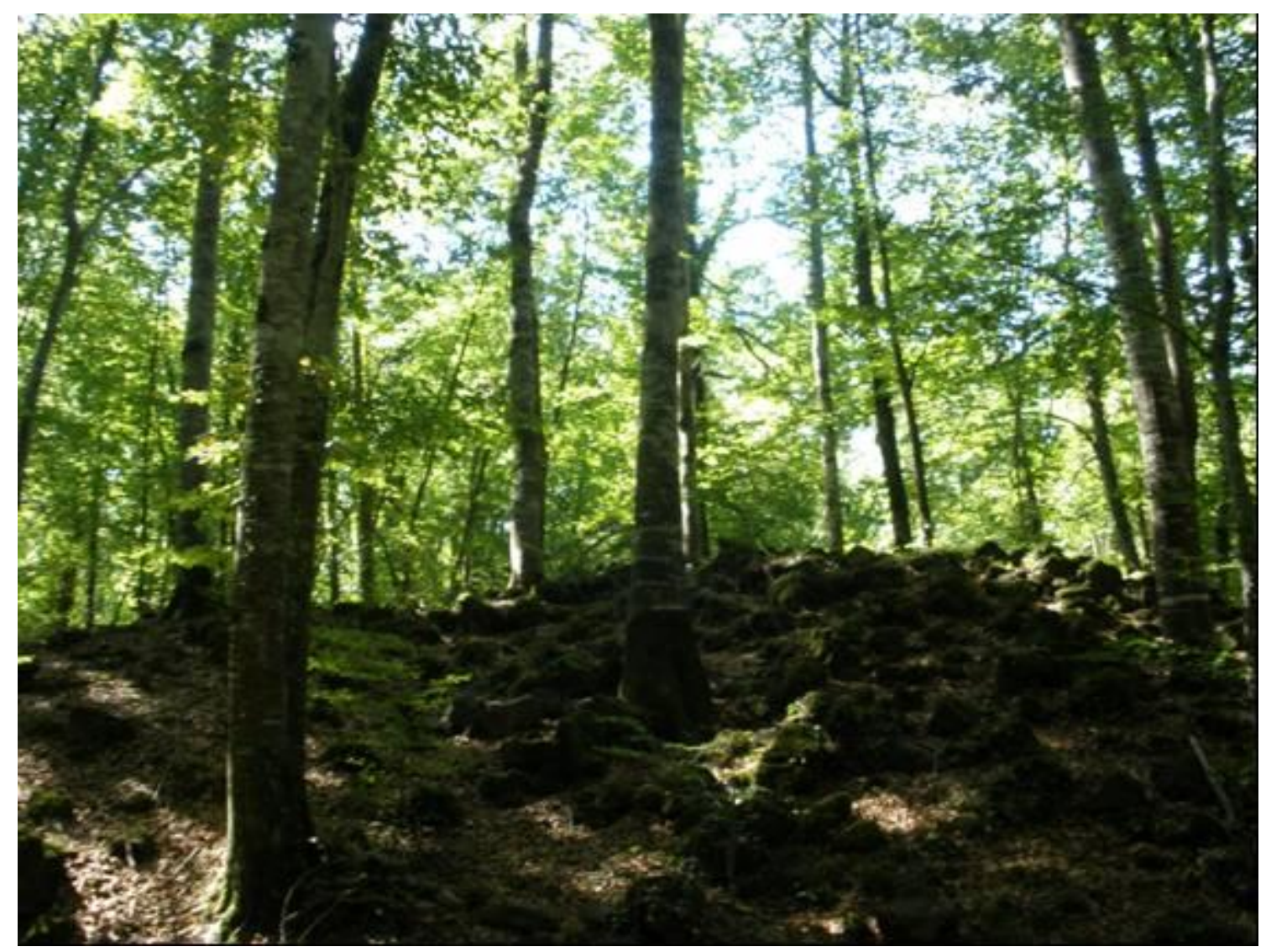

Bosque de hayas en Asturias

Desde el punto de vista jurídico los bosques gallegos, como los del occidente de Asturias, podían ser "de varas" -también llamados "de voces"- y "de mano común" o concejiles. En el primer caso la propiedad y usufructo correspondía, según cuotas desiguales, a las diversas casas porcioneras 235 ; en el concejil la propiedad era del concejo y todos los vecinos de la aldea o parroquia gozaban del derecho a leñas, pasto y rozas. En otros casos, por su naturaleza, se

hay gran abundancia en los montes y tierras públicas y valdías" Cit. en L. GUITIÁN (2001): Ob. cit., p. 146.

234 P. SAAVEDRA: La vida cotidiana en la Galicia del Antiguo Régimen. Barcelona, 1994, p. 83. ${ }^{235}$ En 1755 los vecinos de Córneas (Doncos), que se oponen a la construcción de la ferrería de Neira de Rey, recuerdan que "los montes de dicho coto son del directo dominio del duque de Beragua y Berbek; confinantes con él se hallan los de Neyra de Rey, donde quiere construir la ferrería, que son del conde de Grajal" (AHPLu: 6709/14). 
hablaba de montes bravos y mansos 236 ; y en otros de montes virones 237 y rasos cuando estaban pelados o en los que sólo crecía aulaga o árgoma, utilizada como pasto o cama para los animales. En fecha algo posterior sabemos que, por ejemplo, el bosque lucense era en su mayor parte de aulagas (70.073 hectáreas), brezo (16.828 h.), retama (3.025 ht.) y roble (2.661 ht.) ${ }^{238}$.

Aunque en menor medida, también en el Bierzo existían muchas zonas improductivas y grandes extensiones de bosque. A mediados del siglo XVIII, de los 93.395 cuartales de tierra de que se compone, 36.326, es decir, el $38,8 \%$, eran terrenos de montes considerados improductivos 239 . En la primera década del siglo XIX, Munárriz hablaba del Bierzo como una tierra cubierta de árboles hasta las más empinadas montañas, recalcando que "abunda mucho el brezo, de cuyas raíces, llamadas vulgarmente cepos, se hace carbón muy bueno para las fraguas y herrerías" ${ }^{240}$. Este bosque se cree que era más abundante en el oeste de la comarca que en el este, ya que allí hubo más ferrerías, y porque Datoli afirmaba que las construidas por Lemaur en Torre del Bierzo, en el este, pararon por causa del combustible ${ }^{241}$.

Los aprovechamientos forestales eran muy diversos; por esa razón sobre el monte se proyectaban muchos intereses y conflictos ${ }^{242}$. Desde el siglo XVI, los

\footnotetext{
${ }^{236}$ Foro de la ferrería de Lourenzá de 1519: el abad afora a Fernando Rodríguez la ferrería con "aguas e presas et rio et montes et fontes plantados e por plantar mansos e bravos" (AHN. Códice 181/B, ff. 47v.).

237 AHRG. Hombreiro: 21/70: "memorial de los montes brabos que llaman virones de la encomienda de Quiroga aforados a Francisco Vázquez de Quiroga (1562), Manuel José de Neyra (1681) y don Sancho de Neyra (1761)". AHN. Clero, libro 6495: “Tres memoriales simples de los montes virones del directo dominio de la encomienda de Quiroga de los que se proveen de carvón las herrerías de Rodela y Quintá". AHPLu: 2431/1: Venta por los vecinos de Saceda en 1845 de "una porción de monte virón a donde llaman monte de Conejeira y Trigareja”., etc. Monte virón debe aludir no a un topónimo sino a un tipo de monte bravo. ${ }_{238}$ J. VILLAAMIL (1866): Crónica general de España. Provincia de Lugo. Madrid, p. 75. 239 J. BALBOA (1994): "El Antiguo Régimen. La economía”. En Historia del Bierzo. Ed. del Diario de León, p. 98.

240 J. M. MUNÁRRRIZ: Ob. Cit., p. 112

${ }^{241}$ F. J. DATOLI: Ob. Cit., p. 46

${ }^{242}$ En 1549 Rodrigo de Hebia, vecino de Villaviciosa, denuncia que "algunos vecinos de la dicha villa y tierra contra las leyes y premáticas de nuestros reinos que hablan sobre la conservación de los montes los an cortado y destruido y los oficiales de zapatería quitan las cortezas y deshollan los dichos árboles y por esta causa se secan y destruyen y otros cortan las dichos montes por los meses de Abril y Mayo que diz que en estos meses se aguan y destruyen los dichos montes lo qual es en gran daño y perjuicio de toda la tierra". Tomado de L. FERNÁNDEZ MARTÍN (1975): Ob. Cit., p. 322.
} 
reyes aprobaron leyes para su protección; también hubo ordenanzas concejiles en ese sentido, aunque no todos estaban de acuerdo en ello243. El bosque fue propiedad de algunas grandes órdenes militares, como las encomiendas de la Barra y Quiroga, de instituciones religiosas (benedictinos y cistercienses) o de la nobleza, como el marqués de Villafranca, el conde de Lemos, el marqués de Santa Cruz, el conde de Toreno (el bosque de Muniellos) y otros pequeños señores; pero también hubo muchos bosques arrendados o aforados por los pueblos, como ocurría con algunos montes de la merindad de Aguiar en el Bierzo $^{244}$. Otros eran montes comunales o concejiles sobre los que tenían libertad de uso los vecinos. Por eso, la construcción de una ferrería, además de las licencias pertinentes, tenía que contar con el permiso de sus propietarios.

Algunas ferrerías, en su origen, las levantaron aquellos grandes propietarios de montes o de las jurisdicciones en que se emplazaron 245 ; en otros casos, fueron los concejos los que, con determinadas condiciones, permitieron tales construcciones ${ }^{246}$, e incluso los dueños al aforarlas incluían montes y leñas 247 . Hasta el siglo XVIII, con las licencias reales en la mano, los permisos de construcción de ferrerías o la construcción de las mismas parten fundamentalmente de los grandes señores de la tierra. Lo vemos en las que construyen los condes de Lemos en el Bierzo, como las de Valcarce, Arnado y Pontepetre; lo sabemos en las que, con anuencia de las encomiendas de la Barra

\footnotetext{
${ }^{243}$ En el concejo de Llanes, ante las cortas abusivas de montes y castaños, cuyas maderas llevaban a vender por mar a otras partes, con gran daño a para los vecinos pobres, solicita que se hicieran unas ordenanzas "para que de aqui en adelante no se cortasen los dichos montes $e$ castaños los quales eran muy útiles y provechosas al bien público de la dicha villa y su tierra"; pero algunos pidieron que no se aprobaran porque en ellas "se dispone que no se puedan sacar ni cortar las maderas de los montes ni benderlas era muy perjudicial y dañosa a los vecinos del dicho concejo porque allaríamos que todas las heredades de castaños y nogales heran de vecinos particulares y no tenían otras heredades de pan ni bino porque la tierra hera muy estéril y en las heredades ay muy crecidas maderas las quales cortan y venden los vecinos del dicho concejo y por una que cortan plantan quatro de nuevo"; y esto atentaba contra las leyes que permiten al propietario vender lo que es suyo y que este comercio era beneficioso para ellos y para el concejo. En L. FERNÁNDEZ MARTíN (1975): Ob. Cit., p. 290.

${ }^{244}$ Los había arrendado el marqués de Villafranca en diferentes momentos de los siglos XVII y XVIII a los pueblos de Villarrubín, Gestoso y Arnado (Archivo privado de la familia de Llano, Villafranca).

245 Por ejemplo las de Lor, Quintá, etc.

246 Por ejemplo las de Piago, Seoane, Serviz, etc.

247 Foro de la ferrería de Montealegre a Pedro de Mindirichaga en 1571: "que podais coger e cortar en cualquier monte comarcano para obras de la dicha herrería de sus casas e reparos della e para carbón, la madera e leña que fuera menester, el qual corte podais açer e agais según e como e de manera que se acostumbra" (J. LÓPEZ y A. GRAÑA (1998): Ob. cit., p. 126.)
} 
y Quiroga, se erigen en el Caurel, Quiroga o la zona de Incio (ferrerías de Quiroga, Lor, Quintá, Valdomir, Lousadela, Soldón, etc.).

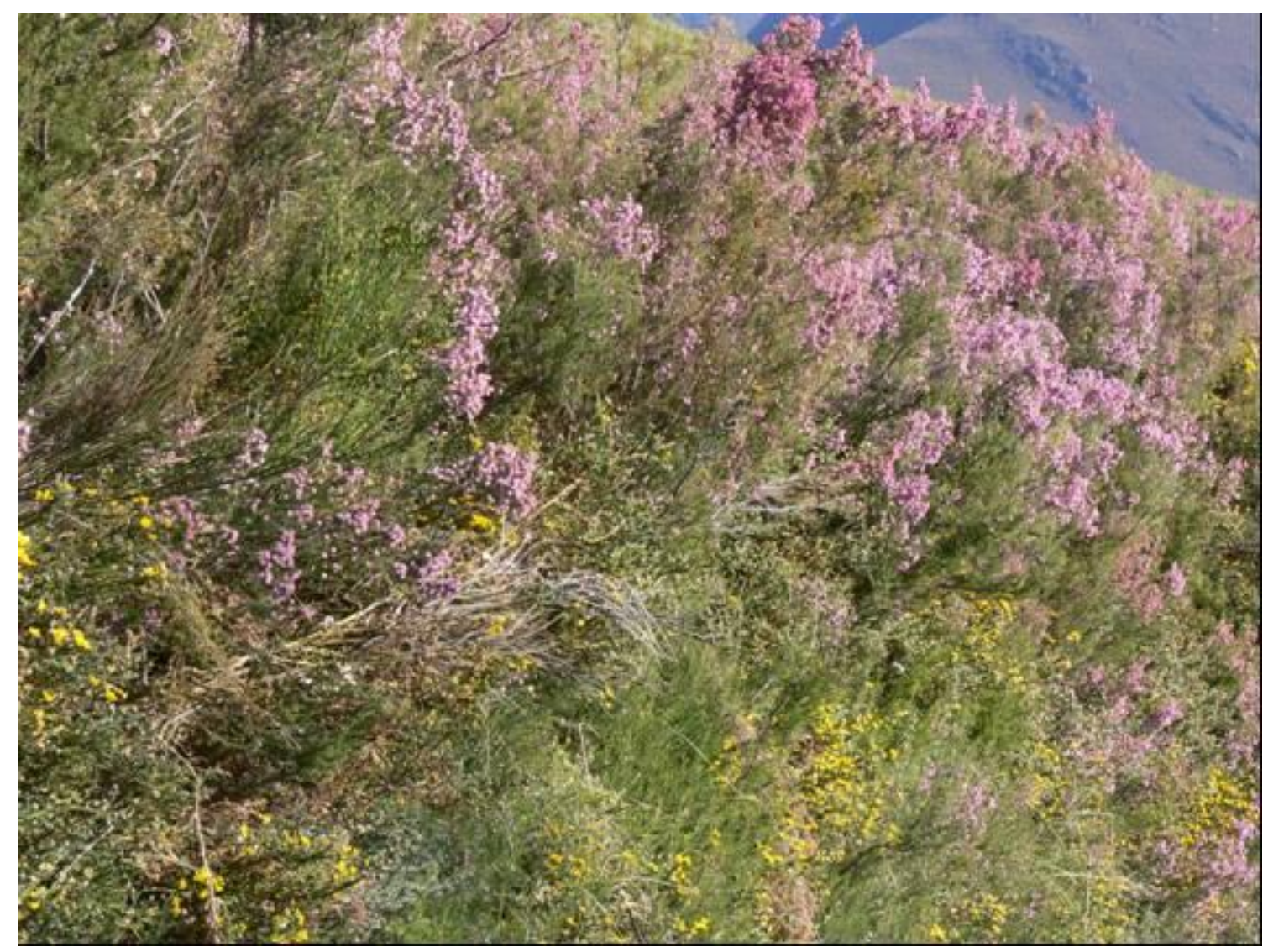

Brezo de cuyos cepos se hacía carbón

Todas ellas se edifican en zona de bosques abundantes y como un medio para desarrollar comarcas pobres de montaña ${ }^{248}$. A veces los vecinos, temerosos de sus pastos o de que les falten las leñas para uso doméstico, plantean dudas sobre si habrá o no suficiente arbolado para la fabricación de carbón ante tantas construcciones ${ }^{249}$. La razón fue que a lo largo de los siglos XVII y XVIII los

248 Por ejemplo la encomienda de Quiroga permite la construcción de la ferrería de Lor atendiendo a que en el coto de Lor "auia muchos montes propios (de su) directo dominio, sin que estos sirviesen de utilidad alguna (para) el aprovechamiento de ellos" (AHRG. R. A.: $3020 / 42)$.

${ }_{249}$ AHRG. R. A.: 1662/4. En 1692, en el pleito sobre la construcción de la ferrería de Quintá, varios testigos responden: "Dijeron que en quanto a si ay carbon bastante para dichas Ererias no lo sauen ni sauen el grandor de los montes, mas de que todos son de uz y tojo quales en Castilla llaman breço y de la raiz se ace carbon, y del que llaman albar no es tan bueno; $y$ dicho montes tienen de uno y otro, mas no tienen monte alto de roble ni de otro genero de arboles, sino sotos de castañas de particulares y que la leña para dicha erraría vieja para las raguas donde cuecen la vena es toda de castaño que lo compran para dicho efecto"; y añaden 
bosques climácicos fueron retrocediendo hasta quedar acantonados en los tramos encajados de los valles de los principales ríos. Por esa razón, los conflictos por el bosque hasta el siglo XVIII fueron escasos ${ }^{250} \mathrm{y}$ pocas las ferrerías que se cerraron por esa causa ${ }^{251}$; pero no ocurrió así cuando nuevamente se reinició la construcción de ferrerías en aquel siglo. El consumo de leñas y carbones por las ferrerías, la madera que necesitaba la industria naval y el gasto de los vecinos -también la roturación del monte- puso en peligro el bosque, que vio disminuir constantemente su superficie. Esto sí fue objeto de una gran conflictividad ${ }^{252}$, como ya veremos.

El uso abusivo del bosque con fines industriales, por ejemplo para ferrerías u otros ingenios, como las tenerías o la construcción naval, ayuda a entender la carestía de madera y, a menudo, la deforestación y el desequilibrio ecológico, argumentos aducidos como justificación para realizar una fuerte oposición social tanto en el mundo rural como en el urbano, con consecuencias a veces difíciles de ponderar, por ejemplo en Asturias253. En algunos casos se cuestiona incluso que ferrerías con mucha antigüedad tuvieran bosques privativos de los que abastecerse, por lo que tanto los vecinos como los dueños de las nuevas ferrerías exigen igual derecho a ellos ${ }^{254}$. Pero lo que pocos

que es cara porque no la cortan de buena voluntad pues por ser tierra pobre viven de los castaños.

250 Como veremos más adelante, esto no significa que no hubiera conflictos por el bosque y sus usos, todo lo contrario. El momento álgido de conflictividad en la Edad Moderna se produjo entre 1580 y 1640 , pero este no afectó de forma intensa a las ferrerías o al carboneo, sino a cuestiones sobre propiedad o alteraciones en el uso colectivo del monte, roturaciones, pasto de ganado, etc. Ver O. REY (1997): "La propiedad colectiva en la España moderna". Studia Histórica, $H^{a}$ Moderna, 16, p. 8.

${ }^{251}$ La ferrería de Viloalle, de la que era propietario el obispado de Mondoñedo, la cedió en 1571 al cabildo y concejo para que la explotasen no como ferrería sino como mazo por falta de combustible.

${ }^{252}$ O. REY (1997): Ob. cit., p. 14

$253 \mathrm{M}^{\circ}$ A. FAYA y L. ANES (2007): Nobleza y poder en la Asturias del Antiguo Régimen. Oviedo, p. 159.

${ }^{254}$ AHRG. R. A.: 9090/4. En un pleito de la ferrería de Valdomir por la venta de carbón, en 1787, el testigo Antonio Álvarez, de San Cristóbal de Fisteus, "Dixo que nunca supo ni oio que las Errerías de Quiroga, Quintá, Baldomir y mas de este contorno tubiesen montes peculiares y privativos para el surtido de carbón de cada una. Que no sabe tampoco de quien es el Dominio de los montes de dicha jurisdición de Courel; que menos sabe si los dueños de las Herrerías de Baldomir y Lousadela observaban o no la saca del carbón de los montes de dicha jurisdicción de Courel ni de que partes se surten estas Herrerías. Que en la Herrería de Quiroga solo estubo un año de oficial, $y$ en otras sirbio también de oficial en unas un año y en otras dos como fueron las de Rugando y San Vizente y la de Incio, viniendo todas los meses a casa, que están las dos primeras la una a distancia de una legua, otra legua y media y la última a cinco 
negaban era que estas, al margen de su interés económico, constituían la principal causa de la deforestación ${ }^{255}$.

La Corona, a través de una legislación continuada desde el siglo XVI, intentó hacerse con importantes recursos forestales para la construcción naval de la Armada256. Por provisiones dadas entre 1562 y 1566 por Felipe II, en las regiones cantábricas se reservaban dos leguas en torno a la costa y hacia el interior, exigiendo mantener una política de repoblación de robles, poco obedecida por cierto; pues en 1574 nuevas ordenanzas vuelven a prohibir talar árboles sin licencia, lo que lleva a las autoridades del Principado en 1595 a insistir en que en Asturias se realizaban excesivas talas. Lo mismo ocurre en Galicia en donde las autoridades multan a los que cortan árboles por el pie ${ }^{257}$. La deforestación continuó en el siglo XVII, en gran parte por un intenso proceso de cercamiento de espacios de monte para su explotación individual y como consecuencia de la roturación del mismo por los campesinos ${ }^{258}$. Esto provocó la carestía de la leña y su elevado precio respecto a otros bienes. Si tomamos como índice 100 en 1607-1614, el carro de leña llega a 293 en 1664, mientras que el de la paja sólo alcanza el 172 y el del cereal se queda en $122^{259}$.

leguas. Que desde la Erreria de Baldomir no se ben los sitios en que lleba dicho haber fabricado carbon".

255 AHPLu. P.N.: 2576/2. En 1727 los vecinos de varios lugares de la encomienda de Quiroga dan su poder a don Blas Cores para que los defienda ante la Audiencia de La Coruña "pues con ocasión de hauer en este valle de Quiroga, siendo tan corto, dos herrerías, la una en esta dicha jurisdicción y del directo dominio desta encomienda y la otra en el coto de San Cristóbal que es del real monasterio de Samos y tener los fabricantes de el carbon así naturales de esta jurisdicción como de fuera della arruinados los montes por el arranque que azen de coza y carbon que en ellos fabrican de manera que dentro de poco tiempo se acabarán por ser muy cortos y no suficientes todos los montes que ay en esta dicha jurisdicción, según el destrozo que en ellos azen para mantener de caruon diez años las dichas herrerias". Añaden no se arranque ni fabrique carbón, y si es necesario solo para una ferrería, la de Quiroga.

${ }^{256}$ Aunque se trata de una fuente del siglo XIX, puede servirnos para conocer la madera necesaria para construir algunos tipos de buques. En febrero de 1848 el ministerio de Marina sacó un anuncio para el acopio de maderas para ocho barcos que construirían los astilleros de Cádiz, Cartagena y Ferrol. Los de este último astillero, por lo que nos afecta, son una fragata de 196 pies de eslora, 54 de manga y 26 de puntal; una corbeta de 159 pies de eslora, 43 de manga y 20 de puntal; y un bergantín de 114 pies de eslora, 33 de manga y 17 de puntal. Para los tres se necesitan 14.259 codos cúbicos de madera de roble, 12.350 de madera de pino (de Segovia o de Segura), y 147 de nogal. (BOPA, 15 de marzo de $1848, \mathrm{n}^{\circ} 32$, p. 3).

257 En 1614 el corregidor de Vivero manda castigar a dos carboneros que en las fragas de Bravos han cortado "por el pie mas de ducientos robles" para hacer carbón para la ferrería de ese nombre, contraviniendo las ordenanzas que prohiben hacerlo por el pie (AHRG. R. A.: $16.987 / 28)$.

${ }_{25}$ A. REY (1997). Ob. cit., p. 13 y B. BARREIRO (1997): Ob. cit., p. 48.

259 B. BARREIRO (1994): Ob. cit., p. 248-249. 
Los Borbones harán prevalecer los intereses del Estado sobre los de las comunidades, con una política más dura y protectora del bosque, aunque también realizarán talas masivas de árboles en Asturias para abastecer a los arsenales del Ferrol en la segunda mitad del siglo XVIII ${ }^{260}$. Igualmente las hacían las ferrerías, como denuncian en 1727 los vecinos de varios lugares de la encomienda de Quiroga contra la fabricación de carbón en sus montes, que tienen "arruinados" por el "arranque que azen de coza y carbon que en ellos fabrican”261. Pero la causa no era sólo el consumo sino la ausencia de una política de reforestación. El padre Feijóo recordaba en ese siglo la mucha madera que España producía en época romana, y la poca de su tiempo. No es por culpa del suelo, criticaba, "sino de los naturales, cuya aplicación al plantío era muy otra entonces que ahora" y, sobre todo, de las autoridades que no establecen reglas y leyes para ello262.

La Corona, preocupada por la deforestación, intentaría atajar el problema, como muestra la Novísima Recopilación en su libro VII, título XXIV: "De los montes y plantíos, su conservación y aumento", en el que se recopilan todas las leyes que en la Edad Moderna dictaron los monarcas para su conservación. La Real Ordenanza de 7 de julio de 1748, de Fernando VI, que afectaba por igual a montes de particulares y de los pueblos, exigía la conservación del bosque, estableciendo que los acopios de leñas se hicieran a partir de maderas muertas o de ramas, o que si necesariamente había que cortar árboles, se hiciera con licencia real ${ }^{263}$. De hecho, esa Ordenanza establecía toda una serie de requisitos para cortar árboles: petición de tala a la Comisaría de Montes, visita de inspección del Ingeniero Agrimensor, valoración económica de

\footnotetext{
${ }^{260} \mathrm{M}^{\mathrm{a}}$ A. FAYA y L. ANES (2007): Ob. Cit., p. 197. También puede verse el informe del conde de Toreno de 1783 en respuesta a los proyectos de Antonio Bravo: "A consecuencia de los crecidos acopios anuales de madera echos en Asturias para la construzion de Diques, Bajeles y carenas de la Real Armada desde que principiaron las grandes obras del Ferrol hasta la actualidad, se hallan todos sus montes tan aniquilados que con dificultad se halla donde cortar un palo útil, a excepzion de algunos que por su situazion montañosa y remota son casi inhazesibles". En J. OCAMPO (1987): "La economía asturiana al final de Antiguo Régimen. Las manufacturas, 1750-1850. Oviedo, p. 143.

261 (AHPLU. P.N.: 2576/2)

262 P. FEIJÓO: Teatro crítico universal: "Honra y provecho de la agricultura”, XVI. ${ }^{263}$ NOVÍSIMA RECOPILACIÓN DE LAS LEYES DE ESPAÑA. Madrid, 829, p. 519.
} 
la corta, subasta al mejor postor, control de que sólo se hiciese carbón y no se vendiese madera para otros usos, etc. ${ }^{264}$

Otra Real Instrucción de Carlos III, de 19 de abril de 1762, pedía a los corregidores de la capital de partido, que remitieran anualmente datos sobre las mejoras hechas en los montes y las repoblaciones de árboles efectuadas. Según testimonio de esos corregidores al Consejo Real de Castilla, cada año se plantaban muchos árboles, aunque probablemente no los suficientes, como vemos en el CUADRO XI. No conozco más datos anuales de repoblaciones que los de esos años, pero por los mismos parece evidente, contra lo que opinarán algunos a finales del siglo ${ }^{265}$, de que se hacían y que su número no era tan escaso, pues para esas dos provincias de León y Orense supone cantidades cercanas a una media de 200.000 árboles anuales, aunque parece que no era suficiente $^{266}$. De estos árboles, el $61,4 \%$ fueron plantados en la provincia de Orense y el $38,6 \%$ en la de León.

\section{CUADRO XI. ÁRBOLES PLANTADOS EN LEÓN Y ORENSE EN LOS AÑOS DE REFERENCIA}

\begin{tabular}{|l|l|l|l|l|l|l|}
\hline & 1755 & 1756 & 1759 & 1761 & TOTAL & $\%$ \\
\hline LEÓN & 86.723 & 87.316 & 65.810 & 75.145 & 314.994 & 38,6 \\
\hline ORENSE & 145.235 & 153.133 & 114.500 & 88.280 & 501.148 & 61,4 \\
\hline TOTAL & 231.958 & 240.449 & 180.310 & 163.425 & 816.142 & 100 \\
\hline
\end{tabular}

FUENTE: AGS. Secretaría de Marina, leg. 560²67

\footnotetext{
264 IBIDEM

265 Por ejemplo Datoli en su informe de 1797.

${ }^{266} \mathrm{El}$ comisario don Julián de Ibarguren, encargado por la Corona para informar sobre el estado de los bosques en Asturias y su remedio, propone para aumentarlos y poder contar con madera para los astilleros reales, aplicar las ordenanzas con más rigor, ya que los pueblos prefieren roturar el monte antes que protegerlo porque obtienen más beneficio (y también era una necesidad ante el crecimiento de la población), y obligarles a replantarlos. Cit. en L. ADARO (1989): Datos y documentos para una historia minera e industrial de Asturias. Gijón, p.192199.

${ }^{267}$ Plan General del Estado de los montes y plantíos en este año de.... (ahí el año del cuadro) según resulta de testimonios y certificaciones remitidos por los señores corregidores a don Joseph Aparicio Ordoñez de el Consejo de S.M en el Real de Castilla.
} 
Esta política contra la deforestación se recoge en muchas ordenanzas concejiles $^{268}$. Las razones son siempre las mismas: el bosque ha disminuido por las quemas, la puesta en explotación de nuevas tierras y el consumo de las ferrerías, poniendo en peligro la cabaña ganadera de estos pueblos. Por tanto, en esas ordenanzas no solo se obliga a proteger el bosque, también a replantarlo269. Hubo en esa época conflictos por la roturación del monte ${ }^{270}$, porque para todos era perceptible la deforestación generalizada ${ }^{271}$.

A partir de entonces las ferrerías empiezan a sufrir dificultades para abastecerse de madera y carbón de sus montes propios, teniendo que adquirirlo en los pueblos vecinos, con el permiso de unos concejos que solo ante su gran necesidad aceptan venderla ${ }^{272}$. Todos estos pueblos de montaña, situados en zonas marginales y pobres, eran conscientes del valor de sus montes, ligados a su precaria economía ganadera y a las bouzas, searas y estivadas para cultivar centeno. Quizá por eso se suscitaron muchos pleitos por el uso del monte, discutiéndose el dominio directo o útil del mismo, como veremos en otro capítulo.

\footnotetext{
${ }^{268}$ AHPL. P.N.: 3103: Ordenanzas de Friera de 1673: "Ordenamos, que ninguna persona sea ossada a cortar ni talar en las deesas... de este concejo poca ni mucha cantidad" 268 ; exigiendo al mismo tiempo a sus regidores que controlen aquella que sea necesario cortar: "ordenamos que quando se huviere de cortar en las dehesas alguna leña para quemar en tiempo de invierno ... se nombren quatro ombres que señalen lo que cada uno a de cortar y el que sin orden cortare pague seis maravedis".

${ }^{269}$ La villa de Ribadeo tenía la obligación de plantar anualmente en los Reales Bosques de 800 a 1.000 árboles (robles, fresnos y nogales), cuya madera se utilizaba principalmente en la construcción de navíos para la Armada. Los visitadores del monasterio de Villanueva de Oscos, por su parte, mandan a los priores de la ferrería que todos los años deben repoblar los montes de los que hubieran sacado madera para la fábrica: desde 1730 se ordena que sean 50 pies de robles y desde 1803 mandan plantar 200 robles anuales. Cit. en D. PAZ (1991): Ob. cit., p. 149150

${ }_{270}$ AHPL. P:N.: 3576. En 1742 se desata un pleito entre los vecinos de Arnadelo y Oencia porque éstos querían roturar el monte.

${ }^{271}$ En 1778 Ibáñez, el constructor de la fábrica de Sargadelos, escribía quejándose de los incendios: "Ya no se ven aquellas espesuras de leñas y malezas que en otro tiempo obstentaban los montes. Los bosques más soverbios de roble, muy comunes antes de ahora en Asturias y Galicia, han desaparecido en la mayor parte, y en su lugar solo se miran las montañas decepadas, valles talados, colinas desbaratadas, y en tal qual parte algunos troncos, reliquias que atestiguan la confusión y el desorden". Cit. en E. CASARIEGO (1950): El marqués de Sargadelos o los comienzos del industrialismo capitalista en España. Instituto de Estudios Asturianos. Oviedo, p. 269-270

272 AHPL.PN.: 3341 (1733): El concejo de Sobrado que vende madera para carbón a la ferrería de Ponte Petre en 1733, por su necesidad para financiar la construcción de una fragua vecinal; pero "con condición que tampoco venden más de lo que fuere suficiente para comprar dicha fragua, atendiendo a los pocos y pobres montes que tiene este dicho lugar de Sobrado, por tirar a mantener los que ay y si faltasen se despoblarían sus vecinos".
} 
Por esta razón, varias de las ferrerías que se construyen en el siglo XVIII se localizan en aquellos lugares en los que anteriormente no existía ninguna, y que por ello todavía contaban con abundantes bosques, como las de Tejedo de Ancares, Montes, Pombriego y Soto Rodrigo. Por el contrario, los intentos de Carlos Lemaur de construir varias ferrerías entre Torre y Bembibre, zona escasamente arbolada, terminarían en fracaso ${ }^{273}$. En otras zonas, la oposición de los propietarios de las ferrerías preexistentes impedirá, momentáneamente, la construcción de otras nuevas, como le ocurrió al marqués de Villafranca en 1764 y $1797^{274}$. En Galicia sucedió lo mismo con la oposición de la ferrería de Loureiro a la construcción de la de Lor en $\mathbf{1 7 2 2}{ }^{275}$; la de la Rodela contra la de Quintá en $1721^{276}$ o la oposición a la construcción de las de Neyra de Rey y Biduedo, de la que da noticia Larruga ${ }^{277}$. En lugares cercanos a la costa sabemos que fue entonces cuando se cerraron las ferrerías gallegas de Bravos y Silán 278, cosa que también ocurrió en la parte oriental de Asturias, con las de Amandi y Dueñes.

Todos estos pleitos se debían a que, pese a los decretos y ordenanzas, no había una política clara de la monarquía sobre el bosque, que se explotaba de forma bastante indiscriminada 279 . En el noroeste, por ejemplo, se desconocen prácticas como la del trasmochado, tan frecuente en el País Vasco como abasto de leña para la fabricación de carbón ${ }^{280}$, por lo que la deforestación fue más intensa y rápida. Nadie ha sido tan drástico en su juicio sobre la precaria situación del bosque berciano como Datoli en su informe de 1797. En numerosos lugares del mismo repite que los bosques de la comarca están en la mayor decadencia y que esta es la principal razón por la que las ferrerías han de suspender su trabajo durante varios meses al año. Sin embargo, más que el

\footnotetext{
273 Esta es la opinión de F. J. DATOLI (1992): Ob. cit., p. 46.

274 AHPL. P.N.: 3287 (1764).

275 AHRG. R. A.: 3020/42

276 AHRG. R. A.: 26.319/20.

277 LARRUGA, E. (1794): Ob cit., T. XLV, p. 337.

${ }^{278}$ MEIJIDE PARDO, A (1979): Documentos para la historia de las Reales Fábricas de Sargadelos. Sada, p. 39, $\mathrm{n}^{\mathrm{O}} 12$.

279 AHRG. R. A.: 25207/61: En 1738 los vecinos de Viloalle denuncian a los de Masma y Villamor por cortar en los montes comunes porque "concurrieron a destrozarlos, sacar de ellos leña en abundancia y lo peor ha sido que a muchos de los árboles les sacaron las raíces de manera que quedaron imposibilitados de producir y este es el motivo de ocurrir los de Viloalle a pedir coto en los referidos montes"

${ }^{280}$ URIARTE AYO, R. (1998): "Economías campesinas y explotación forestal en el País Vasco durante el Antiguo Régimen”. Zainak, 17, p. 106
} 
consumo denuncia el comportamiento de propietarios y concejos, despreocupados por completo de la repoblación del bosque; pese a que esta política no sólo deforestaba sino que encarecía cada vez más el precio del combustible y por tanto el del hierro ${ }^{281}$.

En otros lugares se creía que los árboles eran perjudiciales para los cultivos $^{282}$. En otros casos, la causa de la deforestación eran los incendios o las talas para madera, como se lamentaba Antonio R. Ibáñez en 1778²83. Quizá por esa razón o más probablemente por la deforestación a causa de las roturaciones y el consumo de las ferrerías, cerraron algunos de estos artefactos de la costa, como reconocen los vecinos en un pleito contra la construcción de la fábrica de Sargadelos en 1788²84. Antonio R. Ibáñez y J. de Andrés García, en 1791, en su propuesta para levantar una ferrería en Muras, con argumentos contrarios a los de los vecinos, hablan de que la ferrería de Bravos ha cerrado recientemente; pero que una buena política de reforestación haría inextinguibles estas fábricas ${ }^{285}$. Es decir, la culpa no era de las ferrerías sino de la despreocupación o ausencia de la más mínima política forestal.

\subsection{El bosque en el siglo XIX}

Esta situación empeoró aún más durante la primera mitad del siglo XIX, en el que se construyeron nuevas ferrerías, pero sobre todo debido a la

\footnotetext{
${ }^{281}$ F. J. DATOLI (1992): Ob. Cit., p. 56

${ }^{282}$ En 1799 el cura de una aldea de la zona de Ribadeo denunciaba la nula reforestación de los vecinos por estar "fanáticamente imbuidos de que la sombra de los árboles quita a los campos el dar el fruto". Cit. en F. LANZA: Ob. Cit., p. 216.

${ }^{283}$ Este escribía en un memorial: "ya no se ven aquellas espesuras de leñas y malezas que en otro tiempo obstentaban los montes. Los montes más soberbios de robles, muy comunes antes de ahora en Asturias y Galicia, han desaparecido en la mayor parte, y en su lugar solo se miran las montañas decepadas, valles talados, colinas debastadas”. Cit. en CASARIEGO, E. (1975): Ob. cit., p. 269-270.

284 "De que tienen los exponentes dos ejemplares bien recientes, en las dos (herrerías) que se construyeron, en los valles de Oro y Bravos, y en que después de que sus dueños asolaron los montes de la circunferencia llevándose las utilidades de ellos, desamparan las fábricas, actualmente abandonadas, $y$ dejando a los naturales del país en la mayor penuria de leñas $y$ maderas". Cit. en A. MEIJIDE (1979): Ob. cit., p. 104, $\mathrm{n}^{\circ} 33$

285 "El sistema contrario que la maledicencia querrá objetar de que las herrerías han destruido los montes, nada prueba, ni nada puede hallar protección sino en la ignorancia y en la barbarie; pues aunque es cierto que en la provincia de Mondoñedo han quedado a yermo algunas de aquellas fábricas por falta de leñas, y últimamente una en la jurisdicción de Bravos, distante tres leguas de la puente de Muras, no ha sido sino por el abuso y desorden de sus dueños, o más bien por el de sus arrendatarios, en cuya ambición no cabe otro interés que el de enriquecerse con avaricia". Cit. en A. MEIJIDE (1979): Ob. cit., p. 39, nº 12
} 
roturación de numerosos bosques de comunidades religiosas, señoriales o del común en los primeros años del siglo ${ }^{286}$, y especialmente con las medidas desamortizadoras de Mendizábal. Desamortización y deforestación son términos complementarios en la totalidad de los análisis sobre las transformaciones agrarias en la España del siglo XIX. Hasta 1855 las fuerzas privatizadoras centrarían su acción sobre el patrimonio eclesiástico, por lo que los pueblos lograron, en lo fundamental, conservar sus bienes. El decreto de las Cortes de Cádiz de 14 de enero de 1812 ponía en suspenso toda la legislación anterior en materia forestal, dejando en manos de los propietarios una absoluta libertad de uso. Mendizábal, además de desamortizar los bienes del clero regular, autorizó a los ayuntamientos a vender los terrenos de propios que creyeran oportuno, con la posibilidad de talar el monte alto287.

Pero fue con la Ley de Desamortización General de Madoz de mayo de 1855 cuando comenzó el triunfo de los “depredadores”, como llama Jesús Sanz al grupo progresista partidario de una desamortización sin cortapisas. Con la fórmula mágica de "propiedad privada igual a riqueza y progreso", los progresistas iniciaron un movimiento expropiador calificado como "el mayor desastre ecológico de nuestra historia forestal"288; pese a que el decreto de $26 \mathrm{de}$ octubre de 1855 limitaba sus efectos, al establecer que los montes de abetos, hayas, castaños y robles quedaran de dominio público sin poderse enajenar, pero sí podían venderse los encinares, alcornocales, fresnedas, monte raso, etc. ${ }^{289}$.

\footnotetext{
286 AHPL.P.N.: 3576. Poder del administrador de la ferrería de San Vicente de Leira, el P. José Noriega, en 1818, para llevar ante los tribunales a los vecinos de este pueblo, a los que el monasterio de Samos aforó su término en 1.400 rs. vn. anuales cuando valía más de 4.00o anuales con la "consideración que habían de abastecer el artefacto de los suficientes materiales a los precios corrientes, conservar una porción de monte sin roturar para la mayor permanencia de aquel, no pribar las aguas cuando fuesen necesarias para la fábrica...", por no observar puntualmente estos requisitos.

${ }^{287}$ F. SIMÓN (1973): La desamortización española del siglo XIX. Madrid, p. 57.

288 J. SANZ (1985): Ob. cit., p. 201-207.

289 F. PARRONDO (1984): "La deforestación en la provincia de Madrid como consecuencia del proceso desamortizador”. Estudios Geográficos, nº 177, p. 475-476.
} 


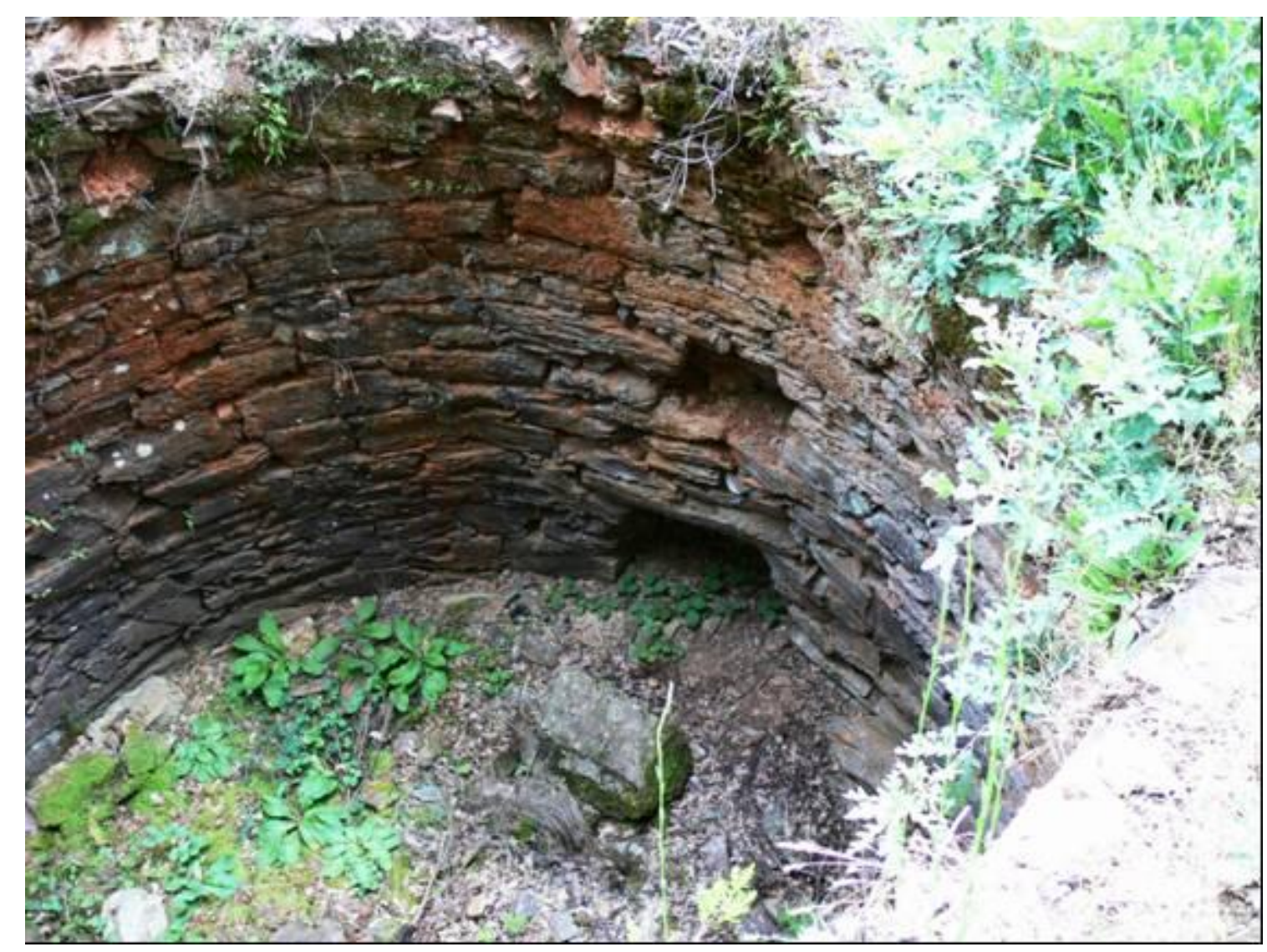

Horno para la calcinación del mineral en el Bierzo

Tal expropiación, sin embargo, no afectó de igual modo a todas las regiones españolas. En el noroeste, donde la masa forestal catalogada en 1859 fue relativamente baja respecto a la extensión total, y los montes de pocas hectáreas, los efectos sobre el paisaje y la propiedad fueron pequeños ${ }^{290}$. El número de montes enajenados fue casi el 35\% del total y en alguna provincia, como Lugo, el $57,4 \%$ pero se trataba en general de montes de muy pequeño tamaño (en el conjunto de Galicia, por ejemplo, el 63\% era menor de $1 \mathrm{ha}$ ). Aunque con diferencias provinciales en algún caso notables, como en Oviedo, donde se enajenó el 21,3\% de sus hectáreas de monte, sólo el 8,7\% del total de las hectáreas del área estudiada fueron enajenables frente a un $91,2 \%$ que fueron exceptuados de la desamortización (CUADRO XII), lo que es una proporción muy baja.

290 J. SANZ (1985): Ob. cit., p. 212-214 


\section{CUADRO XII. MONTES PÚBLICOS ENAJENABLES Y EXCEPTUADOS EN LA DESAMORTIZACIÓN}

\begin{tabular}{|l|l|l|l|l|l|l|l|l|}
\hline PROVINCIA & \multicolumn{4}{|l}{ ENAJENABLES } & \multicolumn{4}{l|}{ EXCEPTUADOS } \\
\hline & $\mathrm{N}^{\mathrm{O}}$ & $\%$ & HECT. & $\%$ & $\mathrm{~N}^{\mathrm{O}}$ & $\%$ & HECT. & $\%$ \\
\hline LEÓN & 354 & 16,2 & 44.655 & 7,4 & 1.381 & 83,7 & 557.583 & 92,5 \\
\hline LUGO & 1.066 & 57,4 & 2.338 & 1,4 & 789 & 42,5 & 156.736 & 98,5 \\
\hline ORENSE & 695 & 45,3 & 5.393 & 10,1 & 837 & 54,6 & 47.571 & 89,8 \\
\hline ASTURIAS & 182 & 12,6 & 32.575 & 21,3 & 1.311 & 87,4 & 120.290 & 78,6 \\
\hline TOTAL & 2.304 & 34,7 & 84.961 & 8,7 & 4.318 & 65,2 & 882.180 & 91,2 \\
\hline
\end{tabular}

FUENTE: Clasificación de los montes públicos de 1859

Sin embargo, las medidas liberalizadoras sí que tuvieron efectos importantes sobre el bosque, lo que en cierto modo explica el nuevo auge de las ferrerías. Desde finales del siglo XVIII, el Consejo de Castilla instaba a las Sociedades Económicas a que promocionaran el uso del carbón de piedra, como ya se venía haciendo en Inglaterra. Pero tras los reiterados fracasos en su uso, la Administración tomó nuevas medidas para la conservación del bosque, como el Real Decreto de 6 de julio de 1845, por el que se creaba el servicio de Guarda de Montes; y que estos guardas, en contacto con los alcaldes, comisarios e ingenieros de montes, vigilaran constantemente la tala de árboles ${ }^{291}$, que con frecuencia se subastaban por los concejos (Apéndice II, 2), aunque las denuncias por cortas y carboneo ilegal se repitieron una y otra vez ${ }^{292}$. Es cierto

\footnotetext{
${ }^{291}$ Cosa que no siempre se hacía, lo que obligaba a reiterados avisos de las autoridades. Por ejemplo, el gobernador de Oviedo en 1859, ante las numerosas denuncias de daños causados a los montes, por la poca vigilancia, manda a los guardas que los recorran constantemente y recuerda que las cortas de madera, tanto en montes públicos, de propios o comunes, no se podrán realizar sin el preceptivo permiso de la autoridad competente y solo de aquellos árboles que se señalaren (BOPA, 21 de febrero de 1859).

${ }^{292}$ El libro del Guarda Mayor de Montes del distrito de Villafranca del Bierzo, por ejemplo, es un buen exponente de esta situación. El 15 de enero de 1853 anota el guarda: "pasé a Puente de Rey a recombenir a Francisco Rodriguez, a Antonio Rodriguez y José Rodriguez por haber cortado unos haces de encina en el monte llamado el Encinar, del común de aquel pueblo, habiendo hecho lo mismo con los carboneros que lo fabrican de vrezo"; el 17 de abril de 1856 vuelve a anotar: "hice un reconocimiento de los montes del común del pueblo de Pradela y habiendo advertido descepe de brezo practiqué las diligencias para indagar los contraventores. Resultando ser Pascual Soto, Rosendo Rodriguez y varios vecinos de dicho Pradela que
} 
que algunas instituciones trataron de animar la repoblación del bosque, pero las especies no siempre eran las más adecuadas ${ }^{293}$.

Por esa razón, se sigue hablando del mal estado de los bosques gallegos, pese a que aún así se seguían levantando ferrerías 294 . Su construcción se incrementó considerablemente en el siglo XIX, con un total de 48, lo que supone un 38 por ciento del total de las del noroeste; pero hubo también muchos conflictos por este motivo, como ocurrió con las de Ríocabo ${ }^{295}$, Valincarro ${ }^{296}$, Vilarbacú ${ }^{297}$; otras quedaron en el intento como las de Paradasolana, Valdesanpedro y Peñalba ${ }^{298}$, y las de Burbia, Villarbón y Lumeras todas en el Bierzo 299 ; las de la Somoza maragata ${ }^{300}$, la de Ferramulin en el Caurel ${ }^{301}$, y las cuatro proyectadas en el bosque de Muniellos ${ }^{302}$. La mayor parte

carboneraron en los montes del común denominados Maderaboa y Campairo, por lo que puse oficio de la denuncia al alcalde constitucional de Travadelo"; por último, por no seguir poniendo ejemplos, continúa en 1861 que fue a Dragonte, "pasando al monte de la Nevera de los Corrales, noticioso de que intentaban carbonear en este sitio, resultando cuatro hoyos que demostraban habían hecho cuatro sacos de carbón de vrezo".

293 La fábrica de Trubia, por ejemplo, en numerosas ocasiones ofreció plantones, casi siempre de pino que traía del extranjero, en venta a precios módicos y en cantidades superiores a veces a los 100.00o ejemplares (BOPA, 19 de marzo de 1851, 26 de enero de 1852, 16 de enero de 1857).

294 SCHULZ (1938): Ob cit., p. 391: "No obstante el malísimo estado de los montes en la mayor parte de Galicia, es todavía bastante lucrativa la fabricación del hierro en muchos puntos, y se construyen sucesivamente nuevas herrerías en unos mientras en otros se abandona alguna que otra de estas fábricas".

295 Pleito con Francisco Javier Argumosa, propietario de la ferrería de Arnado, en los años 1828 y 1829 alegando aquel que el terreno de la ferrería no estaba comprendido en el foro dado por el marqués de Villafranca en 1797 al pueblo de Arnado. En I. GARCÍA TATO (200o): Ob. cit., apéndice 10.

${ }^{296}$ Francisco Javier Argumosa se opone a la construcción de la de Valincarro en 1837 a causa del agua y montes para su uso (Arch. Privado de la familia Llano y Ovalle. Papeles sueltos).

297 Denuncia en la Audiencia de La Coruña en 1838 contra la construcción de la ferrería de Vilarbacú por los dueños de las ferrerías de Quinta y Paleiras (AHRG. R. A.: 5909/40)

${ }^{298}$ Paradasolana (AHPL. P.N.: caja 2636, año 1856), Valdesampedro (AHPL. P.N.: caja 2723, año 1859), Peñalba (BOPL. 12, agosto, 1861, $\mathrm{n}^{\circ}$ 96). En el libro de actas del ayuntamiento de Ponferrada $\mathrm{n}^{0}$ 30, (AMP, de 5 de septiembre de 1862) hay un escrito del alcalde de San Esteban de Valdueza en el que denuncia los perjuicios que a ambos ayuntamientos acarrearía la ferrería de Peñalba: "considerables perjuicios que causan al país dichos artefactos no solo por el consumo de combustibles que los pueblos necesitan, sino también porque concluyen con las maderas de construcción que producen los montes".

299 Fue solicitado el permiso de construcción por Francisco Andrés Válgoma, de Cacabelos (BOPL.: 30, de abril de 1858, $\mathrm{n}^{\circ}$ 52, p. 4 y 18 de julio de 1862, $\mathrm{n}^{\circ}$ 86, p. 1) y Ubaldo González de Vega de Espinareda (BOPL.: 12 de diciembre de 1860, $n^{0} 149$, p. 1)

300 D. Andrés Martínez Criado, vecino de Sabero, solicitó la construcción en esta comarca leonesa de dos ferrerías. BOPL.: 14 de enero de 1857, $\mathrm{n}^{\circ} 6$, p. 3 y 23 de febrero de 1857, $\mathrm{n}^{\circ}$ 23, p. 3

${ }^{301}$ AHPLU: $2563 / 7$

${ }^{302}$ Según el BOPA de 1861, $\mathrm{n}^{0}$ 11, se autorizó al Crédito Mobiliario Barcelonés a "establecer cuatro forjas catalanas para la fundición de minerales en Pie Cordera (Cangas de Tineo -hoy de Narcea-), pudiendo alimentarse con combustible vegetal del monte inmediato de Muniellos". 
de las veces, aunque no siempre, fue a causa del monte y del carbón303; por ello, si las ferrerías no contaban con bosques propios de los que obtener combustible, sus propietarios tuvieron que comprar árboles y montes en los alrededores de las mismas, como revela la documentación, pues la Administración fue más permisiva304.

Pero la situación del bosque se fue haciendo cada vez más insostenible, no sólo por el consumo de las ferrerías y otros usos, también por su roturación. En Asturias, se hablaba en 1838 de que ya había varias ferrerías paradas por falta de combustible vegetal, aunque se reconoce que aún hay bosque en los concejos del interior montañosos, "cuya madera y combustible no se aprovecha (...) por no haber caminos para su extracción" 305 ; y en Galicia, aunque hay minerales, "la falta de monte en sus inmediaciones impide su aprovechamiento”. Unos años antes, Schulz, después de informar que aún hay en esta comunidad "cerca de treinta ferrerías", asegura que la mayor parte están en decadencia "por falta de combustible" ${ }^{306}$ o por el elevado precio del carbón vegetal. En 1860, en una protesta de varios propietarios de ferrerías al gobernador de Oviedo por la construcción de la ferrería de A Cabanada, en Castropol, hablan de un número excesivo de ferrerías y martinetes en la zona307. Argumentos parecidos podríamos traer a colación en el caso del Bierzo 308 o de Galicia309.

Esas forjas no se construyeron pues la empresa se dedicó a sacar madera por el río Narcea hasta el puerto de San Esteban de Pravia.

303 AHPLU: 2377/4. En 1838 los vecinos de Villamor dan un poder para "seguimiento de la demanda en propiedad (en el tribunal de primera instancia de Quiroga) que les ha puesto don Manuel Losada y otros vecinos de Vilar sobre privar a los constituyentes el aprovechamiento y carvoneo de los montes altos y vajos llamados de Armada y da costa comprendidos en los propios términos de Villamor".

304 AHPLu. P.N.: 2431/1. En 1845 los vecinos de San Silvestre de Saceda venden en 800 rs. vn. a José Seoane "una porción de monte virón a donde llaman monte de Conejeira y Trigareja".La ferrería de Villarín compró en 1859 "el aprovechamiento para carbón de todas las leñas que contienen la tercera parte de los términos del lugar de Probo".Cit. J. LÓPEZ y A. GRAÑA (1998): Ob. cit., p. 29 nota 19.

305 G. SCHULZ (1838):Ob. cit., p. 385; IDEM (1838): "Reseña geognóstica del principado de Asturias". Anales de Minas, p. 363

${ }^{306}$ G. SCHULZ (1838): Ob. Cit., p. 391; IDEM (1835): Descripción geognóstica del Reino de Galicia. Madrid. Ed. facsimil en Ediciones do Castro. A Coruña (1994), p. 47.

307 "Viniendo a resultar un consumo inmenso, que no es bastante a sostener el estado de los montes del país, así es que por eso ha disminuido considerablemente en las herrerías de los exponentes, y en otras la elaboración del fierro y muchos martinetes se han cerrado". Cit. en J. LOPEZ y A. GRAÑA (1998): Ob. cit., p. 147

${ }^{308}$ En 1864, la Estadística Minera refiriéndose a las ferrerías bercianas señala que "cada día va siendo más difícil el beneficio de las menas en forjas catalanas, por la carestía del 
El bosque, sujeto a un consumo abusivo y a quemas irresponsables, fue lentamente desapareciendo hasta su parcial reconstrucción en el siglo XX, aunque ya no el bosque climácigo tradicional sino uno nuevo, con otras especies vegetales de mayor productividad y más rápido crecimiento, como los pinos y eucaliptos, sobre los que cada verano se ceban los incendios.

\subsection{El carbón vegetal}

En la siderurgia preindustrial la reducción del hierro en el horno de la ferrería se hacía exclusivamente con carbón vegetal, producto de la carbonización de la madera, ya que su poder calorífico es mucho mayor (aproximadamente, dependiendo del tipo de madera y árbol, de 29.000 a 35.000 kilojulios/kilogramo el carbón vegetal frente a 12.000 a $21.000 \mathrm{kj} . / \mathrm{kg}$. la madera). Aunque esta tiene un 50\% de carbono, en las carboneras tradicionales rara vez se obtenía más del $18 \%{ }^{310}$, sobre todo si era verde; con leña seca aumentaba algo más, pero por regla general, incluso con buena leña, se producía una merma de $3 / 4$ del peso del producto, por lo que era normal rendimientos del 20 al 25\%311. Por eso para este fin se solía utilizar madera dura, de textura compacta y elevada densidad: roble, haya, castaño y más frecuentemente en esta zona el cepo de la urz o brezo.

combustible"; razón que reitera en 1873 señalando que es debido "a la escasez de combustible vegetal y a su elevado precio" (ESTADÍSTICA MINERA: 1864, p. 24 y 1873, p. 63). En 1857 el maestro de ferrerías Francisco González, en un inventario de las ferrerías de Riocabo, al señalar que una de ellas, la más deteriorada, debería abandonarse y demolerse lo explica "porque escasea el carbón y la primera fábrica se sostendrá doble tiempo, tanto porque se hallará más bien surtida de aquel mineral, cuanto que los montes no quedarán tan pronto exhaustos y por otra parte los de casa prometen nueba vegetación o carbón nuevo, que es mucho más fuerte que el viejo, según está provado". Cit. en I. GARCÍA TATO (2000): Ob. cit., p. 140.

309 "La metalurgia de esta provincia (de Lugo), dice un informe de 1879, está representada por las forjas a la catalana, cuya existencia es cada día más precaria por dos causas: la primera, y por hoy la más importante, la falta de combustible barato, efecto de haberse hecho el carboneo sin orden ni previsión, talando los montes sin replantar, con lo cual, no solo han perjudicado su industria, sino que dejando el suelo directamente expuesto a la acción denudadora de las aguas (...); y la segunda, que siendo poco a poco más fáciles los transportes, los hierros del país no pueden competir en baratura, siquiera les aventajen en bondad, con los que produce la gran industria" (ESTADÍSTICA MINERA, 1879, P. 52).

${ }^{310}$ L. M. DÍAZ DE SALAZAR (1983): Ferrerías en Guipúzcoa (siglos XIV-XVI). San Sebastián, t. I, p. 132

${ }^{311}$ L. GUITIÁN (2001): Ob. cit., p. 139 


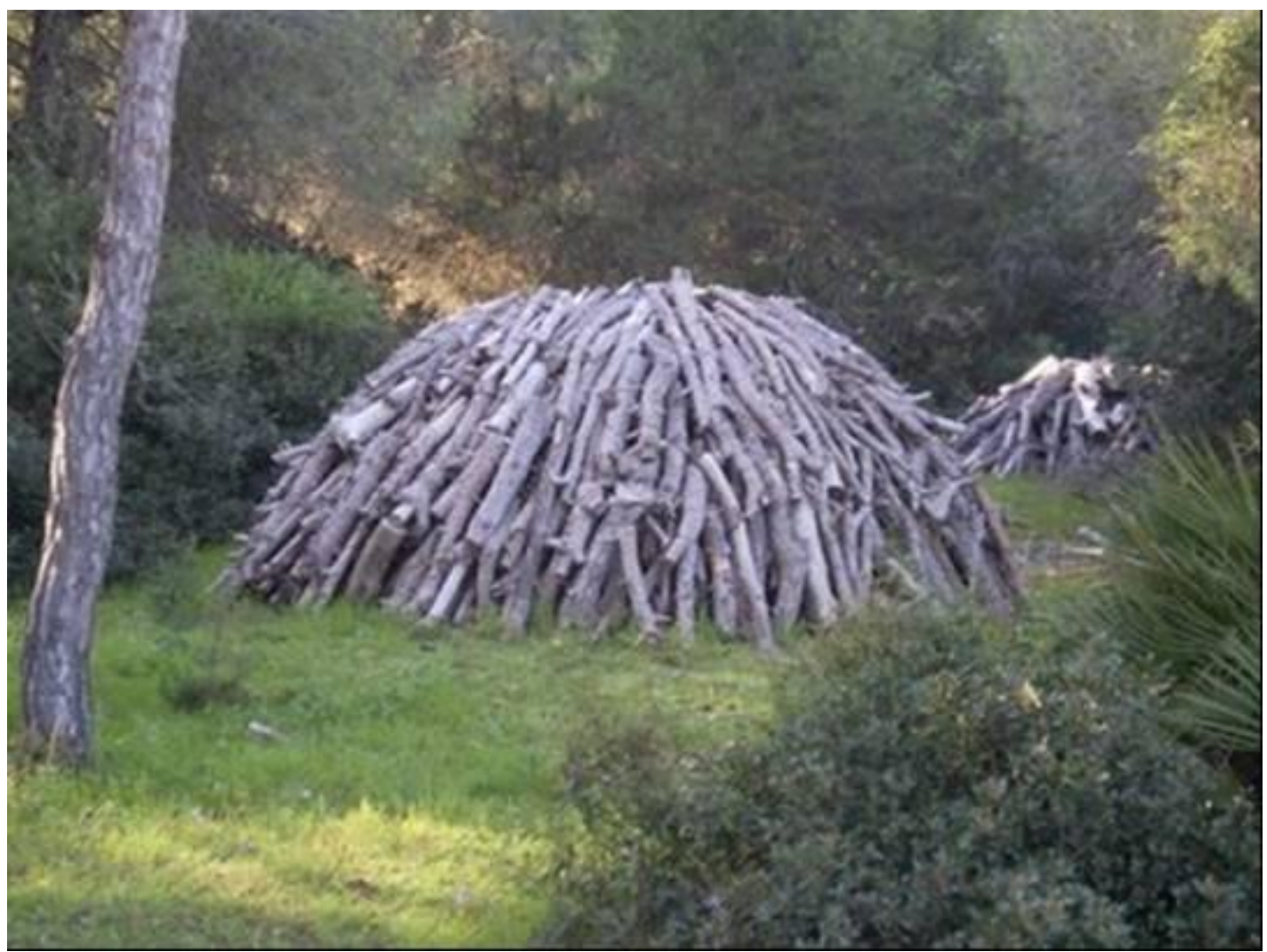

Carbonera

En cada hornada o ágoa entraban trece arrobas de mineral de hierro y doce o trece cargas de carbón, con un peso cada carga de unas dos arrobas ${ }^{312}$; es decir, dos arrobas de carbón por cada arroba de mineral, en realidad una proporción de 1,9. Schulz da unas proporciones algo menores, pues supone que en Galicia para reducir 95.00o quintales de vena, en 1838, hicieron falta 130.00o quintales de carbón lo que da una relación de 1,36; y en Asturias para reducir 44.000 de vena se usaron 70.000 quintales de carbón, es decir 1,59 de carbón por quintal de vena ${ }^{313}$. Con las cantidades primeramente citadas, Munárriz dice que se elaboran unas cinco o seis arrobas de hierro estirado en bandas, lo que arroja una proporción de 1 a 4,5 aproximadamente 314 ,

312 J. M. MUNÁRRIZ: (1992): Ob. Cit., p. 131.

313 G. SCHULZ (1938): Ob. Cit., p. 385 y 391.

314 Esa proporción de una a cinco es semejante a las ferrerías navarras y vasca: Laiburu habla de 4,5 a 5 cargas (de $80 \mathrm{~kg}$. carga), dependiendo del tipo de leña, por cada quintal de hierro (de 70 kg.); Zuarznavar, señala que $100 \mathrm{~kg}$. de hierro precisa 463 de carbón y Esparza habla de que las ferrerías de Lesaca produjeron $80.000 \mathrm{~kg}$. de hierro con $400.000 \mathrm{~kg}$. de carbón en 1876, es decir cinco a uno. En A. GARCÍA SANZ(1982): "El aprovechamiento de carbón en las ferrerías de Elcorri. Cálculo de su consumo y precios (1802-1867)". Cuadernos de Etnología y Etnografía de Navarra. Pamplona, XIV, p. p. 396. En nuestra zona, C. González habla de 5,1 en las ferrerías gallegas, mientras que P. Saavedra en la de Villanueva de Oscos encuentra una media de 7,3. La Revista Minera se acerca a esta cifra, pues hablando de las ferrerías de Lugo y Orense dice que 
probablemente más, incluso seis, como ya dijimos ${ }^{315}$. Pero para hacer ese carbón se exigía aproximadamente cuatro o cinco veces más cantidad de madera. En las carboneras vascas, por ejemplo, la proporción era de 1 a $5^{316}$.

El carbón se hacía de roble y haya, que eran maderas duras, de elevada densidad y daban un buen combustible, aunque también se fabricaba de castaño y de la raíz de la urz o brezo, del que existían dos tipos: moural y blancal o albar. En Asturias era preferentemente de haya y roble, aunque se fabricaba alguno con castaño; en Galicia, sobre todo en las zonas de interior, el carbón era de roble, encina y uz (urz) ${ }^{317}$. Este carbón también se llamaba de coza ${ }^{318}$. En el Bierzo generalmente se hacía de brezo, de cuyas raíces denominadas "cepos", se fabricaba un tipo de una calidad excelente ${ }^{319} \mathrm{y}$ muy abundante ${ }^{20}$, aunque en esto no todos estaban de acuerdo321.

en 1866 el consumo de combustible fue de seis a siete quintales métricos de carbón por cada quintal métrico de hierro producido (R.M., t. XIX, 1868, p. 759 y 760).

315 M. CORBERA (2000): La siderurgia tradicional en Cantabria. Oviedo, p. 74 . El autor menciona consumos medios de carbón por unidad de hierro que van de 3,23 en ferrerías francesas de Arlès hasta 9,47 en St. Paul de Assou (Bajos Pirineos). Las vascas y cántabras consumen en torno a 4,6 y 4,9, y las catalanas entre 7,4 y 9,1. C. MAS (2000): Ob. cit., p. 227 habla de que en el siglo XVIII las fargas de la val Ferrera necesitaban 629,9 kg. de carbón por cada $100 \mathrm{~kg}$. de hierro, pero que en el siglo XIX la media llegó a subir a $750 \mathrm{~kg}$. por cada $100 \mathrm{~kg}$. de hierro.

316 L.M. DÍEZ DE SALAZAR (1984): Ob. cit. t. I, p. 132-138

${ }^{317}$ Lo dicen expresamente numerosos documentos: en 1638 en un juicio contra el herrero Domingo Barreiro incoado por la justicia de Sobroso por carbonear en los montes de Abelleira, alega éste que "en los montes no ay ni xamás hubo robles ni otros árboles sino uzes en gran abundancia de cuyos troncos se haze carbón" (AHRG. R. A.: 10.882/20); ; en 1692 en un pleito contra la ferrería de Quintá, los testigos dijeron que los montes "son de uz y tojo cuales en Castilla llaman breço y de la raíz se hace el carbón, y del que llaman albar no es tan bueno" (AHRG. R. A.: 1662/4); en un informe de 1760 sobre la ferrería de Viduedo, se dice que las ferrerías cercanas tienen montes que "producen un género de maleza, que llaman vulgarmente uz, y de la raíz de ésta que denominan cepa, fabrican carbón, que es más fuerte aún que el de encina" (cit. en LARRUGA, E. (1794): Ob. cit., t. XLV, p. 350).

${ }^{318}$ AHRG. R. A.: 3269/9. En 1791 en el pleito de los vecinos de Parada, en la feligresía de Santa Eulalia de Bendollo, encomienda de Quiroga, contra los de Bendollo, Castillo, Nobais y Sequeiros, dicen que estos "se entrometen a rozar el monte y arrancar la coza y llebarla". En otro pleito de los vecinos del lugar do Val, feligresía de San Vicente de Paradela, en 1813, contra un herrero (AHRG. R. A: 11.304/2) hablan "sobre el arranque que este quería hacer de coza para fábrica de carbón en los montes comunales".

319 J. M. MUNÁRRIZ (1992): Ob. Cit., p. 150.

${ }^{220}$ MADOZ: Ob. cit., p. habla de un gasto de este arbusto en fraguas y ferrerías, en estas "por lo menos un millón de arrobas al año, calcúlese cual será la abundancia y maravillosa reproducción de este arbusto, cuando no escasea el combustible, a pesar de hacerse de las raíces".

${ }^{321}$ F. J. DATOLI (1992): Ob. Cit., p. 56: Señala que no había ningún método para cultivar ni arrancar el brezo, por lo que "suele no volver a salir en el mismo parage, o se tarda veinte, treinta o mas años en hacer carbón con él, según la especie de brezo y calidad del terreno". Opinión que compartía mucha gente: Los vecinos de Lobanes se querellaron en 1695 contra tres herreros afirmando que "la fabrica de carbón es perjudicial porque en donde se aran las cepas no nacen otras por ser la tierra esteril" (AHRG. R.A.: 10.899/41). 
El carbón se fabricaba por medio de carboneras, que solían ser de varios tipos: generalmente eran pequeñas, aunque las había grandes porque fue frecuente, sobre todo en las zonas costeras de Galicia y Asturias, contratar la fabricación de carbón a carboneros vascos y navarros, cuyos métodos diferían de los utilizados por los autóctonos. La carbonera vasca y navarra, que era la utilizada por esos profesionales, tenía forma troncónica, de unos cinco metros de altura y unos $32.000 \mathrm{~kg}$. de leña. Esta se colocaba verticalmente -en tono a un poste que luego se quitaba y hacía de chimenea, en pisos de espesor decreciente, de la que se obtenía unas 50 cargas o 160 sacas de 35 a $40 \mathrm{~kg}$., es decir, unos $6.400 \mathrm{~kg}$., aunque esto era lógicamente variable de acuerdo con su tamaño. Dependiendo de las cargas, el tiempo para su carbonización podía durar sobre 15 días, luego se dejaba enfriar o se mojaba con agua322. El carbón solía hacerse en verano (de mayo a septiembre), aunque las leñas las cortaban en invierno, dejando que secara durante la primavera. El sistema catalán era muy parecido a este con menos cantidad de leña y una duración entre 6 y 15 días 323.

En el oriente de Asturias, en los concejos de Ponga, Cangas de Onís y Amieva donde era muy abundante el haya, el carbón se hacía de esta madera, como comprobamos por los contratos que realiza la ferrería de Soto Rodrigo, que solía consumir dos o tres mil cargas de carbón anualmente. Después de que los ingenieros señalaran los árboles (entre 700 y 1.500), estos se cortaban en invierno, entre enero y marzo, dejando luego que la madera secara324. El carbón se solía hacer a principios de noviembre en cinco o seis carboneras -dependía de la cantidad de árboles- prefijadas por aquellos, en las que trabajan cuadrillas de carboneros locales con un capataz normalmente vasco, a veces del occidente de Asturias. El proceso consistía en cavar una hoya de un metro de profundidad por dos de diámetro, con una cama vegetal sobre la que se colocaban ordenadamente las maderas secas de mayor a menor tamaño, cubriendo el conjunto con tierra vegetal, evitando todo posible respiradero. La cocción,

\footnotetext{
${ }^{322}$ L.M. DÍAZ DE SALAZAR (1984): Ob. Cit., t. I, p. 136 y ss.; R. URIARTE (1988): Estructura, desarrollo y crisis de la siderurgia tradicional vizcaína (1700-1840). Bilbao, p. 97 y 98

323 C. MAS (2000): Història de la farga catalana. Lleida, p. 215

324 De los expedientes se deduce que el número de hayas taladas oscilaba de 1.000 a 1.500 cada año, de las que se obtenían de 225.000 a $450.000 \mathrm{~kg}$. de carbón vegetal, aunque estos datos puede que no sean los totales. En A. MATO (2010): Ob. cit., p. 122
} 
controlado día y noche por los carboneros que solía vivir en una cabaña temporal, duraba varios días. Cuando terminaba el proceso, se dejaba enfriar y luego en sacos se transportaba a la ferrería en carros o caballerías ${ }^{225}$.

En el Bierzo y las zonas del interior de Galicia y Asturias las carboneras locales eran de pequeñas dimensiones, aunque muy variables; desde las que fabricaban uno o dos costales de carbón, a las que hacían de una vez uno, dos o más carros. El método, sin embargo, era siempre el mismos. Sobre el terreno que previamente había sido descepado, se abría una "poza", "hoya", "tola" o "foya" de dos metros de largo por otros tantos de ancho, por medio o un metro de profundidad ${ }^{26}$. Esta, como hemos dicho, era variable de acuerdo con la cantidad que se pretendía carbonizar. Sobre el piso de la poza o foya se colocaba un lecho de leña seca al que se le prendía fuego. Cuando comenzaba a arder, se añadía una capa de cepo de urz encima hasta que se ponía al rojo; sobre ésta se superponía una nueva capa y así sucesivamente hasta colmar la poza. Llegado a este punto, se tapaba con tierra impidiendo que pudiera respirar327. Luego, se la dejaba hasta su completa carbonización, operación que podía durar de uno a tres días, de acuerdo con la cantidad de cepos.

Las carboneras las hacían los campesinos en sus tiempos libres, pero también las ferrerías fabricaban carbón ${ }^{328}$ mediante carboneros profesionales, como hemos dicho. Muchos campesinos fabricaban pequeñas cantidades con las que complementar sus escasos recursos pecuniarios329. En el coto de Villanueva

325 A. MATO (2010): Ob. cit., p. 127-130

${ }^{226}$ AHRG. R.A.: 26643/46. En 1625 denuncia ante el alcalde de Mondoñedo de vecinos de Adelán, San Martín de Figueira, Couboeira, etc. por carbonear. Un testigo dice que "Pedro de Loussada, vecino de esta feligresía de Couboeira a echo y ace cantidad de carbon en foyas de los carballos de esta feligresia, jurisdicción de Mondoñedo, y de otros arboles y lo bende en carros para la ferrería de la abadia de billanueba".

327 En el libro del Guarda Mayor de Montes del distrito del Bierzo hay numerosas referencias al carboneo; por ejemplo el 18 de mayo de 1861 dice: "Al pueblo de Dragonte, pasando al monte de la Nevera de los Corrales, noticioso de que intentaban carbonear en este sito, resultando cuatro hoyos que demostraban habían hecho cuatro sacos de carbón de vrezo", p. 59 v.

${ }^{228}$ Un testigo en un pleito en 1787 , después de declarar que cree que los montes bravos de Courel son de la encomienda de la Barra, añade que se acuerda que "habrá cosa de veinte años poco mas o menos una carbonera en dicho lugar de Froxán en donde se acopeaba el carbón y desde ella lo conduzían en carros y caballerías para la Errería de Lousadela, de quien era dicha carbonera" (AHRG. R.A.: 9090/4)

329 J. M. MUNÁRRIZ (1992): Ob. Cit. , p. 128-129: Las ferrerías no hacen carbón "por su cuenta, sino que lo compra a los carboneros aventureros que llegan a venderlo, y por lo regular son labradores pobres que lo fabrican en cortas cantidades, en las estaciones que no tienen otro trabajo, y lo portean al hombro en dos pequeños costales, por lo que les dan de cuatro reales a 
de Oscos, por ejemplo, en la mitad del siglo XVIII había 146 explotaciones agrarias y en el de Carballido otras 78, a las que en teoría les correspondía unas 8 hectáreas de terreno a cada una aproximadamente, en realidad muchas menos. En Villanueva, el 56,1\% de los propietarios tiene menos de 3 hectáreas y detentan menos del 29,9\% del total. Este grupo, que en Carballido es algo menor, necesitaba imperiosamente complementar esta superficie agraria con las parcelas de monte y otras actividades no relacionadas directamente con la agricultura, como "acarbonar" en los montes o en la arriería 330.

En muchas ocasiones, los permisos vecinales para construir una nueva ferrería tienen como razón última este carboneo, y ejemplos de esto los hemos mencionado reiteradamente en las páginas anteriores (ferrerías de Tejedo de Ancares, Neira, Serviz, Lusío, Seoane del Caurel, Soto Rodrigo, etc.); otros muchos simplemente se dedicaban temporalmente a esa actividad ${ }^{331}$, usando los propios montes comunales o pasando indistintamente de unos a otros, de los que a veces eran porcioneros $33^{2}$. Con frecuencia esta actividad fue objeto de crítica por los párrocos, pues creían que por ella los campesinos abandonaban la

cuatro y medio; este carbón es generalmente de brezo". Los vecinos de Cernego, en Valdorras, recuerdan en 1814 que viven a las faldas de una sierra "que poco o nada produce, consistiendo el mas de sus haveres el emplearse en arrancar leña para la Errería de san Vicente (de Leira) en la misma jurisdicción, con cuyo sudor y trabajo se alimentan y a sus familias" (AHN. Consejos: Leg. 34.760, $\mathrm{n}^{0}$ 252, f. 1r-3r.)

330 A este grupo debe referirse el monasterio de Villanueva cuando rebate un memorial de los vecinos de su coto en 1707, diciendo "que los vecinos de esta jurisdicción no son perjudicados por la herrería, sino beneficiados por ella, porque muchos no se mantienen de otra cosa que de hacer carbón y venderlo a la herrería, y si esto faltara perecerían". Cit. en D. PAZ (1991): El monasterio de Villanueva de Oscos: de la Reforma a la Exclaustración. Oviedo. p. 119

${ }^{331}$ Así, un labrador de San Mamed de Fisteus, Andrés Losada de 60 años, dice en un juicio en 1787 que "desde la edad de quinze años asta lo de presente conduxo carbón a dicha erreria de Quiroga haziéndolo cada año en temporadas, y en unos mas y en otros menos, fabricaba dicho carbón no solo en los términos de Quiroga sino en los de la jurisdicción de Courel". (AHRG. R. A.: 9090/4).

332 AHRG. RA: 9090/4. En un pleito por la venta de carbón, un testigo de San Cristóbal de Fisteus, de 53 años, dijo: "que con motibo ... de haberse ejercitado algunos años, que no puede numerarlos, en fabricar carbon, sabe y ha visto que los vezinos de la jurisdicción de Courel no solo del citado lugar de Froxán, sino también del de Vidallón, Campa y Folgoso condujeron siempre carbón a la Erreria de Quiroga, sin que jamás supiese ni biere que por persona alguna se les hubiese impedido el extraerlo fuera de dicha jurisdicción, antes bien el mismo testigo y otros de su lugar fueron también varias vezes a quemar duicho carbón a la misma jurisdicción de Courel y sitios que llaman de Tras do Campo do Lago y Pico, y sin embargo de estarlos biendo otros vecinos de la misma jurisdicción de Courel que también estaban quemando el carbón no se lo impedian ni estorbaban nunca por ser costumbre el pasar los vecinos de unos lugares a otros y quemando en los montes donde encuentran coza y conducirlo a las errerias que les tienen mas conveniencia". 
agricultura y las buenas costumbres familiares333, dado que los carboneros por su vida agreste tenían fama de sucios, poco sociales $y$, especialmente, que no cumplían con las prácticas religiosas.

A veces, las ferrerías contratan con campesinos de los alrededores la adquisición de carbón, como vemos en la ferrería de Lorenzana que se concierta en 1627 con los vecinos de Cedofeita para que en las "fragas" de la comunidad hagan 2.500 carros de carbón, a real cada uno 334. En 1841 un vecino de Villarrubín declara en un pleito que la ferrería de Arnado aunque consume carbón de los montes de los alrededores, no son suyos, solo lo usa cuando lo hacen los vecinos y lo llevan a vender a la fábrica335. También encontramos que las ferrerías lo compran directamente a carboneros profesionales ${ }^{336}$. A mediados del siglo XVIII, el Catastro de Ensenada menciona a personas que tienen ese oficio de carboneros 337 . Con mucha frecuencia estos profesionales carboneros eran vascos o navarros 338 , carboneros profesionales a los que se les denuncia por sus prácticas 339 .

333 En 1752 ante la construcción de la ferrería de Biduedo (Lugo), la Iglesia critica que los trabajadores "con la codicia del jornal que pillan al día" no trabajan en los campos ni les llega el pan hasta Navidad ni pagan los diezmos (E. LARRUGA (1800): Ob. cit., vol. XLV, p. 346). En 1802, el párroco de Oencia (León), dice que lleva diez años intentando instruir a sus feligreses por medio de una escuela de invierno, pero que lo olvidan todo después distrayéndose de este objeto, "dedicándose a fabricar y conducir carbón y otros utensilios a las Errerías de las inmediaciones" (AHPL. PN.: 3679).

334 AHN. Clero: libro 6.596, ff. 209-212

335 Archivo de la familia del Llano Ovalle (Villafranca del Bierzo). Papeles sueltos, ff. 199v.

${ }^{336}$ AHPL. P.N.: caja 2909: En 1593 el rendero de la ferrería de Valcarce, Felipe de Garbiso, se concierta con dos vecinos que le han "de hacer y dar echo quinientas cargas de carbón desde oy día de la fecha a fin del mes de septiembre de este presente año".

337 Así en Pacios de la Sierra (Laurel) un 33 por ciento de los miembros del estado llano se ocupan temporalmente a fabricar carbón; en las parroquias asturianas de Piantón, Paramios y Abres había 32 vecinos que durante 4 meses hacían carbón; en las parroquias de Santa María de Coaña, San Cosme de Villacondide y San Juan de Trilles había 17 carboneros. (CATASTRO DE ENSENADA, R. G.)

${ }^{338}$ Por ejemplo, en 1630 el propietario de la ferrería de Vilaseca se ajusta con dos vizcaínos para el suministro de 1.000 cargas de carbón (ANM.D. Ferreira (1630), f. 152-126. Cfr. P. SAAVEDRA (1985): Economía, política, y sociedad en Galicia: la provincia de Mondoñedo, 1480-183o. Santiago., p. 331, nota 94). A finales del siglo XVIII, la Compañía de la Vega de Ribadeo escribe una carta a don Joaquín de Menguibar, de Vergara, en la que le solicita dos cuadrillas de carboneros vascos como los que ya trabajaban para el propietario de Sargadelos. En A.M.P.L. Libro de cartas de la Compañía de Ribadeo. Cit. P. QUINTANA (2005): La labranza y transformación artesanal del hierro en Taramundi y los Oscos. Oviedo, t. I, p. 70-71.

339 AHRG. R. A.: 21.708/6. En 1640 vecinos de Ourol y San Pantaleón se enfrentan a Carboneros de la ferrería de Bravos, acusando al arrendatario de que "dende nuebe o diez meses a esta parte usando officiales carboneros dieron a meterse en las fragas a cortar y talar en ellas y hacer oyas y fossas para carbón haciendo gran cantidad para el servicio y fábrica de dicha herraria, con que les tienen a mis partes destruidas las dichas fragas", lo que arruinaba el monte. El propietario de la ferrería de Bravos, Pedro Fernández de Cora, por su parte, denuncia que son 
Por último, el carbón debía de ser transportado a las ferrerías. Este no aguanta las largas distancias, tanto porque se pulveriza con el traqueteo, como porque se encarece considerablemente. Se hacía a lomos de caballerías, en carros y a hombros de los propios carboneros. En la zona catalana de la vall Ferrera la elaboración del carbón suponía un $40 \%$ de su precio final, pero en la década de los setenta del siglo XVIII el transporte alcanzó casi el 70\%, y entre el 60 y el 70\% en el siglo XIX ${ }^{340}$. En Vizcaya, la estructura del coste del carbón era diferente porque variaba con la distancia a las ferrerías. Constaba de tres factores: la leña, la elaboración y el transporte. En 1827, dependiendo de las comarcas, la leña costaba entre el 35 y el 55\%, la elaboración del 32 al 34\% y el transporte del 12 al 32\%. En Guipúzcoa era muy parecido, aunque se constata para el siglo XVIII que mientras el coste de la mano de obra se mantuvo prácticamente constante a lo largo del siglo, el del carbón subió casi un 40\% por el incremento del valor de la leña y el transporte341.

Respecto al noroeste no tenemos datos para conocer la estructura de costes del carbón, aunque si precios y su evolución, que veremos en el capítulo sexto. En el Bierzo a finales del siglo XVIII las ferrerías no solían hacer carbón por su cuenta sino que lo adquirían a campesinos que, tras hacerlo, lo transportaban a hombros en pequeños costales por los que se les pagaba de $4 \mathrm{a}$ 4,5 reales el costal342. Desconocemos el peso del costal y, por tanto, no podemos relacionar el precio por kg. ni la estructura del precio. Probablemente, en este caso, sólo incluya el trabajo de hechura y transporte y no la madera que extraían de los montes públicos, a veces jugándose el que los prendieran los guardas y los multaran 343 .

\footnotetext{
los vecinos quienes se han "entrometido a perturbarle el cortar de los montes y fragas que llaman de Cauana y Serradaorra, pertenecientes a dicha erraria y contradecir a una querella dada por los sobredichos y a cada uno de ellos contra Juanes de Belderrayn, rendero de la dicha erraria $y$ sus oficiales y carboneros".

340 C. MAS (2000): Ob. cit., p. 221

${ }^{341}$ I. CARRIÓN (1991): La siderurgia guipuzcoana en el siglo XVIII. Bilbao, p. 53

342J. M. MUNÁRRIZ (1992): Ob. Cit. , p. 128-129

343 En el Libro del Guarda Mayor de Montes del distrito de Villafranca del Bierzo se mencionan muchas multas por carbonear, como ya hemos visto en la nota 158 .
} 


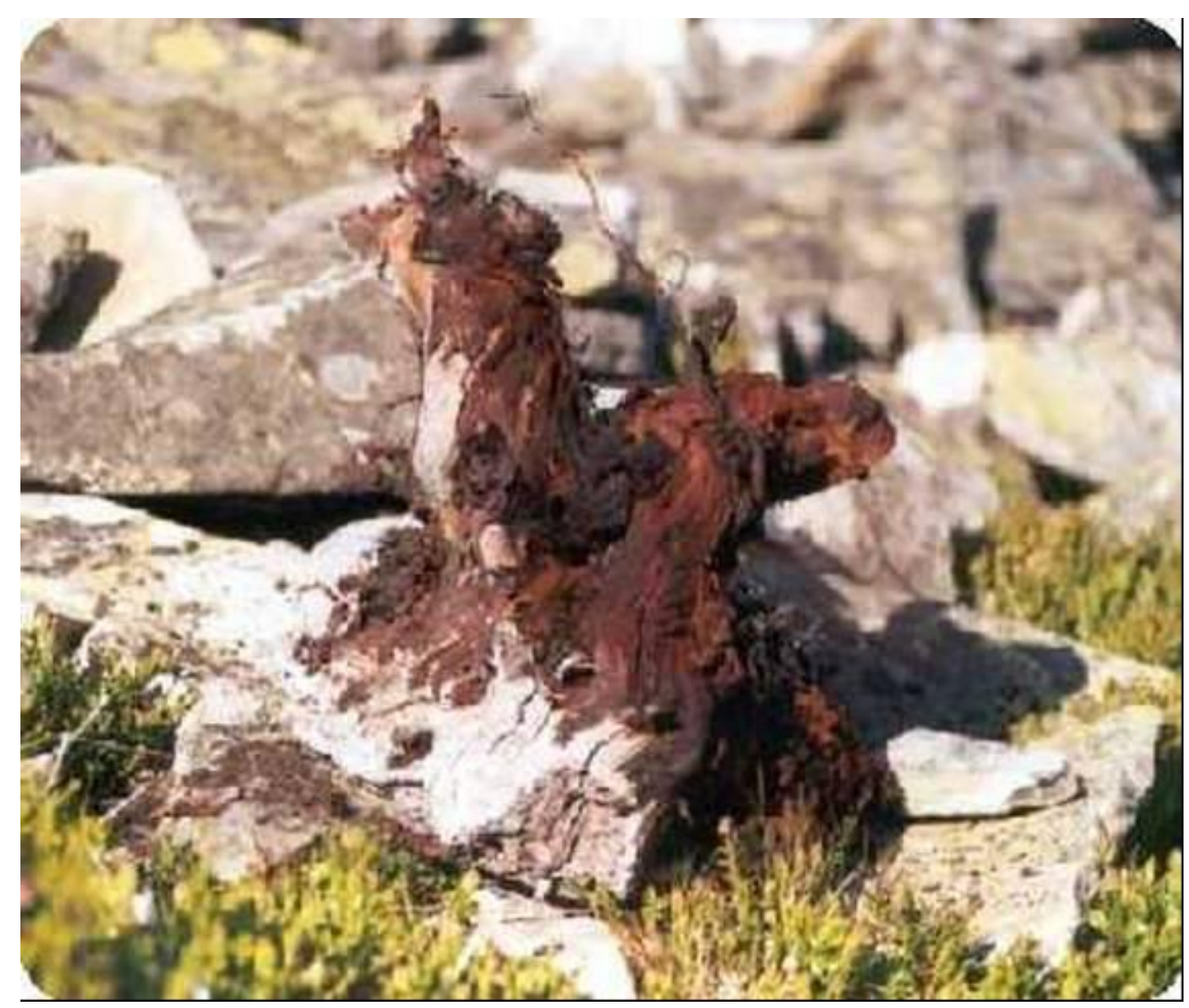

Cepo de Urz

\subsection{El carbón mineral}

Las ferrerías nunca utilizaron carbón mineral aunque ya se conocía en Asturias desde principios del XVI, pues de esos años data el descubrimiento de una mina de carbón en Arances (Castrillón) por el carmelita fray Agustín Montero. Tal descubrimiento debió de ser un hecho aislado porque no volvieron a mencionarse minas de carbón hasta el último tercio del siglo XVIII344. A partir de 1785, los protocolos notariales asturianos registran las primeras escrituras de contratos de arrendamiento mineros, así como de asientos de carbón con destino a El Ferrol y la Cavada. Por entonces se explotan por algunos vecinos minas en los concejos de Siero, Langreo y Bimenes345.

344 R. ANES (1997): Asturias, fuente de energía. El carbón asturiano en la economía española. Oviedo, p. 17.

345 J. OCAMPO (1990): Ob. cit., p. 218-219. 
Carlos Lemaur cuando realizaba las obras de la carretera de Madrid a La Coruña encontró en las cercanías de Torre del Bierzo, en la Cuesta del Morueco, hacia 1756, una mina de carbón de piedra que pretendió utilizar en sus ferrerías de Torre y Navaleo, no para reducir el mineral de hierro, sino para las fraguas que pensaba construir a su alrededor346. En este carbón cifraba en resolver el problema del combustible tan escaso en esa parte del Bierzo.

A finales de ese mismo siglo, Jovellanos menciona con frecuencia el carbón en sus diarios, y en un informe de 1789 habla de la gran riqueza que encierran los montes asturianos de este combustible 347 , pero fue la Compañía de la Vega de Ribadeo la primera que en Asturias defendió su uso en las fraguas ${ }^{348}$. El fundador de Sargadelos en 1792, en un informe a la Marina sobre el carbón del concejo de Langreo creía poder utilizarlo en las ferrerías349; pero ni él ni Casado Torres, en Trubia, lograrían fundir hierro con carbón mineral350. Estos

\footnotetext{
346 Lemaur comprobó que "en la combustión no da mal olor alguno: su actividad es igual al mejor que se conozca y su efecto en la fragua tan bueno, como el de cualquier carbón”. Afirmó la riqueza del yacimiento, al señalar que sus capas ocupan "leguas enteras, y una legua quadrada de un solo banco producirá mas de dos mil millones de arrobas de carbón". Cit. en M. OLANO, M. (2008): Ob. cit., p. 221 y 222.

347 R. ANES (1997). Ob. cit., p. 17

348 J. LÓPEZ y A. GRAÑA (1998): Ob. cit., p. 17

349 "Mucha será la felicidad y beneficio que los pueblos pueden recibir del uso de este fósil en las ferrerías y hornos de fundición". Cit. en E. CASARIEGO (1950): ob. cit., p. 124

350 IBIDEM, p. 146
} 
fiascos, que contrastan con el sistema de pudelado inglés introducido con éxito por Cort en 1785, explican en gran manera el fracaso de modernización de la siderurgia española hasta mediados del siglo XIX. 


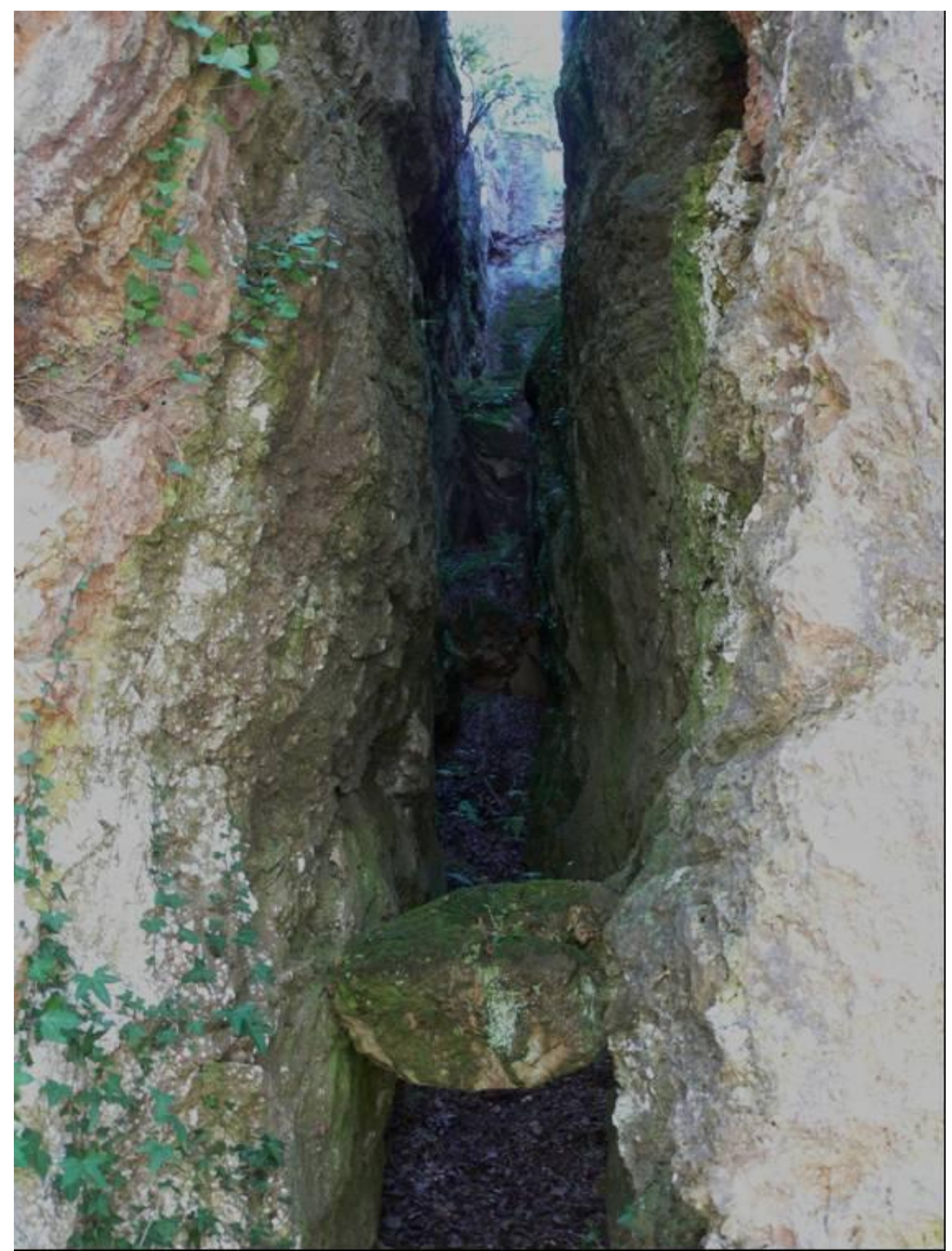

Mina de mineral de hierro de la Chana de Borrenes (León) 


\section{LAS CONDICIONES MATERIALES DE LAS FERRERÍAS: EL MINERAL DE HIERRO.}

La siderurgia es la metalurgia del hierro; por tanto, el mineral de hierro, la vena como frecuentemente denominan las fuentes documentales a aquel, es la materia prima más importante para el desarrollo de esta actividad; sin ella no es posible ponerla en marcha. Pero el hierro no fue un problema excesivamente grave para la siderurgia tradicional: primero porque es muy abundante en la naturaleza y segundo porque, a diferencia del agua e incluso del carbón, se puede transportar a grandes distancias y, por tanto, las ferrerías pueden importarlo, siempre que por este motivo su precio no se vea excesivamente incrementado. El hierro, en ese sentido, no es un factor geográfico decisivo para la existencia de ferrerías en una determinada región, aunque contar con el puede ser un aliciente para invertir en fábricas de fundición.

El hierro es uno de los elementos químicos más abundantes y repartidos por la corteza terrestre 351 , ya que se encuentra en numerosos minerales: la pirita, un bisulfuro de hierro no utilizado para obtener este sino azufre y ácido sulfúrico; la magnetita, un óxido ferroso férrico, que es una buena mena de hierro; la siderita, carbonato de hierro de elevado rendimiento pero que previamente hay que transformar en un óxido; el oligisto, óxido férrico, que se presenta bajo la forma de hematites roja; la limonita, un hidróxido de hierro, cuya principal variedad es la hematites parda, y algunos otros. En la siderurgia tradicional, sin embargo, solo los óxidos fueron utilizados en los pequeños hornos para su reducción mediante un procedimiento directo, pues dicho método exigía minerales de gran pureza y punto bajo de fusión, propiedades que se encuentran sobre todo en la hematites roja y parda y en la siderita. Por eso, de todos los minerales de hierro los más frecuentemente explotados fueron:

351 K. KELLEMBERZ (1977): El desarrollo económico de la Europa Continental (1500-1750). Madrid, p. 106: afirma que los yacimientos de hierro son muy abundantes en Europa, aunque se encuentran muy dispersos, pues los hallamos desde los Pirineos, pasando por los Alpes, hasta Escandinavia y Rusia. 
- $\quad$ La hematites roja u Oligisto (Fe2 O3): rojo, gris, azul y negro; 69,9\% de hierro; difícil de reducir.

- $\quad$ La hematites parda o Limonita (Fe2 O3 hidratado): amarillo, ocre y blando; $60 \%$ de hierro; fácil de reducir.

- La Goethita $\{\mathrm{FeO}(\mathrm{OH})\}$ : Óxido de hierro hidratado de color negro brillante a pardo amarillento, de dureza y fragilidad intermedia; $60 \%$ de hierro; fácil de reducir.

- $\quad$ La Magnetita (Fe3 O4): gris-negro, magnético, duro y pesado; $72,4 \%$ de hierro; muy difícil de reducir.

Muchas de estas menas fueron conocidas en la Antigüedad y profusamente explotadas en la Edad Media en nuestro ámbito de estudio352 en hornos de monte y en primitivas ferrerías hidráulicas, como vimos en el capítulo primero. Posiblemente muchos de los ferrarius medievales fueron a la vez herreros y venaqueros o mineros que, al tiempo que fundían el mineral y fabricaban útiles domésticos o para la labor de los campos, prospectaban yacimientos superficiales de este mineral, algunos de los cuales, como el de Chana de Borrenes en el Bierzo, siguieron siendo explotados hasta el siglo $\mathrm{XX} 353$.

El cambio sustancial que se produce en la Edad Moderna, probablemente desde finales del siglo $\mathrm{XV}$, es el descubrimiento de algunos extraordinarios yacimientos como los de Formigueiros y Rocas; pero también el uso de vena vasca, especialmente la de Somorrostro. En este sentido creo que la novedad más importante, a la que ya aludimos al hablar de la tecnología y a la que extensamente nos referiremos en el próximo capítulo, fue la presencia de ferrones y venaqueros vascos. Fueron ellos no solo los que trabajaron en las

352 F. J. SÁNCHEZ PALENCIA (Ed.) (2000): Las Médulas (León). Un paisaje cultural en la Asturia Augustana. León, p. 264-265; J. L. GUTIÉRREZ et alii (1993): "Minería y metalurgia en torno a la Cordillera Cantábrica. Primeras evidencias arqueológicas y propuesta de estudio". IV Came, tomo III, p. 907-908; J. A. BALBOA (1990): Hierro y herrerías en el Bierzo preindustrial. León, p. 65-83; E. PORTELA y M ${ }^{a}$ C. PALLARÉS (2000): "El complejo siderometalúrgico de la granja cisterciense de Constantín. Bases para el desarrollo de una investigación en arqueología medieval”. Arqueología y territorio medieval, 7, p. 81-91; J. J. ARGUELLO (1996). "Minería y metalurgia en Muñás y Carcéu (Valdés-Asturies)". Actas de las I jornadas sobre minería y tecnología en la Edad Media peninsular. León, p. 134 y ss.

353 De este yacimiento tenemos noticias desde el siglo XIII al XX. En M. MARTÍNEZ (1997): Cartulario de Santa María de Carracedo (992-1500). Ponferrada, t. $\mathrm{I}^{\circ}$, p. 298, ${ }^{\circ} 428$, y J. REVILLA (1906): Riqueza minera de la provincia de León. Madrid. 
nuevas ferrerías que se construyen a partir de entonces, o los que las arriendan y en algún caso levantan, sino que también fueron los que prospectaron los nuevos e importantes yacimientos mencionados. Igualmente fueron los que importaron vena vasca, cuya calidad conocían sobradamente. En ese sentido, la vena autóctona no fue un elemento indispensable para poner en funcionamiento las ferrerías, siempre que el mineral vasco se pudiere transportar a precios razonables; pero sí lo fue el descubrimiento de ricos yacimientos de hierro en la provincia de Lugo para muchas ferrerías gallegas y bercianas.

Por ello creo que se puede establecer una cierta regionalización de las ferrerías en razón del mineral de hierro. Como vimos en el capítulo segundo, al hablar de la geografía ferrera, podemos establecer tres ámbitos diferentes. El primero abarca el entorno de los yacimientos de Formigueiros, Rocas y minas aledañas. Este ámbito abastece aproximadamente el $42 \%$ de todas las ferrerías del noroeste en las provincias de León, Lugo y Orense. El segundo fue el de las ferrerías abastecidas con mineral vasco, a veces mezclado con vena local. Este segundo ámbito, con un 32\% aproximadamente de las ferrerías, se extiende por las zonas costeras de Lugo y Oviedo. Un intenso tráfico de cabotaje hizo posible que, sin muchas dificultades, estas ferrerías pudieran abastecerse durante siglos. El último ámbito, con un $25 \%$ de ferrerías, se abasteció de los minerales de pequeños yacimientos locales de mala calidad o insuficiente producción. Muchas de estas ferrerías se encuentran en zonas del interior, aisladas y, por ello, con dificultades para vender sus hierros, generalmente de poca calidad.

\section{EL MINERAL AUTÓCTONO}

La zona Asturoccidental-leonesa es muy abundante en yacimientos minerales 354 , especialmente de hierro 355 . Estas mineralizaciones están constituidas mayoritariamente por depósitos sedimentarios, encontrándose asimismo mineralizaciones de relleno de fisuras (filonianos) y supergénicas derivadas de aquellas. Los depósitos sedimentarios corresponden a niveles

354 F. RUIZ ARIAS y C. LUQUE CABAL (1988): "Metalogenia de la zona Asturoccidental Leonesa". Revista de la Sociedad Geológica de España, 1, (1-2), p. 239-247.

355 Muchos topónimos del tipo Ferraria, Ferreira o Ferrera no aluden a ferrerías sino a minas de hierro, pues "ferraria" en latín significa mina de hierro. También aluden a este mineral, con frecuencia, topónimos del tipo Venero, Veneiro/a, Vieiro, Veneru. 
intercalados en series detríticas en distintas posiciones dentro de las series estatigráficas:

- $\quad$ Serie de Transición (Ordovícico inferior-medio) con potencias irregulares $(0,4-2 \mathrm{~m})$ y notables variaciones laterales en la composición mineralógica. Se hallan oolitos de siderita rellenos de una masa hematítica, con magnetita y clorita, también se encuentran limonita y goethita como materiales supergénicos.

- $\quad$ Pizarras de Luarca (Ordovícico medio) con capas de potencia variable (0,1-8 $\mathrm{m})$ formadas por magnetita, siderita y clorita, frecuentemente de textura oolítica y con contenidos medios en hierro entre el 47-55\%.

- $\quad$ Formación Agüeira (Ordovícico superior) muy semejante al anterior y con contenidos en hierro entre 45 a $60 \%$. Los depósitos filonianos en zonas de fracturación suconcordantes con la estratificación, formadas por hematites, goethita $\mathrm{y}$ limonita, frecuentemente con textura brechoide. Por último, los depósitos supergénicos, derivadas de la alteración de los tipos precedentes, la forman limonita, goethita $\mathrm{y}$ hematites principalmente 356 .

Estos yacimientos aparecen en esta zona formando dos alineaciones que, a grandes rasgos, siguen las directrices hercínicas y constituyen dos arcos paralelos, denominados interno y externo por su posición en el geosinclinal Hespérico. El arco interno, más occidental, comienza en Vivero (Lugo), pasa por el oeste de Villalba, se interrumpe y continúa por las inmediaciones de Incio y Caurel hasta el Teleno, ya en Astorga (León); sus principales yacimientos son los de Vivero, Incio, Caurel y Gestoso. El externo se extiende desde Ribadeo por Villaodrid, Fonsagrada y Villafranca del Bierzo hasta Ponferrada y Astorga; sus yacimientos son los de Villaodrid, San Pedro del Río, Órrea, Fonfría y los cotos mineros leoneses de San José, Vivaldi, Wagner y San Bernardo. Dichas alineaciones de hierro quedarían situadas: la interna sobre el flanco este del

${ }^{356}$ F. RUIZ ARIAS y C. LUQUE CABAL (1988): ob. cit., p. 240 
anticlinal del "ollo de sapo" y la externa, sobre el flanco oeste del antiforme del Narcea, y entre ambas el asomo precámbrico denominado "lomo de Lugo"357.

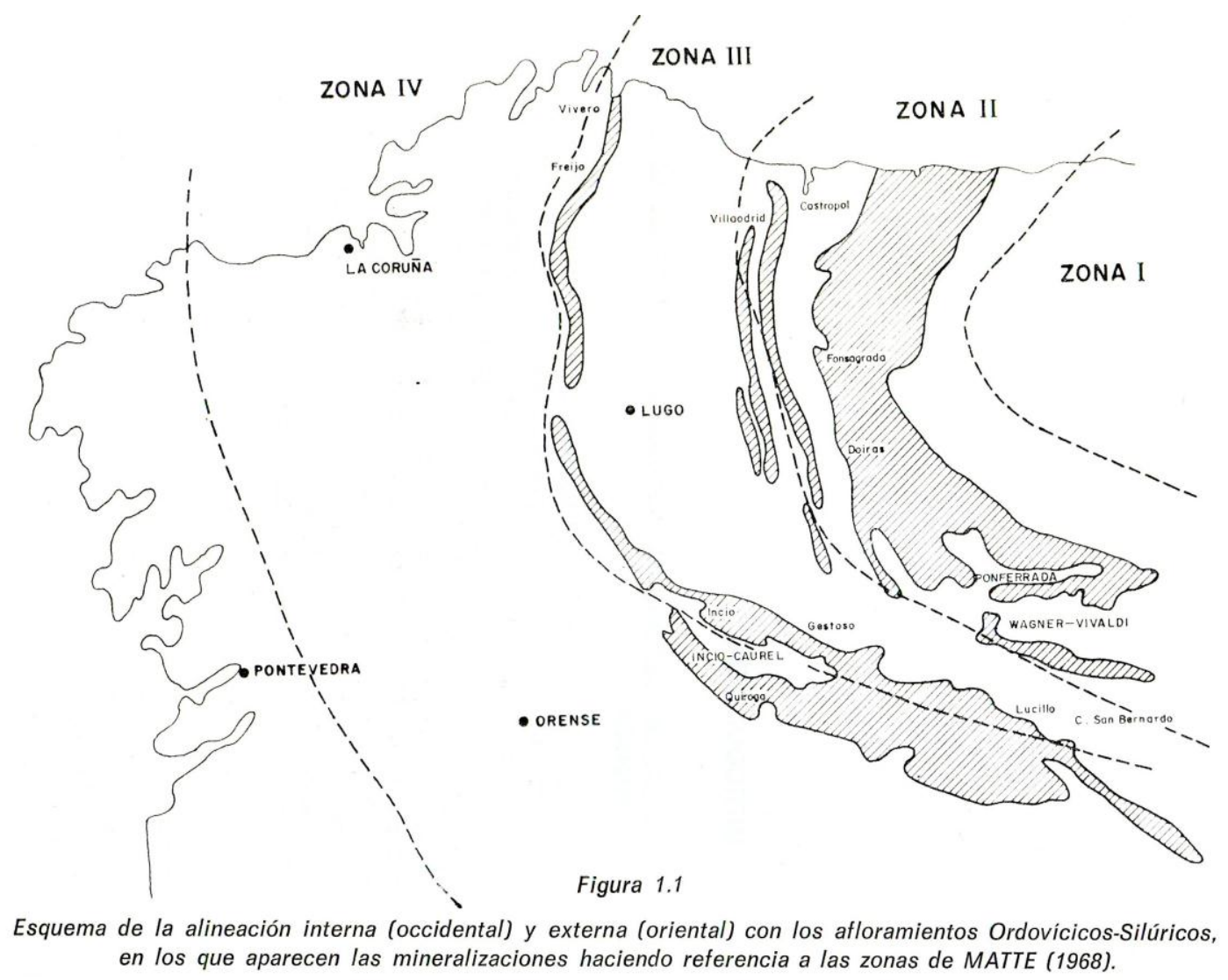

Afloramientos de hierro. Tomado de R. LUNAR (1977): Mineralogénesis de los yacimientos de hierro del noroeste de la pensínsula. Madrid.

Los minerales de hierro aparecen en forma de capas interestratigraficadas, en un tramo pizarroso de bajo grado de metamorfismo y con algún nivel intercalado de cuarcitas, denominadas pizarras de Luarca. Los afloramientos de las capas de hierro son escasos, y cuando afloran presentan fenómenos superficiales de limonitización 358 . Las menas exhiben generalmente textura oolítica, y aparecen formando una o varias capas de espesor variable, que oscilan entre algunos centímetros y varios metros. A veces estas capas se pueden seguir a lo largo de varios kilómetros, encontrándose deformadas por procesos diastróficos. Los minerales principales son óxidos (magnetita),

357 R. LUNAR HERNÁNDEZ: Mineralogénesis de los yacimientos de hierro del noroeste de la Península. Memoria del Instituto Geológico y Minero de España, t. 9o. Madrid, p. 13 ${ }^{358}$ IBIDEM, p. 65. 
carbonatos (siderita) y silicatos (cloritas), y como accesorios pirita, calcopirita, etc., con un contenido en hierro entre el $46 \%$ y $57 \% 359$.

Con excepción de los óxidos, estos minerales apenas han sido utilizados por la siderurgia tradicional, por lo que el número de grandes yacimientos explotados es realmente escaso; solo los de Formigueiros, Rocas, Valdecaballos y La Chana, en el arco interior anteriormente mencionado, han sido beneficiados de manera intensa durante muchos siglos; también lo fueron, en menor medida, otros pequeños afloramientos superficiales gallegos y bercianos, pues las minas se han explotado casi siempre a cielo abierto o por medio de pequeñas galerías ${ }^{360}$. En Asturias, con numerosos criaderos de hierro, fueron pocos los minerales autóctonos que beneficiaron sus ferrerías en época preindustrial, ya que consumieron normalmente hierro vasco 361 , a veces mezclado con alguna vena local.

\subsection{Yacimientos gallegos}

Las primeras noticias documentales a minas de hierro en Galicia datan del siglo X en relación con el monasterio de Celanova (Orense): dos menciones en los alrededores del Arnoya en 958 y una tercera, del año 959, cerca de la villa de Monforte. En la primera un presbítero vende al abad san Rosendo una mina en el monte Termenorio, de la que se indica concretamente su condición de hierro ${ }^{362}$; en la otra, en Ancarini, solo se habla de una cova aunque se sobreentiende de hierro. La del año 959 es una donación del rey Sancho al abad y a los monjes de Celanova de una mina de hierro en Lemos, probablemente en

\footnotetext{
359 IBIDEM, p. 169

360 Un estudio de los yacimientos gallegos, con numerosas referencias históricas a minas antiguas, puede verse en P. HERNÁNDEZ SAMPELAYO: Criaderos de Hierro de España. T. IV, Hierros de Galicia. Madrid I (1922), II (1931), III (1935). Respecto de la minería de León: J. REVILLA (1906): Riqueza minera de la provincia de León. Madrid.

${ }^{361}$ Tomás González, en su Registro de Minas, de 1831, sólo cita tres minas de hierro: Pinos (1602), Oviedo (1625), Lena (1630). Cit. por L. ADARO (1916): Criaderos de hierro de España. T. II (Asturias). Madrid, p. 51. Este autor ofrece abundantes datos sobre la minería en Asturias. También menciona algunas minas Jovellanos en sus diarios (G. M. DE JOVELLANOS: Diarios. Ed. de J. M. Caso González. Barcelona, 1992, p. 206 y 198). El BOPA menciona en la segunda mitad del siglo XIX numerosas denuncias de yacimientos de hierro en Asturias, pero esas fechas quedan al margen de nuestro estudio porque sus minerales, en la mayoría de los casos, no fueron utilizados por la siderurgia tradicional.

362 "ipsa vena unde ferrum faciunt et ipsa cova unde venam sacant" (A.H.N.: Tumbo de Celanova, ff. 133r)
} 
el mismo lugar donde posteriormente estuvo la explotación de Freijo 363 . También en el siglo X, sabemos que el monasterio de Sobrado de los Monjes (Coruña) poseía una mina en Parga364. En el siguiente, al señalar los límites y propiedades del monasterio de Samos se menciona una mina ${ }^{365}$ que estaba en sus cercanías. En el XIII, el monasterio de Meira prevé en sus dominios, entre Formariz y Gasallo, la existencia de minas de hierro, que se reserva para su uso366.

En la Edad Moderna los yacimientos de los que tenemos noticia fueron numerosos, aunque su estudio geológico y minero no se haría hasta finales del siglo XVIII y principios del XIX 367 . En el siglo XX los estudiaría exhaustivamente Hernández Sampelayo 368 , amenizando este estudio con algunos datos históricos, que vamos a completar ahora. Entre estos yacimientos se encuentran los siguientes:

\subsubsection{Criaderos del Caurel: Mina de Formigueiros}

La comarca lucense del Caurel (Courel), al sureste de la provincia, es una zona montañosa -la sierra del Caurel-, abrupta y escabrosa, de elevada altitud, que supera los 1.600 metros en Formigueiros y Pía Páxaro; salpicada de valles estrechos de fuertes pendientes por los que discurren numerosos ríos y arroyos jerarquizados en torno al Lor, que se une al Sil en Augasmestas, ya en Quiroga.

Toda la zona presenta multitud de yacimientos de hierro, que están relacionados con las líneas de depresión y bajada de aguas; y así vemos cómo los depósitos se encuentran ya en el río Lor, desde Barja de Lor hasta Villamor y

\footnotetext{
363 IBIDEM, ff. 132r.

364 P. LOSCERTALES (1976): Tumbos de monasterio de Sobrado de los Monjes. Madrid, t. I. $\mathrm{n}^{\mathrm{o}}$ 6: "et illo uenario de Parriga medio".

365 LUCAS (1982): Tumbo del monasterio de Samos, no 4, p. 68: Año 1082: "tras illas lomas de Humano ubi sacant vena ferrea".

366 Dice el texto: "possit ipsum ferrum tirare monasterium et habere in pace et sine contradictione". En M. I. REVENGA PORTELA y J. M. CARNICERO (1996): "Notas documentales en torno a la minería y herrería del noroeste peninsular (siglos $\mathrm{X}$ al XV). Actas de las I jornadas sobre minería y tecnología en la Edad Media peninsular. León, p. 306-307.

${ }^{367}$ Lo harían por Datoli y Munárriz. Los informes de estos en J.A. BALBOA DE PAZ (1992): Datoli y Munárriz, dos militares en la historia económica del Bierzo. Ponferrada; y sobre todo Schulz (1835): Descripción geognóstica del Reino de Galicia. Madrid. Edición facsimil Ediciones do Castro (1994).

368 P. HERNÁNDEZ SAMPELAYO: Hierros de Galicia. Madrid, 1922-1935.
} 
Tousa, en la unión del Caurel (nombre del Lor en su curso alto) y el Lózara, continuando por la ladera izquierda de este río, alojados siempre en los arroyos que a él convergen. Hay que hacer excepción de Formigueiros, cuyo renombrado yacimiento está encajado en las más altas barrancadas que miran al Selmo369. Son numerosos los lugares en los que se descubren labores antiguas, trabajos mineros que se relacionan con su utilización en las ferrerías cercanas 370 .

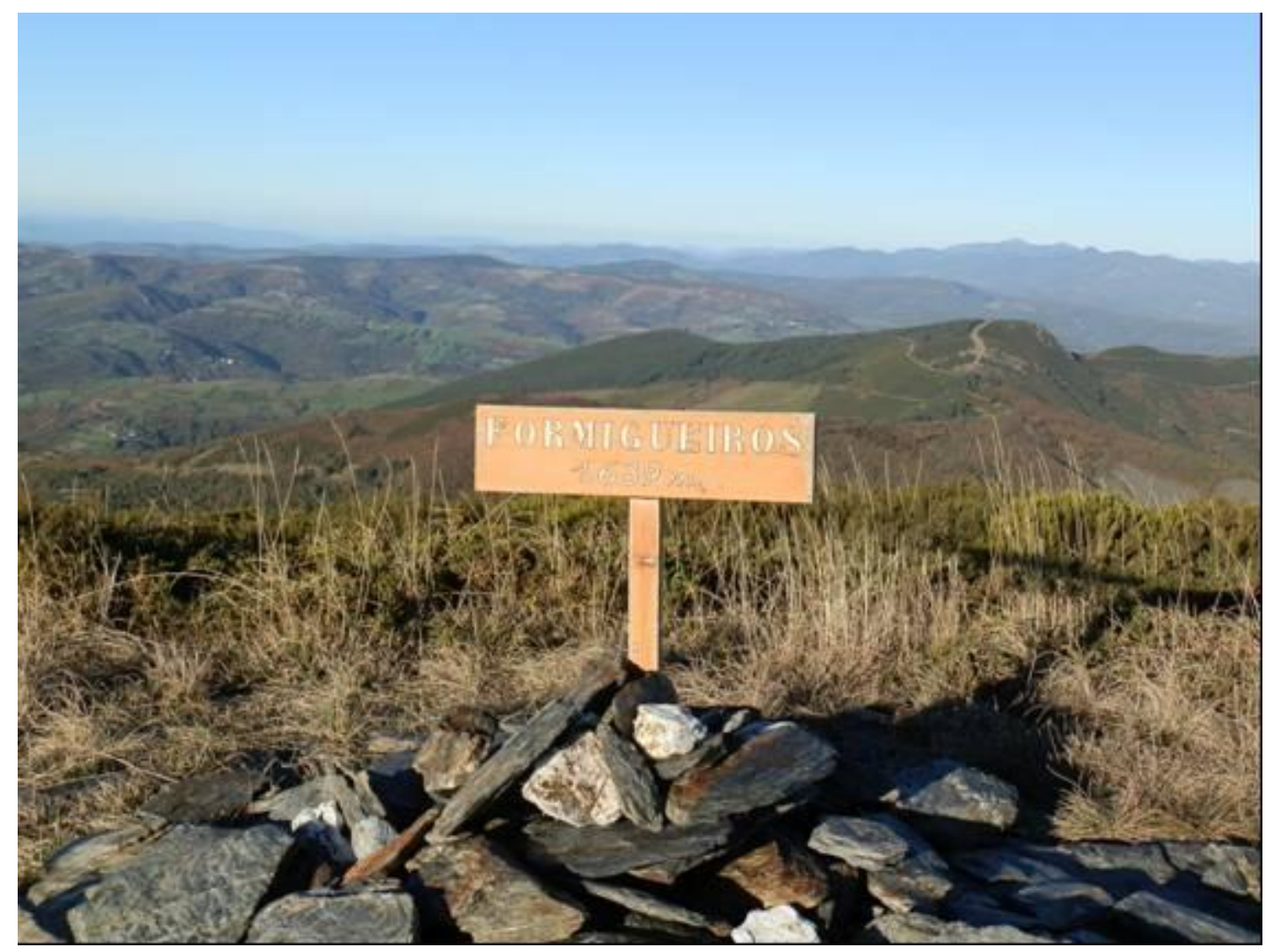

Monte de Formigueiros en el Caurel lucense

La mina más importante es la de Formigueiros que se halla en el límite de Lugo con León, en el municipio o concejo de Folgoso de Courel371. El yacimiento

369 P. HERNÁNDEZ SAMPELAYO, P. (1935): Hierros de Galicia, t. III, $1^{\circ}$, p. 2

370 Así a la derecha del Lor, desde Touzón a Sobredo hay varios yacimientos con labores antiguas, uno de ellos es el llamado Forno de Roxolongo, una cueva que, sobre el mineral, tendrá unas dimensiones de tres por cuatro metros, y ocho o diez accesibles de entrada. También en San Vicente de Villamor, en el paraje denominado Novido, en lo que luego fue Mina Tercera, hay un lugar -el Vieiro- con labores antiguas, que consisten en un socavón practicado según el buzamiento del filón, con doce metros de ancho y dos o tres de altura, donde se sacó abundante hematites parda. Igualmente entre Saceda y Sobredo, en Cova d'Arca y el las Veneiriñas se descubren restos de explotaciones antiguas. Cit. en IBIDEM, p. 51, 54-55 y 80. ${ }^{371}$ De este yacimiento dice Munárriz: "El territorio en que se halla este mineral es uno de los más elevados de las sierras que bajan de Cebreros y Caurel a unirse con las de Aguiar, y está 
ocupaba la depresión meridional del monte de Formigueiros, un barranco profundo que vierte aguas hacia Ferramulín y el Selmo. Los depósitos están situados sobre la misma línea de talweg, donde las masas de hidróxido segregado fueron formando acumulaciones de hierro372. Su cubicación puede fijarse, "como cifra límite máxima", en 1.550.00o toneladas373, riqueza que ya era conocida siglos antes, como se evidencia de la declaraciones de un testigo en 1692 en el juicio por la construcción de la ferrería de Quintá374.

El yacimiento tenía en la Edad Moderna una extensión de más de un cuarto de legua, con un espesor en sus capas de 3 a 15 pies (es decir de o,83 a 4,18 m). La parte superior estaba constituida por una capa de 6 a 12 pies de gruesa $(1,67$ a $3,34 \mathrm{~m})$, descompuesta en muchos lugares, por lo que se trabajaba como si fuera una cantera375. En el siglo XX la extensión máxima sería de unas 80 a 90 hectáreas, pues el largo, según la dirección del barranco, era de unos 1.300 a 1.500 metros por unos 600 de ancho en sentido transversal, casi de E. a O. ${ }^{376}$. Los afloramientos principales se reparten en cuatro centros: Retorta y Veneiras Vellas, que comprende todos los trabajos más antiguos en la parte alta; Caborco y Pozo, que abarca la parte media de la ladera y el mayor depósito de mineral; la parte baja del Pozo y los Carros; y Las Ferreñas, que comprende los depósitos de la línea de vaguada377.

El mineral consiste en un hierro pardo, compacto y esponjoso, con poca hematites parda o limonita; en parte descompuesto y mezclado con ocres, pardos, amarillos y rojizos, que tiene por ganga cuarzo, pizarra y brecha ${ }^{378}$. Su

entre Mediodía y Poniente de Villafranca, a seis leguas de ella, y como dentro de los límites de Galicia, por la parte en que este reino confina con el Bierzo". MUNÁRRIZ, p. 133.

372 P. HERNANDEZ SAMPELAYO (1922-1935): Criaderos de hierro de España, tomo IV. Hierros de Galicia. Memorias del Instituto Geológico y Minero de España, Madrid, 1935, t. III., p. 41 y ss.

373 IBIDEM, p. 48

374 AHRG. R. A. : 1.662/4: Al testigo se le preguntó si habría vena bastante, pues en diez leguas ya había 16 ferrerías, y contestó: "que en quanto a vena que habrá aunque sea para muchas más en el monte de Formigueiros que esta a quatro o zinco leguas de dichas herrerías".

375 MUNÁRRIZ, p. 124.

376 P.HERNÁNDEZ SAMPELAYO (1935): Ob. Cit. T. III, fasc. $1^{\text {o }}$, p. 134 y 41

377 IBIDEM, p. 42.

378 MUNÁRRIZ: Ob. Cit. p. 134 afirma que venaqueros y ferrones lo dividían en ocho clases:

NOMBRE VULGAR MOMBRE MINERALOGICO

Bazo de buey Hierro pardo compacto

Retoita o

Hierro pardo esponjoso en rojas 
calidad fue muy celebrada379, como aseguran Munárriz ${ }^{380}$ y Tomás de Morla381; y su abundancia enorme ${ }^{382}$. De este mineral, sobre todo de los afloramientos de la Retorta y Veneiras Vellas, se abastecieron en los siglos XVI al XVIII las ferrerías bercianas de Valcarce, Ponte Petre, Arnado y San Vicente de Leira; y las gallegas de Puente Nuevo/Pontenova (Sobradelo), Soldón, Lousadela, Rugando, Quintá, Gorgueira, Rodela, Paleiras, Ferreirós, Bueyes/Bois, Visuña, Pallares y Baldomiro o Valdomir. En el siglo XIX, a estas ferrerías se añadieron las bercianas de Riocabo, Valincarro, Lusío, Valdelouro, Arnadelo, San Vitul, Serviz, Corporales, Barjas y Portela de Valcarce; y las gallegas de Vilarbacú, Fonquente, Outeiro y Seone; ferrerías distantes no más de cinco leguas, aunque los caminos de acceso al yacimiento eran estrechos y frecuentemente se encontraban en mal estado.

Ignoramos si este yacimiento fue explotado en la Antigüedad y en la Edad Media, aunque puede que sí pero solo en una pequeña parte y muy superficialmente ${ }^{383}$. La existencia de una forja en el siglo XV en el Vieiro, al lado de La Seara, probablemente haya que relacionar con este yacimiento384; pero su explotación intensiva debió comenzar en el siglo XVI. A principios de ese siglo,

\footnotetext{
vena cerrada trojas o laminosamente torcido

Goroleira Hierro pardo poroso

Muerta Hierro descompuesto

Bermellón Ocre pardo, rojizo y amarillento

Lápiz Hierro pizarroso

Barrera Hierro arcilloso

Riorenca Hierro cuarzoso

379 En un juicio por la ferrería de Soldón de 1603, uno de los testigos dice que ésta utiliza vena de Formigueiros "que es la mejor vena que ay en este reino". (AHRG. R. A.: 20.441/70).

380 MUNÁRRIZ: Ob cit. p. 47: por su abundancia y bondad "es de los más apreciables de la Europa".

${ }^{381}$ T. MORLA (1816): Tratado de Artillería. Segovia, t. I, p. 468. Este mineral "da un hierro dúctil y propio para la construcción de fusiles y otros usos delicados, pues el hierro de las demás ferrerías (de la zona, que no lo usan) sale más o menos agrio, y solamente a propósito para clavazón, aperos de labranza, lingotes y otros usos semejantes".

382 A la contestación del testigo del juicio por la construcción de la ferrería de Quintá,de 1692 (AHRG. R.A.: 1662/4), añadimos este testimonio: en 1797 el párroco de San Esteban de la Rúa, en contestación a Tomás López, le dice un tanto hiperbólicamente: "esta (sierra) de Formigueyros es la que produce la vena de yerro tan abundante, que es capaz de surtir las herreryas de España, y me quedo corto" (B.N. ms. 7305. Diccionario Geográfico Orense Pontevedra, fol. 717r-720).

${ }^{383}$ No hay ninguna documentación que pruebe esto ni tampoco evidencias arqueológicas, que no se han hecho. La mención a un topónimo como Fornos de Céramo ha llevado a algunos a pensar en algún tipo de ferrería de monte, que utilizaría el mineral cercano de Formigueiros.

384 P. OTERO PINEYRO (2007): Colección documental del archivo de la casa de Otero de Quiroga (siglos XIII-XVIII). Lugo: Una sentencia de 1425 habla de la "forga de Vieyros", y de "setenta y sete masas da mina forga", etc.
} 
en 1513, don Antonio Velasco, señor de Cervera y comendador de la encomienda de la Barra (orden de Santiago), a quien pertenecía la jurisdicción de la tierra de Caurel, con el monte Formigueiros, lo aforó a Alonso López de Lemos, hijo de Diego Alonso de Lemos casado con Mayor de Ulloa, hermana del primer conde de Monterrey385. De ese siglo XVI datan las primeras referencias al uso de su mineral 386 .

Pese a algunos pleitos con la encomienda de la Barra387, el yacimiento siguió en manos de los descendientes del mencionado Antonio López de Lemus, señor de Layosa, y de su mujer Elvira de Novoa, señora de Maceda, como Antonio de Novoa y Lemos, “cuyas son las beneiras de Formigueiros” a quien Agustín de Iriarte, rentero de Paleiras en 1596, se obliga a pagar 36 ducados por la vena que su cuñada Graciana Galarza trajo para esa ferrería388. Su biznieto, Alonso de Lanzós y Novoa, sería el primer conde de Maceda, título concedido en 1654, y por enlaces matrimoniales posteriormente añadirían otros, entre ellos,

385 Alonso López de Lemus, cuya bisabuela Teresa López de Ulloa había tenido aforada de la encomienda de la Barra la granja de la Fervenza, solicitó al comendador Antonio de Velasco que le aforara la sierra de Formigueiros, que traía en foro Pedro de Ferbenza en 300 mrs., por la que pagaría $1.000 \mathrm{mrs}$. mientras no hiciese ferrerías y 3.000 en caso de hacerlas. El comendador le aforó la granja de Fervenza en 2.000 mrs. y asimismo a él y a otras tres personas más "la dicha tierra de Courel con sus benas y beneros y montes, robles para que podades hacer ferrería o ferrerías desde Bieyros fasta Lago y fasta Orios y fasta Sarriá y daredes vos y las dichas tres personas después de vos en cada un año a mi y a los otros comendadores (...), daredes 2.00o mrs. en cada un año vos y las dichas 3 voces que son asi 3.000 mrs. por la dicha sierra e ferrerías, pagados al dicho mayordomo de Courel por el dicho día de San Martín e que al fallecimiento de la dicha postrimera persona de las dichas 3 después de vos, quede libre e quita e desembargada la dicha sierra e ferrerías". AHPOU, Casa do Castro, caja 112, $\mathrm{n}^{\circ} 16,3^{\circ}$. Cit. Por I. GARCÍA TATO (2000): "Las ferrerías de Río Cabo y Pombriego en el siglo XIX". Rev. Bierzo (Ponferrada), p. 104.

${ }_{386}$ En 1558, en el inventario de Juan Ortiz, rendero de Soldón, se mencionan "quinientas quintales de bena por cozer junto a la ragua de dicha ferrería (...) y otros quinientos quintales de bena cocida en los Formigueiros donde se saca" (AHRG. R.A.: 19.768/32); en 1567 Beltrán de Celaya, rendero de la ferrería de Paleiras, acuerda con unos arrieros que le traigan de la venera de Formigueiros 300 quintales de vena de hierro, de 133 libras cada quintal, a precio de real y medio el quintal (AHPL. PN. : 1487); en 1573 se arrienda a Miguel Ortiz la ferrería de Ferreirós por cuatro años y 120 "quintales de fierro labrado de la bena de las beneras de Formigueros e Paradela" 386 ; en 1586 Felipe de Garbisso, rendero de la ferrería de Valcarce, se concierta con Alonso Mayo, de Molinaferrera, para que con sus recuas le traiga 200 quintales de vena de Formigueiros (AHPL. PN.: caja 2874); y que en 1588 adquiere de Marcos Castro, Andrés Alonso y Aparicio Alonso, vecinos de Molinaferrera, "seiscientos quintales de vena del venero de Formigueros y la pondrán en Vega de Brañas a precio cada quintal de a real y medio" (AHPL. PN.: 2850).

387 En 1612 se expidió una ejecutoria del Consejo Real de Órdenes a favor de don Antonio de Novoa y Lemos contra el comendador de la Barra, pues este intentaba modificar el foro alegando defectos de forma. Hubo pleito y el Real Consejo emitió una sentencia favorable el 23 de diciembre de 1611 a favor del mencionado Antonio Novoa, descendiente de Alonso López de Lemus. (I. GARCÍA TATO (2000): Ob. cit., p. 106. Posteriormente este foro fue integrado en la fundación del vínculo de Layosa, y agregado con otros mayorazgos al título de conde de Maceda. ${ }^{388}$ AHPLu:2407/9 
el de marqueses del Villar, a quienes pertenece el yacimiento en el siglo XIX. A esta familia, ferrerías y mineros pagaban cierta cantidad de dinero en concepto de foro por su usufructo ${ }^{389}$, como señalan el Catastro de Ensenada 390 , Munárriz ${ }^{391}$, o las numerosas solicitudes de foro del siglo XIX ${ }^{392}$. Según estas solicitudes, el canon anual pagado por las ferrerías en el siglo XIX se situaba entre 320 y 400 Rs., lo que por ejemplo en 1867 (Apéndice II, 3) le suponía al conde aproximadamente unos 600 escudos de renta total (7.231 rs. vn.)393.

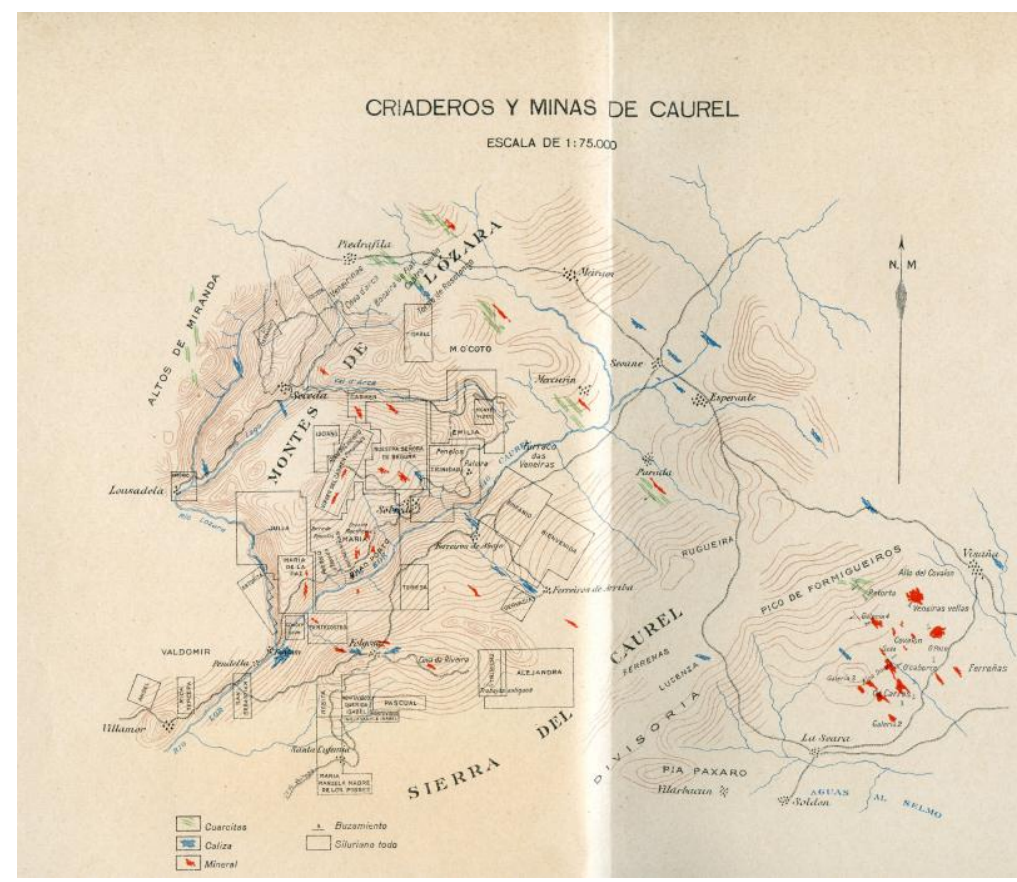

Minas de hierro del Caurel. P. HERNÁNDEZ SAMPELAYO (1935): Criaderos de hierro de España. Hierros de Galicia. Madrid.

\footnotetext{
389 AHN. Estado: leg. 1739, $\mathrm{n}^{0}$ 16: Se habla de que el señor de Noceda, dueño de la ferrería de Bueyes, debe desde 1682 a 1687 "a razon de trescientos y cincuenta reales en cada uno de dichos años, dos mil y cien reales" por el derecho de la vena. También AHRG. R. A.: 6800/4. En un pleito por abrir una zanja, dice un monje de Samos que la ferrería de la Rodela paga "cada año quatrocientos reales de vellón al conde de Mazeda por razón de la vena que consume y saca de dicha venera que la gaste o no".

390 CATASTRO DE ENSENADA. R. G.: Visuña: En 1752 "Dijeron que en esta Fra. (...) hay un mineral de yerro al sitio Formigeiros propio de Exmo. Conde de Maceda el que le rinde de utilidad en cada año, (...) tres mil setecientos y doce reales vellón, los quales le contribuyen los Dueños de las Ferrerías de este Reyno por la vena que necesitan y gastan en ellas de que según han oido tienen combenios como dicho Exmo. Conde". Este derecho que pagan, dice Antonio Núñez, maestro de carpintería en un juicio de 1756, se llamaba "de beneras que pagan y pagaban a dicho conde llos dueños de las errarias del sitio y monte de Formigueiros" (AHRG. R. A.: 190/33).

391 MUNÁRRIZ, p. 134.

392 Por ejemplo, la de la ferrería de San Vitul, en 1844, solicita al conde de Maceda un foro para la vena, pues "antes de ahora construyó una herrería de fundir y labrar hierro en términos de la expresada parroquia (de San Pedro de Villarrubín) y su varrio de San Vitul, para cuya elaboración le es indispensable del mineral de la venera del monte nombrado Formigueiros" (AHPL. P.N.: caja 3581).
}

393 I. GARCÍA TATO (2000): Ob. cit. p. 167-168. 


\subsubsection{Minas de Folgoso y Paradela}

Entre Ferreirós y Sobredo, igualmente en el Caurel, hay un paraje denominado Furaco das Veneiras en el que hay abundante mineral de hierro, y cerca de Folgoso se encuentra la Cova da Riveira en la que se aprecian trabajos antiguos. En uno de ellos parece que se extrajo en el pasado mineral para la ferrería de Ferreirós. Igualmente antes de Sobredo, sobre el arroyo de Paradela, hay afloramientos de mineral -oligisto y limonita- con restos de explotaciones de alguna importancia, pues aún es visible un hueco de más de veinticinco metros de ancho por treinta de entrada y seis de potencia394. A estas minas se refieren documentos de los siglos XVI y XVII, como explotadas ya por aquella fecha395.

\subsubsection{Criaderos de Incio: Venera de Rocas}

Enlazado con el criadero del Caurel, al norte de esta sierra, se encuentra el de Incio, cuyos yacimientos están distribuidos por las laderas y alturas de la margen izquierda del río Cabe, desde el monte Viduedo, frente a Oútara, hasta la Casela y Pena Redonda, donde ya domina la vertiente del Lor frente a los montes de Lózara. Los tres yacimientos más importantes fueron la Cova das Choyas, las labores antiguas entre Mompedroso a Monte Redondo y la venera de Roquis. Tanto en la Cova das Choyas, en la margen derecha del Cabe, cerca de la ferrería de Oútara, como en otras cuevas entre Mompedroso y Monte Redondo (Cova d' Avion, Cova de Bocón, Cova del Buey, Cova d'Ouso, galería de San Mamede, Penedo Veneiro) hay numerosas explotaciones antiguas, que dejaron de beneficiarse hacia la mitad del siglo XIX, de las que no conocemos más que restos arqueológicos y escorias 396 .

394 P. HERNÁNDEZ SAMPELAYO (1935): Ob. cit., t. III, $1^{\circ}$, p. 25

395 Así en 1573, en el arrendamiento de la ferrería de Ferreirós a Miguel Ortiz se estipula que la renta ha de pagarla en 120 "quintales de fierro labrado de la bena de la beneras de Formigueiros e Paradela" (AHRG. R.A.: 2472/120); y en 1594, cuando ante el alcalde mayor del Caurel se establecen los límites de esta jurisdicción y Sobredo, se menciona un mojón: "el qual confina con la jurisdicción de Sobredo, y hacia abaxo aguas bertientes hacia el rio, ba a dar al Pear de Azerias que está cabe el rio que corta derecho hacia la Benera de Ferreirós, que dizen de Paradela, donde ya es jurisdicción de Courel" (AHRG. R.A.: 9090/4). En 1612 en un poder de María Pérez a su marido para pleitear contra el rendero de Ferreirós, Antonio de Arechaga, se habla de la "ragua mayor de la venera de Paradela, que siendo suya se entró por fuerza a querer coger la vena en ella" (AHPLU: 2408/2).

396 P. HERNÁNDEZ SAMPELAYO (1935): Ob. Cit., t. III, fasc. $1^{\text {o }}$, p. 119 y 127 
La Venera de Rocas (Veneira de Roquis), en el ayuntamiento o concejo de Puebla (Pobla) de Brollón y feligresía de Ferreirós, se encuentra en la loma que, desde el alto de Rocas, baja al pueblo por el arroyo de la Veneira. Los trabajos antiguos se sitúan en las laderas de la margen izquierda del arroyo mencionado, desde el alto llamado del Grail (1080 metros) y van descendiendo hasta unos 900 metros en el Bocón; pero también hay labores al este del pueblo hasta llegar casi a las casas, donde se interrumpen, y prosiguen luego al oeste, aunque con menor desarrollo que en la parte alta, en la que se extrajeron de 30.000 a 40.000 toneladas de mineral. Todas las explotaciones fueron realizadas a cielo abierto y son muy irregulares, aprovechándose sólo los sitios donde era más abundante397. La mena es excelente y de varios tipos: limonita parda compacta, otra con formas butroides, negras y lustrosas, y un óxido rojo, granuloso y pesado, cuya riqueza es del $57 \% 398$.

Como dijimos se ven muchas labores antiguas, aunque muy irregulares, con canteras abiertas a cielo abierto en las que se explotó el mineral, al menos, desde el siglo XVI399; aunque nunca aparece de forma clara la propiedad de este yacimiento. Se hallaba en tierras jurisdiccionales del condado de Lemos, quizá

\footnotetext{
397 IBIDEM, p. 136-140.

398 IBIDEM

399 En 1576 Juan de Ormaçabal "se obligaba y obligó con su persona y bienes de quebrantar mill e quinientos quintales de bena (de la venera de Rocas) a Juan Beltrán de Achega rendero de Gundriz a precio cada quintal de quinze mrs. y medio que sea buena y limpia y buena para carretar en requa, los quales los despedazará en esta manera, los quinientos quintales en el doce de este mes de abril y los mil quintales de oy hasta san Miguel primero...”. Juan Ormazábal confiesa recibir por adelantado 24 ducados y 3 reales. En el juicio entablado entre ambos en 1581, un testigo afirma que "también residía con el dicho Juanes (de Ormazábal) en la dicha benera y sacaba la mena en el mismo penedo donde la sacaba el susodicho"; y que los criados y carreteros "la carretaban e la llebaban a la ferrería de Gondriz donde entonces auitaba el dicho Juan Beltrán". Añade que aquel le entregó los 1.500 quintales "aunque no lo bio pesar, por causa de que pesa en la ferrería y no en la dicha benera". Quizá no era exactamente así porque Juan Beltrán le dice que lleve a la ferrería de Ferreirós, de la que ahora es rendero, lo que falta de esos 1.500 q., y aquél se queja de que está muy lejos, por lo que le pide que use la vena de Formigueiros (AHRG. RA.: 2837/19). En 1583 Antonio de Achega contrata con un arriero de Quintanilla que le traiga 300 quintales de vena de la venera de Rocas a las ferrerías de Rial y Gondriz, en la abadía de Samos, a precio de un real y quartillo por quintal (AHPL.PN.: caja 1490); en 1585 el mismo arrendatario contrata con otro arriero del mismo lugar, al lado de Astorga, que le traiga de Rocas 150 quintales de vena al mismo precio (AHPL. P.N.: caja 2849); y en 1610 Pedro de Cegama, venaquero, dice ser vecino de la venera de Rocas (AHPLU.: 2547/3).
} 


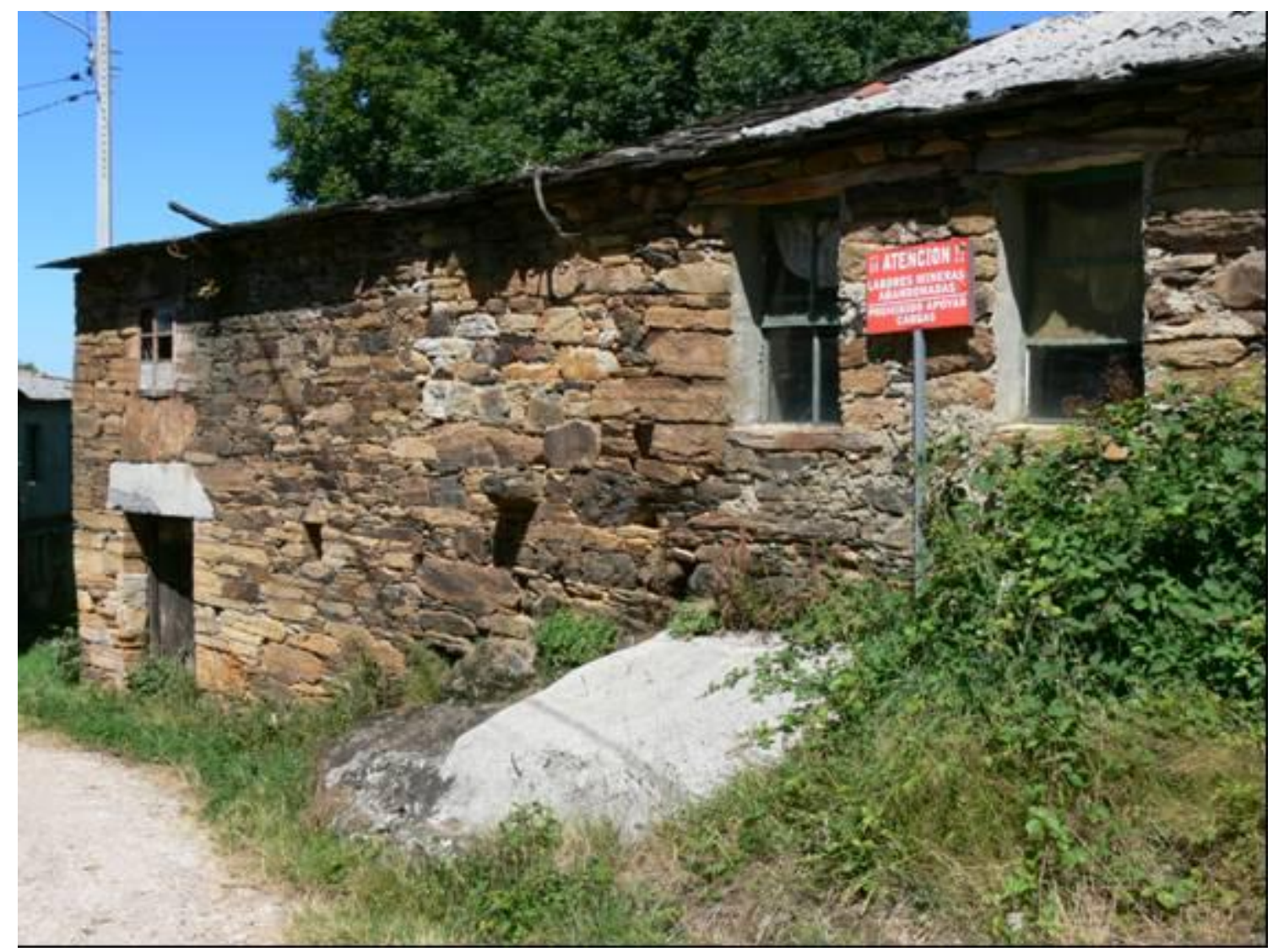

Venera de Rocas. El mineral aflora bajo las casas

por ello los condes se arrogaban derechos sobre el, aunque probablemente no todo el terreno de la venera era suyo ${ }^{400}$. En el siglo XVII parece que su explotación era libre y solo se pagaban derechos de alcabala al rey401. Aunque

400 En 1555 la Chancillería de Valladolid dictó sentencia a favor de la ferrería de Incio por un pleito contra Menendo Coque, alcalde mayor de Monforte de Lemos, quien en nombre de la condesa, doña Beatriz de Castro, tres años antes había sido denunciado en el tribunal de Santiago por el comendador de Quiroga e Incio, Gonzalo Ruiz de Medina, y el arrendatario de las ferrerías de este último lugar, Domingo de Zarauz, forero de la encomienda, por el uso de la vena. Al parecer el alcalde mayor, con hombres armados, había entrado violentamente donde extraían vena para las ferrerías de Incio, arrebatándoles animales, herramientas y vino. El comendador alegaba que esa zona de Rocas donde trabajaban estaba dentro de su jurisdicción, lo que negaba la condesa de Lemos. La sentencia de la Chancillería deja claro que no era así, pues ampara los derechos del comendador y del rendero de Incio en su derecho a explotar "las veneras de la pena de Rocas" y manda "que la condesa de Lemos ny otra persona alguna le perturbe ny moleste so pena de cinquenta mill maravedís para la cámara e fisco de su magestad por cada vez que lo hiziere" (ARCHV.: Registro de ejecutorias: caja 830,54).

${ }_{401}$ En 1633 Pedro de Armesto y Balboa, dueño de la ferrería de Incio, pleitea contra el merino de Puebla de Brollón y varios venaqueros de Rocas, pues teniendo la ferrería el derecho "de azer quebrantar y arrancar toda la bena de yerro que ay en ella para la dicha herraria arrancandolo y llevandolo y aprobechandose del (...) asta que podrá aber seis meses poco mas o menos que los dichos acusados por fuerça y contra boluntad de mi parte se an ydo a la dicha erraria y le an arrancado y llebado mucha cantidad de hierro"; pero lo más grave es que no quisieron permitirle sacar vena de Rocas, pese a que "siempre hestubieron en (...) la posesión de quebrantar arrancar llebar y traer a ella toda la bena de yerro que hera necesaria de las 
ignoramos porqué razón, parece que había propietarios que contaban con trozos del yacimiento sobre los que trabajaban o podían vender libremente402. Otros suponen, como ya hemos dicho, que era de los condes de Lemos403; pero el Catastro de Ensenada atribuye su propiedad a los vecinos, dueños de porciones en la venera404. Quizá los condes de Lemos se creían con derecho al yacimiento por poseer la jurisdicción de la zona, pero el venero debía de ser una regalía de la Corona y de uso libre para los venaqueros.

beneras de Rocas sin por razón dello pagar cosa ninguna a ninguna persona sino solamente la alcabala que se debe y paga en el partido del Yncio ... a su magestad". Un testigo dice que la ferrería además del hierro de la venera de Rocas tenía "una benera de yerro que era de la dicha ferraria en las dichas beneras de Rocas donde ninguna podía arrancar genero de bena sino solamente los dichos renderos de Yncio o con su licencia” (AHRG. R. A.: 3.070/39).

${ }^{402}$ En 1704 vemos como don Pedro Andrés Valcarce, dueño de la ferrería de Lusío, compra a Francisco Ormazábal y a su cuñado José Valcarce un penedo en la venera de Rocas, que estos tenían desde hacía 14 años, por 2.000 reales, para explotar hierro y consumirlo en su ferrería. Sin embargo, no estaban claros los límites de ese penedo, pues sobre ellos litigaban don Diego de Valcarce y Balboa, dueño de la ferrería de Loureiro, y el tal Ormazábal. Martín Díaz dijo en el juicio que el peñasco era suyo y lo había cedido a don Diego, y que el tal peñasco estaba "sito en dicho lugar de la venera de Roques, que es un peñasco de vena de hierro que se compone de trescientas brazas de ancho poco mas o menos, que se demarca por una parte con peñasco que solían llevar los vecinos de Loçarela, que oy lleua y posee Francisco Antonio de Ormazabal vecino en la misma venera", y que este "le arrancó alrededor como se reconoce", con dolo más de 14.00o quintales de vena que vendió a los renderos de las ferrerías de la zona. Ormazábal no aceptaba esos límites, pues eran más pequeños (solo 5 brazas) y tampoco que fuera el dueño, porque con el consentimiento del citado Martín Díaz ya lo trabajaba incluso su padre, Baltasar Ormazábal, que había sacado de él más de 2.000 quintales de vena (AHRG. RA.: 3176/59). En el texto se mencionan como vecinos de la venera a Francisco Díaz de Cegama y Manuel Ormazábal, sin duda vascos.

403 Eugenio Larruga, copiando un informe de 1752, señala que "esta venera la tiene aforada la señora condesa de Lemus a estas herrerías, quienes le pagan su respectivo contingente". En E. LARRUGA: Ob. Cit., XLV, p. 349

404 CATASTRO DE ENSENADA. R. G.: Ferreirós: "Dixeron que en dicha fra. y su termino no ai salinas, batanes, ni otro artefacto mas que tan solamente un mineral de fierro al sitio que llaman la Venera de Roque de la que usan y disfrutan don Caietano Valcarce y otros vecinos de la mencionada fra. De Ferreirós, a los quales regulan la utilidad que les dexa en 3.ooo rs. vn. al año". Esto parecen confirmarlo documentos como este: en 1788 don Pedro Antonio Fernández arrienda a Domingo Díaz y José Ormazábal, vecinos de la Veneira de Rocas, mancomunadamente "la porcion de vena que puedan trauajar en el espacio de un año (...) en el mineral de fierro que el otorgante tiene en dicho lugar de la venera" (cuyos límites son otras veneras de José y Juan Ormazábal) “cuyos arrendatarios han de trauajar el arranque de dicha vena por la delantera que mira al frente de las casas que dicho otorgante tiene en el dicho lugar" (AHPLU: P.N.: 2478/1). 


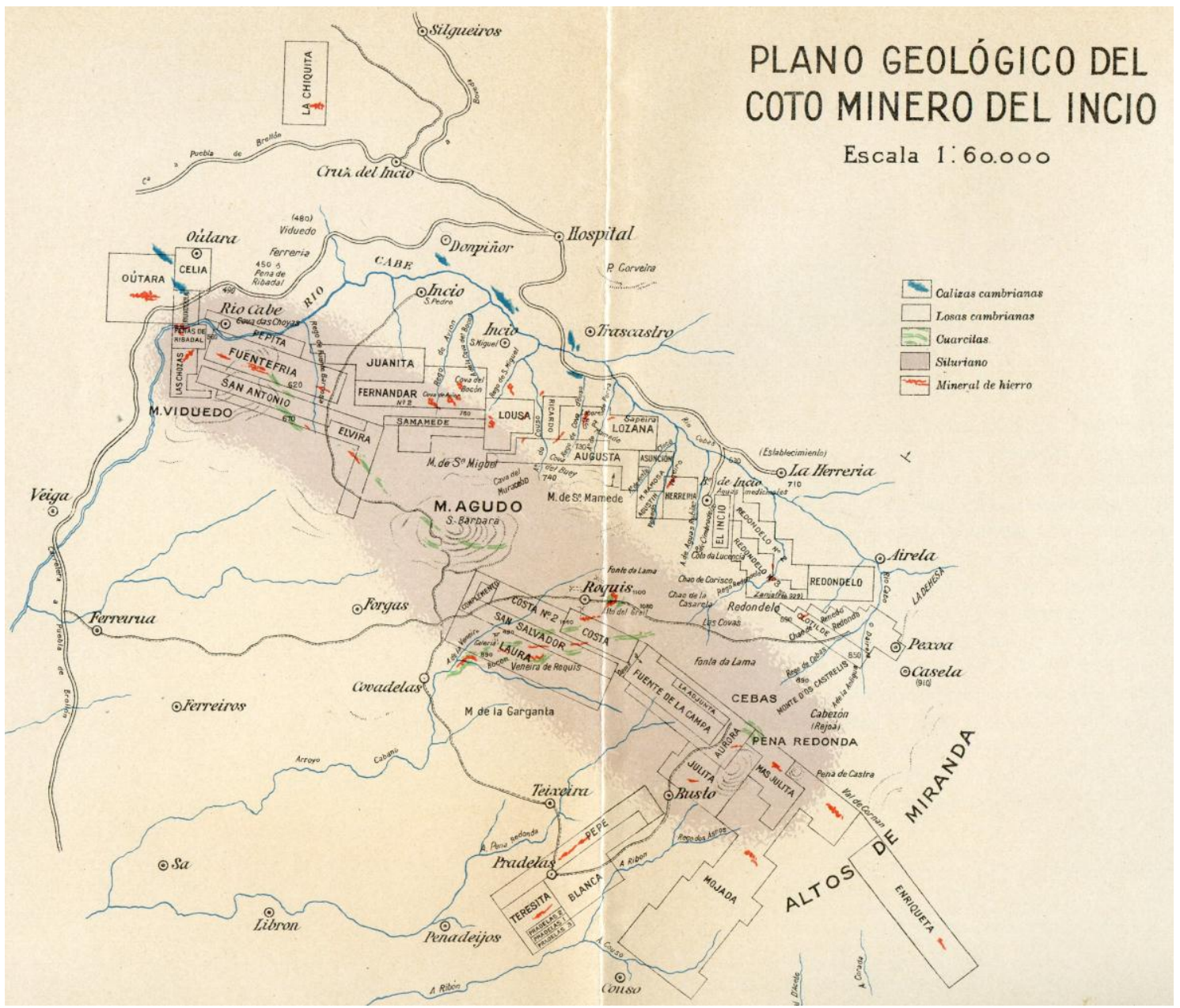

Coto minero de Incio. P. HERNÁNDEZ SAMPELAYO (1935):

Criaderos de hierro de España. Hierros de Galicia. Madrid.

Con este mineral se abastecían las ferrerías de Lor, Gondriz, Santalla, Biduedo, Incio, Lusío o Rial, Loureiro, Gónzar, Penacova y Lousadela.

\subsubsection{Minas de Loureiro}

En el mismo municipio de Puebla de Brollón, las montañas entre Domiz y Recemonde, que se extienden de NO. a SE. y enlazan con la sierra de Librán, contienen mucho hierro en parajes como los montes de Viduedo, O'Castro, Carrozo, O Bacelo, La Rodela, el monte Todrigo, entre el arroyo Loureiro y el río Lor, y Paramedela, en la ladera que desciende hasta este citado río. En todos estos lugares hay restos de escorias, socavones y galerías que delatan su explotación en tiempos antiguos. En la Rodela, en una explanada que baja al río 
Loureiro hay más de 50 toneladas de escorias, lo que demuestra la fácil reducción de estas menas, un óxido ligero y rojo de formación reciente ${ }^{405}$.

También en el monte Todrigo se trabajó una mina hasta la mitad del siglo $\mathrm{XX}$, por lo que se conservan aún algunas bocas de mina, galerías y respiraderos, descubiertas casualmente en 2009 cuando se limpiaba el bosque, situadas a escasa distancia unas de otras. Tres de ellas están en la margen izquierda del río Loureiro -a diferentes alturas de la ladera- y la cuarta en la margen derecha. La mina de Todrigo se explotó en el siglo XIX para abastecer de mineral de hierro a la ferrería de Loureiro, que además usaba desde el siglo XVI el de Rocas. El transporte del mineral se hacía a lomos de mulos por un sendero que une la mina con la ferrería y por el que difícilmente podrían circular los carros debido a lo empinado del terreno406.

\subsubsection{Minas de Freijo}

No muy lejos de aquí, a seis kilómetros al sur de Monforte de Lemos, se encuentran las minas de Freijo, de minerales magnéticos, compactos y muy cloritosos, pero también con abundante hematites roja. Las capas de mineral son delgadas, de 0,40 a 2,5 metros y unos 2.000 metros de largo por 300 ó 400 de ancho. Hay escorias en muchos lugares: en las labores antiguas del Sur, en las galerías altas de Ferreira, en Marcelle, y particularmente abundantes cerca de Freijo, camino de Neiras 407.

En el siglo XV se menciona una mina de hierro cerca de Monforte, que posiblemente sea esta de O Freixo, con cuyo mineral, propiedad del conde de Lemos, se hacían armas y que, según un documento del archivo municipal de Monforte, guardaban hombres armados: "los guardias de Freixo". La mina también se explotó en el siglo XX, entre 1913 y 1958 por una empresa alemana dirigida por el ingeniero Federico Guillermo Cloos408.

\footnotetext{
405 P. HERNÁNDEZ SAMPELAYO (1935): Ob. cit., t. III, 1o, p. 6-7

406 La Voz de Galicia, 19-2-2009

407 P. HERNÁNDEZ SAMPELAYO (1935): Ob. Cit. T. III, fasc. $2^{\circ}$, p. 473, 477, 480 y 483.

408 www.jrcasau.com/monforte/freixo.minas.htm
} 


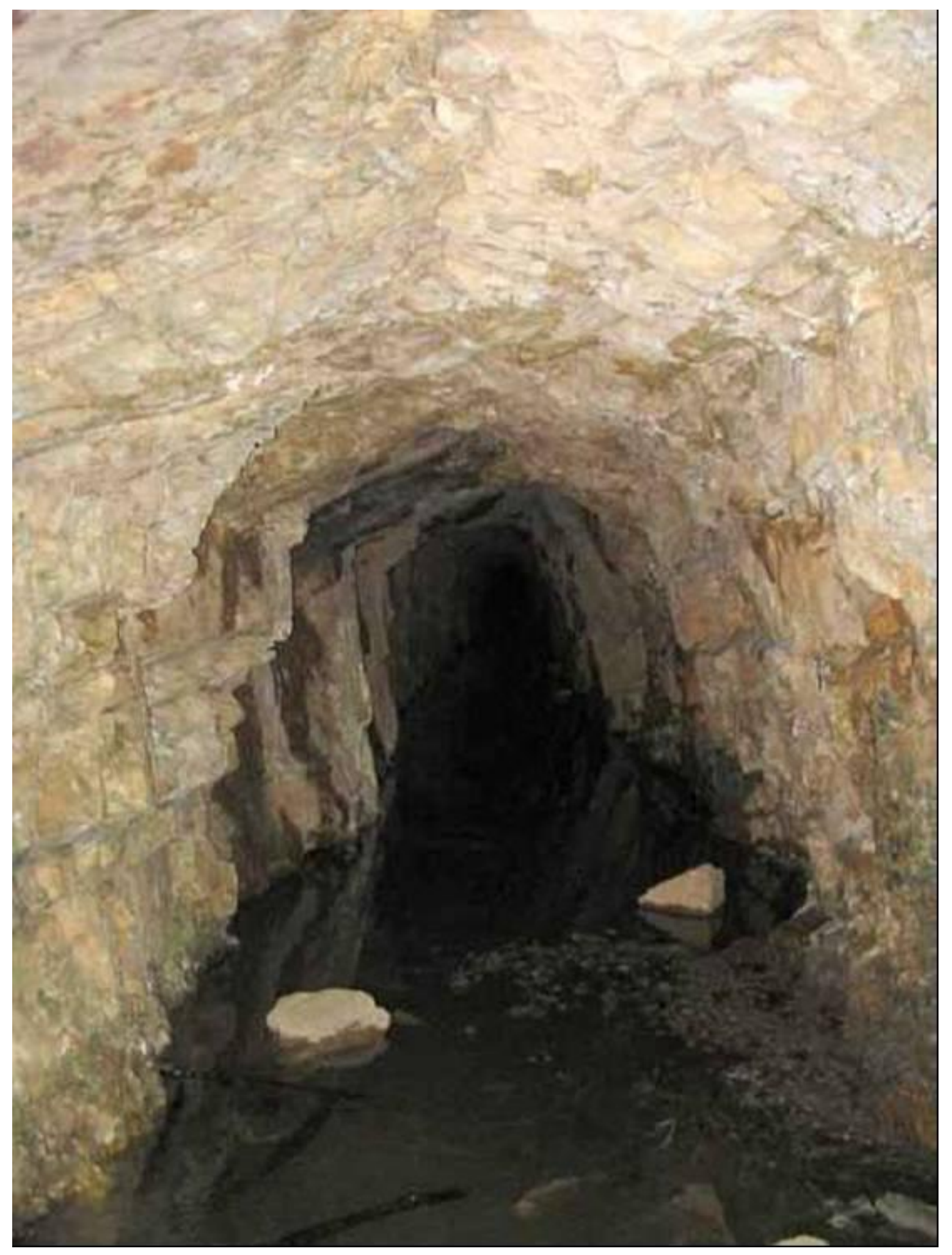

Mina de Freixo (Monforte de Lemos) 


\subsubsection{Minas de Lousadela y Piedrafita.}

Estas minas se hallaban entre Portomarín y Monterroso409. Muy cerca se encontraba también la mina de hierro de Eirige, en Monterroso, que el dueño de la ferrería de Ombreiro solicitó explotar en $1834^{410}$. Al lado de Pallares estaba la vena de Villajuste, en la parroquia de San Pedro (Portomarín), usado en la ferrería de este nombre ${ }^{411}$. Cuando se vende esta ferrería, en la desamortización del trienio liberal, se incluye igualmente esta venera 412.

\subsubsection{Criaderos de Fonsagrada.}

En el occidente de Lugo, entre Cervantes y Fonsagrada se explotaron algunas pequeñas vetas de hierro. En Paderne y Cova d `a Mora, cerca de Doiras, hay excavaciones antiguas e irregulares sobre los afloramientos de una capa de óxidos rojo y pardo, con una potencia desde medio hasta cuatro metros, que está extendida por una longitud de unos 200 metros, y que el mineral arrancado se aprovechó en la ferrería del Mazo413. Probablemente a esta mina se refiera una noticia de 1628414; pero seguramente con más certeza es el yacimiento del que habla un informe de 1752, que cita Larruga415. Muy cerca debía de estar la mina

409 Schulz en 1838 señala que en Galicia, junto con los yacimientos de Formigueiros y Rocas, "hay además las veneras de Lousadela y Piedrafita, de donde se surten las herrerías de Pallares y Ombreiro, cerca de la ciudad de Lugo, que consumen al año sobre seis mil quintales, empleando en su arranque quince obreros". En G. SCHULZ (1938): "Ojeada sobre el estado actual de la minería en el distrito de Asturias y Galicia”. Anales de Minas, t. I, p. 390; y Madoz confirma que la ferrería de Ombreiro utiliza mineral de Lousadela y Piedrafita (MADOZ: Ob. cit. t. IX, p. 217).

410 BOP de Lugo, $\mathrm{n}^{\circ} 25$ de 27 de julio de 1834: "D. Guillermo Schulz (...) hago saber: Que Don Buenaventura Miguel Plá, natural de la villa del Ferrol, vecino y del comercio de Lugo, y propietario de la herrería de Ombreiro, se me presentó instancia haciendo denuncio de una mina de hierro sita en términos del lugar de Eirige, parroquia de Santa María de Marzan, jurisdicción de Taboada, cuya mina fue esplotada en algún tiempo por cuenta de $\mathrm{D}^{\mathrm{a}}$ Jacoba Páramo, vecina de Santiago, quien la abandonó muchos años hace; por lo que el denunciante pide permiso para explotarla y solicita su posesión legal”, que le concede de acuerdo con la ley de Minas de 1825.

${ }^{411}$ AHRG. R. A.: 1687/29. El administrador de la ferrería de Pallares, fr. Gregorio Sarmiento, contesta en 1814 a los vecinos de Villajuste, que protestan por el uso de la vena en la ferrería: “¿De que forma se esterilizan los montes con el arranque de la bena? Claro está que esta se compone de unos duros peñascos situados en terrenos que en lo que alcanzan aquellos no producen leña ni pasto".

${ }^{412}$ C. GONZÁLEZ (1994): Ob. cit., p. 39.

413 P. HERNÁNDEZ SAMPELAYO (1931): Ob. Cit., t. II, p. 460

414 Cit. por CANGA ARGUELLES (1834): Diccionario de hacienda. Madrid.

415 E. LARRUGA (1794): Ob. cit., t. XLV, p. 337 y 338 (hablando del proyecto para la construcción de la ferrería de Neira de Rey): "Se pudo averiguar que en un monte público, a distancia poco más de tres quartos de legua, se descubrió un mineral de vena, al que tuvo noticia 
de Cancelada, que pertenecía a la condesa de Amarante416. También en Vilares, al lado de San Martín en Neira de Rey, se menciona una mina en 1836417.

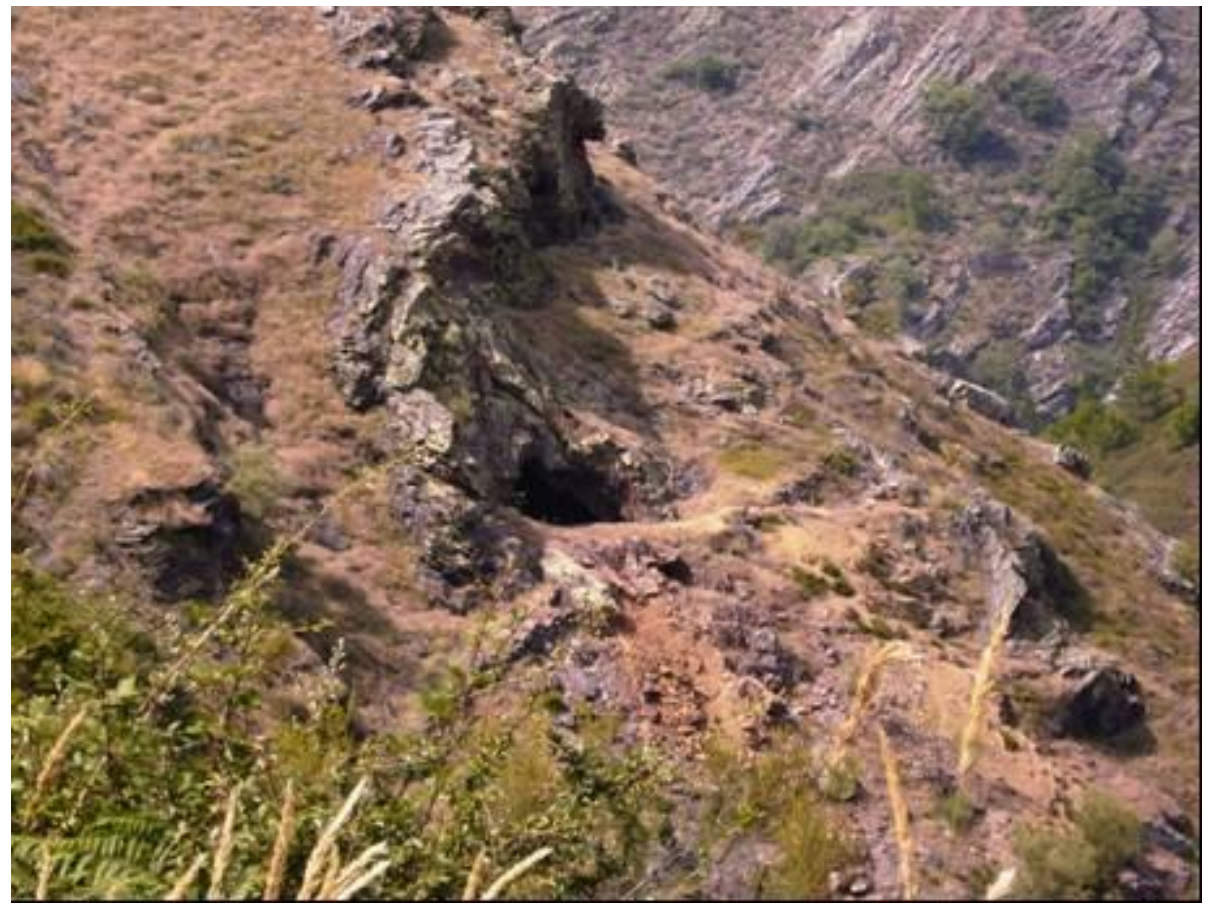

Mina de hierro cerca de Vilar de Cuiña (Lugo)

Cerca de Fonsagrada se encuentra la mina de Monteseiro, de la que hay varias noticias de su uso en la ferrería de Cuiña418. Probablemente muy cerca

don Josef (de Quiroga), y sacó algunas piedras con secreto; pero no tanto que dexase de saberse, de que hizo prueba en la herrería de Lincio (sic) tan a su gusto, que le dio motivo a emprender la nueva fábrica, sin que se descubriera otra en sitio común ni particular más de la que se sirve el señor de Noceda para su herrería (la de Bueyes), y dista del valle de Neyra más de dos leguas. El descubrimiento del mineral, de que parece quiere usar don Josef, se debe a don Josef Pardo de Rivas, quien no ha mucho tiempo pretendió fabricar otra ferrería en las Puentes de Gatín, y se la denunció el señor de Noceda, por los perjuicios que representó seguirsele, y no tuvo efecto".

${ }^{416}$ AHPLU: 6709/14. En 1755 los vecinos de Córneas (Doncos) se oponen a la construcción de la ferrería de Neira de Rey a causa del combustible. En el texto dicen que "el mineral que quiere utilizar (don José Quiroga) es el de la jurisdicción de Cancelada, de la condesa de Amaranta”. 417 BOP de Lugo, $\mathrm{n}^{\circ} 33$ de 24 de abril de 1836: "Don Guillermo Schulz (...) hago saber que por D. Juan María Quiroga, señor de las casas de Orbán, Basille y otras de Galicia, vecino de la ciudad de Lugo, se ha pedido la concesión legal de una mina de hierro descubierta por el mismo, y sita á orillas del arroyo Vilares inmediato al lugar de este nombre, en términos de San Martín del valle de de Neira de Rey, en esta provincia de Lugo".

${ }^{418}$ AHPLU. P.N.: 1501/2 (1794): En 1795 se dice que "en la casa de la Eraria titulada el buen retiro de la Cuiña conzejo de Burón", don Andrés Valdés y más vecinos del lugar de San Bartolomé de Monteseiro, de una parte, y de la otra don Diego Munilla, dijeron "que en el precitado lugar y feligresía de Monteseiro existen algunos minerales que lo regular es, sea su qualidad yerro, el qual como neczesario para Esta Erraria, y sauedor de ello D. Diego y más por quien haze, determinaron contratar en el particular con los otorgantes sobre su aprovechamiento". Acuerdan "que todos los precitados minerales de yerro u otro qualquiera mineral que produzcan los términos del dicho lugar y parroquia y sean nezesarios a la Erraria, ha de ser bisto aprobecharse esta de ellos a su arbitrio y boluntad". A cambio don 
estaba el yacimiento de Formigueiro, en Sena (concejo de Ibias), cuyos vecinos acuerdan en 1800 con los apoderados de la Compañía de la Vega de Ribadeo, que explotaba la ferrería de Cuiña, para que puedan aprovechar la mina que en aquel lugar había descubierto el director de la Compañía don Antonio González Viejo. A cambio de poder explotar la mina, los vecinos de Sena recibirían en concepto de montazgo 400 reales en dinero y 200 libras de hierro, además de valerse de operarios de dicho pueblo para la extracción de la vena con preferencia a otros419. También en Cervantes, el mineral de Poso, el Corozo y el Vieiro, se arrancó bastante, y se benefició hacia 1835-1840 en la ferrería de Murias de Rao y en una fábrica de potes que hubo próxima420.

\subsubsection{Veneras de Lorenzana}

El monasterio de Lorenzana era propietario de las veneras de su jurisdicción 421 , aunque su explotación corría a cargo de los vecinos. Conocemos varios contratos de saca de vena tanto para esta ferrería como para la de Vilaseca. Por ejemplo en 1609 varios vecinos de Ferreiravella se obligan a extraer para la ferrería del monasterio 1.774 quintales de vena por el precio de 630 reales $^{422}$. En 1639 Bastián García, Pedro de Ron y otros, vecinos de Santa María la Mayor (Mondoñedo) se obligan a sacar para el monasterio igualmente 1.000 quintales de vena limpia (quizá raguada) que han de llevar a la ferrería del monasterio 423 .

$\mathrm{Al}$ oeste de Lorenzana, cerca del río Torto y de los lugares de Ferreiravella y Ferreira, se menciona un yacimiento ferrífero, denominado de Ríotorto y

Diego Munilla y sucesores de la Compañía pagarán cada año, mientras exista la ferrería, 440 reales.

419 J. LÓPEZ y A. GRAÑA ((1998): Ferrerías, mazos y fraguas en Asturias. Servicio de Publicaciones del Principado de Asturias, p. 15, nota 2 420 P. HERNÁNDEZ SAMPELAYO (1931): Ob. Cit., t. II, p. 489 y 490.

421 AHRG. Monasterios, 54/67: Dicen los monjes que son de ellos "todas las beneras que estaban dentro de su jurisdición", por lo que según el procurador del mismo en 1628, "ninguna persona, asi de los basallos de la jurisdición como en lo que no lo son, pueda entrar a abrir ninguna de las dichas beneras, sino es con licencia de mi parte y pagándole el quinto de toda la bena que sacare. Cfr. P. SAAVEDRA (1985): Economía, política, y sociedad en Galicia: la provincia de Mondoñedo, 1480-1830. Santiago.p. 329-330

${ }_{422}$ AHM. García de Cordido (1609), ff. 43. Cf. P. SAAVEDRA (1985): Ob. cit., p. 330, nota 89.

${ }_{423}$ Estos vecinos han de sacar "mil quintales de bena limpia y bien acondicionada para hacer dicho metal de yerro en la herrería de esta villa que es suya de dicho convento, los quales dichos mil quintales de bena darán puesta y sacada en las bocas de las Benas de dicho monasterio en su jurisdicción y territorio". Cfr. C. GONZÁLEZ (1994): Ob. cit. p. 174. 
Aguaxosa, en el que a lo largo de un kilómetro se veían grandes trabajos antiguos, en su mayoría a cielo abierto. El mineral que se extrajo debió beneficiarse en Ferreira y Ferreiravella, dos pueblecitos a orillas del Torto, en donde hubo forjas catalanas, sostenidas por el abundante carbón vegetal de la zona424.

Estas veneras del Valle del Oro son probablemente las mismas que las que posteriormente se conocieron como yacimientos de San Martín de Mondoñedo, de hematites y limonita, que se explotaron hacia la mitad del siglo XIX en Sargadelos; pues entre ellas hay labores visibles más antiguas, por ejemplo en Cano dos Mouros, donde existe una galería de unos 50 metros; también cerca de Mondoñedo, en el barrio de Reiriz, hay señales de antiguas labores y abundante chirla menuda de limonita con granos de magnetita como núcleo. Sin embargo, la mayor explotación debió de estar en los poblados de Balsa y Ferreiravella425.

\subsubsection{Yacimientos costeros}

Cerca de la costa lucense, entre Ribadeo y San Miguel de Reinante se hallan varios yacimientos de hierro que fueron explotados por alguna ferrería y, posteriormente, por los altos hornos de Sargadelos. Uno fue el del monte Mondigo, cerca del pueblo de Noceda, uno de cuyos lugares de explotación se conoce por Forjas, cerca del molino de Recouco, donde según Sampelayo debió haber una ferrería por los años 30 del siglo XIX. Los minerales del monte Mondigo se consumieron en la primera época de Sargadelos, pero debieron agotarse pronto 426 .

La mina de San Miguel de Reinante, compuesta de hematites parda, estaba cerca de Ribadeo. Al parecer, en octubre de 1796 don Raimundo Ibáñez contrató con los vascos, naturales de Somorrostro, Antonio de Berganza, Francisco de Larrea, Ramón de Larrea y Ramón Gil, residentes en San Miguel de Reinante, la explotación y arranque de vena, a la manera como lo habían hecho hasta entonces, a jornal, en el yacimiento de San Miguel de Reinante, poniendo

424 P. HERNÁNDEZ SAMPELAYO (1931): Ob. Cit., t. II, p. 295

425 IBIDEM, p. 20-26.

426 P. HERNÁNDEZ SAMPELAYO (1931): Ob. Cit., t. II, p. 33. 
peones, por tiempo de seis meses y bajo ciertas condiciones: explotar la mina metódicamente, dejando testeros para que las galerías o cuevas no se vinieran abajo, ya que si se arruinaran sería por su cuenta ponerlas otra vez limpias y corrientes; también sería por su cuenta extraer y conducir fuera de las veneras no sólo el mineral sino la piedra, tierra y escombro; que la vena limpia la pagaría por cada quintal macho de 155 libras castellanas a un real de vellón; y que para pagar a los operarios se les adelantaban al mes 1.000 rs. vn. ${ }^{427}$. Se siguió explotando en el siglo XIX, pues sabemos que en la campaña 1827-28 se arrancaron en ella 12.408 quintales gallegos ${ }^{428}$.

También cerca de Foz se descubren labores antiguas, y según testimonios recogidos por Hernández Sampelayo hacia los años 1820 a 1838 se fletaban veleros cargados de mineral con rumbo a la fábrica de Sargadelos, aunque su historia duró poco por la escasez de este criadero429. Y lo mismo podríamos decir de algunos pequeños yacimientos superficiales en las cercanías de Vivero, Galdo y Muras, que probablemente fueron explotados y beneficiados en las ferrerías de Bravos y Muras, ya que en sus inmediaciones hay abundantes escorias ${ }^{430}$.

\subsection{Yacimientos orensanos}

En Orense se mencionan varios yacimientos de hierro en la Rúa, Fontei, Robledo, Montefurado, Pardellán, Los Peares; pero no tengo referencias a que hubieran sido explotados en la Edad Moderna, aunque sí en el siglo XIX, por ejemplo la mina "San Benito" en La Rúa, de la que en diversos años se extrajeron algunos miles de quintales de mineral que fue trabajado en ferrerías de la provincia431. Quizá también la ferrería de Mondón utilizó vena local, ya que en sus inmediaciones se construyó a finales del siglo XIX un balneario de aguas ferruginosas, signo de que en la zona debía haber veneras de hierro.

\footnotetext{
427 Ct. Por P. HERNÁNDEZ SAMPELAYO (1935): Ob. Cit., p. 43 y 44.

428 IBIDEM, p. 41

429 IBIDEM, p. 17-19

430 IBIDEM, p. 214, 233 у 243.

${ }^{431}$ IBIDEM, p. 581-582
} 


\subsection{Yacimientos Leoneses}

En León conocemos la existencia de escorias de hierro ya en época romana, pero las primeras referencias documentales a este mineral datan de los siglos XII y XIII, especialmente en la zona de Astorga y el Bierzo432. Pero en la Edad Media el ámbito minero provincial fue más amplio, pues se citan minas cerca de Boñar y en los alrededores de León433, lo que no ocurrirá en la Edad Moderna en la que solo hay referencias a explotaciones en el Bierzo, como ahora veremos.

\subsubsection{Yacimientos del arco interno}

En el Bierzo existen dos grandes zonas con mineralizaciones de hierro, que atraviesan la comarca de este a oeste: una por el sur y otra por el norte. La primera es continuación de la que anteriormente hemos llamado arco interno, y lo constituyen numerosos filones de óxido de hierro, entre las pizarras y cuarcitas del Silúrico, desde la zona de Gestoso hasta Molinaferrera. La potencia de estas capas es, en general, pequeña, de 0,5 a 2 metros. En el pasado sólo se explotaron con una cierta intensidad tres yacimientos:

\subsubsection{Los hierros de Gestoso}

En las cercanías del yacimiento de Formigueiros se encuentran los denominados "hierros de Gestoso", nombre de un lugar y de un arroyo que, en las inmediaciones de la ferrería de Arnado, desemboca en el Selmo. El término

432 En 1146 Alfonso VII dona a la iglesia de Astorga "illam venariam ferri, que es juxta Biminetam, quam dicunt Pratum Regis"; es decir una mina de hierro entre Brimeda y Prado Rey, en los límites entre el Bierzo y Astorga, en lo que hoy es el coto San Bernardo (AHN. Códices, $\mathrm{n}^{\circ}$ 970). No muy lejos de allí, en Molinaseca, en el año 1210 se menciona una "massam de ferro" que Miguel Peláez y su esposa deben pagar cada año al arcediano Gonzalo Fernández, a cambio del hospital de Molinaseca. En P. LOSCERTALES (1976): Tumbos del monasterio de Sobrado. Madrid, t. II, p.220. También en el Bierzo, donde luego se explotará la mina de La Chana, en 1227, Ordoño Pérez y su esposa donan al monasterio de Carracedo "nostram partem hereditatis ferri de Ysorga"(ADA: C.C., ff. 433v).

433 En las cercanías de Boñar, en 1225 el rey Alfonso IX cede al monasterio asturiano de Valdediós el "venarium de ferrum de Busnovo", el actual Voznuevo, mina que probablemente abastecía a las ferrerías de Corniero; y en los alrededores de León, Enrique II concede en 1369 al cabildo de su iglesia "las ferrerías e venas de fierro e de asero que se descobrieron en termino de Villamoros, çerca de León". Cf. C. ALVAREZ (1996): "El hierro en el medievo leonés". Actas de las I jornadas sobre minería y tecnología en la Edad Media peninsular. León, p. 349-362. 
de Gestoso ocupa el límite Noroeste de la provincia de León, rayando con las de Lugo y Orense, y en la divisoria que establecen la Sierra de Encina de la Lastra y la Sierra de los Caballos (Serra dos Cabalos), que separan la cuenca del Selmo de la de los ríos Sil y Quiroga.

Esta zona es rica en afloramientos de hierro, por lo general hematites parda, algo fosforosa. Se conoce un filón de hierro magnético correspondiente a la capa de Gestoso, que tiene una longitud de kilómetro y medio desde el arroyo de Valdeloya hasta cerca del puente de Valmayor, con una potencia de ocho metros434. A comienzos del siglo XX el ingeniero José Revilla hablaba de la bondad de estos hierros y como demostración de la misma señalaba "la existencia de unas 14 ferrerías al carbón vegetal, que vivían holgadamente antes de que los hornos altos monopolizaran la industria" 435 , aunque la mayoría no se abastecía de este hierro sino del de Formigueiros.

El yacimiento de Gestoso creemos que puede relacionarse con el que los documentos del siglo XVII denominan "veneras de Valdecaballos", que surtían de hierro a las ferrerías de Arnado y Ponte Petre; como se infiere del contrato que en 1.666 hace don Lucas de Acevedo, arrendatario de la ferrería de Ponte Petre, con dos vecinos de Gestoso por el que éstos se comprometen a que le traerán cocida vena de las veneras de Valdecaballos 436 .

\subsubsection{Mina de la Chana}

La mina de la Chana se sitúa en el actual coto de San Genadio, que se extiende por los términos de Lucillo, Bouzas, Peñalba, San Pedro de Montes, Ferradillo, Paradela, La Chana y Lago de Carucedo. Ocupa este coto una extensión de 500 hectáreas, con una potencia en sus capas de cuatro a seis metros. El mineral es hematites de una notable riqueza, que a principios del

\footnotetext{
434 J. REVILLA (1906): Riqueza minera de la provincia de León. León, p. 25 435 IBIDEM, p. 24.

${ }^{436}$ AHPL. P.N.: 2936: Traerán, en el año 1666, "ciento y cinquenta cargas de bena de las beneras de Baldecaballos para el consumo de la ferraria"; y en 1668 el arrendatario de la ferrería firma con Antonio Cereijo para que le traiga "tres cargas de vena cruda de dar y tomar quebradas en las beneras de Valdecaballos" (AHPL. P.N.: 2936).
} 
siglo XX se calculaba en unos 19 millones de toneladas437. La mina o venera de Chana se encontraba en el término de dicho lugar, en la jurisdicción de Borrenes, hacia el SO. del pueblo, en una zona de calizas en las que el río Isorga ha abierto un estrecho, recoleto y ameno valle. El mineral, un óxido ferrosoférrico, se halla formando bolsadas sobre una extensión de unas 80 hectáreas, en las que se advierten numerosos vestigios de labores antiguas.

Estas labores tienen orígenes muy remotos, pues probablemente la mina fue beneficiada en época romana, en relación con las explotaciones auríferas de las Médulas, que están en sus inmediaciones 438 . En época medieval está plenamente confirmada su explotación en la documentación del monasterio de Carracedo desde los inicios del siglo XIII 439. La mina esta en la zona del Vieiro440 al lado del arroyo Isurga, donde probablemente hubo una ferrería por esa época ${ }^{441}$. Posiblemente, dado que no existe ninguna ferrería en la zona hasta el siglo XVIII, la mina fue abandonada. En ese siglo, el monasterio de San Pedro de Montes adquiere, de la familia Andrade de Ponferrada, una cédula que estos poseían para explotar esa y otras minas del Bierzo ${ }^{442}$.

437 J. REVILLA (1906): Ob. Cit., p. 21-22.

${ }^{438}$ T. MAÑANES (1981): El Bierzo prerromano y romano. León, p. 396.

439 ADA: C. C., ff. 433v: En 1227 Ordoño Pérez (Ordonius Petri) y su esposa donan a dicho monasterio "nostram partem hereditatis ferri de Ysorga". El copista del siglo XVIII, para evitar confusiones, aclara al margen de la escritura "Chana Ysorga".

440 Probablemente derivado de veneiro, de vena.

441ADA: C. C., ff. 434: Un documento de 1245 por el que el abad de Carracedo afora las propiedades que tiene en la Chana aclara que de dicho foro retiene para el monasterio todo lo necesario para elaborar hierro: "et hoc vendimus preter terminum in quo invenitur vena ad faciendum ferrum, quem terminum retenimus nobis liberum ad extraendam venam, et faciendam inde ferram, et molineras possimus facere in rivo Yssorga".

${ }_{442}$ Del abad don Manuel Amigo (1737-1741), dice el P. Herrezuelo que "terminó el pleyto sobre la mina de hierro, comprando a los Andrade en treinta y dos mil reales la Zédula Real para el aprovechamiento de las de Chana y demás del Vierzo". Cf. en P. HERREZUELO: Historia de San Pedro de Montes. Manuscrito en ADA, ff. 319. 


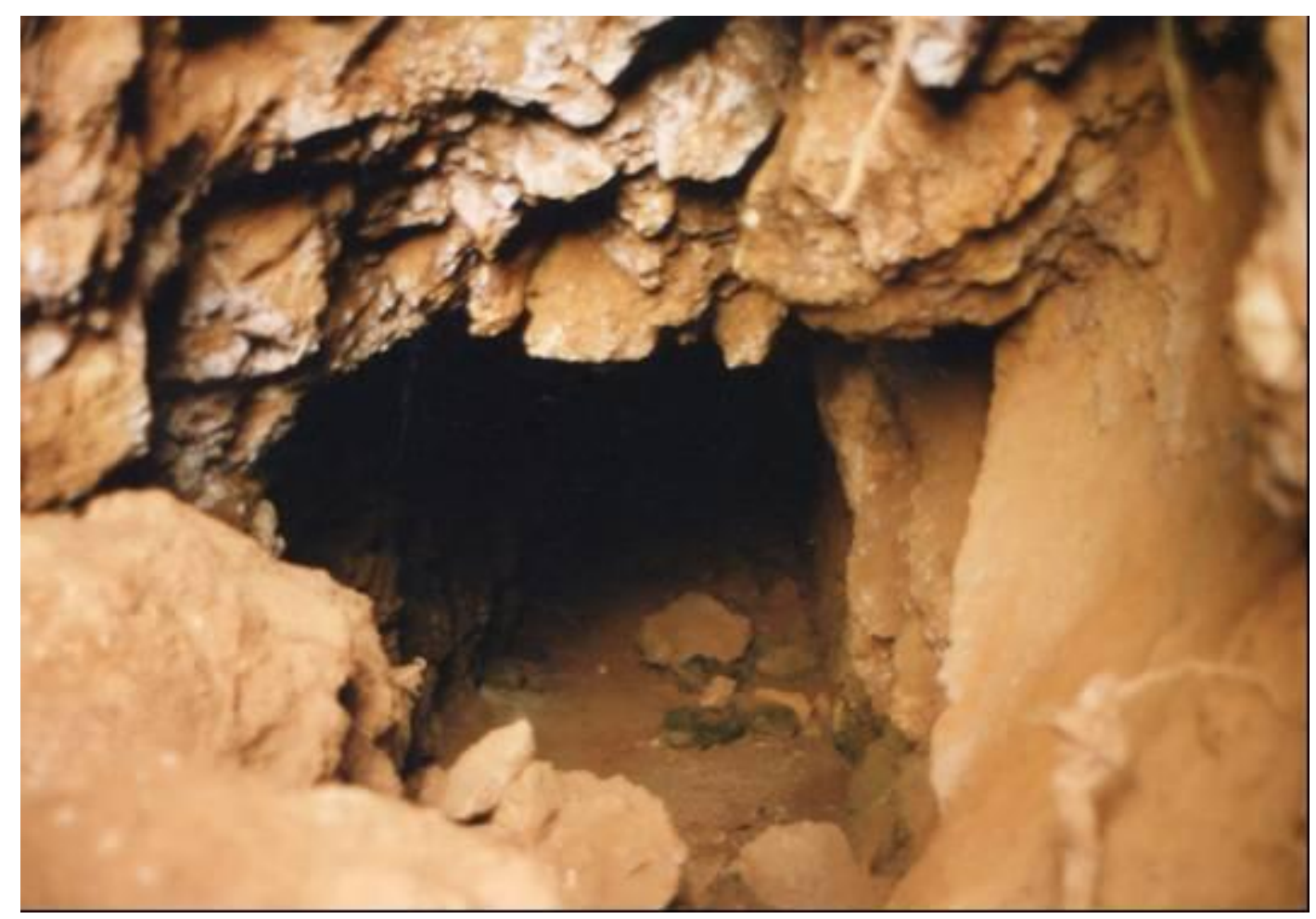

Mina de La Chana de Borrenes (León)

En manos del monasterio, la mina abasteció sus ferrerías de Linares y Pombriego hasta la exclaustración. Según Munárriz, hacia 1805, esta era la única mina de hierro que se beneficia en terreno propio de los monjes Benedictinos de Montes, y del que se abastecían las mencionadas ferrerías443. Tras la exclaustración pasó a manos privadas, que la explotaron en diferentes lugares con los nombres de Mina Casualidad, Misteriosa, Será Suerte y la Rescatada; algunas de las cuales pertenecían a la familia Quiñones de Ponferrada444. Además de aquellas dos ferrerías445, en el XIX suministró vena a las ferrerías de Compludo, Llamas y Riodolas 446 .

443 MUNÁRRIZ: Ob. Cit., p. 118: Dice que "Este mineral es el que los mineralogistas llaman hierro rojo compacto, mezclado con algo de hierro negro y especular, y tiene por ganga la piedra caliza granujienta".

444 J.M. SOLER (1883): Reseña geológico-minera y catálogo de minerales, rocas, etc. en la provincia de León. Madrid, p. 8 y 35

445 MADOZ: Ob. Cit., p. 104.

446 Respecto de Riodolas y Llamas (REVISTA MINERA, t. XVI, 1865, p. 113). Un documento de 1891 afirma que "la mena de que se surte esta forja (de Pombriego) viene de la Chana, que dista tres leguas, rinde un 33\% por la mucha arcilla que contiene, y se paga á boca-mina á 1,09 pesetas el quintal métrico, el cual, por el transporte á la fábrica, cuesta 1,63 pesetas ( ESTADÍSTICA MINERA. Año 1891. Provincia de León, p. 193). 
En el mismo coto, cerca de la localidad de Peñalba de Santiago, hubo otra mina, la de Cantagallo que también se explotó en las ferrerías de Montes y Compludo447.

\subsubsection{Mina de Pombriego}

La ferrería de Pombriego, construida por los monjes de Montes en el siglo XVIII, beneficiaba mineral de la Chana y del que se encontraba en sus alrededores. Soler habla de la existencia de dos minas en Pombriego, "Perseverancia" y "Pedrita", de hierro peroxidado manganesífero, con una potencia de 0,75 a 1'5 metros de espesor, aunque añade que no había más labores que una zanja de 20 metros de longitud. "La mena, dice, se beneficia en la forja de Pombriego" 448. Posiblemente también en la de Llamas que, construida hacia 1859, se encuentra en sus inmediaciones.

\subsubsection{Yacimientos del arco externo}

Este segundo yacimiento es de una gran extensión, y se le considera el más abundante en hierro de toda Europa. Sus reservas se estiman en más de 370 millones de toneladas sólo en los cotos Wagner y Vivaldi. Se integra en los denominados criaderos llamados de Maragatería-Bierzo-Cervantes, los cuales constituyen una alineación de capas de mineral de hierro que, desde Astorga, se extienden hasta Fonsagrada, en un arco de 117 kilómetros de longitud. Dicho arco está subdividido en varios subsectores, correspondiendo a la zona del Bierzo los cotos Wagner, Vivaldi y San José.

Los minerales de este criadero pueden clasificarse, en líneas generales, como óxidos ferroso-férricos y férricos carbonatados (magnetitas, sideritas y cloritas), con un contenido en hierro entre el 46\% y 57\%; aunque su contenido en fósforo, sobre el o'8\%, ha sido, junto a otras razones de orden estructural, uno de los factores que han imposibilitado su explotación en época 
preindustrial. Solo de manera marginal sabemos que se trabajaron algunas minas.

\subsubsection{Mina de Paradasolana}

Las minas de Paradasolana comprenden una superficie de unas 160 hectáreas, entre Castropodame y Molinaseca. El mineral, entre pizarras arcillosas, es un óxido de hierro manganesífero, hierro peroxidado rojo y hierro acerado mezclado de arcilla y pizarra. Según Soler producía un hierro excelente, trabajado en la ferrería de Montes449.

A una mina de este extenso yacimiento debe referirse una escritura del monasterio de Sobrado de los Monjes, sito en la provincia de la Coruña, y propietario de numerosos bienes en la zona de Molinaseca, del año 1210, en la que se menciona una "massam de ferro" que Miguel Peláez y su esposa deben pagar cada año al arcediano Gonzalo Fernández, a cambio del hospital de Molinaseca450. Posiblemente a este mismo yacimiento pertenezca la "Mina de Molinaseca” de 1605, que aparece en la Relación de minas de Tomás Gonzalez ${ }^{451}$. El mineral de Paradasolana se usó en las ferrerías que construyó Carlos Lemaur a mediados del siglo XVIII en la zona de Torre del Bierzo452, aunque algunos creen que este mineral no reunía buenas condiciones para la forja453. Esa era la opinión de Datoli y Munárriz, aunque Soler en 1883 dice que era excelente y que se trabajaba "en forjas a la catalana en las ferrerías de Montes, Pombriego, Compludo y Llamas”454.

\footnotetext{
449 J. M. SOLER (1883): Ob. Cit., p. 9

450 P. LOSCERTALES (1976): Tumbos del monasterio de Sobrado. Madrid, t. II, p.220

${ }^{451}$ J. CANGA ARGÜELLES (1833): Diccionario de Hacienda. Madrid, 1833, t. II, p. 314

$45^{2}$ DATOLI: Ob. Cit., p. 46.

453 M. OLANO (2008): OLANO, M. (2008): "Carlos Lemaur y la industria del hierro y del carbón en la cuenca del Boeza”. En Actas del VI congreso internacional sobre patrimonio geológico y minero. X sesión científica de la SEDPGYM. Fabero del Bierzo, 19 septiembre-2 de octubre de 2005, p. 219

454 J.M. SOLER (1883): Ob. cit., p. 220
} 


\subsubsection{Minas de la Somoza}

La Somoza se encuentra situada en el curso alto del Burbia, en lo que antes era el Ayuntamiento de Paradaseca, hoy en el de Villafranca del Bierzo. Sus minas, en el actual coto San José, no fueron nunca explotadas; pero su interés radica en el informe que el general Munárriz elaboró hacia 1805 por encargo del gobierno, para iniciar la construcción de una fábrica de hierro en aquellos parajes. Aunque los indicios de mineral de hierro eran muy abundantes en toda la zona, Munárriz señaló cuatro que podrían beneficiarse con rentabilidad: Los de Valderebolo, Corballón de Rodicales, Sotelo y sobre todo el yacimiento de la Mirandela; este último cercano a las explotaciones auríferas de la Leitosa, y con escorias en sus alrededores. La calidad del mineral, su abundancia y la cercanía al lugar en el que se ubicaría la fábrica aconsejaban, según este autor, su utilización 455.

\subsubsection{Mina de Ancares}

La mina de Ancares se hallaba situada en el puerto de la Magdalena, en el límite entre los Ancares leoneses y los gallegos. Según Munárriz, el yacimiento era abundante pero su mineral tenía una calidad inferior a la de los restantes yacimientos bercianos y, por supuesto, al de Formigueiros; al parecer, por su alto contenido en cobre. El mineral era beneficiado en la ferrería de Tejedo, pero tenía poca aceptación por la poca calidad del hierro obtenido456.

455 MUNÁRRIZ: Ob. cit., p. 153-156.

${ }^{456}$ IBIDEM, p. 136 


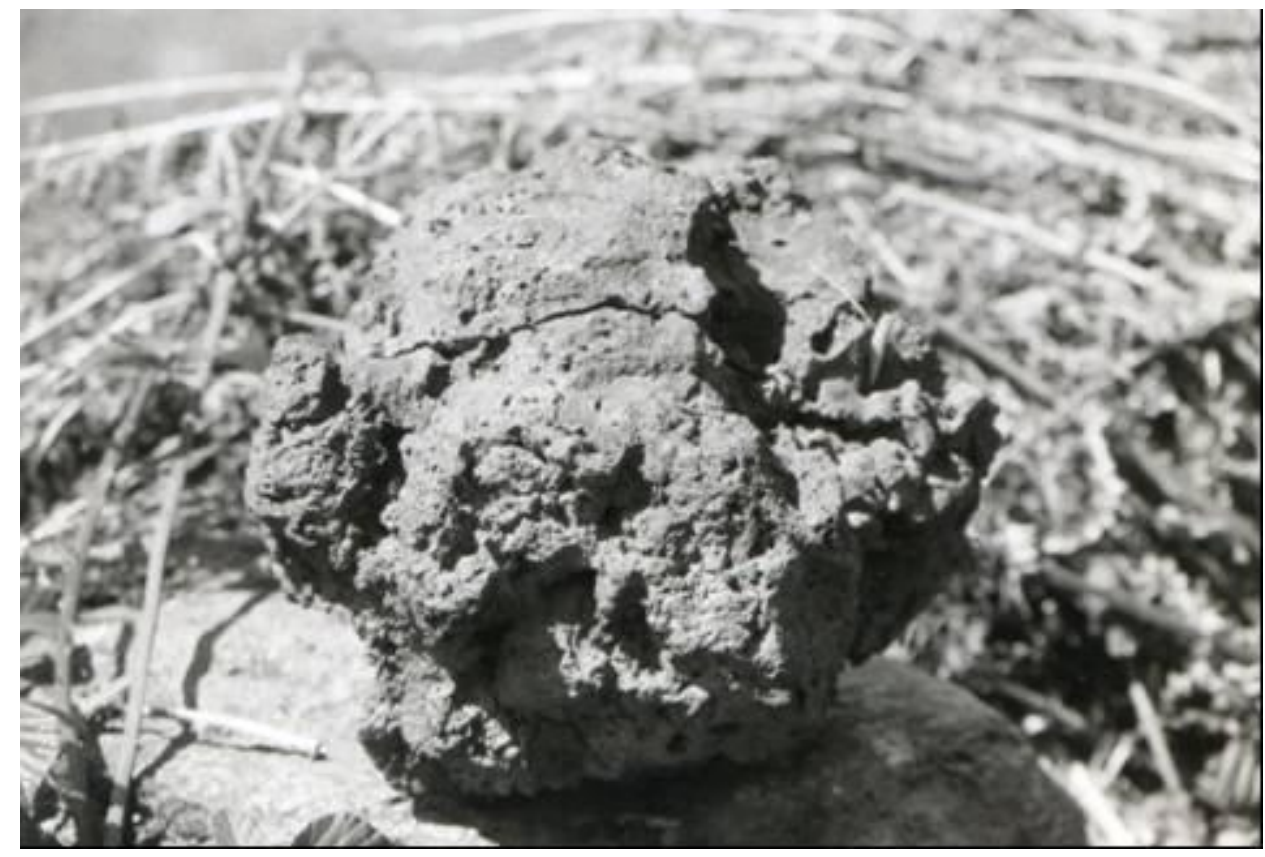

Escoria de hierro de la ferrería de Tejedo

Como en otros yacimientos bercianos, la existencia de escorias de hierro cercanas a explotaciones auríferas puede ser indicio de su beneficio desde tiempos remotos. A esta mina ha de referirse el documento de 1172, por el que el obispo de Astorga, don Fernando, concede a sus canónigos los "diezmos del hierro de Ancares"457. Hasta el siglo XVIII no volvemos a encontrar menciones a este mineral; pero sí después. A él se refieren los habitantes de Tejedo en 1788 al conceder el permiso para la construcción de la ferrería del mismo nombre 458 y poco después Datoli y Munárriz hablan de el pero creen que es de mala calidad459.

\footnotetext{
457 ADA: Indice de Particulares, $\mathrm{n}^{\mathrm{O}} 123$ $45^{8}$ AHPL. P.N.: 3492 (1788)

459 DATOLI: Ob. Cit., p. 67. Hablando de la calidad de los minerales utilizados por la ferrería de Ancares, escribe en 1797: “que a la herrería de Ancares podrá aplicársele otro mineral que está a legua y media de ella, pasado el puerto de la Magdalena, jurisdicción de Galicia (...). Siendo así que la Compañía de la Vega de Ribadeo impidió a los dueños de la dicha herrería el que arrancasen aquel mineral que dice ser mejor, el qual es de ínfima calidad, como ya he reconocido y lo ha experimentado la citada compañía, por ensayo hecho en una de sus herrerías, lo qual obligará naturalmente a servirse para la herrería que está construyendo del mismo mineral que se sirve para las otras" 459 . Para MUNÁRRRIZ: Ob. cit., p. 136, este mineral de la Magdalena era de calidad inferior, pues estaba muy mezclado con cuarzo: "La herrería de Tegedo, distante de allí una legua, es la que se surte de este mineral; pero como no hace ninguna elección de él, saca muy poco y mal hierro; está desacreditada y es la que menos reditua, siendo así que por la proximidad al mineral, abundancia de leña, carbones y aguas, y mejor conservación del edificio y máquinas podría sobresalir entre todas las del Bierzo, tomándose el trabajo de separar el mineral de la parte terrosa y cobriza con que está mezclado".
} 


\subsection{Yacimientos asturianos}

Las referencias documentales más antigua a la minería del hierro se remontan al año 905, en el que el rey Alfonso III dona a la iglesia de Oviedo la iglesia de San Juan de Muñás con sus veneros de hierro 460. Aunque el documento es uno de los pertenecientes al obispo Pelayo, y por tanto hay que tomarlo con precaución, es evidente la existencia de minas de hierro en ese lugar, que posteriormente confirmarán otros textos, incluso sabemos que hubo ferrerías que lo utilizaron ${ }^{461}$. Todo lo cual indica que se explotaron algunas venas locales, probablemente de no mucha riqueza.

En el siglo XVI hay varias menciones a minas de hierro, como la merced que en 1512 se concede a Pedro de Porras, repostero de cámara, de un minero de hierro y de los otros metales que se hallaran en el término de la villa de Avilés, en el monte de la Pinilla462. Posteriormente, Tomás González cita minas en Pinos (1662), Oviedo (1625) y Lena (1630); y el conde de Toreno en 1785 habla de minas de hierro en los Hornos, parroquia del Franco, en el Bao de Cangas, en la parroquia de Campos y en el lugar de Carlés, concejo de Salas463; pero las que realmente se explotaron en la Edad Moderna fueron pocas, pues las ferrerías asturianas usan vena de Somorrostro, "excepto algunos centenares de quintales que la de Agüerina mezcla de vena del país" 464.

En Asturias hay multitud de yacimientos de hierro por toda la región 465, presentes en todas las formaciones geológicas, aunque no impregnan de igual

460 Alfonso III dona la iglesia "cum suis adiacenciis et cum suos ueneros de ferro". Cf. en J. J. ARGÜELLO MENÉNDEZ (1996): Minería y metalurgia en Muñás y Carceu (Valdés-Asturies). Actas de las I jornadas sobre minería y tecnología en la Edad Media peninsular. León, p. 134161.

${ }^{461}$ En 1112 la reina doña Urraca dona a la catedral de Oviedo en la Sierra del Aramo "suis veneris de ferro et cum suis ferrarias sive et carpentarias". Cf. IBIDEM.

${ }^{462}$ AGS. RGS.: 18 de enero de 1512

463 CONDE DE TORENO (1785): Descripción de varios mármoles, minerales y otras diversas producciones del principado de Asturias y sus inmediaciones. Ed. facsimil Biblioteca Popular Asturiana. Oviedo, 1978, $\mathrm{n}^{\circ} 41,42,44$ y 46.

464 G. SCHULZ (1838). "Ojeada sobre el estado actual de la minería en el distrito de Asturias y Galicia”. Anales de Minas, t. I, p. 384; también IDEM (1838): Reseña geognóstica del principado de Asturias. Anales de Minas, p. 365 y 368: (en terrenos cambrianos) "Hay muchos criaderos de hierro de diversa calidad y riqueza, entre ellos algunos de piedra imán y varios carbonatos de hierro... En la parroquia de Aroncedo, concejo del Franco, hay un cúmulo de pirita magnética maciza"; y (en terrenos silurianos) "tampoco faltan buenas venas de hierro en los concejos de Somiedo, Miranda, Pravia, Santo Adriano y Carreño).

465 L. DE ADARO (1916): Criaderos de hierro de España, t. II, criaderos de Asturias. Memorias del Instituto Geológico de España. Madrid. 
modo todos sus tramos, sobresaliendo los de la formación silúrica, en la parte occidental, y de la carbonífera en la central y oriental. El número de menas es muy abundante (siderita, magnetita, oligisto, limonita, etc.) siendo algunas manganesíferas, lo que debió dar a los hierros asturianos características muy apreciadas. Destacan entre los yacimientos enclavados en el Silúrico, los criaderos del Narcea, con numerosos puntos de explotación, y los de los alrededores de Luarca y Castropol, además de algunos, como los del Sueve, en la costa oriental. La formación devónica se extiende desde el Cabo de Peñas hasta el puerto de Ventana ya en León, y en ella se sitúan los yacimientos de Belmonte y Somiedo, con Camayor, y el de Castañedo del Monte; por último en el Carbonífero los yacimientos se extienden por la sierra del Aramo, la zona central e incluso llegan hasta Penamellera.

Hay vestigios de numerosos escoriales y trabajos antiguos (en la sierra de Betules, Montealegre, los Oscos, Bobia, Muñás, Aramo, Penamellera, y muchos otros) ${ }^{466}$, lo que prueba que, al menos los más superficiales y fáciles de trabajar, fueron explotados desde época romana. La mayoría de estos yacimientos, muy numerosos en la zona oeste de Asturias -la de mayor presencia de ferrerías-, no se explotaron en época preindustrial, solo a finales del siglo XIX se conocieron y estudiaron por geólogos e ingenieros de minas, lo que nos permite saber su composición, riqueza y rentabilidad económica; también se crearon algunas empresas mineras para beneficiarlos en los altos hornos de Trubia, Mieres y otros pronto desaparecidos. Pese a esto, sí poseemos algunos datos, pocos realmente, sobre algunas minas que abastecieron a ferrerías en época preindustrial467. Son estas:

\footnotetext{
${ }^{466}$ IBIDEM p. 127, 130, 136, 142.

467 Como ya hemos dicho, en el BOPA hay, desde los años cincuenta del siglo XIX, numerosos datos de registros de minas de hierro (por ejemplo, 31 de enero y el 3 de febrero de 1851 hay una larga relación de minas registradas en 1849 y 1850, lo mismo en 6 de junio de 1857) lo que no significa que se explotaran y menos en las ferrerías, aunque sí en los nuevos hornos altos de Mieres, Lena y La Felguera.
} 


\subsubsection{Mina de Brueba}

Adaro incluye esta mina, situada en el concejo de Miranda, dentro del yacimiento de El Courio, del Silúrico (15,4 millones de toneladas cubicadas), y menciona que son visibles galerías antiguas en la llamada capa número 1, en la que abunda hidróxido de manganeso; pero también en otras capas o filonescapas cercanas hay hematites parda y otras menas de hierro 468 . Los filones ferruginosos se alinean E-O y buzan $30^{\circ}$ hacia el norte, con potencias entre $1,5 \mathrm{y}$ 8 metros.

La ferrería de Aguerina utilizaba, en parte, mineral de hierro de Brueba, del que luego se surtiría la Real Fábrica de Trubia, además de vena vasca469; de hecho era una de las pocas ferrerías asturianas que mezclaban vena de Somorrostro con pequeñas cantidades de la del país ${ }^{470}$. En la sierra de Brueba se han localizado restos de fundición de hierro, cerca de Belmonte.

\subsubsection{Mina de Camaior.}

En la zona de Belmonte y Somiedo surcada por los ríos Pigueña, Somiedo y Saliencia, y entre elevadas montañas, se encuentran numerosos yacimientos de hierro en las calizas devonianas. La mineralización encaja en los niveles basales de la Caliza de Montaña, y está formada por hemetites, que cementa grandes fragmentos de dolomía y caliza471. Uno de los yacimientos explotados en el siglo XIX es el de Camayor, en la parroquia de Saliencia, en el concejo de Pola de Somiedo472.

\footnotetext{
468 IBIDEM, p. 230

469 BN. ms 7295, fs. 224-226. Cfr. G. ANES: Economía y sociedad en la Asturias del Antiguo Régimen, 1988, p. 113.

470 G. SCHULZ (1838): "Ojeada sobre el estado actual de la minería en el distrito de Asturias y Galicia”. Anales de Minas, t. I, p. 384; También en S. FERNÁNDEZ PENEDO (1964): "Los primeros altos hornos al coque y la primera acería de España”. Revista del Instituto del Hierro y el Acero, $\mathrm{n}^{\circ}$ 93, p. 448 ${ }^{471}$ M. GUTIÉRREZ y C. LUQUE (1993): Recursos del subsuelo de Asturias. Oviedo, p. 98 472 L. ADARO (1916): Ob. cit., p. 279-282
} 
Hablando de la ferrería de Somiedo, dice un informe de 1805 que esta consumirá mineral de Camayor 473. Probablemente se refiere a esta mina Jovellanos en 1795 al hablar de la vena descubierta por Álvaro de Cienfuegos Miranda474.

\subsubsection{Mina de Castañedo del Monte}

En las inmediaciones del pueblo de Castañedo del Monte se localiza el yacimiento de este nombre de 513 hectáreas. Según Adaro, en el arroyo las Parvas, afluente del Trubia, "se encuentran las areniscas ferruginosas, en donde están las labores de este coto minero, las más importantes, las realizadas por la Fábrica Nacional de Trubia, que explotó las capas 2 y 3; la primera, a roza abierta, en una extensión de unos 100 por 60 metros de altura, y la segunda por huecos y pilares en una longitud de 150 metros y 50 de altura". Añade que el ingeniero Fernández Garrido lo cubicó en 70 millones de toneladas475.

A finales del siglo XVIII, pensando en diversificar las fábricas de armas españolas, excesivamente cerca de la frontera francesa, el Consejo de Estado nombró al ingeniero de la Marina Fernando Casado Torres para que, como técnico, informase de la posibilidad de crear una en Asturias o en Cantabria. Este eligió Trubia porque creía que reunía las condiciones para construir un horno alto, entre ellas la posible existencia de mineral de hierro en la zona que, tras su marcha, nadie encontró. Posteriormente, en 1794, para revisar la viabilidad del proyecto fue enviado el teniente coronel Ignacio Muñoz quien con el capitán Jerónimo Tavern encontraron el criadero de Castañedo del Monte, abundante y de rentabilidad de 48,45\%.

\footnotetext{
473 RAH. Fondo Martínez Marina: ms. 9/6033: "El mineral de Cacmayor de que va a usar y con que se hicieron en otras ferrerías, pero por cuenta de esta, ensayos y pruebas felices aun para hierros de cañones de fusil. Se descubrió hace pocos años en la braña de su nombre términos de Saliencia; pero como hasta ahora no principió su explotación y laboreo formal ni se ha reconocido bastante toda su superficie, no puede hacerse el examen físico o análisis minucioso de que es mui digno. Solo si se sabe y reconoce a buen ver, que está al S.O. de la peña de Guanga y aunque presenta la textura y forma expática del de la Somoza en el Vierzo: es de no menos fácil fusión y tan maleable y ductible su hierro como los mejores de Vizcaya" 474 JOVELLANOS: Diarios, p. 206

475 L. ADARO (1916): ob. cit., p. 303
} 
Con sus informes favorables se aprobó el proyecto y se nombró como director al brigadier Francisco Vallejo quien muy pronto pudo constatar la escasez y mala calidad del mineral de hierro asturiano. Ya Jovellanos había calificado "temeraria" la situación de la fábrica en Trubia, "lejos de las venas y carbones" 476; pero Vallejo no escuchó tal opinión y mantuvo la explotación en Castañedo y Linares477, aunque mandó hacer algunos informes sobre el hierro asturiano tomando la decisión, por su mala calidad, de importarlo del País Vasco 478 .

Por Real Orden de 7 de marzo de 1844 esta mina fue declarada propiedad del Estado "como lo estuvo hasta principios de este siglo bajo la inspección del cuerpo de Artillería"479. Años más tarde, cuando en 1849 se apruebe la Ley de Minería, el artículo 32 establece que las minas de hierro, en Navarra y Asturias, que abastecen de mineral a las fábricas nacionales de Trubia, Orbaiceta y Eugui, quedarán reservadas para el Estado480. Con frecuencia se anuncia en el BOPA el transporte de mineral de Castañedo a la fábrica de Trubia ${ }^{481}$.

\subsubsection{Mina de Caso}

A mediados del siglo XVIII hubo en el concejo de Caso un proyecto para construir dos ferrerías que promovieron don Antonio Agustín de Antayo y don Pedro Antonio de Peón al descubrir en ese lugar "una copiosa vena de Fierro" que, en los ensayos, produjo una tercera parte de hierro de buena calidad. Por orden del rey, don José de Colosia, que años después aparece como intendente de Marina de la villa de Avilés, envía un informe al marqués de la Ensenada,

${ }^{476}$ Respecto al mineral de Castañedo del Monte dice que "fueron ensayadas en la ferrería de mi hermano, son malas, agrias, sin liga y de escasísimo producto". Cit. en A. MENÉNDEZ GONZÁLEZ (1989): "Navarros y carboneros. Las Reales Fábricas de Armas d y Municiones de Asturias (1794-1809). BIDEA, $\mathrm{n}^{\circ}$ 132, p. 812

477 Esta mina de Linares también estaba al lado de Trubia: Según Jovellanos, la encontró Vallejo, su vena "da 39 por ciento". Cit. JOVELLANOS: Diarios, p. 817.

${ }^{478}$ L. ADARO (1986): "Los comienzos de las Fábricas de Municiones Guresas de Trubia y Oviedo, 1792-1799". BIDEA, $\mathrm{n}^{\mathrm{0}} 118$, p. 375.

479 ANALES DE MINAS, t. III, 1845, p. 30. Parece ser que el director de la fábrica solicitó al gobierno que no se adjudicase a particulares "la mina de hierro que con el nombre de Castañedo existe en el concejo de Santo Adriano, provincia de Asturias. La reina emitió un decreto por el que se declaraba propiedad del Estado (BOPA, 10, de mayo de 1844, p. 2 y 3 ).

480 BOPA, 17,19 y 21 de septiembre de 1849.

${ }^{481}$ BOPA, 9 de mayo de 1856, 16 de octubre de 1857 y 30 de mayo de 1858: Los precios tienen como límite 40 maravedís el quintal en 1856, un real y 18 céntimos en 1857 , y un real y 25 céntimos en 1858 . 
fechado el 29 de junio de 1749, en el que dice haber visitado la zona y comprobado la abundancia de arbolado, su dificultad de su transporte hasta el mar y la abundante vena de hierro; por ello concluye aprobando la solicitud 482 . Aunque se concedió el permiso el 23 de julio de 1749, creo que no se construyeron y, por tanto, no se utilizó aquel mineral.

\section{EL MINERAL DE HIERRO VASCO}

El mineral de hierro vasco de Somorrostro lo utilizaron las ferrerías del noroeste más cercanas a la costa, como las asturianas de Villanueva de Oscos, Trasona, Setienes, Brieves, Parlero, Bullimeiro, Froseira, Peñaseita, Meredo, Deva, Amandi, Dueñes, Soto Rodrigo; y las gallegas de Viloalle, Bravos, Muras, Lorenzana, Saramugo e incluso alguna tan alejada como Vilar de Cuiña483. La razón era el desconocimiento de minas de hierro autóctonas, la pobreza y escaso contenido metálico de las venas locales o el tipo de hierro difícil de reducir en el horno bajo484. Algunas ferrerías, como la de Agüerina, mezclaban el mineral vasco con vena local485; también las de Froseira y Villanueva de Oscos.

El yacimiento de Somorrostro se sitúa en el monte Triano a unos cinco kilómetros de la costa486. De él provenía la casi totalidad de la vena del Señorío

482 AGS. Secretaría de Marina: $\mathrm{n}^{\circ} 555$ (24 de julio de 1749): “Tengo por conveniente que siendo S.M. servido puede conceder licencia para que usen de dichos montes para los carbones que necesiten para la provisión de las Herrerías en los quales siendo en abundancia las venas de fierro que se encuentran en aquel conzejo y de la calidad que se asegura especialmente en la Campa de Escobalín, Buesomerón y Govezanes que son inclusos en el enunciado concejo y asimismo en su inmediación y sitio de las Señales término de Maraña concejo de Baldeburón, rayando con el antecedente de Caso. Y también en el de Piloña y sitio de Espinaredo que confina con el sobredicho de Caso, y el de Ponga".

483 G. SCHULZ (1838): "Ojeada sobre el estado actual de la minería en el distrito de Asturias y Galicia”. Anales de Minas, t. I, p. 384: "Hay en Asturias trece herrerías ó forjas catalanas en actividad, que todas benefician vena de Somorrostro en Vizcaya, con excepción de algunos centenares de quintales, que la de Agüerina mezcla de vena del país".

484 J.J. ARGÜELLO (1996): Ob. cit., p. 137. También en ACADEMIA DE LA HISTORIA. Fondo Martínez Marina: Ms 9/6033 menciona hacia 1805 que durante la guerra con Francia de 1794 se pensó en hacer una fábrica de fusiles en Asturias "pero el país presentaba entonces grandes obstáculos para el establecimiento de una fábrica tan complicada y grandiosa: carecía o por lo menos se ignoraba que hubiera minerales de yerro a propósito y a precios equitativos, pues las ferrerías de que abunda, se probeen de menas de Somorrostro o de venas agrias de su suelo que aún mezcladas en pequeñas cantidades producían yerros demasiado frágiles y son por lo común unas pobres ferrerías sin fondos ni vigor".

485 G. SCHULZ (1838): "Ojeada sobre el estado actual de la minería en el distrito de Asturias y Galicia”. Anales de Minas, t. I, p. 384

${ }^{486}$ L. ALDANA (1851): "Descripción de la mina de hierro de Triano en Somorostro". Revista Minera, t. II, 1851, p. 302-388. Una moderna síntesis de este yacimiento, producción y 
de Vizcaya que se exportaba. Francisco Elhuyar, en el siglo XVIII, identificó en las minas de Vizcaya y, posteriormente en otras del País Vasco, cuatro tipos de minerales de hierro: 1. Vena (hematites roja) muy rica en hierro, 2. Campanil (también hematites roja), con menos concentración de hierro, 3. Rubio (hematites parda) y 4. Hierro espático, un carbonato de hierro. La riqueza de estos minerales era, según aquel químico, muy alta, entre el 38 y el 50\%, aunque las ferrerías no alcanzaban esos rendimientos ${ }^{487}$. Por su parte Lucas de Aldana habla de diversos tipos de vena: negra, roja, rubia, etc., con una ley entre el 46 y el $61 \%{ }^{488}$. Sin embargo, la siderurgia tradicional sólo utilizó la vena o hematites roja, cuya ley era del 57\% llegando en algunos casos de vena muy dulce hasta un $65 \%$; su composición en fósforo además fue insignificante: 0,015\%489.

A diferencia de lo que ocurría en el resto de España, donde regía el principio regalista establecido en las ordenanzas de Felipe II, las minas de Somorrostro pertenecían al Señorío de Vizcaya, aunque a veces hubo problemas de competencia entre el Señorío y las Encartaciones. La legislación foral vizcaína disponía que las minas eran de libre disfrute de todos los vecinos. Por esa razón y por lo fácil de su extracción no hubo realmente empresas mineras ${ }^{490}$. En la Edad Moderna trabajaban en Somorrostro unos 400 mineros desde mayo a octubre.

Aunque el fuero de Vizcaya prohibía la exportación de la vena vizcaína "para reynos extraños" ${ }^{491}$, era libre su venta a otras zonas de la Corona ${ }^{492}$. Hasta 1640 no pagaba impuestos, pero en ese año un Real Decreto impuso un

comercialización del mineral, en R. URIARTE (1988): Estructura, desarrollo y crisis de la siderurgia tradicional vizcaína (1700-1840). Bilbao, cap. 1. La minería, p. 13-80.

487 L. SILVÁN (1976): "La evolución de los procesos metalúrgicos y su aplicación a la siderurgia del País Vasco". En III a Semana de Antropología Vasca (Bilbao, 1973). Bilbao, t. II, pp. 38.

${ }^{488}$ L. ALDANA (1851): Ob. cit., p. 342.

489 L. M. BILBAO y E. FERNÁNDEZ DE PINEDO (1982): "Auge y crisis de la siderometalurgia tradicional en el País Vasco (1700-1850)". En TEDDE, P.: La economía española al final del Antiguo Régimen. II: Manufacturas. Madrid,p. 140, nota 3.

${ }^{490}$ R. VAZQUEZ DE PRADA (1974): Historia económica y social de España. Los siglos XVI y XVII., p. 608.

${ }^{491}$ Ley 17, título $1^{0}$ : "que ningún natural, ni extraño, así de dicho señorío de Vizcaya, como de todo el Reyno de España, no pueda sacar a fuera de dicho Señorío para Reynos extraños, vena, ni otro metal alguno para labrar fierro".

${ }^{492}$ En 1505 se menciona una prohibición de exportar vena de Guipúzcoa, en el texto se indica "como en Asturias y Galicia había necesidad de vena vizcaina porque mesclaban tres o cuatro quintales de la suya con una de Vizcaya, porque así salía un hierro bien frío (que) sufría el martillor". Cit. en L. M. DÍEZ DE SALAZAR (1983). Ob. cit., t. I, p. 345, nota 760. 
gravamen de ocho maravedís por quintal macho de 155 libras por seis años, que se convirtió en permanente en los siglos XVII y XVIII pese a las protestas. Durante la guerra contra la Convención francesa, en 1794 se incrementó ese gravamen en medio real, ascendiendo a 25 maravedís por quintal de 155 libras, el cual se mantuvo hasta 1842 en que lo suprimió un decreto de Espartero493.

La vena se exportaba sin raguar, transportándola en carros o a lomos de mulos hasta los puertos fluviales de Bilbao, Portugalete, Galindo, Ugarte y Múskiz. Desde estos puertos, la vena era transportada en barcos de pequeño tamaño (pataches, quechemarines, lanchas), cuyos patrones eran siempre vizcaínos, monopolio que se mantuvo, con pocas excepciones, hasta bien entrado el siglo XIX 494. Este tráfico de cabotaje solía hacerse en verano y otoño, en parte por presiones de los ferrones vizcaínos que primero querían abastecerse ellos y luego exportar fuera el resto de la vena. Sabemos que a finales del siglo XVIII se autorizó a Manuel Antonio de Mardaras, vecino de Portugalete, que transportase vena para Asturias y Galicia fuera de época, con el expreso compromiso de retornar con la nave cargada de maíz495; también en el siglo XIX hemos visto que el tráfico, aunque se hacía principalmente de mayo a octubre, se mantenía a veces en pleno invierno (APÉNDICE II, 4).

El uso de mineral vasco está atestiguado en las ferrerías asturianas y gallegas al menos desde los primeros años del siglo XVI496, lo que corrobora nuestra afirmación de relacionar tal importación con la dispersión de ferrones y venaqueros vascos por el noroeste. Contamos con muchos datos sueltos de los siglos siguientes sobre importación de hierro en barcos que se fletaban para ese

\footnotetext{
493 La revista ANALES DE MINAS, t. III, del año 1845, p. 17, señala que en 13 de septiembre de 1842, ante las repetidas peticiones de supresión del arancel de hierro de Vizcaya, Espartero emite una orden aboliendo el "impuesto de veinte y cinco maravedís, que la Diputación provincial de Vizcaya exige por cada quintal de vena de hierro que se esporta de las minas de Somorrostro...declarando libre el mencionado artículo, ya se estraiga por tierra para Castilla, o por mar para las demás provincias de la corona".

494 J. Ma CARRIÓN ARREGUI: La siderurgia guipuzcoana en el siglo XVIII. Bilbao, 1991, p. 7183. El BOPA registra algunos años, día a día, las entradas de estos barcos cargados con mineral de hierro, por ejemplo en los años 1859 y 1861.

495 R. URIARTE (1988): Ob. cit., p. 31.

${ }^{496}$ J. LÓPEZ Y A. GRAÑA: Ob. cit., p. 15. Según estos autores la primera mención de hierro vasco en Asturias es de 1503.
} 
cometido497; pero el mejor y más completo ejemplo lo tenemos en Villanueva de Oscos, cuya vena (más de quince millones de kg.) procedía casi en su integridad de Vizcaya probablemente porque como otras ferrerías de la zona no tenían o habían agotado las venas locales. La cantidad media anual fue de unos 1767 quintales (unas diez toneladas), siendo los años de 1730 a 1810 cuando esta cantidad aumenta de forma considerable.

Los precios de la vena vizcaína los analizaremos en el capítulo sexto, pero por lo que ahora atañe diremos que su elevación a finales del siglo XVIII, no solo por la "maior estimación que han tomado todas las cosas", sino por el aumento del arancel, como hemos visto, provocará el cierre de algunas ferrerías de la zona de San Tirso de Abres, e incluso llevaría a la Junta General del Principado a solicitar que se le eximiera de los derechos de la vena vasca498. En algún caso, especialmente durante la guerra con Francia entre 1793-1795, que puso en dificultades la navegación por el Cantábrico, se buscaron alternativas locales, por ejemplo en Villanueva de Oscos, pero el hierro era de "calidad inferior al que sale de la vena vizcaína y solamente aplicable en ciertos usos"499. Ignoramos las cantidades totales que se importaban, con excepción de algunos datos muy parciales. Por ejemplo, en 1791-1793 se exportaron a Galicia

497 Por ejemplo: En 1600 dos vecinos de San Julián de "Mosques" -Músquiz (Vizcaya)- afirman haber venido cargados de vena para la ferrería de Bravos, por acuerdo con su dueño, Gonzalo Pérez de Cora, quien "les dio en pago de su flete dos botas (una pipa) de vino a honce ducados cada una”. Cf. P. SAAVEDRA (1985): Ob. cit., p. 330; En 1641 Juan de Balderraín, residente en la ferrería de Bravos, acuerda con el vizcaíno Juan de Montano que le traiga 1.0oo quintales de vena de la mejor que hallare, a precio de 3,17 reales: "Parecieron presentes Joannes de baldeRayn bizcayno Residente en la herreria de la feligresía de santiago de bravos de la una parte y de la otra joan de montano vezino de san julian de musquez de la encartazion de bizcaya e dixeron estauan conbenidos y conzertados el uno con el otro de quel dicho juan de montano le a de traer en su navio para en todo el mes de setiembre o del de octubre que viene deste presente año mil quintales de vena y la que pudiere venir en dos baxeles de los quel dicho juan de montano tiene, puesta en el puerto desta dicha villa en la parte donde se acostumbra descargar la dicha vena aya de ser de la mexor que se allare y a satisfazion del dicho Juanes de Baderayn y trayda la dicha vena y puesta en la dicha parte y pesada por el peso real" por la que le ha de pagar a tres reales y medio el quintal. Uno de los bajeles se fletará en el mes de agosto y otro en septiembre (AHPLU: 4030/4). Ejemplos del siglo XVIII en P. SAAVEDRA (1985): Ob. cit., p. 333 y A. MEIJIDE PARDO (1971): Economía marítima de la Galicia Cantábrica en el siglo XVIII. Valladolid, p. 113.

498 J. OCAMPO SUÁREZ-VALDEZ (1987): La economía asturiana al final del Antiguo Régimen. Las manufacturas, 1750-1850. Oviedo, p. 38.

499 IBIDEM: p. 38. 
1.717 Q.M./año y a Asturias 19.666 Q.M./año, lo que representa sólo el o,89\% y el 10,21\% respectivamente de todo el mineral exportado de Vizcaya50o.

El uso de vena vasca en las ferrerías del noroeste se mantuvo en el siglo XIX, pese a los numerosos yacimientos de hierro local que se denunciaron, como puede verse en el BOPA a partir de los años cuarenta. Schulz afirma que todas las ferrerías que están en funcionamiento en Asturias usan hierro de Somorrostro y que en el año en que escribe, 1838, habían consumido 44.0oo quintales de vena501; por el contrario, de Galicia escribe que solo dos consumen este tipo de mineral502, cantidad que probablemente debió aumentar con la desaparición del arbitrio de la vena vasca suprimido por Espartero en 1842503, y que explica quizá la solicitud de permiso de nuevas ferrerías. En los años 18291842 por el puerto de Portugalete504 se exportaron a Galicia 8.021 Q.M./año y a Asturias 13.931 Q.M./año, lo que representaba el 4,95\% y el 8,60 respectivamente de todo los exportado, siendo el tercero y cuarto lugar después de Guipúzcoa $(57,45 \%)$ y Santander $(26,71 \%)^{505}$.

En la segunda mitad del siglo XIX, las dieciséis ferrerías asturianas de la zona occidental y las dos de la parte oriental seguían consumiendo mineral de Somorrostro506. La Revista Minera afirma en 1859 que las dieciséis forjas catalanas de Asturias benefician al año unos 60.000 quintales de vena de Somorrostro507; y la Estadística Minera en 1864 habla de cómo las siete ferrerías asturianas que trabajaron ese año produjeron 1.701 quintales de hierro "procedente de menas de Somorrostro en Vizcaya" 508 . Esa misma revista señala en 1867 que las ferrerías gallegas más cercanas a la costa también consumen ese

\footnotetext{
${ }^{500}$ R. URIARTE (1988): Ob. cit., p. 67. Anota que la documentación de estos años no permite un cálculo exacto, aunque si muy aproximado.

${ }^{501}$ G. SCHULZ (1838): "Ojeada sobre el estado actual de la minería en el distrito de Asturias y Galicia”. Anales de Minas, t. I, p. 384-385.

502 IDEM, p. 390

503 ANALES DE MINAS, t. III, año 1845, p. 17.

504 La mayor parte de la vena se exportaba por Portugalete, menos del 10\% lo hacía por otros puertos vascos (R. URIARTE (1988): Ob. cit., p.56).

505 R. URIARTE (1988). Ob. cit., p. 67

506 A. PÉREZ MORENO (1858): "Estado de la minería en Asturias durante el año 1856, con algunas consideraciones interesantes". Revista Minera IX, p. 729. Dice el autor que ese mineral "puesto en los puntos más próximos del litoral suele costar 4 rs./quintal"

507 REVISTA MINERA, t. X, 1859, p. 486

508 Citado por LÓPEZ, J. y GRAÑA, A. (1998). Ob. cit., p. 19
} 
mineral509. La ferrería de Peñaseita fabricó en 1870 y 1871260 y 200 q.m. de hierro forjado, respectivamente, empleando solo hierros de Somorro510. Todo esto nos indica que estas fábricas, pese a los registros de numerosas venas locales, preferían la vena vasca, probablemente más fácil de reducir en estas forjas ancestrales.

\section{LA EXPLOTACIÓN DEL MINERAL}

Desde la Edad Media, las minas se consideraban una regalía de la corona, un derecho exclusivo del rey, que este podía ceder a terceros. Hasta el siglo XVI la minería estuvo poco regulada y la legislación sobre ella siguió siendo la establecida en Las Partidas (siglo XIII) y el Ordenamiento de Alcalá (siglo XIV). En la primera mitad del XVI, el interés que entonces cobra la minería, llevó a los soberanos a conceder licencias a personas influyentes para buscar y explotar minerales511. La minería del hierro, que también era una regalía de la corona, la cedieron los reyes como mercedes o premio a determinados señores e instituciones. Esto fue lo que ocurrió probablemente con las minas en manos de la encomienda de la Barra y las del conde de Lemos ${ }^{512}$. No tenemos datos sobre los derechos que esa explotación producía a la Corona, ya que los únicos que parecen cobrar el canon de las ferrerías son los dueños de los yacimientos, pero generalmente aquella ingresaba $1 / 8$ ó 1/10 del producto513. Además el hierro, como cualquier mercancía, pagaba el derecho de alcabala514.

\footnotetext{
509 ESTADISTICA MINERA, 1867, P. ...: “algunas ferrerías de esta provincia (de Lugo), que se hallan en mejores condiciones de relación con la costa, consumen mena de Somorrostro, cuyo costo en Vivero, puerto principal de arribo, se calcula en 10 o 12 reales quintal métrico (cinco reales en el punto de arranque y cinco en el flete)

${ }^{510}$ M. FUERTES ACEVEDO: Mineralogía asturiana, 1884, p. 144.

${ }^{511}$ Como ocurrió con el privilegio que Carlos V concedió al canciller Gattinara para explotar los veneros de Galicia y Asturias en 1525. Cf. L. FERNÁNDEZ MARTÍN, L. (1975): "Provisiones reales a favor de Asturias durante la regencia de los reyes de Bohemia" (1641-1551). BIDEA, $\mathrm{n}^{\mathrm{o}}$ 84-85, p. 229.

512 Ya lo hemos visto en el caso de los yacimientos de Formigueiros y Rocas. De igual modo lo vemos en este texto de 1628 en que el monasterio de Lorenzana se declara propietario de "todas las beneras que están en su jurisdicción", por lo que prohibe que "ninguna persona, asi de los basallos de la jurisdicción como de los que no lo son, pueda entrar a abrir ninguna de las dichas beneras, sino es con licencia de mi parte y pagándole el quinto de toda la bena que sacare" (AHRG. Monasterios. 54/57)

513 En la concesión al canciller Gattinara de 1525 se obliga "a dar la nuestra Cámara la dézima parte de lo que quedase de ganancia de los dichos mineros sacada la costa que en ellos se hiziere”. L. FERNÁNDEZ MARTÍN (1975). Ob. cit., p. 229.

514 En 1633, un testigo en el juicio de la ferrería de Incio por el uso de la vena de Rocas, dice que él y sus antecesores "hestubieron siempre en la possesion de quebrantar, arrancar, llebar y
} 
Una pragmática de 1599 reguló el permiso, hallazgo y registro ante las autoridades, la explotación y canon que había de pagarse al propietario del suelo y a la Corona por cada mina descubierta o por descubrir, por parte de los particulares515; y en 1563 aparece el primer ordenamiento legal de la minería, que se completaría posteriormente con las Ordenanzas de 1584, que rigieron la explotación del subsuelo sin a penas modificaciones hasta la Ley de Minas de 1825. En 1624 Felipe IV creó una "Junta de Minas" a la que se dio jurisdicción en todos los asuntos relativos a la minería, segregándolos del Consejo de Hacienda. Esta junta, reformada en 1629, fue suprimida en 1643 con lo que los asuntos mineros volvieron a la competencia del Consejo de Hacienda. Carlos II restableció la Junta en 1672 pero por breve tiempo; sólo en 1677 adquirió plena independencia y atendió en exclusiva los asuntos referentes a minería, aunque integrada en la Junta General de Moneda, Comercio y Minas516.

\subsection{La minería del hierro}

En las licencias de construcción, las ferrerías incluían siempre el derecho de la vena, es decir, la posibilidad de obtener mineral de hierro de algún yacimiento cercano, como vimos anteriormente con los foros que los dueños de ferrerías suscriben con el conde de Maceda respecto de la vena de Formigueiros. En algunos contratos de arriendo se menciona igualmente este requisito, así como dar expeditos los caminos de la vena517. Pero eso no significa que las

traer a ella toda la bena de yerro que era necesaria de las beneras de rocas sin por razón dello pagar a ninguna persona sino solamente la alcabala que se debe y paga en el partido del Yncio donde ella hestá sita (jurisdicción de la encomienda de San Juan) cuya alcabala pagan a su magestad" (AHRG. R.A.: 3070/39).

515 A. RODRÍGUEZ (2004): "Economía y sociedad". En Historia de España. Espasa Calpe. Madrid, p. 151

516 VÁZQUEZ DE PRADA (1974): Ob. cit., p. 604

${ }_{517}$ AHRG. R. A.: 2472/120. En 1573 Juan Pérez de Errazti arrienda a Miguel Ortiz la ferrería de Ferreirós por 4 años y renta de 120 quintales "de fierro labrado de la bena de los beneros de Formigueros y Paradela", con las siguientes condiciones: 1) "yo el dicho Juan Pérez darrazti sea obligado de dar hecho el camino que va desde la herreria de ferreirós al benero de formigueros por donde bos el dicho Miguel Ortiz lo señalaredes dentro de dos meses primeros siguientes a mi costa comisión sin que bos seais obligados de poner ninguna costa"; 2) "yo el dicho Juan Perez darrazti obstengo de dar a bos el dicho maestro de herrerias los dichos beneros de Formygueros y Paradela libres e sin costa alguna y para que podais bos e vuestro mandado sacar y llebar toda la bena que ubieredes menester en la dicha herreria a my costa desde los veynte y ocho dias deste dicho mes de junio en adelante durante los dichos quatro años en ansi mismo me obligo de os dar libres todos los mas beneros que estan junto a la dicha 
ferrerías explotaran directamente las minas; de hecho, sólo algunas, como la de Bueyes, tuvieron permiso para beneficiar en exclusiva algún venero en Formigueiros, y otras, como Loureiro, tuvieron venas propias, cuyo mineral mezclaban con el de Rocas o el de Formigueiros. Eso hacían también algunas de las ferrerías que mezclaban venas locales con el mineral de Somorrostro.

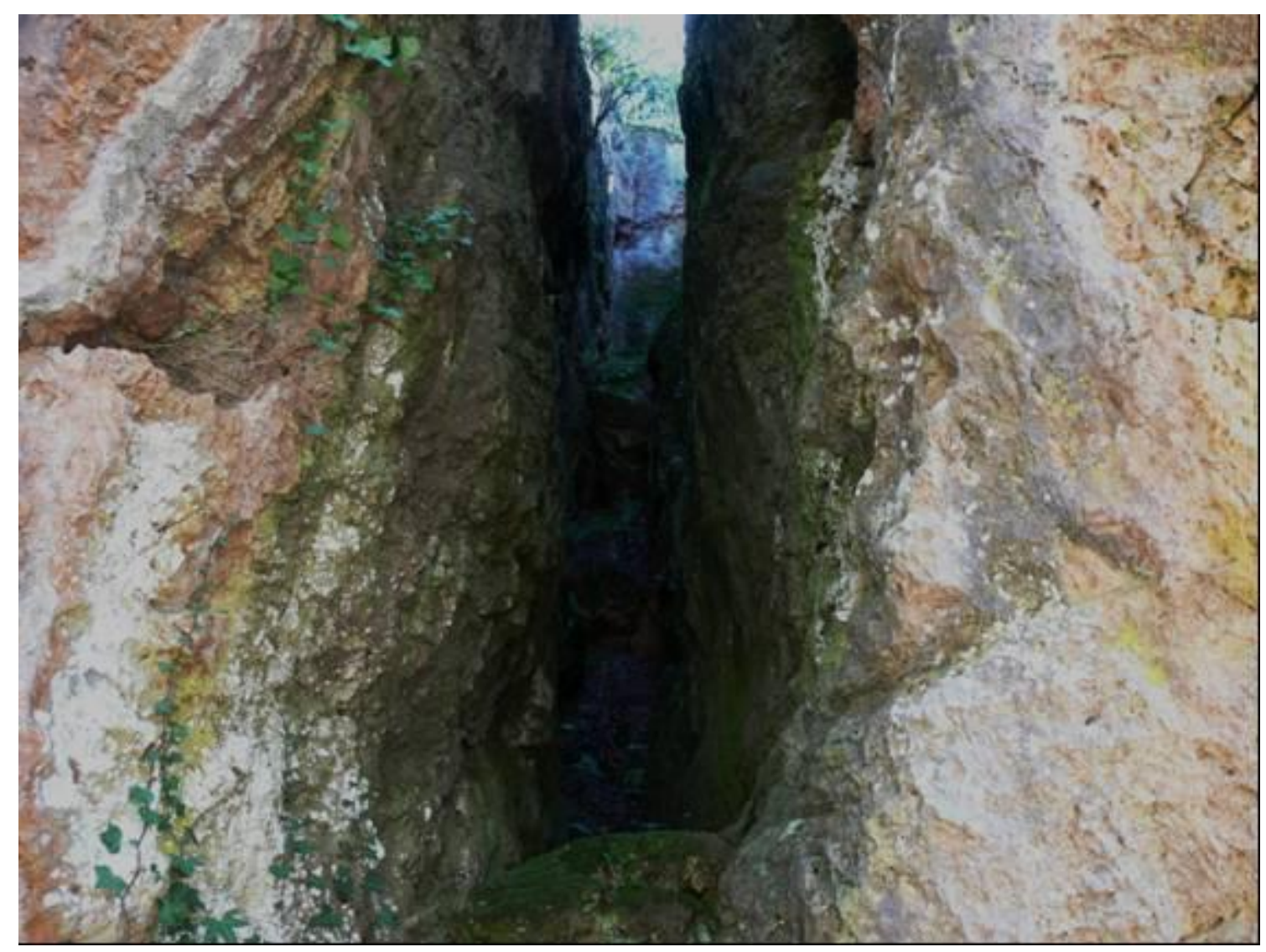

Explotación de vetas de hierro en La Chana (León)

Ahora bien, todo el complejo mundo de la técnica minera, así como los métodos de organización y trabajo de los mineros en las minas del noroeste nos son conocidos sólo muy parcialmente, al contrario de las minas de Somorrostro, sobre las que hay una abundante bibliografía 518 . Los datos son escasos, dispersos y referidos la mayoría de ellos a los siglos XVIII y XIX, aunque creemos que los mismos pueden extrapolarse, sin grandes visos de error, a épocas precedentes de la Edad Moderna, porque realmente hasta la segunda

herreria y en toda la tierra de courel a my costa según dicho hes para la dicha herreria y no mas".

${ }_{518}$ R. URIARTE (1988): Ob. cit., p. 38-53. 
mitad del siglo XIX no se ensayaron muchas innovaciones en el sector de la minería del hierro desde los avances que esta vivió en el siglo XV.

A diferencia de otros metales, el hierro se encuentra en la naturaleza en forma de minerales muy diversos, muchos de ellos en niveles superficiales, lo que facilita su extracción que no requiere técnicas muy complejas. Basta con localizar los afloramientos y extraer el mineral a cielo abierto, a partir de trincheras o vaciando cavidades cársticas rellenas de óxidos de hierro. De hecho hasta el siglo XIX, la explotación de los yacimientos mineros generalmente no se hizo por galerías sino a cielo abierto: así se extraía, por ejemplo, en las veneras de Rocas y Formigueiros, las más importantes del noroeste como hemos dicho. Sólo en algunas minas se hacían cuevas o pequeñas galerías como aún es posible apreciar en algunos de los yacimientos de Lugo, como la Cova da Riveira, Cova das Choyas, Cova d'Ouso, Galería de San Mamede y otras.

En Formigueiros el mineral se hallaba prácticamente a flor de tierra o cubierto por una delgada capa de pizarra descompuesta, por lo que se trabajaba como si fuera una cantera a cielo abierto. La explotación no seguía ningún plan previo; era, por el contrario, bastante anárquica, realizándola compañías o cuadrillas de mineros de los pueblos vecinos. Según Datoli, el mineral se arrancaba en tres parajes diferentes por dichas cuadrillas ${ }^{519}$ que, en el verano que los visitó Munárriz (hacia 1807), eran siete, todas ellas trabajando indistintamente para todas las ferrerías ${ }^{20}$. El mineral se arrancaba en grandes trozos por medio de barras y cuñas, por lo que se desperdiciaba una gran parte

\footnotetext{
519 DATOLI, p. 54: "El arranque del mineral, el qual es muy abundante, y, aunque de roca, muy fácil de arrancar, por hacerse a taxo descubierto, principalmente si se usara de algunos barrenos, lo tienen ajustado por medio real el quintal de a $7^{1 / 2}$ arrobas castellanas. Al presente se arranca en tres parages, en quienes sin embargo de estar comprendidos en muy corto espacio, no dexa de diferir bastante en su calidad; pero los mineros, que forman todos una compañía, separan con barras o a fuerza de cuñas, grandes trozos de mineral; y los carreteros, ajustados también a 4, 6 y 5 reales por el mismo quintal, según la distancia de las herrerías, que es de 4, 6 y 3 leguas, dibiden con la almayna dichos trozos en pedazos proporcionados para cargar sus carros, en los quales, no teniendo cestos ni caxón hecho al intento, no conducen lo menudo".

${ }^{520}$ MUNÁRRIZ, p. 134: "Los venagueros son vecinos de los lugares inmediatos, y cada cuadrilla escoje el sitio que mejor le parece y que no está ya ocupado por otra. El verano pasado había siete, y todas ellas trabajaban indistintamente para todos los dueños de las herrerías, y los carreteros escogen y conducen el mineral de donde más les conviene o de donde le hallan arrancado. El quintal macho gallego, o de siete arrobas y media castellanas, cuesta actualmente 20 maravedies de arranque, y respecto a su conducción cada dueño hace el ajuste que puede, con arreglo a la distancia y naturaleza de los caminos, que todos son malísimos".
} 
del mismo, sobre todo los menudos, ya que los carros que lo transportaban carecían de cestos o cajones para recogerlo adecuadamente. También era así la explotación del yacimiento de Rocas, en el que distintos propietarios tenían pequeñas veneras dentro del propio yacimiento521.

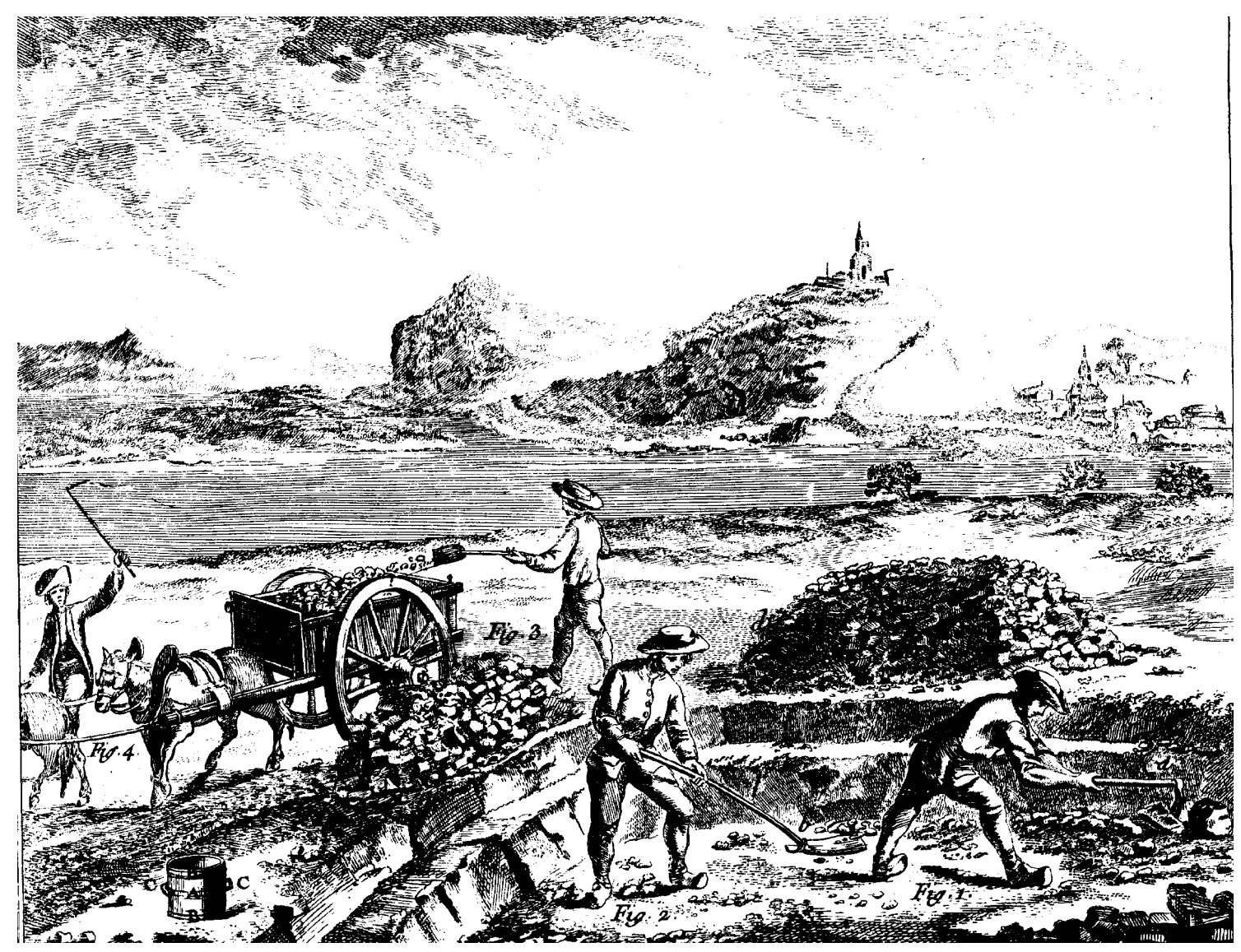

Mina a cielo abierto (La Enciclopédie: Forges ou l'art du fer. Barcelona, 1988, plancha II)

Estas minas a cielo abierto se explotaban por cuadrillas de venaqueros o por estos individualmente, muchos de los cuales eran en los siglos XVI y XVII vascos $5^{22}$. A veces, el sitio exacto de los trabajos dependía de hallazgos

${ }^{221}$ AHPLU: 2478/1 (1788): En 1788 don Pedro A. Fernández arrienda a Domingo Díaz y a José Ormazábal, vecinos de la Veneira de Roques, mancomunadamente "la porción de vena que puedan trabajar en el espacio de un año (...) en el mineral de fierro que el otorgante tiene en dicho lugar de la Venera" (sus límites por arriba y por abajo son con veneras de José y Juan Ormazábal),(...) "cuyos arrendatarios han de trauajar el arranque de dicha vena por la delantera que mira al frente de las casas que dicho otorgante tiene en el dicho lugar".

522 Por ejemplo, Miguel de Loreaga, navarro de Lesaca, aparece en 1629 como venaquero en Pontepetre (AHPL. P.N.: caja 2969). En un poder de 1629, que Juan de Ybalza da a su padre Juan García de Ybalza para que cobre en San Sebastián a Miguel Martínez de Vicuña, acemilero que había sido en la ferrería de Pontepetre, 50o rs. que le debe, confirman la escritura Esteban de Argarese, Juan de Michael Pericena, también venaqueros. (AHPL. P.N.: caja 3186). 
personales523, lo que daba lugar a una cierta anarquía. En Formigueiros hubo, a fines del siglo XVIII, algún intento para racionalizar la explotación del mineral, como el que protagonizó en 1791 don José María Tineo, propietario de la ferrería de Bueyes, que pretendió acotar una parte del yacimiento para explotarlo personalmente. Fracasó por la oposición de los propietarios de las restantes ferrerías, encabezados por don Manuel Armesto y Omaña, propietario de la de Visuña, alegando que el aprovechamiento del yacimiento era común desde tiempo inmemorial 524. En el pleito se dice que la vena la llevan indistintamente para las ferrerías desde cualquier lugar, con la excepción de la ferrería de Bueyes que la toma de una venera llamada Ulloa, en Formigueiros525.

En Chana de Borrenes, en el Bierzo, la mayor parte del mineral se extraía igualmente a cielo abierto, como podemos comprobar por los restos

523 AHRG. Doc. de San Martín de Ombreiro, caja 19: "En la herreria de Quiroga a diez dias del mes de diciembre de mill y seiscientos y setenta y nueve años, nosotros Juan do Lago, Domingo Alvarez, Andres do Bao y Bastian de Vieiros, vecinos del coto de la Seara decimos que por quanto nosotros emos descubierto un peñasco de vena de yerro en la venera de Formigueiros el qual está pegado a una venera en que arrancan don Francisco y don Juan de Seoane por la parte de avajo, decimos que todo el derecho que tenemos al dicho peñasco y venera lo cedemos y traspasamos a don Antonio de Neyra, vecino de la herreria de Quiroga, y se lo bendemos por precio y quantía de diez ducados que nos pagó en plata y vellón en presencia de los testigos desta cédula, que lo fueron el licenciado Antonio Núñez residente en la herrería...”. También AHN. Estado: leg. 1739, nº 16. En 1718 don Pedro de Ulloa, dueño de Bueyes, pleitea contra varios vecinos de Visuña por arrancar vena en Formigueiros en un lugar en el que, con esfuerzo, ha descubierto tres o cuatro minerales.

524 AHPL. P.N.: 3377 (1791). En un poder de don José Ma Tineo, dueño de la ferrería de Bueyes, se puede apreciar alguno de los métodos de trabajo. Dijo "que a imitacion de sus causantes (...) siempre estubo (...) aprovecharse de una venera (en) Formigueiros (...). Arrancando de ella (...) toda la vena necesaria para el consumo de su Herreria (...), hasta que en el año pasado por el Administrador de la Herreria de Soldon (...) por si y medio de operarios (...) se propasaron a introducirse en la citada venera Arrancando y extraendo considerable numero de carros de vena, a pretesto de suponer tener derecho en aquellos Minerales y su termino (pese a que) le constaba que el Peñasco o canto donde verificó la infraccion, hera propio anexo a la Venera que (sus) proxenitores descubrieron, (y que explotaron), lo mismo que sucede con respecto a las otras Veneras (....) de que usan con independencia sus respectivos Dueños, quedando al arbitrio de cada una el descubrimiento de las que le parezcan en aquella Montaña (...). No solo continuó en Arrancar y extraer de dho. canto o Peñasco, sino que (...) otro mas arriua que ygualmente es anexo dela expresada venera del sr. Otorgante llevando mucha porcion de ella (...) y alló con otros mas que le acompañaban, clara y manifiesta, la tropelia y nuebo atentado ejecutado por las contrarias y sus Venaqueros (...) quienes aparejados y en distintos sitios de la misma venera (...) se mantubieron Arrancando y dando vena a diferentes careteros (y entraron en) la caseta para el abrigo y resguardo de los Operarios y Herramientas (...) propasandose asimismo a Violentar y franquear la Cerradura y Puerta de dicha caseta y extraer de ella las Herramientas y mas Aperos que alli dejo su Administrador y Cachican, y haciendo finalmente un uso espotico de todo, llebando entan corto tpo. mas de Nuebezientos carros de vena, introduciendolos en dicha venera y sacandolos por el mismo camino que tiene el sr. Otorgante. De manera que apoco tpo. seallará del todo arruinada y desfalcada dha. venera, en conocido perjuicio de sus intereses".

525AHN. Estado: leg. 1739, no 16 
arqueológicos o las referencias bibliográficas. En la zona del Vieiro (derivación de Veneiro) son perfectamente observables las enormes tajaduras practicadas en la caliza. Las vetas de mineral se atacaban abriendo "pequeñas excavaciones, zanjas o pozos que vuelven a rellenar después y a sembrar el terreno superficial" 526 . Munárriz, que visitó estas explotaciones hacia 1805, habla de pozos de gran profundidad y costosa extracción, lo que sugiere algún tipo de minería subterránea527. Este sistema, que pudiera complementar el anterior, requiere sin duda la acción de verdaderos profesionales mineros y la solución de algunos problemas técnicos, como la ventilación y drenaje. No fue la única mina donde se observan pozos ${ }^{528}$; en el siglo XIX también se mencionan en Formigueiros 529 .

El trabajo se hacia con picos y palas que se guardaban en casetas al lado de las explotaciones, herramientas que era necesario enderezar y afilar en fraguas que había para ello en las cercanías de los yacimientos530. El número de mineros que trabajaban en las minas de hierro nos es prácticamente desconocido antes del siglo XIX, aunque conocemos los nombres de muchos venaqueros, como veremos en el capítulo cuarto. Sólo del yacimiento de Formigueiros conocemos algunos datos de los primeros años del siglo XIX. Por ellos sabemos que en el trabajaban siete cuadrillas pero no cuántos integraban cada cuadrilla ${ }^{51}$. En los años centrales del siglo se mencionan datos más concretos, que nos permiten cifrar en 60 y 70 obreros para las minas de Rocas y Formigueiros, respectivamente532. En el Bierzo, en 1864, en varias minas, 325 operarios sacaron 21.431 quintales métricos de mineral de hierro, lo que da una

${ }^{526}$ SOLER (1883): Ob. Cit,, p. 9.

527 MUNÁRRIZ, p. 118: "su extracción es muy costosa por la mala dirección que siguen en los trabajos, y al día la sacan a hombros de más de sesenta varas de profundidad por una especie de caracol, formado por las mismas vetas y con escalas de mano muy incómodas".

${ }^{28}$ P. HERNÁNDEZ SAMPELAYO (1935): Ob. cit., t. III, fasc $1^{\circ}$, p. 83, menciona en términos de Parada d'os Montes y Villamor, en el Caurel, cerca del arroyo de Forján "un gran trabajo antiguo, que es un pozo donde dicen extrajeron mucho mineral; en realidad no se veía más que mineral suelto y trozos de escorias, quizá de alguna forja instalada cerca".

529 I. GARCÍA TATO (2000): Ob. cit., p. 161

530 AHPLu: P.N.: 2478/1 (1788): En 1788 don Pedro A. Fernández arrienda a Domingo Díaz y a José Ormazabal, vecinos de la Veneira de Roques, mancomunadamente, una venera para que la exploten y les arrienda también "la casa de fragua con esta para componer y recoger las herramientas con que trauajan".

${ }^{531}$ MUNÁRRIZ, p. 134. En 1869 La Revista Minera habla de 11 grupos que trabajan para 17 ferrerías. Cit. P. HERNÁNDEZ SAMPELAYO (1935): Ob, cit., t. III, $1^{\circ}$, p. 35.

${ }^{532}$ G. SCHULZ (1838): Ob. cit., p. 38. 
media por operario pequeña; por último, en 1873, 35 obreros, también en el Bierzo, obtuvieron 7.400 quintales métricos 533 .

\subsection{El transporte del mineral}

El mineral se adquiría sin raguar, es decir sin cocer o calcinar la vena, o raguado.534. La mayoría de la vena, en general, se transportaba sin cocer hasta las inmediaciones de las ferrerías o en campo abierto, donde se procedía a raguarlo en pilas al aire libre535. Munárriz dice haber visto en Valcarce raguar una pila que "tenía tres mil quintales de mineral y doscientos carros grandes de leña" 536 . En la ferrería de Villanueva de Oscos las raguas (una o dos veces al año) también utilizaban doscientos carros de leña; en 1702, este monasterio hizo una "que llevó mil y trescientos quintales de vena"537. En este caso, que sabemos que utilizaba mineral de Somorrostro, porque la vena vizcaína se exportaba siempre sin raguar por la escasez de madera de aquella región.

La ragua se hacía en el monte o más generalmente en las "plazas” que había al lado de las ferrerías538. Antes de calcinar la vena normalmente se la sometía a un lavado para eliminar la tierra y otras impurezas en el arroyo cercano a la fábrica539. Con la ragua, por tanto, aquella perdía aproximadamente un $40 \%$ de su peso, aunque aumentaba el rendimiento del mineral540. En todo

533 ESTADÍSTICA MINERA, años 1864 y 1873

534 MUNÁRRIZ, p. 131: "Antes de echar en la fragua el mineral se calcina o ragua fuera de la herrería, al aire libre, formando una gran pila de mineral y madera verde, gruesa y sólida, de roble y castaño; está ardiendo regularmente seis a ocho días y otros tantos o más tarda el mineral en concentrarse y enfriarse, pues llega a ponerse en estado casi metálico; esta operación preliminar la ejecuta algún paisano de las inmediaciones práctico en ella, ayudado de tres o cuatro personas; regularmente no se hace más que una vez al año"

535 Esto a veces lo hacían los propios venaqueros, por lo que contaban con caballerías para transportarlo hasta el lugar de la ragua. En 1629 el venquero Miguel de Loreaga, que está en la ferrería de Pontepetre, compra al contador del marquesado de Villafranca, por 39 ducados, un macho con sus albardas, cargas y cabeceras (AHPL. P.N.: 2669).

536 MUNÁRRIZ, p. 131.

537 AHN. Clero: libro 9437

${ }_{538}$ En el inventario de Juan Ortiz, rendero de Soldón, de 1558, se menciona "quinientos quintales de bena por cozer junto a la ragua de la dicha ferrería" y "otros quinientos quintales de bena cocida en los Formigueiros donde se saca” (AHRG. R. A.: 19.768/32).

539 En el informe sobre la ferrería de Pombriego de 1891 se dice concretamente que "antes de calcinar la vena se somete á un lavado por medio del agua de un arroyo inmediato á la fábrica, para purgarla de la tierra que contiene”. ESTADÍSTICA MINERA, 1891, p. 193

540 IBIDEM: "con una ragua de 6.90o kilogramos de vena y 4.600 de leña, se obtienen 4.025 kilogramos de hierro, que representan una ley de 58\%; es decir, que por la operación del lavado aumenta el rendimiento, como debe suceder" 
caso, la ragua era un dispendio de leña. No existían, lo hemos visto y lo confirma Datoli, hornos de calcinar con lo que economizar aquella541 que, al parecer, ya se utilizaban en el país Vasco542, aunque también hubo alguno en el noroeste, como en la Somoza, que aún se conserva en buen estado, y en la ferrería de Linares543. Por esta razón, los contratos, con mucha frecuencia, estipulan el tipo de vena que adquieren las ferrerías: raguada o sin raguar. En ocasiones, un mismo arrendatario compra indistintamente uno u otro tipo544. En las cuentas de la ferrería de Quintá se menciona siempre vena de los dos tipos545.

El transporte de la vena se hacía en caballerías y, como dice Datoli, también en carros ${ }^{546}$. A veces, las ferrerías disponen de medios para el transporte, pero más frecuentemente lo realizan arrieros547. En algunos casos tales arrieros están ligados a las ferrerías por deudas contraídas con los arrendatarios 548 . Munárriz dice que las ferrerías, normalmente, no tenían

${ }^{541}$ DATOLI, p. 55: "Esta operación la executan en la misma herrería por el método ordinario, porque no conocen en aquella provincia el uso de los hornos de calcinar, con lo que economizarían considerabemente los montes, que están en la mayor decadencia”.

542 La Real Sociedad Vascongada, hacia 1773, impulsó pruebas en este tipo de hornos que resultaron muy positivas. En J. ALMUNIA (1951): Ob. cit., p. 17 y 18

543 A.M.S.: Estado General de Cuentas del Monasterio de Montes (18249: El abad (1818-1821) "hizo también un horno para cozer la vena en la herrería de Linares".

544 AHPL. P.N.: 2936 (1666) Por ejemplo, en Ponte Petre, don Lucas de Acevedo adquiere en 1666 a Lorenzo de la Peña y Antonio de la Rivera, vecinos de Gestoso, "ciento y cinquenta cargas de bena de las beneras de Baldecaballos para el consumo de dicha ferraria, que sea vien cozida y separada a satisfación de los oficiales que la ayan de trabajar, y a su quenta y mensualmente la an de dar a la manera referida de aquí a día de Santiago deste presente año en la rragua donde la a de embiar a buscar dicho don Lucas de Acevedo con las cabalgaduras de arrieros y las suyas". Añade que cada cabalgadura ha de traer quintal y medio, y que pagará por cada carga 4 rs. vn. por lo que las 150 cargas ascienden a 600 rs., de los que a la firma del contrato reciben 400 rs. "en pan, vino, dinero y otras cosas" y cuando terminen, los 200 rs. restantes. Por el contrario, en 1668, el mismo arrendatario compra a Antonio Cereijo "tres cargas de bena cruda de dar y tomar quebrada en las beneras de Valdecaballos" que debe de traer diariamente desde diciembre hasta mayo (AHPL. P.N.: 2936).

545 AHRG. Marqués de Ombreiro. Documentación de la ferrería de Quintá.

546 Ya hemos visto anteriormente la mención de carreteros en 1756 (AHRG. R.A.: 190/33).

547 Es lo más frecuente y son muchos los ejemplos que lo confirman: Felipe de Garbisso en 1586 se concierta con Alonso Mayo, arriero de Molinaferrera, para que con sus recuas le traiga 200 quintales de vena de Formigueiros (AHPL. PN.: 2874 (1586); y en 1588 adquiere de Marcos Castro, Andrés Alonso y Aparicio Alonso, vecinos de Molinaferrera, 600 quintales de vena de Formigueiros para la "ferraria de Valcarce" (AHPL. PN.: 2850 (1588).

548 AHPL. P. N.: 3025 (1651): Así Juan Rodríguez, arrendatario de la ferrería de Pontepetre, firma un contrato en 1651 con el mulatero Santiago Lameyra, por el cual este le compra a aquel tres cabalgaduras con sus aparejos en 58 ducados, que le pagará en tres años "en travajo de su persona y dichas cabalgaduras a la dicha ferraria, ansí de bena, carbón, como lo demás pagándole conforme suele pagar a los demás arrieros que traen dichos materiales a dicha herrería"; o el contrato de obligación que con don Lucas de Acevedo, arrendatario de la misma ferrería, firma en 1674 el arriero Francisco Yañez, por ciertas deudas contraídas, que le devolverá "en travajo de cabalgaduras, acarretos de vena, con ellas y su persona" (AHPL. P. N.: 2936, (1674) 
caballerías propias y que contrataban el transporte con mulateros lo que suponían un gasto entre 4 y 18 reales por quintal macho gallego, según la distancia de la ferrería al mineral549. En el siglo XIX se habla de que los venaqueros sacaban el quintal gallego de mineral por medio real, mientras que costaba seis reales llevarlo a las ferrerías, lo que es justo pues en realidad es mucho más costoso el acarreo en estos países que el arranque de la vena blanda por los profesionales llamados venaqueiros550.

El precio de la vena, que analizaremos en el capítulo quinto, era pues diferente en la mina que puesto en la ferrería, porque el transporte la encarecía considerablemente, siendo ese coste diferente para cada ferrería en razón de las distancias, que variaban mucho de unas a otras. Munárriz dice que las cinco ferrerías bercianas y las diez gallegas, que se abastecen de mineral de Formigueiros, acuerdan el precio con los carreteros de acuerdo con la distancia "y los caminos, que son malísimos" ${ }_{511}$, y Datoli añade que los carreteros, también lo ajustaban a 4, 6 y 5 reales por el mismo quintal (de $7^{1 / 2}$ arrobas castellanas), según la distancia de las herrerías, que es de 4, 6 y 3 leguas552. La ferrería de Soldón, que consumía vena de Formigueiros, estaba a " $a$ dos jornadas francas al día"553, la de Quintá se hallaba a unas seis leguas y las bercianas entre tres y seis leguas. Por su parte, la ferrería de Lor se encontraba a tres leguas del yacimiento de Rocas554 y la de Tejedo distaba una legua del mineral de la Magdalena555.

Para transportar esa vena desde los yacimientos a las ferrerías, estas contaban normalmente con caminos propios, los llamados "caminos de la

\footnotetext{
549 MUNÁRRIZ, p. 128

$55^{\circ}$ P. HERNÁNDEZ SAMPELAYO (1935): Ob. Cit., t.III, p. 88. En 1810, el apoderado de la marquesa de Viance señala cómo el acopio de materiales hay que hacerlo con buen tiempo "porque en país tan montañoso y escabroso, qual es este en que la abundancia y copiosidad de nieve descarga sin medida ni términos, no permite descubrimiento de los pisos y por consiguiente se hallana interceptados e intransitables los caminos por espacio de meses; razón porque no debe malograrse la suave y apacible estación actual que concede permisión para acopiar todo lo que requieren las fábricas" (AHRG. RA.: 25.291/28).

${ }_{551}$ MUNÁRRIZ, p.134

${ }^{552}$ DATOLI, p. 54

553 AHRG. R. A.: 20.441/70: Se trata de un documento de 1603 un tanto ambiguo, creo que quizá habría que entender cómo que al día se podían hacer dos viajes.

554 CATASTRO DE ENSENADA. R. G.: Barja de Lor.

555 MUNÁRRIZ, p. 136
} 
vena" 556 . Las ferrerías, en los contratos de arrendamiento, solían incluir cláusulas en las que se precisaba que tales caminos había que darlos expeditos para el acarreto de la vena557. Había así, como hemos dicho, caminos que específicamente se denominaban "caminos de la vena", porque su construcción estaba directamente relacionada con esa función558; pero no siempre todos los caminos eran privativos para conducir la vena, sino que los comunales también se utilizaban para el transporte de cosas y personas, como el que desde Formigueiros usaba la ferrería de Bueyes, que seguía en parte por el Camino Real que iba por el Cebreiro559, o el que atravesaba el valle de Quiroga, que también era utilizado por las ferrerías de la zona para transportar la vena desde aquel mencionado yacimiento560.

En este último caso no está claro si originariamente había sido exclusivamente un camino de la vena, como arguyen los monjes de Samos en el juicio que sostienen con el dueño de la ferrería de Quintá en 1808, o un camino comunal. En otros así era realmente, porque los caminos de la vena eran con frecuencia una construcción de las propias ferrerías para su servicio, como ocurría con la mencionada de la Rodela, del monasterio de Samos, que

556 AHRG. R. A.: 2619/20. En 1721 en un pleito de los vecinos contra don Bernardo Neira, de la ferrería de Quiroga, se señalan los límites en Campos de Vila: "desde el arroyo de la Toca asta el camino de la vena"; y en Varxas "desde el rigueiro do castro de malcatan subiendo a la sierra asta mas adelante del camino de la vena".

557 AHRG. R. A.: 2472/120: En 1573 en el arriendo a Miguel Ortiz de la ferrería de Ferreirós, el arrendador está "obligado a dar hecho el camino que va de la ferrería de Ferreirós al benero de Formigueros por donde bos el costa".

${ }_{558}^{8}$ AHRG. R.A.: 26319/20: En un pleito contra don Bernardo Neira, en 1721, se menciona en Campos de Vila, los montes "desde el arroyo de la thoca asta el camino de la vena" y en Varxas "desde el rigueiro do castro de Malcatán subiendo a la sierra asta más adelante del camino de la vena".

559 AHPLU: 2417/5: En 1752 don Pedro de Ulloa, dueño de la ferrería de Bueyes, alega en un juicio que él y sus mayores estuvieron siempre "en la quieta y pacífica posesión de transitar con bueis y carros para conducir la bena de hierro desde el mineral llamado de Formigueiros para su erraria de Bueis por el camino Real que ba desde el lugar de Piedrafita del Zebebro y de allí a la trabiesa del mismo nombre del zitado mineral a Baldeorras, Orense hasta llegar al reino de Portugal.

560 AHPLU: 2406/6: Los vecinos Soldón y Villarbacú, del coto de La Seara, denuncian en 1808: "que desde tiempo inmemorial a esta parte, ellos y los de quienes deriban, junto con los más vecinos de los lugares de todo este partido, han conducido en carros y cavallerías la vena del Monte de Formigueiros, situado entre este coto y el de Visuña, para todas las herrerías de la circunferencia, y entre ellas lo son la de Quintá, propia del señor don José $M^{a}$ de Prado, vecino de Lugo, y la de la Rodela del Real Monasterio de Samos, por el camino carretero que ba desde este dicho coto, atravesando por los lugares de Besarredonda, Bustelo y Lama, separándose más abajo de este, los dos que cogen, uno a la de Quintá, y otro a la Rodela; cuia carretera siempre sirvió, no solo para la conducción de bena, leña y más materiales de las dos Fábricas, sino también para otros distintos servicios de estas montañas y todo el valle de Quiroga, por hallarse en su embocadura, sin que jamás se experimentase la menor contradicción". 
disputaba a otras fábricas la propiedad de esos caminos por el valle de Quiroga561. Estas polémicas se mantuvieron en el siglo XIX 562 y, por los pleitos que conocemos no afectaron a esta sola ferrería sino a otras muchas 563.

Como los caminos eran generalmente intransitables durante los meses de invierno, había que transportar la vena en el verano, que, por otro lado, era cuando se la extraía de las minas como ya dijimos564. En general las fechas límites se situaban entre el día de Santiago hasta Nuestra Señora de septiembre, es decir entre el 25 de julio hasta el 8 de septiembre565, aunque estas fechas no eran muy rígidas, pudiéndose alargar hasta la caída de las primeras nieves. A partir de esta fecha, estos caminos de montaña se hacían impracticables por la

${ }^{561}$ AHRG. R. A.: 190/33: En 1756, en un juicio por abrir una zanja que rompe un camino, al testigo Antonio Núñez se le pregunta: "si sabe que la erraria de Rodela del Real Monasterio no se surte de bena por un camino o puerto del Rio que dexa depuesto mas de tan solamente desde mediado agosto asta mediado octubre porque antes están ocupados los carreteros de ella en todo el término del berano en sus labores y después cubre la niebe el camino de la conduzión y por el solo biene en dicho tiempo por el del puerto referido", a lo que contesta: "que en alguna o mas ocasiones y tiempos que bino a este pais al fin tiene depuesto benya y tropezaba en el camino y puesto que atrabiesa el citado rio Quiroga algunos onbres y personas que no conocia con bueies y carros cargados de bena para dicha erraria por verles enderezar y pesarla en ella por el peso según costumbre y regla de errarias y si por dicho sitio y camino se surte la erreria motibada" (y no sabe mas)

562 En 1813 aún se mantenía la vieja polémica entre aquellas dos ferrerías. Samos argumentaba que "por medio de operarios y alarifes, antiguamente, (había) construido a sus espensas y para la más cómoda conducción de bena para esta fábrica (de La Rodela) un camino carretal" que se denomina de Valdeseara, que va por Teso de la Portela, Porcariña y Aira de Redondos hasta llegar al lugar de Bustelo; camino que es privativo suyo pero que los administradores de la ferrería de Quintá utilizan, por lo que se querellan contra ellos; pero por no gastar en pleitos acuerdan que "el padre prior de La Rodela por hacer gracia y merced a don Pedro Rigueiro le concede permiso para que por si y sus carreteros de bena pueda transitar por el citado camino del monasterio y conducir desde primero de diciembre hasta el quince de abril de cada año a la erraria de Quintá, sin que él, sus subcesores, dueños de ella ni mandatarios lo puedean usar en los meses restantes del año". Don Pedro, por su parte, añade que usará, como ya lo hacía antes, el camino de Chao dos Boys y Coedo, que debe de ser otro distinto al anterior, para la conducción de la vena que necesite sin necesidad de permiso alguno (AHPLu: 2467/12)

${ }_{563}$ AHRG. R.A. 23088/72: En 1824 el administrador de Incio, Juan Fariñas, lo hace contra don Bernardo de Prado Quiroga, administrador de la ferrería de Gonzar o Paredes por el uso de leña y por abrir un camino para raguar la vena de Roques en San Miguel, en Incio, antes de llevarla a su ferrería; juicio que continúa en 1827 con la condesa de Campomanes, como dueña de la ferrería de Incio, por el mismo motivo; es decir, abrir un camino desde el monte de Chao Lamelas " $y$ por él conducir vena del mineral de Roques para depurarle de la primera escoria $y$ cocer raguar junto a la dicha casa de San Miguel, para el consumo de la Herrería de Paredes o de Puerto Marín".

564 AHRG. R. A.: 25.291/28: Juicio en 1810 contra Fco. Rivadeneira, rendero de Lousadela y Ferreirós: "Porque un país tan montañoso y escabroso, qual es este en que la abundancia y copiosidad de nieve descarga sin medid ni términos no permite descubrimiento de los pisos y por consiguiente se hallan interceptados e intransitables por expacio de meses; razón porque no debe malograrse la suave y apacible estación actaul que concede permisión para acopiar todo lo que requieren las fábricas".

565 AHN. Estado: leg. 1739, no 16: En 1694 don Pedro de Ulloa, dueño de la ferrería de Bueyes, da permiso a Francisco García de las Llanas, de la ferrería de Pontepetre, para transportar por el camino de Faro vena de Formigueiros a su ferrería "desde el día de Santiago hasta Nuestra Señora de septiembre”. 
nieve566, que suele caer copiosamente. Por otro lado, la ragua, que como hemos dicho se hacía una o dos veces al año, también era mejor hacerla hacia el otoño o en los últimos meses del año.

\section{EL RENDIMIENTO DEL MINERAL}

El mineral de hierro utilizado en la siderurgia tradicional, es decir, los óxidos (hematites roja, limonita, goethita o magnetita) tiene una riqueza elevada, superior al 60\%, pero las ferrerías no lograban un rendimiento mayor del 30 al 35\%. Aunque con la ragua se obtenía una mayor concentración del mineral, como ya hemos visto, luego en el horno no se alcanzaba un rendimiento más allá del mencionado. Cornide, hacia 1780, afirma que el rendimiento del mineral local era de entre un 30 y un 33 por ciento567; Munárriz (1807) habla de un 30 a un 35\%568, un informe de 1891 de un 33\%, Cueto Noval (1910) de un 35\%, y lo mismo dice Antonio Eleizegui (1910)569.

Este rendimiento es parecido al del mineral vasco, ya que normalmente se necesitaban tres unidades de mineral por una de hierro, lo que supone igualmente un rendimiento del $33 \% 570$. Schulz señala que a excepción de la de Agüera todas las ferrerías asturianas consumían mineral de Somorrostro, unos 44.00o quintales de vena al año que producían unos 12.500 quintales de hierro,

\footnotetext{
566 Datoli escribe que el mineral de Formigueiros que piensa utilizar en la ferrería de La Somoza habrá de traerse en el verano "como lo executan las herrerías de Valcarce y Bueyes, por causa de la mucha nieve que cae en el monte llamado los Fornos de Céramo" (DATOLI, p. 59). En un pleito de las ferrerías de Lousadela y Ferreirós (AHRG. R.A.: 25.291/28) se habla de la zona de Quiroga y Caurel así: "porque en un pais tan mantañoso y escabroso, qual es este en que la abundancia y copiosidad de la nieve descarga sin medida ni términos no permite descubrimiento de los pisos y por consiguiente se hallan interceptados e intransitables los caminos por expacio de meses; razón por la que no deve malograrse la suave y apacible estación actual (verano) que concede permisión para acopiar todo lo que requieren las fábrica". En 1808, en un juicio por el uso de caminos por las ferrerías de Quintá y La Rodela en el valle de Quiroga, se habla de uno, distinto al general, "que viene por distinta sierra y que sólo sirve para unos tres meses de berano, por hallarse los más cubierto de nieve" (AHPLU: 2406/6).

567 C. GONZÁLEZ (1994): Ob. cit., p. 44

568 MUNÁRRIZ, p. 156. Dice que el mineral para ser trabajado en el horno bajo (a la catalana porque ésta destruye y quema mucho metal) debe ser muy rico, que no baje de 50 a 60 por 100 , como el de Formigueiros, pues "no se saca en las herrerías más que un 30 a 35 por ciento".

569 Cit. Por P. HERNÁNDEZ SAMPELAYO (1935): Ob. Cit., t. III, $2^{\circ}$, p. 676

570 R. URIARTE (1988): Ob. cit., p. 142, presenta una relación de regiones del sur de Francia y norte de España, del año 1827, y las cifras van de 2,97 a 3,18 partes de mineral para cada unidad de hierro,lo que supone porcentajes muy semejantes a ese $30-35 \%$.
} 
lo que no llega ni siquiera a un 30\% de rendimiento57. Creo que un $33 \%$ es una cifra media del rendimiento del mineral local, como se deduce de los datos del CUADRO XIII.

CUADRO XIII RENDIMIENTO DEL MINERAL EN 1874

\begin{tabular}{|l|l|l|l|}
\hline FERRERÍA & $\begin{array}{c}\text { MINERAL } \\
\text { (en q.m.) }\end{array}$ & $\begin{array}{l}\text { HIERRO } \\
\text { (en q.m.) }\end{array}$ & $\%$ \\
\hline FERREIRÓS & 600 & 200 & 33 \\
\hline LOUSADELA & 850 & 400 & 47 \\
\hline ORREOS & 500 & 175 & 34 \\
\hline PALEIRAS & 102 & 34 & 33 \\
\hline RODELA & 450 & 150 & 33 \\
\hline RUGANDO & 1.350 & 450 & 33 \\
\hline SEOANE & 300 & 100 & 33 \\
\hline SOLDÓN & 1.719 & 573 & 33 \\
\hline VALDOMIR & 600 & 200 & 33 \\
\hline VILARBACÚ & 600 & 200 & 33 \\
\hline TOTAL & 7.071 & 2482 & 35 \\
\hline
\end{tabular}

Fuente: Estadísticas Mineras. Cit. P. HERNÁNDEZ SAMPELAYO (1935):

Ob. cit., t. III, $1^{o}$, p. 39-4O.

${ }^{571}$ G. SCHULZ: Ob. Cit., p. 384 


\section{LAS CONDICIONES HUMANAS: PROPIETARIOS, RENTEROS Y TRABAJADORES}

Para poner en marcha una ferrería, además de agua, combustible y mineral de hierro, había que contar con el permiso de las autoridades y con el de los dueños de las tierras (señores y concejos); pero sobre todo había que poseer recursos financieros, porque las cuantiosas inversiones que requería su construcción no estaban al alcance de cualquiera. El coste de estos artefactos era muy elevado, exigía un capital fijo del que sólo muy pocos podían disponer o lograr los créditos, bajo la forma de censos, necesarios para ello. Dicha construcción fue promovida unas veces por los propietarios del suelo, montes y aguas (nobleza e instituciones religiosas) para explotar esos recursos, cuyo valor agrícola, en muchos casos, era escaso; en otras ocasiones la iniciativa partió de la hidalguía rural e incluso de los mismos ferrones vascos que lograron de aquellos propietarios las aguas, montes y tierras en arrendamiento para poderlas levantar.

La explotación de las ferrerías se hizo ya de forma directa por el propietario o por un administrador, que adquiría la vena y el carbón y contrataba los oficiales de la ferrería, ya arrendándola por años a persona interesada y experta en la materia, o a largo plazo, aforándola. En cualquiera de los casos, tal explotación era un negocio costoso por las materias primas y los salarios, lo que exigía un capital circulante igualmente elevado. En general, durante el siglo XVI y en parte del XVII las ferrerías fueron generalmente arrendadas a corto plazo, aunque luego sus dueños prefirieron aforarlas porque entendían que así se protegían mejor tales artefactos y los montes que las abastecían 572. Por el contrario, las órdenes religiosas desde finales del siglo XVII tendieron a explotarlas directamente por medio de un monje, al que con frecuencia se le denomina prior rendero, el cual dirige la ferrería y da cuenta a

572 AHRG. R. A.: 19.768/32: En 1550 la encomienda de Quiroga afora a Juan Ortiz la ferrería de Soldón, porque pra el comendador y los que le sucedieran, pero sobre todo para la ferrería, era mejor "el hazer della fuero por años que no arrendarla de tres en tres años porque a causa de la tener por tan poco tiempo la dexaban ir a yermo e asolaban los montes necesarios para las maderas della". 
la comunidad de los gastos y beneficios573. La pequeña nobleza, la hidalguía y algunos foreros también solían arrendarlas, aunque desde el siglo XVIII la explotación directa por medio de administradores, muchos de ellos presbíteros 574, fue muy frecuente. Este mismo sistema será el más generalizado en el siglo XIX, aunque hay casos de gestión directa.

Arrendatarios o foreros y administradores explotaron las ferrerías mediante la contratación de oficiales o ferrones que, al menos en los siglos XVI y XVII, fueron vascos; luego vecinos de los alrededores de las ferrerías, en unos casos herederos de aquellos; en otros no, pero conocedores igualmente de la técnica. Además para el comienzo de la campaña anual debían adquirir la vena a los venaqueros, transportarla a las ferrerías por medio de mulateros y carreteros y, por último, comprar el carbón a los carboneros. Todo esto implicaba a un considerable número de trabajadores, la mayoría indirectos -venaqueros, arrieros, carboneros y los que atendían a los arreglos, como barquineros, ferramenteros, tubereros, etc.-, y otros directos, como los ferrones. Aunque no es posible cuantificar con exactitud ese número por ferrería, seguramente pasaban de cuarenta o cincuenta575, lo que dado el número de estas, suponían varios miles de personas las directa e indirectamente ligadas a ellas, eso sin contar los que trabajaban en mazos y fraguas.

\section{LA CONSTRUCCIÓN DE LAS FERRERÍAS}

Además de las condiciones naturales del medio, los ferrones y la tecnología, para poner en marcha una ferrería fueron necesarios permisos y capitales. Los permisos a lo largo de la Edad Moderna los concedían la Corona y los propietarios del terreno. Tanto las minas como los beneficios del mineral

573 MUNÁRRIZ, p. 127

574 La razón de que fueran presbíteros es que sabían llevar la contabilidad, dado que en las ferrerías había varios libros -de oficiales, de la vena, de carboneros, de tratantes-, como por cumplir con el precepto dominical, ya que en general estaban bastante lejos de pueblos e iglesias.

575 L. M. DÍEZ DE SALAZAR (1983): Ferrerías en Guipúzcoa. San Sebastián, t. I, p. 122, habla de 40/50 por ferrería ern Guipúzcoa en el siglo XV I. En ese siglo XVI se dice respecto de la construcción de la ferrería de Quiroga: "dicha ferreria e cassas que en ella y para ella han de acer donde siempre abrá quarenta o cinquenta ombres para el servicio y onrra de esta casa y encomienda y comendadores (...) e que hizo asimismo gran provecho e utilidad por razon de la dicha Herreria e xente que en ella abra las rentas de la dicha encomienda baldrán más" (AHRG. R. A.: 26.319/20). 
eran desde la Edad Media una regalía que, de acuerdo con el ordenamiento de Alcalá de 1348, el rey cedía a terceros mediante licencia y pago a la Corona de un canon. Con algunas variaciones introducidas por la Ley de Minas de 1584 de Felipe II, esa legislación pervivió hasta el siglo XIX en lo que atañe a la mayoría de los minerales. Sin embargo, los recursos no metálicos y especialmente la sal, la piedra y también el mineral de hierro estuvieron vinculados a los antiguos derechos jurisdiccionales de los señoríos 576 . Por eso, son estos los que han dar asimismo el permiso en sus tierras para construir las ferrerías, como vemos en muchas ocasiones de las que tenemos noticia expresa.

\subsection{Licencias de construcción}

Sin embargo era preceptiva la licencia de la Corona, que delimitaba el espacio y señalaba el uso de montes y aguas577, como venía siendo de uso y costumbre desde tiempos medievales, especialmente respecto de los ferrones vascos que gozaban de tal privilegio, como específicamente declara el documento de fundación de la ferrería de Quiroga, en Lugo578. Posteriormente, en los siglos XVI y XVII, fue el Consejo de Hacienda el órgano competente en cuestión de minas, hasta que en 1624 Felipe IV creó una Junta de Minas que se encargó de todo lo relativo a temas mineros y a su beneficio. A finales del siglo XVII, en 1679, en el marco del pensamiento mercantilista y de una política más proteccionista, el rey Carlos II creó una Junta de Comercio para el desarrollo del comercio, las fábricas y el progreso de España. Esta política fue continuada por Felipe V, que en 1730 aprobó una nueva Junta de Comercio y Moneda, cuya secretaría fue la encargada de despachar todas las cédulas y órdenes necesarias,

${ }^{576}$ R. SERRA (2000): "La minería y la metalurgia durante la Edad Moderna". Primer simposio sobre la minería y la metalurgia antigua en el $S W$ europeo. Serós, p. 360.

577 En 1814, en un juicio del monasterio de Samos contra los vecinos de San Pedro de Villajuste, cuyo alcalde pretende impedir el uso de vena y carbón a la ferrería de Pallares, el monje administrador alega "que la mencionada herrería fue erigida como todas las demás, con facultad Real, y con señalamiento de términos para usar de los precisos materiales" (AHRG. R.A.: $1887 / 29)$.

578 En 1566, cuando se construye la ferrería de Quiroga, se recuerda que tal fundación se hace "para que él (Francisco Vázquez) y sus renderos, braseros y ofiçiales y biscaynos que en ella y en los términos della estuvieren y vineren, puedan gozar y se aprovechar de la possesion, privilegios, libertades y franquessas que los reyes e prinçipes de Castilla les an dado y conçedido a las tales errerias e renderos, hazedores y ofiçiales y biscaynos estando en tal proposito y estado para ussar dello mediante la graçia divina de su magestad. Luego oy dicho dia, y luego en consiguiente, para ussar y gozar él e los tales de los privilegios, livertades, franquesas e fueros de Viscaya y España, e ussos y costumbres de errerías" (AHRG. Hombreiro: leg. 19). 
sin intervención de Consejo, tribunal ni ministro alguno, para la buena marcha de estos asuntos. En 1747 Fernando VI agregó a esa Junta los temas mineros, quedando configurada como una Junta del Comercio, Moneda y Minas579, la cual fue la encargada de conceder los permisos para la construcción de nuevas ferrerías. En el siglo XIX, a partir de la Ley de Minas de 1825, esta competencia pasó a la Dirección General de Minas hasta $1836^{580}$, aunque a partir del decreto de 6 de diciembre de 1836 la creación de de este tipo de establecimientos fue libre581; pero desde 1846 se requería una licencia por el uso del agua de los ríos y arroyos $5^{82}$.

Son numerosas las ferrerías de las que tenemos noticia de esas licencias reales o de permisos para su construcción en los siglos XVII al XIX, expedidos por la Junta de Comercio; pero no respecto de las del siglo XVI, de las que sólo conocemos algún caso concreto, como el de la ferrería de Quiroga, de la que ya hemos hablado. De la de Paleiras, que erigió en el siglo XVI el vasco Martín de Aldunzín en territorio propio de la encomienda de la Barra, se habla igualmente de un fuero real583. Esta debía de ser la norma, aunque carezcamos de datos más abundantes para confirmarla en las muchas ferrerías que se erigieron en ese siglo. Por el contrario, en el XVII y sobre todo en el XVIII y el primer tercio del XIX vemos que se construyen siempre "en virtud de Real licencia", "porque ganó una cédula de su magestad", "con permiso de la Junta de Comercio", etc.584. Desde 1836, como hemos dicho, aunque la construcción de este tipo de

$579 \mathrm{M}^{\mathrm{a}}$ C. CALDERÓN y E. ROMERO (2010): "Génesis y competencias de las Juntas de Comercio, Moneda y Minas”. De re metálica, 14, p. 61 y ss.

${ }^{580}$ En 1827 en el pleito entre las ferrerías de Incio y Paredes se dice: "la Dirección General de Minas, en quien residen las atribuciones de la antigua Junta de Comercio, Moneda y Minas de la villa y corte de Madrid" (AHRG. R. A.: 23088/72).

${ }_{581} \mathrm{BOPA}, 25$ de enero de $1837, \mathrm{n}^{\mathrm{o}} 7$. El artículo $1^{\circ}$ de este decreto decía que todos los españoles y los extranjeros avecindados en España "podrán libremente establecer las fábricas o artefactos de cualquier clase que les acomode sin permiso ni licencia alguna".

582 Real Orden de 14 de mayo de 1846. Solicitudes de este tipo podemos ver en el BOPA: 13 de mayo de 1857 (ferrería de Renueva), 27 de mayo de 1857 (ferrería de Bullimeiro), 1 de septiembre de 1859 (ferrería de Abantro), 2 de septiembre de 1859 (ferrería de Vionga). También en el BOPL: 26 de enero de 1856 (ferrería de Llamas), 28 de enero de 1856 (ferrería de Compludo), etc.

${ }_{583}$ AHRG. Hombreiro: leg. 19: "que bien sabe cómo por el Rey nuestro señor me fue dado en fuero los montes, Aguas y pastos para la mi Erraria de las Paleras, que yo edifiqué de nuebo en término de dicha Encomienda".

${ }^{584}$ Sirvan de ejemplo: En 1755 se dice que don Josep Quiroga "ganó cédula de Su Magestad" para edificar una ferrería en Neira de Rey (AHPLU: 6709 (1755); en 1753, el señor de la Casa de Maside, después de obtener el foro y permiso de la condesa de Lemos para construir una ferrería en Penacova, solicitó a la Junta de Comercio, Moneda y Minas el permiso pertinente 
establecimientos fue libre era preceptivo una licencia para el uso del agua por si este perjudicaba a otros beneficiarios.

Además de la licencia real, era también necesario el permiso de los propietarios del terreno, frecuentemente la nobleza, los monasterios, las encomiendas militares y los concejos. Así debió ocurrir con las ferrerías de Arnado, Pontepetre y Valcarce, en el Bierzo; Quintá, Soldón, Rodela, Incio, Ferreirós, Valdomir, Loureiro, Órreos, Santalla, Gondriz, Lorenzana, Peón, y otras muchas gallegas y asturianas. No hay que olvidar que frecuentemente son los señores jurisdiccionales los más interesados en promover su construcción, como comprobamos en el caso de la ferrería de Lor, que se levantó en los primeros años del siglo XVIII en tierras propias de la encomienda de Quiroga. Bulas y decretos repetían a los comendadores que buscaran aumentar la riqueza de esa zona tan pobre585, algo que parece común a otras.

En ocasiones se recuerda que, pese a la propiedad, para poder vender una ferrería se necesitaba el permiso de los señores de la tierra, como comprobamos en el ejemplo de la de Paleiras, construida por Martín Alduncín en tierras aforadas a la encomienda de Quiroga. Cuando este pretende venderla en 1587, dice que no puede hacerlo sin el consentimiento de aquella. Este, después de alegar que "es assi que yo quiero hirme para mi tierra", pretende vendérsela a Francisco Vázquez, que le ofrece 2.000 ducados; pero antes añade que "si la quiere por el dicho precio el dicho comendador" se la vende, y si no la quiere, solicita que le conceda licencia para vendérsela al susodicho Francisco Vázquez,

(AHRG. R. A.: 19.877/30); lo mismo hizo en 1802 Carlos A. García para construir la ferrería de Fonquente y las hermanas Gil de Taboada para la de Gonzar en 1797 (ambos permisos en AGS. Junta de Comercio y Moneda: leg. 295).

${ }_{585}$ AHRG. Real Audiencia: 3020/42. Por eso dice el documento de fundación: atendiendo a que en el coto de Lor "auia muchos montes propios (de su) directo dominio, sin que estos sirviesen de utilidad alguna (para) el aprovechamiento de ellos, ni se cobraba renta por no residir en aquel paraje los comendadores y muchas personas sin titulo ni facultad se entrometían en ellos cortando y talando la leña", el 1 de julio de 1719 la encomienda aforó a don Joaquín Pardo Rivadeneira por la vida de tres reyes, los montes del mencionado coto para que construyera una ferrería " $y$ que éste pudiese usar de la leña de dichos montes, piedra, aguas del río Lor para la fábrica de casas y lo necesario para hacer dicha herrería en que se fabricase hierro". 
dueño de la ferrería de Quiroga. Se trata, como vemos, de una especie de derecho de retracto que tiene el dueño del suelo ${ }^{586}$.

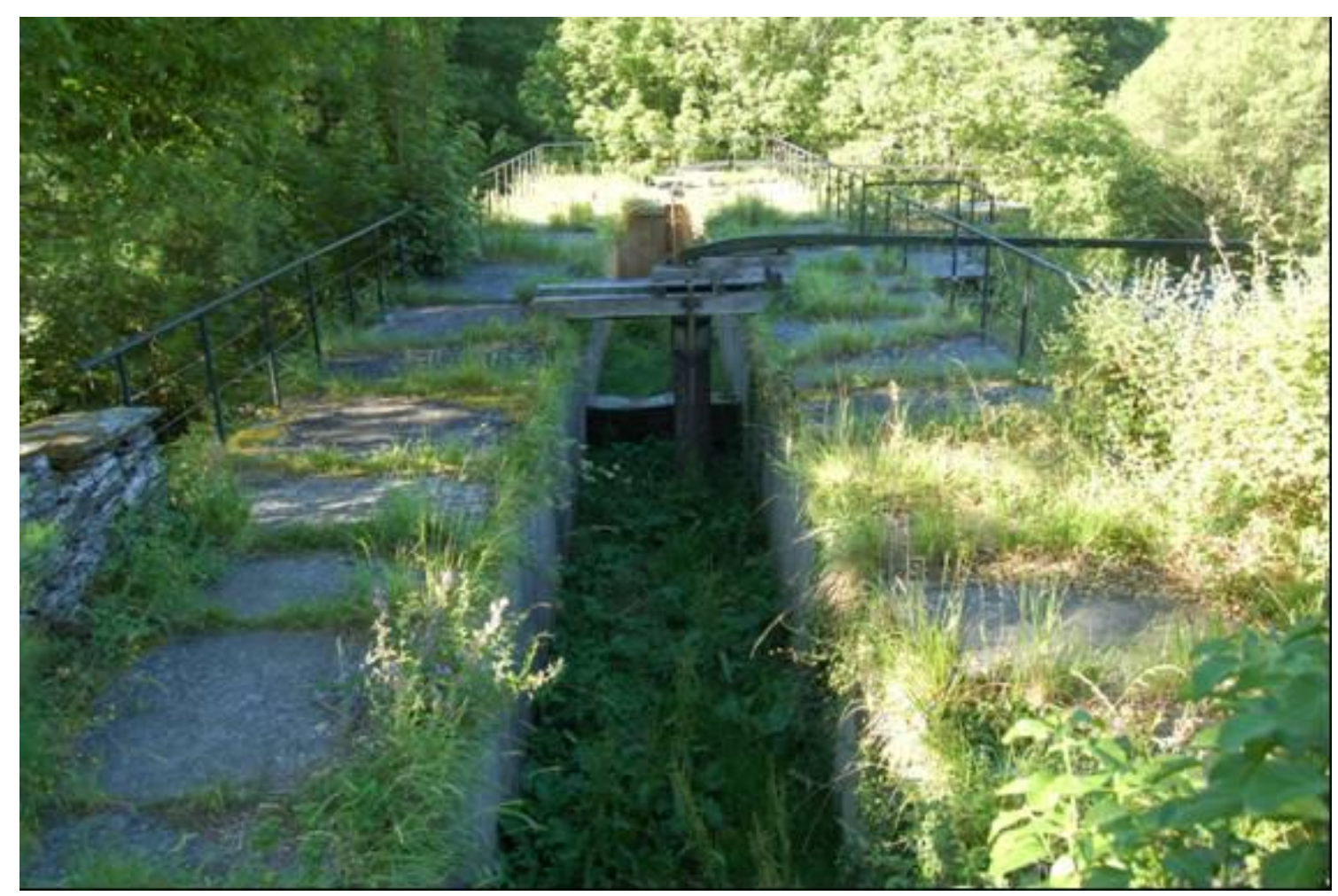

Banzadillo de la ferrería de Seoane del Caurel

Además de los señores jurisdiccionales, los pueblos y concejos, muchas veces propietarios del terreno y los bosques, han de dar igualmente su permiso y licencia para construirlas, porque podían tener ventajas, por ejemplo en el carboneo, pero también muchos inconvenientes. Lo observamos en el caso de numerosas ferrerías de los siglos XVIII y XIX, de los que sólo damos algunos ejemplos; otros pueden seguirse en el el Catálogo de las ferrerías. En 1788 los vecinos de Tejedo y Pereda de Ancares daban su consentimiento para la construcción de la ferrería de Tejedo, porque además de contar con abundantes bosques, tal artefacto sería de una gran utilidad para los vecinos de aquel valle. El permiso incluye la donación de toda la piedra, agua, vena de hierro y leña necesarios para el funcionamiento de la misma, con varias condiciones587. En

\footnotetext{
${ }^{586}$ AHRG. Hombreiro: leg. 19. En esta ocasión, el factor de la encomienda, Juan López, dirá que "no tiene dinero de la dicha encomienda para la compra de la herrería, ni la encomienda tiene necesidad de ella" por lo que consiente en su venta, como así se hizo.

${ }^{887}$ AHPL. P. N.: caja 3492 (1788): Conceden el permiso porque "tenemos superabundantes montes para coadyuvar a la perpetua existencia de la propuesta fábrica sin ser necesario tocar, ni entrometerse a arrancar en los vedados y contados que abundantemente tenemos
} 
1797 los vecinos de varios lugares de la parroquia de Santiago de Fontaneira, en la jurisdicción de Neira de Rey, le conceden un permiso semejante a don Vicente María Pardo Erbón y Rivadeneyra, señor de la casa de Ribas, en el valle de Oselle, y a su socio don Ramón de Ulloa y Valcarce, dueño de la casa de la Peña, en la jurisdicción de Neira de Rey, para construir la ferrería de Piago588.

La ferrería de Seoane del Courel la construyó, entre 1815 y 1817, don Antonio Somoza y Pardo, dueño y vecino de la Casa del Río, en San Martín del Río, en la jurisdicción de Villauzán (La Somoza). El 19 de febrero de 1815, los vecinos de las parroquias de San Juan de Seoane y San Pedro de Esperante, arguyendo que viven en una zona de montaña muy escabrosa con montes y aguas abundantes le dan permiso para construir aquella ferrería 589 . Por último, el ponferradino Nemesio Fernández solicitó en 1823 a los vecinos de Serviz (Barjas) autorización para construir una ferrería en su jurisdicción, a orillas del río Barjas, que le conceden atendiendo a la gran abundancia de urz existente en su término para surtir a una fábrica de hierro y a las ventajas que la misma les iba a reportar para dar salida a la producción de sus montes, exigiendo que sean ellos los que los fabriquen y que no traiga carboneros de fuera590.

para edificios, como tampoco en los fructíferos"; y porque dicha ferrería sería de gran utilidad "a nosotros y demás naturales y residentes en este pueblo, y demás de este Real Valle, tanto por tener a mano y con más comodidad el hierro cuanto por seguirse el que con motivo de la misma fábrica y su construcción, se emplearán sucesivamente". Lo conceden con varias condiciones, que pueden leerse en la monografía correspondiente.

588 AHPLU: 6792/2 (1797). Los mencionados señores intentaban "construir de nuevo una Erraria en terreno suio propio, en el río Neira y sitio denominado da Retorta, términos del lugar de Papín, feligresía de Santa María de Peñarrubia inclusa en esta dicha jurisdición”. Para ello solicitaron permiso para erigirla "en atenzión a que el sitio referido da Retorta, su zircunferencia y a mucha distancia ay número crezido de montes poblados de Brezo, zepa o coza para su surtido, consumo reproduzible a pocos años de su arranque que no sirven para frutificar ni tienen otra utilidad". Permiso que los vecinos les conceden "para que puedan hazer y fabricar la mencionada Erraria disfrutando la leña o coza de los montes en que respectivamente son partizipes", porque así no tendrían que ir lejos a vender el carbón, por ejemplo llevando "a veneficiar (el carbón) semanalmente a la ziudad de Lugo distante más de zinco leguas, mazos de Orizón y otras partes".

589 Dicen los vecinos "que la maior parte de las estaciones del año se ben precisados a no poder cultibar sus granjerías y por consiguiente carecen del forzoso y debido sustento", y que al mismo tiempo por ambas parroquias "gira el río que llaman Lor y que a las orillas de él se miran montes de mucha elevación de producción de leña de roble, cepa de ucedo y otros con bastante abundancia y que igualmente lo hacen de piedra de vena, materiales para fabricar fierro de superior calidad", por lo que es muy idóneo para construir una ferrería, dan su poder a Domingo García, como procurador síndico, para que negocie con alguien su construcción. Haciendo uso de ese poder, el 21 de febrero del año 1815, cede los derechos de ambos concejos a don Antonio Somoza para construir la ferrería. (AHPLU: 2474/4).

590 AHPL. P.N.: caja 3577 (1823) 


\subsection{Oposición a la construcción de ferrerías}

Frente a este interés de algunos vecinos para que se construyan en sus términos ferrerías a las que abastecer de carbón y en las que encontrar, aunque fuese indirectamente, trabajo; por lo general lo que hallamos es una oposición férrea para que no las levanten, arguyendo daños en el bosque591, las aguas o, más frecuentemente a otros artefactos. La oposición más dura suele venir de propietarios de ferrerías establecidas anteriormente sobre el mismo río, pero también de los que utilizan el agua para riego o para mover las ruedas de molinos, batanes y otros usos.

La mayoría de los problemas derivaban de la pluralidad de intereses en torno al agua y el bosque. No hay que olvidar que hasta mediados del siglo XIX la historia de la industria es la historia del agua, y mucho más la de la siderurgia592. El agua era la más importante de las energías pero, al mismo tiempo, era también una fuente de conflictos por los intereses que se suscitaban en torno a ella, tanto de los molinos, batanes, mazos y ferrerías instalados en un mismo río, como por otros usos, especialmente el riego. De ahí que no sólo se originaran pleitos entre ferrerías, que a veces lograron paralizar la construcción de otras nuevas, también con los otros artefactos: molinos y batanes; pero sobre todo con los campesinos y concejos por el riego de sus campos593.

${ }^{591} \mathrm{El}$ monasterio y los vecinos de Campos de Vila, Barxa, San Mamed de Fisteus y otros lugares pleitean contra don Bernardo de Neira en 1721, porque "con la ocasion de hauer fabricado una Herreria nueua en dicha jurisdicion de quiroga pretenden ynpedir a mis partes y mas vecinos del uso y aprovechamiento de dichos montes, su leña y carbon subponiendo tener a ello derecho y posesion", a lo que alega don Bernardo que no es cierto, pues por foros sucesivos desde 1562 todos esos montes son suyos y no libres ni de Samos a quien venden el carbón (AHRG. R. A.: 26.319/20). En 1623 se solicitó la construcción de una ferrería de obra nueva en el lugar de Pumar de Veiga, en Santiago de Abres, argumentando que "con la dicha obra y herrería no hacemos daño ninguno ni perjuicio a la dicha feligresía ni a otra persona ninguna ni a los concejos de Santiago ni Santiso ni Taremunde ni en el dicho rio que jamás ningún paso ni hacemos presa". Además de no hacer daño en el agua tampoco lo hacía en el monte, porque los dueños de la ferrería "tienen mucha cantidad de montes propios por mas de cincuenta años". Los vecinos parece que no estaban de acuerdo con estos argumentos por lo que iniciaron un pleito que, sin embargo, no interrumpió la construcción de la ferrería (A.D.O. Parroquia de Santiago de Castropol, caja 14.3.218)

592 D. WORONOFF (1994): Histoire de l'industrie en France. E. Seuil. Paris, p. 106.

593 Según P. SAAVEDRA (1994): La vida cotidiana en la Galicia del Antiguo Régimen. Barcelona, p. 112 "en la zona interior de Lugo la extensión del cultivo de la patata en la $2^{\text {a }}$ mitad del siglo XVIII implicó profundos cambios en la rotación de cultivos y en la distribución anual del trabajo; porque además fue acompañado de un aumento de la superficie de prado, de ahí la abundancia de pleitos por las aguas”. 
Las razones que se alegaban más frecuentemente eran la escasez de agua para los diferentes usos o que al embalsarla aguas abajo de una ferrería o de un molino podía "encorar" o embalsar el agua e impedir que aquella pudiera mover sus ruedas. Por eso en muchos lugares fue necesario regular su uso mediante ordenanzas o fueros, aunque, a diferencia del País Vasco, en el noroeste no hemos hallado ningún Fuero de Ferrerías594. Los pleitos que nos interesan son, evidentemente, los que afectan a las ferrerías, cuyo número es más pequeño, pero constituyó un problema que no dejó de inquietar a sus dueños por los gastos que suponían. Podemos clasificarlos en dos tipos: los que afectan a ferrerías con concejos y vecinos y los que se suscitan entre ferrerías.

1. Conflictos con concejos y vecinos: probablemente se trata del que suscitó mayor número de pleitos entre ferrerías y uso del agua. En la mayoría de los casos, como hemos dicho, el problema derivaba de la necesidad de regar los campos, pero también porque aquellas alteraban u ocupaban los caminos. Xosé M. Candal sostiene que la causa más importante de los numerosos pleitos que se suscitan en el siglo XVIII en la Real Audiencia de La Coruña -unos 1.434 instruidos o que se conservan (otros muchos ni siquiera llegaban a esa instancia)-, en un 95\% fueron debidos a conflictos por el uso de agua para el riego, especialmente por el aumento en la segunda mitad del siglo de las tierras dedicadas a prados, aunque también hay un porcentaje, entre un 8 y un $11 \%$ de conflictos entre riego y molinería. Los labradores (50\%) o los grupos vecinales (21\%) son los principales promotores de esos juicios, pero los grupos privilegiados, que sólo representan el $2 \%$ de la población, sostienen entre el 27 y el 35\% de los mismos595. Los que afectaron a campesinos y ferrerías fueron poco numerosos, pero existieron y los siguientes pueden servirnos de ejemplo:

\footnotetext{
594 M. K. CAMPOS y B. FERNÁNDEZ (1996): "Fuero de ferrerías del valle de marquina de Suso". En Actas de las I Jornadas sobre minería y tecnología en la Edad Media peninsular. León, p. 625-637; J. A. LEMA PUEYO (1996): "Instituciones en el fuero de Ferrerías de Vizcaya (siglo XV)". En Actas de las I Jornadas sobre minería y tecnología en la Edad Media peninsular. León, p. 691-698; J. L. ORELLA ANZUÉ (1996): "El fuero de Ferrerías de Guipuzkoa (1338). Fijación crítica del texto y estudio de sus instituciones". En Actas de las I Jornadas sobre minería y tecnología en la Edad Media peninsular. León, p. 567-604.

595 X. M. CANDAL (1993): "Pleitos de aguas en la Audiencia coruñesa durante el siglo XVIII". Obradorio, $n^{o}$ 2, p. 85-103
} 


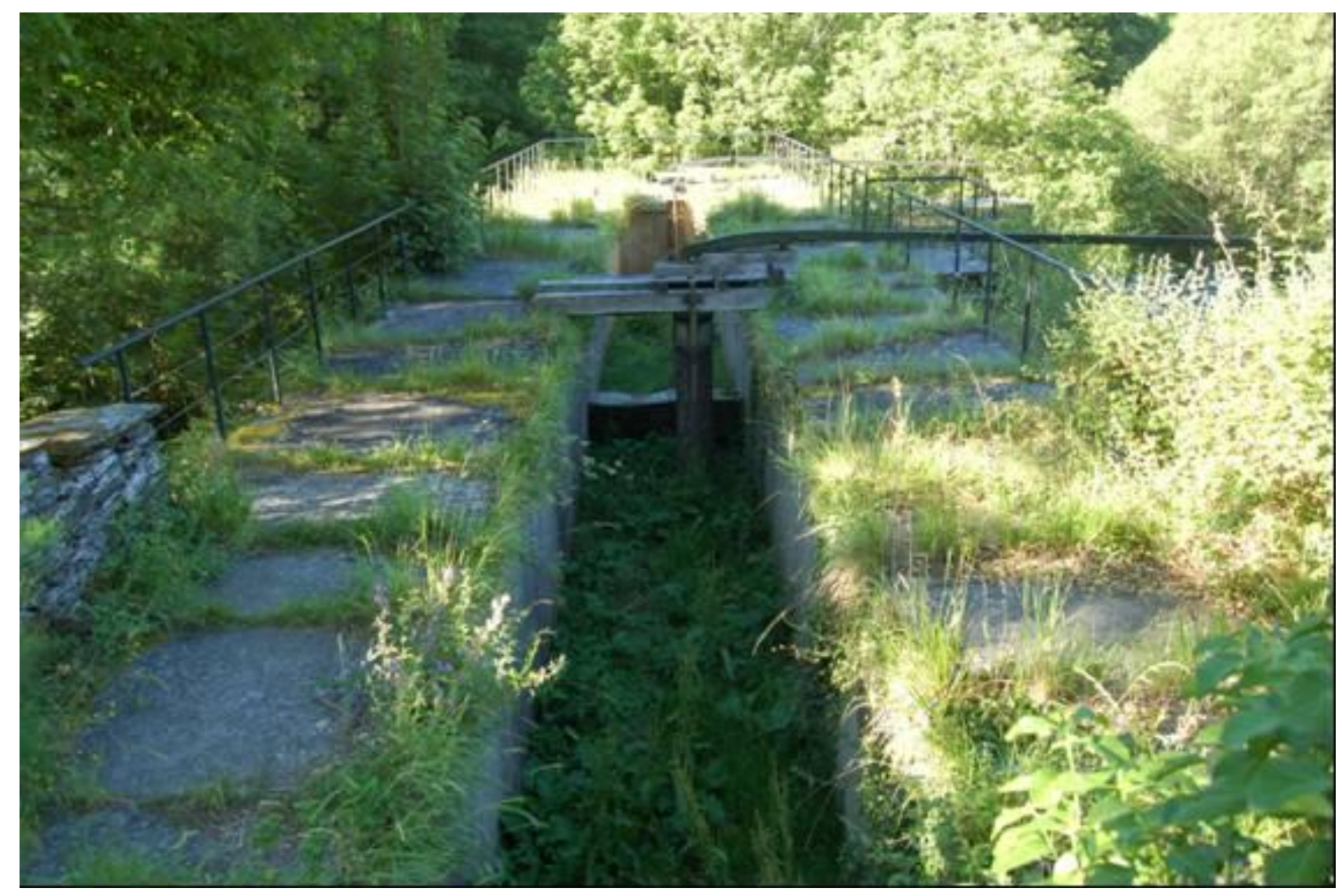

Fueron frecuentes los conflictos por el uso del agua, por ejemplo con molinos

* En 1549 Gutierre de Hebia, vecino de Villaviciosa, pretendió hacer una ferrería en una heredad suya y traer agua de un arroyo que pasaba cerca, atravesando un par de sendas o caminos. Los vecinos se lo impiden pese al daño que eso ocasionaba a "la república" porque "las herrerías son en ellas muy necesarias"596. También a causa de un camino pleitean el propietario de la ferrería de Sueiro, en Asturias, en 1625, con Diego García de la Vega que pretendía erigir al lado una nueva, aunque el pleito oculta otros intereses, como veremos luego597.

* En 1619 Pedro Díaz denunció a vecinos del lugar de Santa Eufemia por abrir una presa para regar sus prados, alegando que la ferrería de Valdomir tenía un fuero real para el uso del agua y los montes, por los que pagaba renta a la encomienda de la Barra598. El inicio de la

596 L. FERNÁNDEZ MARTÍN (1975): Ob. Cit., "Provisiones reales a favor de Asturias durante la regencia de los reyes de Bohemia (1541-1551)". BIDEA, $\mathrm{n}^{\circ} 84$ y 85, p. 322

597 ACh.V. Registro de Ejecutorias, caja 2489,47

598 AHRG. R. A.: 5951/55 : Dice tener "en fuero real la dicha ferrería de Valdomill, aguas, montes y beneras a ella anejos y pertenecientes para el uso y exercicio della de que paga fuero y rrenta al rey nuestro señor y al comendador de la Varra en su nombre". Añade además que no solo él sino su padre, Juan de Zuluaga, "y mas antecesores están en la posesión quieta y 
querella era más antiguo, pues en 1612 el propietario se había concertado con los vecinos para que estos no hicieran la presa a cambio de cuatro quintales de hierro al año; pero no cumplieron lo acordado599.

* El cura de Fisteus, don Francisco Rodríguez de Losada, su hermana y los hijos de esta mantuvieron un largo y engorroso pleito con el monasterio de Samos por abrir aquellos, por debajo de la ferrería de la Rodela, un cauce "de más de quatro baras y media de alto" para regar un prado; pues tal presa o chapacuña para desviar el agua la encoraba e impedía que las ruedas de la ferrería pudieran moverse. El pleito se inició en 1756 y pese a las sentencias favorables para el monasterio en 1759, aquellos y sus herederos volvieron a reiniciarlo en 1763, 1799 e incluso en 1826, siempre con sentencia favorable para los monjes 600 .

* La ferrería de Soldón pleiteó entre 1791 y 1793 contra varios vecinos de Outeiro por abrir unas zanjas, una en el sitio de la Mallada de Montouto y otra por la parte de abajo de la Fervenza, para regar un prado, lo que perjudica a la ferrería que estaba por debajo601. Al final propietario y vecinos se conciertan en que estos han de terraplenar las zanjas, no podrán privar a la ferrería del agua y pagarán las costas del juicio.

* Las familias Sánchez y Arza, que llevan las fraguas del mazo de Folgoso, que trabaja con las aguas del río llamado "do Mazo" permiten en 1807 a Manuel Sánchez Bullín abrir una presa para regar un prado en las Valiñas, con la condición de que no falte nunca agua al mazo ${ }^{602}$.

pacífica de llebar a la dicha ferrería toda la agua del río de Santa Eufemia para la labrança della". 599 AHRG. R. A.: 5951/55

6oo AHRG. R. A.: 190/33, 6.800/4, 13.895/2, 7.199/6. En 1826 el sobrino del cura, Francisco Losada, dueño de la casa del Puente, aprovechándose de la situación creada durante el Trienio "conoció ocasión oportuna para conseguir lo que hasta allí no pudiera y empezó a arrojar al albero del río piedra, cascajos, maleza, etc.". El odio al monasterio debió de ser persistente.

${ }^{601}$ AHRG. R.A.: 11.587/10: El dueño, don José Ignacio Quiroga Ulloa, alega que su ferrería "trabaja con el agua que baja del riachuelo a que da nombre aquella fábrica, y se compone de los arroyos denominados de Montouto y Seara, de cuia agua ha usado siempre".

602 AHPLU: 2454/7 
* El dueño de la ferrería de Soldón denuncia en 1813 a Domingo Rodríguez, del lugar de Soldón, por la construcción de una presa para regar un prado. Para evitar los costosos gastos del juicio aquel le permite la construcción de la presa pero sin perjudicar a la ferrería ${ }^{603}$.

2. Conflictos con otras ferrerías: fueron muchos los conflictos entre ferrerías a causa del agua, aunque probablemente esta oposición encubría intereses sobre el bosque o sobre la competencia en la venta del hierro. Si la nueva ferrería se construía aguas arriba de la más antigua se alegaba que aquella le quitaba el agua o que el río no proporcionaba agua suficiente para ambas, aunque los expertos solían negar esta razón porque el agua de una servía para la otra. Por el contrario, si se construía aguas abajo, la nueva encoraba o estancaba el agua y esto, al subir el nivel, detenía el movimiento de las ruedas ${ }^{604}$. Veamos algunos ejemplos:

* Pedro Bolaño Ribadeneira, propietario de la ferrería primitiva de Bueyes, pleiteó en 1611 con Vasco Sánchez de Ulloa y Rivadeneira, señor de la casa de Noceda de Doncos, en cuya jurisdicción se encontraba aquella ferrería, porque este pretendía hacer otra en el mismo río de Bueyes, a distancia de media legua de la anterior605. El señor de Noceda alegaba que el agua no perjudicaba a la primitiva ferrería, porque se situaba por encima de la que deseaba construir, y porque además hacía

\footnotetext{
${ }^{603}$ AHPLU: 2406/1: Se lo permite "sin perjuicio de su herrería, de modo que siempre que se necesite el agua para ella la han de poder cortar sus administradores o arrendatarios en la motivada zanja"

604 AHRG. R.A.: 1662/4. En el pleito por la construcción de la ferrería de Quintá, varios maestros de ferrerías contestan en 1692 como testigos y explican lo que ocurre con el agua: Francisco Ferreiro "dixo que dicha herrería y banzado anda asi y puede andar otros veinte o treinta años o más, pero que si lo quiere levantar que no se le puede quitar; y que no por eso haze agrabio porque ay lugar río arriba para subir la presa de la herrería de dicho convento hasta fin de la estacada que está enfrente de la presa en tierra de la encomienda, junto a un castaño mayor que los otros en aquel soto que está en la punta del rayro por donde iba el agua de la estolda, y que coxiendo allí el agua puede levantar dicho vanzado aunque sea un estado y que después si lo quisieren subir no podrán, y que llegando allí la presa de dicha herrería biexa ará daño a la estolda de la del dicho don Antonio, porque con lo que levante la presa detendrá o represará el agua, y la ará volver atrás, y volviendo que estorbará andar las ruedas".

605 AHRG. R. A.: 21477/96: En 1611 dice: "que teniendo él una herrería en el río de Bueis mi parte aze otra herrería en el dicho río con que le quita el agua y se aprobecha de sus montes"; otro escrito de 1612 añade: "debe declarar no se poder dar licencia al sobredicho para poder edificar la dicha erraria por todo lo general y lo otro porque la mitad del río en que se edifica la dicha erraria es de mi parte y el sobredicho saca la dicha agua de la madre del dicho rio siendo caudaloso y le quita su corriente y la agua que vaya para las molyendas y el regar los prados que están junto al dicho río".
} 
más de treinta años no trabajaba por falta de combustible al ser suyos los montes. La querella, dice, no es sino una venganza. Sánchez de Ulloa lograría al fin construir la nueva ferrería de Bueyes6o6.

* La solicitud en 1623 para construir en Santiago de Abres una ferrería se argumenta con que no hará daño a nadie, ni en las aguas ni en los montes, que además son suyos. Los vecinos no están de acuerdo con estos argumentos por lo que iniciaron un pleito que, sin embargo, no interrumpió la construcción de la ferrería ${ }^{607}$.

* Don Fernando de Sanjurjo, dueño de la ferrería de Sueiro, denuncia en 1625 a Diego García de la Vega porque pretende construir una ferrería aguas abajo de la suya, sobre un antiguo molino llamado de la Lameyra. Primero alegó que la mitad del molino era suya, luego que Diego García la había construido ocupando parte de un camino vecinal. En el fondo era un problema de competencia, por lo que la Chancillería de Valladolid sentenció a favor de este último ${ }^{608}$.

* Don Antonio de Neira en 1686 reconstruyó un antiguo machuco y sobre el edificó poco después la ferrería de Quintá. Cuando estaba casi construida, los monjes de Samos lo denunciaron aduciendo supuesta privación de agua a su ferrería de la Rodela609. En el juicio se nombraron dos peritos "maestros carpinteros de herrerías", uno por cada litigante. Ambos reconocieron que había muchas ferrerías, dieciséis en un radio de diez leguas. Respecto al agua uno testificó que no había para una y, por

${ }^{606}$ AHRG. R. A.: 21477/96

607 A.D.O. Parroquia de Santiago de Castropol, caja 14.3.218: "con la dicha obra y herrería no hacemos daño ninguno ni perjuicio a la dicha feligresía ni a otra persona ninguna ni a los concejos de Santiago ni Santiso ni Taremunde ni en el dicho rio que jamás ningún paso ni hacemos presa". Además de no hacer daño en el agua tampoco lo hacía en el monte, porque los dueños de la ferrería "tienen mucha cantidad de montes propios por mas de cincuenta años".

608 AChV. Registro de Ejecutorias: caja 2489,47

${ }^{609}$ AHRG. R. A.: 26.319/20. Escrito de los monjes de Samos para oponerse a la construcción de la ferrería de Quintá. "No se deue admitir la fabrica de su pretendida Herrería por el gran daño que se sigue a la de mi parte, porque si se diera lugar a ella desaguará la corriente de el río con notorio agravio de la de mi parte y ahora priuarle totalmente de la liuertad y posesión inmemorial en que está y estubo siempre de traer el agua del rio a su vançado de que necesita dicha Herreria (...) para la conseruación suya de tal manera que del todo quedara destruida y no se pudiera conseruar si diera lugar a semejante obra nueua (...) y porque asi mesmo el daño es yrreparable respecto de que aun con toda el agua de dicho río la herreria de mi parte para dos y tres meses en el verano por falta de agua...” 
tanto, menos habría para dos; pero el otro matizó que el agua de la de arriba servía lo mismo para la de abajo610. La chancillería de Valladolid sentenció a favor de la ferrería de Quintá611. Sin embargo los juicios entre ambas continuaron durante el siglo XVIII ${ }^{612}$.

* La encomienda de Quiroga aforó en 1719 a don Joaquín Pardo Rivadeneira los montes del coto de Lor para que construyera una ferrería y usar las aguas y montes de los alrededores ${ }^{613}$. Pero cuando en 1722 comenzaba la construcción de la ferrería, don Pedro Valcarce, dueño de la ferrería de Loureiro, trató de impedirlo por la fuerza porque esa obra perjudicaba a la suya, querellándose con el y con el comendador de la encomienda ${ }^{614}$.

* Cuando hacia 1752 don Lucas Somoza y Losada solicitó permiso para la construcción de la ferrería de Vidueiro se le pusieron grandes impedimentos, entre ellos, según un jesuita de Monforte, por la Iglesia porque temía que por su causa disminuyeran los diezmos ${ }^{615}$.

* A finales de los años cincuenta del siglo XIX, Domingo Vázquez Villamil, del concejo de Castropol, solicitó una Real licencia para construir en el Porcia una ferrería, lo que suscitó la oposición de los dueños de las que había en los alrededores. Estos, en julio de 1859, alegando defectos de forma en la solicitud, enviaron un escrito al gobernador de Oviedo en el que exponían las razones de su oposición,

${ }^{610}$ AHRG. R. A.: $1662 / 4$

${ }^{611}$ AHRG. R. A.: 26.319/20: Pero la sentencia señala que esta "no solo no pueda represar el agua en su ferrería en los quatro meses preuenidos en dicha sentencia, sino que tampoco lo pueda hacer en el tiempo de yelo".

612 AHRG. R. A.: 9090/4

${ }^{613}$ AHRG. R. A.: 3020/42

614 AHRG. R. A.: 3020/42: Querella por "obra nueba contra D. Joachin Pardo y Riuadeneira, maestros y alarifes que fabrican una herreria", denunciando al "yntitulado gobernador de la encomienda de Quiroga y contra los maestros que trabajan y fabrican en la herreria en el rrio Lor cerca de la de mi parte por los agrauios que a unos y a otros hacía dicha herreria así en las tierras como en los sotos".

615 E. LARRUGA (1800): Memorias políticas políticas y económicas sobre los frutos, fábricas, comercios y minas de España. Vol. XLV, Madrid, p. 346: Porque "con la codicia del jornal que pillan al día (los trabajadores) muchos no cultivan ni media fanega de sembradura, y por consiguiente no tienen pan por Navidad; a que se sigue la decadencia en los diezmos, tributos y rentas de los dueños". 
que eran fundamentalmente la gran carestía de carbón 616 . Por su parte, Domingo Vázquez alega que aquellos se oponían por envidia, pues desde 1852 en que arrendó la ferrería de A Veguiña, había subido los precios del carbón, que estaban muy bajos, elevando de ese modo el nivel de vida de los campesinos de la zona; por eso, los dueños de las ferrerías, que se habían visto obligado a pagar más por la competencia, no le perdonaban su actitud ${ }^{617}$.

\subsection{El valor de las ferrerías}

Toda esta oposición no fue obstáculo suficiente para la construcción de nuevas ferrerías en los siglos XVI al XIX. Tampoco lo fueron los capitales necesarios, aunque no siempre se contaba con ellos y había que pedir a censo créditos o asociarse con los que los tenían. Las ferrerías que conocemos a comienzos de la modernidad ya están en marcha, en unos casos arrendadas y en otros explotadas directamente por sus propietarios. Ignoramos quiénes las construyeron, aunque suponemos que en unos casos fueron los señores quienes arrostraron con los desembolsos iniciales, como probablemente ocurrió con el conde de Lemos cuando levanta las ferrerías en el Selmo leonés, que ya a finales del siglo XV tiene arrendadas, pero que eran de su propiedad no solo los terrenos sino los edificios ${ }^{618}$.

En otros casos, por ejemplo en territorios de las encomiendas de Quiroga o de la Barra, en Lugo, parece como si estas solo cedieran en foro el terreno,

\footnotetext{
${ }^{616}$ "En efecto, señor gobernador civil, a la distancia de una y dos leguas del sitio que designa Vázquez, existen nueve forjas catalanas y otras siete hasta la distancia de seis leguas, todas las que se elimentan con carbón vegetal. Trabajan con el mismo combustible una infinidad de martinetes y fraguas, que hay en el territorio que ocupan estas herrerías, viniendo a resultar un consumo inmenso, que no es bastante a sostener el estado de los montes del país, así es que por eso ha disminuido considerabablemente en las herrerías de los exponentes, $y$ en otras, la elaboración del fierro y muchos martinetes han cerrado". Cit. en J. LÓPEZ y A. GRAÑA: Ferrerías, mazos y fraguas en Asturias, 1998, p. 147

617 "Pero como la envidia se desarrolla contra los buenos administradores, muy pronto llegó esta a la puerta de mis amos y les aconsejó que me despojasen; lo hacieron así y visto mis adversarios que no podían salir al mercado por no tener en donde consumir, volvieron a retirar un tanto los precios. Apesar de todo y contra el genio de mis adversarios en el periodo que se cuenta de ocho años el país sin ser visto otra cosecha de patatas, pagó las contibuciones atrasadas y ha vuelto a ponerse en el mejor estado que antes tuvo y nunca esperaba tener". Cit. en J. LÓPEZ y A. GRAÑA: Ferrerías, mazos y fraguas en Asturias, 1998, p. 148 ${ }^{618}$ A. FRANCO SILVA (1981): "Bienes, rentas y vasallos del señorío de Villafranca del Bierzo al término del siglo XV". Archivos Leoneses, $\mathrm{n}^{\circ}$ 69, p. 48.
} 
aguas y bosque, pero quienes las construyen son otros, por ejemplo vascos aunque también hidalgos locales. Así la ferrería de Paleiras la construyó en el siglo XVI el vasco Martín de Aldoncín o Aldunzín ${ }^{619}$, en territorio de la encomienda de la Barra, a la que paga de renta anual de 4.000 maravedís. Ignoramos quien puso el dinero para ella, pues su valor era elevado, como comprobamos en 1587 cuando la vende ${ }^{620}$ a Francisco Vázquez en $\mathbf{2 . 0 0 0}$ ducados, de los que 400 se los debía por haberselos prestado a sus padre anteriormente. Le da además cuatro años de plazo para pagar los 1.600 ducados restantes $\mathrm{y}$, por supuesto, ha de pagar los 4.000 maravedís de fuero a la encomienda de la Barra621.

Francisco Vázquez fue el constructor de la ferrería de Quiroga o la Rodela primitiva de Quintá-, cuando la encomienda de Quiroga, de los hospitalarios de San Juan, que tenían en el lugar de Hospital su castillo y capital del señorío, le ceden en foro ${ }^{622}$ en 1562 los lugares y montes de Campos de Vila, Carballo, Barxa, Arxubín, A Hermida, Vilanán, Campodola, Outeiro, Barxas y Casa do Vello por una renta de 2.500 reales $^{623}$ y dos docenas de herraje de clavo (mitad mular, mitad caballar). Este foro, con el que la encomienda de San Juan

\footnotetext{
619 Este Aldoncín es el mismo apellido de Miguel Aldunzín, rendero de la ferrería de Bueyes y rendero de la del puente de Quiroga, que está presente en la toma de posesión de la ferrería de Quintá en 1566.

${ }^{620}$ AHRG. Hombreiro: leg. 19. Contrato del 9 de junio de 1587 hecho en Villafranca del Bierzo: "otorgo e conozco que por esta presente carta que bendo, cedo y traspaso e doy en venta Real por juro de heredad para agora y para siempre jamás a vos Francisco Vázquez de Quiroga, vecino de la Encomienda de Quiroga, para vos y para vuestros hijos, herederos (...) la mi Herraria de las Paleiras sita en dicha Encomienda de la Barra con todas sus casas nuebas e viejas, molinos, heredades (...) con más los montes, pastos y Aguas".

${ }^{621}$ AHRG. Hombreiro, leg. 19: Los 2000 ducados "suman y montan 750.0oo maravedis" de los cuales "me distes y pagastes luego 150.000 mrs. que son 400 ducados, recibiéndoles en quenta y pago de otros 400 ducados que os debía y me alcanzaste de todo el tiempo y año que yo e mi ermano y mi padre difuntos trujimos en arrendamiento e gozamos de buestra herraria de Quiroga".

${ }^{622}$ Francisco Vázquez era hijo de Alvaro de Quiroga, quien en tiempo de las Comunidades había defendido la fortaleza de O Incio, propia de la encomienda, frente a la condesa de Lemos, por lo que ésta le había usurpado parte de la hacienda que tenía en Castro Caldelas. De ahí las relaciones estrechas de esta familia con la orden de San Juan: En 1562 "Recibió en fuero de esta encomienda la campa do moiño, los montes, aguas, yerbas en atención de que abía perdido mucha hacienda en tierra de Caldelas que le quitó la condesa de Lemos por auer su padre Alvaro Vázquez de Quiroga defendido de la dicha condesa la fortaleza y casa de el Yncio en tiempo de las Comunidades" (AHRG. R. A.: 1662/4)

${ }^{623}$ De esos 2.500 reales, 2.00o por la vega del Campo do Moiño y montes, y los 500 restantes "por razon de un machuco que mas auajo de la dicha Herreria quereis hacer" (y aunque no lo hagan tendrán que pagarlos igualmente).
} 
pretende fomentar la siderurgia en la zona624, se suscribe cuando Francisco Vázquez ya ha invertido 800 ducados (299.200 maravedís) en su construcción en Campa do Muiño625.

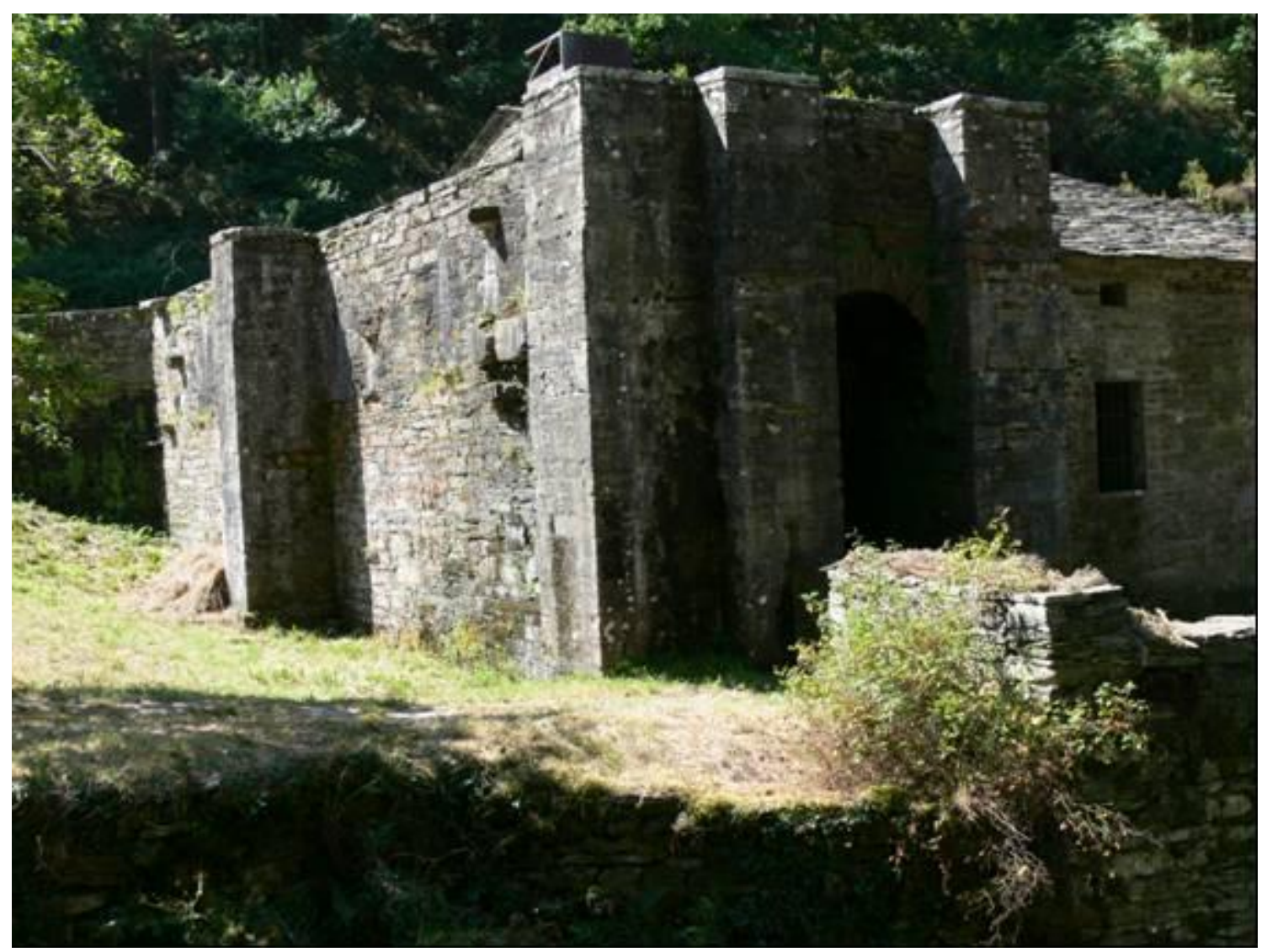

Ferrería de Bogo (Lugo)

Otras veces los propietarios son monasterios, como Samos, Montes o Villanueva de Oscos. Unas veces poseen los recursos para construirlas o hacerse con ellas; por ejemplo Samos parece tener los recursos pues en 1546 adquirió un

624 AHRG. R. A.: 26.319/20: "dicha ferreria e cassas que en ella y para ella han de acer donde siempre abrá quarenta o cinquenta ombres para el servicio y onrra de esta casa y encomienda y comendadores (...) e que hizo asimismo gran provecho e utilidad por razon de la dicha Herreria e xente que en ella abra las rentas de la dicha encomienda baldrán más".

625 AHRG. R. A.: 26.319/20: "Digo que por quanto Francisco Vazquez de quiroga de mi consentimiento que en nombre del dicho comendador mi señor vos determinasteis e hicisteis una ferrería de fundir hierro mas arriua de el lugar de A Ponte donde dicen a campa de Moiño que es dentro de esta jurisdicion de quiroga porque en el dicho nombre bos prometí que de los montes e yerba e del sitio que esta cauo della os aria un fuero combenible y moderado y vos debajo de esta palabra ycisteis la dicha ferreria y aora me pedis os haga el dicho fuero e yo teniendo respecto a que en hacer la dicha ferrería aueis gastado mas de ochocientos ducados y aún para la acauar de açer haueis de gastar muchos mas Dineros y a que de auer echo la dicha ferrería se sigue gran utilidad y provecho a esta encomienda y acrecentamiento della". 
mazuco en Gondriz en 300.000 maravedís ${ }^{626}$, sobre el que construyeron en 1555 una ferrería ${ }^{627}$. Respecto de la Rodela o Quiroga, construida por el mencionado Francisco Vázquez, en terreno de Samos (en el coto de Fisteus), mediante foro; al finalizar este, los monjes pleitearon por la restitución de la propiedad, lo que, después de largos y costosos juicios, lograron en 1689, previo pago a los herederos de aquel, de 3.000 ducados 628 .

Con frecuencia los monjes tuvieron que solicitar créditos a diferentes instituciones y personas físicas, por carecer de sumas tan crecidas. Así lo hace también Samos cuando a comienzos del siglo XVIII construye las ferrerías de San Vicente de Leira y Rugando. Respecto de esta, construida entre 1701 y 1705, se invirtieron en ella más de 7.000 ducados, por lo que tuvo que pedir un crédito ${ }^{629}$. La de San Vicente de Leira se levantó entre 1717 y 1721, mediante un empréstito de 6.000 ducados pedido a un indiano de Layosa ${ }^{630}$, que fue redimiendo con las ganancias obtenidas de la venta del hierro, como recuerdan varias actas de visita de los años 1720 y 1723 y otros documentos ${ }^{631}$. La ferrería de San Pedro de Montes, en León, contruida hacia 1730 exigió del abad Benito Monteagudo tomar a censo 7.000 ducados ${ }^{632}$, que el monasterio pagaría entre

\footnotetext{
${ }^{626}$ AHN. Clero: Libro 6695: "En este mismo número hai una venta antigua de el mazuco de seis fraguas de Gondriz en precio de 300.000 mrs. hecha a este convento en 1546”, ff. $119 \mathrm{v}$.

627 A.M. SAMOS. Casa de Lusío: Libro Becerro de 1715, p. $7 \mathrm{v}$ y 8.

${ }^{628}$ AHRG. R. A.: 26.319/20.

${ }^{629}$ M. ARIAS CUENLLAS (1992): Historia del monasterio de San Julián de Samos. Monasterio de Samos y Diputación de Lugo. Samos. p. 187.

${ }_{630}$ AHN, sección Clero: Libro 6.695, ff. 151-16o, que dice: "Esta Herrería se fundó siendo Abbad el Yllmo Sarmiento, para cuio fin se tomaron a censo seis mill ducados, que se redimieron el año siguiente a su fundazión, que fue el 721", f. 158v.

${ }^{631}$ M. ARIAS CUENLLAS (1992): Ob. cit., p. 288: en la visita de 1720, del general Benito Peñelles dice "para que este monasterio logre el beneficio de desempeñarse redimiendo el zenso de seys mill ducados que ha tomado para la fábrica de la herrería de San Vicente de Leyra al indiano de Layosa, mandamos en virtud de Santa obedienzia y so pena de excomunión mayor y de privazion de abbadia al P. Abad que al presente es o por tiempo fuere, que todo el producto de dicha herrería se emplee en la paga de réditos anuales de dicho zenso; y lo que se restare y sobrare pagados dichos réditos, se vaya depositando sin que se pueda divertir ni emplear en otra cosa más que en la redempzión del principal”. Así debió hacerse, pues en AHN, clero: Libro 6495, en 1721, se anota: "está aqui una escritura de redencion de seis mil ducados de censo que este monasterio tomó para fabricar la Herraria de san Vicente que pasó ante Pedro Fernández de Rego en 1721", f. 87. En la visita de 1723, del general Antonio Sarmiento, en cuyo abadiato se hizo la ferrería, se dice sin embargo, que los 6.000 ducados fueron prestados por diferentes monjes de la casa. Habrá que entender que con dinero propio de los monjes se desquitó el préstamo del indiano de Layosa, pero luego el monasterio se lo debía a los monjes.

${ }^{632}$ HERREZUELO, p. 308
} 
1733 y $1745^{633}$. Algo semejante podríamos decir del monasterio de Villanueva de Oscos, cuya ferrería fue construida hacia 1677 después de pedir un censo de 4.00o ducados al monasterio de Lorenzana, con un interés del 5\%; dinero que no fue suficiente a tenor del estado de cuentas del abad Estrada, quien en la apertura de caminos, salarios de carpinteros, acarreo de maderas, jornales de oficiales, porteo de la vena, barquines, etc. gastó 51.823 reales ${ }^{634}$.

También empresarios privados tuvieron que solicitar créditos o buscarse socios para llevar a cabo sus proyectos. Algunos de estos nuevos empresarios derivaban sus fortunas del comercio o del ejercicio de funciones administrativas o militares. Por ejemplo, Carlos Lemaur, el militar ingeniero que realizó el camino real de La Coruña a la Meseta, viendo las posibilidades de desarrollo siderúrgico en el Bierzo, donde había descubierto una mina de carbón de piedra, pensó en la construcción de varias ferrerías, de las que levantó dos. La de Torre del Bierzo se construyó entre 1768 y 1769 con un coste de 267.603 reales que, al parecer, fue sufragado a partes iguales por Lemaur y el lucense Agustín Álvarez de la Iglesia, administrador de la Real Gracia del Excusado635. La de San Andrés de las Puentes o de Navaleo, que construyó poco después, obligó a Lemaur a suscribir un préstamo de 109.500 reales con Miguel Valls, vecino de La Coruña, cuyos réditos anuales suponían 3.285 reales, por lo que hubo de hipotecar "la mitad de la herrería de Torre y el todo de la iniciada en San Andrés" ${ }_{3} 6$.

Se trata, como vemos de cantidades considerables que exigían el concurso de varias personas o la formación de compañías, como sucederá normalmente a finales del siglo XVIII y en el XIX, cuando algunos empresarios se interesen por el negocio siderúrgico. Por ejemplo, la ferrería de Tejedo de Ancares fue construida en 1788 por tres socios de origen ancarés aunque comerciantes en el Ferrol: los hermanos Bernardo y Jerónimo Rodríguez y Francisco Abella. No

633 IBIDEM, p. 311: En el trienio 1742-1745 se "redimió cinco mil ducados de los siete que había tomado a censo en el anterior y lo hubiera redimido todo a no tener que atender a otros gastos indispensables".

${ }^{634}$ D. PAZ (1991): El monasterio de Santa María de Villanueva de Oscos: De la reforma a la exclaustración. Oviedo, p. 149.

635 M. OLANO, M. (2008: "Carlos Lemaur y la industria del hierro y del carbón en la cuenca del Boeza”. En Actas del VI congreso internacional sobre patrimonio geológico y minero. X sesión científica de la SEDPGYM. Fabero del Bierzo, 19 septiembre-2 de octubre de 2005, p. 217.

${ }^{636}$ IBIDEM, p. 225 
sabemos el coste de su inversión, pero cuando en 1799 se rompe la sociedad y se hace un reparto de bienes, solo la tasación de la ferrería, realizada por don Miguel Antonio Uría, maestro arquitecto y director de las Herrerías de la Compañía de Ribadeo, su valor ascendía a 135.270 reales y 33 mrs637.

Solo estas compañías o el Estado, directa o indirectamente, podían sufragar esos gastos tan cuantiosos. La ferrería de la Somoza, que pensaba construir el gobierno en los primeros años del siglo XIX, según informe del maestro de obras villafranquino Pedro Landejuela, podría calcularse en unos 350.000 reales ${ }^{638}$, pero su coste fue mayor. La ferrería de Somiedo la erigió Alvaro Flórez Estrada (1766-1853), político y economista asturiano, natural de Pola de Somiedo ${ }^{639}$, con la ayuda del Estado (la Regencia en este caso), que no sólo le concedió el permiso en 1811 sino un anticipo de 300.000 reales. Sin embargo, las dificultades de la guerra y de la postguerra retrasaron su construcción. En 1820 el rey Fernando VII amplió a 500.00o reales el mencionado anticipo, al tiempo que mandaba que el ministerio de la Guerra adelantara los primeros 300.000 reales, que Flórez Estrada debería devolver en un plazo de cuatro años, con hierro de la propia ferrería que habría de entregar al arma de Artillería ${ }^{640}$.

\footnotetext{
637 AHPL. P.N.: caja 3494 (1799). La tasación, hecha el 29 de enero de 1798, fue de este tenor: La presa y cauces de la herrería, sus paredones, pozo, compuertas y excavaciones: 39.550 rs.; la excavación y cimientos del edificio y máquinas: 12.500 rs.; los paredones del edificio y estolda, inclusas sus puertas, ventanas y arcos: 20.948 rs.; los techos cubiertos de todo el edificio de la herrería y carbonera: 10.150 rs.; el banzao o depósito de agua, fábrica de carpintería: 6.552 rs.; la fragua de barquines, con su correspondiente máquina: 8.862 rs.; las máquinas del mazo, sin inclusión del herrage: 3.580 rs.; el herrage de todas las máquinas, herramientas de todo uso y otras que hay de repuesto: 11.520 rs.; el molino harinero con dos piedras y muelas de mediano tamaño: 2.000 rs.; la casa de la fragua de mano contigua a aquel: 1.300 rs.; las herramientas de la misma fragua: $787 \mathrm{rs}$.; la plaza y terreno de la ferrería, molino y fragua: 400 rs.; la casa de la Magdalena: 900 rs. Total de lo proindiviso: 135.270 rs. y $33 \mathrm{mrs}$.

${ }^{6} 8$ J. A. BALBOA (1992): El Bierzo en la obra de dos militares del siglo XVIII: Datoli y Munárriz. Ponferrada, p. 81.

639 ACADEMIA DE LA HISTORIA: Fondo Martínez Marina: ms. 9/6033: "Pertenece la ferrería a un hacendado de la Pola acreedor por esta empresa a todo elogio y reconocimiento".

${ }^{640}$ L. ADARO (1916): Criaderos de hierro de Asturias, p. 56: Real Orden de 3 de noviembre de 1820: "Enterado el Rey N.S. de la solicitud que ha hecho D. Alvaro Flórez Estrada, refiriéndose a la Orden de la Regencia del Reino, expedida por este ministerio del cargo de V.E. en 6 de octubre de 1811 a efecto de que se verificase la anticipación en ella prevenida de 300.000 reales y que ahora amplía a 50o.ooo, para fomento de la Ferrería que hay en Asturias, en el concejo de Somiedo, se ha servido mandar Su Majestad que se lleve a efecto la anticipación de 300.000 reales para fomento de la expresada finería, cargándose al presupuesto de Guerra y reintegrándolo Flórez de Estrada, en cuatro años, con fierro que entregará a la Artillería". Tomado de la Colección de Manuscritos de la Biblioteca del Instituto de Jovellanos, Gijón.
} 


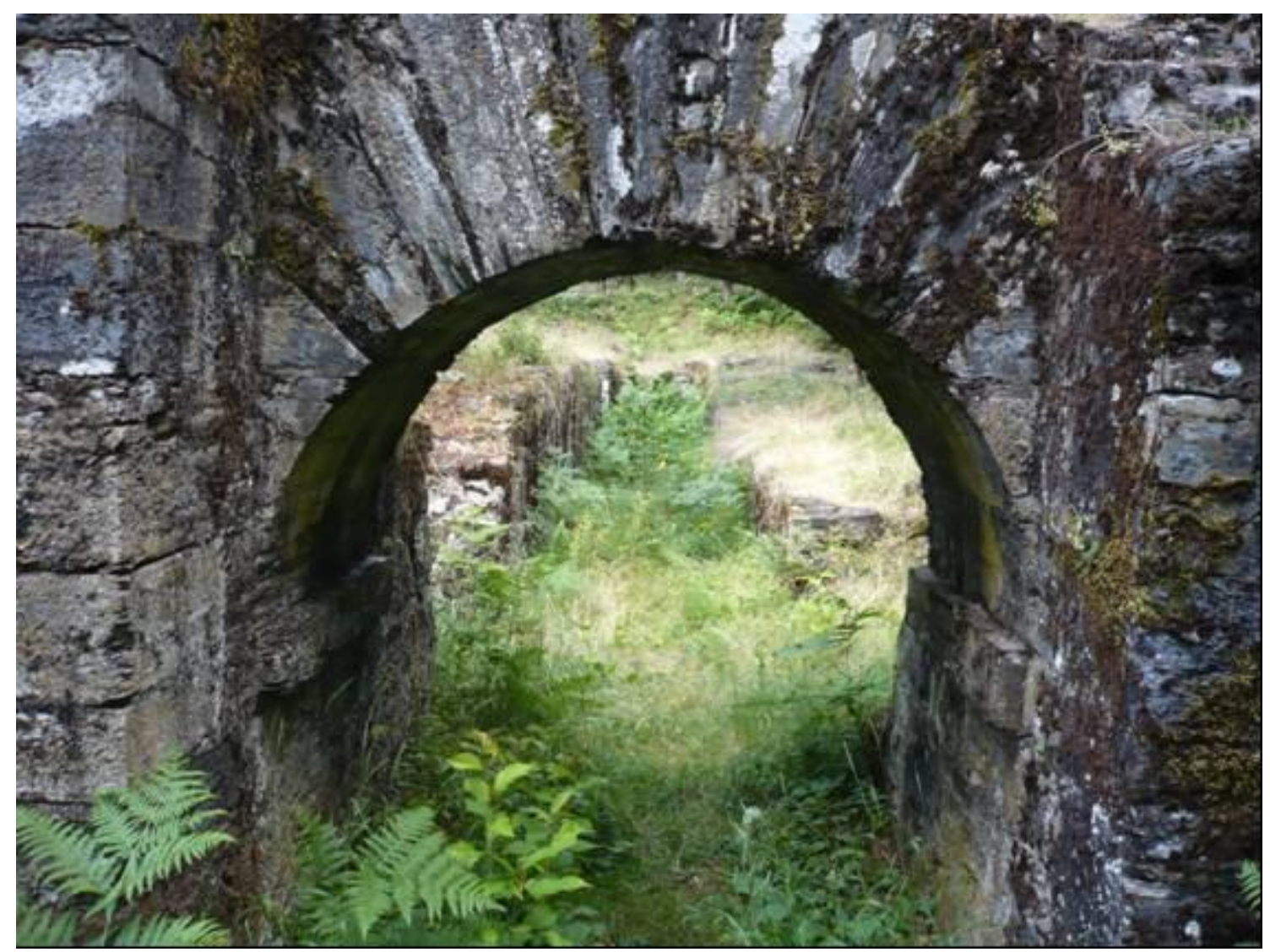

Ferrería de La Somoza (León)

Otras veces nos encontramos con verdaderos empresarios con recursos suficientes. La ferrería de Vegas de Camba, en la orensana Tierra do Bolo, construida en el primer tercio del siglo XIX por Estanislao Peñafiel, curador y administrador de Apolinar Suárez de Deza, señor de Bóveda, fue cedida a este el 24 de marzo de 1824, por alcance de 170.000 reales en las cuentas de la curadoría, al parecer gastados en su construcción ${ }^{641}$. La de Llamas de Cabrera (León) la erigió hacia 1859 Nemesio Fernández, en cuyo inventario de bienes, realizado en 1859, se dice que aún no estaba terminada y que por eso se valoraba en 100.000 reales ${ }^{642}$, aunque poco después sus herederos aumentaban

${ }^{641}$ I. GARCíA TATO ((2000): "Las ferrerías de Río Cabo y Pombriego en el siglo XIX". Rev. Bierzo (Ponferrada), apéndice 7: En Bergondo, a 20 de febrero de 1824 ante el escribano, don Apolinar Suárez de Deza y don Estanislao Peñafiel, su curador, "dijeron que resultando de alcanze en las quentas de dicha curadoría ciento setenta mil reales vellón a favor de dicho señor, los cuales había ymbertido dicho curador en la fábrica de la Errería de Begas de Camba, no pudiendo pagarle en metálico, estaban convenidos en la manera siguiente, a saber: el referido don Estanislao cede y traspasa en pago de dicha cantidad el dominio pleno de dicha fábrica con sus derechos de montes, aguas y más regalías para que dicho señor don Apolinar la disfrute como suia propia (...) cede tanvién el referido Peñafiel y dicho don Apolinar acepta el derecho que le han dado los vecinos de Arnado, para hacer una Erraria en el término de Rio Cauo, la qual está por acabarse" ${ }^{642}$ AHPL. P.N.: caja 2724 (1859) 
su tasación a 160.000 reales $^{643}$. Aunque no sea lo mismo valor que coste de construcción, el valor de algunas ferrerías, como podemos ver en el apéndice II5 , nos sirven de referencia para conocer las fuertes inversiones necesarias para su construcción o el valor que llegaron a adquirir en ciertos momentos como en la Desamortización, en que se pagaron cantidades superiores al medio millón de reales por algunas ferrerías de Samos, incluso por la de Rugando se llegó a pagar 1.120 .000 reales $^{644}$.

\section{LA PROPIEDAD DE LAS FERRERÍAS}

En la Edad Moderna, al menos hasta el siglo XVIII, todas las ferrerías fueron construidas o promovieron su construcción los señores laicos, la alta nobleza en algún caso pero sobre todo la pequeña nobleza y la hidalguía rural y urbana; también el estamento eclesiástico, como las órdenes militares y religiosas y algún obispado. Por el contrario, desde finales de ese siglo y en el XIX nuevos sectores sociales entran en el negocio de las ferrerías, unas veces formando compañías, otras a título particular; en ese sentido la propiedad se diversifica un poco. La calificación de esos nuevos sectores sociales es un tanto complicada, porque algunos pueden identificarse con la vieja hidalguía rural; pero hay otros a los que deberíamos considerar como una incipiente burguesía por su interés por el negocio, ya como productores de hierro, ya como comerciantes del mismo pero interesados en la producción, lo que podríamos identificar como una forma de verlagssisten. En muchos casos, los nuevos propietarios son antiguos arrendatarios, expertos en el negocio del hierro que, al ser más permisivas las leyes, solicitan directamente a la administración la concesión de permisos para la construcción de ferrerías.

\subsection{El papel de los vascos en las ferrerías del noroeste}

En el origen de la siderurgia tradicional del noroeste, es decir, la que comienza con la modernidad, los vascos jugaron un papel de primer orden. Quizá lo más evidente, por la enorme información que poseemos de los siglos

643 AHPL. P.N.: caja 2723 (1859).

${ }^{644}$ C. GONZÁLEZ (1994): Ob. cit., p. 206 
XVI y XVII, es su actividad como trabajadores o, mejor dicho, como oficiales de las ferrerías, ya que la inmensa mayoría de estos oficiales tenía origen vasconavarro. Fueron ellos los introductores de la técnica descrita en el primer capítulo, porque tal técnica era desconocida en la zona hasta su llegada ${ }^{645} \mathrm{y}$ porque sabemos que, desde la segunda mitad del siglo XV, se solicita su presencia para esos trabajos especializados en el noroeste de España y en el norte de Portugal. Con anterioridad a 1461 conocemos que mineros vizcaínos ya trabajaban en el vecino Portugal, y en 1441 este país reclamaba la presencia de ferrones vascos para levantar los ingenios ferreros de Caria ${ }^{646}$. En las ferrerías de Arnado y Pontepetre trabajaban vascos a finales del siglo XV y lo mismo podríamos decir en algunas ferrerías asturianas ${ }^{647}$.

La diáspora de vascos por algunas regiones de España se debe a varios factores, el más importante sin duda el crecimiento de la población de la corona de Castilla en ese siglo en general, y en el del propio País Vasco y Navarra en particular ${ }^{648}$, lo que provocó, además de enfrentamientos civiles como las guerra de bandos, que afectaron a las ferrerías ${ }^{649}$, una mayor expansión agraria y una demanda de útiles de hierro. Otro sería el incremento de las actividades bélicas como consecuencia de la política europea de los Austrias, lo que promovió una mayor demanda de armas (espadas, picas, arcabuces), cuyo hierro hubo de salir de más ferrerías repartidas por otras regiones españolas, además de las del País Vasco y Navarra, como Cantabaria, Aragón y

645 La prueba más evidente de su presencia en nuestra región es el elevado número de palabras de origen vasco que se emplea para denominar las partes que componen la maquinaria y otras cosas relativas a ella. Cf. E. ALARCOS (1980): "Elementos vascos en el léxico de las ferrerías asturianas". En Cajón de sastre asturiano, 2. Ayalga, Salinas, pp. 107-116.

${ }^{646}$ Según Gual Camarena, que cita al portugués Gama Barros, a finales del siglo XV "sabemos que en algunas minas (portuguesas) trabajaban los vizcaínos”. M. GUAL CAMARENA (1970): "El hierro en el medievo hispano". En La minería hispana e iberoamericana. León, p. 282. L. M. DUARTE (1996): "A actividade mineira em Portugal durante a Idade Media (Tentaiva de sintese)”. Actas I ${ }^{a}$ jornadas de Minería y tecnología. León, p. 87, dice que Fernao Rodriguez recibió de la corona portuguesa 330.000 reales de adelanto en 1490 para poner en marcha la ferrería de Barcarena, al norte de Portugal, de los que 60.000 "se destinaban a contratar, na Biscaia, os artesaos que viriam fazer as forjas e despois traballar nelas" y que, al parecer estuvo cuatro meses en Vizcaya buscando maestros de ferrerías en 1487 y en 1490 "volta a Castela e á Biscaia para contratar os mellores mestres que achasse", lo que consiguió.

647 En el siglo XVI, las ferrerías de Montealegre, Labayos, Raicedo.

648 J. L HERNÁNDEZ y S. PIQUERO (1988): "Informe sobre el estado de la cuestión demográfica vasca (1500-1850)", p. 344; A. GARCIA-SANZ (1988): "El estado de la cuestión de la demografía histórica en Navarra desde el siglo XVI hasta el presente”, p. 328. Ambos trabajos en V. PÉREZ MOREDA y D. REHER (Ed.): Demografía histórica en España. Madrid

649 F. GARCÍA DE CORTAZAR y M. MONTERO (1980): Historia de Vizcaya. San Sebastián, t. I., p. 58-60. 
especialmente en el Noroeste; y por último, los cambios técnicos que crearon, en el propio País Vasco y en Navarra, una población excedentaria de ferrones que no encontraron trabajo en su tierra y que debieron buscarlo fuera650.

Durante los dos siglos mencionados, los vascos fueron numerosos en todas las ferrerías del noroeste, en las que vemos que ejercen oficios relacionados con el trabajo directo del hierro: aroza, tirador, fundidor, tazador (APÉNDICE II-6); pero también hay maestros de ferrerías, es decir expertos en su construcción, ferramenteros, venaqueros e incluso mulateros. También hubo, como no podía ser de otra manera, numerosos arrendatarios de ferrerías ${ }^{651}$. En ocasiones, las fuentes especifican los lugares de procedencia de estos vascos: Juanes de Hezpeleta vecino de Lesaca, Navarra652; Miguel y Juan de Loreaga, navarros653, Miguel Martínez de Vicuña, vecino de la villa de Legazpi654; Martín Zuarcalde, de Legazpia "de donde es natural"655; Francisco Bengoechea, del valle de Oyarzun ${ }^{656}$; Juanes de Arrillaga, "natural del lugar de Enrieta",

\footnotetext{
${ }^{650}$ La crisis en el País Vasco se puede seguir en I. ARBIDE y J. URCELAY (1993): "Ferrerías de agua. Primeros datos sobre ellas en Legazpi y posterior evolución técnica". I Simposi Internacional sobre la Farga Catalana, Ripoll, p. 309; I. ARBIDE y J. URCELAY (1993). "Instalaciones primitivas utilizadas para la obtención del hierro en Legazpi". En I ${ }^{\circ}$ Simposi Internacional sobre la Farga Catalana. Ripoll, p 289; L. M. DÍAZ DE SALAZAR ((1983): Ferrerías en Guipúzcoa (siglos XIV-XVI), 2 t. L. Haranburu Editor. San Sebastián., t. I, p. 113. ${ }^{6}{ }^{1}$ En 1558 Martín de Berganza era rendero y en 1596 Domingo de Arechaga, ambos vascos, de la ferrería de Visuña (AHRG. R. A.: 19.768/32 y AHPLU: 2407/9).En 1564 Juan Beltrán de Achega lo era de Ferreirós, siendo su administrador Juanes de Ibarreta (AHPL. P. N: caja 1488); Miguel Ortiz, en 1573, toma en arriendo de Juan Pérez de Errazti esa misma ferrería (AHRG. R.A.: 2472/120); Pedro de Errazti y Armesto, en 1596, era igualmente rendero de Ferreirós y lo mismo Juan de Arechaga (AHPLU: 2407/9). En 1573 el vasco Francisco Sánchez de Vidarte era rendero de Lorenzana (AHRG. R.A.: 1140/65); ; en 1602 Martín de Guizaburuaga era rendero de Santalla (AHPLU: 2408/2); Lorenzo Bordes, vizcaíno, rendero en "la herrería nueua que haçe el dicho Vasco Sánchez de Ulloa en bueis" (AHRG. R.A.: 21477/96). La de San Pedro de Bogo se arrendó en 1537 a Juan de Belastegui (P. SAAVEDRA (1985): Ob. cit., p. 327); la asturiana de Labayos la tenía arrendada en 1578 el vasco Juan Ortiz (R. Ch.V. R. E., caja 900, 13); y la de Peón al vizcaíno Martín de Beitia (R.Ch.V.: R. E., caja 1107,69).

${ }^{652}$ AHPL. P. N.: caja 3186 (1609). Años después, en 1629, este Juan de Ezpeleta se encuentra en Lesaca, pues ese año, María Martín, viuda de Miguel de Loreaga, vecina de Oencia, le da su poder "para que pueda administrar la casa y bienes que tiene en Lesaca" (AHPL. P.N.: caja 3189).

653 Miguel y Miguel de Loreaga aparecen en 1629 como venaqueros en Pontepetre, probablemente son hermanos o padre e hijo (AHPL. P.N.: caja 2969). De Juan sabemos que era hijo de Juan García de Ybalza y de Catalina de Loreaga, de Lesaca, en el reino de Navarra, aunque su padre, al que da su poder, vivía en San Sebastián. Dicho poder, de 1629, es para cobrar en esa ciudad a Miguel Martínez de Vicuña, acemilero que había sido en la ferrería de Pontepetre, 500 reales que le debe. Confirman la escritura Esteban de Argarese, Juan de Michael Pericena, venaqueros. (AHPL. P.N.: caja 3186).

654 IBIDEM, año 1609.

655 AHPL. PN.: caja 1547 (1584).

${ }^{656}$ IBIDEM, caja 2936 (1668).
} 
Vizcaya 657 , Juan de Olazabal, vizcaíno ${ }^{658}$, Sebastián de Arburu, vecino de Oyarzun ${ }^{659}$, Ambrosio de Olasio ${ }^{660}$, vizcaíno, Graciana de Galarza, vizcaína ${ }^{661}$, Juanes de Balderraín, vizcaíno ${ }^{662}$, Lorenzo Bordes, vizcaíno663, Inés de Olarra, de Mondragón 664, Juan de Segastiberre de Durango665, Juan de Lizalde ${ }^{666}$, vizcaíno, Juan de Vidarte, vizcaíno667, Martín de Celaya y Juan de Valderre, vizcaínos ${ }^{668}$, Juan de Ibarreta, “vizcaino abitante en la ferrería de Loureiro"669; o nombres y apellidos indicativos de villas vascas: Juan Durango, Juanico Biscaíno, Juan de Mondragón, Juan de Lesaca, Domingo de Vergara, Diego de Vergara, Bartolomé de Vergara, Pedro de Vergara, Domingo de Ochandiano, etc.

Que hay trabajadores y arrendatarios vascos en las ferrerías del noroeste no cabe la menor duda; ahora bien lo que nos interesa es conocer el papel de los vascos como promotores y constructores de estas, no como técnicos, cosa que que conocemos bien ${ }^{670}$, sino como empresarios. Sobre esto, aunque los datos no son tan abundantes, quizá porque no fueron todas sino solo algunas ferrerías las levantadas por vascos, creemos que en muchas ocasiones estas nacieron de la iniciativa de empresarios y ferrones de aquella región. Por ejemplo, la de Paleiras sabemos que la levantó el vasco Martín de Alduncín en tierras de la encomienda de La Barra ${ }^{671}$, aforando el suelo y los montes pero construyéndola con su propio dinero. A Domingo de Zarauz la encomienda de Quiroga le aforó

657 IBIDEM, año 1672.

${ }_{658}$ AHRG. R.A.: 1140/65, año 1573

659 AHRG. R.A: 4030/4

660 AHRG. RA.: 7013/1

${ }^{661}$ AHPLU: $2407 / 9$

662 AHPLU: 4030

663 AHRG. R.A: 21477/96, año 1612

664 AHPL. P.N.: 3443 (1707)

665 P. SAAVEDRA (1982): "Un aspecto de la economía monástica: la producción de hierro. El ejemplo del monasterio de Villanueva de Oscos". En XV centenario del nacimiento de San Benito, Oviedo, p. 533, nota 8

666 IBIDEM

667 IBIDEM

668 IBIDEM

669 AHRG. R.A.: $2837 / 19$

670 AHRG. R.A.: 21447/96. Vasco Sánchez de Ulloa, cuando hacia 1610 construye la ferrería de Bueyes, se queja, a causa de la querella interpuesta, de los gastos de estar parada la obra, pues "tiene muchos obreros que por su sueldo trabaxan en la dicha obra y por azerles pagar de bacio el tiempo que no trabaxaren por ser como son bescaynos", lo que indica que era una mano de obra cara.

${ }^{671}$ El vasco Martín de Aldoncín o Aldunzín, en territorio de la Encomienda de la Barra, levanta la ferrería de Paleiras: "que bien sabe cómo por el Rey nuestro señor me fue dado en fuero los montes, Aguas y pastos para la mi Erraria de las Paleras, que yo edifiqué de nuebo en término de dicha Encomienda", fuero por el que paga una renta anual de 4.000 maravedís (AHRG. Hombreiro, leg. 19). 
en 1550 la ferrería de Incio, y en el mismo foro se incluyó terreno para que erigiese otra en el Barreiro, que efectivamente levantó ${ }^{672}$. Esta misma encomienda le aforó a Juan Ortiz de Artunduaga en 1550 la ferrería de Soldón porque con su dinero la había reconstruido ${ }^{673}$, algo semejante a lo que hace el conde de Lemos con Martín de Basoa el Viejo respecto de la ferrería de Montoxo. ${ }^{674}$ Por último, por no seguir, la de Valdomir, que desde el siglo XVI aparece aforada a Juan Ortiz, también debió de ser construida o, al menos, reconstruida por este ${ }^{675}$. Todos estos datos corroboran el papel de los vascos en la construcción de nuevas ferrerías en el noroeste.

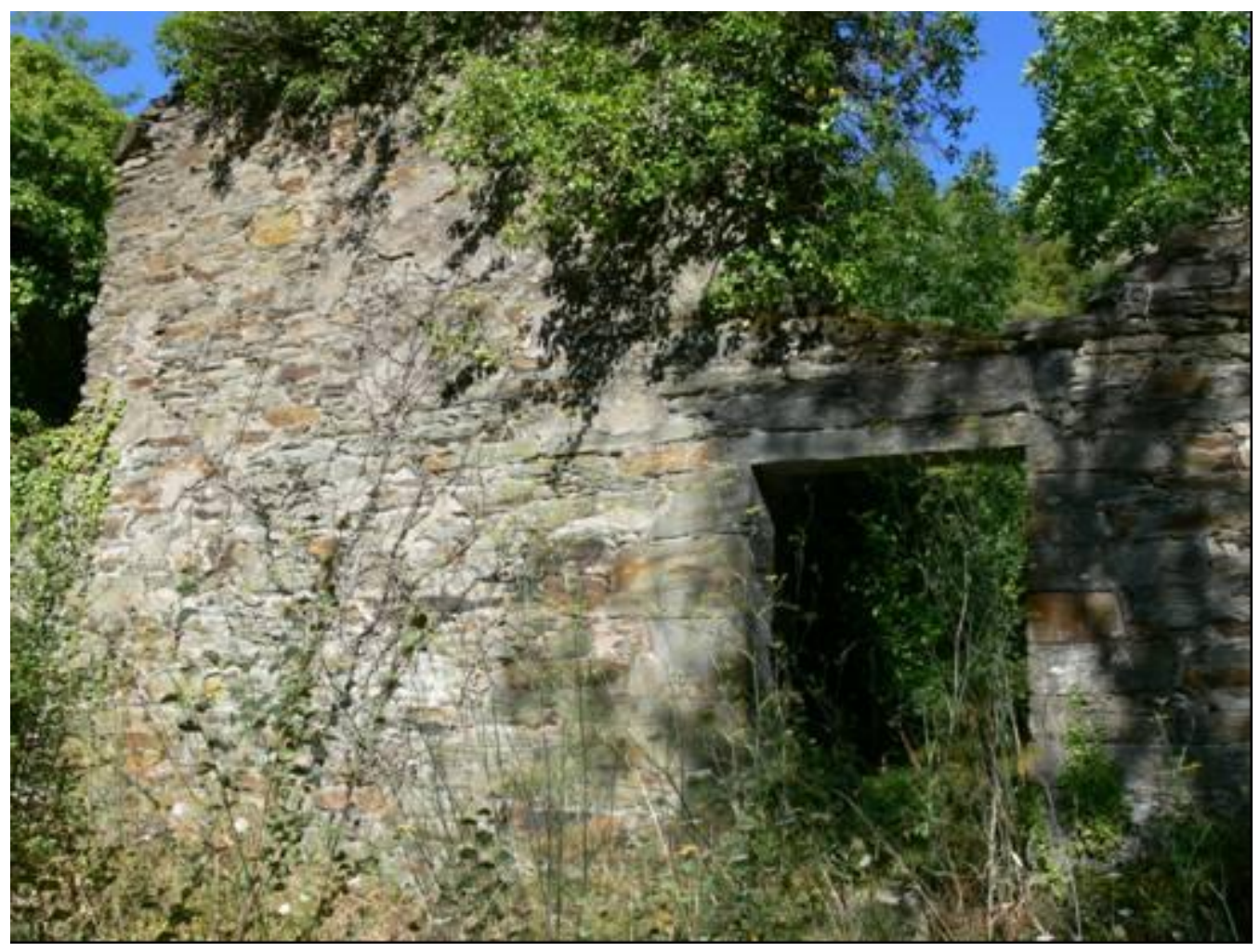

Ruinas de la ferrería de La Rodela (Lugo)

${ }^{672}$ AHRG. R. A.: 23088/72

673 AHRG. R. A.: 19.768/32: El comendador Francisco Giral le afora por "los muchos e buenos e leales seruicios que bos Juan Ortiz (que por entonces debía ser también forero de la ferrería de Valdomir), que estades presente hasta aqui aveis fecho, ansi en fauorecer las cosas de mi religion como de las dichas mis encomiendas e que aveis hecho muchos buenos hedeficios en mejoramientos en la herreria de Soldon que es de la dicha mi encomienda de Quiroga estando como ella estaba para se yr a yermo e que aveis gastado mas de trescientos ducados, los quales aveis fecho por mi mandado e consentimiento e prometiendo bos de bos hazer fuero della".

674 AHRG. R. A.: 5.773/33

675 AHRG. R. A.: 19.768/32 
Las reconstrucciones de ferrerías, probablemente medievales, puede ser un indicio de la introducción de nuevas técnicas más productivas por estos empresarios y ferrones vascos. Otro indicio del papel de estos como promotores puede ser el ritual que conocemos para la toma de posesión, como el que se describe con enorme precisión y prolijidad de datos en la inauguración de la ferrería de La Rodela (Quiroga) en 1566. Según el texto, se sacrificó un toro en el mazo, movido por el agua y la rueda hidráulica, y con su sangre se fueron marcando los límites de la propiedad676. Este ritual lo hemos visto citado en otros casos, por ejemplo en la ferrería de Soldón ${ }^{677}$, y creemos que se trata de un ritual de posesión de origen vasco. En ambos casos hubo mucha presencia de vascos, normalmente oficiales de otros artefactos cercanos, y, por lo que sabemos de la ferrería lucense de Lusío, se trata de una "una costumbre antigua de Vizcaya para adquirir algunas preeminencias"678. Es decir, que tanto al construir una ferrería como al tomar posesión de ella se solían hacer rituales de tradición vasca, lo que revela el papel de estos en tales construcciones.

\subsection{La nobleza y la Iglesia como promotores de la construcción de las ferrerías en los siglos XVI y XVII}

Aunque los vascos fueron en ocasiones los constructores o los que reedifican viejas ferrerías medievales como modernas ferrerías hidráulicas en nuestra región durante los siglos XVI y XVII, lo hicieron con el permiso de los propietarios de la tierra, siendo con frecuencia estos mismos los promotores, debido al interés por explotar los recursos de agua, carbón y mineral de hierro que poseen en sus jurisdicciones o de los que son propietarios eminentes. Quiénes fueron los impulsores del desarrollo siderúrgico no podemos saberlo con seguridad; pero es indudable que los señores estuvieron bien dispuestos a la iniciativa de los ferrones vascos, si no fueron ellos mismos, como ocurre en Portugal679, los que los llamaron para poner en marcha esa actividad, y los que invirtieron grandes sumas en la construcción de las ferrerías del interior. En el caso de las ferrerías cercanas a la costa, que usaban mineral de Somorrostro, el

\footnotetext{
${ }_{676}$ AHRG. Hombreiro, leg. 19.

677 AHRG. R. A.: 19.768/32.

${ }^{678}$ ARCHIVO DE SAMOS: Casa de Lusío, libro becerro 81715), f. $7 \mathrm{v}$.

${ }^{679}$ L. M. DUARTE (1996): "A actividade mineira em Portugal durante a Idade Media (Tentaiva de sintese)”. Actas I jornadas de Minería y tecnología. León, p. 87
} 
papel de la hidalguía rural y de algunos comerciantes y regidores de Avilés, Gijón, Castropol y Vivero parece evidente, aunque ignoramos los lazos económicos que los vincularon a los ferrones vascos.

Estos propietarios de la tierra al comienzo de la Edad Moderna fueron la nobleza y el clero. La alta nobleza, con algunas excepciones, fue poco proclive a este tipo de actividades, aunque hubo varios ejemplos, quizá el más notable el del conde de Lemos. Pedro Álvarez Osorio, primer conde de Lemos tras la recuperación de este título en el siglo $\mathrm{XV}$, se interesó mucho por la siderurgia, quizá para forjar armas para sus ejércitos durante la Guerra Irmandiña ${ }^{680}$, quizá para dinamizar económicamente zonas de sus estados pobres pero cercanas a los yacimientos de Formigueiros y Rocas, y con abundantes recursos carboníferos en sus bosques y montes. Ignoramos si fue él quien levantó las ferrerías del Selmo (Arnado y Pontepetre) y las del valle del Valcarce (Herrerías y San Fiz), pero en todo caso a fines del siglo XV era suyas ${ }^{681}$; también lo fueron las de Lousadela ${ }^{682}$ y Montoxo ${ }^{683}$. Las cuatro primeras, las del Bierzo, pasaron en 1486 por herencia a los marqueses de Villafranca, que además poseyeron en el siglo XVI las de Marciel, cerca de Bembibre ${ }^{684}$.

En los ingresos del marquesado estas ferrerías, en los dos primeros siglos casi siempre arrendadas a vascos, no jugaron un papel notable si los comparamos con el obtenido por las alcabalas de lugares como las villas de Villafranca y Cacabelos (del total de los ingresos monetarios del marquesado en 1555, sólo el 5,1\% provenía de la renta de las ferrerías mientras que las alcabalas suponían un $73 \%{ }^{685}$ ); sí lo jugaron en cambio, de manera indirecta, por la vitalidad demográfica y económica que imprimieron a zonas de su jurisdicción

\footnotetext{
${ }^{680}$ El conde de Lemos arma un ejército de más de 15.00o hombres. Cf. I. BECEIRO (1977): La rebelión irmandiña. Madrid, p. 139

${ }^{681}$ A. FRANCO SILVA (1981): "Bienes, rentas y vasallos del señorío de Villafranca del Bierzo al término del siglo XV". Archivos leoneses, 69, p. 46

682 AHPLU: 2048/2: En un subforo de esta ferrería de 1606 a Jerónima de Villasur, viuda de Francisco López, los subforeros dice que la hacen, "por las vidas y voces en que la tenía el dicho Francisco López" del conde de Lemos.

${ }^{683}$ AHRG. R.A. 5.772/33. Foro del conde de Lemos en 1537 a Martín de Basoa para que la construya sobre otra anterior de su propiedad.

684 A. FRANCO SILVA (1982): Ob. cit., p. 92.

685 J. A. BALBOA: "La economía de marquesado de Villafranca en la Edad Moderna". Ponencia en el congreso sobre el Marquesado de Villafranca, celebrado en Ponferrada el 27 al 30 de septiembre de 2007. En prensa.
} 
pobres y marginales. Esta es la razón por la que los marqueses muestran tanto interés en las ferrerías, colocándolas al mismo nivel que sus lugares y jurisdicciones, como puede verse en el pleito seguido a la muerte del conde Pedro Álvarez Osorio. A su hija Juana, futura marquesa de Villafranca, le van a corresponder las tierras bercianas del condado de Lemos y entre ellas las ferrerías ${ }^{686}$. Del mismo modo en 1528, Pedro de Toledo y María Osorio, segundos marqueses de Villafranca, cuando con licencia de Carlos I y la reina Juana creen su mayorazgo, las incluirán entre los bienes que vinculan al mismo 687 .

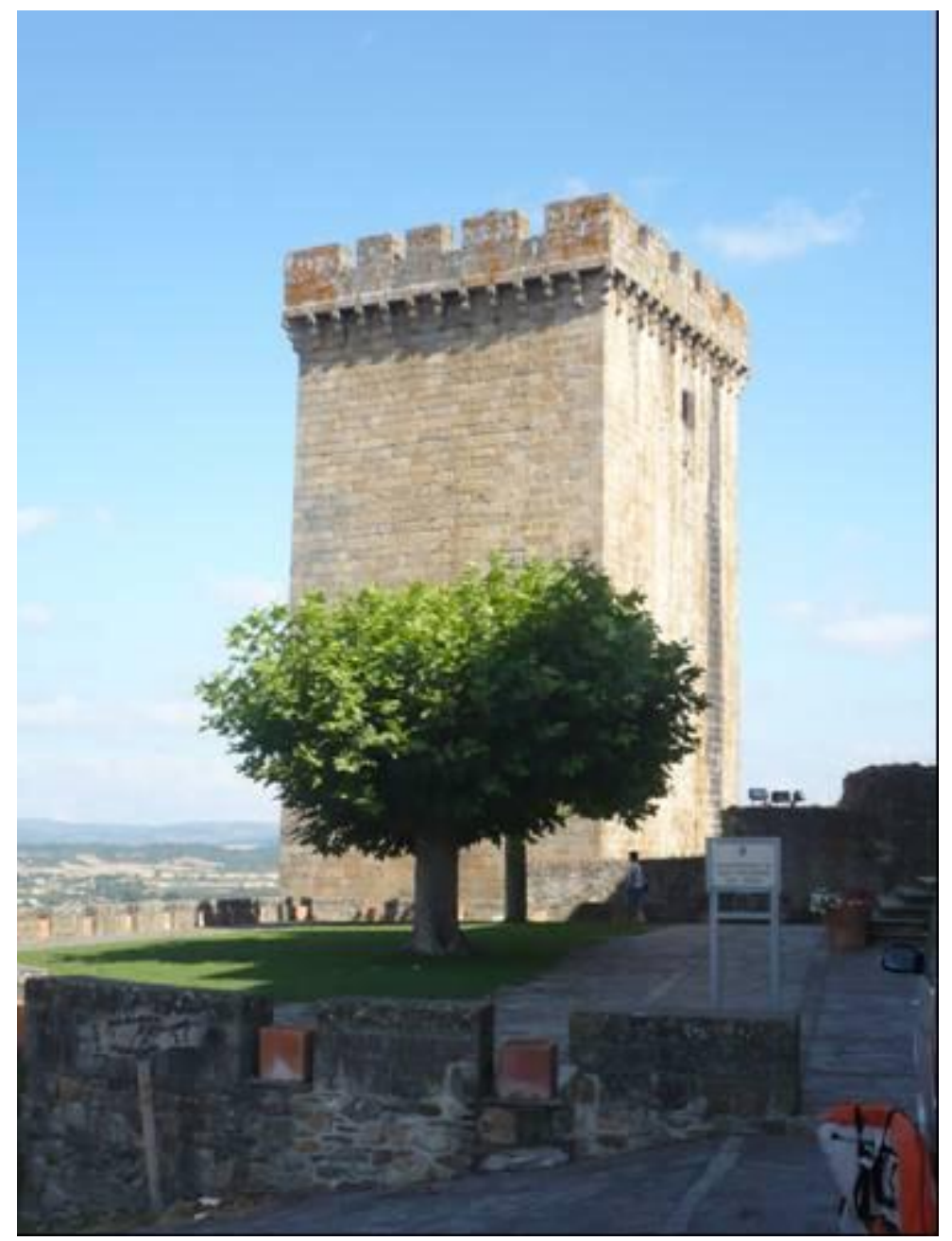

Castillo de los condes de Lemos en Monforte

${ }^{686}$ IBIDEM, p. 66 , apéndice 5: "las dichas tierras e coto de Balboa, e tierra de Aguiar con las fortalezas de Cerresín e Balboa e Losio, con tierra de Arganza e los lugares de Valdemora e Palazuela, con todos sus vasallos, logares, cotos e ferrerías, e jurisdicciones"

687 I. GARCÍA TATO: (1999): "La colegiata de Villafranca del Bierzo". Revista Bierzo, p. 132: La merindad de Aguiar con sus fueros "e con las Herrerias de Pontepetri e Santo Bota". 
Otros miembros de la alta nobleza, como el conde de Ribadavia o el marqués de Astorga, también fueron promotores de ferrerías o, al menos, las poseyeron. El primero la de Valdeorras, del siglo XVI. El conde la arrendó a la familia Gil antes de 1586, año en que la traía en foro Juan Gil "el Viejo"688. El marqués de Astorga, por su parte, construyó la ferrería asturiana de Montealegre, posiblemente en el siglo XV, aunque luego la vendió a Pedro de Miranda ${ }^{689}$. En 1531 este la volvió a vender a Juan Nuñez Pardo Donlebún y Pero González de Abulí, de Castropol, en cuatrocientos ducados oro, junto con la jurisdicción civil y criminal 690 . A finales del siglo la ferrería pertenecía íntegramente a la casa de Presno, probablemente por compra de los Pardo Donlebún a los Gonzalo de Abulí, señalando aquellos en 1571 que la tenían desde tiempo inmemorial. Estos la arrendaron al vasco Pedro de Mindirichaga, quien, para su buen funcionamiento, debió invertir una buena suma de dinero ${ }^{691}$.

Al lado de esta alta nobleza, otros grandes promotores de ferrerías fueron las órdenes militares de Santiago y San Juan de Jerusalén, propietarias de extensas zonas en la provincia de Lugo: las encomiendas de Quiroga, de los hospitalarios de San Juan, las ferrerías de Quintá, Soldón, Rodela e Incio; y la de la Barra, de la orden de Santiago, las de Paleiras, Ferreirós, Valdomir, Loureiro y Hórreos o Visuña. La mayoría de estas ferrerías no las construyeron esas órdenes sino empresarios y ferrones vascos (lo hemos visto en el caso de las ferrerías de Paleiras, Ferreirós, Soldón, Valdomir, Incio y Loureiro) o hidalgos rurales (Rodela ${ }^{692}$, Quintá693) a los que aquellas órdenes arrendaron los lugares para emplazarlas y los montes para abastecerlas de combustible. Por tanto, más que promotores hay que ver a tales encomiendas como perceptores de rentas de zonas montañosas poco aptas para los cultivos, que se aprovecharon de sus

\footnotetext{
688 AHPOU. PN.: caja 554 (1586).

${ }^{689}$ Esta noticia de la venta del marqués de Astorga la proporciona el documento de la nota siguiente.

690 J. LÓPEZ y A. GRINDA: Ob. cit. p. 25

${ }^{691}$ IBIDEM, p. 125

${ }^{692}$ Francisco Vázquez era hijo de Álvaro de Quiroga, quien en tiempo de las Comunidades había defendido la fortaleza de Incio, propia de la encomienda, frente a la condesa de Lemos, por lo que ésta le había usurpado parte de la hacienda que tenía en Castro Caldelas. De ahí las relaciones estrechas de esta familia con la orden de San Juan, que en 1562 le aforó la Campa do Moiño (AHRG. R. A.: 1662/4)

693 La encomienda de Quiroga se la aforó en el siglo XVII a los Neira
} 
recursos forestales y de la cercanía a los yacimientos de Rocas y Formigueiros. Este último, como hemos dicho, se hallaba incluso en tierras de la encomienda de la Barra694.

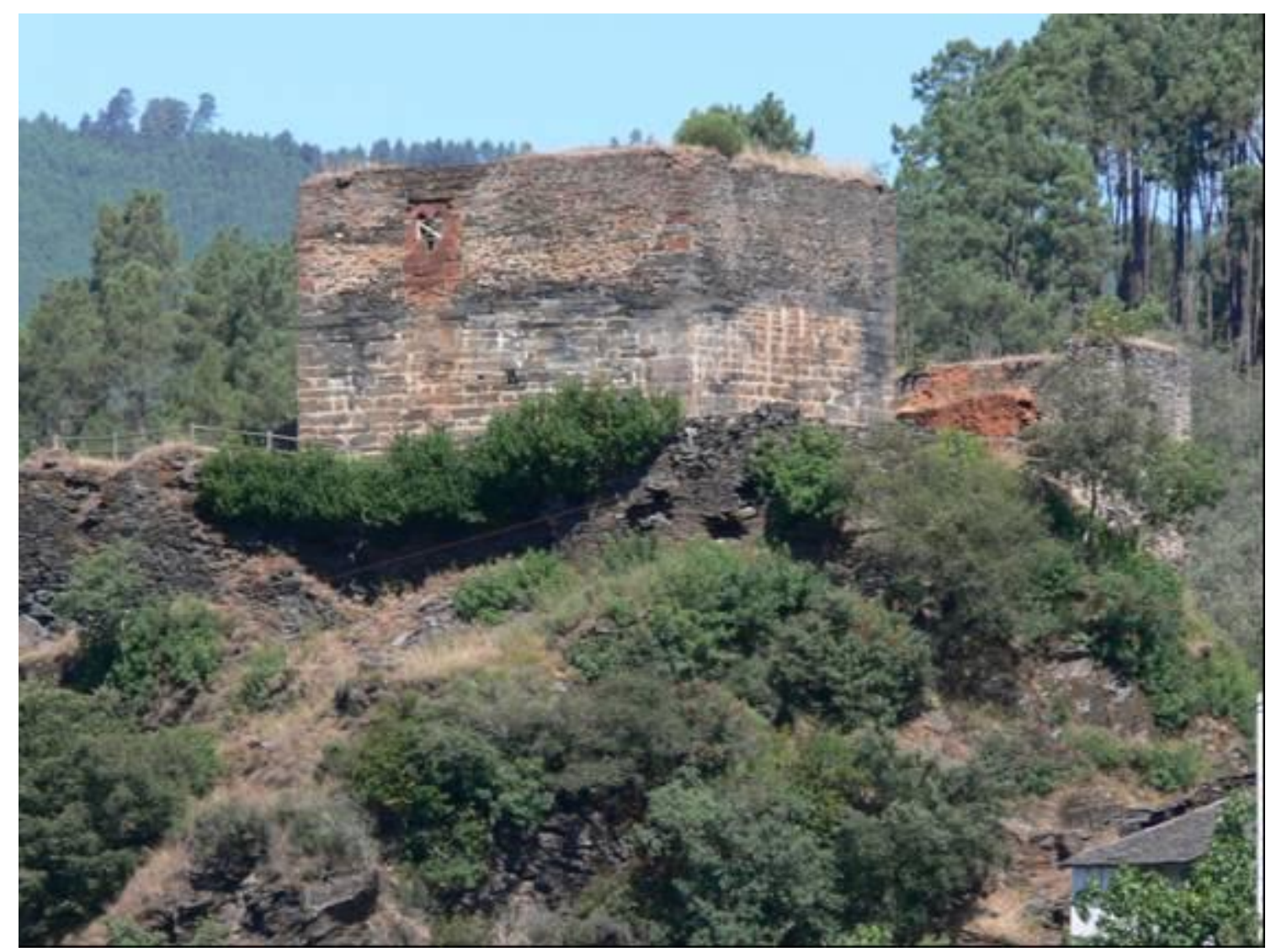

Castillo de Torres Novaes (casa central de la comienda de Quiroga)

Un tercer grupo de propietarios fueron los monjes de algunas grandes abadías, como Lorenzana, Samos y Valdediós, y el obispado de Mondoñedo. A este último hay que relacionarlo con las ferrerías medievales de Bravos y Viloalle, esta última transformada en mazo en 1571 por falta de combustible. La de Bravos, también medieval, la traía en foro en el siglo XVI la familia Pérez de Cora. El monasterio benedictino de Villanueva de Lorenzana poseía igualmente ferrerías en la Edad Media, que fundían hierro con vena local. Una de estas fue la de Vilaseca pero sobre todo la de Lorenzana o del Saltejo, al lado del monasterio, de la que tenemos noticias ya en 1429. A comienzos del XVI fue aforada a Fernando Rodríguez de Aguiar en 3.000 maravedís de renta695, y en

${ }^{694}$ AHPOU, Casa do Castro, caja 112, $\mathrm{n}^{0}$ 16, $3^{\circ}$. Cit. Por I. GARCÍA TATO: "Las ferrerías de Río Cabo y Pombriego en el siglo XIX”. Rev. Bierzo (Ponferrada), 2000, 104.

695 AHN. Clero: Lourenzá, códice 181/B, f. 47v 
1569 al vizcaíno Francisco Sánchez de Vidarte por tres vidas y 8.100 reales al año696. Del mismo modo, el monasterio asturiano de Valdediós construyó en el siglo XV la ferrería de Peón, que desde 1538 los monjes aforaron a Gregorio García de Jove, propietario además de las de Dueñes y Amandi697.

El monasterio de Samos también se interesó por explotar sus recursos. En el siglo XVI erigió las ferrerías de Santalla y Gondriz, a las que añadió otra en el siglo XVII. La de Santalla se levantó en los primeros años del siglo XVI cuando fray Juan de Estella, reformador de Samos, aforó a Diego Velón y a su mujer Velasquida González de Cancelada las aguas y montes de la zona para hacer una ferrería a cambio de una renta anual de 750 maravedís ${ }^{698}$. Se trata probablemente de una familia hidalga bien relacionada con el convento. A la muerte de Diego Velón, fue traspasada y vendida por su mujer al vasco Domingo de Zarauz, rentero de Incio; venta que acarrearía problemas con los herederos de Diego Velón que, después de largos pleitos, la gozaron hasta mediados del siglo XVII 699. Gondriz, por su parte, fue en su origen un mazo que Samos adquirió en 300.000 maravedís y sobre el que en 1555 construyó la ferrería, arrendada a ferrones vascos hasta el siglo XVII, en el que recuperaría ambas $^{700}$. En ese mismo siglo levantó la de Pallares ${ }^{701}$. También los monjes de Belmonte construyeron la ferrería de este nombre en el XVII y hacia 1676 los de Villanueva de Oscos la suya ${ }^{702}$.

Por último, la pequeña nobleza hidalga se embarca igualmente en el siglo XVI en la industria del hierro de la que obtendría sustanciosos beneficios. Algunas ferrerías son anteriores aunque renovadas, otras se construyen de nuevo, siendo frecuentemente arrendadas a vascos. La lucense de Silán era probablemente medieval, aunque la primera referencia que conocemos es de 1553 en que Fernán Cao de Cordido, en nombre del señor Juan López de

${ }^{696}$ AHN. Clero: Lorenzá. Libro 6.622. Tabla de pergaminos, t. I., ff. 326-327

${ }^{6}$ M. DE ABOL-BRASÓN (2011): Documentos escogidos de la Casa de Jovellanos en el Archivo de Mohías. Gijón, p. 23

698 AHRG. R. A.: 931/44

699 AHRG. R. A.: 70/80

700 AHN. Clero: Libro 6695, ff. 119; M. ARIAS CUENLLAS: Ob. cit., p. 291

701 M. ARIAS CUENLLAS: Ob. cit., p.199 y 286.

702 AHN. Pap. Leg. 136. Cfr. PRIETO BANCES (1976):Ob. cit., p. 102, nota 286. 
Prabeo, su propietario, contrata como aroza al vasco San Juan de Aguirre703. La de Bogo la construyó el hidalgo Pedro Miranda, de la casa de Ribadeneira, a principios del XVI, pero en 1537 la traía arrendada al vasco Juan de Belastegui704. La primitiva de Bueyes la erigió don Pedro Bolaño Ribadeneira, señor de la casa fortaleza de Torés a finales del XV o principios del XVI705. La de Rial o Lusío, al lado del monasterio de Samos, la levantó Lope Vázquez de Villameixe hacia 1570, transformado un mazo en ferrería, pese a la oposición de los monjes ${ }^{706}$. Las de Pesqueira y Saramugo fueron de Pedro Pardo de Aguiar, señor del coto de Saramugo; la primera en unión con el hidalgo Pedro Maseda. En 1571 la aforaron al vasco Pedro Sánchez de Vidarte, rendero de Lorenzana707.

De igual modo ocurre con las asturianas que, en este siglo, en su mayoría se encuentran en la zona central y oriental de la región. Así las de Deva y Dueñes estaban en la zona central asturiana y pertenecieron a Juan García de Jove, que ya tenía aforada a los monjes de Valdediós la de Peón. La primera pasó a su hijo Alonso Ramírez, tenido de su segunda mujer Isabel Ramírez de las Alas; las de Peón y Dueñes quedaron en manos de su primogénito Gregorio García de Jove "el Viejo". Ambas familias hidalgas se dedicaban al comercio y a la explotación de sus tierras 708 . Respecto a los Alas de Avilés creo que también les pertenecieron las ferrerías de Labayos, construida hacia $1494^{709}$, y Raicedo, que ya existía en 1537 como propia de Hernando de las Alas ${ }^{710}$. La de Penamellera, situada en el extremo oriental de la provincia, era a finales del XV de Gutierre Rávago y Sancha de Turana ${ }^{711}$; por último, las de Boimouro y Sueiro de Arriba, en la zona occidental, fueron de Ares de Omaña el Rubio'12; y la de Arganza la

\footnotetext{
703 AHPLU: 3973/2

704 P. SAAVEDRA, P. (1985): Ob. cit., p. 327

705 AHRG. R.A.: 21477/96

706 ARCHIVO DEL MONASTERIO DE SAMOS: Casa de Lusío, libro becerro (1715), p. 7v.

707 AHRG. R.A.: 714/16 y 21.859/105

${ }^{708}$ M. DE ABOL-BRASÓN (2011): Documentos escogidos de la Casa de Jovellanos en el Archivo de Mohias. Gijón, p.

709 AGS. RGS.: leg. 149404,534.

710 ACh.V.: Pleitos civiles Fernando Alonso (E). Caja 207,5

${ }^{711}$ AGS. RGS: 8 de julio de 1517

${ }^{712}$ La de Boimouro se cita en un documento de 1520: "Yo Ares de Omaña cavallero señor de la casa e puente de Omaña e del lugar de Omañón e casas de Villar e coto de Prediñán e ferrerias de Vaymouro" (A.Ch.V. R. E.: caja 1633,50); la de Sueiro de Arriba existía ya en 1548 como deducimos de un juicio entre Ares de Omaña y su arrendatario Martín San de Viana (AGS. RGS.: octubre de 1548).
} 
construyó a finales del siglo otro Ares de Omaña, probablemente nieto del anterior ${ }^{713}$.

En el siglo XVII se levantaron nuevas ferrerías pero en mucho menor número que en el siglo anterior, quizá debido a la crisis demográfica, económica y política, aunque esta afectó de manera desigual a unas regiones y otras ${ }^{714}$. En la primera mitad se construyeron las de Bueyes en Lugo ${ }^{715}$, y en Asturias las de Abres (Vegadeo) hacia 1623, pese a la oposición de los vecinos ${ }^{716}$; la de Veiguiña poco antes antes de 1622, cuya propiedad estaba dividida en tres partes: una era de don Juan Nuñez Pardo y doña María Valledor y Presno, otra de Pedro Nuñez de la Veguina y su hermano, y la tercera de Domingo de Valderrendero o Valderraín717. La de Sueiro de Abajo la erigió hacia 1625 Diego García de la Vega, alcalde de El Franco, tras un largo pleito con los propietarios de la de Arriba $^{718}$. Posteriormente se levantó la de La Fanosa, que promovió la casa de Tineo ${ }^{719}$.

De toda esta historia podemos concluir que la construcción y explotación de ferrerías en el noroeste de España fue una buena opción para los propietarios de la tierra; pues en general se sitúan en zonas poco aptas para el cultivo agrícola, pero ricas en recursos forestales, agua y cercanas al aprovisionamiento de mineral de hierro (de venas locales o del de Vizcaya). Primero la alta nobleza

\footnotetext{
${ }_{713} \mathrm{M}^{\mathrm{a}}$ A. FAYA y L. ANES (2007): Nobleza y poder en la Asturias del Antiguo Régimen. Madrid, p. 246-247.

${ }_{714}$ Aunque no se puede hablar de una crisis generalizada, es evidente que hubo problemas demográficos, crisis agrarias (J. DÍAZ (2005): "Crisis agrarias en la Asturias del siglo XVII. Una aproximación a su estudio". Revista de Historia Moderna, $\mathrm{n}^{0}$ 23, p. 307-322), devaluación de la moneda (AHPLU: 2547/1. En un juicio sobre los bienes de Juan Pérez de Irazti, los testigos hablan de cómo "al presente tyene la azienda poco valor (...y...) los byenes... no tienen el balor que solian"). Sin embargo, algunos autores ponen en duda, en lo que a las ferrerías vascas se refiere, esa crisis: J. PH. PRIOTTI (2011): "Producción y comercio del hierro vizcaíno entre 1500 y 1700". Eusko Ikaskuntza, no 57, p. 18; A. ARAGÓN (2011): "La actividad siderometalúrgica guipuzcoana durante el siglo XVII: transformación y productividad". Lurralde: Invest. Espac. 34, p. 109-149; ID (2012): "Las ferrerías guipuzcoanas ante la crisis del siglo XVII". Cuadernos de Historia Moderna, 37, p. 73-102.

715 AHRG. R. A.: 21477/96: La levantó Pedro Vasco de Ulloa hacia 1612, pese al juicio que hubo de entablar con el dueño de otra ferrería cercana: "que teniendo él una herrería en el Río de bueis mi parte aze otra herrería en el dicho río con que le quita el agua y se aprobecha de sus montes".

716 AHDO: Parroquia de Santiago de Castropol, caja 14-3-218.

717 AHDO: Parroquia de Santiago de castropol, 14-3-669, f. 32

${ }_{718}$ A.Ch.V. R. E.: caja: 2489,47

${ }^{719}$ AHA: Francisco López Sierra, caja 15.635. Cfr. J. LÓPEZ y A. GRAÑA (1998): Ferrerías, mazos y fraguas en Asturias. Oviedo, p. 128-129.
} 
y las órdenes militares, luego las órdenes religiosas y la hidalguía rural se convirtieron, más que en empresarios, en promotores de esa industria, porque generalmente no explotaron las ferrerías de forma directa sino indirecta, mediante arrendamientos o foros, muchas veces con ferrones vascos, ya que estos conocían la técnica e incluso contaban con el dinero necesario para poner en marcha los ingenios ferreros, quizá con el apoyo de comerciantes, lo que nos permitiría hablar de un temprano verlagssystem en la zona, aunque no hemos podido documentarlo 720 .

La mayoría de estas construcciones se emprenden antes de la segunda mitad del siglo XVI, luego parece decaer el interés de la nobleza. La mentalidad nobiliaria, por ejemplo en Asturias, fue un lastre para el desarrollo de la industria y el comercio, ya que la huida de las inversiones productivas hacia las rentas, especialmente agrarias, que tuvo lugar entre 1550 y 1625 en que se fundaron o reforzaron el $62,5 \%$ de los mayorazgos asturianos, restó posibilidades al desarrollo económico de esta provincia. Sus fundadores habían sido muy activos en los primeros años del siglo XVI, pero pronto abandonaron estas actividades industriales y comerciales por las rentas ${ }^{721}$, como vemos en casos como los Alas, los Hevia o los Jove, comerciantes y marinos enriquecidos con el comercio y posteriormente ennoblecidos. Esa misma actitud podemos ampliarla a la hidalguía de todo el noroeste, quizá como un síntoma de una cierta pérdida del interés por la industria y el comercio y su refugio en bienes más estables, como las tierras y los cargos públicos, y de más prestigio social.

\subsection{Continuidad y diversificación en la propiedad de las ferrerías durante el siglo XVIII}

En el siglo XVIII se produce un nuevo auge en la construcción de ferrerías y se diversifica su propiedad con una más amplia gama de propietarios. Así, las órdenes religiosas, que desde finales del XVII recuperan la propiedad de

${ }^{720}$ Sabemos, por ejemplo, que la ferrería de Paleiras, cuyo valor era de unos 2.000 ducados la construyó el vasco Martín de Aldunzín, pero desconocemos de dónde obtuvo el dinero para erigirla, aunque probablemente una parte se la prestó el hidalgo Francisco Vázquez, a quien luego se la vendería.

${ }_{721}$ B. BARREIRO (1988): "Agricultura e industria en Asturias en el siglo XVIII". En E. FERNÁNDEZ DE PINEDO y J. L. HERNÁNDEZ (Ed.): La industrialización del norte de España. Barcelona, p. 48 
sus viejas ferrerías antes aforadas, añaden ahora otras a las que ya tenían, e incluso algunos monasterios las construyen por primera vez a imitación de sus compañeros, dada su rentabilidad e interés para el sostén de sus comunidades. Samos construye ahora las ferrerías de San Vicente de Leira y Rugando; y San Pedro de Montes, en el Bierzo, a imitación de Samos, ambos monasterios benedictinos, levanta las de Linares y Pombriego. También la nobleza y la pequeña hidalguía se interesan por estos artefactos, que les suministran suculentas rentas. Así los marqueses de Santa Cruz del Mercenazgo, las de Arbón y Bullimeiro; los marqueses de Vista Alegre, la de Riera; los marqueses de Santa María del Villar, herederos de Ares de Omaña, la de Boimoro, y los marqueses de San Esteban del Mar reconstruyen la de Deva. La pequeña hidalguía, por su parte, promoverá igualmente la construcción de numerosas ferrerías ${ }^{722}$ :

- Pontenova: don Antonio Flórez Estrada, señor del Castro de Valdeorras

- Neira de Rey: don José Quiroga y Armesto, dueño de la casa de Horbán

- Lor: don Joaquín Pardo Ribadeneira, señor de Val de Fariña, Portomeñe, etc.

- Papín o Piago: Don Vicente Pardo Herbón Ribadeneira, señor de la casa de Ribas, en el valle de Ouselle, y don Ramón Ulloa y Valcarce, señor de la casa de la Peña, en la jurisdicción de Neira de Rey

- Penacova: familia Arias, señores de la casa de Maside

- Biduedo: don Lucas Somoza y Losada, señores de Layosa.

- Gorgueira: Don Juan Quiroga, señor de la casa de Reda

- Gonzar: Jacoba y María Gil de Taboada, ricas propietarias de Santiago

- Froseira: casa y vínculo de Berdín

- Nafarea: Jacinto Pardo Valledor, señor de la casa de Presno

- Soto Rodrigo: Vicente Ignacio Argüelles, regidor perpetuo de Piloña

- Agüerina: Alvaro Cienfuegos Miranda, regidor perpetuo de Pravia.

- Brieves: don Jacinto Avella Fuertes, señor de la casa de Llamas (Canero) y regidor perpetuo del concejo de Valdés

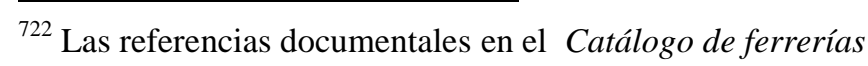


- Setienes: don Matías Menéndez y Luarca, regidor perpetuo del regimiento de Valdés.

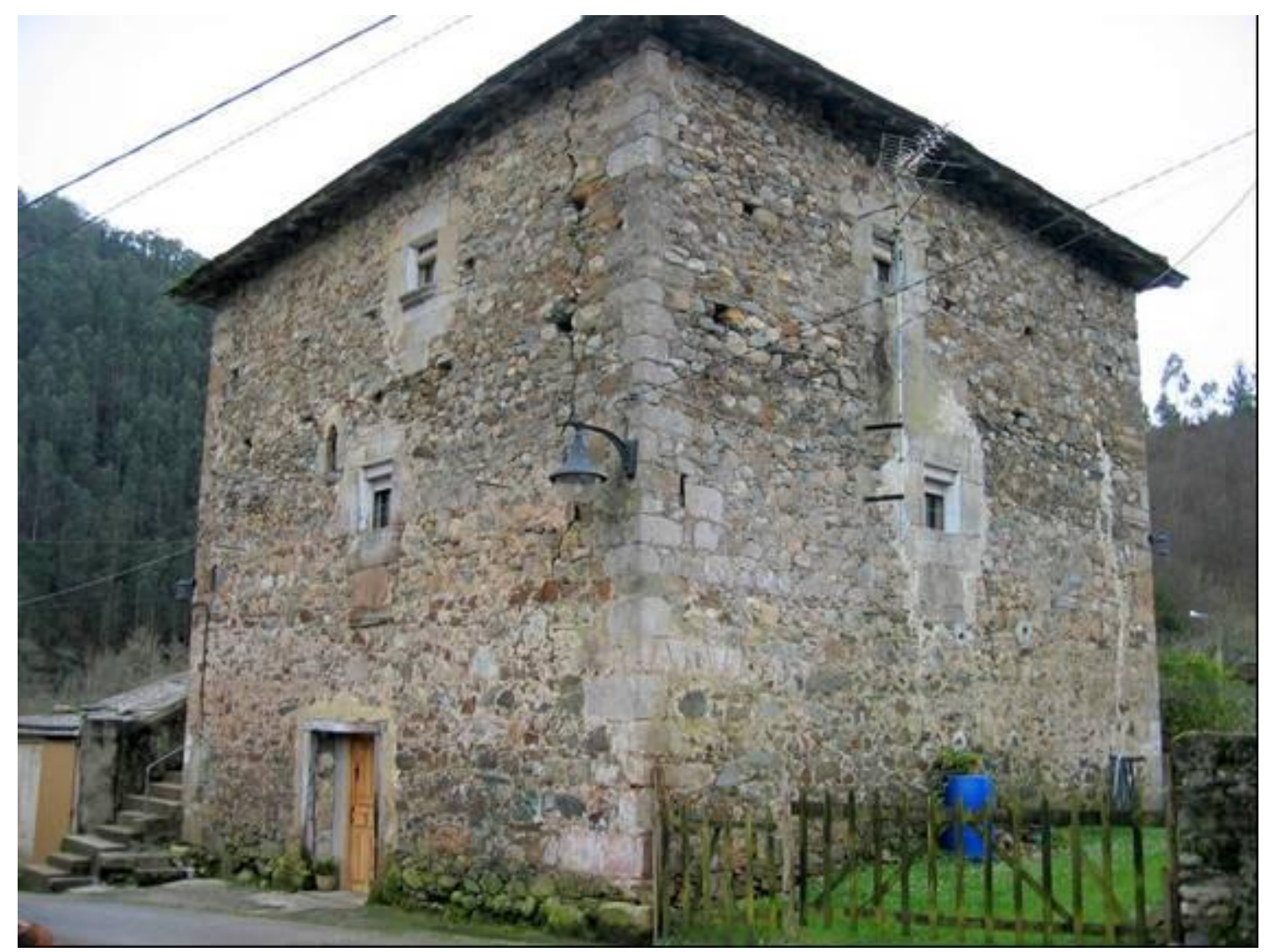

Torre de los Avello. Ferrería de Brieves

Una novedad a finales del siglo XVIII, que anuncia nuevos tiempos, será la formación de compañías integradas por socios capitalistas para la explotación siderúrgica: La Compañía de la Vega de Ribadeo, propietaria de tres ferrerías, dos en Asturias y una en Galicia, promovida por Andrés Bravo Bermúdez²3; la compañía de la ferrería de Tejedo, formada por tres socios dedicados anteriormente al comercio ${ }^{724}$; por no hablar de empresarios privados como el

723 AGS. Junta de Comercio y Moneda: leg. 295.

$724 \mathrm{El} 25$ de agosto de 1788 se formaliza el acuerdo para la constitución de la Compañía y construcción de la ferrería de Tejedo. Don Jerónimo y don Bernardo Rodríguez, ancareses comerciantes en Ferrol, ponían el dinero y don Francisco un prado a orillas del río, en Tejedo, valorado en 21.0oo reales, en el que se levantaría. Acuerdan guardar buena armonía, exigiendo cuentas puntuales al encargado, y que si en el futuro se proyectase mejorar las instalaciones, debería hacerse con el acuerdo de todos, "concurriendo cada uno con lo que le corresponde hasta perfeccionar dicha fábrica” (AHPL. PN.: caja 3492). 
militar Carlos Lemaur (ferrerías de Torre y Navaleo)725, don José Álvarez de la Braña (fábrica de Rao) ${ }^{726}$ y Francisco Antonio Ibáñez que construye la fábrica de Sargadelos y promueve ferrerías en el occidente de Asturias y en Galicia727. Tanto las órdenes religiosas, aunque con criterios económicos no capitalistas, como estos nuevos empresarios explotarán directamente, o por medio de administradores o directores, estos nuevos ingenios, que les proporcionaron suculentos ingresos.

\subsection{La burguesía industrial como promotora de la actividad industrial en el siglo XIX}

En el siglo XIX se diversifica todavía más la propiedad de estas ferrerías, en parte por la Desamortización y en parte por la actividad constructora de esos años. La mayoría de las que se levantan en el siglo XIX son propiedad de antiguos renteros de ferrerías de la zona; y a diferencia de los propietarios de siglos pasados, estos administran directamente las suyas, aunque no siempre. Es el caso, por ejemplo, de Jacinto Fariñas, administrador de la ferrería de Visuña hacia 1819 y posterior constructor y propietario de la de Lusío en Oencia; Ramón Ovalle, arrendatario por los años veinte de las ferrerías de Puente Nuevo y Arnado y posterior propietario de la de Arnadelo y Valdelouro; Benito del Valle que construyó las de Valincarro y San Vitul; Manuel Díaz Lombán y su cuñado José Lombardero, propietarios de las de Pontigón y Renueva; Fernando Pérez Villamil, arrendatario de la de la Veiguiña y promotor de la de Lagar.

También hay algunos señores, propietarios de ferrerías, que igualmente construyen otras nuevas, como Apolinar Suárez de Deza, marqués de Bóveda, que además de las de Valdomir, Lousadela, Bueyes y Valcarce, construye las dos

725 M. OLANO (2008): "Carlos Lemaur y la industria del hierro y del carbón en la cuenca del Boeza”. En Actas del VI congreso internacional sobre patrimonio geológico y minero. X sesión científica de la SEDPGYM. Fabero del Bierzo, 19 septiembre-2 de octubre de 2005, p....

${ }^{726}$ AHRG. Protocolos: leg. 1.617, ff. 54

727 Sobre Sargadelos: J. E. CASARIEGO (1974): El marqués de Sargadelos o los comienzos del industrialismo en España. Oviedo; A. MEIJIDE PARDO (1979): Documentos para la historia de las Reales Fábricas de Sargadelos. Sada; BORREGUERO GARCÍA, E. (1994): Documentos para la historia de las Reales Fábricas de Sargadelos en el Archivo General Militar de Segovia. A Coruña; CARMONA BADÍA, J. (1993): "Sargadelos en la historia de la siderurgia española". Revista de Historia Industrial, $n^{\circ} 3$, p. 11-39; SUÁREZ MÉNDEZ, R. (2001): Las Reales Fábricas de Sargadelos y Trubia. Competencia, rivalidad y apoyo. Sada. 
de Río Cabo, en el Bierzo, y la de Camba, en Orense; Antonio Somoza y Pardo, dueño de la Casa del Río, en San Martín del Río, jurisdicción de Villauzán (La Somoza), que levanta las de Seoane (en 1815) y La Mezquita, etc.; Juan Bernardo Quiroga, señor de la casa de Lamela (Quiroga), diputado en Cádiz, que construye la ferrería orensana de Mondón poco después de 1813; y los señores del pazo de Herbes, propietarios de la de Soldón, que construyen la de Vilarbacú hacia 1830 . Se trata, en general, de una hidalguía que conoce, por tradición, el valor de estos artefactos de los que obtienen una parte muy importante de sus ingresos, en muchos casos emparentados entre si y que, en el siglo XIX, alcanzarán títulos de nobleza con Isabel II: marquesados de Hombreiro, Torrenovaes, Gastañaga, etc ${ }^{728}$.

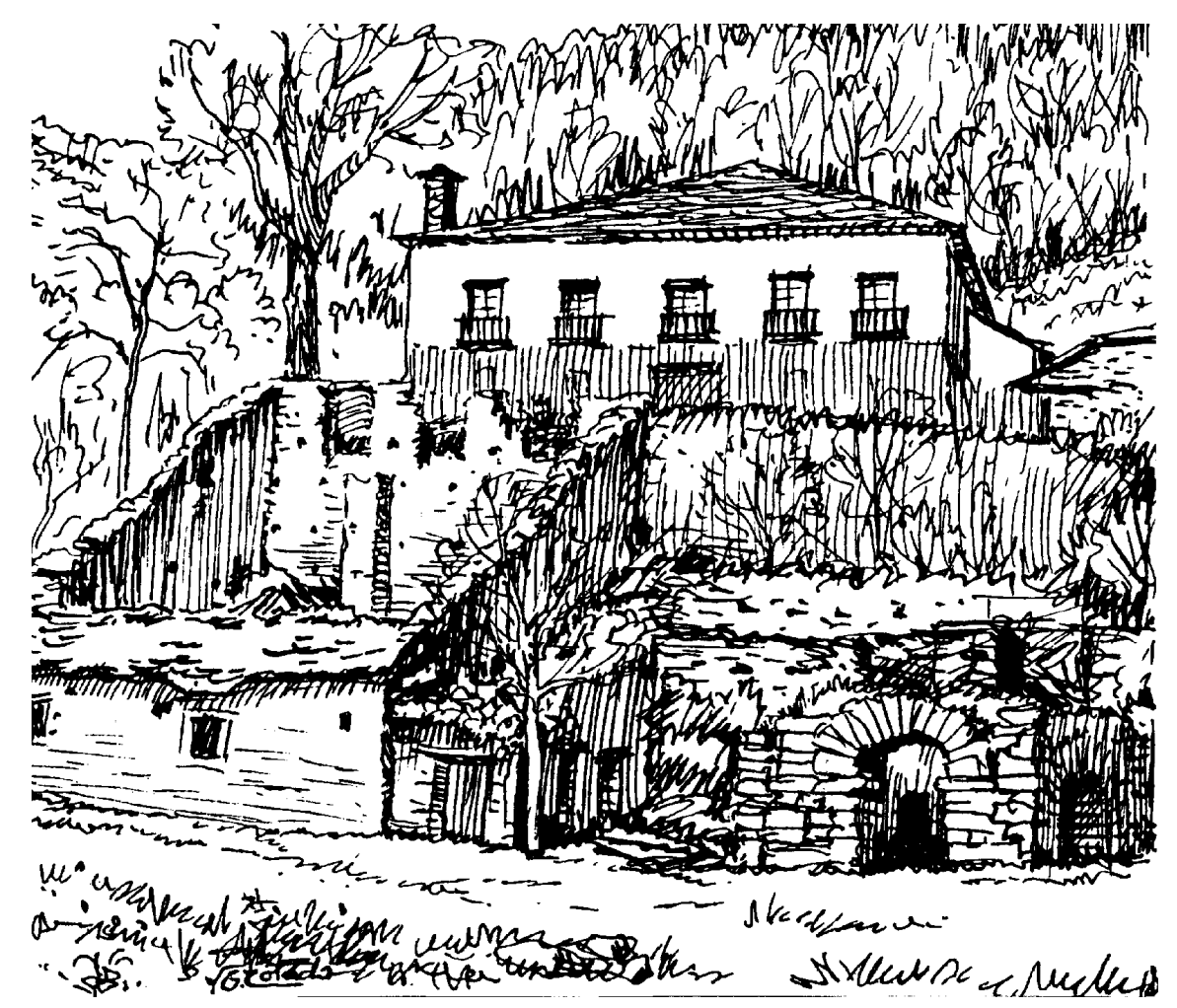

Ferrería de La Portela (dib. P. G. Cotado)

Un caso muy interesante es el del ponferradino Nemesio Fernández, prototipo de industrial ferrero, que se inicia como arrendario de la ferrería de Pontepetre en los años veinte y que, por compra o nueva construcción, llegará a poseer las ferrerías de Montes (adquirida en la Desamortización), Serviz, Portela, Corporales y Llamas de Cabrera, así como los permisos para la

${ }^{728}$ Las referencias documentales en el Catálogo de ferrerías 
construcción de otras en Paradasolana y Valdesampedro, que no llegará a levantar, aunque alguna de ellas la construirá su hijo Felipe, como la de Compludo. Se trata de un hombre de ideas liberales, que participó en política (fue senador) enriquecido con las ferrerías y comprador de muchos bienes desamortizados, incluida la ferrería de Montes. Por el inventario de bienes, realizado en 1859, conocemos el valor en que se tasaron sus ferrerías: entre 140.00o reales la de Corporales y 220.000 la de Portela729. Fue un hombre hecho asimismo, que al final de su vida se convertirá en el mayor hacendando de Ponferrada 730.

Los Armestos gallegos, uno de cuyos vástagos emparentó con una hija de Nemesio Fernández, fueron propietarios, a su vez, de las ferrerías de Folgoso, Valdomir y parte de la de Ferreirós de Abajo. A los Ribadeneyra gallegos, familiares de los marqueses de Viance, les pertenecía la de Vilaboa, y algunas otras a sus diferentes ramas familiares, incluida la de Tejedo de Ancares que adquieren en el siglo XIX por compra731. La ferrería de la Ceneya (Amieva) construída en 1838 por Antonio Vega se vendió en 1866 a Domingo Vázquez, dueño de la ferrería de A Cabanada (Castropol), en 100.000 reales732. Hubo, por tanto, continuidad en muchas familias pero igualmente aparecieron nuevos propietarios, la mayoría hidalgos, en algún caso profesionales y políticos liberales, sectores sociales que caracterizaron la vida política y económica del reinado de Isabel II.

Estos sectores liberales se interesaron por hacerse con las ferrerías monásticas en el proceso de la Desamortización, en el que se llegaron a pagar cantidades considerables. Por ejemplo en la de Mendizábal se vendieron las de San Vicente de Leira, rematada en 1839 en 550.000 reales733; las de la Rodela y Rugando las compró en 1839 por 620.500 reales 734 y 1.120 .000 reales 735 ,

\footnotetext{
729AHPL. P. N.: caja 2724 (1859): inventario de bienes de Nemesio Fernández.

730 J. A. BALBOA (2008): Nemesio Fernández. Un político y empresario del siglo XIX. Ponferrada, p. 61

${ }^{73}$ C. GONZÁLEZ (1994): A producción tradicional do ferro en Galicia: as grandes ferrerías da provincia de Lugo. E. Diputación Provincial. Lugo, p. 103 $73^{2}$ J. LÓPEZ y A. GRINDA (1998). Ob. Cit., p. 19, nota 6.

733 I. GARCÍA TATO (1996): Valdeorras de cara al año 20oo, t. II, p. 56.

734 AHPLU. Desamortización, leg. 10-2 (2)

735 AHPLU. Desamortización, leg. 10, 2 (2)
} 
respectivamente, el madrileño Gregorio López ${ }^{736}$. También el madrileño Antonio Santamarina adquirió ese mismo año la de Gondriz en 455.133,12 reales737. La de Pallares la compró el lucense Modesto $M^{\mathrm{a}}$ Arango Trabadelo en 599.000 reales 738 . Las dos de del monasterio leonés de San Pedro de Montes, como acabamos de decir, las compraron Nemesio Fernández (La de Linares) y Apolinar Suárez de Deza (la de Pombriego). Por último la asturiana de Villanueva de Oscos la adquirieron Gabriel Bermúdez, Manuel Quintana y José Pérez de Barcia, vecinos de Santalla de Oscos739.

En general, las ferrerías solían ser de una dola familia; pero hubo algunas que estuvieron divididas en quiñones o ágoas y fueron, por tanto, de varios propietarios, como la de Valdomir y la de Ferreirós. La de Valdomir era desde el siglo XVI de varias personas, probablemente por herencia740. La de Ferreirós estaba dividida desde el siglo XVII en 72 ágoas. Todavía en 1868 seguía dividida en esas mismas agoas, de las que ocho pertenecían al yerno de Nemesio Fernández, don Rafael Armesto, y el resto a otras cinco personas ${ }^{741}$. Sin embargo, este tipo de propiedad es menos frecuente en el noroeste que, por ejemplo, en el País Vasco, donde ya en la segunda mitad del siglo XVI se percibe una división de la propiedad en dos, tres y cuatro manos ${ }^{742}$.

Por último, decir que cuando la explotación de la ferrería era realizada por los propios dueños, estos solían encargar esa tarea a un administrador743.

\footnotetext{
736 AHPLU: 2376/6 (1846). En mayo de 1846 los propietarios de la ferrería de Folgoso solicitan un préstamo de 15.000 reales a D. Gregorio María López, vecino y del comercio de la villa de Madrid, a quien se lo devolverán en ocho años "en la mencionada casa de la Rodela como propia del señor emprestamista”. También lo era en los años cincuenta (I. GARCÍA TATO (2000): Ob. cit., p. 167).

737 AHPLU: Desamortización: leg. 10, 2 (2)

${ }^{738}$ M. ARIAS CUENLLAS (1992): Ob. cit., p. 292

739 J. LÓPEZ y A. GRAÑA (1998): Ob. cit., p. 109

740 AHRG. R. A.: 2489/48. Juicio por la quinta parte de la ferrería: "e que no sabe que al dicho licenciado balle (que reclamaba esa quinta parte) le ayan dado su parte ni quiñón ni llamándole para que labrare en ella su dia e dias conforme a la parte que en ella le cabe”.

741 AHPL. P. N.: 9113 (1868): inventario de Rafael Armesto y Arias.

742 Á. ARAGÓN (2012): "Las ferrerías guipuzcoanas ante la crisis del siglo XVII". Cuadernos de Historia Moderna, 37, p. 84.

743 Estos administradores no siempre gozaban de buena fama. En unos consejos que Sancho de Neyra deja escritos a sus sucesores para el gobierno de la ferrería de Quintá, les dice que "para maiordomos de esta herrería no tomes gente del país que no son (aconsejables)..., porque tienen cerca sus parientes, y mucho menos gente de Valdeorras porque han prouado mui mal en esta casa, y si los tomas anda sobre auiso y_quenta y razon con ella". En otros casos sabemos que contrajeron deudas con los propietarios o que dilapidaron los bienes de éstos, lo
} 
Esto fue bastante frecuente en los siglos XVIII y XIX en las ferrerías en manos de la nobleza e hidalguía (Apéndice II-7). Muchos de estos administradores fueron presbíteros, es decir hombres de letras, que llevan la contabilidad del artefacto, compran la vena, pagan a los ferrones y venden el hierro; actúan como los arrendatarios pero no lo son: su beneficio es su salario ${ }^{744}$. El gobierno económico y facultativo era muy uniforme en todas ferrerías del noroeste ${ }^{745}$; en ellas se llevaba una contabilidad bastante rigurosa, pues solía haber en ellos cinco libros: de tratantes, de carboneros, de oficiales y el de carreteros y venaqueros; además del libro general donde se resumían todos los gastos y existencias que, al comienzo del año laboral, se encontraban en la ferrería. ${ }^{746 .}$

\section{LA EXPLOTACIÓN DE LAS FERRERÍAS: ARRENDATARIOS Y FOREROS}

Durante la Edad Moderna, los grandes señores propietarios de ferrerías, como los marqueses de Villafranca, los condes de Rivadavia, los monasterios, las encomiendas militares (en este caso las tierras, montes y aguas) y algunos

que dio lugar a largos y costosos juicios ((AHRG. Marqués de Hombreiro). El 1 de julio de 1745 el dueño de la ferrería de Quintá escribe: "despedí al dicho D. Francisco (Rodríguez Losada, presbítero) por su mala administración". Parece que en tres años dirigiendo la ferrería no le dio cuentas y se quedó con más de 40.000 rs. (IBIDEM).

744 Por la ferrería de Quintá sabemos que los administradores, que se nombraban por varios años, eran frecuentemente presbíteros; pues además de saber de letras y números para llevar las cuentas, se encargaban de decir misa en la capilla de la ferrería. En 1772 el dueño de esa ferrería, don Sancho de Neyra, nombra como tal a don Juan Antonio Amago Miranda, vecino de Penzol (Castropol), al que pagará 800 reales anuales de sueldo más otros 200 por la limosna de cien misas que ha de decir en la capilla, con las condiciones siguientes: 1) dar cuenta todos los años del caudal, deudas, producción, gastos y ganancias del artefacto; 2) cobrar la renta que el dicho don Sancho tienen en el valle de Quiroga, además de cuidar de la ferrería para que vaya en aumento y no en disminución; 3) velar por la chapacuña de la otra ferrería (la de la Rodela, de los monjes de Samos) para que no fijen estacas en ella para recoger agua; 4) sólo podrá contraer deudas inferiores a 500 reales/año, especialmente con los carboneros, pues si contrajere deudas más altas será de su cuenta satisfacerlas (AHRG. Hombreiro: Leg. 19).

745 MUNÁRRIZ, p. 129: En todas las herrerías del Bierzo y Galicia: "hay un administrador o mayordomo a cuyo cuidado está toda la fábrica, y por su cuenta se hacen todos los trabajos, y este tiene un mozo que le ayuda con el título de pasante, con 40 ó 50 ducados anuales y su manutención y algunas gratificaciones y arbitrios, y es el que recibe y lleva cuenta del mineral y carbón que va entrando y de las provisiones y demás gastos menudos que se ofrecen; estos son los dos únicos empleados que hay en estos establecimientos para su gobierno y dirección".

${ }_{746}$ En 1789, don Juan Antonio Asenjo Rodil, presbítero, dice que desde 1780 ha sido administrador de la ferrería de Valcarce, y que su dueño le enseñó cómo regirla, y lo hizo "según me lo enseñó y la practica de los más artefactos de este país con separación de lo que correspondía a carbón en el libro de carbón, vena en el venaquero, consumos y gastos de la casa y otras cosas en las libretas, los corresponsales en las mismas, salarios y consumos de los oficiales en libros separados, rendimiento de yerro en otro, como también las consignas de administración, coadjutor, ama de llaves y criados" (AHPLU: 3376). 
señores locales tuvieron sus ferrerías generalmente arrendadas, bien a largo plazo, es decir, aforadas, bien por algunos años, generalmente de uno a tres. El arrendamiento es un contrato por el que una persona (arrendador) se obliga a proporcionar a otra (arrendatario), durante un cierto periodo de tiempo, el uso o el goce de una cosa o un derecho a cambio de una prestación cualquiera747. Tal relación contractual entraña una serie de derechos y deberes para cada una de las partes. El arrendador debe poner el bien a disposición del arrendatario corriente y moliente, y este debe devolverlo en el mismo estado, además de pagar la renta estipulada.

En unos casos, como ocurre con las encomiendas, el foro de tierras y bosques fue una opción desde el primer momento, aunque hay algún ejemplo en el que esos bienes están simplemente arrendados por años, normalmente por dos o tres años. Sin embargo, esta opción no fue muy frecuente en los dos primeros siglos, porque los señores prefirieron arrendar las ferrerías mediante foros enfitéuticos o de mayor duración, por ejemplo por tres vidas o por la vida de tres reyes (los foros representan, según el cuadro XIV, el 52,6\% de todos los tipos de arrendamiento en el siglo XVI y el 46,1\% en el XVII), porque creían que los arrendamientos cortos perjudicaban a los artefactos por el interés de los renderos en obtener el máximo beneficio en el menor tiempo, a costa claro está de la propia ferrería ${ }^{748}$. Luego, en el siglo XVIII, la inflacción llevó a los arrendadores a contratos más cortos para poder soportar mejor la pérdida del valor del dinero (el 60\% son arrendamientos a corto plazo). En el siglo XIX, aunque hubo arrendamientos (que constituyen el 100\%), fue muy frecuente la explotación directa o por medio de administradores, como vemos en el caso de Nemesio Fernández.

\footnotetext{
747 M. ALBADALEJO (1991): Compendio de Derecho Civil. Barcelona, p. 230.

748 AHRG. R. A.: 19.768/32: En 1550 la encomienda de Quiroga afora a Juan Ortiz la ferrería de Soldón por 29 años y renta anual de 14.000 maravedís y siete docenas de herrage, la mitad caballar y la otra mitad mular. Se le afora por "los muchos e buenos e leales seruicios" y porque "aveis hecho muchos buenos hedeficios en mejoramientos en la herreria de Soldon que es en la dicha mi encomienda de Quiroga estando como ella estaba para se yr a yermo e que aveis gastado mas de trescientos ducados, los quales aveis fecho por mi mandado e consentimiento e prometiendo bos de bos hazer fuero della". Añade además que tanto para él como para los comendadores que le sucedieran, pero sobre todo para la ferrería, es mejor "el hazer della fuero por años que no arrendarla de tres en tres años porque a causa de la tener por tan poco tiempo la dexaban ir a yermo e asolaban los montes necesarios para las maderas della"
} 


\section{CUADRO XIV. TIPOS DE ARRENDAMIENTOS DE FERRERÍAS}

\begin{tabular}{|l|c|c|c|c|l|}
\hline SIGLOS & TOTAL & FOROS & $\%$ & $\begin{array}{l}\text { ARRENDA- } \\
\text { MIENTOS }\end{array}$ & \\
\hline XVI & 19 & 10 & 52,6 & 9 & 47,3 \\
\hline XVII & 13 & 6 & 46,1 & 7 & 53,8 \\
\hline XVIII & 10 & 4 & 40 & 6 & 60 \\
\hline XIX & 26 & 0 & 0 & 26 & 100 \\
\hline TOTAL & 68 & 20 & 29,4 & 48 & 70,5 \\
\hline
\end{tabular}

FUENTE: elaboración propia a partir del apéndice II-8, 11 y 12

\subsection{Los foros}

Los foros son arrendamientos a largo plazo. Como vemos en el apéndice II-8 en unos casos son perpetuos (como los del marquesado de Villafranca), en otros se firman normalmente por una o tres vidas: de los 15 foros en los que se indica el tiempo, 9, es decir, el 60\%, se firman por tres vidas. Fue frecuente también que, al acabar estas, se suscriban de nuevo, mejorando a veces las condiciones del foro, en favor del dueño. Por ejemplo, la ferrería de Santalla, que era de Samos, se aforó en 1504 a Diego Velón y a su mujer Velasquida González de Cancelada y a otras dos personas más en 750 reales de renta anual. Cuando en 1595 acabó el tiempo del foro, pues a Diego Velón le sucedieron su yerno Rui Sánchez de Orozco y su nieto Álvaro Sánchez de Orozco, los monjes pleitearon con su heredero, Antonio Sánchez de Orozco, para recobrar el uso de la ferrería; al final se la volvieron a aforar por su vida y otras dos más, y por doce ducados de renta más749.

Los foros se hacen con diversas condiciones: pagar la renta (como vemos en el cuadro es muy variable de unas ferrerías a otras y de unos siglos a otros, lo que nos impide valorarlas en sus justos términos), mejorar las instalaciones para que vayan en aumento y no en detrimento, no vender la ferrería, etc. Por ejemplo, el que suscriben los señores de Presno con Pedro de Mindirichaga y su

749 AHRG. R.A.: 931/44 y 70/80. 
mujer María Ortiz de Bedia sobre la de Montealegre, en 1571, estipula una renta de 8.00o maravedís al año, pagados por Navidad, que en el caso de impago sucesivo durante tres años provocaría la perdida del foro. Esa renta la han de pagar pese a las avenidas, guerras o pestes. La ferrería ha de ir en aumento y debe de estar bien aderezada para que pueda, sin contratiempos, labrar hierro; podrán además utilizar la madera de los montes propios de la familia Presno, fuera del coto de la ferrería, pagando lo que normalmente se paga por la madera y el carbón; por último, los señores de Presno están obligados a proporcionar la madera necesaria para el árbol mayor y otros usos de la ferrería750.

Otro ejemplo es el foro que en 1571 firmaron Pedro Pardo de Aguiar, señor del coto de Saramugo, y Pedro Maseda de Aguiar con el vizcaíno Francisco Sánchez Vidarte, rendero de Lorenzana, y su mujer María Sánchez, ausente, sobre la ferrería y machuco de Pesqueira. La renta habría de ser de 6.00o maravedís anuales, con varias condiciones: reparar a su costa y a la de sus herederos la ferrería y machuco para que siempre funcionase; no venderla, empeñarla o traspasarla salvo a persona llana; y, en caso de no pagar la renta tres años seguidos perderían los derechos del foro751. Dicha renta habría de pagarse por mitad a cada uno de los dos propietarios y a sus respectivos descendientes. La ferrería de Lorenzana, por su parte, se afora en 1569 después de poner anuncios en la puerta de la iglesia al vizcaíno Francisco Sánchez de Vidarte como mejor postor, por tres vidas o voces. Entre otras condiciones, como la de no poder vender sin permiso del abad y esto pagando al monasterio un quinto del precio de venta, se exige que a la muerte del forero su sucesor debe presentarse antes de treinta días al abad752.

Fue frecuente en los foros del siglo XVI incluir en ellos la justicia civil y criminal de las tierras aledañas a la ferrería, como vemos en los ejemplos de

\footnotetext{
${ }^{750}$ Condiciones: "abeis de tener bien adereçada e reparada la dicha herrería de todos los adereços y reparos que fueran menester, de manera que ella pueda labrar hierro liberalmente (...); el arbol mayor o menor, çepos e dormientes, e puercas o maderas principales o mayores, ansi de la presa como de la herrería o camarado". Cf. LÓPEZ y GRINDA: Ob. cit., p. 125-127 ${ }^{751}$ AHRG. R. A.: 21.859/104. Aforan "aquella nuestra herraria e machuco que se dize da Pisqueira que está sita en la dicha feligresía de Santa Cruz con todas sus casas, torre y molino, huertas, sotos y árboles que hestán entre las aguas de la dicha ferrería e con todos los aparatos e yngenios e artifiçios y herramientas de la dicha ferraria".

752 AHRG. R.A.: 145/76
} 
Montealegre753, Lorenzana o el Saltejo754 y Santalla755; aunque a veces se excluía expresamente tal derecho756. Esto fue más frecuente en los foros realizados a fines del XVII o en el XVIII, como los de las ferrerías del marqués de Villafranca, en las que no se concede ese privilegio, que el señor retiene en sus manos. Vamos a detenernos en este ejemplo, porque creo que ilustra la situación que vive la alta nobleza a finales del siglo XVII y en el XVIII, en el que aforan las ferrerías no solo por cobrar la renta sino por el dinero que los foreros han de pagar al cumplimentarse el foro.

Los marqueses de Villafranca, que durante mucho tiempo arrendaron sus ferrerías, luego las aforaron probablemente por esa necesidad de dinero por sus cuantiosos gastos en Villafranca pero sobre todo en la corte o en sus destinos políticos, como el virreinato de Nápoles757. La de Arnado la aforaron don Fadrique de Toledo Osorio, marqués de Villafranca, y su primogénito don José Fadrique de Toledo Osorio, duque de Fernandina, el 17 de julio de 1685, " $a$ fabor de D. Mateo de la Flor Calderón, abad de San Juan de Camba, en la

\footnotetext{
753 LÓPEZ y GRINDA: Ob. cit., p.125-127: "la dicha herrería de Montealegre e su coto e jurdiçion, e todo lo que en dicho coto e jurdiçión tengo e sus casas, presas, bançado e aguas, $e$ heredades, e términos, e molinos, e ruedas, e edificios, e bienechos e plantados, según al presente están que es todo lo que para dicha herrería labrar hierro conbiene".

754 AHN. Clero, Lourenzá: códice 181/B, f. 47v. Cfr. Ma . X. RODRÍGUEZ GALDO (1976): Señores y campesinos en Galicia. Siglos XIV-XVI. Santiago, p. 83: . En 1519 el abad fr. Rodrigo Gumiel aforó a Fernando Rodríguez de Aguiar la ferrería de Lorenzana o del Saltejo en precio de 3.000 maravedís con todo lo a ella perteneciente: "con el palacio et casas del rendero de la dicha ferraria et entradas et salidas de la dicha ferraria et palacio et casas cuantas han et aver deben (...) aguas et presas et rio et montes et fontes plantados et por plantar mansos et bravos et con más el edificio, artificio, carpentarias (...) mando et señorio çebil et criminal et con todo lo mas a la dicha ferraria debido (...). Además le faculta para "poner rendero, mayordomo, fundidores, carboneros, carreteros, y un juez que entienda en dicha ferrería en lo civil y criminal según era uso y costumbre".

755 AHRG. R. A.: 931/44. En 1504 fray Juan de Estella, reformador de Samos, afora a Diego Velón y a su mujer Velasquida González de Cancelada, y a otras dos personas más, un terreno para construir la ferrería de Santalla: "un sitio en el Rio o fontes de Loçara o en otro cabo qualquier que vos el dicho diego belon quisieres so el signo de Seoane de Loçara para que fagades una ferreria corriente y moliente, la qual os aforamos con todas sus aguas corrientes $y$ estancas y manantes (...) con todos los montes y cosas pertenecientes a ferraria"; pero además con la justicia civil y criminal "alto e bajo e mero misto imperio". Se lo aforan con la renta anual de 750 maravedís.

756 AHRG. R. A.: 19.768/32: por ejemplo en 1550 cuando el comendador de la encomienda de Quiroga, fray Francisco Giral, afora a Juan Ortiz la ferrería de Soldón señala que "no bos afuero jurisdicion civil ni criminal ni luctuosas ni penas de camara ni benero de oro ni plata ni otro metal alguno que sea saluo si fuere de yerro porque esto reservo para mi y para dicha encomienda".

757 V. FERNÁNDEZ (2007): El señorío y marquesado de villafranca del Bierzo a través de la documentación del Archivo Ducal del Medina Sidonia. Ponferrada.
} 


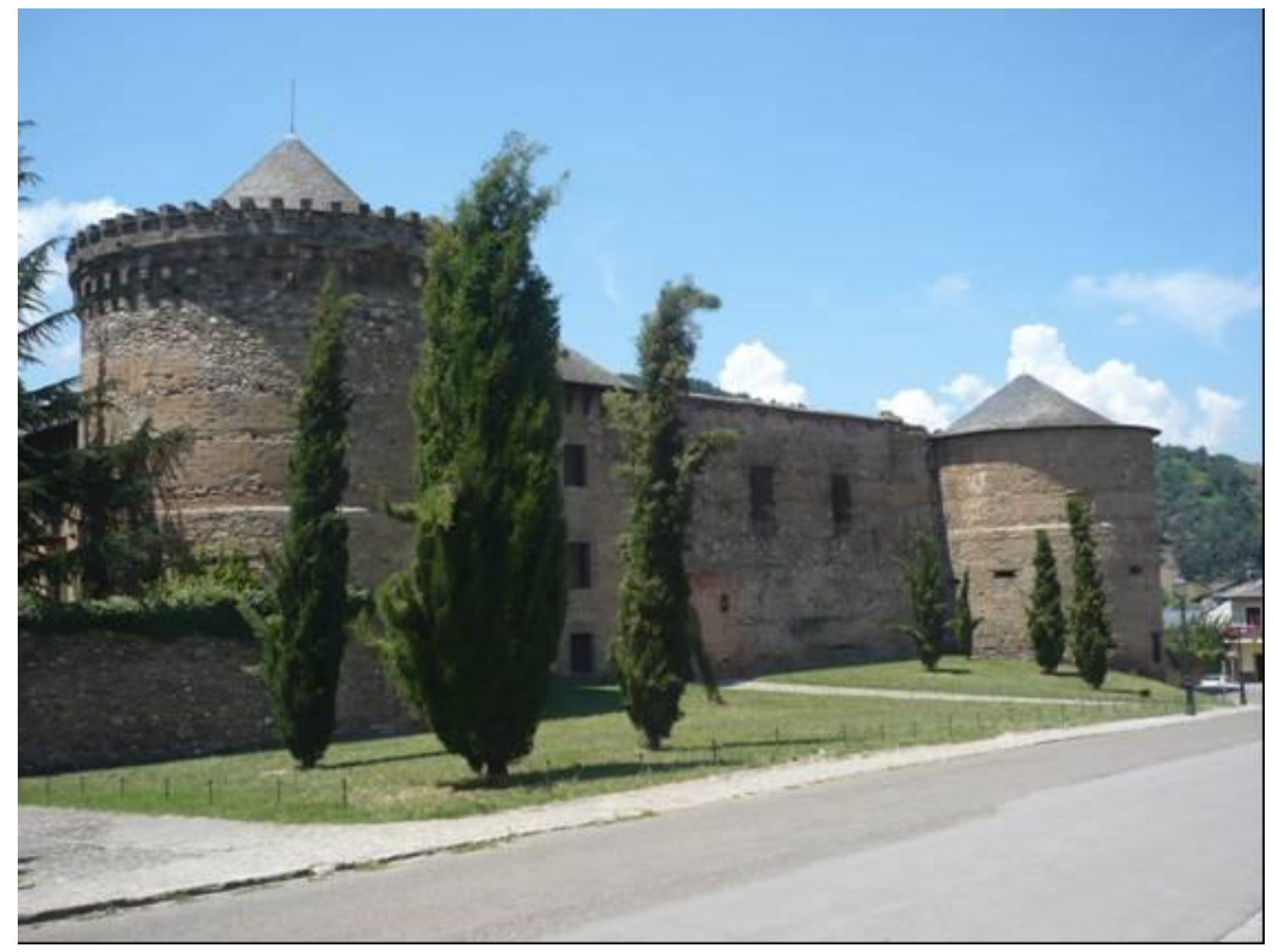

Castillo de los marqueses de Villafranca del Bierzo

jurisdicción de Candelas"; y con la ferrería, la casa habitación, herramientas demás pertrechos, cauce de agua, prados y montes, todo "por precio y cuantía de mil ducientos ducados de once reales", además de 850 reales de renta perpetua al año758. En agosto de ese mismo año el apoderado de don Mateo de la Flor, don Manuel Ceballos, recibía la ferrería con un molino caído y unos prados en Leyroso 759 .

La de Ponte Petre, arrendada a finales del siglo XVII a Francisco García de las Llanas ${ }^{760}$ le sería dada en foro el 10 de agosto de 1706 a este mismo por 12.000 reales en una sola vez y 600 reales de renta anual perpetua, con las

${ }_{758}$ Archivo privado de la familia LLano y Ovalle. Pleito por la utilización de los montes de Villarrubín por las ferrerías de Arnado y otras, ff. 130.

759 Ibidem, ff. 130v. Probablemente mantuvieran al mismo rendero, pues en marzo de ese mismo año, Manuel Guzmán, residente en la ferrería de Orreos, daba a su hijo un poder para que pudiera "arrendar y tomar en arriendo por el tiempo que le pareciere la herrería de Arnado, feligresía de Oencia, perteneciente a su excelencia el marqués de Villafranca" (AHPL. P.N.: caja 2937).

${ }_{760}$ En julio de 1694 don Pedro de Ulloa, dueño de la ferrería de Bueyes, da permiso para que pueda transportar, por el camino de Faro, toda la vena que necesite de Formigueiros a la ferrería de Pontepetre, desde Santiago (25 de julio) hasta Nuestra Señora de septiembre (8 de septiembre) (AHN. Estado: leg. 1739, ${ }^{\circ}$ 16.) 
condiciones generales de este tipo de contratos: traerla reparada y en buen funcionamiento, etc. Parece que la ferrería no se hallaba en buenas condiciones por lo que el forero hubo de gastar diez u once mil ducados para ponerla en funcionamiento ${ }^{761}$. Francisco García de las Llanas era natural de Anguiano, en la Rioja, pero residía en Ponferrada desde 1670, donde ejercía el oficio de tesorero de alcabalas reales por nombramiento del marqués de Villafranca, a quien pertenecían. En 1697 dicho Francisco compró el oficio de regidor perpetuo de Ponferrada y posteriormente, en 1718, su hijo fundaría mayorazgo ${ }^{762}$. Esta familia permaneció en Ponferrada donde construyó una lujosa casa, que aún se conserva.

La de Valcarce fue aforada el 7 de abril de 1680 a favor de Francisco de Soto, en la cantidad de 80.000 reales. En sus manos y en las de su familia permaneció hasta 1720 en que la vendieron a Francisco Saco en 143.00o reales, en los que se incluían 33.00o reales de bienes libres que aquellos habían agregado. Pero el tal Saco sólo debía de ser un testaferro, por lo que la marquesa puso pleito, por tanteo, que ganón ${ }^{763}$. Sin embargo, no parece que dispusiese de las cantidades que habría de abonar a los Soto, por lo que como el marqués debía a don Pedro Luis de Ulloa, señor de Noceda, 64.000 reales, más otros 62.350 consignados para el tanteo y 6.00o más que había gastado en reparos, es decir, 132.350 reales más una deuda del marqués de 25.750 con don Esteban García de las Llanas y otras cantidades, doña Catalina de Moncada y Aragón, en nombre de su marido don José Fadrique de Toledo Osorio, la aforó el 12 de febrero de 1726 a favor del señor de Noceda por todo ese dinero, que ascendía a 247.000 reales, y con la pensión anual de 400 reales764. Este Pedro José de Ulloa, propietario de la ferrería de Bueyes, la uniría a su mayorazgo.

\footnotetext{
${ }^{761}$ AHPLU: 6701/13

${ }^{762}$ V. FERNÁNDEZ (2012): Ponferrada, artística y monumental. Ponferrada, p. 486. Un descendiente, Manuel García de las Llanas, en 1745, afirma que es "lexitimo dueño y poseedor de la herrería de Ponte Petre afecta al vinculo y mayorazgo que fundó don Esteban García de las Llanas su abuelo, vecino y rexidor de dicha villa (de Ponferrada)" (AHPL. P.N.: caja 3342). ${ }_{763}$ AHPLU: 6701/13: : "aunque sonava haverse echo a favor de don Francisco Saco era para el rector y colegio de la compañía de Jesús de Villafranca”.

${ }_{764}$ AHPLU: 6701/13. Se otorgó en 12 de febrero de 1726 escritura de foro perpetuo de la "ferraria comunmente llamada de el Valcarce, perteneciente a dicho marquesado de Villafranca, con todos sus pertrechos, atalajes, erramientas, casa de vibienda, caballerizas, molino, agua, plaza de la dicha ferraria, con su huerto y caruedo de dos fanegas de sembradura y una cortina a espaldas de dicha ferraria de dos fanegas de sembradura, montes, pastos, derechos de vena y todos los demas vienes muebles y rayces a ella anejos"
} 
Hay también casos de denuncia del foro, lo que unas veces se consigue con dinero, y otras no. Por ejemplo el monasterio de Samos lograría recuperar las ferrerías aforadas para explotarlas directamente, así ocurre con la ferrería de la Rodela, primitiva de Quintá. Los monjes no eran propietarios de dicha ferrería, solo lo eran del suelo donde se había construido -el coto de Fisteus-. Sin embargo, cuando finalizó el foro del solar en donde se aquella asentaba, el monasterio lo denunció para hacerse con ella. Lo consiguió en 1689, después de largos y costosos juicios, previo pago a los Neiras, herederos de Francisco Vázquez de Quiroga, a quien se la había aforado la encomienda de Quiroga, de 3.000 ducados 765 . Los monjes, por el contrario, no pudieron impedir que los Neira, con la anuencia de la encomienda, pudiesen levantar la nueva ferrería de Quintá, pese a los pleitos que le pusieron.

Lo mismo ocurre con la de Santalla, que ya hemos mencionado anteriormente. Samos la aforó a Diego Velón y su mujer en $1504^{766}$, que la gozaron hasta la muerte del primero, pues poco después la mujer "la traspasó y vendió a Domingo Zarauz, rendero de la herraria de Incio". Posteriormente, el yerno de Velón y Velasquida, Rui Sánchez de Orozco, casado con su hija Elena González de Balboa, recobró la ferrería y la tuvo hasta su muerte, que ocurrió hacia 1550. A Rui Sánchez de Orozo, segunda voz en el foro, sucedió su hijo Alvaro Sánchez de Orozco767. Estos Sánchez de Orozco explotaron la ferrería por medio de renderos, como Antonio da Chega, María Dargandona y María de Guisaburuaga768. En 1595 el monasterio de Samos pleitea con Antonio Sánchez de Orozco, porque con su padre había finalizado las voces del foro de 1504. Sin embargo, este alega que su abuelo, Rui Sánchez había muerto antes de su suegra Velasquida, por lo que su padre Alvaro sería la segunda y el la tercera voz769. La querella de Samos, con sentencia favorable al monasterio, debió terminar en arreglo: en 1596 el convento volvía a aforar a Antonio Sánchez de Orozco y dos

\footnotetext{
765 Ver lo dicho sobre esta ferrería en lo dedicado a la de La Rodela. ${ }^{766}$ AHRG. R. A.: 931/44

${ }_{767}$ AHRG. R. A.: 70/80: "el qual como hijo mayor de los dichos sus padres fue alçado por ultima voz del fuero de la dicha herreria y como tal la llebo y goço el tiempo que bibio".

${ }^{768}$ Como consta en AHRG. R. A.: 70/80: Foro a Antonio Sánchez de Orozco, de 15 de julio de 1596.

769 AHRG. Real Audiencia: 931/44
} 
vidas más la ferrería, con la justicia civil y criminal (aunque solo en primera instancia), con la renta de doce ducados anuales ${ }^{770}$.

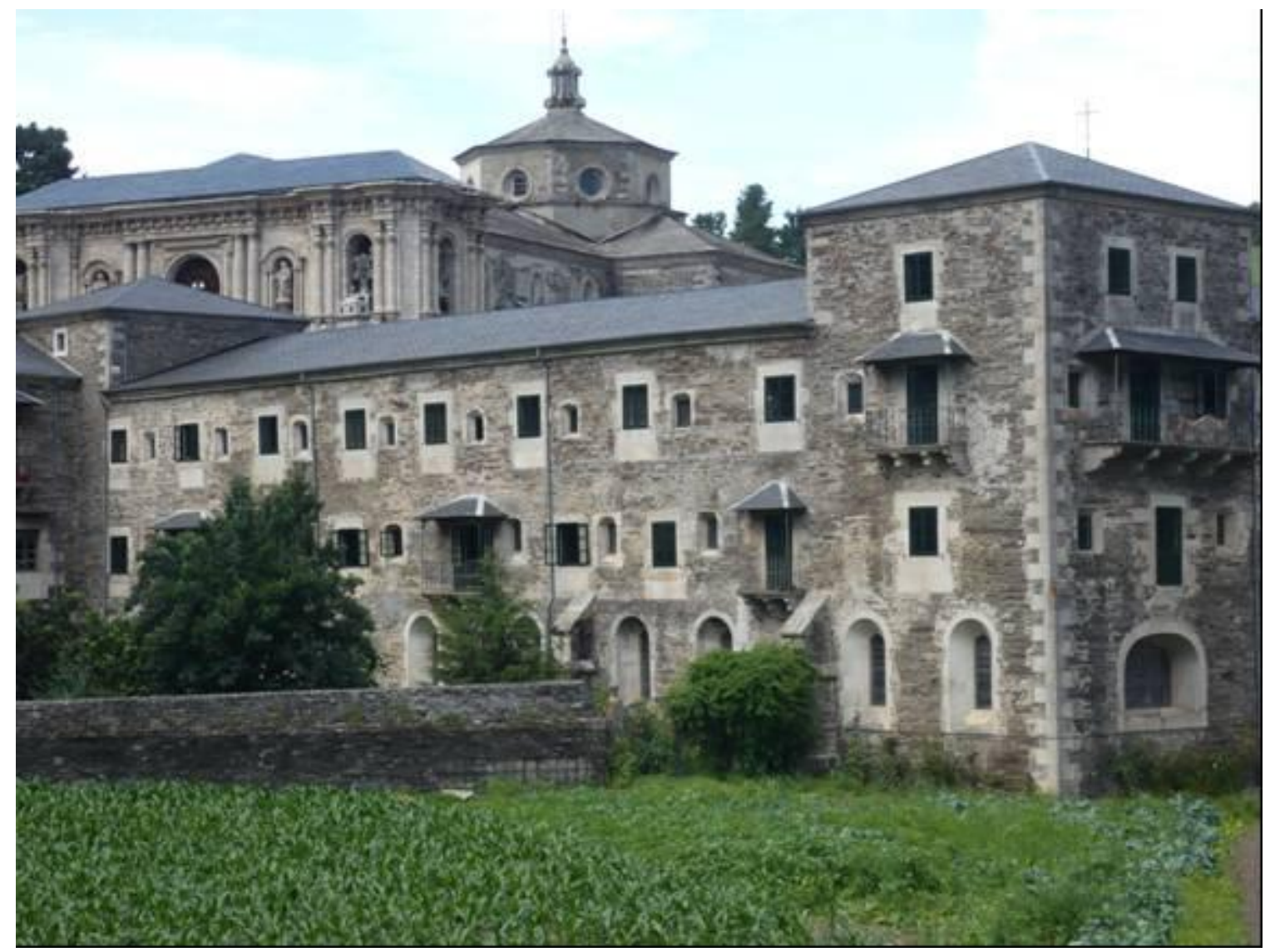

Monasterio de Samos (Lugo)

En 1610 Diego Sánchez de Orozco, merino y juez del valle de Incio y dueño de la granja de Dompiñor, y Alvaro González de Rivadeneira, su cuñado, en nombre de su mujer, María de Quiroga, y en el de su sobrina María de Losada, la subaforaron a Martín de Guiçaburuaga, por las voces del foro y con la

\footnotetext{
770 AHRG. R. A.: 70/80: Foro a Antonio Sánchez de Orozco, de 15 de julio de 1596: "que al presente en nuestro nombren traen maria dargandona y maria de guisaburuaga su hija con todas sus casas herramientas barquines y rraguas y todo lo demás a ella anejo y perteneziente segun nos perteneze y nos fue entregada y a este nuestro monasterio por mandando del señor don luys de molina oydor y alcalde mayor deste reyno y bisitador de los obispados de Lugo y Orense y Mondoñedo en ejecucion del auto y sentencia por el dado entre nos y bos el dicho Antonio Sánchez de Orozco (...) la qual dicha ferraria esta libre y baca por dejacion que oy dia della hiço antonio da chega del fuero della que le estaba hecho segun se contiene en la escritura que de ello hiço.."
} 
obligación de pagar los 12 ducados al monasterio más 35 a ellos cada año771. Fuero que se modificó al año siguiente en el sentido siguiente: asegurando Martín de Guiçaburuaga, mediante hipoteca, los 12 ducados al monasterio, y eliminando la renta de los 35 ducados a los Orozco a cambio de 500 ducados en dinero y 40 quintales de hierro, que valían otros 100 ducados 772 . Las vicisitudes de los subforeros no acabaron aquí. En 1621 los Orozco, que no debían estar contentos con la venta del foro, se querellaron con Martín de Guisaburuaga exigiéndole más dinero. Este alegaba que se había gastado más de 800 ducados en poner nuevo banzado y ruedas, más otros arreglos; pero por no pleitear acuerda pagarles 3.000 reales más, 1.500 a cada cuñado 773 . Sin embargo en 1627, Domingo Pérez y su mujer, sobrina de aquellos, dicen no estar de acuerdo con el reparto, con lo que la nueva reclamación vuelve a afectar otra vez a Martín de Guisaburuaga, que debe pagarles otros 5.000 reales: 2.500 para Diego, 900 para Álvaro y 1.600 a Domingo Pérez. En total pagó 14.00o reales por el fuero de la ferrería 774, aunque aún tendría que desembolsar al monasterio, por el traspaso de la misma, el quinto de esos 14.000 reales -1.800 reales-, que el monasterio le exigió en 1649 y que para evitar nuevos juicios pagó religiosamente775. En 1658 fue el monasterio el que se querelló con el sobrino de Martín de Guisaburuaga, que lleva el mismo nombre de su tío, alegando que por esa fecha habían finalizado de nuevo las voces del fuero hecho a Antonio Sánchez de Orozco, por lo que pasó al dominio directo del monasterio ${ }^{776}$.

También el marquesado de Villafranca intentó recuperar sus ferrerías en el siglo XVIII sin lograrlo. En 1759 parece que el marqués puso pleito ante el corregidor de Villafranca, con la intención de recobrar las de Valcarce y Pontepetre. Pedro Luis de Ulloa, hijo del anterior forero de la de Valcarce, se opuso por no ser competente aquel tribunal y recurrió a la Chancillería de Valladolid, pero al mismo tiempo se desplazó a Madrid donde logró arreglar el

\footnotetext{
${ }^{771}$ AHRG. R. A.: 14.701/11: Le hicieron "fuero de su fuero de la dicha herraria con sus casas y jurisdicion civil y criminal como ellos lo tenian en fuero de dicho convento de Samos (...)"y que cumpliese con todas las mas condiciones y grabamenes del dicho fuero".

772 IBIDEM

773 En realidad 2.00o reales a Diego y 1.000 a Alvaro

774 AHRG. R. A.: 14.701/11

775 AHRG. R. A.: 70/80

776 M. ARIAS CUENLLAS (1992): Ob. cit., p. 286
} 
asunto777. Para formalizar el acuerdo se pidió permiso al rey, pues al parecer para otorgar las escrituras de foro no se había solicitado anteriormente778. En junio de 1763, Pedro Luis Ulloa da un poder para revalidar su escritura de foro perpetuo, aunque con algunas modificaciones: la renta sube otros 660 reales, por lo que deberá pagar anualmente 1.100 reales; además, por una sola vez, le entregará 12.000 reales 779 . Aquella cantidad era la que pagaba en años sucesivos como foro de la ferrería ${ }^{780}$. Desconocemos si eso mismo ocurrió con la de Pontepetre aunque creemos que sí, aunque no nos consta documentalmente ${ }^{781}$, si sabemos que la renta subió igualmente a 1.100 reales ${ }^{782}$. Desde entonces hasta su desaparición, la ferrería se mantuvo en manos de la familia García de las Llanas y herederos ${ }^{783}$.

\subsection{Los Arrendamientos}

Los arrendamientos a corto plazo fueron un tipo de contrato muy corriente. Según el cuadro XV el mayor porcentaje de contratos que hemos hallado pertenece al siglo XIX, con el 54,1\% del total, aunque también fueron frecuentes en los siglos XVI y XVII, probablemente incluso más de lo que refleja el cuadro. Los contratos tienen una duración variable, entre uno y diez años. De los 48 contratos documentados, el 58,33\% de los mismos tienen una duración de uno a tres años, el 31,25\% de cuatro a seis años y sólo el 10,41\% tienen más de seis años. Sin embargo, fue frecuente la renovación de los mismos, por lo que

\footnotetext{
777 Creo que en el arregló debió pesar no sólo el valor de la ferrería sino los enormes gastos desembolsados, que ascendían a más de 179.775 reales (AHPLU: 6701/13).

${ }_{778}$ AHPLU: 6701/13: "para otorgar ambas escrituras de foro (se refiere a las de las ferrerías de Pontepetre y Valcarce) no se sacó facultad real, intentó reintegrarse en ellas". Para ello, solicitó al rey que su Real Consejo de Cámara, después de explicarle los antecedentes, concediese "su Real facultad para reualidar dichas dos escrituras de foro", lo que así se hizo el 24 de agosto de 1762.

779 AHPLU: 6701/13: "para ymbertirlos en venefizio y utilidad de dicho estado y maiorazgo de Villafranca". Los 400 reales más 660 solo son 1060 ; es posible que fueran antes 440 reales.

${ }_{780}$ Así en las cuentas de 1798 se dice "Dn. José María de Tineo, señor de Nocedal, debe satisfacer en cada un año un foro de ella (Herrería de Valcarce), un mil y cien reales". Arch. Particular: Papeles del marquesado (gentileza de Mariano Higuera)

${ }^{781} \mathrm{En}$ el foro de 1706 se paga de renta $600 \mathrm{rs}$./año, pero sabemos que posteriormente, al menos en 1876 esa cantidad era de 1.100 reales, por lo que probablemente fue estipulada en el acuerdo de 1763 (AHPL. P.N.: 9.137).

782 AHPL. P.N.: 9.137

${ }_{783}$ AHN. Estado: leg. 1739, $\mathrm{n}^{\mathrm{0}}$ 16: en 1791, en el pleito por el mineral de Formigueiros, se menciona a Manuel García de las Llanas y Venero, caballero profeso de la militar orden de Alcántara, capitán del Regimiento Provincial de León, regidor perpetuo de la villa de Ponferrada, como dueño "en el útil de la ferrería de Pontepetre".
} 
encontramos renteros que permanecen en una misma ferrería entre 10 y 20 años: don Lucas de Acevedo y de la Cueva estuvo como arrendatario de la de Pontepetre desde antes de 1663 hasta 1674; doña Angela Martínez Torres entre 1722 y 1745 en esta misma ferrería; y Juan Francisco Ribadeneira dice en 1811 "que hace más de 23 años que lleba en arrendamiento la fábrica de hierro de Lousadela” y parte de la de Ferreirós784. En el siglo XIX hay igualmente arrendatarios durante muchos años: Jacinto Fariñas, en la de Visuña, estuvo al menos diez años; Diego de Ovalle de 1801 a 1816 en la de Pontepetre; Valentín Curiel de 1810 a 1820 y Ramón Ovalle de 1820 a 1840 en la de Arnado; Paulino Arias, de 1872 a 1891 en Pombriego, por poner algunos ejemplos785.

\section{CUADRO XV. DURACIÓN DE LOS ARRIENDOS}

(en años)

\begin{tabular}{|l|c|c|c|c|c|}
\hline SIGLO & 1 a 3 & 4 a 6 & Más 6 & TOTAL & $\%$ \\
\hline XVI & 7 & 1 & 1 & 9 & 18,7 \\
\hline XVII & 4 & 2 & 2 & 7 & 14,5 \\
\hline XVIII & 2 & 3 & 0 & 6 & 12,5 \\
\hline XIX & 15 & 9 & 2 & 26 & 54,1 \\
\hline TOTAL & 28 & 15 & 5 & 48 & 100 \\
\hline$\%$ & 58,3 & 31,2 & 10,4 & 100 & \\
\hline
\end{tabular}

FUENTE: Muestra a partir de los datos del apéndice II-11 y 12

En los siglos XVI y XVII muchos arrendatarios son de origen vasco, posteriormente (APÉNDICE II-9 y 10) son gentes del lugar o cercanos y, en cierto modo, parecen formar parte de una incipiente burguesía industrial, miembros de las oligarquías urbanas de las villas de los alrededores, de las que suelen ser regidores; comerciantes en algún caso que, a través de los beneficios obtenidos en las ferrerías, adquieren tierras, se ennoblecen o emparentan con las familias más linajudas, como Francisco Antonio Guerra Donís, arrendatario 
de la ferrería de Ponte Petre y comerciante que tramita su expediente de hidalguía en $1735^{786}$; o el ya citado Nemesio Fernández, arrendatario primero, posterior propietario de nuevas ferrerías que deja en herencia la crecida suma de 2.630.810 reales ${ }^{787}$. Este sistema de organización se reproducía igualmente en las ferrerías benedictinas y cistercienses de San Pedro de Montes, San Julián de Samos y Villanueva de Oscos, en las que también encontramos la figura del monje rendero o administrador, al que suele llamarse "prior rendero"788. Este monje administrador solía hacer su contrata con el monasterio en cierta cantidad líquida anual, siendo de su cuenta la compostura y todos los gastos ${ }^{789}$.

Las ferrerías se arriendan por medio de un contrato de arriendo, documento jurídico hecho ante el escribano o notario, por el que propietario y arrendatario se comprometen a cumplir una serie de cláusulas que en el se estipulan790. El propietario debe poner en manos del arrendatario la ferrería "corriente y moliente"; es decir, con todos los elementos para poder fundir y trabajar el hierro. Esto quiere decir, la presa, banzado, mazo y los barquines o trompas en perfecto estado, además de las casas de habitación, el bosque y tierras propias de la ferrería. El arrendatario, cuando cumpla el periodo del contrato, a su vez deberá dejarla en las mismas condiciones en las que la encontró791. Normalmente las obras mayores que ocasionan las avenidas de las aguas en la chapacuña, banzado y edificios suelen ser de cuenta del propietario, mientras que las menores las ha de pagar el arrendatario, a no ser que se

\footnotetext{
${ }^{786}$ F. GONZALEZ (1981): Hidalgos bercianos. Ponferrada, 1983, p. 72

787 J.A. BALBOA (2008): Ob. cit., p. 17

788 De la de San Vicente de Leira, propia del Monasterio de Samos, dice el Catastro de Ensenada que en ella "hay un monje benito del combento de Samos a cuio cargo está la herrería" (CATASTRO DE ENSENADA. R. G.: San Vicente de Leira). De las de Santalla y Gondriz, también de Samos, se recuerda en 1825 que "desde tiempo inmemorial administraba y cuidadaba dichas herrerías, vienes y rentas dos monjes elegidos al objeto según los estatutos y reglas de la orden" (AHRG. R.A.: 1.389/7).

789 MUNARRIZ, p. 127.

790 Frecuentemente se anunciaban públicamente los arriendos, siendo el elegido como arrendatario el mejor postor (AHRG. R.A.: 25.291/28) .

${ }^{791}$ AHPL. P. N.: Caja 3582 (1848): arriendo de la ferrería de San Pedro de Orreos: "Qué ha de conservar la casa fábrica y bienes en el mismo estado que los recibió”; AHPL. P. N.: caja 9114 (1870): contrato de arriendo de la ferrería de Oencia; "Que a la conclusión de los dos años que comprende este arriendo, sin necesidad de desaucio ni otro requisito, ha de quedar libre la herrería, sus dependencias, edificios, y bienes bien dispuestos sin el menor menoscabo ni defecto, en términos que estando correiente pueda trabajarse en ellis sin obstáculo alguno".
} 
estipule lo contrario792. Pero no siempre los arrendatarios cumplían con sus obligaciones, lo que era fuente de numerosos conflictos793.

Durante los dos primeros siglos parece que los arrendamientos se sacaban a subasta pública, recayendo en el mejor postor. Por ejemplo cuando en 1577 Catalina de Armesto arrienda a su yerno Juan Beltrán de Achega la ferrería de Ferreirós por cuatro años y “çierto preçio", Miguel Ortiz, que entonces era rendero en ella, la lleva a pleito por no haber sacado dicho arrendamiento a pregón, tal como solía hacerse 794 . Miguel Ortiz afirma que el pagaría más por el arrendamiento. Algunos testigos en el juicio, sin embargo hablan de que las pragmáticas reales y las costumbres imponen que se ha de preferir en las ventas y arrendamientos a los próximos antes que a los extranjeros, quizá por eso, porque Juan Beltrán era yerno de Catalina, ganó el juicio795. Luego parece que hubo bastante libertad en esa materia, porque los dueños de los artefactos los arriendan a los que les parece, aunque casi siempre entre personas que conocen bien el oficio. Como hemos dicho hay individuos que permanecen muchos años como renteros en la misma ferrería o en otras diferentes.

El propietario, a cambio del arrendamiento de la ferrería, percibe una renta, pagada normalmente en dinero, aunque en algún caso se realiza en especie, sobre todo antes del siglo XVIII. Lo vemos en el caso de la ferrería de Soldón en $1603^{796}$ y lo deducimos del contrato de arriendo de la mitad de la

792 "Todos los descalabros mayores y menores que sucedan en los artefactos, chapacuña y demás edificios y oficinas de las referidas fábricas" los debe arreglar el arrendatario "a excepción de que si el arbol mayor se inutilizase enteramente y se cayere alguna pared de las herrerías y casas" que se pagará a medias. Contrato de las ferrerías de Río Cabo a Antonia San Miguel, en 1848. En I. GARCİA TATO (2000): ob. cit., p. 131.

793 AHRG. Hombreiro: leg. 19: En 1605 don Álvaro de Quiroga arrendó a Lorenzo Alza, rendero de su ferrería de Quiroga, la de Paleiras por ocho años y una renta anual de 150 ducados más 4.00o maravedís de foro a la encomienda de la Barra. Entre las condiciones se estipula que ha de dejarla como la encuentra, es decir, en condición de trabajar. A este contrato siguieron otros a Miguel de Alza, probablemente su hijo, quien "ha dejado disminuir dicha ferrería de Paleras, causa que al presente está damnificada y en ella no se puede trabajar, y la casa de la dicha ferrería aunque palacio principal" está medio abandonada. Por ello, para que no se arruine aún más, en 1625 don Francisco de Quiroga se la arrienda a Antonio da Chega y Simón de Obide por cuatro años sin renta alguna, excepto los 4.00o maravedís de foro a la encomienda. Sólo estarán obligados a "reparar, aderezar y redificar la dicha ferrería de Paleras, casa y palacio".

794 AHRG. R. A.: 2472/120: "arrendamiento hecho sin traer a pregón la dicha herreria a quien mas diera por ella...como suele hacerse"

795 AHRG. R. A.: 2472/120

796 AHRG. R. A.: 20.441770: En 1603 se interroga a un testigo en un juicio de esta ferrería "si saben el que puede auer un año poco mas o menos tiempo que la doña Jerónima arrendó las 
ferrería de Arnado del año 1634, en que Antonio Mosquera recuerda a Miguel de Loreaga que este ha de pagar al marqués de Villafranca la mitad de los tres quintales y un cuarto de hierro delgado que como renta ha de satisfacer cada una de las 52 semanas del año797. En 1596 la renta de la ferrería de Valdomir se estipuló en la mitad de la producción, lo que parece excesivo798.

La renta varía mucho de unos siglos a otros, pero sobre todo de unas ferrerías a otras en razón de su estado, producción, bienes que posee, etc. En el siglo XVI, al menos en los contratos que conocemos (APÉNDICE II-11), no parece que varíe mucho de uno años a otros. Por ejemplo, la ferrería de Valcarce se arrienda por cantidades entre los 16.000 y los 22.500 maravedís a lo largo de todo el siglo XVI, como vemos en los años 1486, 1500, 1555 y 1581. Las ferrerías de Arnado y Pontepetre, que se arrendaban juntas, en 1499 se arrendaron en 64.00o maravedís y en los años 1555 y 1556 en 52.000 maravedís cada uno de ellos, cantidades no muy diferentes a las de otras ferrerías lucenses, como Valdomir y Paleiras. Durante el siglo XVII, por el contrario, parece que el valor subió aunque no de una forma acusada (cuadro XVI).

Tampoco conocemos la relación entre renta y producción. En Guipúzcoa durante los siglos XV-XVIII esta renta era de un 10\% de la producción; es decir, un quintal de hierro por cada 10 quintales de producción, aunque con variaciones799. Sabemos, por ejemplo, que la renta de la ferrería asturiana de Raicedo en 1536 era de 60 quintales/año ${ }^{800}$, pero ignoramos si eso representa el 10\%. Quizá sería interesante relacionar el valor de la ferrería y el de la renta, pero sólo conocemos algún ejemplo, que no podemos generalizar. Así, en 1597 se valoró la ferrería de Valdomir en 1950 ducados, es decir, 729.300 maravedís y dos años después, en 1599, se arrendaba por 49.980 maravedís, lo que supone

tres partes de la dicha herraria (de Soldón por cuatro años) a Joanes de Fagoaga en sesenta y seys quintales de hierro cada año (...) y cada quintal de hierro vale a tres ducados y medio". 797 AHPL. P. N.: caja 2126 (1634).

${ }^{798}$ Quizá se deba a que Juan de Zuluaga, dueño de una tercera parte de la ferrería, ponía esta con ruedas, mazos, barquines, etc. mientras que el arrendatario, Domingo de Arechaga, contraba a los oficiales y compraba el carbón, y la explotaban a medias (AHPLU: 2407/9).

799 Á. ARAGÓN (2012): Ob. cit., p. 87; L. M. DÍEZ DE SALAZAR (1983): Ob. cit., t. I, p. 231-232, añde, que ese diez por ciento que en el siglo XVI se cobraba en Guipúzcoa de renta era una cantidad, justa, suficiente y rentable. Menos precio se estimaba como un perjuicio para la propia ferrería que, debida a tan escasa rentabilidad, debería cerrar. También añade que esa relación de 10/1 es la que se encuentra en las Ordenanzas de los siglos XV y XVI, p. 232.

${ }^{800}$ A.Ch.V.: Pleitos Civiles, caja 207,5 
un $6,8 \%$ de su valor; algo semejante ocurre con la ferrería de Paleiras, que en 1587 se vendió en 750.000 maravedís y cuya renta en 1605 fue de 60.084 maravedís, un $8 \%$, cantidades ambas que deben considerarse moderadas.

En el siglo XVIII, las rentas suben de manera exponencial, como vemos en el cuadro XVI, en el ejemplo de la ferrería de Paleiras (ver también Apéndice II-12). En el siglo XVII, la renta subió de 68.000 maravedís en las dos primeras décadas a 78.0oo maravedís en los años treinta. Tomando como índice 100 esos años (1620 a 1632) cien años después, entre 1746 y 1757 ese índice había subido a 258 y en la primera década del siglo XIX a 949; es decir la renta pasó de 204.000 a más 750.00o maravedís. Por tanto, se fue incrementando desde finales del siglo XVIII hasta el primer tercio del siglo XIX, luego bajó de forma notable, algo que también podemos constantar en otras ferrerías, aunque los datos sean más irregulares. Según Munárriz, en el siglo XVIII la renta que percibían los propietarios de las ferrerías bercianas era muy alta y una de las causas de la pobreza material de las mismas ${ }^{801}$; sin embargo, las cantidades conocidas, 10.500 reales hacia 1750, y 20.000 reales hacia finales del siglo XVIII ${ }^{802}$, no suponían con respecto a los costes totales de producción más que un $15^{\prime} 6$ y un 17 '7 por ciento respectivamente, cantidades no excesivas si pensamos que con ellas los propietarios tenían que hacer frente a las reparaciones de las mismas ${ }^{803}$.

\footnotetext{
${ }^{801}$ MUNARRIZ, p. 126.

${ }^{802} \mathrm{La}$ de Froseira, en Asturias, estaba arrendada a finales del siglo XVIII EN 10.000 reales, según J. LÓPEZ y A. GRINDA (1998): ob, cit., p. 74.

${ }^{803}$ En un foro de la ferrería de Montealegre (Castropol), efectuado en 1571, el dueño se obliga a proporcionar, cuando sea preciso reponer "las pieças de árbol mayor o menor, e çepos e dormientes, e puerca o maderas prinçipales o mayores, ansi de de la presa como de la herrería o camarado", además de todas las personas y bueyes necesarios para el acarreto de dichas piezas hasta la ferrería, siendo obligación del forero darles "de comer e beber a la tal jente". Cit. Por J. LÓPEZ y A. GRINDA (1998) : Ob. cit., p. 24.
} 


\title{
CUADRO XVI. EVOLUCIÓN DE LA RENTA
}

\author{
EN LA FERRERÍA DE PALEIRAS
}

Índice base 100: 78.778 mrs. ${ }^{*}(1629-1632)$

\begin{tabular}{|l|l|l|l|l|l|}
\hline AÑOS & RENTA & ÍNDICE & AÑOS & RENTA & ÍNDICE \\
\hline 1596 & 68.000 & 86,3 & 1746 & 204.000 & 258,9 \\
\hline 1604 & 60.084 & 76,2 & 1747 & 204.000 & 258,9 \\
\hline 1605 & 60.084 & 76,2 & 1748 & 204.000 & 258,9 \\
\hline 1606 & 60.084 & 76,2 & 1749 & 204.000 & 258,9 \\
\hline 1607 & 60.084 & 76,2 & 1750 & 204.000 & 258,9 \\
\hline 1608 & 60.084 & 76,2 & 1751 & 204.000 & 258,9 \\
\hline 1609 & 60.084 & 76,2 & 1752 & 204.000 & 258,9 \\
\hline 1610 & 60.084 & 76,2 & 1753 & 204.000 & 258,9 \\
\hline 1611 & 60.084 & 76,2 & 1754 & 204.000 & 258,9 \\
\hline 1612 & 60.084 & 76,2 & 1755 & 204.000 & 258,9 \\
\hline 1629 & 78.778 & 100 & 1756 & 204.000 & 258,9 \\
\hline 1630 & 78.778 & 100 & 1757 & 204.000 & 258,9 \\
\hline 1631 & 78.778 & 100 & & & \\
\hline 1632 & 78.778 & 100 & & & \\
\hline
\end{tabular}

* Renta en maravedíes

FUENTE: AHPLU 2407/9 (1596), AHRG. Hombreiro, leg.

19 (1605-1612 y 1629-1632), AHRG. R. A.: 14147/12 (1746-1757),

AHPLU: 2455/2 (1809-1813)

Como organizadores de la producción, los arrendatarios eran los más directamente beneficiados, puesto que si los propietarios y foreros percibían rentas, los arrendatarios obtenían beneficios. Unos por el capital fijo, otros por el capital circulante. Este era, sin duda, importante y el que corría unos riesgos mayores; de ahí la importancia de sus beneficios ${ }^{804}$. El rentero, al igual que los

\footnotetext{
804 Estos arrendatarios manejaban grandes cantidades de dinero. Por ejemplo en 1827, se dice que a la muerte de Domingo Fernández Rigueiro, arrendatario de la ferrería de Quintá, el 26 de agosto de 1826, quedaron como herencia más de 300.000 reales en "hierro, vena, carbón, deudas, etc.". Sus herederos denuncian que al hacer el inventario de bienes por gentes no versadas o interesadas sólo lo evaluaron en 82.000 y pico rs., lo que no es cierto, por lo que lo denuncian ante la justicia (AHPLU: 2406/14)
} 
administradores, contrataba a los oficiales de la ferrería, adquiría la vena y el carbón, se encargaba de la venta (muchas veces al fiado) a comerciantes y arrieros que la distribuían por pueblos y ciudades de la propia región y zonas circundantes. Era, por tanto, el personaje clave en el proceso de producción.

Como arriesgaban mucho, Munárriz les achaca que su único interés se reducía a obtener la mayor rentabilidad en el menor tiempo, sin preocuparse lo más mínimo por introducir en dichos establecimientos reformas técnicas ${ }^{805}$, pese a que los beneficios que conocemos de algunos de estos arrendatarios suponen el doble o el triple de las rentas: 20.706 reales hacia 1750 y 97.561 reales a fines del siglo XVIII de beneficio frente a 10.500 y 20.000 reales de renta ${ }^{806}$. Claro está que estas cifras no podemos generalizarlas para todas las ferrerías, ni todos los arrendatarios obtenían esos beneficios. El que a veces estos mismos subarrienden una parte de la misma o se asocien con antiguos oficiales vizcaínos, buenos conocedores del oficio, puede ser una medida cautelar para impedir el fracaso económico y rentabilizar estos negocios.

Del estudio de costes de las ferrerías vascas se viene a la conclusión de la importancia enorme del capital circulante frente al capital fijo ${ }^{807}$; por ello, ¿de dónde obtenían los arrendatarios el dinero para poner en marcha esta industria; es decir, para pagar la renta, adquir la vena y el carbón, contratar oficiales, etc? En el siglo XVI los grandes comerciantes vizcaínos no poseían ferrerías y, en muchos casos, ni siquiera controlaban la producción, aunque intervenían en ella de algún modo. En realidad el protagonismo estaba en manos de los grandes caballeros, pues eran estos los que con sus extensos patrimonios rurales controlaban la producción de vena y madera y, por ello, la fabricación del hierro. Por ejemplo, en el siglo XVI, Juan Alonso Butrón y Mújica, con su mujer, poseían unas 25 ferrerías, aproximadamente unos 31.00o quintales de hierro, es decir el $20 \%$ de toda la producción de Vizcaya ${ }^{808}$. Sin embargo, el papel de los comerciantes se iría incrementando en los siglos siguientes hasta acabar en un

\footnotetext{
805 MUNÁRRIZ, p. 126.

806 Ver capítulo sexto.

$807 \mathrm{M}^{\mathrm{a}}$ L. BILBAO y E. FERNÁNDEZ DE PINEDO (1982): “Auge y crisis de la siderometalurgia en el País Vasco (1700-1850)”. Madrid, p. 174

808 J. Ph. PRIOTTI (2011): "Producción y comercio del hierro vizcaíno entre 1500 y 1700”. Eusko Ikaskuntza, 57, p. 20-21
} 
verlagssystem; es decir, en un sistema económico en el que los comerciantes financian la producción pero al mismo tiempo la controlan. Sin duda el papel preponderante del capital circulante ayude a comprender la hegemonía de ese verlagssystem en el sector. Los comerciantes no necesitaban invertir en el capital fijo de las ferrerías para controlar la producción, les bastaba conceder créditos para financiar el capital de explotación necesario para poner en funcionamiento la ferrería ${ }^{809}$.

En el caso de las ferrerías del noroeste la cuestión no es tan clara o no hemos podido contar con una documentación abundante que la aclare. En algunos casos conocemos arrendatarios que solicitan, por medio de censos, dinero ${ }^{810}$; pero no hemos hallado muchos documentos que informen sobre una financiación previa de comerciantes, como ocurre en el verlagssystem, tan típico por ejemplo de la siderurgia vasca en los siglos XVII y XVIII ${ }^{811}$. Sí se aprecia una estrecha ligazón entre esta industria y comerciantes de las villas más importantes, pero más por la compra de cantidades importantes de hierro que por el adelanto de dinero, aunque conocemos algunos ejemplos: en 1600 el mercader de Villafranca Pedro Méndez presta dinero a Pedro de Azcoiti y Juana Regil, renteros de Órreos ${ }^{812}$; también en 1682 Francisco de Sotogayoso, mercader de Villafranca, presta, en diferentes partidas, 47.00o reales a Juan Fernández de Guzmán y a su esposa, arrendatarios igualmente de la ferrería de Órreos ${ }^{813}$. En muchos casos, los prestamistas de censos eran las instituciones religiosas ${ }^{814} \mathrm{o}$ incluso la hidalguía rural $\mathrm{u}$ otros arrendatarios ${ }^{815}$.

809 Ma L. BILBAO y E. FERNÁNDEZ DE PINEDO (1982): Ob. cit., p. 174

810 Por ejemplo, en 1584 Juan Ortiz, forero de la ferrería de Soldón, pide un préstamo a Francisco López de Quiroga de 570 ducados para "adereçar el bançado y traer el arbol e bena e adereços de la dicha herrería” (AHRG. R. A.: 20.441/70). En 1741 doña Angela Martínez Torres, arrendataria de la ferrería de Pontepetre, da poder a su yerno, don Joaquín Perejón, para que tome a censo "redimible y al quitar" de los canónigos y cabildo de la catedral de Astorga 12.00o reales, y si estos no los tuvieren busque otras personas con las que tomarlo (AHPL. P.N.: caja 3341).

811 M. GONZALEZ PORTILLA (1977): "La industria siderúrgica en el País Vasco, del Verlangssysten al capitalismo industrial". En Crisis del Antiguo Régimen e industrialización en la España del siglo XIX. Madrid, p. 117 y ss.

812 AHPLU: $2408 / 1$

813 AHPL. P.N.: 2923 (1682)

814 Conocemos cómo algunos arrendatarios piden dinero a los canónigos de Astorga (AHPL. P.N.: caja 3341), o cómo la ferrería de Villanueva de Oscos pide dinero a censo al monasterio de Lorenzana para construir la ferrería (D. PAZ (1991): ob. cit., p. 149).

815 AHPLU: 2417/11. En 1791 Manuel Sánchez, de Santa Marina de Folgoso, arrienda la ferrería de Paleiras (que con su hijo tendrá luego en arriendo hasta 1820). Por ello, "para su surtido y manejo, por hallarse necesitado de algunos dineros" pide un préstamo de 20.000 reales al 
Pese a la falta de datos, tan cicateros en las fuentes consultadas, el conjunto de relaciones económicas tejidas en torno al sector podrían, sin embargo, tipificarse igualmente dentro del modelo de "Verlagsystem". A la disociación entre capital fijo y circulante, se unía la distinción entre propiedad y explotación, entre producción y venta en mercados exteriores. A ello habría que añadir la figura del "tratante-mercader" que entrega géneros al fiado, y la de una mano de obra especializada que alternaba el trabajo del hierro con las labores del campo ${ }^{816}$.

\section{LOS TRABAJADORES}

La actividad siderúrgica, organizada en torno a los arrendatarios o mayordomos, contaba con un numeroso grupo de trabajadores, directos e indirectos: oficiales, mineros o venaqueros, carboneros, mulateros, arrieros, etc. Es difícil precisar el número exacto de personas que trabajan en cada una de las ferrerías, pues dependía de la magnitud de estas y de la época; pero probablemente ese número oscilara entre 25 y $40^{817}$. Schulz en 1838 , hablando de las ferrerías de Asturias y Galicia, ofrece una cifra entre 44 y 46 personas por artefacto $^{818}$. Si aplicáramos esta misma proporción al conjunto de ferrerías de la región, más de ochenta en el siglo XIX, la cifra de trabajadores en ese siglo rondaría los 3.500, siendo menor en los anteriores, en razón de su menor número 819.

ponferradino Francisco de Castro y Delgado, arrendatario de la ferrería de Arnado. Se los devolverá en dos años pagándole "tres reales vellon por cada quintal de hierro que produzca y fabrique en dicha fábrica".

816 J. OCAMPO (1990): Campesinos y artesanos en la Asturias preindustrial (1750-1850), p. 213.

817 AHRG. R. A.: 26.319/20: "dicha ferreria e cassas que en ella y para ella han de acer donde siempre abrá quarenta o cinquenta ombres para el servicio y onrra de esta casa y encomienda y comendadores (...) e que hizo asimismo gran provecho e utilidad por razon de la dicha Herreria e xente que en ella abra las rentas de la dicha encomienda baldrán más”.

818 G. SCHULZ (1938): "Ojeada sobre el estado actual de la minería en el distrito de Asturias y Galicia”. Anales de Minas, t. I, p. 385 y 391. Este autor comenta que las trece de Asturias dan "ocupación y subsistencia durante la mayor parte del año a quinientas ochenta obreros con sus familia, cerca de doscientas caballerías de carga y cien yuntas de bueyes, sin contar con el arranque de la vena" y que las treinta de Galicia proporcionan "ocupación la mayor parte de año a mil quatrocientos obreros, inclusos los carboneros, arrieros y carreteros con un número considerable de caballerías de carga y yuntas de tiro".

819 J. M. DÍAZ DE SALAZAR (1983): Ferrerías en Guipúzcoa, t. I, p. 122: señala que en los siglos XVI y XVII trabajaban en ferrerías de esa provincia 25 personas (1527), 30 (1625), 40/50 (1581), 40 (1542) e incluso 100 (1573), por lo que una media debía de ser de 40 a 50 
Si consideramos que esos trabajadores solían ser cabeza de familia y calculamos que esta -pese a variaciones regionales o temporales- la integraban 4,5 personas, el número de los que directamente dependían de esta actividad podía llegar a las 15.000 personas en toda la región estudiada. Tal número no constituye más que un pequeño porcentaje del total de población del noroeste, que a finales del siglo XVIII alcanzaba una cantidad cercana a 1.800.000 habitantes; pero no es respecto a este con el que hay que compararlo, sino con el de las comarcas en las que realmente existían ferrerías, lo que aumenta considerablemente el valor de esa cifra, especialmente si hablamos de la población activa industrial. Si añadimos los que trabajaban en martinetes y a los herreros, cuyo número alcanza casi los 6.000 en la región, el peso de la población dedicada a actividades relacionadas con el hierro se convierte en verdaderamente significativa.

\subsection{Los ferrones}

En las operaciones propias de la ferrería trabajaban únicamente cinco operarios, denominados oficiales o ferrones. En los siglos XVI y XVII, la inmensa mayoría de ellos fueron de origen vasco-navarro, como ya hemos dicho, luego gente local, a veces herederos de aquellos. Dichos oficiales eran dos tiradores, dos fundidores y un tazador; siendo uno de los tiradores el capataz de toda la cuadrilla con la denominación de aroza o arota820.

Esta cifra de cinco es la más frecuente en las ferrerías de la región, aunque algunos documentos solo hablan de cuatro y otros de seis ${ }^{821}$. En

trabajadores por ferrería. Ver igualmente J. ALCALÁ-ZAMORA (1974): "Producción de hierro y altos hornos en la España anterior a 1850". Moneda y crédito (Madrid), ${ }^{\circ} 128, \mathrm{p} .135$

820 MUNÁRRIZ, p. 131. Igualmente en el informe de la ferrería de Pombriego, de 1891, se dice: "El personal de la fábrica se compone de un capataz o aroza y ejerce las funciones siguientes: vigila a todos los operarios, ayuda al tirador a sacar la goa y en el tiraje y batido de hierro, y arregla la tobera cuando se descompone, que muchas veces es a los quince días, algunas duran un mes y otras un día, y en esta operación suele emplear cuatro horas. Dos fundidores que se ocupan exclusivamente de las operaciones de la fusión. Y un tirador que bate o tira el hierro en el mazo o pisón y prepara el hierro elaborado. Un muchacho que se llama tazador, el cual portea y machaca la vena para echarla en la forja, da o quita el viento a la tobera por medio de unas palancas que van a la compuerta de los chiflones.

${ }^{821}$ Lo más frecuente fueron cinco trabajadores, aunque en 1596 en un acuerdo para explotar conjuntamente la ferrería de Valdomir, Juan de Zuluaga tendrá a su cargo tener la ferrería 
Cantabria se habla de cuatro o cinco oficiales (aroza, dos fundidores, un tirador $\mathrm{y}$, a veces, un aprendiz) con una división del trabajo muy especializada, también de procedencia vasca ${ }^{822}$. En el País Vasco, en las ferrerías mayores trabajaban igualmente sólo cinco operarios: el maestro macero (arotza o txikitzailea), un tirador o laminador (igelea), dos fundidores (urtzaileak) y un aprendiz o prestador (meagilea) ${ }^{823}$. En Cataluña, por último, la farga cuenta con un número reducido de trabajadores, con una dedicación muy específica y especializada y que básicamente son: "el foguer, dos escolans i un maller, mentre que els picamenes actuen d'aprenets", es decir, prácticamente los mismos que en el norte y el noroeste ${ }^{824}$.

Desconocemos si, como otras profesiones de la época, tenían una estructura gremial, con sus maestros, oficiales y aprendices, pero si es así no lo hemos visto reflejado en la documentación; pues a diferencia de los herreros, cerrajeros, armeros, etc., que sí la tenían, no hemos encontrado ningún contrato de aprendizaje entre ferrones, quizá por la endogamia de esta profesión transmitida de padres a hijos. Lo que es seguro es que su carrera constituía una especie de cursus honorum, y el aprendizaje se iniciaba con el oficio de tazador, continuaba con los de fundidor y tirador y culminaba en el nombramiento de "maestro aroza", como se deduce de la vida profesional de Juanes de Arrillaga, que en los años 1668 y 1669 era "tirador" en la ferrería de Ponte Petre y en 1673 era ya "aroza" en la misma ferrería825; Juan Martínez de Manterola oficial en 1668 y aroza en $1679^{826}$; Juan Pol tazador en $175^{0}$ y tirador en $1759^{827}$, por señalar algunos ejemplos.

\footnotetext{
aderezada y reparada y Domingo de Arechaga ha de poner los cuatro oficiales: "y pagar los oficiales nezesarios de ferrería, que son aroza, tirador, dos fundidores abiles y suficientes para dicho oficio", falta el tazador (AHPLU: 2407/9).

822 M. CORBERA (2001): La siderurgia tradicional en Cantabria. Oviedo, p. 139-140.

823 I. CARRIÓN ARREGUI (1991): La siderurgia guipuzcoana en el siglo XVIII. Bilbao, p. 254

824 C. MAS (2000): Historia de la farga catalana. Lleida, p. 111-112.

825 AHPLU: caja 2936, año 1668. Juan Martínez de Manterola, "Oficial de las herrerías y asistente al presente en la herrería de Ponte Petre, que es de su Exc. el marqués de Villafranca" otorga un poder para el cobro de cierto dinero a "Felix de Aminondo, arota y a Juanes de Arrillaga, tirador, residentes en el lugar de Oencia". Ibidem, caja 2936, año 1673, poder que otorga "Juan de Arrillaga, arota en las herrerías de Ponte Petre y resiente en dicho lugar". ${ }^{826}$ AHPLU: 2936

${ }^{827}$ AHRG. R. A.: 6800/4
} 


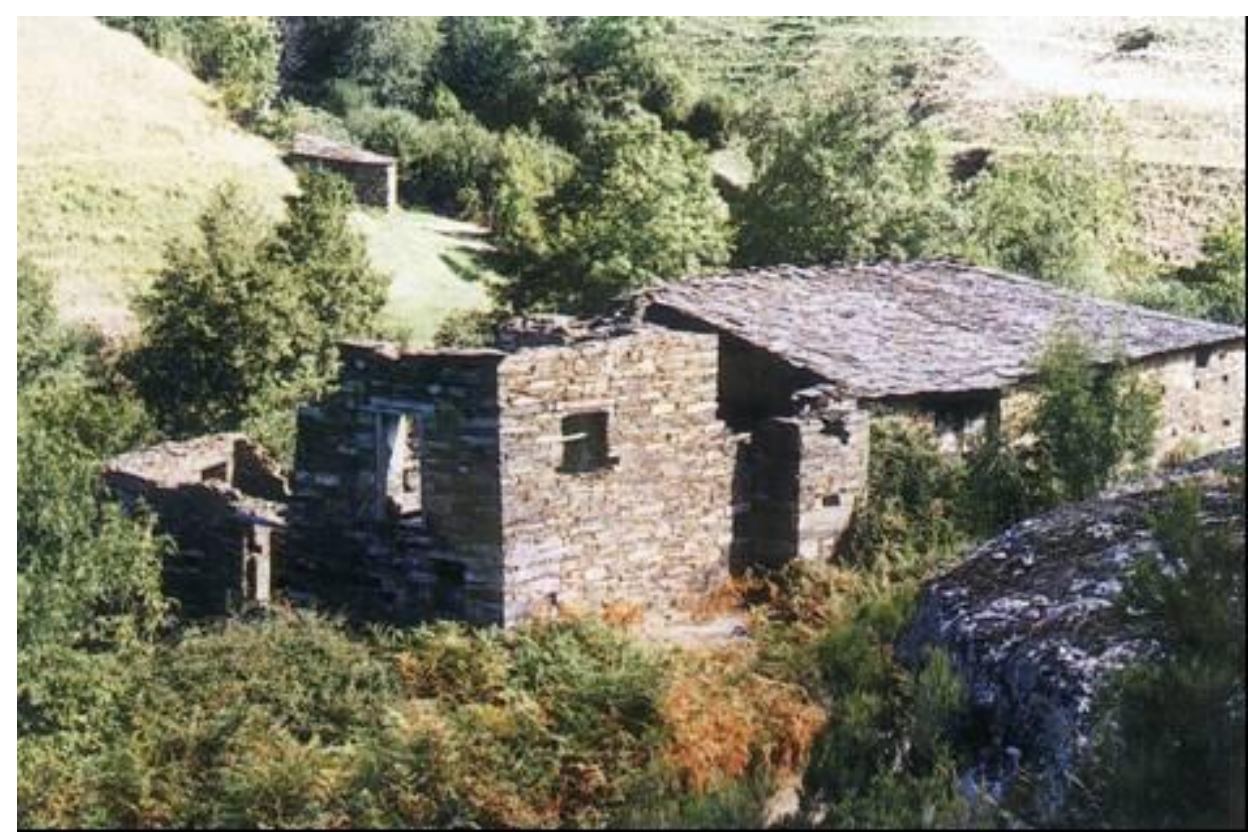

Ferrería de Soldón (Lugo)

El aroza, del vasco arotza ${ }^{828}$, era además del capataz, el único al que los documentos dan la denominación de maestro 829: maestro aroza, como culminación, lo hemos visto en el caso de Juanes de Arrillaga, de una larga carrera profesional; a veces se lo consideraba también el director de la ferrería ${ }^{830}$. El aroza era, pues, la persona que conocía todas y cada una de las partes del proceso de reducción del hierro, así como el experto en el manejo de barquines, mazo y fragua ${ }^{831}$. Como capataz dirigía la ferrería, siendo el

828J. CARO BAROJA (1975): Los vascos. Madrid, 1971, p. 191 dice que el vaco "Arotz" tenía primitivamente el significado de carpintero y herrero; posteriormente con este término se designó a los capataces de las ferrerías.

829 Venta en 1694 de parte de una herencia a Diego de Armesto "maestro aroça" de Lousadela (AHPLU: 25566/4.

$8_{30}$ En la ferrería de Lousadela el Catastro menciona $a$ "Juan Marcos aroza y director de dicha ferrería (CATASTRO DE ENSENADA. R. G.: Seceda).

${ }^{83}$ AHPLU: 3973/2 (1553): Vivero, 15 de julio de 1553, estando presentes "de la una parte Fernan Cao de Cordido en nombre del señor Juan López de Prabeo vezino e regidor de la ciudad de Mondoñedo, como rendero que es el dicho Juan Lopez de la ferreria de Silan e de la otra San Juan de Aguirre bizcayno de la probincia de bizcaya aroza que al presente hes de de la ferrería de Ponte da nobal del condado de Santa Marta en que dixo el dicho San Juan daguyrre que concertaba con el dicho Fernand Cao como fautor del dicho Juan Lopez en esta manera, que el dicho San Juan de Aguyrre se obligó de estar e residir e servir de oficio de aroça en la dicha ferreria de Sylan por tiempo y espacio de un año conplido el qual corre e se a de contar desde el postrero día del mes de agosto deste año de mil e quinientos y cincuenta y tres años y fenescera por el mes de agosto que berná del año de mil e quinientos e cincuenta $e$ cuatro años, $y$ que durante este año el dicho San Juan a de servir el dicho oficio de aroça en todo aquello que a el le sea posible y un aroça hes obligado de hazer en una herreria...". Por ese trabajo le pagarán cincuenta ducados de oro, en varias pagas, más los gajes de cada quintal de hierro y otros que es costumbre pagar a un aroza. 
encargado directo de tener arreglado el mazo y la rueda hidráulica ${ }^{82}$. En la construcción de una nueva ferrería, se recomendaba a los maestros de obra que contaran con la opinión del aroza, pues este sabía la inclinación que deberían llevar las toberas en el horno, los barquines y hasta el tamaño y peso del mazo ${ }^{833}$.

Los tiradores -el aroza era uno de ellos por eso a veces sólo se menciona uno- eran piezas fundamentales en el proceso de forja, ya que de los mismos dependía el sacar la zamarra del horno y estirarla en bandas, a golpes de mazo, y quitarle las impurezas que contenía; por eso también se les llamaba laminadores. Al mismo tiempo, los tiradores cortaban las bandas o barras dándoles diferentes formas, dispuestas para su venta a comerciantes y herreros, con las que estos fabricaban útiles y herramientas ya acabadas.

Los dos fundidores, cuya obligación era tener en perfectas condiciones la fragua y los barquines, estaban encargados de cargar el horno con vena y carbón, vigilar el proceso de reducción, eliminar las escorias y ayudar a sacar la zamarra con unas grandes tenazas, para que los tiradores pudieran estirarla en el mazo; luego preparar de nuevo el horno, pues como ya dijimos, esta operación se hacía cinco veces al día. También cuidaban del horno y de los barquines. El arreglo de estos exigía la presencia de maestros barquineros.

Por último, el tazador, posiblemente un aprendiz y no un oficial, molía el mineral previamente raguado, dejándolo en pequeñas piezas del tamaño de una avellana. Además era el encargado de hacer los recados, tirar de la cadena que abría el chiflón para que el agua permitiese funcionar el mazo o los barquines. En algunas ferrerías de mucha actividad podía haber dos tazadores.

\footnotetext{
832 MUNARRIZ, p. 28.

833 En 1664 cuando se construye la de La Vega de la Fanosa, se exige su presencia, pues "para la barquinera y cepotillos menores y los paraxes y poner la ferrería a de asistir el aroça para que sea a su gusto". Cit. en J. LÓPEZ y A. GRAÑA (1998): Ob. cit., p. 128
} 


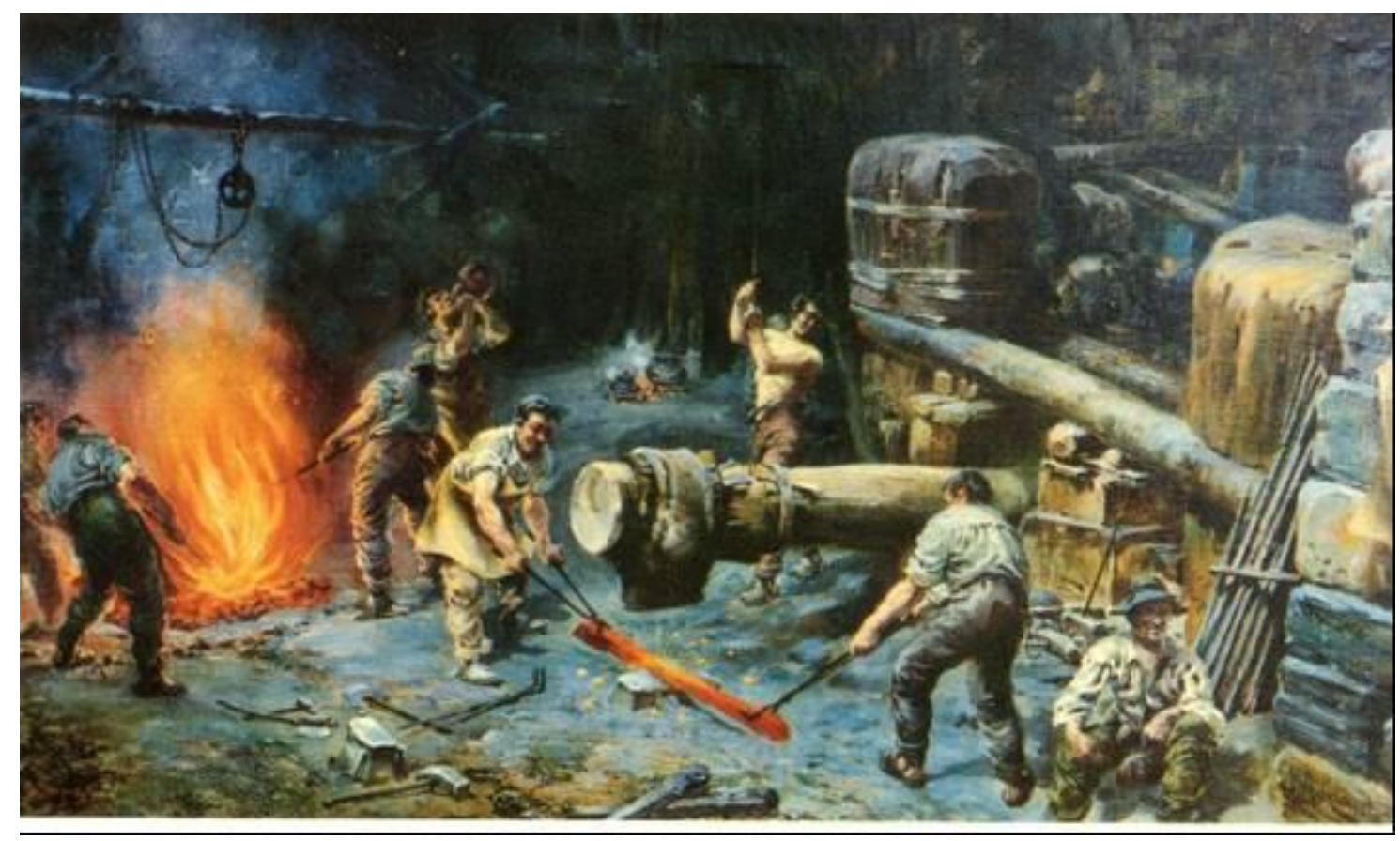

Ferrería de Compludo de P. Álvarez Armesto, entre 1892 y 1895.

Colección Diputación Provincial de León.

La jornada laboral, durante los meses que funcionaba la ferrería, comenzaba el domingo por la noche con el encendido del horno, e ininterrumpidamente continuaba día y noche hasta el sábado siguiente, pues el domingo se descansaba para poder asistir a los oficios religiosos; también se paraba si en medio había alguna fiesta religiosa. Sucesivamente se sacaban del horno cinco o seis ágoas, cada cuatro o cinco horas aproximadamente. Por tanto, el tiempo de descanso se ligaba a ese ritmo, lo que significa que se descansaba o dormía solamente un par de horas o tres y vuelta al trabajo, y así sucesivamente. Por esa razón, en la ferrería, normalmente en la bodega, había un cuarto con algunos camastros o jergones. La vida era por tanto muy dura, no solo por el esfuerzo y el calor agobiante, sino por ese ritmo discontinuo de trabajo y descanso.

Las diversas funciones de los ferrones estaban remuneradas de manera diferente, de acuerdo con su importancia, como puede apreciarse en el cuadro XVII, referido a los salarios de los oficiales a mediados del siglo XVIII, según el Catastro de Ensenada (Apéndice II-13). Aunque había diferencias de salarios entre las distintas ferrerías, los porcentajes entre los diversos oficiales eran muy 
semejantes. El arota venía a cobrar aproximadamente el 30\% del total de lo que se pagaba a estos, mientras que el tirador apenas superaba el 22.5\%. Los dos fundidores cobraban un 18,4\% cada uno y el tazador solamente el 10,3\%. Había, por tanto, grandes diferencias entre estos distintos oficiales, pues el tazador cobra tres veces menos que el aroza y los fundidores sobre poco más o menos la mitad que este.

\section{CUADRO XVII. SALARIOS DE LOS OFICIALES DE FERRERÍA A MEDIADOS DEL SIGLO XVIII (en porcentajes)}

\begin{tabular}{|l|l|l|l|l|l|}
\hline FERRERÍA & AROZA & TIRADOR & FUNDIDOR & FUNDIDOR & TAZADOR \\
\hline Valcarce & 27,7 & 22,2 & 19,4 & 19,4 & 11 \\
\hline Hórreos & 30,7 & 23 & 17,9 & 17,9 & 10,2 \\
\hline Valdomir & 29,7 & 24,7 & 17,3 & 17,3 & 10,8 \\
\hline Paleiras & 29,8 & 22 & 19,3 & 19,3 & 9,3 \\
\hline Ferreirós & 28,9 & 24,1 & 17,3 & 17,3 & 12 \\
\hline Bueyes & 30 & 22,6 & 17,4 & 17,4 & 10,9 \\
\hline Quintá & 31,5 & 21,1 & 18,1 & 18,1 & 11 \\
\hline Rodela & 30,7 & 20,9 & 18,4 & 18,4 & 11,3 \\
\hline Folgoso & 29,7 & 24,7 & 17,3 & 17,3 & 10,8 \\
\hline Soldón & 28,2 & 23,7 & 19,7 & 19,7 & 8,4 \\
\hline Rugando & 30,6 & 20,9 & 18,4 & 18,4 & 11,4 \\
\hline La Veguiña & 27,8 & 21,3 & 21,3 & 21,3 & 7,9 \\
\hline TOTAL & 29,8 & 22,6 & 18,4 & 18,4 & 10,3 \\
\hline
\end{tabular}

FUENTE: PARES (Catastro de Ensenada). Muestra de algunas ferrerías a partir de la pregunta 33 del interrogatorio (apéndice II-13).

Este salario se componía de varias partidas, como vemos en el cuadro XVIII, referido a la ferrería de Bueyes (Bois): salario en metálico, quintalaje y los dones. Munárriz, por su parte, asegura que los oficiales recibían una cantidad por cada quintal de hierro producido -el quintalaje-, más los gastos de alimentación ${ }^{834}$. El quintalaje era, pues, la parte más importante, porque se

834 Así, al menos, lo vemos en la ferrería de Pombreigo en 1891 (ESTADÍSTICA MINERA, año 1891. Provincia de León, p. 190-195). 
pagaba en relación con los quintales de hierro labrados. Este quintalaje, que en quintales debió de ser muy costante, en dinero varió de acuerdo con el precio del quintal. Así a finales del siglo XVII era de "quatro reales y veinte y seis maravedis" en la ferrería de Villanueva de Oscos835; en la de Lorenzana, en 1601, se dice que en la labra del hierro se pagará "quatro reales a los oficiales por cada quintal de hierro tirado y labrado" 836 , y a comienzos del siglo XIX ascendían a nueve reales y medio por cada quintal837. En 1686, en la ferrería del monasterio de Villanueva de Oscos, los cinco ferrones obtuvieron estas cantidades por quintalaje: el aroza nueve quintales y medio de hierro, el tirador seis y medio, los dos fundidores cinco quintales cada uno, y el tazador solamente dos ${ }^{838}$; es decir: el aroza el 33,9\%, el tirador el 23,2\%, cada uno de los fundidores el $17,8 \%$ y el tazador solo el 7,1\%, lo que no difiere mucho de los porcentajes del cuadro XVII.

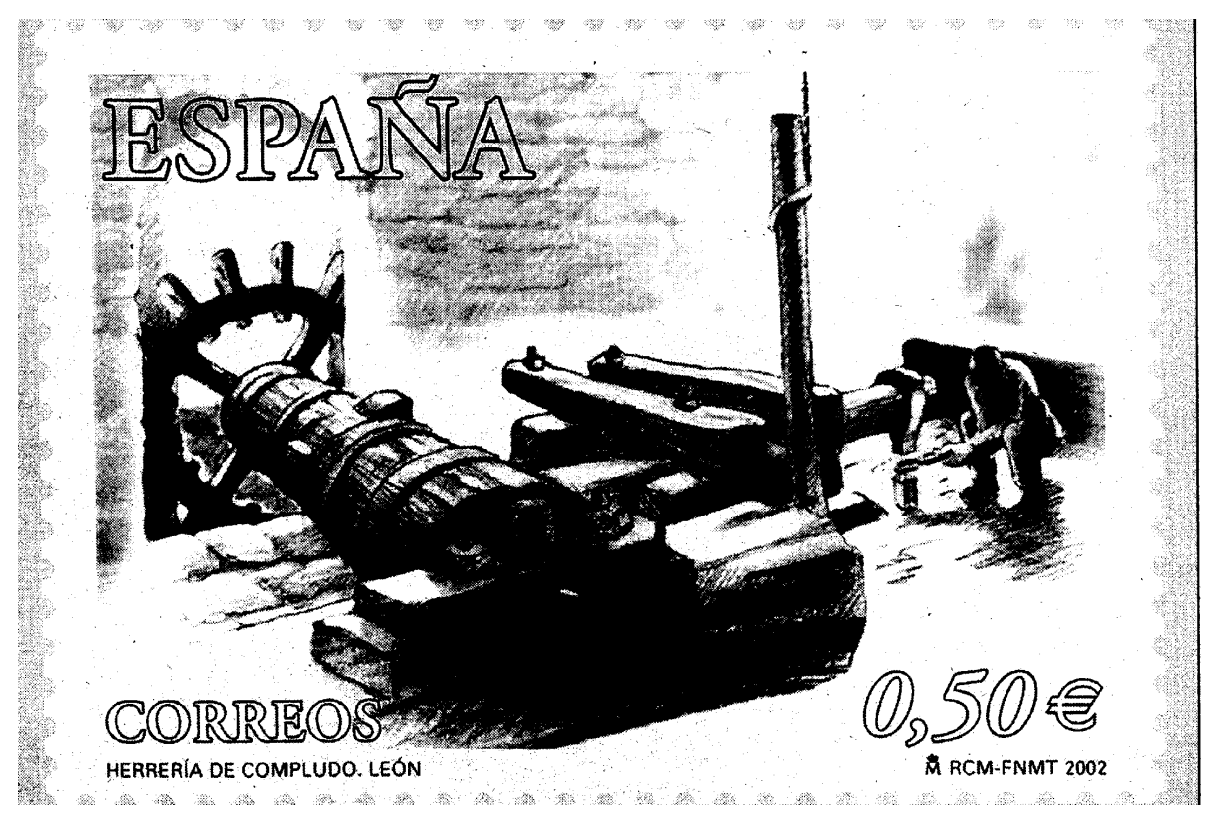

Sello conmemorativo. Ferrería de Compludo

835 AHN. Clero: libro 9437. En 1680 se dice, además, que es costumbre darle a los oficiales 14 ducados para carne por sacar las ferramentas menores cuando es necesario, y también todos los sábados darles un azumbre de vino, y por cada malogrero un cuartillo y por componer cada gorrión una cañada, y cuando vienen a trabajar se les da una cena y una comida (en la que emplea, dice, el prior, 2.640 rs.).

836 AHPLU: 7011/1

837 J. LÓPEZ y A. GRINDA (1998): Ob. Cit., p. 30-31.

${ }^{83}$ AHN. Clero: Libro 9.437 
Estos salarios, como veremos en otro capítulo, parece que evolucionaron al alza a lo largo de los siglos, aunque el peso de los mismos sobre el total de los gastos debió de disminuir.

\section{CUADRO XVIII. SALARIOS (en reales) \\ DE OFICIALES. FERRERÍA DE BUEYES}

\begin{tabular}{|l|c|l|c|l|l|c|}
\hline & SUELDO & $\%$ & QUINTALAJE & $\%$ & TOTAL & $\% / O F I C I O$ \\
\hline AROZA & 600 & & 535 & 47,1 & 1.135 & 30,7 \\
& & 52,8 & & & & \\
\hline TIRADOR & 400 & 47,9 & 455 & 54,4 & 835 & 22,6 \\
\hline FUNDIDOR & 242 & 37,6 & 401 & 62,3 & 643 & 17,4 \\
\hline FUNDIDOR & 242 & 37,6 & 401 & 62,3 & 643 & 17,4 \\
\hline TAZADOR & 176 & 40 & 227 & 52,7 & 430 & 11,6 \\
\hline MEDIA & 332 & 45,3 & 403 & 54,7 & 737 & 100 \\
\hline
\end{tabular}

FUENTE: PARES (Catastro de Ensenada). Respuestas Generales: Noceda de Doncos

Los oficiales de las ferrerías eran oficios muy especializados, por lo que no abundaban. Era frecuente que se les contratara por temporada y que trabajaran de forma ininterrumpida a lo largo de los meses que duraba aquella, con jornadas de 24 horas, descansando solo desde el anochecer del sábado al anochecer del domingo, como hemos dicho ${ }^{839}$. Con frecuencia, el aroza, como jefe del equipo, negociaba directamente con el dueño de la ferrería, firmando un contrato en el que este se comprometía a abastecer al artefacto de las materias primas necesarias para la fabricación del hierro y el aroza a contratar al resto del equipo de operarios. En algunas ferrerías en las que había varios dueños, podía haber varios equipos, aunque lo más frecuente era que el mismo trabajara para todos, aunque distinguiendo el carbón y la vena de cada propietario, como

$839 \mathrm{El}$ informe de la ferrería de Pombriego, de 1891, que hemos visto anteriormente, continúa: "Estos cinco operarios se relevan por mitad cada cuatro horas en la forma siguiente: cada fundidor se retira a descansar después que ha sacado la goa que le corresponde y es sustituido por su compañer; el tazador, después que ha porteado y machacado el mineral correspondiente a una fundición se retira también a descansar mientras continúa la marcha del horno, y se levanta cuando empieza la operación siguiente; el tirador se levanta para ayudar al fundidor a sacar la goa y efectuar el tiraje y batido del hierro, retirándose después a descansar y lo mismo hace el aroza". 
ocurría con la ferrería de Ferreirós, dividida en 72 ágoas pertenecientes a cuatro o cinco propietarios.

En ocasiones se les pagaba por adelantado una parte de sus salarios para evitar así que se fueran a otra ferrería y tenerlos contentos ${ }^{840}$. Esos salarios eran muy superiores a los de los campesinos o artesanos de la época. Según el Catastro de Ensenada, a los oficiales de la ferrería de Valcarce se les regula su jornal diario en 10, 8, 7 y 4 reales respectivamente, es decir del aroza al tazador (es decir, 27,7\%, 22,2\% 19,4\% y 11\%); por el contrario a los maestros herreros del pueblo de Herrerías de Valcarce, donde se encuentra la ferrería, se les regula en cuatro reales, a los oficiales herreros en tres, y a los aprendices en un real ${ }^{841}$; es decir un maestro de herrería cobraba lo mismo que un simple tazador. Por esa misma razón el nivel de vida de estos ferrones era muy superior a la de sus convecinos, podían adquirir algunas propiedades en los pueblos en que habitan o algunos lograban convertirse, con el tiempo, en arrendatarios de esas mismas ferrerías, como hemos tenido ocasión de ver.

Había además bastante movilidad en estos ferrones, pues los encontramos trabajando en ferrerías diferentes a lo largo de los años, como si se contrataran al mejor postor ${ }^{842}$. Aunque también los hay que pasan varios años en la misma ferrería, como Domingo de Zarauza, aroza de Pontepetre entre 1616

\footnotetext{
840 En un pleito de 1759 los monjes de la ferrería de La Rodela hacen esta interesante aclaración: "En toda herrería, como en la del dicho monasterio, para tener oficiales promptos y seguros ay la costumbre de por el mes de diziembre del año que despide ajustarlos para el venidero $y$ aprontarles anticipadamente cantidad de dinero ygual trabaje o no la Herrería. Por razón de dones se da al oficial que sirbe de aroza diez y seis quintales de hierro, una casaca de pardo, que se reputa en cincuenta reales y unos zapatos; al oficial que haze de tirador se le dan nuebe quintales de hierro, unos zapatos y medio cañado de vino; a los dos oficiales que hacen de fundidores se les da quince quintales de hierro, medio cañado de vino, dos pares de zapatos $y$ seis baras de pardo; y al que haze de tazador doscientos reales y un par de zapatos, ciuo hierro se les da en especie o al precio que se beneficia (este año dice que a $64 \mathrm{rs}$./quintal), ygualmente el pardo y los zapatos...; y asi mismo se satisface a los oficiales por razón de quintalaje cuatro reales y medio". Estas afirmaciones las confirma el testigo Juan Pol, que trabajó como tazador en la Rodela y ahora es tirador en San Vicente de Leira (AHRG. R.A.: 680o/4)

${ }^{841}$ CATASTRO DE ENSENADA. R. G.: San Julián.

842 AHRG. R. A.: 9090/4:. En 1787 en un pleito de la ferrería de Valdomir por venta de carbón, el testigo Antonio Álvarez, de 53 años, dijo "que en la Errería de Quiroga solo estubo un año de oficial, y en otras sirbió también de oficial en unas un año y en otras dos, como fueron las de Rugando, San Vizente (de Leira) y la de Incio, biniendo todos los meses a su casa (en San Cristóbal de Fisteus), que están las dos primeras la una a distancia de una legua, otra a legua y media y la última cinco leguas"
} 
y 1622, Juan Manterola oficial en Pontepetre en 1668 y aroza en 1679 en la misma ferrería ${ }^{843}$.

\subsection{Otros oficios relacionados con las ferrerías}

Además de los ferrones, en la ferrería, de forma temporal, trabajaban otros operarios, como canteros, carpinteros, tubereros, ferramenteros ${ }^{844}$, barquineros, ocupados en los arreglos de los edificios y presas, el maderamen, los barquines, las herramientas, etc., de los que en este capítulo ya hemos hecho referencias a sus respectivas ocupaciones, y de los que en el apéndice II-14 ofrecemos algunos nombres. Por otro lado, para la producción del hierro, las ferrerías necesitan abastecerse de mineral de hierro y carbón. El suministro de estas dos materias primas lo realizan los arrendatarios a través de una serie de intermediarios: arrieros, mineros y carboneros. A veces, las ferrerías disponen de medios para el transporte de las mismas ${ }^{845}$; pero, más frecuentemente lo realizan arrieros (apéndice II-15), a veces ligados a las ferrerías por deudas contraídas con los arrendatarios ${ }^{846}$. En algún caso, los propios venaqueros hacían esa labor de transporte ${ }^{847}$, pero no era lo normal, sino trabajo de mulateros y carreteros. En el Catastro de Ensenada hay bastantes referencias a estos. Por ejemplo en Boal (Asturias), dice que hay cinco arrieros, de los que Esteban López, con cuatro caballerías se dedica "al acarreto de fierro y pan

843 AHPL. P. N.: 2936 (1668) y 3104 (1679).

844 AHPLU: 2407/9: en 1596 firman una concordia Juan Pérez de Errazti, rendero de Ferreirós, y Agustín Beltrán, maestro de ferraje. Este ha de servir a Juan Pérez en su oficio por un año, y para hacer ferraje aquel le dará todo el hierro que necesitase a precio cada quintal de hierro grueso a dos ducados y el de hierro delgado a 23 reales. Por cada docena de herraje de todas clases le pagará 4 reales además de la comida.

845 En 1558, en el inventario de Juan Ortiz, forero de la ferrería de Soldón, aparecen, entre otras muchas cabezas de animales (20 bueyes, 80 cabras y ovejas, 12 puercos) cinco machos "del serviçio de la dicha herreria" (AHRG. R.A: 19.768/32)

846 AHPL. P. N.: caja 3025 (1651):Juan Rodríguez, arrendatario de la ferrería de Pontepetre, firma un contrato en 1651 con el mulatero Santiago Lameyra, por el que éste adquiere a aquél tres cabalgaduras con sus aparejos en 58 ducados, que le pagará en tres años "en travajo de su persona y dichas cabalgaduras a la dicha ferraria, ansí de bena, carbón, como lo demás pagándole conforme suele pagar a los demás arrieros que traen dichos materiales a dicha herrería"; AHPL. P. N.: caja 2936 (1674): contrato de obligación que con don Lucas de Acevedo, arrendatario de la misma ferrería, firma en 1674 el arriero Francisco Yañez, por ciertas deudas contraídas, que le devolverá "en travajo de cabalgaduras, acarretos de vena, con ellas y su persona".

847 AHPL. P.N.: caja 2969. En 1629 Miguel de Loreaga, venaquero en la ferrería de Pontepetre, se oblica con Jerónimo González, tesorero general del estado y marquesado de Villafranca, a pagarle 39 ducados por un rocín y un macho que con todos sus aparejos (albardas, cabezadas, etc.) le vendió. 
para sus vecinos”, y otros tres, con dos caballerías cada uno, transportan carbón ${ }^{848}$.

La vena era adquirida a los mineros o venaqueros (apéndice II-16) a veces por los propios mulateros o arrieros, que posteriormente la vendían a los arrendatarios; aunque más frecuentemente estos no eran más que transportistas de unos arrendatarios que pagaban un foro a los propietarios de los lugares en los que se extraía, como en Formigueiros y Rocas, y cantidades a los mineros por el precio del mineral extraído. El Catastro de Ensenada informa que en Formigueiros trabajan, entre otros, 29 vecinos de Visuña, que arrancaban vena uno o dos meses al año ganando cuatro reales al día; y en Rocas trabajan menos mineros pero con una ganancia mayor, pues se le regula a cada uno 3.00o reales al año, lo que quizá signifique que trabajaban más tiempo ${ }^{849}$. Unas veces, la vena era adquirida ya cocida o raguada que, si bien era más cara, evitaba el consumo de la madera cercana a las ferrerías; otras veces, se adquiría directamente sin raguar, haciéndose esta operación en la propia ferrería, una o dos veces al año, por operarios expertos ${ }^{850}$. En ocasiones, un mismo arrendatario adquiría indistintamente uno u otro tipo de vena ${ }^{851}$.

Por último, los arrendatarios, para las operaciones de raguado $\mathrm{y}$ reducción del mineral en el horno, precisaban de grandes cantidades de madera y carbón vegetal. Carbón y madera lo adquirían los arrendatarios de los montes propios de las ferrerías ${ }^{852} \mathrm{o}$ en los bosques vecinales, por acuerdos con sus

\footnotetext{
848 CATASTRO DE ENSENADA. R. G.: Boal

849 Cit. C. GONZÁLEZ (1994): Ob. cit., p. 112

850 AHRG. R. A.: 5951/55: En 1612 se menciona en un pleito de la ferrería de Valdomir a Juan Rodríguez dos Casares "maestro de raguas".

${ }^{85}$ AHPL. P. N.: caja 2936 (1666): Por ejemplo, el de Ponte Petre, don Lucas de Acevedo adquiere en 1666 "ciento y cinquenta cargas de bena de las beneras de Baldecaballos para el consumo de la ferraria, que sea vien cozida y separado a satisfación de los oficiales que la ayan de trabajar, y a su quenta y mensualmente la an de dar a la manera referida de aquí a día de Santiago deste presente año en la rragua donde la a de embiar a buscar dicho don Lucas de Acevedo con las cabalgaduras de arrieros y las suyas"; mientras que, en 1668, el mismo arrendatario adquiere a Antonio Cereijo "tres cargas de bena cruda de dar y tomar quebrada en las beneras de Valdecaballos", diariamente desde diciembre hasta mayo ( AHPL. P. N.: caja 2936).

${ }^{852}$ Foro de la ferrería de Montealegre (Asturias), del año 1571: "Otrosi, ago el dicho fuero con que bos el dicho Pedro de Mindirichaga e las dos vidas después de bos durante el tiempo dellas en los montes que yo tengo en la dicha feligresia que son fuera del coto de la dicha herrería podaís cortar las maderas que fuesen menester para reparos de la dicha herrería e de las casas e edificios della, y el carbón para la dicha herrería e leña para rragua e para lo más conbeniente de la dicha herrería...”. Cit. Por J. LÓPEZ y A. GRINDA (1998): Ob. cit., p. 126.
} 
respectivos concejos, sobre todo esto último en los siglos XVIII y XIX, como ya hemos visto en el capítulo segundo. Sin embargo, la mayor parte del carbón utilizado por las ferrerías procedía de campesinos que en sus tiempos muertos carboneaban en los montes concejiles, exponiéndose a frecuentes multas ${ }^{853}$ aunque no faltaron carboneros venidos de fuera, especialmente del País Vasco.

853 En 1810 en un juicio entre las ferrerías de Lousadela y Ferreirós por el carbón se dice cómo los carboneros y venaqueros sólo lo eran temporalmente: "es notorio por emplearse los fabricantes de carbon y bena en la siembra de frutos y recogimiento de la castaña" (AHRG. R.A.: 25.291/28) 


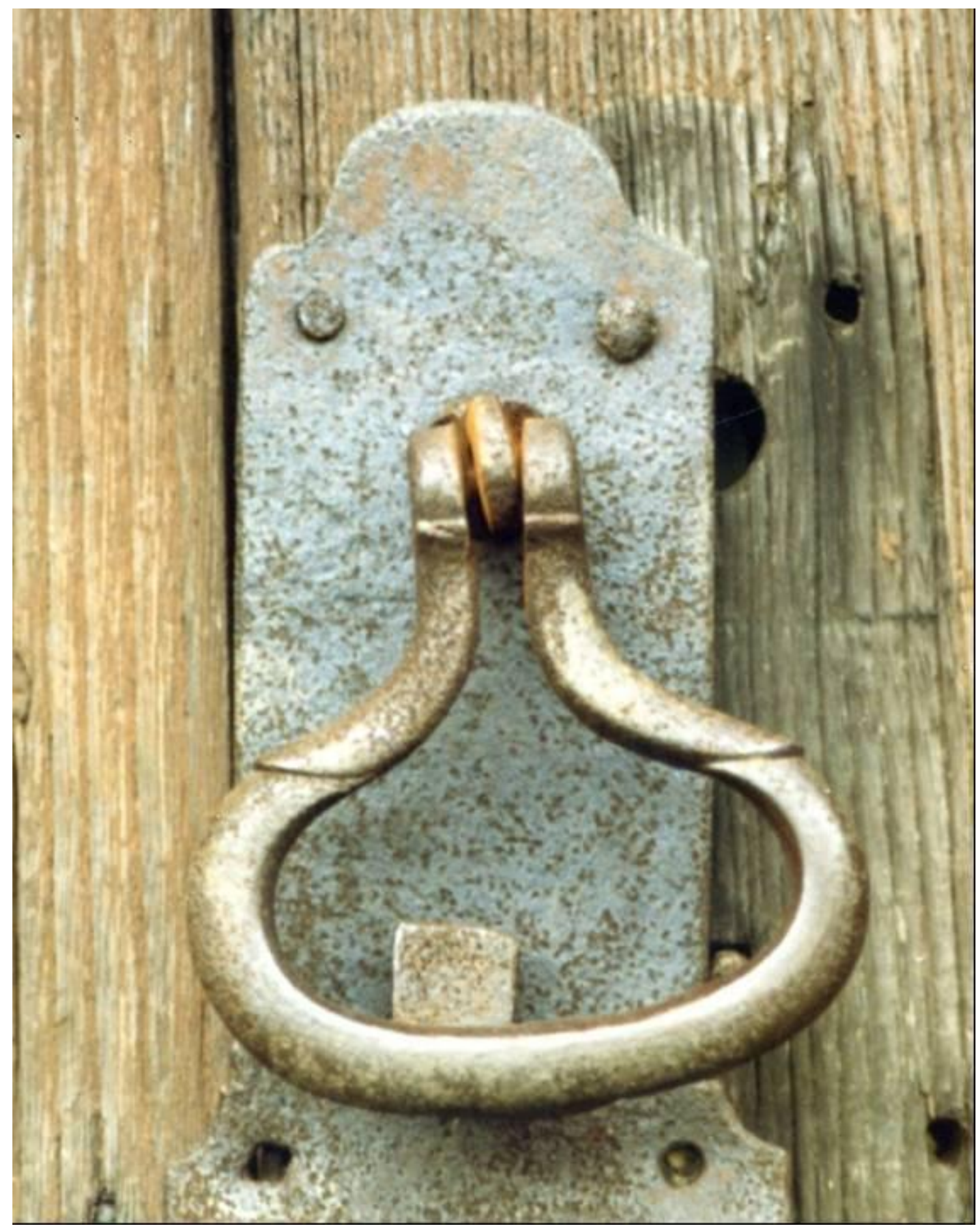




\section{LA PRODUCCIÓN DE HIERRO. COSTES Y RENTABILIDAD DE LAS FERRERÍAS.}

La producción de hierro en las ferrerías exigía instalaciones que, como hemos visto, precisaban de agua, carbón y mineral de hierro, además de capitales y trabajadores; pero esa producción en manos de administradores o arrendatarios estaba sometida a muchas contingencias, en unos casos por falta de recursos o financiación para conseguir las materias primas, como el carbón y el mineral de hierro; en otros por los descalabros que con demasiada frecuencia sufrían esos artefactos, especialmente por las avenidas de las aguas durante la época de lluvias o deshielo. También por los pleitos y dificultades financieras de los dueños y arrendatarios, tanto para construir las ferrerías como para ponerlas en marcha y, por supuesto, por la coyuntura económica y política del país a lo largo de los siglos, ya por la mayor o menor demanda de hierro, ya por los precios a los que se vendía, los cuales dependían de los imputs para fabricarlos pero también de los precios generales del mercado.

Con la excepción de varias ferrerías de las que contamos con datos seriados sobre su producción en periodos relativamente largos (Villanueva de Oscos desde 1680 a 1835) aunque más frecuentemente cortos (Quintá desde 1752 a 1792 y Lusío de 1730 a 1749); así como de las cifras generales del Catastro de Ensenada y algunas anuales que sobre numerosos artefactos publicó la Revista Minera en varios años del siglo XIX ${ }^{84}$, del resto sólo conocemos datos aproximados sobre su producción en fechas muy diversas, que de cuando en cuando nos proporciona la documentación notarial y procesal. De modo que es posible saber aproximadamente la capacidad productiva de las ferrerías y su

\footnotetext{
854 Para la ferrería de Villanueva de Oscos: AHN. Clero: libro 9.437, también: P. SAAVEDRA (1982): "Un aspecto de la economía monástica: la producción de hierro. El ejemplo del monasterio de Villanueva de Oscos”. En XV centenario del nacimiento de San Benito, Oviedo, p. 531-554; D. PAZ (1991): El monasterio de Santa María de Villanueva de Oscos. Oviedo, p. 145-169.; para Quintá: AHRG. Marqués de Ombreiro, también: V. MIGUÉS: (1996): "Un exponente de gestión económica de la "fidalguía" gallega y de producción de hierro en la montaña lucense. La herrería de Quintá durante el Antiguo Régimen”. Studia Histórica, $H^{a}$ moderna, 15, p. 209-242; para la de Rial: cit. por P. SAAVEDRA (1982): ob. cit., p. 537; Revista Minera en www.igme.es/internet/sistemas_infor/biblioteca/ BuscadorRevistas/ RevistaCons.asp
} 
producción en determinados momentos, pero no su evolución a lo largo del tiempo, con alguna excepción.

Por las contabilidades conocidas, esa producción no solo variaba de unas a otras ferrerías en función de los meses de trabajo, sino que también era diferente en un mismo artefacto de unos años a otros en razón de la mayor o menor cantidad de agua disponible, de la vena y carbón; también por los descalabros que sufrían, que solían ser bastante frecuentes, lo que les obligaba a parar durante meses e incluso años. Por eso, aunque conocemos bien la capacidad teórica de las ferrerías, resulta difícil saber cuál fue su evolución a lo largo del tiempo.

En líneas generales, la producción de hierro fue creciendo a lo largo de los siglos XVI al XIX, por varias razones: 1) El mayor número de ferrerías en funcionamiento que, como hemos visto en el cuadro I, pasó de 41 en el siglo XVI a 70 en el siglo XVIII y aproximadamente 90 hacia la mitad del siglo siguiente; 2) La mayor capacidad productiva de las ferrerías que se construyen en los siglos XVIII y XIX; 3) El aumento paulatino del consumo de hierro por habitante, lo que, por otro lado, está ligado al crecimiento de la población de esos siglos en el noroeste de España; y 4) a la política proteccionista de los Borbones al hierro español y la eliminación de aranceles a la venta de hierro al pie de las ferrerías.

\section{LA CAPACIDAD PRODUCTIVA DE LAS FERRERÍAS}

Las ferrerías trabajaban entre 120 y 250 días al año, de acuerdo con el Catastro de Ensenada ${ }^{855}$, el informe del general Munárriz ${ }^{856} \mathrm{o}$ los libros de cuentas de algunas de las anteriormente mencionadas. Un contrato del siglo

\footnotetext{
855 Como ya hemos dicho, las referencias al Catastro de Ensenada se encuentran en www.portal de archivos españoles, Catastro de Ensenada, seguido del nombre de la localidad.

, Catastro de Ensenada, seguido del nombre de la localidad.

${ }_{856}$ J. M. MUNARRIZ, p. 132: "El trabajo de una herrería con otra puede regularse en nueve meses anualmente, ya por falta de agua en verano, ya por los continuos descalabros que padecen, pues aunque las de Oencia y Arnado trabajan algún tiempo más, hay otras, que llaman regateras, que solo lo hacen seis o siete meses". El CATASTRO DE ENSENADA. R. G.: dice de la de Oencia: "Trabaja al año regularmente en un quinquenio doscientos y cinquenta días con sus noches"; de la de Arnado: "Produce al año y en cada uno de los doszientos y cinquenta días en que regula de trabajo".
} 
XVII obligaba a los arrendatarios de la ferrería berciana de Arnado a pagar durante las 52 semanas del año, tres quintales y un cuarto de hierro por semana a su propietario ${ }^{85}$, lo que podría entenderse como un funcionamiento ininterrumpido a lo largo del año, algo bastante insólito pues eran pocas las que así lo hacían. Las ferrerías dejaban de trabajar los domingos y días de fiesta, al menos. El Catastro de Ensenada dice de la de Linares que se le dan de hueco "ciento y veinte días... por las dominicas, festividades y composiciones" ${ }^{58}$, lo que arroja una cifra de 245 días de trabajo, media de lo que suele regularse al resto de las bercianas de esa época (Arnado, Pontepetre y Valcarce) ${ }^{859}$. Francisco Javier Datoli afirma que bien a causa del agua, bien por la falta de carbón, estas sólo trabajaban unos nueve meses, y algunas menos de seis ${ }^{860}$.

En las ferrerías gallegas y asturianas, tal vez por ser más numerosas, la disparidad era aún mayor (CUADRO XIX). La de Lor trabajaba todo el año pero el tiempo efectivo era de solo doscientos días861. Lo normal, sin embargo, era que lo hiciesen de 90 a 150 días. Las de Quintá y la Rodela labraban 120 días, 150 la de Rugando y 90 la de Bueyes ${ }^{862}$. De esta última, el Catastro dice que funciona "quatro meses y medio de ynuierno"; pero en realidad el tiempo efectivo era de solo tres meses ${ }^{863}$. Incluso había algunas que apenas alcanzaban un mes y medio. Estas, situadas a orillas de pequeños arroyos, se las conocía con el nombre de "regateras", por ejemplo las lucenses de Santalla y Lusío, y las asturianas de Deva y La Veguiña. De las 21 ferrerías de las que el Catastro de Ensenada menciona el tiempo de trabajo, el 14,28\% trabajan menos de 100 días,

\footnotetext{
857 AHPL. P. N.: caja 2126 (1634).

${ }^{858}$ CATASTRO DE ENSENADA. R. G.: San Clemente de Valdueza.

859 CATASTRO DE ENSENADA. R. G.: Arnado, Oencia, Valcarce.

860 DATOLI, p. 57-58

${ }^{861}$ CATASTRO DE ENSENADA. R.G.: Lor: "por quanto tiene agua suficiente por todo el año y travaxa todos los días de el, a excepción de los festivos que se obserban todos enteramente y los nezesarios al reparo de los frecuentes excalabros que padece por la rapidez y despeñado de dicho rio, $y$ otros que dexa de trabajar ynundada de sus crecientes, contemplan que revaxados unos y otros, solo travaxase echo el computo por un quinquenio, y sin hacerlo de los excalabros mayores, ducientos días en cada año"

862 CATASTRO DE ENSENADA. R. G.: Os Nogais

863 IBIDEM: "De los quatro meses y medio solo por quinquenio trauajará los tres de ellos que consideran completar nouenta y un días, $y$ el mes $y$ medio restante a cumplimiento de los quatro y medio consideran dicha herraria detenida por los dias de fiesta, dominicas, escalabros de tubera, barquines, gurriones, malogreros, ruedas, su composicion, cauo de martillo, iunque, trilla de agua, aruoles de las ruedas y otras cosas que a cada paso subceden en semejantes artefactos".
} 
el 52,38\% lo hacen de 101 a 199 días y el 33,37\% más de 200 días. La media de todas ellas es de 153,5 días de trabajo (unos cinco meses efectivos más o menos).

\section{CUADRO XIX. TIEMPO DE TRABAJO DE LAS FERRERÍAS DEL NOROESTE EN 1752}

\begin{tabular}{|l|c|l|l|c|}
\hline $\begin{array}{l}\text { TIEMPO } \\
\text { (en días) }\end{array}$ & $\begin{array}{l}\text { NÚMERO } \\
\text { FERRERÍAS }\end{array}$ & $\%$ & $\begin{array}{l}\text { TOTAL } \\
\text { DE DÍAS }\end{array}$ & $\begin{array}{l}\text { MEDIA } \\
\text { (en días) }\end{array}$ \\
\hline-100 & 3 & 14,25 & 270 & 90 \\
\hline $101-199$ & 11 & 52,38 & 1395 & 126,8 \\
\hline+200 & 7 & 33,33 & 1560 & 222,8 \\
\hline TOTAL & 21 & 100 & 3225 & 153,5 \\
\hline
\end{tabular}

FUENTE: PARES (Catastro de Ensenada). Muestra a partir Del apéndice II-17

El tiempo de trabajo normal de una ferrería se extendía desde el otoño hasta comienzos del verano; es decir, desde el mes de octubre o noviembre con las primeras lluvias, hasta el mes de junio o julio en que el estiaje de muchos ríos impedía seguir haciéndolo, aunque el agua no fue nunca el mayor problema, como hemos visto en el capítulo segundo, excepto para construirlas por la oposición de las inmediatas. Los meses del verano solían emplearse en las reparaciones y en el acarreo de la vena desde los yacimientos. En un pleito sobre una zanja que en 1759 sostiene la ferrería de la Rodela, los monjes de Samos hablan de diez meses de trabajo y dos de descanso, los de agosto y septiembre, los cuales se utilizaban para los arreglos necesarios para la siguiente 
campaña ${ }^{864}$. Algo parecido ocurría con la de Pallares, según testimonio de los vecinos de Villajuste en $1816^{865}$.

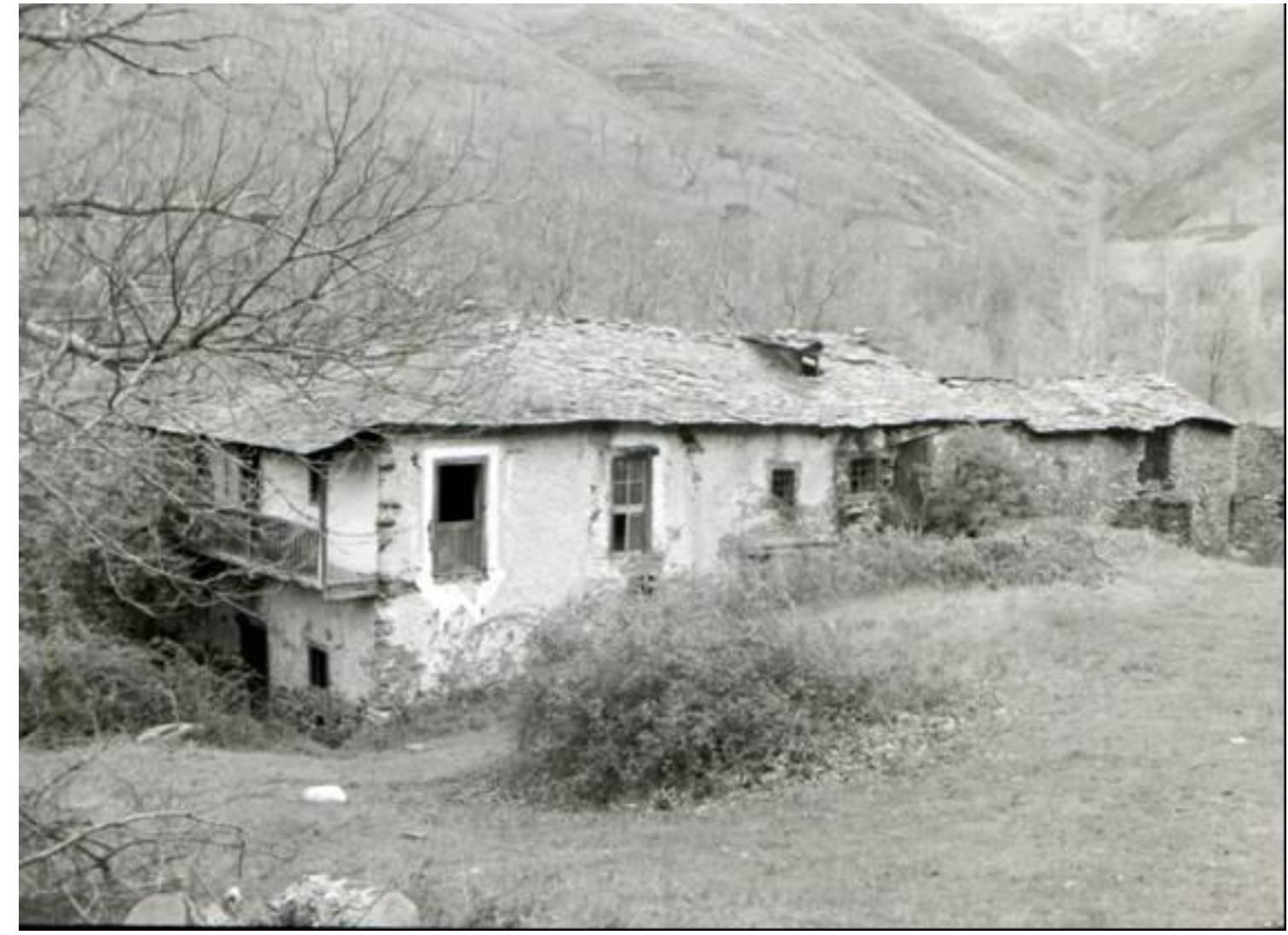

Ferrería de Arnadelo (León)

De la ferrería de Bueyes ya hemos dicho que solo trabajaba en invierno, cuando el río, un pequeño riachuelo, traía agua abundante y había energía suficiente para mover las ruedas; eso mismo ocurría en la de Quintá, cuyas contabilidades indican el momento preciso en que el administrador se hace cargo de la ferrería para un nuevo ejercicio, lo que sucede a finales de agosto o a principios de septiembre de cada año. Así, en las 23 ocasiones, entre 1752 a 1792, de que tenemos noticia de la toma de posesión de los administradores,

864 AHRG. R.A.: 6800/4: "todos los años trabaja enteramente, a excepción de los meses de agosto y septiembre, que abeces sucedia aber poco agua y está detenida, en cuyos meses se reparaban las ruedas, banzado y barquines, para que asi que vinieran las aguas nuebas no tener impedimento alguno". Esto lo confirma un testigo en un juicio en junio de 1756 respecto de esa misma ferrería: "oyó bulgarmente de que en los meses regurosos de brano y estio suele no trauajar por la poca abundancia de agua" (AHRG. R. A.: 190/33). Aunque otro, Juan Pol afirma que, con pequeñas interrupciones por escalabros, trabajó en esta ferrería de la Rodela de julio a julio: "y así desde cada día del Apóstol Santiago asta otro tienen costumbre en toda Herraria asistir, principar y concluir el año, y entonces o se quedan o ajustan para el que uiene o caminan para otra, como acaeció al que depone aquel año hirse para la Herraria de Noceda, que es de don Pedro Luis de Ulloa" (AHRG. R.A.: 6800/4).

865 AHRG. R.A.: 1687/29: "porque la Herrería de Villajuste o Pallares siempre paró por el mes de julio de cada año hasta nobiembre o diziembre". 
cuatro lo hacen en agosto (17,3\%), doce en septiembre (52,1\%), cuatro en octubre (17,3\%), dos en noviembre $(8,6 \%)$ y uno en diciembre $(4,3 \%)$. Aunque esas fechas no signifiquen necesariamente el comienzo de la labra anual, son indicativas y, en general, coinciden con las del Catastro de Ensenada, que señala que esa ferrería trabajaba de diciembre a julio (en algún memorial se dice que hasta Santiago, es decir el 25 de julio) ${ }^{866}$. La ferrería asturiana de Dueñes comenzaba el día de todos los Santos y acababa "a más tardar para el día de Santiago Apóstol”, y la de Villanueva de Oscos lo hacía desde mediados de noviembre hasta finales de mayo ${ }^{867}$.

Estas razones, además de otras estrictamente técnicas, ponían un límite en la capacidad productiva de estos artefactos, que difícilmente podían superar los 2.000 quintales anuales (115.000 kg.) ${ }^{868}$. El Catastro de Ensenada regula, en las ferrerías bercianas, una media de 250 días de trabajo, con una producción diaria de 61/2 quintales de 5 arrobas cada uno, lo que arroja una producción anual de 1.625 quintales. Munárriz, a su vez, señala que en cada ágoa se obtenían 5 ó 6 arrobas de hierro, operación que se hacía seis veces al día, lo que multiplicado por nueve meses de trabajo da una producción anual de 1.500 a 1.600 quintales ${ }^{869}$, que es aproximadamente la misma que ofrece Cornide para las ferrerías de Arnado y Pontepetre (1.500 quintales), y algo menos a la de Valcarce (1000 quintales) ${ }^{870}$. Estas cifras pueden parecer a muchos excesivas, pero un autor tan crítico como Datoli las confirma, rebajándolas a 1.100 y 1.200

866 V. MIGUÉS (1996): Ob. cit., p. 228

867 J. LÓPEZ y A. GRAÑA, A (1998): Ferrerías, mazos y fraguas en Asturias. Servicio de Publicaciones del Principado de Asturias, p. 20

${ }^{868}$ En 1603 en un juicio sobre la ferrería de Soldón se pregunta a los testigos si saben que la mitad de ésta valía 2.000 ducados y su renta 150 ducados, pues era muy buena y no le faltaban ni el bosque ni el agua y, continúa, "que puede labrar ella mas de mill y nuebecientos quintales de hierro cada año y aún dos mill..." (AHRG. R. A.: 20.441/70). Pero dejando de lado esta cita y las que ofrece el Catastro de Ensenada, demasiado generales, en las contabilidades que conocemos de Quintá y Villanueva de Oscos, no hay ningún año que se superen los 1.500 quintales: Quintá, cuya media es de 733 quintales/año, produce en varias ocasiones 1311 q. (en 1761), 1221 q. (en 1760), 1121 (en 1754); y en Oscos, cuya media es de 640 quintales sólo supera los 1.00o q./año en 1732/1733, 1762/1763, 1790/1791, 1798/1799 y 1830/1831.

869 MUNÁRRIZ, p. 132-132

870 CORNIDE, ff. 225: Memoria sobre las minas de Galicia y otras producciones del Reyno mineral". En Real Academia de la Historia: Papeles de Cornide. Cit. CORNIDE. En 1759, en un pleito de la ferrería de la Rodela (AHRG. R.A.: 6800/4), el monje de Samos encargado dice: "no sólo dicha Herraria sino todas las demas quando están corrientes trabajan todos los días sueltos, sino ygualmente las noches correspondientes a los festibos dos horas antes de la media noche y dos después según costumbre introducida de que también se debe hacer consideración atento a que en veinte y quatro horas se dan sacados dichos siete a ocho quintales de hierro". 
quintales ${ }^{871}$, por lo que la producción anual debe moverse entre 1.200 y 1.500 , es decir, unas 70 a 90 toneladas, aunque probablemente las medias en periodos más largos fueran más bajas.

Estas cifras de las ferrerías bercianas contrastan con las que conocemos de las gallegas y asturianas. Según el Catastro de Ensenada, la producción anual de las ferrerías de la Rodela y Rugando, propias del monasterio de Samos, se estimaba en 660 y 825 quintales respectivamente, aunque se mencionan algunas con mayor producción, como la de San Vicente de Leira (1.650 quintales), la de Froseira (1.200 q.) y la de Lor (1.00o q.). Los monjes de Samos en 1759 aseguran que en la ferrería de la Rodela, que trabajaba diez meses al año, producía de siete a ocho quintales diarios ${ }^{872}$; pero ignoramos los días que trabajaba efectivamente en esos diez meses. Por esas mismas fechas, el Catastro afirma que sólo lo hacía 120 días y que producía 660 quintales, aunque seguramente haya alguna ocultación porque 120 días por 7 q./día resulta una producción de 840 quintales (700 es lo que supone Cornide que produce) ${ }^{873}$. Respecto de la ferrería de Soldón contamos con datos que nos permiten conocer

\footnotetext{
${ }^{871}$ DATOLI, p. 56: "Cada herrería de las que trabaxan aún en el tiempo de la mayor seca, produce unos 1.00o a 1.200 quintales de a cinco arrobas al año".

872 AHRG. R. A.: 6800/4: "regularmente un día por otro de los diez meses que siempre trabajaba se sacaban de siete a ocho quintales de hierro de buena calidad". Esto lo confirma en un juicio el testigo Juan Pol, que fue tazador en ella en 1751 (IBIDEM).

873 CORNIDE, ff. 225
} 
que su producción se situaba entre los 750 y 900 quintales 874 , algo menos de los 1.00o de que habla Cornide hacia $1780^{875}$.

Más interesante que los datos cualitativos -aunque el Catastro los supone por un quinquenio- es analizar las medias de todas las ferrerías en un momento dado o a lo largo de un periodo más largo. Por ejemplo en los cuadros XX/a y $\mathrm{XX} / \mathrm{b}$ podemos ver la media de diferentes ferrerías hacia 1752 y 1780. En el primer año, la media de 14 ferrerías de todo el noroeste es de 976,5 quintales/año; por el contrario hacia 1780 la media de 24 ferrerías gallegas y bercianas desciende a 785,4 quintales/año. Ignoramos si ese descenso fue general, como comprobamos en otras ferrerías mejor conocidas, como la de Quintá (Cuadro XXI), o se debe a la generalidad que nos proporcionan estas dos fuentes; pero en todo caso, lo que ahora nos interesa es señalar cómo esa media se mueve entre los 785 y 976 quintales por ferrería y año, lo que supone entre 45 y 56 toneladas por ferrería y año ${ }^{876}$, cifras bastante considerables.

\footnotetext{
874 AHRG. R. A.: 21.702/18: A comienzos del siglo XIX, en el pleito contra el administrador de esta ferrería, don Pedro Quiroga asegura haber producido estas cantidades: 780 quintales entre el 25 de julio de 1820 hasta el 25 de julio de 1821 y 750 quintales en el mismo periodo de 1821 a 1822. Varios testigos confirman y matizan ese dato, que alguno aumenta hasta los 900 quintales: Francisco Pombo afirma que "la erraria de Soldón, propia de la parte por quien declara, trabajó en los años de mil ochocientos veinte y uno y mil ochocientos veinte y dos nuebe meses, con aguas francas, elaborándose fierro en ella, que en cada uno de dichos años, en los que la administró don Pedro Quiroga produjo lo menos nuebecientos quintales, y eso lo sabe con motivo de ser el testigo oficial de dicha erraria en aquel entonces"; Manuel López, por su parte, dice "que es un echo cierto y constante que la Erraria de Soldón (...) trabaja en cada año siete meses con agua franca, y otro mes y medio con medias aguas, en las quales cada año (de los dos años) daba seis quintales de fierro diarios". Manuel González sabe que la ferrería de Soldón "trabajó con agua franca desde el mes de octubre hasta el de abril, y desde este con medias aguas hasta el de junio o julio" y, por oírselo a los oficiales, produjo "al año lo menos nuebecientos quintales de fierro". Por último, Ángel Fernández, que declara en favor del administrador, dice que "sólo trabajó con agua franca cinco meses, que lo fueron nobiembre, diciembre, enero, febrero y marzo, en los cuales solo producía cinco quintales y medio de fierro, unos días más y otros menos, y con medias aguas trabajó los meses de abril y mayo hasta mediados de junio sin que en ese tiempo sepa el fierro que dio"; pero "le parece que sería los sietecientos y cincuenta quintales".

875 CORNIDE, ff. 225

876 Utilizamos el quintal de $57,5 \mathrm{~kg}$. y no el de $71,3 \mathrm{~kg}$, que emplea C. GONZÁLEZ (1994): $A$ producción tradicional do ferro en Galicia: as grandes ferrerías da provincia de Lugo. E. Diputación Provincial. Lugo., p. 19
} 
CUADRO XX/a. PRODUCCIÓN MEDIA DE LAS FERRERÍAS

DEL NOROESTE EN 1752

(en quintales)

\begin{tabular}{|l|l|l|l|l|}
\hline $\begin{array}{l}\text { PRODUCCIÓN } \\
\text { (en quintales) }\end{array}$ & $\begin{array}{l}\text { NÚMERO } \\
\text { FERRERÍAS }\end{array}$ & $\%$ & $\begin{array}{c}\text { TOTAL } \\
\text { PRODUCCIÓN }\end{array}$ & $\begin{array}{l}\text { MEDIA } \\
\text { POR FERRERÍA }\end{array}$ \\
\hline-500 & 3 & 21,4 & 1.277 & 409 \\
\hline $501-999$ & 5 & 35,7 & 3.845 & 769 \\
\hline+1.000 & 6 & 42,8 & 8.600 & $1.433,3$ \\
\hline TOTAL & 14 & 100 & 13.672 & 976,5 \\
\hline
\end{tabular}

FUENTE: PARES (Catastro de Ensenada): Respuesta 17 del interrogatorio (apéndice II-17)

\section{CUADRO XX/b. PRODUCCIÓN MEDIA DE LAS FERRERÍAS \\ DEL NOROESTE HACIA 1780 \\ (en quintales)}

\begin{tabular}{|l|l|l|l|l|}
\hline $\begin{array}{l}\text { PRODUCCIÓN } \\
\text { (en quintales) }\end{array}$ & $\begin{array}{l}\text { NÚMERO } \\
\text { FERRERÍAS }\end{array}$ & $\%$ & $\begin{array}{c}\text { TOTAL } \\
\text { PRODUCCIÓN }\end{array}$ & $\begin{array}{l}\text { MEDIA } \\
\text { POR FERRERÍA }\end{array}$ \\
\hline-500 & 5 & 20,8 & 1.850 & 370 \\
\hline $501-999$ & 12 & 50 & 8.000 & 666,6 \\
\hline+1.000 & 7 & 29,2 & 9.000 & $1.285,7$ \\
\hline TOTAL & 24 & 100 & 18.850 & 784,4 \\
\hline
\end{tabular}

FUENTE: R.A.H.: Papeles de Cornide Saavedra. Galicia, 9/5.917

Aún más interesante es comprobar esa media a lo largo del tiempo. Así, la ferrería lucense de Quintá produjo entre 1752 y 1792 (cuarenta años, de los que hay datos de solo 33, apéndice II-18) una media de 733,71 quintales anuales 877 , unas 42 toneladas. En el CUADRO XXI podemos ver su evolución durante la segunda mitad del siglo XVIII, con índices elevados desde 1753 hasta 1772, en los que supera algunos años el índice 150 e incluso en una ocasión se sobrepasa el 200; por el contrario desde ese año hasta el final del siglo a duras penas se llega al 100, excepto en alguna ocasión, pese a que el precio, como ya veremos,

877 V. M. MIGUES (1996): Ob. Cit, p. 232, ofrece, por el contrario, una media de 758,84 quintales, pero hay algún error y no computa un par de años. 
se incrementó considerablemente en esos años. Por su parte, la de Villanueva de Oscos, ferrería asturiana que cuenta con una serie estadística de 155 años, entre 1680 y 1835 (apéndice II-19), la producción media se estima en 36.813 kilos anuales, es decir unos 640 quintales ${ }^{878}$ (CUADRO XXII); pero la de Lusío, que ya hemos dicho que era regatera, de 1730 a 1749 sólo produjo 20.753,3 kg., ó $360 \mathrm{q} / \mathrm{año}{ }^{879}$. Esta cantidad, entre 40 y $50 \mathrm{tn}$., es la que podríamos calcular como producción media anual de las ferrerías del noroeste por cada artefacto en los siglos XVIII y primera mitad del siglo XIX. Luego fue disminuyendo paulatinamente, incluso a menos de la mitad de esas cifras en las décadas del 70 y el 8o, como podemos ver en el cuadro XXVIII.

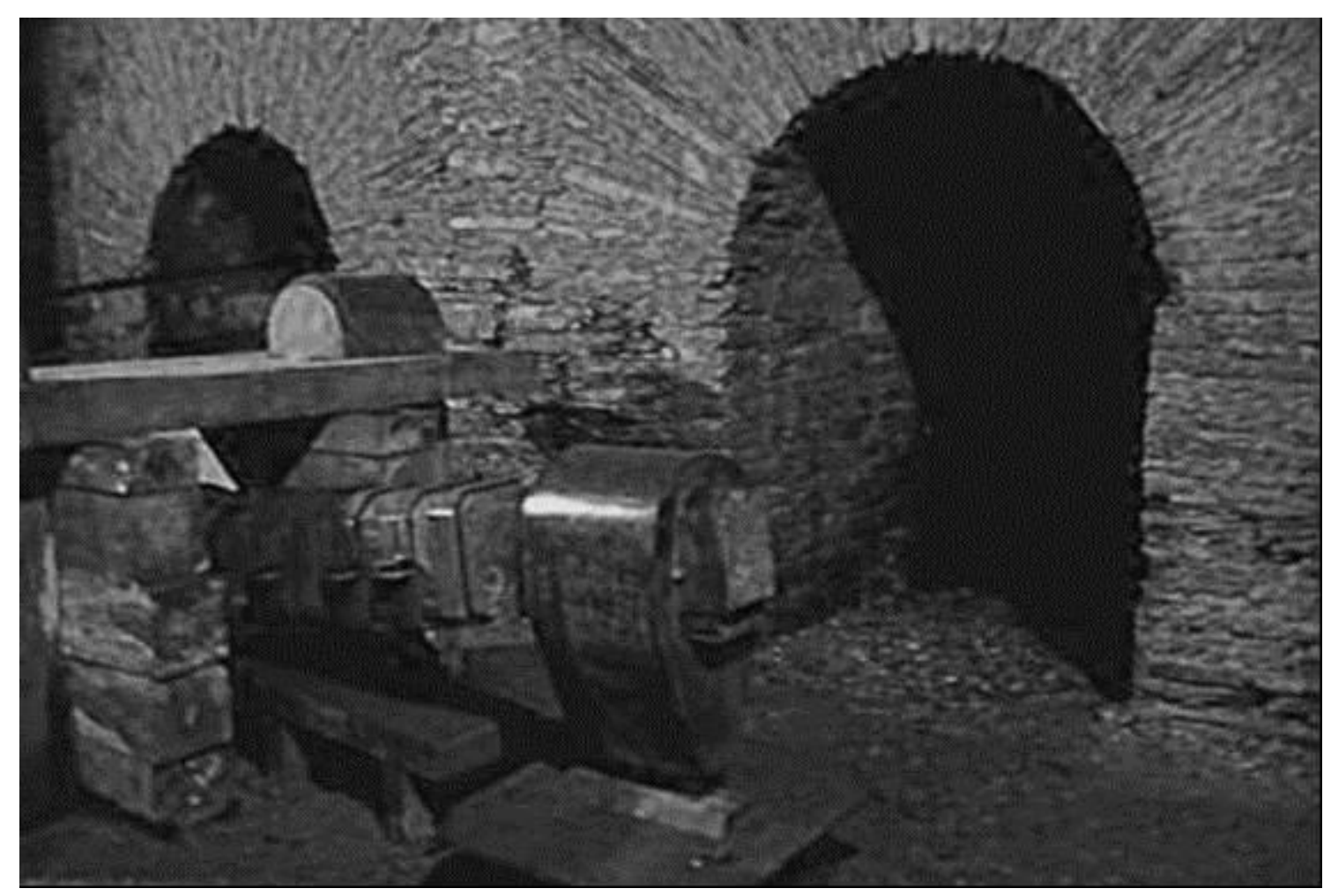

Mazo de la ferrería de Seoane (Lugo)

878 P. SAAVEDRA (1982) Ob. cit., p. 536

879 IBIDEM, p. 537 


\section{CUADRO XXI.- PRODUCCIÓN DE HIERRO E ÍNDICES \\ EN LA FERRERÍA DE QUINTÁ \\ (Indice base 100: 633,4 (1772-1778)}

\begin{tabular}{|l|c|l|l|c|l|}
\hline AÑO & PRODUCCIÓN & ÍNDICE & AÑO & PRODUCCIÓN & ÍNDICE \\
\hline 1753 & 848 & 133,8 & 1773 & 684 & 107,9 \\
\hline 1754 & 1.121 & 176,9 & 1774 & 549 & 86,6 \\
\hline 1755 & 1.102 & 172,9 & 1775 & 592 & 93,4 \\
\hline 1756 & 878 & 138,6 & 1776 & 684 & 107,9 \\
\hline 1757 & 607 & 95,8 & 1777 & 362 & 57,1 \\
\hline 1758 & 954 & 150,6 & 1778 & 663 & 104,6 \\
\hline 1759 & 1.014 & 160 & 1779 & ---- & ---- \\
\hline 1760 & 1.221 & 192,7 & 1780 & ---- & ---- \\
\hline 1761 & 1.311 & 206,9 & 1781 & 323,5 & 51 \\
\hline 1762 & 1.097 & 173,1 & 1782 & 479 & 75,6 \\
\hline 1763 & 884 & 139,5 & 1783 & 612 & 96,6 \\
\hline 1764 & 845 & 133,4 & 1784 & 458 & 72,3 \\
\hline 1765 & ---- & ---- & 1785 & 418,5 & 66 \\
\hline 1766 & 807 & 127,4 & 1786 & 235 & 37,1 \\
\hline 1767 & ---- & ---- & 1787 & 550 & 86,8 \\
\hline 1768 & ---- & ---- & 1788 & 600 & 94,7 \\
\hline 1769 & 795,5 & 125,5 & 1789 & 692 & 109,2 \\
\hline 1770 & ---- & ---- & 1790 & 502 & 79,2 \\
\hline 1771 & ---- & ---- & 1791 & 800 & 126,2 \\
\hline 1772 & 900 & 142 & 1792 & 620 & 97,8 \\
\hline & & & TOTAL & $24.212,5$ & \\
\hline
\end{tabular}

Producción en quintales, precio en reales

FUENTE: AHRG. Hombreiro. Libro de cuentas de la ferrería de Quintá.

Elaboración propia

Estas cifras de producción de las ferrerías del noroeste son muy parecidas a la media de las ferrerías del norte de España. La producción de las vascas se situaba en el siglo XVIII en torno a 739'56 quintales machos ó 54,58 
toneladas/año ${ }^{880}$, cifra algo superior a la que Uriarte Ayo ofrece para 130 ferrerías vizcaínas -incluidas las 24 de las Encartaciones- hacia 1752, que es de 612,43 quintales machos ${ }^{881}$, pero inferior a la de las ferrerías de Guipúzcoa que, también en 1752, se cifra en 815 quintales machos, unas $60 \mathrm{tm}^{882}$. Ojeda San Miguel, con datos de siete años (1779, 1784, 1792, 1832, 1840, 1845 y 1847) asegura que, en conjunto, las nueve ferrerías de Castro Urdiales producían 590 quintales de media al año cada una, aunque dos superaban los 800 y otras dos no llegaban a los 500 quintales ${ }^{88} 3$. Manuel Corbera, que publica la producción de numerosas ferrerías cántabras en el año 1799, distingue entre antiguas y nuevas. Las antiguas trabajaron entre 4 y 6 meses y su producción fue de unos 695 quintales de media; por el contrario, las nuevas, es decir, las levantadas en los cincuenta y sesenta del siglo XVIII, trabajaron entre 7 y 12 meses con una producción entre 1.166 y 1.200 quintales. La razón de esta diferencia no es tanto las mejoras técnicas de las segundas sobre las primeras como el mayor tiempo anual de trabajo 884 .

Tales cifras contrastan, por el contrario, con las fargas catalanas, cuya capacidad productiva parece algo mayor, aunque los datos son dispares y poco concluyentes. Pere Molera escribe que la producción normal era de unos 1.000 quintales métricos anuales (100 tn.) ${ }^{885}$. Jordi Maluquer, por su parte, con información de los años cuarenta del siglo XIX, afirma que las fargas producían una media de 2.000 quintales métricos (200 tn.) anuales ${ }^{886}$. Carlos Mas, con datos de finales del siglo XVIII para tres fargas de la vall Ferrera y Llavorsí, dice que producían sobre 1.300 quintales, volumen que desciende en el siglo XIX a la

880 LUIS Ma BILBAO y E. FERNÁNDEZ DE PINEDO (1982): "Auge y crisis de la siderometalurgia tradicional en el País Vasco (1700-1850)". En La economía española al final del Antiguo Régimen. Madrid, t. II, p. 164.

${ }^{881}$ R. URIARTE (1988): Estructura, desarrollo y crisis de la siderurgia tradicional vizcaína (1700-1840). Bilbao, p. 160-161 habla de que los niveles medios de producción se situaban en torno a las $45 \mathrm{Tm}$. por ferrería y año, aunque se trata de una magnitud fluctuante en el tiempo y divergente en cada una de las empresas.

882 I. CARRIÓN (1991): La siderurgia guipuzcoana en el siglo XVIII. Bilbao, p. 265.

883 R. OJEDA SAN MIGUEL (2003): "Tendencias en la producción de las ferrerías de Castro Urdiales (1615-1848)". Gaiak, p. 29. Las medias las he obtenido de sus datos.

884 M. CORBERA (2001): La siderurgia tradicional en Cantabria. Oviedo Ob. cit., p. 72-72

885 P. MOLERA (1980): La farga. Barcelona, p. 5

886 J. MALUQUER (1984): "La producción de hierro en la farga catalana". L'avanç, p. 25. Maluquer señala que "la qual cosa resulta aparentement superior a las capacitats més generalment atribuïdes a les ferreries basques". 
mitad y aún menos después de $1860^{887}$. En general, pese a estas divergencias, parece que eran de mayor producción, lo que ya venía de antes como confirman algunas fuentes, porque frente a los seis o siete quintales diarios de las ferrerías del noroeste, Jean Canteloube afirma que en el siglo XVII Jean Pierre Alexis, hablando de las forjas a la catalana del sur de Francia, estimaba que "une forge qui a l'eau et le charbon à suffisance rend 10 quintaux de fer de 24 heures en 24 heures" 888 , lo que supera entre un 30 y un $40 \%$ a las mejores del noroeste ${ }^{889}$.

\section{LA EVOLUCIÓN DE LA PRODUCCIÓN}

Si aceptamos las cifras mencionadas para las ferrerías del noroeste nos encontramos ante unos artefactos que tienen una alta capacidad de producción, en torno a 40/ 50 toneladas anuales; producción semejante a la que cita AlcaláZamora como media de las ferrerías españolas ${ }^{890}$ y que considera como un rendimiento estimable. ¿Cuál fue la evolución de la producción en la Edad Moderna? La evolución, al menos desde el punto de vista teórico, está ligada a dos parámetros: la capacidad de producción por ferrería y el número de ferrerías. Del primero hemos hablado en el punto anterior, aunque ignoramos si esa capacidad fue la misma a lo largo de todos los siglos, aunque probablemente no, ya que en los siglos XVI y XVII parece menor. Nef habla respecto de la siderurgia europea que estos artefactos producían en esos siglos unas 20 toneladas por año, es decir algo menos de 400 quintales (de $57,5 \mathrm{~kg}$.) ${ }^{891}$, aunque no todos están de acuerdo con esto ${ }^{892}$. A partir del siglo XVIII, como hemos

\footnotetext{
887 C. MAS (2000): Història de la farga catalana. Lleida, p. 232-234

888 J. CANTELAUBE (1993): "Apparition et èvolution de la forge à la catalane dans l'est des Pyrènèes françaises, XVIIème-XIXème siècles”. I Simposi Internacional sobre la Farga Catalana. Ripoll, p. 28. Este autor señala, en la pág. 65, que hacia 1840 todavía existían unas 50 forjas en el departamento de Ariége (sobre todo en Foix y Vicdessos). Por entonces se consideraba que una forja del cantón de Vicdessos en plena actividad podía hacer unos 1.000 feux (es decir, ágoas) al año y en cada uno de ellos $153 \mathrm{~kg}$; es decir, unos $153.000 \mathrm{~kg}$., lo que en quintales de $57,5 \mathrm{~kg}$, significa una producción de 2.660 quintales.

889 Como indica el texto tenían esa capacidad pero eso no significa que siempre la alcanzaran.

890 JOSE ALCALÁ-ZAMORA (1972): "Aportación a la historia de la siderurgia española". Moneda y crédito, $\mathrm{n}^{\circ} 120$, p. 135.

891 J. NEF (1967). Ob. cit., p.

${ }^{892}$ L. M. DÍEZ DE SALAZAR (1983): Ob. cit., t. I, p. 273. Habla el autor de que en el siglo XVI, en Guipúzcoa "un nivel «óptimo» serían producciones por encima de 1.500 qq./año. Pero teniendo en cuenta todas las dificultades que sobrevenían, en esta obra consideramos como cifra-índice aplicable a cada ferrería, la labranza de 1.250 qq./año, superior a los 1.000 qq. de que hay multiplicadas noticias, e inferior a la citada labranza óptima”.
} 
visto, esa cantidad aumentó más del doble, entre 40 y 50 toneladas (es decir algo más de 700 quintales).

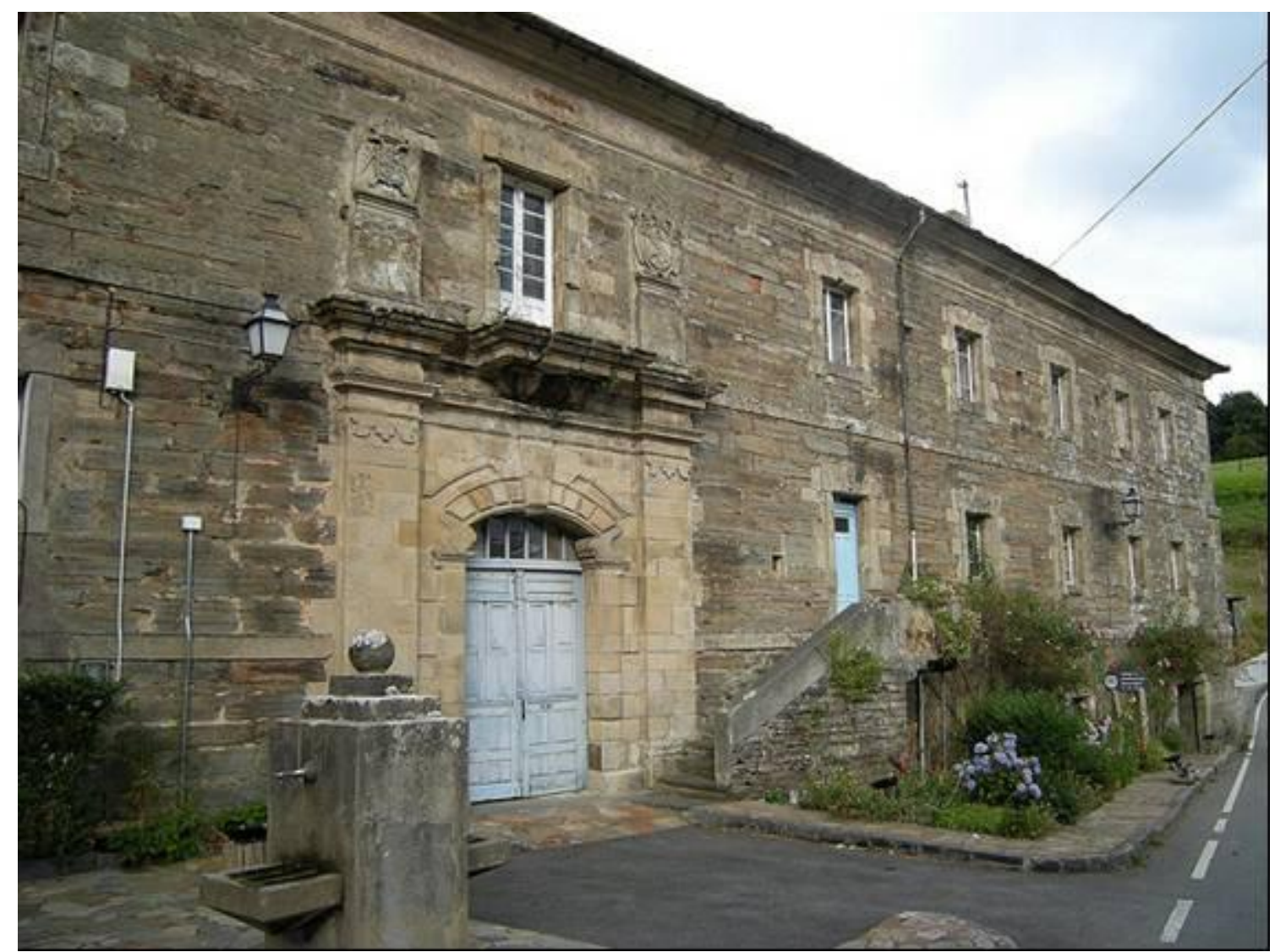

Monasterio de Villanueva de Oscos (Asturias)

¿Cuál fue la razón de ese aumento en la capacidad de producción de las ferrerías? Quizá el perfeccionamiento de la tecnología siderúrgica en el siglo XVIII, aunque no necesariamente. Sabemos que el cambio más importante en este tipo de instalaciones se produjo en el siglo XVI, en el que aparecen las ferrerías llamadas "a la genovesa", es decir, las tiraderas o martinetes, diferentes de las ferrerías mayores, lo que mejoró la productividad y con ello la producción del conjunto. Se cree que en la segunda mitad del siglo XVII y principios del XVIII tuvo lugar en Vizcaya, como una adaptación a las nuevas necesidades, un cambio en esta doble tipología: las “cearrolas", unas ferrerías de menor tamaño que sin necesidad de recalentar el tocho producían barras de alta calidad, de menos peso y menor gasto de combustible, pero de gran rentabilidad. Esto no parece haberse propagado ni hacia Guipúzcoa ${ }^{893}$, ni hacia el noroeste, donde

893 I. CARRIÓN (1991): La siderurgia guipuzcoana en el siglo XVIII. Bilbao, p. 120-121. 
siempre se mantuvo la distinción entre ferrerías y mazos. Sin embargo, los datos de la ferrería de Villanueva de Oscos que, por quinquenios, recogemos en el CUADRO XXII, hablan de producciones anuales relativamente pequeñas a finales del siglo XVII, una media en los últimos 23 años de 367,9 quintales/año, que se incrementan considerablemente en la primera mitad del siglo siguiente, hasta 655,9 quintales/año, para alcanzar cifras aún más elevadas en la segunda mitad de ese siglo, 709,5 quintales/año.

\section{CUADRO XXII. PRODUCCIÓN Y PRECIO DEL HIERRO EN LA FERRERÍA DE VILLANUEVA DE OSCOS (Índice base 100: 2.336 quintales (1700-1719)}

\begin{tabular}{|l|l|l|l|l|l|}
\hline AÑOS & PRODUCCIÓN & ÍNDICE & AÑOS & PRODUCCIÓN & ÍNDICE \\
\hline $1677-79$ & 1.122 & & $1755-59$ & 4.025 & 172,3 \\
\hline $1680-84$ & 1.841 & 78,8 & $1760-64$ & 4.161 & 178,1 \\
\hline $1685-89$ & 1.269 & 54,3 & $1765-69$ & 4.010 & 171,6 \\
\hline $1690-94$ & 1.422 & 60,8 & $1770-74$ & 3.052 & 130,6 \\
\hline $1695-1699$ & 2.808 & 120,2 & $1775-79$ & 2.494 & 106,7 \\
\hline $1700-04$ & 1.791 & 76,6 & $1780-84$ & 2.819 & 120,6 \\
\hline $1705-09$ & 2.356 & 100,8 & $1785-89$ & 2.830 & 121,1 \\
\hline $1710-14$ & 2.615 & 111,9 & $1790-94$ & 4.104 & 175,6 \\
\hline $1715-19$ & 2.582 & 110,5 & $1795-99$ & 4.245 & 181,7 \\
\hline $1720-24$ & 3.407 & 145,8 & $1800-04$ & 2.982 & 127,6 \\
\hline $1725-29$ & 3.826 & 163,7 & $1805-09$ & 3.056 & 130,8 \\
\hline $1730-34$ & 3.988 & 170,7 & $1810-14$ & 1.782 & 76,2 \\
\hline $1735-39$ & 3.956 & 169,3 & $1815-19$ & 1.292 & 55,3 \\
\hline $1740-44$ & 3.969 & 169,9 & $1820-24$ & 536 & 22,9 \\
\hline $1745-49$ & 4.305 & 184,2 & $1825-29$ & 3.290 & 140,8 \\
\hline $1750-54$ & 3.737 & 159,9 & $1830-35$ & 3.223 & 137,9 \\
\hline & & & TOTAL & 7.746 .659 & \\
\hline
\end{tabular}

FUENTE: Elaboración propia a partir de los datos de P. Saavedra (1982). Ob. cit., p. 545-548

No eran necesarios grandes cambios tecnológicos para lograr un aumento de la producción. Ya hemos visto que las ferrerías del noroeste, desde el punto de vista técnico, tenían capacidad para producir 40 ó 50 toneladas anuales de 
hierro. Hay que pensar en otros factores, como la mayor demanda de hierro por habitante, lo que a su vez está directamente relacionado con el crecimiento o disminución de la población, también con las necesidades del Estado por razones bélicas o de otro signo o, como ocurre con los Borbones, por las medidas proteccionistas al hierro castellano. Esto, aparentemente, choca con el segundo parámetro antes mencionado, el mayor número de ferrerías en funcionamiento a lo largo de los siglos (CUADRO I). Si las ferrerías técnicamente tenían más capacidad de producción ¿̇por qué se construyen otras nuevas? La respuesta no es sencilla pero existen razones que dificultan el aumento de la producción, especialmente los problemas en el abastecimiento de las materias primas, como el carbón y sobre todo su transporte. En ese sentido, como se dice en los permisos de construcción, se levantan en los lugares donde pueden abastecerse más fácilmente y a menor coste.

De acuerdo con dichos parámetros y las razones señaladas podemos ahora matizarlas temporalmente y comprobar su incidencia en la evolución de la producción. Una de esas razones está ligada a la demanda de hierro, cuya labranza cobra en el siglo XVI un nuevo auge en el noroeste, al compás de las transformaciones del comienzo de la modernidad, en que se aprecia un mayor consumo de hierro, tanto por el crecimiento demográfico interno y el mercado que supuso el Nuevo Mundo, como por las necesidades de la corona española, embarcada en continuas guerras en Europa, en armas y buques ${ }^{894}$. AlcaláZamora cifra ese consumo en el siglo XVI entre 0,75 y 2 kilogramos por habitante en Europa, proponiendo para la España de Felipe II una cantidad en torno a 1,45 kilogramos/habitante, lo que significaría una producción de ocho mil toneladas métricas ${ }^{895}$. Otros autores hablan de cantidades algo mayores, pues suponen que la producción total europea habría que estimarla entre 40.000 y 100.000 toneladas, de las cuales el País Vasco produciría unas 15.000 toneladas, es decir entre un 15 y un $37,5 \%$ del total ${ }^{896}$. ¿Qué cantidad le

894 P. SAAVEDRA (1985): Economía, política, y sociedad en Galicia: la provincia de Mondoñedo, 1480-1830. Xunta de Galicia. Santiago, p. 327; M. CORBERA (2001): La siderurgia tradicional en Cantabria. Oviedo, p. 15

895 J. ALCALÁ-ZAMORA (1974): Ob. cit., p. 131 y 148

896 J. PH. PRIOTTI (2003): "El comercio de los puertos vascos peninsulares con el noroeste europeo durante el siglo XVI". Revista de Estudios Marítimos del País Vasco, no 4, p. 197; también en M. BARKHAN HUXLEY (2003): "El comercio marítimo vizcaíno y guipuzcoano con el Atlántico peninsular (Asturias, Galicia, Portugal y Andalucía) y con los archipiélagos de 
corresponde al noroeste? Probablemente no más allá de un $1 \%$ a un 2,5\%, es decir sobre unas 1.000 toneladas poco más o menos.

Si pensamos que el interland del hierro del noroeste, dejando a parte algunas partidas que se venden en Andalucía y Portugal como veremos en el próximo capítulo, se extiende por León, Asturias y Galicia, dicha región alcanza, de acuerdo con el censo de 1591, una población de 1.131.625 habitantes ${ }^{897}$. Esta población fue consecuencia del notable crecimiento demográfico que experimenta la Corona de Castilla en ese siglo898. Tal crecimiento, con más o menos diferencias, lo constatamos en los diversos territorios de nuestro estudio. La provincia de León pasa de los 127.953 habitantes del 1528 a 223.510 en 1591, es decir un $75 \%$ de aumento ${ }^{899}$. Si aceptamos las cifras de algunos vecindarios, sin duda discutibles, la población gallega habría experimentado en el siglo XVI un crecimiento demográfico en torno al 90\% (de 300.000 habitantes a casi 600.000), que habría sido sensiblemente mayor en la primera parte 900 . También crece la población asturiana, aunque en menor medida. Diversas fuentes atestiguan ese crecimiento, pese a que hacia finales del siglo la población solo alcanzaba unos 150.000 habitantes, con una densidad de apenas $10 \mathrm{hb} . / \mathrm{km}^{2}$, menor que la de Galicia e incluso que la de la Meseta901.

Esos 1.131. 625 habitantes, de acuerdo con el consumo de 1,45 kg/hab. antes mencionado, supondrían unos 1.600 toneladas aproximadamente, más de las que teóricamente habrían producido las ferrerías del noroeste; pero lógicamente no todo lo que se consumía provenía de aquí, también se importaba hierro del País Vasco. No contamos con ningún dato cuantitativo, por lo que hablar de la producción total en el siglo XVI no nos es posible. Sólo podemos señalar que a lo largo del siglo se construyen y van a estar en funcionamiento 41

Canarias y Madeira al principio de la Edad Moderna”. Itsas Memoria. Revista de Estudios Marítimos del País Vasco, 4, p. 148.

897 A. EIRAS ROEL (1984): "L'Espagne au XVIIe siècle: aspects demographiques". En Conversaciones Hispano-Holandesas de Historia. Leiden.

898 J. NADAL (1973): La población española (siglos XVI a XX). Barcelona, p. 34-35.

899 J. PÉREZ (1999): "Demografía leonesa en el Antiguo Régimen (1500-1850). En L. RUBIO: Historia de León. Universidad de León, t. III, p. 189

900 N. SOBRADO CORREA (2007): "A Galicia do Antiguo Réxime (1480-ca1835): poboación e economía. A Gran Historia Galicia, t. XI, v. 1, p. 22-30

901 B. BARREIRO MALLÓN (1978): "La demografía asturiana en los siglos XVI y XVII: evolución y factores demográficos". En Historia General de Asturias, t. III, p.... 
ferrerías, pero desconocemos lo que realmente producía cada una y por tanto la producción total. Un documento de 1588 sobre la compra de 600 quintales de vena de Formigueiros por la ferrería de Herrerías de Valcarce podría permitirnos suponer que con esos quintales se podrían elaborar unos 200 ó 300 quintales de hierro, cantidad probablemente inferior a la realmente producida; pero no podemos avanzar más. Poco después, en 1634, se obliga al arrendatario de Arnado a pagar de renta, durante las 52 semana del año, $3^{1 / 4}$ qq. al dueño de la ferrería. Si dicha renta fuera, como suele ser normal, el 10\% de la producción estaríamos hablando de 1690 qq., lo que probablemente es excesivo pero no imposible.

Tampoco podemos conocer la producción del siglo XVII más allá de algunas ideas generales, que parecen confirmar el profundo bache, la crisis de la que hablan muchos autores. Hubo sin duda crisis demográfica (pestes y malas cosechas) ${ }^{902}$, pero no afectó del mismo modo a todo el noroeste. Fue muy dura en León cuya población tardó siglo y medio en recuperarse ${ }^{903}$. En Galicia, aunque las calamidades se suceden por las mismas razones desde el último cuarto del XVI, sin embargo la población no solo no disminuyó sino que todos los datos apuntan a un importante crecimiento, especialmente en la segunda mitad del siglo: los 629.336 habitantes de 1591 eran ya 735.570 en 1631, y 1.067.856 en 1709. En Asturias, cuya población cayó hasta un 20 ó 25 por ciento por las mortandades que tuvieron lugar en los años 1598 y 1599904, mejoró la situación en la segunda mitad. A finales del XVII contaba con 280.000 habitantes, lo que supone un aumento del $86 \%$ pese a las reiteradas crisis agrarias ${ }^{905}$.

Respecto de la crisis económica que muchos afirman, en la industria siderúrgica fue muy desigual. Las ferrerías de la zona de Castro Urdiales viven el siglo XVII con verdadera dificultad. Sus problemas llegaron a ser tan graves, que el concejo de Castro Urdiales dejó de recaudar el "derecho del fierro", que gravaba los embarques del hierro elaborado en su jurisdicción, durante la

902 J. NADAL (1975): Ob. cit., p. 37 y ss.

903 J. PÉREZ (1999): Ob. cit., p. 190

904 G. ANES (1988): Economía y sociedad en la Asturias del Antiguo Régimen. Barcelona, p. 15.

905 J. DÍAZ (2005): "Crisis agrarias en la Asturias del siglo XVII. Una aproximación a su estudio”. Revista de Historia Moderna, n ${ }^{0}$ 23, p. 307-322. 
segunda mitad del seiscientos906. En el País Vasco varios autores niegan que descendiera de forma notable la producción siderúrgica. Según Priotti hacia 1628 había en Vizcaya más de 110 ferrerías, algunas de las cuales producían 1800-200o quintales de hierro al año, y, añade que todavía en 1640 seguían funcionando, por lo "lo cual descarta que hubiera una crisis profunda de este sector en la primera mitad del siglo XVII”907. También Aragón Ruano pone en tela de juicio esa crisis para el hierro guipuzcoano, ya que refuta la disminución del número de ferrerías (habla incluso de nuevas construcciones o reconstrucciones entre 1570 y 1620), aunque sí fue un tiempo de reajustes y reconversiones908; y lo mismo dice Carmen Ceballos respecto de Cantabria, donde el número de ferrerías pasa de 28 en el siglo XVI a 38 en el siglo XVII909.

En el noroeste sabemos que, aunque cerraron varias ferrerías, también se construyeron hasta doce nuevas, lo que nos permite hablar de unas 48 que estuvieron normalmente en funcionamiento, lo que justificaría una mayor producción de hierro. La ferrería de la Corredoira (Castropol) se consideraba capaz de producir, en 1642, veinticinco quintales gallegos por semana, esto es, unos $40.000 \mathrm{~kg}$./año, suponiendo que trabajase, como la de Villanueva de Oscos, veintiocho semanas, desde mediados de noviembre hasta finales de mayo910. En 1668 los dos renderos de Arnado se comprometen a dar a don Lucas de Acevedo, arrendatario de la vecina ferrería de Pontepetre, 200 quintales de hierro cada uno (100 picado y 100 sin picar) de octubre a junio, es decir siete meses, lo que significa que, al menos, habrían producido entre ambos 400 quintales ${ }^{911}$. Sin embargo conocemos que esta ferrería, tanto en 1634 como hemos visto, como en el siglo XVIII, trabajaba todo el año, por lo que la producción podría ser superior seguramente a 1.000 quintales. La producción de la ferrería de Villanueva de Oscos fue en los años finales del siglo de unos

906 R. OJEDA SAN MIGUEL (s/f.): "Tendencias en la producción de las ferrerías de Castro Urdiales (1615-1848)". http://www.euskonews.com/o227zbk/gaia22704es.html

907 J. PH. PRIOTTI (2011): "Producción y comercio del hierro vizcaíno entre 1500 y 1700 ". Eusko Ikaskuntza, $\mathrm{n}^{\circ}$ 57, p. 18

${ }_{908}$ A. ARAGÓN (2011): "La actividad siderometalúrgica guipuzcoana durante el siglo XVII: transformación y productividad". Lurralde: Invest. Espac. 34, p. 109-149; ID (2012): "Las ferrerías guipuzcoanas ante la crisis del siglo XVII". Cuadernos de Historia Moderna, 37, p. 73102.

909 C. CEBALLOS (2001): Arozas y ferrones: las ferrerías de Cantabria en el Antiguo Régimen. Santander, p. 22-59, y cuadro $1^{\circ}$ de la página 58.

910 IBIDEM, p. 537

${ }^{911}$ AHPL. P. N.: 2936 (1668) 
384,63 quintales/año ${ }^{912}$, pero esta seguramente no es la media del resto de ferrerías. La producción total de las 48 ferrerías pudo superar ampliamente las 1.500 toneladas, lo que significaría que la producción había aumentado claramente respecto de la del siglo XVI.

A partir del siglo XVIII contamos con datos más fiables, los cuales nos permiten valorar el extraordinario crecimiento de la producción, que probablemente se duplicó e incluso se triplicó respecto de los dos siglos anteriores. El primer dato elocuente fue la construcción de treinta y una nuevas ferrerías en todo el noroeste, especialmente en las provincias de Lugo y Oviedo. Hubo algún cierre, sobre todo a finales del siglo, pero en general se puede hablar de que hacia mediados de siglo había en funcionamiento unas 70 ferrerías, es decir, un $62 \%$ más que en el XVII. También se incrementó la producción real por artefacto, pues como ya dijimos analizando los datos del Catastro de Ensenada y especialmente las series de ferrerías como Villanueva de Oscos y Quintá, la media por ferrería superaba los 700 quintales/año.

Este aumento del número de ferrerías y de la productividad de las mismas está ligado a una mayor demanda de hierro, por varias razones. La primera por el crecimiento de la población, en parte debido a las mejoras agrícolas (introducción del maíz en el siglo XVII) y al nuevo modelo demográfico galaicoasturiano ${ }^{113}$. En Galicia el crecimiento fue notable, especialmente en la primera mitad del siglo, pues de 1.100.00o habitantes en 1700 pasó a 1.299 .312 en 1752 y a 1.346.405 en 1787; crecimiento de un $3 \%$ anual, luego ralentizado por las sucesivas crisis de subsistencias hasta $1810^{914}$. En Asturias, la población creció de 230.000 almas a comienzos del siglo a 364.238 al final915, lo que elevó la densidad hasta cifras superiores al 33 $\mathrm{hb} / \mathrm{km}^{2}$. Ese crecimiento fue menor en León que solo hacia la mitad del siglo había recuperado la población de finales del siglo XVI916.

\footnotetext{
912 P. SAAVEDRA (1982): "Un aspecto de la economía monástica: la producción de hierro. El ejemplo de 1 monasterio de Villanueva de Oscos". En Semana de historia del monacato cántabro-astur-leonés. Monasterio de San Pelayo, p. 545

913 J. PÉREZ (2004): “La demografía”. Historia de España. Madrid, t. VII, p. 30-31

914 N. SOBRADO CORREA (2007): Ob. cit., p. 59-63.

915 G. ANES (1988): Ob. cit., p. 17

916 J. PÉREZ (1999): Ob. cit., p. 194-195.
} 
Por otro lado, la nueva dinastía borbónica apoyó con firmeza el desarrollo siderúrgico, tanto por la política arancelaria como por la mayor demanda de hierro del Estado. Aquella se relaciona con la prohibición en 1775 de importar hierro extranjero, especialmente sueco y ruso; pero también por las dificultades del hierro vasco, que desde 1782 pierde el monopolio del mercado español por los gravámenes a que es sometido ${ }^{917}$. También influyó la exención de aranceles a la venta de hierro a pie de fábrica918. Por su parte la demanda del Estado afectó a algunas ferrerías, mazos y artesanos herreros por la compra de clavazón para la Maestranza de La Coruña y los arsenales de la Habana, Mahón y el Ferrol119. Esto explica la enorme concentración de herreros en la comarca del Eo, la creación de algunas sociedades como la de la Vega de Ribadeo y los proyectos constructivos de nuevas ferrerías y hornos altos, como el de Sargadelos. La comarca del Eo, en contraste con las zonas productoras del País Vasco que asisten al derrumbe de sus mercados exteriores, se manifiesta a finales del siglo XVIII como el núcleo ferretero más dinámico del país920, y en general todo el noroeste vive ese mismo dinamismo.

La política constructiva del siglo XVIII habla de una buena coyuntura en la producción y comercialización del hierro, por las razones apuntadas pero también por el aumento del precio del hierro. En la primera mitad del siglo parece que los precios se mantuvieron en torno a 50 rs./quintal, con pequeñas fluctuaciones que se aprecian a mediados del siglo 921. Sin embargo, la prohibición que Carlos III estableció en 1775 de no importar hierro extranjero

\footnotetext{
917 L. M. BILBAO y E. FERNANDEZ PINEDO (1982): "Auge y crisis de la siderometalurgia tradicional en el País Vasco (1700-1850)”. En TEDDE, P.: La economía española al final del Antiguo Régimen. II: Manufacturas. Madrid, p 160.

918 AHN. Órdenes Generales de Rentas, libro 37, exp. 4939: 1793, julio, 26 El rey "ha resuelto que las ventas de yerro que se hagan al pie de las ferrerías de las provincias de Castilla y León de las labranzas de las mismas, sean exentas por ahora de los derechos de alcabalas y cientos; pero de las ventas que se executen fuera de las mismas ferrerias, ya por los dueños de ellas, o ya por los herreros, cerrageros o qualesquiera otra persona, se exija en todos los pueblos de dichas provincias de Castilla y León el quatro por ciento conforme de lo dispuesto en los reglamentos generales del año 1785 para los efectos de tratos y oficios en general".

919 Conocemos el pliego de condiciones suscrito por la Compañía de la Vega de Ribadeo para el surtimiento de herrajes, clavazones y herramientas que puedan necesitar los arsenales de La Habana y Mahón, u otro cualquiera, del año 1789. Cit. J. LÓPEZ y A. GRAÑA (1998): Ob. cit., p. 137-139.

920 J. CARMONA (1993): "Sargadelos en la historia de la siderurgia española". Revista de Historia Industrial, $\mathrm{n}^{\mathrm{O}} 3$, p. 12

${ }^{921}$ AHPL. P. N.: caja 3342. En 1750, en el subarriendo de la ferrería de Arnado, se habla de "como también por la suba que está experimentado tiene el dicho yerro".
} 
favoreció el crecimiento de los precios que, desde 1780 a 1800, llegaron a subir más de un 94,27\%. Hacia 1780 Cornide cree que "aunque en estos últimos años ha subido el valor del fierro a 115 y 120 rs. el quintal, se puede regular por un quinquenio a 110 reales" ${ }^{922}$; pero a finales había subido hasta más de 150 reales/quintal. Esto no sólo fue a causa del arancel, sino por la elevación generalizada de los precios como consecuencia de la crisis finisecular, aunque esto no siempre fue así923.

La evolución de la producción, de acuerdo, con los datos de la ferrería de Villanueva de Oscos, parece positiva. Tomando como índice 100 la producción de los primeros veinte años del siglo XVIII, dicho índice llega al 145 en el quinquenio 1720-24 y alcanza el 170 en los años siguientes hasta 1769 , en que por dos décadas la producción se hunde en un profundo bache que solo supera en el último decenio del siglo. La producción de la ferrería de Quintá sobrepasa ampliamente el índice 150 entre 1754 y 1762, para caer por debajo del índice 100 desde 1774 hasta 1792, con un par de excepciones. En cantidades totales no nos es posible conocer más que algunos datos parciales. Si la producción media por ferrería fuera, como dijimos, de unas $40 \mathrm{tn} /$ artefacto, esta superaría las 2.800 tn en todo el noroeste, quizás más. A finales del siglo de las aproximadamente 25.000 toneladas que produce anualmente España, unas 4.000 se elaboran en Asturias y Galicia, es decir, el 15\% del total924. Esta cantidad es algo más elevada de la que supusimos anteriormente, pero no debe de estar muy alejada. Cornide habla de que a fines del XVIII las 21 ferrerías de Galicia y las 3 del Bierzo produjeron 20.000 quintales ${ }^{925}$, si añadiéramos las asturianas podríamos hablar de 2.500 toneladas o quizá algo más, por la ocultación que siempre suele haber en estos datos. Si es cierto ese $15 \%$ del total nacional, el peso del noroeste habría evolucionado muy positivamente respecto a los siglos anteriores, en que suponía menos del $3 \%$.

\footnotetext{
922 C. GONZÁLEZ (1994): Ob. cit., p. 234

923 D. PAZ (1991): Ob. cit., p. 154

924 J. ALCALÁ-ZAMORA (1974): Ob. cit.,p. 151 y 149.

925 Utilizamos el quintal de 57,5 kg. y no el de 71,3 kg, que emplea C. GONZÁLEZ (1994): $A$ producción tradicional do ferro en Galicia: as grandes ferrerías da provincia de Lugo. E. Diputación Provincial. Lugo., p. 19
} 
Este incremento de la producción y su porcentaje sobre el total nacional aumentaría notablemente en el siglo XIX, no solo por el crecimiento de la población del noroeste sino por la decadencia de la siderurgia vasca; en el noroeste, por el contrario, se siguen construyendo nuevas ferrerías y aumenta el peso de la producción de hierro en el total español. Esto en parte fue por el atraso y aislamiento, pero también por el crecimiento de la población. La de León, sin ser muy espectacular, pasó de 250.134 habitantes en 1787 a 348.760 en 1860 , lo que supone un crecimiento del $39,4 \%{ }^{926}$. Galicia, que ya a fines del XVIII era una de las zonas más pobladas de España, vivió en el cambio de siglo una conjunción de crisis alimentarias y guerras que limitaron su crecimiento, que entre 1787 (censo de Floridablanca, 1.406.567 hab.) y 1860 (primeros registros oficiales, 1.799.224 hab.) supuso solo un incremento del 28\%. Luego en la segunda mitad sería mayor927. En Asturias, las tasas de crecimiento anual en la primera mitad del XIX debieron oscilar en torno al $5 \%$, superiores a la media española, lo que se tradujo en un considerable aumento de la población que pasó de los 350.662 del censo de Floridablanca a unos 540.586 en 1860928, es decir un $54 \%$.

Las cifras de producción, excepto en los primeros años a consecuencia de la Guerra de la Independencia, aumentan en la primera mitad del siglo XIX, en el que se construyen más de cuarenta nuevas ferrerías, aunque también hubo varios cierres. Hacia 1838, refiriéndose a una treinta de ferrerías gallegas, Schulz afirma que produjeron 25.00o quintales de hierro, lo que arroja una media de 833 quintales por ferrería ${ }^{29}$. Este sector industrial tuvo su punto álgido en los años cuarenta del siglo, momento en el que se construyen numerosas ferrerías. Este hecho llama la atención por su contraste con lo que sucedía en los ámbitos siderúrgicos tradicionales, cuyo número de ferrerías disminuye desde 1820 a 1850 , aunque al parecer aumenta el rendimiento medio

926 J. PÉREZ (1999): Ob. cit., p. 196.

927 R. VILLARES y A. ARTIAGO (2007): "Galicia no século XIX". En A Gran Historia de Galicia, t. XII, vol. 1, p. 15 y ss.

928 J. L. SAN MIGUEL y G. OJEDA (1984): “La población”. Historia de Asturias, t. IX. Edad Contemporánea II. Oviedo, p. 26 y ss.

929 G. SCHULZ (1838): "Ojeada sobre el estado actual de la minería en el distrito de Asturias y Galicia". Anales de minas (Madrid), tomo I, p. 391: "la temporada de su trabajo anual varía de cuatro a once meses, según lo permiten las aguas motrices y el surtido de carbón. Puede calcularse su producción en veinte y cinco mil quintales de buen hierro que valen más de dos millares de reales" 
de las mismas930. En el País Vasco ese número desciende en casi un 40\% de 1790 a 1819, pasando de 170 a 119, cifra que se reduce aún más en 1840 en el que tan sólo funcionan 106 ferrerías931. En el noroeste, por el contrario, su

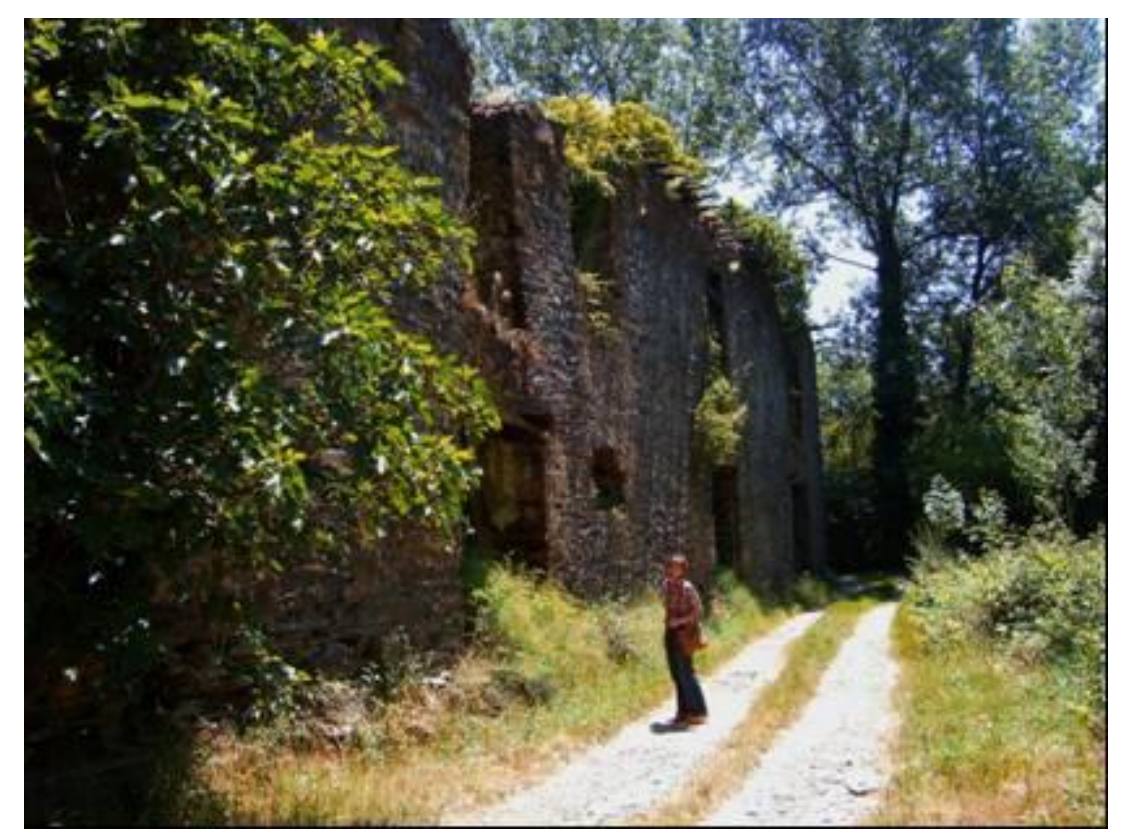

Ferrería de San Vicente de Leira (Orense)

número crece constantemente en esos mismos años, como hemos visto932. De hecho, en este siglo se construyen en el noroeste 49 ferrerías, lo que supone el $36,8 \%$ de todas las que se erigieron en esta región desde el siglo $\mathrm{XV}$ y algunos mazos; con ellas el número de las que estuvieron trabajando fue aproximadamente de 100, aunque no siempre todas a la vez.

Ese mayor número de ferrerías se une a una producción que crece en esos años, con un máximo entre los años 40 y 50, para descender lentamente a partir de los 6o. Solamente entre 1850 y 1856 la producción de hierro español en hornos altos logró igualar y aún superar la de las ferrerías, cuya producción nacional llegó a rozar algunos años las 20.00o toneladas933. En 1844 Ezquerra del Bayo señalaba que la producción total de hierro forjado de nuestro país ascendía a 15.637 toneladas, de las cuales 3.037 correspondían al distrito de Asturias y Galicia, en el que creemos no incluido el Bierzo, que no aparece en la

930 J. ALCALÁ-ZAMORA (1974): Ob. cit., p. 152

${ }^{931}$ L. Ma BILBAO y E. FERNÁNDEZ DE PINEDO (1982): Ob. cit., apéndice II-9, p. 224

932 G. SCHULZ, G. (1838): Ob. cit. , p. 379-397

933 J. ALCALÁ-ZAMORA (1974): Ob. cit., p.154 
fuente citada934, lo que supone casi un 20\% del total de la producción. Un año más tarde, la Revista Minera 935 cifraba la producción de hierro de las 15 ferrerías bercianas en funcionamiento en 18.000 quintales castellanos, lo que significa algo más de un millón de kilos, con una media por ferrería en torno a los 1.200 quintales; cantidad que prácticamente se mantiene a lo largo de esos años, aunque no conozcamos más que datos parciales, como los 12.000 quintales que se produjeron en el año 1848936. Fettyplace eleva la producción de hierro forjado en 1855 a 229.100 quintales, de los cuales 60.000 corresponden a Galicia y Asturias, lo que representa un 26,18\% del total, solo superado por el País Vasco (43,64\%), y aún falta por incluir el Bierzo937. Este volumen de producción se explica, como ya dijimos, por la mayor demanda de hierro, ante un crecimiento demográfico positivo y una mayor utilización de útiles de hierro en las tareas domésticas y agrícolas.

\section{CUADRO XXIII. OFICINAS Y PRODUCCIÓN EN 1845}

\begin{tabular}{|l|c|c|c|}
\hline & ESPAÑA & NOROESTE & $\%$ \\
\hline OFICINAS & 424 & 76 & 17,92 \\
\hline EN ACTIVO & 295 & 56 & 18,98 \\
\hline TRABAJADORES & 11.014 & 2.860 & 25,96 \\
\hline BESTIAS DE TIRO & 4.055 & 1.332 & 32,84 \\
\hline HIERRO* & 445.633 & 81.500 & 18,28 \\
\hline
\end{tabular}

*Hierro maleable o forjado

FUENTE: Anales de Minas (1846): Memoria sobre el estado de la minería, t. IV, p. 506

A partir de la mitad del siglo el descenso es ya acusado, tanto por el cierre constante de ferrerías como por la menor producción de estas. A partir de los años sesenta las cantidades producidas van lenta pero inexorablemente disminuyendo, disminución que aún se incrementará más a lo largo de las

934 IBIDEM, p. 153. Esta cantidad supone unos 53.000 quintales castellanos de $57,5 \mathrm{~kg}$., cantidad que es muy semejante a la que en 1845 nos ofrece, para Galicia y Asturias, los Anales de Minas: "la producción anual de hierro maleable, dice éste, en Asturias y Galicia asciende aproximadamente a unos 65.000 quintales, que valen cerca de 5.000.000 de reales, y ocupan cerca de 2.000 obreros. A esta cantidad habría que sumar los 18.00o quintales del Bierzo, lo que suman 78.00o quintales.

935 REVISTA MINERA, t. IV, 1846, p. 486

936 IBIDEM.

937 E. FETTYPLACE (1856): Memoria sobre la industria ferrera en España. Madrid, p. 11. 
décadas siguientes, como muestra el cuadro que hemos reconstruido, para un periodo de casi treinta años con las ferrerías del Bierzo (CUADRO XXIV). Esta situación del Bierzo puede extrapolarse, sin grandes visos de error, a Galicia y Asturias, regiones de las que no conocemos series tan largas pero sí datos parciales (apéndice II-20).

\section{CUADRO XXIV- FERRERÍAS Y PRODUCCIÓN EN EL BIERZO}

(Indice base 100: 3120 (1871-1880)

\begin{tabular}{|l|l|c|l|c|}
\hline AÑO & $\begin{array}{l}\text { NÚMERO } \\
\text { FERRERÍAS }\end{array}$ & $\begin{array}{c}\text { PRODUCCIÓN } \\
\text { TOTAL } \\
\text { (quint. métricos) }\end{array}$ & ÍNDICE & $\begin{array}{c}\text { PRODUCCIÓN } \\
\text { MEDIA POR } \\
\text { FERRERÍA }\end{array}$ \\
\hline 1860 & 13 & 8.053 & 258,1 & 619 \\
\hline 1861 & 13 & 5.875 & 188,3 & 452 \\
\hline 1862 & 13 & 5.885 & 188,6 & 453 \\
\hline 1863 & 15 & 5.900 & 189,1 & 393 \\
\hline 1864 & 16 & 7.021 & 225 & 439 \\
\hline 1865 & 15 & 8.244 & 264,2 & 549 \\
\hline 1866 & 15 & 5.855 & 187,6 & 390 \\
\hline 1867 & --- & ---- & ---- & ---- \\
\hline 1868 & 14 & 3.857 & 123,6 & 276 \\
\hline 1869 & --- & ---- & ---- & ---- \\
\hline 1870 & --- & ---- & ---- & --- \\
\hline 1871 & 10 & 3.864 & 123,8 & 386 \\
\hline 1872 & 12 & 4.925 & 157,8 & 410 \\
\hline 1873 & 11 & 3.496 & 112 & 317 \\
\hline 1874 & 11 & 2.357 & 75,5 & 214 \\
\hline 1875 & 11 & 2.503 & 80,2 & 227 \\
\hline 1876 & 10 & 4.111 & 131,7 & 411 \\
\hline 1877 & 11 & 3.496 & 112 & 317 \\
\hline 1878 & 10 & 2.120 & 67,9 & 212 \\
\hline 1879 & 11 & 2.184 & 70 & 198 \\
\hline 1880 & 10 & 2.144 & 68,7 & 214 \\
\hline
\end{tabular}




\begin{tabular}{|l|c|c|l|c|}
\hline 1881 & 6 & 1.230 & 39,4 & 205 \\
\hline 1882 & 4 & 690 & 22,1 & 172 \\
\hline 1883 & 7 & 1.830 & 58,6 & 261 \\
\hline 1884 & 7 & 1.460 & 46,7 & 208 \\
\hline 1885 & 6 & 1.370 & 43,9 & 228 \\
\hline 1886 & ---- & ---- & ---- & ---- \\
\hline 1887 & ---- & 890 & 28,5 & ---- \\
\hline 1888 & 5 & 1.115 & 35,7 & 223 \\
\hline 1889 & 4 & 1.701 & 54,5 & 425 \\
\hline
\end{tabular}

FUENTE: Elabortación propia a partir de los datos de producción que menciona anualmente La Revista Minera (IGME) en esos años.

De acuerdo con el cuadro, del año 1860 al 1865 las cantidades producidas parecen haberse reducido a la mitad de las del decenio anterior, con cifras que se mueven en torno a los 6.700 quintales métricos de media anual. Desde ese último año hasta 1873 la producción se reduce nuevamente a la mitad, situándose en los 4.000 q. m. de media, con un número de instalaciones en funcionamiento que todavía se mantiene en torno a los once. Nuevamente estas cantidades vuelven a descender desde ese año hasta 1880, a partir del cual el número de ferrerías se reduce drásticamente y con ello la producción, que en algún año no llega a superar los 1.000 quintales de producción total. A diferencia de los años 40 y 50, desde los 60 la evolución seguida por la producción de las ferrerías del noroeste fue muy semejante al de la siderurgia tradicional del País Vasco, como ponen de manifiesto los datos de Luis $\mathrm{M}^{\mathrm{a}}$ Bilbao y Emiliano Fernández de Pinedo ${ }^{938}$. Las pocas ferrerías que aún quedaban en pie cierran definitivamente en la década de 1880-1890. 


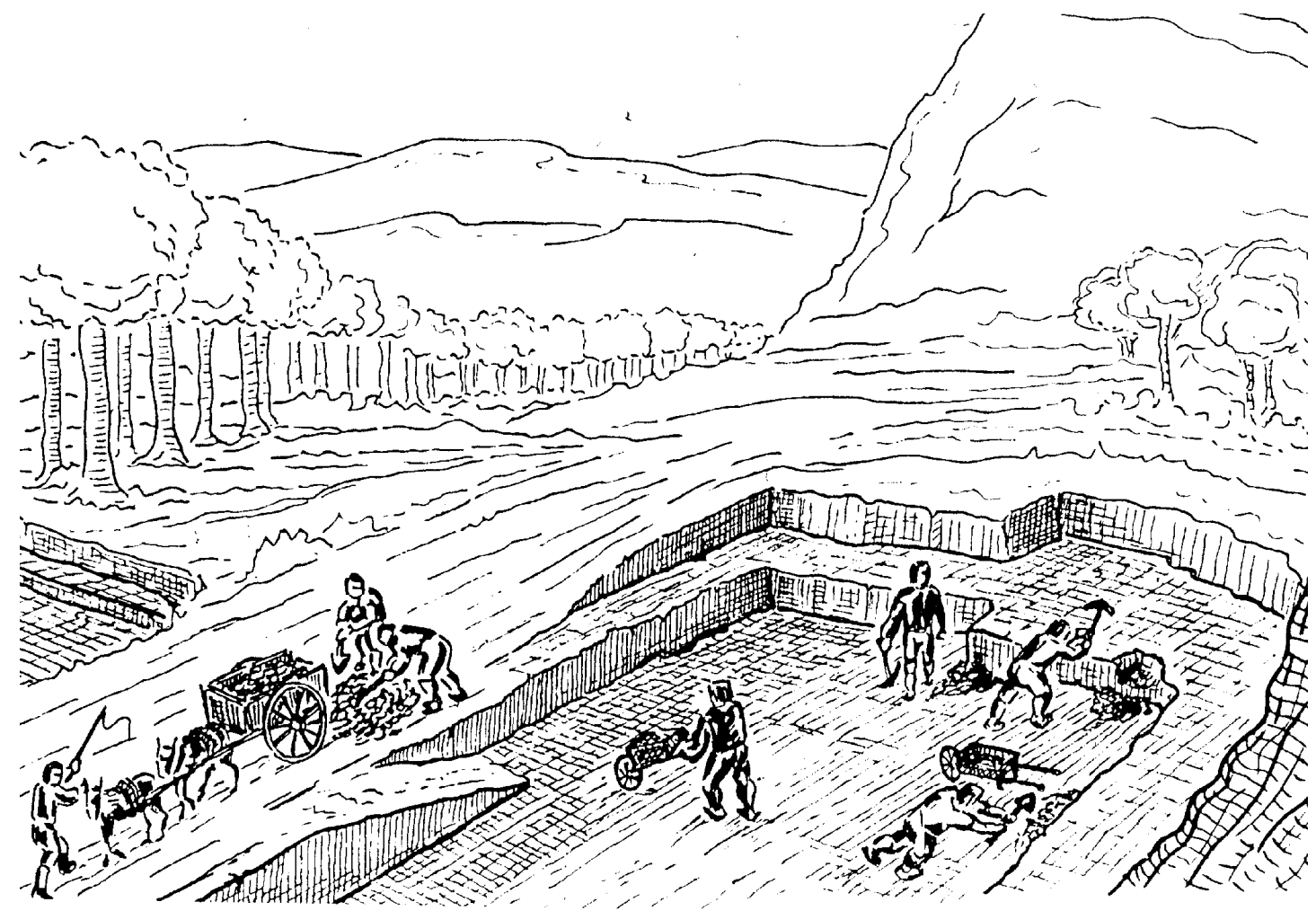

Explotación de mineral de hierro a cielo abierto (Asociación de Amigos del Museo del Hierro de Legazpi. Burdinola. Ferrerías, p. 14)

\section{LOS COSTES DE PRODUCCIÓN}

Los costes de producción de una ferrería incluían numerosos conceptos: carbón, mineral de hierro, salarios de los oficiales, descalabros, amortización de los capitales y gastos generales (depende de si las ferrerías tenían o no administrador, pero incluían alimentos, salarios del administrador, ama de casa y criados) 939 . De todo ello ya hemos hablado en sus respectivos capítulos,

939 En estas dos relaciones se pueden apreciar claramente los costes de la fabricación del hierro: 1) El dueño de la ferrería de Quintá expone a su hijo en un memorial de 1749 el valor y lo que por experiencia sabe sobre el coste de la producción del hierro. Ese coste es el siguiente: " $e l$ caruon cada saco 6 quartos vellón y cada arroua de caruon que son quince sacos once reales de vn.; la vena cada quintal puesto en la herrería tres reales y medio al que la trae, y un quartillo de vino a cada carro, y al que la arranca y quiebra en la uenera por cada quintal tres quartos; el quintal de leña para cocer la ragua o uena puesta en la herreria seis quartos; los mangos para los mazos puestos en la plaza de la herreria 33 reales y de estos se necesitan un año con otro de cuatro a cinco; los escudos para la rueda de macear tiene de coste de ocho a nueue reales, los de la barquinera de cinco a seis; los malogreros cada uno un real; para hacer una tubera dándole el cobre que se necesita quince reales; para hacer unos barquines cien reales y ferrando las tablas de nuevo trescientos rs. y de comer"; además cuatro reales y medio por quintalaje (AHRG. Ombreiro: leg. 19). 2) En 1759 en un pleito a causa de la ferrería de la Rodela, dice el monje administrador: "es constante que cada quintal de hierro solo necesita dos quintales y medio de vena, y cada uno puesto en dicha herrería yncluso la rebaja de las dos 
aunque vamos a matizarlo ahora, además de ver lo que esas cantidades suponían respecto de la producción y los beneficios que se obtenían. Para ello hemos confeccionado el CUADRO XXV que recoge los datos de varias ferrerías en diferentes momentos de los siglos XVII, XVIII y XIX, que luego analizaremos pormenorizadamente, aunque ya podemos señalar, como visión general, que el carbón suponía casi el $43 \%$ del total, frente a la vena $(29,8)$, o el trabajo de los operarios $(12,7 \%)$ y arreglos y otros conceptos (16\%).

\section{CUADROS XXV. COSTES DE PRODUCCIÓN Y BENEFICIOS \\ (en porcentaje)}

\begin{tabular}{|l|l|c|c|c|c|c|}
\hline FERRERÍA & AÑOS & CARBÓN & MINERAL & SALARIOS & ARREGLOS & OTROS \\
\hline V. OSCOS & $1680 / 85$ & 27,2 & 36,8 & 18,5 & 4,9 & 12,6 \\
\hline QUINTÁ & 1745 & 44,5 & 35,3 & 11,3 & 2,5 & 6,1 \\
\hline SAMOS & 1749 & 44,4 & 38 & 14,2 & 3,1 & \\
\hline BERCIANAS & 1752 & 53,6 & 16,8 & 13,7 & & \\
\hline BUEYES & 1752 & 45,9 & 25,3 & 16,3 & 12,3 & \\
\hline RODELA & 1759 & 40 & 35,2 & 10,5 & 4,7 & \\
\hline QUINTÁ & $1772 / 73$ & 35,5 & 31,3 & 11,6 & 4,1 & 17,1 \\
\hline BERCIANAS & 1807 & 56 & 15,8 & 10,5 & & 17,6 \\
\hline V. OSCOS & $1803 / 13$ & 40,7 & 35 & 7,7 & 11,2 & 5,2 \\
\hline V. OSCOS & $1828 / 34$ & 41,8 & 29,4 & 13,3 & 7,2 & 2,9 \\
\hline MEDIAS & $1680 / 1834$ & 42,9 & 29,8 & 12,7 & 6,2 & 10,2 \\
\hline
\end{tabular}

FUENTE: Oscos (P. Saavedra (1982): ob. cit., p. 542), Quintá (AHRG. Hombreiro: Libro de cuentas de la ferrería de Quintá), F. Bercianas (J. A. Balboa (1990): Ob. cit., p. 118), Bueyes (C. E. R. G.. Doncos, San Juan de Noceda), La Rodela (AHRG. . R. A.: 680o/4)

Los costes de las ferrerías del noroeste son bastante parecidos a los de las ferrerías vascas y catalanas (CUADRO XXVI), aunque en las vascas el porcentaje del carbón es siempre más alto (62,6\% de media) y mucho más bajo

quiebras de leña para quemarla o cozerla, construcción de la ragua, un quartillo de vino que se da por cada carro de vena a los que la conducen de la venera tiene todo ello de coste cinco reales, y cada quintal de hierro consume veinte sacos de carbon y cada uno veinte y quatro maravedis tiene de coste. $Y$ asi mismo se satisfacen a los oficiales por razón de quintalaje quatro reales y medio" (AHRG. R. A.: 6800/4). 
el coste del mineral (20,2\%), tanto porque no pagaban determinados aranceles como por el menor coste del transporte, factor que incrementaba considerablemente el precio en otras regiones. En las fargas catalanas el peso del carbón (46\%) es menor que en las vascas, aunque mayor que en las de noroeste. Quizá su menor peso se deba a que el trabajo estaba mejor remunerado, pues el porcentaje de este respecto al total es bastante alto (20,7\%), lo que contrasta con el de las ferrerías del noroeste (12,7\%) o el de las vascas $(9,8 \%)$. El porcentaje de estos costes cambió de unas épocas a otras, aunque los datos no nos permiten, en el caso del país Vasco y Cataluña, un conocimiento muy pormenorizado, excepto para el periodo que va desde la mitad del siglo XVIII a la mitad del XIX, como vemos en el cuadro XXV.

\section{CUADRO XXVI. COSTES DE PRODUCCIÓN EN EL PAÍS VASCO Y CATALUÑA \\ (en tantos por ciento)}

\begin{tabular}{|l|l|l|l|l|l|l|l|l|}
\hline & \multicolumn{4}{|c|}{ FERRERÍAS VASCAS } & \multicolumn{3}{c|}{ FERRERÍAS CATALANAS } \\
\hline AÑOS & $1769 / 71$ & 1799 & 1827 & 1866 & 1773 & 1829 & $1857 / 69$ & $1841 / 64$ \\
& & & & & & & & \\
\hline CARBÓN & 55,47 & 77,31 & 62,02 & 55,91 & 55,6 & 43,3 & 39 & 46,1 \\
\hline MINERAL & 24,57 & 13,37 & 18,44 & 24,75 & 17 & 33,9 & 14,7 & 29,9 \\
\hline SALARIOS & 11,59 & 9,30 & 9,98 & 8,85 & 20,7 & 16,3 & 31 & 14,8 \\
\hline OTROS & 8,37 & & 9,54 & 10,50 & 6,6 & 6,5 & 15,3 & 8,5 \\
\hline
\end{tabular}

FUENTE: Ferrerías vascas: Ma L. Bilbao y E. Fernández de Pinedo (1982): Ob. cit., p. 171 Ferrerías catalanas: C. Mas (2001): Ob. cit., p. 245 y 246

\subsection{El combustible}

El capítulo más costoso en las ferrerías del noroeste era el carbón, aunque variaba mucho de unos lugares a otros en razón de su mayor o menor abundancia y de la coyuntura siderúrgica, es decir, del precio del hierro. La documentación que hemos conseguido reunir (la mayoría de protocolos notariales o pleitos) es muy fragmentaria en los siglos XVI y XVII, pues se 
refiere a la compra de cargas o carros de carbón940, lo que no nos permite saber qué porcentaje significaba el combustible sobre el coste total del hierro, aunque probablemente no supusieran porcentajes superiores al 30\%941. A finales de ese siglo, en la ferrería de Villanueva de Oscos el carbón suponía un 27,2\%, menos que el de la vena (36,8\%), lo que indica que por entonces no había problemas con el bosque mientras que el transporte de la vena desde el país Vasco era muy costoso. Esto no era corriente, sin embargo, en las ferrerías que se abastecían de mineral local.

A mediados del siglo XVIII la situación cambia por lo que conocemos de varias ferrerías del noroeste, pues el porcentaje del carbón sobre el total supera el 44\% (Cuadro XXV), pese a que "los precios del carbón y de la leña no subieron anormalmente durante dicho siglo (...). Hay un gran paralelismo entre los precios del carbón y de la leña y los precios de los productos agrícolas más representativos" 942 . A finales del siglo XVIII, sin embargo, como consecuencia del alza generalizada de los precios, pero también de la deforestación, el precio se incrementó considerablemente, como recuerda Datoli respecto de las ferrerías del Bierzo ${ }^{943}$. Munárriz afirma que estas ferrerías no hacen directamente el carbón sino que lo compran a "carboneros aventureros", que lo suelen fabricar normalmente de brezo, porteándolo al hombro en dos pequeños costales, por los que les dan de cuatro reales a cuatro y medio944. De acuerdo con estas cifras y las que da del precio del hierro, el carbón venía a suponer más

940 En 1593 la ferrería de Valcarce compra 500 cargas de carbón a 3 quartillos la carga (AHPL. PN.: Caja 2909); la ferrería de Lorenzana se concierta en 1627 con los vecinos de Cedofeita para que en las "fragas" de la comunidad hagan 2.500 carros de carbón, a real cada uno (AHN. Clero: libro 6.596, ff. 209-212); la de Silán acuerda en 1630 con Bartolomé de Leibas la adquisición del carbón que vaya fabricando en un monte del propietario de la ferrería en Vilaouriz a 1,2 reales la carga y tres ducados por "dones" (ANM. D. Ferreira (1630), f. 152); En 1745, en las cuentas de la ferrería de Pontepetre, el precio de la carga era de 2 reales: "Yten se le reciue en data doscientos y catorce rs.vn. que importan ciento y siete cargas de carbón que dio arrancado y achegado" (AHPL. P.N.: caja 3342).

${ }^{941} \mathrm{Si}$ calculamos, con los datos anteriores del precio por carga, y suponemos que para fabricar un quintal de hierro hacían falta unas cinco cargas de carbón más la leña y lo comparamos con el precio del hierro, el porcentaje del combustible debe estar por el 30\%, más o menos, en esos siglos.

942 G. ANES (1970): Las crisis agrarias en la España moderna. Madrid, p. 186-191

943 DATOLI, p. 62: . Decía este autor que en las ferrerías bercianas el carbón de brezo, pese a su mucho consumo, "cuesta de 8 hasta 11 reales la carga mayor, pues en el mismo día arranca el carbonero la cantidad de raíz necesaria, la reduce a carbón y lo conduce a hombros a la herrería, fragua o mercado". Del de roble dice que se usa poco y que sale, en Villafranca "a $3^{1 / 2}$ reales la arroba, que viene a ser 21 reales la carga", lo que es un precio abusivo.

944 MUNÁRRIZ, P. 129 
del $55 \%$ del total del coste de producción, cifra muy elevada, que contrasta con las de Villanueva de Oscos citada y la de Quintá, que hacia 1773 era de solo el 35 '5\%, aunque Munárriz habla de los primeros años del siglo XIX en los que la inflación había encarecido mucho los precios, por lo que hay que suponer que los de Quintá también tuvieron que subir.

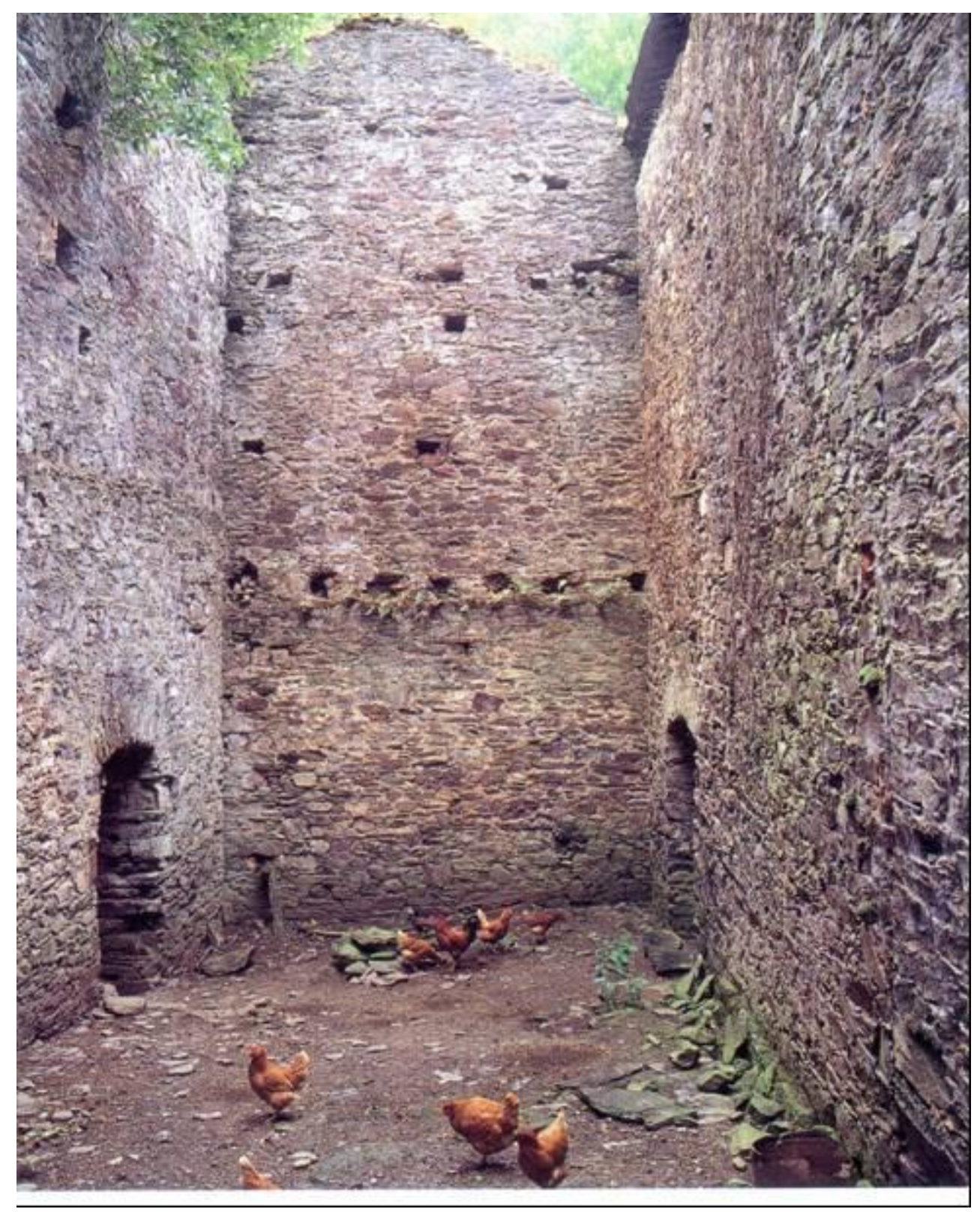

Carbonera de la ferrería de Froseira (Asturias)

Aunque tampoco sepamos el porcentaje del carbón en la fabricación de hierro es evidente que no bajó en la primera mitad del siglo XIX, a tenor de los datos que conocemos del precio de la carga de carbón. Por ejemplo, la ferrería 
asturiana de Froseira contrató en 1813 con el guipuzcoano Antonio Aizmendi la hechura de carbón de cortezas de robles y leñas muertas a 3 reales y medio la carga y una onza cada mil cargas en los montes de Coiredo; al año siguiente la misma ferrería contrata con dos vecinos del lugar de Sarzol 600 cargas, hechas entre marzo y octubre de ese mismo monte y en el de Orubio, a tres reales y medio y media onza de oro de regalo, más dos reales por carga por acarrearlas desde el monte a la ferrería; y con otro carbonero otras 400 a 500 cargas en el monte de Villoria (Brañas de Sella) a dos reales la carga más medio real por el porte945. Es decir, que el precio de la carga se mantuvo muy semejante, e incluso lo superó algo con el transporte946, como menciona Munárriz a finales del XVIII, lo que nos obliga a pensar que debería suponer porcentajes semejantes, en torno al $55 \%$.

En resumen, de acuerdo con el CUADRO XXV, en general los porcentajes del combustible superan casi siempre el $40 \%$ y, en ocasiones, hasta más del 50\%. No parece que ese porcentaje, a diferencia del País Vasco o Cantabria, se incrementase considerablemente con el paso del tiempo, aunque como hemos visto en el capítulo segundo, las protestas por el consumo del bosque fueron numerosas a partir del siglo XVIII, que es cuando mayor número de ferrerías hay y más alto es su precio. En el mencionado informe de 1749 dice el dueño de Quintá que en esta se gastan cada día de 80 a 100 sacos de carbón por la buena calidad del mismo "que en otras herrerías se gastarán más". Pegerto Saavedra dice que en Villanueva de Oscos el consumo de carbón era muy elevado, y aún fue más pronunciado en la segunda mitad del siglo XVIII. "Se sabe, comenta este autor, que en las ferrerías tradicionales consumían de un 400 a un 450 por cien, pero en este caso se doblan esos porcentajes, sin que adivinemos las causas concretas"947, probablemente por la peor calidad del carbón.

\footnotetext{
945 J. LÓPEZ y A. GRAÑA (1998): Ob. cit., p. 142: Libro de cuentas de la ferrería de Foseira, f. 94v.

946 En la ferrería de Soto Rodrigo, que utilizaba anualmente de dos a tres mil cargas de carbón el transporte costaba de 1,5 a 4 reales la carga, según año y distancia, aunque desconocemos el precio de su elaboración, probablemente otro tanto. En A. MATO (2010): La sociedad rural en el concejo de Ponga (1750-1930). Oviedo, p. 129. En 1866, en un contrato se dice: "Asimismo se obliga a portear desde dicho Borondones a precio de cuatro reales unas tres mil cargas de carbón anuales durante el término de quince años". (Ibidem, p. 126).

947 P. SAAVEDRA (1982) Ob. cit., p. 537
} 


\subsection{El mineral}

El mineral no era en sí costoso pero su precio se incrementaba considerablemente por el transporte, razón por lo que variaba de unas ferrerías a otras en relación de la distancia desde los yacimientos a las fábricas. En la ferrería de Quinta, que estaba a unas seis leguas de Formigueiros, de donde traía la vena, esta apenas costaba en la mina a mediados del siglo XVIII de o,35 a 0,45 reales el quintal, pero el transporte la encarecía en casi tres reales y medio948. Además había que sumarle otro real más por el gasto de ragua para su calcinación. La contabilidad de esta ferrería discrimina siempre el precio de la vena si es cruda o cocida. Por poner un ejemplo de un año de la ferrería de Quintá: en 1774 el mineral costaba en la venera 0,39 reales (13 mrs.), pero puesto en la ferrería subía a 4,5 reales (153 mrs). Esto significa que el transporte lo encarecía en 140 mrs. Cocer la vena costaba, a su vez, un real/quintal (34 mrs.), por lo que el precio final de la vena raguada era de 5,5 reales o 187 maravedís. Esto significa que el transporte suponía el 74,8\%, la ragua el 18,1\% y el mineral sólo el 7,1\%949.

Las ferrerías gallegas y bercianas, que usaban vena de Formigueiros abonaban pequeñas cantidades en concepto de foro de la vena al conde de Maceda, además de pagar a los venaqueros y carreteros. Los venaqueros, como dijimos en el capítulo tercero, trabajaban indistintamente para todas las ferrerías, pero algunas tenían mineros propios. En todo caso esto no era lo más gravoso, sino el transporte, como hemos visto. A finales del siglo XVIII Datoli dice que el mineral de Formigueiros puesto en la ferrería de La Somoza, que está a nueve leguas, podría ser de 9 a 10 reales el quintal de 7 arrobas y media castellanas, es decir de de 304 a 340 mrs/quintal950; y a comienzos del siglo XIX, según Munárriz, el porte que pagaban por la conducir el mineral desde Formigueiros era de 4,5 a 18 reales el quintal macho gallego, según la distancia de la ferrería a la mina y el ajuste hecho con los conductores, "pues ninguna

948 AHRG. Hombreiro. Libro de cuentas: "cada quintal (de vena) puesto en la herreria (se paga a) tres reales y medio al que la trae, $y$ un quartillo de vino a cada carro, $y$ al que la arranca $y$ quiebra en la uenera por cada quintal tres quartos".

949 AHRG. Hombreiro. Libro de cuentas

950 DATOLI, p. 59 
herrería tiene ganado propio para la conducción de la vena"951; es decir de 153 a $612 \mathrm{mrs}$./quintal. Si suponemos que el mineral no superaba entonces los 34 maravedís por quintal, el precio del transporte podía oscilar del $81 \%$ al $327 \%$.

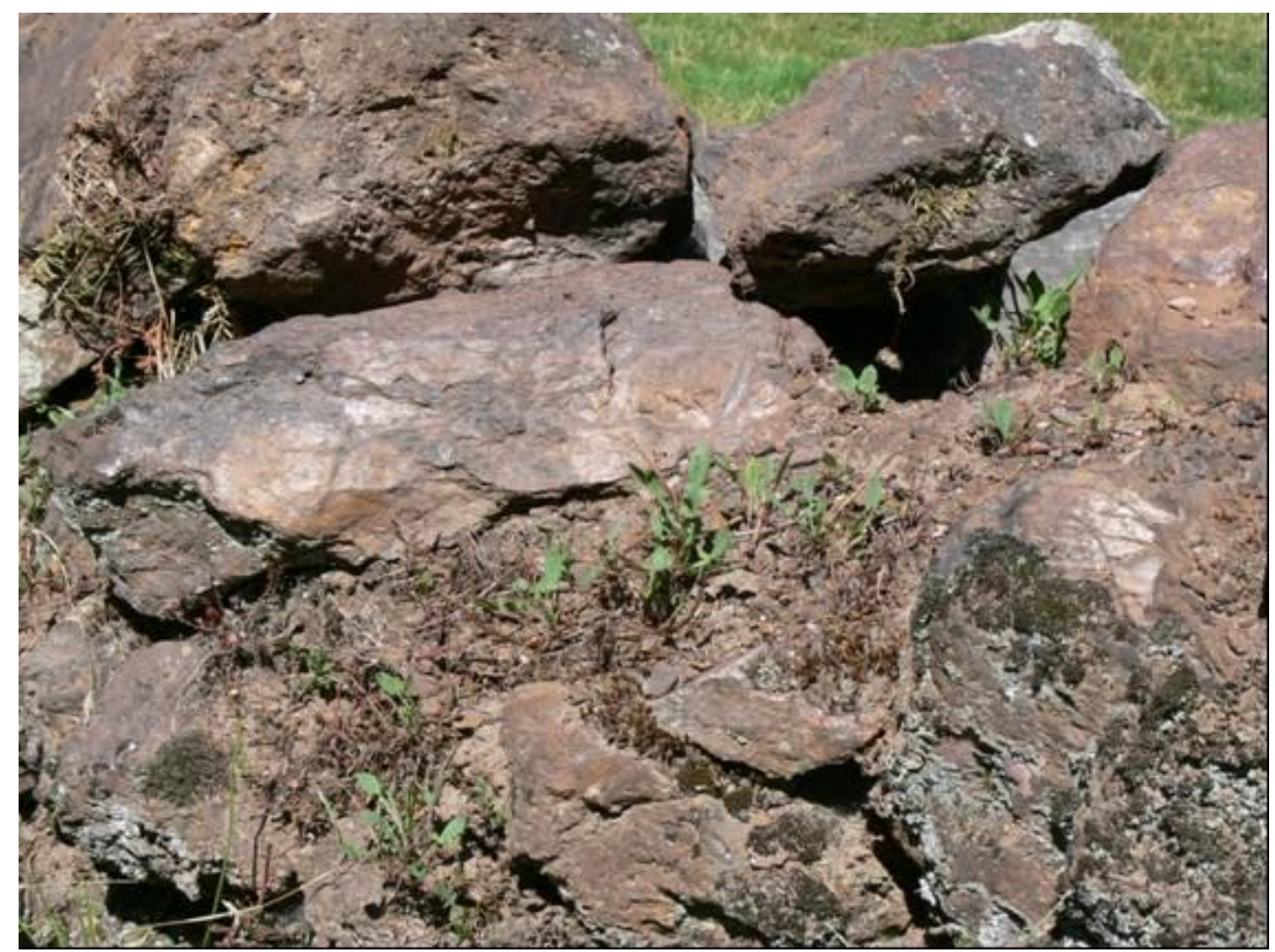

Mineral de hierro del Caurel lucense

No es posible conocer con exactitud la evolución del precio de la vena, pues los datos son escasos y no seriados, con alguna excepción; con todo sí podemos trazar algunos rasgos de esa evolución. A finales del siglo XVI sabemos que el mineral de Rocas valía en la mina en los años 1576,1583 y 1585 a 15,5 maravedís el quintal, pero su precio en las ferrerías se doblaba e incluso se triplicaba: por ejemplo puesto en las ferrerías de Gondriz y del Rial, cerca de Samos, costaba 42,5 maravedís, casi tres veces más952. Si el precio fuese el mismo en Formigueiros, es decir 15,5 mrs., puesto en Pontepetre y Paleiras costaba 51 mrs. en 1566 y 1567953 y en la de Valcarce, a mayor distancia, ese

951 MUNÁRRIZ, p. 128 952 AHPL. P. N.: 1490 (1583) y 2849 (1585) 953 AHOL. P. N.: 1487 (1566) y 1487 (1567) 
precio subía entre $51 \mathrm{mrs}$. y 76 mrs., es decir 3,4 y 5 veces más954; pero solo 34 mrs. en la de Soldón en el año 1574955. En el siglo XVII el precio de la vena parece que se mantuvo en niveles semejantes a los de los años finales del siglo anterior. De hecho, en 1666 sabemos que la ferrería de Pontepetre compró vena de Valdecaballos a $66 \mathrm{mrs}$./quintal la vena cruda y a $85 \mathrm{mrs}$./quintal la vena cocida, lo que significa que la ragua incrementaba en más de un $26 \%$ el precio de la vena 956 .

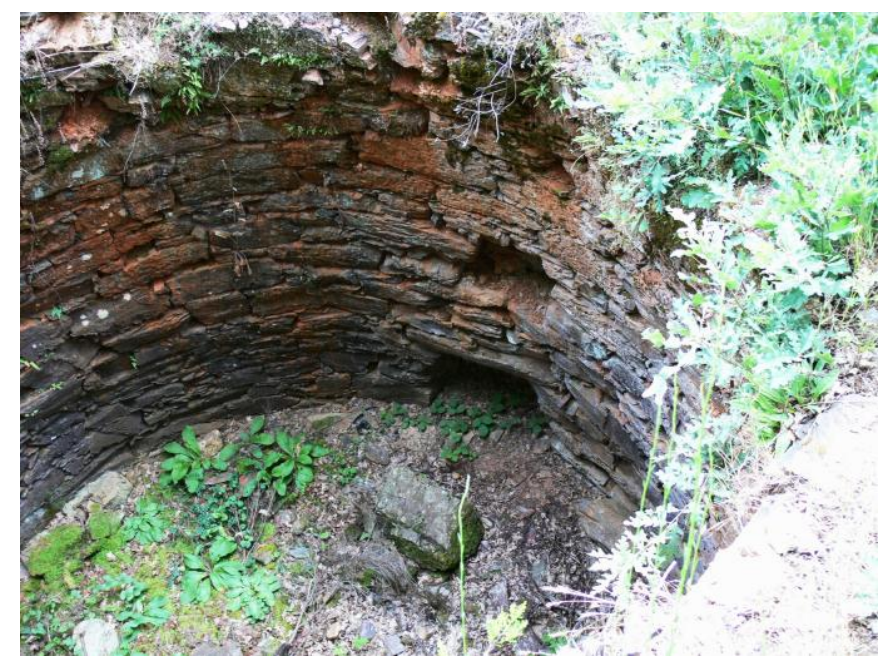

Horno de calcinación. La Somoza (León)

El precio de la vena subió de forma drástica en el siglo XVIII, al menos es lo que apreciamos en la ferrería de Quinta en la segunda mitad del siglo XVIII, que es de la que contamos con datos seriados 957. Pagaba esta ferrería por el mineral 170 mrs./quintal, precio que se mantuvo estable hasta los años

noventa, con dos pequeñas subidas: en los setenta pasó de 170 a 187 mrs./quintal y en los ochenta de 187 a 204 mrs./quintal, probablemente por el precio de la ragua y el transporte. Aunque el CUADRO XXVII está reducido a una cantidad única por quintal de vena, en realidad el Libro de Cuentas de dicha ferrería especifica si es vena cruda o cocida, con una diferencia aproximada de unos $34 \mathrm{mrs}$. (un real) de mayor coste de la vena cocida que la cruda. De esta cantidad, más del 75\% se pagaba por el transporte, pues se encontraba a unas seis leguas de Formigueiros, de donde se extraía. La vena apenas costaba en la mina de 0,35 a 0,45 reales el quintal, pero se encarecía en casi tres reales y medio el transporte, como ya hemos dicho; además había que sumarle otro real más por el gasto de ragua para su calcinación958. Las fluctuaciones porcentuales

\footnotetext{
954 AHPL. P. N.: 2874 (1586) y 2850 (1588)

955 AHRG. R. A.: 19.768/32

956 AHPL. P. N.: 2936 (1666)

${ }_{957}$ En 1745 la ferrería de Pontepetre adquirió 451 quintales de vena de Formigueiros a 128 mrs./quintal

${ }_{958}^{8}$ AHRG. Hombreiro: Libro de cuentas de la ferrería de Quintá.
} 
son muy pequeñas, entre el 90\% (entre 1752 y 1769) y el 109 (entre 1782 y 1791) respecto el nivel de base 100 (1770 y 1779).

\section{CUADRO XXVII.- PRECIO DE LA VENA EN EL SIGLO XVIII EN LA FERRERÍA DE QUINTA \\ (Indice base 100: 187 (1770-1779)}

\begin{tabular}{|c|c|c|c|c|c|}
\hline$\overline{\mathrm{ANOO}}$ & $\begin{array}{l}\text { PRECIO } \\
\text { (en mrs.) }\end{array}$ & ÍNDICE & AÑO & $\begin{array}{l}\text { PRECIO } \\
\text { (en mrs.) }\end{array}$ & ÍNDICE \\
\hline $175^{2}$ & 170 & 90,9 & 1773 & 187 & 100 \\
\hline 1753 & 170 & 90,9 & 1774 & 187 & 100 \\
\hline 1754 & 272 & 145 & 1775 & 187 & 100 \\
\hline 1755 & 170 & 90,9 & 1776 & 187 & 100 \\
\hline 1756 & 170 & 90,9 & 1777 & 187 & 100 \\
\hline 1757 & 170 & 90,9 & 1778 & 187 & 100 \\
\hline $175^{8}$ & 170 & 90,9 & 1777 & 187 & 100 \\
\hline 1759 & 170 & 90,9 & 1780 & 187 & 100 \\
\hline 1760 & 170 & 90,9 & 1781 & & 109 \\
\hline 1761 & 170 & 90,9 & 1782 & 204 & 109 \\
\hline 1762 & 170 & 90,9 & 1783 & 204 & 109 \\
\hline 1763 & 170 & 90,9 & 1784 & 204 & 109 \\
\hline 1764 & 170 & 90,9 & 1785 & 204 & 109 \\
\hline 1765 & 170 & 90,9 & 1786 & 221 & 118,1 \\
\hline 1766 & 170 & 90,9 & 1787 & 221 & 118,1 \\
\hline 1767 & 170 & 90,9 & 1788 & 204 & 109 \\
\hline 1768 & 170 & 90,9 & 1789 & 204 & 109 \\
\hline 1769 & 170 & 90,9 & 1790 & 204 & 109 \\
\hline 1770 & 187 & 100 & 1791 & 204 & 109 \\
\hline 1771 & 187 & 100 & 1792 & 238 & 127,2 \\
\hline 1772 & 187 & 100 & & & \\
\hline
\end{tabular}

FUENTE: AHRG. Hombreiro: Libro de cuentas de la ferrería de Quintá. Elaboración propia

A partir de finales del siglo XVIII los precios, siguiendo la tónica de los productos agrícolas (los cerales especialmente), inician una fuerte fase alcista 
que culmina con la crisis de 1804, como hemos visto anteriormente respecto de las ferrerías del Bierzo 959. En el siglo XIX, esos precios se mantuvieron cierto tiempo pero luego tendieron a bajar. La ferrería de Portela de Valcarce, que está a cinco leguas de Formigueiros, compraba el mineral en 1857 a 0,27 pesetas el q.m y costaba el transporte 2,17 pts. 960 , lo que supone un porcentaje del $11 \%$ para el mineral y un 88,9\% para el transporte. La ferrería de Llamas en 1881 compró 221 quintales de mineral de la Chana a 204 mrs./quintal, y 164 quintales de Ferradillo a $170 \mathrm{mrs}$./quintal961, pero desconocemos el peso del transporte en ese precio. A finales de siglo aún bajó más, pues en 1891 se dice que la mena que surte a Pombriego viene de la Chana "y se paga á boca-mina á 1,o9 pesetas el quintal métrico, el cual, por el transporte á la fábrica, cuesta 1,63 pesetas", es decir $40 \%$ el mineral y $60 \%$ el transporte ${ }^{962}$. En este caso, el peso tan alto del valor del mineral se debe al mayor coste de la minería subterránea y a que Pombriego no está muy lejos, por lo que el transporte era más barato.

En las ferrerías que se abastecían de hierro de Somorrostro, los fletes y el transporte desde el puerto hasta la propia ferrería también incrementaba considerablemente los costes; por eso los porcentajes que supone en el total es muy diferente de unas ferrerías a otras, debido a las diferentes distancias a los puertos. En Villanueva de Oscos, la vena vizcaína (casi el total de los 36.997.483 $\mathrm{kg}$. que consumió en sus 155 años de funcionamiento) era transportada en barco hasta Ribadeo, de allí en barcas hasta el Pouso y luego en carros hasta la propia ferrería, situada a 35 kilómetros, todo lo cual encarecía el mineral en un 35\% desde el puerto asturiano963, al que habría que añadir el coste desde Vizcaya. No es extraño así que a finales del siglo XVII en esta ferrería el coste porcentualmente más alto fuera la vena y no el carbón, como solía ocurrir con las ferrerías que consumían vena local. Por otro lado, sabemos que la vena vizcaína estaba gravada con $8 \mathrm{mrs}$./quintal macho desde 1640, a los que se añadieron otros $17 \mathrm{mrs}$. en 1794 por lo que su encarecimiento a finales del siglo, 25 maravedís, fue muy grande, como podemos ver en el CUADRO XXVIII. El

959 DATOLI, p. 59 y MUNÁRRIZ, p. 128

960 CÁMARA DE COMERCIO DE LEÓN: Pequeña historia de la economía leonesa, p.

${ }_{961}$ Archivo particular. Papeles de la ferrería de Llamas.

962 ESTADÍSTICA MINERA, año 1891

963 D. PAZ (1991): Ob. cit., 154 
índice del precio de la vena es inferior a 100 desde 1680 a 1729, con la excepción del quinquenio 1690-99; pero desde 1740 se mantiene en torno a 110 para subir de forma drástica en el decenio 1790-1799. Coincide esta con la subida del impuesto de la vena en $17 \mathrm{mrs}$./quintal y con la general de los precios del fin del siglo XVIII. Por el contrario, el índice del coste del porte se mantiene más o menos constante entre 1690 y 1749 para subir luego de forma acusada hasta los primeros decenios del siglo XIX, en que los índices superan el 200 e incluso el 299,2 en 1810-1819.

\section{CUADRO XXVIII. PRECIO DE LA VENA Y TRANSPORTE VASCO EN VILLANUEVA DE OSCOS (en medias decenales)}

(Índice base 100: vena: 143, porte: 68,1 (1720/1749)

\begin{tabular}{|l|l|l|l|l|l|}
\hline AÑOS & $\begin{array}{l}\text { TOTAL } \\
\text { (en qq.) }\end{array}$ & $\begin{array}{l}\text { PRECIO } \\
\text { (mrs./qq.) }\end{array}$ & ÍNDICE & $\begin{array}{l}\text { PORTE } \\
\text { (mrs./qq.) }\end{array}$ & ÍNDICE \\
\hline $1680-89$ & 10.408 & 102,7 & 71,8 & 77 & 113 \\
\hline $1690-99$ & 14.455 & 158,6 & 110,7 & 63,3 & 92,9 \\
\hline $1700-09$ & 12.900 & 106,8 & 74,6 & 73,3 & 107,6 \\
\hline $1710-19$ & 14.895 & 133,4 & 93,2 & 67,5 & 99,1 \\
\hline $1720-29$ & 20.217 & 125,8 & 87,9 & 68 & 99,8 \\
\hline $1730-39$ & 23.891 & 146,9 & 102,7 & 68,5 & 100,5 \\
\hline $1740-49$ & 23.702 & 156,5 & 109,4 & 68 & 99,8 \\
\hline $1750-59$ & 23.032 & 175,8 & 122,9 & 82,1 & 120,5 \\
\hline $1760-69$ & 23.283 & 155,9 & 109 & 90,5 & 132,8 \\
\hline $1770-79$ & 16.895 & 147,4 & 103 & 102 & 149,7 \\
\hline $1780-89$ & 18.007 & 190,2 & 133 & 102 & 149,7 \\
\hline $1790-99$ & $25 \cdot 500$ & 245,6 & 171,7 & 131,6 & 193,2 \\
\hline $1800-09$ & 19.717 & 284,6 & 199 & 157,7 & 231,5 \\
\hline $1810-19$ & 10.162 & 315,1 & 220,3 & 203,8 & 299,2 \\
\hline $1820-29$ & 10.411 & ---- & ---- & ---- & ---- \\
\hline $1830-35$ & 7.110 & ---- & ---- & ---- & ---- \\
\hline
\end{tabular}

FUENTE: Elaboración propia con los datos de P. Saavedra (1982): Ob. cit., p. 549-554 
En el siglo XIX, los precios de la vena vasca nos son conocidos por los datos de la ferrería de Froseira, años veinte y treinta: valía en torno a 4,5 y 5,5 rs./qq., a los que había que añadir otros 3,5 rs./qq. por el flete desde Portugalete hasta el puerto de Coaña 964 . La vena llegaba en barco hasta Navia, se transportaba por el río hasta las veneras de Porto, en Coaña, y desde allí se llevaba hasta la ferrería en carros o caballerías ${ }^{965}$. El diccionario de Madoz, que menciona numerosos datos de mineral de hierro vasco descargado en los puertos asturianos, hablando del río Navia, por ejemplo, dice que es navegable una legua más arriba del lugar de Navia, pudiendo fondear barcos de más de 100 toneladas 966 . En este puerto entraban todos los años una media de 7.382 quintales de mineral de hierro967 (según el CUADRO XXIX) entre el 36 y el 51\% de todo el hierro vasco que llegaba a Asturias). La Estadística Minera de 1864 habla de cómo las siete ferrerías asturianas que trabajaron ese año produjeron 1.701 quintales de hierro "procedente de menas de Somorrostro en Vizcaya"968.

\footnotetext{
964 J. LÓPEZ y A. GRAÑA (1998): Ob. cit., p. 139 y ss.

965 J. LÓPEZ y A. GRAÑA: Ob. cit., p. 139 a 143. Así: 7 septiembre de 1821: "Recibi en las beneras de Porto (Coaña) de D. Pedro de las Heras 500 q. de vena a 6 reales y medio el quintal, que remitió por el capitán D. Gabriel San Fuertes (de Portugalete); 22 de julio de 1826 los mismos D. Pedro de la Hera y el capitán San Fuertes: Recibí 600 quintales a 5 reales y medio, por todo su coste 3.30o rs.; el mismo día pagué por el flete 2.125 rs. Y 10 mrs. a razón de 34 cuartos y maravedí cada quintal. A esto hay que añadir los días ocupados (tres) en llevar y pesar la vena, comida de caballerías, etc.; 10 de mayo de 1827: en Porto recibí del capitán San Fuertes 600 quintales a 18 pesos cada barcada de 150 q. Que importan 1080 rs. Por el flete de los 600 q. al señor Fuertes a 30 quartos en quintal 2.117 rs con 22 mrs.; 18 de julio de 1830: en Porto 350 q. de bena de orden del sr. Heras que me entregó el capitán Ormaza, pagué a éste 1.111 rs y 26 mrs. Del flete en razón a 27 cuartos cada quintal; 21 de julio de 1830: entregó en Porto el capitán San Fuertes de orden del señor Heras 420 q. De vena; 5 de julio de 1832: en Porto don Gabriel san Fuertes 420 q. de vena por cuenta del señor Heras a 4 reales y medio más 480 rs. de flete a San Fuertes y se le resta a él 853 rs. y 32 mrs. a razón de 27 cuartos quintal; 11 de julio de 1832: entregó el capitán D. José Antonio de Prada, de cuenta del sr. Heras otros 600 q. de vena a cuatro reales y medio y al dicho capitán de orden del sr. Heras 1.905 rs. y $30 \mathrm{mr}$. del flete a 27 cuartos cada quintal: 30 de agosto de 1833: en Porto a San Fuertes de orden del sr. Heras 420 q. de vena a cuatro reales y medio a San Fuertes 1.684 rs. por el flete a razón de 26 cuartos quintal".

966 P. MADOZ: Ob. cit., p. 253: "las que conduce material para las herrerías de Bullimero en la feligresía de Parlero y para la de Frouseyra en el ayuntamiento limítrofe de Boal"

967 P. MADOZ: Ob. cit. p. 254

${ }_{968}$ Citado por LÓPEZ, J. y GRAÑA, A. (1998). Ob. cit., p. 19
} 


\section{CUADRO XXIX.- ENTRADAS DE HIERRO \\ EN PUERTOS ASTURIANOS (en quintales)}

\begin{tabular}{|l|c|r|r|l|}
\hline PUERTO & AÑO 1844 & \multicolumn{1}{l|}{$\%$} & \multicolumn{1}{l|}{ AÑO 1845 } & $\%$ \\
\hline FIGUERAS & 9.791 & 37,4 & \multicolumn{1}{l|}{------} & \\
\hline GIJÓN & 1.367 & 5,2 & 11.167 & 28,4 \\
\hline LASTRES & 86 & 0,3 & 51 & 0,1 \\
\hline LLANES & 85 & 0,3 & 36 & 0,09 \\
\hline NAVIA & 9.477 & 36,2 & 20.017 & 51,0 \\
\hline VEGA & 51 & 0,1 & 75 & 0,1 \\
\hline VEGADEO & 5.276 & 20,1 & 7.852 & 20,0 \\
\hline TOTAL & 26.133 & 100 & 39.198 & 100 \\
\hline
\end{tabular}

FUENTE: P. Madoz (1845-1850): Diccionario geográfico-estadísticohistórico de España y sus posesiones de ultramar. Madrid. Ed. facsimil de Ámbito (1985): tomo de Asturias, p. 165, 178, 208, 229, 254, 425,

\subsection{Salarios}

Los oficiales o ferrones cobraban el quintalaje, cantidad estipulada por cada quintal producido, que variaba de unas ferrerías a otras; por ejemplo en las de Quintá y Rugando suponía unos 4,5 reales por quintal producido en el siglo XVIII. Sin embargo, en la mayoría fue frecuente que a cada oficial se le pagara una cantidad fija, es decir, una soldada que variaba según la función de cada uno, siendo la más alta la del aroza y la más baja la del tazador. A esa soldada había que añadir además el quintalaje, en este caso menor, y además los llamados dones, como ya hemos visto en el capítulo anterior. También lo podemos ver respecto de la ferrería de Bueyes ${ }^{969}$ o de las bercianas a finales del siglo XVIII970. En general el salario de los trabajadores representaba en torno a

${ }_{969}$ En la de Bueyes "el aroza que es el que domina los mas operarios y por cuia quenta corre la fabrica tiene de salario al año seiscientos rs. vn., por solo el trauaxo del tiempo que queda espresado y por cada quintal de hierro que produce la herraria se le paga un real y seis mrs. de vn., propina que llaman quintalaxe, que en los quatrocientos cinquenta y cinco quintales ymportan quinientos treinta y cinco rs. $y$ dies mrs. vn., que xuntos con los de arriua suman un mil ciento treinta y cinco rs. y diez mrs. vn. Y así el resto de los trabajadores". (CATASTRO DE ENSENADA. R. G.: Noceda.

${ }_{970}$ MUNÁRRIZ, Ob. cit., p. 131, afirma que en las ferrerías del Bierzo cobran los operarios lo siguiente: el aroza gana 1800 reales al año, y real y cuartillo por cada quintal de cinco arrobas de 
un $12,5 \%$ del total de los costes de producción de la ferrería, pero fluctuaba de unas a otras y de unas épocas a otras, entre el 7 y el $18 \%$.

Aunque no contamos con datos seriados que nos permitan conocer la evolución de los salarios, sin embargo, parece que el porcentaje del trabajo en el total de los costes fue disminuyendo a lo largo de tiempo, lo que no quiere decir que estos descendieran. Todo lo contrario, parece que los salarios evolucionaron al alza, como ocurrió en otras zonas de España con ferrerías. En Cantabria, por ejemplo, los salarios de los oficiales crecieron en el siglo XVIII un 28\% y lo mismo en Guipúzcoa (29,2\%)971; pero dado el crecimiento general de los precios en realidad la situación de los trabajadores empeoró en lugar de mejorar.

\subsection{Gastos de obras}

No nos referimos a las obras de construcción de una ferrería, ni tampoco a las reconstrucciones por destrucción, incendio etc., sino a las reparaciones por el uso, a los escalabros, como suelen denominarlos los contratos de arrendamiento. De acuerdo con dichos contratos, las obras mayores (arreglo de la chapacuña, banzado y reparaciones de los edificios) suelen ser de cuenta del propietario, mientras que las obras menores las ha de reparar el arrendatario, a no ser que en el contrato se estipule otra cosa, cosa que recae en ellos más veces de las que deseaban, de ahí los pleitos con los dueños972. Mientras que las obras mayores requieren gastos cuantiosos, los gastos menores representan porcentajes del 4 al 7\% del total de los gastos, con una media de 6,2\%.

\footnotetext{
hierro que se fabrica. El otro tirador -el aroza también lo es- gana 1200 reales al año y un real por quintal de hierro. Cada fundidor 850 reales y 30 maravedíes por quintal de hierro, y en el tiempo que estén trabajando es de su obligación tener arreglada la fragua y barquines. El tazador que muele el mineral, dejándolo en pedazos como avellanas, y ayuda a todos los demás en los ratos desocupados, gana 400 reales al año y medio real por cada quintal de hierro que entra en el almacén".

971 M. CORBERA (2001): Ob. cit., p. 140

972 Contrato de arriendo de las ferrerías de Río Cabo a Antonia San Miguel, en 1848: "Todos los descalabros mayores y menores que sucedan en los artefactos, chapacuña y demás edificios y oficinas de las referidas fábricas" los debe arreglar el arrendatario "a excepción de que si el arbol mayor se inutilizase enteramente y se cayere alguna pared de las herrerías y casas" que se pagará a medias. En I. GARCÍA TATO (2000): ob. cit., p. 131.
} 


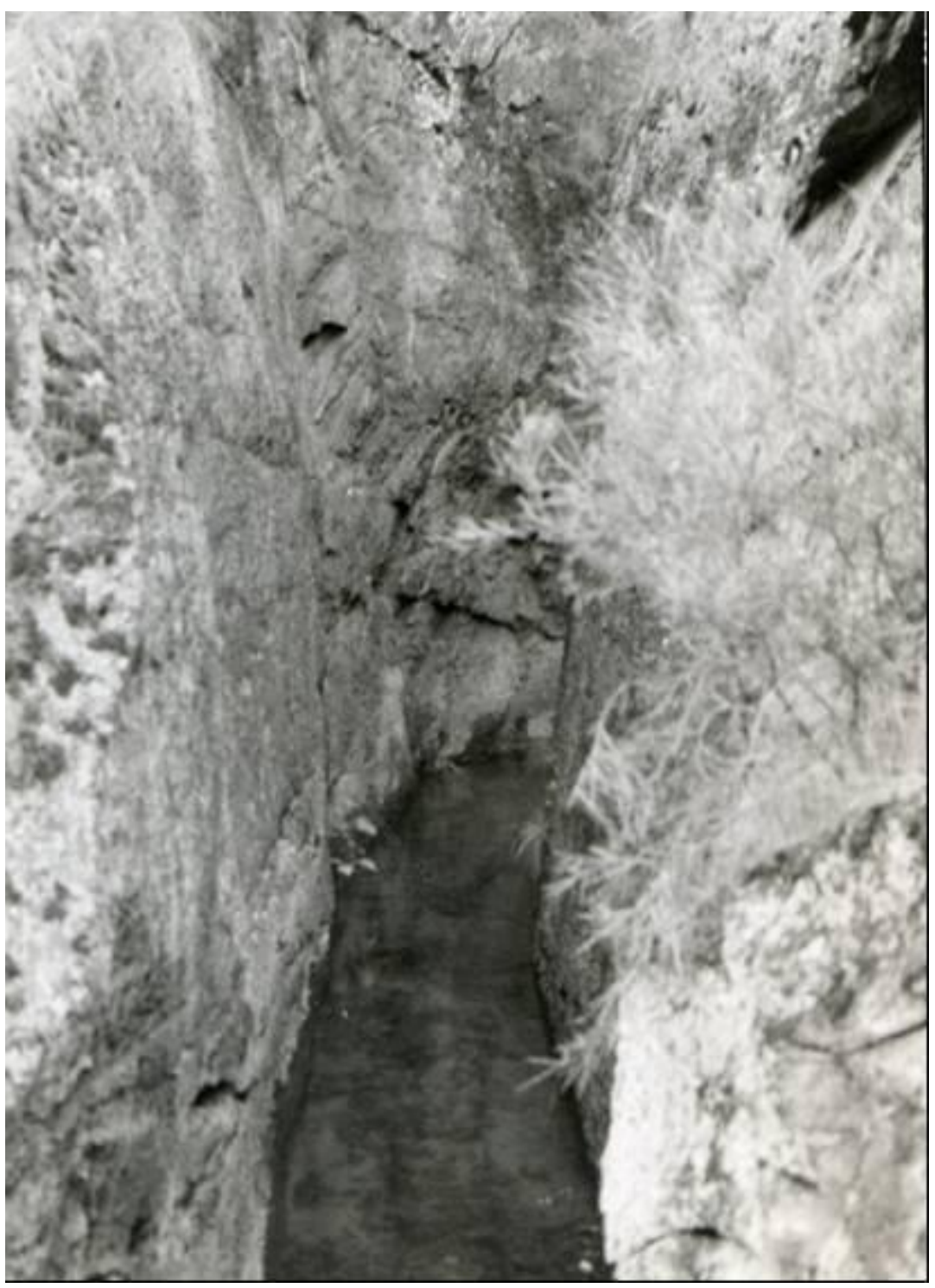

Presa de la ferrería de Pombriego

Respecto de las obras mayores, la reparación de las chapacuñas y presas eran sumamente costosas 973 , ya que algunas presas son verdaderas obras de ingeniería974 como la de San Vicente de Leira, construida en 1721, y cuyo muro de contención, hecho de piedra labrada, tenía 18 varas de alto (unos 15 metros) 975. Otras están labradas sobre la roca, como las de Pombriego,

973 Pleito de la ferrería de Santalla entre Diego Sánchez de Orozco y Martín de Guizaburuaga, año 1627: "los mayores gastos de una herrería son los vançados y rruedas los quales con el agua permanecen poco tiempo, y es necesario repararlos y rehedificarlos" (AHRG. R.A.: 14.869/12).

974 En 1603 un testigo menciona que cuando se reedificó la ferrería de Soldón en 1550, sus dueños, Juan Ortiz y su esposa, "para su fundamento y edificio rompieron peñas y montes, escabaron acequia muy onda y larga para dar toda la agua de la dicha herreria y mejorar la presa della" (AHRG. RA.: 20.441/70).

975 P. ARIAS (1950): Historia del Real Monasterio de Samos, p. 251. 
Lousadela976 y Soldón977, lo que aumentaba su coste. También fueron frecuentes las reparaciones del banzao y el banzadillo. Son, por ello, numerosos los documentos que recuerdan esos destrozos, así como la cuantía de las reparaciones, como la que tuvieron que hacer los propietarios de la ferrería de Lousadela en 1612, que supuso un coste de 3.000 ducados978. En esta misma ferrería, en 1641, hubo nuevamente que reparar la presa, reponer las ruedas hidráulicas y un nuevo árbol para el mazo, en los que se gastaron unos 2.000 ducados979. De la de Villanueva de Oscos, se dice que el abad Juan Cerrato (1677-1680) "reedificó el canal tres veces en dos años, gastando en la obra más de 16.000 reales." 980 . También el mazo era costoso y había que repararlo con mucha frecuencia, ponerle cellos de hierro, o sustituirlo981. Frente a estas obras mayores, las menores en general se trata de pequeñas reparaciones, cuyo valor no supera, como hemos dicho, el 6\% de los gastos totales.

\subsection{La conflictividad}

Un gasto difícil de cuantificar pero de gran importancia en la vida de las ferrerías fue el generado por los conflictos. Ya hemos hablado de los conflictos por el agua que, con frecuencia fueron, la razón última para impedir o retrasar la construcción de nuevas ferrerías sobre el mismo río o arroyo; pero en relación con los costes de producción fueron más importantes los conflictos por el monte, la madera y el carboneo, que se repiten insistentemente, sobre todo desde mediados del siglo XVII hasta el siglo XIX, hasta el punto de constituir el mayor número de pleitos en la Audiencia de Galicia. El análisis de la actividad de la Audiencia revela que los litigios por alteraciones de los usos colectivos

${ }_{976}$ En 1632 dicen haber gastado "en hacer la presa y bançado de la dicha ferrería de Lousadela” 233 ducados (AHRG. RA.: 19.816/8).

977 En 1603 dice que sus padres, que traen en fuero la ferrería de Soldón, la reedificaron haciendo de nuevo el cauce para lo que "rompieron peñas, montes, escaba y acequia muy onda y larga para dar toda el agua de la dicha herrería” (AHRG. . A.: 20.441/70)

978 AHPLu: 2408/2: en 1612 Pedro Martínez de Giocoechea y su mujer Lucía Díez de Zuloaga afirman que años antes habían aforado la ferrería de Lousadela a doña Jerónima de Villasur, pero que por seguridad y poder trabajar "tuvieron que hacer una presa de nuebo, de canto y argamasa, rompiendo rocas, etc", que les costó 3.000 ducados.

979 AHRG. R. A.: $19.816 / 8$

980 D. YAÑEZ (1973): "El monasterio de Villanueva de Oscos". Bidea, 8o, p. 683. También en 1755 en la ferrería de Paleiras una avenida se llevó el banzado y una pared por lo que el rentero pretendía un descargo en la renta de 5.000 reales gastados en "reedificar la estolda, banzado y pared principal de la Herrería que se auia arruinado con la abenida en el año cincuenta y cinco" (AHRG. R.A.: 14.147/12).

${ }_{981}$ CATASTRO DE ENSENADA. R. G. : Doncos(San Juan de Noceda) Ver apéndice. 
eran la causa más frecuente en los pleitos entre comunidades y entre estas y particulares, de modo que el $25,5 \%$ de los litigios se referían a propiedad y posesión de montes y comunales: el 39,8\% en XVI/2, 24,7\% en XVII/1, 12,8\% en XVII/2, $18,6 \%$ en XVIII/1, 27,7\% en XVIII/2 y un 45,5\% en el primer tercio del siglo XIX. De 1550 a 1834, el periodo de máxima conflictividad se produjo entre 1580 y 1640 , en especial en $1600 / 1630$ y a lo largo del XVII y del XVIII no vuelven a darse situaciones de conflicto generalizado, salvo un repunte a mediados del setecientos y otro más acusado en 1790/1810982.

La mayor parte de estos conflictos en el tránsito del XVI al XVII tuvieron como causas fundamentales las roturaciones de tierras, cercamientos y talas de árboles. Un siglo más tarde, las causas más numerosas se refieren a la posesión y aún a la propiedad del monte, y sus aprovechamientos y usos son una faceta complementaria. A principios del siglo XVIII, en una fase económica positiva, se constata la tendencia a la reducción de la conflictividad, con un menor número de demandas ante la Audiencia por colectivos vecinales y las roturaciones ya no son la causa fundamental de los pleitos. Menudean ahora aquellos que se refieren a usos industriales de la madera y la leña, lo que evidencia su escasez. A lo largo del siglo XVIII el número de pleitos llegados a la Audiencia se mantuvo en un nivel bajo, aunque con un breve repunte por efecto de la aplicación de las nuevas Ordenanzas de Montes de 1748 y otro más intenso en 1790/1810 probablemente mixtificados y confundidos con pleitos de aguas, de los que ya hemos hablado por la transformación del monte en prados. Nuevamente en el primer tercio del siglo XIX aumenta la conflictividad en gran parte debida a los usos industriales del monte, en especial al carboneo por la construcción de nuevas ferrerías.

Aunque nosotros no pretendemos hacer un análisis exhaustivo de estos conflictos industriales, si podemos confirmar la mayor conflictividad por usos industriales en los siglos XVIII y XIX. De los 47 juicios que hemos analizado referidos a montes y ferrerías (APÉNDICE III), solo hemos encontrado 1 del siglo XVI, 9 del XVII, 26 del XVIII y 11 del XIX, lo que quiere decir que el 55\% de los mismos se sustanciaron en el XVIII y el 23\% en el XIX, siglos en los que

982 O. REY (1997): Ob. cit., p. 9 
la construcción de nuevas ferrerías suscitó el temor de los pueblos por el monte y la escasez de leña. La mayoría de estos juicios no discuten la propiedad, sino el derecho a carbonear. En unos casos por carbonear en montes en disputa (del común de varas de los que son porcioneros); pero sobre todo por vender carbón a ferrerías diferentes a las que -de ahí el conflicto- aquellos montes estaban adscritos por viejas escrituras forales. La razón frecuente es que en otras ferrerías les pagan más el carbón, lo que es un signo de las dificultades para el abastecimiento, y por ello la competencia y las diferencias de precios. Esto también lo encontramos en ferrerías asturianas, como pone de manifiesto el pleito de la ferrería de Villanueva de Oscos contra los vecinos de la feligresía de Presno, de $1750^{983}$.

En menor medida, también hubo conflictos por la propiedad y el uso de los yacimientos de hierro. Por ejemplo, en el de Formigueiros. Aunque la propiedad de la mina pertenecía a los condes de Maceda, su explotación era libre por los venaqueros, que en cuadrillas abastecían indistintamente a las ferrerías gallegas y berciana, como señalan Datoli y Munárriz. Ninguna ferrería explotaba directamente minas en Formigueiros, a excepción de la de Bueyes, cuyo dueño sostuvo con otros propietarios un sonado y prolongado pleito984. Éste debió iniciarse hacia 1790 en la Real Audiencia de Galicia985. En escrito de 1791 se explicitan los motivos de la querella contra el presbítero don José Díaz, administrador de la ferrería de Soldón, pues este con sus operarios se había introducido en una venera a extraer un mineral que, según don José María

${ }_{983}$ "Los vecinos de Castro, Obanza, Santa Colomba y otros de la feligresía de Sta Eulalia de Presno, concejo de Castropol, sobre aprovechamiento de los montes comprendidos en los foros (...) capitularon entre otras cosas, que el carbón que se hiciese en dichos montes se había de conducir a la ferrería de dicho monasterio y a la de D. García Fco Balledor y Presno de Montealegre y Nafarea, por ser las más antiguas (...) en caso de reincidencia, por cada carro de carbón que llevasen a otra alguna ferrería (...) pagarían 15 reales de vellón con las costas y daños y más que se contiene y refiere en la escritura otorgada el 14 de diciembre del año pasado de 1727'. Cit. en P. QUINTANA (2005): Ob. cit, t. I., p. 72

984 Esta ferrería de Bueyes ya mantuvo en 1718 otro juicio con vecinos de Visuña por arrancar vena en Formigueiros, en un lugar en el que con esfuerzo su dueño descubrió tres o cuatro minerales y aquellos se los arrancaron (AHN. Estado, leg. 1739, $\mathrm{n}^{\mathrm{0}} 16$ ).

985 AHN. Estado: leg. 1739, $\mathrm{n}^{\circ}$ 16: escrito a la Audiencia de la Coruña: “que en junio de $1790 \mathrm{D}$. Diego García Pelagra, administrador de la Herraria de Bueys y apoderado del D. Joseph María Tineo dueño de ésta se querelló contra $D^{a} M^{a}$ Antonia Pardo y Quindós, como madre de D. Joseph Ygnacio Quiroga, dueño de la Herraria de Soldón, por decir le perturbaba en la posesión privativa de arrancar vena en una de las veneras del citado monte de Formigueiros". 
Tineo, dueño de Bueyes, le pertenecía desde tiempo inmemorial986. La sentencia fue condenatoria para el dueño de Bueyes, quien en marzo de 1792 recurrió ante la Chancillería de Valladolid sin, al parecer, mejor resultado987.

En el juicio, que se alargó hasta finales de siglo, pleitearon contra don José María Tineo los propietarios de la mayoría de las ferrerías de la zona, entre ellos el monasterio de Samos (La Rodela), José Quiroga Losada (Gorgueira), Manuel Armesto y Omaña (Órreos), José Alfonso Pertierra (Pontenova), Benito María de Prado (Quintá) y María Antonia Pardo (Soldón); a los que se añadieron después los de Paleiras, Pontepetre y Arnado988. Como dice en 1796 el dueño de la ferrería de Órreos o Visuña, don Manuel de Armesto, porque siendo el aprovechamiento de Formigueiros común a todas las ferrerías de la zona, don José María Tineo quería aprovecharse del mejor y más provechoso sitio del yacimiento ${ }^{989}$. Lo cierto, como dice el dueño de la de Gorgueira, el foro de la vena daba derecho a que cada uno la sacase "en la parte que más le acomoda"990. La Chancillería debió confirmar la sentencia de la Audiencia.

Las leyes mineras del siglo XIX suscitaron nuevos conflictos por el intento de registrar la mina por miembros de la burguesía local, lo que obligó al conde de Maceda a defender sus antiguos derechos, para lo que contó con el apoyo de los dueños de las ferrerías. Así en 1842 se entabló un pleito contra varios vecinos de Monforte (José Fariñas, profesor de Medicina; José María Méndez, profesor de Cirugía, José Casares, profesor de Farmacia, Francisco Fariña, abogado, etc.), que intentaban registrar diferentes minas del yacimiento en lugares como Aira

\footnotetext{
986 Según el escrito de demanda él y sus antecesores siempre se hallaron "posehedores, cada uno en sus respectivos tiempos, de usar y aprovecharse de una venera situada en la montaña llamada de Formigueiros, a consecuencia de títulos lexítimos, arrancando de ella, con independencia de otro alguno, toda la vena necesaria para el consumo de su herrería de Bueyes"'(AHPL.PN.: caja 3377 (1791).

987 AHN. Estado: leg. 1739, $\mathrm{n}^{\circ}$ 16: "que con el motibo de corresponder a sus mayorazgos una mina de bena de fierro en la sierra titulada de Formigueiros para surtir con ella una ferrería nombrada de Bueies, propia también de su mayorazgo, y el haberse intrusado en dicha mina, por medio de su mayordomo y operarios, doña Antonia Pardo, extraiéndole mucha porción de vena para surtir otra ferrería, se había querellado de fuerza en la Real Audiencia de la Coruña".

988 AHN. Estado: leg. 1739, $\mathrm{n}^{\circ} 16$.

989 AHPL. PN.: caja 3339 (1796): “intentó aprovecharse del sitio más pingüe y productivo (...) para surtir su Herrería llamada de Bueyes haciendo un voluntario amojonamiento del referido sitio e intentando perturbar este común aprovechamiento al esponente y demás interesados con igual título".

990 AHPLU: 2555/2 (1797).
} 
Dura, Coba de Formigueiros, Pena dos Carros, Retorta de Formigueiros, Barreiriñas, Cabana de Formigueiros y Cabalón de Formigueiros, suponiéndolas abandonadas, por no explotarlas los cuatro operarios exigidos en la ley de minas de 1825; pero en este caso los dueños de las ferrerías apoyaron al conde de Maceda en sus derechos ${ }^{991}$, porque aunque Ezquerra del Bayo sostendría en 1845 que la minería del hierro era enteramente libre en España, no por eso se podían conculcar los derechos legítimamente adquiridos ${ }^{992}$. Hubo otros conflictos por impago de derechos, como la demanda que en 1869 presentó el conde de Maceda contra su primo don Apolinar Suárez de Deza, dueño de las ferrerías de Río Cabo y otras, para que se abstuviera de continuar explotando el mineral de la sierra de Formigueiros y le pagase la renta por la vena consumida por sus dos ferrerías de Ríocabo desde el año 1865, pleito que finalizó con una fallo en 1870 favorable al conde de Maceda993.

\section{LA RENTABILIDAD DE LAS FERRERÍAS}

Los beneficios y rentabilidad de las ferrerías son una cuestión compleja, porque su actividad afecta económicamente a muchas personas. Por tanto, no se trata sólo de comprobar los beneficios directos que aquellas generan a los dueños y arrendatarios, sino que hay que incluir a los que se benefician directa o indirectamente por los trabajos que realizan en ellas o para ellas: ferrones, venaqueros, transportistas, carboneros, mazuqueros, comerciantes, etc. 994 Son

991 Pues como dice un documento posterior, esos dueños de más de 40 ferrerías "están en la quieta, pacífica e inmemorial posesión de surtirse para su fundición de las minas de fierro de Formigueiros y Roques, además de haber adquirido la propiedad por legítimos títulos, que siendo necesario presentarán. No obstante Fariñas y compañeros, las han registrado, ocultando las circunstancias particulares de estas minas, por lo cual se sigue pleito". Cit. en I. GARCÍA TATO (2000): Ob. cit., p. 161.

992 ANALES DE MINAS, t. III, 1845, p. 439. Dice del Bayo: "los ingenieros del gobierno no tienen en ella (en la minería del hierro) otra intervención, que la de formalizar los expedientes de concesión de pertenencias y amparar y sostener la propiedad adquirida con arreglo a la ley".

993 I. GARCÍA TATO: Ob. cit., p. 103 y 167: "fallo que debo declarar y declaro que la sierra de Formigueiros con sus criaderos de hierro de hierro pertenece a don Baltasar Losada Miranda, conde de Maceda", condenando a Apolinar Suárez de Deza a "abstenerse de continuar en la explotación del mismo en lo que a la repetida fábrica se refiere y a que pague a aquel la renta de la explotación".

994 Por ejemplo, los carboneros y transportistas de carbón y vena realizaban ese trabajo muchas veces en temporadas sin trabajo en el campo. En la ferrería de Villanueva de Oscos se ha calculado que ese trabajo generaba unos 30.000 reales anuales, lo que suponía unos 200 reales por habitante del coto. A comienzos del siglo XIX el porte de la vena ocupaba 30 parejas de bueyes, 19 caballos y 6 mulas. En D. PAZ (1991): Ob. cit., p. 162 y 155. En la ferrería de Soto 
muchos, probablemente cuarenta o cincuenta personas por ferrería, y en total unos cuantos miles en toda la zona. Además, el trabajo del hierro en martinetes y fraguas multiplicaba ese número hasta alcanzar cifras superiores a los siete $\mathrm{u}$ ocho mil en la región estudiada. Por eso, no podemos estar de acuerdo con Alcalá-Zamora cuando dice que este tipo de empresas, por sus pequeñas dimensiones productivas y el elevado coste de explotación, eran modestas, permitiendo un desahogado pasar del propietario, porque siendo esto cierto, también lo es que proporcionaban trabajo y bienestar a muchas otras personas y constituían una parte notable del producto interior bruto de estas comarcas montañosas.

Respecto de los propietarios, las ferrerías generaban ingresos sustanciosos que se añadían a las rentas de la tierra, ya que normalmente estas contaban también con bienes en los alrededores (campos de cereal, prados, huertos, ganado), que se aforaban o arrendaban casi siempre junto con los artefactos 995. Tanto monjes como propietarios laicos eran conscientes de la enorme rentabilidad de estos artefactos. Sancho de Neyra, en un memorial de 1749 escribe: "advierto a mis sucesores que no descuiden de esta alaja, pues es de estimar, y solo los que la manejan sauen su ualor"996. El dueño de la ferrería gallega de Lusío recuerda en 1715 que Lope Vázquez de Villameixe, que la había levantado en el siglo XVI, les dejó "una alaja que les sirbe de recreo, autoridad e ynterés por poco que sea y de mortificación y rabia a los contrarios”, porque gracias a los beneficios obtenidos por la renta del hierro habían acrecentado sus antepasados el patrimonio familiar997. Al dueño de la ferrería de Valcarce le computa el Catastro de Ensenada unas rentas de 74.00o reales, lo que lo

Rodrigo, en 1866 , se firma un contrato para transportar 3.000 cargas de carbón durante 15 años, que se llevarán a la ferrería "después de la siembra del maíz o sea desde el quince de mayo hasta el dieciséis de julio en que principia la recolección de la yerba y después de ésta o sea desde el ocho de septiembre hasta que el temporal lo permita". En A. MATO (2010): Ob. cit., p. 126

995 Así lo vemos, por ejemplo, en el arriendo que en 1827 hace don Juan Bernardo Quiroga a "Felipe Fernández de Prada del lugar de Puertomorisco, jurisdicción del Bollo, la Herrería de Mondón, con su casa y diestros, como son Molino, soto, guerta y el prado del Bollo, que acostumbra a disfrutar ó andar unido con dicha Herrería, en la cantidad cada año de ocho mil $y$ doscientos reales" (AHPLU: 2406/14)

996 AHRG. Ombreiro

997 ARCHIVO DEL MONASTERIO DE SAMOS: Casa de Lusío, libro becerro (1715), p. 8. 
convierte en el mayor hacendado de la zona de Villafranca del Bierzo 998 . Nemesio Fernández, propietario de varias ferrerías en el siglo XIX, hizo su fortuna con ellas, convirtiéndose en el hombre que más contribución pagaba en el Partido de Ponferrada. Cuando muere en 1859 deja un capital valorado en 2.630.810 reales, del que las ferrerías suponían 821.500 reales, y el dinero en efectivo en 505.760 reales 999 .

\section{CUADRO XXX.- INGRESOS, GASTOS Y BENEFICIOS DE LA FERRERÍA DE QUINTÁ}

(en reales)

\begin{tabular}{|l|l|l|l|l|}
\hline AÑO & INGRESOS & GASTOS & BENEFICIOS & $\begin{array}{l}\text { \% INGRESOS/ } \\
\text { BENFICIOS }\end{array}$ \\
\hline 1753 & 59.360 & 37.951 & 21.409 & 36,06 \\
\hline 1754 & 77.349 & 45.625 & 31.724 & 41,01 \\
\hline 1755 & 77.140 & 46.051 & 31.089 & 40,30 \\
\hline 1756 & 61.460 & 47.807 & 13.659 & 22,22 \\
\hline 1757 & 42.490 & 31.369 & 11.121 & 26,17 \\
\hline 1758 & 66.780 & 52.749 & 14.031 & 21,01 \\
\hline 1759 & 60.843 & 44.977 & 15.863 & 26,07 \\
\hline 1760 & 73.365 & 46.282 & 26.978 & 36,77 \\
\hline 1761 & 78.660 & 54.235 & 24.425 & 31,05 \\
\hline 1763 & 53.040 & 43.486 & 9.554 & 18,01 \\
\hline 1764 & 50.700 & 35.577 & 15.143 & 29,86 \\
\hline 1766 & 50.034 & 41.687 & 8.347 & 16,68 \\
\hline 1772 & 55.800 & 42.359 & 13.441 & 24,08 \\
\hline 1773 & 42.408 & 33.383 & 9.025 & 21,28 \\
\hline 1774 & 34.038 & 22.302 & 11.736 & 34,54 \\
\hline 1775 & 39.072 & 22.416 & 16.656 & 42,62 \\
\hline 1776 & 45.144 & 28.874 & 16.270 & 36,04 \\
\hline 1777 & 23.892 & 16.732 & 7.160 & 29,96 \\
\hline & & & & \\
\hline
\end{tabular}

998 J. GONZÁLEZ VECIN (1984): "Los mayores hacendados del partido de Ponferrada a mediados del siglo XVIII". Tierras de León, $\mathrm{n}^{\circ}$ 57, $\mathrm{p}$.

999 J. A. BALBOA (2008): Nemesio Fernández. Un político y empresario del siglo XIX. Ponferrada, p. 16-17. 


\begin{tabular}{|l|l|l|l|l|}
\hline 1778 & 43.758 & 30.792 & 12.966 & 29,63 \\
\hline 1781 & 21.998 & 21.976 & 22 & 0,73 \\
\hline 1782 & 32.572 & 25.999 & 6.573 & 20,17 \\
\hline 1783 & 43.453 & 24.289 & 19.164 & 44,10 \\
\hline 1784 & 35.266 & 16.243 & 19.023 & 43,94 \\
\hline 1785 & 33.480 & 20.415 & 13.065 & 39,02 \\
\hline 1786 & 21.150 & 13.591 & 7.559 & 35,73 \\
\hline 1787 & 57.750 & 39.664 & 18.086 & 14,00 \\
\hline 1788 & 61.200 & 44.184 & 17.016 & 27,80 \\
\hline 1789 & 70.584 & 46.887 & 23.693 & 33,56 \\
\hline 1790 & 48.694 & 40.747 & 7.947 & 16,32 \\
\hline 1791 & 80.000 & 55.988 & 24.012 & 30,01 \\
\hline 1792 & 62.000 & 46.343 & 15.657 & 25,25 \\
\hline TOTAL & 1.603 .549 & 1.121 .136 & 482.413 & 30,08 \\
\hline
\end{tabular}

FUENTE: AHRG. Hombreiro. Libro de cuentas de la ferrería de Quintá Elaboración propia

Del cuadro XXX podemos comprobar que el porcentaje de beneficios de la herrería de Quintá fue, a lo largo de los años computados, de un 30\%, aunque las diferencias anuales son acusadas, con fluctuaciones desde el $14 \%$ al $44 \%$. Con todo, la rentabilidad media parece bastante elevada, aproximadamente unos 15.518 reales de media al año, lo que coincide con el aprecio de sus dueños por esta "alaja". Los beneficios de las ferrerías del Bierzo, como podemos deducir del cuadro XXXI suponen un 23,59\% a mediados del siglo XVIII y un $46,45 \%$ a principios del siglo XIX, lo que no deja de ser igualmente una fluctuación muy elevada; probablemente la rentabilidad media se sitúe poco más o menos en torno al 30\%. Los de la ferrería de Villanueva de Oscos, para un periodo más amplio, esa rentabilidad media desciende hasta el 18,64\%, probablemente por gastos en juicios y el coste más elevado de la vena vizcaína (CUADRO XXXII). Este porcentaje significa unos 9.318 reales anuales, que descontados de los intereses y redención de los censos suscritos para construir la ferrería, supone unos ingresos anuales de 7.00o reales al año en los 155 años 
que estuvo en funcionamiento ${ }^{1000}$, que para Pegerto Saavedra equivalían a la renta de un pequeño mayorazgo hidalgo ${ }^{1001}$.

CUADRO XXXI.- COSTES Y BENEFICIOS DE FERRERÍAS BERCIANAS (en reales)

\begin{tabular}{|c|c|c|c|c|}
\hline \multicolumn{5}{|c|}{ COSTES DE PRODUCCIÓN Y BENEFICIOS } \\
\hline & \multicolumn{2}{|c|}{ Hacia 1750} & \multicolumn{2}{|c|}{ Hacia 1800} \\
\hline CONCEPTO & COSTES & $\%$ & COSTES & $\%$ \\
\hline MINERAL & 11.294 & 16,84 & 17.867 & 15,89 \\
\hline CARBÓN & 36.000 & 53,69 & 63.000 & 56,03 \\
\hline SALARIOS & 9.250 & 13,79 & 11.572 & 10,29 \\
\hline RENTA & 10.500 & 15,66 & 20.000 & 17,68 \\
\hline $\begin{array}{l}\text { TOTAL } \\
\text { COSTES }\end{array}$ & 67.044 & & 112.439 & \\
\hline INGRESOS & 87.850 & & 210.000 & \\
\hline BENEFICIOS & 20.706 & & 97.561 & \\
\hline
\end{tabular}

FUENTE: J. A. BALBOA (1990): Hierro y herrerías en el Bierzo preindustrial. León, p. 118

Los beneficios de las ferrerías monásticas los conocemos por la contabilidad de Villanueva de Oscos y por los Estados de Cuentas de varios monasterios benedictinos. De la primera ya hemos hablado, solo concluyo diciendo que los beneficios de la ferrería sobre el total de los ingresos de esta supusieron en toda su historia un 18,64\%, con fluctuaciones muy grandes, incluso negativas en los primeros quinquenios, lo que se explica por la compra que los monjes hicieron a los Ochoa, a quienes se la habían aforado años antes, y las inversiones que tuvieron que realizar a continuación. Si computamos solo 
los años 1755 a 1794, es decir los mismos de la ferrería de Quintá los beneficios alcanzan un 20,21\%, aún bastante inferior a los de esta última, que fueron del 30,08\%. Frente a los 15.518 reales de media anual de beneficios de Quintá, Villanueva de Oscos obtiene 12.236 reales, pero en sus 158 años de funcionamiento solo 9.141 reales. Creo que la razón habría que buscarla en el coste mayor de la vena vizcaína que utilizaba, que a causa del transporte era más del doble que el de la ferrería de Quintá, e incluso en el del carbón en una zona ya muy deforestada.

\section{CUADRO XXXII. INGRESOS, GASTOS Y BENEFICIOS DE LA FERRERÍA DE VILLANUEVA DE OSCOS (en reales)}

\begin{tabular}{|l|l|l|l|l|l|}
\hline AÑOS & INGRESOS & GASTOS & BENEFICIOS & $\begin{array}{l}\% \\
\text { BENEFICIOS/ } \\
\text { INGRESOS }\end{array}$ & $\begin{array}{l}\text { ÍNDICE } \\
\text { B. 100: 24,1 } \\
(1720-1744)\end{array}$ \\
\hline $1677-79$ & 101.010 & 78.833 & 22.177 & 21,95 & 90,8 \\
\hline $1680-84$ & 98.082 & 71.899 & 26.183 & 26,69 & 110,5 \\
\hline $1685-89$ & 63.025 & 55.429 & 7.596 & 12,05 & 49,8 \\
\hline $1690-94$ & 69.767 & 82.023 & -12.256 & $-17,56$ & $-72,7$ \\
\hline $1695-99$ & 122.872 & 138.634 & $-15 \cdot 762$ & $-12,82$ & $-52,3$ \\
\hline $1700-04$ & 87.599 & 90.654 & -3.055 & $-3,48$ & $-14,4$ \\
\hline $1705-09$ & 115.583 & 122.235 & -6.648 & $-5,75$ & $-23,8$ \\
\hline $1710-14$ & 127.269 & 95.117 & 32.152 & 25,26 & 104,5 \\
\hline $1715-19$ & 133.853 & 110.475 & 23.377 & 17,46 & 72,2 \\
\hline $1720-24$ & 201.035 & 165.256 & $35 \cdot 779$ & 17,79 & 73,6 \\
\hline $1725-29$ & 212.878 & 155.628 & 57.250 & 26,89 & 111,3 \\
\hline $1730-34$ & 268.959 & 181.643 & $87 \cdot 316$ & 32,46 & 134,4 \\
\hline $1735-39$ & 217.180 & 167.699 & 49.481 & 22,78 & 94,32 \\
\hline $1740-44$ & 222.947 & 176.457 & 46.490 & 20,85 & 86,3 \\
\hline $1745-49$ & $227 \cdot 353$ & 202.634 & 24.719 & 10,87 & 45,0 \\
\hline $1750-54$ & 289.235 & $197 \cdot 333$ & 91.902 & 31,77 & 131,5 \\
\hline $1755-59$ & 238.829 & 187.717 & 51.112 & 21,40 & 88,6 \\
\hline $1760-64$ & 299.635 & 220.253 & 79.382 & 26,49 & 109,6 \\
\hline & & & & & \\
\hline
\end{tabular}




\begin{tabular}{|l|l|l|l|l|l|}
\hline $1765-69$ & 274.438 & 223.521 & 50.917 & 18,55 & 76,8 \\
\hline $1770-74$ & 233.101 & 183.921 & 49.180 & 21,09 & 87,32 \\
\hline $1775-79$ & $245 \cdot 410$ & 200.974 & 44.436 & 18,10 & 74,9 \\
\hline $1780-84$ & 339.124 & 269.202 & 69.920 & 20,61 & 85,3 \\
\hline $1785-89$ & 300.907 & 257.254 & 43.653 & 14,50 & 60,0 \\
\hline $1790-94$ & 429.114 & 340.602 & 88.512 & 20,62 & 85,3 \\
\hline $1795-99$ & 634.038 & 459.328 & 174.710 & 27,55 & 114,0 \\
\hline $1800-04$ & 442.675 & $375 \cdot 381$ & 67.294 & 15,20 & 62,0 \\
\hline $1805-09$ & 481.934 & 389.137 & 92.797 & 19,25 & 79,7 \\
\hline $1810-14$ & 328.916 & 264.453 & 64.463 & 19,59 & 81,1 \\
\hline $1815-19$ & 257.827 & 254.250 & 3.577 & 1,38 & 4,8 \\
\hline $1820-24$ & 14.336 & 27.566 & -13.230 & $-92,24$ & $-381,9$ \\
\hline $1825-29$ & 300.000 & 256.087 & 44.012 & 14,67 & 60,7 \\
\hline $1830-35$ & 367.630 & 300.748 & 66.883 & 18,19 & 74,2 \\
\hline TOTAL & 7.746 .659 & 6.302 .345 & $1.444 \cdot 314$ & 18,64 & 77,1 \\
\hline
\end{tabular}

Elaboración propia a partir de los datos de Daniel Paz González 1991): El monasterio de Villanueva de Oscos: de la Reforma a la Exclaustración. Oviedo, p. 157.

Los beneficios de las ferrerías benedictinas de Montes y Samos nos son conocidos por varios Estados de Cuentas de los siglos XVIII y XIX (CUADRO XXXIII). Mientras que a la ferrería de Linares se le computan 15.000 reales de beneficio en 1753, en los dos Estados de Cuentas de 1777 a 1785, la media de esos ocho años es de 12.060 reales, lo que no entraña una gran diferencia. La de Pombriego era mucho más productiva y seguramente más rentable, como vemos en el cuadro, con cifras superiores a los 80.000 reales. Respecto de las ferrerías de Samos no hay datos para poder compararlas todas, pero sí las de Gondriz, Santalla y Pallares. A Gondriz le adjudica el Catastro una media de 11.000 reales, mientras que los Estados de Cuentas del monasterio hablan de 6.825 reales de media anual en ocho años; la de Santalla, el Catastro ofrece un rendimiento de 3.500 reales y el Estado de Cuentas del siglo XVIII 8.277,5; la de Pallares, el Catastro cifra su rendimiento en $\mathbf{1 . 0 0 0}$ reales y el Estado de Cuentas lo aumenta a 2.950,75 reales de media. Las más rentables, sin embargo, eran las de San Vicente de Leira, Rugando y Quiroga. 
¿Qué significaban estas cantidades en el total de los ingresos de estas abadías? No lo sabemos con exactitud, pero de Samos conocemos en dos momentos, 1785 y 1824, el porcentaje de dinero que representaba respecto al total recibido. Así en 1785 las herrerías ingresaron 309.803 reales de los 839.356 reales, lo que supone un 36,90\%; y en 1824 (después de los problemas del Trienio, con la desamortización de algunas ferrerías) el 9,28\%, es decir 77.848 frente a un total de 838.764 reales ${ }^{1002}$, lo que quiere decir que estas sufrieron más en esos años, algunas estuvieron paradas e incluso la de Pallares fue desamortizada y vendida al marqués de Valladares en 476.750 reales ${ }^{1003 .}$

CUADRO XXXIII. BENEFICIOS DE LAS FERRERÍAS DE MONTES Y SAMOS (en reales)

\begin{tabular}{|l|l|l|l|l|l|l|l|l|}
\hline FERRERÍAS & $\begin{array}{l}1777^{-} \\
1781\end{array}$ & $\%$ & $\begin{array}{l}1781- \\
1785\end{array}$ & $\%$ & $\begin{array}{l}1818- \\
1821\end{array}$ & $\%$ & $\begin{array}{l}1821- \\
1824\end{array}$ & $\%$ \\
\hline MONTES & & & & & & & & \\
\hline Linares & 48.707 & 36,3 & 47.784 & 36,1 & 35.011 & 27,1 & 4.288 & 10,7 \\
\hline Pombriego & 85.263 & 63,6 & 84.562 & 63,9 & 93.977 & 72,8 & 35.489 & 92,2 \\
\hline TOTAL & 133.970 & 100 & 132.310 & 100 & 128.988 & 100 & 39.777 & 100 \\
\hline & & & & & & & & \\
\hline SAMOS & & & & & & & & \\
\hline S. Vicente & 90.480 & 31,7 & 108.500 & 35,0 & 47.000 & 24,4 & 31.023 & 34,1 \\
\hline Rugando & 86.000 & 30,1 & 96.000 & 30,9 & 62.000 & 32,3 & 20.840 & 22,9 \\
\hline Quiroga & 42.000 & 14,7 & 36.000 & 11,6 & 14.000 & 7,2 & 13.202 & 14,5 \\
\hline Santalla & 28.720 & 10,0 & 37.500 & 12,1 & 29.500 & 15,3 & 1.600 & 1,7 \\
\hline Gondiz & 35.000 & 12,2 & 19.600 & 6,3 & 20.225 & 10,5 & 14.357 & 15,8 \\
\hline Pallares & ------ & & 11.803 & 3,8 & 19.170 & 9,9 & 9.170 & 10,0 \\
\hline TOTAL & 285.180 & 100 & 309.839 & 100 & 191.895 & 100 & 90.822 & 100 \\
\hline
\end{tabular}

FUENTE: Archivo del monasterio de Silos. Documentos de la Congregación de Valladolid. Estado General de Cuentas, ff. 148 y ss. y 378 y ss..

1002 M. ARIAS (1992): Historia del monasterio de San Julián de Samos. Samos, p. 320 y 362. 1003 C. GONZÁLEZ (1994): Ob. cit., p. 170 
De otras ferrerías contamos con los datos del Catastro y Cornide para la segunda mitad del siglo XVIII. En esas cantidades hay dos datos diferentes: en algún caso, lo que hallamos son datos brutos de producción, como en las ferrerías de Arnado, Pontepetre (87.750 reales), Valcarce (71.250 rs.) y Bueyes (20.930) rs.; en el resto son rendimientos netos, aunque probablemente haya mucha ocultación (van de los 20.930 rs. de Villanueva de Oscos, 16.00o rs. de la de Froseira y 15.000 rs. de la de Linares a poco más de 1.000 rs. en las de Ferreiós y Santalla). Solo en el caso de la ferrería de Lor se especifica que la producción de los 1.000 quintales, vendidos a 47 reales, generaron 47.000 reales brutos, pero que el rendimiento neto fue solo de 1.100 reales, lo que supone únicamente un 2,34\% que es una cantidad muy pequeña ${ }^{1004}$. En la ferrería de Bueyes, lo hemos dicho, hacia el año 1753 produjo 455 quintales que a $46 \mathrm{rs} /$ quintal, que fue el precio al que se vendieron, supusieron unos ingresos de 20.930 rs. vn. Como los gastos se cifraron en 14.560 rs. los beneficios fueron de 6.370 rs., un 30,43\% del total. Datoli, hablando de las ferrerías bercianas a finales del siglo XVIII, dice que cada una de ellas "da de ganancia a su dueño desde quatro a seis mil ducados al año"1005, es decir, de 44.000 a 66.000 reales, cifras muy importantes.

En el siglo XIX todavía fueron muy rentables y por eso se construyen tantos nuevos artefactos entre 1835 y 1855 , como hemos visto. Las benedictinas lo demuestran en números, pese a que en el CUADRO XXXIII vemos cómo su producción se reduce en los años difíciles del Trienio Liberal (1820-1823), pero el resto se recupera. Después de 1860, el encarecimiento del carbón y la competencia de los hornos altos provocaron el cierre de muchas de estas instalaciones, pero las que se mantuvieron no dejaron de ser rentables, siendo sus beneficios parte sustancial de las rentas de unas familias que se ennoblecen durante el reinado de Isabel II (caso de los marqueses de Ombreiro, Torresnovaes, etc.).

\footnotetext{
1004 Quizá estos pequeños beneficios sean sólo coyunturales, probablemente por alguna obra de reparación que no se cita, pues las ferrerías dejaban entre un 18 y un 30\% de beneficios anuales; o sencillamente es falsa.

1005 DATOLI, p. 56
} 
De la ferrería de Llamas, en La Cabrera, que se construyó en 1859 conocemos la contabilidad de un año completo de finales del siglo XIX que puede arrojar alguna luz sobre la complejidad de la misma y también su interés para los propietarios (CUADRO XXXIV) ${ }^{1006}$. El tiempo de trabajo se computa desde el mes de octubre (los cinco oficiales, anota el administrador Domingo Parada, llegan el 13 de octubre de 1880) hasta el mes de agosto siguiente. Los ingresos son en su mayor parte por la venta de hierro, tanto en bruto (374 quintales a 95 rs/q. suponen 35.530 rs.), como el de las rejas, batederas, etc. que fabricaron los mazuqueros en el verano; pero también hay pequeñas cantidades por la venta de vino y centeno a los arrieros, carboneros, etc., e incluso por el peaje por pasar por el puente sobre el río Cabrera. Los gastos, que anota minuciosamente, se refieren a la compra de vena (2.096,65 rs.) y carbón (9.829,47 rs.), los salarios de los oficiales (soldada -2.06o, 9 rs. y quintalaje $1.776,50$ rs.-, y vino cuando hacen trabajos extraordinarios en la presa, poner la tobera, arreglar el mazo), los gastos de la familia y criados. Los beneficios son un $33,8 \%$, lo que significa una cantidad muy semejante proporcionalmente a las del siglo XVIII.

CUADRO XXXIV.- LA FERRERÍA DE LLAMAS 1880/1881

(en reales)

\begin{tabular}{|l|l|l|c|c|}
\hline MESES & INGRESOS & GASTOS & BENEFICIOS & $\begin{array}{l}\text { \% BENEFICIOS/ } \\
\text { INGRESOS }\end{array}$ \\
\hline $\begin{array}{l}\text { OCTUBRE- } \\
\text { DICIEMBRE }\end{array}$ & $5.471,04$ & $5.409,90$ & 61,14 & 1,1 \\
\hline ENERO & 467,19 & 261,46 & 205,73 & 44,0 \\
\hline FEBRERO & $3.122,35$ & $2.158,12$ & 946,23 & 30,3 \\
\hline MARZO & $5.849,24$ & $2.832,89$ & $3.016,35$ & 51,5 \\
\hline ABRIL & $11.551,95$ & $8.624,82$ & $2.927,13$ & 25,3 \\
\hline MAYO & $9,589,13$ & $6.826,67$ & $2.762,46$ & 28,8 \\
\hline JUNIO & $5.621,36$ & $2.749,64$ & $2.871,72$ & 51,0 \\
\hline JULIO & $4.540,34$ & $1.845,09$ & $2.695,25$ & 59,3 \\
\hline
\end{tabular}

${ }^{1006}$ Documentación privada que tenía Manuel Rodríguez, maestro de Toral de los Vados, de su abuelo, que gentilmente me proporcionó. 


\begin{tabular}{|l|l|l|c|c|}
\hline AGOSTO & $4.669,54$ & $2.954,90$ & $1.714,64$ & 36,7 \\
\hline TOTAL & $50.882,13$ & $33.663,49$ & $17.200,65$ & 33,8 \\
\hline
\end{tabular}

FUENTE: Archivo privado de Manuel Rodríguez (copia del autor).

Elaboración propia

Lo que resulta más complicado de determinar es qué cantidad de ese 30 por ciento se llevaban propietarios y arrendatarios. Como hemos dicho en otro capítulo, una rentabilidad del 10 por ciento era normal para los propietarios, aunque probablemente varió de acuerdo con los siglos; de hecho hemos visto en el caso de las ferrerías del Bierzo porcentajes en torno al 15 y 17 por ciento, lo que para Munárriz era excesivo. Si eso fuera sí, la rentabilidad de los arrendatarios, que eran realmente quienes corrían con los gastos de producción más cuantiosos habría que computarlos en menos del 20 por ciento, quizás algo más. Tal vez por eso, sobre todo en los siglos XVIII y XIX, muchos propietarios las preferían explotar por medio de administradores. Como hemos dicho, los salarios de los ferrones y los pagos a venaqueros y transportistas, aunque costes de producción, también era riqueza social para las personas y las comarcas donde existían este tipo de instalaciones fabriles. 


\section{VI.- LA COMERCIALIZACIÓN DEL HIERRO. MAZOS Y HERREROS}

El objetivo de la actividad siderúrgica que hemos descrito, la producción de hierro en las ferrerías, fue lógicamente su venta a mazos y martinetes, a fraguas y talleres artesanales para, a partir de los tochos, barras o pletinas, elaborar útiles de todo tipo y, en definitiva, un producto final necesario para su clientela. Todo ello con el fin de abastecer el mercado y obtener un beneficio. La comercialización del hierro es, por tanto, una parte sustancial de la historia de la siderurgia, que afecta a los comerciantes y arrieros; pero que beneficia al conjunto de la sociedad, al ofrecer no solo el hierro en bruto sino una gama amplia de productos artesanales que, sin la menor duda, mejoraron la calidad de vida de las gentes que los consumieron. La comercialización, por ello, se inicia en las ferrerías pero se difunde luego a otros ámbitos productores y, en definitiva, por el territorio que constituyó su hinterland, que en este caso fue todo el noroeste, algunas zonas de la meseta de Castilla y León e incluso el norte de Portugal.

Los comerciantes jugaron probablemente un papel importante en la producción de hierro, pero sobre todo en su comercialización. En ese sentido, las ferrerías deben de incluirse en una forma de verlagsystem, aunque no tanto por la financiación de la producción -que también, como hemos visto anteriormente-, como por el papel de los comerciantes en la venta del producto. Esta se hacía directamente como hierro en bruto o bien con una primera transformación. Una parte muy pequeña del hierro en bruto se elaboraba en las propias ferrerías en clavazón, herraje, hierro putrical y acero; pues como ya dijimos, en unos casos las había que contaban con un mazo auxiliar para este fin, o bien la propia ferrería elaboraba hierro en los periodos en los que no lo fundía, normalmente en el verano, si disponía de agua suficiente. Sin embargo, la mayor parte se vendía a los mazos y martinetes de los alrededores, y también a las fraguas y herreros de un hinterland mucho más vasto. Este comercio estaba en gran parte mediatizado por arrieros y comerciantes. 
Para esa venta directa, las ferrerías contaban en determinadas villas y ciudades con lonjas o depósitos; en otros casos eran los arrieros y comerciantes quienes lo adquirían en bruto, como hierro en barras o banda, y también como vergallón, cuadradillo, etc., que luego comercializaban por ámbitos más extensos. Lo normal fue que los arrieros solo lo transportaran por cuenta ajena, aunque hubo arrieros, sobre todo maragatos, que lo comercializaron y lo distribuyeron por todo el amplio hinterland que recorrían con sus recuas. Sin embargo, al menos desde el siglo XVII, los arrieros son normalmente transportistas que lo transportan por cuenta ajena, para comerciantes con tienda abierta en villas y ciudades, los cuales abastecen de hierro a las pequeñas fraguas y herreros comarcanos. Estos, a su vez, venden en sus propios establecimientos el hierro elaborado o frecuentan las ferias de la región con sus mercancías, como ya veremos; se trata, al revés que con el hierro en bruto, de un pequeño comercio que abastece de útiles domésticos, aperos de labranza y quincallería a los vecinos y consumidores locales e incluso regionales.

Un papel muy importante en el comercio del hierro lo jugó la propia Administración, sobre todo en época de los Borbones, no solo por leyes que permitieron la venta del hierro a pie de fábrica sin aranceles ${ }^{1007}$, sino por la creación de arsenales, como el del Ferrol o la maestranza de La Coruña, que fueron grandes consumidores de este, especialmente como clavazón ${ }^{1008}$. Esto en parte explica el gran número de herreros que encontramos en el siglo XVIII en la zona de los Oscos y Ribadeo, en los que se citan a varios miles, e incluso proyectos de construcción de nuevas ferrerías como los que llevan a cabo algunas compañías empresariales, como la Compañía de la Vega de Ribadeo, o experiencias como las de la fábrica de Sargadelos de Antonio Raimundo Ibáñez. Pero ni siquiera estas nuevas construcciones fueron capaces de abastecer ese

\footnotetext{
1007 AHN. Órdenes Generales de Rentas, libro 37, exp. 4939: 1793, julio, 26 El rey "ha resuelto que las ventas de yerro que se hagan al pie de las ferrerías de las provincias de Castilla y León de las labranzas de las mismas, sean exentas por ahora de los derechos de alcabalas y cientos; pero de las ventas que se executen fuera de las mismas ferrerias, ya por los dueños de ellas, o ya por los herreros, cerrageros o qualesquiera otra persona, se exija en todos los pueblos de dichas provincias de Castilla y León el quatro por ciento conforme de lo dispuesto en los reglamentos generales del año 1785 para los efectos de tratos y oficios en general".

${ }^{1008}$ Conocemos el pliego de condiciones suscrito por la Compañía de la Vega de Ribadeo para el surtimiento de herrajes, clavazones y herramientas que puedan necesitar los arsenales de La Habana y Mahón, u otro cualquiera, del año 1789. Cit. J. LÓPEZ y A. GRAÑA (1998): Ob. cit., p. 137-139.
} 
mercado, por lo que la importación de grandes cantidades de hierro vasco y cántabro se hizo absolutamente necesaria para esta pequeña industria artesanal ${ }^{1009}$.

\section{EL COMERCIO DEL HIERRO}

Desde el siglo XVI, una parte del hierro del noroeste, en barras o en bruto, era exportado hacia Castilla y León e incluso en ciertas épocas hacia Portugal, Sevilla y América; pero la mayoría era transformado ya en las propias ferrerías o más frecuentemente en los mazos y fraguas de la región estudiada. El hierro se exportaba normalmente en barras, banda, vergajón, cuadradillo, plancha y planchuela ${ }^{1010}$; pero algunas ferrerías transformaban una pequeña parte en clavazón, herraje y utensilios domésticos. Por ejemplo el Catastro de Ensenada señala que la de San Vicente de Leira, en los años de menor venta, convertía 75 quintales en herraduras, de los que obtenía seis docenas por quintal, a precio de 5 rs./docena; y 15 quintales en clavos de herraje (5.00o clavos por quintal, que vendía a $16 \mathrm{rs}$./millar). Pero esos 90 quintales no representaban más que un $6 \%$ de la producción total de la ferrería ${ }^{1011}$. La de Quintá (CUADRO XXXV) producía sobre todo hierro en bruto -en una proporción respectiva de 1 a 3-, además de herraje y clavazón, y en cantidades casi insignificantes acero y hierro putrical. En esta ferrería la media de los inventarios efectuados en otoño, el valor de los productos almacenados previo a la venta era de $65,19 \%$ de hierro, $17,93 \%$ de clavazón y 16,87\% de herraje ${ }^{1012}$. Probablemente esa era la proporción de la mayoría de las ferrerías, quizá con un mayor porcentaje de hierro en bruto (hierro en banda o barras).

\footnotetext{
1009 J. CARMONA (1993): "Sargadelos en la historia de la siderurgia española". Revista de Historia Industrial, $\mathrm{n}^{\mathrm{O}} 3$, p. 12

1010 J. LÓPEZ y A. GRAN̂A (1998): Ob. cit., p. 144. Informe de 1833 para la Real Junta de Aranceles realizado por Francisco Lombán y Juan Méndez de Vigo, miembros de la Sociedad Económica de Amigos del País de Asturias sobre las ferrerías asturianas: "No es posible fijar el número de quintales a cada clase de las que señala la Real Junta de Aranceles; ni la nomenclatura y formas son correspondientes. Barras y planchuelas se nombran bandas $y$ plantina; y de éstas solo se trabaja la parte del yerro duro o acero natural que se emplea en erramientas e instrumentos de labores agrícolas, achas, oces y demás de esta clase. Los tochos se llaman aquí puntas y es la forma más común porque reune la cantidad suficiente para formar una gran plancha de caldera o caldero según la expresión del país". ${ }_{1011}$ CATASTRO DE ENSENADA. R. G. Villamartín de Valdeorras. ${ }_{1012}$ V. M. MIGUÉS (1996): Ob. cit., p. 228 y nota 72
} 
CUADRO XXXV. VENTA DE HIERRO DE LA FERRERÍA DE QUINTÁ

\begin{tabular}{|l|l|l|l|l|l|l|l|l|l|l|l|}
\hline AÑO & \multicolumn{2}{l}{ BANDA } & \multicolumn{2}{l|}{ PUTRICAL } & \multicolumn{2}{l|}{ HERRAJE } & \multicolumn{2}{l|}{ CLAVOS } & \multicolumn{2}{l|}{ ACERO } \\
\hline & C & P & C & P & C & P & C & P & C & P \\
\hline 1773 & 148 & 62 & 0,5 & 18 & 66 & 11,5 & 34,2 & 20 & & \\
\hline 1774 & 275 & 62 & 9 & 18 & 231 & 11,5 & 71,5 & 20 & 109 & 1 \\
\hline 1775 & 57 & 66 & 6 & 18 & 202,5 & 12 & 121 & 20 & 150 & 1 \\
\hline 1776 & 212 & 66 & 7 & 18 & 179 & 12 & 63 & 20 & 123 & 1 \\
\hline 1777 & 67 & 66 & 19 & 18 & 256 & 12 & 235 & 20 & 79 & 1 \\
\hline 1778 & 41 & 66 & --- & --- & 33 & 12 & 145 & 20 & 494 & 1 \\
\hline 1779 & --- & --- & --- & --- & --- & --- & --- & --- & --- & --- \\
\hline 1780 & 176 & 68 & 1 & 18 & 21 & 12,5 & 92 & 20 & 1033 & 1 \\
\hline 1781 & 39 & 68 & 6 & 18 & 98 & 12,5 & 39 & 20 & 496 & 1 \\
\hline 1782 & 116 & 68 & 5 & 18 & 228 & 12,5 & 97 & 20 & 318 & 1 \\
\hline 1783 & 71 & 71 & 13 & 19 & 181 & 13 & 136 & 21 & 276 & 1 \\
\hline 1784 & 181 & 77 & 3 & 19 & 4 & 13 & 73 & 22 & 250 & 1 \\
\hline 1785 & 49 & 80 & 14 & 22 & 26 & 14 & --- & --- & --- & --- \\
\hline 1786 & 14 & 90 & --- & --- & --- & --- & 7 & 26 & --- & --- \\
\hline 1787 & 27 & 105 & 9 & 28 & 273 & 18 & 86 & 28 & 41 & 1,1 \\
\hline 1788 & 25 & 102 & 2 & 27,5 & 59 & 18 & 19 & 27,5 & 27 & 1,1 \\
\hline 1789 & 47 & 102 & 11 & 27,5 & 72 & 18 & 6 & 40 & & --- \\
\hline
\end{tabular}

C: cantidad: Banda en quintales, putrical y herraje en docenas, clavos en millares, acero en libras.

P: precio: hierro en banda en reales por quintal, putrical y herraje en reales por docena, clavos

en reales por millar, acero en reales por libra.

FUENTE: AHRG. Hombreiro. Libro de cuentas de la ferrería de Quintá.

Elaboración propia

La documentación de los siglos XVI y XVII permite detectar la importancia de las exportaciones de hierro en dirección a Sevilla y otros puntos de la península, de ferrerías del concejo de Castropol pero también de Ibias y otras zonas más al interior ${ }^{1013}$, aunque la mayor parte se distribuía en la región, como hacía el monasterio de Lorenzana, que hacia 1600 vendía prácticamente

1013 P. SAAVEDRA (1982): Ob. cit., p. 532, en que cita como ejemplos de cargas de hierro en los protocolos de Ribadeo, los del escribano Pedro García Bermúdez, año 1638, fo 32. 
toda su producción a los herreros de la zona de Taramundi1014. También en ocasiones el hierro asturiano se vendió en Francia ${ }^{1015}$ y en otros lugares de Europa $^{1016}$. Un ejemplo del comercio a larga distancia lo encontramos en Juan Núñez de Pardo y su hijo Pedro, vecinos de Castropol, que con un barco de su propiedad trafican a comienzos del siglo XVII con Portugal y Andalucía. Eran además copropietarios de las ferrerías de La Veguina y Abres ${ }^{1017}$. En las cuentas de su herencia, que realizan sus albaceas en 1637, se habla de que importaban a Asturias aceite y vino y llevaban a Andalucía madera y hierro. Del total de las deudas a su favor de mercaderes de Sevilla (Bartolomé López Pineyro, Antonio Rodríguez de Cancio, Bernabé Pérez), que superan los 15.00o reales, más de 10.00o los adeudan los herederos de Bernal Pérez "mercader que fue de la ciudad de Sevilla". También hay débitos en su contra del mercader Alonso Álvarez de Vilarello, del Puerto de Santa María e incluso de un flamenco1018. Probablemente algunas partidas de ese hierro se embarcaban en Sevilla para América mezclado con hierro vasco.

El comercio más intenso, sin embargo, debió realizarse por la propia región, Castilla y León e incluso Portugal. José Cornide, hacia 1780, señala que de los 20.000 quintales de hierro producidos de media por un quinquenio en Galicia y el Bierzo, 5.00o pasan al reino de Portugal (25\%), 7.000 al de León y Castilla (35\%) y los 8.000 restantes se consumen en Galicia, lo que significa que en la región solo quedaba el $40 \%$ mientras se exportaba el 60\% restante ${ }^{1019}$. Ahora bien, no todas las ferrerías, como hemos dicho, vendían lejos su hierro,

\footnotetext{
1014 P. SAAVEDRA(1982): Ob. cit., p. 531

1015 En un acta de la Junta del Principado de Asturias de 22 de abril de 1644 (Actas, tomo IV) se habla de una Cédula Real que permite a los naturales de Asturias, ante las cortas cosechas y el elevado precio del pan de Castilla, el poder traer de Francia hasta la cantidad de 10.000 fanegas de pan " $y$ en pago de ellas podáis dar la mitad en hierro y la otra mitad en otros frutos de la tierra".

${ }^{1016}$ En otra acta de 5 de abril de 1632 (Actas, tomo III), se habla de un auto del gobernador que para pagar los 6.000 ducados que cuestan cien soldados, entre otros impuestos, se pueda poner uno "en el yerro que en el se labra, que se saca fuera".

1017 En el testamento de Juan Nuñez de Pardo, de 1633, afirma ser "onbre que trato en madera, fierro y otras cossas en esta tierra y en los rreynos de Andalucía y Portugal” (A.Ch.V. Pleitos civiles. Pérez Alonso (f), caja 2682,2).

1018 A.Ch.V. Pleitos civiles. Pérez Alonso (f), caja 2682,2

1019 Cit. por C. GONZÁLEZ (1994): Ob. cit., p. 125. Clodio cree que esos quintales son de 155 libras, es decir, de $71,3 \mathrm{~kg}$. lo que arroja una producción de 1.426.00o kg. de los que se exportan $855.600 \mathrm{~kg}$.
} 
porque en sus alrededores contaban con mazos y fraguas que lo trabajaban ${ }^{1020}$. Es decir, que el hierro abastecía a los mazos y fraguas de los alrededores y lo que se exportaba eran, además de hierro en bruto, productos manufacturados, como clavazón, herraduras y utensilios domésticos. Esta era la realidad del comercio del hierro: una parte se comercializaba en bruto hacia fuera, otra la trabajaban los mazos y herreros cercanos a las ferrerías, y lo que se vendía en ferias y comercios eran los productos ya elaborados. Incluso, a veces, las propias necesidades de la región exigieron importar hierro vasco y cántabro para abastecer a los mazos y fraguas de Asturias y Galicia, cuyo número llegó a superar los sesenta mazos y el de fraguas algunos millares, como veremos.

La comercialización del hierro en bruto la realizaban directamente las propias ferrerías o en mayor proporción lo hacían los arrieros locales y maragatos, pero sobre todo los comerciantes de los núcleos urbanos más importantes: Vivero, Ribadeo, Avilés, Monforte, Ponferrada, Villafranca, Orense, La Bañeza y León, que solían tener tiendas abiertas para dicha comercialización. Los propietarios y renteros vendían directamente su hierro ya en la misma ferrería, ya en lonjas propias situadas en lugares estratégicos. Muchas de las ventas se hacen directamente en la fábrica, aunque fueran luego arrieros quienes lo transportaban a sus lugares de destino, frecuentemente mercaderes o directamente a los herreros; a aquellos en grandes cantidades, a estos en pequeñas partidas ${ }^{1021}$. A veces los propios arrendatarios se desplazaban a las ferias a vender su hierro ${ }^{1022}$, aunque esto no era lo más frecuente, pese a que lo hemos visto alguna que otra vez en el siglo XVI'1023.

\footnotetext{
1020 Por ejemplo, un documento del monasterio de Villanueva de Oscos, señala que en el siglo XVIII el hierro de su ferrería "se consume en el Coto y lugares inmediatos (donde hay siete mazos y más de 150 fraguas), pero el clavazón y calderos lo llevan los arrieros para los reinos de Galicia, Castilla y varias partes de este Principado, y vienen a dichas fábricas a buscar los géneros". En D. PAZ (1991): Ob. cit., p. 151

${ }_{1021}$ AHPLU: 3573/1 (1551): Carta de obligación de Pedro de Carnoza, rendero de la ferrería de Brabos, "que es del $q^{\circ}$ de bibero, que soy presente, que daré a Fernan Díaz, mercader vecino de la villa de bibero", diez quintales de hierro "labrado de banda las dos tercias e una tercia de bergallón, y que la banda sea de tres cavas, y a de ser bueno", a precio cada quintal de 14 reales; el mercader de Vivero Juan García de Castrillón acuerda en 1583 con el arrendatario de la ferrería de Pesqueira, Francisco Sánchez Vidarte, para que le venda 30 quintales de hierro pletina (P. SAAVEDRA (1985): Ob. cit., p. 329, nota 87; el rendero de la ferrería de Rial vende en 1584 al vecino de Zamora Nicolás Valderas, probablemente también un mercader, 200 quintales de hierro (AHPL. P.N.: caja 2872); .

${ }_{1022}$ Como sabemos que hizo en 1581 Juan Beltrán de Achega, rendero de Ferreirós, "con quatro cargas de fierro y herrage a vender a la feria de Orense" (AHRG. R.A.: 2837/19).
} 


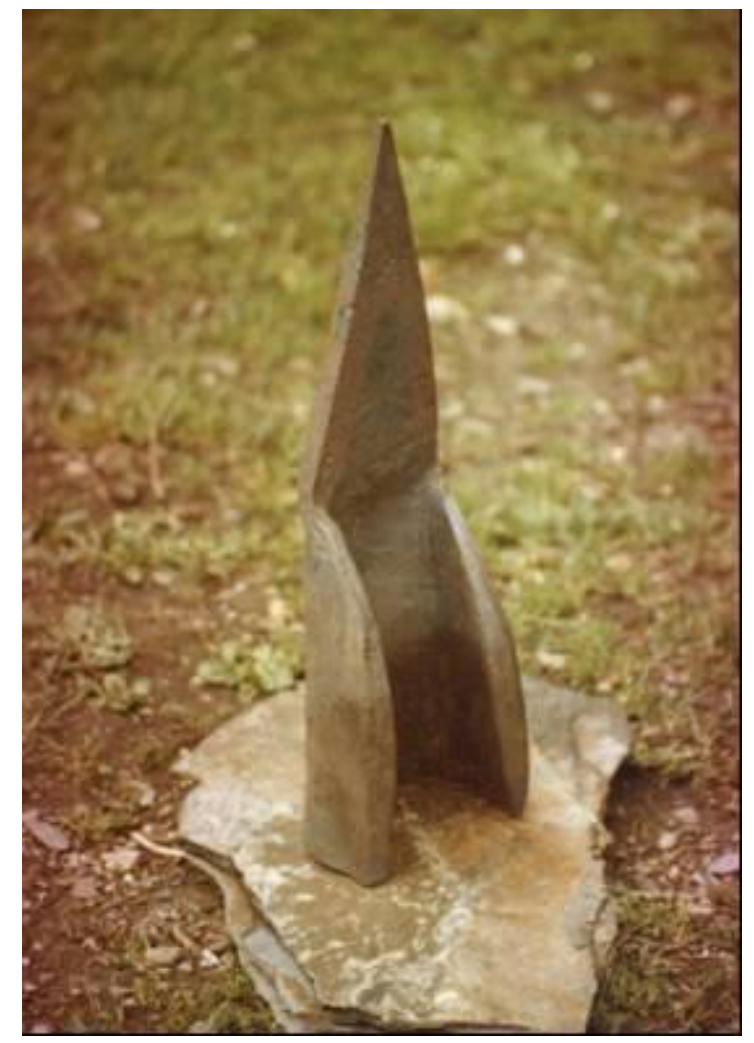

En todas las ferrerías solía haber un

libro de tratantes, en el que se anotaban las cantidades y los compradores, pero eso no impedía que las ventas de hierro se realizaran por medio de contratos de obligación firmados ante notario ${ }^{1024}$. Las cantidades más grandes las adquirían normalmente comerciantes, mientras que los herreros compraban generalmente pequeñas partidas ${ }^{1025}$. De la ferrería de Tejedo de Ancares

1023 AHPL. P.N.: caja 2849: El vizcaíno Miguel Ortiz, rendero de Ferreirós, otorga en 1578 en Ponferrada un poder a su yerno Juan de Lesaca para cobrar 100 quintales de hierro y 12.000 clavos en Cacabelos, probablemente vendido en sus famosas ferias anuales.

1024 Don José Martínez de la Fuente, sobrino del arrendatario de Arnado, don Francisco Antonio Guerra Donís, afirma contar con un poder de su tío para firmar contratos de obligación, por lo que se obliga en $175^{2}$ con el leonés don Francisco Fernández San Martín, a venderle 350 quintales de hierro a 61 rs./quintal, que le entregará en dos veces (el día de año nuevo de 1753 y por san Juan de junio) en la ferrería de Arnado a su cuenta y riesgo (AHPL. P.N.: caja 617). Al año siguiente doña Manuela Herrero y su yerno, vecinos de León, se obligan a pagar al mencionado arrendatario de Arnado 13.300 rs. vn. por 200 quintales de hierro, a 66 rs./quintal, que les entregará en este caso en León de cuenta y riesgo del dicho Guerra Donís, y de ahí quizá la diferencia en el precio de 61 a 66 rs./quintal (AHPL. P.N.: caja 618). En 1810 Atanasio Fernández Rey, de Ponferrada, se obliga en enero a pagar al administrador de la ferrería de Montes, fray Pablo Rivera, 10.000 reales "de diversas partidas de fierro que le saque de dicha herrería al fiado"; y en marzo hace lo mismo Santiago Álvarez en esta ocasión por 2.220 reales que su padre quedó debiendo (AHPL. P.N., caja 2792).

${ }_{1025}$ Juan de la Iglesia, herrero de Pereje, dice en 1789 que hará año y medio que sacó de la ferrería de Montes doce quintales de hierro a 110 rs./quintal, pero que por lo calamitoso de los tiempos no pudo pagarlo en plazo por lo que se obliga ahora, bajo hipoteca de una viña y linar, a pagárselos a fray Manuel Álvarez, administrador de la ferrería (AHPL. P.N.: caja 3465). En 1797, siendo administrador de la ferrería de Órreos el presbítero don Juan Castrillón, el herrero de Villafranca Antonio Blanco, alias Meixaus, se obliga a pagarle 1.518 reales y 12 mrs. que le debe de cuentas "dimanadas del yerro fiado que en diferentes ocasiones y porciones le he sacado de la dicha Herreria", para lo que hipoteca diferentes bienes entre ellos "la casa fragua cubierta 
conocemos numerosas escrituras de obligación de los años 1811 a 1814 de algunos herreros por pequeñas partidas de hierro ${ }^{1026}$. Sólo en los días 13, 14 y 15 de mayo de 1830 se protocolarizan 36 escrituras de obligación a favor de Ramón Ovalle, arrendatario de la ferrería de Arnado, por un valor de 22.616 reales igualmente por pequeñas partidas de hierro ${ }^{1027}$.

Algunas de estas partidas probablemente eran adquiridas por arrieros locales ${ }^{1028}$, aunque los más directamente relacionados con este comercio eran los maragatos, tanto en el Bierzo como en Galicia. Los arrieros normalmente eran transportistas por cuenta ajena, pero también adquirían el hierro y lo vendían a los mazos y fraguas de los alrededores, transportándolo incluso hasta la meseta castellana. En el interrogatorio del Catastro de Ensenada hay muchas referencias a estos arrieros locales ${ }^{1029}$. Los maragatos, por su parte, se movían por todo el norte con cargas de mayor consideración, arrostrando muchos peligros por la inseguridad y mal estado de los caminos. En 1755 en la declaración de testigos sobre el estado del real camino a Galicia por Valdeorras, uno de ellos se queja del mal estado y los peligros que presenta entre San Justo

de losa con sus fuelles, yunque, martillos, tenazas y demás aperos de ella y necesarios al ejercio y oficio que este otorgante tiene de Herrero" (AHPL. P.N.: caja 3337). Santos Bello, de Carucedo, se obliga en 1803 con el administrador de Pombriego, a pagarle 450 reales "procedidos de hierro que le dio al fiado" (AHPL. P.N.: caja 3635).

${ }^{1026}$ AHPL. P.N.: caja 3761: En 1811 Matías Abella, de Tejedo, se obliga con el administrador de la ferrería a pagarle 2.392 reales por hierro que le dio al fiado; 1813 Matías González, de Suertes, por la misma razón se obliga en 10.000 rs. (por 100 quintales); en ese mismo año dos herreros de San Martín de Moreda se obligan en 5.50o rs. (por 50 quintales); en 1814 Lorenzo Alonso, vecino de Espinaredo, se obliga en 10.315 rs., etc.

1027 AHPL. P.N.: 3677

${ }_{1028}$ Miguel Ortiz, "rendero que fue de la ferrería de Ferreirós y estante al presente en Ponferrada", en 1581 renueva el poder a su yerno Juan de Lesaca para que en su nombre cobre varias partidas de hierro en diferentes lugares del Bierzo y Galicia, que han llevado de su ferrería (AHPL. P.N.: caja 2849). El poder lo da para cobrar "primeramente ... quintales de hierro que tengo en la villa de Ponferrada e mas todo el hierro que tengo en la villa de Cacabelos y en el lugar de hesperante, lo que tengo en el dicho lugar que son quatro quintales e más doze myllares de clabo que tengo en el dicho lugar, y más todo el fierro que se allare en la mi casa de Baldomill e mas ocho quintales de fierro que tengo en la casa de Francisco López de la Hermida, tierra de Quiroga, e más el fierro que tengo en casa de sebastián Gómez de los Pedro, e ansi mismo podeis cobrar los setenta y ocho ducados que me deben Joan Beltrán de Hachega que pasó ante Francisco López y asi mismo todo lo que me debe Beltrán de Celaya rendero de las ferrerías de las Paleras". Como testigos firman Martín de Alduncín, rendero de la ferrería de Quiroga y Beltrán de Celaya rendero de Paleiras.

1029 Catastro de ensenada. R. G.: Feligresía de Santa María de Carballido (A Fonsagrada): Por ejemplo en esta feligresía "ay trece arrieros de los que diez (se dedican) al tráfico de fierro que llevan a vender a las ferias y mercados de las Riveras, bolviendo con cargas de vino". Regulan que en cada viaje -y hacen uno al mes- ganan 40 reales. 
y la Pontenova ${ }^{1030}$; en otras ocasiones protestan por los peajes que han de pagar o por los gastos en el arreglo de puentes ${ }^{1031}$.

Los arrieros maragatos eran gente fiable pero a veces remolona en los pagos, como se infiere de los numerosos poderes notariales que hemos visto para cobrarles deudas por hierro ${ }^{1032}$. Estos documentos muestran el hinterland de las ferrerías bercianas y gallegas por tierras gallegas y leonesa ${ }^{1033}$, que los

${ }^{1030}$ Cit. por I. GARCÍA TATO (1998): "proyecto de reparación y modificación del trazado del camino Real a su paso por Valdeorras (1755-1805)". VIa semana de Historia de Valdeorras. IEV. C.M., $\mathrm{n}^{0}$ 25, p. 124: "también por lo estrecho del camino y la pendiente del terreno, en el año 1753 un arriero maragato, frente a las casas de Nogueiras caminando con sus machos cargados de hierro, intentando guiarlos con solo tocarle uno de dichos machos con el tercio del lado de abajo lo despeñó y cayendo sobre unas peñas quedó de repente muerto en el acto". ${ }^{1031}$ M. A. GARCÍA (1987): "Documentos sobre Arriería del siglo XVII”. Astorica, 6, p. 159.

${ }^{1032}$ En 1743 la arrendataria de la ferrería de Pontepetre, doña Ángela Martínez de Torres, y el vecino de Oencia Francisco Gallego, en sendas escrituras (de marzo y noviembre respectivamente) dan su poder a Bartolomé Carballo, su convecino, para que en su nombre pase a Combarros, Tabladillo, Villa de Golfer y Laguna de Negrillos a cobrar diferentes partidas de hierro que entregaron a diversos arrieros (AHPL. P.N.: caja 3341). El primer documento, el de Ángela Martínez habla de pasar a "los lugares de Combarros, tierra de Maragatos, a cobrar de Antonio García, Manuel García de Luna, Simón Domínguez y Domingo Prieto; al lugar de Tabladillo de Pedro Criado, Blas Alonso, Phelipe Blas, Francisco Caballero, Miguel Blas, Pedro Alonso y Gabriel Criado; y a Villar de Golfer de Marcos Mendaña, Domingo Mendaña, Phelipe Nieto, Fernando Cordero y Santiago Parandones las cantidades de maravedis y reales que constan en el libro de quentas según el memorial jurado que se le entregará al dicho Bartolomé Carballo"; y la otra le piden que pase a Laguna de Negrillos " $y$ cobre de Antonio de la Cuesta ciento y nobenta y dos rs. vn procedidos de quatro quintales de yerro que le entregó al otorgante quedando por su fiador Joseph Macia, arota de la herrería de Pontepetre". En agosto de 1750 los vecinos de Campazas, Josep Carlón y Félix Herrero, se obligan a pagar a don Francisco Antonio de Losada, administrador de Órreos, 2.300 rs. vn., que "confiesan estarle debiendo de el balor de diferentes porciones de yerro que me ha remitido de dicha herrería por cuia cantidad y trescientos rs. más le tenía hecho bale en la villa de la Bañeza en los once de octubre del año pasado de mil setecientos cuarenta y nueve"; acuerdan que se lo pagarán de una sola vez por san Miguel de septiembre en La Bañeza (AHPL. P.N.: caja 616). El administrador de Paleiras da su poder en 1813 a Juan Domingo Mazaira para cobrar deudas "procedentes de la fabrica de hierro y rejas de su oficina y mazo en diferentes lugares de Galicia, Astorga, León, etc.” (AHPLU: 2467/12). En 1826 otro administrador de esa ferrería y de la de Soldón dice haber dado al fiado hierro a numerosas personas de Galicia (Monterrey, Caldelas) y a maragatos del reino de León, y que pese a que han vencido los plazos todavía no se lo han pagado (AHPLU: 2398/5).

1033 A los documentos anteriores, añadimos el poder que don Gregorio Martínez, vecino de Benavides (León), administrador de la ferrería de Pontepetre y arrendatario de la de Arnado, otorga en 1761 al vecino de Astorga don Ventura García Teixo, en el que nuevamente se mencionan los lugares en que viven los deudores por el hierro sacado de ambas ferrerías, lo que nos muestra el amplio hinterland de este comercio: coto de Visuña, Jurisdicción de Valcarce, Barjas, Villafranca, Puebla de Sanabria, tierra de Frieras, Tabladillo, Combarros, Brazuelo, Villalibre y Laguna de Somoza; estos últimos, como indica al final el documento, "tierra de maragatos", cuyos arrieros comercializaban hierro gallego y berciano (AHPL. PN.: caja 3341): Esos arrieros y vecinos de los pueblos mencionados "me estan debiendo varias cantidades de maravedis procedidos de hierro, que les he vendido al fiado ansi en dicha herrería (de Pontepetre) como en la Nueba, por medio de la persona de D. Manuel Martínez mi hermano que la administra; de dinero prestado, machos y otras caballerías que a algunos de dichas personas tengo vendido al fiado". También Roque Martínez, vecino de Serviz, afirma en 1830 que en el pueblo de Combarros y otros inmediatos de la Maragatería le están adeudando varias partidas de maravedís "procedidas de yerro que llevaron al fiado de la ferrería de Oencia", y 
arrieros recorrían con sus recuas transportando pescado pero también mucho hierro. Aunque con la llegada del tren la arriería decayó considerablemente, todavía en 1881 se computa en la ferrería de Llamas seis cuartillos de vino "dado a los arrieros que vinieron por hierro"1034. Por su parte, la ferrería asturiana de Soto Rodrigo, además de vender pequeñas partidas a las fraguas de los alrededores, enviaba grandes cantidades a la Tierra de Campos (Sahagún, Villalón, Palazuelos, etc.) ${ }^{1035}$.

Sabemos que algunas ferrerías tenían lonjas o almacenes para la venta en villas y ciudades. La ferrería de Quintá tuvo un almacén en Viana del Bollo'o36; pero probablemente tuviera otros, pues el hinterland de su comercio se extendía por las provincias de Orense y Lugo. Según una relación de deudores del año 1773 la provincia de Orense aparece como la principal zona de comercialización de su hierro: Viana, Limia, La Mezquita, Montederramo, Trives; y de foma más dispersa por Celanova, Monforte, San Clodio, etc ${ }^{1037}$. Los monjes de Samos, por su parte, construyeron en 1767 una casa en La Bañeza para la venta de hierro atendida por un monje nombrado por el abad ${ }^{1038}$; pero el hinterland del hierro del monasterio se extendía por buena parte de Galicia, logrando incluso exenciones en algunos mercados ${ }^{1039}$. No era el único monasterio exento, pues en 1685 una sentencia favorable de la Chancillería de Valladolid a los monjes de Belmonte les reconocía igualmente el derecho a no pagar tributo alguno por la venta de hierro en la ciudad de Oviedo ${ }^{1040}$.

que pese a los avisos no le han pagado por lo que da su poder a Pedro García para que pueda hacerlo (AHPL. P.N.: caja 3675)

1034 Archivo personal. Cuentas de la ferrería de Llamas, 1881.

1035 A. MATO (2010): Ob. cit., p. 115-116. Habla de que en 1844 vendió en Sahagún 3.700 arrobas de hierro (3.00o a Alejandro Vidanes, 400 a Lino Núñez y 300 a Ildefonso Núñez). En una instancia que hace el arrendatario Pedro López Llano, en 1837, al ayuntamiento de Ponga protestando por el peaje de dos reales por caballería destinado a limpiar la nieve del Camino Real, dice que "Tengo que despedir para cumplir con mis corresponsales varias contratas en Sahagún, Villalón y otros puntos, donde tengo que mandar en este mes de marzo a abril muy cerca de 2.000 arrobas de hierro de mi fábrica”. Esas arrobas suponían más de 250 caballerías y por tanto un desembolso grande.

${ }_{1036}$ "en donde también tiene almacén de fierro hesta herraria, que es bien publica y notoria su conducción de esta para aquella" (AHRG. R. A.: 3199/43).

1037 V. M. MIGUÉS (1996): Ob. cit., p. 229-230

${ }^{1038}$ M. ARIAS (1992): Historia del monasterio de San Julián de Samos. Lugo, p. 291

1039 Ya en 1612 conocemos cómo el corregidor de Orense dicta una sentencia por la que hace libre la alcabala del hierro "que se sacare de la herrería del convento de Samos con la condición de que quien lo llevare a vender lleve testimonio de que ese hierro es de las ferrerías del convento" (AHN. Clero: libro 6.695).

1040 AHN. Pap. Leg. 136. Cfr. PRIETO BANCES (1976): Ob. cit., p. 102, nota 286. 


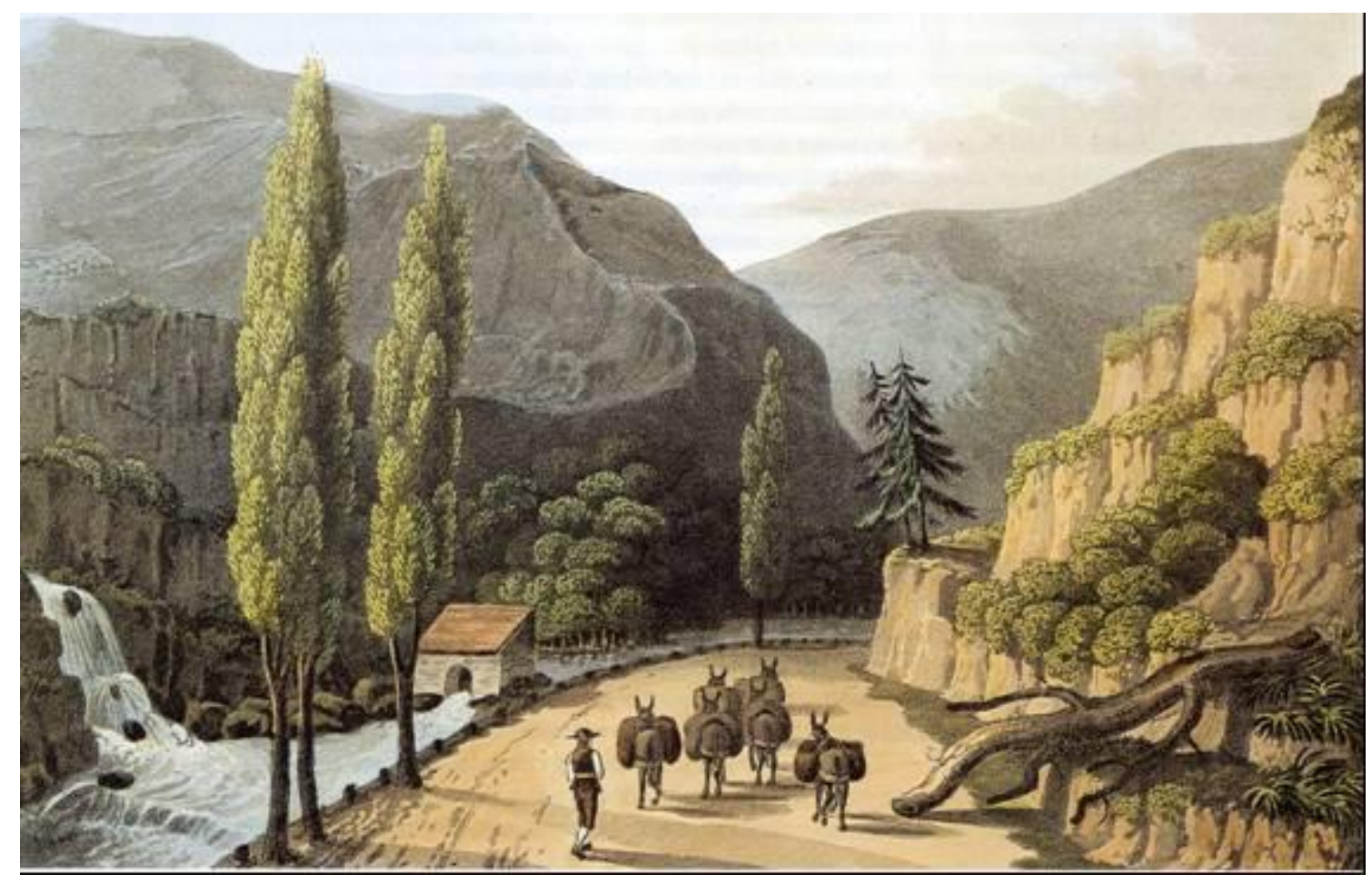

Valle del Valcarce, al lado de Villafranca del Bierzo.

Dibujo de W. Bradford, grabado por I. Clark (1809)

Uno de los gravámenes, sino el más importante, era el de alcabalas, que era un impuesto real que gravaba todo tipo de compraventa, también el hierro, con un $4 \%$ aproximadamente. Con frecuencia este impuesto estuvo enajenado por la Corona en favor de señores y ciudades. Las alcabalas del hierro y el diezmo viejo de las ferrerías asturianas, por ejemplo, fueron cedidas al doctor Rodrigo Maldonado por la reina Isabel en 1475, aunque poco después, en 1485, la misma reina revocó tal merced ${ }^{1041}$. Las del Bierzo fueron adquiridas, generalmente por compra, por el marqués de Villafranca en diversos momentos del siglo XVI y XVII ${ }^{1042}$; por eso algunos mercaderes de hierro se concertaban con el tesorero del marquesado para su pago, que normalmente se hacía no por cada partida de hierro sino por un tanto alzado, algo así como una

${ }^{1041}$ AGS. RGS., vol I, ff. 693 y vol. III, f. 13. En el último año promete a los dueños de las ferrerías que jamás volverá a hacer merced a nadie de ese derecho.

1042 A. FRANCO (1982): Ob. cit., p. 105-106; J. D. RODRÍGUEZ CUBERO (2011): "Los marqueses de Villafranca y de Villanueva de Valdueza administraron las alcabalas de Ponferrada”. Revista Bierzo, p. 65-76. 
avenencia ${ }^{1043}$; los arrieros, por su parte, lo pagaban en los diversos fielatos a su paso por el Bierzo.

Quizá por esa razón, Villafranca del Bierzo, capital del marquesado, aparece frecuentemente como una villa en la que se comercializa mucho hierro, en la que residen numerosos comerciantes, como Juan Díaz de Valcarce y Pedro de Sotogaioso ${ }^{1044}$, y desde el siglo XVIII varios conocidos propietarios de ferrerías, como los Armesto, los Ulloa y otros construyen en ella su residencia. Conocemos varias escrituras del mencionado Pedro Sotogaioso y de otro Francisco de Sotogaioso, también mercader de Villafranca, en los años 1670 a $1680^{1045}$. En el siglo XVIII, Antonio Blanco y Vega era tratante en hierro en esa

\footnotetext{
1043 El tesorero Jerónimo González se concierta en 1634 con Francisco de Valcarce Balboa, mercader de hierro de Villafranca, de esta manera: "que el dicho Francisco Valcarce por rrazón de la alcabala del yerro que bendiere en su casa y tienda por tiempo y espazio de dos años cumplidos que comenzaron a correr y contarse desde prinzipio deste presente asta ser fenezidos y acabados a de dar y pagar a dicho marqués y al dicho tesorero que es o fuere en su nombre ducientos y sesenta y zinco reales de abenecia por cada uno de los dichos dos año" (AHPL. P.N.: caja 2126). Ese mismo año Bartolomé Arias, también mercader de hierro de Villafranca, se obliga a pagar al marqués de Villafranca 330 rs./año durante tres años, "por razón de la abenenzia y alcabala de su tienda de mercader de yerro y azero, cavazón y ferraxe" (AHPL. P. N.: caja 2126).

1044 En 1659 don Juan Díaz de Valcarce y doña María Ordoñez, vecinos de Villafranca, se obligan con su sobrino y arrendatario de la ferrería de Valdomir, don Antonio Díaz de Valcarce, a pagarle "doce doblones de a quatro y diez y seis de a dos" por una parte y por otra $2.024 \mathrm{~ms}$. vn. "procedidos del balor de quarenta y quatro quintales de fierro picado que le a de entregar desde aquí a fin de agosto que biene de este presente año puestos en esta villa a precio de quarenta y seis reales el quintal (AHPL. P.N.: caja 2698). En mayo de 1669 el mercader de Villafranca Pedro de Sotogaioso se obliga con don Antonio de Valcarce y Martínez, arrendatario de la ferrería de Lousadela, a proporcionarle "diez quintales de yerro delgado y picado puestos y pagados en dicha errería para el día fin de setiembre que biene deste dicho año", por el precio de 50 ducados de vellón. La escritura añade que también Bartolomé de Arce y Armesto, cuñado del anterior y asimismo rendero de esa misma ferrería, junto con Juan López, vecinos ambos de la feligresía de San Silvestre, en octubre de 1668 se habían comprometido con el citado mercader a proporcionarle 40 quintales de hierro, 12 de ellos para diciembre de $1668 \mathrm{y}$ otros 16 en febrero, cosa que a la fecha de 24 de mayo de 1669 habían incumplido por lo que pensaba ejecutar la obligación, acción que paralizó a ruego de dicho don Antonio Valcarce (AHPL. P.N.: caja 2945).

1045 AHPL. P.N.: caja 3149 (1670), 2945 (1671), 3150 (1673). En una de estas, la de 1670, don Francisco San Juan se obliga con el mercader don Francisco de Sotogayoso a pagarle 8.924 rs. que le prestó; en otra de 1671, don Alonso Lamas y Andrade, de Cervantes, se obliga con el mismo a pagarle 1.274 rs. de mercadurías que le dio al fiado de su tienda; y en 1673, Pedro de Armesto, vecino de la Campa de Valdomir, se obliga con el mismo mercader a pagarle "cuatro cargas de rellas de ha onze arrobas cada carga por raçon que confiese de averselas vendido a precio de veinte y tres ducados cada carga"; en otra de ese mismo año, Domingo de Soto, vecino de Sotogayoso, se obliga a pagarle 228 rs. de "ciertas mercadurias" y en 1680 (AHPL. P.N.: caja 2923) Juan Fernán de de Guzmán y su mujer se obligan con el mismo a pagarle 47.00o rs. que confiesan deberle. En 1688 embargan al cerrajero Diego de Vergara, vecino de Ruitelán, por una deuda de 50 ducados con el mencionado Sotogaioso (AHPL. P. N.: 3299)
} 
misma villa ${ }^{1046}$. En la Bañeza, además de la lonja de Samos, había varias personas que contaban con tienda para la venta del hierro y cuyas rentas eran bastante elevadas ${ }^{1047}$. De uno de estos mercaderes bañezanos conocemos la compra de 300 quintales de hierro a la ferrería de Arnado en $1726^{1048}$. Igualmente había mercaderes de hierro en Los Barrios ${ }^{1049}$, Ponferrada, León ${ }^{1050}$, Mondoñedo ${ }^{1051}$, Vivero y otros muchos lugares, que compraban directamente el hierro a las ferrerías. Luego estos, al por menor, lo vendía a los herreros de la zona $^{1052}$. En esa reventa obtenían beneficios cuantiosos, probablemente entre un 20 y un $30 \%{ }^{1053}$.

1046 AHPL. P.N.: caja 3378 (1793): Obligación de Tomás López de pagarle a Antonio Blanco 740 rs. por 7 quintales y 32 libras de hierro que le dio al fiado.

1047 Alonso Gómez con tienda de hierro y acero cuenta con una renta anual de 6.00o reales; Ana Díez con tienda de hierro goza de 5.000 reales de renta y Tomás Fernández, también con una tienda de acero y otros productos, tiene de renta 7.00o reales. En L. RUBIO (1987): La Bañeza y su tierra (1650-1850). Un modelo de sociedad rural leonesa. León, p. 357.

1048 AHPL. P.N.: 3333: Convenio entre don Francisco Guerra Donis, administrador de la ferrería de Arnado, y Manuel de Prado, de La Bañeza: aquel le "a de dar ...treszientos quintales de yerro en banda de que se fabricase en dicha herrería de Arnado puestos en ella, los quales ha de entregar al susodicho y a quien su orden y poder tubiere desde oi dia de la fecha asta el día último del mes de septiembre deste presente año, con tal que como dicho es lo fabrique dicha herrerría a razón cada quintal de a zinquenta y cinco reales de moneda de vellón".

1049 Don Pedro Frechilla Bravo, mercader de hierro de los Barrios, se ajusta en 1725 con don Francisco Antonio Guerra, arrendatario de la ferrería de Arnado, para comprarle 400 quintales de hierro en banda a 44 rs./ quintal para su tienda (AHPL. P. N.: caja 2457).

${ }^{1050}$ En León Manuel Álvarez Escaja cuenta con tienda abierta en que, entre otras mercancías, vende hierro. En febrero de 1751 éste y su mujer doña Manuela Fernández se obligan con don José Gómez Noboa y Taboada, vecino de Ponferrada y curador del propietario de la ferrería de Pontepetre, a pagarle 8.400 reales por el importe de 150 quintales de hierro (AHPL. P.N.: caja 617). Cantidad por la que pagará 600 reales mensuales.

${ }^{1051}$ En 1594 Pedro Fernández Sanjurjo, vecino de Villanueva de Lorenzana, se obliga a pagar al mercader Jácome Folón, vecino de Mondoñedo, 18 quintales de hierro de la herrería de Villanueva, de a 100 libras gallegas/quintal a 18'5 rs./quintal, que suman 38 ducados y 3 rs., que aquel acepta haber recibido (AHRG. R.A.: 21130/75).

${ }^{105^{2}}$ En 1751 Manuel Álvarez Escaja, comerciante de León, que en febrero había comprado a la ferrería de Pontepetre, en el mes de marzo, 150 quintales de hierro, le vende a Pedro Andrés, vecino de Cubillos, 101 arrobas y 6,5 libras de hierro por 1.610 rs. vn., hierro "que oy dia de la fecha he sacado y me a entregado de su tienda" (AHPL. P.N.: caja 617).

${ }_{1053} \mathrm{Si}$ el precio pagado por quintal a la ferrería de Pontepetre por Manuel Álvarez Escaja fue de 56 reales y lo vendió a 78 reales, quiere decir que obtuvo unos beneficios de 22 reales por quintal, aunque probablemente sea mucho menor por los portes, si no es que contaba también con algún almacén en el Bierzo. 


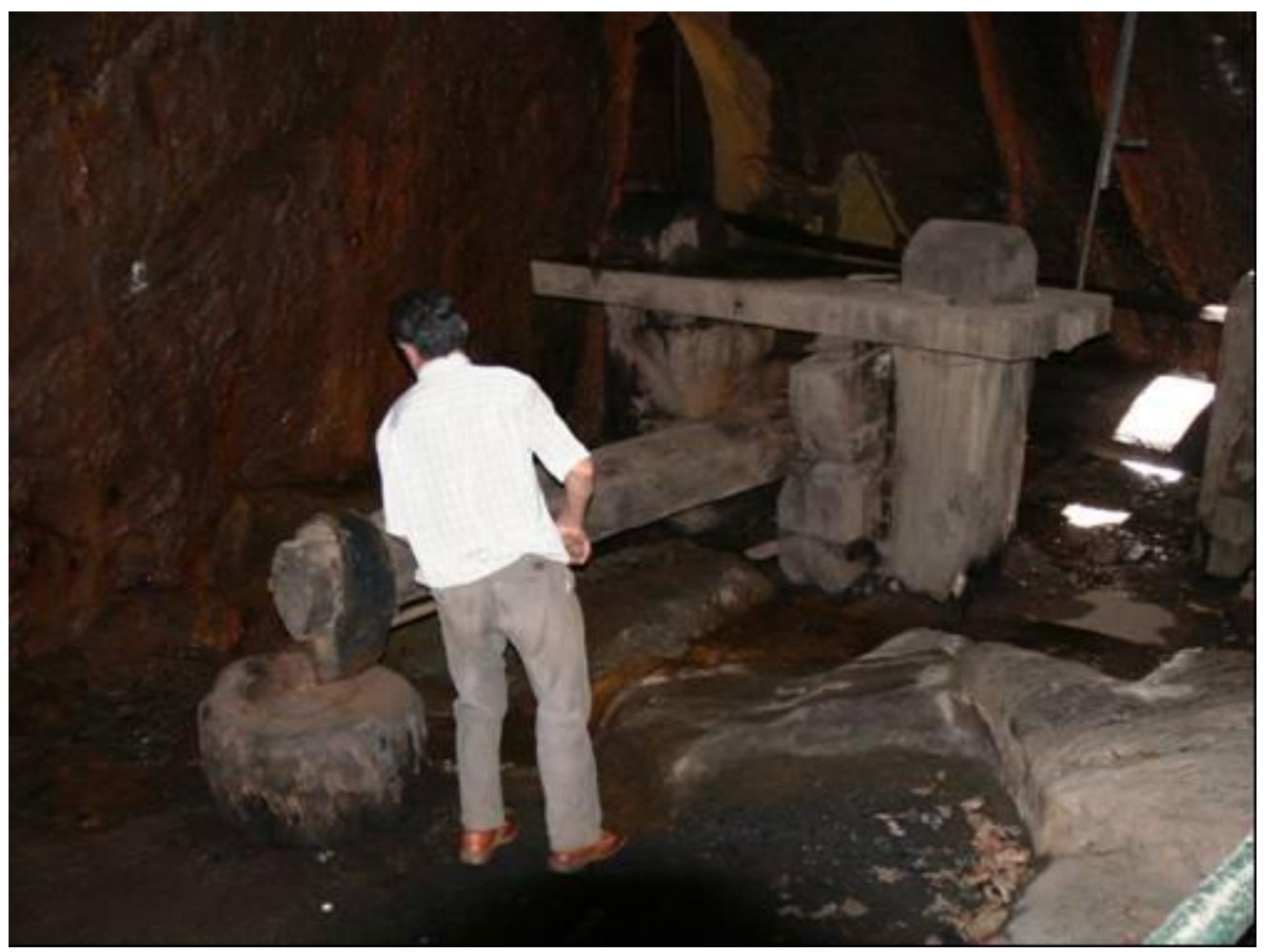

Ferrería de Penacova (Lugo)

\section{LOS PRECIOS DE HIERRO}

Los precios de hierro variaron considerablemente a lo largo de los siglos, como podemos comprobar en los CUADROS XXXVI Y XXXVII. En los siglos XVI y XVII se mantuvieron bastante estables, en torno a los 20 rs./quintal; precio que sube ligeramente a comienzos del XVII, sobre los 26 a 27 rs./qq. Sólo a finales del último siglo parece que su precio se dobla, alcanzando entonces cifras en torno a los casi 50 rs./qq., e incluso en la ferrería de Villanueva de Oscos en los años 1677 a 1684 aumenta hasta los 90 y 107 reales, sin que sepamos muy bien la razón. Aunque se trata de ferrerías diferentes y, por tanto, los precios diferían de unas a otras, hay que pensar que no lo harían excesivamente por lo que podemos compararlos, con todas las salvedades posibles. El índice que observamos en el cuadro XXXVI muestra precios por debajo de 100 en toda la segunda mitad del siglo XVI, probablemente por la competencia de las numerosas ferrerías que se construyen en el mismo; luego supera ligeramente ese índice 100 al menos hasta el primer tercio del siglo XVII, 
y desde la segunda mitad sobrepasa el índice 200 hasta finales ${ }^{1054}$, e incluso el 400 en varios lustros (en Villanueva de Oscos), probablemente por la inflacción y las bajas de la moneda que caracterizaron ese siglo.

\section{CUADRO XXXVI.- VENTA Y PRECIO DEL QUINTAL DE HIERRO. SIGLOS XVI Y XVII}

\begin{tabular}{|l|l|c|c|c|}
\hline AÑOS & FERRERÍA & $\begin{array}{c}\text { CANTIDAD } \\
\text { (en quintales) }\end{array}$ & $\begin{array}{c}\text { PRECIO } \\
\text { (en reales) }\end{array}$ & $\begin{array}{c}\text { INDICE } \\
\text { Base 100: } 22 \\
\text { (1590) }\end{array}$ \\
\hline 1535 & Raicedo & 40 & 44 & 200 \\
\hline 1551 & Bravos & 10 & 14 & 63,6 \\
\hline 1558 & Soldón & 2 & 22 & 100 \\
\hline 1584 & Soldón & 10 x semana & 19 & 86,3 \\
\hline 1590 & Arnado & 400 & 22 & 100 \\
\hline 1594 & Lorenzana & 18 & 18,5 & 84 \\
\hline 1596 & Loureiro & 11 & 22 & 100 \\
\hline 1596 & Loureiro & 15 & 22 & 100 \\
\hline 1596 & Ferreirós & ----- & 22 & 100 \\
\hline 1599 & Valdomir & 24 & 22 & 100 \\
\hline 1603 & Soldón & ----- & 38 & 172,7 \\
\hline 1611 & Santalla & 40 & 27,5 & 125 \\
\hline 1615 & Valcarce & 50 & 29 & 131,8 \\
\hline 1628 & Pesqueira & 30 & 33 & 150 \\
\hline 1659 & Valdomir & 44 & 46 & 209 \\
\hline 1668 & Arnado & 200 & 57 & 259 \\
\hline 1669 & Lousadela & 10 & 55 & 250 \\
\hline $1677-79$ & Vill. Oscos & 1.122 & 90 & 409 \\
\hline $1680-84$ & Vill. Oscos & 1.841 & 107,5 & 488 \\
\hline $1685-89$ & Vill. Oscos & 1.269 & 49,6 & 225,4 \\
\hline $1690-94$ & Vill. Oscos & 1.422 & 49 & 222,7 \\
\hline $1695-99$ & Vill. Oscos & 2.808 & 43,7 & 198,6 \\
\hline
\end{tabular}

1054 En los casos de las ferrerías asturianas de Raicedo, cuyo precio en 1535 es muy elevado, y Villanueva de Oscos, con esos índices tan altos, quizá se deba, en el primer caso a que no es hierro sino probablemente acero; y en el segundo al precio mayor de la vena vasca, lo que encarecía el precio del hierro. 
FUENTE: Raicedo (ACh. V. Pleitos civiles, caja 207,5); V. de Oscos (P. SAAVEDRA (1982): Ob. cit., p. 549). Otras: AHPLU: cajas 2407/9 2474/5, 2547/1 y 3973/1;

AHPL. P. N.: cajas 1663, 1489, 2860, 2936, AHRG. R. A.: 19768/32, 20441/70, 21130/75

Elaboración propia

En la primera mitad del siglo XVIII parece que los precios se mantuvieron en torno a esa cifra de finales del XVII, es decir, unos 50 rs./quintal, con algunas pequeñas fluctuaciones, que aumentan desde mediados de siglo ${ }^{1055}$. La prohibición que Carlos III estableció en 1775 de no importar hierro extranjero favoreció el crecimiento de los precios que, desde 1780 a 1800 llegaron a subir más de un 94,27\%, lo que no difiere mucho en su evolución respecto del País Vasco, por ejemplo ${ }^{1056}$. El cuadro XXXVII nos permite comprobar, por ejemplo en la ferrería asturiana de Villanueva de Oscos, que toda la primera mitad del siglo el índice de precios está por debajo de 100 (tomando por base 100 los años 1755-1759), con la excepción del quinquenio 1730-34; luego en la segunda mitad los precios suben ligeramente hasta 1780 en superan el índice 200 y muchos años el 175 para alcanzar los últimos años de siglo el índice 250. En otras ferrerías, aunque con menor intensidad, los precios siguen un crecimiento semejante en la segunda mitad del siglo XVIII.

Hacia 1780 el ilustrado gallego, José Cornide, afirma que "aunque en estos últimos años ha subido el valor del fierro a 115 y 120 reales el quintal, se puede regular por un quinquenio a 110 reales"1057, lo que era un precio muy alto; pero a finales del siglo aún alcanzaría cotas mayores, sobrepasando los 140 reales/quintal. Esto no fue solo a causa de aquel arancel, sino por la elevación generalizada de los precios como consecuencia de la crisis finisecular, aunque esto no siempre fue así; pues en ocasiones el precio del hierro, así como la producción, variaban sensiblemente respecto de los precios agrarios, lo que habría que interpretar, siguiendo a Labrousse, como que tanto la producción del hierro como los precios suelen bajar después de las crisis de subsistencia, como

1055 AHPL. P. N.: caja 3342. En 1750, en el subarriendo de la ferrería de Arnado, se habla de "como también por la suba que está experimentado tiene el dicho yerro".

${ }^{1056}$ Si utilizáramos en Villanueva de Oscos como índice 100 de esa evolución (años 1735-1749), veríamos que desde 1700 a 1719 ese índice está entre 89 y 94; luego sube un poco entre 1720 y 1734, llegando en el quinquenio de 1730-1734 al 123; vuelve a descender en los tres quinquenios siguientes, incluso por debajo de cien en alguno de ellos. Luego, desde 1760 a 1774 se eleva por encima de 130, y desde 1775 por encima de 180-190, alcanzando en 1795-1799 el índice 273. Comparar con el cuadro de R. URIARTE (1988): Estructura, desarrollo y crisis de la siderurgia tradicional vizcaína (1700-1840). Bilbao, p. 217.

1057 C. GONZÁLEZ (1994): ob. cit., p. 234 
puede observarse en Villanueva de Oscos en 1694-95, 1712-13 y 1770-71. Los campesinos obligados a comprar cereal más caro no disponen de dinero para adquirir herramientas de hierro, por lo que caen la producción y los precios ${ }^{1058}$, y es que como señala P. Saavedra al comparar la producción y los precios del hierro (Villanueva de Oscos) con los del trigo (Mondoñedo) los índices de producción corroboran la dependencia de la industria de la coyuntura $\operatorname{agraria}^{1059}$.

\section{CUADRO XXXVII. PRECIO DEL HIERRO EN LOS SIGLOS XVIII Y XIX} Índice base 100: Villanueva de Oscos: 59,3, Quinta: 68; otras: 64

(1755-1759)

\begin{tabular}{|l|c|c|l|l|l|l|}
\hline AÑOS & $\begin{array}{l}\text { V. OSCOS } \\
\text { reales }\end{array}$ & ÍNDICE & $\begin{array}{l}\text { QUINTÁ } \\
\text { reales }\end{array}$ & ÍNDICE & $\begin{array}{l}\text { OTRAS } \\
\text { reales }\end{array}$ & ÍNDICE \\
\hline $1700-04$ & 48,91 & 82,4 & & & & \\
\hline $1705-09$ & 49,05 & 82,7 & & & & \\
\hline $1710-14$ & 48,66 & 82 & & & & \\
\hline $1715-19$ & 51,84 & 87,4 & & & & \\
\hline $1720-24$ & 59,00 & 99,4 & & & 44 & 68,9 \\
\hline $1725-29$ & 55,63 & 93,8 & & & & \\
\hline $1730-34$ & 67,44 & 113,7 & & & & \\
\hline $1735-39$ & 54,89 & 92,5 & & & & \\
\hline $1740-44$ & 56,17 & 94,7 & & & 48 & 75,2 \\
\hline $1745-49$ & 52,81 & 89 & & & & \\
\hline $1750-54$ & 77,39 & 130,5 & 67,66 & 99,5 & & \\
\hline $1755-59$ & 59,33 & 100 & 68 & 100 & 64 & 100 \\
\hline $1760-64$ & 72,01 & 121,4 & 60 & 88,2 & & \\
\hline $1765-69$ & 68,43 & 115,3 & 64 & 94,1 & & \\
\hline $1770-74$ & 76,37 & 128,7 & 62 & 91,1 & & \\
\hline $1775-79$ & 98,40 & 165,9 & 66 & 97 & & \\
\hline $1780-84$ & 120,20 & 202,6 & 70,4 & 103,5 & & \\
\hline $1785-89$ & 106,32 & 179,2 & 95,8 & 140,8 & 110 & 171,8 \\
\hline
\end{tabular}




\begin{tabular}{|l|l|l|l|l|l|l|}
\hline $1790-94$ & 104,55 & 176,3 & 99 & 145,5 & 104 & 162,5 \\
\hline $1795-99$ & 149,36 & 251,8 & & & 140 & 218,7 \\
\hline $1800-04$ & 184,44 & 311 & & & & \\
\hline $1805-09$ & 157,70 & 265,9 & & & 105 & 164 \\
\hline $1810-14$ & 184,57 & 311,2 & & & 145 & 226,5 \\
\hline $1815-19$ & 199,55 & 336,5 & & & & \\
\hline $1820-24$ & 26,74 & 45 & & & & \\
\hline $1825-29$ & 91,18 & 153,4 & & & & \\
\hline $1830-35$ & 114,06 & 192,3 & & & & \\
\hline
\end{tabular}

Fuente: P. Saavedra (1982): Ob. cit., p. 549 y ss.; AHRG.: Hombreiro. Libro de cuentas de la ferrería de Quinta; AHPL. P. N.: cajas 617, 3465, 3761; AHPLU: 2070/6, 2474/5; AHRG: $6800 / 4$

Los primeros años del siglo XIX, en el contexto de la crisis del Antiguo Régimen y de la guerra de la Independencia, los precios del hierro se elevan aún más, con un índice que supera ampliamente el $200 \mathrm{y}$, en algún quinquenio (1815-19) llega hasta 291. Luego, aunque bajan, se mantendrán altos pues también se habían encarecido algunos de sus componentes, como el carbón vegetal1060. Todavía en 1880 y 1881, la ferrería de Llamas vendió su hierro entre 95 y 105 reales el quintal, aunque en este caso se trata de quintales métricos y no castellanos, es decir de $100 \mathrm{~kg}$. y no de $57,5 \mathrm{~kg}$., lo que significa un valor menor, casi de la mitad, lo que quizá se explique por la dificultad de estos artefactos para competir con los hornos altos una vez que, con los ferrocarriles, España se convirtió en un mercado mejor articulado.

El precio del hierro variaba enormemente si el hierro era viejo o nuevo, pues parece que aquel tenía más dificultades para la venta y de ahí que descendiera respecto al nuevo; por eso, las ferrerías solían mezclarlo con el nuevo ${ }^{1061}$. Por

\footnotetext{
${ }^{1060} \mathrm{Si}$ seguimos con el índice 100 (1735-1749) de los precios de la ferrería de Villanueva de Oscos, hasta 1809 éste supera 270, luego, entre 1810 a 1819 alcanza cifras por encima de los 350, para descender poco a poco hasta los 166 entre 1825-1829 y 208 entre 1830-1835.

${ }^{1061}$ AHRG. R. A.: 25.291/28. En un escrito de alegaciones contra el desahucio que la marquesa de Viance pretende sobre el arrendatario de las ferrerías de Lousadela y Ferreirós en 1811, Francisco Rivadeneira escribe que "el hierro viejo que conserba el esponente por faltar la circulación del comercio (por la guerra), escede de seis mil quintales, equibalentes a más de treinta mil pesos fuertes, para cuio beneficiamiento se necesita acompañarlo del nuebo, porque este es el que se busca siempre con preferencia".
} 
otra parte, el hierro tenía un precio mucho mayor cuando se adquiría a los comerciantes que en las propias ferrerías, porque el beneficio de estos lo encarecía considerablemente. Aunque no son muchos los datos seriados que podemos ofrecer, creo que la comparación del precio pagado por el monasterio berciano de Santa María de Carracedo y el precio del hierro en la ferrería ${ }^{1062}$ puede darnos una idea, a pesar de ser un ejemplo precario (CUADRO XXXIX). En general, con alguna excepción la diferencia entre ambos precios es de algo más de un 30\% el que debe pagar Carracedo que el que se paga en la ferrería, probablemente más, aunque no todo son ganancias para el mercader ya que hay que descontar el precio del transporte, posiblemente pequeño por adquirirlo en ferrerías de la propia comarca.

CUADRO XXXIX. PRECIOS DEL HIERRO AL POR MENOR

(en Rs./qq.)

\begin{tabular}{|l|c|c|c|}
\hline AÑO & FERRERÍA & POR MENOR & $\begin{array}{c}\text { DIFERENCIA } \\
\text { EN } \%\end{array}$ \\
\hline 1771 & 62 & 100 & 61,2 \\
\hline 1775 & 66 & 90 & 36,3 \\
\hline 1776 & 66 & 85 & 28,7 \\
\hline 1777 & 66 & 100 & 51,5 \\
\hline 1778 & 66 & 90 & 36,3 \\
\hline 1779 & 66 & 90 & 36,3 \\
\hline 1780 & 68 & 90,5 & 33 \\
\hline 1781 & 68 & 95 & 39,7 \\
\hline 1782 & 68 & 90 & 32,3 \\
\hline 1810 & 170 & 182,5 & 7,3 \\
\hline 1811 & 160 & 165 & 3,1 \\
\hline 1812 & 160 & 162,5 & 1,5 \\
\hline 1813 & 173 & 224 & 29,4 \\
\hline 1818 & 114 & 228 & 100 \\
\hline P.MEDIO & 98,07 & 122,25 & 24,65 \\
\hline & & & \\
\hline
\end{tabular}

FUENTE: ADA: Libro de Caja del monasterio de Carracedo; AHRG. Hombreiro. Libro de caja de la ferrería de Quintá; P. SAAVEDRA (1982): Ob. cit., p. 553-554.

1062 Hemos tomado en los años 1771 a 1782 los precios de la ferrería de Quintá; de 1810 a 1818 la de Villanueva de Oscos. 


\section{MAZOS Y MARTINETES}

El trabajo del hierro que se fundía en los hornos de las ferrerías se completaba en los mazos y fraguas. Los mazos o martinetes trabajaban los tochos que se fundían en las ferrerías para fabricar aperos de labranza o ajuares domésticos, pero también adelgazaban el hierro para, posteriormente, hacer en las fraguas clavazón, herraje u otros útiles domésticos o laborales. Parece que los mazos y martinetes datan su origen del siglo XVI y se relacionan con lo que en el País Vasco llaman ferrerías "a la genovesa”, ferrerías menores o tiraderas, que fueron realmente una especialización en el trabajo del hierro, que aumentó notablemente la productividad de la actividad siderúrgica.

Desde comienzos de la Edad Moderna hubo en el noroeste mazos, unas veces solos, lo que en los siglos posteriores sería frecuente, otras veces formando parte de las ferrerías. Del primer tipo, sabemos que en el siglo XVI ya funcionaban los de Melezna en el Bierzo ${ }^{1063}$ y el de Folgoso en Lugo ${ }^{1064}$. Aquel fue propiedad de varios herreros, que trabajaban en sus fraguas y lo utilizaban en determinados "días de mazo", como veremos posteriormente ${ }^{1065}$. El de Folgoso fue propiedad, en parte, de Pedro Rodríguez y sus herederos; y en parte de los descendientes de un Juan de Zuluaga ${ }^{1066}$. Este machuco siguió en

\footnotetext{
1063 Un documento de 1587 nos hace pensar que, probablemente, en su origen fue una ferrería convertida posteriormente en mazo, que es lo que fue hasta el siglo XX. El 21 de junio de 1587 Bartolomé Sánchez recibió de Juan Pérez, rendero de la ferrería de Melezna, el salario por los cinco años que había servido en su casa (AHPL. P. N.: 1587, f. 161.

1064 AHPLU: 2407/9. El 13 de enero de 1596 estando en el "machuco de Folgoso", Pedro Rodríguez, probablemente herrero en dicho machuco, se obligó con Juan de Zuluaga, rendero de la ferrería de Loureiro, a pagarle 31 ducados "por razón de quinze quintales y medio de fierro".

1065 AHPL. P. N.: 2126 (1669).

1066 En 1612, Martín de Guizaburuaga, rendero de la ferrería de Santalla, pleiteó contra Antonio Rodríguez y Antonio Rodríguez Chantada, ferramenteros, "vecinos de dicho lugar de Folgoso sobre la mytad del maçuco de folgoso y una fragua, barquines, yunque y más aderentes del con el derecho de mazerar" ante el alcalde ordinario de la Tierra de Caurel, quien sentenció que se diera "al dicho Martin de Guisaburuaga la posesión pro yndibiso de la mytad del dicho mazuco de folgoso con la fragua y aderentes della". Al mismo tiempo este Guisaburuaga, tras tomar posesión del mazuco, aforó a aquellos Rodríguez "la mytad enteramente de el dicho maçuco de folgoso con su presa y banzado y mazo de mazear con más una fragua con sus varquines, yunque y más aderentes a ella nezesarios", por el canón de ocho ducados de renta al año, pagados por el mes de septiembre, además de traerlo reparado, que no fuera en disminución sino en aumento, etc. (AHPLU: 2408/2). En realidad debió tratarse de un subforo, pues como declara el documento citado, Martín de Guizaburuaga "mobio el pleyto como zesonario de Diego de Zuluaga, hijo y heredero que quedó de Juan de Zuluaga, rendero que fue de la ferrería de Loureiro", los cuales seguramente eran los dueños del artefacto (IBIDEM).
} 
funcionamiento hasta bien entrado el siglo XIX ${ }^{1067}$. También fue frecuente la asociación de ferrería y mazo, que suelen integrarse en el mismo edificio o en dos, cercanos entre si; por ejemplo, en Valdomir había a mediados del siglo XVI una ferrería y un mazo ${ }^{1068}$. De igual modo la ferrería de Pesqueira tuvo a su lado un machuco, que en 1571 Pedro Pardo de Aguiar, señor del coto de Saramugo, y Pedro Maseda de Aguiar aforaron al vizcaíno Francisco Sánchez Vidarte, rendero de la ferrería de Lorenzana ${ }^{1069}$. También ocurría eso mismo en las ferrerías de Sardiñeira1070, Valdeorras ${ }^{1071}$, Quintá1072, Loureiro ${ }^{1073}$ y Gundriz, este último rodeado de seis fraguas ${ }^{1074}$.

${ }^{1067}$ AHPLU. 2377/2: En 1836, Andrés, Rosa y Domingo Sánchez se declaran "participes en el mazo viejo sito en el arroyo del referido Folgoso, con sus respectivas fraguas para desfazer el fierro que compran y conducen de las Fábricas del país, distribuyéndole en diferentes clases de herrages que venefician hasta larga distancia de la circunferencia, como también para fundir cobre y hazer tuberas para arcas, trompas y barquines de todas las fábricas de Galicia".

1068 Lo deducimos de un documento de 1574 en el que se tasan los bienes de Marina de Zarauz, rendera de la ferrería: "tasaron los contadores y tasadores ante la dicha Marina de Sarauz los aRiendos que a Rentado la ferrería de baldomir con maçuco y casas -y palomar y huertas. Cada año setenta ducados por quince a esta parte que falleció el dicho Juan Ortiz hacen 1.10o ducados" (AHRG. R. A.: 19.768/32). Poco después, al morir en 1597 Pedro de Armesto y Errazti, deja: "la tercia parte de la herreria de Valdomir con todos sus pertrechos y adereços, excepto los barquines de fundir y tuberas y el entallo que sacó cabe la rueda barquinera, que esto es de los herederos que quedaron de Juan de Çuluaga, rendero de Loureiro, defunto, con mas la tercia parte de la casa que estaba cabe la dicha ferraria (...) y la octaba parte del machuco de baldomill que al presente trahe el vecino de San Martino" (AHRG. R. A.: 5951/55).

${ }^{1069}$ Le aforan "aquella nuestra herraria e machuco que se dize da Pisqueira que está sita en la dicha feligresía de Santa Cruz con todas sus casas, torre y molino, huertas, sotos y árboles que hestán entre las aguas de la dicha ferrería e con todos los aparatos e yngenios e artifiçios y herramientas de la dicha ferraria", en precio y renta de 6.000 maravedís anuales, con varias condiciones. Entre ellas la de reparar a su costa y a la de sus sucesores la ferrería y machuco para que siempre funcione; que no la puedan vender, empeñar o traspasar salvo a persona llana; y, además, que si no pagan tres años seguidas la renta perderán los derechos del foro (AHRG. R. A.: 21.859/104).

${ }^{1070}$ En un documento de 1628 Pedro López de Santa Cruz, vecino de Tierra de Saviñao, se querella contra Juan Marino y sus hijos Gregorio y Pedro Marino, porque teniendo aquel "en la Errería e machuco questá en el rrio de la Sardineira abaxo del lugar de la ciudad su parte e quiñón, y por razon dello los dichos acusados que trabaxan en el dicho machuco dende diez y seis años a esta parte, adreçaban a mi parte (al denunciante) sus logomes, açadones, fouces y machados, hierros de arada y calderos y todas las demás herramientas y axuares sin por raçon de todo ello llebarle ningún derecho" (AHRG. R.A.: 20527/ 41).

1071 AHPOU. PN.: caja 473 (1669).

${ }^{1072}$ Existía desde el siglo XVI, porque cuando al principio del siglo XVIII pleitean Samos y los Neira por la ferrería de Quintá se dice: "Ygualmente es cierto que en dicho sitio de Quintá auia un mazuco o martinete que gozó y posseyó Francisco Bázquez de Quiroga (que vivió en el siglo $X V I), y$ le gozaron y posseyeron sus succesores hasta que el rio llevó parte de el y quedó la zanja y otros vestigios y señales". (AHRG. Hombreiro, leg. 19).

1073 Lo cita P. MADOZ (1845): Ob. cit., t. X, p. 48

1074 En 1629 una escritura señala que los herederos de Juan de Souto deben de pagar a Samos once ducados por una fragua en el mazuco de Gundriz, mazuco que ya existía en el siglo XVI cuando el abad fray Lope de la Barrera, en 1577, se lo entrega a Martín de Urichaga (AHN. Clero: Libro 6695). 


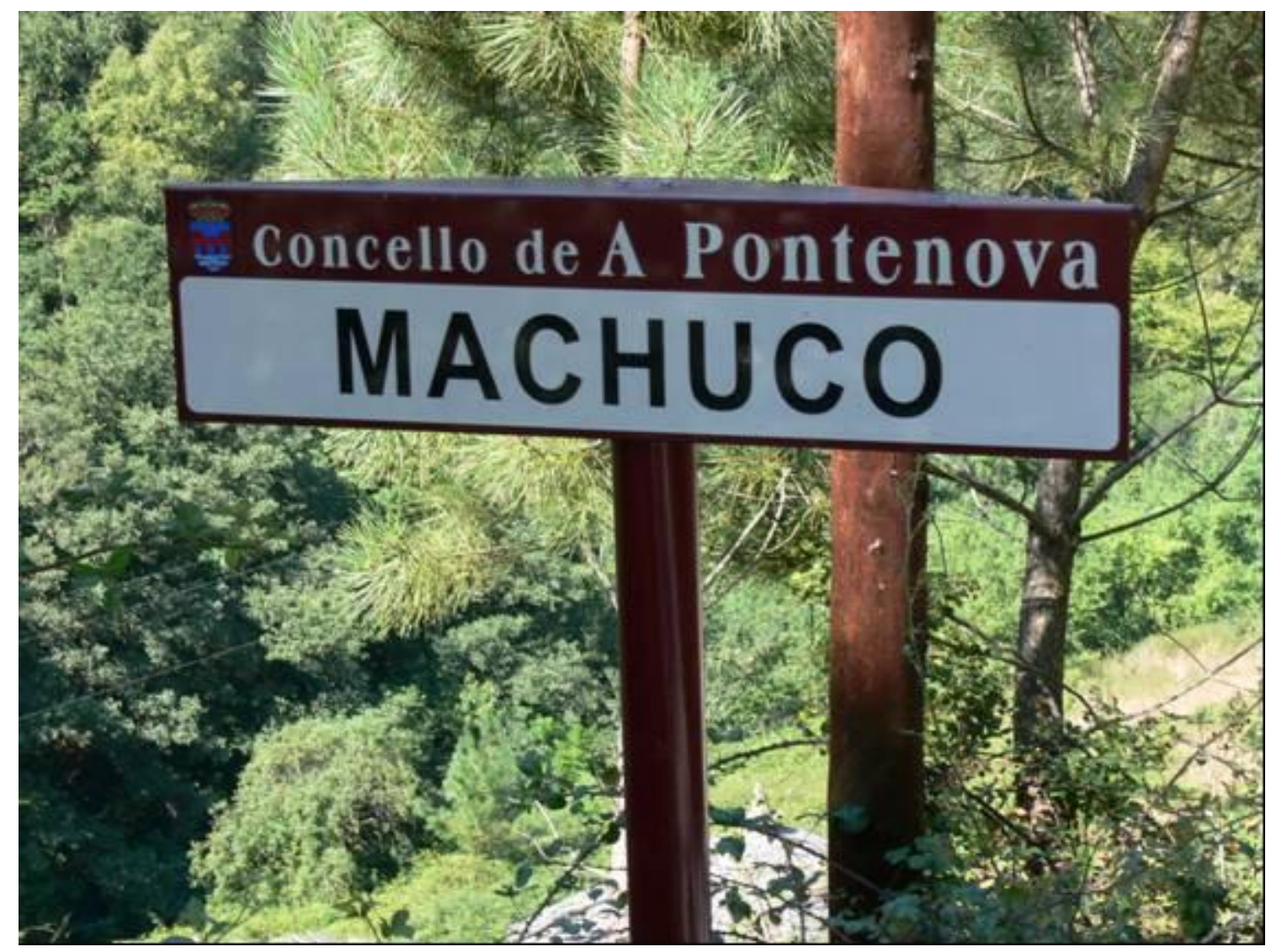

Machuco al lado de la ferrería de Bogo

Sin embargo, lo más frecuente fue la existencia de mazos solos, sin dependencia con ferrería alguna, aunque lógicamente compraban el hierro a estas o directamente de Vizcaya, pues no lo fabricaban. Su número fue singularmente grande en Asturias y en Lugo durante el siglo XVIII, como podemos ver en el CUADRO XL y en el apéndice II-22), aunque posiblemente esta lista de 65 mazos sea incompleta por ocultación ${ }^{1075}$. Como vemos, el 58,4\% se encontraban en Asturias, especialmente en los partidos judiciales de Castropol y Valdés, y en Lugo (38,4\%), sobre todo en los de Mondoñedo y Becerreá. Aún se incrementaría su número en el siglo XIX donde vemos cómo se construyen los de Outeiro, Villajuste, Villasibil, Robledo de Domiz, Pontigón, A Veguiña, Os Penedois, Portela de Valcarce; alguno de ellos junto a alguna

\footnotetext{
1075 Por las mismas fechas del Catastro, cuando los vecinos del coto de Córneas (Doncos) se oponen en 1755 a la construcción de la ferrería de Neira de Rey, lo hacen porque hay muchos mazos en los alrededores: "Hay dos mazos en la Borriqueira, ynclusos en el distrito de dicha jurisdicción de Ouselle, que son de don Joseph de Erbón; otros quatro en el de Neyra deRey, los dos y medio de don pedro Santiso y don pedro Osorio, y el uno y medio de dicho Quiroga (don José Quiroga que quiere levantar la mencionada ferrería)". (AHPLU: 6709/14).
} 
ferrería, como el mazo nuevo de Santa Eulalia de Oscosio76, o en algún caso, convertidos posteriormente en ferrerías. De igual modos, algunas de estas, a finales del siglo XIX, terminarían como simples mazos, como Compludo. La construcción de tan gran número de machucos no dejó de suscitar protestas tanto en el siglo XVIII'1077, como en el XIX ${ }^{1078}$.

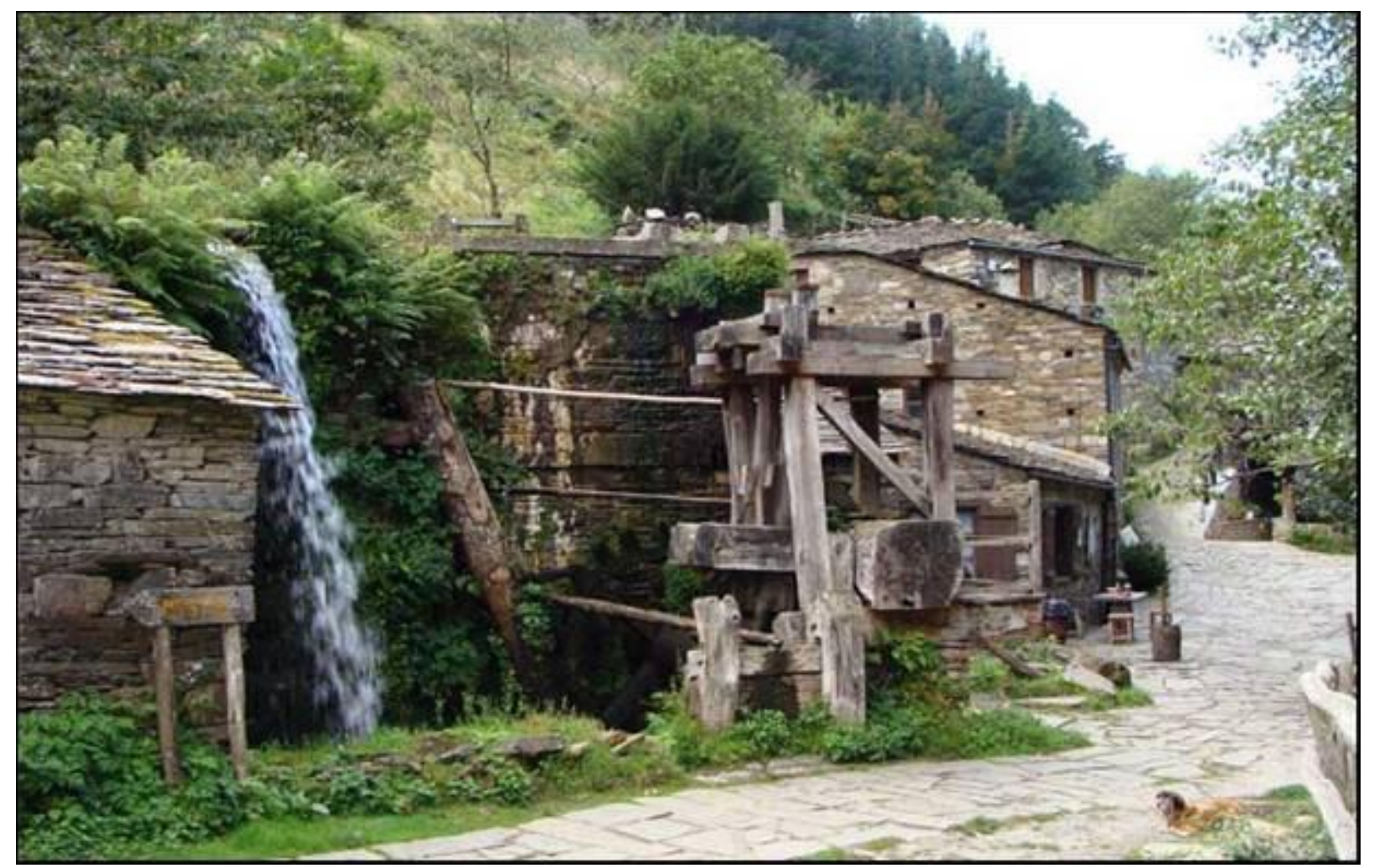

Mazo de Taramundi (Asturias)

${ }^{1076}$ Se menciona en 1815 como lugar en el que mora don Manuel Rodríguez Arango alcalde mayor de dicho lugar (AHPLU: 2070/4).

1077 En 1758 Benito Dieguez, vecino de Avilés, a quien se le concedió licencia para construir un martinete en 1754 en esa villa denuncia a los vecinos de las parroquias de Trasona y Luanco, concejo de Gozón, porque quieren hacer otro en la hacienda de don Manuel Trelles, a menos de medio cuarto de legua, porque, dicen, no habrá carbón para abastecer a ambos (AGS. Sección Marina: Leg. 560)

${ }^{1078}$ En 1859 varios propietarios que se oponen a la construcción de una nueva ferrería en el río Porcía, escriben al gobernador de Oviedo exponiendo las razones de su oposición, siendo la principal la gran carestía de carbón para tantos artefactos: "En efecto, señor gobernador civil, a la distancia de una y dos leguas del sitio que designa Vázquez, existen nueve forjas catalanas y otras siete hasta la distancia de seis leguas, todas las que se alimentan con carbón vegetal. Trabajan con el mismo combustible una infinidad de martinetes y fraguas, que hay en el territorio que ocupan estas herrerías, viniendo a resultar un consumo inmenso, que no es bastante a sostener el estado de los montes del país, así es que por eso ha disminuido considerabablemente en las herrerías de los exponentes, y en otras, la elaboración del fierro $y$ muchos martinetes han cerrado". Cit. en J. LÓPEZ y A. GRAÑA (1998): Ob. cit., p. 147. 
CUADRO XL. MAZOS EN EL NOROESTE DE ESPAÑA A MEDIADOS DEL SIGLO XVIII

\begin{tabular}{|c|c|c|c|c|}
\hline PROVINCIA & $\begin{array}{l}\text { PARTIDO } \\
\text { JUDICIAL }\end{array}$ & MAZOS & \% P.J. & \% PROV. \\
\hline LEÓN & El Bierzo & 1 & 100 & \\
\hline TOTAL PROVINCIA & & 1 & & 1,5 \\
\hline \multirow[t]{5}{*}{ LUGO } & Becerreá & 6 & 24 & \\
\hline & Fonsagrada & 4 & 16 & \\
\hline & Mondoñedo & 9 & 36 & \\
\hline & Monforte & 2 & 8 & \\
\hline & Vivero & 3 & 12 & \\
\hline TOTAL PROVINCIA & & 25 & & 38,4 \\
\hline ORENSE & Valdeorras & 1 & 100 & \\
\hline TOTAL PROVINCIA & & 1 & & 1,5 \\
\hline \multirow[t]{4}{*}{ OVIEDO } & Cangas de Narcea & 3 & 7,8 & \\
\hline & Castropol & 23 & 60,5 & \\
\hline & Tineo & 1 & 2,6 & \\
\hline & Valdés & 11 & 28,9 & \\
\hline TOTAL PROVINCIA & & 38 & & 58,4 \\
\hline TOTAL NOROESTE & & 65 & & 100 \\
\hline
\end{tabular}

FUENTE: PARES: Catastro de Ensenada. Respuesta 17 del interrogatorio. Apéndice II-22

La propiedad de los mazos fue muy diversa, pues como en el caso de las ferrerías hay miembros de la nobleza y la hidalguía (conde de Peñalba, marquesa de Viance, los Valledor, la Casa de Tineo, la Casa de Trasona, etc.); pero sobre todo particulares, frecuentemente en propiedad compartida, a los que, por ejemplo el Catastro de Ensenada, regula como beneficios cantidades diferentes, aunque generalmente pequeñas (Apéndice II-22). Como propietarios o arrendatarios son los herreros de mazo los que trabajan en esos martinetes'079. En unos casos lo hacen directamente sobre el mazo, aunque lo más frecuente

1079 "Para servir un martinete, dice un informe asturiano del siglo XVIII, se necesitan dos o quatro obreros, ordinariamente no son más que dos. Cesan de obrar a la hora de comer y a la noche, y dos obreros pueden forjar 5 qq. de hierro al día" (A.M.N. Col. Guillén, CMLXXIII. F. de Armas). 
fue la existencia de fraguas en los alrededores, cuyos herreros utilizaban colectivamente el mazo en los llamados "días de mazo", por ser todos copropietarios de partes o quiñones del mismo ${ }^{1080}$. Las fraguas, utilizaban el mazo por días. El de Melezna, que tenía en sus alrededores ocho fraguas ${ }^{1081}$, los herreros poseían cada uno una parte o quiñón, materializado en días de mazo ${ }^{1082}$.

Los salarios de estos herreros de mazo eran menores que los de las ferrerías, aunque mayores que las de los herreros de fraguas. En Taramundi, dice el Catastro de Ensenada, que hay 24 herreros de mazo y 7 aprendices; 79 herreros de clavo y 7 aprendices, 11 cerrajeros y 2 aprendices, los cuales cobran las siguientes cantidades: 4 rs./día los herreros de mazo; 11/2 rs./día los herreros de clavo menudo y 2 rs./día los cerrajeros. A los aprendices de todos esos oficios, añade, no les reporta dicho oficio "ninguna utilidad mientras lo son por aprovecharse los maestros de el trauajo de ellos en pago de la enseñanza"1083. En general, el Catastro atribuye ganancias de 3 a 4 rs./día a los herreros de mazo, mientras que a los herreros de lima, como a veces les llama, sólo les regula 2 ó 3 rs./día; salarios que contrastan con los que hemos visto de los ferrones. Muchos de estos además sólo trabajan temporalmente, pues buena parte del año se dedicaban a labores agrícolas.

Una parte del hierro se vendía directamente por las ferrerías a mazos y martinetes, algunos de los cuales formaban parte de los propios complejos siderúrgicos, y otros eran mazos o machucos independientes. En los primeros,

1080 Así del mazo de Gundriz sabemos que en el siglo XVI tenía seis fraguas a su alrededor (AHN. Clero: Libro 6695). También el de Folgoso:, en 1606 los ferramenteros Antonio Rodríguez y Antonio Rodríguez Chantada arriendan a Juan Fernández, también ferramentero, y a su primo "una fragua con el serbicio de maço y agua y yunque en el mazuco que tienen en este lugar de Folgoso" por tres años en precio de 12 ducados en cada uno de dichos años (AHPLU: 2555/1).

${ }^{1081}$ CATASTRO DE ENSENADA. R. G.: Melezna: Hay en este lugar "ocho fraguas de distintos dueños, teniendo todos igual derecho a usar de dicho mazo".

1082 Un documento de 1669 refiere que Francisco Pérez vendió "antes de ahora al dicho Juan de Gurriarán toda la parte y quiñón que le tocaba y pertenecía en el dicho maço y herrería" de Melezna ( AHPL. P. N.: 2936). Era además frecuente la venta de esos quiñones o días de mazo: en 1646 Juan Quiroga, su mujer e hijos, vecinos del mazo de Santigoso, venden a Jacinto Álvarez varas propiedades "más un día de mazo menos quarto cada semana, que les corresponde con los más herederos en el mazo que se alla en este dicho lugar en la fragua del medio; mas benden a dicho jacinto y Rafael Albarez, vecino asimismo de este dicho lugar, un día de mazo cada semana en dicho mazo y fragua" (AHPL. P. N.: 2126).

1083 CATASTRO DE ENSENADA. R. G.: Taramundi 
los trabajadores o ferramenteros lo hacían por cuenta del empresario ${ }^{1084}$, mientras que en los mazos independientes lo hacían por su propia cuenta o para comerciantes que les proporcionaban el hierro o el dinero. Los mazuqueros compraban el hierro en bruto ${ }^{1085}$, que luego transformaban en aperos y utensilios domésticos ${ }^{1086}$. Estos machucos no solo trabajaban el hierro de las ferrerías cercanas, también lo adquirían de mercaderes que lo traían del País Vasco y Cantabria. Esto fue muy frecuente en toda la Edad Moderna porque con ese hierro se fabricaba el clavazón necesario para abastecer a los pequeños arsenales de la costa cantábrica (Foz, Vivero, Ribadeo, Avilés, Gijón) ${ }^{1087}$.

En el siglo XVI muchas ciudades costeras gallegas destacaron en la construcción de barcos, cuyo papel en la carrera americana fue muy notable ${ }^{1088}$; también participaron en ella y en el comercio con Sevilla muchos barcos asturianos, así como en el transporte de tropas, en relación con la política europea de los Austrias ${ }^{1089}$, y en el corso, actividad para la que se construyeron o se utilizaron centenares de barcos ${ }^{1090}$. Esta actividad no decayó en el siglo XVII pese a los problemas de deforestación del monte gallego; y aún se incrementó más durante el XVIII con la construcción de los astilleros del Ferrol, en el que llegaron a trabajar más de 5.400 trabajadores, y el de la Real Maestranza de La

1084 AHPLU: 2547/1. En 1599 en la ferrería de Valdomir, que contaba con un machuco, se elaboraba herraje. Conocemos una venta de 157 docenas de herraje a 6 rs./docena.

${ }_{1085}$ Estos mazuqueros compraban cantidades de hierro considerables, como vemos en el caso de Antonio Rigueiro, vecino del mazo de Soldón, que se obliga a pagar en 1842 a Juan Fariñas 85.530 reales de hierro que le vendió al fiado durante los 9 años que administró la ferrería de Soldón, por lo que le hipoteca las casas que habita en el mazo de Soldón "con el mismo artefacto del mazo y sus fraguas" (AHPL. P. N.: caja 3580). Se trata de una cantidad muy considerable, pues al precio de la época podía suponer más de $35.000 \mathrm{~kg}$.

${ }_{1086}$ En un informe de 1833 sobre las ferrerías asturianas, después de hablar del hierro que sale de las ferrerías y lo que trabajan ellas directamente, añade: " $Y$ el resto también en tochos $o$ puntas se prepara en los martinetes, como el que se emplea en la plancha espresada, conforme a los objetos o empleos a que se destina, de herrages de carros, herraduras y clavazones". Cit. en J. LÓPEZ y A. GRAÑA (1998): Ob. cit., p. 144.

1087 Hay noticias de ese comercio desde principios del siglo XVI. Por ejemplo, en el testamento de Esteban de Olaverri (1502) confesaba haber entregado 8 quintales de hierro a Sabat de Cornoch en cargazón hacia Galicia. Cit. por L. M. DÍEZ DE SALAZAR (1983): Ob. cit., t. I, p. 345 , nota 760 .

1088 L. GUITIÁN (2001): La destrucción histórica del bosque en Galicia”. Semata, v. 13, p. 131133. Habla de unos 500 barcos en activo en Galicia, más o menos, cuya vida no superaba los 10 años, lo que supone una actividad constructiva considerable.

$1089 \mathrm{M}^{\mathrm{a}}$ C. SAAVEDRA 1996). Galicia en el camino de Flandes. A Coruña.

1090 E. OTERO LANA (1992): Los corsarios españoles durante la decadencia de los Austrias. Madrid, p. 119 y 125. Solo entre 1621 a 1697, el autor menciona 707 barcos de distintos tipos y tonelaje:. Navíos, fragatas, bergantines, pataches, etc., de los que 36 en Asturias y 89 en Galicia. 
Coruña, además de los pequeños astilleros tradicionales ${ }^{1091}$. En ese siglo se construyeron solo en Ferrol 111 barcos (46 navíos, 30 fragatas, 3 corbetas, 13 bergantines, 9 paquebotes y 10 goletas), los cuales exigieron mucha madera y mucho hierro ${ }^{1092}$.

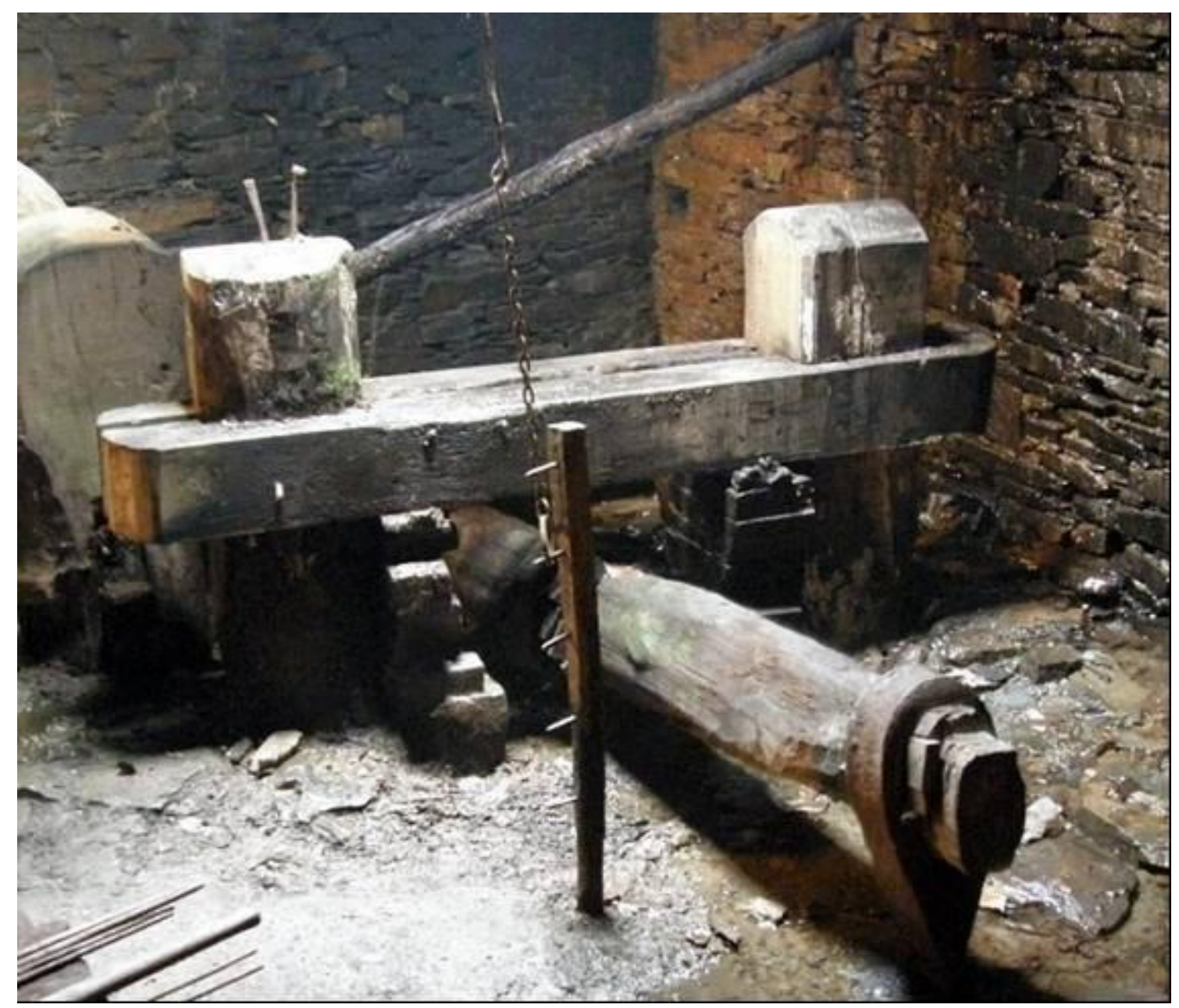

Mazo de Meredo (Asturias)

La fabricación de clavazón por los numerosos mazos y fraguas del occidente de Asturias y del oriente gallego, muchos de ellos construidos en el siglo XVIII, necesitaba de grandes cantidades de hierro para su transformación en clavazón, hierro que adquirían en las ferrerías cercanas pero también, como

1091 P. SAAVEDRA (1985): Economía, política, y sociedad en Galicia: la provincia de Mondoñedo, 1480-1830. Xunta de Galicia. Santiago, p. 320. En nota (50) menciona algunos contratos para la construcción de pataches en Ribadeo en el siglo XVIII.

${ }^{1092}$ L. GUITIÁN (2001): Ob. cit., p. 133 
hemos visto, en las vascas, pues al parecer les salía más barato ${ }^{1093}$. Por esa razón, en la segunda mitad del siglo XVIII la comarca del Eo desarrolló una importante industria transformadora, de manera que en las forjas de Taramundi, Boal o Castropol no solo se convertía en clavazón, herraduras u otros utensilios el hierro de las ferrerías de la comarca sino también con hierro procedente de Vizcaya ${ }^{1094}$, también de Cantabria ${ }^{1095}$.

Aunque no disponemos de series completas, existen datos suficientes para detectar la animación de las transacciones de hierro vasco y cántabro por mar con los puertos asturianos y gallegos. Por ejemplo por el ribero de Limpias, entre 1727 y 1742, salieron con destino a aquellos puertos 1.180 quintales machos de hierro, lo que significa una cantidad pequeña de unos 78 quintales anuales, pero en 1748, 1749 y 1750 la media anual fue de 433 quintales machos $^{1096}$. Por su parte el hierro vasco, con dificultades para vender en sus mercados tradicionales europeos a partir de la segunda mitad del siglo XVIII, encontrará en América y en la Península un amplio mercado: por ejemplo hacia Galicia y la costa cantábrica saldrían del puerto de Bilbao desde 1760 cantidades cada vez mayores ${ }^{1097}$, pues de acuerdo con el CUADRO XLI pasan de representar sólo el 4,9\% en 1760 al $25 \%$ en 1790 y 1805 , llegando en 1800 a suponer el 44,4\% de todo el hierro exportado desde Bilbao. La mayor parte de este hierro lo traen mercaderes en barcos vascos pero también hay gallegos y asturianos que se dedican a este comercio ${ }^{1098}$.

\footnotetext{
1093 Quizá con cierta exageración, un testigo en un juicio en 1788 afirmaba que la ferrería de Bravos vendía "a 11 cuartos la libra y los vizcaínos la daban desde 4 cuartos". AHN. Consejo: leg. 1.137, Cit. en P. SAAVEDRA (1985): Ob. cit., p. 333.

1094 J. CARMONA BADÍA (1993): "Sargadelos en la historia de la siderurgia española". Revista de Historia Industrial, 3, p. 12.

1095 En un informe de 1782 que escribe Arias Mon contra los proyectos de José María Bravo dice aquél que para dar trabajo a tantos herreros como supone Bravo "no son suficientes las doce herrerías que hay en Asturias, sino que se introducen inmensas partidas de hierro de Vizcaya". Cit. en P. QUINTANA (2005): La labranza y transformación artesanal del hierro en Taramundi y los Oscos. Siglos XVI-XIX. Taramundi, t. I., p. 91

1096 M. CORBERA (2001): Ob. cit., p. 35.

1097 M. GONZÁLEZ PORTILLA (1977): "La industria siderúrgica en el País Vasco: del verlangssystem al capitalismo industrial". En Crisis del Antiguo Régimen e industrialización en la España del siglo XIX. Madrid, p. 150

${ }^{1098}$ En 1780 don José Valdés Busto, de Vegadeo, fletó un navío de Setúbal para traer a la ría de Ribadeo desde Vizcaya 2.00o quintales mayores de hierro y otras mercancías; también ese mismo año, don Antonio Bravo, de la zona de los Oscos, afirmaba haber fletado un navío portugués para traer de Bilbao hierro, lino, etc. hasta 800 quintales machos. Cit. por P. SAAVEDRA (1985). Ob. cit., p. 333
} 
CUADRO XLI. EXPORTACIÓN DE HIERRO EN BRUTO DESDE BILBAO

\begin{tabular}{|l|c|l|l|l|l|l|l|l|l|l|l|l|}
\hline DESTINO & 1760 & $\%$ & 1770 & $\%$ & \multicolumn{1}{|l}{1780} & $\%$ & 1790 & $\%$ & 1800 & $\%$ & 1805 & $\%$ \\
\hline Noroeste & 3.646 & 4,9 & 16.070 & 21,0 & 12.940 & 16,9 & 17.447 & 25,5 & 13.507 & 44,4 & 5.620 & 25,8 \\
\hline Andalucía & 13.926 & 18,7 & 20.696 & 27,1 & 9.107 & 11,9 & 35.865 & 52,5 & ---- & & 68 & 0,3 \\
\hline Portugal & 7.647 & 10,3 & 4.531 & 5,9 & 26.784 & 35 & 4.965 & 7,2 & 7.155 & 23,5 & 3.308 & 15,2 \\
\hline Francia & 22.040 & 29,7 & 18.366 & 24,0 & 17.308 & 22,6 & 4.350 & 6,3 & 423 & 1,3 & 3.003 & 13,8 \\
\hline Holanda & 7.878 & 10,6 & 4.807 & 6,2 & 4.416 & 5,7 & 1.155 & 1,6 & ----- & & ----- & \\
\hline Inglaterra & 6.776 & 9,1 & 10.411 & 13,6 & ----- & & 721 & 1 & ----- & & ----- & \\
\hline TOTAL & 74.182 & 100 & 76.342 & 100 & 76.506 & 100 & 68.191 & 100 & 30.361 & 100 & 21.742 & 100 \\
\hline
\end{tabular}

FUENTE: M. GONZÁLEZ PORTILLA (1977): Ob. cit., p. 132 Elaboración propia con datos de la fuente citada

Por esa razón, al contrario de lo que estaba ocurriendo en el País Vasco, que va a sufrir una caída pronunciada en su producción de hierro por la competencia del sueco y ruso, la comarca del Eo se manifiesta en la segunda mitad del siglo XVIII como el núcleo ferretero más dinámico del país, incluso superior al País Vasco y Cantabria, y es dentro de ese contexto en el que hay que explicar tanto la construcción de nuevas ferrerías, como ya hemos visto en el capítulo primero, como algunos innovadores proyectos, como el horno alto de Sargadelos o las ferrerías y martinetes que levantan Andrés Antonio Bravo y su Compañía de la Vega de Ribadeo, o José Álvarez de la Braña con su proyecto de "fábrica de ollas de hierro colado" en el pueblo de Rao (Lugo) ${ }^{1099}$, y también el elevado número de mazos que hemos visto anteriormente en los partidos de Castropol y Mondoñedo.

A comienzos del siglo XIX se perdieron para el hierro vasco y cántabro algunos mercados internacionales, sobre todo América tras la independencia; por ello la exportación de hierro hacia puertos gallegos y asturianos se incrementó aún más considerablemente. Así entre 1817 y 1820 se embarcó en Castro Urdiales una cantidad equivalente a más o menos la cuarta parte de lo producido en Cantabria, del que una parte era vasco; pero otra, posiblemente la más importante, correspondía a ferrerías cántabras. De dicho hierro (31.765 quintales machos de 155 libras, es decir, 2.422,4 Tm.), más del 70 por ciento 
tuvo como destino diversos puertos de Galicia y Asturias: 9.363 quintales machos a Asturias y 13.086 a Galicia ${ }^{1100}$, pues aquí se va a mantener hasta los años finales del siglo, pese a la desaparición del astillero ferrolano, una importante industria de transformación en los mazos y fraguas.

\section{LAS FRAGUAS Y LOS ARTESANOS DEL HIERRO}

El último proceso en el trabajo del hierro se hacía en las fraguas. Las había por todas partes, en las ciudades y villas pero también en la mayoría de los pueblos y aldeas, porque el herrero era una profesión imprescindible para fabricar y arreglar los aperos de labranza, calzar arados, hacer herraduras, fabricar potes y sartenes, cuchillos, navajas y hoces. Por esa razón, casi todos los pueblos contaban con su herrero. Si no lo había, no era raro que estos se trasladaran de forma itinerante de unos pueblos a otros, o que los pueblos se concertaran con alguno para que trabajaran en ellos, al menos ciertos días a la semana ${ }^{1101}$.

Había zonas de especial concentración, como señalan algunas fuentes del siglo XVIII. Por ejemplo en el valle del Valcarce (el Bierzo), en torno a la ferrería de Herrerías, se mencionan 12 maestros herreros, 21 oficiales y 6 aprendices; en Boal, Asturias, había 191 herreros, 178 de los cuales de clavo menudo y el resto de sartenes y calderos; en la antigua provincia de Mondoñedo se contabilizan 97 herreros (46 en la cuenca del Eo, 41 en el concejo de Viveiro y 10 en la Montaña), y en 1787 se habla de 143 fraguas ${ }^{1102}$. En las inmediaciones de

\footnotetext{
${ }^{1100}$ M. CORBERA (2001): Ob. cit., p. 66

${ }^{1101}$ En 1620 Gregorio Touzón, herrero vecino de Camponaraya, en el Bierzo, se concierta con el concejo del vecino pueblo de Fuentesnuevas para servirle hierro en la fragua comunal y en ella "aprestar, aguzar y todo lo menester, asistiendo tres días a la semana (lunes, miércoles y viernes) y si faltare alguno pague cuatro reales de pena". El contrato o avenencia lo hace con los precios siguientes: por cada calzadura de hierro de azada y azadón del hierro del viejo (es decir, del de los propios útiles) le pagarán a $12 \mathrm{mrs}$. la calzadura y a $6 \mathrm{mrs}$. la media calzadura, pero siendo hierro del herrero a 24 y 12 respectivamente. Además si a esto "se abinieren con él se a de dar por un par de bueyes con que labrare un quartal de centeno y por quatro bueyes media fanega; y a los que ansy se avinieren a diez mrs. por la calzadura y a seis por la media del hierro del viejo, y del suyo del herrero a diez y a beinte mrs." (AHPL. P.N.: caja 2823).

1102 P. SAAVEDRA (1985): Ob. cit., p. 322 y 327
} 
Ribadeo, un informe de 1795 menciona 548 fraguas ${ }^{1103}$, y lo mismo podríamos decir de los Oscos, del que un memorial de 1782 contra los proyectos de José María Bravo, denuncia que en el concejo de Santa Eulalia de Oscos hay más herreros que en los otros concejos cercanos que "se ocupan solamente en trabajar el (hierro) que Bravo y otros, que mantienen este trato, les entregan para reducirlo a clavazón" ${ }^{1104}$, lo que debe de ser cierto a tenor del número de mazos de los alrededores.

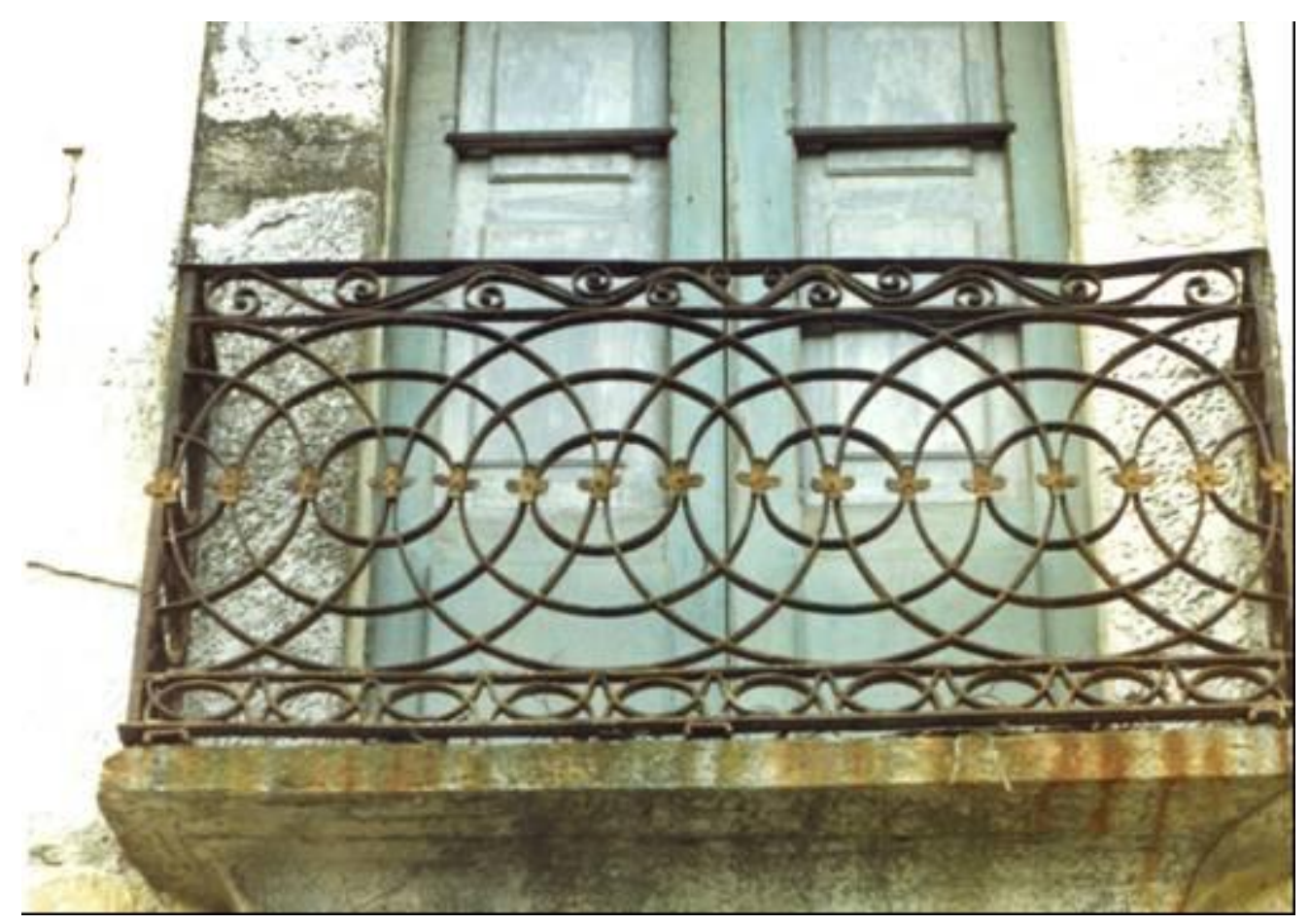

Balcón de hierro forjado

Había también, sobre todo en villas y ciudades, una cierta especialización dentro de los herreros, distinguiéndose los simplemente herreros, de los cerrajeros y armeros. Un resumen de ello lo hemos visto en el Cuadro II del capítulo I, en el que se mencionan casi 6.000 herreros en toda la región, lo que representa algo más de un 10\% del total del artesanado del todo el noroeste, aunque con diferencias regionales grandes, pues mientras León y

1103 MUSEO NAVAL: C. GUILLÉN, ms. 2.175, f. 4: A esas 548 fraguas añade en una nota: "pudiera nombrar sitios y dueños de estas individualmente, dejo de hacerlo por no creerlo necesario pero se puede contar con muchas más, en el supuesto de lo difícil que es una investigación precisa que no ha sido my obgeto".

1104 P. QUINTANA (2005). Ob. cit., p. 90 
Asturias suponen juntas el 13\%, Galicia apenas llega al 8\%1105. Hay algunos apellidos que se repiten con cierta insistencia desde el siglo XVI: Lombardía, Lombardero, Chavarría, Arza, etc. Se trata de apellidos de origen vasco que llegan al noroeste en el curso de los siglos XVI y XVII, en unos casos como ferrones pero también como simples herreros ${ }^{1106}$.

La mayoría de estas fraguas contaban con maestros, oficiales y aprendices, lo que nos obliga a suponer que incluso en las zonas rurales existía algún tipo de estructura gremial, aunque probablemente un tanto laxa y sin ordenanzas que la regulasen, pues no hemos localizado ninguna en la documentación consultada. Pero el hecho de que existan verdaderas sagas de herreros, como las mencionadas antes, indica que si no agremiado, el oficio tendía a seguirse en el seno de la familia, por lo que no hay que pensar que los oficios rurales fueran completamente libres, pues en muchas ocasiones aparecen las mismas restricciones que en los núcleos urbanos. También en el mundo rural se conocen contratos de aprendizaje y existen igualmente exámenes para alcanzar el grado de maestro ${ }^{1107}$.

Además de en el mundo rural, los herreros eran numerosos en la mayoría de las villas y ciudades del noroeste, como vemos en el cuadro XLIV referido a la actual provincia de León. Aunque desde el siglo XVI, los oficios urbanos suelen aparecer ya agrupados en gremios, en Galicia y Asturias se trata de corporaciones débiles y escasamente especializadas, que solo tras imposiciones y multas por los corregidores se logró encuadrar en los mismos, como se deduce del caso de Orense ${ }^{1108}$. De este modo, poco a poco se va imponiendo el sistema

1105 GRUPO 75 (1977): La economía del Antiguo Régimen. La Renta Nacional de la Corona de Castilla. Madrid, p. 134.

${ }^{1106}$ Por ejemplo los Fernández Lombardía, que eran vizcaínos, se establecieron en los Oscos donde llegaron a crear una saga de conocidos herreros.

1107 P. SAAVEDRA (19859: Economía, política y sociedad en Galicia: La provincia de Mondoñedo, 1480-1830. Santiago, p. 312.

${ }^{1108}$ AHRG. R. A.: 14936/6. En 1602 el corregidor encarcela a catorce personas "todos cerrajeros de esta ciudad de Orense", que se habían querellado contra éste y su teniente, que los persigue "por dezir que no son examinados, cosa que nunca jamás se ha visto en este Reyno", secuestrándoles sus bienes "sin que en la dicha ziudad de Orense se aya ningún examinador de semejantes oficios ni nunca en ella ni en todo este Reyno ubo semejantes examinadores". En el pleito que se sustancia en la Audiencia de La Coruña, un testigo añade que "siendo como el testigo es biejo, y se acuerda de más cinquenta años que es en la dicha ciudad de Orense nunca ubo examinador de el oficio de cerrajeros ni herreros, $y$ aunque algunos corregidores an benido a la dicha ciudad nunca de ello han tratado sino agora por la dicha ocasión de llebar 
gremial en las villas y ciudades (maestros, oficiales y aprendices), mediante una asociación profesional obligatoria, exclusiva y privilegiada. Los padres de los aprendices firmaban normalmente contratos de aprendizaje con un maestro, quien solía dar casa y manutención al muchacho durante los años en los que aprendía el oficio, que solían ser tres o cuatro normalmente ${ }^{1109}$. Para alcanzar el grado de maestro era necesario pasar un examen ${ }^{1110}$.

\section{CUADRO XLII.- HERREROS EN LAS PRINCIPALES VILLAS LEONESAS}

\begin{tabular}{|l|c|c|c|c|l|}
\hline LUGAR & MAESTROS & OFICIALES & APRENDICES & TOTAL & $\%$ \\
\hline LEÓN & 12 & 4 & 1 & 17 & 23,6 \\
\hline BOÑAR & 2 & & & 2 & 2,7 \\
\hline VALENCIA & 4 & 3 & 2 & 9 & 12,5 \\
\hline SAHAGÚN & 4 & 3 & & 7 & 9,7 \\
\hline VALDERAS & 5 & & 1 & 6 & 8,3 \\
\hline ASTORGA & 4 & & & 4 & 5,5 \\
\hline LA BAÑEZA & 4 & 1 & & 5 & 6,9 \\
\hline BENAVIDES & 1 & & 1 & 6 & 8,3 \\
\hline PONFERRADA & 4 & 1 & 2 & 7 & 9,7 \\
\hline CACABELOS & 5 & & 1 & 2 & 2,7 \\
\hline VILLAFRANCA & 1 & & & & 1,3 \\
\hline
\end{tabular}

sus haciendas siendo como son muchos de ellos gente onrrada y ricos y andando ausentes de sus casas pierden muchos reales en sus oficinas de cerrajeros y herreros".

${ }_{1109}$ En 1679 Alberto Varela, en nombre del herrero Santiago Domínguez, vecino de La Coruña, dice que "el año pasado de setenta y siete por el mes de octubre, Domingo de Riua, vecino de esta dicha ciudad, asi mismo herrero entregó a mi parte a Pedro de Gazón, vecino de la fa de Santa Mariña de Beyra para que le enseñase el oficio de errero de la arte que se estila en los maestros de su oficio y que auía de asistir a dicha mi parte por el espacio de tres años, etc." (AHRG. R.A.: 21.873/18). También en 1688, Pedro Fernandez se concierta con el herrero de Pereje, al lado de Villafranca del Bierzo, Ignacio Fernández para que le instruyese durante cuatro años en dicho oficio, "al cauo de (los quales) le auia de dar enseñado todo jénero de azer erramientas de corte y de vajo de tierra, erramientas y clauos de herraje y lo mas que dicho maestro saue" (AHPL. P.N.: caja 3084). En 1759 Juan Antonio Gutiérrez, como padre de Felipe Antonio, firma un contrato con el herrero José de la Infiesta, de Gijón, para que le enseñe el oficio de herrero. Texto en OCAMPO, J. (1987): Ob. cit., p. 141-142

1110 AHPL. P. N.: caja 2945: En 1670 Juan Marcos es examinado ante tres maestros herreros en Villafranca, los cuales le capacitaría para "hacer y obrar clavazón de todo género, rejas de arar, azadas y azadones, ozes y machados y calçar dichas herramientas y todo lo más tocante al dicho oficio de herrero". El corregidor de la villa, tras el examen, expidió el correspondiente certificado que le facultaba "para que como tal maestro examinado pueda ussar y ejercer el dicho oficio de herrero en todo lo tocante a él, ansi en esta villa, su jurisdicción, estado y marquesado y otras partes de estos reynos". 


\begin{tabular}{|l|c|c|c|c|l|}
\hline LOS BARRIOS & 2 & & & 2 & 2,7 \\
\hline BEMBIBRE & 1 & & & 1 & 1,3 \\
\hline PÁRAMO & 2 & & & 2 & 2,7 \\
\hline PALACIOS & 1 & & & 1 & 1,3 \\
\hline TOTAL & 52 & 12 & 8 & 72 & 100 \\
\hline
\end{tabular}

FUENTE: PARES: Catastro de Ensenada. Respuesta 33 del interrogatorio general de los referidas villas

Como el de herrero, los oficios de armero y cerrajero se transmitían de forma familiar, pero fueron frecuentes los contratos de aprendizaje a gentes de fuera del círculo familiar. Así en 1679 Sebastián Fernández das Coroas, de Ribadeo, se compromete a enseñar el oficio de cerrajero y ferramentero de obra blanca al hijo de Juan Mengoechea "el Viejo", vecino de la ferrería de Lorenzana; o en 1700 se suscribe un contrato en Ribadeo, en el que el aprendiz empleará seis años para hacer cerraduras, cuchillos, tijeras, etc. ${ }^{1111}$ Muchos de estos aprendices, convertidos luego en oficiales, sufrían exámenes para alcanzar el grado de maestro ${ }^{1112}$.

Estos artesanos suelen vender sus mercancías en los talleres donde trabajan ${ }^{1113}$, pero también acuden a las ferias de otros pueblos y ciudades a venderlas ${ }^{1114}$; aunque en las villas y ciudades encuentran, a veces, obstáculos

1111 P. SAAVEDRA (1985): Ob. cit., p. 315, nota 33

1112 En 1634 se menciona el "examen que hace Francisco Guaco, maestro de armería, pabonar y dorar, vecino de León, a Domingo Correas, vecino de Villafranca, con preguntas y repreguntas para que pueda ejercer el oficio de armería, pabonar y dorar" (AHPL. P. N.: caja 3299).

${ }_{1113}$ En 1775 Domingo Gregorio García, maestro herrero y cerrajero, residente en Pacios de Veiga (jurisdicción de Puebla de Brollón) denuncia al merino y juez ordinario de esa jurisdicción, el cual le encargó en "su fragua de manos" que tiene en dicho Pacios "una balconada de fierro de debujo para su casa", ajustada a 31 cuartos la libra; pero una vez terminada no la quiso y no solo eso, sino que un primo de aquel entró en la fragua descerrajando la puerta, llevó la balconada y destrozó la fragua (AHPLU: 2417/5). En 1791 Francisco Pol, maestro herrero "de fabricar clavo y lamias de herrejar de hierro para carros", vecino de San Vicente de Villamor vendió al fiado a don Diego Castro, de Castro Caldelas, dos herrajes en 211 reales, que le quedó debiendo y no le paga (AHPLU: 2417/11)

${ }_{1114}$ En 1769 el cerrajero Benito Fernández Lombardía, vecino del mazo de Cancillós, dice que varios vecinos de Ponferrada y del principado de Asturias "le han sacado al fiado varios géneros de calderería, ascendiendo su pecuniaria suma a 6.20o y más reales", y como no se los han pagado pide al alcalde mayor de la villa de Cacabelos, a cuya ferias de San Marcos han venido "a vender sus los gérnos de calderería" se las embargue (AHPL. P.N.: caja 3337). 
gremiales que se lo impiden ${ }^{1115}$. En general sus establecimientos también contaban con elementos propios de la fragua ${ }^{1116} \mathrm{y}$, de igual modo, firmaban contratos de obligación en los que se comprometían a entregar sus mercancías en los tiempos estipulados ${ }^{1117}$.

Las compras de estos herreros suelen ser pequeñas, de solo algunos quintales ${ }^{1118}$, aunque a veces esas cifras no lo son tanto ${ }^{1119}$. Por esa razón, en muchos casos, tales herreros están mediatizados por los arrieros y tratantes de hierro, que se lo prestan o trabajan para ellos ${ }^{1120}$; incluso la Compañía de la Vega de Ribadeo cedía hierro a los herreros para hacer clavazón, que luego vendía a los astilleros y otros compradores ${ }^{1121}$. En este sentido, tales artesanos

1115 En 1618 los herreros y cerrajeros de Padrón se querellan contra el alcalde mayor y juez de la Quintana, y los alcaldes ordinarios de Santiago de Compostela, porque "no hestando proybido que se puedan vender en las ferias y mercados ... todo género de herrage, y que de unos lugares se pueden lleuar a vender a otros, y ansimismo no hestando proyvido que los herreros puedan vender qualquiera obra de su oficio aunque no hestén examinados, los jueces de la ciudad de Santiago a ynstancia y pedimento de los herreros de la ciudad de Santiago an procedido contra mis partes por decir venden obra de su oficio como son açadones, palas (...) y otros herrages del género en la dicha ciudad y que los veinen a vender desde la uilla de Padrón" (AHRG. R.A.: 9746/37).

${ }^{1116}$ Lo podemos ver en la subasta de bienes del cerrajero de Ruitelán, Diego de Bergara en 1688, por una deuda de 50 ducados: "le sacaron unos barquines de fragua usados, una yunque de setenta libras, poco más o menos, un torno de madera de andar los barquines, dos martillos pequeños de seis libras ambos y dos, y otro martillo que pasará dos libros; una clavera vieja de hazer clavo de zapato, una talladera que pesa una libra, un bufete pequeño con su cajón..." (AHPL. P.N.: caja 3299).

1117. En 1629 Miguel Ibarra, vecino de Oencia, se obliga a dar y pagar a Francisco de san Miguel, vecino de Villafranca, "çinco millares de clavo de herrar de yerro de a nueve libras el millar por raçon de que echas nuestras quentas que ambos teníamos ansi de lo que me avia dado como de lo que yo avia pago asta oy dia de la fecha (19 de abril) me alcança en la dicha cuenta en los dichos cinco millares de clavo, de los quales me doy por vien pago y contento". Debe dar dos millares por san Marcos y otros tres millares por la feria de san Juan (AHPL. P.N.: caja 2969). También los vecinos de Oencia se obligan a pagar Alonso Fernández, su convecino, 342 rs. y 268 rs. por 38.000 clavos y 29.000 clavos de herrar, al precio de 9 rs./millar (AHPL. P.N.: caja 2969).

1118 Por ejemplo Diego Ovalle, arrendatario de Pontepetre, vende en 1802 a Juan Martínez, de Corullón, 12 '5 quintales de hierro (que ya se llevó) y otros 10 quintales que le ha de remitir, total 22 '5 quintales a precio de 140 rs./q., lo que suma 3.150 rs. para su fragua (AHPL. P.N.: caja 3618). Manuel Nonide, de Villafranca del Bierzo, se obliga a pagar en 1826 a Ramón Ovalle, 1505 reales y 7 mrs. que le adeuda "de yerro que le sacó al fiado para trabajar en su oficio"( AHPL. P.N.: caja 3675).

1119 Como la deuda de 18.780 reales que José Carballo reconoce deber en 1833 al dueño de la ferrería de Seoane “de hierro que le vendió al fiado" (AHPLU: 5341/2).

${ }^{1120}$ En 1828 Manuel Díaz, vecino del mazo del Ángel, del que lleva en foro una parte y que luego finaliza su obra en una fragua propia, afirma que "en el dicho trato no es mío más que el trabajo, puesto que el fierro lo dan los arrieros y tratantes a los herreros para que lo trabajemos pagándonos tan solamente nuestro trabajo". Cit. en P. QUINTANA (2005): Ob. cit., t. II, p. 168

${ }^{1121}$ En un informe de 1796 dice que "por lo que respecta al coste de los clavazones de 10 a 20 pulgadas, que le remití en 20 cajones por el citado Patrón y Barco, diré: que dichas clavazones las pagué a 56 maravedís/libra gallega, que viene a salir a 41 por la castellana, y que en el 
no solo eran el último elemento en la transformación del hierro, también lo eran con frecuencia socialmente. Frente a los dueños o renderos de las ferrerías, normalmente hidalgos, o los herreros de mazo que trabajaban buena parte del año, estos herreros de lima se veían obligados a compaginar su trabajo con las tareas agrícolas para poder subsistir. Su vida no debió de ser fácil.

fierro que les di para hacerlas tan solo nos quedan de utilidad 2 reales y cuartillo en cada quintal" (AMPL. Carpeta de la Casa de Ribadeneira. Cartas de la Compañía de la Vega de Ribadeo, 22 de abril de 1796. Cit. P. QUINTANA (2005): Ob. cit., t. II, p. 174). 


\section{CONCLUSIONES}

La principal conclusión que se desprende de este estudio es la importancia de la siderurgia en la economía y vida social del noroeste de España, tanto desde el punto de vista cualitativo como del cuantitativo. No se trató de una actividad marginal, ni su importancia fue inferior a la de otras regiones siderúrgicas como Cantabria o el País Vasco, todo lo contrario. Hablamos de 131 ferrerías, más de 80 machucos y miles de fraguas las que -no al mismo tiempo sino a lo largo de los siglos XVI al XIX- estuvieron en funcionamiento, afectando a miles de trabajadores directos, a los que habría que añadir los carboneros y venaqueros, mulateros y transportistas de la vena, arrieros, comerciantes y tratantes de hierro.

El número de ferrones y herreros no es quizá un porcentaje muy grande respecto del total de la población, pero sí lo fueron respecto al artesanado de los siglos estudiados, en torno a un 10\% probablemente, y aún más si contamos a sus familias y a los otros grupos implicados. Pero su importancia fue aún mayor por lo que significaba esa actividad para la agricultura y la industria, o para las familias; ya que les proporcionaba hierro en bruto, aperos de labranza, clavazón para la construcción naval, armas para el ejército, utensilios para muchas profesiones y ajuares domésticos. La siderurgia mejoró la calidad de vida de las gentes de aquellos siglos.

Con el nombre de siderurgia tradicional nos referimos no a toda la siderurgia de los siglos XVI al XIX, sino a aquella que utiliza el horno bajo para la reducción del mineral. Por tanto, a las ferrerías o forjas, nombre este que desde Cataluña se extendió al resto de España, sobre todo en el siglo XIX por obra de los ingenieros de minas. El término que se más frecuentemente se utiliza en el nororoeste, por influencia vasca, es el de ferraria, ferrería o herrería castellanizando el primer nombre. Sin embargo este último término, así como el de herrero, lo vamos a utilizar únicamente para denominar a los que trabajan en las fraguas o herrerías. Los trabajadores u oficiales de las ferrerías no son 
herreros sino ferrones. No incluimos en la siderurgia tradicional los hornos altos aunque también trabajaron en esos siglos tanto en Cantabria, por ejemplo en Liérganes y la Cavada, como en el noroeste, Sargadelos.

A comienzos del siglo XVI hemos visto surgir ciertas innovaciones en la siderurgia tradicional, que desde la Edad Media era ya una técnica hidráulica al utilizar ruedas movidas por agua para accionar los mazos y barquines. Entre esas innovaciones hay que señalar el de las "ferrerías a la genovesa", término que no alude, como pensaron algunos autores, a las ferrerías hidráulicas, sino a su especialización en ferrerías mayores y menores, estas últimas llamadas en el noroeste machucos, mazos o martinetes. Mientras las primeras fundían el mineral de hierro para transformarlo en hierro forjado, las segundas elaboraron ese hierro para convertirlo en herramientas, aperos domésticos y de labor.

Estas innovaciones las introdujeron en España expertos italianos, como Juan Tomás de Fabricario, y afectaron directamente al País Vasco, zona con numerosas ferrerías en la Baja Edad Media, lo que provocó a finales del siglo XV y comienzos del siguiente una diáspora de ferrones por varias regiones de España en las que existían condiciones para fabricar hierro, pues el crecimiento demográfico de ese siglo y las guerras aumentaron la demanda del mismo, que aquella región no pudo satisfacer probablemente por falta de combustible. Fue esa diáspora la que explica la presencia de tantos ferrones Vascos en Galicia, Asturias y León, y la construcción -en algunos casos renovación-de ferrerías en el noroeste.

El número de las que se construyeron o se renovaron, pues existía en nuestra zona de estudio una larga tradición medieval, fue en el siglo XVI de 41 ferrerías, lo que representa el $31,2 \%$ del total de las que se construyeron en el noroeste de España en los siglos XVI al XIX. Esto creó una dinámica y una cultura del hierro que permitiría, en las diversas coyunturas posteriores, ir aumentado ese número paulatinamente: 12 ferrerías más en el siglo XVII (9,1\%), 31 en el siglo XVIII (23,6\%) y 47 en el siglo XIX (35,8\%). También hubo algunos cierres, entre un 10 y un 15 por ciento aproximadamente, antes de su fin definitivo en la segunda mitad del siglo XIX. Por eso, podemos decir que en si 
en los siglos XVI y XVII su número osciló entre las 40 y 50 ferrerías, en los siglos XVIII y XIX estuvieron en funcionamiento aproximadamente unas 70 en el primero y unas 100 en el segundo. Este simple hecho cuantitativo, junto a los numerosos machucos en su alrededores, tuvo enormes consecuencias por lo que se refiere a la producción, la comercialización y los beneficios obtenidos.

El espacio geográfico de la siderurgia tradicional en el noroeste lo acotamos porque no hubo ferrerías ni, con alguna excepción, mazos en León ni Galicia, solo en el Bierzo leonés y en las provincias gallegas de Lugo y Orense, pero incluso en estas su existencia se redujo a algunas comarcas: en el interior solo las más cercanas a los yacimientos de hierro de Formigueiros y Rocas contaron con ellas. Así Valdeorras, Caurel, Quiroga e Incio, con alguna otra marginal, como la zona entre Cervantes y Fonsagrada en que se aprovechó varias veneras locales; y en la costa o sus inmediaciones porque en ellas fue posible utilizar el hierro vizcaíno de Somorrostro. Sólo en Asturias su difusión fue algo mayor, aunque especialmente se localizaron en el oeste, en el límite con Galicia, entre la costa Cantábrica y Somiedo, por el bajo Eo y los Oscos, y en menor número en la parte oriental para aprovechar los caudalosos ríos que bajan de los Picos de Europa y las masas arbóreas de las estribaciones de la cordillera Cantábrica.

Las razones que explican esta actividad siderúrgica y su distribución geográfica son numerosas. La primera, como hemos dicho, la presencia de numerosos ferrones y arrendatarios vascos. La documentación, muy generosa en este sentido, no deja la menor duda. Los vascos aportaron la técnica, su experiencia ferrona e incluso los capitales para poner en marcha las ferrerías y machucos. Sabemos que, por ejemplo, en Portugal fueron requeridos por la monarquía para poner en marcha los ingenios de Caria o para montar la ferrería de Barcarena, al norte de ese país. En el oeste de España no hubo tal necesidad porque los vascos, como súbditos de la monarquía hispánica, no encontraron impedimento para moverse, por lo que habría que suponer que fueron ellos mismos los que se desplazaron al conocer las potencialidades de la zona. 
También es posible que fueran llamados por algunos señores, porque tanto la alta nobleza como las órdenes militares, propietarios de zonas ricas en agua y bosque, estuvieron interesados en explotarlas mediante esta actividad. En muchos casos, las ferrerías fueron construidas por empresarios vascos, de lo que tenemos varios ejemplos; pero más frecuentemente lo que hallamos en la documentación son vascos como arrendatarios y oficiales. Casi podríamos decir que la mayoría de los ferrones de los siglos XVI y XVII (hasta la primera mitad de este aproximadamente) son vascos y también lo son una buena parte de los arrendatarios. Los vascos igualmente ejercieron otros oficios, como ferramenteros, barquineros, venaqueros e incluso transportistas de la vena y carboneros. La mayoría provenían de Vizcaya pero, entre los que citan su lugar de procedencia, hay guipuzcoanos y algunos navarros.

Los vascos, como he dicho, difundieron las nuevas técnicas siderúrgicas. No hallamos ninguna diferencia entre las ferrerías vascas y las del occidente; es más, buena parte de la terminología de ciertas partes de las ferrerías y los procesos fabriles son de origen vasco: ciguillo, veterría, bergamazo, cadenarte, aldabarra, estolda, agoa, zamarra, arota. Esa difusión, al principio, estuvo restringida a los propios vascos, pues aunque no hemos detectado que formaran gremios con su específica organización y estatutos, sin embargo sí que transmitían el oficio entre los miembros de su familia; había, por así decirlo, un cierto secreto profesional. Por esa razón hasta mediados del siglo XVII es difícil encontrar nombres de oficiales ferrones que no sean de procedencia vasca. Luego el oficio se difunde entre las poblaciones locales, aunque siempre encontraremos apellidos vascos en esta tierra: Chavarrías, Ortiz, Ezpeletas, Gurriaranes, Lombardías, etc.

La difusión de la siderurgia por el noroeste encontró en la zona unas condiciones muy adecuadas, especialmente cursos de agua y combustible. Sin agua no hay ferrerías por que se trata, lo hemos dicho, de ingenios hidráulicos que necesitan una corriente de agua para accionar los mazos y barquines, estos para inyectar aire al horno y lograr temperaturas adecuadas para fundir el mineral de hierro, por encima de los 1000 grados; aquellos para compactar las 
fibras de hierro, estirarlo y darles las formas precisas para su comercialización: banda, pletina, cuadradillo, etc.

El noroeste cuenta con muchos y caudalosos ríos y arroyos susceptibles de ser utilizados con ese fin, por ser una zona montañosa de clima húmedo. Por otro lado, las condiciones climáticas de la Edad Moderna, más frías y lluviosas que en la actualidad, permitieron caudales abundantes. El agua no fue el mayor problema, lo que no quiere decir que no hubiera conflictos por ella. Los hubo especialmente en los siglos XVIII y XIX, porque entonces no solo aumentó el número de ferrerías sino también el de otros artefactos, como molinos y batanes, y sobre todo el riego de los prados.

Mayores problemas causó el combustible. Las ferrerías, además de leña para raguar o calcinar el mineral, utilizaban solo carbón vegetal para reducirlo; por lo que fue necesario la existencia de abundantes bosques para alimentarlas. La proporción de carbón por quintal fundido es aproximadamente de 1 a 6 , pero para fabricar esos 6 quintales de carbón se precisan, dependiendo del tipo de árbol utilizado, casi 30 de madera. Si aceptamos una media de 700 quintales de hierro por ferrería y año su consumo fue enorme, lo que explica las quejas sobre la deforestación que provocaban tales artefactos. Por sus condiciones físicas y climáticas, el área estudiada fue rica en ese recurso (roble, haya y raíz de la urz); pero la negligente política forestal seguida por arrendatarios y autoridades acabó arruinando el bosque.

No fueron solo las ferrerías, sin duda grandes consumidoras de madera y carbón, o los astilleros de la Armada para los que se guardaban los mejores ejemplares de árboles bravos, las que despoblaron los montes, sino la ausencia durante siglos de una decidida política repobladora. Por eso algunos viajeros e inspectores se extrañaban que en comarcas de tantas ferrerías no hubiera plantíos para raguar el mineral, ni se cortara la madera o se arrancara el brezo de forma racional para fabricar carbón. Esta negligente política y la desaparición del bosque se convertiría, a finales del siglo XVIII, en un factor limitador para la expansión de las ferrerías, que momentáneamente se paliaría en el siglo XIX con la desamortización, que puso en manos privadas más hectáreas de bosque, y un mayor control de este por las autoridades. Pero los 
conflictos tan numerosos sobre el uso del bosque o el carboneo, especialmente en los siglos XVIII y XIX, son síntoma de su precariedad.

El mineral de hierro explica la localización de muchas ferrerías pero no fue el factor más importante, porque la vena autóctona no constituyó la exclusiva materia prima para poner en funcionamiento las ferrerías, siempre que el mineral vasco se pudiere transportar a precios razonables, lo que fue así efectivamente. Sin embargo el descubrimiento de ricos yacimientos de hierro en la provincia de Lugo sí explica la construcción de numerosas ferrerías gallegas (del interior de Lugo y Orense) y bercianas. Por ello creo que se puede establecer una cierta regionalización de las ferrerías en razón de la procedencia del mineral de hierro y hablar de tres ámbitos diferentes.

El primero abarca el entorno de los yacimientos de Formigueiros, Rocas y minas aledañas. Este ámbito abastece aproximadamente el $42 \%$ de todas las ferrerías del noroeste en las provincias de León, Lugo y Orense. El segundo fue el de las ferrerías abastecidas con mineral vasco, a veces mezclado con vena local. Este segundo ámbito, con un 32\% aproximadamente de las ferrerías, se extiende por las zonas costeras -o cercanas a la costa- de Lugo y Oviedo. Un intenso tráfico de cabotaje hizo posible que, sin grandes dificultades, estas ferrerías pudieran abastecerse durante siglos. El último ámbito, con un 25\% de ferrerías, se abasteció de pequeños yacimientos locales, generalmente de mala calidad o insuficiente producción. Muchas de estas ferrerías se encuentran en zonas del interior, aisladas y, por ello, con dificultades para vender sus hierros, casi siempre poco apreciados por su baja calidad.

En las licencias de construcción, las ferrerías incluían siempre el derecho de la vena, es decir, la posibilidad de obtener mineral de hierro de algún yacimiento cercano, como ocurre con los foros suscritos por los propietarios de ferrerías con el conde de Maceda respecto de la vena de Formigueiros, monte que tenía aforado a la encomienda de la Barra. En algunos contratos de arriendo se menciona igualmente este requisito, así como dar expeditos los caminos de la vena, generalmente privativos de las ferrerías. Pero eso no significa que las ferrerías explotaran directamente las minas; de hecho, sólo algunas, como la de 
Bueyes, tuvieron permiso para beneficiar en exclusiva algún venero en Formigueiros, y otras, como la de Loureiro, tuvieron venas propias, cuyo mineral mezclaban con el de Rocas o Formigueiros. Eso también lo hacían varias ferrerías asturianas que mezclaban vena local con el mineral de Somorrostro.

En general la explotación de las minas, casi siempre a cielo abierto, lo hacían cuadrillas de venaqueros que indistintamente vendían la vena a las ferrerías de los alrededores mediante contratos anuales. El transporte de esa mena que, antes de fundir, había que raguar o calcinar lo realizaban arrieros en sus recuas de mulos o transportistas en carros. Este transporte suponía más del $70 \%$ de valor de la mena, e incluso más dependiendo de la distancia. La riqueza de los minerales era generalmente alta, superior al $60 \%$; pero normalmente eran necesarios tres quintales de vena por quintal de hierro fundido, lo que daba tal riqueza se reducía al $33 \%$ aproximadamente. El mineral vasco se transportaba en barcos hasta los puertos gallegos y asturianos y desde allí, bien en barcazas siguiendo el curso de algún río, bien en carros se transportaba a las ferrerías. Solo en este último tramo su precio se encarecía en más de un 35\%, al que habría que añadir el transporte desde Vizcaya y los aranceles; por tanto, el porcentaje del transporte era incluso aún mayor que en las del interior.

Para poner en marcha una ferrería, además de agua, combustible y mineral de hierro, había que contar con el permiso de las autoridades -la Corona, la Secretaría de Hacienda, el ministerio de Fomento, según los tiemposy con el de los dueños de las tierras (señores y concejos); pero sobre todo había que poseer recursos financieros, porque las cuantiosas inversiones que requería no estaban al alcance de cualquiera. El coste de estos artefactos era muy elevado (de 50.000 a 300.000 reales según las épocas), exigía un capital fijo del que sólo muy pocos podían disponer o lograr los créditos, casi siempre bajo la forma de censos, con un interés en torno al $5 \%$.

Por eso, la construcción de ferrerías fue promovida unas veces por los propietarios del suelo, montes y aguas (nobleza e instituciones religiosas) para así sacar provecho de unos recursos de escaso valor agrícola. Así lo parece en el 
caso del conde de Lemos que levantó dos ferrerías en el Selmo leonés, y que ya a finales del siglo XV tenía arrendadas a vizcaínos. En otros casos, por ejemplo en territorios de las encomiendas de Quiroga o de la Barra, parece como si solo cedieran el terreno, las aguas y el bosque, pero quienes realmente las construyen son otros, por ejemplo vascos o hidalgos locales, como ocurre con la ferrería de Paleiras construida en el siglo XVI por el vasco Martín de Aldunzín, en territorio de la encomienda de la Barra, o la de primitiva de Quintá, levantada por Francisco Vázquez en tierras de la encomienda de Quiroga. Otras veces los propietarios son monasterios, como Samos, Montes o Villanueva de Oscos, que las construyen con sus propios recursos o pidiendo créditos a diferentes instituciones y personas físicas, por carecer de sumas tan crecidas.

Si hasta el siglo XVIII las ferrerías fueron construidas o promovidas por la nobleza e hidalguía laica, las órdenes militares y religiosas, desde la segunda mitad de ese siglo y en el XIX entran nuevos grupos sociales en el negocio, unas veces formando compañías, otras a título particular; en ese sentido la propiedad se diversifica un tanto. La calificación social de este nuevo grupo es complicada, porque algunos pueden identificarse con la vieja hidalguía rural; pero a otros los deberíamos considerar como una incipiente burguesía interesada en el negocio del hierro, en su producción o en su comercialización, lo que podríamos identificar como una forma de verlagssisten. En muchos casos, los nuevos propietarios son antiguos arrendatarios, expertos en el negocio del hierro que, al ser más permisivas las leyes, solicitan directamente a la Administración la concesión de permisos para la construcción de ferrerías.

Esos nuevos empresarios tuvieron que solicitar créditos o buscarse socios para llevar a cabo sus proyectos. Algunos derivaban sus fortunas del comercio o del ejercicio de funciones administrativas o militares. Por ejemplo, Carlos Lemaur, el militar ingeniero que realizó el camino real de La Coruña a la Meseta, construyó en las cercanías de Torre del Bierzo dos ferrerías en la segunda mitad del XVIII solicitando sendos créditos de 267.603 y 109.500 reales, respectivamente, al lucense Agustín Álvarez de la Iglesia, administrador de la Real Gracia del Excusado y al vecino de la Coruña Miguel Valls. Los enormes costes de estos artilugios obligaron al concurso de varias personas o la 
formación de compañías, como vemos en los casos de la ferrería de Tejedo o en el de la Compañía de la Vega Ribadeo, que construyó y explotó varias ferrerías gallegas y asturianas.

Otras veces nos encontramos con verdaderos empresarios con recursos suficientes como para adquirir ferrerías desamortizadas o construir las suyas propias, como el ponferradino Nemesio Fernández, propietario en el siglo XIX de las ferrerías de Montes, Corporales, Serviz, Portela y Llamas de Cabrera, las cuatro última construidas personalmente por él. En otros casos, los matrimonios permiten formar grandes patrimonios ferreros, como ocurre con Nemesio Fernández cuya hija se casa con los Armesto gallegos, propietarios de las ferrerías de Valdomir, Folgoso y Ferreirós (8 ágoas). Apolinar Suárez de Deza, señor de Bóveda y marqués de Viance, por su parte, reúne por herencia, compra y construcción las ferrerías de Lousadela, Ferreirós, Pombriego, Vegas de Camba y Río Cabo, a las que añadió las de Bueyes y Herrerías de Valcarce por su matrimonio con $\mathrm{M}^{\mathrm{a}}$ Teresa de Tineo, señora de Noceda.

La explotación de las ferrerías se hizo bien de forma directa por el propietario o por un administrador, que adquiría la vena y el carbón y contrataba los oficiales de la ferrería; bien arrendándola por años a persona interesada y experta en la materia, o aforándola a largo plazo. En cualquiera de los casos, tal explotación era un negocio costoso por las materias primas y los salarios, lo que exigía un capital circulante igualmente elevado. En general, durante el siglo XVI y parte del XVII las ferrerías fueron generalmente arrendadas a corto plazo, aunque luego sus dueños prefirieron aforarlas porque entendían que así se protegían mejor tales artefactos y los montes que las abastecían. Por el contrario, las órdenes religiosas desde finales del siglo XVII tendieron a explotarlas directamente por medio de un monje, un prior rendero, que dirige la ferrería y da cuenta a la comunidad de gastos y beneficios. La pequeña nobleza y la hidalguía también tendió a arrendarlas, aunque desde el siglo XVIII la explotación directa por medio de administradores, muchos de ellos presbíteros, fue frecuente. Este mismo sistema sería el más generalizado en el siglo XIX, aunque hay casos de gestión directa. 
Arrendatarios y administradores explotaron las ferrerías mediante la contratación de oficiales o ferrones que, al menos en los siglos XVI y XVII, fueron vascos; luego vecinos de los alrededores de las ferrerías, en unos casos herederos de aquellos, en otros conocedores de la técnica. El número de ferrones en cada ferrería fue generalmente de cinco, aunque las hubo con cuatro y con seis: aroza, tirador, dos fundidores y el tazador. Hubo entre ellos una especie de cursus honorum que comenzaba por el tazador, un aprendiz que además de partir la vena ayudaba a sus compañeros, y terminaba en el aroza, jefe y director de la cuadrilla. Cada ferrón tenía un cometido preciso en el proceso de reducción del mineral y tiraje del hierro. Sus salarios, por ello, eran diferentes y generalmente estaban relacionados con la producción, con el quintalaje. Gozaban de gran movilidad porque se ajustaban al mejor postor.

Para el comienzo de la campaña anual, los administradores o arrendatarios adquirían la vena a los venaqueros, la transportaban a las ferrerías por medio de mulateros y carreteros y, por último, compraban el carbón a los carboneros. Todo esto, además de los ferrones, implicaba a un considerable número de trabajadores, la mayoría indirectos -venaqueros, arrieros, carboneros y los que atendían a los arreglos, como barquineros, ferramenteros, tubereros, etc. Aunque no es posible cuantificar con exactitud ese número por ferrería, seguramente pasaban de cuarenta o cincuenta, lo que dado el número de estas, suponían varios miles de personas las ligadas a ellas, eso sin contar los que trabajaban en mazos y fraguas. La vida era dura, especialmente la de los ferrones, pero el salario de estos estaba muy por encima de los artesanos de la época.

Diversas razones (agua, problemas con la vena y el carbón, paradas por fiestas y escalabros), además de otras estrictamente técnicas, ponían un límite a la capacidad productiva de estos artefactos, que difícilmente podían superar los 2.000 quintales anuales (115.000 kg.). Aunque los datos con los que contamos son fragmentarios y a veces poco rigurosos y contradictorios (Catastro de Ensenada, informes de Cornide Saavedra o Munárriz, diversas contabilidades, Estadísticas Mineras) se puede afirmar con bastante fiabilidad que la producción media anual de estas ferrerías, al menos en los siglos XVIII y XIX, 
fue de unos 700 quintales de cinco arrobas (unas 40 toneladas). Había ferrerías que trabajaban todo el año y alcanzaban producciones superiores a los 1.500 quintales, pero también las hubo regateras que no superaron los 300 quintales. Por eso, la media indicada puede aceptarse sin grandes visos de error.

Más difícil resulta conocer la producción media anual de todas las ferrerías por siglos, porque no hemos encontrado datos estadísticos suficientes para evaluarla. En líneas generales, sin embargo, creemos que la producción de hierro fue creciendo a lo largo de los siglos XVI al XIX, por varias razones: 1) El mayor número de ferrerías en funcionamiento que, como hemos visto pasó de 41 en el siglo XVI a 70 en el siglo XVIII y aproximadamente 100 hacia la mitad del siglo siguiente; 2) La mayor capacidad productiva de las ferrerías que se construyen en los siglos XVIII y XIX; 3) El aumento paulatino del consumo de hierro por habitante, lo que, por otro lado, estuvo ligado al crecimiento de la población de esos siglos en el noroeste de España; y 4) a la política proteccionista de los Borbones al hierro español y la eliminación de aranceles a la venta de hierro al pie de las ferrerías. Por ello, esa evolución nos permite evaluar la producción entre 1.500 toneladas en los siglos XVI y XVII a 4.000 a fines del siglo XVIII y algo más de 5.000 en los mejores momentos del siglo XIX. Porcentualmente estas cantidades supusieron en el total de la producción nacional de hierro forjado desde menos de un $3 \%$ en el XVI al 15\% en el XVIII y un 26\% hacia la mitad del siglo XIX.

Los costes de producción de una ferrería incluían numerosos conceptos: carbón, mineral de hierro, salarios de los oficiales, descalabros, amortización de los capitales y gastos generales (dependía esto de si las ferrerías tenían o no administrador, pero incluían alimentos, salarios del administrador, ama de casa y criados). Podemos señalar, como visión general aunque variable a lo largo de los siglos, que el carbón supuso casi el $43 \%$ del total, frente a la vena $(29,8)$, el trabajo de los operarios (12,7\%) y otros conceptos (16\%), en estos se incluye, por ejemplo, desde los arreglos a los gastos en pleitos. Estos porcentajes no difieren sustancialmente de los que conocemos de otras ferrerías españolas, quizá con la salvedad del carbón que en las del noroeste fue siempre algo inferior, por ejemplo respecto al consumo de las ferrerías vascas y catalanas, por lo que las 
ferrerías del noroeste fueron siempre bastante competitivas, siendo su hierro considerado de bastante buena calidad.

Los beneficios y rentabilidad de las ferrerías son una cuestión compleja, porque su actividad afectó a muchas personas. Por tanto, no se trata sólo de comprobar los beneficios directos que aquellas generaron a sus dueños y arrendatarios, sino que debemos de incluir a los que se beneficiaron directa o indirectamente por los trabajos que realizan en ellas o para ellas: ferrones, venaqueros, transportistas, carboneros, mazuqueros, comerciantes, etc. Son muchos, probablemente cuarenta o cincuenta personas por ferrería, y en total varios miles en toda la zona. Además, el trabajo del hierro en martinetes y fraguas multiplicaba ese número hasta alcanzar cifras superiores a los siete $\mathrm{u}$ ocho mil en la región estudiada. Por eso, aún cuando este tipo de empresas por sus pequeñas dimensiones productivas y el elevado coste de explotación, eran modestas, permitieron un desahogado pasar de sus propietarios y renderos; pero también proporcionaron trabajo y bienestar a muchas otras personas.

Respecto de los propietarios, las ferrerías generaban ingresos sustanciosos que se añadían a las rentas de la tierra, ya que normalmente estas contaban también con bienes en los alrededores (campos de cereal, prados, huertos, ganado), que se aforaban o arrendaban casi siempre junto con los artefactos. Tanto monjes como propietarios laicos fueron conscientes de la enorme rentabilidad de estos artefactos y así lo señalaron en notas y memoriales de los que tenemos noticia, como declara el dueño de la ferrería de Quintá en 1749. Aunque es difícil generalizarlo para todas las ferrerías, sí podemos cuantificar el beneficio de aquellas de las que tenemos datos seriados: un 30 por ciento del total de los ingresos, como rentabilidad media.

Tal porcentaje ofreció a dueños y arrendatarios cantidades muy jugosas, que explican su buen vivir -alguien las ha comparado con los ingresos de un pequeño mayorazgo- y el enriquecimiento de algunos. Los monasterios de Montes y Samos, por ejemplo, emprendieron grandes obras en sus edificios monásticos por los ingresos extraordinarios de sus ferrerías. Al dueño de la ferrería de Valcarce le computa el Catastro de Ensenada unas rentas de 74.000 
reales, lo que lo convierte en el mayor hacendado de la zona de Villafranca del Bierzo. Nemesio Fernández, propietario de varias ferrerías en el siglo XIX, hizo su fortuna con ellas, convirtiéndose en el hombre que más contribución pagaba en el Partido de Ponferrada. Cuando muere deja un capital valorado en 2.630.810 reales, del que las ferrerías suponían 821.500 reales, y el dinero en efectivo en 505.760 reales. Son ejemplos bien expresivos.

Más complicado resulta determinar qué cantidad de ese 30 por ciento se llevaban propietarios y arrendatarios. En los siglos XVI y XVII se consideraba normal una rentabilidad para los propietarios del 10 por ciento; pero esto debió de variar en otros siglos y en las diferentes ferrerías. De hecho, en ejemplos de ferrerías bercianas, sabemos que en la segunda mitad del siglo XVIII el porcentaje de esas rentas se encontraba entre el 15 y 17 por ciento, lo que Munárriz en su informe consideraba excesivo. Si eso fuera sí, los ingresos de los arrendatarios, que eran realmente quienes corrían con los gastos de producción más cuantiosos, habría que computarlos en menos del 20 por ciento, o en torno a esa cantidad. Tal vez el mencionado 30 por ciento, muchos propietarios preferían explotar las ferrerías directamente, por medio de administradores.

El objetivo de la actividad siderúrgica fue la venta de la producción de hierro a los mazos y martinetes, de los que llegó a haber en el noroeste más de 80, y a las fraguas y talleres artesanales para, a partir de los tochos, barras o pletinas, elaborar útiles de todo tipo y, en definitiva, un producto final necesario para su clientela. Todo ello con el fin de abastecer el mercado y obtener un beneficio. La comercialización del hierro es, por tanto, una parte sustancial de la historia de la siderurgia, que afectó a los comerciantes y arrieros; y benefició al conjunto de la sociedad, al ofrecer no solo el hierro en bruto sino una gama amplia de productos artesanales que, sin la menor duda, mejoraron la calidad de vida de las gentes que los consumieron. La comercialización, por ello, se inicia en las ferrerías pero se difunde luego a otros ámbitos productores y, en definitiva, por el territorio que constituyó su hinterland, que en este caso fue todo el noroeste, algunas zonas de la meseta de Castilla y León e incluso el norte de Portugal. 


\section{APÉNDICES, FUENTES \\ Y BIBLIOGRAFÍA}




\section{APÉNDICE I}

\section{MEDIDAS PONDERALES EN LA SIDERURGIA DEL NOROESTE}

La unidad básica de peso en la Corona de Castilla desde el siglo XIV hasta la introducción del sistema métrico en el siglo XIX fue la libra, que equivale a 0,4601 kilogramos. Sus múltiplos eran la arroba de 25 libras $(11,5 \mathrm{~kg}$.) y el quintal de 100 libras (46 kg.). A su vez, la libra se subdividía en 16 onzas.

Aunque hubo en Castilla bastante uniformidad respecto a las medidas ponderales, también hubo excepciones regionales y respecto de ciertos productos. Por ejemplo, el País Vasco y Galicia, también el hierro, tuvieron pesos y medidas particulares, especialmente porque, en unos casos, el número de onzas por libra fue diferente, lo que, a su vez, modificó el tipo de arrobas y quintales, o bien porque el hierro y la vena se pesaban por quintales de pesos diferentes.

En Galicia, pero también en buena parte de la zona objeto de estudio como el Bierzo y Asturias, la libra era de 20 onzas, por lo que el quintal de 100 libras tenía $57,5 \mathrm{~kg}$. y no $46 \mathrm{~kg}$. Por eso en Asturias se hablaba de pesos menores (libra de 16 onzas), pesos medios (libra de 20 onzas) e, incluso, de pesos mayores (libras de 24 onzas) ${ }^{1122}$. Por otra parte, como he dicho, se utilizaban pesos diferentes para la vena y el hierro; también para el carbón.

\section{El hierro}

Como he dicho, en nuestra zona el quintal más frecuente para el peso del hierro fue el quintal de 100 libras de 20 onzas la libra; también llamado quintal de cinco arrobas castellanas. Su peso era de $57,5 \mathrm{~kg}$. A veces se habla del quintal de 125 libras de 16 onzas, cuyo peso era lógicamente el mismo: 57,5 kg. En Galicia, donde la arroba pesaba 14,375 este quintal se denominaba de 4 arrobas, igualmente con ese mismo peso. Ignoramos si la libra de 25 onzas era la misma de la de 20 onzas. En 1535 se arrienda la ferrería asturiana de Raicedo con una renta de 60 quintales "pesados por el quintal de la dicha ferrería a veynte y cinco onzas por libra e cien libras el quintal"1123, lo que probablemente significa que pesaba el quintal esos mismos $57,5 \mathrm{~kg}$.

\footnotetext{
${ }_{1122}$ BOPA, 3 de noviembre de 1852, p. 1 y 2. Aunque hay diferencias por concejos, en general el tipo de libras y onzas es el referido en el texto. En el concejo de Navia, sin embargo, añade esta aclaración: "con la única advertencia de que en este concejo no solo forman arrobas y quintales con libras de 16 onzas, sino con las de 20 y 24; así que hay arrobas de 25 libras castellanas, de 25 libras de 20 onzas y de 25 libras de 24 onzas, sucediendo una cosa análoga con los quintales". 1123 A.Ch.V. Pleitos civiles, caja 207,5.
} 
Este era el peso normal del quintal del hierro y es el que, si no se especifica, utilizaremos nosotros cuando hablemos de dicha medida ponderal. El Catastro de Ensenada dice, por ejemplo, que las ferrerías de Arnado y Pontepetre producían al día "seis quintales y medio de yerro cada uno de cinco arrobas"; o que la de Valcarce producía "seis quintales y un quarto de yerro, constando cada quintal de ciento y veinte y cinco libras"1124. Datoli hablaba a finales del siglo XVIII que las ferrerías del Bierzo producían "unos 1.ooo a 1.200 quintales de cinco arrobas cada uno al año" 1125 . Eran, pues, quintales de peso de $57,5 \mathrm{~kg}$.

Además de este quintal, se suele mencionar otro llamado quintal macho, que Clodio González denomina macho castellano-leonés, de 155 libras castellanas o 71,3 Kg. de peso. Datoli dice que "el hierro del Bierzo puesto en los almacenes de la fábrica (de armas de Asturias) constaría 308 reales el quintal macho de 155 libras castellanas"; o "el coste del hierro en dicha herrería sería, quando más, de 115 reales el quintal macho de a 155 libras castellanas"1126; por tanto, con los mencionados $71,3 \mathrm{~kg}$.

En una ocasión hemos visto vender cargas de hierro de 10 arrobas la carga, por lo que su peso ( $115 \mathrm{~kg}$ ) no es sino dos quintales (de $57,5 \mathrm{~kg}$.), que, por otro lado, es lo que solía transportar un mulo como carga1127.

Solo si las fuentes especifican que se trata de quintales machos lo mediremos por ese peso, en caso contrario siempre lo haremos por el quintal normal de $57,5 \mathrm{~kg}$.

\section{La vena}

Para la vena o mineral de hierro parece que se utilizaba un quintal macho diferente, el llamado macho gallego, que pesaba siete arrobas y media castellanas, es decir, 86,25 kg. Datoli habla que "el arranque del mineral (de Formigueiros) (...) lo tienen ajustado por medio real el quintal de $7^{1 / 2}$, arrobas castellanas"; y lo mismo escribe Munárriz: "el porte que pagan estas herrerías por la conducción del mineral es desde cuatro y medio hasta dieciocho reales el quintal macho gallego, o de siete arrobas y media castellanas".

Según Castro Pérez, en la zona de Castropol el quintal macho era de 154 libras castellanas, que componen $70,85 \mathrm{~kg}$. y era el utilizado en el hierro y la vena procedentes de Vizcaya, aunque en esta región el quintal macho que se utilizaba para el hierro era de 150 libras $(69,3 \mathrm{~kg})^{1128}$; también se usaba el de 155

\footnotetext{
1124 CATASTRO DE ENSENADA. R. G.: Arnado, Oencia, Herrerías de Valcarce.

1125 DATOLI: Ob. cit., 56

1126 DATOLI, p. 51

${ }_{1127}$ En 1590 el rendero de la ferrería de Arnado se obliga con un mercader de Zamora a venderle 200 cargas de acero de 10 arrobas la carga por 8.800 reales, es decir 44 reales la carga (AHPL.

P. N.: 2860).

${ }^{1128}$ L. M. SALAZAR (1983): Ob. cit., t. I, p.103
} 
libras castellanas, como se menciona en 1796 en la mina de San Miguel de Reinante (Lugo), cerca de Castropol ${ }^{1129}$, lo que equivale a $71,31 \mathrm{~kg}$.

En alguna ocasión he visto citar quintales de 133 libras para el peso del mineral de hierro, lo que nos da 61,18 kg.: en 1567 Beltrán de Celaya, rendero de la ferrería de Paleiras, acuerda con unos arrieros que le traigan de la venera de Formigueiros 300 quintales de vena de hierro, de 133 libras cada quintal, a precio de real y medio el quintal ${ }^{1130}$.

\section{El carbón}

La unidad de medida era la carga, es decir lo que cargaba o podía portear una caballería, compuesta de dos sacos, uno a cada costado, en unas cargillas. Se trata de una medida bastante imprecisa, que variaba de unos lugares a otros. En el País Vasco se consideraba que el saco equivalía a 34-40 kg., lo que significa que la carga se encontraba entre los 70 y $80 \mathrm{~kg}$.

Desconocemos el peso de la carga en el Noroeste, aunque no debe ser muy inferior a la vasca. A finales del siglo XVIII, Datoli afirmaba que en las ferrerías bercianas el carbón de brezo, pese a su mucho consumo, "cuesta de 8 hasta 11 reales la carga mayor, pues en el mismo día arranca el carbonero la cantidad de raíz necesaria, la reduce a carbón y lo conduce a hombros a la herrería, fragua o mercado". Del de roble dice que se usa poco y que sale, en Villafranca "a $3^{1 / 2}$ reales la arroba, que viene a ser 21 reales la carga", lo que es un precio abusivo ${ }^{1131}$. Esto quiere decir que la carga equivalía a 6 arrobas, es decir, $69 \mathrm{~kg}$.

En la ferrería de Vilar de Cuiña en 1794, la carga de carbón se componía de cuatro fanegas castellanas, lo que significa que en este caso el carbón no se media por peso sino por capacidad, dado que la fanega castellana equivalía a unos 55 '5 litros.

Otra media era el carro, que en el País Vasco equivalía al peso de tres cargas o seis sacos, es decir entre 210 y $240 \mathrm{~kg}$., aunque no conocemos con exactitud si esta era igualmente la carga de los carros que también se mencionan en el noroeste.

\footnotetext{
1129 Cit. por P. HERNÁNDEZ SAMPELAYO (1935): Ob. cit., p. 44 1130 AHPL. PN. : 1487 (1567).

${ }^{1131}$ DATOLI, p. 62.
} 


\section{APÉNDICE II}

CUADROS SOBRE FERRERÍAS, SUBASTA DE ÁRBOLES, TRANSPORTE DE VENA, TRABAJADORES VASCOS, ARRENATARIOS, PRODUCCIONES, MAZOS

\section{FERRERÍAS DEL NOROESTE POR CUENCAS FLUVIALES}

FERRERÍAS EN LA CUENCA DEL SIL

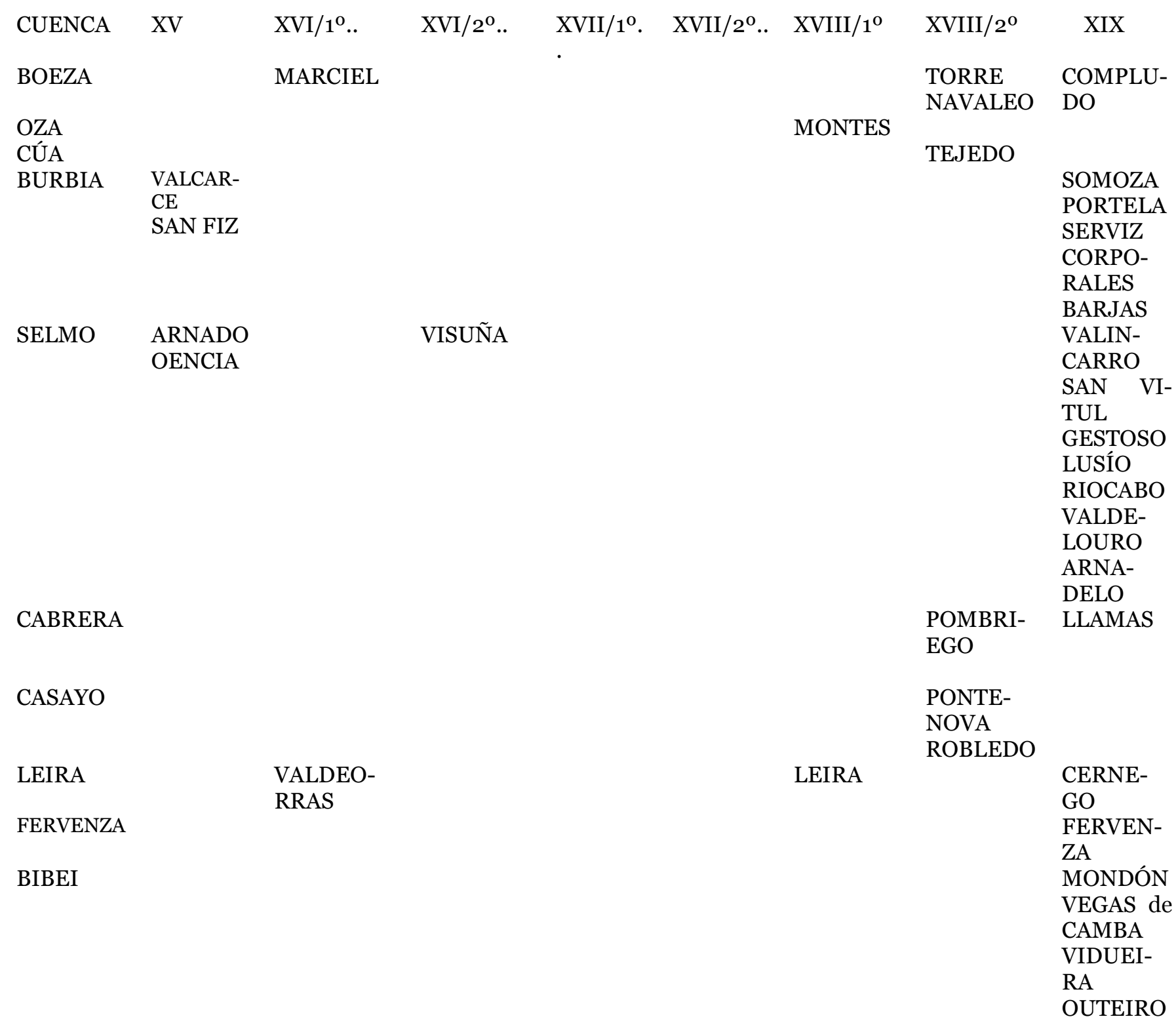




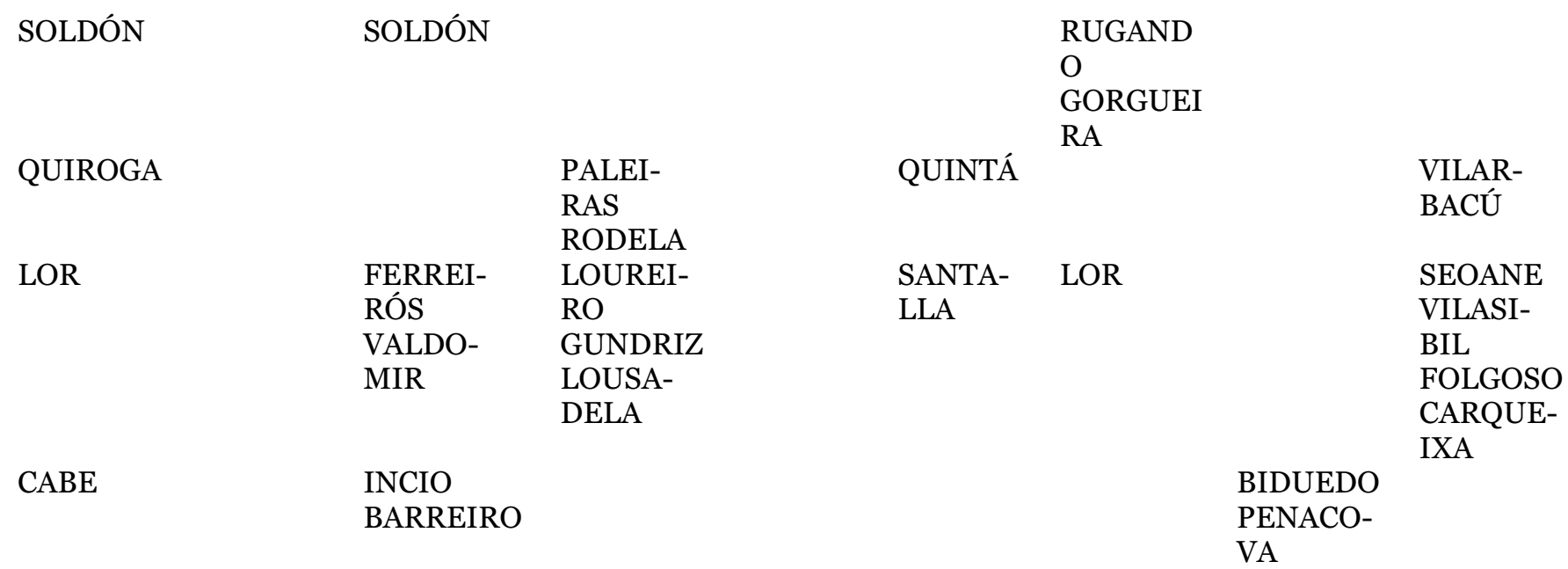
RIO SIL
4
7
7
o
2
8
23

\section{FERRERÍAS EN LA CUENCA DEL MIÑO}

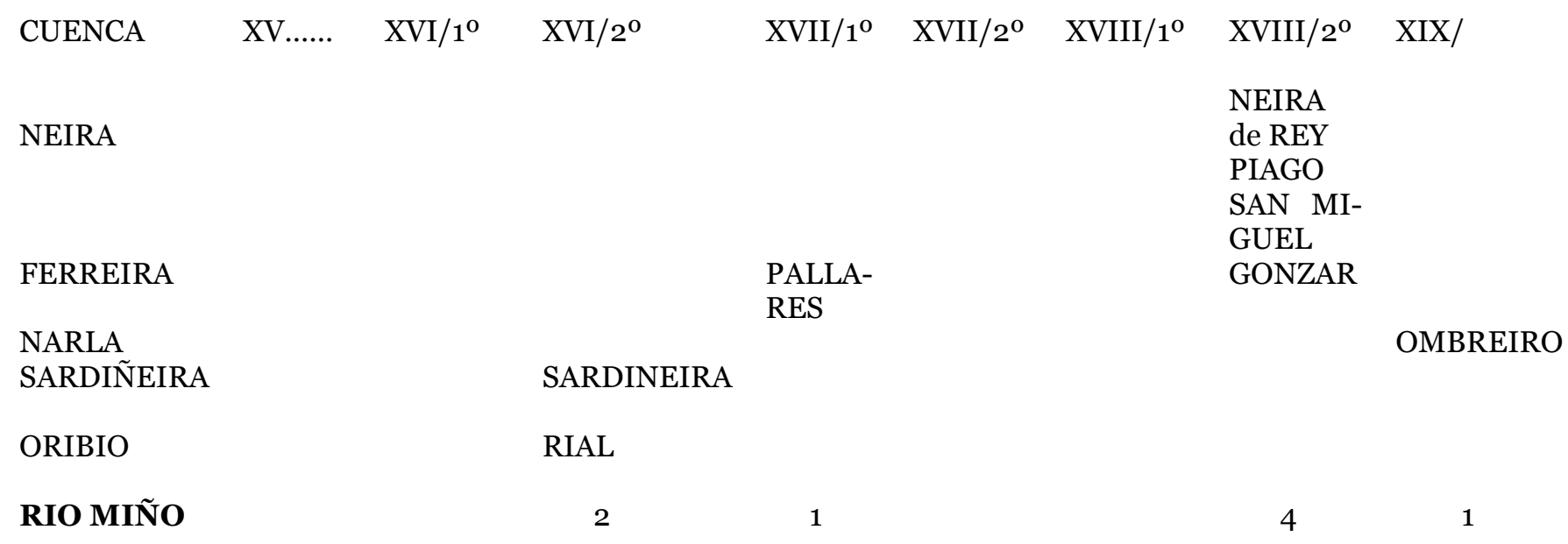




\section{FERRERÍAS EN CUENCAS DE LA VERTIENTE CANTÁBRICA}

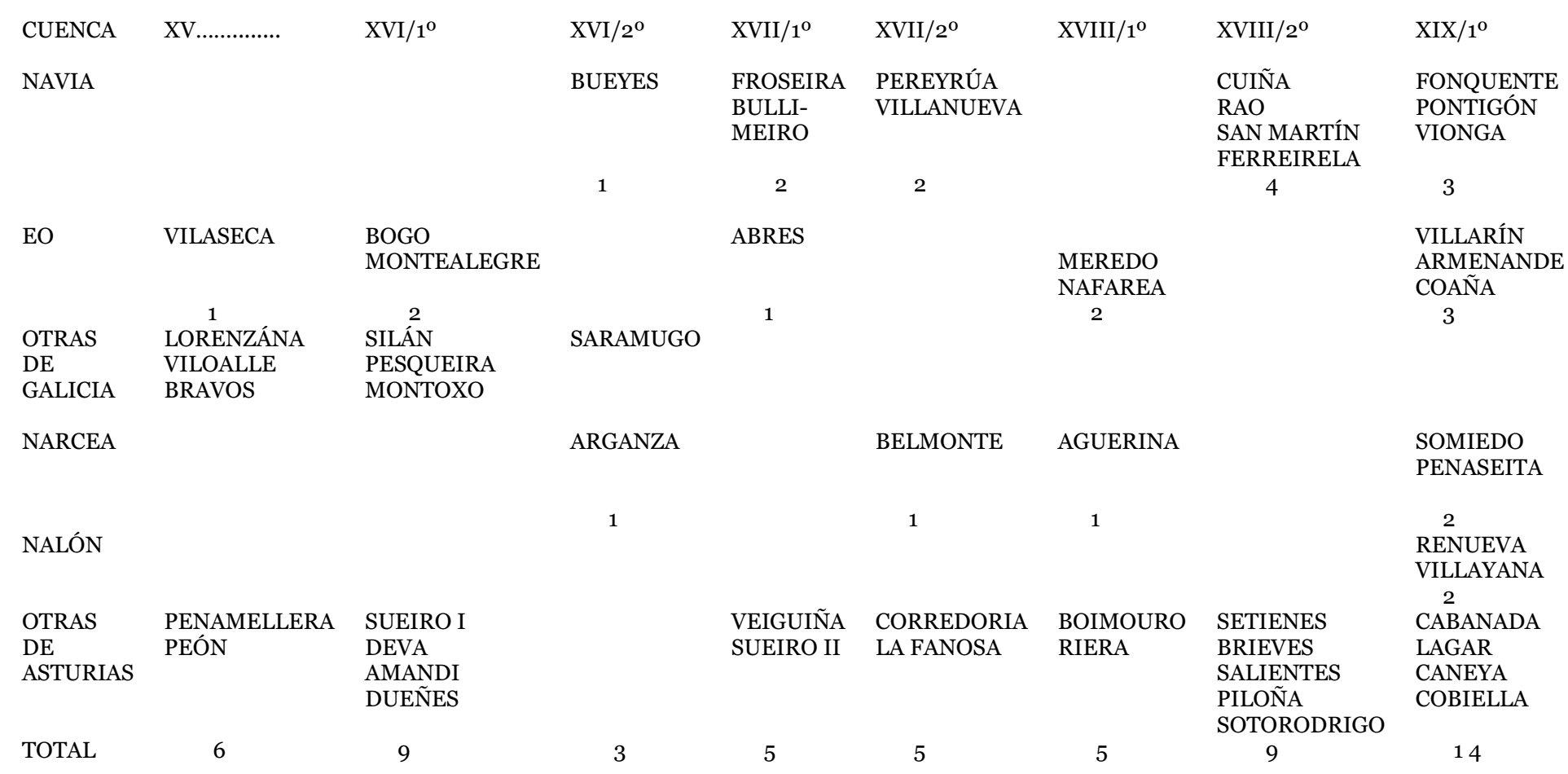

Elaboración propia con los datos del Catálogo de ferrerías 


\section{SUBASTAS DE ÁRBOLES EN ASTURIAS (AÑOS 1847 AL 1860)}

\begin{tabular}{|c|c|c|c|c|c|c|}
\hline AÑO & MUNICIPIO & CLASE & EJEMPLARES & MONTE & OBJETO & BOPA \\
\hline 1847 & Penamellera & Haya & 182 & \begin{tabular}{|l|} 
Común \\
\end{tabular} & & $13-8-47$ \\
\hline 1847 & Ponga & Haya & 258 & Común & & $27-8-47$ \\
\hline 1847 & Penamellera & Encina/brezo & & Común & 800 c/carbón & $27-8-47$ \\
\hline 1847 & Navia & Roble & 105 & Común & & $\begin{array}{l}15^{-12-} \\
47\end{array}$ \\
\hline 1848 & Soto del Barco & Roble & 239 & \begin{tabular}{|l|} 
Común \\
\end{tabular} & & $21-1-48$ \\
\hline 1849 & Penamellera & Encina & & Común & 300 c/carbón & $26-2-49$ \\
\hline 1849 & Penamellera & Leñas & & Común & 1.800 c/carbón & $26-2-49$ \\
\hline 1849 & Penamellera & Encina/brezo & & Común & 300 c/carbón & $12-3-49$ \\
\hline 1849 & Penamellera & Haya & & Común & Duela & $12-3-49$ \\
\hline 1849 & Penamellera & Encina/brezo & & Común & 200 c/carbón & $12-3-49$ \\
\hline 1849 & Amieva & Haya/leña & 1.500 & Común & 3.500 c/carbón & $14-3-49$ \\
\hline 1849 & Amieva & Haya/leña & 1.500 & Común & 2.680 c/carbón & $8-6-49 c$ \\
\hline 1849 & Grado & Robles & 89 & Estado & & $24-8-49$ \\
\hline 1850 & Ponga & Haya & 500 & Común & Carbón & $15-1-50$ \\
\hline 1850 & Ponga & Haya & 256 & Común & & $19-7-50$ \\
\hline 1850 & Villaviciosa & Roble & 159 & Estado & Ferrocarril & $\begin{array}{l}30-9- \\
50\end{array}$ \\
\hline 1851 & Amieva & Haya & 2.000 & Común & Carbón & $14-2-51$ \\
\hline 1851 & Penamellera & Encina/brezo & 100 & Común & Carbón & $10-3-51$ \\
\hline 1851 & Villaviciosa & Roble & 1.398 & \begin{tabular}{|l|} 
Común \\
\end{tabular} & Ferrocarril & $26-5-51$ \\
\hline 1851 & Colunga & Roble & 206 & Común & & $26-5-51$ \\
\hline 1851 & Penamellera & Encina/brezo & 300 & Común & Carbón & $\begin{array}{l}10-11- \\
51\end{array}$ \\
\hline 1852 & Ponga & Haya & & Común & 6.000 c/carbón & $28-1-52$ \\
\hline 1852 & Proaza & Roble & 30 & Común & Para Trubia & $2-4-52$ \\
\hline 1852 & Cabrales & Roble & 515 & Común & Ferrocarril & $14-5-52$ \\
\hline 1852 & Penamellera & Encina/brezo & & Común & 1.500 c/carbón & $28-5-52$ \\
\hline 1852 & Penamellera & Haya & 3.000 & Común & Carbón & $5-12-52$ \\
\hline 1854 & Penamellera & Haya & 555 & Común & Carbón & $6-9-54$ \\
\hline 1856 & Ponga & Haya & 1.574 & \begin{tabular}{|l|} 
Común \\
\end{tabular} & 7.000 c/carbón & $20-2-56$ \\
\hline 1856 & Amieva & Haya & & Común & 3.000 c/carbón & $29-2-56$ \\
\hline 1856 & Amieva & Haya & 300 & Común & Carbón & $9-4-56$ \\
\hline 1857 & Amieva & Haya & 400 & Común & & $14-1-57$ \\
\hline 1857 & Taramundi & Roble & 26 & \begin{tabular}{|l|} 
Común \\
\end{tabular} & & $29-5-57$ \\
\hline 1857 & Aller & Roble & 8 & Común & & $29-5-57$ \\
\hline 1857 & Aller & Haya & 100 & Estado & & $30-5-57$ \\
\hline 1857 & Laviana & Roble & 11 & Estado & & $30-5-57$ \\
\hline 1857 & Cangas de Onis & Haya & 70 & Común & & $3-6-57$ \\
\hline 1857 & Aller & Haya & 100 & Común & & $8-6-57$ \\
\hline 1857 & Ponga & Haya & 300 & Común & & $20-7-57$ \\
\hline 1857 & Ponga & Haya & 300 & Común & Vecinos & $28-8-57$ \\
\hline 1857 & Amieva & Haya & 900 & Común & Vecinos & $28-9-57$ \\
\hline 1857 & Amieva & Roble & 200 & Común & & $3-10-57$ \\
\hline 1857 & Piloña & Haya & 40 & Común & & $27-11-57$ \\
\hline 1857 & Caso & Haya & 170 & Común & & $27-11-57$ \\
\hline 1857 & Ponga & Haya & 300 & Común & Vecinos & $27-11-57$ \\
\hline 1857 & Ponga & Haya & 600 & Común & Vecinos & $5-12-57$ \\
\hline 1857 & Qller & Haya & 200 & Común & A. García Ciaño & $\begin{array}{l}28-12- \\
57\end{array}$ \\
\hline 1857 & Amieva & Haya & 900 & Común & Alcalde & $\begin{array}{l}28-12- \\
58 \\
\end{array}$ \\
\hline 1858 & Amieva & Haya & 250 & Común & A. Naredo & $2-1-58$ \\
\hline
\end{tabular}




\begin{tabular}{|c|c|c|c|c|c|c|}
\hline 1858 & Boal & Roble & 100 & Estado & Benito González & $16-4-58$ \\
\hline 1858 & Ponga & Roble & 17 & Común & Diego González & $16-4-58$ \\
\hline 1858 & Illano & Roble & 67 & Estado & Bernardo Fdez. & $16-4-58$ \\
\hline 1858 & Ponga & Haya & 200 & Común & Pedáneo & $28-5-58$ \\
\hline 1858 & Illano & Roble & 107 & Estado & $\begin{array}{l}\text { López } \\
\text { Castrillón }\end{array}$ & $23-6-58$ \\
\hline 1858 & Cangas de Onís & Haya & 200 & Común & Julián Iglesias & $\begin{array}{l}20-8- \\
58 \\
\end{array}$ \\
\hline 1858 & Boal & Roble & 30 & Estado & Domingo Fdez. & $23-8-58$ \\
\hline 1858 & Villaviciosa & Roble & 133 & Estado & & $\begin{array}{l}25-12- \\
58\end{array}$ \\
\hline 1859 & Ponga & Haya & 200 & Común & José Muñiz & $2-2-59$ \\
\hline 1859 & Villaviciosa & Roble & 133 & Estado & & 9-2-59 \\
\hline 1859 & Aller & Haya & 100 & Común & José Quintanal & $11-2-59$ \\
\hline 1859 & Ponga & Haya & 400 & Común & & $5-3-59$ \\
\hline 1859 & Illano & Roble & 400 & Estado & $\begin{array}{l}\text { López } \\
\text { Castrillón } \\
\end{array}$ & 5-3-59 \\
\hline 1859 & Amieva & Haya & 500 & Común & & 5-3-59 \\
\hline 1859 & $\begin{array}{l}\text { Villanueva } \\
\text { oscos }\end{array}$ & Roble & 223 & Estado & Pedro López & 5-3-59 \\
\hline 1859 & Ponga & Haya & 1.419 & Común & Benito Pérez & $5-3-59$ \\
\hline 1859 & Amieva & Haya & 4.000 & Común & Antonio Vega & $22-8-59$ \\
\hline 1859 & Penamellera & Haya & 2.000 & Común & $\begin{array}{l}\text { Cristóbal de } \\
\text { Caso }\end{array}$ & $22-8-59$ \\
\hline 1859 & Pravia & Roble & 110 & Estado & López Arango & $27-8-59$ \\
\hline 1859 & Illano & Roble & 60 & Estado & & $\begin{array}{l}29-10^{-} \\
59\end{array}$ \\
\hline 1859 & Boal & Roble & 33 & Estado & Domingo Fdez & $\begin{array}{l}29-10^{-} \\
59\end{array}$ \\
\hline 1859 & Boal & Roble & 100 & Estado & Benito González & $10-12-59$ \\
\hline 1859 & Illano & Roble & 107 & Estado & $\begin{array}{l}\text { López } \\
\text { Castrillón }\end{array}$ & $24-12-59$ \\
\hline 1860 & Cangas de Onis & Haya & 300 & Común & José del Valle & $16-1-60$ \\
\hline 1860 & Cangas de Onis & Haya & 500 & Común & $\begin{array}{l}\text { Manuel } \\
\text { Ramírez }\end{array}$ & $30-3-60$ \\
\hline 1860 & Amieva & Haya & 728 & Común & $\begin{array}{l}\text { Manuel } \\
\text { González }\end{array}$ & $30-3-60$ \\
\hline 1860 & Mieres & Roble & 128 & Común & Vecinos & $4-4-60$ \\
\hline 1860 & Penamellera & Haya & 2.000 & Común & $\begin{array}{ll}\text { Cristóbla } & \text { de } \\
\text { Caso } & \\
\end{array}$ & $4-4-60$ \\
\hline 1860 & Lena & Haya & 450 & Común & & $20-4-60$ \\
\hline 1860 & Illano & Roble & 107 & Estado & $\begin{array}{l}\text { López } \\
\text { Castrillón }\end{array}$ & $18-5-60$ \\
\hline 1860 & Amieva & Haya & 4.000 & Común & Antonio Vega & $18-5-60$ \\
\hline 1860 & Ponga & Haya & 400 & Común & $\begin{array}{ll}\text { Manuel } & \text { de } \\
\text { Nava } & \\
\end{array}$ & $7-7-60$ \\
\hline 1860 & Ponga & Haya & 200 & Común & Pedáneo & $7-7-60$ \\
\hline 1860 & Cangas de Onis & Haya & 300 & Común & $\begin{array}{l}\text { F. Gómez del } \\
\text { Valle }\end{array}$ & $7-7-60$ \\
\hline 1860 & Cangas de Onis & Haya & 46 & Común & Eusebio el Viejo & $7-7-60$ \\
\hline 1860 & Caso & Haya & 114 & Común & Madreñas & $23-7-60$ \\
\hline 1860 & Ponga & Haya & 400 & Común & Pedáneo & $3-9-60$ \\
\hline 1860 & Boal & Roble & 100 & Estado & Benito González & $8-9-60$ \\
\hline 1860 & Ponga & Haya & 400 & Común & Manuel Nieva & $24-9-60$ \\
\hline 1860 & Amieva & Haya & 4.000 & Común & Antonio Vega & $24-9-60$ \\
\hline
\end{tabular}

FUENTE: Boletín Oficial de Asturias. (Antes, Boletín Oficial de la Provincia de Oviedo, puede consultarse integramente en internet: https://sede.asturias.es/portal/site/Asturias/ template.PAGE/menuitem 


\title{
3. CANÓN QUE PAGABAN LAS FERRERÍAS AL MARQUÉS DE SANTA MARÍA DEL VILLAR POR EL USO DE LA VENA DE FORMIGUEIROS A MEDIADOS DEL SIGLO XIX
}

\author{
FERRERÍA
}

REALES

- La de Oencia de don Esteban Llanos de Ponferrada ......... 150

- La de Visuña del sr. Conde de Campomanes..................... 396

- La de Arnado de don Juan de la Puebla............................... 150

- La de Puentenueva del Sr. de Villoria................................. . 100

- La de Soldón de don Antonio Ribadeneira.......................... 400

- La de Paleiras de don José Pardo......................................... 400

- La de San Vicente de el exmonasterio de Samos.................. 350

- La de Rugando de don Gregorio López................................ 200

- La de Rodela también de don Gregorio López...................... 400

- La de Gorgueira de don Manuel Vázquez ............................... 300

- La de Ferreirós de don Ignacio Barraganes.......................... . 147

- La de Valdomir de don Rafael Armesto.. ………………......... 50

- Las dos unidas de Seoane de don Juan Manuel Somoza..... 600

- La de Unteiro de Soldón de don Juan José Vila.................. 400

- La de Serviz de Nemesio Fernández, hoy de R. Armesto.... 300

- La de Corporales del mismo señor Armesto........................ 60

- La de Portela del mismo......................................................... 300

- La de Arnadelo de don Isidoro Ovalle..................................... 300

- La de Belincarro de don Benito Aballe.................................... 320

- La de Folgoso del mismo sr. Armesto...................................... 200

- La de San Vitul del mismo señor Aballe................................... 320

- La de Lusío de don Jacinto Fariñas...................................... 250

- La de Villarvacú de don Antonio Rivadeneira........................ 320

- La de Bueyes del sr. de Láncara............................................ 330

- La de los Valcárceles del mismo señor..................................... 400

- La de Lousadela del mismo señor............................................ 88

- TOTAL............................................................................. 7.231

FUENTE: I. GARCÍA TATO (200o): Ob. cit., p. 167-168 


\section{BARCOS PARA EL TRANSPORTE DE MINERAL}

Capitanía del puerto de Gijón

Estado de los buques que han entrado en este puerto en 1859 con mineral de hierro

\begin{tabular}{|c|c|c|c|c|}
\hline TIPO BARCO & NOMBRE & ORIGEN & FECHA & BOPA \\
\hline Quechemarín & Feliciano & Bilbao & 22 de marzo & 1-IV-1859 \\
\hline Idem & $\mathrm{N}^{\mathrm{a}} \mathrm{S}^{\mathrm{a}}$ del Carmen & Castro Urdiales & 5 de abril & $8-I V-59$ \\
\hline Idem & Juan Benito & Idem & 6 de abril & $8-I V-59$ \\
\hline Idem & Juan José & Bilbao & 6 de abril & $8-I V-59$ \\
\hline Idem & Natividad & Idem & 7 de abril & $8-I V-59$ \\
\hline Idem & María & Idem & 8 de mayo & $13-V-59$ \\
\hline Idem & Dolores & Idem & 9 de mayo & $13-V-59$ \\
\hline Idem & Ramiro & Idem & 16 de mayo & $18-V-59$ \\
\hline Idem & Correo de S. Sebastián & Idem & 20 de mayo & $23-V-59$ \\
\hline Idem & Santos & Idem & 21 de mayo & $25-V-59$ \\
\hline Idem & Nuevo San Juan & Idem & 21 de mayo & $25-V-59$ \\
\hline Bergatín-goleta & Joven Antonio & Idem & 22 de mayo & $25-V-59$ \\
\hline Quechemarín & Feliciano & Idem & 31 de mayo & 3 -VII-59 \\
\hline Idem & El sí & Idem & 31 de mayo & $3-\mathrm{VI}-59$ \\
\hline Idem & Pepita & Idem & 31 de mayo & $3-\mathrm{VI}-59$ \\
\hline Idem & San José y Ánimas & Idem & 4 de junio & $11-\mathrm{VI}-59$ \\
\hline Idem & Juana Pepa & Idem & 6 de junio & $15-\mathrm{VI}-59$ \\
\hline Idem & Delfín & Idem & 7 de junio & $15-\mathrm{VI}-59$ \\
\hline Idem & Suerte & Idem & 8 de junio & $15-\mathrm{VI}-59$ \\
\hline Idem & San José & Idem & 10 de junio & $17-\mathrm{Vi}-59$ \\
\hline Galeón & San José & Idem & 15 de junio & $18-V I-59$ \\
\hline Quechemarín & San José y Ánimas & Idem & 27 de junio & $2-$ VII-59 \\
\hline Idem & San José & Idem & 28 de junio & 4-VII-59 \\
\hline Pinaza & Dolores & Idem & 5 de julio & 9-VII-59 \\
\hline Quechemarín & Santos & Idem & 7 de julio & 9-VII-59 \\
\hline Idem & Pronto & Idem & 9 de julio & $13-\mathrm{VII}-59$ \\
\hline Idem & María & Santander & 9 de julio & $13-\mathrm{VII}-59$ \\
\hline Pailebot & Ramiro & Bilbao & 7 de octubre & $12-X-59$ \\
\hline Quechemarín & $\mathrm{N}^{\mathrm{a}} \mathrm{S}^{\mathrm{a}}$ de Albóniga & Idem & 7 de octubre & $12-X-59$ \\
\hline Lancha & San José, Ánima & Idem & 28 de octubre & $4-X I-59$ \\
\hline Idem & Primavera & Luanco & 7 noviembre & $11-\mathrm{XI}-59$ \\
\hline Quechemarín & Magdalena & Bilbao & 8 noviembre & 12-XI-59 \\
\hline Pailebot & Corzo & Idem & 8 noviembre & 12-XI-59 \\
\hline Quechemarín & Oria & Idem & 8 noviembre & $12-X I-59$ \\
\hline Idem & Carmen & Idem & 10 noviembre & $12-X I-59$ \\
\hline Idem & Emilio & Idem & 10 noviembre & $12-X I-59$ \\
\hline Idem & Natividad & Idem & 10 noviembre & $12-X I-59$ \\
\hline Idem & Amelia & Idem & 10 noviembre & $12-X I-59$ \\
\hline Pailebot & Ramiro & Idem & 11 noviembre & $18-X I-59$ \\
\hline Quechemarín & Die Monas & Idem & 11 noviembre & $18-X I-59$ \\
\hline Idem & $\mathrm{N}^{\mathrm{a}} \mathrm{S}^{\mathrm{a}}$ de Albóniga & Idem & 11 noviembre & $18-X I-59$ \\
\hline Idem & San José & Idem & 11 noviembre & $18-X I-59$ \\
\hline Idem & San José y Ánimas & Idem & 11 noviembre & $18-X I-59$ \\
\hline Idem & Dolores & Idem & 11 noviembre & $18-X I-59$ \\
\hline Idem & Alberta & Idem & 12 noviembre & $18-X I-59$ \\
\hline Idem & Primos & Idem & 12 noviembre & $18-X I-59$ \\
\hline Idem & Ramiro & Idem & 13 noviembre & $18-X I-59$ \\
\hline Idem & Isabel & Idem & 13 noviembre & $18-X I-59$ \\
\hline
\end{tabular}




\begin{tabular}{|l|l|l|l|l|}
\hline Idem & San José & Idem & 14 noviembre & 19-XI-59 \\
\hline Idem & Reino & Idem & 14 noviembre & 19-XI-59 \\
\hline Lancha & Primavera & Idem & 14 noviembre & 19-XI-59 \\
\hline Idem & San Nicolás & Idem & 14 noviembre & 19-XI-59 \\
\hline Idem & San Juan & Idem & 15 noviembre & 19-XI-59 \\
\hline Idem & Flecha & Idem & 15 noviembre & 19-XI-59 \\
\hline Quechemarín & San José & Idem & 16 noviembre & 19-XI-59 \\
\hline Lancha & Primavera & Luanco & 22 noviembre & 26-XI-59 \\
\hline Idem & San Juan & Idem & 22 noviembre & 26-XI-59 \\
\hline Idem & Primavera & Idem & 23 noviembre & 26-XI-59 \\
\hline
\end{tabular}

NOTA: hemos reseñado un año, el 1859, porque es el primero que aparece en el Boletín Oficial de Oviedo (BOPA), luego hay más años pero se repiten los mismos tipos y barcos.

FUENTE: Boletín Oficial de Asturias. (Antes, Boletín Oficial de la Provincia de Oviedo, puede consultarse integramente en internet: https://sede.asturias.es/portal/site/Asturias/ template.PAGE/menuitem 


\section{VALOR DE LAS FERRERÍAS}

Precio que se pagaron por las ferrerías que se mencionan en diferentes años de los siglos XVI al XIX.

\begin{tabular}{|l|l|l|c|}
\hline AÑO & FERRERÍA & PROVINCIA & PRECIO \\
\hline 1531 & Montealegre & Asturias & 4.400 \\
\hline 1587 & Paleiras & Lugo & 22.000 \\
\hline 1597 & Valdomir & Lugo & 21.450 \\
\hline 1603 & Soldón & Lugo & 44.000 \\
\hline 1622 & La Veguiña & Asturias & 12.106 \\
\hline 1640 & Valdomir & Lugo & 24.300 \\
\hline 1676 & Villanueva & Asturias & 51.823 \\
\hline 1690 & La Rodela & Lugo & 33.000 \\
\hline 1700 & Ferreirós & Lugo & 19.800 \\
\hline 1705 & Rugando & Lugo & 77.000 \\
\hline 1720 & San Vicente de Leira & Orense & 66.000 \\
\hline 1730 & Montes & León & 77.000 \\
\hline 1797 & La Somoza & León & 350.000 \\
\hline 1798 & Tejedo de Ancares & León & 135.270 \\
\hline 1820 & Somiedo & Asturias & 500.000 \\
\hline 1821 & Pallares & Lugo & 476.750 \\
\hline 1825 & Río Cabo & León & 15.000 \\
\hline 1839 & San Vicente de Leira & Orense & 560.000 \\
\hline 1839 & Rugando & Lugo & 1.120 .000 \\
\hline 1839 & Gondriz & Lugo & 455.133 \\
\hline 1839 & Santalla & Lugo & 599.000 \\
\hline 1841 & Valincarro & León & 54.000 \\
\hline 1855 & Pontigón & Asturias & 32.000 \\
\hline 1859 & Serviz & León & 160.000 \\
\hline 1859 & La Portela & León & 220.000 \\
\hline 1859 & Corporales & León & 140.000 \\
\hline 1859 & Montes & León & 200.000 \\
\hline 1859 & Llamas & León & 160.000 \\
\hline 1862 & Ferreirós & Lugo & 72.000 \\
\hline 1866 & La Caneya & Asturias & 100.000 \\
\hline 1868 & Valdomir & Lugo & 58.000 \\
\hline 1868 & Folgoso & Lugo & 2.000 \\
\hline 1876 & Pontepetre & León & 168.000 \\
\hline 1879 & Pontepetre & León & 90.000 \\
\hline
\end{tabular}

* Florines de los Países Bajos

FUENTE: En Catálogo de ferrerías están las referencias de los archivos en que constan tales datos. 


\section{OFICIOS EJERCIDOS POR VASCOS EN LA SIDERURGIA DEL NOROESTE}

\begin{tabular}{|c|c|c|c|c|}
\hline AÑO & NOMBRE & FERRERÍA & OFICIO & REFERENCIA \\
\hline 1531 & Pedro de Miranda & Viloalle & Tirador & E. CAL (1992) \\
\hline 1555 & Juan de Aguirre & Silán & Aroza & AHPLU: $3973 / 2$ \\
\hline 1557 & Martín de Urichaga & Gondriz & Machuquero & AHN. Libro 6695 \\
\hline 1558 & ¿ Estíbariz & Soldón & Aroza & AHRG: $19768 / 32$ \\
\hline 1558 & Domingo de Padria & Soldón & Tirador & Idem \\
\hline 1558 & $\begin{array}{ll}\text { Martín } & \text { de } \\
\text { Sagarminade }\end{array}$ & Soldón & Tirador & Idem \\
\hline 1563 & $\begin{array}{ll}\text { Martín } & \text { de } \\
\text { Barrulaça } & \end{array}$ & Valdomir & Aroza & Idem \\
\hline 1563 & Juan de Butrón & Soldón & Aroza & Idem \\
\hline 1563 & Juan de Lasarte & Soldón & Mestro ferrage & Idem \\
\hline 1563 & Juan de Zamudio & Soldón & ----------- & Idem \\
\hline 1573 & Miguel Ortiz & Ferreirós & Maestroferrerías & AHRG.: 26179/54 \\
\hline 1576 & Juan de Ormazabal & ------ & Venaquero & AHPLU: $2837 / 19$ \\
\hline 1577 & Juan de Ezpeleta & Ferreirós & Aroza & AHRG. 24727120 \\
\hline 1582 & Juan Martín & Valdomir & Tirador & AHRG. 2489/48 \\
\hline 1595 & Juan de Liçanza & San Fiz do Seo & Herrero & AHPL. P. N.:2878 \\
\hline 1596 & Martín de Artiaga & Paleiras & Mulatero & AHPLU: $2407 / 9$ \\
\hline 1596 & Juanes de Sunbie & Paleiras & Fundidor & Idem \\
\hline 1596 & Juanes de Cala & Paleiras & Tirador & Idem \\
\hline 1596 & $\begin{array}{ll}\text { Gabriel } & \text { de } \\
\text { Angorena } & \end{array}$ & Pontepetre & Fundidor & Idem \\
\hline 1596 & Juanes de Andana & Lousadela & Aroza & Idem \\
\hline 1596 & Juanes de Fagoaga & Ferreirós & Aroza & Idem \\
\hline 1599 & García de Yribarri & Lousadela & Aroza (fue) & AHPLU: 2447/1 \\
\hline 1610 & Pedro de Legama & ------- & Venaquero & AHPL: $2547 / 3$ \\
\hline 1612 & Juanes de Arza & Lousadela & Aroza & AHPLU: $2408 / 2$ \\
\hline 1612 & Luis de Urrutia & Lousadela & Tirador & Idem \\
\hline 1612 & Martín Tirador & Lousadela & Fundidor & Idem \\
\hline 1612 & Martín Azconeta & Lousadel/Rial & Tirador & Idem \\
\hline 1612 & Miguel de Salazar & Lousadela/Rial & Fundidor & Idem \\
\hline 1612 & Miguel Lecumberri & Lousadela/Valdomir & Aroza & Idem \\
\hline 1612 & $\begin{array}{ll}\text { Juanes } & \text { de } \\
\text { Chavarria } & \end{array}$ & Lousadela & Aroza & Idem \\
\hline 1612 & $\begin{array}{ll}\text { Miguel } & \text { de } \\
\text { Gurriarán } & \\
\end{array}$ & Lousadela & Tirador & Idem \\
\hline 1612 & Juanes de Zamora & Lousadela & Fundidor & Idem \\
\hline 1612 & $\begin{array}{l}\text { Cristóbal } \\
\text { Urbaneta }\end{array}$ & Lousadela & Fundidor & Idem \\
\hline 1612 & Juanes de Lusame & ------ & Tirador & Idem \\
\hline 1612 & $\begin{array}{l}\text { M.Pérez } \\
\text { Goyzueta }\end{array}$ & Soldón/Valdomir & Fundidor & Idem \\
\hline 1612 & Juanes de Laolaza & --------- & Mayordomo & Idem \\
\hline 1612 & Martín de Yarza & Ferreirós & Aroza & Idem \\
\hline 1612 & Pedro de Ochoa & ------- & Carpintero & AHRG.: 5951/55 \\
\hline 1616 & $\begin{array}{l}\text { Domingo } \\
\text { Zarauza }\end{array}$ & Valdomir & Aroza & AHPLU: $2555 / 1$ \\
\hline 1622 & Juanes de Ysasueta & Ferreirós & Tuberero & AHPLU: $2548 / 1$ \\
\hline 1622 & Pedro de Zubiri & Ferreirós & Tirador & Idem \\
\hline 1622 & $\begin{array}{l}\text { J. Pérez } \\
\text { Arribillaga }\end{array}$ & ------- & Venaquero & Idem \\
\hline 1622 & Sebastián de Celaya & Lousadela & Aroza & Idem \\
\hline 1622 & Domingo & Valdomir & Aroza & Idem \\
\hline
\end{tabular}




\begin{tabular}{|l|l|l|l|l|}
\hline & Zarauza & & & \\
\hline 1625 & Simón de Obide & Paleiras & Aroza & $\begin{array}{l}\text { AHRG: Hombreiro, leg. } \\
19\end{array}$ \\
\hline 1651 & $\begin{array}{l}\text { Bartolomé } \\
\text { Lamegarcía }\end{array}$ & Pontepetre & Fundidor & AHPL. 3025 \\
\hline 1668 & Felipe de Minondo & Pontepetre & Arota & AHPL. 2936 \\
\hline 1668 & Juanes de Arrillaga & Pontepetre & Tirador & Idem \\
\hline 1668 & Francisco de Alza & Pontepetre & ---- & Idem \\
\hline 1668 & $\begin{array}{l}\text { Juan Mz. } \\
\text { Manterola }\end{array}$ & Pontepetre & Oficial & Idem \\
\hline 1668 & Fco. Bengoechea & Arnado & Arota & Idem \\
\hline 1673 & Juanes de Arrillaga & Pontepetre & Arota & AHPL: 2936 \\
\hline 1673 & Juan Novo Mz. & Pontepetre & Oficial & Idem \\
\hline 1674 & Félix de Aminondo & Pontepetre & Arota & Idem \\
\hline 1679 & Juan & Arontepetre & Aroza & AHPL: 3104 \\
\hline 1679 & Juan Bengoechea & Lorenzana & Ferramentero & $\begin{array}{l}\text { P. SAAVEDRA (1985), } \\
\text { p. 315 }\end{array}$ \\
\hline 1694 & Diego de Armesto & Lousadela & Arota & AHPLU: 2566/4 \\
\hline
\end{tabular}

\section{ADMINISTRADORES DE FERRERÍAS (SIGLOS XVIII Y XIX)}

\begin{tabular}{|c|c|c|c|}
\hline $\mathrm{AÑO}$ & NOMBRE & FERRERÍA & REFERENCIA \\
\hline 1692 & $\begin{array}{l}\text { Gómez Lodeiro, } \\
\text { presb. }\end{array}$ & Lousadela & AHPLU: $2566 / !$ \\
\hline 1700 & A. Sánchez Somoza & Soldón & AHPLU: $2514 / 5$ \\
\hline 1700 & $\begin{array}{ll}\text { Fray } & \text { Bernardo } \\
\text { Laguna } & \end{array}$ & Gondriz & AHPLU: $5088 / 2$ \\
\hline 1704 & $\begin{array}{l}\text { Glez.Reymundez, } \\
\text { preb. }\end{array}$ & Lousadela & AHPLU: $2567 / 1$ \\
\hline 1721 & Diego Tiesta & Soldón & AHPLU: $2570 / 6$ \\
\hline 1727 & Fc. Rodríguez Losada & Quintá & AHPLU: $2576 / 2$ \\
\hline 1741 & Fray Benito Cadagua & Rodela & AHN. Cleo: 6695 \\
\hline 1747 & $\begin{array}{ll}\text { Fco. } & \text { Rodríguez } \\
\text { Losada } & \\
\end{array}$ & Quintá & AHPLU: $2463 / 2$ \\
\hline 1752 & Fray pablo de Castro & Leira & AHPLU. 2463/6 \\
\hline 1752 & $\begin{array}{ll}\text { Fco. } & \text { Pardo } \\
\text { Rivadeneira } & \end{array}$ & Lor & AHPLU: $2463 / 2$ \\
\hline 1755 & Fco. A. Losada (fue) & Órreos & AHPLU: $2463 / 5$ \\
\hline 1758 & Marcos Díaz & Lor & AHPLU:2463/8 \\
\hline $\begin{array}{l}1761 \mathrm{a} \\
1768\end{array}$ & José Piñeiro & Valcarce & AHPL: 3353 \\
\hline 1771 & G. de Armesto, presb. & Valdomir & AHPLU:2417/2 \\
\hline $\begin{array}{l}1780 \mathrm{a} \\
1792\end{array}$ & $\begin{array}{l}\text { J. A. Asejo Rodil, } \\
\text { presb. }\end{array}$ & Valcarce & AHPL: 3379 y 3463 \\
\hline 1782 & A. Arias Ulloa, presb. & Lousadela & AHPLU:2417/8 \\
\hline 1791 & José M. Díaz Castro & Soldón & AHN. Estado: $1739, \mathrm{~N}^{\circ} 16$ \\
\hline 1791 & José Pasarín & Paleiras & AHPLU:2417711 \\
\hline $\begin{array}{l}1791 \mathrm{a} \\
1813\end{array}$ & A. de Mon Rancaño & Valcarce & AHPLU: $2474 / 3$ \\
\hline 1797 & Fray Eufrosio Robles & Rodela & AHPLU:255572 \\
\hline
\end{tabular}




\begin{tabular}{|c|c|c|c|}
\hline 1804 & Diego Antonio Ovalle & Pontepetre & AHPLU: $2454 / 3$ \\
\hline $\begin{array}{ll}1806 \\
1808\end{array}$ & Tomás González & Ferreirós & AHPLU: $2454 / 6$ y $2455 / 1$ \\
\hline $\begin{array}{ll}1808 \quad a \\
1811\end{array}$ & González de la Galera & Montealegre & AHPLU: 2069/4 у 2069/7 \\
\hline $\begin{array}{ll}1808 & a \\
1814 & \\
\end{array}$ & J. Rodríguez Gallego & Soldón & AHPLU:2468/2 \\
\hline 1809 & Pablo de Lago & Lor & AHPLU: $2468 / 4$ \\
\hline 1810 & Jacinto Fariñas & Visuña & AHPLU: $2455 / 4$ \\
\hline 1813 & Fray B. Carbajal & Rodela & AHPLU: $2467 / 12$ \\
\hline 1813 & Juan F. Ribadeneira & Lousadela & AHPLU: $2474 / 3$ \\
\hline $\begin{array}{l}1813 \\
1815\end{array}$ & Tomás González & Ferreirós & AHPLU: $2474 / 3$ y $2474 / 2$ \\
\hline 1814 & Manuel A. Sánchez & Paleiras & AHPLU: $2467 / 11$ \\
\hline 1814 & $\begin{array}{ll}\text { Pedro } & \text { Rigueiro, } \\
\text { presb. } & \end{array}$ & Quintá & AHPLU: $2406 / 2$ \\
\hline 1816 & Tomás González & Lousadela & AHPLU: $2474 / 5$ \\
\hline 1817 & Manuel Díaz Lombán & Froseira & AHPLU: 207076 \\
\hline 1818 & Manuel Castrillón & Miranda & AHPLU: $2070 / 7$ \\
\hline 1818 & Fray José Nareiga & Leira & AHPL: 3576 \\
\hline 1818 & Ignacio Arias, presb. & Loureiro & AHPLU:2406/6 \\
\hline 1820 & Fray Eufrosio Robles & Rodela & AHPLU: $2474 / 9$ \\
\hline 1820 & Pedro Teixelo & Tejedo & AHPL.: 3736 \\
\hline 1821 & Manuel López Saco & Soldón & AHPLU:2406/11 \\
\hline 1821 & Fray Bernardo Guerra & Leira & AHPLU: $5340 / 5$ \\
\hline $\begin{array}{ll}1824 & a \\
1828 & \end{array}$ & $\begin{array}{ll}\text { Fray } & \text { Veremundo } \\
\text { Peña } & \\
\end{array}$ & Leira & $\begin{array}{l}\text { AHPLU: } 2406 / 15 \text { Y AHPL: } \\
3577\end{array}$ \\
\hline 1826 & J. M ${ }^{\mathrm{a}}$ Maceda, presb. & Soldón & AHPLU: $2468 / 2$ \\
\hline 1827 & Manuel Lombán & & AHPLU: $2071 / 8$ \\
\hline 1828 & Juan Martínez & Rugando & AHPLU: $2406 / 15$ \\
\hline 1833 & Roque Martínez & Serviz & AHPL.: 3677 \\
\hline 1833 & Fco. Pablo Ruiz & Bueyes & AHPLU:2376/3 \\
\hline 1839 & Miguel Somoza & Rodela & AHPLU: $5431 / 8$ \\
\hline 1842 & José Teijón & Corporales & AHPL.: 3580 \\
\hline 1845 & Pedro Pombo & Lousadela & AHPLU: $2431 / 1$ \\
\hline 1850 & Pedro Rodríguez & Villarrubín & AHPLU: $2431 / 3$ \\
\hline 1862 & P. de Cela y Bolaño & Lousadela & AHPLU: $2431 / 6$ \\
\hline
\end{tabular}




\section{FOROS, FOREROS, TIEMPO Y RENTAS DE FERRERÍAS EN LA EDAD MODERNA}

\begin{tabular}{|c|c|c|c|c|c|c|}
\hline AÑO & DADOR & TOMADOR & FERRERÍA & TIEMPO & $\begin{array}{l}\text { RENTA } \\
\text { ( mrs.) }\end{array}$ & REFERENCIA \\
\hline 1504 & $\begin{array}{l}\text { Monasterio } \\
\text { de Samos }\end{array}$ & Diego Velón & Santalla & 3 vidas & 750 & $\begin{array}{l}\text { AHRG. R. A. } \\
931 / 44\end{array}$ \\
\hline 1517 & $\begin{array}{l}\text { Conde } \\
\text { Lemos }\end{array}$ & $\begin{array}{l}\text { Martín de } \\
\text { Basoa }\end{array}$ & Montoxo & ------ & 3.000 & $\begin{array}{lll}\text { AHRG: } & \text { R. } & \text { A. } \\
\text { 5772/33 } & & \\
\end{array}$ \\
\hline 1519 & $\begin{array}{l}\text { Monasterio } \\
\text { de Lorenzana }\end{array}$ & $\begin{array}{l}\text { Rodriguez de } \\
\text { Aguilar }\end{array}$ & Lorenzana & 1 vida & 3.000 & $\begin{array}{l}\text { AHN. Clero, libro } \\
6.622\end{array}$ \\
\hline $\begin{array}{l}\text { Antes } \\
1550\end{array}$ & $\begin{array}{l}\text { Comendador } \\
\text { de la Barra }\end{array}$ & $\begin{array}{l}\text { Martín de } \\
\text { Alduncín }\end{array}$ & Paleiras & 3 vidas & 4.000 & $\begin{array}{l}\text { AHRG.: } \\
\text { Hombreiro, } 19\end{array}$ \\
\hline 1550 & $\begin{array}{l}\text { Comendador } \\
\text { de Quiroga }\end{array}$ & $\begin{array}{l}\text { Domingo de } \\
\text { Zarauz }\end{array}$ & Incio & 3 vidas & 13.600 & $\begin{array}{l}\text { AHRG. R. A. } \\
23088 / 72\end{array}$ \\
\hline $155^{0}$ & $\begin{array}{l}\text { Comendador } \\
\text { de Quiroga }\end{array}$ & Juan Ortiz & Soldón & 29 años & $\begin{array}{l}14.000 \\
(1)\end{array}$ & $\begin{array}{l}\text { AHRG.: } \\
20.441 / 70\end{array}$ \\
\hline 1562 & $\begin{array}{l}\text { Comendador } \\
\text { de Quiroga }\end{array}$ & $\begin{array}{l}\text { Fco. Vázquez } \\
\text { de Quiroga }\end{array}$ & Quiroga & 3 vidas & ------ & $\begin{array}{l}\text { AHRG. R. A. } \\
1662 / 4\end{array}$ \\
\hline 1569 & $\begin{array}{l}\text { Monasterio } \\
\text { de Lorenzana }\end{array}$ & $\begin{array}{l}\text { Fco. Sánchez } \\
\text { de Vidarte }\end{array}$ & Lorenzana & 3 vidas & 8.100 & $\begin{array}{lll}\text { AHRG: } & \text { R. } & \text { A. } \\
\text { 145/76 } & & \end{array}$ \\
\hline 1571 & Pedro Pardo & $\begin{array}{l}\text { Fco. Sánchez } \\
\text { de Vidarte }\end{array}$ & Pesqueira & $\begin{array}{ll}---- \\
\end{array}$ & 6.000 & $\begin{array}{l}\text { AHRG. R. A.: } \\
21859 / 104\end{array}$ \\
\hline 1579 & $\begin{array}{l}\text { Comendador } \\
\text { de Quiroga }\end{array}$ & $\begin{array}{l}\text { Juan Ortiz y } \\
\text { otros }\end{array}$ & Soldón & $\begin{array}{l}3 \text { vidas }+ \\
29 \text { años }\end{array}$ & 18.000 & AHRG.: 20441/70 \\
\hline 1604 & $\begin{array}{l}\text { Jerónima } \\
\text { Villasur }\end{array}$ & $\begin{array}{l}\text { Andrés } \quad \text { Díaz } \\
\text { Piñeiro }\end{array}$ & Lousadela & ----- & $\begin{array}{l}18.700 \\
(2)\end{array}$ & AHRG.: 19816/8 \\
\hline 1610 & $\begin{array}{l}\text { Diego } \\
\text { Sánchez de } \\
\text { Orozco }\end{array}$ & $\begin{array}{l}\text { Martín de } \\
\text { Guisaburuaga }\end{array}$ & Santalla & 3 vidas & 17.625 & $\begin{array}{l}\text { AHRG. R. A. } \\
14701 / 11\end{array}$ \\
\hline 1620 & $\begin{array}{ll}\text { Diego } & \text { de } \\
\text { Prada } & \end{array}$ & $\begin{array}{l}\text { Hermanos } \\
\text { Celaya }\end{array}$ & Soldón & $\begin{array}{ll}---- \\
\end{array}$ & 37.400 & $\begin{array}{l}\text { AHPOU:caja 90, } \\
n^{0} 173\end{array}$ \\
\hline 1630 & $\begin{array}{l}\text { P. Martínez } \\
\text { Goicoechea }\end{array}$ & $\begin{array}{ll}\text { Diego } & \text { de } \\
\text { Valcarce } & \\
\end{array}$ & Lousadela & $\begin{array}{l}----- \\
\end{array}$ & $\begin{array}{l}112.200 \\
(3)\end{array}$ & AHRG.: 19816/8 \\
\hline 1681 & $\begin{array}{l}\text { Comendador } \\
\text { de Quiroga }\end{array}$ & $\begin{array}{l}\text { José de Neira } \\
\text { y Quiroga }\end{array}$ & Quintá & 3 reyes & $\begin{array}{l}2.300+ \\
\text { herrage }\end{array}$ & $\begin{array}{l}\text { AHRG. R. A. } \\
1662 / 4\end{array}$ \\
\hline 1685 & $\begin{array}{l}\text { Marqués de } \\
\text { Villafranca }\end{array}$ & $\begin{array}{l}\text { Mateo de la } \\
\text { Flor }\end{array}$ & Arnado & Perpetuo & 28.900 & $\begin{array}{l}\text { Archivo de Llano } \\
\text { y Ovalle }\end{array}$ \\
\hline 1706 & $\begin{array}{l}\text { Marqués de } \\
\text { Villafranca }\end{array}$ & $\begin{array}{l}\text { Fco. García de } \\
\text { las Llanas }\end{array}$ & Pontepetre & Perpetuo & $\begin{array}{ll}---- \\
\end{array}$ & AHPLU: $6701 / 13$ \\
\hline 1719 & $\begin{array}{l}\text { Comendador } \\
\text { de la Barra }\end{array}$ & $\begin{array}{l}\text { Joaquín } \\
\text { Pardo } \\
\text { Rivadeneira }\end{array}$ & Lor & 3 vidas & 4.000 & AHRG.: 3020/42 \\
\hline 1722 & $\begin{array}{l}\text { Comendador } \\
\text { de Quiroga }\end{array}$ & $\begin{array}{l}\text { Manuel } \\
\text { Orozco }\end{array}$ & Incio & 300 años & 13.668 & AHRG.:23088/72 \\
\hline 1726 & $\begin{array}{l}\text { Marqués de } \\
\text { Villafranca }\end{array}$ & $\begin{array}{l}\text { Pedro } \\
\text { Sánchez } \\
\text { Ulloa } \\
\end{array}$ & Valcarce & Perpetuo & 37.400 & AHPLU: $6701 / 13$ \\
\hline
\end{tabular}

(1) y siete docenas de herraje.

(2) Y 24 docenas de clavos

(3) Más 30 cañadas de vino y 60 arrobas de pan 


\section{ARRENDATARIOS DE FERRERÍAS (S. XVI y XVII)}

\begin{tabular}{|c|c|c|c|}
\hline AÑO & NOMBRE & FERRERÍA & REFERENCIA \\
\hline 1486 & Martín González & Valcarce & AGS. RGS. \\
\hline 1499 & Juan Martínez & $\begin{array}{ll}\text { Arnado } & \mathrm{y} \\
\text { Pontepetre } & \end{array}$ & AGS. RGS \\
\hline 1537 & Juan de Belastegui & Vilaboa & \\
\hline 1553 & F. Cao de Cordido & Silán & AHPLU: $3973 / 2$ \\
\hline 1553 & Juan de Lagún & Bravos & AHPLU: 4026 \\
\hline 1557 & Fco. Sagastizábal & Arnado & \\
\hline 1566 & Miguel de Aldunzín & Bueyes & \\
\hline 1566 & Juanes de Aldunzín & Quiroga & \\
\hline 1571 & Pedro de Mindirichaga & Montealegre & \\
\hline 1578 & Miguel Ortiz & $\begin{array}{l}\text { Valcarce } \\
\text { Ferreirós }\end{array}$ & AHPL: 2849 \\
\hline 1581 & $\begin{array}{l}\text { Miguel Ortíz y Juan de } \\
\text { Lesaca }\end{array}$ & Valcarce & \\
\hline 1582 & Juan de Arriaga & Arnado & \\
\hline 1585 & Lorenzo de Alza & Bueyes & AHPL: 2849 \\
\hline 1586 & Lorenzo de Alza & Bueyes & AHPL: 2874 \\
\hline 1586 & Felipe de Garbiso & Valcarce & AHPL: 2874 \\
\hline 1588 & Felipe de Garbiso & Valcarce & AHPL: 2850 \\
\hline 1592 & Juanes de Lesaca & Paleiras & \\
\hline 1593 & Felipe de Garbiso & Valcarce & AHPL: 2850 \\
\hline 1595 & Pedro de Armesto & $\begin{array}{l}\text { Ferreiros } \\
\text { Valdomir } \\
\end{array}$ & AHPLU: $2407 / 9$ \\
\hline 1596 & Juan de Arechaga & Ferreirós & IDEM \\
\hline 1596 & Juan de Zuluaga & $\begin{array}{ll}\begin{array}{l}\text { Loureiro } \\
\text { Valdomir }\end{array} & \text { y } \\
\text { (mitad) } & \end{array}$ & IDEM \\
\hline 1596 & Domingo de Arechaga & Valdomir (mitad) & IDEM \\
\hline 1596 & $\begin{array}{l}\text { Juan Pérez de Echarri y } \\
\text { hnos. }\end{array}$ & Ferreirós & IDEM \\
\hline 1596 & Graciana de Galarza & Paleiras & IDEM \\
\hline 1596 & Juanes de Ezeolaga & Soldón & IDEM \\
\hline 1596 & Pedro de Garbiso & Visuña & IDEM \\
\hline 1596 & Juanes de Celaya & Pontepetre & IDEM \\
\hline 1596 & Agustín de Iriarte & Paleiras & IDEM \\
\hline 1596 & Juan de Regil & Visuña & IDEM \\
\hline 1596 & Juan de Arechaga & Ferreirós & IDEM \\
\hline 1596 & Pedro de Garbiso & Órreos & IDEM \\
\hline 1597 & Juan Martinez de Vicuña & Arnado & AHPLU: $2408 / 1$ \\
\hline 1597 & Domingo de Arechaga & Ferreirós & IDEM \\
\hline 1599 & $\begin{array}{l}\text { Juan Pérez de Errazti y } \\
\text { hnos. }\end{array}$ & Ferreirós & AHPLU: 2547/1 \\
\hline 1599 & Andrés Díez de Piñeiro & Loureiro & IDEM \\
\hline 1599 & Diego de Zuloaga & Valdomir & IDEM \\
\hline 1600 & Juan de Regil & Visuña & AHPLU: $2408 / 1$ \\
\hline
\end{tabular}




\begin{tabular}{|c|c|c|c|}
\hline 1600 & 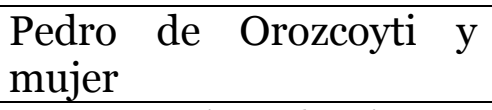 & Visuña & IDEM \\
\hline 1600 & Juan Martínez de Vicuña & Arnado & IDEM \\
\hline 1600 & Pedro Sánchez de Orozco & Ferreirós & IDEM \\
\hline 1601 & Juan de Durango & Lorenzana & AHPLU: $7011 / 1$ \\
\hline 1606 & Juan de Zuloaga & $\begin{array}{l}\text { Loureiro } \quad \mathrm{y} \\
\text { Valdomir }\end{array}$ & AHPLU: $2408 / 2$ \\
\hline 1610 & A. López Piñeiro & Loureiro & AHPLU: $2547 / 3$ \\
\hline 1612 & Martín de Guisaburuaga & Santalla & AHPLU: $2408 / 2$ \\
\hline 1612 & Miguel de Alza & Quiroga & IDEM \\
\hline 1612 & Antonio de Achega & Ferreirós & IDEM \\
\hline 1612 & $\begin{array}{l}\text { Pedro Martínez de } \\
\text { Goicoechea }\end{array}$ & Lousadela & IDEM \\
\hline 1612 & Juan Pérez de Errazti & Ferreirós & IDEM \\
\hline 1612 & Juan de Arechaga & Ferreirós & AHPLU: $2047 / 9$ \\
\hline 1615 & Pedro Sánchez de Orozco & Ferreiros & AHPLU: $2408 / 1$ \\
\hline 1615 & Pedro de Opaeda & Valcarce & AHPL: 1663 \\
\hline 1615 & Juanes de Celaya & Valcarce & AHPL: 3186 \\
\hline 1615 & Juanes de Segastiberre & Lorenzana & AHRG: 1013/1 \\
\hline 1616 & Juan Mtz. de Goicoechea & Lousadela & AHPLU: $2555 / 1$ \\
\hline 1616 & Pedro Díez de Zuloaga & Valdomir & AHPLU: $2555 / 1$ \\
\hline 1616 & Miguel de Lecumberri & Visuña & IDEM \\
\hline 1616 & Pedro Sánchez de Orozco & Ferreirós & IDEM \\
\hline 1616 & Juanes de Fagoaga & Soldón & IDEM \\
\hline 1616 & Juan Pérez de Errazti & Ferreirós & IDEM \\
\hline 1616 & Beltrán de Aguirre & Pontepetre & IDEM \\
\hline 1622 & Pedro Díez de Zuluaga & Valdomir & AHPLU: 2548/1 \\
\hline 1622 & Antonio de Achega & Ferreirós & IDEM \\
\hline 1622 & María Pérez de Armesto & Ferreirós & IDEM \\
\hline 1622 & $\begin{array}{l}\text { Juan Martínez de } \\
\text { Goicoechea }\end{array}$ & Lousadela & IDEM \\
\hline 1630 & Andrés Mosquera & Arnado & AHPL: 2969 \\
\hline 1634 & Antonio Mosquera & Arnado & AHPL: 3126 \\
\hline 1634 & Miguel de Loreaga & Pontepetre & IDEM \\
\hline 1635 & Juan de Lizalde & Bogo & $\begin{array}{l}\text { SAAVEDRA (1985), P. } \\
327\end{array}$ \\
\hline 1637 & Pedro de Armesto Balboa & Incio & AHPLU:2566/4 \\
\hline 1640 & $\begin{array}{ll}\text { Antonio } & \text { Rodríguez } \\
\text { Mosquera } & \end{array}$ & $\begin{array}{l}\text { Arnado } \\
\text { Pontepetre }\end{array}$ & MIGUÉS (1996), p. 239 \\
\hline 1641 & Juan de Balderraín & Bravos & AHPLU: $4030 / 4$ \\
\hline 1641 & Juan López & Ferreirós & AHRG: $19816 / 8$ \\
\hline 1644 & Marcos Fernández & Arnado & AHPL: 3024 \\
\hline 1646 & Marcos Fernández & Arnado & IDEM \\
\hline 1651 & Juan Rodríguez & Pontepetre & AHPL: 3025 \\
\hline 1663 & Lucas de Acevedo & Pontepetre & AHPL: 2936 \\
\hline 1663 & Andrés de Cela & Arnado & IDEM \\
\hline 1663 & Andrés González Felpete & Rodela & AHPLU: $2386 / 3$ \\
\hline 1668 & $\begin{array}{l}\text { A. de Cela } \\
\text { Bengoechea }\end{array}$ & Arnado & AHPL: 2936 \\
\hline
\end{tabular}




\begin{tabular}{|l|l|l|l|}
\hline 1669 & $\begin{array}{l}\text { J. de Oya Cabral y Ana } \\
\text { de Oya }\end{array}$ & Valcarce & AHPL: 3195 \\
\hline 1672 & $\begin{array}{l}\text { A. de Cela y F. } \\
\text { Bengoechea }\end{array}$ & Arnado & AHPL: 3103 \\
\hline 1674 & Lucas de Acevedo & Pontepetre & AHPL: 2936 \\
\hline 1676 & Fco. De Soto Gayoso & Valcarce & AHPL: 3316 \\
\hline 1679 & Alonso Ocapo Balboa & Pontepetre & AHPL: 3104 \\
\hline 1681 & M $^{\text {a de Balboa y Quiroga }}$ & Incio & AHPLU: 2567/10 \\
\hline 1685 & Manuel Guzmán & Arnado & AHPL: 2937 \\
\hline 1689 & Francisco de Herrera & Quiroga y Soldón & AHRG: $1662 / 4$ \\
\hline 1693 & $M^{a}$ de Balboa y Quiroga & Incio & AHPLU:2566/3 \\
\hline 1694 & Tomás Salazar de Soto & Valcarce & $\begin{array}{l}\text { AHN. Estado, leg. 1739, } \\
n^{0} 16\end{array}$ \\
\hline 1694 & Fco. García de las Llanas & Pontepetre & IDEM \\
\hline 1697 & Tomás Salazar de Soto & Valcarce & IDEM \\
\hline 1698 & $M^{a}$ de Balboa Quiroga & Incio & AHPLU: $2566 / 8$ \\
\hline
\end{tabular}

\section{ARRENDATARIOS DE FERRERÍAS (SIGLO XVIII Y XIX)}

\begin{tabular}{|c|c|c|c|}
\hline AÑO & ARRENDATARIO & FERRERÍA & REFERENCIA \\
\hline 1700 & Fray Bernardo Laguna & Gondriz & AHPLU: $5088 / 2$ \\
\hline 1704 & $\begin{array}{lll}\mathrm{M}^{\mathrm{a}} \text { de } & \text { Balboa } & \mathrm{y} \\
\text { Quiroga } & & \end{array}$ & Incio & AHPLU: $5088 / 7$ \\
\hline 1726 & Fco. Guerra Donís & Arnado & AHPL: 3333 \\
\hline 1727 & $\begin{array}{lll}\text { Juan A. Somoza } & \text { y } \\
\text { Quiroga } & & \\
\end{array}$ & Soldón & AHPLU: $2570 / 2$ \\
\hline 1728 & Fco. Guerra Donís & Soldón & IDEM \\
\hline 1733 & $\begin{array}{l}\text { Angela } \\
\text { Torres }\end{array}$ & Pontepetre & AHPL: 3341 \\
\hline 1745 & $\begin{array}{l}\text { Angela María } \quad \text { de } \\
\text { Torres }\end{array}$ & Pontepetre & IDEM \\
\hline 1749 & Idem y Juan Perejón & Pontepetre & AHPL: 3342 \\
\hline 1752 & Pedro Lombán & Froseira & OCAMPO (1987), p. 42 \\
\hline 1752 & Fco. Guerra Donís & Arnado & AHPL: 617 \\
\hline 1753 & Fco. Guerra Donís & Arnado & IDEM \\
\hline 1753 & Pedro Arango & Bullimeiro & OCAMPO (1987), p. 42 \\
\hline 1759 & Pedro de Ortiz & Amandi & AGS. Marina, 561 \\
\hline 1760 & Baltasara Guerra & Arnado & AHPL: 3341 \\
\hline 1762 & José de la Vega & Bravos & AHPLU: $2679 / 8$ \\
\hline 1769 & $\begin{array}{l}\text { José Martínez de la } \\
\text { Fuente }\end{array}$ & Arnado & AHPL: 3353 \\
\hline 1791 & Manuel Sánchez & Paleiras & AHPLU: $2417 / 11$ \\
\hline 1795 & Cia. Vega de Ribadeo & Montealegre & $\begin{array}{l}\text { M. NAVAL: col. Guillén, } \\
\text { ms. } 2175\end{array}$ \\
\hline 1795 & Cia. Vega de Ribadeo & Nafaroa & IDEM \\
\hline 1795 & Antonio Lombán & Froseira & IDEM \\
\hline
\end{tabular}




\begin{tabular}{|c|c|c|c|}
\hline 1796 & $\begin{array}{ll}\text { Benito } & \text { Méndez } \\
\text { Losada } & \\
\end{array}$ & Bueyes & AHPL: 3329 \\
\hline 1797 & Fray Eulogio Robles & Rodela & AHPLU: $2555 / 2$ \\
\hline 1800 & Manuel A. Sánchez & Paleiras & AHPLU: $2454 / 3$ \\
\hline $\begin{array}{l}1800 \\
\mathrm{a} \\
1810\end{array}$ & Manuel A. Sánchez & Arnado & AHPLU: $2454 / 7$ \\
\hline $\begin{array}{l}1801 \\
\mathrm{a} \\
1816\end{array}$ & Diego Ovalle y esposa & Pontepetre & $\begin{array}{l}\text { ARCHIVO de la Familia de } \\
\text { Llano Ovalle }\end{array}$ \\
\hline $\begin{array}{l}1802 \\
\mathrm{a} \\
1806\end{array}$ & $\begin{array}{l}\text { Andrés Celaya } \quad \text { y } \\
\text { Rendarte }\end{array}$ & Tejedo & AHPLU 2475/4 \\
\hline 1807 & Manuel A. Sánchez & Paleiras & AHRG.: 12446/45 \\
\hline 1808 & Manuel A. Sánchez & \begin{tabular}{|ll} 
Paleiras & $y$ \\
Arnado &
\end{tabular} & IDEM \\
\hline 1809 & Gregorio Martínez & Ferreirós & AHPLU: 2455/2 \\
\hline 1809 & Manuel A. Sánchez & Paleiras & AHPLU: $2454 / 7$ \\
\hline $\begin{array}{l}1810 \\
\mathrm{a} \\
1820\end{array}$ & Valentín Curiel & Arnado & AHPLU: $2455 / 1$ \\
\hline 1811 & \begin{tabular}{ll|}
$\begin{array}{l}\text { José } \\
\text { Gallego }\end{array}$ & Rodríguez \\
\end{tabular} & Soldón & AHPLU: $2406 / 3$ \\
\hline $\begin{array}{l}1811 \mathrm{a} \\
1814\end{array}$ & Domingo A. González & Tejedo & AHPL: 3783 \\
\hline 1814 & A. de Mon Rancaño & Valcarce & AHPLU 2467/11 \\
\hline 1814 & Manuel A. Sánchez & Paleiras & AHPLU: $2467 / 11$ \\
\hline 1814 & Manuel A. Sánchez & Soldón & IDEM \\
\hline 1815 & Manuel A. Sánchez & Soldón & AHPLU: $2406 / 3$ \\
\hline 1815 & $\begin{array}{ll}\text { José } & \text { Rodríguez } \\
\text { Gallego } & \\
\end{array}$ & Soldón & AHPLU: $2406 / 11$ \\
\hline 1815 & Manuel A. Sánchez & Paleiras & AHRG: 12446/45 \\
\hline $\begin{array}{l}1816 \\
\mathrm{a} \\
1824\end{array}$ & Nemesio Fernández & Pontepetre & AHPL.: 3576 \\
\hline 1818 & \begin{tabular}{lll|}
$\begin{array}{l}\text { Antonio } \\
\text { Pardo }\end{array}$ & Somoza & $\mathrm{y}$ \\
\end{tabular} & Loureiro & AHPLU: $2406 / 6$ \\
\hline $\begin{array}{l}1818 \\
\mathrm{a} \\
1821\end{array}$ & Ramón Ovalle & Pontenova & AHPL.: 2576 \\
\hline 1818 & Manuel A. Sánchez & Paleiras & AHPLU: $2474 / 7$ \\
\hline $\begin{array}{l}1820 \\
\mathrm{a} \\
1840\end{array}$ & Ramón Ovalle & Arnado & AHPL: 3576 \\
\hline 1820 & Manuel A. Sánchez & Loureiro & AHPLU: $2474 / 9$ \\
\hline 1821 & 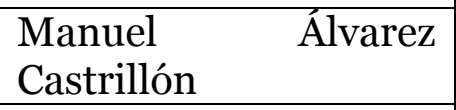 & Bogo & AHPLU: $2071 / 2$ \\
\hline 1822 & Domingo Rigueiro & Quintá & AHPLU: $2406 / 10$ \\
\hline 1824 & Francisco Ibarbia & Bogo & AHPLU: 2071/6 \\
\hline 1824 & Juan Fernández & Paleiras & AHPLU: $2406 / 11$ \\
\hline
\end{tabular}




\begin{tabular}{|c|c|c|c|}
\hline 1824 & $\begin{array}{ll}\text { Manuel } & \text { Rodríguez } \\
\text { Arango } & \end{array}$ & Bullimeiro & AHPLU: $2071 / 5$ \\
\hline 1826 & Domingo Rigueiro & Quintá & AHPLU: $2406 / 16$ \\
\hline 1827 & $\begin{array}{l}\text { Felipe Fernández de } \\
\text { Prada }\end{array}$ & Mondón & AHPLU: $2406 / 14$ \\
\hline 1829 & Gregorio Martínez & Ferreirós & AHPLU: $2376 / 3$ \\
\hline 1829 & A. Fernández Rigueiro & Quintá & AHPLU: $2406 / 16$ \\
\hline 1829 & Santiago Rodríguez & Mondón & AHPLU: $2406 / 16$ \\
\hline 1930 & Tomás del Real & Mondón & AHPLU: $2406 / 17$ \\
\hline 1832 & F. Pérez Villamil & Lagar & $\begin{array}{l}\text { LÓPEZ y GRAN̂A (1998), } \\
\text { 95 }\end{array}$ \\
\hline 1835 & Enrique Celeiro & Mondón & AHPLU: $2406 / 27$ \\
\hline 1837 & $\begin{array}{l}\text { Antonio Somoza } \\
\text { Pardo }\end{array}$ & Rugando & AHPLU: $5431 / 6$ \\
\hline 1838 & Juan Fariñas & Soldón & AHPLU: $2406 / 25$ \\
\hline 1838 & Santiago Montero & Río Cabo & $\begin{array}{l}\text { GARCÍA TATO (2000), p. } \\
13\end{array}$ \\
\hline 1839 & Francisco Maceda & Folgoso & AHPLU: $2431 / 4$ \\
\hline 1845 & Santiago Olmo & Río Cabo & AHPL.: 3581 \\
\hline $\begin{array}{l}1846 \\
\mathrm{a} \\
1855\end{array}$ & Enrique Celeiro & Pontenova & AHPLU: $2376 / 6$ \\
\hline 1847 & Estefanía Rivas & Visuña & AHPLU: $2563 / 9$ \\
\hline 1849 & Antonia San Miguel & Río Cabo & $\begin{array}{l}\text { GARCİA TATO (2000), p. } \\
\text { 100 }\end{array}$ \\
\hline 1853 & Estafanía Rivas & Visuña & AHPLU: $2563 / 9$ \\
\hline 1853 & Francisco Maceda & Folgoso & AHPL: 9113 \\
\hline $\begin{array}{l}1857 \\
\mathrm{a} \\
1865\end{array}$ & Antonia San Miguel & Pombriego & $\begin{array}{l}\text { GARCÍA TATO (2000), } \\
\text { apéndice } 18 \text { y } 21\end{array}$ \\
\hline $\begin{array}{l}1857 \\
\mathrm{a} \\
1863\end{array}$ & Ramona Martínez & Río Cabo & $\begin{array}{l}\text { GARCÍA TATO (2000), p. } \\
100\end{array}$ \\
\hline 1868 & Paulino Arias & $\begin{array}{ll}\text { Pontenova } & \mathrm{y} \\
\text { Riodolas } & \end{array}$ & BOPOU, 7 enero 1868 \\
\hline $\begin{array}{l}1872 \\
\mathrm{a} \\
1891\end{array}$ & Paulino Arias & Pombriego & Estadística Minera, 1891 \\
\hline
\end{tabular}




\section{DURACIÓN DE LOS ARRENDAMIENTOS Y RENTAS \\ (S. XVI yXVII)}

\begin{tabular}{|c|c|c|c|c|}
\hline AÑO & FERRERÍA & $\begin{array}{l}\text { TIEMPO } \\
\text { (en } \\
\text { años) }\end{array}$ & $\begin{array}{l}\text { RENTA ANUAL } \\
\text { (en mrs.) }\end{array}$ & REFERENCIA \\
\hline 1486 & Valcarce & +10 & 16.000 & AGS. RGS \\
\hline 1499 & $\begin{array}{ll}\text { Arnado } & y \\
\text { Pontepetre } & \end{array}$ & 1 & $64.000\left(^{*}\right)$ & AGS. RGS \\
\hline 1500 & Valcarce & 1 & 18.500 & FRANCO (1982) \\
\hline 1500 & $\begin{array}{l}\text { Arnado } \\
\text { Pontepetre }\end{array}$ & 1 & 34.000 & IBIDEM \\
\hline 1555 & Valcarce & 1 & 22.500 & IBIDEM \\
\hline 1555 & $\begin{array}{l}\text { Arnado } \\
\text { Pontepetre }\end{array}$ & 1 & 52.000 & IBIDEM \\
\hline 1556 & $\begin{array}{ll}\text { Arnado } & \mathrm{y} \\
\text { Pontepetre } & \end{array}$ & 1 & 52.000 & IBIDEM \\
\hline 1581 & Valcarce & 5 & 22.500 & AHPL: 2871 \\
\hline 1596 & Valdomir & 3 & Mitad producción & AHPLU: $2407 / 9$ \\
\hline 1596 & Paleiras & -- & 68.000 & AHPLU: $2407 / 9$ \\
\hline 1599 & Valdomir & -- & 49.980 & AHPLU: $2547 / 1$ \\
\hline 1603 & Soldón (mitad) & 4 & 66 qq. hierro & AHRG: $20441 / 70$ \\
\hline 1605 & Paleiras & 8 & 60.084 & $\begin{array}{l}\text { AHRG. Hombreiro, } \\
\text { leg. } 19\end{array}$ \\
\hline 1614 & $\begin{array}{l}\text { Lousadela } \\
\text { (mitad) }\end{array}$ & 3 & $\begin{array}{ll}---- \\
\end{array}$ & AHPLU: 2555/1 \\
\hline 1616 & $\begin{array}{l}\text { Visuña } \\
\text { (subarriendo) }\end{array}$ & 9 meses & $\begin{array}{l}---- \\
\end{array}$ & AHPLU: 2555/1 \\
\hline 1625 & Paleiras & 4 & Arreglo + 4.00o & $\begin{array}{l}\text { AHRG.: Hombreiro, } \\
\text { leg. } 19\end{array}$ \\
\hline 1627 & Pontepetre & -- & $4,5 \mathrm{qq} \times$ semana & \\
\hline 1629 & Paleiras & 4 & 78.778 & $\begin{array}{l}\text { AHRG.: Hombreiro, } \\
\text { leg. } 19\end{array}$ \\
\hline 1634 & Arnado & 3 & 169 qq. hierro & AHPL.: 3126 \\
\hline 1692 & Lousadela & 2 & $\begin{array}{l}68.000+300 \text { qq. } \\
\text { hierro }\end{array}$ & AHPLU: $2566 / 2$ \\
\hline
\end{tabular}

* En la renta se incluía, además de las dos ferrerías, otros bienes a ellas anexos 


\section{DURACIÓN DE LOS ARRENDAMIENTOS Y RENTAS (S. XVIII y XIX)}

\begin{tabular}{|c|c|c|c|c|}
\hline AÑO & FERRERÍA & $\begin{array}{l}\text { DURACIÓN } \\
\text { (en años) }\end{array}$ & $\begin{array}{l}\text { RENTA } \\
\text { ANUAL } \\
\quad \text { (en mrs.) }\end{array}$ & REFERENCIA \\
\hline 1722 & Pontepetre & $22(*)$ & 357.000 & AHPL: 3342 \\
\hline 1728 & Soldón & 4 & 196.214 & AHPLU: $2570 / 2$ \\
\hline 1729 & Visuña & 3 & $\begin{array}{l}108.460 \quad\left(1^{0}\right. \\
\text { año }) \\
130.900 \quad(2 \quad y \\
\left.3^{0}\right)\end{array}$ & AHPL: 3333 \\
\hline 1746 & Paleiras & 6 & 204.000 & AHRG: 14147/12 \\
\hline 1752 & Paleiras & 6 & 204.000 & IDEM \\
\hline 1760 & Arnado & 2 & 374.000 & $\begin{array}{l}\text { ARCH. González del } \\
\text { Villar }\end{array}$ \\
\hline 1769 & Arnado & 3 & 464.100 & IDEM \\
\hline 1775 & Navaleo & 2 & 159.800 & OLANO (2008), 312 \\
\hline 1797 & $\begin{array}{l}\text { Lousadela- } \\
\text { Ferreirós }\end{array}$ & 9 & 1.360 .000 & AHRG: $25291 / 28$ \\
\hline 1802 & Tejedo & 4 & 272.000 & AHPL: 3783 \\
\hline 1806 & $\begin{array}{l}\text { Lousadela- } \\
\text { ferreirós }\end{array}$ & 3 & 1224.000 & AHRG: $2529 / 28$ \\
\hline 1809 & Paleiras & 5 & $\begin{array}{l}748.000 \\
+ \text { tributos }\end{array}$ & AHPLU: $2455 / 2$ \\
\hline 1812 & Valcarce & 6 & ------- & AHPLU: $2467 / 11$ \\
\hline 1813 & $\begin{array}{l}\text { Ferreirós } \\
\text { ágoas) }\end{array}$ & 6 & 204.000 & AHPLU: $2474 / 3$ \\
\hline 1814 & Soldón & 6 & 1.394 .000 & AHPLU: $2467 / 11$ \\
\hline 1821 & Bogo & 3 & 361.760 & AHPLU: $2071 / 2$ \\
\hline 1823 & $\begin{array}{l}\text { Santalla } \\
\text { Gondriz }\end{array}$ & 2 & $\begin{array}{l}612.000 \\
+24 \text { jamones } \\
y \\
17 \text { cabritos }\end{array}$ & AHRG: $1389 / 7$ \\
\hline 1824 & Bogo & 3 & $\begin{array}{l}544.000 \quad\left(1^{0}\right. \\
\text { año) } \\
612.000\left(2^{\circ}\right) \\
680.000\left(3^{\circ}\right)\end{array}$ & AHPL: 2071/6 \\
\hline 1825 & $\begin{array}{l}\text { Ferreirós } \\
\text { ágoas) }\end{array}$ & 2 & 238.000 & AHPLU: $2475 / 5$ \\
\hline 1825 & Lousadela & 9 & $\begin{array}{l}------ \\
\end{array}$ & AHPLU: $5341 / 3$ \\
\hline 1827 & Mondón & 4 & 278.800 & AHPLU: $2406 / 4$ \\
\hline 1829 & Mondón & 1 & 163.200 & AHPLU: 2406/16 \\
\hline 1830 & Mondón & 2 & 176.800 & AHPLU: $2406 / 17$ \\
\hline 1830 & $\begin{array}{l}\text { Ferreirós } \\
\text { ágoas })\end{array}$ & 5 & 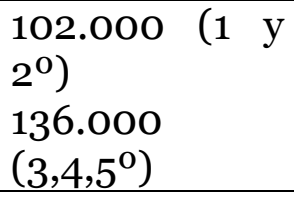 & AHPLU: $2376 / 3$ \\
\hline
\end{tabular}




\begin{tabular}{|l|l|l|l|l|}
\hline 1835 & Mondón & 3 & 79.322 & AHPLU: $2406 / 27$ \\
\hline 1838 & Rial & 3 & 149.600 & AHPLU: 2406/25 \\
\hline 1846 & Rial & 2 & 112.200 & AHPLU: $2376 / 6$ \\
\hline 1846 & Pontenova & 9 & 170.000 & AHPLU: 2376/6 \\
\hline 1848 & Visuña & 6 & $\begin{array}{l}425 \cdot 000 \\
+\quad \text { foro de } \\
\text { venera }\end{array}$ & AHPLU: 2563/9 \\
\hline 1848 & Rial & 2 & 102.000 & AHPLU: $2376 / 7$ \\
\hline 1849 & Río Cabo & 4 & 408.000 & AHPLU: $2409 / 3$ \\
\hline 1852 & $\begin{array}{l}\text { Ferreirós } \\
\text { ágoas) }\end{array}$ & 1 & 108.800 & AHPLU: 2409/7 \\
\hline 1855 & $\begin{array}{l}\text { Ferreirós }(19 \\
\text { ágoas) }\end{array}$ & 1 & 74.800 & IDEM \\
\hline 1857 & Río Cabo & 2 & 374.000 & G. TATO (2000), 100 \\
\hline 1860 & $\begin{array}{l}\text { San Vicente de } \\
\text { Leira }\end{array}$ & 4 & 918.000 & AHPL: 2724 \\
\hline 1864 & Pontepetre & 4 & $595.000(7)$ & AHPL: 2729 \\
\hline 1870 & Pontepetre & 2 & 238.000 & AHPL: 9114 \\
\hline
\end{tabular}

* En esos 22 años desconocemos los contratos que se realizaron ni la duración de los mismos, solo que el arrendatario permaneció ese tiempo y la renta anual fue esa en cada uno de los años.

\section{SALARIOS DE LOS OFICIALES DE FERRERÍA A MEDIADOS DEL SIGLO XVIII (en reales) (*)}

\begin{tabular}{|l|l|l|l|l|}
\hline FERRERÍA & AROZA & TIRADOR & FUNDIDOR $(* *)$ & TAZADOR \\
\hline Visuña & 600 & 450 & 350 & 200 \\
\hline Valdomir & 600 & 500 & 350 & 220 \\
\hline Paleiras & 540 & 400 & 350 & 170 \\
\hline Ferreirós & 600 & 500 & 360 & 250 \\
\hline Folgoso & 600 & 500 & 350 & 220 \\
\hline Soldón & 500 & 420 & 350 & 150 \\
\hline A Veguiña & 780 & 600 & 600 & 224 \\
\hline Bueyes & 1.135 & 853 & 643 & 403 \\
\hline Quinta & 1.717 & 1.150 & 988 & 600 \\
\hline Rodela & 1.742 & 1.184 & 1.044 & 644 \\
\hline Rugando & 1.732 & 1.184 & 1.044 & 644 \\
\hline
\end{tabular}

(*) En las siete primeras ferrerías no estácomputado el quintalaje, en las otras sí y por eso sus salarios son más altos

$\left.{ }^{* *}\right)$ Los fundidores son dos, cada uno de los cuales cobra la cantidad referida FUENTE: PARES: Catastro de Ensenada, muestra de ferrerías a partir de la respuesta 33 del interrogatorio general.. 
14. TRABAJADORES NO FERRONES EN LAS FERRERÍAS

\begin{tabular}{|c|c|c|c|c|}
\hline AÑO & NOMBRE & OFICIO & FERRERÍA & REFERENCIA \\
\hline 1558 & Martín Santo.. & Barquinero & & $\begin{array}{l}\text { AHRG: } \\
19768 / 32\end{array}$ \\
\hline 1563 & Juan de Lasarte & Maestro de herrage & Soldón & IDEM \\
\hline 1563 & $\begin{array}{ll}\text { Martín } & \text { de } \\
\text { Barrulaça } & \end{array}$ & Ferramentero & Ferreirós & IDEM \\
\hline 1565 & Antonio Vázquez & Maestro de herrage & Gondriz & AHPL: 2868 \\
\hline 1596 & Juan de Bergara & Ferramentero & Ferreirós & AHPLU: $2407 / 9$ \\
\hline 1599 & Diego Sánchez & Ferramentero & & AHPLU: $2547 / 1$ \\
\hline 1609 & Juan de Ezpeleta & Carpintero & Pontepetre & AHPL: 3186 \\
\hline 1612 & Pedro de Ochoa & Carpintero & & AHPLU: $2408 / 2$ \\
\hline 1616 & Pedro de Alza & Barquinero & Lousadela & AHPLU: $2555 / 1$ \\
\hline 1616 & $\begin{array}{l}\text { Francisco } \\
\text { González }\end{array}$ & Ferramentero & Valdomir & AHPLU: $2551 / 1$ \\
\hline 1616 & Diego de Arcilla & Maestro de herrage & Valdomir & AHPLU: $2555 / 1$ \\
\hline 1622 & Juan de Isasueta & Tuberero & Ferreirós & AHPLU: $2548 / 1$ \\
\hline 1630 & Juan Núñez & Carpintero & Arnado & AHPL: 2969 \\
\hline 1634 & Juan de Zauregui & $\begin{array}{l}\text { Maestro } \\
\text { barquinero }\end{array}$ & Pontepetre & AHPL: 2126 \\
\hline 1660 & Juan Ferrero & Maestro carpintero & & AHPL: 2936 \\
\hline 1668 & Juan Ferrero & $\begin{array}{l}\text { Mtro. } \\
\text { ferrerías }\end{array}$ & Pontepetre & AHPL: 2936 \\
\hline 1679 & Pedro de Alça & $\begin{array}{l}\text { Maestro } \\
\text { barquinero }\end{array}$ & Pontepetre & AHPL: 3104 \\
\hline 1692 & Antonio da Vila & Mtro carp. ferrerías & Quintá & AHRG: $1662 / 4$ \\
\hline 1692 & Francisco Ferreiro & $\begin{array}{l}\text { Mtro. } \\
\text { ferrerías }\end{array}$ & Quintá & IDEM \\
\hline
\end{tabular}

\section{MULATEROS/ARRIEROS DE VENA}

\begin{tabular}{|l|l|l|l|l|}
\hline AÑO & NOMBRE & LUGAR & FERRERÍA & REFERENCIA \\
\hline 1586 & Marcos de Castro & Molinaferrara & Valcarce & AHPL.: 2850 \\
\hline 1586 & Andrés Alonzo & Molinaferrara & Valcarce & AHPL.: 2850 \\
\hline 1596 & Martín de Artiega & & Paleiras & AHPLU: 2407/9 \\
\hline 1609 & Miguel Ttz. De Vicuña & Legazpi & Pontepetre & AHPL.: 3186 \\
\hline 1612 & Blas Fernández & & & AHPLU: 2408/2 \\
\hline 1612 & Domingo Domínguez & & & AHPLU: 2408/2 \\
\hline 1651 & Bartolomé Lameyra & Arnado & Pontepetre & AHPL.: 3025 \\
\hline 1666 & Antonio de la Rivera & & Pontepetre & AHPL.: 2936 \\
\hline 1666 & Lorenzo de la Peña & & Pontepetre & IDEM \\
\hline 1668 & Antonio Cereijo & Gestoso & Pontepetre & IDEM \\
\hline 1673 & Bartolomé de la Fava & Visuña & Pontepetre & IDEM \\
\hline 1674 & Francisco Yañez & & Pontepetre & IDEM \\
\hline
\end{tabular}




\section{VENAQUEROS}

\begin{tabular}{|l|l|l|l|l|}
\hline AÑO & NOMBRE & LUGAR & FERRERÍA & REFERENCIA \\
\hline 1576 & Juan de Ormazábal & Rocas & & AHPLU: $2837 / 19$ \\
\hline 1609 & Esteban de Argarese & & Pontepetre & AHPL.: 3186 \\
\hline 1609 & Miguel Pericena & & Pontepetre & IDEM \\
\hline 1609 & Juan de Loreaga & & Pontepetre & IDEM \\
\hline 1610 & Juan de Legama & Rocas & & AHPLU: $2547 / 3$ \\
\hline 1612 & ¿ Grabide & & & AHPLU: $2408 / 2$ \\
\hline 1622 & Juan Pérez de Arrebillaga & & & AHPLU: $2548 / 1$ \\
\hline 1629 & Miguel de Loreaga & & Pontepetre & AHPL: 2969 \\
\hline 1629 & Juan de Loreaga & & Pontepetre & AHPL.: 3186 \\
\hline 1629 & Juan Miguel Pericena & & Pontepetre & IDEM \\
\hline 1629 & E. Castiñeiro & & Pontepetre & IDEM \\
\hline 1629 & Esteban de Algarese & & Pontepetre & IDEM \\
\hline 1633 & Juan Grande e isabel Díaz & Rocas & & AHRG.: 3070/39 \\
\hline
\end{tabular}




\section{DÍAS DE TRABAJO Y PRODUCCIÓN DE LAS FERRERÍAS}

\begin{tabular}{|l|l|c|c|}
\hline FERRERÍA & \multicolumn{1}{|c|}{ DÍAS } & \multicolumn{2}{c|}{ PRODUCCIÓN (en quintales } \\
\hline & & CATASTRO & CORNIDE \\
\hline Linares & 120 & 1.550 & \\
\hline Arnado & 250 & 1.625 & 1.500 \\
\hline Pontepetre & 250 & 1.625 & 1.500 \\
\hline Valcarce & 200 & & 1.000 \\
\hline Visuña & 120 & & 600 \\
\hline Lousadela & & & 950 \\
\hline Valdomir & 105 & & 550 \\
\hline Lor & 200 & 1.000 & 1.000 \\
\hline Quintá & 120 & 660 & 500 \\
\hline Rodela & 120 & 660 & 700 \\
\hline Rugando & 150 & 825 & 1.500 \\
\hline Ferreirós & 120 & & 900 \\
\hline Paleiras & 200 & & 700 \\
\hline Góndriz & & & 500 \\
\hline Santalla & & & 700 \\
\hline Biduedo & & & 200 \\
\hline Incio & & & 650 \\
\hline Rial/ Lusío & & & 150 \\
\hline Loureiro & & & 550 \\
\hline Penacova & & & 550 \\
\hline Soldón & & & 600 \\
\hline Gorgueira & & & 1.500 \\
\hline San Vicente de Leira & 250 & 1.650 & 500 \\
\hline Bueyes & 90 & 455 & 550 \\
\hline Pontenova & & & \\
\hline Villanueva de Oscos & 210 & 472 & \\
\hline Deva & 90 & & \\
\hline Arbón & 120 & 800 & \\
\hline Agüerina & & 1.200 & \\
\hline Froseira & & $800 / 1.000$ & \\
\hline Boimouro & 120 & & \\
\hline La Veguina & 90 & & \\
\hline Montealegre & 150 & & \\
\hline Setienes & 150 & 300 & \\
\hline FUENa & & \\
\hline
\end{tabular}

FUENTE: Días de trabajo: PARES: Catastro de Ensenada, respuesta 17 del interrogatorio general Producción: Catastro de Ensenada (idem) y José Cornide: R.A.H.: Papeles Cornide Saavedra. Galicia, 9/5.917 


\section{PRODUCCIÓN Y PRECIO DEL HIERRO EN LA FERRERÍA DE QUINTÁ}

\begin{tabular}{|c|c|c|c|}
\hline AÑOS & $\begin{array}{l}\text { PRODUCCIÓN } \\
\text { (en quintales) }\end{array}$ & $\begin{array}{l}\text { PRECIO } \\
\text { (en reales) }\end{array}$ & $\begin{array}{c}\text { VALOR } \\
\text { (en reales }\end{array}$ \\
\hline 1752 & & 64 & \\
\hline 1753 & 848 & 70 & 59.360 \\
\hline 1754 & 1.121 & 69 & $77 \cdot 349$ \\
\hline 1755 & 1.102 & 70 & 77.140 \\
\hline 1756 & 878 & 70 & 61.460 \\
\hline 1757 & 607 & 70 & 42.490 \\
\hline 1758 & 954 & 70 & 66.780 \\
\hline 1759 & 1.014 & 60 & 60.840 \\
\hline 1760 & 1.221 & 60 & 73.365 \\
\hline 1761 & 1.311 & 60 & 78.660 \\
\hline 1762 & 1.097 & 60 & 65.820 \\
\hline 1763 & 884 & 60 & 53.040 \\
\hline 1764 & 845 & 60 & 50.700 \\
\hline 1765 & & 62 & \\
\hline 1766 & 807 & 62 & 50.034 \\
\hline \multicolumn{4}{|l|}{1767} \\
\hline 1768 & & 66 & \\
\hline 1769 & 795,5 & 66 & 52.503 \\
\hline 1770 & & 62 & \\
\hline 1771 & & 62 & \\
\hline 1772 & 900 & 62 & 55.800 \\
\hline 1773 & 684 & 62 & 42.408 \\
\hline 1774 & 549 & 62 & 34.038 \\
\hline 1775 & 592 & 66 & 39.072 \\
\hline 1776 & 684 & 66 & 45.144 \\
\hline 1777 & 362 & 66 & 23.892 \\
\hline 1778 & 663 & 66 & 43.758 \\
\hline \multicolumn{4}{|l|}{1779} \\
\hline 1780 & & 68 & \\
\hline 1781 & 323,5 & 68 & 21.998 \\
\hline 1782 & 479 & 68 & 32.572 \\
\hline 1783 & 612 & 71 & 43.453 \\
\hline 1784 & 458 & 77 & 35.266 \\
\hline 1785 & 418,5 & 80 & 33.480 \\
\hline 1786 & 235 & 90 & 21.150 \\
\hline 1787 & 550 & 105 & 57.750 \\
\hline 1788 & 600 & 102 & 61.200 \\
\hline 1789 & 692 & 102 & 70.584 \\
\hline 1790 & 502 & 97 & 48.694 \\
\hline 1791 & 800 & 100 & 80.000 \\
\hline 1792 & 620 & 100 & 62.000 \\
\hline TOTAL & $24.212,5$ & & 1.721 .800 \\
\hline
\end{tabular}

FUENTE: AHRG. Hombreiro. Libro de cuentas de la ferrería de Quintá 


\section{PRODUCCIÓN Y PRECIO DEL HIERRO EN LA FERRERÍA DE VILLANUEVA DE OSCOS}

\begin{tabular}{|c|c|c|c|}
\hline AÑOS & $\begin{array}{l}\text { PRODUCCIÓN } \\
\text { (en quintales) }\end{array}$ & $\begin{array}{l}\text { PRECIO QUINTAL } \\
\text { (en reales) }\end{array}$ & $\begin{array}{c}\text { VALOR } \\
\text { (en reales) }\end{array}$ \\
\hline $1677-79$ & 1.122 & 90,02 & 101.010 \\
\hline $1680-84$ & 1.841 & 107,59 & 198.082 \\
\hline $1685-89$ & 1.269 & 49,66 & 63.025 \\
\hline $1690-94$ & 1.422 & 49,06 & 69.767 \\
\hline $1695-99$ & 2.808 & 43,75 & 122.872 \\
\hline $1700-04$ & 1.791 & 48,91 & 87.599 \\
\hline $1705-09$ & 2.356 & 49,05 & 115.583 \\
\hline $1710-14$ & 2.615 & 48,66 & 127.269 \\
\hline $1715^{-19}$ & 2.582 & 51,84 & 133.852 \\
\hline $1720-24$ & 3.407 & 59,00 & 201.035 \\
\hline $1725-29$ & 3.826 & 55,63 & 212.878 \\
\hline $1730-34$ & 3.988 & 67,44 & 268.959 \\
\hline $1735-39$ & 3.956 & 54,89 & 217.180 \\
\hline $1740-44$ & 3.969 & 56,17 & 222.947 \\
\hline $1745-49$ & 4.305 & 52,81 & 227.353 \\
\hline $1750-54$ & 3.737 & 77,39 & 289.235 \\
\hline $1755-59$ & 4.025 & 59,33 & 238.829 \\
\hline $1760-64$ & 4.161 & 72,01 & 299.635 \\
\hline $1765-69$ & 4.010 & 68,43 & 274.438 \\
\hline $1770-74$ & 3.052 & 76,37 & 233.101 \\
\hline $1775-79$ & 2.494 & 98,40 & 245.410 \\
\hline $1780-84$ & 2.819 & 120,20 & 339.124 \\
\hline $1785-89$ & 2.830 & 106,32 & 300.907 \\
\hline 1790-94 & 4.104 & 104,55 & 429.114 \\
\hline $1795-99$ & 4.245 & 149,36 & 634.038 \\
\hline $1800-04$ & 2.982 & 148,44 & 442.675 \\
\hline $1805-09$ & 3.056 & 157,70 & 481.934 \\
\hline $1810-14$ & 1.782 & 184,57 & 328.916 \\
\hline $1815^{-19}$ & 1.292 & 199,55 & 257.827 \\
\hline 1820-24 & 536 & 26,74 & 14.336 \\
\hline $1825-29$ & 3.290 & 91,18 & 300.000 \\
\hline $1830-35$ & 3.223 & 114,06 & 367.630 \\
\hline TOTAL & 7.746 .659 & & \\
\hline
\end{tabular}

FUENTE: P. SAAVEDRA (1982): Ob. cit., p. 545-554

Elaboración propia a partir de sus apéndices 


\section{FERRERÍAS Y PRODUCCIÓN EN EL SIGLO XIX}

\begin{tabular}{|c|c|c|c|c|c|c|}
\hline \multirow{2}{*}{ AÑOS } & \multicolumn{3}{|c|}{ BIERZO } & \multicolumn{3}{|c|}{ LUGO } \\
\hline & $\mathrm{N}^{\mathrm{O}}$ & PRODUCCIÓN & RENDIMIENTO & $\mathrm{N}^{\mathrm{O}}$ & PRODUCCIÓN & RENDIMIENTO \\
\hline 1860 & 13 & 8.053 & 619 & & & \\
\hline 1861 & 13 & 5.875 & 452 & & & \\
\hline 1862 & 13 & 5.885 & 453 & & & \\
\hline 1863 & 15 & 5.900 & 393 & 23 & 3.805 & 165 \\
\hline 1864 & 16 & 7.021 & 439 & 23 & 3.648 & 159 \\
\hline 1865 & 15 & 8.244 & 549 & 16 & 3.172 & 198 \\
\hline 1866 & 15 & 5.855 & 390 & 12 & 4.781 & 398 \\
\hline 1867 & & & & & & \\
\hline 1868 & 14 & 3.857 & 276 & & & \\
\hline 1869 & & & & 17 & & \\
\hline 1870 & & & & & 7.379 & \\
\hline 1871 & 10 & 3.864 & 386 & & & \\
\hline 1872 & 12 & 4.925 & 410 & & & \\
\hline 1873 & 11 & 3.496 & 317 & & & \\
\hline 1874 & 11 & 2.357 & 214 & & & \\
\hline 1875 & 11 & 2.503 & 227 & & 2.460 & \\
\hline 1876 & 10 & 4.111 & 411 & 8 & 1.975 & 246 \\
\hline 1877 & 11 & 3.496 & 317 & & & \\
\hline 1878 & 10 & 2.120 & 212 & 8 & 900 & 112,5 \\
\hline 1879 & 11 & 2.184 & 198 & 6 & 460 & 76 \\
\hline 1880 & 10 & 2.144 & 214 & 5 & & \\
\hline 1881 & 6 & 1.230 & 205 & & & \\
\hline 1882 & 4 & 690 & 172 & & & \\
\hline 1883 & 7 & 1.830 & 261 & 4 & 620 & 155 \\
\hline 1884 & 7 & 1.460 & 208 & 2 & 480 & 240 \\
\hline 1885 & 6 & 1.370 & 228 & 2 & 80 & 40 \\
\hline 1886 & & & & & & \\
\hline 1887 & & 890 & & & & \\
\hline 1888 & 5 & 1.115 & 223 & & & \\
\hline 1889 & 4 & 1.701 & 425 & & & \\
\hline
\end{tabular}

La producción y rendimiento en quintales métricos

FUENTE: IGME: Revistas Mineras

Elaboración propia. 
21. PRECIO DE LA VENA EN EL SIGO XVI

\begin{tabular}{|l|l|l|l|l|l|}
\hline AÑOS & FERRERÍA & MINA & $\begin{array}{l}\text { CANTIDAD } \\
(\text { Quintales })\end{array}$ & $\begin{array}{l}\text { PRECIO } \\
(\mathrm{mrs} . / q q .)\end{array}$ & REFERENCIA \\
\hline 1566 & Pontepetre & Formigueiros & 250 & 51 & AHPL: 1487 \\
\hline 1567 & Paleiras & Formigueiros & 300 & 51 & AHPL: 1487 \\
\hline 1574 & Soldón & Formigueiros & 500 & $\begin{array}{l}\text { AHRG: } \\
19768 / 32\end{array}$ \\
\hline 1574 & Soldón & Formigueiros & 500 & 34 & IDEM \\
\hline 1576 & Góndriz & Rocas & 1.500 & 15,5 & AHPL: 1490 \\
\hline 1583 & Góndriz/Rial & Rocas & 300 & 42,5 & IDEM \\
\hline 1585 & Góndriz/Rial & Rocas & 150 & 42,5 & IDEM \\
\hline 1585 & Bueyes & Formigueiros & 300 & ---- & AHPL: 2489 \\
\hline 1586 & Valcarce & Formigueiros & 200 & 76 & AHPL: 2874 \\
\hline 1586 & Valcarce & Formigueiros & 300 & 76 & IDEM \\
\hline 1586 & Valcarce & Formigueiros & 250 & 76 & IDEM \\
\hline 1586 & Valcarce & Formigueiros & 600 & 76 & IDEM \\
\hline 1588 & Valcarce & Formigueiros & 600 & 51 & AHPL: 2850 \\
\hline
\end{tabular}

22. MAZOS EN ASTURIAS Y LUGO A MEDIADOS DEL SIGLO XVIII

\begin{tabular}{|c|c|c|c|c|}
\hline MUNICIPIO & LUGAR & PROPIEDAD & MESES & $\begin{array}{l}\text { RENDIMIENTO } \\
\text { (en reales) }\end{array}$ \\
\hline \multicolumn{5}{|l|}{ ASTURIAS } \\
\hline \multirow[t]{4}{*}{ Allande } & De arriba & Conde de peñalba & & \\
\hline & De abajo & Idem & & \\
\hline & Colobredo & Idem & & \\
\hline & La Puente & Idem & & 1.606 \\
\hline \multirow[t]{8}{*}{ Boal } & $1^{0}$ & D. Bernardino Carbajal & 5 & 500 \\
\hline & $2^{0}$ & Capellanía S. José & 3 & 280 \\
\hline & $3^{0}$ & Hnos Fdez Santa Eulalia & 3 & 340 \\
\hline & $4^{0}$ & Hnos Fdez Mejica & 3 & 340 \\
\hline & $5^{\circ}$ & D. Quintana y otros & 2 & 240 \\
\hline & 6 & F. Prelo Castrillón & 3 & 340 \\
\hline & $7^{0}$ & G. J.Castrillón & 3 & 340 \\
\hline & $8^{\circ}$ & Hnos González y otros & 2 & 240 \\
\hline \multirow[t]{3}{*}{ Cangas de Narcea } & Villarmental & $\mathrm{D}^{\mathrm{a}}$ Teresa de Peón & 6 & 200 \\
\hline & $2^{0}$ & D. Fernando Flórez & 4 & 66 \\
\hline & Besullo & Pedro del Llano & & 330 \\
\hline \multirow[t]{6}{*}{ Castropol } & Serantes & B. Fernández et alii & 4 & 440 \\
\hline & Sta. Eulalia & D. J. Pablo Valledor & 6 & 500 \\
\hline & $3^{0}$ & Marqués de Santa Cruz & 6 & 500 \\
\hline & Castropol & D. Gonzalo Sanjurjo & 4 & 800 \\
\hline & $5^{\circ}$ & & & \\
\hline & $6^{0}$ & & & \\
\hline \multirow[t]{2}{*}{ El Franco } & Boimouro & Capellanía S. Antonio & & \\
\hline & $2^{0}$ & D. Fdez Santa Eulalia & 4 & 200 \\
\hline
\end{tabular}




\begin{tabular}{|c|c|c|c|c|}
\hline & Cobas & Antonio Turr. & 2 & 140 \\
\hline Grandas de Salime & Pontigón & D. Miguel de Ron & 4 & 132 \\
\hline & $2^{0}$ & Pedro Linares y otros & 2 & 110 \\
\hline Illano & Puente de Abaixo & Roque López & 6 & 250 \\
\hline \multirow[t]{2}{*}{ Navia } & Cavernoso & Domingo López y otros & 2 & 60 \\
\hline & Villayón & D. Juan Fernández & & 150 \\
\hline \multirow[t]{4}{*}{ Santalla de Oscos } & $1^{0}$ & Fdez Lombardía y otros & 12 & \\
\hline & $2^{0}$ & D. Ant. Mtz. Lastra & & \\
\hline & $3^{0}$ & & & \\
\hline & $4^{0}$ & & & \\
\hline Tineo & La Fanosa & Casa de Tineo & & 440 \\
\hline \multirow[t]{7}{*}{ Taramundi } & $1^{0}$ & D. García Bermúdez ,alii & & 132 \\
\hline & Aguillón & José Lombardía et alii & & 176 \\
\hline & De Bres & Gabriel Pérez et alii & & 176 \\
\hline & Las Tingas & D. Juan Cancio & & 268 \\
\hline & Vegas de Toria & D. García Bermúdez, alii & & 132 \\
\hline & Teixoes & Pedro Legaspe et alii & & 132 \\
\hline & Vega de Zarza & D. García Bermúdez & 6 & 132 \\
\hline Villanue. de Oscos & Villanueva & Ignacio y Juan López & 4 & 275 \\
\hline \multicolumn{5}{|l|}{ LUGO } \\
\hline Baralla & Penarrubia & Juan Fdez y consorte & 8 & 274 \\
\hline Becerreá & Ouselle & Fdez. Lombardía et alii & 12 & 420 \\
\hline \multirow[t]{4}{*}{ Cervantes } & San Pedro & Hnos. Núñez & 12 & 1.100 \\
\hline & Cancillós & Juan y Agustín Fdez. & 12 & 1.000 \\
\hline & Doiras & S. Lombardía et alii & 12 & 1.000 \\
\hline & Donís & S. Lombardía et alii & 6 & 600 \\
\hline Cervo & Sta. Ma de la Rúa & D. Alonso del Busto & & 132 \\
\hline \multirow{2}{*}{ Folgoso del Caurel } & Valdomir & A. Ferreiro y consortes & 6 & 60 \\
\hline & Mazo & Carlos Sánchez y const. & 8 & 300 \\
\hline \multirow[t]{4}{*}{ Fonsagrada } & $\mathrm{S}^{\mathrm{a}} \cdot \mathrm{M}^{\mathrm{a}}$ Carvallido & Juan A. Méndez & & 375 \\
\hline & S. Juan de Freixo & D. A. Bernardo de Neira & 8 & 350 \\
\hline & S. Pedro de Neiro & F. Ramaño y consorte & 12 & 400 \\
\hline & S. Pedro del Río & D. Antonio Moscoso & 8 & 600 \\
\hline Incio & San Miguel & Diego Besteiro y consote & 6 & 120 \\
\hline Mondoñedo & Viloalle & A. y J. Rubiños et alii & 6 & 300 \\
\hline Ourol & Cabanas & D. Fco Jerónimo de Cora & 9 & 150 \\
\hline \multirow[t]{3}{*}{ Pontenova } & Vilaboa & D. Carlos de Oya & & 360 \\
\hline & Varreiros & Rodrigo Caldalona & & 44 \\
\hline & Conforto & D. Ant. Méndez et alii & & 374 \\
\hline Río Torto & Ferreiravella & Domingo F. Boulloso & & 400 \\
\hline \multirow[t]{4}{*}{ Valadouro } & Pesqueira & D. José Sánchez & & Arruinado \\
\hline & Pesqueira & D. Juan Fdez Rubiños & & Arruinado \\
\hline & Alaxe & ---------- & & 100 \\
\hline & Areal & Patricio de Cé et alii & & 100 \\
\hline Vivero & Miñotos & D. Joaquín Velarde & 9 & 150 \\
\hline
\end{tabular}

FUENTE: PARES: Catastro de Ensenada. Respuesta 17 del interrogatorio general. 


\section{APÉNDICE III}

\section{PLEITOS EN LA REAL AUDIENCIA DE LA CORUÑA RELATIVOS A MONTES Y FERRERÍAS}

1580: Pleito de don Pedro de Montenegro contra los vecinos del concejo de Tourón por carbonear. Les acusa de poner fuego a los montes, hacer carbón y venderlo fuera de la jurisdicción ${ }^{1132}$.

1635: La justicia de Mocelos contra el herrero Pedro de Castro, vecino de la feligresía de Santa María de Xermar, por “decir azía carbón en los montes de Moncelos (...) siendo dichos montes comunes y estando en uso y costumbre (tanto éste como otros herreros) de azer carbón en ellos por ser en utilidad de los vezinos, porque sin él no se podía labrar los arados, hoces y mas pertrechos nescesarios para la labranza"1133.

1640: Los vecinos de la feligresía de Ourol, jurisdicción de Vivero, contra los arrendatarios y carboneros de la ferrería de Santiago de Bravos, porque "dende nuebe a diez meses a esta parte, usando officiales carboneros, dieron en meterse en las fragas a cortar y tallar en ellas y hacer oyas y fosas para carbón haciendo gran cantidad del para el servicio y fábrica de dicha herraria, con que les tienen a mis partes destruidas las dichas fragas" 1134.

1640: Vecinos de Parada de los Montes, feligresía de Santigoso, contra Juan de Sopeña, alcalde del partido del Caurel. Según su abogado se querellan porque "estando mis partes en posesión quieta y pacífica desde muchos años y tiempo inmemorial a esta parte de cortar, cabar bouças y arrancar y pastar con sus ganados en los montes y valles que se dicen de Santigoso, Ayra do Castelo, Valdegaliñas y en los más de esta feligresía de Villamor" en la jurisdicción del Caurel, dicho alcalde les impide ejercer sus derechos pese a que son porcioneros en esos montes ${ }^{1135}$.

1650: El monasterio de San Salvador de Lorenzana contra el capitán Fernán Basanta de Saavedra, porque éste "a secuestrado çierta cantidad de carbón y leña que mi parte tenía comprada a unos carboneros y a otras personas para una herrería y machuco donde labra hierro", con la intención de obligar a la ferrería de Lorenzana a cerrar, después de causarle, dicen los monjes, más de doscientos ducados de pérdida. A su vez el procurador del capitán contesta que "en dicha jurisdición de Valle de Oro está la herraria das Pesqueiras en que mi parte tiene parte y es util y prouechosa para los vezinos de el"; y por el contrario, en los montes de Picano, donde carboneaban los carboneros de Lorenzana, son de los vecinos de Adelán y Valle del Oro; y añade "porque dicha jurisdición”, están los dueños de la ferrería en posesión de llevar carbón de tales montes sin que se pueda vender en jurisdicciones foráneas ${ }^{1136}$.

\footnotetext{
${ }^{1132}$ AHRG. R.A.: 756/30

${ }^{1133}$ AHRG. R.A.: 23900/20

1134 AHRG. RA: 21708/6.

1135 AHRG. R.A.: 28281/3

${ }^{1136}$ AHRG. R. A.: 67/18
} 
1650: Don Lope Saco de Armesto, señor de Pacios, contra vecinos de Padornelos, Sabugo, Porfía y Pallarvello por vender carbón a Samos para su ferrería de Gundriz, alegando que hacía más de 50 años que los montes de Casarinos y Fontaos los habían comprado sus antepasados a un tal Cabana, y que en él hacían leña y carbón sin que nadie se lo impidiese ${ }^{1137 .}$

1661: El herrero Domingo Ferreiro, vecino de la feligresía de Castro, contra la justicia de Meira, que lo arrestó y multó "por haber fabricado carbón para gastar su fragua" en los montes de dicha jurisdicción de Meira, "siendo asi que (...) quando lo hiciera hera porcionero en dichos montes, y desde tiempo inmemorial (...) en dichos montes siempre lo an echo"1138.

1674: Siendo administrador de la ferrería de Gundriz el P. Alonso Fernández Gotera, los carboneros de esta ferrería fueron a hacer carbón al monte de Castelo, a lo que se opuso el señor de Lusío, don Pedro Valcarce, alegando que de ese monte y de los de Serrón y Dos Nogueiros se abastecía la ferrería de Rial, y que por tanto Gundriz nunca había utilizado aquel carbón. La Audiencia de la Coruña dictó sentencia favorable al monasterio ${ }^{1139}$.

1694: $\mathrm{D}^{\mathrm{a}}$ María de Balboa y Quiroga, rendera de la ferrería de Incio, contra los vecinos del Hospital de Incio y Foillebar por arrancar cepa y hacer carbón en montes de la citada fábrica para venderlo a otras ferrerías ${ }^{1140}$.

1695: Los herreros Tomé Bernardez y Alonso y Pedro Álvarez contra la justicia de Lobanes porque "desde tiempo inmemorial a esta parte están en posesión y costumbre de azer y fabricar carbón en los montes baldíos de dicho coto, que son anejos a los lugares de dicha jurisdicción, sin que ningún juez se lo ympidiese hasta qua agora Francisco González, juez de dicho coto, por ser amigo de sus intereses y enemigo capital del otorgante ...les persigue $y$ amenaza para que no agan dicho carbón"1141.

1708: La ferrería de Valdomir contra los vecinos de Farja por vender carbón a la ferrería de La Rodela, del monasterio de Samos ${ }^{1142}$.

1719: La jurisdicción del Caurel, junto con don Carlos Manuel de Oca, dueño de la ferrería de Lousadela, prendieron a varios vecinos de Praducelo, en el valle de Lóuzara, por quemar el monte y hacer carbón. A éstos y a otros de Meiraos, Vilela, Mirás, Paderna y Pedrafita los llevaron a juicio por vender carbón a la ferrería de Gundriz, en el valle de Lóuzara, fuera de la jurisdicción.

\footnotetext{
1137 M. ARIAS CUENLLAS (1992): Historia del monasterio de San Julián de Samos. Samos, p. 290

${ }_{1138}$ AHRG. R.A.: 10.899/41

1139 M. ARIAS CUENLLAS (1992): Ob.cit., p. 290

${ }^{1140}$ AHPLU: 2566/4: Porque "ellos y sus familias arrancaban cepa y della hacían carbon en los terminos y montes desta dicha herraria del Yncio que son los que hestan dentro de los limites y mojones de la dicha encomienda para llebar dicho carbon a otras herrarias de fuera desta en que conocen aver cometido delito".

${ }^{1141}$ AHRG. R.A.: 23499/85

${ }^{1142}$ AHN.Clero: libro 6495
} 
Por esta causa y por atentar con fuego contra esos montes fueron condenados ${ }^{1143}$.

1721: El monasterio de Samos y los vecinos de Campos de Vila, Barxa, San Mamed de Fisteus y otros lugares contra don Bernardo de Neira porque "con la ocasion de hauer fabricado una Herreria nueua -la de Quintá- en dicha jurisdicion de quiroga pretenden ynpedir a mis partes y mas vezinos del uso $y$ aprovechamiento de dichos montes de leña y carbon subponiendo en tener a ello derecho y posesion, privandoles de la que tienen ynmemorial libertad $y$ regalias al uso y aprovechamiento de ellos". A esto alega don Bernardo que no es cierto, pues por foros sucesivos desde 1562 todos esos montes eran suyos y no libres ni de Samos, a quien venden el carbón ${ }^{1144 .}$

1722: Pedimento de don Bernardo Neira, dueño de la ferrería de Quintá, contra Francisco Santín, vecino de Campos de Vila, el cual "pasó a vender cantidad de leña y estraherla a otra herrería fuera de la jurisdicción de la encomienda, lo qual es en perjuizio de la conserbazión de dicha mi herrería por nezesitarla y deber ser preferido en la compra de ella, y lo demás que ubiere en esta dicha encomienda asi por ser vezino de ella como por ser mi herrería forera del sr. Comendador y éste ser señor del directo dominio de dicho lugar de Campos de Vila". Suplica se le embargue la leña y la venda a don Bernardo, cosa que el escribano público del rey, Antonio Velasco, hace tras leer el pedimento. Pero fr. Antonio Rivera, administrador de la ferrería de La Rodela pide, a su vez, que no se le embargue la leña que compró a Francisco Santín, alegando que como monje está exento de la jurisdicción ordinaria "y solo sujeto a su santidad, legados y prelados de su religión"; que él compró legalmente la leña, que no niega el dominio directo de la encomienda sobre el lugar, pero el dominio útil es de Francisco Santín "y más personas que como colonos de dicha encomienda le poseen", y nadie puede privarle de vender la leña a quien quisiere. Hubo pleito y una concordia en la Audiencia en 1723 por la que los vecinos habrían de vender por mitad a ambas ferrerías la leña y carbón que, bajo pena de 500 ducados, se debió de cumplir hasta 1742. Este año don Bernardo Neira vuelve a querellarse por incumplimiento de la concordia. El rey obliga al corregidor de Ponferrada a que se cumpla bajo pena de 500 ducados ${ }^{1145}$.

1724: La ferrería de Valdomir contra vecinos de lugares del Caurel a los que acusa de que el carbón que hacen en sus montes lo "conduzen a las herrerías de Loureiro, jurisdicción de la Puebla" y a otras, y no a la de Valdomir a quien pertenecen ${ }^{1146}$. Los Armesto, dueños de Valdomir, alegan que desde tiempo inmemorial pueden aprovecharse de "la coza y caruon que ay en los montes de dichas feligresias para el auasto de la erraria de Valdomir" por foro de la encomienda de la Barra. Pero los vecinos denuncian que los Armesto no tienen derecho a los montes de Boy de Bustelín, Lago, Cabeza de Meda y otros de la jurisdicción de Caurel, pues ellos están en posesión de "talar, cortar, hacer caruon en ellos", igualmente por fuero de la mencionada encomienda; que los montes son suyos, y que desde siempre han vendido el carbón a quien han

\footnotetext{
1143 AHRG. R. A.: 14.100/84

1144 AHRG. R. A.: 26.319/20

1145 AHRG. R.A.: 26319/20

1146 AHRG. R. A.: 15.167/24
} 
querido, a la de Valdomir, pero también a la vieja de Quiroga, a las de Quintá, Loureiro, Paleiras y otras; pues estos pagan mejor el carbón ${ }^{1147}$.

1727: Los vecinos de La Hermida, San Vitorio, Pacios, Villaberde, etc., que son forales de los montes y bosques de Fondo de Vila, bosque de los Mondelos, Nuestra Señora de la Hermida, y otros del directo dominio de la Encomienda de Quiroga dan su poder a don Blas Lores de Castro, de la Audiencia de La Coruña para que logre una Real Provisión "para que en los montes desta jurisdicción no se arranque ni fabrique caruon alguno"; pues las dos ferrerías, una del directo dominio de la Encomienda y otra del monasterio de Samos, tienen "arruinados los montes" por el "arranque que azen de coza y carbon que en ellos fabrican (sus carboneros y vecinos) de manera que dentro de poco tiempo se acabarán por ser muy cortos y no suficientes todos los montes que ay en esta dicha jurisdicción según el destrozo que en ellos azen para mantener de carbon diez años las dichas dos herrerías"1148. La razón que alegan es que faltándoles las ramas de brezo no podrán cultivar sus haciendas "pues les faltará totalmente el abono para ellas".

1738: La ferrería de Quintá contra vecinos de Barxa y Arxubín por vender carbón a la ferrería de La Rodela1149.

1738. Los vecinos de Viloalle contra los de Masma y Villamor por cortar en los montes (que al parecer son comunes a todos ellos): "concurrieron a destrozarlos, sacar de ellos leñas en mucha abundancia y lo peor ha sido que muchos de los árboles les sacaron las raices de manera que quedaron imposibilitados de produzir y este es el motivo de ocurrir los de Viloalle a pedir coto en los referidos montes"1150.

1740: El dueño de las ferrerías de Lousadela y Valdomir contra el monasterio de Samos porque "es constante que haviendo D. Antonio Bernardo de Oca, marqués de Biance (...) yntentado que los vecinos de Villamor, Leigasos, Vidallón, Froxán y otros no fabricasen carbón sino para sus errarias de Lousadela y Valdomir, y obtenido el efectivo despacho de dicha inquisición se obpuso a ello el real Monasterio de Samos y obtuvo despacho por el que los mismos inquisidores declararon ser libre en dichos vecinos el fabricar carbón y llevarlo a donde quisieren" 1151.

1741: La ferrería de Quintá contra La Rodela a causa del carbón ${ }^{1152}$.

1741: La ferrería de Valdomir intenta impedir "la condución del carbon a la herreria nombrada de Quiroga correspondiente al monasterio de Samos", cuyo administrador se opone alegando "la posesion en que se hallaba de abastecerse del carbón fabricado en la jurisdicion de la encomienda de Quiroga como en la Real de Caurel"1153.

\footnotetext{
1147 AHRG. R.A.: 15.167/24

1148 AHPLU: 2576/2

${ }^{1149}$ AHN. Clero: libro 6495

${ }^{1150}$ AHRG. R.A: 25207/61

${ }^{1151}$ AHRG. R. A.: 7.059/15

${ }^{1152}$ AHN.Clero: libro 6495.

${ }_{1153}$ AHRG. R. A.: 7059/15
} 
1751: Don Sancho de Neira, dueño de la ferrería de Quintá, contra $D^{a}$ Ana Rodríguez Losada por el monte de Quintá1154.

1762-1767: Don Rodrigo Sánchez Orozco, dueño del pazo de Dompinor y de la ferrería de Incio, contra “ $D$. Lucas Somoza dueño de la Herrería de Biduedo sobre el uso de los montes y aprobechamientos de sus producciones para sus respectivos artefactos" 1155 .

1774: Los vecinos de Gestoso, de la jurisdicción de Quiroga, carbonean en la jurisdicción de Caurel, en montes de la ferrería de Valdomir, y lo venden fuera de ésta, al monasterio de Samos. Una Real provisión de 3 de noviembre de ese año lo prohibe ${ }^{1156}$.

1786: auto ante las justicias de la encomienda de Quiroga por don Juan Casas como administrador de la ferrería de Quintá, propia de don Sancho de Neyra, contra Francisco Macía y otros vecinos de Paradapiñol "por haver impedido la fábrica de carbon para dicha herraria en el monte llamado de Sobradelo". Los vecinos alegan un foro de la encomienda de 1746 sobre varias piezas del monte cercano a la ferrería de Paleiras y Quintá, y otros en los alrededores de la ferrería de Rugando ${ }^{1157 .}$

1787: La ferrería de Valdomir contra los vecinos de Froixán, Castro de Portela, Vilar, Villadón, etc., de la jurisdicción del Caurel, por vender carbón a otras ferrerías de Quiroga y Puebla de Brollón. Los problemas venían de antiguo, como hemos visto en 1741 y 1774. Ahora resurgen de nuevo. Los vecinos alegan que están "en posesión de fabricar carbón en los montes de su pueblo (...) y conducirlo a las errarias que se hallan en sus inmediaciones según su voluntad y a proporción de la utilidad que les rinden los dueños de tales errarias sin que en ello se les pusiere en tiempo alguno limitación por ser libre el uso de dicho carbón". Añaden además que de no hacerlo así "se verán lo más constreñidos en la maior servidumbre y suxetos a abandonar el tráfico y comercio del carbón o dexarlo por el precio que voluntariamente quiera el querellado, mayordomo y factores de la herraria de Valdomir". Pero la justicia falla a favor de Valdomir, pues "la encomienda de la Barra es dueño jurisdicional de la jurisdicion del Courel y también territorial de los montes en ella consistentes; que el aprovechamiento de estos ha sido siempre de la Herraria de Baldomir, y como tales se las aforó en el año de mil seiscientos diez la expresada encomienda al poseedor que era de aquella Pedro Díaz de Zuluaga", y que tanto él como sus sucesores han sido dueños del directo dominio ${ }^{1158}$.

1787: El abad Fulgencio Aguirre de San Pedro de Montes lleva ante la Chancillería de Valladolid a sus vasallos de San Alejandro y Santalavilla, pues "se han propasado a prender a los operarios de el carbón, llevándoles los instrumentos con que lo arrancaban y fabricaban", pese a que el concejo y

1154 AHPLU: 2463/7.

1155AHRG. R. A.: 23.088/72

1156 AHRG. R.A.: 7059/15

1157 AHRG. Hombreiro: leg. 19

${ }^{1158}$ AHRG. R. A.: 9090/4 
vecinos conocían, por público y notorio, la cédula de Felipe $\mathrm{V}$ por la que se concedía permiso para construir la ferrería de Linares y el aprovechamiento de los montes próximos a ella ${ }^{1159}$.

1788/1790: la ferrería de Valdomir contra los vecinos de Farja por vender carbón a La Rodela, del monasterio de Samos ${ }^{1160}$.

1791: Los vecinos de Parada, en la feligresía de Santa Eulalia de Bendollo, en la encomienda de Quiroga, contra vecinos de Bendollo, Castillo, Nobais y Sequeiros porque "se entrometen a rozar el monte y arrancar la coza y llebarla para sus lugares con otros diversos daños que hacen con sus ganados maiores y menores" 1161.

1792: La ferrería de Lousadela contra varios vecinos de la jurisdicción de Lózara (Samos) por talar y descepar para hacer carbón ${ }^{1162}$.

1792: Samos contra la marquesa de Viance. Según Samos los administradores de la ferrería de Santalla "siempre han usado por medio de operarios del carbón necesario que produce el monte de Lago, sito en terminos de San Silbestre de Seceda", hasta que vecinos de la jurisdicción del Caurel, con el apoyo de la marquesa de Viance, se lo quieren impedir ${ }^{1163}$. Por el contrario Juan Francisco Rivadeneira, administrador de los bienes de su tía la marquesa de Viance, sostiene que la ferrería de Lousadela "siempre ha estado por medio de sus domésticos (...) en el limitado uso absoluto y aprobechamiento de la coza y carboneo que producen los montes de la jurisdicción de Caurel, impidiendo su extracción”, por medio de guardas y celadores. Ambas partes delimitan los montes que dicen pertenecerles, señalando los mojones o hitos de cada uno de ellos ${ }^{1164}$.

1796:La ferrería de Quintá contra el monasterio de Samos porque en agosto de 1795, mientras una cuadrilla de cinco personas fabricaba carbón "llegaron seis hombres dando a los expresados fabricantes de carbón varios palos, sacándoles las azadas, costales, cuerdas, rodos, cestos y todos los ynstrumentos que tenían (...) quitando a los carboneros las cinco azadas que tenían para fabricar el carbón, cuerdas y sacos de su conduccion, y desafiándoles les avían de matar y a las mujeres las avían de dejar en cueros, lo que ubieran echo, o a lo menos maltratándolos gravemente a no haverse uhido los carboneros a carrera tendida"1165.

1810: Los propietarios de la ferrería de Penacoba contra los vecinos del coto de Acebedo y otras jurisdicciones, a causa de la ferrería de Biduedo. Éstos decían que desde tiempo inmemorial se hallaban en la posesión "de hacer carbón, benderlo a todo xenero de personas y lo mismo la zepa de leña (...) y venderlo a la Herrería de Viduedo, villa de Monforte y a barios herreros del

\footnotetext{
1159 RODRÍGUEZ CUBERO: Diario de León, 13-XII-1998

1160 AHN. Clero: libro 6495

${ }^{1161}$ AHRG. R.A.: 3169/9

1162 AHPLU: 2528/4

1163 AHRG. R. A.: 103/4

1164 AHRG. R.A.: 103/4

1165 AHRG. R.A.: 9.219/55
} 
Balle de Lemos"; pues los montes son del colegio de Montederramo, al que ellos pagan foro' ${ }^{1166}$.

1811: Don Antonio $M^{a}$ Vázquez, dueño de la ferrería de Lusío, sostiene que la suya es una de las ferrerías más antiguas de Galicia, y que desde tiempo inmemorial él y sus antepasados tuvieron la exclusiva "de carbonear en todos los montes del contorno, aguas vertientes a la fábrica y en algunas más de las laderas y encañadas opuestas". Por lo que siempre que otros han pretendido carbonear o cortar leña fueron denunciados, teniéndose que allanar y reconocer sus derechos. Hace así un recorrido de esos pleitos en el siglo XVIII (1759, 1762, 1767, 1793) para terminar denunciando nuevamente en 1811 a Cristóbal Vilela, quien en 1808 había construido un mazo, que denunció pero luego permitió, y ahora se puso a "arrancar por si y por medio de otros la coza, cepa y leña de los dichos montes y hacer carbon en ellos, que efectivamente extraxo y ha consumido en el mazo, con grave perjuicio del otorgante y su herraria de Lusío, que nada más tiene de donde surtirse y no alcanza la coza, cepa y leña para el gasto ordinario de cada día, por cuia falta está detenida muchas veces"1167.

1818: Poder de José Noriega, monje de Samos, administrador de la ferrería de San Vicente de Leira para pleitear contra los vecinos de ese pueblo a los que, muchos años antes a sus antecesores, había aforado el convento todos sus términos por "la nimia cantidad de mily cuatrocientos reales anuales, siendo así que balía más de quatro mil", a condición de que "habían de abastecer el artefacto de los suficientes materiales a los precios corrientes, conserbar una porción de monte sin roturar para mayor permanencia de aquel, no pribar de aguas quando fuesen necesarias a la fábrica, etc.", cosa que no hacen, incumpliendo las condiciones del foro ${ }^{1168}$.

1824: Querella de los vecinos de San Lorenzo de Villarmiel por perturbar el arranque de cepa de urz para hacer carbón ${ }^{1169}$.

1829: José Quiroga contra varios vecinos de Outeiro, pues como dueño de la ferrería de Soldón "está en la quieta y pacífica posesión de usar y aprovecharse del carbón que necesita y producen todos los montes del coto de la Seara, según lo contienen y abrazan las demarcaciones del foro que en el año mil setecientos cuarenta y siete hizo de dichos montes y otros vienes el administrador de la Encomienda de Quiroga a favor de don Pedro Carlos de Quiroga y Lemos, dueño de la casa de Erbes"1170. Así fue hasta que en 1826 se querelló contra varios vecinos de Outeiro por vender carbón a la "Herrería que

\footnotetext{
1166 AHRG. R. A.: 19.877/30

1167 AHPLU: 2468/2

1168 AHPL. P.N. 3576

${ }^{1169}$ AHN.Clero: libro 6495

${ }_{1170}$ AHRG. R. A.: 7415/13. En 1747 el administrador de la encomienda de Quiroga aforó los montes del coto de la Seara a don Pedro Carlos de Quiroga, dueño de la casa de Erbes, para su ferrería de Soldón. En él se decía "que nadie por lo mismo pueda ni deba aprovecharse a hacer carbon en dichos montes no siendo para la herreria de Soldón pagando el administrador de la misma los precios corrientes". El foro demarcaba los montes de la ferrería que "principian desde la parroquia de Fisteus de sobre el golado da silba hasta donde concluyen en el pazo que se dice de Lontra que está en el sitio titulado de Soldón".
} 
en el lugar de Outeiro tiene Josef Pérez"1171. Parece que se allanaron pero poco después volvían a extraer carbón para venderlo a la ferrería susodicha, por lo que nuevamente se querelló contra ellos, logrando una Real provisión de la Audiencia de la Coruña a su favor ${ }^{1172}$.

1830: La ferrería de Quintá contra los vecinos de Villañan y Framil, de la parroquia de San Salvador de Hospital, porque siendo de don José María de Prado y Neira, dicho señor está en la posesión de "arrancar la coza de todos los montes de este Balle de Quiroga (en virtud de varios fueros) y azer carbon, dejando a los vecinos el uso libre de rozar la leña"; pero éstos hacen carbón y lo venden fuera ${ }^{1173}$.

1837: Juan Antonio Montero y su padre Santiago Montero contra Manuel Álvarez y otros vecinos de Ferreirós por robarle, a instancia de don Antonio Somoza y Pardo, dueño de Seoane, carbón y vena que aquel había reunido. Se condenó a don Antonio ${ }^{1174}$.

1837: Numerosos vecinos del lugar de Figueiredo, parroquia de San Martín de Peites, partido de Quiroga, denuncian "que teniendo igual derecho todos los vecinos de dicho pueblo al aprovechamiento de sus montes, supuesto todos pagan igual renta por ellos al señor don Juan Bernardo Quiroga, dueño de la casa de Lamela, se pretende por unos cuantos de los más ricos pribar a los pobres del uso de la coza o raíz del brezo para hacer carbón y venderlo (único fruto que pueden utilizar del monte) mientras que los ricos disponen a su antojo y respectivamente gastan cuadruplicado así de la raíz como de la rama, ya para el cultibo de sus vienes, ya para quemar, ya para vender a los pueblos confinantes y pagar con su producto las cargas y contribuciones del pueblo, resultando por consiguiente para ellos aunque pocos casi todo o el principal beneficio como principales contribuyentes. $Y$ no siendo esto justo tratan los a qui expresados de oponerse hasta conseguir o el libre uso y aprovechamiento del monte, o su división por iguales partes entre todos los vecinos" 1175.

1838: Don Manuel Losada, dueño de la casa de Lama (Moreda), y otros vecinos de Vilar contra vecinos de Villamor por carboneo en los montes "altos y vajos llamado da Armada y da Costa comprendidos en los propios términos de Villamor"1176.

1838: Don José $M^{a}$ Valcarce, dueño de la ferrería de Loureiro, contra $D^{a}$ Josefa Monseo por perturbar en el uso y aprovechamiento del carbón de Sierra de Paramedela, en términos de Puebla de Brollón "con el que por medio de operarios se ha surtido privatibamente y debe surtir en su citada herrería vieja de Loureiro en fuerza de los diversos foros y más documentos justificativos" que acredita su derecho'1177.

\footnotetext{
1171 IBIDEM

1172 IBIDEM

1173 AHRG. Ombreiro: leg. 21

1174 AHPLU: 6709/5

1175 AHPLU: 2406/24

1176 AHPLU: $2377 / 4$

1177 AHPLU: 2377/4
} 
1844: Don Antonio María Vázquez, dueño de la ferrería de Lusío o Rial, contra Domingo Montero, del pueblo de San Gil, en el juzgado de Sarria sobre uso del monte propio de la ferrería, del que salió condenado; pero el tal Domingo persistió cortando y quemando en el monte de Meda y San Gil do Carballo -montes privativos de la ferrería desde tiempo inmemorial-, por lo que le puso una nueva querella criminal ${ }^{1178}$. 


\title{
APÉNDICE IV
}

\section{SELECCIÓN DE DOCUMENTOS SOBRE SIDERURGIA DEL NOROESTE}

\section{SIGLO XV}

$-1-$

\begin{abstract}
1486, octubre. Palacios de la Valduerna
Carta de los Reyes católicos a las justicias de Ponferrada, el Bierzo, Villafraca y valle de Valcarce para que la marquesa de Villafranca no cobre a Martín Gonzalez, rentero de las ferrerías de Valcarce, las rentas ya pagadas al conde de Lemos.

Archivo General de Simancas. Registro General del Sello, X-1486-125
\end{abstract}

Don Fernando e doña Isabel etc. al que es o fuere nuestro alcalde mayor de la villa de Ponferrada e de la prouinçia del Vierzo e a los allcaldes e otras justiçias qualesquier de la villa de Villafranca e al merino del valle de Valcarçel e a cada uno e a qualquier de vos, salud e gracia. Sepades que Martin Gonçales rentador de las ferrerias del dicho valle de Valcarçer nos fiso relaçion por su petiçion que ante nos en el dicho consejo presento disiendo que podra aver dies años que ovo arrendadas e arrendo del conde viejo de Lemos e de la condesa las dichas ferrerias por dies e seys mill mrs. en cada un año con los quales dis que acudio al dicho conde en su vida et despues al conde don Rodrigo Enriques Osorio su nieto de manera que en su poder non quedan mas de ocho mill mrs. et dis que vos el dicho merino le demandays las rentas de las ferrerias de tres años pasados en nombre de la marquesa de Villafranca disiendo que las dichas rentas e ferrerias pertenesçen a la dicha marquesa en lo qual dis quel resçibiera grande agrauio e daño sy auiendo pagado a los dichos condes ouiese de pagar otra ves et nos suplico cerca dello con pronunciamiento de justicia lo mandasemos proueer o como la nuestra merced fuese et nos touimoslo por bien porque vos mandamos que pues el dicho don Rodrigo Osorio conde de Lemos tenia e poseya por entonces la tierra de Valcarçe donde son las dichas ferrerias et el dicho Martin Gonzales non era poderoso para lo restituyr que lleuase los frutos e rentas dellas que de tyenpo quel dicho conde tomo las dichas rentas non las pidades ni demandedes al dicho Martin Gonzales e le resçibays en cuenta todos los mrs. que mostro aver pagado al dicho conde de Lemos e non gelos demandedes ni fagays pagar otra ves. Et vos las dichas justiçias non dedes lugar a ello antes apremies a los mayordomos e fatores de la dicha marquesa que les resçiban en cuenta todo lo que ansy touiere dado e pagado de la dicha renta al dicho don Rodrigo conde de Lemos et a los dichos sus mayordomos e fatores et los unos nin los otros non fagades ni fagan ende al por ninguna manera sopena de la pena de dies mil mrs. para la nuestra camara et demas mandamos al ome que vos esta nuestra carta mostrare que vos enplase que parescades ante nos en 
la nuestra corte doquier que nos seamos del dia que vos emplasare fasta quinse dias primeros syguientes so la dicha pena so la qual mandamos a qualquier escriuano publico que para esto fuera llamado que de ende al que vos la mostrare testimonio sygnado con su sygno porque sepamos como se cunple nuestro mandado.

Dado en Palaçios de Valduerna a veynte e tres dias del mes de otubre anno del nasçimiento de nuestro señor Ihesu Christo de mill e quatroçientos e ochenta e seys años. Yo el rey, yo la Reina, yo Fernand Aluares de Toledo secretario del rey e de la reyna nuestros señores lo fis escreuir por su mandado, Rodericus dotor.

\section{SIGLO XVI}

$$
-2-
$$

\section{3, abril, 6. Valladolid}

Don Antonio de Velasco, comendador de la Encomienda de la Barra de la Orden de Santiago, afora a Alonso López de Lemos la sierra de Formigueiros en el Caurel AHPOU, Casa do Castro, caja 112, $n^{0}$ 16, $3^{\circ}$.

En la noble villa de Valladolid estando onde la Corte Chancillería de la reina nuestra señora a 6 dias de abril de 1513 años en presencia de mi escribano e notario público e testigos de yuso escritos, estando presente el muy magnífico señor don Antonio de Velasco, señor de Cerbera, comendador de la Encomienda de la Barra, paresció presente Alonso López de Lemos e dijo dicho señor don Antonio que por cuanto Teresa López de Ulloa, su visabuela, e otras sus antecesores habían tenido en fuero de la dicha su encomienda la granja de Fervenza (tachado: que pedía por merced que le aforase la sierra de los Formigueiros que es en la jurisdición de Courel, feligresía de la dicha Encomienda que coge) Pedro de Ferbenza que es en tierra de Lemos por 300 mrs. que le pidio por merced que se la aforase al dicho Alonso López que el daría $2.000 \mathrm{mrs}$. de fuero por ella en cada un año e que asi mismo le pedía por merced que le aforase la sierra de los Formigueiros, que es en su jursidicción de Courel, feligresía de la dicha Encomienda e que él daría por ella en cuanto no fisiese ferrería $1000 \mathrm{mrs}$. en cada un año de renta a la dicha Encomienda e faciendo ferrería en cuanto la dicha ferrería labrase, le daría $3000 \mathrm{mrs}$ en cada un año de renta por la dicha ferrería e sierra con beneros de monte, robles e que la fundición de la dicha ferrería quedase de la dicha Encomienda; e luego el dicho señor don Antonio dijo que él quería haber información de lo era susodicho e que si fuese en utilidad e provecho de la dicha Encomienda o en acrecentamiento de las rentas de ella, que le haría el dicho foro, testigos que fueron presentes el señor Gutiérrez Quesada, señor de Villagarcía, e Pedro de Bargas e Gonzalo Rodríguez, criado de Alonso López de lemos, e despues desto en la dicha villa de Valladolid a 7 dias del mes de abril del dicho año, ante mi el dicho notario e testigos de yuso escriptos el dicho magnífico señor don Antonio de Velasco dijo que él había recibido información de cómo los sobredichos bienes que el dicho Alonso López de Lemos le pedía en fuero eran bienes que por muchos años avían andado fuera de la mesa de la dicha Encomienda y eran bienes acostumbrados a aforamiento, que este fuero que el dicho Alonso López le pedía e con las condiciones e calidades que lo pedía era útil e provechoso a él 
e a la dicha su Encomienda e que sobre esto él había tomado todas las informaciones necesarias e sabía en realidad de verdad que le era provechoso, por ende que del le placía e plugo de otorgar el dicho fuero, segund e de la manera que el dicho Alonso López ya lo había pedido e a mayor abundamiento dijo que otorgaba e otorgó el contrato e instrumento que sigue:

Sepan cuantos este público instrumento de foro vieren cómo yo don Antonio de Belasco, señor de Cervera, comendador de la Encomienda de la Barra, otorgo e conosco por esta carta que aforo a vos Alonso López de Lemos, que presente estades, e a otras tres personas después de vos una cual voz nombrádares en vuestra vida o al tiempo de vuestro fallecimiento y la segunda cual nombrase la primera y la tercera cual nombrase la segunda, todas tres sucesivamente en pos de otra e non siendo nombradas, que por persona y voz de este dicho foro aquel que de derecho heredare la mayor parte de vuestros bienes e de los dichos vuestros sucesores. Conviene a saber, que vos aforo como dicho es la granja de Fervenza, que es en tierra de Lemos, con todos sus casares y heredades, terminos dellos e montes e afontes, segund que los coge por mi Pedro de Fervenza, con todas sus rentas de pan e vino y carne e dineros e con todo lo que a la dicha granja anexo e perteneciente, a tal pleito y condición, que tengades los succesores de dicha granja poblados e bien reparados y las heredades labradas como no se pierdan por mengua de reparo e daredes de pensión e foro cada un año vos e las dichas tres voces después de vos a mi e a los otros comendadores que fueren de la dicha Encomienda 2000 mrs. pares de blancas, pagados en cada un año por el día de San Martín de noviembre (...).

Y asimismo vos aforo para vos y las dichas tres personas después de vos, segund dicho es en la dicha tierra de Courel con sus benas y beneros y montes, robles para que podades hacer ferrería o ferrerías desde Bieyros fasta Lago y fasta Orios y fasta Sarria y daredes vos y las dichas tres personas después de vos en cada un año a mi e a los otros comendadores que después de mi vinieren en la dicha Encomienda mil mrs., pagados por el dicho día de San Martín al que cogiera las otras rentas de la dicha tierra de Courel e si ficiéredes ferrerías en el dicho tiempo, daredes más 2000 mrs. en cada un año vos y las dichas tres voces que son asi $3000 \mathrm{mrs}$. por las dicha sierra e ferrerías, pagados al dicho mayordomo de Courel por el dicho día de San Martín e que al fallecimiento de la dicha postrimera persona de las dichas tres después de vos, quede libre e quita e desembargada la dicha sierra e ferrerías, segund que entonces estuviere a la dicha Encomienda de vos facer este dicho foro de las dichas Granja e Sierra e de paz e de vos la non quitar por mas ni por menos e doyvos poder cumplido para que por vos o por vuestro procurador podades tomar e aprender la posesion real, actual de la dicha casa-granja e sierra e usar dello como de cosa vuestra propia libre e quita y desembargada e os mando a Macía de Monseiro, mi mayordomo de courel, que vos la dé a vos y al dicho vuestro procurador e vos ponga en la dicha posesión dello e vos defienda en este dicho vuestro aforamiento. E yo el dicho Alonso López, que presente estoy, ansi lo recibo con las condiciones arriba contenidas e obligo a mi e a mis bienes e de los dichos mis herederos e susuesores de cumplir e guardar e pagar todo lo en esta carta contenido (...).

En firmeza de lo cual, otorgamos nos ambas las dichas partes este dicho contrato y instrumento de aforamiento en la manera e forma susodicha e la firmamos de nuestros nombres en el registro ante el presente escribano e notario público e testigos de yuso escritos, que fue hecha e otorgada en la noble 
villa de Valladolid, estando ende la Corte e Chancillería de la reina nuestra señora a 7 dias del mes de abril, año del nasciemiento de Nuestro Señor Jesucristo de 1513 años, testigos que fueron presentes al otorgamiento de lo susodicho e vieron firmar sus nombres en el registro donde donde otro tanto queda en mi poder Jofre de Contans, aposentador del rey nuestro señor, e Francisco de Ysla, criado del señor obispo de Osma e felipe Jofre, camarero del dicho señor obispo de Osma, e Ruy Sanchez, criado del dicho Alonso López= Don Antonio Velasco $=$ Alonso López de Lemos $=\mathrm{E}$ yo Juan de Temino, escribano de la nuestra señora e su notario público en la su Corte e en todos los sus reinos e señoríos (...).

1519, junio, 3

$$
-3-
$$

Foro de la ferrería del Saltojo, del monasterio de Lorenzana, a Fernando Rodríguez de Aguiar Archivo Histórico Nacional, Códice 181/B, f. 47

Vos aforamos la ferrería del casal de saltojo cerca de esta dicha villa (...) con el palacio et casas del rendero de la dicha ferraria et entradas et salidas de la ferraria et palacio et casas cuantas han e aver deben alto y baixo cielo y tierra y agua et presas et rio et montes et fontes plantados et por plantar mansos et bravos et con más el edificio, artificio, carpentaria (...) et con todas las suas cosas et censo et censos e deevicion et deeviciones, rendaria, ferraria, mando et señorio çebil et criminal et con todo lo mas a la dicha ferraria debido (...) aveys de apostar et adobar los dichos palacios et casas que están derrocados et mal adereçados e ansy mesmo aveys de apostar los vanzados, presas e represas et arboles et rodas et maço et toda la dicta ferraria et buscar toda la madeira, piedra wt fierro et ferraje et clavaje que oviere menester et fuere necesario de se buscar (...).

$$
-4-
$$

\section{6, septiembre, 4. Ferrería de Quintá}

Escritura de posesión de la ferrería de Quintá, Quiroga.

Archivo del Reino de Galicia. Fondos privados, Familias (Ozores, marqués de San Martín de Ombreiro), leg., 19.

En la ferrería nueva de Quintá do Reconco da Mieira, que es jurisdiçión de la Encomienda de Quiroga de la Orden del Señor San Juan de Jerusalén, [al margen: 4 de setiembre 1566] a quatro días del mes de septiembre del año del Señor de mil y quinientos y sessenta y seis años. En pressençia e por ante mi, escrivano e testigos de yusso escriptos, paresció pressente Francisco Bázques de Quiroga, tenedor de la dicha errería da beyga de Quintá, e dijo que él avía echo y edeficado la dicha errería en su territorio y propiedad para que con efecto del serviçio de Dios y de Su Magestad y fundir el (sic) labrar en ella fierro, en la qual avía gastado muchos dineros y azienda asta ponerla, como la pusso, en los términos para lo sobredicho y para que él y los renderos, braseros y ofiçiales y biscaynos que en ella y en los términos della estuvieren y vinieren, puedan gozar y se aprovechar de la possesión, previlejos, libertades y franquessas que los reyes e prínçipes de Castilla les an dado y conçedido a las tales errerías e 
renderos, hazedores e ofiçiales y biscaynos, estando en tal propósito y estado para ussar dello mediante la graçia divina de Su Magestad. Luego que oy dicho día, y luego en consiguiente, para ussar y gozar él e los tales de los previlejos, livertades, franquesas y fueros de Viscaya y España, e ussos y costumbres de errerías, quería luego hazer, e hizo, el auto e diligençias que en tal casso se requiere, no perjudicando en lo demás que por los tales previlexos y costumbres de errerías el (sic) es dado, y se pueda [tachado: gozar] husar el señorío prinçipal e jurisdiçión de Su Magestad y de los señores de las jurisdiçiones en cuyos términos es o fuere, e de quien e de derecho lo deva haver, no alterando, ni ynnovando, ni añadiendo en lo demás en [tachado: que] cossa alguna más de aquello, como dicho tiene. Conforme a lo sobredicho dixo e pidió a mí, el dicho escrivano, estuviesse pressente y le diesse fe y testimonio de lo que viesse y oyesse zerca. $\mathrm{Y}$ en razón de lo sussodicho, y estando dentro de la dicha cassa y errería da Veyga de Quintá el dicho Francisco Bázques de Quiroga e Ysabel Bázques de Canida, su mujer, fundadores, hacedores, propietarios de la dicha errería, y mucha parte de los vezinos y moradores çercanos y conmarcanos (sic) de la dicha tierra de Quiroga e ferrería, e públicamente, y estando al pressente Miguel de Aurtíz, biscayno y maestro que fue de la dicha errería, e Miguel de Aldunzín, rendero de la ferrería de Boeys, e Juanes de Aldunzín, rendero de la errería de la puente de Quiroga, y Miguel de Aranburçe, e Juan M[...]orro e Sanjuan, e Lopo de Espella, maestros de ferraxe, e Miguel Morán, macheador, e Juanico Bizcayno e Andrés de Bedía, que son arossa (sic) tirador e fundidor y tassador, y braseros y oficiales de la dicha errería, luego trajeron y metieron dentro de la dicha errería, por ante mi, escrivano e testigos e personas arriva e avajo contenidas, un toro marón presso con dos sogas, una atrás y otra adelante, y lo sacaron los dichos braseros y ofiçiales y biscaynos y perssonas por la puerta prinçipal de la dicha errería y lo llevaron al llano y beyga que se dize el de Quintá, al camino que está sobre del pozo que se dize das Boussas, donde llega el término y demarcaçión de la otra errería, y lo passaron por el río y cabeza del dicho poço, y llo (sic) llevaron por entre el término y demarcaçión de la dicha otra ferrería de avajo, asta llegar al camino y al marco que alli estava dol[...]y pussieron junto a él otra piedra e marco, y dende alli lo llevaron derecho por el camino que va para la lossera que es eredad del dicho Francisco Bázques, y jurisdiçión que al presente posse[e] el señor Diego de Quiroga por el su coto de San Christobo. Y pussieron dos marcos, uno en medio del camino y otro en el tesso y camino de la losera, y dende alli al derecho avajo asta sobre del poço sobre del reguero del Reconco da Mieira, que es sobre del poço de la dicha herrería, donde está un penedo grande, y dende alli passaron otra vez de la otra parte del río y lo llevaron por el camino devajo la sierra y pussieron alli un marco, y dende alli çercaron la dicha Veiga de Quintá, todo por riba del camino y por el monte y eredad del dicho Francisco Bázques, y pussieron un marco en el dicho monte, y dende alli lo llevaron derecho al dicho camino y marcos del término de la dicha ferrería, de manera que bolvieron a donde primero le avían llevado, de manera que hizieron el dicho cercuyto enteramente, en el qual el dicho Francisco Bázques pusso, e mandó poner, marcos e mojones según arriva se contiene. Y de ello, pediéndome el dicho Francisco Bázques a mi, el dicho escrivano, por fee e testimonio, y a los pressentes le fuessen testigos. Y echo lo sussodicho se bolvieron él y los ofiçiales y personas a la dicha errería con el dicho toro y le ataron las piernas y lo derrivaron sobre la yunque, teniéndole por los cuernos y sogas. Y el dicho Francisco Bázques e Ysabel Bázques, su mujer, tiraron por el palo de la tapadera del chifrón y dieron agua a la rueda del mazo, 
el qual dio de golpes en el pescuesso del dicho toro, de los quales golpes se cortó de presto carne, cuero y güessos, asta que se lo acabó de cortar. Y, partido, tomaron la dicha caveça los dichos ofiçiales y brasseros, corriendo sangre por ante mi, el dicho escrivano e testigos, salieron por la puerta sussodicha de la dicha ferrería y cercaron por donde antes anduvieron con el dicho toro siendo bivo, bañando y mojando [tachado: con la sangre que dicha] los dichos marcos y mojones con la sangre que de la dicha caveza salía. Y çercaron todo los sussodicho enteramente, como dicho se es. El qual dicho Francisco Bázques me lo pidió por testimonio. Y continuando la dicha possesión e auto, teniendo fundido una augoa de fierro con bena de la venera tasada, y la hizo fundir a los dichos oficiales y la sacaron de la fragua donde se fundió ardiendo. Y la pussieron devajo del dicho mazo y la hizieron e srrepillaron (sic) devajo dél, y la tajaron con la taxadera y la sacaron de vajo del mazo.Y de la dicha augoa hizieron dos bandas de fierro, de manera que fundió y sacó fierr[o]. Lo qual todo el dicho Francisco Bázques me pidió por testimonio, y que lo azía por goçar y ussar, como protestó ussar y goçar, de los previlejios, livertades e franquessas y ussos y costumbres de ferrerías, que meresçen y se acostumbran y son conçedidas a las tales ferrerías. Y ussando la dicha possesión y derecho, y continuando el dicho Francisco Bázques la dicha possesión, mandó dar muchas vezes agua al mazo, abriéndolo y çerrándolo por el chifrón, mandando y proçeyendoen cossas neçessarias, como tal posseedor propietario de la dicha ferrería. Estando pressentes por testigos a todo lo sussodicho los arriva con (sic) contenidos e María Bázques e Álvaro da Zeara, vecino del coto de San Christobo, jurisdiçión del Señor Diego de Quiroga, e Gregorio do Cabo e Antonio do Castro e Gregorio Sánchez, ferramenteros, e Gonçalo do Soto, vecinos de la feligresía del Ospital de Quiroga, desta jurisdiçión, e Pedro de Rossende e Lopo Fernández dos Portos e Blas dos Baños de Molgas, estantes e ressidentes en tierra de Quiroga. Y el dicho Francisco Bázques lo firmó de su nombre, Francisco Bázques. Passó ante mi, e doy fee conosco a las partes, Antonio Rodríguez, escrivano. E yo, el dicho Antonio Rodríguez de Caneda, escrivano e notario público en las encom[i]endas de Quiroga y en el coto y audiençia de San Cristobo, a lo que dicho es pressente fui, juntamente con los dichos testigos y partes, que doy fee conosco, y lo escriví en el registro, donde lo saqué de pidimiento de la parte del dicho Francisco Bázques, e fiçe mi signo en nombre a tal. En testimonio de verdad, Antonio Rodríguez, escrivano. [Al margen: Traslado sinple de la possesión de la herrería de Quintá, dada / a Francisco Vázquez de Quiroga. Número 18.]

\section{$-5-$}

1571, julio, 1

Foro de la ferrería de Pesqueira que hacen Pedro Pardo de Aguiar, señor del coto de Saramugo, y Pedro Maseda de Aguiar al vizcaíno Francisco Sánchez de Vidarte y a su mujer.

AHRG. R. A.: 21859/104

En el nombre de Dios, amen. Sepan quantos esta carta de fuero, censo y trebuto para siempre xamas bieren como nos Pedro Pardo de Aguiar, Señor del coto de Saramugo e Pedro Maseda de Aguiar, vecino de la feligresia de Santa Cruz del balle de oro, que hestamos presentes, de nuestras libres y espontaneas boluntades, otorgamos e conocemos por esta presente carta por nos mesmos y 
en nombre y em boz de todos nuestyros herederos y subcesores presentes e de por benir que damos en fuero, censo y trebuto para siempre jamas a bos Francisco Sanchez de Vidarte, bizcayno, rendero de la ferraria de Billanueba de Lorençana, que hestais presente, e a buestra muger Maria Sanchez, ausente, para bos ambos e para todos buestros herederos y subcesores presentes e futuros, e para quien de bos y dellos titulo y causa tubiere, en qualquier manera, combiene a sauer que ansio bos aformaos e damos en este censo aquella nuestra herraria e machuco que se dize da Pisqueira, que esta sita en la dicha feligresia de Santa Cruz, con todas sus casas, torre y molino, huertas, sotos y arboles que hestan entre las aguas de la dicha ferraria, y con todos aparejos e yngenios e artifiçios, y herramientas de la dicha ferraria, segun y de la manera que al presente los tienen e ansimesmo bos la aforamos con todo el derecho y señorio e libertades que tubiere y tenga la dicha erraria, ansi para cortar en los montes, como en otra qualquiera manera, que a la dicha erraria pertezca, e ansimesmo bos la aforamos e damos en este dicho censo con qualquier derecho que tengamos a qualquier tarreo -sic- o heredad que pertenezca a la dicha erraria, y con todas sus entradas y salidas y serbentias, suelo y tierra, alto y baxo, quantas ba y auer debe y le pertenescen y pertenescer deuen de fecho y de derecho, y entiendase que no ba ni entra en este fuero los barquines que hestan en la dicha ferreria porque no bos los aforamos y esto por razon de que bos el dicho Francisco Sanchez de Bidarte e buestra muger y herederos y subcesores y ada uno de bos en su tiempo, nos deis y pagues, en cada un año, para siempre jamas, de renta y trebuto, a nos e a nuestros herederos y subçesores seis mill marabedis, pares de blancas, que seis cornados haçen un marabedi de la moneda corriente en el reino de Castilla, pagos a buestra costa, mision y riesgo en la dicha ferraria de pisquiera, en esta manera, la mitad dellos por el dia de san Juan del mes de junio de cada un año y la otra mitad por dia de nabidad del mes de diciembre, asimesmo de cada un año, para siempre jamas, y sera la primera paga, que nos abeis de hazer para el dia de san Juan de junio primero que biene del año de mill e quinientos e setenta y dos años, e dende en adelante las mas por su horden; y se entienda y hes de sauer que a mi el dicho Pedro Pardo y mis herederos y sucesores nos habeis de pagar cada un año por la dicha orden e a los dichos plaços los tres mil marabedis puestos e pagos en la dicha herraria o en otra quaquier parte do fueredes allado, e pedido bos el dicho Francisco de Vidarte y los buestros en nuestras manos o de quien para ello nuestro poder tubiere. Y los otros tres mill marabedis a mi el dicho Pedro Maseda de Aguiar e mis herederos y subcesores pagos a los dichos plaços e terminos cada un año, por la dicha horden, en nuestras manos o de quien nuestro poder para ello tubiere, pagos en la dicha herraria o en otra parte do fueredes allado el pedido bos el dicho Francisco de Vidarte y los buestros sin falta ni desquento alguno, y esto porque cada uno de nos los dichos PedroPardo e pedro de maseda, tiene y es suia la mitad de la dicha herraria e machuco, y lo arriva contenido, lo qual todo bos aforamos en damos en censo e trebuto con las condiciones siguientes:

Primeramente, con condiçion que a buestra costa e mision bos el dicho Francisco de Vidarte, e buestros herederos, y subcesores abeis de reparar e perfectar las hichas herrarias y machuco y casas e molino y todo lo susodicho que ansi bos aformos de todos los edifiçios yngenios y mexoramientos de que tubiere neçesidad, haciendo y deshaciendo en ello de tal manera que baia en aumento e no benga en disminuiçion sin que por ello se os pague cosa alguna. 
Otrosi con condiçion que bos ni los dichos buestros herederos e suçesores non podais bender enpeñar trocar ni traspasar la dicha erraria e machuco e açienda arriua contenida, ni derecho deste fuero ni parte dello a persona de las en derecho defendidas salbo a persona llana e abonadas e semajante de bos, que cumpla e pague este dicho censo e condiciones del, e sin que primero y ante todas cosas nos requirais e a nuestros subcesores si lo queremos por el tanto quanto otro por ello bos diere y prometiere e queriendolo que lo aiamos, e no lo queriendo, que en tal caso lo podais hazer, e otorgar qualquier escritura sobre ello, sin ympedimento alguno pasando todabia con el dicho cargo de censo e trebuto e condiciones desta carta, e no de otra manera.

Otrosi condiçion, que si bos el dicho francisco de bidarte, e los dichos buestros herederos e subcesores y cada uno de bos en su tiempo no cumplieredes e guardades las dichas condiçiones que son a buestro cargo, y cada una de ellas, e sino pagarades en tres años continuos, uno en pos de otro,, el dicho censo e trebuto de los dichos seis mill marabedis que por ello e por cada una cosa e parte dello que no cumplieredes, cayays en pena de comiso y perdais el derecho deste fuero y esciptura, en ansi nos lo dexeis libremente, con sus perfectos e mexoramientos, sin que por ello se hos pague cosa alguna, y sin que en ello preçeda ni ynterbenga otra mas sentencia ni declaracion alguna, e todabia finque en nuestra (borroso) y eleçion de bos lo tomar o de bos lo dexar. E si lo susodicho que ansi bos damos en este çenso bale mas e puede baler de la dicha renta de cada un año, lo que no aze de la demasia, vos haxemos gracia, qita e donaçion acabado e cerca dello renunciamos la lei del hordenamiento real que abla sobre estas raçon, y desde oi para siempre nos apartamos e desapoderamos, e a nuestros herederos e subcesores de la rreal corporal tenencia, posesion, propiedad e señorio (...).

Otro si es condiçion que bos el dicho francisco de bidarte e buestra muger en buestros dias tengais y poseais este dicho censo e derecho del, e no lo podays partir ni dibidir e despues de buestro fallescimiento tampoco se pueda partir ni dibidir la dicha açienda e derecho deste fuero, sino que siempre ande en una sola cabeça e persona y esta sola pague la renta y cumpla este fuero (...). Lo firman, esxcepto Pedro Vidarte, que no sabe, en Santa Cruz del balle de oro, a quatro dias del mes de julio año del nascimiento de nuestro salbador Jesuchristo de mill e quinientos y setenta y una años.

$-6-$

1586, julio, 16. Villafranca del Bierzo

Concierto entre Felipe de Garbiso, rendero de la ferrería de Valcarce, y el arriero Alonso Mayo para que le traiga de la venera de Formigueiros 200 quintales de vena.

AHPL. P. N.: 2874

En la villa de Villafranca a diez y seis dias del mes de julio de mill y quinientos y ochenta y seis años, anate mi el escribano y testigos de yuso nombrados, parescieron presentes Phelipe de Garbisso rendero de la herraria de Valcacer de la una parte y de la otra Alonso Mayo vecino de Molina Herrera tierra de Astorga e dixeron que hellos estaban concertados conbenidos e ygualados en esta manera, en que el dicho Alonso Mayo con sus requas cavalgaduras le a de traer e acarretar ducientos quintales de bena del benero de Formigueros y la ha 
de poner en el lugar de Vega de Brañas, la qual ha de encomençar a traer y caretar desde dia de Nuestra Señora de agosto primera que biene de este presente año y a de acabar de dar puestos los dichos ducientos quinatles de bena en el dicho lugar de Vega de Brañas para fin del mes de setiembre de este dicho año y por hello el dicho Phelipe de Garbisso le a de dar e pagar dos reales y ocho maravedis por cada quintal y le da e paga luego para en pago dello sesenta y seis reales y lo demas se lo ha de hir pagando ansi como fuere acarretando la dicha bena de manera que para fin del dicho mes de setiembre quando a de acabar de acarretar la dicha bena este pagado todos los dichos maravedís que en ellos se montan. Por tanto cumpliendo lo contratado el dicho Alonso mayo dixo que se obligaua e obligó con su persona e vienes muebles e raices auidos e por auer de acarretar e traer al dicho Phelipe de Garbisso los dichos ducientos quintales de bena de dicho benero de Formigueros al dicho lugar de Vega de Brañas y encomençará a traer desde dia de santa María de Agosto y la acabará de traer para fin del mes de setiembre deste año al prescio susodicho y para en pago dello confeso auer resçibido del dicho rendero sesenta y seis reales de los quales se dio por pagado y contento a su voluntad (...).

\section{SIGLO XVII}

\section{$-7-$}

1615, enero, 21. Ponferrada

Obligación del rendero de la ferrería de Valcarce, Pedro de Opalda, de entregar 50 quintales de hierro al vecino de Ponferrada Juan Cubero, al precio de 29 reales/quintal

AHPL. P. N., caja 1663

En la villa de Ponferrada a veinte y un dias del mes de henero de mil y seiscientos y quince años, por ante mi escriuano publico y testigos parecieron presentes de la una parte Pedro de Opalda, rendero de las ferrerias del Valcarce, estante al presente en esta dicha villa, y de la otra Juan Cubero, vecino de esta dicha villa e dixeron que ellos heran conzertados en esta manera: que el dicho Pedro de Opalda a de dar y entregar al dicho Juan Cubero cinquenta quintales de fierro bueno a precio de veinte y nueue reales cada quintal desde oy dia de la fecha asta en todo el mes de abril primero que viene deste dicho año de mil y seiscientos y quince. Y el dicho Juan Cubero le a de dar e pagar por cada quintal veinte y nueue reales, los quales le a de pagar la tercia parte de el dinero que montan los dichos cinquenta quintales de fierro para el dia (tachado dia) postrero dia de el mes de março deste dicho año y la otra tercia parte para el dia de la feria franca primera venidera y la otra tercia parte para el dia de la feria de setiembre plaços primeros benideros deste dicho año so pena de execucion, costas, daños, perdidas e yntereses e menoscabos que sobre ello se le causaren, y el dicho Pedro de Opalda a de dar y entregar los cinquenta quintales de fierro al dicho Juan Cubero o a quien su poder hubiere puestos en la dicha villa, so pena de las costas y daños que sobre ello se siguieren (...). Y el dicho Juan Cubero a de dar y pagar al dicho Pedro de Opalda o a quien su poder hubiere lo que montaren los dichos cinquenta quintales de fierro a los plazos segun y de la manera que en esta escriptura se contiene so pena de execucion y de las costas 
(...). Lo firman ellos y los testigos Sebastián Rodríguez y Juan del Vesrrero y Francisco Turrón.

$-8-$

1629, abril, 19.

Obligación de Miguel de Ybarra, vecino de Oencia, de dar a Francisco San Miguel, vecino de Villafranca del Bierzo, cinco millares de clavo de herrar.

AHPL. P. N., caja 2969

Sepasse como yo Miguel de Ybarra, vecino doençia me obligo con mi persona y bienes avidos y por aver de dar y pagar a Francisco de San Miguel, vecino de Villafranca, o a quien su poder ubiere çinco millares de clavo de herrar de peso de nuebe libras en el millar por raçon de que echas nuuestras quentas que ambos teniamos ansi de lo que me avia dado como de lo que yo avia pago asta oy dia de la fecha me alcanço en la dicha quenta en los dichos çinco millares de clavo de los quales me doy por vien pago y contento a mi voluntad (...), (de los cuales le ha de dar) dos millares a dia de san Marcos primero que vienen y los otros tres millares a la feria de san Juan, plaços primeros y benideros de este presenta año. Ante Alonso Diaz.

1659, junio, 18. Villafranca

Compra de cuarenta y cuatro quintales de hierro a la ferrería de Valdomir.

AHPL. P.N.: Caja 2698, ff. 120r-120v.

En la uilla de uillafranca a diez y ocho dis del mes de junio de mill y seiscientos y cinquenta y nuebe años por ante mi el escribano y testigos parecieron presentes don Juan diaz de balcarce y dona maria hordonez, su muger, becinos de dha uilla con licencia que primeramente y ante todas cosas que pidio a dho su marido y el se la dio y ella la aceto y rescibio de que yo el escriuano doy fe, y della usando otorgaron que se obligan y obligaron con sus personas y biens auidos y por aber de pagar realmente y con efeto a don antonio diaz de balcarce su sobrino vecino y ssor. de la herreria de baldomir y a quien su poder ubiere y es a saber doze doblones de a quatro y diez y seis de a dos por una parte y por otra dos mill y veinte y cuatro reales en moneda de bellon procedidos del balor de cuarenta y cuatro quintales de fierro picado que le a de entregar dende aqui a fin de agosto que biene este presente año puesto en esta villa a precio de cuarenta y seis reales el quintal que montan los dichos dos mill y veinte y cuatro reales sobre que renunciaron la (falta) dela primera pedunia leyes de la entrega prueba de la paga y mas del caso como en ellas se contiene. y ponen por plazo a pagar los dhos doze doblones de a cuatro y diez y seis de a dos en la misma especie y los dhos dos mill y veinte y quatro reales de bellon todo junto en una paga para dia de nabidad que biene de seiscientos y sesenta puestos y pagados en el lugar de la herreria en su poder y mano llanamente pena de execucion y costas de la cobranza, e para lo cunplir dieron todo su poder cumplido a las justicias y juezes de su magestad, etc.... ante mi el escribano siendo testigos 
antonio Rodriguez al (...) de la carcel, y francisco garcia de llanos (...) balgara, vecinos y estantes en esta dha uilla y los otorgantes a quuien yo el escribano doy fee conozco lo firmaron. Ante mi Antonio Cid.

1668, noviembre, 27. Ferrería de Pontepetre

Oblicagión de traer a la ferrería de Pontepetre tres cargas de vena cruda de las veneras de Valdecaballos

AHPL. P. N., caja 2936

En la herrrería de Pontepetre, a veinte y siete dias del mes de noviembre de mill y seiscientos sesenta y ocho años, ante mi el escriuano y testigos paresçio presente Antonio Cereijo, vecino de Gestoso, y se obligó con su persona y vienes auidos y por auer de dar y pagar a don Lucas de Azeuedo y la Cueba, arrendatario de dicha herreria, o a quien su caussa ubiere tres cargas de bena cruda de dar y tomar quebrada en las beneras de Valdecauallos a satisfacion del dicho don Lucas, el qual le a de ynbiar a buscar con sus requas y criados desde primero de diziembre que viene de este año asta fin de mayo del año entrante de mill y seiscientos y sesenta y nuebe sin que pueda trauajar para otra persona ni herreria durante dicho tienpo y en caso que las dichas cabalgaduras bayan a las dichas beneras y no allen carga cumplida para las tres en la forma referida no constando estar malo el dicho Antonio Cereijo a de ser obligado a pagar el porte al dicho Don Lucas con los menoscauos que se le siguieren en la dicha herreria por no auer cumplido con dicha condizion y se le a de pagar por cada carga que quebrare se le a de dar a precio de a Real y por espacio del tiempo que ba referido. Y por quiebra de la que fuere dando confeso el dicho Antonio Zereijo auer resciuido de mano del dicho Don Lucas de azeuedo duzientos Reales de uellon de que constituyo por verdadero deudor y renuncio a las leyes de la entrega prueba y paga y mas del caso cpmo en ellas se contiene y so obligó con supersona y uienes que cumplira lo que ba referido en esta escriptura y pena que pagara al dicho Don lucas o a la persona que tubiere su poder quatrocientos maravedis de salario por cada uno de los dias que se ocupare en la cobrança (etc.) Siendo testigos el licenciado Domingo Corcoba clerigo presvitero, Santiago Lopez y Francisco Ferrero, estantes en la dicha herrería. Escribano Alonso de Ocampo Balboa.

1669, mayo, 24. Villafranca

Obligación de los arrendatarios de la ferrería de Lousadela con el mercader de Villafranca Francisco Soto Gayoso

AHPL., PN., caja 2945, ff. 422r-423v.

En la villa de Villafranca A beynte y quatro dias del mes de mayo de mill seiszientos y sesenta y nuebe Años ante mi escribano y testigos parezio presente Don Antonio de Valcarze Martinez vecino de la erreria y Rendero de Lousadela tierra de courel felegresia de san silbestre de sezeda y se obligo con su persona y bienes muebles y rrayzes abidos y por heredar y pagar y que pagara Realmente y con efetto A Pedro de sotogayoso mercader vecino desta uilla y a quein su porder ubiere en qualquier manera es a saber diez quintales de yerro delgado y 
picado puestos y pagados en dha erreria para el dia fin de setiembre que biene deste dho año a su costa y rriesgo pena de apremio, execucion costas y salarios que adelante Yran espresados.

Los quales dhos diez quintales de yerro son por razon de aberselos bendido oy dho dia en prezio de zinquenta ducados de bellon que dicho pedro de soto por ellos le dio y pago Aora de contado y el susodho hotorgante rrecibio y passo a su parte y poder Realmente y con efeto en mi presencia y testigos desta carta de que doy fee. Por cuya causa se obligo de pagar dhos diez quintales de yerro al plazo y en la parte que ba señalado y no lo aziendo y cumpliendo pagara a la persona que fuere a su cobranza por cada un dia que se ocupare en ella quinientos mrs. de salario asi de la yda como de la estada y buelta y por dho salario consiente ser executado como por el prinzipal. Y ansi mesmo dijo que por quanto bartolome de arze y armesto y juan lopez vecinos de dha felegresia de san silbestre y el dho bartolome de arze ansi mismo Rendero en dha erreria de Lousadela ambos de mancomun se abian obligado a pagar al dho pedro de soto gayoso quarenta quintales de yerro delgado y picado y de buena calidad pagados en dha erreria doze dellos afin Diziembre del año se sesenta y ocho y otros doze afin de enero deste Año y otros diez y seis a cumplimiento de los dhos quarenta a fin de febrero del. Como mas largamente consta de la escritura de obligacion otorgada por los susodhos ante mi dho escribano en cinco de octubre de dho año seiszientos y sesenta y ocho a que se remite y por se aber pasado los dhos plazos el dho pedro de soto abia sacado la dha obligacion y dado y dado poder a persona para que la fuese executar y por ser el dho bartolome de arze y armesto su cuñado y estar casado con Doña Ynes de Valcarce su ermana le a pedido suspendiese el ynbiar a azer dha execuzion el qual por le Azer buena obra a benido en ello a calidad que se obligase el susodho hotorgante por si mesmo a la paga de los dhos quarenta quintales de yerro que contiene dha obliacion y una mas que ansi mesmo consta deberlepor asiento del libro. $\mathrm{Y}$ diesse fiador de cunplirlo ansi por tanto mediante la dha suspension que da a la dha execuzion y cumpliendo con lo tratado entre ellos se obligo en la dha forma de pagar por el dho su cuñado los dhos cuarenta y un quintales de yerro de la calidad y bondad susodha al dho pedro de Soto y a quien su poder ubiere los beynte dellos en tod el mes de junio que biene deste dho año y diez en todo el mes de agosto y los otros onze rrestantes en tod el dho mes de setiembre que co $\mathrm{n}$ los diez de su deuda azen zinquenta y un quintales, los quales pagara a los plazos y tienpo que señalado en la dha erreria de Lousadela sobredha pena de apremia execuzion y costas y salarios que ban dhos y espresados en la primera obliacion desta escritura de los dhos diez quintales.

$\mathrm{Y}$ es declaracion y condicion que passado qualquiera de dhos plazos y estando cunplido si el dho pedro de soto gayoso ynbiare por el dho yerro a la dha erreria de lousadela y en ella no se le entragare bolbiendo de bazio pagara los alquileres de las cabalgaduras que llebare a razon de quatro reales cada una por cada dia y otros quatro a la tal persona que fuere con ellasen la qual deja deferido y en su declazion los dias y bezes que fuere y cabalgaduras que llebare sinple o jurada sin que prezeda otra aberiguacion alguna y por lo que ynportare consiente y quiere ser ejecutado como por el prinzipal costas y salarios, y para en quanto a lo que mira a dho su cuñado y por la buena obra que le yço en suspender dho pedro de soto dha execuzion mediante esta obligacion que le aze de pagarle dhos quarenta y un quintales de yerro, que por el sale a pagar por este efecto y para todo lo mas que contiene esta escritura dio por su fiador a Juan de bergara maestro de zerrageria vecino de diho lugar de Sezeda el qual 
estando presente salio por tal su fiador y anbos de mancomun a boz de uno y cada uno por si y por el todo in solidun renunicando como renuncian las leyes de la mancomunidad dibision yescursion de bienes y mas del caso como en ellas se contiene y aciendo como azen en quanto a lo que mira el salir pagar por otros de deuda y fho axeno suyo propio se obliganron y a sus bienes y personas abidos y por aber de pagar al dho Pedro de Soto los dhos zinquenta y un quintales de yerro a los plazos y tienpos que van expresados y en la parte y sitio que ba declarado so la dha pena de apremio execuzion costas y salarios. Y para que ansi lo cumpliran dieron porder cumplido a las justicias y juezes que de sus causas puedan y deban conozer para que eles apremien y a sus erederos por todo rigor de derecho y bia executiua renunciaron las leyes y fueros y derechos de su fabor en forma y ansi lo hotorgaron siendo testigos Don Francisco Albarez de Miranda y Castelo, Martin Fernandez y Gregorio Becin y Bernardo Lopez vecinos desta villa. Los otorgantes lo firam uno de ellos y a rruego del otro un testigo de cuyo conozimiento de anbos se contento la parte y tan bien les conoze el dho Martin Fernandez. Ante mi Juan de Zela.

\section{3, octubre, 29. Villafranca}

Venta de cuatro cargas de rejas de 11 arrobas cada carga y precio de 23 ducados.

\section{AHPL. P. N.: caja 3150}

Sepasse como yo Pedro de Armesto vecino del lugar de la campa do baldomiro, tierra de Courel, que me obligo con mi persona y vienes muebles y rrayces auisos y por auer de dar y pagar y que dare y pagare realmente y con efecto a Francisco de Soto Gaioso, mercader vecino de esta uilla, o a quien su poder ubiere, es a sauer quatro cargos de rellas de a honce arrobas cada carga por raçon que confieso averselas vendido a precio de veinte y tres ducados cada carga oy dia de la fecha, de cuya cantidad me doy por pagado, contento, satisfecho a mi voluntad y por la entrega y y reciuo de presente no pareze renuncio la ley (etc.), y pongo plazo cierto para pagar las dichas quatro cargas de rellas para primero de março del año que viene demill y seiscientos y setenta y quatro puestas y pagadas en el lugar de Folgoso en casa del cura del dicho lugar llanamente, pena de execucion y costas y no pagandolas al dicho plazo pagare de salario a la persona que fuere a la dicha cobranza de ellas por cada un dia de los que en ellas se ocupare de yda, estada y buelta (...) quatrocientos mrs. (etc.). Testigos: Antonio del Valle Arroyo y Andrés dela Pedrosa e Ygnacio López Arias. Ante mi Pedro Ramos.

\section{$-13-$}

1679, mayo, 23.

Carta de pago del arreglo de los barquines de la ferrería de Pontepetre

\section{AHPL. P.N.: caja 3104, ff. $123 r$ y $123 v$.}

En la Herreria de Pontepetre A veinte y tres dias del mes de maio de mill y seis Cientos y setenta y nuebe por ante mi el escriuano publico y testigos de ynfraescritos, parescio pressente Pedro de Alça maestro de varquines, vezino del 
lugar de ferreiros Reino de Galicia= y dijo y confesso aber Rescuido de Alonso de Ocanpo yBaluoa escriuano de su Magestad y del numero desta merindad de Aguiar dela Lastra como arendatario dela dicha herreria con ynteruenczion de su merced el sr. Don Lucas de Azeuedo y Cueba contador mayor y juez hordinario de rentas rios montes y bosques de este estado de uillafranca, conuine a sauer quatro mill y sessenta y tres Rs. de uellon para la fabrica delos barquines nuebos que hiço en esta dicha herreria para el Excmo. sr. marques deste dho. estado, sus aderentes y trauajo de su persona cuia cantidad reciuio y se compone de las partidas siguientes $=$

Primeramente nuebe pellejos de bueyes que costaron nuebecientos Rs. = mas cinquenta libras de unto para ellos que costaron ziento y cinquenta reales $=$ mas duzientos Rs. que costaron las tablas de los varquines= mas setezientos Rs. de ssiete quintales de yerro que lleuaron los dhos varquines y del tiraje y uino delos oficiales $=$ Yten mas trezientos y quarenta Rs. que costaron los cañones para dhos varquines $=$ mas veinte $\mathrm{y}$ siete Rs. de lana $\mathrm{y}$ pellejas de carnero para las cauezadas $\mathrm{y}$ ventanas de dhos varquines= mas de gasto de su persona fragua, manos herrero y ayudantes honbres que ayudaron a trinjar las tablas, carpinteros y personas que curtieron los queros sietezientos y ssesenta Rs. y medio $=$ mas otros doce Rs. y medio de gasto que el sussodho ... de tres dias postreros que se ocupo en assentar dhos barquines= mas cinco Rs. de ojadelata para deuajo delos cañones dellos= mas diez y ocho Reales del propio que fue a buscar el dho otorgante $=$ mas nuebecientos y cinquenta Rs. ue se le pagaron por toda la obra de manos y trauajo de su persona en la echura de dhos barquines $=$ Por manera que todas las partidas atras contenidas ynportan los dhos quatro mill y settenta y tres Rs., que lo uno y otro le fue entregado y pago antes de aora para la fabrica y estado de dhos barquines que quedan molinetes y corrientes de mano del dho alonso de ocanpo valuoa. Y con la ynteruenzion de susso y de toda la dha cantidad le otorga carta de pago y finiquito en forma y ssobre la entrega que de presente parece por ser cierta y verdadera renuncio las leies dela prueba execucion de .....=yse obligo con su persona $\mathrm{y}$ vienes muebles y raizes auidos y por auer que los dhos nuebecientosy cinquenta Rs. que ynporto la obra de manos y trauajo de personas le son vien pagos y no seran bueltos apedir al dho alonso ocanpo valuoa ni a ala persona de su exc. y si lo yciere no se aga oydos a ello en juicio ni fuera del, y de que pagara anssimesmo las costas y daños que se les causaren y para lo assi cunplir da poder a las justicias y jueces de su magestad y en especial a las de fuero que sean conpetentes para que de ello le conpelan y reziuio por ssa. pasada, etc. Siendo testigos el lizenciado Domingo Coua y Vasquez presuitero Domingo aluarez y Juan Monterola arota de dha herreria que dijo y declaro dejar dho. Pedro alca dichos barquines molientes y corrientes y doi fe. Ante mi Joseph moran.

1680, agosto, 11. Ferrería de Visuña

Obligación de los renderos de la ferrería nueva de Visuña de pagar al mercader de Villafranca 47.000 reales que les prestó en diferentes partidas

AHPL. P. N.: Caja 2923 
En la herrería nueva, feligresia de Santa Eufemia del lugar de Vesuña, tierra de Courel, a onçe dias del mes de agosto de mil y seiscientos y ochenta, por ante mi el escriuano y testigos parecieron pressentes Juan Fernandez de Guzman y Ana fernandez, su muxer, arrendatarios de la dicha herreria y vecinos del dicho lugar de Vesuña y la susodicha con licencia que primero y ante todos cosas pido al dicho su marido para aver y otorgar esta escriptura, el qual se la dio (etc.). Dixeron que se obligaban y obligaron con sus personas y vienes muebles y raiçes auidosy por auer de dar y pagar y que pagaran con efecto a Francisco de Soto Gaioso, vecino de la villa de Villafranca del Uierço y a quien su poder y derecho uuiere, es a sauer quarenta y siete mil reales de moneda de vellon, los quales confiesan deverle por otra tanta cantidad que presto a los otorgantes antes de aora en diferentes partidas asta oy dia de la fecha desta escriptura, de que se dieron por entregados a su voluntad y se constituyen por reales y uerdaderos deudores de los dichos quarenta y siete mil reales, y porque no pareçieron de presente renunzian las leyes (...). Y la dicha cantidad la an de pagar en la dicha uilla de uillafranca a su cuenta y riesgo para el dia onçe de agosto del año que uiene de mil y seiscientos y ochenta y dos, pena de execucion, decima y costas y ducientos maravedis de salario a la persona que uiniere a su cobrança por cada uno de los dias que se ocupare en ella. (Se obligan con todos sus bienes, etc.). Testigo Luis Santín, presbíetero vecino del lugar de Villarrubín, y Felipe de Guzman hijo de los otorgantes, y Pedro López. Ante el escribano Pedro Amigo.

\section{SIGLO XVIII}

$-15^{-}$

1729, octubre, 16. Cabarcos.

Arriendo de la ferrería Nueva de Visuña que hace D. Matías Armesto y Ron, de Villafranca del Bierzo, a D. Lorenzo de Prada, vecino del monasterio de Jagoaza (Valdeorras)

AHPL. PN.: Caja 3333, ff. 127r-128v

En la villa de Cabarcos a diez y seis dias del mes de octubre de mill setezientos y veinte y nuebe ante mi el escribano y testigos parezio Don Mathias de Armesto y Ron, vezino de la villa de Villafranca y dijo que por tiempo i espacio de tres años continuados que empiezan desde oi día de la fecha asta ser fenezidos arrienda y da en arrendamiento a Don Lorenzo de Prada vezino del lugar de Monasterio de Juagaza (sic) jurisdizión de Baldeorras la Herrería que llaman la nueba segun la esta poseiendo con todo lo a ella anejo y perteneciente por zesion que por vía de alimentos le hizo Don Gonzalo de Armesto y Ron su padre por scritura que passo por testimonio de Phelipe garcía escribano de la jurisdizión de Toreno el año pasado de mill settezientos y veinte y tres a que se remite; porque en el primero de dichos tres años le hade dar y pagar en una paga y al fin deel doszientos y cinquenta ducados de vellon y en en cada uno de los dos ultimos y al fin de ellos treszientos y veinte ducados también de vellon puestos unos y otros en dicha villa de Villafranca en mano y poder del otorgante y de quien su poder y derecho hubiere con cargo de execuzión dezima y costas y de quatrozientos mrs. de salario a la persona que fuere a su cobranza por cada uno 
de los días que en ella se ocupase de ida estada y buelta astta el real y efectiuo pago por los quales quiere y consiente se le execute como por la deuda principal de que en casso necessario se ha de constituir por real y verdadero deudor.

Cuio arriendo haze asimismo con las condiziones siguientes: que el otorgante ha de dar en cada uno delos dichos tres años al dicho Don Lorenzo de Prada y a quien su poder y derecho hubiere quarenta anegas de zenteno que tiene de renta en los lugares de Besuña, Ferramolín, y otros circunvezinos a dicha herrería; cuio pan han de percibir el dicho Don Lorenzo delos colonos al tiempo y plazo que suelen pagarlo y asimismo le zede los reditos delos zensos que al otorgante se le deben en el lugar de Villarubín y caieren durante el tiempo deste arriendo y no mas como el usso de una cassa que tiene en dicho lugar, el usufruto y aprobechamiento de tres prados que los dos de ellos estan inmediatos a dicha herrería y el otro en dicho lugar de Besuña.

Que el el coste que tubieren los reparos del Banzado y Barquines que al presente ai han de ser por quenta de dicha renta y se ha de estar y passar por la declarazión simple o jurada que hiziere el dicho Don Lorenzo de Prada en que desde luego queda diferido.

Que los perfectos y mejoras y abonos que se hizieren en dicha herrería dentro de los referidos tres años ademas de lo arriba expresado lo ha de hazer buenos el otorgante al dicho Don Lorenzo de Prada y descontarselos de dicha renta con tal que sean precissosy necessarios para la fabrica aumento y conserbazión de dicha herrería.

Yasimismo es condizión que si fenecido este arriendo hubiere algunas desmejoras en ella las ha de satisfacer y pagar el dicho Don Lorenzo al otorgante y a quien su derecho hubiere a tasazión de personas que tengan entero conozimiento de ellas.

Que si el primer año de este arrendamiento acaeziere arruinarse con abenidas y en otra forma la chapacuña dela pressa con que fabrica dicha herrería la ha de componer el dicho Don Lorenzo de Prada y pagar la metad del coste que tubiere su reparo, y la otra metad ha de ser a quenta de dicha renta. Que todos y qualesquiera escalabros que durante este arriendo se hizieren y causaren en dicha herrería assi maiores como menores han de ser por quenta del dicho Don Lorenzo de Prada sin ser uisto pretender se le rebaje ni desquente cosa alguna de la referida renta.

Yasimismo es condizión expresa de esta escritura que el dicho Don Lorenzo de Prada ha de recibir las caballerías que el otorgante le diere para el uso y manejo de dicha herrería las quales se han de apreciar y fenezido que sea este arrendamiento se las ha de bolber y si entonces no valieren lomismo en que se aian valuado ha de satisfacer el susodicho al otorgante las desmejoras que tubieren luego que sean apreciadas por la persona y personas que ambas partes nombraren en casso de conformarse como también el otorgante ha de satisfacer al susodicho el aumento y valor que tubieren demas las que le entregare debajo de dicha conformidad y nombramiento.

Que el dicho Don Lorenzo de Prada ha de recibir del otorgante el Carbon y Bena que al presente tiene para el uso de dicha herrería a tasazión en casso de no conformarse los dos como también fenezido que sea este arriendo el otorgante ha de recibir del susodicho la Bena, Carbón y Leña que le sobrare, pan, vino, azeite y carne salada al precio en que se ajustaren y de no a tasazión.

$\mathrm{Y}$ es también condizión que si durante dichos tres años se originaren pleitos en razon de una escritura de compromiso otorgada por el dicho Don Gonzalo de Armesto y Don Joseph de Quiroga y Lemos vezino del valle de Quiroga en razon 
de los Montes y otras cosas de que se aprobecha dicha herrería los gastos que en ellos tubiere el dicho Don Lorenzo de Prada se han de rebajar de dicha renta para lo qual ha de avissar al otorgante por si quiere asimismo seguirlos.

Que fenecido que sea este arrendamiento el dicho Don Lorenzo de Prada ha de dejar libremente dicha Herrería al otorgante y darsela corriente y moliente y en este mismo estado la ha de dejar el susodicho con sus pertrechos instrumentos, erramientas, vienes, y alajas que por recuento e ymventario sele entregaren de que ha de der el otorgante reciuo de todo lo que podra usar sin que por ello se le pida cosa alguna aun en caso que con el tiempo y uso se desgasten.

Cuio arreindo haze el otorgante en la manera dicha y deque por el referido tiempo sera zierto y seguro al dicho Don Lorenzo de Prada y no quitado por mas por menos ni por el tanto que otra persona dé y prometa por dicha Herrería pena de no ser oido en juizio ni fuera del y de pagar las costas y daños que se causaren.

Y estando presente el dicho Don Lorenzo de Prada acceto esta escritura segun y como en ella se contiene y protesto usar deella y de cumplir con todas sus condiziones que ha por repetidas y de que en cada uno de los dichos tres años dara y pagara al dicho Don Mathias de Armesto y a quein su poder y derecho hubiere las cantidades de mrs. segun y en la conformidad que ba expresado a los plazos y partes referidas sin ser visto pretender desquento ni rebaja alguna aun en caso que en dicha Herrería sus cassas y prados nominados suceda algun caso fortuito pena de execuzión dezima y costas, etc....

Asi lo otorgaron ante mi dicho escribano siendo testigos Don Thomas de Armesto y Ron Retor de esta dicha villa, Joseph de Noboa vezino deella y Don Ygnacio Ossorio Barba vezino de la referida Villafranca, y los otorgantes que doy fe conozco lo firmaron. Ante mi Antoniode Noboa.

\section{3, noviembre, 16. Sobrado}

Acuerdo entre los vecinos de Sobrado y la arrendataria de Pontepetre, Doña Angela Martínez de Torres, para adquirir urz para carbón de la ferrería.

\section{AHPL. PN.: Caja 3341, ff. 94r-94v.}

En el lugar de Sobrado jurisdion de Carracedo a diez y seis días deel mes de Moviembre de mill setecientos y treinta y tres años, parecieron presentes por ante mi el escribano y testigos Tirso Diaz, Juan Antonio Albarez y Francisco de la Granja vecinos de este lugar y Dixeron que dicho conzejo de Sobrado estando juntos y congregados para las cosas de gobierno les abían nombrado por ombres buenos que confiriesen y tratasen por una vez vender un poco de zepa de uz de los montes de Sobrado a D ${ }^{\mathrm{a}}$ Angela María de Torres Arrendataria de la Herreria de Pontepetre de Oenzia; y en su nombre a Don Lorenzo Fernandez Lombardía como poderabiente de dicha $\mathrm{D}^{\mathrm{a}}$ Angela, quien dijo si nezesario fuese lo presentara cada y quando le sea pedido. $Y$ en esta conformidad estando presente dho. Don Lorenzo Dixeron los dichos ombres nombrados que benden por una bez la zepa que fuere necesaria de uz para azer carbon y se arbitrare por dhos ombres nombrados y conzejo con las condiziones y grauamenes siguientes:

Primeramente que por allarse dicho conzejo en precission de azer una fragua con su erramienta para la agricultura de sus labranzas y por no tener Dinero ni erramienta a la mano queel dcho mayordomo auía de dar una marra de una 
arroua poco mas o menos y una barra de hierro deel mismo pesso o mas. Y con condizion que sea bisto no tener dicha Errería ni mayordomo ni otro ningun arrendatario tener derecho alguno ni posesion Real actual ciuil vel quasi a lo demas que no quieran dar dichos vecinos ni nunca pretendan derecho ninguno en ningun tiempo, ni tampoco por la venta que se le haze mas que por una vez y la que quissieren dar dhos ombres nombrados y conzejo. Yten condicion que tanpoco venden masde lo que fuere suficiente para comprar dicha fragua atendiendo a los pocos y pobres montes que tiene este dho. lugar de Sobrado por tirar a mantener los que ay y si faltasen se despoblarían sus vecinos. Y estando presente dho. Don Lorenzo dixo que como Apoderado de dha. $\mathrm{D}^{\mathrm{a}}$ Angela que se a visto azetua y azeto esta escriptura con todas las clausulas y condiziones que tiene, y por una vez azetaba la zepa que los dhos ombres nombrados y conzejo le quissiesen dar y dara la marra y palanca que se le piden y cumplira con lo mas que va echo mencion. Y para que mas me perjudiquen y a los venideros a dha errería las he aqui por ynsertas y repetidas de nuebo por conoczer que solo aze dho. conzejo a la dha mi ama $\mathrm{D}^{\mathrm{a}}$ Angela María de Torres y no estar dicho conzejo obligado con sus montes socorrer la erreríani con carbon ni leña ni otro genero alguno, contra lo qual ni contra cosa ni parte de ello se opondra ni alegara excepcion de su derecho a unque la tenga legitima. Y si lo intentare no quiere ser oydo en virtud de dho poderque ofreze presentar en juicio y fuera deel. , etc.... Ansi lo otorgaron ante el presente escribano, siendo testigos Francisco Albarez, Joseph Vizcayno y Don Diego de Canzelada vecinos de este lugar de Sobrado. Y los otorgantes a quienes yo el escribano doy fee conozco lo firmaron de sus nombres. Ante mi. Joseph Antonio Tavano.

$-17-$

1745, marzo, 2. Cervantes

Foro que otorga don José Manuel Navia y Llamas a favor de José Fernández Lombardía y otros dos Fernández Lombardía, todos del principado de Asturias, de un mazo de trabajar hierro con tres fraguas, más una casa y un prado. Archivo del autor

En el lugar y feligresia de nuestra Señora de la Conzepzion del Pando, conzejo de Cervantes, a dos dias del mes de marzo de mil setezientos quarenta y cinco, ante mi el escribano del numero y testigos parecio Dn. Joseph Manuel Navia y Llamas, vecino de el, y dijo que por si y en nombre de sus hixos, herederos y subzesores presentes y por benir, y por el tiempo y vidas de tres señores reies de España que la prima ha de ser y es la del Señor Dn. Pheliphe quinto (que Dios guarde y conserue dilatados años) y despues las de otros dos señores reyes que le suzcedan, uno en pos de otro; y fenezidas dichas tres vidas veinte y nueve años mas; aforamos, aforo y dio en foro a Joseph Fernandez Lombardia, natural del lugar dos Teixois, Santiago Fernandez Lombardia, natural del lugar de Veiga de Llano, ambos del concejo de Taramunde, y a otro Joseph Fernandez Lombardia, natural del lugar de Cuyrio, conzejo de Miranda, todos en el Principado de Asturias, y al presente residentes en este conzejo de Zeruantes, y tanto al uno como al otro, hixos y herederos de todos tres durante dichas vidas y años, a sauer lo que así les afora y da en este dicho foro un Mazo de trauajar fierro, despalmar calderos y hazer todas herramientas con tres fraguas, y cada 
una con sus barquines de cuero, y tres yunques de fierro para cada fragua la suia, martillos mayores de dos yunques; dos ruedas, la una que es la maior y la otra que llaman la barquillera; y finalmente dicho Mazo con su Arbol, tulla, zepos mayores y menores. Paredado de piedra, cubierto de lossa y todo moliente y corriente segun es nezesario para dicho exercicio; tambien les afora una casa de piedra cubierta de paja que esta junto al dicho Mazo; un prado de dar yerba con sus zanjas y riega de agua que le corresponde sito junto y pegado a dicho Mazo. Y toda la parte y porcion de propiedad corresponde a los alrededores de uno y otro, que uno y otro pertenece al otorgante en el sitio y rio llamado de Pradeliña, termino de brañas y Pradela, cuios vienes que asi afora son suios propios, diezmo a Dios, libres de toda carga de zenso, tributo, pension, hipoteca, ni otra alguna, y por tales lo da en este dicho foro tanto al uno como al otro de suerte que los tres y herederos de cada uno los han de lleuar, perzibir y gozar por terceros partes. $\mathrm{Y}$ a todos con las condiziones, calidades, penas, grauamenes y comision siguiente. La primera que los susodichos los an de traer bien gouernados cubiertos los techos y de manera que uno y otro baia en aumento y no en disminuzion. La segunda que por todo ello los susodichos y sus herederos anualmente an de dar y pagar al otorgante y los suios trescientos y sesenta y tres reales de vellon de que corresponde a cada uno ciento y veinte y un reales de dicha moneda, y asi mismo an de darle todos tres la herraxe de herradura y clavo que dicho otorgante y despues de el quien le subzeda, necesitare para la caualleria de que andare de a cauallo, pagada dicha cantidad de dinero por la Natividad de nuestro Señor Jesucristo de cada un año, y dicha herraxe cada vez y quando que el otorgante y quien le subzeda la necesite para dicha caualleria (...). La tercera es que todas las quiebras mayores que aia y pueda hauer en dicho mazo an de ser de quenta y riesgo su composizion de el otorgante y sus herederos y no de los recipientes ni los suios y solo de la de estos an de ser la de las menores quiebras y materiales que en dicho mazo acaezcan. La quarta es que en todos los alrededores de el referido mazo , casa y prado de este foro dichos recipientes desde el Penedo llamado Monte do Pando hasta el Prado dos Lamocos y de alli hasta sobre el Prado da Ponte, puedan labrar, cultiuar, zerrar y perfectar todo lo que les parezie correponder a dos baras de heredad corridas y cada una de doze palmos que a dicho otorgante tocan en dicho termino de brañas, sin incluirse ni yntroducirse desde el sebeiro de brañas ariua porque desde dicho sebeiro se lo priua para que en ninguna manera ni en ningun puesto se puedan entrometer a cosa alguna de dicho cultivo, cierra y perfectos y solo lo an de poder hacer en las partes que quedan destinadas. La quinta que el pagamento de dichos trescientos y sesenta y tres reales que quedan expresados y herraxe mencionada se ha de hazer y executar por los sobredichos y despues de ellos sus herederos a los plazos y tiempo que queda señalado. $\mathrm{Y}$ todo en este dicho lugar y casa de el otorgante o en la de quien represente su derecho en este foro. Y no lo haziendo, ademas de que queda su arbitrio la pena de comiso, puedan ser executados por ello y pagar las costas que por no lo hazer se causaren; y todo diferido a la voluntad de dicho otorgante y sus herederos. La sexta es que estando tres años continuos sin pagar dicha renta de vellon y herraxe sea visto caer en comiso este foro y dicho otorgante o quien le subzeda sin mas autoridad que la suia puedan entrometerse en los venes de el y quitarlo a los rezipientes sin para ello llamarles ni emplazarles a juicio contencioso sino que por la simple o jurada declaracion que aia de quarquier gente, persona que represente la de dicho otorgante porderseles quitar sin otro requisito. La septima que fenecidas dichas tres vidas y años los susodichos y sus herederos an 
de dejar dichos vienes libres y desembarazados al otorgante y los uios con todos y qualesquiera perfectos que en ellos hubieren echo y mejorado, sin por uno no otro pedir ni demandar cosa alguna (...). La octaua es que si porr morosidad o negligencia de los recipientes o sus herederos el referido mazo y vienes estubieren por reparar y componer de las quiebras y reparo que quedan de su cargo sea visto que el otorgante y los suios los puedan mandar hazer y reparar y por su ymporte sin mas declarazion que la de quien los hiziere simple o jurada poderles executar y en todo acontezimiento ni por eso se ha de dejar de pagar dicha renta anualmente y por ella deuer ser executados como ni tampoco por quaquiera caso fortuito que subzeda del cielo a la tierram yncendio o otro motivo (lo que Dios nuestro Señor no permita) a menos que sea por morosidad del otorgante y sus herederos el no concurrir a executar las quiebras maiores que tambien quedan de su carga que en este caso mientras no lo hizieren no se podra cobarar dicha renta. Con las quales dichas condiciones y no sin ellas que cada una de por si ha de ser executiua y no conminatorias ni ad terrorem les haze dicho foro del mazo y bienes aqui expresados (...). Lo firman ellos y los testigos.

1745, abril, 3. Oencia

Cuentas de la ferrería de Pontepetre que da su arrendataria $D^{a}$ Angela Martínez de Torres a don José Gómez de Noboa Taboada, tutor de don Manuel García de las LLanas, su propietario. AHPL. PN.: Caja 3342, ff. 26v-29v.

En el lugar de Oencia a tres dias de Abril de mill setecientos quarenta y cinco años ante mi el escribano y testigos parecieron el Lizenciado Don Joseph Gomez de Noboa Abogado, vecino de la villa de Ponferrada como tutor y lexitimo Administrador de la persona y vienes de don Manuel Garcia de las LLanas, lexitimo Dueño y poseedor de la Herreria de Pontepetre afecta al vinculo y Mayorazgo que fundo Don Esteban Garcia de las Llanas su Abuelo, vecino y rexidor que fue de dicha villa, que goza y posee el dicho don Manuel de una parte; y de otra Doña Angeles Martínez de Torres viuda de Don Francisco Muro difunto vecino que fue, y la susodicha lo es deste dicho lugar Arrendatarios que han sido de la dicha Herreria desde el dia ocho de septiembre del año pasado de mill setecientos veinte y dos hasta otro tal dia del proximo pasado de mill setecientos quarenta y quatroen virtud de escritura de arriendo otorgada entre los susodichos por testimonio de Antonio de Noboa escribano del numero dela merindad de Aguiar en uno de los dias del mes de nouiembre de el dicho año de mill setecientos veinte y dos, y de otros papeles y escripturas de obliacion prorrogacion dedicho arriendo posteriores; y digeron : que entre los otorgantes han liquidado y ajustados quenta final de todas las prebenziones y surtimientos de vena nueba y vieja, carbon, regua y mas pertrechos de dicha Herreria que reciuio el dicho Don Francisco Muro de mano de dho Don Esteuan al tiempo del citado arrendamiento y de todas las rentas vencidas en el referido tiempo por la qual dicha quenta resulto alcanzada la dicha $\mathrm{D}^{\mathrm{a}}$ Angela Martinez Torres en veinte y tres mill quatrocientos y nouenta reales, y dos mrs. vellosn en que se comprehenden e incluyen Diez y siete mill y setenta y dos reales que importaron las partidas de vena nueba y vieja, carbon y regua, que habia reciuido el dho. Dn. Francisco Muro, quando entro en el arriendo de dha Herreria segun cosnta 
de dha quenta, que firmada del dho Lizenciado Don Josph Gomez y de Don Joachín Perejon hierno de la dicha $\mathrm{D}^{\mathrm{a}}$ Angela entregaron a mi el escribano para que la inserte en esta escriptura y su tenor es el siguiente

Aqui la quenta

Quenta final que se forma entre la Señora $\mathrm{D}^{\mathrm{a}}$ Angela Martinez de Torres, vecina del lugar de Oencia, y arrendataria que ha sido de la Herreria de Pontepetre, y el sr. Lizenciado D. Joseph Gomez de Noboa, abogado de los qq. vecino de la villa de Ponferrada como tutor de Don Manuel García de las LLanas dueño de dicha Herreria.

Primeramente se le cargan a dicha $\mathrm{s}^{\mathrm{a}}$ nueue mil treszientos y treinta y siete rs. $\mathrm{y}$ diez y nueue mrs. los mismos que contra ella resultaron dealcance hasta el dia 8 de marzo deel año pasado de 1722 en la ultima quenta que dio en Ponferrada a 16 de febrero deel mismo año. 9.337 rs. 19 mrs.

Yten se la hace cargo de cinco mil doscientos y cinquenta rs. los mismos que importa la rentadeel medio año que cumplió en ocho de septiembre de de dicho año de 22. $5.250 \mathrm{rs}$

Yten se la hace cargo de diez y siete mil y setenta y dos rs. que importan las partidas de vena nueba, vieja, carbony requa que reciuio Don Francisco Duro marido que fue de la expresada $\mathrm{D}^{\mathrm{a}}$ Angela quando entró en el arriendo de dha herreria . $17.072 \mathrm{rs}$. Yten se le cargan duzientos y tres rs. y medio vn. los mismos que suman las alajas tasadas y valuadas que dha $\mathrm{D}^{\mathrm{a}}$ Angela dejo de entregar de las que por inventario reciuio dho. su marido y se apreciaron de conformidad en ocho de septiembre de dicho año de 22. $.203^{1 / 2}$ rs.

Yten se la hace cargo de treinta rs vn. mitad deel salario y precio que lleuo a mano Santín que taso la requa como maestro Albeitar y constan de su recibo.$30 \mathrm{rs}$.

Ymportan las partidas deel cargo treinta y un mil ochocientos y nouenta y tres rs. y dos mrs. vn. salbo yerro, y queda por carga hasta que se liquide lo que importa el coste que hubiere que hacer en la presa por hauer quedado descompuesta quando dha $\mathrm{D}^{\mathrm{a}}$ Angela hizo la entrega de la Herreria; por ser condizion expressa de la escriptura primera de arriendo otorgada entre Don Esteban García de las Llanas y dicho Don Francisco Muro que hauía de dejar dha presa reparada y compuesta con su estacada, con cuia advertencia para admitirsele a dha sra. la data siguiente:

Data

Primeramente se le reciuen en data mil ducientos y sesenta y seis rs., los mismos que suman diferentes materiales que dha. $\mathrm{s}^{\mathrm{a}}$ dejo en ser para el suministro de dha. Herreria y reparos que hizo en las casas de su vivienda, y en la panera de Penedelo.

1.266.

Yten se la reciuen en data mil y ochocientos rs. que importaron a tasazion dos machos y quatro rocines que dejo dejo de requa............................................. 1.800. Yten se la reciuen en data mil seiscientos y noventa y ocho rs. que dejo en vena por cozer y tazar que hauiendo sido quatrocientos y cinquenta y uno al precio de tres rs. y veinte y seis mrs.cada quintal importaron dha. cantidad.................. 1698. Yten se la reciue en data doscientos y catorce rs. vn. que importaron ciento y siete cargas de carbon que dió arrancado y achegado. .214. 
Yten tres mil quatrocientos y veinte y cinco rs. que dha $\mathrm{S}^{\mathrm{a}}$ libro a favor de dho. Don Josph Gomez contra Thomas de Valcarce vezino de dha. villa de Ponferrada, los mismos que la estaba deuiendo de alcance del liquido deel yerro que hauía embiado

a 3.425

Ymportan las partidas de la data ocho mil quatrozientos y tres rs. vn que conferidos con los treinta y un mil ochocientos y noventa y tres y dos mrs. del Cargo le que ba hecho. 31.892-2. resta deuer la referida $D^{a}$ Angela a dho. Dn. Josep Gomez en nombre de su menor veinte y tres mil quatrocientos y nouenta rs. y dos mrs. 23.490-2. salvo error, Y se aduierte que dela partida de los doscientos y tres rs y diez y siete mrs. se la rebajan a la citada $\mathrm{D}^{\mathrm{a}}$ Angela ciento y treinta y dos rs. importe de tres cubas que hauía reciuido dcho. su marido en la Portela de aguiar y queda obligada a entregarlas. $\mathrm{Y}$ a este quenta asintio dha. $\mathrm{D}^{\mathrm{a}}$ Angela en Oencia a tres dias de Abril de mil setezientos y quarenta y cinco años. Ante mi el escribano.

Y aora por parte del expresado Don Joseph Gomez de Noboa como tal tutor y administrador de la persona y vienes de Don Manuel García de las LLanas se a pedido y requerido a la dha. $\mathrm{D}^{\mathrm{a}}$ Angela que otorgue a su fauor escriptura de obligacion y seguro en forma por la expresada cantidad y por ser justo ha venido en ello. Por tanto la mencionada $\mathrm{D}^{\mathrm{a}}$ Angela Martinez de Torres en la forma que mejor haya lugar de derecho y mas firme sea, estando y sauedora de que en este caso la pertenece, confiesa y reconoce, que la dha. quenta esta legitimamente tomada y arreglada y que las partidas de su Cargo y data son ciertas y verdaderas, y su alcance lexitimo y justo, que por lo mismo lo tiene consentido y nuebamente consiente; y por la presente sin que sea visto alterar ni innobar en cosa alguna la zitada escriptura de el dho. arriendo, sus clausulas y condiziones y en espezial la que contiene la obligacion de lapaga de las dhas. partidas de vena nueba y vieja, carbon y requa, que asi reciuio el dicho don Francisco Muro antes, si dejandola, como la deja en su fuerza y vigor y derecho anterior añadiendo fuerza a fuerza , y contrato a contrato, otorga que se obliga con su persona y vienes muebles, semovientes y raizes, derechos y acciones hauidos y por hauer de dar y pagar, y que dara y pagara realmente y con efecto al dho.Don Manuel Garcia de las LLanas y en su nombre al expresado don Josep Gomez de Noboa, como tal su tutor, y Administrador de su persona y viens, o a quien por la cobranza su poder o derecho huuiere, los referidos veinte y tres mil quatrozientos y nobenta reales y dos mrs. del dho. alcaze en monedas usuales y corrientes al tiempo de la paga, los quales confiesa deuerle por las razones sobredichas y del se contiene por real y verdadera Deudora, y da por entregada, contenta etc (...)

Y el dicho Lizenciado don Joseph Gomez de Noboa en nombre deel expresado don Manuel García de las LLanas, su menor, y como tal su tutor, auiendo visto la obligacion a su fauor hecha por la dha. $\mathrm{D}^{\mathrm{a}}$ Angela Martinez de Torres, dijo: que la aceptaba y acepto para usar de ella como mejor le combenga. Y es condizion expresa entre dichos otorgantes que si la referida $\mathrm{D}^{\mathrm{a}}$ Angela probare clara y distintamente y en forma jurídica

no estarle anteriormente auonados los gastos y expensas que dize hizo y suplio en la retificacion de la Descarga, o caualleriza de la dicha Herreria el dho menor y su tutor en su nombre se los auonara en quenta de los dichos veinte y tres mil quatrocientos y nobenta rs. y dos mrs. de el expresado alcaze, o se los satisfara de los viens y efectos de dicho menor y a ello quiere que se le compela por 
Justicia via execucion y todo rigor de derecho y a pagar las costas y daños, que de lo contario se la siguieren y causaren. Como tambien la referida $\mathrm{D}^{\mathrm{a}}$ Angela Martinez de Torres se abliga en la misma conformidad a que justificandose por el Lizenciado Don Joseph Gomez que la presa y vanzado de dha Herreria su caja $\mathrm{y}$ armazon estaua todo ello muy bien compuesto y reparado al tiempo que entro en el arrendamiento dicho Don Francisco Muro, que quando fenecio el de la sobredicha y hizo entrega de dha Herreria a dho Lizenciado Don Joseph Gomez le pagara realmente y con efecto el ymporte integro, todos los desauonos y desmejoras a cuia paga consiente ser apremiada por via executiva y todo rigor en derecho a pagar todas las costas y salarios que en este particular se causaren, et.....Y asi lo firmaron ambos ante mi dicho escribano, siendo testigos Don Gregorio Martínez Delgado (rendero o residente d) n dicha Herreria de Pontepetre; Bernardo de Duicias natural de dicha villa de Ponferrada y Francisco Lopez criado de dicha $\mathrm{D}^{\mathrm{a}}$ Angela y de los otorgantes a quienes doy fee y conozco, firmo el que supo y un testigo de la que dijo no sauer. Ante mi Joseph Antonio Tavano.

\section{$-19-$}

1746, octubre, 9. Froxan

Poder de Bernardo San Martín, del Mazo de Santigoso, que fue fiador de Francisco Alvarez, arrendatario de la ferrería Nueva, propia del señor de Veyga de Forcas.

AHPL. PN.: Caja 3342, ff.

En el lugar de Froxan, feligresia de san Vizente de Villamor, jurisdicion del Courel, a nuuebe días del mes de octubre, Año del mil setecientos quarenta y seis. Ante mi escribano de su Magestad publico y testigos, parecio presente Bernardo de san Martín vecino del lugar del Mazo de santigoso, de esta dicha feligresia, y dejo, que en la mejor via, que en derecho aya lugar, firme y valedero sea da, y otorga, todo su poder cumplido, quan bastante, y el que de derecho se requiera, con clausula expresa, de que lo puedan jurar, y substituir las veces necesarias; Y en las personas, que les pareciere, a Silvestre Rodriguez, vecino del lugar y feligresia de santa Marina de Folgoso, y a Pedro Ramos, vecino de este dicho lugar; y a cada uno deellos, insolidum, para que en nombre del otorgante, y representando su persona, puedan parecer y parezcan ante Juan Antonio Alvarez de Lamas, escribano de su Magestad dela Gobernacion deel Valcarce; y le defiendan en una ejecucion en que entiende con reales Provisiones, de la Real Audiencia de este Reyno ganadas apedimento de Don Mathias Hernando de Armesto y Ordoñez Dueño de las Jurisdiciones de Veyga de forcas, contra Francisco Alvarez, sobre la paga de la Renta de la Herraria nueba, que ha llebado en arriendo de mano de dicho Mathias, en la que pretende dicho escribano comprehender la persona y vienes de dho. otorgante, como fiador que ha sido, con otros, deel referido Aluarez, sin preceder primero la rigurosa extincion, o escursion de todos sus vienes, derechos, y acciones. Y en razon de todo ello, presenten pedimentos, papeles, testigos, provanzas, pidan testimonio, querellen de exceso, etc... Asi lo otorgó y no firmó, porque dijo: no sauer, a su ruego lo hizo un testigo, que lo fueron presentes Don J. Antonio Valcarce, vecino de la Herreria de Valdomir, Juan Ramos vecino de este lugar, y Jacinto 
Alvarez el menor vecino del dicho lugar del Mazo. E yo escribano de todo ello doy fee; y que conozco el otorgante. Ante mi Joseph Antonio Tavano.

-20-

1749, septiembre, 3. Ferrería de Arnado

Subarriendo de la ferrería de Arnado, propia de don Juan de la Puebla, que hacen don Joaquín Perejón, doña Teresa Muro y doña Angela Martínez Torres a don Agustín Morais y a su mujer doña Margarita Losada.

AHPL. PN.: Caja 3342, ff. 36r-37-r.

En la Herrería de Arnado a tres dias del mes de septiembre de mil setezientos y quarenta y nueue años, parezieron presentes ante mi escribano publico y testigos Don Joachín Perejon, Doña Theresa de Muro su mujer, y Doña Angela Martínez de Torres, todos vezinos del lugar de Oencia, y con lizencia que primeramente y ante todas cosas que pidió la dha. Doña Theresa a dho. su marido el se la dió y ella la azetó, de cuya lizenzia y azetazión doy fee. Y todos tres juntos de man comun, a voz de uno, y cada uno de porsi y por el todo in solidum, renunziando como dixeron renunziaban las leyes de la man comunidad, diuision, y excurxion de bienes como en ellas y en cada una de ellas se contiene. Dixeron que desde luego hazen suelta dela Herrería de Arnado que tienen arrendado a Don Juan de la Puebla de todo el tiempo que les falta de dho. arriendo, segun consta de la escritura principal que tienen echo arriendo, y con las mismas clausulas y condiziones que en dicha escritura se contienen; hazen la zesion, buena, mera, perfecta, e irreuocable, a fabor de Don Agustin Morays de Losada y a Doña Margarita Losada y Guerrero, vezinos de San Esteban de Baldeorras, por que han de dar y pagar realmente y con efecto en cada un año de los que la administraren a Don Juan de la Puebla, vezino de Carandia lo que contiene la escritura echa a fauor de este, puesta y paga esta cantidad donde preuiene dha. escritura y ademas de esto sea visto que dicho Don Agustin y su mujer se obligan a pagar asi mismo a los dichos Don Joachin, Doña Theresa y Doña Angela cien quintales de yerro de lo que produgese dicha Herrería bueno de dar y tomar, en cada un año delos que administrasen dho. arriendo en tres plazos como los señala la escritura echa en fauor de dho. Don Juan, Y empieza a correr este arriendo desde el día veinte del presente mes y año, Y es condizión que en terminos que los fiadores que han afianzado a dhos Dn Joachín, Da. Theresa y Da. Angela no se contenten con el abono de dicho Dn. Agustín y Da. Margarita Losada y Guerrero sea visto que estos hayan de dar fianzas abonadas y aprobadas por la justizia hordinaria de la Jurisdizion de Baldeorras con zitazion de dhos fiadores. Y tambien es condizion que la dicha Herrería quando la haya de dexar quede en la misma conformidad y disposizion que se la entregamos, a vista de hombres de inteligenzia que lo reconozcan, como tambien las alajas y pertrechos de la Herrería las aya de reziuir y despues entregar en la misma conformidad que las reziuiese. Y los dichos Dn Joachin, Da. Theresa y Da. Angela se obligan en forma por mas o menos que otros dieren a hazer seguro este arriendo, y dicho Dn. Agustin y Da. Margarita Losada y Guerrero azetaron esta escritura como ba stipulado con todas las condiziones que expresa como la que dho D. Joachin hizo a fauor de dho. Dn. Juan de la Puebla, y por obiar prolixidad las ha aqui insertas y repetidas de nueuo. Y unos, 
y otros se obligan con sus personas y bienes, presentes y futuros, y renunziazión de todas leyes, fueros y derechos de su fauor, y dan poder a las Justizias, y Juezes de su Magestad competentes, cada uno a los de su fuero se lo hagan cumplir, reziuiendo como por sentenzia dada, y pronunziada en authoridad de cosa juzgada, consentida y no apelada, etc... En cuya firmeza la otorgan asi todos juntos, ante mi el escribano, siendo testigos Dn. Francisco Antinio de Alua, cura de Jestoso, Josph Rodriguez Alcalde hordinario de esta merindad de Aguiar, vezinos de la Vega de Cascallana, y Antonio Balcarze, vezino de el lugar de Oenzia, y los otorgantes, a quienes doy fee conozco firmaron los que supieron y por los que dixeron no sauer lo firmó uno de los testigos. Ante mi Joseph Antonio Tavano.

$-21-$

1750, junio, 9. Oencia

Convenio entre el arrendatario de la ferrería de Arnado y sus fiadores

AHPL. PN.: Caja 3342

En el lugar de Oencia marquesado de Villafranca del Vierzo a nuebe dias deel mes de Junio de mil sietezientos y zinquenta, parezieron presentes por ante mi el escribano publico y testigos Dn. Joaquín Perejon $\mathrm{D}^{\mathrm{a}}$ Maria Theresa Muro su lexitima mujer y con lizencia que pidio para otorgar esta escritura a su marido el se la dio y ella la azepto de qu doi fee. $\mathrm{D}^{\mathrm{a}}$ Angela Martinez de Torres viuda de Dn. Francisco Muro Dn Agustín Morais de Losada= Antonio de Losada= Francisco de Arze $=$ Esteban de Zela $=$ Pasqual Abid $=$ Juan de Zela $=$ Antonio Rodríguez el mozo hijo de AntonioRodríguez difunto, vezinos deste dho lugar de Oencia y dho. Dn Agustín Administrador de la errería de Arnado, Marcos Simon y Domingo Rodríguez vecinos de Losío dijeron que como fiadores y principales pagadores deel dho D. Joachín su mujer y dha Da. Angela y el dho D. Agustín no... y fuera de este los demas de mancomun y cada uno por lo que les toca se conbinieron y ajustaron con dho. Dn. Agustín Morais arrendatario de dha Errería de Arnado en que este les ha de dar y entregar ziento y zincuenta quintales de yerro, los ziento en este presente mes y los zinquenta en el mes de Junio proximo que biene cuios ziento y zinquenta que son por la razon dela obliacion del subarriendo que hizo a los referidos de arriba y gananzia que dho Dn. Agustín tiene ofrezido al citado Dn. Joaquín y estos entiende los años que faltan que daran principio a correr desde el dia beinte y zinco de Julio que biene; cuya obligazion de los dhos dos años la misma que tenía echa dho. Dn. Agustín constta de Doszientos quintales en los referidos dos años y los zinquenta que ban demas por razon de antizipar estos ziento y zinquenta para sus nezesidades les hazen grazia y donazion buena mere perfecta e yrrebocable deellos al menzionado Dn. Agustín como también por la suba que se está experimentando tiene el dho yerro tambien por la continjenzia y riesgo que se expone dho. D. Agustín de que puede benir el escalabro maior de la chapacuña y parar la fabrica de la errería mas de medio año. Y por lo que viera al tiempo que administro dho Dn. Agustín asta beinte y zinco de Diciembre proximo pasado del yerro que abia de dar a dho Dn. Joaquín le damos contenta y rezibo feniquito en forma y por los dos plazos el uno que caio en beinte y zinco de marzo pasado y otro que ha de caer en beinte y zino de julio que biene que 
importan dhos dos plazos sesenta y seis quintales y sesenta y seis libras estos los reserban y consignan en mano de dho Dn. Agustín para que D. manuel de Quiroga vecino de Villafranca Administrador de los caudales de su Excelencia se cobre de la renta que dho Dn. Joaquín y mas nominados fiadores debian de pagar al sr. marques por razon de la referida errería. Y no llegando los sesenta y seis quintales y sesenta y seis libras sehauisto se han de sacar de dhos ziento y zinquenta quintales los que el dho. Dn. Manuel contemplase nezesitar para su credito y espauto y conzicion que por lo que viera a los sesenta y seis quintales y libras que se reserban para el menzionado Dn. Manuel acen que los plazos se cumplan antes deel mes de Octubre proximo que biene queda porquenta y riesgo deel dho Dn. Joaquín y mas fiadores el sacar espera asta todo dho mes deel menzionado Dn. Manuel y por su riesgo paguen las costas y daños que se causaren $\mathrm{Y}$ asi mismo es pacto y condizion que los ziento y cinquenta quintales nominados se han de entregar a Dn. Thomas García Salamanca cura de este dho lugar de Oencia y por el recibo que diese seha visto lo aprobamos como si fuera dado por nosotros mismos y en esta conformidad unos y otros se obligaron en forma a cumplir con lo que arriba ba expresado y se obligan con sus personas y vienes a cumplir con lo capitulado y a las costas que se causaren y para lo cumplir asi dieron poder en bastante forma a las Justizias y Juezes de su Magestad conpetentes para su conozimiento, etc.... En cuya firmeza la otorgan asi todos juntos ante mi dho sno. que firmaron los que supieron y por los que dijeron no saber lo firmó un testigo, siendolos Domingo Lopez Besunas Juan de Villaga, solteros y Juan rodriguez vecinos de este lugar de Oencia, y a los otorgantes a quienes duy fee conozco. Ante mi Josph Antonio Tavano.

$-22-$

\section{3, febrero, 10. San Juan de Noceda (Doncos)}

Contestación al interrogatorio, pregunta 17, de las Respuestas Generales del Catastro de Ensenada sobre la ferrería de Bueyes AGS. C.E. R.G., libro 181, ff. $10606 \mathrm{v}$ y ss.

Teniendo presentes a Domingo de Val de el oficio de arroza, Fernando de Chao, que le tiene de fundidor, peritos en el arte, que en vista de la respuesta (en la que dicen saber responder los encargados del interrogatorio) antecedente se an nombrado por su merced y el juez hordinario de esta dicha $\mathrm{fr}^{\mathrm{a}}$, los quales vaxo el juramento y aceptazion que tienen echo en que se afirman y rratifican de que declaran la verdad en lo que alcanzaren conforme a su arte e intelixencia todo ello en devida forma de que io el escriuano doi fe ...dixeron:

Que dentro del termino de esta fra ${ }^{\mathrm{a}}$, al sitio de Bueis de ella, se halla una Herraria o Artefacto de Fabricar fierro que trauaxa quatro meses y medio de ynuierno, con el agua de el Arroio de Aguas Rubias y con la de nieues y lluvias (no obstante que en el presente año no llega a trauaxar mes y medio por la esterilidad de aguas), la qual mantiene buena plazuela y libre de auenidas, pero si de malisimas entradas y salidas por hallarse encumbrada entre peñas y riscos, que ympiden y azen costoso su bastimiento y breue condicion de caruon, maderas y venas, que esta se alla a la distancia de seis leguas de mala tierra, en cuio distrito se hacen dos transitos. 
Abunda de leña y caruon, sin enuargo que mucho de este es conducido a ella de dos y a tres leguas, declaran que de los quatro meses y medio solo por quinquenio trauajara los tres de ellos que consideran completar nouenta y un dias y el mes y medio restante a cumplimiento de los quatro y medio consideran dicha herraria detenida por los dias de fiesta, dominicas, escalabros de tubera, barquines, gurriones, malogreros, ruedas, martillo, su composicion cauo de martillo, iunque, trilla de agua, aruoles de las ruedas, y otras cosas que a cada paso subceden en semejantes artefactos de esta calidad, la qual pertenece enteramente a don Pedro Luis de Ulloa Miranda y Rivadeneira, dueño y señor de esta dicha $\mathrm{fr}^{\mathrm{a}}$,

y regulan que de los quatro meses y medio, los tres que componen nouenta y un dias ser laborables y que en las veinteyquatro horas que cada uno yncluie producira dicha herraria cinco agoas o masas de hierro cada una de peso de cien libras que hazen quintal, que a este respecto en los nouenta y un dia que por quinquenio lleuan regulados de trauaxo, componen quatrocientos cinquenta y cinco quintales de dicha especie, en bruto o vanda que llaman, y por quanto esta especie su precio no tiene cota fixa, porque en unos años suue y en otros vaxa, y aun en un mismo año acontece tener diferentes precios el quintal como son a quarenta, quarenta y dos, y a este respecto consecutiuos asta cincuenta i dos al que al presente se vende, y a cuio precio ha ascendido por la esterilidad de agua y carestia del año, ni poder ascender a mas por privarse en tal caso el dueño de el consumo y saca que no se verificara artefactos de esta calidad por allarse asistidas de maiores conveniencia, ser mas faciles y menos costosas sus entradas y salidas; en cuia atencion haciendo una formal consideracion rregulan su precio y valor por quinquenio en quintal en quarenrenta y seis reales de vellon, a cuio precio ymportan los nominados quatrocientos cinquienta y cinco quintales, computo principal de dicha herraria, veinte mil nueuecientos y treinta reales vellon, producidos en los nouenta y un dias laborables ya citados, en cuia suma dan por incluidos todos gastos asi de coste de maderas, leña, caruon y vena; como de operarios, aruoles, ruedas, malogresos, gurriones, zepa, martillo, telar, barquines, y por otro nombre fuelles, tulla y otras cosas pertenecientes a la manutencion de dicha herraria que a juicio prudencial y por lo que les consta, regulan en catorze mil quinientosy sesenta rs. vn. que por menor distribuyen en la manera siguiente:

Tiene de coste el aruol maior mil y ciento reales de vellon solo el trauajarla y conducirla al sitio de la herraria, la qual durará quarenta años, de cuia cantidad corresponde a cada uno veinte y siete reales y diez y siete mrs. de la misma moneda.

La rueda de el aruol antecedente tiene de coste su echura, maderas y clauazon quinientos reales de vn., permanece seis años de cuia cantidad corresponde a cada uno ochenta y tres reales y veinte y dos mrs. vellon que juntos con veinte y quatro reales que en cada un año ser precisos para su edificacion ymportan ciento y siete reales y veinte y dos mrs. de dicha moneda.

El aruol menor de la rueda varquinera tiene de coste solo el palo trauajado y puesto al pie de la obra quinientos y cinquenta rs. vn., permenece este aruol doce años de cuia cantidad toca a cada uno quarenta y un rs. y $17 \mathrm{mrs}$. de la nominada moneda. 
La rueda de el aruol antecedente tiene de coste de su echura, madera y clauacion quatrocientos reales de vn., permanece ocho años y cada uno corresponde cinquenta reales que con doce reales que en cada un año regulan precisos para su rehedificacion ymportan sesenta y dos reales.

Los gurriones de estas dos aruoles lleuan trescientas libras de hierro que en bruto ymportan ciento treinta i ocho reales, su echura quarenta i ocho, y porque esto subcede rromperse de hordinario con el crecido peso y trauaxo de loas aruoles y rruedas no pueden hazer su forma rregular solo si la espresion que al tiempo de rromperse los de la rueda maior tienen de coste veinte y quatro rs. vn. el sacar las porciones que de ellos quedan methidos en aruol, y otros tantos de meterlos en ella, y los de la rueda menor solo de meterlos y sacarlos tienen de coste veinte y quatro rs.vn., pero porque el yerro de ellos se aprouecha consideran esta utilidad refundida y compensada con algunos escalabros que en este capitulo se notan, y por lo mismo haciendo una formal consideracion regulan que en los tres meses laborables son precisosy necesarios un juego de ellos a cada rueda que al respecto de arriba ymportan ducientos cinquenta $\mathrm{i}$ ocho rs. vn.

Los malogreros de la rueda maior son de palo de enzina de que careze este rio, y por lo mismo se conduzen del Reino de Castilla, los quales por consumirse muchos y a cada paso, regulan su principal coste, conducion, labrarlos y asentarlos en quatrocientos rs. de vn. en los tres meses laborables.

El martillo haciendose nueuo o en los cinco quintales que importan quinientas libras de hierro en bruto que al precio de regulado de quarenta y seis rs., componen trescientas y treinta rs., la qual llega permanecer quarenta años haciendole la uoca y añadiendole yerro en sus composiciones de cuia cantidad corresponden a cada uno de dichos años ocho reales y ocho mrs. vn. que con treinta en que regulan el yerro y trauaxo de su rehedificazion suman treintaiocho rs. y ocho mrs. y medio de gastos en cada un año.

Regulan al martillo que precede tres caua (cauz) de palo en los tres meses laborables y en cada uno el suio, y cada cauo tiene de coste el cortarlo, labrarlo, su conducion y echarlo treinta rs. vn. que ymportan nouenta rs.

La voga de dicho martillo para azer de nueuo lleua dos quinatles y medio de hierro que a dicho precio ymportanciento y dieciocho rs., dura esta boga veinte años y corresponde a cada uno cinco rs. y veinte y cinco mrs. vn. que con die rs. vn. que regulan thener de coste en cada uno año el apuntarle sus voca y aladicion de yerro suman quinze rs. y veinte y cinco mrs. de dicha moneda.

Los quatro cepos maiores que mantiene el aruol, rueda maior y martillo tienen de coste ciento y veinte rs. vn. y aunque estos zepos pudieran permanecer diez y seis años subcede auer alguno que a los primeros golpes se rompen y por lo mismo regulan poder durar doce años que a este respecto corresponden a cada un año de gastos diez rs. vn.

El iunque lleua quintal y medio de hierro en bruto, su coste a dicho precio ymporta sesenta y nueue reales vn. permanece rehedificandola quarenta años, 
corresponde a cada uno un real y veinte y quatro mrs. vn. que juntos con treinta reales que de ierro composicion regulan se necesitan en cada un año de añadicion a la uoca que a cada paso se gasta completan treinta y un rs. y veinte y quatro mrs. vn.

Los barquines o fuelles de dicha herraria tienen de coste mil y quinientos rs. vn. con sus maderas y cueros y clavazon, estos permanecen dos años, las maderas y los cuaros se gastan cada año, unos estos de por si solos con clauazon, cortido y trauajo de hazerla tienen de coste mil rs. vn. el motiuo de gastarse tam pronto es el de no trauaxar en los siete meses y medio de el año, en cuio tiempo con el descanso se apolillan y carcomen de manera que siempre hes preciso renouarlos, y computando su coste un año con otro regulan thener en cada uno el de mil ducientos y cinquenta rs. vn.

Las tuberas en que se se encaxan los cañones de los barquines son de cobre, estas a cada paso se derriten y consumen, tienen de coste cada una cien rs. vn., la composicion de cada una ymporta la que menos treinta y tres rs. y la que mas quarenta y quatro, y por que estas composicion son muchas en el discurso de el truaxo de dicha herraria y no poder con realidad asemptar su ymporte cierto regulan que en los tres meses lauorables se gastaran y consumiran, por quinqueneo, quatro tuberas, que a dicho precio ymportan quatrocientos rs. vn.

El telar de los barquines tiene de coste su fabrica ciento y cinquenta rs. vn., permanece quando mas ocho años, de cuia cantidad corresponde a cada uno dieziocho rs. vn.

La tulla de el agua esta reputada y es cosa asentada tiene de coste tres mil rs. vn, los dos mil de ellos que corresponde a los palos maiores que mantienen la tulla, su conducion, fabrica y asiento, estos permanecen veinte años, y los mil restantes estan regulados al tablado, su echura y clauazon, y este permaneze seis años y no mas por consumirles las aguas y computada una con otra cantidad con los mismos años corresponden de gastos a cada uno, junto con veinte rs. vn. que regulan precisa para la rehedificacion de dicho tablado en cada uno de los seis añosde su permanencia, trescientos ochenta y seis rs. y veinte y dos mrs.

Y por quanto el tiempo que zesan las aguas y consiguiente el trauaxo de dicha herraria subcede quedar la caruonera en unos años casi llena de caruon y en otros al medio y este se descompone y reduce la maior parte de el a polvo, de suerte que quando principia a trauaxar a la entrada de las aguas no sirue de cosa alguna, regulan un año con otro este desfalco y merma ascender a setecientos y cinquenta rs. vn. al año, porque al tiempo de la fabrica de el caruon subcede que despues de cubiertas las oias se encienden y rompen de noche con el aire de manera que por ello no se aprouecha ninguno consideran esta perdida, un año con otro, en trescientos rs. vn. por hazerse dicha fabrica de quenta del dueño de la herraria.

Este herraria compone cinco oficiales que la son precisos y necesarios a los quales pagan los salarios y propinas siguientes: aquella manquenta laxe el aroza que es el que domina los mas operarios y por cuia quenta corre la fabrica tiene de salario al año seiscientos rs. vn., por solo el trauaxo del tiempo que queda espresado y por cada quintal de hierro que produce la herraria se le paga un real 
y seis mrs. de vn. propina que llaman quintalaxe, que en los quatrocientos cinquenta y cinco quintales ymportan quinientos treinta y cinco rs. y dies mrs. vn., que xuntos con los de arriua suman un mil ciento treinta y cinco rs. y diez mrs. vn.

El tirador tiene por su salario quatrocientos rs. vn. al año y en cada quintal un real de vn. por razon de quintalaxe, que en los 455 quint. De la principal producion ymportan otros tantos reales y juntos con lo de arriua suman ochocientos treienta y cinco rs. vn.

Dos fundidores tiene cada uno de salario ducientos quarenta y dos rs. vn. de su salario al año y por las propinas de quintalaxe perciue cada uno treinta mrs. vn. que en los 455 quint. Ymportan los pertenecientes a los dos fundidores ochocientos dos rs. y treinta y dos mrs. que juntos con los de sus salarios suman un mil ducientos ochenta y seis rs. y treinta y dos mrs. vn. al año.

$\mathrm{Y}$ asi mismo tienen un tazador que su salario annual es el de ciento setenta y seis rs. vn y en cada quintal por razon de propinas diez y siete mrs. de que en los dichos 455 quint. que llevan regulado producir dicha herraria suman ducientos veinte y siete rs. y diez y siete mrs. vn. y juntas estos con los de su salario ymportan quatrocientos treinta rs. y diez ys siete mrs. de dicha moneda.

Las partidas parece suman siete mil ochocientos sesenta y nueve rs. y un mrs. y medio de vn. y los seis mil sescientos nouenta rs. y treinta y dos mrs. y medio vn. restantes a cumplimiento de los dichos catorze mil quinientos y sesenta rs. vn. del computo principal de gastos los consideran precisos y necesarios (antes mas que menos) para el coste de arranco de vena, su conducion, fabrica y consumo de caruon, leña para el cocimiento de vena, ceuada de las cauallerias que conducen el caruon, paga de salarios a los caruoneros i maiodormo que corre con la dispensa y recoximiento de hierro que no sauen lo que ymportan, remitense a lo que ellos o el dueño dixere por sus asientos, y reuajados (reusanados) de los veinte mil trescientos y treinta rs. de vn. de la producción principal de dicha herraria, los dichos catorce mil quinientos y sesenta que le regulan de gastos quedan de liquido para el dueño seis mil trescientos y setenta rrs. Vn. que al año le consideran de util sobre el poco mas o menos.

Y en lo que mira a la dispensa en que se despacha pan cocido, y ai la preuencion de carne, vino, azeite, pescado y queso para la manutención de los oficiales declaran que por estar la herreria en un monte desierto, retirada de toda vereda y sin ninguna vecindad, y por lo mismo no thener mas consumo que el que hazen los propios oficiales, dispensero y dos caruoneros en los quatro meses y medio de el truaxo de dicha herreria, por lo qual regulan su utilidad en quinientos y cinquenta rs. vn. al año. 
1760, diciembre, 7. Portela de Aguiar

Venta de cepo de urz del concejo de Portela de Aguiar al administrador de la ferrería de Pontepetre

AHPL. PN.: caja 3340.

En el lugar de la Portela de Aguiar a siete dias deel mes de Diciembre de mill setecientos y sesenta años, ante mi escribano y testigos parecieron presentes los Regidores oficiales vecinos y conzejo deeste dho lugar, segun tienen estilo juntarse en el sitio acostumbrado para conferenciar las cosas utiles al beneficio de su población, expecialmente Francisco Lopez, Matheo Alvarez, regidores, Joseph Barba procurador; Antonio Quiroga, Francisco Marcos, Thirso Garzía, xrisptoual Ares, Lorenzo Santin, Julian Ares, Joseph Chamorro, Bernardo Diaz Mendez, Francisco García Diego, Marcos, Phelipe Marcos, Dionisio Rodriguez, Carlos Rodríguez, Joseph de Prada y Basilio Franco, quienes confesaron ser la mayor y mas sana parte tocante a vecinos de que se compone dho concejo, y por los ausentes enfermos e impedidos, que no pudieron ser hauidos prestan voz y caucion de rato grato et iudicatum solvendo, en que estaran y pasaran por lo que en virtud de este se hiciere, so expresa obligacion que hacen de sus personas y vienes, quienes asi juntos todos de mancomun a voz de uno y cada uno de por si $\mathrm{y}$ por el todo insolidum renunciando como renunciaron las leies de la mancomunidad diusison y escursion de viens y mas del caso como en ella y en cada una se contiene dijeron que se obligan con sus personas y vienes muebles y raices presentes y futuros, y con los juros y rentas de dho concejo a pagar realmente y con efecto en arranca de cepo de urcedal hasta el cumplimiento y cantidad de quatrocientos y cincuenta rs. de vellon en el discurso de este presente ymbierno para la herreria de Pontepetre, a favor de su Administrador Don Gregorio Martínez Delgado, que ha de efectuar la entrega de dha cantidad en mano deel dho Julian Arias al qual consienten sera bien dada y efectuadaques ea se constituien reales y verdaderos deudores deella, y por no ser presente renuncian sus leies de la citada entrega y mas del caso, cuia satisfaccion de arranca executaran en dho tiempo y con la brebedad posible uajo pena de execucion y costas y la de diez cañadas de vino aplicadas al dho concejo que han de pagar las personas que faltaren el día que se les asignare por su turno e nombrado por el citado concejo en razon de dho arranque, para ciua execucion dan todo su poder a las justicias de su magestad competentes que a ello les apremien por todo rigor de derecho y via executiva, etc. Siendo testigos Don Pedro Quartas, Mathias Castellano, residentes en dicho lugar, y Francisco Ferreiro, vecino del de Oencia, y los otorgantes que dou fee conozco firmaron los que supieron y por lo que no uno de dhos testigos. Ante mi Bentura Castellano.

1761, abril 23. Ferrería de Pontepetre

Poder del arrendatario de las ferrerías de Pontepetre y Visuña para cobrar deudas por la venta de hierro.

AHPL. PN.: Caja 3341. 
Don Gregorio Martínez Delgado vecino de la villa de Benavides, Administrador de la herrerá de Pontepetre, sita en la Merindad de Aguiar de la Lastra, reinode León, y Arrendatario de la herrería Nueba sita en el real coto de Besuña, Reino de Galicia, digo: que por quanto diuersas personas assi vecinas de esta merindad y Real coto de Besuña, como otras de las jurisdiciones deel Balcarce, Barjas, Villafranca, Puebla de Sanabria, Castromil, Tierra delas frieiras, Tabladillo, Combarros, Brazuelo, Villalibre y Lagunas de la Somoza, tierra de Maragatos, me estan debiendo varias cantidades de mrs. procedidas de hierro, que les he vendido al fiado, assi en esta dha herreria como en la Nueba, por medio de la persona de Don Manuel Martínez mi hermano que la administra; de dinero prestado, machos y otras caballwerias que a algunas de dhas personas tengo vendido al fiado, cuios plazos entan fenecidos, para su Recaudacion, percepcion y cobranza, judicial y extrajudicialmente, doi y otorgo todo mi poder cumplido, el que de derecho se requiere, mas pueda y deba baler al sr. Licenciado Don Bentura Garcia Teixo (d) Abagado de los Reales Consejos, vezino de la ciudad de Astorga, y a dho don Manuel Martinez mi hermano, a ambos y acada uno insolidum para lo que va expresado; y con la facultad de que lo puedan jurar y sustituir en las personas y veces que les parecieren revocar los substitutos y crear otros de nuebo para pedir execuciones , pagos, seguir pleitos y demandas, y no mas. En virtud deel qual puedan dichos apoderados haver, cobrar y percivir todoas las cantidades que se esten debiendo, etc....En testimonio de lo qual, lo otorgo por firme este poder ante el presente escrivano, en la dicha herreria de Pontepetre a veinte y tres dias deel mes de Abril de este año de mil setecientos i sesenta y uno. El otorgante que io el escrivano doi fe conozco lo firmó y firmé, siendo testigos Antonio Lopez, Pedro Franco y Domingo Besuña, todos veci nos de el lugar de Oencia. Doy fe Castellano.

$-25^{-}$

\section{2, mayo, 27. Real cédula a favor de D. Antonio Tomás Flórez Losada para la construcción de una ferrería en las aguas que bajan de Robledo de Domiz. AHPO. Archivo de la Casa do Castro, no 647, caja 137}

Don Carlos por la gracia de Dios Rey de Castilla, de León, de Aragón, de las dos Sicilias, de Jerusalem, de Navarra, de Granada, de Toledo, de Valencia, de Galicia, de Mallorca, de Cerdeña, de Cordova, de Corcega, de Murcia, de Jaen, señor de Vizcaya y de Molina: A vos las justicias ordinarias de la villa de Castro de Valdeorras, en el Reyno de Galicia, y demas ministros y personas a quien lo conthenido en esta nuestra Carta, tocare, y fuere notificada, salud, y Gracia, saued que a instancia de don Antonio Thomas Flores de Losada, Somoza y Moscoso, vecino de dicha villa de el Castro de valdeorras, por decreto de los del nuestro Consexo de ocho de julio del año pasado de mill setecientos cinquenta y siete, se le concedió licencia y facultad para que sin incurrir en pena alguna en el sitio de valdefuero, término del castro de Valdeorras pudiese construir y fabricar de nuebo una Herreria con los adherentes correspondientes a su uso, y permanencia abriendo la zanja combeniente para llebar a ella el Agua desde el Rio deel Robledo de Domiz, que vaxa de los montes de Casayo, y cusoyo (sic), y pasa inmediato a dicho sitio, rompimiento de tierras para las minas, y conducir la vena para surtir dicha Herreria en los terminos de san miguel de viobra, 
lugares de villar de silba, Pardolan y demas Pueblos nominados en la instancia hecha por el citado Losada, a quien se le libró el Despacho correspondiente en once del referido mes de julio de dicho año de mill setecientos cinquenta y siete y por parte de este se ocurrió al nuestro Consexo en once de febrero pasado de este año, refiriendo lo antecedente y facultad que se le hauia despachado para la construccion de la dicha Herrería, y para el arranque de piedras, vena para el ministerio y provision de ella, preuiniendose no se le embarazase el que la ... en los minerales del distrito, y sus cercanias y Reyno de Leon, en virtud de lo qual hauia fabricado la expresada Herreria, y la hauia puesto, y tenia corriente sin contradiccion, ni oposicion de persona alguna, y nos hizo relacion que hauiendose requerido a las justicias ordinarias de aquellos territorios, al nuestro Correxidor Yntendente de la ciudad de Leon y su Alcalde maior que la hauian aceptado, y dado el deuido cumplimiento, segun resultaba del testimonio que tambien presentó, pero sin embargo de todo ello experimentaba el referido su parte, la nobedad de que por diferentes Personas que le profesan desafecto, odio y mala voluntad se ha procurado y procura embarazar el corriente de la citada Herreria, y el arranque y conduccion de la piedra vena para ella sin mas motiuo que el de perjudicarle en los crecidos caudales, que expendió en aquella fabrica, y esta contrabencion la toleraban vos las Justicias de esa villa, a lo menos tacitamente denegandoos a mandar se diesen a su parte los testimonios, que repetidas vezes ha pedido para formalizar la correspondiente quexa, lo que cede tanto en su perxuicio, quanto en querer por este medio dexar Ylusorio lo resuelto por el nuestro consexo en la prenotada Real cedula Nos suplico fuesemos seruido mandar librar a fauor de su parte Real Provision sobre carta, para que vos las justicias de esa referida villa cumpliesen en todo y por todo con su thenor, sin contrauenirle, ni permitir que persona alguna le contrabenga, ymponiendoos para que assi lo cumplieseis las multas y aperciuimientos que fuesen de nuestro superior agrado y que vaxo de las mismas diesen a su parte los testimonios que fuesen conducentes para la defensa de su Justicia. Y visto por los de nuestro Consexo con los demas antecedentes a lo referido tocantes, y lo que en su razon se expuso por el nuestro Fiscal por auto que probeieron en once de este mes se acordó dar esta Nuestra carta. Por la qual os mandamos que luego que con ella fuereis requeridos le mandeis dar y entregar a dicho Don Antonio Thomás Flores de Losada, Somoza y Moscoso, los testimonios que pidiere delo que constare y fuere de dar en razon de lo referido con el aperciuimiento que os hacemos que si assi no lo hiciereis, y cumpliereis se procederá contra vos a lo que hubiere lugar en derecho, y que ... y es nuestra voluntad, que en las instancias, que en este asumpto le ...rran al citado Don Antonio Thomas Flores de Losada Somoza y Moscoso acuda a la nuestra Real Chancilleria y unos y otros lo cumplireis pena de la nuestra Merced y de cinquenta mill maravedis para la nuestra Camara lo qual mandamos a qualquier nuestro escribano que lo notifique y de ello doy testimonio. Dada en Madrid a veinte y siete de mayo de mill setecientos sesenta y dos.

\section{$-26-$}

1768, septiembre, 22. Villafranca

Poder del señor de Noceda, dueño de la ferrería de Herrerías de Valcarce, a don José Piñeiro, mayordomo en su ferrería para que pueda cobrar las rentas, poner pleitos, etc.

AHPL. PN.: Caja 3353. 
En la villa de Villafranca a veinte y dos dias de el mes de septiembre de mil setecientos sesenta y ocho años, ante mi escribano y testigos parecio presente Don Joseph Piñeiro vezino y residente en el lugar de la herraria de Valcarce y maiodormo de Don Pedro Luis de Ulloa, Miranda y Riba de Neira dueño de la Jurisdicion de Noceda, residente en la villa y corte de Madrid, y dijo que este en treinta y uno de Jullio del año pasado de mill setezientos sesenta y uno le dio y otorgó Poder especial y General para la Cobranza y percepcion de sus rentas, poner y seguir qualesquiera Pleitos, y Demandas amplio y sin limitazion y con clausula de sobstituirle siempre que fuere necesario segun constaua de dicho poder que paso por mi testimonio que es el siguiente.

Poder

En el lugar de la Herraria de Valcarce Jurisdicion y merindad de este nombre, a treinta y un dias deel mes de Jullio, Año de mill Setecientos y sesenta y uno, ante mi el escribano y testigos parecio presente Don Pedro Luis de Ulloa Miranda Riua de Neira Florez y Omaña Dueño de la villa y Jurisdicion de Nozeda y otras en el Reyno de Galicia, y de la Herraria que reside en este dho lugar con regia facultad para su conseruazion y Dijo, da y otorga todo su Poder cumplido el que en derecho se requiere sean necesario mas pueda y deua valer a Don Joseph Narciso Lopez de Quiroga Presbitero y Don Joseph Piñeiro de estado soltero residentes en dicho Herraria, a ambos juntos, y cada uno de por si con clausula expresa

$-27-$

1769, junio, 12. Villafranca.

Arriendo de la ferrería de Arnado a don José Martínez de la Fuente, vecino de Ponferrada, por tres años y renta anual de 13.750 reales AHPL. PN.: caja 3353

En la villa de Villafranca A doze días deel mes de Junio año de mill setecientos sessenta y nueue, Ante mi el essno. y testigos parecio presente Don Joseph Martínez de la Fuente, vecino de la villa de Ponferrada y Dijo se obligaua y obliga y obliga (sic) con su persona y uienes muebles y rraices presentes y futuros, de dar y pagar y que dará y pagará realmente y con efecto al exmo. señor Marqués de estos estados mi señor, y a su Administrador General que es o fuere en este dicho estado y a quien su Poder y derecho ubiere en qualquiera manera A sauer trece mill seiszientos y zinquenta reales vellon en cada un año de tres que tienen principio en el día veinte y cinco de Jullio proximo venidero de este presente año y fenecen en otro tal de el mill setezientos settenta y dos. La mesma cantidad en que al otorgante se le remató por el sr. Don Manuel Ventura Blanco theniente de Correxidor y administrador General de las rentas y efectos deeste dicho estado y marquessado como a maior postor, la Herrería de Arnado propia de este estado y de que se alla poseedor dicho exmo. señor Marqués mi señor, con la expresa condición de que siempre que dicho herrería tenga escalabro en la chapacuña y aruoles maiores y zepos de dicha Herrería An der ser de quenta de dicho excmo. señor Paredones y chiflones según costumbre de todas las demás Herrerías, y los Reparos Menores de quenta del otorgante tanuien segun costumbre; cuia cantidad de dichos trece mill seis zientos y zinquenta reales de vellon dará y pagará en cada uno de dichos tres años en dos 
pagas y plazos yguales Nauidad que uiene y Santiago de cada uno y la primera la ha de acer para el dia de Nauidad de este presente año de la fecha, y la segunda para el día de santiago deel proximo venidero de mill setezientos y settenta, y las demás pagas por dichos dias y plazos llanamente y sin escusa alguna pena de execución, etc. (....) siendo testigos don Joseph de Alua e Bentura MonteAgudo y Thomas de Otero vecinos de esta villa, el otorgante, lo firmó A quien doy fee conozco. Ante mi

$$
-28-
$$

1769, septiembre, 11. Ferrería de Quintá Cuentas de la ferrería de Quintá que presenta el administrador don José de Ron a su dueño don Sancho de Neira. AHRG. Hombreiro. Libro de cuentas de la ferrería de Quintá

El caudal que yo Dn. Jph. De Ron Administrador de la herrería de Quintá de que es dueño el Sr. Dn. Sancho de Neira, entrego a Dn Juan de la Peña, nuebo Administrador puesto por dho. Señor, con assistencia de dn. Pasqual Portela comissionado para este effecto por el predho. Señor, es el siguiente:

Primeramente consta estarse adeudando a dha. Herreria de los Libros de Carboneros onze mil quinientos treinta y tres rs. y veinte y siete mrs.

Mas se adeuda a dicha Herrería del Libro de tratantes siete mil seiszientos treinta y un rs. y tress mrs.

Assimismo consta estarse adeudando a dicha Herreria del Libro de Oficiales mil doszientos treinta y cinco rs. y tres mrs. en que quedan rebajados cinquenta y cinco rs. y diez y seis mrs. de la compra de dos tuberas, y tres libras y media de cobre, que adeudaba Ron, y debe satisfacer dn. Juan Peña.

Del Libro de carreteros y Benaqueros assimismo consta estarse adeudando a dha. Herreria dos mil treze rs. y diez y seis mrs.

Por manera que suman las partidas arriba expresadas veinte y dos mil quatrozientos y trece rs. con quize mrs. 22..413 rs. 13 mrs.

\section{Caudal existente}

En vena cocida ochozientos veinte y seis quintales, y medio quarto, que a razon de cinco rs. y medio el quintal cargado importan quatro mil quinientos quarenta y tres rs. con veinte y tres mrs.

En vena cruda consta asimismo hallarse existentes en la Plaza ochozientos quarenta y dos quintales y medio qto.; que a razon de quatro rs. y medio el quintalsuman tres mil sietezientos ochenta y nuebe rs. con diez mrs.; que juntos con cinquenta y dos rs. y catorce mrs que deja satisfechos de la quiebra en la venera de ciento quarenta y ocho quintales y medio; y sesenta y nuebe rs. y diez y ocho mrs. importe de la quiebra en la plaza de los ochozientos quarenta y dos quintales incluso el medio cantaro de vino, que les corresponde a los mil quintales que le deja pago por vte. Rs. suman en todo tres mil nuebezientos y onze rs. y ocho mrs.

En yerro en la Bodega picado y por picar se hallan existentes nobenta y siete quintales con settenta y quatro libras, que a sesenta y seis rs. el quintal vendido, suman seis mil quatrozientos cinquenta rs. y veinte y ocho mrs. 
En clabo se hallan existentes ciento setenta y quatro millares nuebezientos cinquenta clabos, que a razon de veinte rs. el millar vendido, importan tres mil quatrozientos nobenta y nuebe rs.

En Herraje Baladia doszientas setenta y quatro dozenas, que a doze rs. vendida la dozena, suman tres mil doszientos ochenta y ocho rs.

En Putrical se hallan existentes veinte dozenas y media, que a diez y ocho rs. la dozena suman treszientos sesseta y nuebe rs.

En la Carbonera, segun la regulacion que se tiene hecho de ella, que son diez mil rs. llena, se hallan existentes nuebe mil duzientos sesseta y tres rs.

En pan en grano se hallan existentes ciento setenta y quatro ferrados y medio; sin incluir diez y ocho ferrados de la renta de la casa, que ya estabn en la panera, y las pensiones del foral de Albira y Pedro Rodriguez, que ya estaban pagadas por Ron; y de estos los nobenta y nuebe y medio a diez y ocho rs. el ferrado suman mil sietzientos nobenta y un rs.; y los setenta y cinco restantes a doze rs. el ferrada importan nuebezientos rs.; que ambas partidas componen dos mil seiszientos nobenta y un rs.

En Azeyte se hallan existentes dos arrobas y tres quartas, que a cinquenta y ocho rs. su coste, suman ciento cinquenta y nuebe rs. y diez y siete mrs

En vino quatro cañados y medio, que a quarenta rs. su coste suman ciento ochenta rs

En Lino qurenta rs

En Leña se regularon existentes en la plaza sessenta y siete carros, que tienen de coste treszientos setenta y dos rs.

En sal quinze ferrados y medio, que a quinze rs. su coste, suman doszientos treinta y dos rs. y diez y seis mrs.

Mas se agregan por caudal existente setenta rs. que dio Ron a Antonio para la embarda de Moreda, que en esta quenta quedarán rebajados a Dn. Juan de Peña.

Por manera, que suman todas las partidas arriba expresadas treinta y cinco mil sessenta y nuebe rs. con veinte y quatro mrs. 35.069 rs. $24 \mathrm{mrs}$.

De cuyo caudal asta aqui expresado se rebajan las partidas siguientes, que adeudaba dicho dn. Jph de Ron a diferentes personas, segun anotacion que se halla en su Libro de Carboneros.

Primeramente nuebezientos rs. que adeuda a Cayetano Caldelas vezino de Bustelo.

Yten treszientos y un rs. y seis mrs. al Señor Prior del Hospital

Con mas seiszientos dos rs. y doze mrs. a Joseph Mellide carpintero.

Yten ciento y seis rs. a Joseph Zeballo vezino de Carballo.

Asimesmo se rebajan doszientos nobenta y seis rs. que se adeudan a Francisco Lopez Vezino de San Vitorio.

Yten se rebajan treszientos rs. que se adeudan a Andres Perandones, maragato... Con mas se rebajan nuebezientos rs. que se adeudan al referido Perandones.........

Assimismo se rebajn doszientos veinte rs. que se adeudan al P. fray Angel Guerra.

Yten se rebajan tres mil doszientos ochenta y ocho rs. que se adeudan a la Señora de Guntin

Con mas quatrozientos rs. a la obra pia de Carballo 
Yten se rebajan ciento ochenta y nuebe rs. con veinte y quatro mrs.de las pensiones que se pagan al Comendador y son correspondientes l Sr. Andres de sessenta y ocho.

Mas se rebajan ciento sessenta y un rs. adeudados a Antonio resto de su salario, con lo que le queda satisfecho hasta onze de julio de ssenta y nuebe.

Mas se rebajan ciento setenta y dos rs. que se adeudan a Benita de su salario...... Yten se rebajan ciento veinte y dos rs. con veinte y dos mrs., que se adeudan a Domingo, resto de su salario del año que fenece en veinte y dos de septiembre de sesseta y nuebe.

Yten se rebajan los setenta rs. que entregó Ron a Antonio para la embarda.

Asimismo se rebajan cinquenta rs. y veinte y quatro mrs. que satisfizo dn. Juan de la Peña de los derechos de tributos y sisa correspondiente al tercio fin de Agosto de este año de sesseta y nuebe.

Con mas se rebajan doszientos rs. que adeuda Antonio al señor de Goyan........... Cuyas partidas suman en todo ocho mil treszientos nobenta y cinco rs. con veinte y dos mrs.; que rebajados de los treinta y cinco mil y sesseta y nuebe rs. y veinte y quatro mrs. caudal existente en dicha Herreria, quedan en liquido veinte y seis mil seiszientos setenta y tres rs. y dos mrs.

De cuyo caudal asisi liquidado, que suma, despues de pagadas las deudas, veinte y seis mil seiszientos setenta y tres, y dos mrs. importe de los generos que se hallan existentes, se rebajan las partidos siguientes:

Treinta y ocho rs. para ocho mangos

Mas treszientos para la composicion de la Herreria

Mas quinientos rs. para manutencion de la familia asta que llegue a andar la Herreria.

Que suman estas tres partidas mil ciento y ocho rs., que rebajados de los veinte y seis mil seiszientos setenta y tres rs. con dos mrs., quedan en liquido para las aguas de sesseta y nuebe en setenta, veinte y cinco mil quinientos sessenta y cinco rs. y dos mrs. Caudal que queda en dicha Herreria, y de que se haze entrega a dn. Juan de la Peña, como Administrador que queda en dicha Herreria.

Con mas el importe de las deudas, que se deben a dicha Herreria, quedando a su cargo su cobranza con los Libros que las contienen, de todo lo qual queda entregado, sumando el total de dichas deudas veinte y dos mil quatrozientos y treze rs. con treze mrs.; quedando al cargo de dicho dn. Joseph Ron la cobranza de las que hubiere ocasionado en su tiempo; de cuyas partidas que cobrare se anotarán para rebajarlas del total de todas ellas,en que ban inclusas; y para que conste lo firmamos en dicha herreria a onze dias del mes de septiembre año de mil y setezientos sessenta y nuebe. Firman Pasqual Portela y Juan de la Peña.

$-29-$

1788, agosto, 14. Tejedo de Ancares

Permiso del concejo de Tejedo para la construcción de una ferrería en su término.

AHPL. P.N.: Caja 3492, ff. 88r-89v

A favor de don Bernardo Rodriguez y compañia 
Notorio sea a todos los que este publico Ynstrumento vieren como nos los vecinos y concejo de este lugar de Texedo hallandonos juntos y congregados a son de campana tañida en el sitio y forma acostumbrado como lo hacemos siempre que se ofrece tratar delas cosas pertenecientes a el biencomun de este Pueblo y estando presentes especial y espresamente para el efecto de que abajo se hara mencion Mateo Rodriguez Rexidor, Santiago Rodriguez balcarce, Matias Alonso el Mozo, Pedro Rodriguez, Manuel Josef Matias, Juan Cristobal, Francisco, otro Francisco y otro Matias, Alverto y otro Josef Abella, Santiago Matias Domingo Josef Bernardo Marcos, Julian Roque Manuel, Juan, otro Josef y otro Santiago Martin, otro Josef otro Manuel otro Matias otro Josef y Francisco Rodriguez, Tomas Alonso Santiago Alfonso, Antonio Santiago Martin Santos Juan Lucas Pedro Julian y Domingo Alonso y Juan Taladrid, todos vecinos de este lugar de Texedo y la mayor parte de que al presente hay en el, y por los ausentes enfermos e impedidos por quienes prestamos voz y capcion en bastante forma quienes estaran y pasaran por lo que nosostros hicieremos y otorgaremos y estando assi todos juntos de mancomun a boz de uno y cada uno de nos por si insolidum renunciando como renunciamos las leyes de la mancomunidad como en ellas se contiene division excursion de vienes y lo demas del caso a una voz nemine discrepante, decimos que por quanto Don Bernardo Rodriguez Don Francisco Abellas vecinos de este lugar y Don Geronimo Rodriguez de el de Pereda intentan construir o edificar a sus propias expensas una Herreria o Fabrica de Hierro en termino de este lugar mediante que tenemos superabundantes Montes para la perpetua existencia de la propuesta Fabrica sin ser necesario tocar ni entrometerse a arrancar en los vedados y cotados Montes de que abundamos para Edificios a todos quantos servicios necesitamos en nuestras labranzas como tampoco en los fructiferos; pues con este motivo se exterminaran las fieras que crian y abitan en los mui frondosos Montes que tenemos;ademas de que considerando como consideramos la crecida utilidad que se sigue á nosotros y demas naturales de este real Valle, tanto por tener a mano y con mas comodidad el Hierro, quanto por seguirse el que se emplearan muchos jornaleros en las misma Fabrica sin que salgamos ni salgan por el Mundo, como salimos y salen a servir mendigar y traficar, por la esterilidad del Pais que no produce mas que pan zenteno y alguna castaña para crecida vecindad que contiene este real valle; hemos tenido a bien conceder, como desde luego por el tenor de la presente y en aquella via y forma que mas bien en derecho lugar haya, vajo el cierto supuesto de la aprobacion de esta Escriptura concesion o permiso sobre el efecto de la prenotada Herreria por quien competa, otorgamos que concedemos por nuestra parte licencia, facultad y permiso a dicho Don Bernardo y Compañia para la construccion de aquella a cuyo efecto desde aora para siempre jamas les hacemos gracia y donacion pura mera perfecta e irrebocable que el derecho llama intervivos de toda la piedra agua vena y leña que para dicha Herreria necesiten y sea necesaria en los Montes del puerto y terminos de este pueblo con las precisas condiciones siguientes:

$1^{\text {a }}$ Primeramente es condicion que el susodicho ni compañeros no han de poder propasarse por si ni otra persona alguna a cortar ni arrancar leña, ni arbol fructifero alguno en los sitios Montes vedados y cotados, como tampoco obligar a ello a sus Dueños, quienes accediendo voluntariamente a ello sera por el justo valor, como tambien en el Arranque de Vena a cuya venta tan solamente podran obligar aunque se halle en posesion de estimacion. 
$2^{\mathrm{a}}$ Yten es condicion que el Don Bernardo ni Compañia no han de poder admitir a otro alguno por compañero no siendo vezino en este real Valle de donde precisamente tambien lo ha de ser y quien y los que subcediesen en ella.

$3^{\text {a }}$ Yten es condicion que si quisiese o quisiesen estos o aquel y quien en dicha Herreria subscediese pasar a arrendar, vender, o permutar a persona alguna que sea vecina de fuera de este real valle la precitada Fabrica despues de hecha o antes de perfeccionarse en ninguna de estas ocasiones lo puedan hacer ni aun intentar y si lo hiciesen ha de ser preferido este Concejo y caso de que por algun evento no le acomodase el de Pereda, y si a este tampoco adoptase qualesquiera de este real Valle.

Con cuyas condiciones y cada una de ellas otorgamos esta Escriptura a fabor del susodicho Dn. Bernardo Campañia sus herederos y demas subcesores perpetuamente, y estando aquellos presentes decimos aceptamos esta Escriptura con la mayor estimacion de la gracia que dichos vezinos y concejo nos hacen y nos obligamos a cumplir las prenotadas condiciones; y ass, otorgantes como aceptantes al cumplimiento de lo que dicho es obligamos nuestras personas y vienes muebles y raizes abidos y por aber y los comunes y particulares de este concejo y damos poder el que se requiere a las Justiccias que competentes sean para que nos compelan a lo aqui contenido que recivimos por sentencia definitiva pasada en autoridad de cosa juzgada cerca de lo qual renunciamos todas las leyes fueros derechos de nuestro fabor con la general de ellas en forma. Y assi lo otorgamos en este lugar de Texedo á catorce dias del mes de Agosto de mil setecientos y ochenta y ocho años ante el infraescripto Escribano y testigos, siendolo presentes Manuel Rodrigo mozo soltero natural del lugar de Espinareda, Favian Abella, Diego y otro Manuel Rodriguez tambien solteros naturales de este lugar y de los otorgantes y Azeptantes a quien doi fee conozco firmaron los que dijeron saver y por lo que no lo hizo uno de los testigos y en fee de ello lo firmo. Ante mi DomingoRodriguez Carballo.

1789, junio, 2. Villafranca

Obligación e hipoteca de bienes para pagar al administrador de la ferrería de Montes hierro sacado al fiado. AHPL. PN.: caja 3465, ff. 127r-127v.

En la villa de Villafranca a dos dias deel mes de Junio de mil setecientos y ochenta y nuebe años, ante mi el escribano publico y testigos parecio presente Juan de la Yglesia vecino de la de Pereje y dixo: que abra año y medio poco mas o menos passo a la Herreria de Montes y sacó al fiado al P. Fr. Manuel Nuñez, digo Albarez deel Horden de ntro. P. San Benito su Administrador con carta que le dio a dicho fin Don Antonio Vidal y Figueroa vecino de San Jorge de Sacos Arzobispado de Santiago Reyno de Galicia y residente en esta dicha villa doze quintales de yerro a precio cada uno de ziento y diez rs. vn. y aunque paso el plazo que le asignó para su satisfaccion, con mucho exceso, no lo pudo azer por lo calamitoso deel año y barios trabajos que le han ocurrido por cuio motivo dho. fr. Manuel Albarez estrecha a la paga al referido Don Antonio Vidal y este esta pronto a azerla de los mil trescientos y veinte rs. vn. que ymportan dhos doze quintales siempre que el otorgante se los asegure, por lo que se obliga con su persona y vienes muebles raices, presentes y futuros, de dar y pagar, que dara 
y pagara a dicho D. Antonio, o a quien su poder y derecho ubiere en esta villa su mano bajo la pena de ejecucion, decimas y costas los referidos un mil trescientos y veinte rs. vn. en una sola paga para el dia ultimo de este mes que rije y sin que la obligacion general derogue, ni perjudique a la especial, ni por el contrario la una a la otra sino que de ambas y cada una se pueda husar hipoteca a la seguridad y cobranza de dha cantidad baxo la clausula de nom alienando: una vila con su porcion de Poulo que tiene al sitio que llaman el Toleiro o chas termino del lugar de Bilela de azer veiente siete jornales de caba que confina por un lado con viña de Don Sebastian Coronel el menor en dias vecino de esta dha villa que le bendio el otorgante y por los demas ayres con caminos publicos, que es libre diezmo a Dios. Y una cortina linar al sitio deel Lameiron de cauida de media fanega de linaza dezmario de dha villa de Pereje, que linda por el nacie nte con linar de Francisco Arias, al mediodia mas de Diego Lopez, al poniente mas de Manuel Lagua y al norte de Domingo de Silba, todos vecinos de esta dha villa de Pereje, con la pension que sobre si tenga al Real Hospital de Nuestra Señora del Cebrero y por libre de otra alguna, cuia viña y linar no bendera trocara, ni en manera alguna enagenerá hasta estar satisfecha dha cantidad antes vien consiente que no pagandola al plazo asignado se pongan en publica venta y rematen al mayor postor Judicial y extrajudicialmente y de su balor y el de los demas sus viens que tiene y tubiere se haga yntegra satisfaccion al ynsinuado Don Antonio, con las costas, salarios y derechos, etc. Asi lo otorgo siendo testigos Don Andres Carracedo natural desta villa, Antonio Ribas vecino deella y Manuel Gonzalez vecino de Parada de Soto, de lo qual doy fe y que adberti al otorgante y dho Vidal que se deuia tomar la razon para llevar de esta escritura en el oficio de Ypotecas. doy fe asimismo que les conozco y lo firmaron y firme. Ante mi. Manuel Quiroga Valcarce.

\section{$-31-$}

1791, mayo, 6. Villafranca

Poder de don José María Tineo, dueño de la ferrería de Bueyes, para la defensa ante los tribunales de su venera en la mina de Formigueiros.

AHPL. P.N.: caja 3377, ff. 171r-173

En la villa de Villafranca del Vierzo a seis dias del mes de mayo de mil sietezientos noventa y uno, constituido personalmente Ante mi el essno. por S.M. y testigos, el señor Don Josef Maria Tineo y Ulloa, osorio, sierra, cienfuegos y Boniseni, Dueño de las cinco villas, delas Regueras, la de San Juan de Noceda y su jurisdicion, cauallero maestrante de la Real de Valencia, Rexidor perpetuo del conzejo de salas Principado de Asturias, y residente en esta expresada villa Dijo: que a imitacion de sus causantes, Dueños y posehedores de la casa y Mayorazgos de Noceda, siempre estubo y se allaron posehedores, cada uno en sus respectivos tiempos de usar y aprovecharse de una venera situada en la Montaña llamada de Formigueiros, aconsequencia de titulos lexitimos, Arrancando de ella, con independencia de otro alguno, toda la vena necesaria para el consumo de su Herreria de Bueyes, a vista, ciencia y consentimiento de todos, hasta que en el año proximo pasado por el Administrador de la Herreria de Soldon, llamado Don Josef Diaz, presvitero, por si y medio de operarios de 
mano maior y caso pensado se propasaron a introducirse en la citada venera Arrancando y extraendo considerable numero de carros de vena, apretesto de suponer tener derecho en aquellos Minerales y su termino, valiendose dela ausencia del Sr. Otorgante, y distancia de sus Administradores para ejecutar dho. atentado, sobre que dio querella de fuerza en el Rl. Tribunal, aque hicieron su contradicion, y evacuó el reconocimiento y vista ocular mandada azer, y con vista de todo se dio Real Auto, por el que se declaró no hauer lugar al hordinario intentado por una y otra parte y que todos usasen sin emulacion, en conformidad de sus foros. Pendiente el recurso, sin emabrgo de que ala contraria le constaba muy vien que el Peñasco o canto donde verificó la infraccion ala posesion, hera propio anexo y correspondiente a la Venera quelos proxenitores del Sr. Otorgante descubrieron, y deque siempre usaron y que en ella ninguno puede ni deue introducirse a Arrancar ni extraer casa alguna, segun plena y concluyentemente esta probado, lo mismo que sucede con respecto a las otras Veneras de aquella continencia, y de que usan con independencia sus respectivos Dueños, quedando al arbitrio de cada una el descubrimiento delas que le parezcan en aquella Montaña, por el dro. promiscuo, aunque limitado, con atencion a aquellos Minerales o Veneras descubiertas por qualquiera particular interesado, en que ninguno despues tiene dro. para inferirse en ella en fuerza dela practica y posesion inmemorial, que por todos, reciprocamente se obserua; Dando la contraria, los mas sus secuazes, otras pruebas del atentado y mala fe conque se condujo, no solo continuó en Arrancar y extraer de dho. canto o Peñasco, sino que adelantó en el mismo a la parte del Naciente y aotro mas arriua que ygualmente es anexo dela expresada venera del sr. Otorgante llevando mucha porcion de ella a tpo. que previno a su Administrador dela motibada Herreria de Bueyes pasase a reconocer, como en efecto lo hizo, en los veinte y dos de marzo pasado de este año, y alló con otros mas que le acompañaban, clara y manifiesta, la tropelia y nuebo atentado ejecutado por las contrarias y sus Venaqueros llamados Santiago Lopez, vezino del lugar de Orreos, Joseph Riuera, del de Ferramolin, Manuel Rodriguez y Manuel Dominguez, de Bieiros, lomismo que Francisco Macia, Francisco Mendez del dela Seara, Alejandro Dochao dela misma Vecindad y Antonio Bieiros, quienes aparejados y en distintos sitios de la misma venera descubierta del sr. Otorgante se mantubieron Arrancando y dando vena a diferentes careteros asta que, a vista de ello, despues que el expresado Administrador Don Diego Pelagra hizo un deslindo del Terreno y Venera que en el xeneral y particular concepto de todos es y corresponde in solidum al sr. Otorgante segun el descubrimiento echo por sus causantes, y en que agotaron muchas sumas de Rs. y sostubieron la caseta para el abrigo y resguardo de los Operarios y Herramientas, y que por su antiguedad acredita lo acotado de aquel terreno y venera; Previno a aquellos se obstubiesen y se parasen de Arrancar ni estraer de alli mas vena, lo que asi ofrecieron cumplir, y sin mas recelo en el pronto, desistieron de su atentado, conociendo sin duda el ningun dro. que tenian para aver de ejecutarlo, publicando que si la hacian hera por influjos delas contrarias y quando se persuadia el sr. Otorgante de que los sobre dhos. se atemperasen asi por esto como por lo decedido ultimamente por el Real Tribunal, experimentó la nueba y mas exacrable inbasion y escandaloso atentado en propasarse los sobre dhos. de acuerdo con sus Mantenedores los Dueños y Administradores delas mas Herrerias inmediatas, e indiscreta y maliciosamente acaudillados todos los citados Benaqueros con una partida mayor de Herramientas de todas clases, se introdujeron nosolo enlas partes o cantos que quedan espresados de dicha 
Venera, sino tambien, con escarneo y vefa, aotra situazion del centro o medio de élla y parte del Poniente que se allaba descubierta por el sr. Otorgante y sus antecesores; Y de donde los proximos anteriores años la llebó para su citada Herreria de Bueyes, propasandose asimismo a Violentar y franquear la Cerradura y Puerta de dicha caseta y extraer deella las Herramientas y mas Aperos que alli dejo su Adminsitrador y Cachican, y haciendo finalmente un uso espotico de todo, llebando entan corto tpo. mas de Nuebezientos carros de vena, introduciendolos en dicha venera y sacandolos por el mismo camino que tiene el sr. Otorgante. De manera que apoco tpo. seallará del todo arruinada y desfalcada dha. venera, en conocido perjuicio de sus intereses, segun que todo ello llego a registrarse en el Viente y siete de Abril proximo, y hauerse allado las citadas Herramientas y mas instrumentos conque dhos. Benaqueros operaban de que en caso necesario se ara expresion por el Apoderado que hira nombrado con otras cosas de echo y derecho terminantes al asumpto, resguardadas en la misma venera, cubiertas con tierra recientemente arrancada, en apoyo del ningun dro. que les asistia para ver de arrancar y estraer lo de que lo hacian en dha. venera del sr. Otorgante. $\mathrm{Y}$ a fin de que y quales delitos, tropelias y atentados no queden impunes y sin el deuido castigo, conoce que da y otorga todo supoder cumplido elque tiene y en dro. se requiera a Don Miguel Arias del Corral, vezino de la villa de Nozeda, con clausula expresa de substitucion y juramento en forma para que a nombre del sr. Otorgante y representado su propia persona pase a la ciudad dela Coruña y mas Tribunales y Juzgados donde sea menester para que por si o por medio de sus substitutos entable la defensa correspondiente, proponiendo y dando las querellas de fuerza, de contravencion y criminales, y las mas acciones y demandas correspondientes para que con areglo alo expuesto y mas instruciones que al caso protesta darle y tenga por combeniente y segun lo que tambien resulte del pleito contrabertido y mas antecedentes y titulos que tiene y existen al sr. Otorgante en defensa y prueba de su claro derecho. Siga las citadas nuebas acciones y querellas en el Tribunal o Tribunales donde pueda y deba, pidiendo se espidan las Rs. Provisiones necesarias, asi para las informaciones, compulsa de papeles, como para qualesquiera reconocimientos, Mapas y Diseños, dando tambien las querellas de exceso, entablando quando el caso lo pida las recusaciones de Juezes, Escribanos, Acompañados, Auditores, tachando y redarguiendo, Alegue y contradiga, oiga autos y sentencias, etc...... asi lo otorgo y firmo, siendo testigos Dn. Pedro Rodriguez, Dn. Manuel Martin Perez y Dn. Carlos Tremier, residentes en esta citada villa de Villafranca del Vierzo, todo lo qual y conocimiento del Sr. Otorgante yo el Escribano doy fee.

$$
-32-
$$

\section{3, julio, 26.}

\section{Exención de derechos a las herrerías de Castilla y León AHN. Ordenes Generales de Rentas, libro 37, exp. 4939}

Conformándose el Rey con el dictamen de Vs. expuesto en informe de 30 de mayo último, ha resuelto que las ventas de yerro que se hagan al pie de las ferrerias de las provincias de Castilla y León, de labranzas de las mismas, sean exentas por aora de los derechos de Alcabalas y Cientos; pero que de las ventas que se executen fuera de las mismas ferrerias, ya por los Dueños de ellas, o ya por los Herreros, cerrageros o qualesquiera otra persona, se exija en todos los 
pueblos de dichas provincias de Castilla y León el quatro por ciento conforme delo dispuesto en los Reglamentos generales del año de 1785 para los efectos de tratos y oficios en general. Lo que de orden de S.M. participo a Vs. para su puntual cumplimiento. Dios guarde a Vd. m. a. Palacio. 26 de julio de 1793. Gordoqui (firma). Srs. Directores Generales de Rentas.

$-33^{-}$

1794, septiembre, 17 y 29.

Permiso a José Álvarez de la Braña para construir una fábrica de ollas de hierro.

AHN. Ordenes Generales de rentas, libro 38, exp. 5093.

El 17 del presente mes se comunicó por el Ministerio de Hacienda a la Superintendencia de ella la Real Orden siguiente: "Con esta fecha comunico al sr. Gobernador Conde de la Cañada la Real resolución siguiente: En primeros de este año acudio por la via de Estado don Josef Alvarez de la Braña, vecino de la ciudad de la Coruña, y oriundo del concejo de Grandas en el Principado de Asturias, exponiendo que en 11 de febrero de 1788 había hecho consulta al Consejo para que a él y Compañía se le concediese facultad para establecer una fábrica de ollas de fierro colado en el propio condejo, permitiéndose a don Francisco Ignacio Richter, capitan retirado de artillería, en la clase de dispenso en el Ferrol que pasase con el propio retiro a Asturiaspara auxiliar el expresado establecimiento, por el conocimiento que tenía en las fundiciones y en su consecuencia pidió que se despachare la referida consulta concediendole a él solo la gracia, mediante que la compañía con que contaba se había ya disuelto por el trascurso del tiempo y otras incidencias.

Este recurso lo pasó el Sr. Duque de Alcudia al Ministerio de Hacienda de mi cargo el 29 de junio de este año, acompañando a él para que diese cuenta al Rey, no la consulta original, sino una certificación de ella dada don don Fernando de Guillermon, archivero del Consejo, el 18 de febrero de 1793, que dicho Sr. Duque dijo haberse encontrado en el archivo de la secretaría de su cargo. Para mayor instrucción del asunto mandó el Rey que se remitiese a informe de los Directores Generales de rentas, como se executó en 10 de julio último, y habiéndolo evacuado estos ministros y dado yo cuenta de todo a S.M. ha servido conceder al expresado don Josef Alvarez de la Braña la correspondiente facultad para que pueda formar el establecimiento de la Fábrica de ollas de fierro colado que intenta, en los términos y bajo las condiciones y regalías que se expresan:

$1^{\circ}$ que el enunciado don Fco. Ygnasi Richter pueda pasar a Asturias con el propio retiro que hoy goza para auxiliar a Braña en su establecimiento.

$2^{\circ}$ que Braña pueda colocar su fábrica en qualquiera de los concejos de Ibias, Navia de Suarna, LLana de Gaña o Naron, existentes en Galicia, Asturias y provincia del Vierzo, o en otros sitios en que no cause perjuicio a la fabrica de igual clase y de herrages que estableció don Andrés Antonio Bravo y Bermudez ni a otros.

$3^{\circ}$ que si el terreno que señalase Braña para la construcción de edificios así de la fábrica como para habitaciones de los operarios y almacenage fuese común, no se le pueda impedir por el concejo a quien corresponda, se mida y tase por 
peritos, pagando su importe principal si fuese de corta estimacion, o el canon anual que se regule, lo qual ha se serbir para aumento de Propios en uno y otro caso.

$4^{\circ}$ que pueda usar de vena que necesite y del parage que le sea mas conveniente, con tal que sacándola de los minerales señalados por el referido don Andrés Antonio Bravo quando trató de establecer sus fábricas, no perjudique a éste o a quien le suceda o haya sucedido en lo que igualmente fuera necesario.

$5^{\circ}$ que ni Braña ni sus subcesores, caso de balerse del carbon de piedra, han de poder usar de mas que el preciso a la misma fabrica.

$6^{\circ}$ que tampoco ha de poder usar de mas leñas que las sobrantes, surtido el vecindario, pagando su importe a tasacion de peritos, reconociendose antes por estos la leña que se ha de cortar, guardándose siempre la ynstrucción de Montes, cuyo importe y el de la que necesite Braña para la construccion de la fabrica y edificios precisos ha de serbir tambien para aumentos del propio concejo a quien pertenezcan y si las leñas fuesen de Montes particulares se deberá entender con los dueños para su compra, reduciendose éstos a equidad por medio de peritos quando pidieren precios excesivos.

$7^{\circ}$ que si se construye algun camino para beneficio de la fabrica se dirija por terrenos abiertos e incultos y solo toque en tierra particular quando no hubiere otro arbitrio a juicio de inteligentes, pagando por tasacion de éstos el importe del terreno ocupado segun su calidad.

$8^{\circ}$ que en punto a exenciones y regalías goze Braña para su fabrica los mismos que se concedieron a Bravo para las suyas reducidas después de las que están acordadas por punto general a todas las de su especie, a la libertad de derechos de alcabalas y cientos en las priemras ventas al pie de la fabrica o para que señaladas como tal cobrándose en las demas ventas solo un dos por ciento por el precio de pie de fábrica, al libre tránsito del hierro que para dicha fabrica se conduzcan a las provincias exentas en solo la cantidad que se emplee en ynstrumentos y máquinas que faciliten los progresos de ella, con la circunstancia de que en cada ocasion que lo necesite de cuenta a la Direccion General de Rentas con expresion de la cantidad y calidad del hierro para que se disponga la introduccion con precauciones que eviten todo fraude y la de que pueda introducir libremente de los Reynos extrangeros todas las maquinas e ynstrumentos que necesite para su fábrica.

$9^{\circ}$ y que por lo resuelto a beneficio de las Fabricas de Bravo de comision al regente de la Audiencia de Oviedo para el establecimiento de la de Braña en la conformidad expresada con facultad de subdelegar en un ministro de la misma Audiencia en caso de ocupacion o quando conviniere pasar a territorios, oyendo la Audiencia a los ynteresados y al fiscal sobre la pertenencia de los terrenos que hubieren de ocupar quando haya dudas en quanto a ella o su legitima posesion, sin perjuicio de la execucion de las obras".

Lo que participo a Vss. para que dispongan su cumplimiento. Dios guarde a Vm muchos años. San Ydefonso, 29 de septiembre de 1794. Gardoqui. 
1796, noviembre, 30.

Poder de Don Manuel de Armesto Omaña, dueño de la ferrería Nueva para defender el uso de la venera de Formigueiros frente a Don José María Tineo, dueño de la ferrería de Bueyes. AHPL. PN.: caja 3339, ff. 309r-309v.

En la villa de Villafranca del Bierzo a treinta de Noviembre de mil setecientos noventa y seis: ante mi el Essno. y testigos parecio Dn. Manuel de Armesto y Omaña dueño de la Jurisdicion de Vega de Forcas, Velesar, Rabaceira y otras en el Reino de Galicia, vecino desta dha villa, y dijo: Le corresponde y posee como suya propia una Herreria llamada la nueba que se surte dela vena que producen los Montes de Formigueiros consistentes en los terminos Jurisdicionales del lugar de Visuña igualmente que otras correspondientes al Real Monasterio de san Julian de Samos orden de N. P. S. Benito, y otras varias, y sin embargo de ser comun el aprovechamiento de dhos Montes y sus veneras, intentó aprovecharse del sitio mas pingue y productivo Don Josef Maria Tineo dueño dela Jurisdicion de san Juan de Noceda, vezino de la ciudad de Astorga, para surtir su Herreria llamada de Bueyes haciendo un voluntario amojonamiento del referido sitio e intentado perturbar este comun aprobechamiento al esponente y demas interesados con igual titulo, por lo que introdujeron la competente querella de fuerza en la Real Audiencia dela Coruña donde se sustanció el juicio por el orden establecido en aquel tribunal con citación y Audiencia del referido Don Josef Maria Tineo, quien hizo recurso ante los señores presidente y oydores dela Real Chanzilleria de Valladolid donde se mandaron remitir los autos, para lo qual se libró Real Provision, y en su vista se suscitó competencia por ambos tribunales para cuya decision occurio dicho Tineo al Real y supremo consejo de castilla, y haviendose remitido los autos a dho. supremo tribunal se sirvió providenciar su retencion, y librar despacho para citar a todos los interesados con que ha sido emplazado el exponente como uno deellos; en cuya consequencia otorga que da todo su poder cumplido el que de dro. se requiere y es necesario a Don Felipe Santiago Gallo y Don Domingo Gomez Serrano, procuradores de dichos Reales consejos, y acada uno insolidum, con clausula de que le puedan sustituir en qn. y las veces que les pareciere, revocar unos y crear otros especial para que asu nombre $y$ representando su propia persona parezcan ante los sres. de dho. supremo tribunal, y en los demas que fuere menester, y con relacion delo expuesto y quanto arrogen los autos, pidan se confirmen las provid. dadas por la Real Audiencia de Galicia, declarando ser comun del otorgante y demas dueños de dhas. Herrerias el aprovechamiento dela vena que producen los montes de Formigueiros para su surtido y que el mendionado D. Josef Maria Tineo no tiene ni le corresponde particular derecho sino que quiso cotar y apropiarse sin justo titulo cometiendo notoria fuerza y violencia, por lo qual debe ser condenado a perpetuo silencio y en todos costas, dejando las cosas en el ser y estado que corresponde al aprovechamiento comun sin que de ningun modo se remitan los autos a Tribunal que no deva conocer deellos, decidiendo la competencia a favor de el de Galicia; y hasta que asi lo consigan con las demas declaraziones utiles y convenientes a favor del exponente presenten pedimentos requrimientos hagan protestas pidan citaziones, etc. ....Asi lo otorgo y firmo aque doy fe conozco, siendo testigos Don Juan Yarza, previtero, Don Josf Maria 
Cancelada y Jose Gonzalez vezinos y natural de dicho villa. Ante mi Thomas de Arteaga.

1797, enero, 10. Villafranca

Obligación del herrero Antonio Blanco, alias Meixaus, de pagar al administrador de la ferrería de Visuña 1518 reales y 12 mrs. de vellón por deudas de hierro que sacó al fiado de dicha ferrería. AHPL. PN.: caja 3337, ff. 175r-175v.

En la villa de Villafranca a diez de Henero de mil setecientos nobenta y siete ante mi el escribano y Testigos parecio presente Antonio Blanco alias Meixaus vecino del Barrio de san Salvador extramuros de esta poblacion; y dijo: Que se obliga y se obligo con su persona y Vienes muebles y raices presentes y futuros a dar y pagar que dará y pagará realmente y con efecto en una sola paga para todo el mes de Diciembre venidero del corriente año dela fecha a Dn. Juan Castrillón Presbitero Administrador dela Herrería nueba propia del sr. Dn. Manuel Armesto y Omaña Señor de Veiga de Forcas y a sus herederos y quien en su derecho hubiere y tubiere la cantidad de un mil quinientos diez y ocho reales y doce maravedis vellón en que declara haberle alcanzado el referido Dn Juan de todas las cuentas que han tenido hasta el día de oy inclusive dimanadas del yerro fiado que en diferentes ocasiones y porciones le ha sacado de la dicha Herrería por si y por medio de otras distintas personas en su nombre; puesta y pagada dicha suma en mano y poder del enunciado presbitero, sus dichos herederos o de quien el suio tenga en esta villa de Villafranca (y para ello hipoteca) la casa de fragua cubierta de losa con sus fuelles, yunque, martillos, tenaces y demas aperos de ella y necesarios al ejercicio y oficio que este otorgante tiene de Herrero la qual esta tras la casa que abita en dicho Barrio de San Salvador yendo para Redoniña xurisdicion de Corullon cuyos terminos son notorios. Yten dos tabladas de huerto detras de la huerta de la Casa grande dezmario de esta villa que confinan por arriba huertos de Manuel Fouceiro, por abjo Pedregal del Rio Burbia, por un lado calleja y por el otro huerto de Don Felipe Montuno, todos de esta vecindad cuyas fragua, aperos y tornas de huerto asi declaradas y deslindadas confiesa ser suias propias y por tales las hipoteca la dicha fragua con el foro que le quepa y se paga a las Monjas y convento de San Josef orden de San Agustín desta villa y las dos tornas con quatro ducados y medio de vellon al Dueño de la Casa grandeque lo es Don Benito Maria Prado vecino de la ciudad de Lugo y por libres de otro grabamen salvo diezmo a Dios; y protesta no venderlas ni enagenar nada de ello en perxuicio de esta escritura (...). Asi lo otorgó ante mi el escribano siendo testigos Bernardo Gonzalez Francisco Gonzalez, Francisco Lopez y Miguel de Ochoa, vecinos del lugar de la Pobladura, y el otorgante a quien doy fee conzco lo firmó. Tambien doy fee de haber prevenido a Don Juan Castrillon presbitero saque la copia deesta escritura y acuda a tomar razon de ella al oficio de Hipotecas establecido en este Partido dentro de un mes, pena de su nulidad. Ante mi Gregorio Balboa. 
1797, enero 29. Vega de Espinareda

Poder del administrador de la ferrería de Valcarce para cobrar una deuda de hierro a los herederos de don francisco González de Nuño, difunto.

AHPL. PN.: Caja 3295

En la villa de Bega de San Andres de Espinareda a beinte y nuebe dias del Mes de Henero de mil setecientos Nobenta y siete anos ante mi escribano y testigos Ymfraescriptos parecio presente Don Andres de Mon Rancaño Residente en la Herrería del Valcarce y Dijo que en los ocho de Marzo del año pasado de mil setecientos nobenta y dos Don Josef María de Tineo y Ulloa señor de las Arregueras Noceda y otros pueblos caballero Maestrante de la real Maestranza de Valencia vecino y rejidor perpetuo a la propia ciudad en la de Astorga y por testimonio de Josef Antonio Lopez escribano del Numero y unico de Ayuntamiento de ella por el quel dicho señor le elijio y nombro por su Administrador en birtud de su poder General que para ello le dió para que rigiese cuide y administrase la referida casa y Herrería como si fuera el dho señor propio con amplias facultades para vender, percibir, cobrar, demandar y ejecutar, como asi mismo para dar recibos, cartas de pago finiquitos y gasto, y con el motibo de haber tratado y comerciado en yerro Don Francisco Gonzalez de Nuño vecino del lugar de San Pedro de Olleros haora difunto y haberle quedado a dever porcion de yerro que saco de su poder y expresada Herrería la cantidad de trescientos veinte y nuebe rs. y medio de vellon usando de la clausula de sobstitucion que tambien por dho. poder se le confirio cuia copia del comprobada me manifesto y debolbi (de que doy fee) a fin de recaudarles desde luego con referencia a la Demanda que tiene puesta a sus vienes sobstituia y sobstituio dho poder para la cobranza de la citada cantidad en Don Thoribio Carro, vecino del lugar de Ozero y le releba y relebo segun por derecho es relebado concediendole como le concede, etc.... siendo testigos Don Manuel Gonzalez Manrriquez, Antonio Rodriguez y Alejandro Sanchez, vecinos de esta dicha villa y el otorgante a quein yo escribano doy fee conozcolo. Ante mi Mathias Alvarez Obregon.

1797, abril, 27. Villafranca del Bierzo

Poder de Don Manuel Armesto y Omaña para oponerse a la construcción de una ferrería en Barjas por el marqués de Villafranca.

AHPL. PN.: Caja 3329, ff. 33r y 33v.

Don Manuel de Armesto y Omaña, vecino de esta villa de Villafranca del Bierzo, dueño de las Jurisdiciones de Vega de Forcas, Rabaceira, Velesar y otras en el Reino de Galicia y Principado de Asturias, dijo: que habiendose intentado por parte del Excmo. señor Marques desta dicha villa la construcion de una Ferreria en los terminos de la Jurisdicion del coto de Barjas hize mi oposicion con otros varios interesados por los imponderables perjuicios que se seguirian ala que poseo llamada nueva, y otras existentes asu inmediación, y estando sustanciandose el espediente ante los sres. del Real y Supremo consejo de 
castilla se sirvieron dar auto segun tengo entendido en el proximo pasado mes de marzo, mandando que que por peritos que nombremos las partes y tercero de oficio en caso de discordia, se reconozca el sitio en que dicho Excmo. sr. Marques solicita la construcion dela expresada ferreria, los montes y mina de mena de que se havia de surtir, declarando si de dicha construcción se podran seguir perjuicios alas inmediatas, con otras cosas que resultarán del referido Real auto, cuya execución se ha cometido al sr. correxidor de la villa de Ponferrada, y no permitiendome mis ocupaciones la personal elección de dhos peritos y practicar las demas diligencias que en tal caso me competen: otorgo y doy todo mi poder cumplido el que de dro. se requiere y es necesario a Don Josef Arias de Prada vezino de dha. villa con clausula de que le pueda sustituir en quien y las veces que le pareciere, rebocar unos y crear otros, especial para que a mi nombre y representando mi propia persona parezca ante el referido señor correxidor de la villa de Ponferrada, y en los demas tribunales que convengan, y con relacion delo expuesto nombre por mi parte el perito o peritos que tubiere por convenientes, recusando los que en contrario se elijan teniendo causa legal, y facilite su aceptacion, etc.... Asi lo otorgo ante el presente Escrivano en esta dha. villa de Villafranca del Bierzo a veinte y siete de Abril de mil setecientos nobenta y siete, siendo testigos Don Juan Yarza, Don Antonio Garcia, presviteros, y Josef Gonzalez y natural de esta villa y el sr. Otorgante que yo el escrivano doy y conozco lo firmo. Ante mi Thomas de Arteaga.

\section{$-38-$}

1797, noviembre, 8. Madrid.

Franquicia de derechos en las ventas al pie de la fábrica de Villafranca del Vierzo de aceros y limas. AHN, Ordenes Generales de Rentas, libro 41, exp. 5662

El Exmo. Sr. Principe de la Paz en fecha de ocho del presente nos dize lo que sigue: "A consulta de la Junta General de Comercio y Moneda se ha dignado el rey aprobar la Fabrica de Azeros y Limas que ha ofrecido establecer en Villafranca del Vierzo Don Josef de Ocampo Balboa, concediéndole S.M. la exención de los derechos de Alcabalas y Cientos en las venta que haga de su Azero y limas al pie de su Fábrica y en el almazen que tenga o en el pueblo de ella, o donde residiere si se abecina en alguno diverso de aquel, con calidad de no mezclar con los artefactos de la suia los de qualquiera otra; pues en este caso habrá de satisfacer de todas las ventas el quatro por ciento; y si el Azero y limas fueren de dominios extraños el diez por ciento, exigiéndosele tambien el mismo cuatro por ciento sobre el Acero y limas de su Fábrica que venda fuera de los parajes expresados y quando se haga por otras distintas manos en las provincias de Castilla y León; lo que participo Vss. de orden del rey para su cumplimiento".

Y nosotros a Vm. para el propio fin y que traslade esta Real resolución a todos los Administradores de rentas provinciales de esa provincia, para que disponga su observancia. Madrid, 14 de noviembre de 1797. Don Francisco Carriedo del Valle.

\section{SIGLO XIX}


1801, febrero, 8. Santa María de Rao

Convenio entre los vecinos de Murias y el dueño de la ferrería de Rao sobre la utilización de un camino y arreglo de un puente AHPLU: 1377/2

En el lugar de la Vega de Abeado, terminos del lugar de Robledo, parroquia de Santa María de Rao, concejo de Navia de Suarna, a ocho dias del mes de febrero año de mil ochocientos y un. Ante mi escribano de S. M. y testigos infraescriptos, de una parte D. Antonio Gonzalez Viejo, socio Director tesorero y apoderado general de la conpañia titulada de la Vega de Riuadeo, segun consta del que a su fauor otorgo en veinte y ocho de enero proximo a testimonio de D. Antonio Fernandez Reguero escriuano de numero del concejo de Castropol con referencia al general con que se alla de los cavalleros socios que componen dicha compañia y le otorgaron en viente y seis de mayo de mil sietecientos noventa y ocho a testimonio de D. Manuel Ysidro Valdes del Canpo escriuano de pro...y de comisiones de la Real Casa y Corte que uno y otro tiene presente, y de la otra D. Manuel Perez ...previtero, D. ... Albarez Murias, D. Alonso Albarez Murias, D. Gonzalo, D. Pedro Fernandez, D. Antonio Suarez, D. Antonio Perez Fresno, otro D. Manuel Perez, D. Antonio Fernandez Canzela, Don Juan Albarez de la Peña, D. Juan Albarez del Valle, D. Juan Albarez Rellan, D. Manuel Lopez, D. Pedro Lopez, D. Francisco Albarez Murias y Don Vicente Perez Murias, vecinos todos del lugar de Murias de esta parroquia, por lo que a si toca y a nombre de los mas vecinos de el, enfermos y ausentes por quienes en caso necesario prestan la suficiente capcion, et.

Dicen que haviendose construido por cuenta de la referida conpañia una fabrica de fierro o herreria ccon su casa de administracion y otras oficinas $y$ almagacenes -sic- en esta situacion le hera indispensable para su formal establecimiento en observancia de la real facultad que para ello se les espidio servirse de las materias primeras que exsistenen los terminos de dichos dos lugares de Murias y Robledo, para cuia conducion y transporte a la citada fabrica hera tamvien preciso usar de los puentes y caminos reales y vecinales que oy exsisten y establecer otros segun la necesidad y circunstancias locales lo exigiesen vajo .... siguieron hasta aora losoperarios de la fabrica, pero como su frecuencia diese ocasion a la mas pronta ruina y deterioro de puentes y caminos se suscitaron algunos altercados entre los vecinos aqui otorgantes y Directores y Administradores de dicha fabrica, y deseando todos por el vien reciproco que les resulta del establecimiento tranquilizarse para no enpeñarse en pleitos

$-40-$

1802 ,

Arrendamiento de la ferrería de Tejedo

AHPL. PN., caja 3783

Sepase que yo Dn. Geronimo Rodríguez vecino de la villa del Ferrol por mi, y a nombre de mi cuñada $\mathrm{D}^{\mathrm{a}}$ Lucia Afonso viuda de Dn. Bernardo Rodríguez, como 
madre tutora y curadora de sus menores hijos y que le quedaron del difunto, vecino que fue, y ella es de la villa otorgo, que doy en arrendamiento y en renta annual a Dn. Andres Celaya y Remendarte, vecino del lugar de Ferreyrós de arriba, Reyno de Galicia, obispado de Lugo, todo el Artefacto y Fábrica de Fierro que tenemos sita en termino y dezmario del lugar de Texedo a nosotros tocante y perteneciente, que se nos ha adjudicado por parte de los herederos de Dn. Francisco Abella, como también el Molino y Fraugua de manos con todos los pertrechos y herramientas a ellos pertenecientes, que abajo se apuntaremos. Yten todas estas casas contiguas y huerta con el prado grande inmediatos, con otros dos que se hallan a la otra parte superior, y debajo del camino real. Yten el Nabal y tierra labrantía que se halla a la otra parte del rio frente al Artefacto, que los linderos de todos los edificios y (...) con sus cabidas, por ser mui notorios se omiten, y se los arriendo, según dicho es, con quantas herramientas, utensilios, pertrechos, oficinas, entradas, salidas, derechos, acciones, uso de benera, augua, montes tanto alto quanto bajo de cepa de tuergano de urz, y todos aquellos usos costumbres y servidumbres, que sean y se entiendan pertenecientes a dichos bienes, aunque no bayan aquí expresados, que nos correspondan, por cualesquier titulo causa o (...) nos correspondan, y deban corresponder en dichos bienes, Artefacto con todas sus maquinas; que las herramientas de este son las siguientes: tres gorriones, uno mayor, y dos menores; dos escamelas; dos tenazas de (...) otras de repillar, otras burricas, dos tenazas cobas mayores, cuatro menores, dos patelas, otras de cortar las agoas, picacho de sacar las zepas, dos manerales de tubera, picacho mayor, pasador de la ..., subara, un torno de caldear la yunque, rodo del ..., torna carbón, palanca mayor, vira de lebantar las (...), palanca de fundir y palanqueta de limpiar tubera, martillo de enderezar fierro, una marra, una marra vieja, martillo de tazar bena, una barroa de una yunque, una (...) de fierro, una tajadera de cortar agoas, un martillo de dos gallas, una pala, cinco tuberas nuebas y quatro viejas. Que siguen las herramientas de la fraugua de mano y todas aquellas (.................) por dicho arrendatario y expertos que lo han sido Dn. Josef López presvitero del lugar de Texedo, Roque Rodríguez vecino del mismo lugar, y Antonio López natural del lugar de Sub Arbol, a saber: son tres tenazas, unas tigeras, dos martillos grandes, y tres chicos; una vigornia tres claberas de mano y dos de zepo; una cortadera; ocho tufos; una lima de media caña grande; tres cortaderas; todo lo qual doy en arrendamiento a el sobre dicho Dn. Andres por discurso de quatro años corren desde el mes de julio del año que biene de mil ochocientos y tres y fenecen en el julio de mil ochocientos y siete por precio y quantia de ocho mil reales vellón, que me ha de pagar a mi representante en dos plazos, primero la Natividad, segundo la pascua de resurrección de cada un año en nuestra mano casa y podero la de quien nos represente pena de ejecución y costas de la cobranza, y de pagar a la persona que a ella asista cuatrocientos mrs. de salario por cada uno de los dias que lexitimamente ocupe inclusos los de benida estada y buelta por cuios salarios ha de ser ejecutado, y aun mismo tiempo, que por el principal, y cumplir las condiciones siguientes: que durante el estipulado plazo ha de procurar tener en perfeccion xiro y total existencia dichos bienes y quanto ba apuntado de modo que baya en aumento y no se note $\mathrm{y}$ heche de ver minoracion, siendo del cargo del Arrendatario, o quien le excuse en el zelo y cuidado de dicha Fabrica, y demas bienes correr con todos quantos quebrantos y reparos rquieran y sean necesarios, extra de los de los arboles mayores, si llegan a acontecer o alguno de los (....)o de raro contingente, como son de Agua o fuego no dimanando este por descuido de carboneros u otra 
persona dependiente del Arrendatario, que en aquellos eventos ha de ser y correr de mi cuenta, y de la que represento el reparo de los escalabros, hasta poner en xiro la fábrica. Yten es condicion que el sobredicho arrendatario ha de pagar annualmente, según esta escripturado, a el lugar de Pereda dos quintales de fierro y otros dos con cuatrocientos reales en dinero fisico al de Texedo, que son las unicas cargas con que se hallan dichos bienes

$$
-41-
$$

1807, mayo, 2o. Santa Marina de Folgoso

Convenio entre los propietarios del mazo de Folgoso y Manuel Sánchez Bullín sobre el permiso para abrir una presa para regar un prado.

\section{AHPLU: 2454/7}

En la poblacion de Santa Marina de Folgoso, Jurisdicion real de Courel, a veinte dias del mes de Mayo año de mil ochocientos siete. Ante mi Escribano unico de Numero y testigos parecieron presentes de una parte Domingo Sanchez, Carlos Sanchez, Francisco Sanchez Pardin, Francisco de Arza, y de otra Manuel Sanchez Bullin, maiores todos de veinte y cinco años de edad y vecinos de esta vecindad de Folgoso, e dijeron: que respecto los primeros son partícipes y llebadores en las fraguas y artefacto de la ofecina de mazo esistente en los terminos de esta precitada vecindad y rio del do mazo, cuio artefacto se muebe con el agua que por aquel fluie y serle perxudicial una presa y estado de zanjas que proiecta construir el ultimo en el citado Rio y terminos de Valiños para haber de regar el prado de sujoso que da principio en los terminos de Valiños cuia perfeccion le ympedian ya por la posesion que tiene el ynsignado mazo del goce del agua, e ya por evitarse los primeros y mas sucesibos erederos futuras contingencias y trabajos de quebrantar la citada presa para extraccion de aquella, se transigieron y conbienen: que el ynsignado Manuel Sánchez prosiga con la espuesta presa y faccion de zanjas haciendo uso de la agua que contemple nezesaria con tal que no haga falta alguna para el fin referido de macear, a que acedio el Manuel constituyendose a no impedirla en manera alguna pena de las costas y daños que sobre lo referido se causaren y recrecieren y a efecto de evitar futuras cavilaciones se obliga a sacar copia de este ynstrumento de su quenta y riesgo y entregarla a aquellos dentro del preciso termino de quince dias, y unos y otros se obligan con sus respectivas personas y vienes a estar y pasar perpetuamente por lo aquí pactado, pena de todas las costas y daños que se originaren con qualquiera contrabencion, pues por pena condicional lo pactan y a maior abundamiento suxetan dichas sus personas y vienes presentes y futuros a las justicias de S. M. fuero y domicilio que les extrechen con todo rigor a la obserbancia de quanto queda relacionado como si fuera sentencia definitiba de juez competente pasada en juzgado, que por tal lo reciben y renunciaron todas leies de su fabor... Asi lo otorgaron y firman los que saben y por los que dijeron no saber un testigo, siendolo Santiago de Fojo, del lugar de Piedrafita, Juan Rodriguez y Bentura Franco de este lugar, de todo lo qual y conocimiento de los otorgantes yo el escribano doy fe. Manuel López Modelo. 


\section{3, enero, 17. Seoane de Caurel}

\section{Permiso para la construcción del mazo de Vilasibil}

\section{AHPLU: 2474/3}

En la villa de Seoane jurisdiccion de Courel, a diez y siete dias del mes de Enero de mil ochocientos trece, ante mi escribanoEscribano unico de numero y testigos parecieron Domingo Lopez, vecino del lugar de Meiraos, y Dn. Francisco Romero del de Villasivil ynclusos en la Feligresia de Santa María de dicho Meiraos e dijeron que respecto al segundo yntenta construir un artefacto de mazo para desazer fierro en el nombramiento molino do bao terminos de dicho Meiraos, y auer representado el primero seguirsele detrimento motiuado de la eleuacion de tapacuña y coro de agua, lo que en el dia an esperimentado circunda la estolda o azequia de un molino harinero que tiene y dice a la parte superior de la espuesta tapacuña, po lo que y a fin de hevitar futuras continjencias y perjuizios an deliuerado nombrar peritos agrimensores para su reconocimiento y regulacion de daños que sobre el particular se pueden yrogar, y aviendolo ejecutado estos en el dia de esta fecha allaron deuer costear el Romero la reuaja de como cosa de siete brazas de la tapacuña, quedose a la parte superior cuia se fauricó de nueuo y consideraron que teniendo efecto la reuaja referida que ajusta la quenta de cinquenta y seis quartas, y remouiendo la tapacuña o afianzandola en la peña que dice al frontis del prado que posee Josef de Foxo, del recordado lugar de Meiraos, y se alla a la parte ynferior del puente por donde se transita de dicho Meiraos para los montes de Casares y recordado molino, con tal que no tenga mas eleuacion que la regular de manera que no ympida guiro alguno al palo o rodezno que se mueue a lo que el Romero se constituye y obliga en deuida manera con su persona vienes muebles y raizes presentes y futuros bajo pena de execucion, costas y daños que en contrario se motiuen con la de no ver oido en juicio ni fuera del en oposito a la referido, y el Domingo Lopez como representante combiene en que bajo las condiciones estipuladas y no en otra manera realize el Romero o deriuados la demostrada construcion de Artefacto obligandose tambien en ygual manera a no ympedir el uso de aquel, y para firmeza de lo aqui contenido se someten a las justizias de su Magestad, fuero jurisdicion y domizilio que les estrechen a la rigurosa observanzia como si fuera sentenzia definitiva pasada en juzgado con renunciazion de todas las leies fauorables y la General del derecho en forma, asi lo otorgarony firman de sus nombres, de que fueron testigos D. Antonio Alfaya del lugar de Ferreirós, Domingo Rodriguez que lo es del de Losada, y Roque Garcia de esta poblazion. De todo lo qual y conozimiento de los otorgantes y testigos yo escribano doy fe. Ante mi Jose Manuel Lopez Mondelo. 
1813, mayo, 21. Ferrería de La Rodela

Permiso de los monjes de Samos para que el dueño de la ferrería de Quintá pueda usar el Camino de la vena para transportar el mineral de hierro desde la mina.

AHPLU: 2467/12

En la Casa de la Erraria de Rodela in clusa en la jursidiccion de Quiroga, a veinte y un dias del mes de maio de mil ochocientos y trece; ante mi escribano publico de numero de ella y testigos a su final escritos, personalmente constituidos el Rmdo. Dn Fr. Bernardo Carbaxal Administrador de ella de una parte, y de la otra Dn. Pedro Fernandez Rigueiro, pro. Que lo es de la de Quintá contingua y propia de Dn. José María de Prado y Neyra, dijeron que el real Monasterio de San Julián de Samos por medio de operarios y alarifes antiguamente habia construido a sus espensas y para la mas comoda conducion de bena para esta fabrica un camino carretal, que annualmente a sus espensas y por medio de los Administradores Padres Priores que han sido de esta Erraria pribatibamente y se le da el nombre de Bal de Seceira, teso da Portela, Potariña y Aira de Redondos hasta llegar a al lugar de Bustelo, terreno y monte brabo y escabroso comprensivo en los terminos del mismo lugar y jhursidicion de Quiroga, sin que por el de los Dueños y Administradores de la de Quintá ni otra pudiesen conducir la bena para esta ultima; y en contrabencion de esta anticuada posesion y derecho, el segundo otorgante por uno de los dias del mes de Maio ultimo bencido de ochocientos doze ignorando lo referido se propaso a conducir por dicho camino para la que administra por medio de mandatarios con carros y Bueyes porcion de bena, por cuio echo el primero le hizo como era regular las recombenciones y conducentes requerimientos en presencia y suficiente numero de testigos y a su consecuencia se formalizo por el Padre Prior de esta de Rodela, por si y a nombre del real Monasterio de samos la correspondiente Querella de perturbacion de posesion contra el Dn. Pedro Fernandez Rigueiro, que se le admitio y prebino para su preparacion la conciliacion sancionada en el sagrado codigo de nuestra Constitucion y estando para proceder a ella, considerando los largos gastos a que estaban espuestos, instruidos cada uno de su Derecho, se hallan conmbenidos y ajustados en que el Padre Prior de Rodela por hacer gracia y merced al Dn. Pedro Rigueiro le concede permiso para que por si y por sus carreteros de Bena pueda transitar por el citado Camino del Monasterio y conducir desde primero de Diciembre hasta el dia quince de Abril de cada Año para la Erraria de Quintá, sin que e, subcesores, Dueños de ella, ni mandatarios lo puedan hacer en los meses restantes del año, y aun en los que ban capitulados quatro y medio puedan hacerlo sin espreso consentimiento y aprobacion del Padre Abad y mas Monjes del referido monasterio de Samos, con quien se consultara para el fin insinuado, y en interin se berifica o no esta concesion, el dn Pedro segundo otorgante usara como lo hacia del camino do chao dos Boys y Coedo para la conducion de la Bena que necesite, como hasta aora lo hacia sin otra alteracion, consultando tambien esto mismo con el dueño de la Erraria que administra, para que use su derecho, que sin perjuicio del que le asista se aparta de la presente querella de perturbacion y posesion articulada por el primer otorgante; y en esta conformidad para lo que asi toca y el querellante tambien por si y a nombre de la mas comunidad, se apartan del sequito del suscitado litigio para no 
proseguirloen el tiempo ni manera alguna, pena que si lo hicieren (etc.). Testigos: D. José Francisco Pombo, escribao de S. M. y vecino de Triacastela, D. pedro Pombo su hijo y D. José Quebedo de la Puebla de Tribes. Ante Francisco Sánchez y Valcarce.

\section{$-44-$}

1814, octubre, 25. La Coruña

Provisión de Fernando VII para seguir un pleito, iniciado el 17 de mayo de 1808 por Doña María Isabel Orozco y Seijas, condesa de Campomanes, vecina de Madrid, en nombre de su esposo $D$. Domingo Sabino Rodríguez de Campomanes, conde del mismo, en la Audiencia de La Coruña contra Alonso do Olmo y consortes. AHRG. Real Audiencia 12331/27

Sobre que se la mantubiere en la posesion que de ynmemorial tiempo tenía de aprobecharse exclusivamente de la leña y carbón de los montes comunes y demás terrenos pertenecientes de la dicha jurisdición de Incio con destino a la Herrería del mismo nombre perteneciente a los mayorazgos que posehía y de la determinación que había recahido habiais apelado primero vos dicho Alonso Olmo y consortes y pues que dicha providencia de la Real Audiencia hera en parte tambien perxudicial en varios particulares se presentó en grado de apelación en esta dicha nuestra Real Chancillería y pidió que habiéndola por tal se la mandase librar la correspondiente Real provisión”, etc.

Al parecer la paralización del juicio se debió "por las obcurrencias con motivo de la guerra y hoy se halla retrasado el asumpto y para que se pueda seguir sin vicio de nulidad a vuestra Alteza suplico se sirba mandar librar a mi parte buestra Real provisión de emplazamiento de pleito".

Se mandan a la Chancilllería Valladolid 3 legajos con 278 hojas sobre el pleito para proseguirlo allí.

1815, enero, 17. Ferrería de Soldón

Inventario de los efectos y muebles de la ferrería de Soldón que se entregan a don Manuel Antonio Sánchez, arrendatario de dicha herrería.

AHPLU: 2406/3

En la Casa de la Herreria de Soldon coto de la Seara, a diez y siete dias del mes de henero de mil ochocientos quince. Ante mi Escribano Notario publico de su Magestad y testigos que se dirán parecieron personalmente D. Froylán Troche y Romero, Administrador y Apoderado de la Casa, vienes y Rentas de la Rivera de Abajo, propias del Coronel de Exto. y milicias provinciales de la capital y provincia de betanzos, Dn. José Quiroga y Quindós, Dueño asimismo de esta propia Herreria, Dn. José Rodriguez Gallego, actual Administrador de la misma, Dn. Manuel Antonio Sánchez, vecino residente en la Parroquia de San 
Salbador de Pacios de Courel y Herrería de Paleiras, sita en ella y dijeron: Que por Dn Froylan Troche como tal Apoderado del Coronel del referido Coronel, se arrendó al Dn. Manuel Sánchez esta expresada Herreria por espacio de seis años y bajo las condiciones que comprende la escritura al efecto otorgada ante Dn Francisco Sánchez Valg. Escribano del numero de la Jurisdiccion de Quiroga, su fecha veinte y quatro de diciembre del año ultimo; por lo que, y procediendo a su entrega, y de los vienes y efectos pertenecientes a dicha Herreria y su casa, el repetido Dn. Froylan con asistencia de Dn. José Rodríguez Gallego y Dn. Manuel Sanchez, por ante mi se hizo el ynventario del tenor siguiente.

Primeramente, la fábrica corriente con todos sus pertrechos, como son la tubera, barquines, rueda de estos, la de macear bastante vieja y espuesta a escalabros, el mazo, yunque, dos tenazas grandes de caldear, otra de repillar las ágoas, otra que tiene el nombre de borricas, dos tenazas corbas, dos patelas, otra tenaza de cortar las ágoas, otra corbera, otra turquesa, la pala de fierro de echar la vena en las fragua, dos picachos de sacar las ágoas, una ágoa de pedarria, dos talladeras, una de cortar las agoas y otra de picar el fierro, una yunque de enderezarlo, quatro cañas de fierro para el reparo de las parajes, otras dos en el cavezal de la rueda maior, y otras dos de alzar las ágoas, otras dos de fundir, un escazallo de fiero, dos marras, dos martillos, uno de atrupillar y otro de tazar la vena, el rodo de fierro de descubrir la ágoa, otro rodo llanar el carro de vena. Dos tornos de fierro, el carnero de fierro de echar los gorriones, el asador de la tubera, la suara de fierro, un martillo para partir la vena para la ragua, dos trollas nuebas ferradas, dos palos rectos para la cruz de la rueda maior.

La fragua de manos corriente con su tubera de cobre, yunque, dos martillos y dos tenazas. Una rueda de piedra de afilar herramientas, con su manilla de fierro, y la rueda no muy redonda. Una talladeras. Una yunque de fierro en que se taza la bena. El carro de traerla usado. En la carbonera nuebe mil y seiscientos reales de carbón, que prudencialmente regulan entre si el Dn. Manuel Sanchez y Dn. José Rodriguez Gallego.

En la plaza, el peso de la bena con sus pesas de piedra. Dos mil doscientos reales de vena cruda y siete mil quinientos nobenta de vena cocida, que de la misma forma regulan el Gallego y sanchez, cuyas dos partidas componen la de nuebe mil ochocientos diez y nuebe reales.

Una bodega o almacen del fiero. La valanza de pesarlo con su quintal de fierro en dos piezas, una pesa tanbien de fierro de quarenta libras, otra de diez, otra de seis, otra de cinco, otra de quatro, otra de tres, otra de tres y media, la arroba, y la media todo de fierro. Treinta y nuebe quintales y veinte y tres libras de fierro, once de ellos en trocho y el restante en rejas, picado, lampo y algunas repuntas, el que ha de beneficiar el Sanchez para el Dueño de la Herreria, y poner su importe juto con el arriendo en la parte en que de este y sus condiciones resulta. Quatro gorriones, uno de ellos pequeño y dos escamelas usadas, que unos y otros son de peso de quatro quintales y quarenta y siete libras.

(El inventario sigue hablando de la bodega del vino, la despensa, la casa, el molino, el órreo, y los campos y prados). Todos estos bienes ha de cuidarlos, etc. 
1815, febrero, 22. San Juan de Seoane

Permiso de los vecinos a $D$. Antonio Somoza para que pueda construir la ferrería de Seoane del Caurel.

AHPLU: 2474/4

En la villa de San Juan de Seoane jurisdicion Real de Courel, a veinte y dos dias del mes de febrero año de mil ochozientos quince, Ante mi escribano unico de numero y testigos parecieron presentes Joaquin Sanchez, Pedro Lopez, Domingo Lopez Lolo, Vicente Fernandez, D. Antonio Romero, D. Manuel Romero, Jose Bergara, Juan Gallego, Manuel Lopez, Antonio Fernandez, Manuel Goilan, D. Bernardo Diaz, Froilan de Castro, Juan Doral, Domingo Lopez Lier, Jose da Vila, Francisco Rivera, Manuel Aira y santiago de Fojo, vezinos de los lugares de Meiraos, Villasebil, Miraz, Paderne y Piedrafita pertenecientes a la parroquia de Santa Maria de Meiraos; Jose Rodriguez, Pedro Teijeira, Manuel Vilela, Manuel Lolo digo Miguel, Domingo Jato, Jose Carballo, D. Juan Diaz, Antonio Juanes, Pedro Blanco, Juan Gundriz, vezinos de los lugares de Noceda y Vilela, parroquia de San Pedro del mismo Noceda, por si y enrepresentacion de los demas convecinos de los mismos, por los que prestan capcion de rato grado en forma de que estaran y pasaran por lo que ellos hagan y practiquen como asi se lo ofrecieron a los que dicen en concejo de vezinos que tubieron para hacer lo que adelante se expresará, y dijeron: que D. Antonio Somoza, vezino de San Martin del Rio, jurisdicion de Villaouzan, intenta construir al sitio Puente de Seoane una Herrería de fierro, habiendo al efecto cedido en su favor Domingo Garcia, procurador sindico general de este juzgado autorizado competentemente el roze y corte de leña de roble, uzedo y demas que producen los montes de las parroquias de Meiraos, Noceda, Seoane y Esperante, que por la parte de la Lomba de Parada se estienden hasta los montes de Riocereija, continuan al naciente por el penedo y la fuente de Raparon, al norte con la Forca de Teijeira a Chao de Vidalvello, Piedra de Piedrafita, Sierra da Escrita, poniente Labradas de Bustelo, Penaferreira hasta salto de Vales, con las condiciones y demas demarcaciones que constan de escritura otorgada ante el presente escribano el veinte y uno del actual, que va aqui por reproducida y a que se remiten, de la que acaban de ser y se declaran enterados, y para que en todos tiempos conste la conformidad de los otorgantes con esta escritura otorgan que por la presente por si, sus hijos, herederos y sucesores la aprueban, confirman y ratifican cuanto puedan y sea preciso por estar en todo de acuerdo con su contenido, teniendola a mayor abundamiento como lleban dicho aqui por reproducido y expreso por cuanto redunda en veneficio de los otorgantes y sus convezinos por las ventajas que les va a producir; y si acerca del particular se suscitase alguna cuestion confieren al mismo D. Antonio Somoza el poder que tienen, en dercho se requiere, mas firme y valido sea con clausula espresa de que lo jure y sustituya en procuradores, agentes y mas personas que le pareciere a fin de que a nombre de los otorgantes y mas por quien hacen y en representacion de su accion y derecho produzca judicial o estrajudicialmente todas las solicitudes conducentes, alegatos y papeles que le sean dables, etc. Ante mi Josef Manuel Lopez Mondelo. 
1828, abril, quince. Casa de Lamela.

Poder de don Juan Bernardo de Quiroga y Uría a su hermano el abad de Casoyo para la ventas de bienes en Sancedo con los que construir la ferrería de Mondón AHPLU: 2406/14

En la casa y granja de Lamela, parroquia de San Salbador del Hospital, jurisdicción de Quiroga, a quince dias del mes de abril de mil ochocientos veinte y ocho. Ante mi escribano público y testigos, Don Juan Bernardo Quiroga y Uría, dueño y vecino de esta casa, dijo: que en el año del mil ochocientos trece obtubo facultad real para vender sus haciendas de la provincia del Vierzo, Reino de León, e invertir su importe en la construcción de la Herrería de Mondón, que en el dia se alla corriente, aunque faltosa de algunos reparos necesarios para ponerla en estado de perfecta produción; y para ello le es preciso acabar de realizar la venta de todas las comprendidas en dicha Real facultad, para lo qual restan las fincas y rentas que posee en el dicho lugar de Sancedo de la misma provincia; y mediante sus ocupaciones no le permiten pasar personalmente a verificarlo, otorga al efecto y da todo su poder cumplido quanto en derecho se requiere, con clausula de juramento y sustitución, a su hermano Don José Ramón Quiroga, Abad de San Julián de Casoyo, para que en su nombre haga la referida venta de fincas y rentas, y perciva su importe, otorgando el competente instrumento o ynstrumentos a fabor del comprador o compradores; que el poder general o especial que para ello se necesite, se lo confiere sin ninguna limitación, con todas las cláusulas y requisitos de estilo, y que para su validación sean del caso, obligándose en forma a estar a todo tiempo por quanto en su virtud obrare, cerca de que renuncio a todas las leies de su fabor con la general y derechos de ella. Asi lo otorgo y firmo, siendo testigos Don Felipe Dominguez, pro, vecino de esta parroquia del Hospital, Don Froilán Balboa de la de Nuestra Señora de la Ermida y Juan do Bao del coto de la Seara, todos resdientes en esta casa. De lo cual y conocimiento del ortorgante, yo escribano doy fe. Juan Domingo Mazaira.

$$
-48-
$$

1829, enero, 22. Santa Eulalia de Oscos

Venta en favor de don Manuel Arango para la construcción de una población con varias industrias en Asturias.

AHPLU: 2071/10

En la villa y concejo de Santa Eulalia de Oscos a veinte y dos días del mes de enero de mil ochocientos veinte y nuebe, ante mi escribano público y testigos, Dn. Manuel Pereiro, vezino de Sarceda en este concejo, dijo que los terminos de montes Brabos del lugar de su becindad se componen para partirlos entre los herederos de diez y seis baras de a ocho pies cada una, de los cuales corresponden al que dice dos baras y dos pies de dominio util y su directo a $\mathrm{D}^{\mathrm{a}}$ Josefa Linares, vezina de San Pedro de Bogo en el concejo de Miranda. Los restantes terminos corresponden a distintos porcioneros, siendo el principal ynteresado en los montes de la Folgueirosa del Rio de los Amieiros incluso en 
dichos terminos Dn. Manuel Arango, escribano de este concejo, quien en dicha situacion apropió antes de aora aquel terreno y se halla herijiendo una poblacion que puede ser muy util al publico tanto por el acomodo de familias que proporciona como por el impulso que da a la industria y aprovechamiento de unos montes nulos y de ninguna utilidad hasta el dia, y deseando el exponente que dicho Arango realice su proyecto y con el ver aumentada la poblacion, la industria y los brazos utiles al estado como hes consiguiente a tan loable enpresa otorga que bende real y perpetuamente al Dn. Manuel Arango todos los montes brabos, terminos, y mas derechos que le asisten en la expresada situación de la Folgueirosa, y toda la parte de la derecha del río que desciende de los montes de la Candaosa hasta confinar en los terminos de los lugares de Nonide y Branabella sin reservacion de cosa alguna en todo aquel paraje por serle ocioso y de ningun provecho para su labranza, pues que le quedan terminos de Tala y Caba mas que suficientes en los restantes de su becindad sin causar por lo mismo perjuicio alguno al señor del directo dominio, cuya venta y cesion hace por precio y cuantia de seiscientos y cuarenta reales vellon, que confiesa haber recivido antes de aora para este efecto de mano del comprador en dos monedas de ha onza de oro cada una de que le otorga el mas completo recivo y carta de pago en forma, renunciando las leyes de la entrega y mas del caso. Confiesa que los seiscientos cuarenta reales vellon hes el justo y sumo valor que tienen los terminos y vienes vendidos y aun cuando lo tubiesen maior hace hirebocable del que fuere donacion a fabor del comprador renunciando las leyes del particular y terminos del reclamo. Se aparta por si y sus herederos del derecho que tenia a los veines vendidos, y lo transfiere todo en el comprador y los suyos para que forme la poblacion proyectada cualesquiera fabrica o establecimiento que le acomode constituyendose de interin por su inquilino y precario tenedor, confiriendole toda su facultad para que aprenda la posesion judicial sino tubiere por suficiente la personal de que se halla asistido. A la hebiccion obserbancia y cumplimiento de cuanto contiene esta escritura obliga persona y bienes presentes y futuros de toda clase, con sumision a las autoridades de justicia conpetentes y renunciacion de todas leyes en contrario con la que prohibe esta generalidad. Asi lo ortorgó, no firma por no saber hacerlo un testigo a su ruego que lo fueron Santiago Gonzalez de esta vecindad, Dn. Antonio José Rodríguez Quintana de la de Pumares en este concejo, y Dn. Antonio Martinez Villarquille de la de las Cruces en el de Castropol, de todo lo cual conocimiento del ortorgante y adbertencia del registro en el oficio de hipotecas doy fe. Ante mi: Josef Marqués.

1829, agosto, 5.Casa Herrería de Mondón Arriendo de la ferrería de Mondón a don Santiago Rodríguez y otros socios

AHPLU: 2406/16

En la Casa de la Herrería de Mondón, jurisdicción del Bollo, a cinco de agosto de mil ochocientos veinte y nuebe. Ante mi escribano de S. M. y testigos, pareció D. José María Quiroga y Prado, hijo primogénito y apoderado general de D. Juan Bernardo Quiroga y Uría, dueño de la casa de Lamela en Quiroga y otras, cuio poder pasó ante el presente escribano, confiesa no estarle rebocado ni limitado 
en parte alguna; y usando de las facultades que por él se le conceden, dijo: que por espacio de un año contado desde veinte y cinco de julio último, da en arriendo a D. Santiago Rodríguez, vecino del lugar y parroquia de San Pedro de Correjanes, jurisdicción de Baldeorres, a Manuel Rodríguez del lugar de Santalla de Arriba, feligresía de San Juan de Louzara, jurisdicción de Samos y a Antonio Yglesia, del de Forgas, parroquia de San Salbador de Ferreirós, jurisdicción de la Puebla de Brollón, es a saver: esta Herrería y casa con su molino y diestros, como son, soto, guertas y el prado del Bollo que acostumbra andar unido con dicha Herrería, en la cantidad de quatro mil y ochocientos reales, libres de todas contribuciones, menos la de frutos civiles, pagos en dinero metálico en los doce meses del año a prorrata, que corresponde hacerlo al vencimiento de cada uno de quatrocientos reales, puestos en su casa; y además vajo las condiciones siguientes: Primera, que todos los escalabros, no siendo el de arruinarse la chapacuña, o romperse el árbol de macear, quedan de quenta de los arrendatarios. Segunda, que los mismos arrendatarios han de cuidar de la casa y diestros, sin cortar árbol por el pie, mas de limpiarlos de la rama superflua, impidiendo la entrada de todo género de ganados en el soto. Tercera, que la Bodega principal del fierro queda por ahora reservada para Don Juan Bernardo, mientras no veneficie el que tiene almacenado en ella, e igualmente el cuarto de casa mas decente, con cuadras para usar de el quando le acomode, y le han de dar la yerva que necesite, el tiempo que él o quien haga sus veces se le ofrezca pasar por esta casa, y en el Bollo la precisa para el gasto de la cobranza de rentas; siendo de quenta de los arrendatarios abonar el costo que tubo últimamente la siega, y en palleira de ella o dejarla en el mismo estado de concluso el arriendo. Quarta, que de concluso el año de arriendo ha de dejar libre la Herrería, corriente en estado de travajar, con todas sus herramientas y tambien han de dejar libre la casa y diestros haciendo entrega de todos los muebles y herramientas que ya resultan de inventario. Quinta que la renta de los quatro mil y ochocientos reales, la ha de satisfacer conforme se va venciendo uno de los arrendatarios, y en caso de omisión ha de poderse entablar egecución contra todos, o uno solo como mejor combenga al D. Juan Bernardo o representantes. Y como presenciales, el D. Santiago, Manuel y Antonio enterados de esta escritura la acetaron, obligándose de mancomun a la paga de los quatro mil y ochocientos rs. a los plazos señalados y cumpliendo de lo demás que se refiere, acordando entre ellos que dicha paga queda a cargo de D. Santiago Rodríguez y el correr en un todo con los productos de la Fábrica y dispensa, disponen lo que contemple útil para su buena administración, dando cuenta a sus compañeros y estos obrar vajo su dirección. Y para firmeza de quanto queda mencionado en este instrumento se someten todos otorgantes con su persona y vienes presentes y futuros, a las Justicias que de ellas deban conocer, con poder bastante para que les hagan estar por el como si fuera sentencia definitiva pasada en cosa juzgada, cerca de que renunciaron a todas leies de su fabor con la general y derechos de ella. Asi lo otorgaron y firman, siendo testigos Juan de Bao del lugar del coto de la Seara, Joaquín Vila y Manuel González Barrua del de Santa Cubicia parroquia del Hospital de Quiroga. De todo lo cual y conocimiento de los otorgantes, yo el escribano doy fe. Juan Domingo Mazayra. 
1837, marzo, 27. San Martín de Quiroga

Poder de varios vecinos de Figueiredo sobre el uso del monte para carbonear

\section{AHPLU: 2406/24}

En la parroquia de San Martín, jurisdicción y partido de Quiroga, a veinte y siete de marzo de mil ochocientos treinta y siete. Parecieron ante mi escribano de $\mathrm{S}$. M. y testigos, Amaro Pérez, Juan Mondelo, Lázaro Rodríguez, Anselmo Rodríguez, Miguel Álvarez, Francisco García, José González, Juan Fernández, Antonio González, Juan López y Antonio Rodríguez de Arriba, vecinos del lugar de Figueiredo, parroquia de San Martín de Peites, en este partido, y dijeron: que teniendo igual derecho todos los vecinos de dicho pueblo al aprovechamiento de sus montes, supuesto todos pagan igual renta por ellos al señor D. Juan Bernardo Quiroga, dueño de la casa de Lamela, se pretende por unos cuantos de los más ricos pribar a los pobres del uso de la coza o raíz de brezo para hacer carbón y venderlo (único fruto que pueden utilizar del monte) mientras que los ricos disponen a su antojo y respectivamente gastan cuadruplicado así de la raíz como de la rama, ya para el cultivo de sus vienes, ya para quemar, ya para vender a los pueblos confinantes y pagar con su producto las cargas $\mathrm{y}$ contribuciones del pueblo, resultando de consiguiente para ellos aunque pocos casi todo o el principal beneficio como principales contribuyentes; y no siendo esto justo tratan los aquí expresados de oponerse hasta conseguir o el libre uso y aprovechamiento del monte o su división por iguales partes entre todos los vecinos. Y a este fin otorgan todo su poder cumplido a Antonio Rodríguez de Avajo y Santos Conde sus convecinos e interesados que también se allan presentes, a entrabos juntos y a cada uno insolidum, con cláusula se sustitución, para que en razón de lo expuesto y más que sobre el particular ocurra produzcan ante las autoridades competentes todo género de recursos y papeles, den información y provanzas, presenten o se conformen en peritos, hagan recusaciones, etc. (...). Siendo testigos Francisco Rodríguez, Benito Prieto y D. Ynacio Valcarce de esta vecindad. Escribano: Juan Domingo Mazayra.

$$
-51^{-}
$$

1838, mayo, 20. Casa granja de San Martín de Abajo. Arriendo de la ferrería lucense de Lusío AHPLU: 2406/25

En la Casa y Granja de San Martín de avajo, partido de Quiroga a veinte de mayo de mil ochicientos trienta y ocho. Ante mi escribano de S. M. y testigos, el Sr. D. Antonio $\mathrm{M}^{\mathrm{a}}$ Vazquez, Dueño y vecino de esta Casa dijo: que por espacio de tres años contados desde veinte y cinco de julio del corriente, da en arriendo a Manuel Yglesias, del pueblo de la Balsa, en Tracastela, la herraria de Lusio con todos sus pertrechos, casa y prado, que acostumbra andar unido con ella, y la guerta del Bacelo, en la cantidad de cuatro mil y cuatrocientos reales cada año pagos en dos plazos iguales, uno por el veinte y cinco de julio, y otro por veinte y cinco de enero, principiando la primera paga adelantada en el en el veinte y cinco del proximo julio, y asi sucesivamente durante los tres años de este 
arriendo, pena de ejecucion y de ser despojado de la fabrica si fuese omiso en hacer el apronto de lo correspondiente a cada plazo, que ha de ser puesto su importe en esta Casa, y libres los cuatro mil y cuatrocientos reales anuales, de todas contribuciones que quedan a cargo del Yglesias, y lo mismo las pensiones a que esté sujeta la fabrica; y ademas vajo estas condiciones: que todos los escalabros maiores y menores, no siendo el del arbol maior, quedan a cargo del arrendatario; y que este no ha de poder cortar madera, leña, no otra cosa en la dehesa y mas vienes de la Casa sin espreso consentimiento del Señor otorgante o quien le represente; que al entrar en la Herraria o su goze, se ha de formar inbentario circunstanciado de su estado, herramientas, y lo propio el de la casa, y en el mismo estado ha de dejar todo de conclusoy los tres años. Queda tambien de su cuenta cuidar no se estraiga el carbon de los montes propios de la fabrica para otras distintas fraguas y herrarias, asi como el reparar no se haga otra alguna estraccion en la Dehesa y mas vienes de la casa principal, siendo de su obligación dar parte de lo que ocurra, y entablar por de pronto qualquiera queja, para que se le confiere poder bastante. Y en esta conformidad se obliga el sr. otorgante a la certeza de este ariendo; y como presencial el Manuel Yglesias lo acetó, obligandose tambien a la paga de los cuatro mil y cuatrocientos reales en cada uno de los tres años a los plazos estipulados, y a cumplir con todo lo demas condicionado y que refiere esta escritura. Y para su firmeza, se someten ambos otorgantes a las autoridades competentes, para que les hagan estar por su espreso como si fuera sentencia pasada en juzgado cerca de que renunciaron a toas leies de su favor con la gneral y derechos de ella. Asi lo otorgaron y firman siendo testigos D. José de la Peña del lugar de San Julian de arriba en este Balle, D. Ramon Valq (Valcarce?) y Joaquin Fernandez residentes en esta casa y naturales el D. Ramon de Espasantes en Lemos y el Joaquin de Manjar en Samos. De todo ello y conocimiento de los otorgantes yo escribano doy fee. Juan Domingo Mazayra.

$-52-$

1852, septiembre, 27.

Informe que envía el ingeniero de minas, don Cirilo Tornos, al inspector de minas del distrito sobre la situación de diversas minas y el estado de las forjas catalanas en Asturias.

BOPA, 29 de septiembre de 1852, no 117, p. 2 y 3 .

El Sr. inspector de minas del distrito, con fecha 14 de julio último, me participa lo siguiente:

El ingeniero don Cirilo Tornos, destinado al servicio de esta inspección facultativa, me comunica con fecha 12 del corriente lo que copio:

En cumplimiento de lo que ordena el reglamento de nuestro cuerpo y de las órdenes de V.S. (menciona los trabajos que se realizan en diversas minas...).

Pero lo que más ha llamado mi atención, y sobre lo que quiero detenerme un poco, es el estado de las forjas catalanas que son la única industria del O. de la provincia. Nada más desconsolador que el aspecto de estas ferrerías, ni nada que dé una idea más triste del atraso en que se halla la metalurgia en el pais en que será su principal industria. Las forjas existentes hacia la raya de Galicia, están todas montadas como si se hubieran establecido en la infancia del arte: 
alli no hay innovación de ninguna clase, ni en la parte mecánica ni en la puramente metalúrgica. No bien llega el mineral á la fábrica, cuando le amontonan sobre grandes camadas de leños, colocados en las plazas de calcinación, formando montones hasta de 1500 quintales, y pegan después fuego por la chimenea que dejan abierta dentro del mineral. Pero es tal la cantidad de leña que emplean en esta operación que el mineral llega a aglutinarse, y es necesario partirlo después para echarlo en el crisol. Puede V. S. considerar cuanto combustible se desperdiciará en una calcinación que no exige una temperatura tan elevada, que podría verificarse con la llama escedente del hogar y que hasta puede escusarse, dirigiendo convenientemente la operación.

Pero no es esto solo el único defecto que en las tales forjas se observa, sino que en ninguna se ve establecido un medio mecánico cualquiera que tenga pñor objeto facilitar y simplificar la operación, haciéndola más económica; nada de eso, fuera de la rueda hidráulica que dá movimiento al martinetede las trompas, ó de otra rueda que ponga en movimiento los barquines, no se ve ningún medio mecánico empleado.

En cuanto á las ruedas hidráulicas que emplean, sobre ser de viciosa construcción corresponden á las de percusión, eje horizontal y aletas-planas, que como sabe V. S. rara vez producen del 26 al 30 por 100 de efecto útil. La trompa es también uno de los medios más costosos de proporcionarse viento, por que tampoco da más de 16 por 100 de efecto útil, produciendo un aire frio y húmedo que puede tener influencia en la maleabilidad y ductilidad del hierro.

Hasta las canales que conducen el agua desde el punto en que la toman hasta el depósito, son estraordinariamente defectuosas, sin usar en su construcción materiales hidráulicos de ninguna clase, las trazan con un desnivel tan considerable que á poco distancia que exista hasta el punto de la toma, pierden un tercio y hasta la mitad de la caida.

Por último donde existen barquines, no conciben que con una sola rueda puedan moverse a la par que el martinete; y por no emplear un comunicador y un transformador cualquiera, establecen otra rueda de paletas planas dedicadas a darles movimiento. No crea V. S. que este desperdicio de fuerza motriz nace de la abundancia de aguas, nada de eso, la mayor parte de las herrerias paran durante el verano por la disminución de los manantiales.

Muy triste es ver que ya que el atraso de nuestra industria permite el beneficio directo del hierro con enormes utilidades, no se establezcan las forjas de modo que honren al pais y hasta dupliquen tan crecidas ganancias, introduciendo las modificaciones tanto en el hogar, como en el modo de usar la fuerza motriz, y economizando el costoso trabajo de la fuerza de sangre.

En fin, sr. inspector, existe tal igualdad entre todas las forjas que vista una, es escusado ver las demás, por que nada nuevo se encuentra en ellas, y es tal el espíritu de mancomunismo que existe entre los dueños de las forjas que he llegado á sospechar, con vehementes indicios que, para mandar al gobierno de provincia los estados que les exigen para la estadística, se ponen de acuerdo y por esa razón existe en ellos tal uniformidad. 
Pudiendo asegurar a V. S. que no baja de 1300 a 1400 quintales de hierro la producción anual de cada forja, aun suponiendo que pare cuatro meses al año. Para cuya cantidad consumirán unos 3500 quintales de mena y 4100 de carbón vegetal. Este cálculo esta vasado en los datos que tomé en las mismas forjas, inspeccionando las cargas, y onservando los productos ect. Por término medio sacan de 6 a 7 quintales diarios de hierro. Esto es cuanto con referencia á mi última espedición puedo decir a V.S.

Lo que tengo el honor de poner en el superior conocimiento de V. E. para los efectos oportunos.

$-53^{-}$

1862, junio, 15. Santa Marina de Folgoso

Convenio sobre el modo y forma de trabajar en el martinete situado en Folgoso entre sus dueños y partícipes.

AHPLU: 2431/2

En el lugar y parroquia de Santa Marina de Folgoso Distrito de Courel partido de Quiroga, a quince dias de junio de mil ochocientos sesenta y dos. Ante mi Escribano de Numero de dicho Distrito y testigos parecieron presentes personalmente Francisco Arza. Juan e Ygnacio Arza, Luis Sanchez y benito Sanchez, vecinos todos de este referido pueblo y parroquia, quienes de un mismo acuerdo y conformidad a voz de uno y cada uno de por si insolidum renunciando las leyes de la mancomunidad dijeron. Que como llevadores y participes del Martinete que está situado en este mencionado pueblo, se han convenido entre si por la utilidad y mutua conveniencia que les reporta en lo siguiente: que desde hoy dia en adelante los que otorgan, sus hijos y herederos, se priban de trabajar de noche en el citado Martinete por los perjuicios que se le ocasionan a causa de los escalabros que con tal motibo acaecen en dicho Artefacto, imponiendose la pena de doscientos reales al que contraviniere o falte a lo estipulado, puesto que ha descrito ha principiar a trabajar en el repetido Martinete asta que sea claro y dejar de verificarlo al obscurecer, dejando libre y correinte para que el que partícipe que le toque entrar pueda trabajar sin obstaculo que se lo impida, y el escalabro o escalabros que acahezcanestando este trabajando han de ser reparados por cuenta de el que lo esté ocupando, cuya reparacion de estos se entienda de los menores, incluso el martinete y no los mayores, pues estos han de ser por cuenta de todos los partícipes, y para que en todo tiempo se les obligue al cumplimiento de este expreso como si fuere por sentencia definitiba ejecutoria, renuncian a las leyes, etc.

1891, julio, 3 .

$-54-$

Informe técnico sobre la ferrería leonesa de Pombriego Estadística Minera, año 1891, provincia de León, p. 190-195

La ferrería de Pombriego se halla situada en término del pueblo de este nombre, Ayuntamiento de Benuza, en la margen derecha del río Cabrera, á una altitud de 402 metros sobre el nivel del mar (...).Esta herrería fue fundada también, como la de Montes, por los Monjes Benedictinos de San Pedro de Montes, y cuando la 
desamortización de los bienes del clero, en el año 1822, la adquirió del estado D. Apolinar Suárez de deza y Caamaño, vecino de Madrid, y hoy la lleva en arriendo D. paulino Arias desde el año 1872.

Durante las obras del ferrocarril del Noroeste estuvo parada por falta de brazos que condujeran mineral y carbón. Esta forja marcha al año cinco meses escasos por falta de mena.

La disposición general de la fábrica es una cámara de $19 \mathrm{~m}$. 08 por $5 \mathrm{~m} .85$, dividida en dos compartimentos: uno de $7 \mathrm{~m} .83$ por $5 \mathrm{~m}$. 85 para la trompa y una fragua, y otro de $10 \mathrm{~m} 15$ por el mismo ancho para la forja, el mazo y el árbol motor. Hay otra cámara de $19 \mathrm{~m}$. 08 por $8 \mathrm{~m}$. 38 para carbonera, dentro de la cual hay un cuarto para dormir de $5 \mathrm{~m}$. 36 por $2 \mathrm{~m}$. 20, y á continuación de esta cámara se halla un almacén de efectos de $6 \mathrm{~m}$. 75 por $3 \mathrm{~m}$. 76. La carbonera ocupa un espacio de 660 metros cúbicos para el carbón, que es suministrado a la forja por una puerta. El crisol está formado de bandas de hierro todo alrededor y la del ciguillo en el fondo. Es de sección circular y forma de tronco de cono, cuyo diámetro mayor es de $0,85 \mathrm{~m}$., y el menor 0,50 por 0,33 de alto. Dicho crisol está formado por tres planchas de hierro: una de o m. 42 por o,33, y un espesor de o,03, que va debajo de la tobera, y se llama veterría; otra en el fondo del crisol, que se denomina ciguillo, y tiene 0,21 de radio por un espesor de $0,04, y$ la tercera plancha se halla del lado del trabajo o de las manos, y se titula la puerta de la forja, es de 0,03 de espesor, y en su fondo tiene un agujero semicircular para la salida de la escoria, que se llama el canillero. El lado opuesto á la puerta es una peña y se denomina la garandoa, y el opuesto a la tobera, también de peña, se titula las agarrias. Debajo del canillero hay un espacio elipsoidal para el cenicero y la colada de escorias, que se llama la cicatería. La extensión que viene á ocupar el carbón en la parte superior del crisol es de 1,40 m. por 1,30 hasta cubrir la tobera.

La tobera se halla á 0,30 por cima del crisol y tiene un diámetro de 0,48 , que va disminuyendo hacia éste. El viento llega á la tobera por medio de una trompa, en la que la presión del aire se verifica por medio de dos tubos o chiflones que toman el agua de la canal superior y viene encima de la caja ó cilindro de aire de la trompa: así es que la velocidad de éste depende de la altura de caída y de la cantidad de agua que entra en los chiflones, y se regula por medio de una compuerta.

El martillo pilón que llaman mazo, tiene una longitud de $4 \mathrm{~m}$. 20 por un diámetro 0,35 , es de madera de roble ó castaño, gira alrededor de un eje, situado a los $2 \mathrm{~m} .70$ de la cabeza, la cual está formada de un fuerte aro de hierro, que en su parte inferior tiene un ancho de o,10 á o,15, por un largo de o,32, y debajo de ésta existe un fuerte yunque de hierro ó acero sólidamente sujeto al suelo de la fábrica. Este mazo se mueve por medio de un árbol con levas de madera, que tiene un diámetro de 0,57 , cuyo eje de hierro se lubrifica por medio del agua, y en este árbol va una rueda de madera de paletas que tiene un radio de 1,43 m., siendo las paletas de un alto de 0,48 y un ancho de 0,36, que es también el ancho de la rueda. 
El salto de agua es de $5 \mathrm{~m}$. 80 con carga superior de $1 \mathrm{~m}$. 95, que produce en el motor de las paletas una fuerza de 9,78 caballos de vapor, y el canal tiene un ancho de 1,85, por un alto de $2 \mathrm{~m} .20$.

Hay una trompa y un chiflón, y la trompa sirve para una fragua y para la forja; por consiguiente, arrancan de ella las dos toberas correspondientes.

La mena de que se surte essta forja viene de La Chana, que dista tres leguas, ride hoy un 33\%, por la mucha arcilla que contiene, y se aga a boca-mina á 1'o9 pesetas el quintal métrico, el cual, por el transporte á la fábrica, cuesta 1,63 pesetas.

Antes de calcinar la vena se somete á lavado por medio del agua de un arroyo inmediato á la fábrica, para purgarla de la tierra que contiene. Una vez en la fábrica la mena, se somete a la calcinación en montones al aire libre, llamadas raguas, que se disponen de la manera siguiente: Sobre una era o superficie plana inmediata á la fábrica se coloca la leña, que es de chopo, humero, castaño, etc., y se tiene partida en troncos cilíndricos de o’42 á o’63 m. con el grueso de la rama ó tronco, de unamanera radial y formando un cilindro de $5 \mathrm{~m}$. 30 de diámetro y un alto de $1 \mathrm{~m} .75$, dejando en el centro un hueco, también cilíndrico, de o'42 m. de diámetro por la misma altura, y dos canales horizontales que se cruzan en ángulo recto, y sobre este montón de leña se va echando el mineral, empezando por la parte superior de la leña, conteniéndole con algunas estaquillas para que no se caiga fuera de ésta, para cuyo efecto se ponen algunos leños en sentido de la circunferencia hacia la parte exterior. Por el hueco central se echan carbones encendidos y se continúa el montón de mineral hacia la parte superior con $1 \mathrm{~m}$. 50, de manera que parece un sombrero. El fuego se propaga á todo el montón de un modo paulatino que da tiempo á cargar el mineral, y se tiene calcinando venticuatro horas para ser conducido a la fábrica.

Cada ragua de estas dimensiones contiene unos 450 quintales métricos de mena y 300 de leña. Las dimensiones de estas raguas varían mucho entre los límites de 4 á 7 metros de diámetro y de un metro á $1 \mathrm{~m}$. 75 de altura en la leña, y de 1 . 20 á 2 m. 40 de mineral.

El quintal métrico de leña cuesta á o'55 de peseta. Con una ragua de 6.900 kilogramos de mena lavada y 4.600 de leña, se obtiene 4.025 kilogramos de hierro, que representan una ley de $58 \%$; es decir, que por la operación del lavado aumenta el rendimiento, como debe suceder.

La fusión de la mena en la forja se verifica del siguiente modo: Sobre el crisol se echan carbones encendidos, encina, carbón de raíz de urz ó de brezo, se da viento por medio de la trompa y se van echando poco á poco las paletadas de mineral hacia la parte opuesta á la tobera, alternando con otras de carbón en la producción conveniente para que aquel no se liquide desde luego. El fundidor con un rodo de madera va acercando paulatinamente la mena hacia la tobera, echando encima carbón y de vez en cuando rocía con agua para concentrar el fuego abajo, y cuando ya se ha derretido y descendido el mineral de la tobera, se considera terminada la fundición y se procede a sacar la lupa o goa. Antes se da un fuerte golpe de fuego por espacio de media hora, echando mucho carbón, activando el fuego por medio de la trompa y rociando con agua para apagar los 
fuegos y reconcentrarlos abajo, y se conoce que el hierro está fundido y reunido en que se agarra a una palanca o barra de hierro que el fundidor introduce varias veces, tanto para apretar la masa como para reunirla, y sólo quedan alrededor de esta al estado líquido las escorias y sobrenadando la carbonilla. Por medio de unas palancas y ganchos de hierro se saca la goa del crisol hacia la parte de las agarrias; se destapa enseguida el canillero, previamente tapado con arcilla, para la salida de la escoria al cenicero o cicatería, y se somete la goa á la acción del martillo pilón ó mazo.

Es conveniente tapar con arcilla el canillero para que no sangre, porque si se verifica, es mala la fundición. La goa, que es una torta de hierro circular ligeramente cónica hacia abajo, se divide en dos paquetes que se llaman: cabezón, cuando tiene rabo ó apéndice, y cintas cuando no lo tienen; y entre tanto, un muchacho que se denomina tazador, saca la torta de escoria de la citaría ó cenicero por medio de un gancho, y se procede a cargar el horno, echando primero la carbonilla encendida que se había retirado para sacar la goa, y encima bastante carbón; uno de los paquetes se mete entre el carbón, cuya combustión se activa por medio de la trompa, y se echan algunas paletadas de mena en la parte opuesta á la tobera. El otro paquete se pone delante de este mineral y se cubre con carbón y mena. Cuando el primer paquete está suficientemente blando, se somete al batido y tirage por medio del mazo, y se hacen unas planchas que se llama hierro picado, cuya longitud es de $0,83 \mathrm{~m}$., su ancho de 0,07 m. y el grueso de 0.01, y que de 0,16 en 0,16 m llevan hendiduras en todo su ancho practicadas con un cortafríos por medio del pilón, cuyas secciones vienen a pesar $0,58 \mathrm{Klg}$., y se usan para rejas y azadones; hay otro hierro picado para cabezales de rejas de la misma longitud, o,05 $\mathrm{m}$. de ancho y o,01 de grueso que llaman lanulla, que se usa para hociles; otras veces se estira en cuadrillos que llaman vergallón de 0,83 m. por o,02 m. en cuadro, y que se emplea para gallos de azada y otros usos; y por fin, se obtienen planchas para rejas y calzas de figura triangular de $1,26 \mathrm{~m}$. de largo por $0,10 \mathrm{y} 0,01$ en sus anchos máximo y mínimo, y o,01 m. de espesor.

Entre tanto que se ejecutan estas operaciones, el fundidor sigue echando paletadas de carbón y mineral para preparar la segunda fundición que se conduce de la misma manera que la primera, y el segundo paquete se somete también a las mismas operaciones que el primero. La proporción de carbón que generalmente se invierte en estas operaciones es de tres ó cuatro para uno de mena; la del mineral de La Chana era de dos para uno de hierro elaborado, y la del de Parada Solana es de tres de mena cruda para uno de hierro. Se sacan cinco goas al día de veinticuatro horas”.

El personal de la fábrica se compone: de un capataz o aroza y ejerce las funciones siguientes: vigila á todos los operarios, ayuda al tirador á sacar la goa y en el tiraje y batido del hierro, y arregla la tobera cuando se descompone, que muchas veces es á los quince días, algunas duran un mes y otras un día, y en esta operación suele emplear cuatro horas. Dos fundidores que se ocupan exclusivamente de las operaciones de la fusión. Y un tirador que bate o tira el hierro en el mazo ó pisón y prepara el hierro elaborado. Un muchacho que se llama tazador, el cual portea y machaca la vena para echarla en la forja, da ó quita el viento á la tobera por medio de unas palancas que van á la compuerta de los chiflones. 
Estos cinco operarios se relevan por mitad cada cuatro horas en la forma siguiente: cada fundidor se retira á descansar después que ha sacado la goa que le corresponde, y es sustituido por su compañero; el tazador, después que ha porteado y machacado el mineral correspondiente a una fundición, se retira también a descansar mientras continúa la marcha del horno, y se levanta cuaando empieza la operación siguiente; el tirador se levanta para ayudar al fundidor á sacar la goa y efectuar el tiraje y batido del hierro, retirándose después á descansar; y lo mismo hace el aroza.

Los fundidores y el tirador ganan 20 pesetas al mes cada uno y o'215 de peseta por cada quintal métrico de hierro, el aroza 27'50 pesetas al mes y o'347 de peseta, y otras obvenciones, como derechos de marras, picachones, azadas, vino, etc.; y el tazador 12'50 pesetas al mes y o'215 de peseta.

Esta forja paga de matrícula á la hacienda 300 pesetas al año y 125 de consumos.

Se vende el quintal métrico de hierro á 38 pesetas, y como la elaboración sale por todos conceptos á 32'50, se obtiene una ganancia de 5,50 pesetas. 


\section{FUENTES Y BIBLIOGRAFÍA}




\section{FUENTES}

\section{ACADEMIA DE LA HISTORIA}

- Fondo Martínez Marina: manuscritos:

- $\quad 9 / 6034, \mathrm{n}^{0} 1,14,22,25,27,28,31,32,34$;

- $9 / 6036, \mathrm{n}^{0} 15,16$

- $9 / 6033, \mathrm{n}^{0} 5,6$

- Papeles Cornide Saavedra. Galicia: 9/5917

\section{ARCHIVO DE LA CHANCILLERÍA DE VALLADOLID (ACHV.)}

- Registro de Ejecutorias. Cajas: 138/9, 510/37, 830/54, 900/7, 900/13, $1107 / 69,1163 / 50,1432 / 1,1633 / 50,1805 / 1,2489 / 47,2489 / 70,2682 / 2$, 2885/79, 3052/35, 3272/4

- Pleitos civiles: Fernando Alonso: 207/5; Pérez Alonso: 1400/1

- Sala de Vizcaya: 3089/8

\section{ARCHIVO DIOCESANO DE ASTORGA (ADA)}

- Historia de San Pedro de Montes. Manuscrito del P. Herrezuelo

- Cartulario de Carracedo

- Índice de Particulares

\section{ARCHIVO DUCAL DE MEDINASIDONIA}

- $\quad$ Leg. 4963

\section{ARCHIVO GENERAL DE SIMANCAS (AGS)}

- Junta de Comercio y Moneda, leg. 295

- $\quad$ Registro General del Sello (RGS.):Tomo II, 1478, f. 113; t. IV 1494, f. 534; tomo X, 1486, f. 125; t...., 1549, ff...

- Secretaría de Marina: Expedientes: 555, 650, 561

- Expedientes de Hacienda. Legajos: 420,

\section{ARCHIVO HISTÓRICO NACIONAL (AHN)}

- CLERO: Libros, 6495, 6596, 6622, 6694, 6695, 9437,

- CLERO: Códice 181/B

- Tumbo de Celanova

- CONSEJOS: legajos: 12.080 expd. 146, 27197 exp. 4, 28685, exp. 7-3,

- ESTADO: leg. 1739, $\mathrm{n}^{0} 16$

- ÓRDENES GENERALES DE RENTAS: libros 37, exp. 4.939; libro 38, exp. 5.093

- MINISTERIO DE HACIENDA: legajos: 1479 


\section{ARCHIVO HISTÓRICO DE ASTURIAS}

- Protocolos notariales:

V. Prendes, leg. 1945

Ambrosio del Busto, leg.

Juan Álvarez de Cores, leg. 329

Francisco López Sierra, caja 15.635

- Fondos del Palacio del Pidival: C-11249/02, C-11249/04, C11249/05, C-11249/07, C-11249/o8, C-11249/09, C-11249/10, 11249/11, , C-11249/12, C-11249/14C-11250/63

- Fondos del juzgado de Grandas de Salime: cajas 12.709, 1913

- Contaduria de hipotecas, Allande: libros 115, 116, 118

\section{ARCHIVO HISTÓRICO PROVINCIAL DE LEÓN (AHPL.)}

PROTOCOLOS NOTARIALES (P. N.). CAJAS:

SIGLO XVI: 1481, 1487, 1488, 1490, 1547, 2849, 2849, 2850, 2868, 2871, 2872, 2874, 2878, 2909,

SIGLO XVII: 1663, 2109, 2126, 2698, 2923, 2936, 2937, 2945, 2969, 3025, 3103, 3104, 3126, 3150, 3186, 3189, 3195, 3316,

SIGLO XVIII: 616, 617, 618, 2378, 3279, 3283, 3287, 3292, 3295, 3301, 3328, 3329, 3333, 3337, 3339, 3340, 3341, 3342, 3443, 3353, 3377, 3398, 3465, 3376, 3463, 3492, 3493, 3494,

SIGLO XIX: 2126, 2576, 2723, 2724, 2729, 2792, 2793, 2829, 3576, 3577, 3578, 3579, 3580, 3581, 3582, 3675, 3677, 3678, 3695, 3712, 3736, 3749, 3761, 3762, $3783,3791,9113,9114,9116,9117,9123,9137,9162,11390$

\section{ARCHIVO HISTÓRICO PROVINCIAL DE LUGO (AHPLU)}

CAJAS Y LEGAJOS:

SIGLO XVI: 2047/9, 2407/9, 2547/1，3573/1，3973/2，4026/2，4030/1, $21359 / 74$

SIGLO XVII: 2048/2, 2386/3, 2407/9, 2408/1, 2408/2, 2547/1, 2547/3, 2548/1, 2555/1, 2566/1, 2566/2, 2566/3, 2566/4, 2566/8, 2567/10, 4030/4, $7011 / 1$,

SIGLO XVIII: 1501/2, 1501/3, 2417/2, 2417/3, 2417/9, 2417/11, 2463/1, 2463/6, 2463/7, 2467/7, 2474/4, 2478/1, 2478/4, 2514/5, 2528/4, 2555/2, 2566/10, 2570/1, 2570/2, 2570/6, 2576/2, 2679/8, 5088/2, 5088/9, 6701/13, $6709 / 9,6709 / 11,6709 / 14,6792 / 2$, 
SIGLO XIX: 239/3, 1377/2, 1389/7, 1481/5, 1503/2, 2069/3, 2069/4, 2069/7, 2070/4, 2070/6, 2070/7, 2071/2, 2071/5, 2071/6, 2071/8, 2071/10, 2072/8, $2086 / 5,2376 / 3,2376 / 6,2376 / 7,2377 / 1,2377 / 2,2377 / 3,2377 / 4,2398 / 5$, $2406 / 1,2406 / 2,2406 / 3,2406 / 6,2406 / 10,2406 / 11,2406 / 14,2406 / 15$, $2406 / 16,2406 / 17,2406 / 19,2406 / 23,2406 / 24,2406 / 25,2406 / 27,2407 / 5$, 2409/1, 2409/3, 2431/1, 2431/2, 2431/3, 2431/6, 2454/3, 2454/6, 2454/7, 2455/2, 2455/4, 2458/14, 2463/6, 2467/12, 2468/2, 2468/4, 2473/1, 2474/2, $2474 / 3,2474 / 4,2474 / 5,2474 / 6,2474 / 7,2474 / 8,2474 / 9,2475 / 5,2528 / 4$, 2528/10, 2528/11, 2563/6, 2563/7, 2563/9, 2576/6, 5340/2, 5340/3, 5340/5, $5341 / 2,5431 / 1,5431 / 6,5431 / 7,5431 / 8,6709 / 5$,

DESAMORTIZACIÓN: Leg. 10, 2

\section{ARCHIVO HISTÓRICO PROVINCIAL DE ORENSE (AHPO)}

- Protocolos: cajas 528, 547, 473, 550, 554, 566, 605, 694

- Casa do Castro, cajas: 112, 130

- Outarelo-documentos generales: caja 79, $\mathrm{n}^{0} 97$

- Outarelo-genealogía, caja $77, \mathrm{n}^{0} 14,18,19$

- Láncara- Lousadela-Hacienda, caja 90, nº 173

\section{ARCHIVO HISTÓRICO DEL REINO DE GALICIA (AHRG)}

REAL AUDIENCIA: Cajas y legajos:

$54 / 67,67 / 18,70 / 80,103 / 4,145 / 76,190 / 33,714 / 16,756 / 30,931 / 44,1140 / 65$, $1389 / 7,1662 / 4,1687 / 29,2149 / 35,2472 / 120,2489 / 48,2576 / 2,2619 / 20$, 2837/19, 3020/42, 3070/39, 3086/14, 3169/9, 3176/59, 3269/9, 3636/77, 4030/4, 5772/33, 5909/40, 5951/55, 6800/4, 7013/1, 7059/1, 7059/15, 7199/6, $7215 / 3,7415 / 13,7451 / 13,8698 / 87,9090 / 4,9219 / 55,9121 / 2,10862 / 59$, 10882/20, 10899/41, 11587/10, 11837/14, 12331/27, 12446/2, 12446/45, $12476 / 1,12476 / 2,13272 / 28,13895 / 2,14100 / 84,14119 / 58,14147 / 12,14701 / 11$, $14869 / 12,14974 / 45,15167 / 24,15215 / 33,15215 / 33,16987 / 28,18201 / 13$, $18816 / 8,19222 / 30,19223 / 38,19768 / 32,19816 / 8,19877 / 30,20441 / 70$, 20527/41, 21130/75, 21291/28, 21359/74, 21468/32, 21477/56, 21477/96, $21485 / 2,21702 / 18,21708 / 6,21859 / 3,21859 / 104,21859 / 105,22459 / 4$, $22758 / 41,23088 / 72,23716 / 6,23088 / 72,23900 / 20,24680 / 47,24837 / 43$, $25207 / 15,25291 / 28,25514 / 8,26179 / 54,26319 / 20,26643 / 46,28281 / 3$,

Familias: Hombreiro, leg. 13, 19, 21/70, 57/39, 78/2, Protocolos: 1.617

Vecinos: 9214/43, 18201/13, 26643/46

\section{ARCHIVOS MUNICIPALES}

- PONFERRADA: Libro de actas 1794-1799, 1862...

- TORRE DEL BIERZO: Libro de actas del siglo XIX 


\section{ARCHIVOS PRIVADOS}

- Familia Alberto Rodríguez (Cacabelos, León): Libro del Guarda mayor de Montes del Distrito de Villafranca del Bierzo.

- Familia de Llano Ovalle (Villafranca): Pleito por la utilización de los montes de Villarrubín

- Manuel Rodríguez (Toral de los Vados, León): Cuentas de la ferrería de Llamas (León) de los años 1880-1882.

- Mariano Higuera (Ponferrada): Cuentas y cartas de los marqueses de Villafranca a sus mayordomos (siglo XVIII).

\section{ARCHIVO DEL MONASTERIO DE SAMOS}

- Casa de Lusío, libro becerro

\section{ARCHIVO DEL MONASTERIO DE SILOS}

- Congregación de Valladolid. Estados de cuentas, libros XXII y XXIX.

\section{BIBLIOTECA NACIONAL:}

- Manuscritos: 7304, 7295, 13.338,

\section{BOLETIN OFICIAL DE LA PROVINCIA DE LEÓN (BOPL.)}

Años 1835-1880

BOLETIN OFICIAL DE LA PROVINCIA DE OVIEDO (BOPA)

Años 1835-1865

\section{BOLETÍN OFICIAL DE LA PROVINCIA DE LUGO (BOPLU)}

Números sueltos

\section{CATASTRO DE ENSENADA}

- RESPUESTAS GENERALES (R.G.): En PARES

- POBLACIONES CONSULTADAS: ASTURIAS: Allande, Boal, Cangas de Narcea, Caso, Castropol (coto de Montealegre), Corvera, El Franco, Grandas de Salime, Illano, La Nava, Pravia, Santalla de Oscos, Taramundi, Tineo (Villarmilde), Valdés (Santiago de Arriba), Villanueva de Oscos; LEÓN: Arnado, Cacabelos, Herrerías de Marciel, Las Herrerías, Melezna, Oencia, Pombriego, Ponferrada, San Clemente de Valdueza, Villafranca del Bierzo; LUGO: Baralla (Penarrubia), Barxa de Lor, Becerreá (Ouselle), Bravos, Cervantes (San Pedro de Cervantes, Vilarello, Doiras, Donis), Cervo (Santa $\mathrm{M}^{\mathrm{a}}$ de la Rua), El Real, Ferreira de Pallares, Fisteus, Folgoso do Courel, Freixo, Guntín, Hospital, Lamaigrexa, Noceda de Doncos, Órreos, Ourol, Pacios, Pontenova, Río 
Torto, Seceda, Valdelouro, Viloalle, Visuña; ORENSE: San Vicente de Leira.

\section{MUSEO NAVAL}

- Colección Guillén: Manuscritos 2.175,

\section{REAL ACADEMIA DE LA HISTORIA}

- Fondo Martínez Marina. Manuscritos: 9/6033, 9/6034, 9/6036

- Papeles de Cornide Saavedra, ms. 9/5.917 


\section{BIBLIOGRAFÍA}

ABOL-BRASÓN, M. (2011): Documentos escogidos de la Casa de Jovellanos en el Archivo de Mohias. Fundación Foro Jovellanos del Principado de Asturias. Gijón.

ACEVEDO, B.: (1898): Boal y su concejo. Oviedo

ADARO, L. (1916): Criaderos de hierro de España. Tomo II: Asturias. Memorias de la Comisión del Mapa Geológico de España. Madrid.

ADARO RUIZ-FALCÓ, L. (1968): 175 años de la sidero-metalurgia asturiana. Ed. Cámara Oficial de Comercio, Industria y Navegación. Gijón.

ADARO RUIZ-FALCÓ, L. (1986): “Los comienzos de las fábricas de Municiones Gruesas de Trubia y de Oviedo, 1792-1799”. BIDEA (Oviedo), n 118, pp. 339451.

ADARO RUIZ-FALCÓ, L. (1989): Datos y documentos para una historia minera e industrial de Asturias. Documentación de la minería asturiana (1383-1803). Grabado con escenas y planos de la minería española y europea, $t$. II. Suministro Adaro, S.A., Gijón.

AGRÍCOLA, G. (1972): De re metallica. Madrid.

ALARCOS, E. (1980): "Elementos vascos en el léxico de las ferrerías asturianas". En Cajón de sastre asturiano, 2. Ayalga, Salinas, pp. 107-116.

ALCALA-ZAMORA Y QUEIPO DE LLANO, J. (1972): “Aportación a la historia de la siderurgia española”. Moneda y crédito (Madrid), $\mathrm{n}^{\circ} 120$.

ALCALA-ZAMORA Y QUEIPO DE LLANO, J. (1974): "La fábrica de hierro colado de Corduente en Molina de Aragón”. Estudios del Departamento de Historia Moderna. Zaragoza, p. 61-119.

ALCALA-ZAMORA Y QUEIPO DE LLANO, J. (1974): Historia de una empresa siderúrgica española: Los altos hornos de Liérganes y La Cavada (1622-1834). Institución Cultural de Cantabria. Santander.

ALCALA-ZAMORA Y QUEIPO DE LLANO, J. (1974): "Producción de hierro y altos hornos en la España anterior a 1850". Moneda y crédito (Madrid), ${ }^{\circ} 128$.

ALCALA-ZAMORA Y QUEIPO DE LLANO, J. (1976): "Las fundiciones siderúrgicas de Santander y el fracaso de la revolución industrial en España, durante el reinado de Carlos IV". XL Aniversario del Centro de Estudios Montañeses, t. I, (Santander), p. 309-336.

ALCALA-ZAMORA Y QUEIPO DE LLANO, J. (1978): “progresos tecnológicos y limitaciones productivas en la nueva siderurgia andaluza del siglo XVIII" En Actas del I congreso de Historia de Andalucía, t. I. Córdoba. 
ALMUNIA Y LEÓN, J. (1951): Contribución de la Real Sociedad Vascongada al progreso de la siderurgia española afines del siglo XVIII (17771-1793). Madrid.

ALMUNIA Y DE LEON, J. (1953): “Orígenes de la fabricación del arrabio en España”. Revista del Instituto del Hierro y el Acero (Madrid), $\mathrm{n}^{\circ} 1$.

ALMUNIA Y DE LEON, J. (1953): "El ingenio para fundir sin fuelles de Pablo Antonio de Rivadeneira”. Revista del Instituto del Hierro y del Acero (Madrid), $\mathrm{n}^{\circ} 2$

ALMUNIA Y DEL LEÓN, J. (1955): “Las fanderías en España”. Revista del Instituto del Hierro y del Acero (Madrid), $\mathrm{n}^{\circ} 41$.

ALONSO ALVAREZ, L. (1976): Industrialización y conflictos sociales en la Galicia del Antiguo Régimen (1750-1830). Akal, Madrid.

ALONSO BARBA, A (1640): Arte de los metales. Madrid.

ÁlVAREZ, C. (1996): "El hierro en el medievo leonés". En Actas de las I Jornadas sobre minería y tecnología en la Edad Media peninsular. León, p. 349-362.

ALZOLA Y MINONDO, P. (1896): "La industria siderúrgica en España”. Revista Minera, Metalúrgica y de Ingeniería (Madrid), XLVIII, p. 289-293, 303-304, 319-320, 326-328, 335-336 у 341-343.

ALVARGONZÁLEZ, R. Ma (1982): “Ferrerías”. Gran Enciclopedia Asturiana, VII.

ANES ÁlVAREZ, G. (1970): Las crisis agrarias en la España moderna. Madrid.

ANES ÁLVAREZ, G. (1987): "Exenciones y franquicias en los reinados de Carlos III y Carlos IV”. Hacienda Pública Española (Madrid), nº 108/109, p. 101-115.

ANES ÁLVAREZ, G. (1988): "La industrialización de Asturias en el siglo XIX: una transformación económica parcial”. En E. FERNÁNDEZ DE PINEDO y J. L. HERNÁNDEZ (Ed.): La industrialización del norte de España. Barcelona, p. 99-112.

ANES ÁlVAREZ, G. (1988): Economía y sociedad en la Asturias del Antiguo Régimen. Ariel, Barcelona.

ARACIL, R. y GARCÍA BONAFÉ, M. (1980): "La protoindustrialització: un nou concepte en la història econòmica”. L'Avenç (Barcelona), ${ }^{\circ} 32$.

ARACIL, R. y GARCÍA BONAFÉ, M. (1983): "La protoindustrialització i la indústria rural espanyola al segle XVIII”. Recerques, $\mathrm{n}^{\circ} 13$. 
ARAGÓN RUANO, Á (2009): "Una longeva técnica forestal: los trasmochos o desmochos guiados en Guipúzcoa durante la Edad Moderna”. UNED. Espacio, Tiempo y Forma. Serie IV, Historia Moderna, t. 22, p. 73-98.

ARAGÓN RUANO, Á. (2011): "La actividad siderometalúrgica guipuzkoana durante el siglo XVII: transformaciones y productividad. Lurralde: Inves. Espac., 34, p. 109-149.

ARAGÓN RUANO, Á (2011): "Cambio climático y transformaciones económicas en Guipúzkoa entre los siglos XVI y XVII”. Los papeles de Pedro Morgan, I, p. 108-128.

ARAGÓN RUANO, Á. (2012): "las ferrerías guipuzcoanas ante la crisis del siglo XVII". Cuadernos de Historia Moderna, $\mathrm{n}^{0}$ 37, p. 73-102.

ARBIDE ELORZA, I., y otros (1980): Ferrerías en Legazpi. Caja de Ahorros Provincial de Guipúzcoa. Guipúzcoa.

ARBIDE ELORZA, I y URCELAY URCELAY, J. (1993): "Ferrerías de agua. Primeros datos sobre ellas en Legazpi y posterior evolución técnica". $I^{\circ}$ Simposi Internacional sobre la Farga Catalana, Ripoll.

ARBIDE ELORZA, I. (1993). "Instalaciones primitivas utilizadas para la obtención del hierro en Legazpi”. En I ${ }^{\circ}$ Simposi Internacional sobre la Farga Catalana. Ripoll, pp. 289-303.

ARIAS CUENLLAS, M. (1976): "El monasterio de Samos en la época de la Exclaustración (1835-1880)". Centro de estudios e Investigación "San Isidoro". León.

ARIAS CUENLLAS, M. (1992): Historia del monasterio de San Julián de Samos. Monasterio de Samos y Diputación de Lugo. Samos.

ARGÜELLO MENÉNDEZ, J. J. (1996) : "Minería y metalurgia en Muñás y Carceu (Valdés- Asturies)". En Actas de las I Jornadas sobre minería y tecnología en la Edad Media peninsular. León, p. 134-161.

ARMENGAUD, A. (1953): "La fin des forges à la catalane dans les Pyréneés ariegeoises". Annales Économies-Sociétés-Civilisations (Paris), 8, nº 1, pp. 6266.

ARNAIZ, M. (1850): "Breve reseña de las fábricas de fundición de hierro de Navarra, sus recursos y ventajas que pueden reportar al Estado con la protección del gobierno de S. M.”. Memorial de Artillería, serie 1a, t. VI, p. 4991.

ARROYO VALIENTE, P. y CORBERA MILLÁN, M. (1993): Ferrerías en Cantabria. Santander. 
ARROYO VALIENTE, P. y otros (1993): "Medios técnicos de las ferrerías de Cantabria de finales del siglo XVIII. Estudio a partir de los documentos y de los restos físicos". I Simposi Internacional sobre la Farga Catalana, Ripoll.

BALBOA DE PAZ, J.A. (1986) "Las herrerías de Montes y Compludo". Estudios Bercianos (Ponferrada), $\mathrm{n}^{\circ} 5$.

BALBOA DE PAZ, J.A. (1988): “La ferrería de Tejedo de Ancares”. Fuentes (Ponferrada), s/n.

BALBOA DE PAZ, J. A.(1990): Hierro y herrerías en el Bierzo preindustrial. Diputación Provincial, León.

BALBOA DE PAZ, J. A. (1992): Ferrerías bercianas. CDN, Madrid.

BALBOA DE PAZ, J. A. (1993): Datoli y Munárriz, dos militares en la historia económica del Bierzo. Ponferrada.

BALBOA DE PAZ, J.A. (1997). "Las ferrerías de Montes en el siglo XVIII”. Rev. Bierzo (Ponferrada), p. 78-93.

BALBOA DE PAZ, J.A. (2001): "La ferrería de san Blas de Sabero". Revista Bierzo, p. 85-93.

BALBOA DE PAZ, J.A. (2008): Ferrerías y fraguas. Biblioteca de tradiciones leonesas. Edilesa. León.

BALBOA DE PAZ, J. A. (2013): "La ferrería orensana de Mondón". Revista Bierzo, p. 80-90.

BARCIA, E. (1988): Fray Plácido Losada y su Breve noticia del monasterio de Montes”. Aquiana (Ponferrada), nº junio-septiembre.

BARKHAM HUXLEY, M. (2003): "El comercio marítimo vizcaíno y guipuzcoano con el Atlántico peninsular (Asturias, Galicia, Portugal y Andalucía) y con los archipiélagos de Canarias y Madeira a principios de la Edad Moderna”. Itsas Memoria. Revista de Estudios Marítimos del País Vasco, 4, p. 147-164.

BARREDA Y FERRER DE LA VEGA, F. (1948): "Las ferrerías en la provincia de Santander". Anales de la Asociación Española para el Progreso de las Ciencias (Madrid), año XIII.

BARREIRO MALLÓN, B. (1978): "La economía asturiana en los siglos XVI y XVII”. Historia General de Asturias, fascículos 163 y 164.

BARREIRO MALLÓN, B (1988): "agricultura e industria en Asturias en el siglo XVIII”. En E. FERNÁNDEZ DE PINEDO y J. L. HERNÁNDEZ (Ed.): La industrialización del norte de España. Barcelona, p. 37-53. 
BARREIRO MALLÓN, B. (1997): "Montes comunales y vida campesina en las regiones cantábricas”. Studia Historica, $H^{a}$ Moderna, 16, p. 17-56.

BARREIRO MALLÓN, B. (1994): "Masa arbórea y su producto en Asturias durante la Edad Moderna”. En V. CABERO (ed.): El medio rural español. Cultura, paisaje y naturaleza. Salamanca, p. 241-253.

BARTOLOMÉ BARTOLOMÉ, J. M. (2000): La hegemonía de una nueva burguesía en el Bierzo (180o-1850). León.

BELHOSTE, J. F. (1984): "Un reseau technique: la forge au bois". Revue de l'Art, $\mathrm{n}^{\circ} 65$.

BERG, M. (1987): La era de las manufacturas 1700-1820. Una nueva historia de la Revolución Industrial inglesa. Barcelona.

BERTRAND, C. (1882): El verdadero librecambista. Estudio teórico-práctico del desarrollo de la industria metalúrgica y carbonera en Asturias. Oviedo.

BILBAO BILBAO, L.M. (1977): “Crisis y reconstrucción de la economía vascongada en el siglo XVII”. Revista de Estudios Vascos, año I, n ${ }^{\circ}$, p. 157-180

BILBAO BILBAO, L.M. (1984): "La siderurgia vasca, 1720-1885. Atraso tecnológico, política arancelaria y eficiencia económica”. En IX Congreso de Estudios Vascos (Bilbao, 1983). San Sebastián.

BILBAO BILBAO, L.M. (1987): "introducción y aplicaciones de la energía hidráulica en la siderurgia vasca- ss. XIV-XVII-. Studia Historica V (Univ. Salamanca).

BILBAO BILBAO, L.M. (1989). "La industria siderometalúrgica tradicional en el País Vasco (1450-1720)”. Hacienda Pública Española, 108.

BILBAO BILBAO, L.M. y FERNANDEZ PINEDO, E. (1982): “Auge y crisis de la siderometalurgia tradicional en el País Vasco (1700-1850)". En TEDDE, P.: La economía española al final del Antiguo Régimen. II: Manufacturas. Alianza, Madrid.

BONHOTTE, J. y otros (1988): Forges et forgeurs de l'Ariège au XIXème siècle. Archives dèpartementales de l'Ariège.

BONHOTTE, J. y otros (1992): "Forges à la catalane et paysages d'industrie en Ariège”. Midi-Pyrènèes, $\mathrm{n}^{\circ} 181$.

BONHOTE, J. (1993): "Forges à la catalane et charbon de bois: histoire de l'environnement dans les Pyrénées de la haute Ariège". En $I^{\circ}$ Simposi Internacional sobre la Farga Catalana. Ripoll, pp. 191-193.

BORREGUERO GARCÍA, E. (1994): Documentos para la historia de las Reales Fábricas de Sargadelos en el Archivo General Militar de Segovia. A Coruña. 
BUCHANAN, A. (1972): Industrial Arqueology in Britain. Londres.

CAlVO, F. (1964): La España de los metales. Ed. Centro Nacional de Investigaciones Metalúrgicas. Madrid.

CALVO, F. (1977): Momento científico-técnico de la fábrica de hierro de Sargadelos. A Coruña.

CALLE ITURRINO, E. (1963): Las ferrerías vascas. Bilbao.

CÁMARA DE COMERCIO DE LEON (1957): Economía leonesa. Pequeña historia de su evolución. 1907-1957. León,

CAMPOS, M. K. y FERNÁNDEZ, B. (1996): "Fuero de ferrerías del valle de marquina de Suso". En Actas de las I Jornadas sobre minería y tecnología en la Edad Media peninsular. León, p. 625-637.

CAMPOMANES, P. (1991): El fomento de la industria popular. La educación popular de los artesanos. Ed. de Gonzalo Anes. Gea. Oviedo.

CANDAL, X. M. (1993): "Pleitos de aguas en la Audiencia coruñesa durante el siglo XVIII". Obradoiro, $\mathrm{n}^{0}$ 2, p. 85-103.

CANGA ARGUELLES, J. (1833-1834): Diccionario de Hacienda con aplicación a España. Madrid, 2 t.

CANTELAUBE, J. (1993): "Apparition et èvolution de la forge à la catalane dans l'est des Pyrènèes françaises, XVIIème-XIXème siècles". I Simposi Internacional sobre la Farga Catalana. Ripoll.

CARMONA BADIA, J. (1990): El atraso industrial de Galicia. Auge y liquidación de las manufacturas textiles. Barcelona.

CARMONA BADÍA, J. (1990): "Crisis y transformación de la base industrial gallega, 1850-1936". En J. NADAL y A. CARRERAS (Ed.): Pautas regionales de la industrialización española. Barcelona, p. 23-48.

CARMONA BADÍA, J. (1993): "Sargadelos en la historia de la siderurgia española”. Revista de Historia Industrial, $\mathrm{n}^{\circ} 3$, p. 11-39.

CARMONA BADÍA, J. (1994): A etapa de Luis de la Riva e o apoxeo da produccion civil de Sargadelos. A Coruña.

CARO BAROJA, J. (1956): "Sobre maquinarias de tradición antigua y medieval". Revista de dialectología y tradiciones populares, XII.

CARO BAROJA, J. (1986): "La tradición técnica del pueblo vasco". En Vasconiana. Estudios vascos III. E. Xertoa. San Sebastián, p. 103-179..

CARRASCO Y SAYZ, A. (1889): "Fábricas artilleras de Villafranca del Bierzo". Memorial de Artillería (Madrid), tomo XII, serie 4. 
CARRIÓN ARREGUI, J. Ma (1986): “Aspectos técnicos de las ferrerías guipuzcoanas en el siglo XVIII". Actas del III Congreso de la Sociedad Española de Historia de las Ciencias (San Sebastián, 1 al 6 de octubre de 1984). San Sebastián, t. I., p. 151-163.

CARRIÓN ARREGUI, J. Ma (1991): La siderurgia guipuzcoana en el siglo XVIII. Bilbao.

CARRIÓN ARREGUI, J. Ma (1993): "El funcionamiento de la empresa siderúrgica vasca en el siglo XVIII: los ferrones guipuzcoanos”. I Simposi Internacional sobre la Farga Catalana. Ripoll.

CARRIÓN ARREGUI, I. (1998): "La crisis del siglo XVII y la producción de armamento en Gipuzkoa”. Revista de Dirección y Administración de Empresas, $\mathrm{n}^{0} 7, \mathrm{p} .21-31$.

CASARIEGO, J.E. (1950): El marqués de Sargadelos o los comienzos del industrialismo capitalista en España. Instituto de Estudios Asturianos. Oviedo.

CASO GONZÁlEZ, J. (1973): La sociedad económica de Asturias desde su fundación hasta 1808. Boletín del Centro de Estudios del siglo XVIII, Oviedo.

CASTELLANO, L. (1954): "La industria popular del hierro". BIDEA (Oviedo), $\mathrm{n}^{\circ}$ XXII.

CASTRO BOLAÑO, J.M. (1850): Informe sobre el estado de los montes de la provincia de Lugo, y los medios de proveer a su conservación. Lugo.

CAVEDA, J. (1851): Memoria presentada por el Excmo. Señor Ministro de Comercio, Instrucción y Obras Públicas por la Junta clasificadora de los productos de la industria española reunidos en la Exposición Pública de 1850. Madrid.

CEBALLOS CUERNO, C. (2001): Arozas y ferrones. Las ferrerías de Cantabria en el Antiguo Régimen. Santander.

CENTENO, J. (1865): Apuntes sobre las industrias minera y metalúrgica de la provincia de Oviedo. Oviedo.

CIPOLLA, C. M. (1981): Historia económica de la Europa preindustrial. Barcelona.

COLL MARTÍN, S. (1982): "La minería del carbón en España a finales del Antiguo Régimen (1770-1835)". En La Economía española al final del Antiguo Régimen, t. II. Madrid, p. 229-335.

COLL MARTÍN, S. (1984): Jovellanos y la minería asturiana. Texto inédito de D. Gaspar Melchor de Jovellanos. Oviedo.

COLLIS, J. (1989): La Edad del Hierro en Europa. Barcelona. 
CONDE DE TORENO. QUEIPO DE LLANO, J.J. (1785): Descripción de varios mármoles, minerales, y otras diversas producciones del Principado de Asturias y sus inmediaciones. Ed. facsímil Biblioteca Popular Asturiana, Oviedo, 1978.

CORBERA, M. (2001): La siderurgia tradicional en Cantabria. Oviedo.

CORBERA, M.; ARROYO, P. (1989): “Los edificios de las ferrerías, un ejemplo de construcción funcional: Aproximación a una tipología en Cantabria”. Ilustraciones Cántabras. (Institución Cultural de Cantabria, Santander), pp. 311-327.

CORBERA, M. RUIZ, F (1991): "Las ferrerías cántabras. Del auge dieciochesco a la decadencia final". Norte. Serie documentación, $\mathrm{n}^{\circ}{ }_{1}$. Universidad de Cantabria.

CORBERA, M. y otros (1993): "Coyunturas del hierro forjado en Cantabria en los siglos XVIII y XIX”. I Simposi Internacional sobre la Farga Catalana. Ripoll.

CORTÉS, Ma E. (1996): "Las ferrerías del río Hoceseca (Señorío de Molina), a fines del siglo XV”. En Actas de las I Jornadas sobre minería y tecnología en la Edad Media peninsular. León, p. 475-485

CUBILLO, L. (1908): “La fábrica de Trubia”. Memorial de Artillería (número extraordinario)

CUETO NOVAL, R. del (1928): La minería de la Región Gallega. La Coruña.

CUETO NOVAL, R. del y IRIMO, A. (1910): La minería en Galicia (Lugo y La Coruña). La Coruña.

DAUMAS, M.: L'archéologie industrielle en France. Paris, 1980.

DEANE, P. (1977): La primera revolución industrial. Barcelona.

DÍAZ ÁLVAREZ, J. (2005): “Crisis agrarias en la Asturias del siglo XVII. Una aproximación a su estudio". Revista de Historia Moderna, no 23, p. 307-322.

DÍAZ FIERROS, F. y otros (1982): As especies forestais e os solos de Galicia. Publicacións do Seminario de Estudos Galegos. Sada-A Coruña.

DIEZ SALAZAR, L.M. (1983): Ferrerías en Guipúzcoa (siglos XIV-XVI), 2 t. San Sebastián.

DÍAZ DE SALAZAR, L.M. (1997): Ferrerías guipuzcoanas: aspectos socioeconómicos, laborales y fiscales (siglo XIV-XVI). San Sebastián.

DONAPETRY YRIBARNEGARAY, J. (1953): "La obra del marqués de Sargadelos". BIDEA (Oviedo), nº 18, p. 92-109. 
DONAPETRY YRIBARNEGARAY, J. (1953): Historia de Vivero y su concejo. Vivero.

DURANY CASTRILLO, M. (1987): "La actividad minera en el Bierzo medieval (900-1300)”. Revista Bierzo (Ponferrada).

ERICE, F. (1995): Propietarios, comerciantes e industriales. Burguesía y desarrollo capitalista en la Asturias del siglo XIX (1830-1885). Universidad de Oviedo.

EZQUERRA DEL BAYO, J. (1845): "Resumen estadístico razonado de la riqueza producida por la minería en España durante el año 1844". Revista Anales de Minas, III, p. 407-446.

EXPÓSITO, D., ÁLVAREZ, V. y GONZÁLEZ, N. (200 ): "La ferrería de Brieves: un ejemplo preindustrial de la manufactura del hierro en Asturias". En ÁLVAREZ ARECES, M. A.: Arquitecturas, ingenierías y culturas del agua. Gijón.

FAGAN, B. (2008): La Pequeña Edad del Hielo. Cómo el clima afectó a la historia de Europa, 1300-1850. Barcelona.

FALCÓN PÉREZ, Ma I. (1996): "La manufactura del hierro en Aragón en los siglos XIV-XVI". En Actas de las I Jornadas sobre minería y tecnología en la Edad Media peninsular. León, p. 363-383.

FAYA, Ma A. y ANES, L (2007): Nobleza y poder en la Asturias del Antiguo Régimen. Madrid.

FEITO, J.M. (1977): La artesanía popular asturiana. Salinas (Asturias).

FERNÁNDEZ, J. (1991): Forxas hidráulicas, mazos ou machucos no norte galego. A Coruña.

FERNÁNDEZ, R. (Ed.) (1985): España en el siglo XVIII. Homenaje a Pierre Vilar. Barcelona.

FERNÁNDEZ ALBADELEJO, P. (1975): La crisis del Antiguo Régimen en Guipúzcoa, 1766-1833; cambio económico e histórico. Madrid.

FERNÁNDEZ CASADO, V. (1984): “Topónimos de la provincia de León que se relacionan con la riqueza mineral, elevaciones del terreno y depresiones del mismo”. Tierras de León, $\mathrm{n}^{\circ}$ 55, p. 105-121.

FERNÁNDEZ CORTIZO, C. (1990): "La población de Galicia en la primera mitad del siglo XVII: los vecindarios de 1631 y 1651". Obradoiro de historia moderna. Homenaje al profesor Eiras Roel en el XXV aniversario de su cátedra. Santiago, p. 103-130. 
FERNÁNDEZ HUERTA, P. y MAZA OTERO, M. (1996). “Contexto geo-histórico de las ferrerías en Guipúzcoa. Finales del siglo XV”. En Actas de las I Jornadas sobre minería y tecnología en la Edad Media peninsular. León, p. 486-498.

FERNÁNDEZ MARTÍN, L. (1975): "Provisiones reales a favor de Asturias durante la regencia de los reyes de Bohemia (1541-1551)". BIDEA, no 84 y 85, p. 217-327.

FERNÁNDEZ DE PINEDO, E. (1981): Centralismo, ilustración y agonía del Antiguo Régimen (1715-1833). En Historia de España de Tuñón de Lara, t. VII. Barcelona.

FERNÁNDEZ DE PINEDO, E. (1985): "Avances técnicos y consecuencias económicas en la siderurgia española del siglo XIX”. En PESET, J.L. (ed.), La ciencia moderna y el Nuevo Mundo. Madrid.

FERNANDEZ DE PINEDO, E. (ed.) (1988) La industrialización en el norte de España. Barcelona.

FERNANDEZ DE PINEDO, E. (1994): "Nacimiento y consolidación de la moderna siderurgia vasca (1849-1913): el caso de Vizcaya. En J. Hernández y J.L. García (comp.): Lecturas de historia empresarial. Madrid, p. 195-216.

FERNANDEZ PENEDO, S. (1964): "Los primeros altos hornos al coque y la primera acería de España". Revista del Instituto del Hierro y del Acero, $\mathrm{n}^{\circ}$ 93, p. 444-466.

FERNÁNDEZ SUÁREZ, A. (1957): “La herrería de Aguillón”. ABC, 8 septiembre de 1957.

FERNÁNDEZ VÁZQUEZ, V. (2011): Ponferrada. Artística y monumental. Ponferrada, $735 \mathrm{p}$.

FRANCO SILVA, A. (1981): "Bienes, rentas y vasallos del señorío de Villafranca del Bierzo al término del siglo XV”. Archivos Leoneses, nº 69, p. 39-72.

FRANCO SILVA, A. (1982): "El señorío de Villafranca del Bierzo" BRAH, t. CLXXIX, cuad. 1, pp. 35-160.

FUERTES ACEVEDO, M. (1880): Mineralogía asturiana. Oviedo.

FUERTES ARIAS, R. (1902): Asturias industrial. Gijón.

FUlGOSIO, F. (1866): Crónica General de España. Provincia de Orense. Madrid.

GALLARDO, A. y RUBIO, S. (1930): La farga catalana: descripció $i$ funcionament; historia, distribució geográfica. Barcelona.

GARCÍA FUENTES, M. (1987): El camino de acceso a Galicia en el siglo XVIII. Diputación de la Coruña. La Coruña. 
GARCÍA GONZÁLEZ, M.J. (199 ): La Desamortización de Madoz en el Bierzo. León.

GARCÍA GONZÁLEZ, M.J. (1994): La Desamortización de Mendizábal y Espartero en el Bierzo. León.

GARCÍA LINARES, A. (1980): "El consejo de Allande, según el Catastro de Ensenada". BIDEA, $\mathrm{n}^{\circ} 101$.

GARCÍA MONTORO, C. (1977-78): "Fundación de las ferrerías "Ntra Sra de la Concepción” y “El Angel” de Marbella”. Anuario de Historia Moderna y Contemporánea de la Universidad de Granada, nº 4-5, p. 285-293.

GARCÍA MONTORO, C. (1979): “La siderurgia de Río Verde y la deforestación de los montes de Marbella”. Moneda y Crédito, n 150, p. 79-95.

GARCÍA-SANZ MARCOTEGUI, A. (1982): "El aprovechamiento de carbón en las ferrerías de Elcorri. Cálculo de su consumo y precios (1802-1867)". Cuadernos de Etnología y Etnografía de Navarra. Pamplona, XIV, p. 395-420.

GARCÍA-SANZ MARCOTEGUI, A. (1984): "La construcción de ferrerías en la Barranca de Navarra en el siglo XIX". Cuadernos de Sección (Geografía e Historia), n 4 , Eusko Ikaskuntza (San Sebastián), p. 139-146.

GARCIA TATO, I. (1999): Vilanova, Outarelo y San Francisco Blanco. Monografía histórica de una parroquia gallega. Instituto de Estudios Valdeorreses. Cuaderno monográfico $n^{\circ}$ 30, 866 pág.

GARCÍA TATO, I. (2000): "Las ferrerías de Río Cabo y Pombriego en el siglo XIX”. Revista Bierzo, p. 89-169.

GARCÍA TATO, I. (2001): La casa de Outarelo de Valdeorras. Formación y desarrollo de su patrimonio (siglo $X I V-X X$ ). Santiago de Compostela. Colección Trevinca.

GARCÍA TATO, I. y ÁLVAREZ, E. (2012): Las encomiendas gallegas de la orden militar de San Juan de Jerusalén. Estudio y edición documental. Santiago de Compostela, t. II.

GARCÍA VALDEZ, C. (1979-1984): "El concejo de Pravia en el siglo XVIII. Datos que aporta el catastro del marqués de la Ensenada”. BIDEA (Oviedo), $\mathrm{n}^{\circ} 98$ (1979), 605-642); no 99 (1980), 227-265; n 102. (1981), 191-215; no 111 (1984), 89-126.

GARMENDIA LARRAÑAGA, J. (1976): Las ferrerías. San Sebastián.

GELABERT GONZÁLEZ, J. E. (1978): "Algunos aspectos del sistema de transportes entre Galicia y Castilla en los siglos XVII y XVIII". Archivos Leoneses, 63. 
GELABERT GONZÁLEZ, J. E. (1987): “La producción de hierro en Vizcaya y Guipúzcoa hacia 1620”. II Congreso Mundial Vasco. Congreso de Historia (Bilbao, 1987), t. III. Ed. Txertoa, San Sebastián, p. 203-208.

GILLE, B. (1966): Histoire de la Metallurgie. Paris

GÓMEZ MENDOZA, A. (1980): "Los ferrocarriles y la industria siderúrgica (1855-1913)”. Moneda y crédito, nº 155, p. 3-20.

GOMEZ NUÑEZ, S. (1926): El general de artillería Don Juan Manuel Munárriz y la siderurgia del siglo XVIII en la región del Bierzo. Madrid.

GONZÁLEZ, T. (1832): Registro y relación general de minas de la Corona de Castilla, 2 v. Madrid.

GONZÁleZ BUENO, M. (1997): Ferrerías de la Demanda burgalesa. Diputación provincial de Burgos.

GONZALEZ ECHEGARAY, M. C. (1972): "Ferrones vascos en la Montaña". Estudios Vizcainos, III, n ${ }^{\circ}$ 5, p. 185-196.

GONZALEZ ECHEGARAY, M. C. (1974): “Aportación al estudio de las herrerías montañesas”. Instituto de Etnografía y Folklore, tomo IV, Santander.

GONZÁLEZ MUÑOZ, Ma C . (1980): Galicia en 1571, población y economía. Sada.

GONZÁLEZ PÉREZ, C. (1994): A producción tradicional do ferro en Galicia: as grandes ferrerías da provincia de Lugo. Lugo.

GONZÁLEZ PÉREZ, C. (2004): “A minaría e a siderurxia tradicionais do ferro na provincia de Lugo". En Minaría. Expedientes de explotacions mineiras no arquivo histórico provincial de Lugo. Catálogo de exposición. Xunta de Galicia, p. 23-38.

GONZÁLEZ-POLA DE LA GRANJA, P. (1994): Sargadelos 1798. Un motín en la Galicia de finales del Antiguo Régimen. A Coruña.

GONZALEZ PORTILLA, M. (1977): "La industria siderúrgica en el País Vasco: del verlangssystem al capitalismo industrial". En Crisis del Antiguo Régimen e industrialización en la España del siglo XIX. Madrid.

GONZÁLEZ SANCHEZ, I. (2004): "Patrimonio rústico del marqués de San Esteban del Mar en el Gijón del siglo XVIII”. En F. J. ARANDA (cd): El mundo rural en la España Moderna. Cuenca. Universidad de Castilla-La Mancha.

GONZÁLEZ TASCÓN, I. (1987): Fábricas hidráulicas españolas. MOPU. Madrid. 
GONZÁLEZ VECIN, J. (1984): “Los mayores hacendados del partido de Ponferrada a mediados del siglo XVIII". Tierras de León, ${ }^{\circ} 57$.

GORROCHATEGUI, J.; YARRUTI, M.J. y otros (1993): "Paleometalurgia del hierro en Bizkaia. Las ferrerías de monte altomedievales". I Simposi Internacional sobre la Farga Catalana. Ripoll.

GRUPO 75 (1977): La economía del Antiguo Régimen. La "renta nacional” de la Corona de Castilla. Universidad Autónoma, Madrid.

GUILISASTI, J.F. (1776): "Informe sobre la aplicación del cok a las ferrerías". Extractos de la Sociedad Bascongada de los Amigos del País, Vitoria, VI, p. 37 y SS.

GURRIARÁN, R. (2000): Da prerromanización ao Wolfran: Apuntamentos históricos das explotacións mineiras en Valdeorras. Santiago de Compostela, $304 \mathrm{p}$.

HAMILTON, E.J. (1975): El tesoro americano y la revolución de los precios en España, 1501-1650. Barcelona.

HELGUERA QUIJADA, J. (1984): La industria metalúrgica experimental en el siglo XVIII. Las Reales Fábricas de San Juan de Alcaraz, 1772-180o. Valladolid.

HERNANDEZ SAMPELAYO, P. (1922-1935): Criaderos de hierro de España, tomo IV. Hierros de Galicia. Memorias del Instituto Geológico y Minero de España. (Madrid), I (1922), II (1931), III. (1935).

HERNÁNDEZ SAMPELAYO, P. (1956): “Coto minero de Formigueiros (Lugo)”. Instituto del hierro y del Acero, año IX, $\mathrm{n}^{\circ}$ 46, número especial, mayo , p. 561577 .

HERREZUELO, J., Historia de San Pedro de Montes, manuscrito en ADA, Astorga.

HINTZE, H. (1952): Metalurgia del Hierro. Buenos Aires.

IBAÑEZ, R. (1792): "Discurso para establecer herrerías en la provincia de Mondoñedo”. El Espíritu de los Mejores Diarios. Madrid.

IZARD, M. (1979): Manufactureros, industriales y revolucionarios. Barcelona.

JOVELLANOS, G. M. (1992): Diario. Ed. J.M. Caso. Barcelona.

KELLENBENZ, H. (1977): El desarrollo económico de la Europa continental (1500-1750). Madrid.

KARR, E. (1862): Metalurgia del hierro. Ferrerías al carbón vegetal. Zaragoza.

KEMP, T. (1976): La revolución industrial en la Europa del siglo XIX. Barcelona. 
KRIEDTE, P. (1994): Feudalismo tardío y capital mercantil. Barcelona.

KRIEDTE, MEDICK Y SCHULUMBOHM (1986): Industrialización antes de la industrialización. Barcelona.

LABORDE, M. (1952): "Las ferrerías en los ríos guipuzcoanos". Munibe (San Sebastián), X, p. 15-22.

LABORDE, M. (1976): "Actividad de la Real Sociedad Vascongada de Amigos del País en el desarrollo de la técnica industrial minero-metalúrgica durante el siglo XVIII". En III Semana de Antropología Vasca (Bilbao 1973). Bilbao, t. II, pp. 51-78.

LABRADA, L. (1804): Descripción económica del Reino de Galicia. Ferrol. Ed. facsimilar. Galaxia. Vigo, 1971.

LANZA ALVAREZ, F. (1991). Ribadeo antiguo (noticias y documentos). A Coruña.

LARRUGA, E. (1794): Memorias políticas y económicas sobre los frutos, comercio, fábricas y minas de España. Madrid, 41 vol. Ed. facs. Instituto "Fernando el católico". Zaragoza, 1998.

LAZURTEGUI, J. (1918): Una nueva Vizcaya a crear en el Bierzo. Bilbao.

LE THOMAS, P. J. (1969): La metalurgia. Barcelona.

LECUONA, M. (1976): El nombre vasco de la ferrería "ola". En III Semana de Antropología Vasca (Bilbao 1973). Bilbao, t. II, pp. 123-127.

LEITE DE VASCONCELOS, J. (1922): "Ferrería e Ferraría". Boletín de la Real Academia Gallega (La Coruña), ${ }^{\circ} 147$.

LEMA PUEYO, J. A. (1996): "Instituciones en el fuero de Ferrerías de Vizcaya (siglo XV)". En Actas de las I Jornadas sobre minería y tecnología en la Edad Media peninsular. León, p. 691-698.

LEMAUR, C. (1762): Memoria sobre el mineral de carbón hallado entre Bembibre y Astorga. Madrid.

LENCE-SANTAR, E. (1952): "El arbolado en la provincia de Mondoñedo". Boletín de la Comisión de Monumentos de Lugo, $\mathrm{n}^{\circ}$ 37-38.

LENCE-SANTAR, E. (1954): Mondoñedo y el arbolado en el siglo XVI. Vivero.

LILLEY, S (1973): Hombres, máquinas e historia. Madrid.

LÓPEZ ALVAREZ, J. y GRAÑA GARCÍA, A.: (1998): Ferrerías, mazos y fraguas en Asturias. Servicio de Publicaciones del Principado de Asturias. 
LÓPEZ POMBO, L. (2001): Hidalgos y casas señoriales de la provincia de Lugo. Ayuntamientos de As Nogais, Pedrafita do Cebreiro y Triacastela. Diputación Provincial, Lugo.

LORENZO FERNÁNDEZ, X. (1963): “O mazo, a trompa e a moa”, en Actas do I Congresso de Etnografia e Folklore, II. Braga.

LUNAR HERNÁNDEZ, R. (1977): Mineralogénesis de los yacimientos de hierro del noroeste de la Península. Memoria del Instituto Geológico y Minero de España, t. 90. Madrid.

LUNAR HERNÁNDEZ, R.; RUIZ CRUZ, M.D. (1977): "Mineralogía de las rocas de caja de los yacimientos de hierro en los alrededores de Ponferrada (León)". Boletín Geológico y Minero, T. LXXXVIII, p. 434-445.

LUXÁN, F. (1861): Viaje científico a Asturias y descripción de las Fábricas de Trubia, de fusiles de Oviedo, de zinc de Arnau y de hierro de la Vega de Langreo. Madrid.

LLOMBART, V. (1992): Campomanes, economista y político de Carlos III. Madrid.

LLOPIS LLADO, N. (1941): "Sobre la morfología de los Picos Ancares y Miravalles”. Rev. Las Ciencias (Madrid).

MADOZ, P. (1845-1850): Diccionario geográfico-estadístico-histórico de España y sus posesiones de ultramar. Madrid.

MADOZ, P. (1845-1850): Diccionario geográfico-estadístico-histórico de España y sus posesiones de ultramar. Madrid. Ed. Facsímil de León, Valladolid, 1983.

MADRAZO MADRAZO, S. (1977): "Las transformaciones de la red viaria asturiana, 1750-1868”. BIDEA (Oviedo), $\mathrm{n}^{\circ}$ 90, p. 61-137.

MADRAZO MADRAZO, S. (1981): "Precios del transporte, tráfico de mercancías en la España de finales del Antiguo Régimen”. Moneda y Crédito, $\mathrm{n}^{\circ}$ 159, p. 3972.

MADRAZO MADRAZO, S. (1982): Portazgo y tráfico en la España de finales del Antiguo Régimen”. Moneda y Crédito, $\mathrm{n}^{\circ}$ 160, p. 39-84.

MADURELL i MARIMÓN, J. Ma (1972-73): "Fargues, martinets y clavaó (contribució a la seva história)". Anales del Instituto de Estudios Gerundenses, XXI.

MAFFEI, E. y RÚA FIGUEROA, R. (1871-1872): Apuntes para una Biblioteca española de libros, folletos y artículos impresos y manuscritos, relativos al conocimiento y explotación de las riquezas minerales y a las ciencias auxiliares. Madrid. Reeditado Cátedra San Isidoro, León, 1970. 
MALUQUER DE MOTES, J. (1984): "La producción de hierro en la farga catalana”. Revista de Historia Económica, II, $\mathrm{n}^{\circ} 3$, Madrid.

MALUQUER DE MOTES, J. (1984): "La siderurgia tradicional: la farga catalana". L'Avenç, $\mathrm{n}^{\circ} 72$.

MALUQUER DE MOTES, J. (1988): "La siderurgia pre-industrial a l'Europa meditarrània: elements per una comparació". Recerques, $\mathrm{n}^{\circ} 21$.

MARTÍN GALINDO, J.L. (1956): Arrieros maragatos en el siglo XVIII. Madrid.

MARTÍNEZ DOMINGUEZ, B. (1987): Estudio de la desamortización eclesiástica durante el trienio liberal en la provincia de Lugo (1820-1823). Diputación Provicial de Lugo.

MAS ARREDONDO, C. (2000): Història de la farga catalana. Pagès editor, Lleida.

MAS I CANALS, D. (1993): "Evolució de la indústria metal.lúrgica a les Valls d’Andorra”. I Simposi Internacional sobre la Farga Catalana. Ripoll.

MATEU SUBIRÁ, J. (1993): "Glossari dels fargaires". En $I^{\circ}$ Simposi Internacional sobre la Farga Catalana. Ripoll, pp. 215-216.

MEIJIDE PARDO, A. (1979): Documentos para la historia de las Reales Fábricas de Sargadelos. Sada.

MENÉNDEZ GONZÁLEZ, A. (1989): "Navarros y carboneros. Las Reales Fábricas de Armas y Municiones de Asturias (1794-1809). BIDEA (Oviedo), $\mathrm{n}^{\circ}$ 132, pp. 809-832.

MENÉNDEZ GONZÁLEZ, A. (1992): Élite y poder: la Junta General del Principado de Asturias, 1594-1808. Oviedo.

MERINO NAVARRO, J.P. (1981): La armada española en el siglo XVIII. Madrid.

MIGUEL LÓPEZ, I. (1984): "El comercio hispanoamericano a través de Gijón (1778-1795)”. BIDEA, n 132, p. 697-730.

MINGUÉS RODRÍGUEZ, V.M. (1996): “Un exponente de gestión económica de la "fidalguía" gallega y de producción de hierro en la montaña lucense. La herrería de Quintá durante el Antiguo Régimen”. Studia Histórica, Historia moderna (Universidad de Salamanca), $\mathrm{n}^{\circ}$ 15, p. 209-242.

MINGUÉS RODRÍGUEZ, V. M. (1995/96): "Em verbo do surprendente ritual fundacional de umha ferraria quiroguesa no século XVI. Um apontamento histórico-etnográfico". Brigantium. Boletín del Museo Arqueológico de la Coruña, vol. 9, p. 117-136. 
MIÑANO, S. (1826-1829): Diccionario geográfico-estadístico de España y Portugal. Madrid.

MOLAS RIBALTA, P. (1988): "La actitud económica de la burguesía en la España del siglo XVIII”. Espacio, tiempo y forma (UNED), nº 4, p. 407-424.

MOLERA I SOLA, P. (1980): La farga. Barcelona.

MOLERA I SOLA, P. y BARRUECO, C. (1983): LLibre de la farga. Barcelona, .

MORALES MATOS, G. (1976): "Introducción al estudio geográfico de la siderurgia asturiana”. BIDEA (Oviedo), $\mathrm{n}^{\circ} 88-89$, pp. 309-430

MORIS, G. (1986): Las ferrerías asturianas. Gijón.

MORIS MENÉNDEZ-VALDÉS, G. (1998): "Ingenios hidráulicos históricos: molinos, batanes y ferrerías”. En El Agua en la Historia. Valladolid, pp. 121-173.

MORLA, T. de (1784-1786): Tratado de artillería para el uso de la Academia de Caballeros Cadetes del Real Cuerpo de Artillería, 2 t. Segovia.

MORO BARREÑETA, J. Ma (1979): "Los montes públicos en Asturias a mediados del siglo XIX". Agricultura y sociedad, 12, 227-248.

MORO PIÑEIRO, M. J. (1990): "Siderurgia tradicional en Asturias". En García Merino y otros: Los espacios rurales cantábricos y su evolución. Universidad de Cantabria. Santander.

MOYA, M. y otros (1993): "La siderurgia en Málaga en el siglo XIX". En I Simposi Internacional sobre la Farga Catalana. Ripoll, pp. 367-373.

NADAL, J. (1975): El fracaso de la Revolución Industrial en España. Barcelona.

NADAL (1992): Moler, tejer y fundir. Estudios de historia industrial. Barcelona.

NADAL, J. y CARRERAS, A. (Ed.) (1990): Pautas regionales de la industrialización española. Barcelona.

NEF, J. (1967): "La minería y la metalurgia en la civilización medieval". En Historia económica de Cambridge, T. II, Madrid.

NIPHO, M. (1770): Correo general de España. Madrid.

OCAMPO SUÁREZ-VALDÉS, J. (1984): Asturias preindustrial, 1750-180o. Una aproximación”. BIDEA (Oviedo), nº113, p.1049-1072.

OCAMPO SUÁREZ-VALDÉS, J.(1987): La economía asturiana al final del Antiguo Régimen. Las manufacturas, 1750-1850. Consejería de Educación y Cultura del Principado de Asturias. Oviedo. 
OCAMPO SUÁREZ-VALDÉS, J. (1990): Campesinos y artesanos en la Asturias Preindustrial (1759-1850). Gijón.

OJEDA, G. (1985): Asturias en la industrialización española, 1833-1907. Madrid.

OJEDA, G. (1989): "Energía y recursos mineros en la industrialización española". BIDEA (Oviedo), nº 132, pp. 793-807.

OJEDA SAN MIGUEL, R. (2003): “Tendencias en la producción de las ferrerías de Castro (1615-1848). Gaiak, 10, p. 24-31.

OLANO, M. (2008): "Carlos Lemaur y la industria del hierro y del carbón en la cuenca del Boeza". En Actas del VI congreso internacional sobre patrimonio geológico y minero. X sesión científica de la SEDPGYM. Fabero del Bierzo, 19 septiembre-2 de octubre de 2005.

ORDAX-AVECILLA, C. (1888): Memoria referente a la provincia de Lugo redactada por su gobernador. Lugo.

ORELLA ANZUÉ, J. L. (1996): "El fuero de Ferrerías de Guipuzkoa (1338). Fijación crítica del texto y estudio de sus instituciones". En Actas de las I Jornadas sobre minería y tecnología en la Edad Media peninsular. León, p. 567-604.

ORTEGA VALCARCE, J. (1974): Las transformaciones de un especio rural: Las Montañas de Burgos. Universidad de Valladolid. Valladolid.

OTAEGUI ARIZMENDI, A. (1986): "La Real Fábrica de Orbaiceta y el Valle de Aezcoa: Aspectos conflictivos en torno a los montes". I Congreso de Historia de Navarra de los siglos XVIII, XIX y XX, Príncipe de Viana, Pamplona, anejo, $\mathrm{n}^{\circ}$ 5, XLVII, p. 569-575.

OTERO LANA, E (1992): Los corsarios españoles durante la decadencia de los Austrias. El corso español del Atlántico peninsular en el siglo XVII (1621-1697). Madrid.

PAILLETE, A. (1853): "Ojeada sobre los criaderos de hierro de Asturias". Boletín del Ministerio de Fomento, t. V.

PARRONDO, F. (1984): "La deforestación en la provincia de Madrid como consecuencia del proceso desamortizador". Estudios Geográficos, nº 177.

PAZ GONZÁLEZ, D. (1991): El monasterio de Villanueva de Oscos: de la Reforma a la Exclaustración. Universidad de Oviedo.

PÉREZ ALBERTI, A. (1981): “Aproximación xeográfica aos vales fluviais en Galicia”. C.E.G (Santiago), t. XXXI.

PÉREZ ALBERTI, A. (1986): Galicia. A Xeografía. Vigo. 
PÉREZ ÁlVAREZ, Ma . J. (1995): "Los límites de un modelo económico en el norte leonés: el valle de los Ancares (siglo XVIII). Tierras de León, n $^{\circ}$ 97-98, pp. 201-215.

PÉREZ ÁLVAREZ, Ma J. (1996): La montaña noroccidental leonesa en la Edad Moderna. Universidad de León.

PEREZ DE CASTRO, J.L. (1973): "El concejo de Villanueva de Oscos según el Catastro del marqués de la Ensenada”. BIDEA (Oviedo), nº 78, p. 11-31.

PEREZ DE CASTRO, J.L. (1974). "El concejo de Taramundi, según el catastro del marqués de la Ensenada". BIDEA (Oviedo), $\mathrm{n}^{\circ}$ 81, p. 97-118

PEREZ DE CASTRO, J.L. (1976): "Piantón, Paramio y Abres (actual concejo de Vegadeo), según el catastro de Ensenada". BIDEA (Oviedo), 88-89, pp. 583606.

PÉREZ DE CASTRO, J.L. (1976): "El concejo de Castropol, según el Catastro de Ensenada”. Archivum (Universidad de Oviedo), XXVI, p. 261-281.

PEREZ DE CASTRO, J.L. (1977): "Las Tapias, Serantes, Campos y Salave, según el catastro de Ensenada”. BIDEA (Oviedo), nº 90-91, pp.173-189.

PÉREZ DE VILLARREAL, V. (1977): "Ferrerías y ferrones por tierras de Baztán”. Cuadernos de Etnología y Etnografía de Navarra, Pamplona, IX, ${ }^{\circ}$ 27, p. 345-357.

PÉREZ DE VILLARREAL, V. (1984): Ferrerías. Pamplona.

PÉREZ GARCIA, J. M. (1988): "El siglo XVII: Economía y sociedad”. en A. Domínguez Ortiz: Historia de España”, t. 6., p. 175-334.

PÉREZ MOREDA, V. (1998): "El final de la expansión demográfica: la crisis de la mortalidad en los años noventa". Las sociedades ibéricas y el mar a finales del siglo XVI. T IV, Madrid.

PÉREZ MORENO, A. (1856): "Estado de la minería en Asturias durante el año 1856, con algunas consideraciones interesantes”. Revista Minera IX, p. 660$672,689-705,722-744$.

PÉREZ VIÑUALES, P. (1996). « La actividad de la industria del hierro en la comarca del bajo Jalón (Zaragoza) en el siglo XV: tipología documental”. En Actas de las I Jornadas sobre minería y tecnología en la Edad Media peninsular. León, p. 535-542.

PRIETO BANCES, R. (1976): "Apuntes para el estudio del señorío de Santa María de Belmonte en el siglo XVI”. Obra escrita. Oviedo, pp. 45-115.

PRIOTTI, J-PH. (2003): "El comercio de los puertos vascos peninsulares con el noroeste europeo durante el siglo XVI". Revista de estudios marítimos del País Vasco, 4, p. 193-204. 
PRIOTTI, J-PH. (2005): "producción y comercio del hierro vizcaíno entre 1500 y 1700". En http/www.euskomestra.org.pdfanlt/lankidetzan

QUIROS LINARES,F. (1971): "La sociedad palentino-leonesa de minas y los primeros altos hornos al cok de España, en Sabero (1847-1862)". Estudios geográficos (Madrid), XXXIII, 125.

QUINTANA, P. (2005): La labranza y transformación artesanal del hierro en Taramundi y los Oscos. Siglos XVI-XIX. Taramundi, 2 tomos.

RABANAL YUS, A. (1987): Las Reales Fábricas de Municiones de Eugui y Orbaiceta, en Navarra (1766-180o). Pamplona.

RABANAL YUS, A. (1990): Las reales fundiciones españolas del siglo XVIII. Servicio de Publicaciones del EME (Madrid).

RÁBANO, I. (2007): "Expedientes de concesiones mineras de Guillermo Schulz (1805-1877) en el Archivo Histórico provincial de Lugo, años 1834 y 1836". Boletín Geológico y Minero, 118 (1), p. 141-146.

RECHENBERG, H. (1957): "El criadero de hierro "Vivaldi" en Ponferrada, León. Notas y Com. del IGME, $\mathrm{n}^{\circ} 48$.

RELANZÓN LÓPEZ, Ma ${ }^{\mathrm{a}}$ s. (1987): La minería española en la Edad Moderna. Instituto Geológico y Minero. Madrid.

REVENGA, Ma i. y CARNICERO, J. (1996): "Notas documentales en torno a la minería y herrería del noroeste peninsular (siglos X al XV)". En Actas de las I Jornadas sobre minería y tecnología en la Edad Media peninsular. León, p. 305-311.

REVILLA, J. (1906): Riqueza minera de la provincia de León. Su descripción industrial y estudio de soluciones para explotarla. Madrid, 1906.

REY CASTELAO, O. (1997): "La propiedad colectiva en España". Studia Historica, $H^{a}$ Moderna, 16, p. 5-16.

RIU RIU, M (1996): "La metalurgia del hierro en la España cristiana medieval". En Actas de las I Jornadas sobre minería y tecnología en la Edad Media peninsular. León, p. 41-55.

RODRÍGUEZ GALDO, M. X. (1976): Señores y campesinos en Galicia. Siglos $X I V-X V I$. Santiago de Compostela.

RUBIO PÉREZ, L. (1987): La Bañeza y su tierra (165o-185o). Un modelo de sociedad rural leonesa. León.

RUBIO PÉREZ, L. (1990): "Limitaciones al desarrollo económico y respuesta demográfica en tierras Noroccidentales leonesas durante los siglos XVIII y XIX”. Estudios Humanísticos (Universidad de León), nº 12, pp. 157-194. 
RUBIO PÉREZ, L. (1992): "La burguesía mercantil leonesa en el siglo XVIII. Acumulación de capital y actitudes feudales". Estudios humanísticos (Universidad de León), ${ }^{\circ}$ 13, pp. 227-264.

RUBIO PÉREZ, L. (1995): Arrieros maragatos. Poder, negocio, linaje y familia. Siglos XVI-XIX. Fundación Hullera Vasco-Leonesa, León.

SAAVEDRA, P. (1982): "Un aspecto de la economía monástica: la producción de hierro. El ejemplo del monasterio de Villanueva de Oscos”. En $X V$ centenario del nacimiento de San Benito, Oviedo, p. 531-554.

SAAVEDRA, P. (1985): Economía, política, y sociedad en Galicia: la provincia de Mondoñedo, 1480-183o. Xunta de Galicia. Santiago.

SAAVEDRA, P. (1988): "Aportación al estudio de las rentas provinciales de la Galicia del Antiguo Régimen”. Espacio, tiempo y forma (UNED), nº 4, p. 585624.

SAAVEDRA VÁZQUEZ, Ma ${ }^{\mathrm{a}}$. C. (1996). Galicia en el camino de Flandes. A Coruña.

SÁNCHEZ ALBORNOZ, N. (1977): España hace un siglo: un a economía dual. Madrid.

SÁNCHEZ GÓMEZ, J. (1988): "Magia, astrología y ocultismo entre los mineros del siglo XVI”. Studia Histórica, VI, pp. 339-350.

SÁNCHEZ GÓMEZ, J. (1989): De minería, metalúrgica y comercio de los metales. La minería no férrica en el Reino de Castilla, 1450-1650). Salamanca. IGME, 2. t.

SÁNCHEZ RAMOS, F. (1945): La economía siderúrgica española. Madrid.

SANCHO, M. (1993): "Les fargues medievals al sud del Pirineu. Recerca documental i arqueològica”. En La farga catalana en el marc de l'arqueologia siderúrgica. Actes del $I^{o}$ Simposi Internacional sobre la Farga Catalana. Ripoll.

SANCHO, M. (1996): "Aportaciones de la arqueología para el estudio de la producción de hierro en la Cataluña medieval: Estado de la investigación y nuevas perspectivas". En Actas de las I Jornadas sobre minería y tecnología en la Edad Media peninsular. León, p. 436-450

SANTANA, J. (1958): "La industria en Asturias en el siglo XVIII". BIDEA (Oviedo), ${ }^{\circ} 60, \mathrm{pp} .63-88$

SANZ, J. (1985): “La historia contemporánea de los montes públicos españoles, 1812-1930. Notas y reflexiones". Em R. GARRABOU y J. SANZ: Historia agraria de la España contemporánea. T. 2. Expansión y crisis (1850-19oo). Barcelona, p. 193-228. 
SAURÍN DE LA IGLESIA, M.R. (1983): Reforma y reacción en la Galicia del siglo XVIII (1764-1798). La Voz de Galicia, La Coruña.

SCHULZ, G. (1835): Descripción geognóstica del reino de Galicia. Imp. Collado, Madrid. Ed. Facs. Sada, 1985.

SCHULZ, G. (1838): “Ojeada sobre el estado actual de la minería en el distrito de Asturias y Galicia”. Anales de minas (Madrid), tomo I, p. 379 y ss. Madrid.

SCHULZ, G. (1841): Estadística de la minería de Asturias y Galicia. Imprenta Repullés. Madrid.

SCHULZ, G. (1841): "Algunos datos para la historia moderna de la minería de Asturias y Galicia”. Anales de Minas (Madrid), II, 254 y ss.

SHAW, V. (1977): "Exportaciones y despegue económico: el mineral de hierro de Vizcaya, la región de la ría de Bilbao y algunas de sus implicaciones pra España. Moneda y Crédito, ${ }^{\circ}{ }^{142,}$ p. 87-

SILVÁN, L. (1976): "La evolución de los procesos metalúrgicos y su aplicación a la siderurgia del País Vasco”. En III Semana de Antropología Vasca (Bilbao 1973). Bilbao, t. II, pp. 13-50.

SIMÓ I ARIAS (1992): La farga catalana. Barcelona.

SIMÓN, J. y otros (1993): "Estudi de les fases presents en un forn experimental de la farga catalana”. En $I^{\circ}$ Simposi Internacional sobre la Farga Catalana. Ripoll, pp. 139-154.

SOLER, J.M. (1883): Reseña geológico minera y catálogo de minerales, rocas, etc.en la provincia de León. Madrid.

SOMOZA DE MONSORIU, F. (1775): Estorbos y remedios de la riqueza en Galicia. Discurso político legal. Santiago de Compostela.

SOPEÑA PÉREZ, F. y otros (1993): "Reconstrucción y rehabilitación de la ferrería de Cades”. En $I^{\circ}$ Simposi Internacional sobre la Farga Catalana. Ripoll, pp. 269-274.

SOTO CARBAJO, A (1984): Las herrerías bercianas en el siglo XVIII”. Estudios Bercianos (Ponferrada), $\mathrm{n}^{\circ} 2$.

SUÁREZ MÉNDEZ, R. (2001): Las Reales Fábricas de Sargadelos y Trubia. Competencia, rivalidad y apoyo. Sada.

TEIJEIRO FERNÁNDEZ, L.A. (1988): Queiroga, encomienda de San Juan. Concello de Queiroga. Diputación provincial de Lugo.

TELLECHEA, J.I. "Ferrerías guipuzcoanas a fines del siglo XV". Boletín de la Real Sociedad Vasgongadas de Amigos del País (San Sebastián), XXXI. 
TORTELLA, G. (1994): El desarrollo de la España contemporánea. Una historia económica de los siglos XIX y XX. Madrid.

URIARTE AYO, R. (1988): Estructura, desarrollo y crisis de la siderurgia tradicional vizcaína, 1700-1840. Bilbao.

URIARTE AYO, R. (1988): "La minería vizcaína del hierro en las primeras etapas de la industrialización". En E. FERNÁNDEZ DE PINEDO y J. L. HERNÁNDEZ (Ed.): La industrialización del norte de España. Barcelona, p. 154-177.

URIARTE AYO, R. (1993): "La tecnología del horno bajo en el Pirineo y el País Vasco”. I Simposi Internacional sobre la Farga Catalana. Ripoll.

URTEAGA ARTIGAS, Ma M. (1993): "Ferrerías hidráulicas en Guipúzcoa. Aspectos arqueológicos”. En I ${ }^{\circ}$ Simposi Internacional sobre la Farga Catalana. Ripoll, pp. 249-267.

URTEAGA ARTIGAS, Ma M. (1996): "Siderurgia medieval en Guipuzkoa. Haizeaolas, ferrerías masuqueras y ferrerías mazonas". En Actas de las I Jornadas sobre minería y tecnología en la Edad Media peninsular. León, p. 543-554.

VÁZQUEZ DE PRADA, V. (1973): "Las antiguas ferrerías de Vizcaya (14501800)". Mélanges en l'honneur de Fernand Braudel, II. Toulouse, P. 661-671.

VÁZQUEZ DE PRADA, V. (1975): “Aportación al estudio de la siderurgia catalana (siglos XVI-XVIII), Homenaje al Dr. D. Juan Reglá Campistol. Valencia.

VÁZQUEZ DE PRADA, V. (1976): Las ferrerías vizcaínas (siglos XVI-XVIII)”. En III Semana de Antropología Vasca (Bilbao 1973). Bilbao, t. II, pp. 129-134.

VAZQUEZ VAAMONDE, M.C. (1994): Sargadelos, Carril, Santiago. Sada.

VEGA ALONSO, J. (1982): La artesanía del hierro en Asturias: El mazo. Consejería de Educación y Cultura del Principado de Asturias. Oviedo.

VIDAL BOX, C. (1940): "Contribución al conocimiento morfológico de las cuencas de los ríos Sil y Miño”. R.S.E.H.N.(Madrid), t. XXXIX.

VIDAL ROMANÍ, J. (1992): Guillermo Schulz, cuaderno de campo $n^{\circ} 2$ (marzoagosto 1833). Sem. Est. Galegos. Sada-A Coruña.

VILLAAMIL Y CASTRO, J. (1866): Crónica General de España. Provincia de Lugo. Madrid.

VILLA-REAL DE BÉRRIZ, P.B. (1736): Máquinas hidráulicas de molinos y herrerías y govierno de los árboles y montes de Vizcaya. Madrid. Reed. San Sebastián, 1973. 
VILLARES, R. (1982): La propiedad de la tierra en Galicia, 150o-1936. Madrid.

YAÑEZ NEIRA, Fr. D.(1973): "El monasterio de Villanueva de Oscos y sus abades". BIDEA (Oviedo), nº 8o, pp. 647-715.

YBARRA, J. (1955): “Los altos hornos de Guriezo”. Rev. Altamira, n 1,2,3.

ZUBIARRE ECENARRO, J. (1976): "Léxico técnico euskaldun utilizado en las ferrerías”. En III Semana de Antropología Vasca (Bilbao 1973). Bilbao, t. II, pp. 391-397.

ZUDAIRE HUARTE, E. (1979): "Ferrerías del Real Monasterio de Urdax". Cuadernos de Etnología y Etnografía de Navarra (Pamplona), XI, ${ }^{\circ} 31$, p. 125-177.

WORONOFF, D. (1990): Forges et forts. Recherches sur la consommation proto-industrielle de bois. Paris.

WORONOFF, D. (1994): Histoire de l'industrie en France. Paris, 


\author{
UNIVERSIDAD DE LEÓN \\ DEPARTAMENTO DE HISTORIA
}

TESIS DOCTORAL

\author{
TOMO II
}

\title{
CATÁlOGO DE LAS FERRERÍAS DEL NOROESTE DE ESPAÑA
}

JOSÉ A. BALBOA DE PAZ

-Año 2014- 


\section{CATÁLOGO DE FERRERÍAS}

2. LAS FERRERÍAS DE LEÓN.............................................. 9

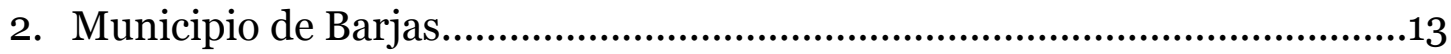

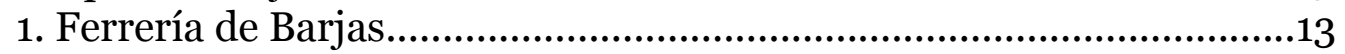

2. Ferrería de Corporales.....................................................................15

3. Ferrería de Serviz...................................................................16

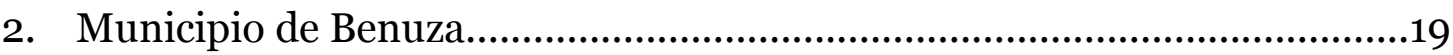

4. Ferrería de Llamas.....................................................................19

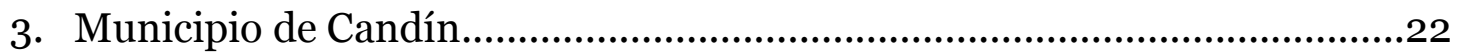

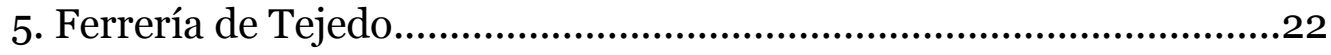

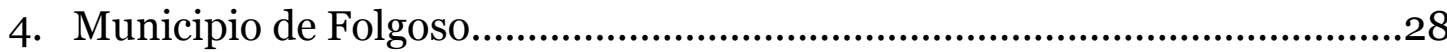

6. Ferrerías de Marciel.......................................................................28

5. Municipio de Oencia......................................................................... 30

25. Ferrería de Arnadelo..................................................................30

26. Ferrería de Arnado.......................................................................32

27. Ferrería de Gestoso.....................................................................41

28. Ferrería de Lusío.........................................................................41

29. Ferrería de Pontepetre...................................................................43

30. Ferrerías de Río Cabo................................................................51

31. Ferrería de San Vitul..............................................................59

32. Ferrería de Valdelouro............................................................61

33. Ferrería de Valincarro...............................................................62

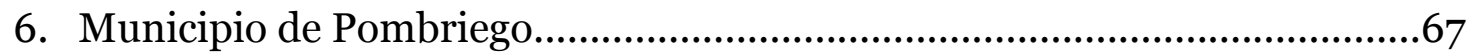

34. Ferrería de Pombriego.............................................................66

7. Municipio de Ponferrada................................................................. 71

35. Ferrería de Compludo.................................................................71

36. Ferrería de Montes................................................................75

8. Municipio de Torre del Bierzo...............................................................82

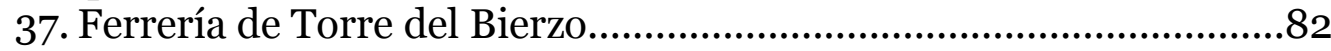

38. Ferrería de Navaleo....................................................................86

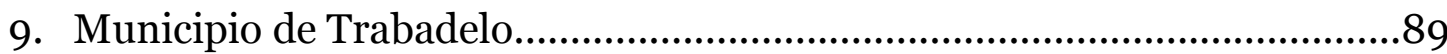

39. Ferrería de San Fiz do Seo..........................................................89

10. Municipio de Vega de Valcarce..............................................................90

40. Ferrería de Herrerías...................................................................90

41. Ferrería de La Portela..................................................................97

11. Municipio de Villafranca del Bierzo.....................................................99

42. Ferrería de La Somoza............................................................99 
1. Municipio de Baralla...........................................................................117

1. Ferrería de Neira de Rey...........................................................117

2. Ferrería de Piago.......................................................................121

2. Municipio de Bóveda.......................................................................123

3. Ferrería de Penacova...................................................................123

3. Municipio de Cervantes....................................................................125

13. Ferrería de Fonquente................................................................125

14. Ferrería de San Martín de Ribera....................................................126

4. Municipio de Courel....................................................................128

15. Ferrería de Ferreirós...............................................................128

16. Ferrería de Folgoso........................................................................139

17. Ferrería de Lousadela..................................................................145

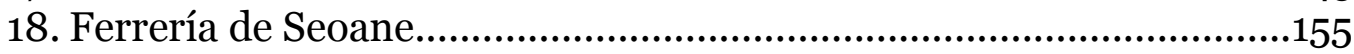

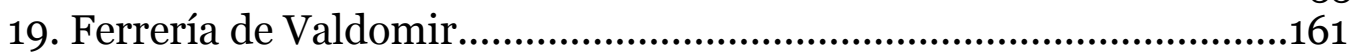

20.Ferrería de Vilasibil...............................................................170

21. Ferrería de Visuña..................................................................171

5. Municipio de Fonsagrada..................................................................181

13. Ferrería de Pereyrúa..................................................................181

14. Ferrerías de Vilar de Cuiña........................................................183

6. Municipio de Guntín......................................................................187

15. Ferrería de Pallares.....................................................................187

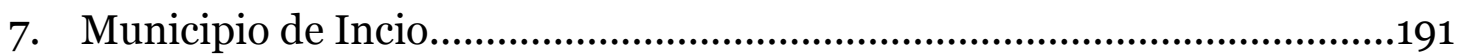

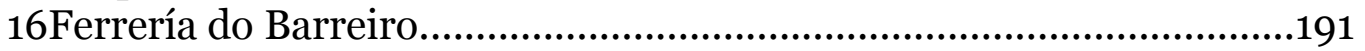

48. Ferrería do Incio....................................................................193

8. Municipio de Lugo..........................................................................198

49. Ferrería de Ombreiro.............................................................. 198

9. Municipio de Mondoñedo................................................................199

50. Ferrería de Viloalle.....................................................................199

10. Municipio de Muras....................................................................201

51. Ferrería de Silán..........................................................................201

11. Municipio de Navia de Suarna...........................................................203

52. Ferrería de Rao...........................................................................203

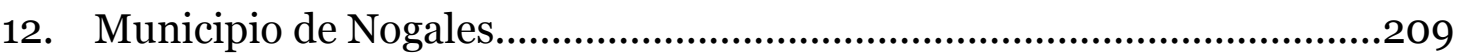

53. Ferrería de Bueyes (Bois) ............................................................209

13. Municipio de Ourol.......................................................................216

54. Ferrería de Bravos..................................................................216 
14. Municipio de A Pontenova...............................................................221

55. Ferrería de Bogo.....................................................................221

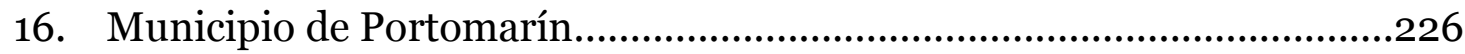

56. Ferrería de Gonzar...................................................................226

17. Municipio de La Puebla (A Pobra) de Brollón........................................228

57. Ferrería de Biduedo................................................................228

58. Ferrería de Lor........................................................................231

59. Ferrería de Loureiro................................................................236

18. Municipio de Quiroga......................................................................242

6o.Ferrería de Gorgueira.................................................................242

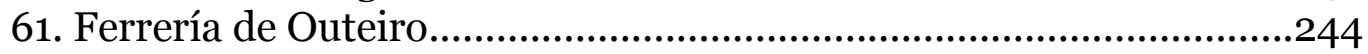

62. Ferrería de Paleiras......................................................................247

63. Ferrería de Quintá.........................................................................254

64. Ferrería de La Rodela...................................................................260

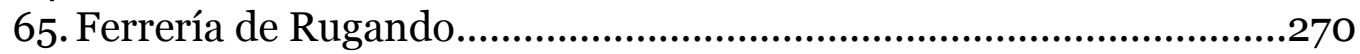

66. Ferrería de Soldón.....................................................................273

67. Ferrería de Vilarcabú..................................................................287

19. Municipio de Ríotorto......................................................................290

68.Ferrería de Vilaseca..................................................................290

20. Municipio de Saviñao...............................................................292

69. Ferrería de Sardiñeira...........................................................292

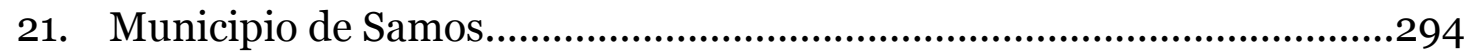

70. Ferrería de Carqueixeda.............................................................294

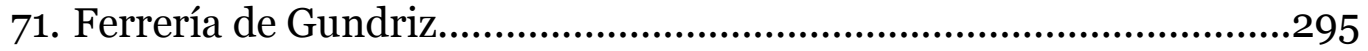

72. Ferrería de Lusío (Rial)............................................................. 300

73. Ferrería de Santalla.....................................................................304

22. Municipio de Triacastela................................................................309

74. Ferrería de Furco.................................................................... 309

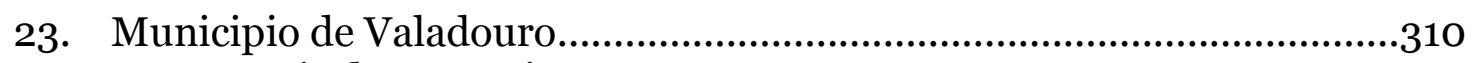

75. Ferrería de Pesqueira................................................................310

24. Municipio de Villanueva de Lorenzana...................................................316

76. Ferrería de Lorenzana....................................................................316

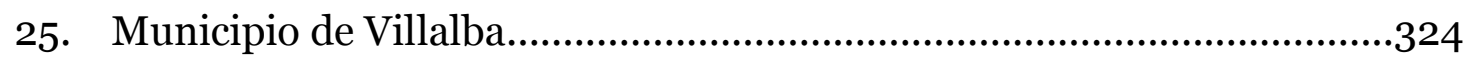

77. Ferrería de Saramugo................................................................324

26. Municipio de Cedeira (A Coruña).....................................................325

78. Ferrería de Montoxo....................................................................325 
1. Municipio del Barco de Valdeorras................................................................333

1. Ferrería de A Fervenza...............................................................................333

2. Municipio de Carballeda.............................................................................334

2. Ferrería da Pontenova...........................................................................334

3. Ferrería de Riodolas................................................................................338

4. Ferrería de Robledo de Domiz.....................................................................339

3. Municipio de El Bollo (O Bolo)................................................................342

13. Ferrería de Mondón...........................................................................342

14. Ferrería de Vegas de Camba.................................................................348

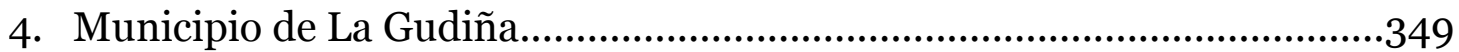

15. Ferrería de Moas....................................................................................349

5. Municipio de La Mezquita........................................................................350

16. Ferrería de La Mezquita.........................................................................350

6. Municipio de Manzaneda.............................................................................. 351

17. Ferrería de San Miguel de Vidueira........................................................351

7. Municipio de Villamartín de Valdeorras......................................................351

18. Ferrería de Cernego.............................................................................351

19. Ferrería de San Vicente de Leira.............................................................353

20.Ferrería de Valdeorras..........................................................................359

\section{LAS FERRERÍAS DE OVIEDO.........................................365}

1. Municipio de Allande..................................................................................369

1. Ferrería de Armenade...........................................................................369

2. Ferrería de Penaseita...........................................................................371

3. Ferrería de Villarín....................................................................................372

2. Municipio de Amieva...................................................................................373

4. Ferrería de La Ceneya.............................................................................373

3. Municipio de Belmonte.............................................................................. 375

49. Ferrería de Agüerina........................................................................375

50. Ferrería de Belmonte.............................................................................377

4. Municipio de Boal................................................................................... 381

51. Ferrería de Froseira........................................................................... 381

5. Municipio de Cangas de Onís..................................................................384

52. Ferrería de Coviella.........................................................................384

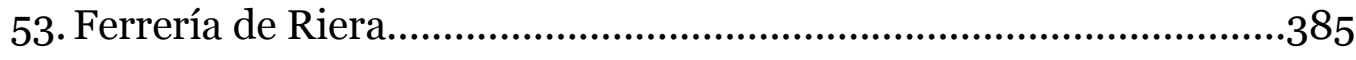

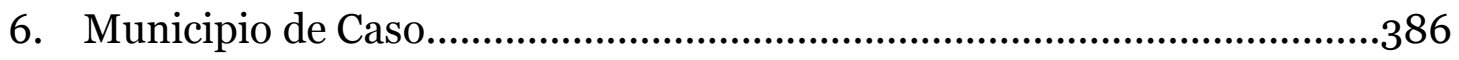


54. Ferrería de Abantro.................................................................386

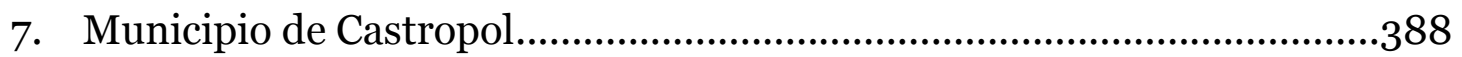

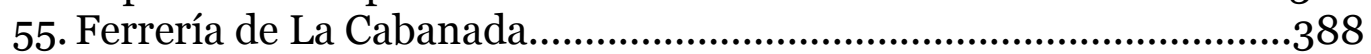

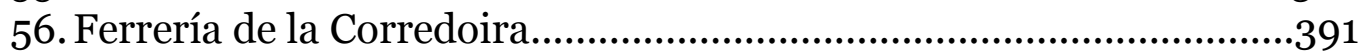

57. Ferrería de Lagar...........................................................................391

58. Ferrería de Montealegre...............................................................393

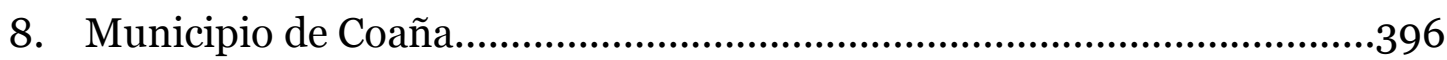

59. Ferrería de Coaña...................................................................396

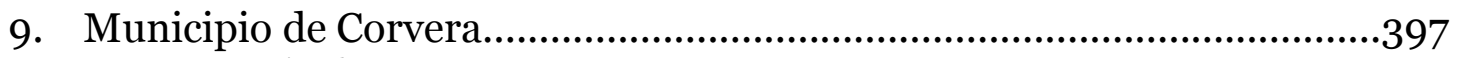

6o.Ferrería de Trasona.........................................................................397

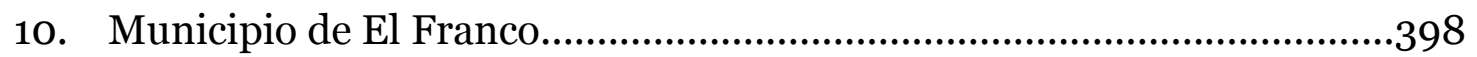

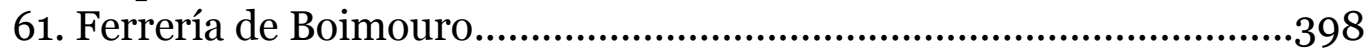

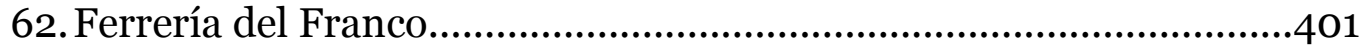

63. Ferrería de Sueiro de Arriba......................................................402

64. Ferrería de Sueiro de Abajo........................................................404

11. Municipio de Gijón.....................................................................405

65. Ferrería de Deva......................................................................405

12. Municipio de Ibias....................................................................409

66. Ferrería de Vionga................................................................409

13. Municipio de La Nava.................................................................410

67. Ferrería de La Nava.......................................................................410

14. Municipio de Penamellera.................................................................. 411

68.Ferrería de Penamellera.............................................................. 411

15. Municipio de Pola de Lena...............................................................413

69. Ferrería de Renueva.................................................................. 413

16. Municipio de Ponga............................................................................414

70. Ferrería de Soto Rodrigo..........................................................4 414

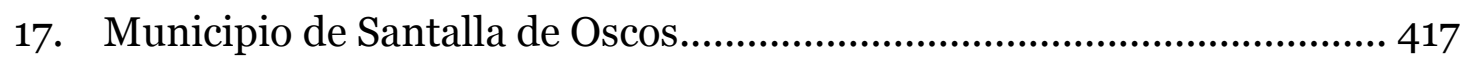

71. Ferrería de Ferreirela.....................................................................417

72. Ferrería del Pontigón..............................................................419

18. Municipio de Somiedo......................................................................421

73. Ferrería de Somiedo................................................................421

19. Municipio de Soto del Barco..........................................................423

74. Ferrería de Labayos....................................................................423

20. Municipio de Tapia de Casariego.....................................................426

75. Ferrería de La Veguiña.............................................................426 
21. Municipio de Tineo..................................................................... 430

76. Ferrería de Arganza....................................................................430

77. Ferrería de Besullo......................................................................431

78. Ferrería de la Fanosa..................................................................432

22. Municipio de Valdés.....................................................................434

79. Ferrería de Brieves......................................................................434

8o.Ferrería de Carcedo......................................................................437

81. Ferrería de Raicedo.......................................................................437

82. Ferrería de Salientes.................................................................. 441

83. Ferrería de Setienes....................................................................442

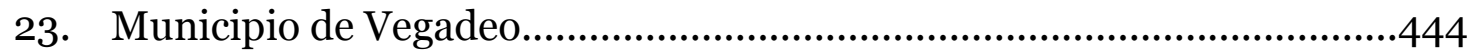

84.Ferrería de Abres.........................................................................444

85. Ferrería de Meredo...................................................................... 446

86.Ferrería de Nafarea......................................................................448

24. Municipio de Villanueva de Oscos.....................................................449

87. Ferrería de Villanueva de Oscos....................................................449

25. Municipio de Villaviciosa..........................................................456

88.Ferrería de Amandi......................................................................456

89.Ferrería de Dueñes.......................................................................458

90.Ferrería de Peón........................................................................ 464

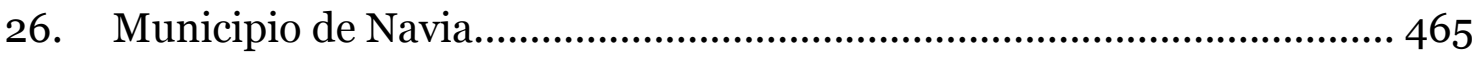

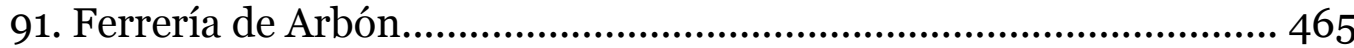

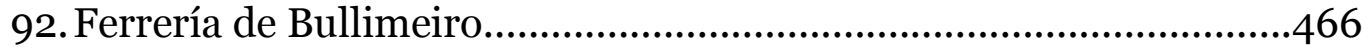




\section{PROVINCIA DE LEÓN}




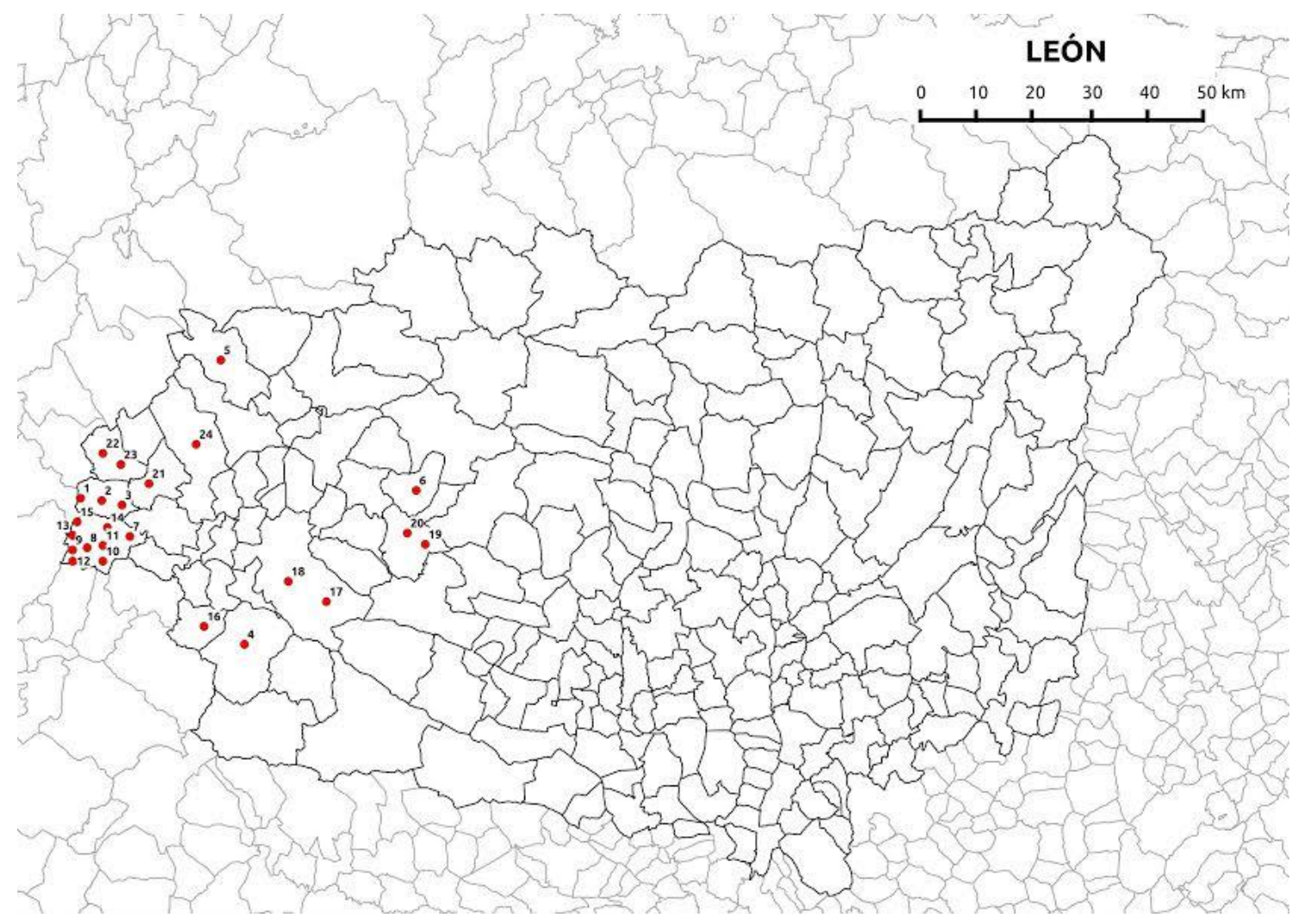

FERRERÍAS DE LEÓN 


\section{MUNICIPIO DE BARJAS}

\section{FERRERÍA DE BARJAS}

LUGAR: Barjas

AYUNTAMIENTO: Barjas

RÍO: Barjas

COORDENADAS: $42^{\circ} 36^{\prime} 34^{\prime \prime}$ N. y $6^{\circ} 58^{\prime} 34^{\prime \prime} \mathrm{W}$.

En el coto de Barjas, a finales del siglo XVIII, el marqués de Villafranca proyectó construir una ferrería. En 1787 don José Álvarez de Toledo dijo "que tiene resuelto construir una Herrería nueba en su coto de Barjas y soto de Güimil, o en otro que sea más a propósito (por) ser mui util al Estado, como también a la Hacienda de S.E.". Por ello da su poder a don Francisco Xavier de Villegas y Jalón, administrador de su Estado de Villafranca, para que "dé las disposiciones conducentes a que tenga efecto la construcción de la predicha nueba Herrería, practicando para ello todas las diligencias que sean precisas, como asimismo para impedir y oponerse a que en los términos de dicho coto se extraiga carbón, ni las maderas que sean útiles para la construcción de la nueba Herrería". Asimismo le añade el poder para realizar "qualesquiera tratos y contratos con los pueblos que tengan derecho a fin de que en lo necesario den $y$ presten su consentimiento con el fin de ebitar controbersias en lo subcesivo $y$ tanto en orden a lo referido, como a la denuncia que el D. Francisco Xabier de Villegas y Jalón tiene hecha contra el Administrador de la Herrería de Pontepetre"1179.

Este proyecto no se llevó a cabo por la oposición de don Manuel Armesto y Omaña, propietario de la ferrería de Órreos, en Galicia, quien con los dueños de otros artefactos que se sentían perjudicados, como el administrador de la ferrería de Pontepetre, denunciaron la obra nueva ${ }^{1180}$. No hay más referencias a

1179 ARCHIVO PRIVADO DE LOS GONZÁLEZ DE VILLAR DE LOS BARRIOS: Cuentas y cartas del administrador de los Marqueses de Villafranca (gentileza de Mariano Higueras, que me permitió consultar los documentos que ha trascrito del mismo).

1180 AHPL. PN.: caja 3329 (año 1797): El 27 de abril don Manuel Armesto y Omaña apodera a Josep Arias de Prada para que en su nombre aclare ante el corregidor de Ponferrada ciertos extremos, pues "haviendose intentado por parte del Exmo. sr. marqués de esta dicha villa (de Villafranca) la construcción de una ferrería en los términos de la jurisdiccion del coto de Barjas hice mi oposición con otros varios interesados por los impoderables perjuicios que se seguirían a la que poseeo llamada la nueba y otras existentes a su inmediación, y estando sustanciándose el expediente ante los señores del Real y Supremo Consejo de Castilla se 
ferrerías en esta zona del municipio de Barjas hasta muchos años más tarde, primero a la de Serviz y luego a la de Barjas.

El proyecto para construir una ferrería en el coto de Barjas debió retomarse en el siglo XIX, pues en el Libro del Guarda Mayor de Montes del distrito de Villafranca del Bierzo, dicho guarda anota en 1860: "(pase a ) Barjas y pueblos inmediatos, tomando informes de los pedáneos sobre esta fábrica y la de Corporales" ${ }^{1181}$. La fiabilidad de este autor, que menciona todas las ferrerías de la zona, nos obliga a dar como buena su existencia, pese a que Madoz no la nombra ${ }^{1182}$.

Posiblemente su construcción, posterior al diccionario del autor mencionado, se relacione con la ruptura de un acuerdo firmado en 1844 entre Rafael Armesto, yerno de Nemesio Fernández, usufructuario aquellos años de la ferrería de Serviz, y Antonio Fariñas, por el que éste se comprometía a destinar a un molino y no a una ferrería o a un martinete el cauce que estaba construyendo ${ }^{1183}$. Si este Antonio fue su constructor, podemos sin duda relacionarlo con los Fariñas, importante familia ligada al hierro, como arrendatarios de varias ferrerías gallegas y propietarios de la berciana de Lusío, een el municipio de Oencia.

ESTADO: Ilocalizable

\footnotetext{
sirvieron dar auto según tengo entendido en el próximo pasado mes de marzo mandando que por los peritos que nombremos las partes y tercero de oficio en caso de discordia, se reconozcan el sitio en que dicho Exmo. sr. marqués solicita la construcción de le expresada ferrería, los montes y mina de vena de que se havia de surtir, declarando si de dicha construcción se podrán seguir perjuicios a las inmediatas....”.

${ }^{1181}$ LIBRO DEL GUARDA MAYOR DE MONTES DEL DISTRITO DE VILLAFRANCA DEL BIERZO, p. 52v, $\mathrm{n}^{\circ} 193$ (Documento en manos de la familia de Alberto Rodríguez, de Cacabelos, que me permitió fotocopiarlo). (Cit. como LIBRO DEL G. M. M.)

${ }_{1182}$ MADOZ, P. (1845-1850): Diccionario geográfico-estadístico-histórico de España y sus posesiones de ultramar. Madrid. Ed. Facsímil de León, Valladolid, 1983, p. 64. Menciona en Barjas: "tres molinos harineros y un batán para paños ordinarios del país, movidos por las aguas de un pequeño riachuelo que toma el nombre del mismo pueblo".

1183 AHPL. PN.: caja 3581 (año 1844).
} 


\section{FERRERÍA DE CORPORALES}

LUGAR: Corporales

AYUNTAMIENTO: Barjas

RÍO: arroyo Corporales

COORDENADAS: $42^{\circ} 36^{\prime} 12^{\prime \prime}$ N. y $6^{\circ} 57^{\prime} 52^{\prime \prime} \mathrm{W}$.

La ferrería se hallaba a orillas del arroyo Corporales o Vegas do Seo, pequeño afluente del Barjas. Se puede acceder fácilmente a ella -a los restos que quedan- por una carretera que, desde la la N. VI a la altura de San Fiz do Seo, sube a Barjas siguiendo el río de este nombre, y desde este pueblo por un camino hasta Corporales, que está al lado.

Ignoramos la fecha de su construcción, aunque debió edificarse a finales de los años treinta del siglo XIX. La primera mención que conozco es de 1842, en que un tal José Teijón ${ }^{1184}$ aparece como apoderado de Nemesio Fernández y administrador de su ferrería de Corporales por el término de ocho añosi185. El poco valor en que fue tasada en el inventario de bienes de Nemesio Fernández, en $1859,140.000$ reales ${ }^{1186}$, nos permite presumir que se trataba de una pequeña ferrería regatera, dato que corrobora los 60 reales de foro que pagaba por la vena de Formigueiros, la cantidad más de baja de todas las ferrerías, a excepción de algunas muy antiguas, como Valdomir y Lousadela, ambas del siglo XVI ${ }^{1187}$.

Por herencia esta ferrería y la de La Portela de Valcarce pasaron a las nietas de Nemesio Fernández, casadas con Adriano Quiñones y Francisco Soto Vega, de Ponferrada y Villafranca del Bierzo respectivamente. El 5 de diciembre

${ }^{1184}$ Este José Teijón debía de ser de la merindad de Aguiar, probablemente de Villarrubín, donde tenía propiedades, y por tanto, relacionado con el mundo de las ferrerías. En mayo de 1842, en Oencia, María de Castro, mujer de José Balboa, dice que hechas las partijas de la herencia de sus padres con su única hermana le corresponden de hijuela 7.875 rs., y que en pago de los mismos recibe de su cuñado Casimiro Teijón bienes en Villarrubín, quien a su vez los había recibido de su hermano José Teijón, "vecino de Corporales como apoderado de $D$. Nemesio Fernández”. AHPL. PN.: caja 3580 (año 1842).

${ }_{1185}$ AHPL. PN.: caja 3580 (año 1842). Francisco Rodríguez, vecino de Castropetre, Francisco Franco y María Balboa, del mismo pueblo dijeron deber a Nemesio Fernández 3.471 rs., rebajados 320 que le habían dado, y "consiguieron espera de D. José Teijón apoderado del $D$. Nemesio y su administrador en la herrería de Corporales, por el término de ocho años, desde luego se obligaron a pagar en el término de esos ocho años".

1186 AHPL. PN.: caja 2724 (año 1859).

1187 GARCIA TATO, I. (2000): "Las ferrerías de Río Cabo y Pombriego en el siglo XIX". Revista Bierzo, p. 168 
de 1859 ambos cuñados otorgan un poder a Ignacio Ferreiras, vecino de Todriz, en Quiroga, para que se haga cargo, porque "por herencia de D. Nemesio Fernández, dicen, les correspondió una herrería en término de Corporales, y no pudiendo administrarla por si, por la distancia que media y por sus muchas ocupaciones...etc. ${ }^{1188 ”}$.

La ferrería no la menciona Madoz, que ni siquiera cita el lugar de Corporales; sí la nombra el libro del Guarda Mayor de Montes en $1860^{1189}$ y un Nomenclator de la provincia de León de 1867, que la denomina como "Herrería do Ferreiro", añadiendo que es una "fábrica de fundición" ${ }^{1190}$. Debió de parar después de 1870.

ESTADO: El único resto de la ferrería es la casa habitación, todo lo demás ha sido derruido y convertido en un prado.

\section{FERRERÍA DE SERVIZ}

LUGAR: Serviz

AYUNTAMIENTO: Barjas

RÍO: Barjas

COORDENADAS: $42^{\circ} 37^{\prime} 10^{\prime \prime}$ N. y $6^{\circ} 56^{\prime} 29^{\prime \prime} \mathrm{W}$.

Se encuentra en la margen izquierda del río Barjas, al otro lado del puente que cruza el río en el camino que iba de San Fiz do Seo hasta Güimil. A este lugar lo denomina un documento de 1824 "la rebuelta de las pedreras"191, y a la ferrería el Nomenclator de 1867 le da el nombre de "La Revuelta". Actualmente puede accederse en coche por una carretera que, desde la la N. VI a la altura de San Fiz do Seo, sube a Barjas siguiendo el río de este nombre.

La ferrería de Serviz fue la primera que construyó el ponferradino Nemesio Fernández, antiguo arrendatario de la de Ponte Petre y posterior propietario de

\footnotetext{
1188 AHPL. PN.: caja 2723 (año 1859).

${ }^{1189}$ LIBRO G.M.M.: 30 de octubre de 1860: "instruyendo otro expediente sobre la fábrica de Corporales"; el día 1 de noviembre "regreso de la herrería de Corporales". 1190 NOMENCLATOR DE LA PROVINCIA DE LEÓN. León, 1867, p. 74.

${ }^{1191}$ AHPL. PN.: caja 3695 (año 1824).
} 
otras cinco más en la comarca del Bierzo. En diciembre de 1823 solicita a los vecinos de Serviz, en la parroquia de San Lorenzo de Corrales, un permiso para la construcción de una ferrería en su jurisdicción, que éstos le conceden ese mismo mes, atendiendo a la gran abundancia de urz existente en su término, "muy suficiente a dar surtido a una fábrica de yerro" y a las ventajas que la misma les iba a reportar, "para dar de esta forma salida a las producciones de sus montes que no la tienen"192. Ciertamente se trata de una zona de montaña cuyo principal recurso era el forestal, pues la agricultura se reduce a pequeños calveros en el monte, donde se cultiva centeno, y a algunos prados en la parte baja de los valles, que alimentan una pequeña cabaña ganadera.

Por esa razón dan su permiso para que "en los términos de esta parroquia pueda construir un artefacto de hacer y labrar yerro en el sitio que alle más cómodo en ella, no siendo en propiedad sin anuencia de su dueño"1193. El permiso se lo conceden a su convecino Manuel Gallego, pero por el documento se adivina que éste no es más que un hombre de paja, al señalar que el permiso se lo "dan a Manuel Gallego para que por si o para otro construya una herrería", o más explícitamente cuando aclara "o a quien su acción o derecho represente" ${ }^{1194}$. Al que representa no es otro que a Nemesio Fernández.

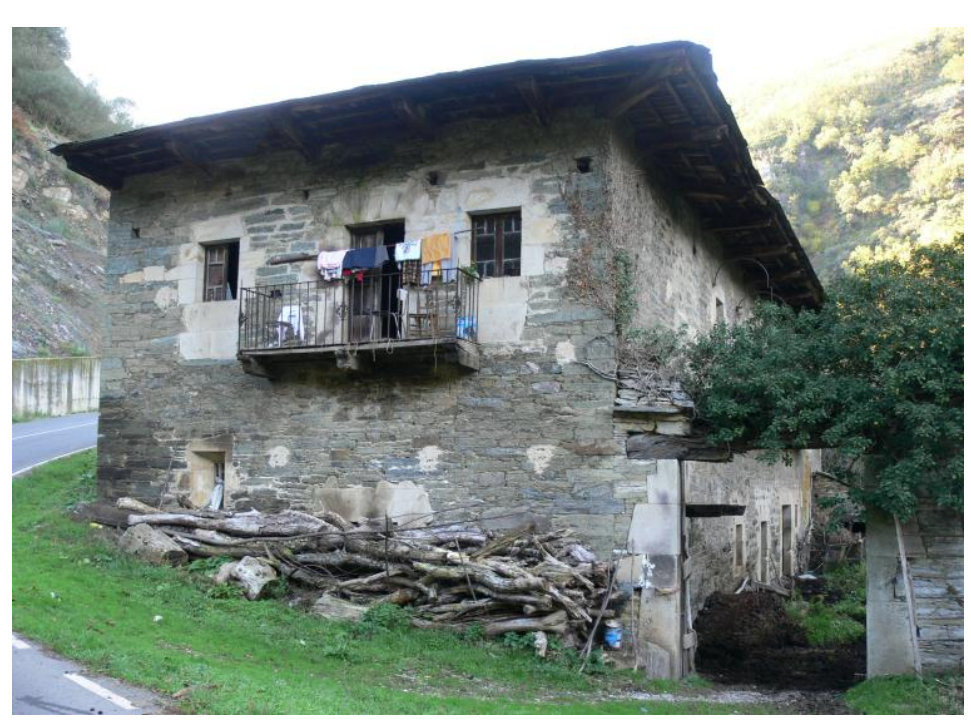

Vivienda de la ferrería de Serviz

El permiso se concede por las razones aludidas, pero con la condición de abonar al concejo 500 libras de hierro al año, pagar por el monte como lo hacen en las otras ferrerías y con la prohibición expresa de no traer carboneros de fuera del concejo sin permiso de éste. En el carboneo, evidentemente, se

${ }_{1192}$ AHPL. PN.: caja 3577 (año 1823)

1193 IBIDEM

1194 IBIDEM 
encontraba uno de los recursos tradicionales de la precaria economía de aquellas gentes.

Al año siguiente empezó la construcción de la ferrería, que hubo que detener por una denuncia contra Nemesio Fernández interpuesta por don Joaquín Bálgoma, de Cacabelos, como apoderado del marqués de Villafranca, alegando que la construía sobre terrenos del dominio directo del marqués. Por ello en abril de 1824 se detuvieron las obras hasta que no se aclarara la propiedad del terreno. Nemesio Fernández afirmaba ser de doña Micaela Blanco ${ }^{1195}$, a quien se lo había aforado, por lo que el marqués no tenía ningún derecho a denunciar la obra. Parece que tenía razón, pues ésta continuó poco después sin más problemas ni dilaciones.

La ferrería se debió terminar pronto, porque ya a finales de esa misma década se menciona en funcionamiento, y a Nemesio Fernández como su propietario ${ }^{1196}$. Pagaba de foro por la vena a los propietarios de Formigueiros 300 reales ${ }^{1197}$. La ferrería no estaba arrendada sino que la explotaba directamente su dueño por medio de un mayordomo; éste era en 1833 Roque Martínez ${ }^{1198}$. En 1834 se da cuenta en el BOPL. de que unos 14 facinerosos, probablemente carlistas, capitaneados por un tal Carballo, alzados en el valle de Valdeorras, atacaron el 13 de diciembre la ferrería de Serviz, aunque no debieron ocasionar graves daños ${ }^{1199}$.

En 1837 Nemesio Fernández la cedió en usufructo a su hija Isabel y a su yerno Rafael Armesto ${ }^{1200}$, con la condición de que en el reparto de la herencia se les calcularía y descontaría el beneficio obtenido en los años de dicho usufructo. Al morir Nemesio en 1859, esta ferrería con la de Montes pasaron a su hijo

${ }_{1195}$ AHPL. PN.: caja 3695 (AÑO 1824). La denuncia dice: "a fin de que cese el otorgante (D. Nemesio) en la construcción de una nueva Herrería que ha principiado en el sitio llamado rebuelta de las pedreras, término de los lugares de Serviz y Corrales del directo dominio del referido Exmo. Sr. Marqués y que causa perjuicios al mismo directo dominio (...); y que se declare en definitiva pertenecer el terreno en que edifica al dominio directo de los herederos de Doña Micaela Blanco y el útil al otorgante".

1196 AHPL. PN.: caja 3677 (año 1830).

1197 GARCIA TATO, I. (2000): Ob. cit., p. 168

${ }^{1198}$ AHPL. PN.: caja 3677 (año 1833). Embargo de un prado a Manuel Fuentes, de Serviz, por deuda de su yerno a D. Roque Martínez "pasante o mayordomo de la Errería de Serbiz".

1199 BOPL. $\mathrm{n}^{\circ}$ 102, 23 de diciembre de 1834

1200 AHPL. PN.: caja 3581 (año 1837). En el año 1844 la tenían ya Rafael y su mujer Isabel 
Felipe Fernández, quien reclamó el dinero de aquel usufructo a sus sobrinos. Un documento posterior, en el que se habla del juicio que hubo de seguir y de la sentencia contraria para sus sobrinos, afirma que éstos tuvieron que pagarle "trescientos ochenta mil reales en que fueron apreciados la mitad de los productos de la Herrería de Serviz durante el tiempo que su padre político el sr. D. Rafael Armesto la disfrutó" ${ }^{201}$. Es decir, que en 22 años la ferrería produjo unos beneficios de 760.000 reales, lo que supone unos 34.545 reales por año, cantidad verdaderamente notable. En el inventario de bienes de Nemesio Fernández fue valorada en 160.000 reales ${ }^{1202}$.

En 1892 Felipe Fernández, de 80 años, dueño de la ferrería, da su poder a José Pol, vecino de Barjas y con residencia en ella, para que la administre así como todos los bienes que aquél posee en la zona de Villafranca ${ }^{1203}$, lo que quiere decir que entonces aún estaba en funcionamiento.

ESTADO: La casa habitación, construida de sillarejo de pizarra, está en buen estado de conservación y habitada. De la ferrería sólo se conserva el banzao y el banzadillo, éste realmente espectacular; sin duda, el mejor de los que actualmente se conservan en el Bierzo.

\section{MUNICIPIO DE BENUZA}

\section{FERRERÍA DE LLAMAS}

LUGAR: LLamas de Cabrera

AYUNTAMIENTO: Benuza

RÍO: Cabrera

COORDENADAS: $42^{\circ} 24^{\prime} 20^{\prime}$ N. y $6^{\circ} 38^{\prime} 10^{\prime \prime} \mathrm{W}$.

La ferrería de Llamas se encuentra en el pueblo de este nombre, aunque algo alejada del núcleo de población, en la margen derecha del río Cabrera, al lado del puente que desde Pombriego cruza en dirección a Sigüeya.

\footnotetext{
${ }^{1201}$ AHPL. PN.: caja 9117 (año 1873).

1202 AHPL. PN.: caja 2724 (año 1859).

${ }_{1203}$ AHPL. PN.: caja 9162 (año 1892).
} 
En febrero de 1856 Nemesio Fernández, de Ponferrada, presentó ante el gobierno de la provincia una solicitud para construir una "herrería o forja à la catalana” en Llamas, ayuntamiento de Sigüeya (ahora Benuza), en un lugar llamado Peña del Puente ${ }^{1204}$. Un año más tarde, dee acuerdo con el dictamen de la Junta consultiva de caminos, canales y Puertos, la reina autorizaba dicha construcción con varias condiciones: no dar a la presa más altura de dos metros, habilitar el paso de la acequia por el arroyo Cambrión haciendo un pontón y ejecutar todas las obras de acuerdo con los planos aprobados ${ }^{1205}$.

La ferrería debió comenzarse a construir poco después, aunque en 1859, en el inventario de bienes de Nemesio Fernández, se menciona como no concluida del todo: "En Llamas de la Cabrera, ayuntamiento de Sigüeya en este partido judicial, una Herrería que aún se está edificando en virtud de Real

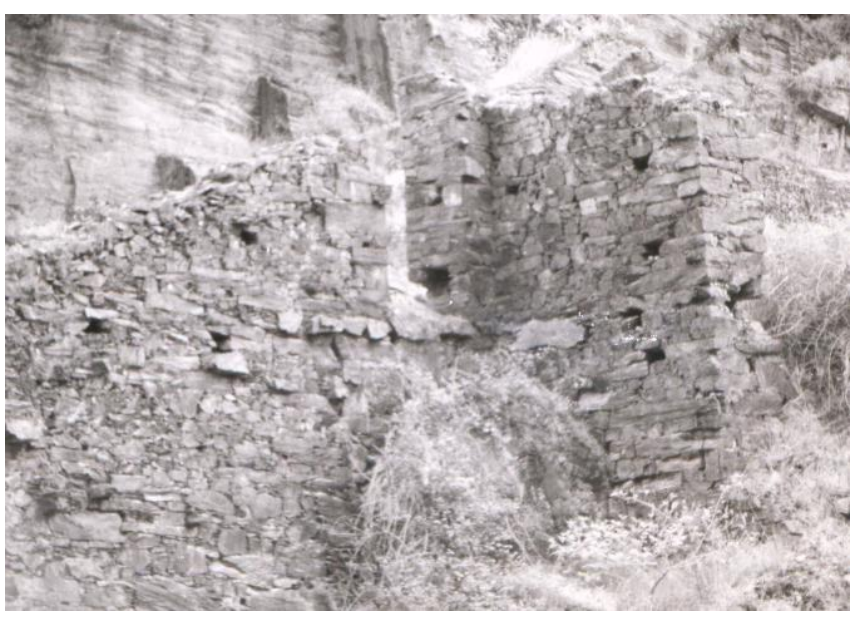
licencia" ${ }^{1206}$. Pese a no estar terminada la ferrería se valoraba en 100.000 reales. Meses después, en un acuerdo entre sus herederos se tasó en 160.000 reales ${ }^{1207}$, lo que indica que debió terminarse en ese mismo año.

\section{Ruinas de la ferrería de Llamas}

La ferrería se adjudicó al lote de las nietas de Nemesio Fernández, previo pago por parte de sus maridos, Adriano Quiñones y Francisco Soto, de 80.000 reales a su tío Felipe Fernández. Con la ferrería se incluían el monte y los criaderos de mineral de hierro denunciados en los alrededores: en Santa Lucía, la mina Fernandina; en Montes, las minas Necesidad y Pombina; las de

\footnotetext{
1204 BOPL., 20 de febrero de $1856, n^{\circ}$ 22, p. 2

1205 BOPL., 26 de enero de $1857, \mathrm{n}^{\mathrm{o}} 11, \mathrm{p} .2$

1206 AHPL. P.N.: caja 2724 (año 1859). Hoy la cabeza de ayuntamiento no es Sigüeya sino Benuza.

1207 AHPL. PN.: caja 2723 (año 1859).
} 
Paradela de Muces y Médulas; así como las maderas ya cortadas con destino a la ferrería $^{1208}$.

La ferrería comenzó a funcionar poco después, por medio de un administrador. La menciona un Niomenclator de $1867^{1209}$. Según documentos posteriores, utilizaba hierro de la Chana de Borrenes y de Ferradillo ${ }^{1210}$, y trabajaba desde el mes de octubre hasta el de junio ${ }^{1211}$. Durante el verano, quizás a causa de la disminución de caudal del Cabrera, se utilizaba como un machuco para fabricar rejas y batederas ${ }^{1212}$. El administrador, Domingo Parada, anota todos los gastos de la ferrería (oficiales, mazuqueros, carboneros) y las de las labores en los campos y fincas que posee de centeno, viñas, prados; también las ventas de hierro ${ }^{1213}$. Cuenta también con algunas cabezas de ganado, a veces cedido a medias a campesinos de los alrededores; cobra peaje por el paso del puente $^{1214}$, compra vino a los arrieros maragatos y lo vende a los carboneros y vecinos ${ }^{1215}$. Debió funcionar hasta finales del siglo XIX.

1208 AHPL.PN.: caja 2723 (1859)
1209 NOMENCLATOR DE LA PROVINCIA DE LEÓN. León, p.46.

1210 En las cuentas de los años 1880-1881, el mineral de la Chana costaba a 6 reales el quintal, mientras que el de Ferradillo salía a 5 rs. quintal. Se trasportaba fundamentalmente durante los meses de mayo a agosto. Concretamente en ese año se adquirieron 382, 42 quintales, que costaron 2.096, 55 reales. (CUENTAS DE LAS FERRERÍAS DE LLAMAS: Archivo privado de Manuel Rodríguez de Toral de los Vados, nieto de Domingo Parada. Poseo, por su gentileza, copia del mismo).

${ }^{1211}$ IBIDEM: En el documento citado se dice: "llegaron los oficiales el día 13 de octubre" (Son cinco: aroza, tirador, dos fundidores y tazador), y entre ese mes y junio fabricaron 374 quintales. En varias ocasiones se mencionan a estos oficiales, por ejemplo al hablar del consumo del centeno, dice que se consumen en la casa 24 cuartales y libra y media "inclusos con la familia de casa los cinco oficiales que hubo que mantenerlos dos días que ocuparon con los criados limpiando el cauce de la herrería y tres días el carpintero haciendo una chapacuña nueba y hechando las llabes de la rueda"; o del vino: "gastado con los cinco oficiales y los dos criados en los días 18 y 19 limpiando el cauce de la herrería en la embocadura de la chapacuña metidos en el agua sin jornal dos cántaros y siete cuartillos".

1212 IBIDEM: gastó en vino "en 4 días que ocuparon los oficiales antes de empezar a travajar arreglando la Herrería que dejaron los mazuqueros descompuesta”. Desde el 27 de agosto de 1880 al 7 de septiembre de ese año, "se hicieron en la ferrería 14 quintales y 80 libras de rejas y un quintal y 30 libras de batederas, que todo hace 16 quintales y 10 libras".

1213 IBIDEM. Entre octubre de 1880 a agosto de 1881 vende 286 quintales y 2 libras de hierro, además de 48 quintales y 100 libras que envía al almacén de Ponferrada.

1214 IBIDEM: "2 reales y 12 cts. cobrados del paso del puente". Añade: "No se cobra nada del paso del puente, porque en el soto llamado Palombas, entre ésta y Sigüeya, con las lluvias marchó el camino completamente y no pasa cavallería alguna y los que van a pie todos pasan el pontón de LLamas".

1215 IBIDEM: Según el estado de cuentas, desde octubre de 1880 a agosto de 1881 la ferrería tiene $50.882,2$ reales de ingresos, de los cuales 27.243,12 son por la venta del hierro (más 4.655 del llevado a Ponferrada); los gastos suman 33.663, 49 reales, y el saldo es de 17.200, 65 reales. 
ESTADO: La carretera, como en otros casos, destruyó la mayor parte de la ferrería; sólo se conservan en pie algunos muros abiertos en la roca.

\section{MUNICIPIO DE CANDÍN}

\section{FERRERÍA DE TEJEDO}

LUGAR: Tejedo

AYUNTAMIENTO: Candín

RÍO: Ancares

COORDENADAS: $42^{\circ} 50^{\prime} 38^{\prime \prime}$ N. y 60 $46^{\prime} 29^{\prime \prime} \mathrm{W}$.

El Ancares es un afluente del Cúa que ha tallado en su curso alto un valle estrecho, de vertientes pronunciadas, poco apto para la agricultura. Se trata de una zona de montaña pobre, de escasos recursos agropecuarios. Quizá por eso, los ancareses han sido durante siglos un pueblo de arrieros, comerciantes al por menor entre los puertos del Cantábrico y los Montes de León. El Real Valle de Ancares, hoy municipio de Candín, lo integran una docena de núcleos de población, entre ellos Tejedo que se localiza en la parte más elevada del valle.

En las afueras de este pueblo, en dirección al puerto Viejo de Antero y Balouta, que conduce a la comarca gallega de Cervantes, hay una pequeña ermita dedicada a la Magdalena, cuya romería goza de un enorme prestigio en el valle. Doscientos metros antes de llegar a la ermita, al otro lado de la carretera, entre ésta y el río Ancares se encuentran los restos de la ferrería de Tejedo.

Desde la Edad Media se mencionan en el Valle de Ancares actividades metalúrgicas ${ }^{1216}$, probablemente en relación con la existencia de mineral de hierro. Munárriz dice que éste se encuentra en el puerto de la Magdalena, en un banco muy abundante aunque de calidad inferior al de Formigueiros, pues está mezclado con cuarzo ${ }^{1217}$. Datoli añade que a legua y media de la ferrería, pasado

\footnotetext{
1216 BALBOA DE PAZ, J. A. (1990): Hierro y herrerías en el Bierzo preindustrial. León, p. 79. En 1172 el obispo de Astorga cede a su iglesia y a los canónigos de la misma el "diezmo del hierro de Ancares", lo que significa que ya entonces se explotaba ese mineral.

1217 BALBOA DE PAZ, J. A. (1992): El Bierzo en la obra de dos militares del siglo XVIII: Datoli y Munárriz, p. 136.
} 
el puerto de la Magdalena, ya en jurisdicción de Galicia, hay otro mineral que cree que produce un hierro más suave que el que se estaba utilizando en ésta y del que se abastecía probablemente la ferrería gallega de Rao ${ }^{1218}$.

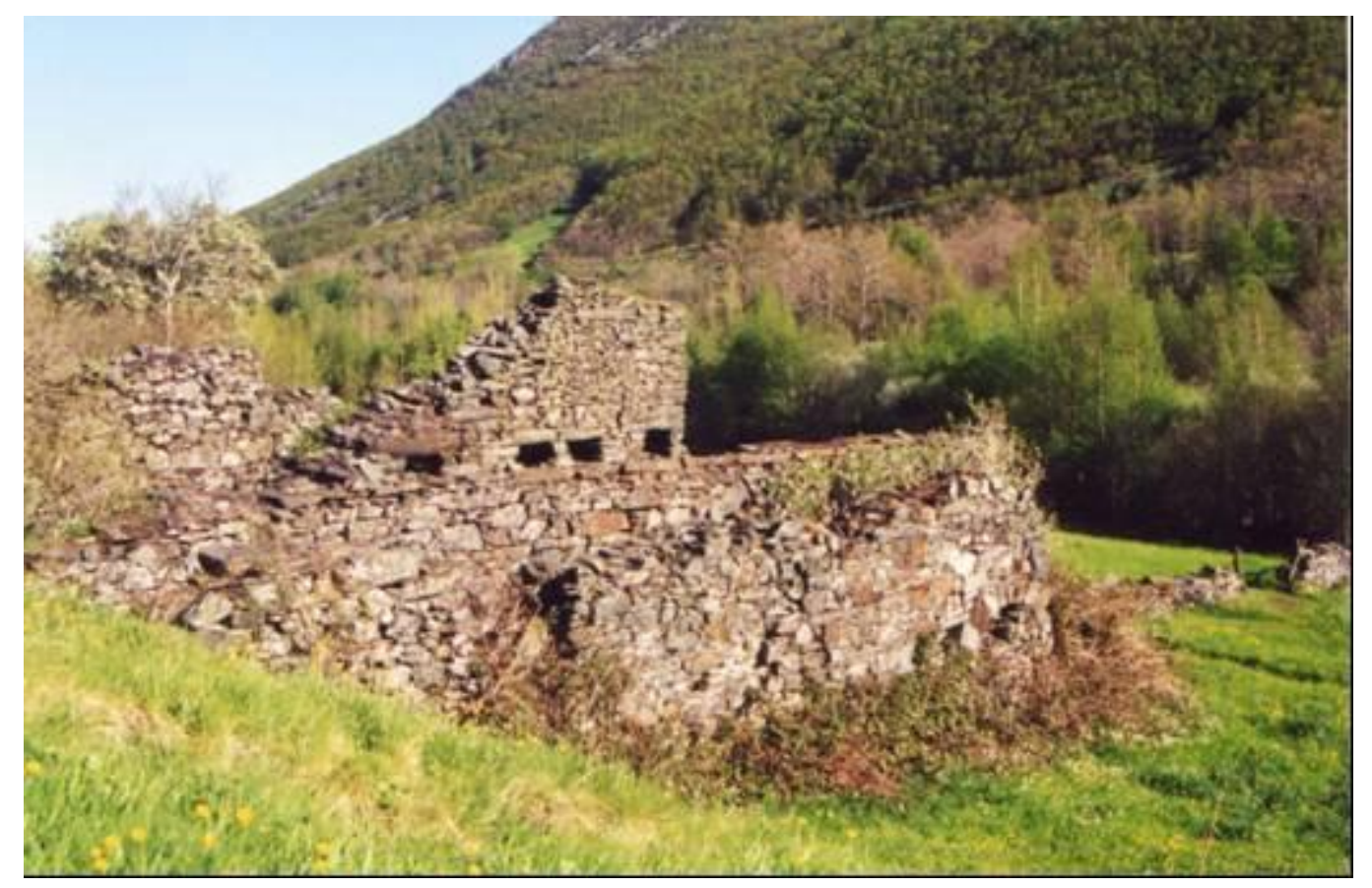

Restos del banzadillo de la ferrería de Tejedo

Los trámites para la construcción de la ferrería de Tejedo se inician en el verano de 1788 , con la solicitud de un permiso a los concejos de Pereda y Tejedo, y con la creación de una Sociedad para su explotación. Formaban ésta don Bernardo y don Jerónimo Rodríguez y don Francisco Abella. Los dos primeros eran hermanos, naturales de Pereda, aunque ambos residían en la villa del Ferrol, dedicados a actividades comerciales, como otros muchos ancareses. El tercero era de Tejedo, lugar en el que residía; pero estaba igualmente ligado al Ferrol, como apoderado en Ancares de don Juan Soler y Compañía "vecino y del comercio en la plaza del Ferrol"1219.

En los días 14 y 16 de agosto del mismo año, los vecinos de Tejedo y Pereda daban el consentimiento para la construcción de la expresada ferrería, porque además de que "tenemos superabundantes montes para coadyuvar a la perpetua existencia de la propuesta fábrica sin ser necesario tocar, ni 
entrometerse a arrancar en los vedados y cotados que abundantemente tenemos para edificios, como tampoco en los fructíferos"; dicha ferrería sería de gran utilidad "a nosotros y demás naturales y residentes en este pueblo, y demás de este Real Valle, tanto por tener a mano y con más comodidad el hierro cuanto por seguirse el que con motivo de la misma fábrica y su construcción, se emplearán sucesivamente" ${ }^{1220}$. El permiso incluye la donación de toda la piedra, agua, vena de hierro y leña necesarios para el funcionamiento de la misma, con las tres condiciones siguientes:

1. "Es condición que el susodicho ni compañeros podrán propasarse ni por si ni por otra persona alguna acotar, ni arrancar leña, ni árbol fructífero alguno en los sitios montes vedados y cotados, como tampoco obligar a ello a sus dueños, quienes accediendo voluntariamente a ello será por el justo valor, como también en el arranque de vena a cuya venta tan solamente podrán obligar aunque se halle en posesión de estimación.

2. "Que el don Bernardo ni compañía no han de poder admitir a otro alguno por compañero, no siendo vecino en este real Valle de donde precisamente lo ha de ser y quien y los que subcediesen en ella.

3. "Es condición que si quisiese o quisiesen éstos o aquel y quien en dicha herrería subcediese pasar, arrendar, vender o permutar a persona alguna que sea vezina de fuera de este Real Valle la precitada fábrica después de hecha o antes de perfeccionarse, en ninguna de estas ocasiones lo pueda hacer ni aún intentar y si lo hiciesen ha de ser preferido este concejo (el de Tejedo), caso de que por algún evento no le acomodase, al de Pereda, y si este tampoco aceptase, cualquiera de este Real Valle"1221.

El 25 de agosto se formalizaba el acuerdo para la constitución de la Compañía y la posterior construcción de la ferrería. Don Jerónimo y don Bernardo Rodríguez ponían el dinero y don Francisco un prado a orillas del río Ancares, denominado el "Carrizal", valorado en 21.000 reales, en el que se 
levantaría dicha ferrería. Acuerdan entre ellos guardar buena armonía, exigiendo cuentas puntuales al encargado de ella, y que si en el futuro se proyectase mejorar las instalaciones, debería hacerse con el acuerdo de todos, "concurriendo cada uno con lo que le corresponde hasta perfeccionar dicha fábrica"1222. En 1791 y 1793 los propietarios adquieren en los aledaños de la ferrería porciones de prados, probablemente pensando en una futura ampliación ${ }^{1223}$ o simplemente para el pasto de las caballerías de la fábrica.

Poco después la ferrería estaba terminada y en funcionamiento. Según Munárriz, aunque no difería de las restantes del Bierzo, estaba mucho mejor ideada y rematada. Su hierro, por el contrario, tenía escasa aceptación, pues era de mala calidad debido al contenido en cobre del mineral de la Magdalena; por ello: "está desacreditada y es la que menos reditua, siendo así que por la proximidad del mineral, abundancia de leña, carbones y aguas, y mejor conservación del edificio y máquinas podría sobresalir entre todas las del Bierzo, tomándose el trabajo de separar el mineral de la parte terrosa y cobriza con que está mezclado"1224. Para Datoli, esta ferrería tenía problemas con el agua, al situarse en la cabecera del Ancares, "por lo que suele estar parada los meses de julio, agosto y septiembre"1225; y pese a lo que dice Munárriz, también los tenía con el carbón ${ }^{1226}$.

En 1799, probablemente poco después de la muerte de los socios don Bernardo Rodríguez y don Francisco Abella, se hizo un reparto de los bienes de la compañía entre sus respectivos herederos -Lucía Afonso, viuda de Bernardo, y los hijos de don Francisco- y don Jerónimo. A cada una de las tres hijuelas le correspondieron 25.600 reales en bienes (parte de la casa, prados, animales y útiles domésticos); además 16.220 reales y $33 \mathrm{mrs}$. en deudas a la Compañía,

1222 AHPL. PN.: caja 3492 (año 1788).

1223 AHPL. PN.: caja 3493 (año 1791): Un tal Manuel cambia un prado de cinco cuartales y medio al sitio de Carrizal, que linda con propiedades de D. Francisco Abella y los hermanos Rodríguez; a cambio le dan varias propiedades y 360 reales en "especie de oro y plata". AHPL. PN.: caja 3493 (año 1793): Como consecuencia de las deudas que dejó su marido (1265 reales en géneros y otros efectos que le sacó al fiado de su almacén), Florentina Abella vende a Juan Rodríguez un prado en Tejedo "al sitio de la ferrería".

1224 BALBOA DE PAZ, J. A. (1992): Ob. cit., p 136.

1225 IBIDEM, p. 58.

1226 AHPL. PN.: caja 3493 (año 1797): Los vecinos de Pereda prenden "a los carboneros del $D$. Francisco (uno de los dueños de la ferrería de Tejedo) en los montes de comunidad de ambos pueblos", lo que da lugar a un juicio y posterior convenio entre concejo y propietario. 
repartidos en tres partes, y 12.500 reales de hierro a don Jerónimo y doña Lucía respectivamente. La ferrería quedaba pro indiviso para las tres herencias y, según el peritaje de don Miguel Antonio Uría, maestro arquitecto y director de las Herrerías de la Compañía de Ribadeo, su valor ascendía a la cantidad de 135.270 reales y 33 mrs. ${ }^{1227}$.

Entre 1799 y 1802, ambos cuñados compraron la parte de la ferrería perteneciente a los herederos de Francisco Abella, como inferimos de un arrendamiento que acuerdan con don Andrés Celaya y Bendarte, vecino de Ferreirós y propietario de varias ágoas de la ferrería de ese lugar de la provincia de Lugo, por cuatro años y renta de 8.000 reales anuales; pues dicen que le arriendan "todo el artefacto y Fábrica de Fierro que tenemos sita en término y dezmario del lugar de Texedo a nosotros tocante y perteneciente, que se nos ha adjudicado por parte de los herederos de D. Francisco Abella"1228. Por este arrendamiento sabemos que anualmente la ferrería ha de pagar dos quintales de hierro y 400 reales anuales a cada uno de los concejos de Pereda y Tejedo ${ }^{1229}$. En 1803, don Jerónimo y su cuñada dicen que el vecino de Navia Josef Alvarez les debe, probablemente de antes del arriendo, 2.253 reales y $25 \mathrm{mrs}$. "procedidos de empréstito y de fierro en expecial que ha sacado al fiado de su Erraria de Ancares" ${ }^{1230}$, lo que confirma lo anteriormente dicho sobre la propiedad de la ferrería.

\footnotetext{
1227 AHPL. PN.: caja 3494 (año 1799). La tasación, hecha el 29 de enero de 1798, fue de este tenor: La presa y cauces de la herrería, sus paredones, pozo, compuertas y excavaciones: 39.550 rs.; la excavación y cimientos del edificio y máquinas: 12.500 rs.; los paredones del edificio y estolda, inclusas sus puertas, ventanas y arcos: 20.948 rs.; los techos cubiertos de todo el edificio de la herrería y carbonera: 10.150 rs.; el banzao o depósito de agua, fábrica de carpintería: 6.552 rs.; la fragua de barquines, con su correspondiente máquina: 8.862 rs.; las máquinas del mazo, sin inclusión del herrage: 3.580 rs.; el herrage de todas las máquinas, herramientas de todo uso y otras que hay de repuesto: 11.520 rs.; el molino harinero con dos piedras y muelas de mediano tamaño: 2.000 rs.; la casa de la fragua de mano contigua a aquel: 1.300 rs.; las herramientas de la misma fragua: 787 rs.; la plaza y terreno de la ferrería, molino y fragua: 400 rs.; la casa de la Magdalena: 900 rs. Total de lo proindiviso: 135.270 rs. y $33 \mathrm{mrs}$.

1228 AHPL. PN.: caja 3783 (año 1802).

1229 Andrés Celaya no debió pagar el arrendamiento, pues en 1822 los hijos de don Jerónimo (Vicente) y Lucía (Ramón, Bernardo y Andrés), todos comerciantes del Ferrol pleitearon con los herederos de aquél por 33.368 reales y 17 mrs. "resto de una suma mayor que en 1806 resultó deudor a D. Gerónimo y $D^{a}$ Lucía Afonso... por el arrendamiento de la ferreria de Ancares". Los herederos llegaron al acuerdo en que los Celaya pagarían, a plazos, 18.0oo reales de aquella deuda (AHPLU: 2475/4).

1230 AHPLU: $1481 / 5$
} 
La ferrería siguió en sus manos hasta poco antes de 1820. Por lo que sabemos, estos cuñados que vivían en Ferrol, no la explotaban directamente sino que la arrendaban, como ya había ocurrido antes con Andrés Celaya. Así, en los años anteriores a 1812 la tenía en arriendo Domingo Antonio González, de Villablino, con el que los dueños tuvieron problemas para el cobro de la renta $^{1231}$.

En 1820 aparece como dueño de la ferrería, por compra, don Juan Francisco de Ribadeneira, vecino de Santa Eulalia de Teyllar, en Galicia ${ }^{1232}$, y arrendatario de las ferrerías de Lousadela y Ferreirós ${ }^{1233}$, propias de su tía la marquesa de Viance, quien las explota por medio de un administrador ${ }^{1234}$ o a veces directamente. La ferrería siguió en manos de esta familia hasta bien entrado el siglo XIX ${ }^{1235}$, aunque probablemente se vendió a la muerte violenta de José María Rivadeneira y Pardo en 18591236; de hecho, en el Nomenclator de 1867 aparece como nuevo dueño de Benigno Valle ${ }^{1237}$. Desconocemos la fecha de su paralización, pero debió de ser ya en los años finales del siglo.

${ }^{1231}$ AHPL. PN.: caja 3761 (año 1813): "D. Gerónimo Rodríguez vecino de la villa del Ferrol por si y a nombre de $D^{a}$ Lucía Afonso su convezina, dueños del Artefacto o fábrica de fierro sita en término de este lugar (de Tejedo), la que trajo en arrendamiento el compareciente años pasados y finalizó en los veinte y cinco de julio de el año de doze, solicitando le satisfaga las aguas vencidas en el mismo día, mes del presente año de la que no se ha utilizado el otorgante mediante estar fenecido el arriendo con respecto a las del anterior, siendo así que ha tiempo oportuno, en el año doce, hizo dejación de dicha Herrería"; pero esto no debe ser totalmente cierto, pues en 1813 y 1814 todavía estaba en la ferrería el mencionado Domingo Antonio González.

${ }_{1232}$ AHPL. PN.: caja 3762 (año 1820): Antonia Rodríguez vende a don Juan Francisco Ribadeneira "dueño de la fábrica de fierro existente en este pueblo y vecino de Santa Eulalia de Teyllar", un prado en 440 rs., dinero que confiesa haber recibido antes de ahora de "D. Pedro Teyxelo mayordomo y administrador del insignuado artefacto".

${ }_{1233}$ AHRG. R. A: 19222/30. En 1829 doña María Josefa Ribadeneira y Pardo afirma que "su difunto marido D. Juan Francisco Rivadeneira y Pardo, cauallero maestrante de Ronda llebó por muchos años en arrendamiento las ferreiras de Lousadela y Ferreirós y poseyó por compra esta (de Ancares) que la constituyente regenta".

1234 AHPL. PN.: caja 3736 (años 1824 y 1825): En estos dos años todavía está como administrador don Pedro Teyxelo, ahora en nombre de la viuda de don Juan Francisco, doña María Froilana Ribadeneira, residente en la ferrería de Lousadela, en Galicia.

${ }_{1235}$ En 1838 era dueña doña María Josefa Ribadeneira y Pardo (AHPL. PN.: caja 3791); en 1843 y 1849 son José María Ribadeneira y Pardo (AHPL. PN.: cajas 3791 y 3712).

${ }^{1236}$ BOPL., 17 de enero de $1859, n^{0}$ 7, p. 4. Se dice que era soltero y, al parecer, natural de Santa María de Castro de Rey. Meses después (BOPL., 27 abril de $1859, \mathrm{n}^{\circ}$ 50, p. 4), el juez de Villafranca del Bierzo emplaza a Domingo Taladrid Abella, alias Raposo, vecino de Tejedo, por el homicidio del dicho José María Rivadeneira.

1237 NOMENCLATOR DE 1867. Este Benigno Valle podría ser el mismo que el Benito del Valle, propietario de las ferrerías de Valincarro y San Vitul, pero lo desconozco. 
ESTADO: Su estado es lamentable, aunque conserva todavía casi íntegramente su estructura, el banzadillo, la forja y carboneras, así como la vivienda. El desmantelamiento de sus cubiertas, la nieve del invierno y los calores del verano han abierto sus paredes, que se alabean, amenazando con venirse abajo.

\section{MUNICIPIO DE FOLGOSO}

\section{FERRERÍAS DE MARCIEL}

LUGAR: Marciel

AYUNTAMIENTO: Folgoso de la Ribera

RÍO: Boeza

COORDENADAS: $42^{\circ} 40^{\prime} 57^{\prime \prime}$ N. y $6^{\circ} 19^{\prime} 40^{\prime \prime} \mathrm{W}$.

Díaz Carro asegura que el lugar de Herrerías de Marciel ha desaparecido sin dejar memoria de su emplazamiento. Después de mucho indagar, supone que estaba junto al arroyo que desciende de Quintana Fuseros al río Boeza, muy cerca del camino que sube hasta dicho pueblo desde la carretera, algo más arriba de Folgoso. "Unas tristes ruinas son testimonio mudo de lo que un día fuera población que, a juzgar por su nombre, debió contar con una pequeña industria del hierro" ${ }^{1238}$.

Sin embargo, Madoz afirma que "los restos del artefacto y habitaciones de los dependientes que constituían la población, se hallan a la orilla derecha del río Boeza á una legua al $N$. del pueblo de este nombre. El abandono de la fábrica y la consiguiente despoblación, se atribuyen a la escasez y mala calidad del mineral y a la construcción de otros artefactos de la misma clase en puntos más accesibles y de caminos mejores para facilitar la estracción"1239.

Desconocemos el origen de esta ferrería que ya existía en el siglo XVI. Un documento del año 1539 menciona en la Tierra de Bembibre dos ferrerías "que

${ }_{1238}$ DÍAZ CARRO, A. (1993): Historia de Bembibre. León, p. 69.

1239 MADOZ, P. (1845-1850): Ob. cit., p. 122. 
rentaban cada una 1.000 mrs. al marqués" de Villafranca ${ }^{1240}$. Pese al laconismo de la cita, creo que estas ferrerías deben relacionarse con las que más tarde fueron conocidas como Herrerías de Marciel, que estaban en aquella jurisdicción. La de Marciel dio origen a un pueblo, hoy desaparecido, pero que aún existía en 1826 , con una población de 18 vecinos ${ }^{1241}$.

En el siglo XVIII, según el Catastro de Ensenada, el artefacto pertenecía al conde de Benavente que lo tenía aforado a Domingo de Omaña y Juan Arias ${ }^{1242}$. Más que una ferrería, en ese siglo, debía de ser solamente un mazo o una simple fragua. El Catastro nos informa, en la pregunta 17, "que no ay nada a escepción de una casa de fragua que sirve solo para fabricar yerros de el campo, perteneciente a Juan Arias y consortes de esta vecindad y otras tres arruinadas totalmente"; es decir, las fraguas que tradicionalmente rodean un mazo. A este Juan Arias "pertenezele dos días en cada veinte y dos en una casa fragua, donde se fabrican yerros de el monte, que se halla en el distrito de dicho lugar de las Herrerías y sobre su parte y porzión paga en cada un año dos reales de vellón por razón de foro perpetuo al dicho sr. conde de Benavente y a su recaudador en su nombre, correspondiendo los otros veinte días a dicho Domingo de Omaña que paga 13 reales y 4 maravedís al conde de Benavente"1243.

ESTADO: No queda el menor rastro de su ubicación.

1240 FRANCO, A. (1982): "El señorío de Villafranca del Bierzo", BRAH, t. CLXXIX, cuaderno 1, p. 92 ${ }^{1241}$ MIÑANO, S. (1826): Diccionario geográfico-estadístico de España y Portugal. Madrid, t. IV, p. 453

${ }^{1242}$ CATASTRO DE ENSENADA: Respuestas generales de Herrerías de Marciel 1243 IBIDEM 


\section{MUNICIPIO DE OENCIA}

\section{FERRERÍA DE ARNADELO}

LUGAR: Arnadelo

AYUNTAMIENTO: Oencia

RÍO: Selmo

COORDENADAS: $42^{\circ} 33^{\prime} 322$ N. y $6^{\circ} 55^{\prime} 4^{\prime \prime} \mathrm{W}$.

Se sitúa en la margen izquierda del Selmo, a poco más de un kilómetro aguas arriba de Arnadelo, pueblo desde el que sale un camino que sigue por esa margen izquierda del río, a veces anegado por el agua en su primer tramo; luego pintoresco y rodeado de castaños, jaras y urces. Antiguamente un puente de madera, hoy derruido y a la altura de la ferrería, permitía un acceso más cómodo desde el camino -hoy carretera asfaltada- de Castropetre a Arnadelo, por la margen derecha.

La ferrería fue construida en la década de 1840 por Ramón Ovalle, probablemente después de la de Valdelouro, que erigió hacia 1835. Fue éste un importante industrial ferrero, arrendatario en las primeras décadas del siglo XIX de las ferrerías bercianas de Arnado, Pontepetre y de la orensana de la Pontenova. Madoz la menciona en el artículo de Arnadelo, señalando que en ese lugar "se encuentra una herrería de dominio particular y un puente de madera" ${ }^{1244}$, siendo por ahora la primera referencia que conocemos de la misma. Pagaba de foro por la vena de Formigueiros, que era la que consumía, 300 reales ${ }^{1245}$.

En 1850 Ramón Ovalle la hipotecó al Exmo. Sr. don Antonio Valdés y Barrio, magistrado del Tribunal Supremo, quien le concedió un préstamo de 24.00o reales. Según el documento, le hipoteca "una fábrica herrería con sus accesorios... en Arnadelo y su término, que linda al mediodía con el río Selmo, norte con monte propiedad de la herrería y tierras de varios vecinos de

1244 MADOZ, P.: Ob.cit, p. 30

1245 GARCIA TATO, I. (2000): Ob. cit., p. 168 
Arnadelo, poniente con puente de la herrería"1246. Si la de Valdelouro era, con toda seguridad, una pequeña ferrería regatera; esta de Arnadelo, por el contrario, fue una fábrica de grandes proporciones, como atestiguan sus restos, signo de la importancia adquirida por esta actividad y de la prosperidad de su dueño.

La ferrería pasó luego a su hijo Isidoro Ovalle, de Villafranca, villa de la que fue procurador síndico, quien en 1868 por medio de su hijo Luis Ovalle, teniente de artillería, pagará a don Antonio Valdés 20.000 reales, quedándole a

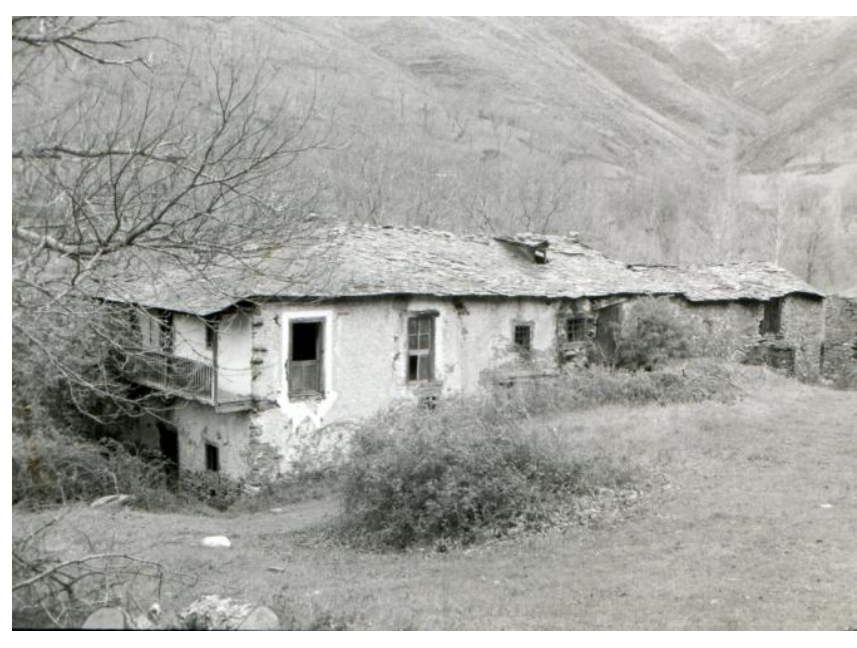

Vivienda de la ferrería de Arnadelo

deber otros 4.00o de aquel antiguo préstamo a su abuelo. Esta cantidad más 100 pesetas por los intereses contraídos los pagará Miguel López en 1872, a quien el nieto de Ramón Ovalle vendería esta ferrería ${ }^{1247}$. Todavía funcionaba en 1881, pues en las cuentas del administrador de la ferrería de LLamas, anota éste como gastos "78 rs. al mazuquero de Arnadelo por la fundición y compostura de 8 tuberas"1248; aunque este termino -mazuquero- pudiera indicar que para entonces no funcionaba sino como un simple mazo o mazuco.

ESTADO: Pese a su estado ruinoso, es una de las mejor conservadas en su estructura, con la vivienda, la capilla hoy restaurada (con porche y hornacinas en su interior), y la ferrería propiamente dicha. El banzadillo, paralelo al río, está bastante buen estado, el resto lo cubre la maleza hasta casi ocultarlo.

\footnotetext{
1246 AHPL. PN.: caja 9116 (año 1850). Probablemente ese préstamo sea un dato que confirme la construcción a finales de los años cuarenta y que para ponerla en funcionamiento hubo de solicitar ese dinero por los gastos en su edificación.

1247 AHPL. PN.: caja 9116 (año 1872)

1248 ARECHIVO PRIVADO (M. Rodríguez): Cuentas de la ferrería de LLamas de 1880-1881.
} 


\section{FERRERÍA DE ARNADO}

LUGAR: Arnado

AYUNTAMIENTO: Oencia

RÍO: Selmo

COORDENADAS: $42^{\circ} 32^{\prime} 15^{\prime \prime} \mathrm{N}$ y $7^{\circ} \mathrm{O}^{\prime} 41^{\prime \prime} \mathrm{W}$

Se encontraba en la margen izquierda del río Selmo, a la salida del lugar de Arnado $^{1249}$, muy cerca del puente que conduce a Gestoso, en la merindad de Aguiar. Se la conoció con los nombres de San Victor, Arnado o Herrería de Arriba. Un documento de 1527 le llama de Santo Bota ${ }^{1250}$, pero debe ser una errata del copista por San Victor.

No se conoce la fecha exacta de su construcción; pero creo que con las de Pontepetre y Valcarce, debió edificarse en el siglo XV, probablemente por los Alvarez Osorio, condes de Lemos, de quienes la heredarían los marqueses de Villafranca en 1486, cuando se produjo la división de los bienes de Pedro Alvarez Osorio entre su hija doña Juana, primera marquesa de Villafranca, y su nieto bastardo don Rodrigo, futuro conde de Lemos ${ }^{1251}$. En un inventario de 1500, hecho para esta primera marquesa de Villafranca, se dice que "en Aguiar hay dos herrerías, la de San Victor y la de Ponte Petre, que se arriendan cada año por 34.00o maravedis"1252; dato que confirma su existencia ya en ese siglo XV. Según un documento del archivo de Medina Sidonia fue reconstruida y, probablemente renovada con los modernos sistemas hidráulicos, en $1542^{1253}$.

\footnotetext{
1249 Arnado, como el resto de la merindad, era del marqués de Villafranca. En un apeo de 1696, sus vecinos reconocen "que no hay cosa propia de persona particular que sea libre". Todo (casas, heredades, molinos, huertos, montes, etc.) era del marqués al que pagaban de foro 8 fanegas de centeno bueno, seco y limpio; además tenía el beneficio curado del lugar por el que se llevaba las 2/3 partes del diezmo. En GARCIA TATO, I. (2000): "Las herrerías de Río Cabo y Pombriego en el siglo XIX". Revista Bierzo, p. 108.

1250 GARCÍA TATO, I. (1999): "La colegiata de Villafranca del Bierzo". Revista Bierzo, p. 132. Documento de fundación del mayorazgo de los marqueses de Villafranca: “... con todos los fueros e rentas e Herrerías e pozos que en ellos en cada uno dellos tenemos e con las Herrerias de Pontepetri e Santo Bota e con la renta que nos es debida en el lugar de Villarrubin...”.

${ }^{1251}$ FRANCO SILVA, A. (1982): "El señorío de Villafranca del Bierzo" BRAH, t. CLXXIX, cuad. 1, p. 58 y ss.

${ }_{1252}$ FRANCO SILVA, A. (1981): "Bienes, rentas y vasallos del señorío de Villafranca del Bierzo al término del siglo XV". Archivos Leoneses, 69, p. 48

${ }^{1253}$ ADMS. Leg. 4963.
} 
Estas tres ferrerías de los marqueses de Villafranca, durante los siglos XVI y XVII, no fueron explotadas directamente por éstos, sino que las arrendaban, primero anualmente, luego por espacios de tiempo más dilatados. En el mencionado inventario, se dice que el año anterior, 1499, las ferrerías de Aguiar fueron arrendadas al vizcaíno Juan Martínez, junto con otras rentas (talla, luctuosa, yantar, foros, etc.) de la mencionada merindad en 64.000 maravedís. ${ }^{1254}$ Ambas fueron nuevamente arrendadas en 1555 y 1556 en 52.000 mrs. anuales ${ }^{1255}$; pero sin duda estos arrendamientos se hacían por separado, porque generalmente los renderos que nos son conocidos, excepto el mencionado Juan Martínez, eran diferentes para cada una de ellas. La mayoría, al menos en el siglo XVI, son vascos, como el Juan Martínez de 1500. En 1557 era rendero Francisco de Sagastizábal, vizcaíno ${ }^{1256}$, y en 1582 Juan de Aguinaga o de Arriaga ${ }^{1257}$, al que sucedió Beltrán de Celaya ${ }^{1258}$. También lo debió ser Juan Martínez de Vicuña, arrendatario de Arnado en $1597^{1259}$ y en $1600^{1260}$; pues un Miguel Martínez de Vicuña sabemos que era originario de Legazpi, Guipúzcoa ${ }^{1261}$.

La ferrería, como hemos dicho, pertenecía a los marqueses de Villafranca, los cuales la incluyeron entre los bienes de su mayorazgo, creado, con licencia de Carlos I y la reina Juana en 1528, por Pedro de Toledo y María Osorio, segundos marqueses de ese título ${ }^{1262}$. Como el resto de sus bienes, las ferrerías eran administradas por el Juez de Rentas o el Contador Mayor del marquesado, que las arrendaba; y al mismo tiempo cuidaba de su conservación y arreglo de

\footnotetext{
1254 FRANCO SILVA, A. (1981): Ob. cit., p. 48.

1255 FRANCO SILVA, A. (1982): Ob. cit. p. 93

${ }^{1256}$ AHPL. PN.: caja 1481 (año 1557)

1257 AHPL. PN.: caja 1490 (año 1582)

${ }^{1258}$ En 1585 este Beltrán de Celaya, rendero entonces de Arnado, dio un poder a Juan de de Aguinaga, el anterior rendero, para que cobrase cierto dinero a Antonio de Valderas, en León (AHPL. P. N.: 1587).

1259 Archivo privado de la familia LLano y Ovalle. Pleito por la utilización de los montes de Villarrubín por las ferrerías de Arnado y otras, ff. 133

1260 AHPLU: 2408/1: en el inventario de Juan de Regil, rendero de la ferrería de Órreos, se menciona a "Juan Martinez de Vicuña, rendero de la ferreria de harnado".

${ }^{1261}$ Este Miguel Martínez de Vicuña, hermano o hijo del anterior, rendero de Pontepetre en 1629, era originario de dicho lugar (AHPL: P.N., caja 3186).

1262 GARCÍA TATO, I. : (1999): "La colegiata de Villafranca del Bierzo". Revista Bierzo, p. 132: La merindad de Aguiar con sus fueros.. "rentas e Herrerías... en con las Herrerias de Pontepetri e Santo Bota".
} 
obras mayores ${ }^{1263}$, porque las menores corrían a cargo de los arrendatarios o renderos ${ }^{1264}$. Algunos de estos renderos, en el siglo XVII, arriendan durante largas temporadas la ferrería, como Antonio Rodríguez Mosquera entre los años $1630^{1265}$ y $1640^{1266}$, aunque algunos de ellos compartiendo el arriendo con Miguel de Loreaga, que a su vez lo era de la de Pontepetre ${ }^{1267}$. En la década del cuarenta el rendero fue Marcos Fernández, que también ejercía de alcalde ordinario de la merindad de Aguiar y arrendatario del diezmo de las Médulas ${ }^{1268}$. Dos nuevos arrendatarios comparten la década del sesenta y parte de los setenta, Francisco Bengoechea y Andrés de Cela ${ }^{1269}$.

${ }_{1263}$ Así, en 1634, Gerónimo González, tesorero del estado del marqués, y Andrés Zereixo, vecino de Gestoso, dijeron que por cuanto el tesorero y licenciado don Antonio de Valcarce y Balboa, corregidor y juez de rentas del marquesado en 31 de enero de 1634 "fueron a visitar las herrerías del dicho sr. marqués para ber los reparos y otras cosas que en ellas faltaban azer y allaron que en la ferrería de Arnado faltaban unas caballerizas que solía aber para las cabalgaduras de los renderos de la dicha herrería por estar como estaban caydas por el suelo y por ser nezesarias para el dicho efecto y aber pedido el rendero que al presente está en dicha herrería que se hiziesen se acordó así por el dicho juez de rentas”. El acuerdo consiste en hacerlas de buena piedra, cubiertas de losa, con dos apartamentos y dos puertas; obra por la que Andrés Cereixo recibirá 30 ducados y una arroba de hierro. (AHPL. PN.: caja 2126, año 1634).

${ }_{1264}$ Así en 1660, Francisco Bengoechea y Andrés de Cela se obligan a pagar a Juan Ferrero 1.124 rs. vn. por ciertos arreglos, pues "se a desmoronado el bançado de la dicha herrería por causa de tener el maderamen podrido". (AHPL. PN.: caja 2936, año 1660).

1265 AHPL. PN.: caja 2969 (año 1630). Aparece un Andrés Mosquera, rendero de Arnado, como testigo en un contrato. No sé si es el mismo Antonio, que unas veces aparece como Antonio Mosquera y otras como Antonio Rodríguez Mosquera, o es un pariente suyo.

1266 MIGUES, V. (1996): "Un exponente de gestión económica de la "fiadalguía" gallega y de producción de hierro en la montaña lucense. La herrería de Quintá durante el Antiguo Régimen”. Studia Histórica. Historia Moderna, $\mathrm{n}^{\circ}$ 15, p. 239. Dice que, en 1641, el marqués de Villafranca hubo de pleitear por el impago de 964 rs. de hierro que Antonio Rodríguez Mosquera le debía después de que éste gozara de la administración de las herrerías de Arnado y Pontepetre.

${ }^{1267}$ AHPL. PN.: caja 3126. En 1634 Antonio Mosquera, rendero de Arnado y Miguel de Loreaga, de la de Pontepetre, "que pertenece a su exma. marqués de Villafranca", dicen que "dicho Antonio Mosquera tiene en renta y arrendamiento la dicha ferrería de Arnado por tres años que comenzaron a correr desde principio de agosto del año pasado de seiscientos treinta y tres asta el dicho dia del año que vendrá de mil seiscientos treinta y seis con ciertas condiciones" (como pagar en cada semana de las 52 del año tres quintales y un cuarto de hierro al marqués) por lo que acuerda subarrendar la mitad de esta ferraría a Miguel de Loreaga, pagando éste su parte correspondiente y cumplir el resto de las condiciones.

${ }_{1268}$ Dos escrituras de 1644 y 1646 en que aparece como rendero de Arnado (AHPL.PN, caja 3024).

1269 AHPL.PN, caja 2936. Varias escrituras de los años 1660 a 1668. En 1660, ambos arrendatarios se obligan con Juan Ferrero para el arreglo del banzado; en 1663, como fiador de Andrés de Cela, Bartolomé Corcoba, vecino de Viobra, se obliga a pagar a las cajas de la contaduría del Estado de Villafranca 1.600 rs. vn "por raçon de la renta y tiempo que falta por correr y a corrido de su arriendo asta el dia de Santiago del año entrante de seiscientos y sesenta y quatro"; y en 1668 ambos se obligan a entregar don Lucas de la Cueva, arrendatario de Pontepetre, 200 quintales de hierro cada uno. En 1672 Francisco Bengoechea y Andrés de Cela "renderos que somos de la herrería de Arnado", se obligan a pagar al canónigo don Pedro de Armesto y Valcarce, de Villafranca, 4.680 rs. de 32 miedros de vino, 170 anegas de pan y 200 mañizos de hierba (AHPL. PN.: caja 3103). 
Las dificultades económicas del marquesado, a finales del siglo XVII y principios del XVIII ${ }^{1270}$, obligaron a los marqueses a desprenderse de sus ferrerías, a cambio de dinero, dándolas en foro perpetuo, como veremos con ésta y con las de Pontepetre y Valcarce. La de Arnado, la aforaron don Fadrique de Toledo Osorio, marqués de Villafranca, y su primogénito don José Fadrique de Toledo Osorio, duque de Fernandina, el 17 de julio de 1685, " a fabor de D. Mateo de la Flor Calderón, abad de San Juan de Camba, en la jurisdicción de Candelas"; y con la ferrería, la casa habitación, herramientas y demás pertrechos, cauce de agua, prados y montes, todo "por precio y cuantía de mil ducientos ducados de once reales", además de 850 reales de renta perpetua al año ${ }^{1271}$. En agosto de ese año el apoderado de don Mateo de la Flor, don Manuel Ceballos, recibía la ferrería con un molino caído y unos prados en Leyroso ${ }^{1272}$.

Este don Mateo de la Flor Calderón, abad del monasterio y abadía de San Juan de Camba, pertenecía a la orden hospitalaria de San Juan y algunos años antes había sido gobernador de la Encomienda de Quiroga ${ }^{1273}$. Debió reunir un importante patrimonio, si es que no lo poseía anteriormente. En su testamento de 16 de junio de 1694, protocolarizado en Castro Caldelas, dejaba por único y universal heredero a su sobrino don Juan Antonio de la Flor, hijo de su hermano don Francisco de la Flor y doña Angela Ceballos, y tras él a sus herederos con la "condición que se agregue esta herencia al vínculo y mayorazgo de la casa de la Flor donde yo nací"1274. Estos herederos serían en el

\footnotetext{
${ }^{1270}$ No existe ningún estudio del marquesado de Villafranca en esta época, pero si muchos datos elocuentes de sus dificultades económicas, por ejemplo en relación con la construcción de la Colegiata de Villafranca: FERNÁNDEZ VÁZQUEZ, V. (2000): Arquitectura religiosa en el Bierzo, siglos XVI-XVIII. Ponferrada, t. II, p. 667 y 668, nota 785; o el hospital de Santiago: BALBOA, J. A. (1999): "El hospital de Santiago de Villafranca del Bierzo". Revista Bierzo, p. 57. ${ }^{1271}$ Archivo privado de la familia LLano y Ovalle. Pleito por la utilización de los montes de Villarrubín por las ferrerías de Arnado y otras, ff. 130.

1272 Ibidem, ff. 130v. Probablemente mantuvieran al mismo rendero, pues en marzo de ese mismo año, Manuel Guzmán, residente en la ferrería de Orreos, daba a su hijo un poder para que pudiera "arrendar y tomar en arriendo por el tiempo que le pareciere la herrería de Arnado, feligresía de Oencia, perteneciente a su excelencia el marqués de Villafranca” (AHPL. PN.: caja 2937).

1273 En 1667 y en 1669 aparece citado como el licenciado fray don Mateo de la Flor "del ábito de San Juan, prior de los prioratos de San Martín de Suarna, gobernador y bicario general de la encomienda de Quiroga, yncio y Osorio"; en 1687 seguía siendo gobernador de Quiroga. Cit. en I. GARCÍA TATO y E. ÁLVAREZ (2012): Las Encomiendas gallegas de la orden de San Juan de Jerusalén. Estudio y edición documental. T. II-2 ${ }^{\circ}$. La Encomienda de Quiroga. Santiago de Compostela, p.733 y 782.

1274 Archivo privado de la familia LLano y Ovalle. Pleito por la utilización de los montes de Villarrubín por las ferrerías de Arnado y otras, ff. 110.
} 
siguiente siglo la familia de la Puebla, vecinos de Carandia, en el valle de Piélagos (Santander). El Catastro de Ensenada dice que la ferrería "es propia de don Juan de la Puebla, vecino de la villa de Carandia, provincia de Burgos"1275; en 1764 aparece como dueño del dominio útil don Francisco Ramón de la Puebla y Velasco ${ }^{1276}$. En el siglo XIX son sus propietarios los Argumosa, herederos de aquéllos por el matrimonio de Francisco Javier Argumosa con doña María Ramona de la Puebla.

Tampoco estos nuevos propietarios administraron directamente la ferrería sino que igualmente la arrendaban, normalmente a verdaderas sagas de arrendatarios ferreros. Así a los Guerra Donís de Ponferrada ${ }^{1277}$, la familia de doña Angela Martínez Torres ${ }^{1278}$ o don José Martínez, que estuvo de arrendatario por lo menos desde 1768 hasta $1773^{1279}$.

Según el Catastro de Ensenada ${ }^{1280}$, la ferrería de Arnado, como la de Pontepetre, trabajaba al año 250 días, en los que producía seis quintales y medio de cinco arrobas cada día, lo que supone una producción de 1625 quintales, algo más de 93 toneladas anuales, cifra realmente muy elevada, que contrasta con la producción de otras ferrerías de los alrededores, que no superan los 1000 quintales. Esta cifra no difiere de la que dará Cornide unos

\footnotetext{
1275 CATASTRO DE ENSENADA: R.G., Libro de Arnado.

1276 AHPL. PN. caja 3287 (año 1764).

1277 Un don Francisco Antonio Guerra, aparece como administrador de la ferrería en 1726 (AHPL. PN., caja 3333); después de muchos años, en 1752, nuevamente encontramos a un don Francisco Antonio Guerra Donís, vecino de Ponferrada, que si no es la misma persona, es su hijo, con quien se obliga un vecino de León a pagarle 21.350 rs. vn., importe de 350 quintales de hierro de su herrería de "Hernao" (AHPL.PN, caja 617). En 1753 el mismo vende a doña Manuela Herrero, de León, 200 quintales en 13.300 rs. vn de su herrería de Arnado (AHPL. PN.: caja 618). Años después, en 1760, los dueños de la ferrería la arriendan a doña Baltasara Guerra García, de 24 años, hija de Francisco A. Guerra Donís. Esta Baltasara la arrienda por dos años y 11.000 rs./año, de los cuales 10.000 rs. al dueño, 850 rs. de foro al marqués de Villafranca y 150 rs. al conde de Maceda, por el foro de la vena (AHPL. PN.: caja 2378).

${ }^{1278}$ En los años cuarenta la ferrería estuvo arrendada a don Francisco Muro y doña Angela Martínez de Torres, que fueron también arrendatarios de la de Pontepetre. Esta mujer, su yerno (don Joaquín Perejón) e hija (doña Teresa Muro) la subarriendan en 1749, por dos años, a don Agustín Morays de Losada y a su mujer, doña Margarita de Losada y Guerrero, vecinos de Valdeorras, arrendamiento por el que estos, además de pagar la renta que ellos pagaban a los de la Puebla, "les ha de dar y entregar ziento y zinquenta quintales de yerro" (AHPL. PN.: caja 3342)

1279 Archivo privado. Documentos del marquesado de Villafranca (Gentileza de Mariano Higuera).

${ }^{1280}$ CATASTRO DE ENSENADA: R.G., libro de Arnado
} 
años después: 1500 quintales ${ }^{1281}$, también superior a las 22 ferrerías gallegas que nombra, con la excepción de San Vicente de Leira y Rugando con una producción muy semejante. Larruga, con evidente exageración, afirma que en los reinados de Carlos V, Felipe II y Felipe III las únicas industrias siderúrgicas de importancia que había en Galicia, en realidad en el Bierzo, eran las ferrerías de Arnelo (Arnado) y Penitepetra (Pontepetre) "con una producción anual de unos cinco mil quintales de hierro"1282, lo que supondría una producción de 2.500 quintales cada una, lo que es excesivo.

Esos 250 días suponían prácticamente todo el año, si descontamos los domingos y fiestas, por esa razón Datoli dice de esta ferrería que anda todo el año; aunque "sus montes propios se reducen a la corta extensión de las vertientes a ella de las montañas que la cercan"1283. No eran el agua o la vena, sino el carbón y la leña su talón de Aquiles, pese a localizarse en una zona con abundante arbolado. Esto le llevará a una oposición sistemática a todo intento de establecer nuevas ferrerías aguas arriba del Selmo: Ocurrirá así en el siglo XVIII con el proyecto del marqués de Villafranca en Villarrubín ${ }^{1284}$; en el siglo XIX con la que construye el belga Nicolás Maximiliano Lesoinne "fabricante de armas de guerra y lujo, vecino de Lieja", en Río Cabo ${ }^{1285}$, y con la que levantan en Valincarro Benito del Valle y Santiago Montero ${ }^{1286}$. Si los de la Puebla pudieron paralizar la primera, no ocurrió así con las dos últimas.

No fueron esos los únicos problemas de la ferrería; otro más grave surgió, en los sesenta del siglo XVIII, entre los marqueses y los señores de la Puebla, que se enzarzaron en un engorroso pleito sobre la propiedad de la ferrería, pleito que inició el marqués en mayo de 1761 contra doña Josefa Teresa de Velasco como madre y tutora de don Francisco Román de la Puebla, para que dejase libre la ferrería, con sentencia favorable al marqués en la Chancillería de

\footnotetext{
${ }^{1281}$ CORNIDE SAAVEDRA, J.: Noticia de las ferrerías de Galicia (Manuscrito). Real Academia de la Historia.

1282 LARRUGA, E.: (1794): Memorias políticas y económicas sobre los frutos, comercio, fábricas y minas de España. Madrid, XLV, P. 331

1283 BALBOA DE PAZ, J. A. (1992): El Bierzo en la obra de dos militares del siglo XVIII: Datoli y Munárriz. Ponferrada,, p. 58

1284 AHPL. PN.: caja 3287 (año 1764).

1285 Ver ferrería de Río Cabo

1286 Ver ferrería de Valincarro
} 
Valladolid en marzo de 1765. La causa del pleito debió la misma de los suscitados con las ferrerías de Pontepetre y Valcarce. En estos dos casos, y aquí me imagino que es igual, los marqueses pretendieron revocar el foro, mediante una argucia legal; pues al parecer no se había pedido permiso al rey para formalizarlo, como era preceptivo al ser bienes del mayorazgo. Si con aquellas dos ferrerías se llegó a un acuerdo para evitar los juicios, siempre costosos, a cambio de dinero, en este caso debió sustanciarse el pleito, pues en la sentencia de la Chancillería de Valladolid se obligó a pagar a los de la Puebla 65.635 reales ${ }^{1287}$, además de devolver la ferrería a los marqueses, cuyo Administrador General de Rentas la arrendó en su nombre en 1769 ${ }^{1288}$; pero los de la Puebla apelaron ante el Supremo Consejo de Castilla, recobrando posesión en $1773^{1289}$.

Según un documento de 1778, parece que el problema era común a todos los foristas que veían cómo los propietarios pretendían recobrar sus bienes, pero las protestas que hubo en Galicia, llevaron al rey en 1763 a disponer "que no se hiciese novedad en todo el dicho Reyno con los foristas, pagando estos el canon o pensión estipulada, interin se resolvía el expediente general que sobre los foros pendía en el Consejo". Antes de que en 1768 se diera una sentencia

1287 AHPL. PN.: caja 3353. Pleito entre el marqués de Villafranca y doña Teresa Josefa de Velasco y Ceballos, viuda de don Juan Bautista de la Puebla, madre y curadora de don Fco. Ramón de la Puebla "sobre la desistencia de la Herrería de Arnado del dominio directo de dicho Excmo. sr. y su casa y maiorazgo, a la que fue condenada con frutos y rentas desde la litties conttestacion por los señores presidente y oidores de la Real Chanzillería de Valladolid por sentencia de vista confirmada en reuista a que se hauia mandado librar y libró real Carta Escritura a la parte de dicho Excmo. sr. por quien se requirió contra ella al sr. corregidor desta villa (de Villafranca), quien hauia dado posesión de dicha Herrería con los autos correspondientes al asumpto, y para liquidar los frutos y Rentas que hauia producido se hauian nombrado personas ynteligentes para su liquidación la que hauia hecho de varias cantidades hasta la de sesenta y cinco mill seiscientas treinta y cinco rs, y dos mrs. de vellón, en cuia atención se habia pedido por parte de S.E. el pago contra la dicha $D^{a}$ Josefa y su hijo, y sus vienes, etc".

1288 AHPL. PN.: caja 3353. Don Manuel Ventura Blanco, teniente de corregidor y Administrador general de las rentas del marquesado de Villafranca, el 12 de junio de 1769, remata el arriendo, por tres años, de la ferrería de Arnado "de que se alla poseedor dicho excmo. sr. marqués" a don José Martínez de la Fuente, de Ponferrada, en 13.650 rs. al año. Este don José Martínez de la Fuente había sido curador de doña Baltasara Guerra y sus hermanos, a quien ésta en 1760 le exige cuentas de esa curadoría (AHPL. PN.: caja 3341, año 1760).

1289 Archivo privado de la familia LLano y Ovalle. Pleito por la utilización de los montes de Villarrubín por las ferrerías de Arnado y otras, ff. 137. Se cita una Real Provisión por la que el Supremo Consejo, a solicitud de don Francisco Ramón de la Puebla, ordena que se restituya a éste la Herrería con lo demás de que se le había despojado, en virtud de sentencia librada por la Chancillería de Valladolid, en pleito seguido por el marqués de Villafranca. Se requirió con dicha real provisión al corregidor de Ponferrada, quien, en 16 de mayo de 1773, en cumplimiento de la misma le dió posesión de la mencionada ferrería, al citado don Ramón quien, en su presencia, "se paseó, tocó los varquines, golpeó en el yunque, abrió y cerró las puertas, tomó llabes, entraron y salieron las gentes que allí havia, y practicó otros varios actos de posesión.”. 
definitiva por la Chancillería de Valladolid, los de la Puebla acudieron al Consejo "prevaliéndose de la citada Resolución", para que aquella suspendiese todo el procedimiento ${ }^{1290}$, como así debió ocurrir, aunque no inmediatamente, pues los marqueses aún tuvieron la ferrería desde el 19 de septiembre de 1768 hasta el 17 de marzo de 1773. En esos cuatro años y medio, según cuentas del marqués, la ferrería produjo 58.021 reales de beneficio, aunque hubo que rebajar por arreglos y otras causas 38.944 reales con lo que el líquido que tuvo que devolver a sus dueños, los de la Puebla, fueron 19.076 reales y 33 mrs $^{1291}$. En 1791 se nombra como administrador y arrendatario a don Francisco Castro y Delgado ${ }^{1292}$.

Nuevamente mantuvieron éstos, por lo menos hasta los años cuarenta del siglo XIX, el viejo sistema de arrendar la explotación de la ferrería. Durante los primeros años de ese siglo la tuvieron en arriendo primero el gallego don Manuel Antonio Sánchez desde 1800 hasta $1810^{1293}$, y luego a los ponferradinos don Valentín Curiel ${ }^{1294}$, que fue oficial del Batallón de Voluntarios Literarios de la Universidad de Santiago y alcalde de Ponferrada en 1823, y a doña Teresa Baylina ${ }^{1295}$, entre los años de 1810 y1820. Más tarde Ramón Ovalle la gozaría desde 1820 hasta $1840^{1296}$, es decir casi veinte años como reconoce su tío Juan

\footnotetext{
1290 A. P. de los GONZÁLEZ DE VILLAR: Papeles del marquesado de Villafranca, año 1778 1291 IDEM, año 1793.

1292 AHN. Estado: leg. 1739, $\mathrm{n}^{\circ} 16$.

1293 En julio de 1808 don Manuel Antonio Sánchez, rendero de la ferrería de Paleiras, da un poder a su primogénito para que pase a Ponferrada y haga contrato de arriendo de la ferrería de Arnado, de que es dueño, dice, don Francisco Ramón de la Puebla Belasco, vecino de Carandia, "quien le tiene facultado suficientemente para disponer de dicha Fábrica en su administración la que en la actualidad administra el que otorga ( es decir él mismo), en virtud de arriendo otorgado por Francisco Onofre Rodriguez, en el año de ochocientos dos, que en aquella época también estaba", por seis años que finalizan el 25 del corriente (AHPLU: 2455/1). Dicha renovación debió hacerse efectiva, pues en agosto de ese mismo año dice el mencionado Sánchez "que por quanto tiene a su comando dos fábricas de Herrerías que es la insignada de Paleiras y la de Arnado" (AHPLU: 2455/1).

${ }_{1294}$ En el mismo pleito y año don José Chamorro, presbítero, vicario de Friera, de 63 años, dice "que con motivo de haver estado de capellán en la herrería titulada de Arnado, de la pertenencia de D. Fco. Argumosa, habrá como unos veinte años, que entonces la llevaba en arrendamiento D. Valentín Curiel de Ponferrada".

1295 AHPL. PN.: caja 3576. El 20 de mayo de 1820 José Ubide, vecino y colector de la contribución de Oencia, dice: "que para cobrar la contribución cargada a D. Valentín Curiel y $D^{a}$. Teresa Bailina, viuda y vecinos de Ponferrada, por el tiempo que administraron la herrería de Arnado".. da su poder etc. Este Teresa debía de ser tía de la mujer de don Valentín, pues ésta se llamaba $\mathrm{M}^{\mathrm{a}}$ del Rosario Castro Baylina.

${ }_{1296}$ En 1820, Juan Delgado y Angela Delgado, su mujer, ya mayores y sin herederos "dan a sus sobrinos D. Ramón Oballe y su mujer $D^{a}$ Jacinta Delgado, arrendatarios de esta herreria (de Arnado) y vecinos de Villafranca", todos sus bienes (AHPL. PN.: caja 3576). En 1821 Juan Oulego reconoce una deuda por hierro de 8.191 reales que tiene contraida con don Ramón
} 
Delgado en 1841 1297. En los años siguientes parece que los dueños, don Francisco Javier Argumosa y su hijo don Francisco Román Argumosa de la Puebla, la administran directamente, o al menos pasan muchas temporadas en ella1298, aunque en 1857 en el Boletín Oficial de la Provincia de León se anuncia su arriendo'1299. En 1862 su propietaria era D ${ }^{a}$ Rufina San Emeterio "heredera universal de D. Francisco Román Argumosa"13о0

Miñano en $1826^{1301}$, Madoz en $1845^{1302}$, el Guarda Mayor de Montes en $1860^{1303}$, el Nomenclator de $1867^{1304}$ y las Revistas Mineras hablan de su funcionamiento hasta los años finales del siglo, en que dejó de funcionar.

ESTADO: Hoy su solar lo ocupa un prado y sólo el molino y la vivienda, muy restaurada, permanecen como únicos vestigios de una de las más antiguas e importantes ferrerías del Bierzo.

Ovalle, arrendatario de Arnado (AHPL. PN.: caja 3576). En 1830 todavía era arrendatario de la ferrería, momento en que hace una relación de deudores, en número de 36 , de los pueblos limítrofes a los que ha prestado dinero; en total suman 22.616 reales (AHPL. PN.: caja 3677). 1297 Archivo privado de la familia LLano y Ovalle. Pleito por la utilización de los montes de Villarrubín por las ferrerías de Arnado y otras, ff. 137. En el pleito por la construcción de la ferrería de Valincarro, dice Juan Delgado, en 1841, cuando contaba 76 años "que con motivo de haver sido administrador de la herrería titulada de Arnado de la pertenencia de D. Francisco Argumosa, que en aquel entonces la trahía en arriendo su sobrino D. Ramón Oballe, habiéndola administrado el testigo por espacio de 17 ó 18 años". Años antes, don Juan Delgado y su mujer doña Angela Delgado, ya mayores y sin hijos, ceden "a sus sobrinos D. Ramón Ovalle y a su mujer $D^{a}$. Jacinta Delgado, arrendatarios de esta herrería (de Arnado) y vecinos de Villfranca" todos sus bienes con la condición de que los reciban en su casa, los atiendan, etc. Por esa razón, aparece como administrador de su ferrería.

${ }^{1298}$ En 1843 vive en la ferrería Francisco Javier Argumosa y Herrera (AHPL. PN.: caja 3580); en 1846, ya viudo de María Ramona de la Puebla, menciona una relación de 46 deudores, que le deben 13.407 reales, por empréstitos, que son vecinos de Gestoso, Arnado y Oencia (AHPL. PN.: caja 3581). Al año siguiente, ya difunto, habita en la ferrería su hijo Francisco Ramón Argumosa (AHPL.PN.: caja 3581). En 1849 este mismo, en un poder firmado en la ferrería, dice que es “dueño de esta fábrica en que vibe" (AHPL. PN.: caja 3582).

1299 BOPL., 30 de septiembre de 1857, $\mathrm{n}^{\circ}$ 117, p. 4. Dice el anuncio que los que quieran arrendar la ferrería pueden dirigirse a su dueño, don Fco. Román Argumosa, que reside en ella.

${ }_{1300}$ GARCÍA TATO, I. (2000): Ob. cit., p. 151

${ }^{1301}$ MIÑANO, S. (1826-29): Diccionario geográfico-estadístico de España y Portugal. Madrid, t. VI, p. 288. Menciona en Oencia "dos ferrerías, la una llamada de Pontepetre y la otra de Arnado, las que trabajan con las aguas del Selmo".

${ }^{1302}$ MADOZ, P: Ob. cit., p. 30: En su término "se encuentra a las márgenes del río Selmo que la baña, una herrería de dominio particular”.

${ }_{1303}$ LIBRO DEL G.M. MONTES: 30 de agosto de 1860: "En Arnado, con igual objeto (hacer expediente de la herrería) que también entregué al perito", p. 50v, $\mathrm{n}^{\circ} 191 ; 10$ de octubre de 1860: “A la herrería de Arnado con igual objeto (que la de San Vitul)”, p. 52v, nº 193.

${ }_{1304}$ NOMENCLATOR de 1867, p. 76 


\section{FERRERÍA DE GESTOSO}

LUGAR: Gestoso

AYUNTAMIENTO: Oencia

RÍO: Gestoso

CORRDENADAS: desconocidas

No conozco más mención de esta ferrería que la de Madoz. En este pueblo del ayuntamiento de Oencia hay "una herrería sobre el río Selmo", dice ${ }^{1305}$. Probablemente era una pequeña ferrería regatera -quizá un mazoconstruida no sobre ese río, sino sobre el arroyo de Gestoso, afluente del Selmo, que pasa por las inmediaciones del pueblo de ese nombre.

Ignoro sus propietarios aunque posiblemente fuera Benito Olmo, arrendatario de las ferrerías de Río Cabo. De hecho, en 1845 Juan Fariñas, residente en el mazo de Soldón, vende en Gestoso a Benito Olmo "todos los vienes que en el lugar de Gestoso y sus términos adquirió por permuta de don Ramón Oballe, vecino de Villafranca, en 1842" por 16.000 reales ${ }^{1306}$. Todos estos nombres, los Fariñas, Benito Olmo y Ramón Ovalle tienen relación estrecha con actividades siderúrgicas, lo que podría ser una prueba de la existencia en este pueblo de una ferrería o, al menos, de un mazo.

ESTADO: No hay el menor rastro de su ubicación.

\section{FERRERÍA DE LUSÍO}


LUGAR: Lusío

AYUNTAMIENTO: Oencia

RÍO: Lusío

COORDENADAS: $42^{\circ} 31^{\prime} 6^{\prime \prime} \mathrm{N} \mathrm{y}^{\circ} 58^{\prime} 33,96^{\prime \prime} \mathrm{W}$

Era una ferrería "regatera", que sólo funcionaba algunos pocos meses al año por falta de agua. Se encontraba en el arroyo de Lusío, que vierte sus aguas al Selmo entre Arnado y Ponte Petre. Según el testimonio de algunos vecinos, se situaba a orillas del arroyo, a medio camino del pueblo de Lusío y el río Selmo, en un lugar hoy indeterminado.

La construyó en 1840-1841 Jacinto Fariñas, natural de Lusío, a quien sus convecinos le conceden el permiso de construcción, convencidos "de la grande utilidad que se les sigue, de que en los términos de este pueblo se haga un artefacto de la clase expresada"1307. En 1842 estaba construida, ya que en dicho año, Jacinto Fariñas solicita al conde de Maceda y San Román un foro de vena del mineral de Formigueros, pues "acaba de edificar un artefacto de hacer hierro"1308. Por dicho foro, este mismo Fariñas pagaba a mediados de siglo al conde de Maceda, 250 reales al año ${ }^{1309}$. Jacinto Fariñas era yerno de José Pérez, propietario de la ferrería de Outeiro, y hermano Juan Fariñas. Se trata de una familia estrechamente ligada al mundo de las ferrerías, de las que fueron administradores o tuvieron en arriendo, antes y después de construir la de Lusío, las de Soldón, Visuña, Outeiro y San Pedro de Órreos.

\footnotetext{
${ }^{1307}$ AHPL. PN.: caja 3580 (año 1840). Los vecinos de Lusío "dueños insolidum de todos los montes que comprende el término de este pueblo, por lo que pagan al Exmo. sr. Marqués de Villafranca, $y$ actualmente a la nación, veinte y una fanegas y tres ferrados de centeno anualmente, y siendo aquellos tan abundantes de cepas de urz y fáciles de reproducirse, y otras maderas, capaces de por si solas de sostener y abastecer una ferrería o fábrica de facer fierro,como que para sacar alguna utilidad de ellos y poder subenir a sus urgencias, se ben obligados a conducirlo a larga distancia, y con poca estimación y utilidad. Combenidos de la grande utilidad que se les sigue de que en los términos de este pueblo se haga un artefacto de la clase expresada por la proximidad y facilidad de despachar dichos combustibles y poder atender a la labranza, otorgan, dan licencia y facultad toda la que en derecho sea preciso a $D$. Jacinto Farñas su combecino y sus herederos para que en los terminos de este pueblo construya y edificque una ferrería o fábrica de hacer fierro para la que podrá usar todos los caminos concejiles y particulares...”. ${ }^{1308}$ AHPL. PN.: caja 3580 (año 1842)

1309 GARCIA TATO, I. (2000): Ob. cit., p. 168
} 
La menciona Madoz, diciendo que sólo trabajaba cinco meses al año por falta de agua ${ }^{1310}$. En 1860 la visita el Guarda Mayor de Montes para hacer expediente sobre ella ${ }^{1311}$ y en 1867 la nombra el Nomenclator de la Provincia de León ${ }^{1312}$. Debió funcionar algunos años más allá de esa fecha.

ESTADO: No hay restos visibles que permitan ubicarla con exactitud.

\section{FERRERÍA DE PONTEPETRE}

LUGAR: Oencia

AYUNTAMIENTO: Oencia

RÍO: Selmo

COORDENADAS: $42^{\circ} 31^{\prime} 58^{\prime \prime}$ N. y $6^{\circ} 57^{\prime} 24^{\prime \prime} \mathrm{W}$.

La ferrería de Pontepetre se hallaba al lado del puente que, al bajar de Castropetre, cruza el Selmo en dirección a Oencia, capital del municipio de ese nombre. Se la conocía también como la ferrería "de abajo"1313 o simplemente de “Oencia” 1314.

Como la de Arnado, la ferrería de Ponte Petre estaba construida en el siglo XV. Probablemente, como hemos dicho, debieron erigirse ambas en ese siglo por los Álvarez Osorio, condes de Lemos, de quienes las heredarían los marqueses de Villafranca en 1486, cuando se dividió la herencia y se creó el marquesado de ese nombre. En un inventario de 1500, hecho para la primera marquesa de Villafranca, se dice que "en Aguiar hay dos herrerías, la de San Victor y la de Ponte Petre, que se arriendan cada año por 34.000

${ }^{1310}$ MADOZ, P.: Ob. Cit. p. 200

${ }^{1311}$ LIBRO DEL G.M. M., p. 5Ov, ${ }^{\circ} 191$.

${ }_{1312}$ NOMENCLATOR DE LEÓN, 1867, p. 76

${ }^{1313}$ En 1596 se menciona una obligación de Juan de Celaya "rendero de la ferreria dabayjo", y otra de ese mismo año cita también a "Juan de Zelaya rendero de la ferreria dabayjo marquesado de Villafranca" (AHPLU: 2407/9); en 1616 se nombra a un Beltrán de Aguirre "rendero de la ferreria de avajo" (AHPLU: 2555/1); ambos lo son en esos años, como ya veremos, de la de Pontepetre. Lo mismo en 1666, poder de don Lucas de Acebedo de la Cueva "asistente al presente en la herreria de auajo, de que soy arrendatario" (AHPL. PN.: caja 2936), o en 1668 acuerdo del contador mayor del estado de Villafranca y un carpintero de herrerías para arreglar el banzado, pues "avía suzedido el llebarse la abenida un pedaço del arca del vanzado de la herreria de avajo cuyo arrendatario es don Lucas de Azevedo de la Cueva" (AHPL.PN.: caja 2936).

${ }_{1314}$ Ferrería de Oencia es una denominación poco frecuente antes del siglo XIX, pero corriente en ese siglo. 
maravedis"1315; dato del que deducimos su existencia en el siglo anterior ${ }^{1316}$. Según un documento del archivo de Medina Sidonia fue reconstruida y, probablemente renovada con los modernos sistemas hidráulicos en 1542, como la de Arnado ${ }^{1317}$.

Ambas ferrerías, durante los siglos XVI y XVII, las arrendaban los marqueses como ya dijimos, primero anualmente, luego por espacios de tiempo más amplios. En el mencionado inventario, se dice que el año anterior, 1499, las ferrerías de Aguiar fueron arrendadas al vizcaíno Juan Martínez, junto con otras rentas (talla, luctuosa, yantar, foros, etc.) de la mencionada merindad en 64.00o maravedís ${ }^{1318}$. Ambas nuevamente fueron arrendadas en 1555 y 1556 en 52.000 mrs. anuales ${ }^{1319}$; pero sin duda estos arrendamientos se hacían por separado, porque generalmente los renderos que nos son conocidos, excepto el mencionado Juan Martínez, eran diferentes para cada una de ellas, como ya hemos dicho al hablar de la de Arnado. Por ejemplo en 1565 era rendero de Pontepetre Miguel Martínez de Viana, que contrata con un ferramentero de Gondriz algunas herramientas para esta ferrería ${ }^{1320}$. Muchos de estos renderos fueron igualmente vascos, Juan de Celaya en 1596 ${ }^{1321}$, Beltrán de Aguirre ${ }^{1322}$ en 1616, Miguel Martínez de Vicuña, de Legazpi, "y rendero que fue de la ferrería de Pontepetre"1323, o Miguel de Loreaga, venaquero en $1629^{1324}$ y rendero en 1634, año en el que subarrienda también la ferrería de Arnado a Antonio de Mosquera ${ }^{1325}$.

1315 FRANCO, A. (1981): "Bienes, rentas y vasallos del señorío de Villafranca del Bierzo al término del siglo XV". Archivos leoneses, 69, p. 48

${ }^{1316}$ De todos modos, creo que tanto una como otra no son muy anteriores; pues es extraño que en la abundante documentación del cartulario de Carracedo respecto a esta zona, en la que posee un priorato, el de Sobrado, no haya la menor mención a ferrerías medievales.

${ }_{1317}$ ADMS. Leg. 4963.

1318 FRANCO, A. (1981). Ob. cit., p. 48.

1319 FRANCO, A. (1982: Ob. cit. p. 93.

1320 AHPL. P.N.: caja 2868 (año 1565)

${ }^{1321}$ AHPLU: 2407/9: "Juanes de Celaya, rendero de la ferreria de Pontepetre" y en otra del mismo año "Juan de Celaya rendero de la ferreria dabayjo".

${ }^{1322}$ AHPLU: 2555/1: "Beltran de Aguirre rendero de la ferreria de avajo".

${ }^{1323}$ En 1629 el navarro Juanes de Loreaga, venaquero en Pontepetre, da un poder a su padre, que al presente vive en San Sebastián, para que cobre una deuda de 500 reales a Miguel Martínez de Vicuña, vecino de Legazpi, "y rendero que fue de la ferraria de Pontepetre" (AHPL.PN, caja 3186);

1324 Nota anterior

${ }^{1325}$ AHPL. PN.: caja 3126. Antes de 1627 Antonio Rodríguez Mosquera, rendero de la ferrería de Quiroga, arrendó también la de Pontepetre al contador del marquesado, don Alonso de Losada y Valdés, por una renta de cuatro quintales y medio de hierro semanales, dándole el contador 100 
Estas ferrerías utilizaban mineral de hierro de Formigueiros, que los renderos solían contratar directamente a arrieros, generalmente maragatos ${ }^{1326} \mathrm{o}$ de pueblos de los alrededores; pero en los siglos XVI y XVII también fue frecuente encontrar venaqueros vascos que trabajan directamente para la ferrería extrayendo y transportando vena ${ }^{1327}$. En ocasiones son los propios arrendatarios quienes prestan dinero a mulateros y arrieros para que adquieran caballerías con las que transportar la vena ${ }^{1328}$. Además de Formigueiros, Pontepetre utiliza el mineral del venero de Valdecaballos, que está más cerca, y que adquiere unas veces cocido, es decir, raguado y otras sin cocer ${ }^{1329}$.

Hasta comienzos del siglo XVII la ferrería, que era del directo dominio del marqués de Villafranca ${ }^{1330}$, se arrendaba, como hemos dicho, primero

ducados anuales por descalabros. Poco después este Rodríguez Mosquera la subarrendó a Álvaro Rodríguez, de Gestoso; pero quedándose con los 100 ducados, por lo que cuando dicho Álvaro la dejó estaba arruinada. En 1627, Rodríguez Mosquera la volvió a subarrendar a Sebastián Macía y a su mujer María de Losada, vecinos de Quiroga, en las mismas condiciones de la escritura original, pero cuando quiso comenzar a trabajar la ferrería aún seguía en malas condiciones y no pudo por lo que le puso una demanda (AHRG. R.A.: 18.251/93).

${ }^{1326}$ AHPL. PN.: caja 1487 (año 1566): A. Campano, vecino de Molinaferrara, se obliga con el rendero de Pontepetre a que traerá de Formigueiros, 250 quintales a precio de real y medio cada quintal.

${ }^{1327}$ Miguel de Loreaga, venaquero en la ferrería de Pontepetre, se obliga en 1629 con Jerónimo González, tesorero general del estado y marquesado de Villafranca, a pagarle 39 ducados por razón de un rocín y un macho con sus aparejos que le vendió (AHPL. PN.: caja 2969).

${ }^{1328}$ AHPL. PN.: caja 3025 (año 1651): Juan Rodríguez "rendero de la herrería de abaxo" se concierta con Bartolomé Lameyra, mulatero, en que a cambio de tres cabalgaduras con sus aparejos, que valen 58 ducados, los pagará "en trauajo de su persona y dichas cabalgaduras en la dicha herrería" duranta tres años, trayendo "bena, caruon como en lo demás necesario pagandole conforme se suele pagar a los demás arrieros que traen dichos materiales a la dicha herreria". AHPL. PN.: caja 2936 (año 1673): Bartolomé de Fava, vecino de Visuña y residente en Pontepetre "arriero en la dicha herrería" se obliga a pagar a su arrendatario, don Lucas de Acevedo, 314 rs. y medio por "raçón de otros tantos que le hiço merced de prestar antes de aora" y que pagará "en trauajo personal en la dicha herrería de Pontepetre sin que lo pueda ir a hacer a otra parte sin licencia de dicho don Lucas", hasta que los pague. (AHPL. PN.: caja 2936 (año 1674): el arriero de Arnado Francisco Jáñez se obliga con don Lucas de Acevedo a pagarle 1.129 reales que le prestó, "en trauajo de cabalgaduras, acarretos de vena con ellas y su persona"; también reconoció tener en su poder, por haberla recibido de don Lucas, una cabalgadura para hacer dicho trabajo.

${ }^{1329}$ AHPL. PN.: caja 2936 (año 1666): acuerdo entre don Lucas de Acevedo, arrendatario de Pontepetre, y los vecinos de Gestoso, Lorenzo de la Peña y Antonio de la Rivera, los cuales cocerán "ciento y cinquenta cargas de bena de las beneras de baldecauallos para consumo de dicha ferrería". AHPL. PN.: caja 2936 (año 1668): Don Lucas de Acebedo contrata con Antonio Cereijo, vecino de Gestoso, que le traerá "tres cargas de bena cruda de dar y tomar quebrada en las beneras de valdecauallos".

${ }^{1330}$ AHPL. PN.: caja 2936 (año 1668): Juan Martínez de Manterola, oficial de las herrerías y asistente al presente en la de Pontepetre "que es de su Excma. el marqués de Villafranca mi señor”; AHN. Estado: leg. 1739, n 16: En 1694 Francisco García de las LLanas arrendatario de Pontepetre, ferrería "propia del marqués de Villafranca". 
anualmente, más tarde por largos periodos de tiempo, como ocurre con don Lucas de Acevedo de la Cueva, vecino y regidor perpetuo de Ponferrada, quien fue rendero al menos desde 1666 hasta $1674^{1331}$; pues posteriormente accedió al cargo de Contador Mayor y juez ordinario de rentas del marquesado de Villafranca ${ }^{1332}$. Como arrendatarios, estos renderos adquirían la vena, contrataban a los oficiales de la ferrería, vendían el hierro que producían a herreros y comerciantes; pero las obras de reparación más importantes eran competencia de los Contadores Mayores del marquesado, que a su vez estaban encargados de arrendar las ferrerías del marqués ${ }^{1333}$.

A finales del siglo XVII era arrendatario Francisco García de las Llanas, natural de Anguiano, en La Rioja, personaje que vino al Bierzo como tesorero de alcabalas reales de Ponferrada y su partido, donde ya lo encontramos en 16591334. En 1694 arrendó por seis años la ferrería de Pontepetre, y en ese mismo año don Pedro de Ulloa, dueño de la ferrería de Bueyes, le da permiso para que pueda transportar, por el camino de Faro, toda la vena que necesite de Formigueiros a la ferrería de Pontepetre, desde Santiago (25 de julio) hasta Nuestra Señora de septiembre ( 8 de septiembre) ${ }^{1335}$, aunque dos años después se enzarzarían ambos en un pleito por la limpieza del camino, que se saldaría

${ }^{1331}$ AHPL. PN.: caja 2936 (año 1666): Poder de Lucas de Acevedo de la Cueva, "asistente al presente en la herrería de auajo, de que soy arrendatario", a su hijo don Bernardo de Acevedo de la Cueva; y AHPL. PN.: caja 2936 (año 1674): Felix Aminondo, arota, se concierta en el pago de algunas deudas con don Lucas de Acevedo de la Cueva, arrendatario de Pontepetre.

${ }_{1332}$ AHPL. PN.: caja 3104: Contrato, hecho en 1679, entre Alonso de Ocampo y Balboa, escribano de la merindad de Aguiar y arrendatario de la herrería de Pontepetre, con intervención de don Lucas de Acevedo, contador mayor y juez ordinario de rentas del marquesado de Villafranca, con Pedro de Alza, maestro de barquines, para hacer "los barquines nuebos" de esta ferrería.

1333 AHPL. PN.: caja 2126 (año 1634) Gerónimo González, tesorero general de estado de Villafranca, en nombre del marqués, se concierta con Juanes de Zauregui para que antes del día de Pascua "aya de azer y dar echos y acabados unos barquines grandes de la fragua major de la herrería de Pontepetre”. AHPL. PN.: caja 2936 (año 1668) Juan Ferreiro, carpintero de las herrerías, se concierta con don Antonio de Valencia Diéguez, contador del estado de Villafranca "la obra y adreço del uanzado de la herrería de avajo", de la que es arrendatario don Lucas de Acevedo, en precio de 50 ducados y 6 cuartales de centeno. AHPL. PN.: caja 3104 (año 1679): Alonso de Ocampo y Balboa, arrendatario de Pontepetre, con la intervención de don Lucas de Acevedo, contador mayor y juez ordinario de rentas del marquesado contrata con Pedro de Alça, maestro barquinero, "la fábrica de los barquines nuebos" de dicha ferrería.

1334 FERNÁNDEZ VÁZQUEZ, V. (2011): Ponferra. Artística y monumental. Ponferrada, p. 486: dice el autor que vino hacia 1670 pero ya aparece como testigo en Villfranca del Bierzo en 1659. En Ponferra se casará con doña Teresa Gamarra y Rosón en 1679 y en 1697 compra el oficio de regidor perpetuo de esa villa.

1335 AHN. Estado: leg. 1739, nº 16. 
pagando a los campesinos que lo habían limpiado cierta cantidad de dinero ${ }^{1336}$. Ese año de 1694 fue el primero de un contrato de arrendamiento por seis años, que poco después se convertiría en foro perpetuo ${ }^{1337}$.

El foro, como ocurrió con las ferrerías de Arnado y Valcarce, se debió a las dificultades económicas de los marqueses. Lo hizo don José Fadrique de Toledo a favor de don Francisco García de las Llanas el 10 de agosto de 1706 por 12.000 reales en una sola vez y 600 reales de renta anual perpetua, con las condiciones generales en este tipo de contratos: traerla reparada y en buen funcionamiento, etc. En el documento de foro se deslinda el territorio anejo a la ferrería con sus montes, aguas y derechos, y se hace inventario ${ }^{1338}$. Parece, por un pleito posterior, que la ferrería no estaba en muy buenas condiciones, por lo que García de las Llanas hubo de gastar diez u once mil ducados "además de 6.0oo rs. que pudo gastar en la reedificación de las dos casillas arruinadas de cocina y caballerizas" ${ }^{1339}$.

La ferrería fue vinculada al mayorazgo que fundó su hijo Esteban en 1718, como recoge una escritura de 1745, que señala cómo "Don Manuel García de las LLanas (es) lexitimo dueño y poseedor de la herrería de Ponte Petre afecta al vinculo y mayorazgo que fundó don Esteban García de las Llanas su abuelo, vecino y rexidor de dicha villa (de Ponferrada)" ${ }^{340}$. Este Esteban García de las LLanas como propietario de la ferrería, la arrendó en 1722 a don Francisco Muro, cuya familia la disfrutaría hasta 1744, primero el mencionado Francisco, y luego su viuda, doña Angeles Martínez de Torres, con su hija Teresa y su yerno don Joaquín Perejón ${ }^{1341}$. Al parecer la renta anual que le pagaban era de 10.500

${ }^{1336}$ AHPL. P.N.: caja 2109. Al parecer el señor de Noceda con algunos campesinos "embarazaba el aprovechamiento de bajar la vena en carros para la ferrería", con el pretexto de que ellos lo habían limpiado.

1337 AHPLU: 6701/13

${ }^{1338}$ AHPLU: 6701/13

1339 AHPLU: 6701/13

${ }^{1340}$ AHPL. PN.: caja 3342 (año 1745). El mayorazgo lo fundó en realidad Francisco García de las Llanas, que lo solicitó en 1711 aunque no lo consiguió hasta 1718 (FERNÁNDEZ VÁZQUEZ, V. (2011): Ob. cit., p. 486

${ }^{1341}$ AHPL. PN.: caja 3342 (año 1745): En las cuentas finales que hacen doña Angela Martínez de Torres con don Josep Gómez de Noboa, tutor de Manuel García de las LLanas, dueño de la ferrería de Pontepetre, se dice que su marido don Francisco Muro arrendó la ferrería a don Esteban García de las LLanas el 8 de septiembre de 1722, y que desde entonces hasta el 8 de septiembre de 1744 la tuvieron en arriendo él o su mujer. En la cuenta final la arrendataria debe 23.490 reales. 
reales $^{1342}$. Para pagar la renta o explotar la ferrería, en 1841 pidieron un censo de 12.00o rs. al cabildo de Astorga ${ }^{1343}$; pero las deudas terminaron arruinando a esta familia, que en 1858 tuvo que vender al dueño de las ferrerías de Bueyes y Valcarce su casa de Oencia y 80 propiedades más en ese lugar, Portela de Aguiar, Hornija, etc. ${ }^{1344}$.

Según el Catastro de Ensenada la ferrería, que era de don Manuel García de las Llanas y Venero, trabajaba al año 250 días, y producía, como la de Arnado, seis quintales y medio, de cinco arrobas el quintal al día ${ }^{1345}$, lo que suponía una produción anual de 1625 quintales o 93.437 kilos, cifra semejante a la que, años más tarde, ofrecerán Cornide ${ }^{1346}$ y Datoli1347. Sin embargo, este último dice que si bien la ferrería tiene agua abundante todo el año, sólo funcionaba ocho meses por falta de carbones, y "en cuanto a la leña de roble tiene la precisa para la calcinación del mineral"1348. De ahí los numerosos contratos que hacen los renderos con los vecinos de los alrededores ${ }^{1349}$. No faltan incluso los pleitos por carbonear o cortar leña ${ }^{1350}$, que aún escaseará más, anuncia Datoli “construida que sea la que intenta hacer el marqués de Villafranca" ${ }^{1351}$; se refiere, como ya hemos visto anteriormente, a la ferrería de Villarrubín, que no se llegaría a construir hasta medio siglo más tarde.

\footnotetext{
${ }_{1342}$ AHPL. PN.: caja 3342 (año 1745) Cuentas de la ferrería: "Yten se la hace cargo de cinco mil doscientos y cinquenta reales que importa la renta de el medio año que cumplió en ocho de septiembre de dicho año de cuarenta y cuatro". Si la renta de medio año eran 5.250 rs. la renta anual eran 10.500 rs.

1343 AHPL. P.N.: 3341

1344 AHPLU: 6709/9

1345 CATASTRO DE ENSENADA: R. G., libro de Oencia.

1346 CORNIDE SAAVEDRA, J.: Noticia de las ferrerías de Galicia (Manuscrito). Real Academia de la Historia. Dice que produce anualmente 1500 quintales

1347 BALBOA DE PAZ, J. A. (1992): El Bierzo en la obra de dos militares del siglo XVIII: Datoli y Munárriz, p. 56. Dice que las ferrerías del Bierzo producen cada una al año de 1000 a 1200 quintales de 5 arrobas.

1348 IBIDEM, p. 58

1349 AHPL. PN.: caja 3341 (año 1733): El concejo de Sobrado vende "por una vez un poco de cepa de urz de los montes de Sobrado" a doña Angela Martínez de Torres, arrendataria de Pontepetre. AHPL.PN., 3340 (1760) El concejo de Portela de Aguiar se oblica a pagar a don Gregorio Martínez Delgado, administrador de Pontepetre, hasta la cantidad de 450 rs. vn. "en arranca de cepo urcedal"

${ }^{1350}$ AHPL. PN.: caja 3301 (año 1752): Pleito de doña Teresa de Sossa y Castro con don José Gómez Noboa, como curador de don Manuel de las LLanas, por "introducirse por si y otras personas en su nombre en la cultura de los montes Luzenales y que se alternan de veinte en veinte años o de treinta en treinta años apropiándose de la cepa y leña que producen y se allan en los terminos de Aguiar apropiando todo para la ofizina de herrería que dicho menor tiene en el sitio de Pontepetre termino del lugar de Oencia, quando son pribativos, así dichos montes como los otros que aconstumbran a labrar los vecinos de los lugares de dicha merindad..."

${ }^{1351}$ BALBOA DE PAZ, J. A. (1992): Ob. cit., p. 58
} 
Hacia la década del sesenta del siglo XVIII, el marqués de Villafranca, don Antonio Álvarez de Toledo y Osorio, amparándose en que "para otorgar ambas escrituras de foro (se refiere a las de las ferrerías de Pontepetre y Valcarce) no se sacó facultad real, intentó reintegrarse en ellas". Puso por ello demanda, pero aconsejado por sus abogados de los enormes gastos que eso le supondría, acordó mantener los foros “de ambas perpetuamente". Para ello, solicitó al rey que su Real Consejo de Cámara, después de explicarle los antecedentes, concediese "su Real facultad para reualidar dichas dos escrituras de foro", lo que así se hizo con fecha de 24 de agosto de $1762^{1352}$. En el caso de la de Valcarce, sus foreros debieron pagar al marqués una importante cantidad. Desconozco si eso mismo ocurrió con la de Pontepetre aunque creo que si, aunque no consta documentalmente ${ }^{1353}$. Desde entonces hasta su desaparición, la ferrería se mantuvo en manos de la familia García de las Llanas y herederos ${ }^{1354}$.

A comienzos del siglo XIX, tras la muerte sin herederos directos del nieto de Manuel, don Angel García de las Llanas en 1800, la ferrería pasó a manos de los descendientes de una tía de aquél, doña Josefa García de las Llanas, que se había casado en 1729 con don Jerónimo de Quiñones, de Villalpando. Estos descendientes fueron los hermanos don Antonio y doña Petra Quiñones. En 1806 doña Ignacia Alfaya, viuda de don Angel Crespo García ${ }^{1355}$, vecino de Oencia, pretende que la Chancillería de Valladolid dé por nulo el arriendo de la ferrería que, en 14 de octubre de 1804, había hecho don Antonio Quiñones, su dueño, a don Diego Antonio Ovalle, vecino de Ponferrada; pues dos días antes, Juan de San Pedro, mayordomo del citado don Antonio, y con poder general de éste, se la había arrendado a su marido ${ }^{1356}$.

\footnotetext{
1352 AHPLU: 6701/13

1353 En el foro de 1706 se paga de renta 600 rs./año, pero sabemos que posteriormente, al menos en 1876 (AHPL. P.N.: 9137) esa cantidad era de 1.100 reales, por lo que probablemente fue estipulada en el acuerdo de 1763 .

${ }_{1354}$ AHN. Estado: leg. 1739, $\mathrm{n}^{\mathrm{o}}$ 16: en 1791, en el pleito por el mineral de Formigueiros, se menciona a Manuel García de las Llanas y Venero, caballero profeso de la militar orden de Alcántara, capitán del Regimiento Provincial de León, regidor perpetuo de la villa de Ponferrada, como dueño "en el útil de la ferrería de Pontepetre".

1355 Este don Angel Crespo aparece como administrador de la ferrería de Pontepetre en 1797 (AHPL. PN.: caja 3329)

${ }^{1356}$ AHPL. PN.: caja 3576 (año 1806)
} 
Ignoro la sentencia del mencionado juicio, pero debió ser favorable a don Antonio Quiñones y Diego Ovalle, pues éste o su familia fueron arrendatarios de Pontepetre desde principios del siglo XIX hasta por lo menos el año 18161357. A partir de entonces, se hará cargo del arriendo de la ferrería el ponferradino Nemesio Fernández ${ }^{1358}$ hasta $1824{ }^{1359}$ y, probablemente, hasta más tarde, aunque no puedo precisarlo. Este industrial inicia por entonces la construcción de sus propias ferrerías, como la de Serviz ya en 1824 y posteriormente las de La Portela, Corporales y Llamas, además de comprar la de Linares.

Cuando en septiembre de 1851 muere don Antonio Quiñones, que estuvo casado con la hermana del magistrado y senador Pascual Fernández Baeza, heredarán la ferrería sus hijos, así como la hija de su hermana Petra. La ferrería estaba dividida en treinta partes, de las que 19 pertenecían a don Antonio y 11 a doña Petra ${ }^{1360}$. Las 19 partes de don Antonio se dividieron entre sus hijos: Adriano, Manuela, Dorotea, Justina, Gabriela, Josefa y Ana; las otras 11 pasaron a Aquilina Aláiz Quiñones, hija de doña Petra. En 1864, Adriano Quiñones compró a su cuñado Manuel Valcarce Ibarrola una septima parte de las

\footnotetext{
1357 Diego de Ovalle era arrendatario en 1801, y probablemente antes. En aquel año, como arrendatario de Pontepetre, pleitea con el procurador del común de Sobredo por la construcción de una carbonera para que los vecinos lleven el carbón y no tengan que hacerlo en la ferrería distante una legua (AHPL. P.N.: caja 3620); lo seguía siendo en 1804 (AHPLU: 2454/3). Diego de Ovalle murió antes de 1809, en 1815 falleció también su viuda, y al año siguiente, sus hijos llegaron a un acuerdo sobre los bienes de la herencia, por el que don Ramón Ovalle, uno de ellos, se quedó con "todos los vienes y efectos muebles y raices de los precitados sus difuntos padres", a cambio de abonar a sus hermanos León y José 60.00o reales a cada uno y 21.000 reales a su cuñado José A. Fuentes por su mujer (ARCHIVO DE LA FAMILIA LLANO y OVALLE DE VILLAFRANCA).

${ }^{1358}$ En el reparto de bienes de Diego Ovalle y su esposa, de 1816, se dice que don Ramón Ovalle paga a su hermano don José 60.000 reales, de los cuales 26.000 en un vale otorgado a favor de don Ramón por don Nemesio Fernández, vecino de Ponferrada. Probablemente ya entonces tenía arrendada dicha ferrería.

1359 AHPL. PN.: caja 3576 (año 1821): José Vide, colector de la contribución de Oencia, dice en febrero de 1821 "Que en la Audiencia del sr. juez de primera ynstancia de este partido está siguiendo expediente executivo contra D. Nemesio Fernández arrendatario de la herrería de Pontepetre, sobre que pague la contribución por si y dueño del artefacto según se le ha repartido"; cosa que al parecer no hace, utilizando ardides y subterfugios, como declarará el mismo José Vide en otro escrito de julio de ese mismo año. AHPL. PN.: caja 3577 (año 1824): Los vecinos de Oencia dan su poder a don Ramón Ovalle para que cobre a don Nemesio Fernández, arrendatario de Pontepetre, y a don Valentín Curiel, arrendatario de Arnado, lo que deben por contribución.

${ }_{1360}$ AHPL. PN.: caja 9123 (año 1879). Al parecer en 1845 ambos hermanos se repartieron todos los bienes de sus padres en Castilla y el Bierzo, decidiendo dividir la ferrería en 30 partes, 19 y 11 para cada uno.
} 
diecinueve que en 1858 éste había adquirido, a su vez, de su cuñado Antonio de Vega Cadórniga ${ }^{1361}$

La ferrería, gravada con el foro al marqués de Villafranca y con el de la vena de Formigueiros ${ }^{1362}$, fue arrendada en 1864 a Juan Manuel Alonso Martínez, propietario de la ferrería de San Vicente de Leira, y a Antonio Nuñez Martínez, vecino de Portela de Valdeorras, por 4 años. Éstos han de pagar, además de los mencionados foros, 15.000 reales de renta el primer año y 17.500 reales cada uno de los otros tres restantes, con las condiciones habituales en estos arriendos ${ }^{1363}$. Al acabar el arriendo, que debió prolongarse dos años más, sus dueños la volvieron a alquilar en 1870 a Jacinto Fariñas, propietario de la de Lusío, por dos años y renta anual de 7.000 reales ${ }^{1364}$.

En 1876, los Quiñones negocian la venta de la ferrería de Pontepetre a Rosendo Díaz Ron, vecino de la Puebla de Burón, quien está dispuesto a pagar, sin éxito, 168.000 reales, en ocho años ${ }^{1365}$. Tres años más tarde, cuando Jacinto García Fariñas adquiera la parte correspondiente a Ricardo Vallina, nieto de Antonio Quiñones, la valoración total de la ferrería no alcanza los 90.000 reales ${ }^{1366}$, signo de la decadencia de estas fábricas. Aún debió de trabajar algunos años más, probablemente hasta los años noventa.

ESTADO: En los años ochenta del siglo XX aún se conservaba la capilla del grandioso complejo de esta ferrería; poco después, se convirtió en la planta baja de una vivienda construida sobre ella. No hay más.

\footnotetext{
${ }_{1361}$ AHPL. PN.: caja 2729 (año 1864).

${ }^{1362}$ AHPL. PN.: caja 9137 (año 1876): la ferrería pagaba anualmente 1.100 rs. al marqués de Villafranca, 150 rs. de foro de vena y 1.575 rs. de pensión a los patronos de la obra pía de Mazariegos. Esta pensión fue creada por don Manuel García de las LLanas sobre sus bienes de mayorazgo, pero don Antonio Quiñones y su cuñado don Pedro Aláiz decidieron que lo fuera sobre la ferrrería de Pontepetre.

1363 AHPL. PN.: caja 2729 (año 1864).

1364 AHPL. PN.: caja 9114 (año 1870).

1365 AHPL. PN.: caja 9137 (año 1876): acuerdan que el primer año pagará 30.0oo reales, los seis siguientes 20.000 rs. cada año, y el octavo, 8.000 reales., además de los foros al marqués (1.100 rs.), de la vena (150 rs.) y de la obra pía de Mazariegos (1.575 rs.).

${ }_{1366}$ AHPL. PN.: caja 9123 (año 1879): Don Isidro Rueda, apoderado de Ricardo Vallinas y Quiñones, capitán de Artillería, vende a Jacinto García Fariñas, diputado provincial, su parte en la fábrica de hierro, cuyo valor total es de 90.000 reales, por lo que cada una de las partes vale 3.000 reales. Ricardo Vallinas posee casi tres, por lo que las vende por 8821 reales.
} 


\section{FERRERÍAS DE RÍO CABO}

LUGAR: Arnado

AYUNTAMIENTO: Oencia

RÍO: Río Cabo

COORDENADAS: $42^{\circ} 31^{\prime} 9^{\prime \prime}$ N. y $7^{\circ} 1^{\prime} 52^{\prime \prime} \mathrm{W}$.

A la altura de Arnado desemboca en el Selmo un pequeño riachuelo que desciende de las faldas del Montouto, al que las fuentes denominan con diversos nombres: río Oscuro, Rebolo o río Cabo'1367. En sus márgenes se construyeron dos ferrerías "regateras" 1368 , una al lado de la otra, en un paraje solitario, a una hora de distancia caminando desde el pueblo de Arnado, siguiendo un camino empedrado a veces, a tramos construido sobre la roca que serpentea en las sinuosidades de su curso, en el que los carros han dejado impresos los relejes de sus ruedas.

La primera de las ferrerías se encuentra en la margen derecha del río, al otro lado del camino, entre el follaje y la maleza que la oculta a la vista. Pese a la humedad y las pésimas condiciones, conserva parte de su estructura, en la que se incluyen el banzadillo, la fragua y carboneras. La segunda se sitúa unos cien metros más arriba, en el camino que hemos seguido desde Arnado, y que al ampliarlo la ha destruido en parte, aunque se conservan varios de sus viejos muros. En un inventario de 1838 se las menciona como ferrerías de "arriba" también "ferrería primitiva"- y de "abajo"1369.

Sus orígenes, al menos el de la primera construida, se remontan al 4 de marzo de 1823 en que el concejo de Arnado, en cuya jurisdicción se encuentran,

${ }^{1367}$ La documentación habla casi siempre de Herrerías de Río Cabo. MADOZ, P.: Ob. cit., p. 254, menciona el río Obscuro, del que dice que "nace en las fuentes del Rebollo -de ahí el otro nombre de este río- y Abedul en el monte de Valdepolcas (sic); corre hacia Arnado, por donde se une al Selmo, fertilizando en su marcha alguna pradería e impulsando las máquinas de dos herrerías llamadas de Rebollo o Río Obscuro".

${ }^{1368}$ GARCÍA TATO, I. (2000): "Las ferrerías de Rio Cabo y Pombriego en el siglo XIX". Rev. Bierzo, p. 163. Así las considera Apolinar Suárez de Deza, su dueño, en el juicio con el conde de Maceda por la vena, cuyo foro reconoció para esta "fábrica regatera o que funciona la tercera parte del año por faltarle agua ocho meses".

${ }_{1369}$ IBIDEM, apéndice 13. 
subafora a Pedro García de Peñafiel, vecino de Carballal de Vila (Valdeorras), como apoderado de su tío don Estanislao de Peñafiel, vecino de Bergondo (La Coruña), la campa de Valdeporcas y Airas do Caurel, para que en ellas pueda construir "una nueva fábrica de fierro, capilla, casa para vivir, cuadras, carboneras tinglados y demás edificios accesorios a una herrería que se ha de hacer". También le dan en foro "la regalía de las aguas con el derecho, uso y aprovechamiento para siempre de cortar y arrancar cuando y como le combenga al aceztante y los suyos toda leña, urz negral y demás maderas" tanto para construir la ferrería como para sostenerla y conservarla ${ }^{1370}$.

Se lo dan todo bajo ciertas condiciones: no tener ganado mayor ni menor, excepto caballerías y cerdos; no arrancar urz blanca, utilizar el agua del río sólo para las ferrerías, etc. Como renta deberá pagar trece fanegas de centeno, que es lo que el concejo contribuye al marqués de Villafranca en concepto de foro, más 300 reales de vellón en dinero para dicho concejo; y en caso de que los arrendatarios redimiesen el foro al marqués pagarán al concejo, además de los 300 reales ya mencionados, otros 400 más ${ }^{1371}$. Entre los fiadores aparece Santiago Montero, vecino de Santalla de Lóuzara, posterior copropietario de las ferrerías de Valincarro y San Vitul, que debió ser poco después su primer arrendatario.

El 24 de marzo de 1824 Estanislao Peñafiel, curador y administrador de Apolinar Suárez de Deza, señor de Bóveda, cede a éste, por alcance de 170.000 reales en las cuentas de la curadoría, al parecer gastados en la construcción de una ferrería en Vegas de Camba, en tierra del Bolo, esta ferrería de Camba y los derechos cedidos por los vecinos de Arnado para construir otra en Río Cabo ${ }^{1372}$. Conociendo el interés de aquella familia por la ferrerías (era dueño de las de

${ }^{1370}$ IBIDEM, apéndice 6

${ }^{1371}$ IBIEM, apéndice 6

${ }^{1372}$ IBIDEM, apéndice 7. En Bergondo, a 20 de febrero de 1824 ante el escribano, don Apolinar Suárez de Deza y don Estanislao Peñafiel, su curador, "dijeron que resultando de alcanze en las quentas de dicha curadoría ciento setenta mil reales vellón a favor de dicho señor, los cuales había ymbertido dicho curador en la fábrica de la Errería de Begas de Camba, no pudiendo pagarle en metálico, estaban convenidos en la manera siguiente, a saber: el referido don Estanislao cede y traspasa en pago de dicha cantidad el dominio pleno de dicha fábrica con sus derechos de montes, aguas y más regalías para que dicho señor don Apolinar la disfrute como suia propia (...) cede tanvién el referido Peñafiel y dicho don Apolinar acepta el derecho que le han dado los vecinos de Arnado, para hacer una Erraria en el término de Rio Cauo, la qual está por acabarse" 
Lousadela y una parte de las de Valdomir y Ferreirós), es posible que Estanislao Peñafiel no sea más que un testaferro de Suárez de Deza y que las hubiera construido por encargo de aquél. Por entonces esta última ferrería estaba ya en construcción, pues el documento del acuerdo firmado entre ambos dice de la de Río Cabo que "está por acabarse, por haver sido denunciada y le cede dicho derecho con todo lo fabricado" 1373 .

La construcción de esta ferrería, como ocurrirá unos años después también con la de Valincarro, sería denunciada por Francisco Javier Argumosa, propietario de la de Arnado; pues se consideraba perjudicado en las aguas, pese a que ésta se situaba en el Selmo, aguas abajo, pero sobre todo por el uso de los montes. Los Argumosa alegaban que los montes de los alrededores, en la vertiente norte del Montouto, estaban comprendidos en el foro de la ferrería de Arnado, mientras que los vecinos consideraban que tanto los montes y tierras de Arnado, por foro inmemorial, como el prado del Abedul y el monte del valle de Río Cabo, con sus demarcaciones, aguas y montes se los había aforado al concejo de Arnado el marqués de Villafranca en 1797 en sendos documentos; este último, por la renta de seis fanegas de centeno ${ }^{1374 .}$

Pese a la denuncia, esta primera ferrería debió terminarse antes de 1825, pues en ese año la adquirió el belga Nicolás Maximiliano Lesoinne "fabricante de armas de guerra y lujo, vecino de Lieja", como se deduce de un escrito, en francés, de 16 de diciembre de 1826, por el que manifiesta haber comprado todos los edificios que Estanislao Peñafiel había construido junto al río Cabo, en el pueblo de Arnado, jurisdicción de Cabarcos, en el reino de Galicia (sic), con todos los derechos de aguas y montes cedidos por los vecinos de Arnado, por precio de 15.00o florines de los Países Bajos, que, aunque figuran como precio de venta, aún no habían sido pagados ${ }^{1375}$.

\footnotetext{
1373 IBIDEM, apéndice 7, p. 113

${ }_{1374}$ IBIDEM, apéndice 5, p. 109. Se trata de una copia de una escritura de foro otorgada por D. Sebastián Villegas, administrador general del estado y marquesado de Villafranca, a favor de D. José González, presbítero, Juan do Bao y José García, apoderados del concejo de Arnado, que comprende el prado que llaman de Avedul y monte del valle de Río Cabo, con sus montes, aguas, etc.

1375 IBIDEM, ap. 8, p. 113. "Je soussigne declare que la vente qui $m$ 'a étè fait en le quinze decembre courant pardevant le notaire Parmentier de cette ville par monsieur Stanislas Peñafiel de touts les édifices que ce dernier a batit dans la commune d'Arnado à l'endroit nommé Rio Cabo, jurisdiction de Cabarcos, royaunnne de Galice ensamble des terreins en
} 
Esta compra de la ferrería de Río Cabo se produce antes de que Nicolás Maximilien Lesoinne y su hermano Adolphe, con los que contacta el gobierno español en 1828 como inversores privados para crear fundiciones a la inglesa en nuestro país, pensaran en Asturias como lugar adecuado para levantar una fábrica de hierro al contar esta región con abundante carbón y fácil suministro

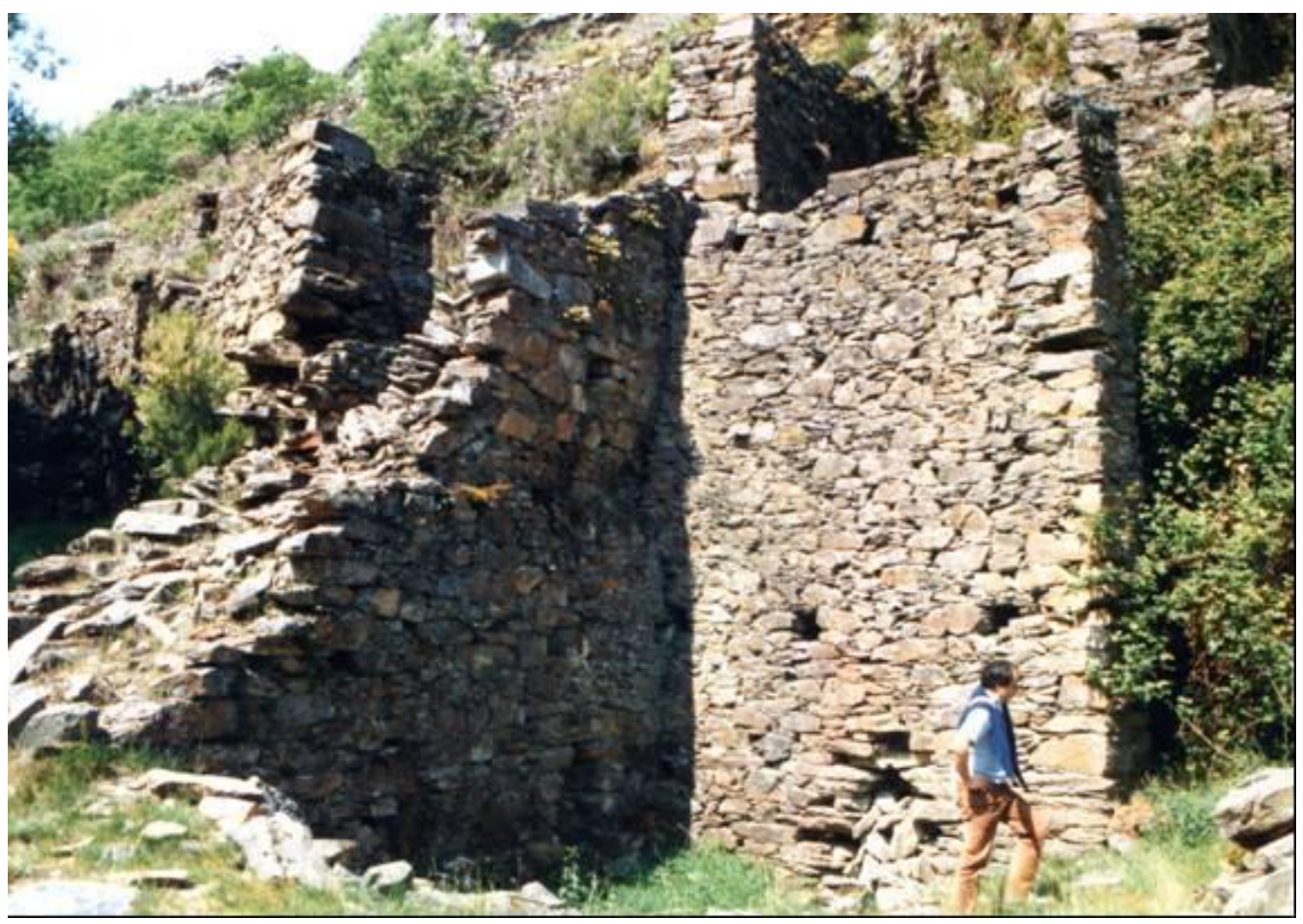

Ríocabo: ruinas de la ferrería de Arriba

dépendant ainsi que de droits sur les eaus et forets qu'il a acquis de la commune et des Bougeois d'Arnado es de ma part un act de complasaisement fait à la requisition du dit Monsieur Peñafiel et que les quinze mille florins des Pays Bas qui y sont mentionnés como prix de la vent $n$ 'ont jamais étès payés por moi”. SCHULTZ, G. (1838): Ob. cit., p. 383 menciona a un Lesoinne, que debe ser este mismo, como uno de los que en Asturias explotaban minas de carbón "conforme a las reglas del arte" en torno a 1834. 


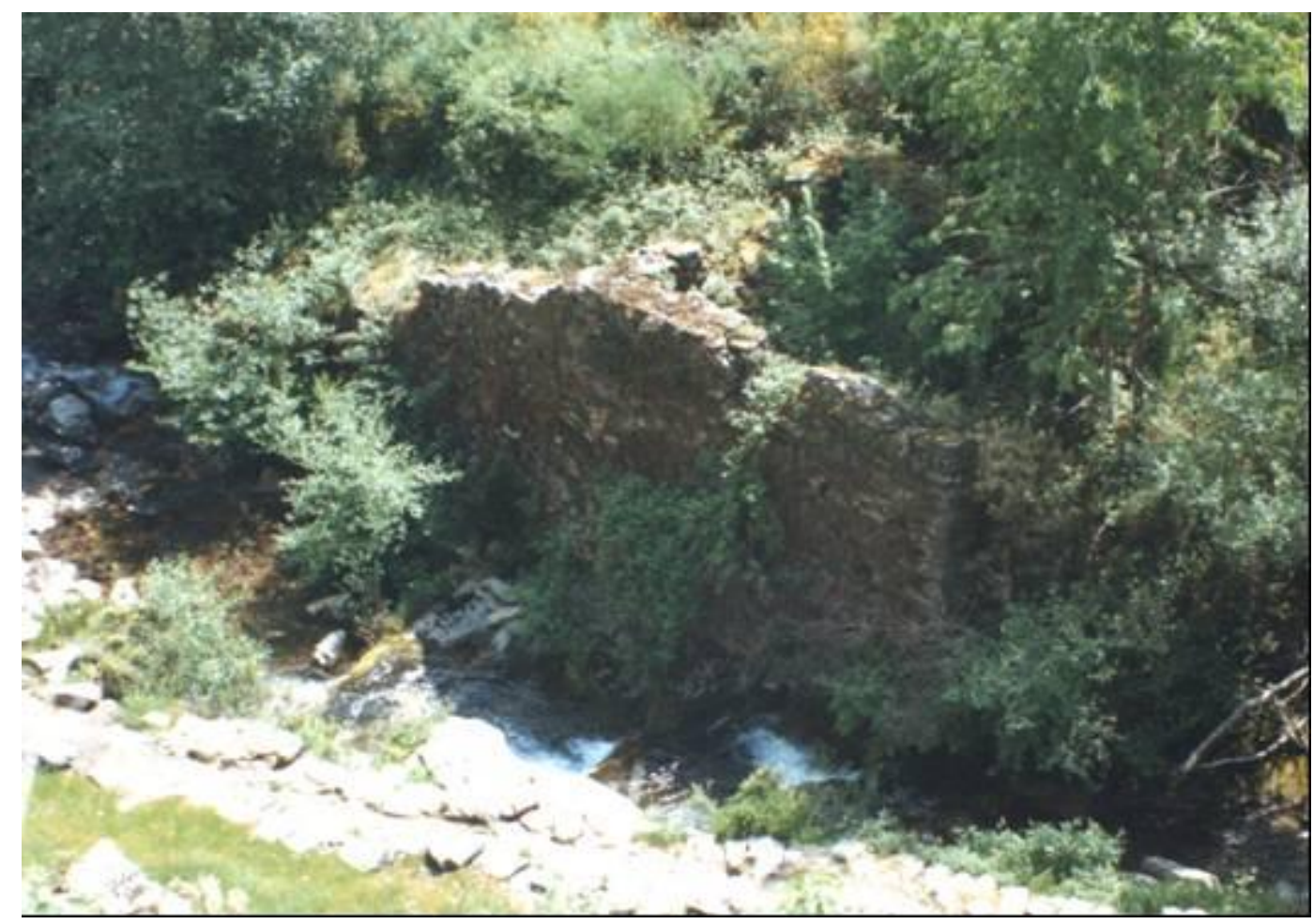

Ríocabo: ruinas de la ferrería de Abajo

de mineral de Somorrostro. Pese a las facilidades que se les dieron en la creación de la Real Compañía Asturiana de Minas de Carbón en 1834, el proyectó fracasó, por lo que la familia Lesoinne decidió reorientar posteriormente su actividad hacia la explotación del plomo y el cinc, lo que hizo a partir de 1849. Incluso un nieto de Nicolás Maximilien, el ingeniero de minas Jules Hauzeur participaría activamente en la explotación de yacimientos de calamina en Reocín (Santander) ${ }^{1376}$.

Volviendo a la ferrería de Río Cabo, nuevamente resurgieron los problemas con los Argumosa. Francisco Javier Argumosa alegaba que los terrenos donde se había construido la nueva ferrería no estaban comprendidos en el foro dado al concejo de Arnado por el marqués de Villafranca en 7 de octubre de 1797, sino en los que, también por un foro anterior, poseía en aquella zona la ferrería de Arnado. El señor Lesoinne, en 1829, después de señalar que "había comprado a don Estanislao de Peñafiel la herrería, fabricada en Rio de Cabo", y aunque

1376 R. ANES (1988): "La industrialización de Asturias en el siglo XIX: una transformación económica parcial”. En E. FERNÁNDEZ DE PINEDO y J. L.. HERNÁNDEZ (ed.): La industrialización del norte de España. Barcelona, p. 104-105. También G. SCHULTZ (1838): Ob. cit., p. 383 menciona a un Lesoinne como uno de los que en Asturias explotaban minas de carbón "conforme a las reglas del arte" en torno a 1834. 
estaba convencido de que le asistía la razón en su defensa, apodera a don Ramón de Llano y Garay, residente en Madrid, "para que transija el pleito pendiente con el referido Argumosa mediante la contribución anual de algunos quintales de hierro, según estime conveniente, que dicho señor Lesoinne o los sucesores en la herrería de Rio Cabo pagarán a los poseedores de la herrería del río Bisuña, entendiéndose sólo en los años en que elabore hierro"1377. Pero Argumosa no debió de aceptar, entablando un pleito por dichos terrenos.

El juicio se celebró en León el 18 de diciembre de 1828 con sentencia desfavorable a Lesoinne, quien tuvo que interrumpir las obras y recurrir la sentencia, que fue modificada el 21 de noviembre de 1829, también en León, lo que le permitió continuar con las obras ${ }^{1378}$. Nuevamente fue recurrida la sentencia en julio de 1830 por el señor Argumosa. Antes, en enero de ese año, Lesoinne había dado un poder a Apolinar Suárez de Deza y al apoderado de éste, Alejo García, residente en Villafranca, para que "concluyan y perfeccionen la expresada fábrica de hierro y tomen posesión de aguas, maderas y carbón de los montes, con arreglo al real decreto de quatro de julio de mil ochocientos veinte y cinco, haciendo y practicando todo cuanto estimen conveniente al interés de la fábrica"1379. Un año después, cansado de todos estos pleitos, la vende nuevamente a Suárez de Deza. La ferrería debió comenzar a fabricar hierro por entonces.

Fueron, pues, los problemas generados por el juicio con Francisco Javier Argumosa, pese a la sentencia favorable, lo que llevó al señor Lesoinne a venderla en 1831 a Estanislao Peñafiel, sin duda como apoderado de Apolinar Suárez de Deza, quien además del precio anteriormente pagado, se comprometía a abonarle también los gastos ocasionados por el pleito, que ascendieron a 5.187 reales y 23 maravedís: "vendía y vendió al expresado don Estanislao de Peñafiel los y a citados edificios, sus accesorios y pertenencias de montes y aguas por el mismo precio de quince mil florines de los Países Bajos, con indemnización de todos los gastos del proceso"1380. Decimos que Peñafiel

\footnotetext{
1377 IBIDEM, apéndice 10, p. 115

${ }^{1378}$ IBIDEM, apéndice 9, p. 114

1379 IBIDEM, apéndice, 10, p. 117

${ }^{1380}$ IBIDEM, apéndice 10, p. 118
} 
debía de ser sólo apoderado de don Apolinar, pues la ferrería siempre estuvo, desde entonces, en manos de éste y de su familia.

La segunda ferrería, la de "abajo", debió de hacerse hacia 1837, pues en mayo de 1836 los vecinos de Arnado deliberaron vender a don Santiago Montero "residente al presente en la ferrería de Río Cabo e Valdeporcas, término de este dicho pueblo, el asiento y sitio para hacer una ferrería con todos sus pertrechos al sitio que llaman fondo del Caudal, también término de este dicho lugar(...), facultándole para hacer la mencionada ferrería en aquel sitio, la qual debía andar y trabajar con la leña y carbón que estaba señalado para otra ferrería que es en la que reside dicho Montero sin variar nada para carbón y leña de lo que contiene la escritura que le habían otorgado para fabricar la primera ferrería a don Estanislao Peñafiel, curador y apoderado general de don Apolinar Suárez de Deza, guardando las condiciones que contiene"1381.

Esta ferrería se hizo igualmente con dinero de don Apolinar Suárez de Deza, pues Santiago Montero, que era arrendatario de la ferrería de "arriba" ${ }^{1382}$, era un simple testaferro: "Que mediante el señor don Apolinar Suárez de Deza Yebra y Caamaño, residente en esta villa (de Villafranca del Bierzo) le ha suministrado todo el dinero del coste de los materiales y obra que ha construido y dirigido hasta ahora de la Herrería mencionada (...) y que también le ha pagado los trescientos reales que por el dicho sitio y derecho de aprovechamiento de carbón y leña" paga a los vecinos; por esa razón "cede, renuncia y traspasa a favor de dicho señor don Apolinar, su señora esposa, hijos herederos y a quien le represente, todos los derechos, propiedad, dominio y acciones" 1383 de la mencionada ferrería.

Ambas ferrerías estaban construidas en 1838 como se deduce del inventario que en ese año hacen Jacinto Fariñas, como perito, y Santiago

\footnotetext{
${ }^{1381}$ IBIDEM, apéndice 12, p. 119

${ }^{1382}$ En un inventario de bienes de 1838, que realizan don Jacinto Fariñas y Santiago Montero, éste último aparece como "arrendatario de dichas fábricas" IBIDEM, apéndice 13, p. 121 1383 IBIDEM, apéndice 12, p. 120
} 
Montero, como arrendatario. Además de las casas, molino y una capilla ${ }^{1384}$, se detallan las partes y materiales de cada ferrería: primero la de arriba: con su chapacuña, banzado, pistones, cuerpo de la ferrería, con sus salas para el árbol de macear y el arca de aire, "en el cuerpo de la herrería y encima de la tajadera de la vena se halla colocado el dormitorio de los oficiales" y carboneras. En la ferrería de abajo poco más o menos los mismos elementos; aquí en el cuerpo de la ferrería "se halla un dormitorio para los oficiales, pisado y cerrado de tablas" y confinante con la carbonera "se halla una caseta terrena cubierta de losa con una puerta, sus bisagras y clabija de fierro en ella, que en el día se halla para el servicio de dormitorio de carboneros". En ambas llama la atención que el sistema de inyección del aire al horno se hace por medio de "arcas de aire" o trompas catalanas y no barquines ${ }^{1385}$, que por lo que sabemos habían sido introducidas poco antes en la ferrería de Montes.

Además de Santiago Montero, que debió de ser su primer arrendatario, tanto de la primera como después de ambas ferrerías, conocemos otros en los años siguientes: en la década del cuarenta debió estar Benito Olmo ${ }^{1386}$ y luego, a partir de 1849, su viuda Antonia San Miguel. El primer contrato de arriendo de esta mujer fue en abril de 1849 por cuatro años y 12.000 reales de renta anual. Siguió como rendera hasta 1857 y nuevamente arrendó las ferrerías en 1863 por varios años más. En 1857 por dos años y 11.000 reales de renta anual la tuvo Isidoro Rodríguez y luego, entre 1859 y 1863, María Ramona Martínez, que también era arrendataria de la de San Vicente de Leira, por una renta entre 5.000 y 7.000 reales, según los años ${ }^{1387}$.

Las ferrerías de Río Cabo las menciona Madoz, con los nombres del Rebolo y Río Obscuro ${ }^{1388}$. Como otras de la zona, utilizaban vena de Formigueiros, con cuyo propietario, el conde de Maceda, tuvo un largo y ruidoso pleito don Apolinar Suárez de Deza por el uso de dicha vena por sus ferrerías de Río

\footnotetext{
${ }_{1384}$ Dada la distancia a Arnado es normal la existencia de una capilla. D. Apolinar solicita al obispo de Lugo, a cuya diócesis pertenecía entonces la parroquia de Santa Eulalia de Gestoso, licencia para poder celebrar misa en ella, que el obispo, por auto de 25 de julio de 1839, concede. ${ }_{1385}$ GARCÍA TATO, I.: Ob. Cit., apéndice 13, p. 121-125

${ }^{1386}$ AHPL. PN.: caja 3581 (año 1845), y caja 3582 (años 1848 y 1849).

1387 GARCÍA TATO, I.: Ob. Cit., p. 100 y apéndices 19 a 28.

${ }_{1388}$ MADOZ, P.: Ob. cit., p. 254
} 
Cabo ${ }^{1389}$. También las cita el Nomenclator de $1867^{1390}$, por lo que probablemente mantuvieron su producción hasta las últimas décadas del siglo XIX.

ESTADO: Se conservan restos de ambas ferrerías, aunque deteriorados.

\section{FERRERÍA DE SAN VITUL}

LUGAR: Villarrubín

AYUNTAMIENTO: Oencia

RÍO: Selmo

COORDENADAS: $42^{\circ} 33^{\prime} 28^{\prime \prime}$ N. y $7^{\circ}$ o' $31^{\prime \prime} \mathrm{W}$.

San Vitul es una de las ferrerías que nombra Madoz en Villarrubín¹391, dado que aquél no es sino un barrio (anejo parroquial se dice a veces) de dicho pueblo. Se encontraba en la margen izquierda del río Selmo, aguas abajo de la de Valincarro, en la angostura del valle, entre prados y una exuberante vegetación.

La debieron hacer, poco antes de 1844, Benito del Valle y Santiago Montero, propietarios de la de Valincarro. Este último solicitó en el citado año al conde de Maceda un foro de vena, pues "antes de ahora construyó una herrería de fundir y labrar hierro en terminos de la expresada parroquia (de San Pelayo de Villarrubín) y su varrio de San Vitul, para cuya elaboración le es indispensable del mineral de la venera del monte nombrado Formigueiros"1392. Por la ubicación y fecha de la solicitud vemos que se trata de una ferrería diferente a la de Valincarro, como por otra parte reconoce Madoz. Por este foro de la vena pagará 320 reales al año1393.

${ }^{1389}$ GARCÍA TATO, I.: Ob. cit., apéndices 26 a 36.

1390 NOMENCLATOR DE LEÓN, 1867, p. 76

${ }^{1391}$ MADOZ, P.: Ob. Cit., p. 326.

${ }^{1392}$ AHPL. P.N.: caja 3581 (año 1844)

1393 GARCIA TATO, I. (2000): Ob. cit. p. 168 
Probablemente era una ferrería regatera y no un simple mazo, como a veces se la califica. En las partijas de José Castrelo, segundo marido de Pascuala González, administradores de la de Valincarro, en 1847, se dice: "debe al mismo (Pedro Rodríguez) la herencia, dos mil doscientos veinte y dos reales de las quentas del mazo de San Vitul"1394; pero si fuera un simple mazo, lo que no creo, no se explica para qué quería el foro de la vena solicitado unos años antes. Pienso que se trata más bien de una pequeña ferrería, poco más o menos como la de Valincarro, aunque probablemente transformada posteriormente en mazo. Un documento de 1850 menciona a un tal Manuel Fernández Bailarín que adeuda 1.080 reales a don Pedro Rodríguez, administrador de la ferrería de Villarrubín ${ }^{1395}$. Dado que se trata del mismo Pedro Rodríguez debe referirse a esta ferrería de San Vitul, quien probablemente era administrador en nombre de Pascuala González.

La ferrería la menciona en 1860 el Libro de Guarda Mayor de Montes; así el 1 de septiembre dice: "pasé a la herrería de San Bitul para ampliar las diligencias en el expediente instruido sobre esta fábrica" ${ }^{1396}$; y el 9 de octubre: "desde este día nos separamos (el perito y yo), y yo pasé a la Herrería de San Bitul para ampliar las diligencias en el expediente instruido sobre esta fábrica, según lo previene en su informe el sr. ingeniero"1397. En 1862 el juez de $1^{\text {a }}$ instancia de Villafranca del Bierzo habla del nombramiento de síndicos para el concurso de acreedores contra don Manuel Soto de la ferrería de San Vitul, que probablemente era su dueño ${ }^{1398}$. Igualmente la menciona el Nomenclator de $1867^{1399}$.

ESTADO: A penas son visibles sus restos, con excepción de la antigua vivienda, que está en la parte más elevada, en el mismo pueblo.

\section{FERRERÍA DE VALDELOURO}

\footnotetext{
1394 AHPL. PN.: caja 3581

1395 AHPLU: $2431 / 3$

${ }^{1396}$ LIBRO G.M.M., ff 51, $\mathrm{n}^{\circ} 192$

${ }_{1397}$ IBIDEM, p. 52 y 52v, n ${ }^{\circ} 193$.

${ }_{1398}$ BOPL., 9 de junio de 1862, $\mathrm{n}^{0}$ 69, p. 4.

1399 NOMENCLATOR DE LEÓN, 1867, p. 76
} 
LUGAR: Valdelouro (Arnadelo)

AYUNTAMIENTO: Oencia

RÍO: Valdelouro

COORDENADAS: $42^{\circ} 32^{\prime} 51^{\prime \prime}$ N. y $6^{\circ} 56^{\prime} 2^{\prime \prime} \mathrm{W}$.

En las inmediaciones de la ferrería de Arnadelo desemboca en el Selmo un pequeño arroyo que baja de la Peña del Seo, denominado Valdelouro; según Madoz, "nace en el monte Toledo, sigue su curso hacia Arnadelo, uniéndose al Selmo por junto a la herrería de aquel nombre"1400. En sus orillas todavía son visibles los restos de una pequeña ferrería regatera, cuyo acceso es extremadamente difícil pues prácticamente se ha perdido el camino, cubierto hoy por una abigarrada vegetación de matorrales y zarzas. Puede llegarse hasta ella desde el pueblo de Oencia, ya que recientemente se ha abierto una pintoresca ruta de senderismo.

La ferrería la construyó en torno al año 1835 Ramón Ovalle, natural de Villafranca y residente en Corullón. Un año antes, el 28 de septiembre de 1834, el Ayuntamiento de Oencia nombra una comisión de ocho miembros para estudiar una solicitud "que ha presentado don Ramón Ovalle, vecino del barrio de San Salvador de Corullón... para hacer una fábrica de herrería con casa y más anecso della en los montes de Baldelouro y sitio de Ruimao con las aguas de aquel sitio" 1401.

Dicha comisión, el 8 de marzo de 1835, le concede el permiso y le dan: “ derecho, permiso y facultad absoluta para construir la expresada fábrica con todo lo anexo a ella para él su mujer, hijos herederos y sucesores; y así mismo le aforan los montes y aguas del sitio de Valdelouro y Ruimao ${ }^{1402}$, en 400 reales de foro anual que empezarán a pagarse a partir del 5 de marzo de 1837 y así sucesivamente, con las siguientes condiciones: 300 ducados por la facultad de abrir caminos, de los cuales confiesan haber recibido ya 1.000 reales; puede hacer la ferrería donde más le convenga; le prohiben traer carboneros de fuera del municipio; por último, se le permite la utilización del monte para uso de la

${ }^{1400}$ MADOZ, P.: Ob. Cit., p. 285 ${ }^{1401}$ AHPL. PN.: caja 3678 (año 1834) 1402 AHPL. PN.: caja 3678 (año 1835) 
ferrería por el canon ya indicado y la posibilidad de introducir en él un rebaño de cabras que no supere la 50 cabezas ${ }^{1403}$.

El mineral también provenía de Formigueiros, por el que pagaba como foro 300 reales ${ }^{1404}$; pero en 1843 Ramón Ovalle registra una mina de hierro en Valdelouro, probablemente con la intención de utilizar dicho mineral en sus propias ferrerías ${ }^{1405}$, aunque desconocemos si realmente la explotó. En 1867 la menciona el Nomenclator de la provincia de León ${ }^{1406}$.

ESTADO: Algunos restos de muros

\section{FERRERÍA DE VALINCARRO}

LUGAR: Villarrubín

AYUNTAMIENTO: Oencia

RÍO: Selmo

COORDENADAS: $42^{\circ} 34^{\prime} 12^{\prime \prime}$ N. y $7^{\circ} 2^{\prime} 9^{\prime \prime} \mathrm{W}$.

La de Valincarro es la primera ferrería del Selmo en su tramo leonés, río que nace en la sierra del Caurel y que en el tramo gallego es conocido como Visuña. Se encontraba en la margen izquierda, a la entrada del Bierzo viniendo de la antigua encomienda de Quiroga, en el pueblo de Villarrubín, en un lugar denominado Valincarro que está en la parte de abajo del pueblo, por donde el río pasa profundamente encajado.

En el siglo XVIII hubo un intento fallido por construir en ese lugar una ferrería, como se deduce del juicio que mantuvieron don Angel Armesto y Goyanes con don Francisco Ramón de la Puebla y Velasco, en 1764. Aquél pretendía establecer una ferrería en Villarrubín, pero Francisco Ramón se oponía como dueño del directo dominio de la ferrería de Arnado, situada aguas

\footnotetext{
1403 IBIDEM

1404 GARCÍA TATO, I: $O b$. cit., p. 168. Por error del copista dice la de Portela, pero es la de Valdelouro, pues la de Portela no era de Isidoro Ovalle sino de Nemesio Fernández. 1405 BOPL.: 22 de marzo de 1843, p. 89.

${ }^{1406}$ NOMENCLATOR DE LEÓN, 1867, P. 76
} 
abajo del mismo río, pese a que el citado Armesto contaba con el permiso del concejo de aquel pueblo y con el del marqués de Villafranca, señor de la jurisdicción, a quien se comprometió a pagar de "foro y pensión anual como dueño que es del Directo Dominio" 300 ducados ${ }^{1407}$. Uno de los testigos del juicio, Miguel García, alegaba a favor de este último, que el Selmo era río de aguas abundantes, suficientes para ambas ferrerías, y que además estarían a una distancia de una legua, con varios arroyos entre ellas desaguando en el Selmo ${ }^{1408}$.

Esta oposición de los dueños de la ferrería de Arnado se reiterará de nuevo, cuando en el siglo XIX Benito del Valle intente construir otra ferrería en ese mismo lugar de Villarrubín. En noviembre de 1837 Francisco Javier Argumosa, heredero de la familia De la Pueba y dueño, por tanto, de la ferrería de Arnado, se quejaba de Benito del Valle por cortar árboles. En diciembre del mismo año, ante el juzgado de Villafranca, le acusaba su procurador de haber "cortado por el pie muchos árboles mayores para maderas y serbicio de una Herrería nueba que está construyendo dentro del alcabalatorio del repetido pueblo (de Villarrubín)"1409. Lo que quiere decir que, con permiso o sin él, este experto arrendatario, del que hemos hablado en relación con otros artefactos de la zona, estaba construyendo una ferrería.

Efectivamente, meses antes, Benito del Valle daba un poder al procurador de Villafranca, Manuel Pérez Asturias, para que lo representase en el juicio que contra él seguía Francisco Javier Argumosa, "suponiendo haberle causado violencia y despojo de posesión que dice tiene en el monte llamado Valiñafermosa y Valdevieiro, dentro del termino dezmatorio y alcabalatorio del expresado Villarrubín, con la corta de maderas que hice en dicho sitio para una Herrería que estoy construyendo en el propio término y sitio de Valincarro"1410. La ferrería, por tanto, se estaba construyendo y efectivamente se edificó. Por esa razón, el juicio prosiguió aún durante varios años; pues los dueños de la ferrería de Arnado pretendían demolerla, alegando que la de

1407 AHPL. PN.: caja 3287 (año 1764)

1408 IBIDEM

${ }^{1409}$ Archivo privado de la familia LLano y Ovalle. Pleito por la utilización de los montes de Villarrubín por las ferrerías de Arnado y otras, ff. 100.

${ }^{1410}$ IBIDEM, ff. 103 y 103v 
Valincarro no tenía maderas para abastecerse, porque los montes de Villarrubín pertenecía a la de Arnado.

Por su parte, Benito del Valle argumentaba que la de Arnado no tenía montes propios, sino que los vecinos, por foro del marqués, eran sus verdaderos propietarios, y por tanto podían vender madera y carbón a quien quisieren, o al menos, los sobrantes de la ferrería de Arnado: "La fabrica, repito, no tubo ni tiene montes propios, al menos que se sepa, prueba de ello es que tanto sus dueños como arrendatarios jamás hicieron carbón por su cuenta, y sí lo compran a los pueblos y a sus vecinos, como leña y más materias que necesitan sin impedir a aquellos este género de industria"1411. Un testigo, Domingo González, vecino de Ferramolín, de 60 años, señalaba en 1841 "que aunque en la herrería llamada de Arnado propia del D. Francisco Xavier Argumosa se consume y se consumió carbón de los terrenos expresados, solo lo es haciéndolo los vecino de Villarrubín y llevándolo a vender a dicha herrería, sin que el testigo hubiera visto ni oido jamás que por parte del Argumosa, se cortasen maderas ni carbonease en los montes citados" ${ }^{1412}$; contestación semejante a la que hacen otros muchos testigos de don Benito del Valle. Sin embargo, creo que no es cierto, pues una ferrería con tantos siglos a sus espaldas, fundada por el conde de Lemos, tenía que contar con bosques propios.

La ferrería la construyeron el mencionado Benito del Valle, vecino de Villarrubín, y el gallego Santiago Montero, de Santalla de Lóuzara, entre 1837 y 1838; pues en 1839 aquél solicitaba, como dueño de la ferrería, al conde de Maceda la concesión de un foro de vena del venero de Formigueiros, porque "con otro compañero acaba de construir un artefacto de hacer y labrar hierro en términos de este pueblo y sitio de Balincarro"1413. Lo que nos indica que ese año ya estaba terminada la ferrería. Por un dato algo posterior sabemos que ésta

\footnotetext{
${ }^{1411}$ IBIDEM, ff. 153V

1412 IBIDEM, ff. 199v

${ }_{1413}$ AHPL. P.N.: caja 3579 (año 1839). En este documento otorga su poder a Benito Olmo, vecino de las ferrerías de Río Cabo y a Francisco Gómez para que firmen en su nombre un contrato de foro sobre uso de la vena de Formigueiros con el apoderado del conde de San Román, como heredero de la condesa de Maceda, su dueño, por 320 reales anuales.
} 
pagaba al marqués de Santa María del Villar, heredero del conde de Maceda, 320 reales por el foro de la vena ${ }^{1414}$.

Este compañero, como hemos dicho, era Santiago Montero, ambos buenos conocedores de esta industria, ya por el arrendamiento anterior de otras ferrerías, ya por su parentesco con los propietarios y arrendatarios de las de Lusío, Río Cabo, Soldón y Visuña. Benito del Valle era primo político de Ignacio Fariñas, por estar casado con una hija de Francisco Pérez, propietario con su hermano José, de la ferrería lucense de Outeiro. Por tanto, un hombre conocedor del mundo del hierro; como también lo era su compañero Santiago Montero, casado con Pascuala González arrendataria de esta ferrería de Valincarro desde su construcción hasta 1849, y tío político de Benito Olmo, arrendatario igualmente de las ferrerías de Río Cabo.

Pascuala González, que enviudó en 1839, casó en segundas nupcias con José Castrelo, del que las partijas de su herencia, realizadas en 1847 cuando murió, señalan que fue "administrador (...) algunos años de esta fábrica"1415. Sus bienes, al no tener descendientes directos, pasaron a sus sobrinos José y Plácido Vilariños, naturales de Parada de Lózara, en el ayuntamiento de Samos. Por su parte, Pascuala cedía un año antes a los sobrinos de su primer marido la parte de la herencia que correspondía a éste. Entre estos sobrinos se encontraba Antonia San Miguel, casada con Benito Olmo, arrendatario de las ferrerías de Río Cabo ${ }^{1416}$.

Poco después, en 1849, la mencionada Pascuala, administradora de la ferrería de Valincarro, y Antonia San Miguel, administradora de las de Río cabo, acuerdan que como dicha “ $D^{a}$ Pasquala quedó única y unibersal heredera de dicho su marido (Santiago Montero) por no haber tenido subcesión (...), quien legó para siempre a la muerte de la $D^{a}$ Pasquala, a su carnal sobrina la Antonia San Miguel, viuda de Benito Olmo, la parte de Herrería que le corresponde en esta de Valincarro. La otorgante a testimonio del mismo escribano en 27 de marzo de 1841 también le donó la parte que en dicha

1414 GARCIA TATO, I. (2000): Ob. cit., p. 168.

1415 AHPL. PN.: caja 3581

1416 AHPL. PN.: caja 3581 
fábrica le toca, reserbando por sus días el usufructo y administración y quatro años más después de su fallecimiento, y como en la aceptación de esta última escritura, por equibocación o inorancia hai circunstancias perjudiciales a dicha Antonia, que daría lugar a pleitos, para evitarlos determinaron rebocar dicho instrumento y poniéndolo en execución en la via y forma que mejor haya lugar la $D^{a}$ Pasquala reboca dicho instrumento (...). Por el mucho afecto que siempre profesó a la Antonia San Miguel nuebamente la hace gracia y donación intervibos de la sesta parte que le corresponde en esta citada herencia de Valincarro", que todo valdrá 9.000 reales ${ }^{1417}$.

Madoz dice que en Villarrubín hay "dos fábricas de hierro que dan ocupación a la mayor parte de los habitantes"1418; una era ésta de Valincarro, la otra era la de San Vitul. Se mantuvo en funcionamiento hasta la segunda mitad del siglo XIX, en que aparece ya como derruida; aún funcionaba en $1867^{1419}$. En 1894, en la denuncia que hace Faustino de Orantes y Magallón, vecino de Visuña, de una mina de cobre en Valincarro, señala como límites de dicha denuncia: "el estribo sur de la presa que se encuentra aguas abajo de la derruida ferrería de Valincarro, sobre el río Selmo"1420.

ESTADO: No se conservan restos

\section{MUNICIPIO DE POMBRIEGO}

\section{FERRERÍA DE POMBRIEGO}

LUGAR: Pombriego

AYUNTAMIENTO: Pombriego

RÍO: Cabrera

COORDENADAS: $42^{\circ} 25^{\prime} 12^{\prime \prime}$ N. y $6^{\circ} 41^{\prime} 49^{\prime \prime} \mathrm{W}$.

Aguas abajo de la ferrería de Llamas se levantaba la de Pombriego, también en la margen derecha del río Cabrera o Ivei. Se encontraba a la entrada

\footnotetext{
1417 AHPL.PN.: caja 3582

1418 MADOZ, P. (1845-1850): Ob. cit. p. 326.

1419 NOMENCLATOR DE LEÓN, 1867, p. 76

${ }^{1420}$ BOPL.: 1894, VII, 6.
} 
del pueblo viniendo de aquella dirección, aunque actualmente no se conserva más que la vivienda convertida en un alojamiento de turismo rural.

Fue de los benedictinos de San Pedro de Montes, que años antes habían edificado otra ferrería a orillas del río Oza, en el Bierzo. Según el P. Herrezuelo su construcción se debió "a las utilidades y aumento que había tenido la casa con la fábrica de la herrería de Linares"1421. Los sustanciosos ingresos de esta ferrería animaron al abad Benito Zoube (1749-1753) a estavlecer otra en Pombriego: "se resolvió a hacer otra en el rio Ivei de la provincia de la Cabrera"1422, en un lugar en el que el monasterio poseía numerosas heredades desde época medieval ${ }^{1423}$.

La construcción de la ferrería de Pombriego plantearía al monasterio muchos problemas, más aún que la de Linares, por la denonada oposición del marqués de Villafranca, señor jurisdiccional de La Cabrera. El monasterio, como ya había ocurrido con la de Linares, hubo de recurrir a la justicia, entablándose un largo pleito que se inició el 17 de julio de 1750 y que, aunque favorable a éste, retrasó el funcionamiento de la ferrería hasta abril de 1761, cuando concluía el segundo abadiato del P. Zoube ${ }^{1424}$. El inicio de la producción de hierro se haría en el gobierno de su sucesor, el abad Genadio Fernández ${ }^{1425}$.

${ }^{1421}$ P. HERREZUELO: Historia de Montes (Manuscrito en el Archivo Diocesano de Astorga). $\mathrm{p}$ 313. 1422 IBIDEM, p. 313.

1423 DURANY, M. (1976): San Pedro de Montes, el dominio de un monasterio benedictino en el Bierzo. León.

1424 P. HERREZUELO: Ob. cit., p. 313: "Esta herrería experimentó aún más embarazos que la otra y de parte más poderosa. Opúsose luego a su construcción el marqués de Villafranca y a 17 de julio de 1750 otorgó poder para seguir el pleito con su excelencia. Venciose éste, pero retrasó tanto la fábrica que no se vió concluida ni corriente hasta abril de 1761, cuando concluía su segundo gobierno".

1425 IBIDEM, p. 315: "En su tiempo -1761-1765- se acabó de arreglar la herrería de Pombriego, y la puso en caudal. Hizo también casa para el administrador y compró algún terreno inmediato para huerta y plazas de la herrería”. 


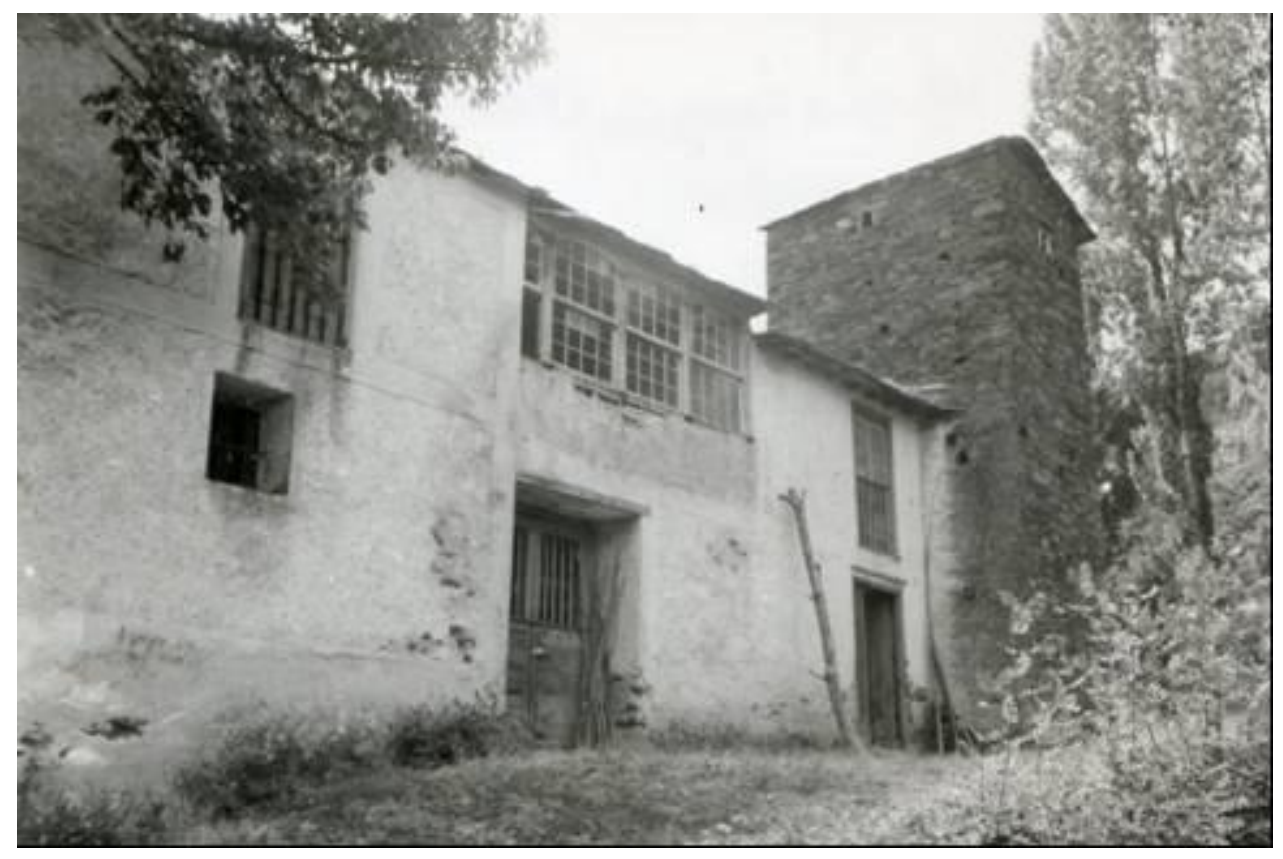

Vivienda de la ferrería de Pombriego

No están claras las razones de la oposición del marqués de Villafranca a este proyecto, ¿fueron motivos jurisdiccionales o económicos los que provocaron ésta?. En principio parecen jurisdiccionales, pues a estas alturas el marquesado prácticamente se ha desprendido de sus ferrerías, de las que obtiene una pequeña cantidad en concepto de foro; sin embargo, a fines de siglo el marquesado nuevamente parece mostrar un cierto interés en el tema herrero, como se desprende de los pleitos con los foreros de las de Arnado, Pontepetre y Valcarce, y las pretensiones por construir nuevas ferrerías en la zona de Arnadelo y Barjas. ¿Significa esta oposición que el marqués pretendía la fundación de alguna nueva ferrería en la Cabrera?. Posiblemente sí. Este interés se explica, probablemente, por el alza de los precios del hierro, lo que convertía estas instalaciones en sumamente beneficiosas.

Como la ferrería comenzó a trabajar después de la elaboración de Catastro de Ensenada desconocemos los días que trabajaba y la producción anual; pero creemos, por datos posteriores, que no diferiría mucho de la de Linares, aunque parece aún más rentable, casi el doble, a tenor de los varios estados de cuentas, que se muestran en el texto. Datoli, sin embargo, dice que escasea en 
carbones ${ }^{1426}$, y son frecuentes en la contabilidad monástica los gastos en reparaciones ${ }^{1427}$. Como la de Linares, también ésta la dirigía un "prior rendero" o administrador ${ }^{1428}$, que organiza la producción y venta, y rinde cuentas a los abades y visitadores de la orden.

Estado de Cuentas de las ferrerías de San Pedro de Montes

$$
\text { 1777-1781 1781-1785 }
$$

(en Rs.)

$\begin{array}{lcc}\text { LINARES } & 48.707 & 47.784 \\ \text { POMBRIEGO } & 85.263 . .27 & 84.562 \\ \text { TOTAL } & 133.970 . .27 & 132.346 . .15\end{array}$

Fuentes: Estado General de Cuentas ${ }^{1429}$

Con la desamortización del Trienio Liberal, la ferrería fue adquirida por don Apolinar Suárez de Deza, señor de Bóveda y vecino de Villafranca, como se deduce de un escrito de fecha posterior, en el que se señala que "en virtud de decreto de las Cortes de mil ochocientos veinte, restablecido por Real Decreto de tres de septiembre de mil ochocientos treinta y cinco, el excelentísimo señor don Apolinar Suarez de Deza y Caamaño, adquirió del Estado la herrería de Pombriego, con todos los bienes y derechos anejos a la misma, sita en el término del pueblo del mismo nombre, distrito municipal de Sigueya, hoy de Benuza, en la provincia de León, cuya herrería había pertenecido al

1426 BALBOA DE PAZ, J. A. (1992): El Bierzo en la obra de dos militares del siglo XVIII: Datoli y Munárriz, p. 58

${ }_{1427}$ P. HERREZUELO: $O b$. cit.: En el abadiato de Josef Rodríguez hubo que hacer de nuevo "la chapacuña de la herrería de Pombriego que había arrastrado el río", p. 319-320; Según el Estado de Cuentas, el abad Genadio Velasco en 1781 "hizo por tres veces la estacada de la de Pombriego"; y su anterior en el cargo, el abad Juan Páramo "en la de Pombriego desmontó la peña que caía sobre la chapacuña". En 1793-97, el abad Fulgencio Aguirre volvió a realizar costosas obras en la ferrería de Pombriego (PASCUAL ZARAGOZA, E.: abadologio del monasterio de San Pedro de Montes. Archivos Leoneses, 74, p. 336.

${ }^{1428}$ En 1789 y 1803 era administrador Fr. Martín Quintana (AHPL.PN, caja 3635); en 1824, Fray Benito Caunedo (AHPL.PN, caja 2793).

1429 ARCHIVO DE SILOS: Estado de Cuentas de la Congregación de Valladolid. 
monasterio de San Pedro de Montes, de la orden de San Benito"1430. Del texto se deduce que fue devuelta a los monjes en $1824^{1431}$. De estos años es el estado de cuentas siguiente, en que los beneficios de Pombriego no sólo aventajan de forma clara a la de Linares, como en años anteriores, sino que vemos también su disminución en los años del Trienio:

Estado de cuentas de las ferrerías de San Pedro de Montes

$\begin{array}{lcc}\text { Ferrería } & \begin{array}{c}1818-1821 \\ \text { ( Rs. Vn.) }\end{array} & \begin{array}{l}1821-1824 \\ \text { LINARES }\end{array} \\ \text { POMBRIEGO } & 35.011 & 4.288 \\ & 93.977 & 35.489\end{array}$

Fuente: Estado General de Cuentas ${ }^{1432}$

Tras la exclaustración en 1835, la ferrería pasó nuevamente a manos de Apolinar Suárez de Deza, propietario de otras ferrerías gallegas y bercianas, quien la mantuvo en arriendo hasta los años finales del siglo XIX ${ }^{1433}$. En 1894, el Boletín oficial de la provincia de León anuncia su arriendo, para lo que hay que dirigirse a don Pedro Seijo, de Madrid ${ }^{1434}$.

ESTADO: Después de la guerra civil fue en gran parte destruida por su propietario, médico en este pueblo; hoy sólo se conserva la antigua casa en que

1430 BARCIA, E. (1988): "Fray Plácido Losada y su breve noticia del monasterio de Montes", Aquiana, $\mathrm{n}^{\circ}$ 851, p. 17; GARCÍA TATO, I. (2000): Ob. cit. p. 101, dice que de este texto no se puede deducir la compra de la ferrería en 1822, sino en 1835. En mi opinión, en 1835, como ocurre con la de Linares, se devuelve a los anteriores compradores. Para confirmar esto, la Estadística Minera de 1891, p. 190-195 dice: "Esta herrería (de Pombriego) fue fundada también como la de Montes por los monjes benedictinos de San Pedro de Montes, y cuando la desamortización de los bienes del clero, en el año 1822, la adquirió del Estado D. Apolinar Suárez de Deza y Caamaño, vecino de Madrid".

${ }^{1431}$ AHPL. PN.: caja 2793 (año 1824): Se nombra ese año a Fr. Benito Caunedo como administrador de la ferrería de Pombriego. También MIÑNANO, S.: Ob. cit. t. IV, p. 136 la menciona como propia de los monjes de Montes.

1432 A. de SILOS: Estado General de Cuentas.

1433 Desde 1856, si no desde antes, y hasta 1865 por lo menos, la tuvo en arriendo Antonia San Miguel, la cual a su vez también tuvo las de Río Cabo. En 1856 presenta las cuentas del arreglo de la chapacuña, que ascedieron a 10.983 reales; en 1858 nuevos arreglos en la herrería, los chiflones, y en la venera que pagó Antonia San Miguel y que factura al dueño de la ferrería, que ascienden a 3.879, 13 reales (en GARCÍA TATO, I. (2000): Ob. cit. apéndice 18 y 21.) Desde 1872 hasta 1891 fue su arrendatario D. Paulino Arias (Estadística Minera, 1891, p. 195).

1434 BOPL.: 2, marzo, 1894. 
habitaba el prior que la administraba, convertida en casa rural, y el canal abierto en plena roca, que desde el río conducía el agua al banzao.

\section{MUNICIPIO DE PONFERRADA}

\section{FERRERÍA DE COMPLUDO}

LUGAR: Compludo

AYUNTAMIENTO: Ponferrada

RÍO: Miera

COORDENADAS: $42^{\circ} 28^{\prime} 44^{\prime \prime}$ N. y $6^{\circ} 27^{\prime} 34^{\prime \prime} \mathrm{W}$.

El pueblecito de Compludo se encuentra en uno de los valles más frondosos y recoletos de los Montes de León, muy cerca del Camino de Santiago. Desde el Acebo, una carretera desciende por empinadas cuestas hasta el fondo del valle. La ferrería se halla antes de llegar al pueblo, siguiendo un sendero que camina paralelo al curso del Miera, un pequeño afluente del Miruelos, poco antes de que ambos confluyan. El Miruelos o Meruelo es afluente del Boeza.

Pese a la leyenda sobre sus orígenes visigóticos, la de Compludo es una ferrería del siglo XIX. Ni documental ni tecnológicamente es posible datarla en época tan remota. Desde el punto de vista documental, ni el Catastro de Ensenada (1752), ni Datoli (1797), ni Munárriz (1808), ni los diccionarios de Miñano (1826) y Madoz (1845) la mencionan, signo negativo de una existencia anterior al siglo XIX ${ }^{1435}$. El teniente coronel Munárriz ${ }^{1436}$ y el P. Herrezuelo, abad de Montes ${ }^{1437}$, aportan algunas precisiones, al señalar que un tal Antonio

\footnotetext{
1435 BALBOA DE PAZ, J. A. ((1986) "Las herrerías de Montes y Compludo". Estudios Bercianos (Ponferrada), $n^{\circ} 5$.

${ }_{1436}$ BALBOA DE PAZ, J. A. (1992): Ob. cit. p. 118 : "D. Antonio Castro, vecino de Ponferrada, va a establecer una herrería al Oriente de dicha villa, en la abadía de Compludo, con un mineral que dice se halla en aquellas inmediaciones, del que no hemos visto màs que una pequeña muestra que promete muy poco".

${ }^{1437}$ P. HERREZUELO: Ob. cit.. Este Herrezuelo fue abad en varias ocasiones; en su segundo abadiato (1805-1814), mientras realizaba obras en el claustro, dice que "fue necesario atender a la solicitud de un particular de Ponferrada que quería hacer una herrería en Compludo y otra en la Texada y servirse para ello de nuestro mineral de la Chana".
} 
Castro $^{1438}$ piensa construir una ferrería en Compludo en los primeros años del siglo XIX. Sin embargo, como consecuencia de la Guerra de la Independencia y la oposición del monasterio de San Pedro de Montes, no debió llevarse a efecto, aunque probablemente sí comenzaron las obras, luego interrumpidas.

No había sólo problemas con el mineral de la Chana, como dice Herrezuelo en su Historia, sino que el propio monasterio tenía una cédula para edificar en ese lugar una ferrería; pero se le adelantó, con la connivencia del concejo de Compludo, un tal Francisco Castro ${ }^{1439}$, al que el monasterio hubo de denunciar ante la Junta Suprema de Minas y luego ante la Chancillería de Valladolid ${ }^{1440}$. El pleito interrumpió la construcción de la ferrería; tampoco se erigió tras la exclaustración.

La ferrería se debió de construir poco antes de 1860. En enero de 1856 Felipe Fernández solicitó permiso para construir una ferrería aprovechando un salto de agua, probablemente de un viejo molino, "que en terreno del recurrente y en término de Compludo" existía. Como exigían las leyes, el gobernador de León, Patricio de Azcárate, dio veinte días para que los que se considerasen afectados por tal construcción pudieran oponerse, motivando su razones ${ }^{1441}$. Debió de construirse poco después, aunque el primer documento que conozco de su funcionamiento es de $1867^{1442}$.

\footnotetext{
${ }^{1438}$ AHPL. PN.: caja 3279 (año 1781): Un tal Antonio Castro, de Ponferrada, pone en 1781 una demanda al apoderado de don Manuel García de las LLanas, propietario de la ferrería de Pontepetre. Probablemente es el mismo que quiere construir la de Compludo. En 1808 aparece un Antonio Castro, sacerdote de Ponferrada, como padrino de un Rafael Baylina (QUINTANA, A. (1987): Juana Baylina, amor y musa de Enrique Gil y Carrasco. Ponferrada, p. 36).

1439 Este Francisco Castro debe de ser un familiar del mencionado Antonio Castro.

${ }^{1440} \mathrm{El} 10$ de febrero de 1808 el abad y convento de Montes "decimos que en virtud de concesiones Reales, adquiridas por justos y legítimos títulos, este referido monasterio tiene facultad para edificar una herrería en los términos de el lugar de Compludo, que hasta ahora no ha tenido efecto su construcción porque no se le ha acomodado. $Y$ sin embargo de este derecho, por D. Francisco de Castro, vecino de la villa de Ponferrada, se ha principiado a edificar una, en perjuicio de esta comunidad, por cuyos motivos acudimos a la Junta Suprema de Minas; y ésta librò su carta-orden al señor intendente de la ciudad de León, para que convoque a las partes, a fin de que se convinieran, en dónde cada una había de edificar la suya. Y en el caso de que no se convinieran, que cada uno entablase demanda sobre su derecho ante la justicia ordinaria. Y como la justicia de Compludo se ha mostrado interesada en favor de don Francisco Castro no solo en la omisión sino informando a la suprema junta... para que cesen esos perjuicios, otorgamos nuestro poder al reverendo padre maestro, fray Agustín Sanz, procurador de nuestra sagrada religión en la Chancillerì de Valladolid, para que...”. Rodríguez Cubero, en Diario de León, 12 de diciembre de 1998.

${ }_{1441}$ BOPL., 28 de enero de 1856, no 12, p. 4

1442 NOMENCLATOR DE LEÓN, 1867, p. 38
} 


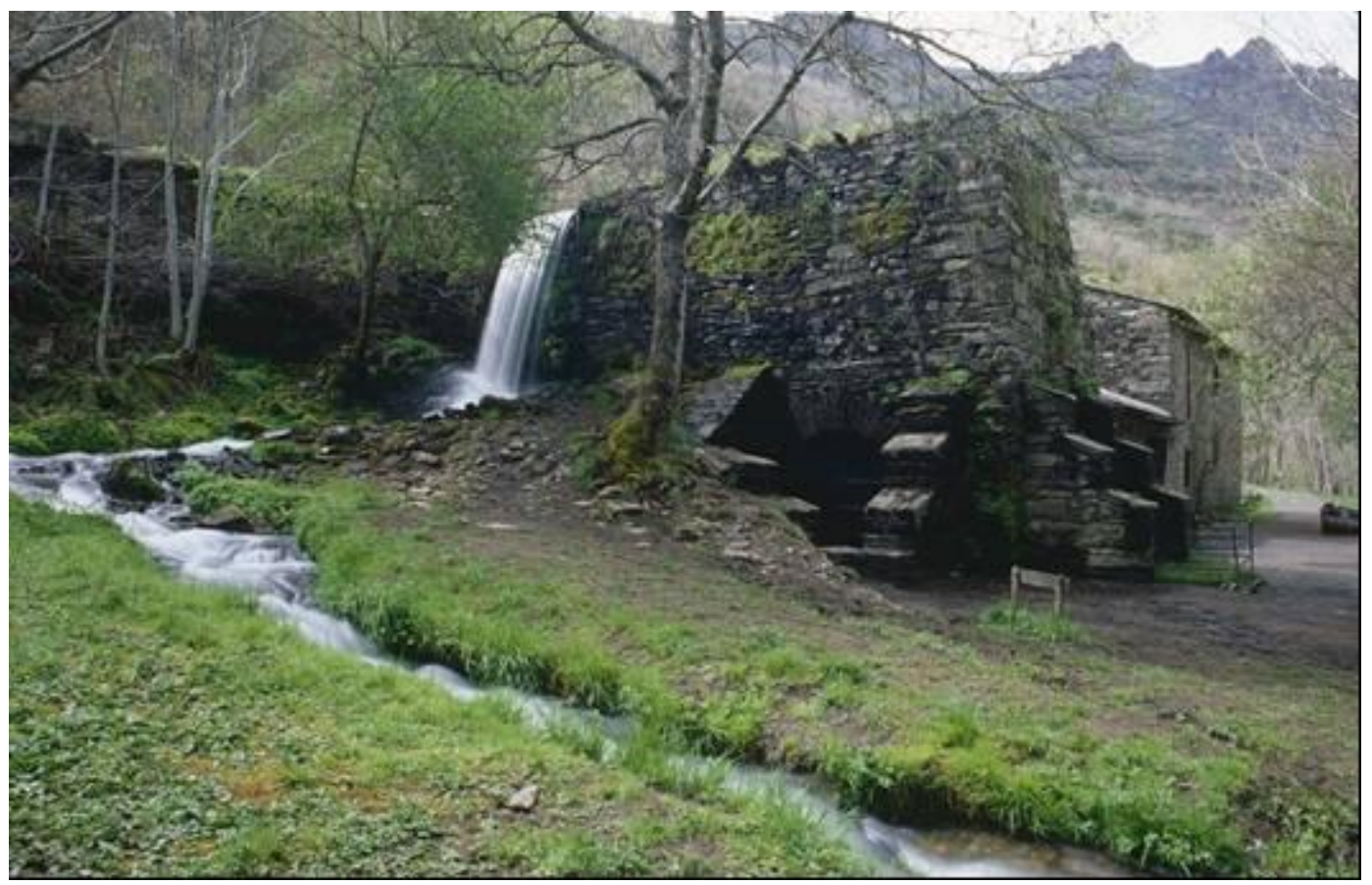

Ferrería de Compludo

Luego aparece citada con frecuencia en la Revista Minera a partir de 1880 y también en los anuarios Bailly-Bailliére de 1884 y posteriores hasta por lo menos 1924. El Nomenclator dice que es de Felipe Fernández, lo mismo que los Anuarios Bailly desde 1884 hasta $1904^{1443}$. Felipe Fernández, hijo de Nemesio Fernández, el mayor industrial ferrero del Bierzo en el siglo XIX, heredó algunas ferrerías de su padre y debió construir otras, como esta de Compludo. En 1883 José María Soler la cita junto a las de Montes, Pombriego y Llamas; en 1884, como hemos dicho, la Estadística Minera la vuelve a nombrar como una de las que trabajaron ese año, pero ya no la cita en 1889 ni en los años siguientes, en los que sí se nombra, por el contrario, a las de Montes, Llamas y Pombriego ${ }^{1444}$.

Felipe aparece como dueño en los anuarios de 1888 hasta 1904, luego la hereda su hijo Nemesio Fernández, de igual nombre que su abuelo, al que se cita

1443 Los Anuarios Bailly-Bailliére no la mencionan en 1880, 1881, 1882 ni 1883; pero si lo hacen a partir de 1884 .

1444 IBIDEM 
desde ese año hasta 1918, y en 1924 a Amadeo Sánchez1445. Probablemente entonces era un simple mazo. Gómez Núñez, en los años veinte, dice que "en esta herrería aún se conservan los artefactos y la forja catalana en disposición de trabajar. Hace dos años la visité. No beneficiaba el mineral, pero el herrero que habitaba en ella se dedicaba a comprar hierro y fabricar con él instrumentos de labor, utilizando el mazo hidráulico y la mandarria, que por cierto manejaba su mujer, único pero vigoroso auxiliar"1446. Según el P. Manjarín, en 1934 ardió la parte dedicada a vivienda, emigrando poco después sus dueños a Barcelona ${ }^{1447}$. Más tarde la adquirió el ingeniero José Rojo ${ }^{1448}$; en 1968 fue declarada BIC.

ESTADO: Se trata de la única ferrería del Bierzo restaurada con fines turísticos; es Monumento Histórico desde 1968. Lo que se conserva no es todo el complejo siderúrgico sino sólo la parte del taller de forja; pero se pueden ver el canal, banzao y bazadillo, la rueda hidráulica y el mazo, y la trompa que inyecta aire al horno.

\section{FERRERÍA DE MONTES}

LUGAR: Linares

AYUNTAMIENTO: Ponferrada

RÍO: Oza

COORDENADAS: $42^{\circ} 27^{\prime} 26^{\prime \prime}$ N. y $6^{\circ} 33^{\prime}$ o6" W.

En la margen izquierda del río Oza, que baja de los montes Aquilianos, a poco más de dos kilómetros por encima de San Clemente de Valdueza y muy cerca del inicio de un antiguo camino que aún conduce al monasterio benedictino de San Pedro de Montes, se hallan los restos de la en otro tiempo famosa ferrería de Montes, también llamada de Linares o San Juan del Tejo, por

\footnotetext{
1445 Anuario Bailly-Bailliére de los años mencionados.

1446 GÓMEZ NUÑEZ, S. (1925): El general de artillería Don Juan Manuel Munàrriz y la siderurgia del siglo XVIII en la regiòn del Bierzo". Madrid, p. 19-20.

1447 FLÒREZ MANJARÍN, F. (1964): Compludo, pueblo leonés con Historia. Ed. Eco Franciscano. Santiago de Compostela, p. 166.

1448 VIÑAYO, A. (1967): "Crónica de las Commemoraciones Leonesas del XIII Centenario de San Fructuoso”. Tierras de León, $\mathrm{n}^{\circ}$ VIII, p. 35.
} 
el pago en que se encuentra ${ }^{1449}$. La carretera a Peñalba, que pasa por el medio de la ferrería, la ha destruido en su mayor parte.

La ferrería, según el P. Herrezuelo, la construyó el abad Benito Monteagudo, que anteriormente había sido monje en Samos (monasterio gallego propietario de varias ferrerías), entre los años 1729 y 1733. Según Herrezuelo, una vez que éste hubo tomado posesión de la abadía "reconoció el terreno de las inmediaciones del monasterio; y observando su hermosa situación con la abundancia de todos los materiales necesarios para la fábrica de una herrería, se determinó a construirla casi al pie de la casa. En ocho de diciembre del mismo año de 1729 dio parte de su pensamiento a los monjes, exponiendo las utilidades que se seguirían al monasterio, como las procuraban a la casa de su profesión otras de la misma naturaleza"1450. Así lo hizo, pero no todo fueron facilidades.

El abad hubo de superar algunos obstáculos: unos con sus propios monjes, a los que tuvo que convencer de la bondad del proyecto para que le dieran "su consentimiento para que se tomase a censo el dinero necesario para su construción"1451; lo que aceptaron, permitiendo al abad tomar prestados 7.000 ducados con los que la obra pudo ser concluida en el propio abadiato del P. Monteagudo. El censo se pagaría durante los dos abadiatos de Gregorio Sánchez. En el primero (1733-1737), Herrezuelo señala que aquél encontró el monasterio muy atrasado "con motivo de la fábrica de la herrería, y el pleyto de las minas de hierro en el que gastó más de veinte y cinco mil reales. El censo de siete mil ducados atrasaba la casa y consiguió aliviarla en parte de esta carga redimiéndolo con otro que tomó a menos réditos”; en el segundo (17411745), "redimió cinco mil ducados de los siete que había tomado a censo en el anterior y lo hubiera redimido todo a no tener que atender a otros gastos indispensables"1452. También este abad "sacó una Zédula Real para hacer caminos de carro para aprovecharse de los montes de Peñalba y otros para

\footnotetext{
1449 CATASTRO DE ENSENADA: R. G. de San Pedro de Montes. Según las respuestas 1 y 17 el lugar se llamaba San Juan del Tejo y el pago La Ramosa. La mayoría de los documentos la llaman Ferrería de Linares o simplemente de Montes.

${ }^{1450}$ P. HERREZUELO: $\mathrm{Ob}$. cit., p. 308

${ }^{1451}$ IBIDEM, p. 308

${ }^{1452}$ IBIDEM, p. 311
} 
surtir a la herrería de leña y de carbón”"1453.

El segundo obstáculo, de mayor entidad, fue la actitud contra dicha construcción que opuso la familia Andrade de Ponferrada. Éstos tenían "una Zédula Real que les concedía la facultad de hacer una herrería, y los minerales de hierro de aguas vertientes al Vierzo; y aunque el monasterio sacó también una Zédula Real para la construcción de la suya ${ }^{1454}$, los Andrade se estuvieron callados hasta que se hallaba ya casi construida. Fue dicha para la casa-sigue diciendo Herrezuelo, abad que fue del monasterio y buen conocedor de la importancia económica de las ferrerías- que no hubiesen puesto antes la demanda, pues tal vez hubiera desistido, pero hallándola con la fábrica hecha, siguió el pleito que duró muchos años"1455. La ferrería, probablemente, estaba terminada ya en $1732^{1456}$.

El problema con los Andrade se solucionaría, después de pleitos, gastos y disgustos, en el abadiato del villafranquino don Manuel Amigo (1737-1741), con la compra a éstos de su Cédula en 32.000 maravedís. De este modo, el monasterio lograba adquirir los derechos sobre la mina de la Chana y, con nuevas cédulas sacadas por este abad, el aprovechamiento de las de Molina Ferrera y LLamas1457: "Nuestro abad, dice Herrezuelo, fue el que acabó de arreglar las cosas de la herrería de Linares y terminó el pleyto sobre las minas de hierro, comprando a los Andrade en treinta y dos mil mrs. la Zédula Real para el aprovechamiento de las de Chana y demás del Vierzo. Sacó también Zédula real para aprovechar las de Molina Ferrera y LLamas y pagó la media anata de dicha zédula"1458. En su segundo abadiato, Manuel Amigo (1745-1749)

\footnotetext{
1453 IBIDEM, p. 311

1454 Según un documento de 1787, publicado por RODRÍGUEZ CUBERO, J. D. en Diario de León, 13-XII-1998, el rey Felipe V concedió al monasterio facultad para construir una ferrería en el pago de Linares, así como el aprovechamiento de los montes circunvecinos a ella.

1455 P. HERREZUELO: $O b$. cit. p. 310.

1456 PASCUAL ZARAGOZA, E. (1974): “Actas de visita del monasterio de San Pedro de Montes". Archivos Leoneses, 69, p.140: Acta de visita del año 1732 "Mandamos en virtud de santa obediencia al P. Abbad que es y en adelante fuere, que de todo lo que quedare en limpio del producto de la herrería nuebamente fabricada y después de cubiertos todos los créditos contraidos para dicha obra y hechos los gastos necesarios para su total perfección, nada pueda expender en otros gastos del Monasterio, sino que todo se reponga en el arca de depósito para los réditos y redempción de los zensos que se tomaron para dicha fábrica".

${ }^{1457}$ Según MADOZ, P.: Ob. cit. p. 104, en Chana de Borrenes "hay una mina de hierro llamada Venera, que surte a las herrerías de Montes y Pombriego".

1458 P. HERREZUELO: Ob. cit, p. 310
} 
acabó de pagar los 2.000 ducados "del censo que se sacó para la herrería”4459.

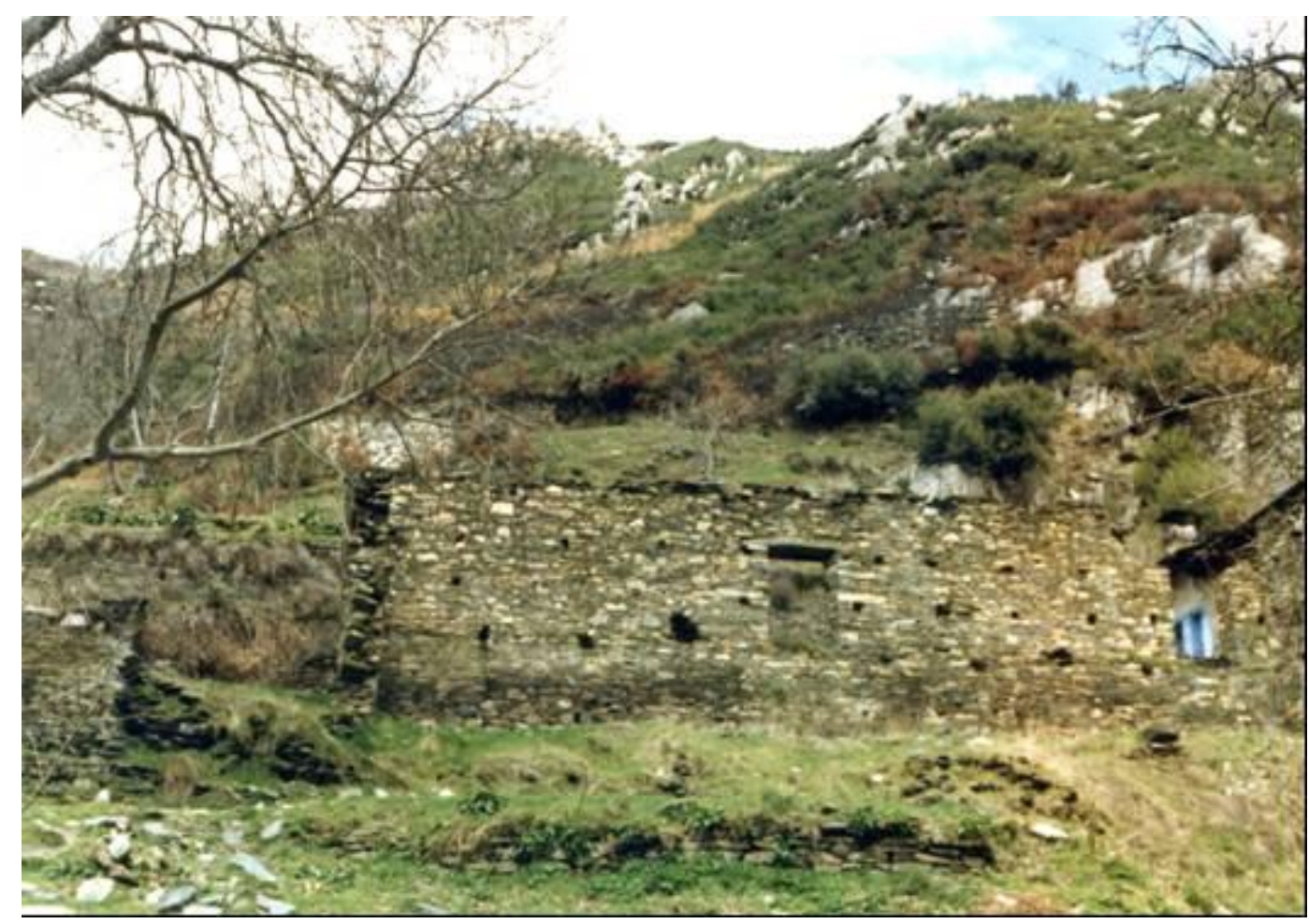

Ruinas de la vivienda del prior de la ferrería de Montes

La inteligente política del abad Monteagudo será continuada de una manera decidida por sus sucesores, mejorando las instalaciones de la ferrería y construyendo posteriormente la de Pombriego, en la Cabrera, zona en la que durante muchos siglos proyectaron su dominio económico los benedictinos de Montes. Ambas ferrerías proporcionarían a la casa cuantiosos ingresos. De hecho, en el siglo XVIII, el monasterio de Montes va a emprender todo un ambicioso programa constructivo, con el que restaurarán la iglesia y construirán dos nuevos claustros, lo que a su vez permitió aumentar el número de monjes de esta comunidad, como no había tenido nunca hasta entonces ${ }^{1460}$.

Según el Catastro de Ensenada, a mediados del siglo XVIII, la ferrería de Linares trabajaba unos 245 días al año, en los que producía una renta que se

1459 IBIDEM, p. 313.

1460 BALBOA DE PAZ, J. A. (1997): “La ferrerías de Montes en el siglo XVIII”. Revista Bierzo, p. 82. 
regulaba en $15.000 \mathrm{Rs}^{1461}$, cifra que nos parece muy baja a tenor de otros datos algo posteriores. Así en un "Estado General de Cuentas", de los cuatrienos que van de 1777 a 1785, los ingresos de las ferrerías de Linares y Pombriego, propias del monasterio de Montes, son bastante más elevados. Los beneficios de éstas son los siguientes:

$\begin{array}{lcc} & 1777-1781 & 1781-1785 \\ \text { LINARES } & 48.707 & 47.784 \\ \text { POMBRIEGO } & 85.263 . .27 & 84.562 \\ \quad \text { TOTAL } & 133.970 . .27 & 132.346 . .15\end{array}$

Fuente: Estado General de Cuentas ${ }^{1462}$

Creo que se trata de ingresos netos, por lo que señalaré más abajo respecto al administrador, aunque el monasterio corría con los gastos de mantenimiento del artefacto. Así el abad Genadio Velasco, en 1781, "gastó unos treinta mil reales en la presa de la herrería de Linares"1463. Este mismo, según el Estado de Cuentas, "reparó la presa y acrecentóla e hizo el molino y la estacada de la herrería de Linares, hizo por tres veces la estacada de la de Pombriego"; y su anterior en el cargo, el abad Juan Páramo "por tres beces costió la fábrica del árbol y rueda mayor de la herrería de Linares. Reparó el vanzado y lebantó algunos paredones de ella, y en la de Pombriego desmontó la peña que caía sobre la chapacuña"1464.

Las ferrerías benedictinas estaban administradas por un "prior rendero", que vivía en la casa construida en sus inmediaciones, ámbito que se consideraba de clausura. Un acta de 1778 señala "por clausura rigurosa fuera de la qual no

\footnotetext{
${ }^{1461}$ CATASTRO DE ENSENADA: R. G.: .: "Asimismo hay en estos zitados términos y en el referido pago de la Ramosa una casa de herrería de fabricar yerro propia de dicho real monasterio, en virtud de conzesión de su Magestad, que Dios guarde, con facultad de hacer abrir en diferentes términos veneras y fabricar carbón, por tener satisfechos por razón de media annata quarenta y cinco ducados de moneda de vellón por una vez por súplica y merzed concedida en lugar de los cinco mil maravedis en cada un quinquenio, con que le fue hecha la referida conzesión (...) y en quanto al producto que anualmente rinde digeron (...) bonificados ya todos los gastos de vena, ragua, carbón, salarios y desperfectos con ciento y veinte días que se le han de hueco por las dominicas, festividades y composiciones, deja anualmente el útil de quinze mill reales de vellón".

1462 ARCHIVO DEL MONASTERIO DE SILOS: Estado de Cuentas de la Congregación de Valladolid.

1463 P. HERREZUELO: Ob. cit., p. 322

${ }_{1464}$ A. MONASTERIO DE SILOS: Ob. cit.
} 
se puede salir sin quebrantar el voto de clausura, no precediendo expresa lizencia del P. Abad en Ferradillo media legua poco más o menos en circunferencia de la casa; en San Turjo otra media legua, excepto quando por razón de la administración de Arnado y de dicho priorato tenga precisión de salir a mayor distancia. En la granja otra media legua en la conformidad que en San Turjo; y lo mismo en las dos herrerías de Linares y Pombriego"1465. A los administradores se les exigían cuentas con cierta regularidad: "mandamos, dice otra acta de visita de 1792, que el P. Abad acompañado de otro monge inteligente tome rigurosas cuentas a los administradores de las herrerías, haciéndoles los cargos y descargos correspondientes sin llebarlos a consexo" ${ }^{1466}$. Conocemos a varios de estos monjes administradores ${ }^{1467}$.

Datoli señala que la ferrería de Montes tiene escasez de leña y carbón, e incluso agua, "por cuya razón está parada uno o dos meses en el verano"1468. Los problemas por el carbón se suscitaron pronto entre el monasterio y los vecinos del valle. En 1787 el abad Fulgencio Aguirre llevaba ante la Chancillería de Valladolid a sus vasallos de San Alejandro y Santalavilla, pues "se han propasado a prender a los operarios de el carbón, llevándoles los instrumentos con que lo arrancaban y fabricaban", pese a que el concejo y vecinos conocían, por público y notorio, la cédula de Felipe $\mathrm{V}$ por la que se concedía permiso para construir la ferrería de Linares y el aprovechamiento de los montes próximos a ella ${ }^{1469 .}$

Con la desamortización de Montes durante el Trienio Liberal, la ferrería de Linares fue adquirida por Nemesio Fernández. El hecho debió ocurrir hacia 1821, pues al año siguiente, un documento del 27 de octubre nos informa de las extrañas circunstancias de esa adquisición. El documento es un poder que el pueblo de Oencia otorga a su alcalde, para que pueda llevar a juicio a Juan

\footnotetext{
1465 PASCUAL ZARAGOZA, E. (1974): "Actas de visita del monasterio de San Pedro de Montes". Archivos leoneses, 69, p.145.

1466 IBIDEM, p. 153.

1467 En 1787 lo era Fr. Manuel Alvarez, a quien adquirió Juan de la Iglesia, de Pereje, 12 quintales de hierro a 110 rs/q. (AHPL. PN.: caja 3465); en 1789 Fr. Plácido Reguera; en 1810 y 1812 Fr. Pablo Rivera, a quien deben numerosas personas dinero por la venta de hierro (AHPL. PN.: caja 2792); en 1824 Fr. Andrés Osorio (AHPL. PN.: 2793) 1468 BALBOA DE PAZ, J. A. (1992): Ob. cit., p. 58 1469 RODRÍGUEZ CUBERO, J. D.: Diario de León, 13-XII-1998.
} 
Martínez Cascallana, pues "habiéndose liquidado por razón de suministros un bale a favor de la extinguida Merindad de Aguiar a que pertenecía el distrito de este Ayuntamiento, comprensibo de cinquenta y seis mil y más reales, se hallan con la noticia de que se empleó en la compra de la herrería de Montes por D. Nemesio Fernández de la villa de Ponferrada, sin que sepan quien se lo haya endosado, sólo si que habiéndose dado poder a don Juan Martínez de Cascallana para liquidación de suministros es presumible que sin más facultad que su despótico capricho lo haya aprovechado en la forma dicha" ${ }^{1470}$. Posteriormente, restaurado Fernando VII en su absolutismo, Nemesio Fernández sería desposeído de la ferrería que fue devuelta a sus antiguos propietarios, como atestiguan Miñano ${ }^{1471} \mathrm{y}$ otros documentos ${ }^{1472}$. Estos acontecimientos se reflejan en los Estados de Cuentas, con una caída considerable de la renta de las ferrerías.

Estado de cuentas de las ferrerías de San Pedro de Montes

Ferrería $\quad 1818-1821 \quad 1821-1824$

( Rs. Vn.)

$\begin{array}{lll}\text { LINARES } & 35.011 & 4.288 \\ \text { POMBRIEGO } & 93.977 & 35.489\end{array}$

Fuente: Estado General de Cuentas 1473

A partir de 1834, tras la exclaustración de Montes y la Desamortización, la ferrería pasó definitivamente a Nemesio Fernández, y como otras suyas la explotará directamente por medio de mayordomos y no por arrendatariosi474. En su inventario de bienes, en el año de su muerte en 1859, la ferrería de Linares se valoraba en 200.000 reales. Por entonces la cita Madoz recordando que "fue la primera del país en que se sustituyeron los fuelles o barquines con unas máquinas que llaman bombas, generalizada después a las demás"1475; dato técnico muy interesante, aunque es difícil referirlo a un año concreto. $\mathrm{Si}$

\footnotetext{
1470 AHPL. PN.: caja 3576 (año 1822).

${ }^{1471}$ MIÑNA, S.: Ob. cit. t. IV, p. 136: Hablando de Ferradillo dice que en este pueblo hacen carbón "para dos ferrerías que hay a 1 y 2 leguas del pueblo, propias del monasterio de Montes"

${ }^{1472}$ AHPL. PN.: caja 2793 (año 1824). En ese año se nombra como administrador de la ferrería a Fr. Andrés Osorio.

1473 A. de SILOS: ob. cit..

1474 AHPL. PN.: caja 2724 (año 1860): Don Miguel de Vega, vecino de Montes, dice que en años anteriores fue mayordomo de la ferrería.

1475 MADOZ, P.: Ob. cit., p197-198.
} 
podemos señalar que hacia 1820, según un estado de Cuentas, el abad "hizo también un horno para cozer la vena en la Herrería de Linares"1476, lo que igualmente es una novedad que ahorraba energía.

A la muerte de Nemesio Fernández le tocó en herencia a su hijo Felipe Fernández, junto con la ferrería de Serviz, quien la explotó hasta 1892, en que la vendió a Daniel Valdés y Barrio para saldar una deuda con su madre, doña María de la Encina Barrio y Prado ${ }^{1477}$.

ESTADO: A mano derecha de la carretera queda la vivienda en que habitaba el monje administrador; a la izquierda, entre ésta y el río, los restos del banzadillo a punto de desmoronarse.

\section{MUNICIPIO DE TORRE DEL BIERZO}

\section{FERRERÍA DE TORRE}

LUGAR: La Herrería

AYUNTAMIENTO: Torre del Bierzo

RÍO: Tremor

COORDENADAS: $42^{\circ} 35^{\prime} 42^{\prime \prime}$ N. y $6^{\circ} 20^{\prime} 3$ ” W.

En la antigua carretera de Torre del Bierzo a Bembibre, entre aquel pueblo y la desviación a Santa Marina, en la margen derecha del río Tremor o de la Silva, afluente del Boeza, existe una lujosa mansión, al que un rótulo denomina "La Herrería", topónimo que igualmente se cita en el mapa topográfico nacional 1/25.00o. Aquí estuvo ubicada la antigua ferrería de Torre.

\footnotetext{
1476 A. DEL MONASTERIO DE SILOS: Estado de Cuentas de la Congregación de Valladolid, año 1818-1821.

1477 AHPL. PN.: caja 9162 (año 1892): Entre otros bienes, por valor de 25.223 pesetas, le vende "una herrería llamada de Linares que consta del edificio de la fábrica de fundición de hierro con la fragua y carbonera en un solo recinto, plaza para el mineral y cauce de una longitud de trescientos metros, con una casa administración, cuadras, pajeras, leñera y corral de muy buena construcción, ocupando todo una superficie de veintidós áreas y linda al Norte monte, Este lo mismo y prado de D. Felipe, Sur río y Oeste prado huerta del dicho D. Felipe..." en precio de 7.933 pesetas, con 33 cts.
} 
Esta ferrería y la de San Andrés de las Puentes fueron construidas por Carlos Lemaur después de 1766. Por entonces, este ingeniero militar dirigía las obras de la nueva carretera a Galicia, cuando muy cerca de este lugar de Torre del Bierzo descubrió en 1764 una mina de carbón mineral, en la cuesta denominada del "Morueco", en el pueblo de Cerezal de Tremor. Los bancos de carbón de dicha mina tenían, según el resumen que del informe de Lemaur hicieron Maffei y Rúa Figueroa ${ }^{1478}$, un pie y medio de grueso cada uno y, en palabras del propio Lemaur eran importantes en una comarca "en la que el vegetal era tan escaso"1479, como muy pronto tendría ocasión de comprobar.

Su primera intención fue la de utilizar esos recursos carboníferos fuera de la comarca. Lemaur estudió incluso el medio para su transporte hacia Castilla y Madrid: un canal. En la propuesta que envía a la Administración, aunque difícilmente viable para la época, se puede ver la gran amplitud de miras de este ingeniero nada utópico, autor también del proyecto del Canal de Castilla. Aquel proyecto, de haberse llevado a la práctica, hubiera posibilitado una comunicación rápida y barata con Castilla y León; pues consistía en abrir un canal que desde las inmediaciones de Astorga concluyera en Valladolid, después de unirse con el Canal de Campos en las inmediaciones de Villalpando ${ }^{1480}$.

Con mayor realismo, Lemaur se planteó la posibilidad de utilizar el carbón descubierto en la fabricación de hierro a partir de los yacimientos de la Paradasolana, con la construcción de tres ferrerías y "varios martinetes para poner el hierro en barras de todas las medidas”, pues “empleando el carbón mineral a este fin se ahorrará el de brezo o de leña, necesario para la fundición de la vena, lo que contribuirá mucho al aumento de este metal y a su baratura en Castilla"1481. Este texto explica claramente que Lemaur pretendía fundir el mineral de hierro con carbón vegetal en ferrerías tradicionales, y con carbón mineral elaborar hierro en barras en martinetes, que debería construir

\footnotetext{
1478 MAFFEI, E. y RÚA, R. (1871-1872): Apuntes para una biblioteca española de libros, folletos.. Reeditado por la Cátedra de San Isidoro. León, 1970, p. 398-399 1479 ANÓNIMO (1976): "Hace doscientos años se descubrió en el Bierzo una piedra que ardía como el carbón". Aquiana, $\mathrm{n}^{\circ}$ 194., p. 17 1480 IBIDEM, p. 17. ${ }^{1481}$ IBIDEM, p. 17
} 
juntamente con aquellas, y así ahorrar madera, escasa en la zona ${ }^{1482}$.

Este proyecto, que presentó al Consejo de Castilla, fue aprobado, por lo que el 12 de enero de 1766 Carlos III le concedió licencia, mediante una Ejecutoria Real, para llevarlo a cabo. Además del permiso para la construcción de las ferrerías en el río Tremor, se le permitía utilizar la madera en un radio de cuatro leguas en torno a los artefactos, lo que supone un territorio que desde la zona del Manzanal llegaba hasta Congosto y Noceda, en el valle del Boeza, lo que traería posteriormente algunos conflictos con los concejos perjudicados por esta medida ${ }^{1483}$.

Lemaur habla también del hierro que ha descubierto, que con el carbón mineral puede abaratar su precio en Castilla " $y$ por consiguiente (contribuir) al aumento del comercio que Vizcaya y las montañas de Santander, pueden hacer de este metal con el extranjero" ${ }^{1484}$. Cuando escribe esto, la siderurgia tradicional vasca ha alcanzado su techo productivo, encontrándose en un momento de esplendor. A partir de entonces su hierro tendrá dificultades en los mercados europeos como consecuencia de la competencia del sueco y ruso ${ }^{1485}$. Está en lo cierto, sin embargo, en las grandes posibilidades de expansión del hierro berciano hacia Castilla. Munárriz, hablando de un mineral cercano a Compludo, señala que "acaso este mineral es el mismo del que se quería valer el ingeniero Lemaur para las dos herrerías que empezó a construir entre Bembibre y la Torre" ${ }^{1486}$. Datoli confirma que ese mineral era el de Paradasolana, y que Lemaur "usó en las herrerías de Torre y San Andrés de las Puentes (de las quales, habiendo parado muchos años hace de resultas de un pleyto sobre el uso de los montes, existen sólo las paredes)"1487.

Pensando en esas posibilidades de desarrollo siderúrgico, Lemaur comenzó

\footnotetext{
1482 IBIDEM, p. 17

1483 OLANO, M. (2008): "Carlos Lemaur y la industria del hierro y del carbón en la cuenca del Boeza”. En Actas del VI congreso internacional sobre patrimonio geológico y minero. X sesión científica de la SEDPGYM. Fabero del Bierzo, 19 septiembre-2 de octubre de 2005, p. 215. ${ }_{1484}$ ANÓNIMO (1976), p. 17

1485 BILBAO, L. M. y FERNANDEZ, E. (1982): "Auge y crisis de la siderurgia tradicional en el País Vasco (1700-1850)”. En TEDDE, P.: La economía española al final de Antiguo Régimen II. Las manufacturas, p. 175 y ss. 1486 BALBOA, J. A. (1992): Ob. cit. p. 118-119. 1487 IBIDEM, p. 46.
} 
la construcción de dos nuevas ferrerías en esta zona del Bierzo: una a orillas del río Tremor, afluente del Boeza, entre las poblaciones de Torre y Santa Marina; la otra, aguas abajo de Torre, entre esta población y Bembibre, en el lugar de San Andrés de las Puentes. La ferrería de Torre del Bierzo se construyó entre 1768 y 1769 con un coste de 267.603 rs. que, al parecer, fue sufragado a partes iguales por Lemaur y el lucense Agustín Álvarez de la Iglesia, administrador de la Real Gracia del Excusado. El complejo constaba, además del propio artefacto de la ferrería y carbonera, de una vivienda de dos plantas, la baja con oficinas, bodega y ferretería; y la alta con habitaciones ${ }^{1488}$.

Los quehaceres de Lemaur como ingeniero militar le impidieron explotar directamente el artefacto, que fue arrendado primero a Manuel Pérez Gómez (1769-1770) y luego a Juan Francisco Balboa y Llamas (1770-1772), ambos de Lugo. Este fue todo el periodo en el que estuvo en funcionamiento. En septiembre de 1772, pocos días después de que este último administrador cese para tomar posesión de un beneficio eclesiástico, aunque la ferrería estaba en buen estado según el inventario que se realizó entonces, ya no volvió a trabajar. En 1778 Miguel Valls certificará "que se halla enteramente abandonada por los demasiados quebrantos que padece (...) y no ttener valor alguno para el fin de su construcción" ${ }^{1489}$. Jovellanos menciona en su Diario de 1792 que ambas ferrerías estaban en ruinas: " $Y$ allí (se encuentran) las desdichadas herrerías que hizo el mismo Lemaur, hoy casi en ruina. Están a la salida del lugar (de Torre), a cierta distancia; a la entrada del mismo un puente por donde pasa el río que las abastece, que viene de las alturas, por la derecha del camino, y sigue luego por la izquierda, casi siempre paralelo con él; este río se llama Bueza o Boeza"1490.

\footnotetext{
1488 OLANO, M. (2008): Ob. cit. p. 217.

1489 IBIDEM, p. 217

1490 JOVELLANOS, G. (1792): Diario. Ed. de J.M. Caso (1992). Planeta, p. 69. Jovellanos se equivoca respecto al río, que no es el Boeza sino el Tremor, un afluente de aquél.
} 


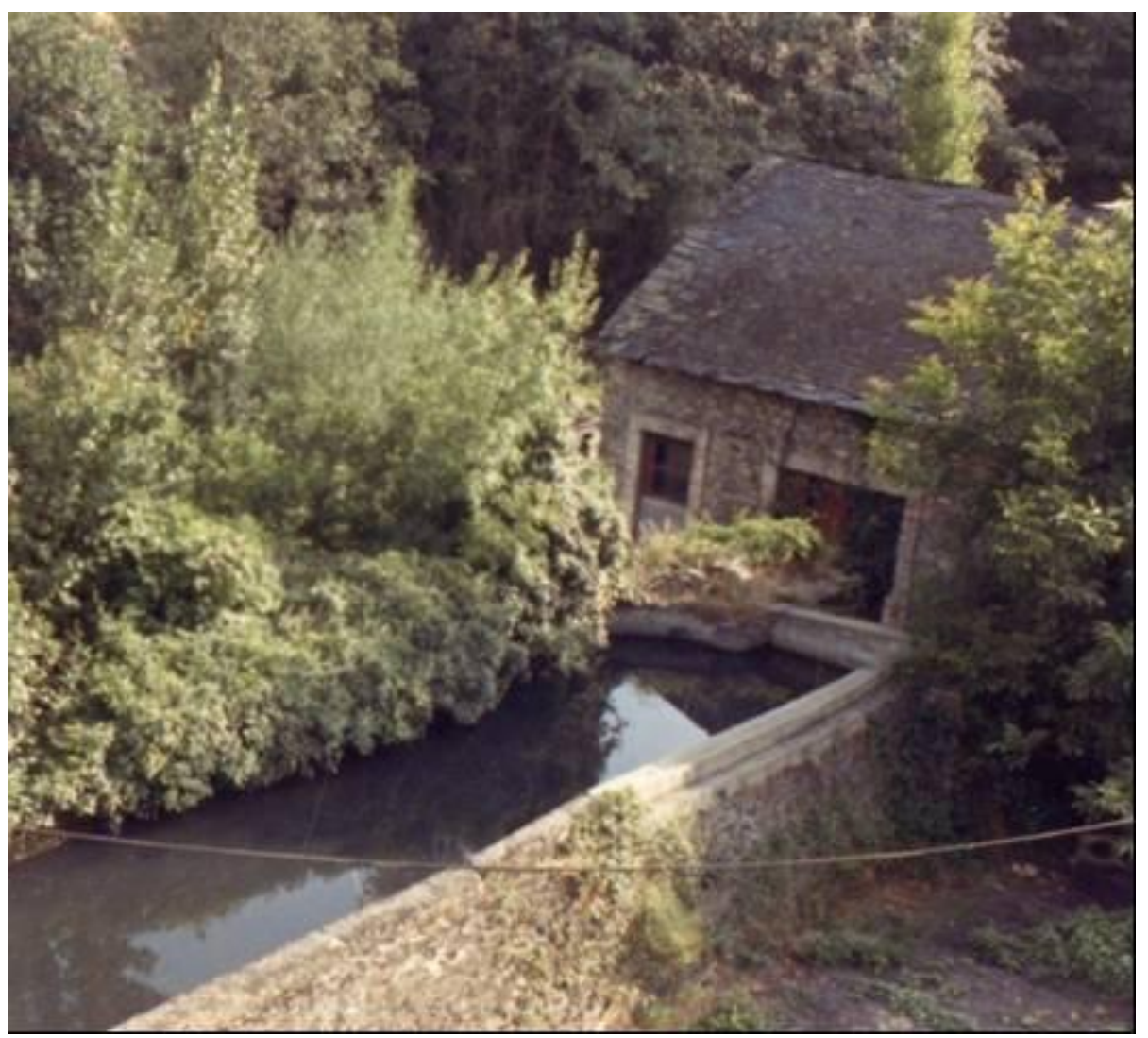

Banzao de la ferrería de Torre del Bierzo

¿Cómo una obra tan bien proyectada pudo venirse abajo en tan corto espacio de tiempo? Manuel Olano cree que fue a causa de la mala calidad del mineral de hierro de Paradasolana, lo que, como ya veremos al hablar de su vecina es bastante probable, aunque el energético debió ser determinante. Posiblemente Lemaur, aunque ingeniero y militar bien preparado, fue incapaz de fundir, como otros muchos en ese siglo, hierro con carbón mineral, lo que solo lograría en España el general Elorza hacia 1840; de hecho, como ya hemos dicho, Lemaur no pretendía otra cosa sino utilizarlo en los martinetes y no en la fundición. Para fundirlo necesitaba carbón vegetal, bastante escaso en esa zona pese a la opinión de Olano ${ }^{1491}$. Datoli afirma que estas ferrerías pararon " $a$ resultas de un pleyto sobre el uso de los montes" 1492 , iniciado por los propios vecinos, de las que habla el propio ingeniero en su informe.

ESTADO: Sólo se conserva el banzao, posteriormente utilizado para mover las ruedas de un molino. 


\section{FERRERÍA DE NAVALEO}

LUGAR: San Andrés de las Puentes

AYUNTAMIENTO: Torre del Bierzo

RÍO: Argutorio

COORDENADAS: $42^{\circ} 35^{\prime} 21^{\prime \prime}$ N. y $6^{\circ} 21^{\prime} 55^{\prime \prime}$ W.

La segunda de las ferrerías construida por Carlos Lemaur se encontraba un poco más abajo, en las cercanías del pueblo de San Andrés de las Puentes, en la orilla izquierda del Tremor en la confluencia con el río de San Andrés de las Puentes, antiguamente llamado Argutorio o Rial, próximo a unos molinos "que les dan el título de Navaleo"1493, de los que eran propietarios los vecinos de San Pedro Castañero, por lo que a veces se la cita también como ferrería de Navaleo.

La edificó Carlos Lemaur en 1769, después de superar algunos inconvenientes con los vecinos de San Pedro Castañero, propietarios de los molinos, al creer que la ferrería los perjudicaba en la utilización del agua. Para su construcción, Lemaur suscribió un préstamo de 109.500 rs. con Miguel Valls, vecino de La Coruña, cuyos réditos anuales suponían 3.285 rs., por lo que hubo de hipotecar "la mitad de la herrería de Torre y el todo de la iniciada en San Andrés"1494. No fueron esos los únicos problemas, pues su construcción suscitó las sospechas del conde de Croix, "comandante accidental" de Galicia, quien en 1770 acusó a Lemaur de desviar dinero del presupuesto de la construcción del tramo de carretera Piedrafita-Manzanal para su artefacto, del que al año siguiente quedó absuelto ${ }^{1495}$. Esta ferrería era parecida a la anterior aunque un poco más pequeña, como se deduce del dinero invertido en su construcción.

La ferrería trabajó cedida a arrendatarios desde 1770 hasta 1776. Primero la tuvo en arriendo Froilán Quirós y Taboada, de Lugo, en 1770-1772; y posteriormente el presbítero Francisco Rodríguez Gómez, de Salas de la Ribera, entre 1772 a 1776. Este último año, la mujer de Lemaur, Juana de la Murere denunció al arrendatario por incumplimiento del contrato. En 1775 Juana había arrendado a Francisco Rodríguez, por tiempo de dos años, la ferrería en la

1493 OLANO, M. (2008): ob. cit., p. 217.

1494 IBIDEM, p. 225

1495 IBIDEM, p. 216 
cantidad de 4.700 rs. que habría de pagar en dos plazos (junio y diciembre) de 2.350 reales cada uno, siendo los destrozos mayores de cuenta del dueño y los menores del arrendatario. En 1776 Juana le puso pleito por el impago de esta renta ${ }^{1496}$.

Pero los problemas venían por otro lado, no por impago de la renta sino de los intereses del crédito a Miguel Valls, al que sólo habían abonado la primera anualidad de 3.285 rs. Luego Lemaur no pudo hacerlo en los años de 1770 a 1776, por lo que aquel le puso un pleito ante el Real y Supremo Consejo de Guerra por la cantidad de 19.162 rs. vn. y 17 mrs. más los gastos del proceso, que aquél falló a favor del prestamista. Se hizo inventario de la ferrería, cuyo valor se estimó en julio de 1778 en 118.452 rs. con la intención de venderse y pagar la deuda. Al no haber comprador, el 29 de octubre de ese año la propiedad pasó a Miguel Valls, a quien debían los 109.500 reales del prestamo más los intereses devengados. Fue un mal negocio, pues en diciembre la malvendía al regidor de León y vecino de Astorga Diego Moreno Escobar y Pernía en 50.000 reales ${ }^{1497}$.

Diego Moreno, después de restaurarla, la puso nuevamente en funcionamiento hasta 1781. Al parecer hizo algunas pruebas con el mineral de hierro de Paradasolana y con el de La Chana, que usaba la ferrería de Montes. Utilizó para ello dos carros de vena de Paradasolana en la ferrería de Montes, con mal resultado, y dos carros de la vena de la Chana en la ferrería de San Andrés, "de cuio experimento resultó mucha abundancia"; pero, bien por la distancia de aquella vena, bien por no poder utilizarla, lo cierto es que ese año abandonó el proyecto. Quizá también el problema del combustible fue otra dificultad insuperable, pues hubo de sostener un largo pleito con la villa y Tierra de Bembibre por "los agrabios y perjuicios de la corta de las maderas y leñas de cuajo y arranque de cepas y raices para la herrería", al considerar los vecinos que se excedía de las atribuciones de la Real Cédula de $1766^{1498}$.

Según Jovellanos en 1792 estaba arruinada, pero aún así un descendiente de Diego Moreno, Ramón Somoza y Moreno arregló la chapacuña y el cauce,

${ }^{1496}$ IBIDEM, p. 229

1497 IBIDEM, p. 226-228

${ }^{1498}$ IBIDEM, p. 218 
como recoge una denuncia que hacen los vecinos de Santa Marina de Torre contra él al ayuntamiento en $1863^{1499}$. La fábrica estuvo parada en la primera mitad del siglo XIX ya que no la menciona Madoz, pero probablemente lo que pretendía Ramón Somoza era ponerla nuevamente en funcionamiento, aunque las protestas de los vecinos se lo impidieron porque no nos consta que volviera a trabajar.

ESTADO: No se conserva nada

\title{
9. MUNICIPIO DE TRABADELO
}

\section{FERRERÍA DE SAN FIZ DO SEO}

\author{
LUGAR: San Fiz do Seo \\ AYUNTAMIENTO: Trabadelo \\ RÍO: Barjas \\ COORDENADAS: $42^{\circ} 38^{\prime} 31^{\prime \prime}$ N. y $6^{\circ} 54^{\prime} 31^{\prime \prime} \mathrm{W}$.
}

Poco después de la ferrería de la Portela desemboca en el Valcarce el Barjas, río que nace en la vertiente septentrional del monte Capeloso. Muy cerca de su desembocadura, a los pies del pueblo de San Fiz do Seo, existió una ferrería medieval. El solar que ocupaba solía denominarse ya en el siglo XVI

\footnotetext{
1499 ARCHIVO MUNICIPAL DE TORRE DEL BIERZO: Libro de Actas Municipales, acta de 2 de octubre de 1870. Se da cuenta de una instancia de los vecinos de Santa Marina de Torre en que se quejan por los abusos del dueño de la herrería de Navaleo, a lo que contesta el secretario: "En cumplimiento de lo que V.E se digna prevenirme debo manifestar: que el expediente a que se refiere la antecedente instancia existe en la sección de Fomento del Gobierno Civil de la provincia desde el ocho de octubre de 1869 del cual resulta que D. Ramón Somoza y Moreno es dueño en propiedad de la Herrería y casa de Navaleo, del cauce y presa de la misma, de la sierra llamada de la Mata de la Manzana y de todo el terreno situado en la parte inferior del cauce (...) Así como también que el citado señor reparó en el anterior mes de agosto de 1863 la presa u chapacuña y cauce sin separarse una linea de la situación que ocuparon siempre (...). y por otra parte porque son sobradas las aguas que conduce dicho cauce para alimentar la fábrica y para fertilizar la pradera y demás terrenos del sr. Somoza sin alterar ni lastimar la corriente natural del río (...) Finalmente debo también manifestar a V.E. en testimonio de la verdad que la instancia suscrita por los vecinos de Santa Marina carece de todo fundamento (...) Tampoco es cierto que fuese destruida la fábrica por sentencia de ningún tribunal y si restablecida en sus derechos como resulta del testimonio o pleito original que acompaña el expediente que V.E. reclama.".
} 
como "Herrería vieja", señal de su anterior construcción150o. A ella y a la de Valcarce se refiere un inventario de 1500 realizado para la primera marquesa de Villafranca, que dice que en Valcarce hay unas herrerías que están arrendadas en 18.500 mrs. ${ }^{1501}$. Todavía en 1555 y 1556 se habla de la renta que percibía el marqués de Villafranca por su alquiler: 3.000 y 3.375 maravedís respectivamente ${ }^{1502}$.

Probablemente se trata de una ferrería medieval1503, convertida en el siglo XVI en un simple mazo, pues en 1595 se dice que Juan de Liçanza, herrero, tiene un mazuco en San Fiz ${ }^{1504}$. Después nunca más vuelve a mencionarse, a no ser como topónimo ${ }^{1505 .}$

ESTADO: Ilocalizable.

\section{MUNICIPIO DE VEGA DE VALCARCE}

\section{FERRERÍA DE HERRERÍAS DE VALCARCE}

LUGAR: Herrerías de Valcarce

AYUNTAMIENTO: Vega de Valcarce

RÍO: Valcarce

COORDENADAS: $42^{\circ} 40^{\prime} 16^{\prime \prime}$ N. y $6^{\circ} 58^{\prime} 31^{\prime \prime} \mathrm{W}$.

El actual pueblo de Herrerías de Valcarce lo componían antiguamente tres núcleos diferentes, que formaban un solo concejo: San Julián, Hospital Inglés y

\footnotetext{
${ }^{1500}$ FRANCO, A. (1982): "El señorío de Villafranca del Bierzo". BRAH, t. CLXXIX, cuad. 1, p. 115, dice que el 17 de marzo de 1544 el marqués de Villafranca afora el "asiento de la herrería vieja de la casa blanca" a los vecinos del lugar de San Fiz, a perpetuidad, por 20 fanegas de centeno anuales.

${ }^{1501}$ FRANCO, A. (1981): "Bienes, rentas y vasallos del señorío de Villafranca del Bierzo al término del siglo XV”. Archivos leoneses, 69, p. 48.

1502 FRANCO, A. (1982): “El señorío de Villafranca del Bierzo”. BRAH, t. CLXXIX, cuad. 1, p 92

1503 BALBOA DE PAZ, J. A. (1990): Hierro y herrería en el Bierzo preindustrial, p. 73-77.

${ }^{1504}$ AHPL. PN.: caja 2878

${ }^{1505}$ Así en 1770 en la venta de un prado en Sotogayoso se dice que está "al sitio que llaman Ferraria vieja término de dicho lugar" (AHPL. PN.: caja 3283); y en 1863, en el Libro del Guarda Mayor, p. 77, $\mathrm{n}^{\circ}$ 229, se dice: "Pasé un oficio al constitucional de Trabadelo por la corta de leña de roble y vrezo en el monte llamado Herrería Vieja, término de san Fiz siendo los aprovechamientos de Sotogayoso".
} 
Herrerías. En este último barrio, en la margen izquierda del río Valcarce, que nace en la fuente de las Forcadas, en Bargelas, al pie de la cordillera que separa las provincias de León y Lugo, todavía son visibles los restos de su antigua ferrería, a la que se accede por una puerta con un elegante arco de medio punto.

Desde la Edad Media se mencionan en este valle e incluso en este pueblo, llamado en la documentación de la época "Fumeterre" ${ }^{506}$ (que alude sin duda al humo de sus fraguas), activades siderúrgicas; sin embargo, la ferrería hidráulica que dio nombre al pueblo actual probablemente debió construirse en el siglo $X V^{1507}$. El primer documento que conocemos es una carta real de 1486, en la que se ordena a los mayordomos de los marqueses de Villafranca que no exijan a Martín Gonçales, "rentador de las ferrerias del valle de Valcarce", la renta de las mismas, pues "podia aver dies años quel avo arrendadas e arrendó del conde viejo de Lemos e la condesa por dies y seys mill maravedís en cada año"1508. Poco después, en 1500, en un inventario de la primera marquesa de Villafranca se dice que "en la tierra de Valcarce, que es merindad de la fortaleza de Sarracín (...) hay unas ferrerías que están arrendadas en 18.500 maravedis"1509. Una de éstas era la de Herrerías; la otra la mencionada de San Fiz.

\footnotetext{
1506 VALIÑA, E. (1971): El Camino de Santiago. Estudio histórico-jurídico. Madrid, P. 123-124 ${ }^{1507}$ BALBOA DE PAZ, J. A. (1990): Hierro y herrerías en el Bierzo preindustrial. León, p. 73-76. ${ }^{1508}$ AGS, RGS, X-1486/125: Los Reyes Católicos al corregidor de Ponferrada y al alcalde y justicias de Villafranca y al merino del Valle del Valcarce: "que sepais que Martín Gonçales rentador de las ferrerías de dicho valle de Valcarce les hizo relación de cómo había arrendado esas ferrerías al conde viejo de Lemos y a la condesa hace diez años en dieciseis mil maravedis cada año, que pagó tanto a dicho conde como a su nieto D. Rodrigo Enriques Osorio y dice que el merino le demandaba las rentas de los tres últimos años en nombre de la marquesa de Villafranca, que dicen pertenecerle, por lo que le ocasionan grave daño si tuviere que pagar lo que ya pagó". Mandan que no se le pidan las rentas de esos años.

1509 FRANCO, A. (1981): Ob. cit., p. 46
} 


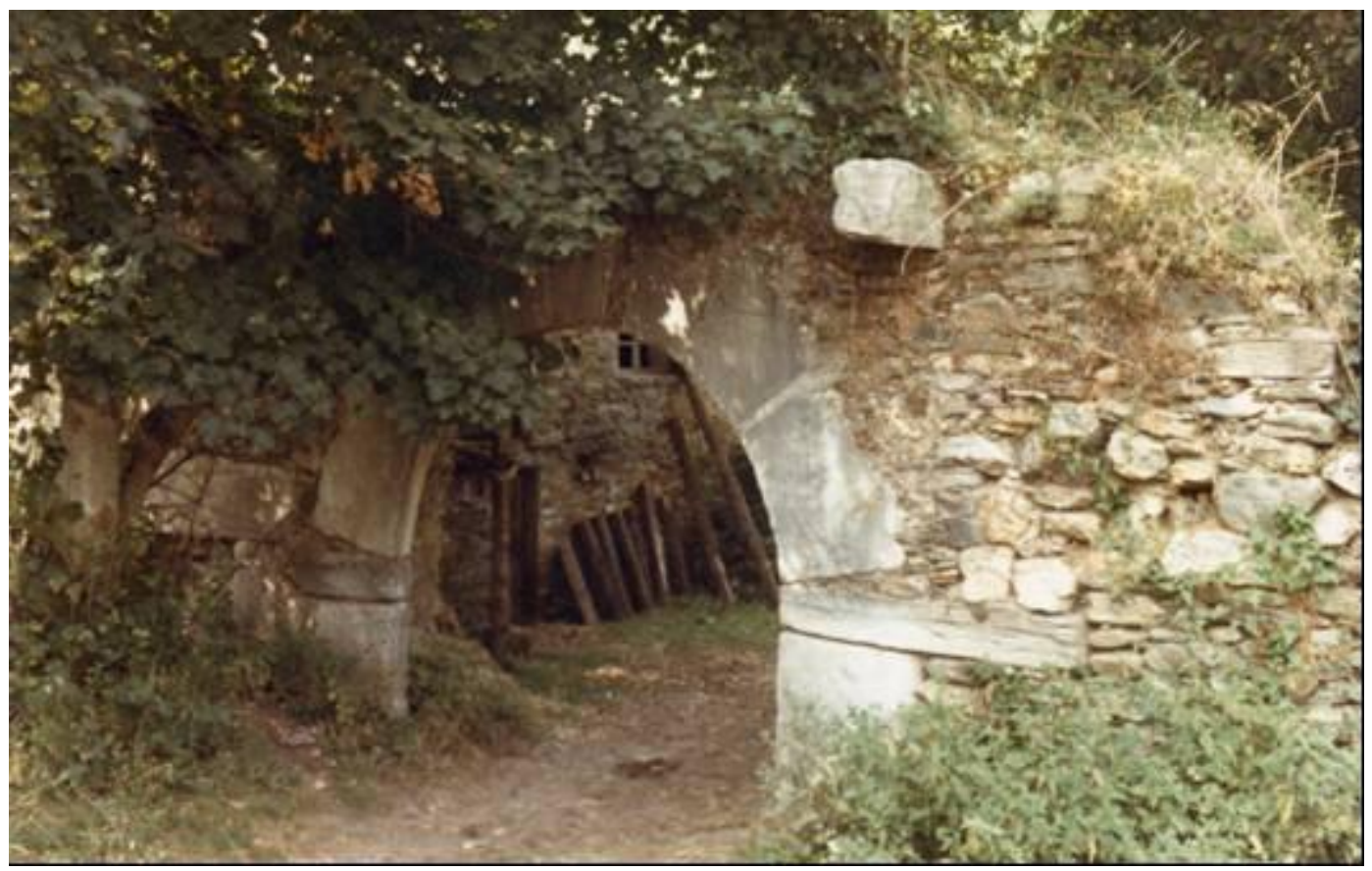

Puerta de entrada a la ferrería de Herrerías de Valcarce

Como las de Arnado y Pontepetre, esta ferrería fue construida por los Alvarez Osorio, condes de Lemos, de los que a finales del siglo XV pasó a sus herederos los marqueses de Villafranca. Como aquéllas, tampoco ésta la beneficieron directamente sino que la arrendaban; así, por ejemplo, sabemos que en 1555 la arrendaron por 22.500 maravedís ${ }^{1510}$. Conocemos igualmente a otros arrendatarios en el siglo XVI: el vizcaíno Miguel Ortiz, quien en 1578 compra vena de Formigueiros ${ }^{1511}$ y a quien en 1581 nuevamente el marqués de Villafranca le arrienda esta ferrería, junto a Juan Lasaca, por cinco años y 22.400 mrs. al año ${ }^{1512}$; Felipe de Garbisso, quien en 1586 se concierta con Alonso Mayo, de Molinaferrera, para que con sus récuas le traiga 200 quintales de vena de Formigueiros ${ }^{1513}$, y que en 1588 adquiere de Marcos Castro, Andrés Alonso y Aparicio Alonso, vecinos de Molinaferrera, 600 quintales de vena de Formigueiros para la "ferraria de Valcarce"1514. Este mismo Felipe Garbisso continúa de arrendatario en 1593, año en que adquiere de Juan López y Pedro Álvarez, vecinos de la Vega, 500 cargas de carbón para su ferrería ${ }^{1515}$.

${ }_{1510}$ FRANCO, A. (1982): Ob. cit. p. 103.

${ }^{1511}$ AHPL. PN.: caja 2849. Este Miguel Ortíz aparece también este mismo año como rendero de la ferrería lucense de Ferreirós (AHRG. Real Audiencia 2.472/120).

${ }_{1512}$ AHPL. P.N. caja 2849 (año 1581)

1513 AHPL. PN.: caja 2874 (año 1586).

1514 AHPL. PN.: caja 2850 (año 1588).

1515 AHPL. PN.: caja 2909 (año 1593). 
A comienzos del siglo XVII, en 1615, era rendero de esta ferrería Pedro de Opaeda, con quien se concierta Juan Cubero, vecino de Ponferrada, en que le venderá 50 quintales de hierro a 29 reales el quintal ${ }^{1516}$. El mismo rendero, en el mismo año, denuncia a Juan García, tazador en su ferrería, porque "me llevó de la dicha ferraria cantidad de yerro sin mi licencia y lo bendió a quien quisso"1517. Este Pedro de Opaeda debía tenerla arrendada a medias, pues en el mismo mes y año de 1615 aparece también como rendero Juan de Celaya1518. A mediados de siglo fueron renderos Juan de Oyarzábal ${ }^{1519}$ y posteriormente sus hijas, las cuales debieron ceder ese arrendamiento al mercader de Villafranca, Francisco de Soto Gayoso ${ }^{1520}$. Este mercader aparece también como rendero en 1676 junto con su mujer Manuela de Salazar ${ }^{1521}$.

De la ferrería de Valcarce habla en 1681 el sacerdote italiano Doménico Laffi en su viaje a Santiago de Compostela. Cuenta que a dos leguas de Villafranca se alcanza Salvaterra -vago recuerdo, aunque erróneo, del Fumeterre medieval-, lugar que está "sú la ripa do medéssimo fiume”, y al que llevan el mineral de hierro pues hay allí "una fornace da cuocerlo" y también que hay allí un "gran martello di ferro che batte a forza d'acqua"1522, descripción elocuente de una ferrería hidráulica como era ésta del Valcarce, cuyas ruedas movían las aguas del río de ese nombre.

\footnotetext{
${ }_{1516}$ AHPL. PN.: caja 1663 (año 1615).

1517 AHPL. PN.: caja 3186 (año 1615).

${ }^{1518}$ AHPL. PN.: caja 3186 (año 1615): escritura de 28 de junio, de Juanes de Celaya y tres fiadores para pagar a Ana Díaz, de Villafranca, el préstamo que hoy le hace de cien ducados.

${ }^{1519}$ En 1664 se menciona a Juan de Oyarzábal, como rendero de la ferrería, en un pleito que contra él suscita el procurador de Villafranca del Bierzo por impago de 2.615 rs., que se le exige (por la renta) como obligado del abastecimiento de las carnicerías de la villa (ARCHV. Registro de ejecutorias: 2885,79)

${ }^{1520}$ AHPL. PN.: caja 3195 (año 1669): Ana María de Oya, hija de Juan de Oyarzábal, difunto y vecino que fue de la Herrería de Valcarce " $y$ rendero que fue de ella", confiesa recibir de Francisco de Soto Gayoso, mercader de Villafranca, 1.000 reales a cuenta de 10.000 reales que a ella y a su hermana Isabel les está debiendo por el ajuste de la herrería.

${ }^{1521}$ AHPL. PN.: caja 3316 (año 1676). Venta de 5 anegas de pan a Francisco de Soto Gayoso, vecino de Villafranca " $y$ rendero de la Herrería de Valcarce" y a doña Manuela de Salazar, su esposa.

${ }^{1522}$ GONZÁLEZ, F. (1984): Domenico Laffi, peregrino observador e inquisitivo. Cuaderno $\mathrm{n}^{\circ} 4$, Ponferrada, p. 19. Este boloñés viajó varias veces a Compostela; de su segundo viaje, en 1670, publicó en 1681 un libro con datos muy interesantes.
} 
Un Tomás de Salazar de Soto, también vecino de Villafranca, hijo de los anteriores Francisco de Soto y Manuela de Salazar se declara, en 1694, "poseedor de la Erreria de Valcarce", y lo mismo en 1697, en que se le menciona como deudor al conde de Maceda de 2.400 reales del foro de la vena, a 400 rs./año ${ }^{1523}$. La razón de esta propiedad es que el 7 de abril de 1680 la ferrería le fue aforada, por las mismas razones que las otras del marqués de Villafranca, a favor de su padre Francisco de Soto, en la cantidad de 80.000 reales. En sus manos y en las de su familia (en los primeros años del siglo XVIII, se menciona a su mujer e hijo, doña Águeda de Losada Ferrara y José Francisco de Soto1524) permaneció hasta 1720 en que la vendieron a Francisco Saco en 143.00o reales, en los que se incluían 33.00o de bienes libres que aquellos habían agregado, pero el tal Saco solo debía de ser un testaferro ${ }^{1525}$.

Sin embargo "aunque sonava haverse echo a favor de don Francisco Saco era para el rector y colegio de la compañía de Jesús de Villafranca”, por lo que la marquesa puso pleito, por tanteo, que ganó ${ }^{1526}$. Pero no parece que dispusiese de las cantidades que debía abonar a los Soto, por lo que como el marqués debía a don Pedro Luis de Ulloa, señor de Noceda, 64.00o rs. más otros 62.350 rs. consignados para el tanteo y 6.000 rs. que había gastado en reparos, es decir, 132.350 rs. más una deuda del marqués de 25.750 rs. con don Esteban García de las Llanas y otras cantidades, doña Catalina de Moncada y Aragón, en nombre de su marido don José Fadrique de Toledo Osorio, se la afora el 12 de febrero de 1726 a favor de don Pedro José de Ulloa, señor de Noceda, por todo ese dinero, que ascendía a 247.00o reales y con la pensión anual de 400 reales ${ }^{1527}$. Éste Pedro José de Ulloa, propietario de la ferrería de Bueyes, la uniría a su

\footnotetext{
1523 AHN. Estado: leg. 1739, $\mathrm{n}^{\circ} 16$.

${ }_{1524}$ AHPL. P.N.: caja 3292 (años 1721 y 1729).

1525 AHPLU: 6701/13

${ }^{1526}$ AHPLU: 6701/13. Los jesuitas se habían establecido en Villafranca, donde con el apoyo económico del marqués y del indiano Gabriel de Robles, habían abierto un colegio. Además de las rentas de los fundadores, los jesuitas adquirieron tierras, prestaron dinero a censo y, por lo que se ve, quisieron incluso entrar en el negocio de las ferrerías. BALBOA DE PAZ, J. A. (2006): La educación en el Bierzo. Ponferrada, p. 46-50

${ }^{1527}$ AHPLU: 6701/13. Se otorgó en 12 de febrero de 1726 escritura de foro perpetuo de la "ferraria comunmente llamada de el Valcarce, perteneciente a dicho marquesado de Villafranca, con todos sus pertrechos, atalajes, erramientas, casa de vibienda, caballerizas, molino, agua, plaza de la dicha ferraria, con su huerto y caruedo de dos fanegas de sembradura y una cortina a espaldas de dicha ferraria de dos fanegas de sembradura, montes, pastos, derechos de vena y todos los demas vienes muebles y rayces a ella anejos"
} 
mayorazgo, por lo que pasaría posteriormente a su hijo primogénito don Pedro Luis Ulloa.

En 1759 parece que el marqués puso pleito ante el corregidor de Villafranca, con la intención de recobrar ésta y la ferrería de Pontepetre. Pedro Luis de Ulloa, hijo del anterior forero, se opuso por no ser competente aquel tribunal y recurrió a la Chancillería de Valladolid, pero al mismo tiempo se desplazó a Madrid donde logró arreglar el asunto ${ }^{1528}$; pero para formalizar el acuerdo se pidió permiso al rey, pues al parecer "para otorgar ambas escrituras de foro (se refiere a las de las ferrerías de Pontepetre y Valcarce) no se sacó facultad real, intentó reintegrarse en ellas”. Para ello, solicitó al rey que su Real Consejo de Cámara, después de explicarle los antecedentes, concediese "su Real facultad para reualidar dichas dos escrituras de foro", lo que así se hizo con fecha de 24 de agosto de 17621529. En junio de 1763, Pedro Luis Ulloa da un poder para revalidar su escritura de foro perpetuo, aunque con algunas modificaciones: la renta sube otros 660 reales, por lo que deberá pagar anualmente 1.100 reales; además, por una sola vez, le entregará 12.000 reales "para ymbertirlos en venefizio y utilidad de dicho estado y maiorazgo de Villafranca" 1530 . Aquella cantidad era la que pagaba en años sucesivos como foro de la ferrería ${ }^{1531}$.

A la muerte de este Pedro Luis Ulloa sin herederos directos en 1787, la ferrería pasó a su sobrino don José María Tineo y Ulloa, quien pondrá a su frente a mayordomos o administradores para su dirección, como recuerda Munárriz, quien la exceptúa del sistema de arriendo característico de las ferrerías bercianas: "La de Valcarce, como hemos dicho, es la única que se administra por el mismo dueño, y aunque no vive en el país no escasea el dinero para cualquiera obra, y así es la que está mas bien cuidada"1532. Así en

\footnotetext{
${ }^{1528}$ Creo que en el arregló debió pesar no sólo el valor de la ferrería sino los enormes gastos desembolsados, que ascendían a más de 179.775 reales (AHPLU: 6701/13).

1529 AHPLU: 6701/13

${ }^{1530}$ AHPLU: 6701/13. 400 reales más 660 solo son 1060; es posible que fueran antes 440 rs.

${ }^{1531}$ Así en las cuentas de 1798 se dice "Don José María de Tineo, señor de Nocedal, debe satisfacer en cada un año un foro de ella (Herrería de Valcarce), un mil y cien reales". Arch. Particular: Papeles del marquesado (gentileza de Mariano Higuera)

${ }^{1532}$ BALBOA, J. A. (1992): Ob cit. p. 126
} 
1761, y al menos hasta 1768, lo era don José Piñeiro'533; desde 1780 hasta 1792 el presbítero don Juan Antonio Asenjo Rodili1534; y desde ese año hasta la segunda decena del siglo XIX lo fue don Andrés de Mon Rancaño ${ }^{1535}$. Éste, de todos modos, aparece a veces como arrendatario, especialmente después de la Guerra de la Independencia ${ }^{1536}$.

Según los informantes y peritos del Catastro de Ensenada ${ }^{1537}$, la ferrería de Valcarce, propia de don Pedro Luis de Ulloa, es "caudalosa y (...) trabaja con todos sus oficiales ducientos días al año". En cada día produce seis quintales y un cuarto de hierro, siendo cada quintal de 155 libras, que regulan, por un quinquenio, en 57 reales vn.; es decir que la producción, según el Catastro, sería de 1250 q. de 155 libras o 1550 q. de 5 arrobas, cifra semejante a la que ofrece el Catastro para las ferrerías de Arnado y Oencia, pero que difiere de la proporcionada por Cornide, quien sólo le da una producción de 1.000 q/ año ${ }^{1538}$. Esta diferencia con aquéllas puede deberse a que la ferrería de Valcarce solo funciona 200 días. Datoli dice que "dexa de andar por lo regular desde mediados de agosto hasta mediados de octubre"1539, y que también escasea de monte: "sus montes propios consisten en dos porciones de robledal, que podrán

\footnotetext{
1533 AHPL. PN.: caja 3353 (año 1768): se habla de un poder dado en 31 de julio de 1761 por don Pedro Luis de Ulloa, señor de Noceda y "dueño de la ferrería de Valcarce" a don José Piñeiro, su mayordomo y residente en la ferrería. AHPL. PN.: caja 3283 (año 1768): Don José Piñeiro "residente en las Errerías de el Valcarce, maiordomo, administrador y apoderado general de D. Pedro Luis de Ulloa, señor de Noceda, coronel del Reximiento de milicias de Lugo".

${ }_{1534}$ AHPL. PN.: caja 3376 (año 1789): Don Juan Antonio Asenjo Rodil, presbítero, capellán de la capilla colativa de Ntra. Sra. de Pasoña, en la parroquia de San Salvador de Abres, Asturias, dice que don Pedro Luis de Ulloa, señor de Noceda, le rogó se hiciese cargo de la administración de la ferrería de Valcarce, de la que es dueño, desde el día 4 de octubre de 1780 hasta el presente. Todavía estaba como capellán en 1794 (AHPL.PN.: caja 3463, año 1794)

1535 AHPL. PN.: caja 3295 (año 1797): Don Andrés de Mon Rancaño, residente en la Herrería de Valcarce, dice: "que en los ocho de marzo del año pasado de mil setecientos nobenta y dos, Don Josef María de Tineo y Ulloa (...), le eligió y nombró por su administrador en birtud de su poder que para ello le dio para que rigiese, cuide y administre la referida casa y herrería". Lo era también en 1802 (AHPL. PN.: caja 3746), año en el que cura de la Faba, don Narciso Alvarez, electo canónigo de la iglesia catedral de Lugo, da un poder a " $D$. Andrés de Mon Rancaño, mayordomo apoderado del señor de Nozeda residente en su casa de Cadena y fábrica de yerro del lugar de la Herrería". E incluso en 1813 (AHPLU: 2474/3) se mencionan deudas con " $D$. Andrés de Mon Rancaño, administrador de la ferrería de Valcarce".

${ }_{1536}$ AHPLU: 2467/11. En 16 de noviembre de 1814, don Andrés de Mon Rancaño dice que don José María Tineo le arrendó el 14 de febrero de 1812 la ferrería de Valcarce, de que es dueño, por tiempo de seis años.

1537 CATRASTRO DE ENSENADA: R. G., libro de Herrerías de Valcarce.

${ }^{1538}$ CORNIDE SAAVEDRA, J.: Noticia de las ferrerías de Galicia (Manuscrito). Real Academia de la Historia.

1539 BALBOA, J. A. (1992): Ob. cit., p. 57.
} 
dar juntos de 400 a 600 carros de leña por una sola vez; asi es que compra la leña a un precio subido" 1540 .

La ferrería, según Datoli, producía un hierro de buena calidad y suave al trabajarlo ${ }^{1541}$, que tenía mucha aceptación, por lo que se abastecían de él muchos herreros de los alrededores; por ejemplo sólo en el concejo de San Julián y sus barrios de Herrerías y el Hospital, con 344 vecinos, había, además de los cinco oficiales de la ferrería, 12 maestros herreros de hacer clavo, 21 oficiales y 6 aprendices ${ }^{1542}$. La ferrería proporcionaba a sus dueños pingües beneficios. Según González Vecín, su propietario tenía en Herrerías de Valcarce una renta, de acuerdo con el Libro del Mayor Hacendado, de 78.546 rs. vn. y 17 mrs., de los cuales 74.550 provenían directamente de la ferrería, lo que da una idea de la enorme rentabilidad de este artefacto ${ }^{1543 .}$

En el siglo XIX la ferrería de Valcarce, con la de Bueyes, pasó a manos de don Apolinar Suárez de Deza, propietario a su vez de otras ferrerías en el Bierzo (Pombriego, Río Cabo) y Galicia (Lousadela y Ferreirós), por su matrimonio con la hija de don José María Tineo, doña $\mathrm{M}^{\mathrm{a}}$ Josefa Raimunda Tineo y Vigo. En manos de esta familia, unas veces arrendada y otras explotada directamente por administradores, permaneció hasta finales del siglo, que es cuando debió dejar de funcionar.

ESTADO: En el interior de la finca resta sólo un edificio, llamado aún "La carbonera".

1540 IBIDEM, p. 57.

${ }^{1541}$ IBIDEM, p. 48

${ }^{1542}$ BALBOA, J. A. (1990): Hierro y herrerías en el Bierzo preindustrial, p. 122.

1543 GONZÁLEZ VECÍN, J. (1984): "Los mayores hacendados del partido de Ponferrada a mediados del siglo XVIII”. Tierras de León, 57, p. 13. 


\section{FERRERÍA DE LA PORTELA}

LUGAR: Portela

AYUNTAMIENTO: Vega de Valcarce

RÍO: Valcarce

COORDENADAS: $42^{\circ} 39^{\prime} 27^{\prime \prime}$ N. y $6^{\circ} 54^{\prime} 53^{\prime \prime} \mathrm{W}$.

Aguas abajo del pueblo de la Portela, en la margen derecha del Valcarce, se levantan los restos de la ferrería de ese nombre. Se accedía a ella desde la gasolinera que hay a la entrada del pueblo, pasando un túnel por debajo de la carretera y un puente de madera sobre el río; pero esto se ha hecho imposible por la construcción de la autovía del Noroeste, que pasa justamente a su lado. Para llegar hoy hay que regresar al pueblo, subir por la carretera de Sotogayoso hasta la parte alta de la Portela y desviarse a la izquierda por un camino que discurre a la vera de la presa de la ferrería.

La ferrería la construyó hacia 1835 el ponferradino Nemesio Fernández, el mayor industrial herrero del siglo XIX en el Bierzo. En octubre de 1834, Nemesio Fernández acuerda con Pedro de Soto y su nuera, doña Manuela Pérez Pimentel, vecinos de Ruitelán, que le permitan "abrir un paso para un cauce de agua que intenta dirigir a una fábrica que piensa construir en los términos del lugar de la Portela, por medio de una tierra cortina llamada da Conda a la otra parte del río término del mismo pueblo"; a lo que acceden con ciertas condiciones, entre ellas poder utilizar el agua de la presa para el riego de sus $\operatorname{prados}^{1544}$.

\footnotetext{
1544 AHPL. PN.: caja 11390 (año 1834): Condiciones:

"Primera que D. Nemesio ha de dar el agua suficiente para el riego de la porción de cortina que queda a la parte de avajo del cauce, entre este y el río, entendiéndose este riego solo para ortalizas y de ningún modo para praderas, ni otro uso, señalando para este riego el día miércoles de cada semana de los meses de junio, julio y agosto de cada un año y no en otros, con la condición de que los que usen del riego, al obscurecer han de cerrar el conducto o albañal de suerte que buelba el agua al cauce principal y no haciéndolo así ha de pagar al criado de la fábrica o persona que baya a hacerlo, y además del día señalado han de poder regar los arrendatarios o posehedores en los días festivos que ocurran en la semana ynclusos los domingos, y a las mismas horas, con la misma obligación de cerrar el cauce o albañal.

"Segunda: que siendo diferentes los prados que toman el agua por devajo de la azuz o tapacuña, que la ha de dirigir a la fábrica, siempre que el río sobrante de aquella no llebe la bastante para suministrar de riego la precisa para el de los prados, se obliga el D. Nemesio a dar de su presa la bastante para el efecto, abisando para esto al que esté en la fábrica para
} 
La ferrería debió construirse a finales de ese año o, probablemente, a comienzos del siguiente, periodo en el que su propietario adquiere numerosas parcelas de monte en sus inmediaciones, en la Portela y Sotogayoso, y hasta en Vega de Valcarce ${ }^{1545}$, sin duda para poder abastecerla de madera y carbón. Madoz dice que los montes de este pueblo de la Portela están poblados de arbustos de roble y brezo y que cuenta con una ferrería ${ }^{1546}$. La vena provenía de Formigueiros a cuyo dueño pagaba de foro 400 reales anuales 1547.

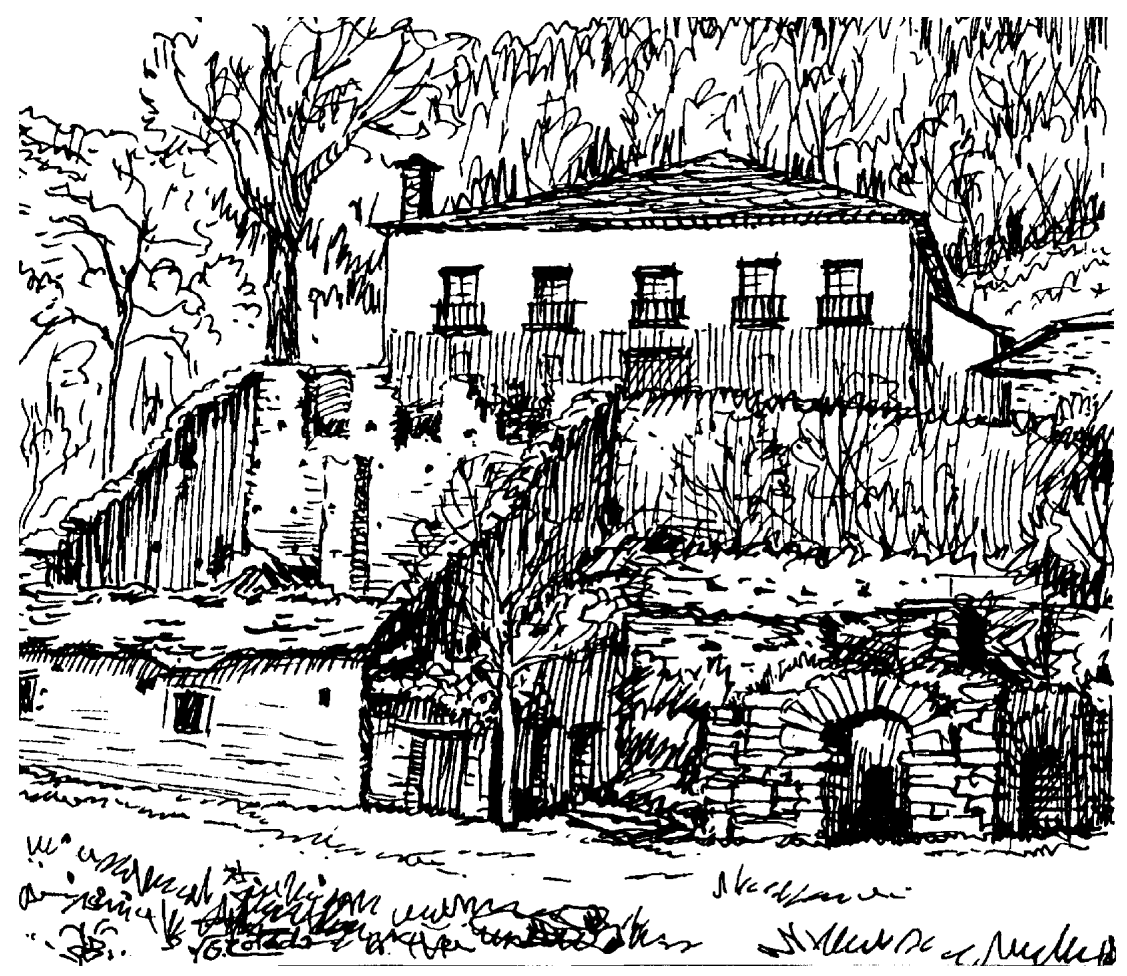

Ferrería de La Portela (dibujo de P. G. Cotado)

La magnitud de esa ferrería se puede deducir por sus restos, pero también por los 220.000 reales en que se tasa su valor en el inventario bienes de Nemesio Fernández de 1859, el más alto de las cinco que posee ${ }^{1548}$; la ferrería

que mande echar la que sea suficiente, y caso de no hacerlo podrán los posehedores de los prados hacerlo por si berificándolo tan solo por la compuerta designada para este efecto". ${ }^{1545}$ Así: en 1834 compra a Manuel Gómez y Josefa España en Vega de Valcarce por valor de 4.370 Rs. (AHPL. PN.: caja 11390); en 1836 adquiere al concejo de Soto Gayoso una dehesa, denominada de Villarinos, de 4 fanegas pobladas de robles, en 400 rs. (AHPL. PN.: 3712); en 1849 compra a Manuel González, de Soto Gayoso, varias tierras, en 835 rs. (AHPL. PN.: 3712). 1546 MADOZ, P.: Ob. cit., p. 240. 1547 GARCIA TATO, I. (2000): Ob. cit. p. 168 1548 AHPL. PN.: caja 2724 (año 1859) 
contaba además con un martinete al lado1549. Con la de Corporales pasó en 1859 a las nietas del dicho Nemesio, Agueda y Petra, casadas con Francisco de Soto Vega, de Villafranca, y Adriano Quiñones, de Ponferrada; pues su madre Isabel había fallecido años antes. Estos cuñados, que heredarían en 1868 las ferrerías gallegas de Valdomir y Ferreirós de su suegro Rafael Armesto, las debieron explotar conjuntamente por medio de administradores. Adriano Quiñones además era copropietario de la ferrería de Pontepetre.

La ferrería estaba en funcionamiento todavía en 1890, año en que compraba el mineral de Formigueiros, a boca mina, a 0,27 pts. el quintal métrico; pagaba de portes 2,17 pts/q. y vendía el hierro fabricado a 43,50 pts. el quintal. El coste por todos los conceptos eran de $37 \mathrm{pts} / \mathrm{q}$, , por lo que sus dueños obtenían una ganancia de 6,50 pts/quintal 1550 .

ESTADO: En parte están desmantelados los tejados de lo que fueron carbonera y fragua, pero se conservan en un buen estado la magnífica mansión de sus propietarios, las caballerizas, el molinos y la estructura general de la ferrería propiamente dicha, con el banzao, banzadillo y fragua. La nueva autovía del Noroeste la ha cercado, e incluso destruido algunos de sus elementos.

\section{MUNICIPIO DE VILLAFRANCA DEL BIERZO}

\section{LA FERRERÍA DE LA SOMOZA}

LUGAR: Soto de la Somoza (Paradaseca)

AYUNTAMIENTO: Villafranca del Bierzo

RÍO: Burbia

COORDENADAS: $42^{\circ} 41^{\prime} 25^{\prime \prime} \mathrm{N}$. y $6^{\circ} 46^{\prime} 20^{\prime \prime} \mathrm{W}$.

El Burbia nace en la Sierra de Ancares, entre Peña Longa y el Mostellar. Su curso alto, antes de abrirse paso por el desfiladero que lo conduce hasta

1549 IBIDEM: Inventario de Nemesio Fernández (1859): "una herrería y a su lado un martinete surtido con las mismas aguas que la herrería".

${ }^{155^{\circ}}$ CAMARA DE COMERCIO DE LEÓN (1957) Economía Leonesa. Pequeña historia de su evolución 1907-1957. León. Desconozco la fuente de dónde han tomado estos datos, pues no la citan, por lo que no los puedo contrastar. 
Villafranca, ya en la hoya del Bierzo, se conoce con el nombre de Merindad de la Somoza. Es esta una tierra pobre, montañosa y deshabitada; pequeñas aldeas mal comunicadas conservan aún vestigios de sus antiguas viviendas, las pallozas, y de una peculiar transhumancia del valle a las brañas, como en Aira da Pedra y Campo de Agua, desaparecida en las últimas décadas del siglo XX.

A la entrada del valle, en la margen izquierda del río, bajo el soto de la Leitosa y frente a Paradaseca y Vegueliña, se construyó en la primera década del siglo XIX la ferrería de la Somoza, que algunos llaman de Godoy. Puede accederse a ella desde Vegueliña, atravesando el puente y recorriendo por un camino la zona de murias y prados que está debajo de la Leitosa; también se llega por la carretera que sube hacia Paradiña, tomando una desviación a la izquierda por un camino de tierra pero transitable para vehículos.

Más que una ferrería, como las tradicionales en el Bierzo, fue un proyecto de fábrica de hierro, construida en la margen izquierda del Burbia. Son visibles, aunque desmantelados y en estado ruinoso, los restos grandiosos de un complejo industrial que nunca llegó a funcionar; pero del que todavía subsisten paredones de las viviendas y oficinas, así como los muros de la propia fábrica, el banzadillo para las ruedas hidráulicas e incluso un horno de calcinación de la mena, algo insólito en la comarca.

Su construcción está íntimamente relacionada con la destrucción de las fábricas de armas de Eugui y Orbaiceta (San Sebastián), en la guerra contra la Francia revolucionaria (1793-1795), y con la paralización de los hornos altos de Liérganes y la Cavada (Santander), por falta de combustible. El gobierno de Carlos IV, que buscaba emplazamientos más adecuados y mejor protegidos para la construcción de nuevas fábricas, envió al teniente coronel Francisco Javier Datoli al Bierzo para estudiar las posibilidades de esta comarca. La tradición herrera y sus bosques habían sido muy valorados por el presbítero don Vicente de la Granja, quien había insinuado al gobierno la construcción en Villafranca de una fábrica de armas ${ }^{1551}$.

${ }^{1551}$ BALBOA DE PAZ, J. A. (1992): El Bierzo en la obra de dos militares del siglo XVIII: Datoli y Munárriz. Ponferrada, 191 pág. Todos los datos de este epígrafe están tomados de este libro mío. 


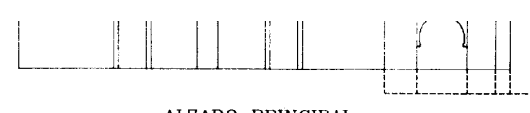

ALZADO PRINCIPAL

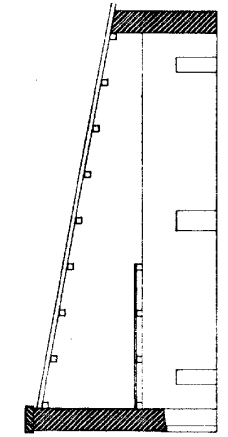

SECCION POR OFICINA DE TIRAR EL HIERRO

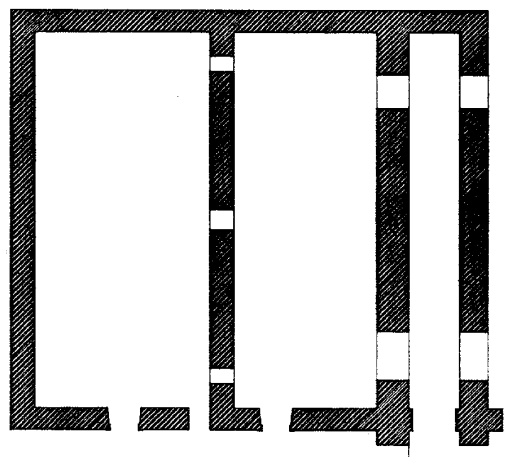

PLANTA GENERAL

Escala gráfica

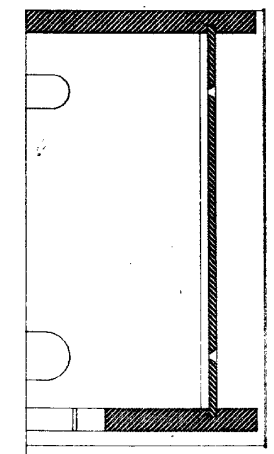

SECCION POR DEPARTAMENTO DE MOTOR HIDRAULICO

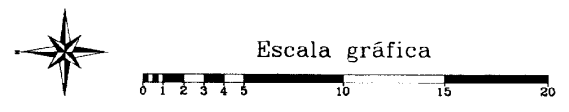

FWIRIEEFIA DE IA SOMOZA

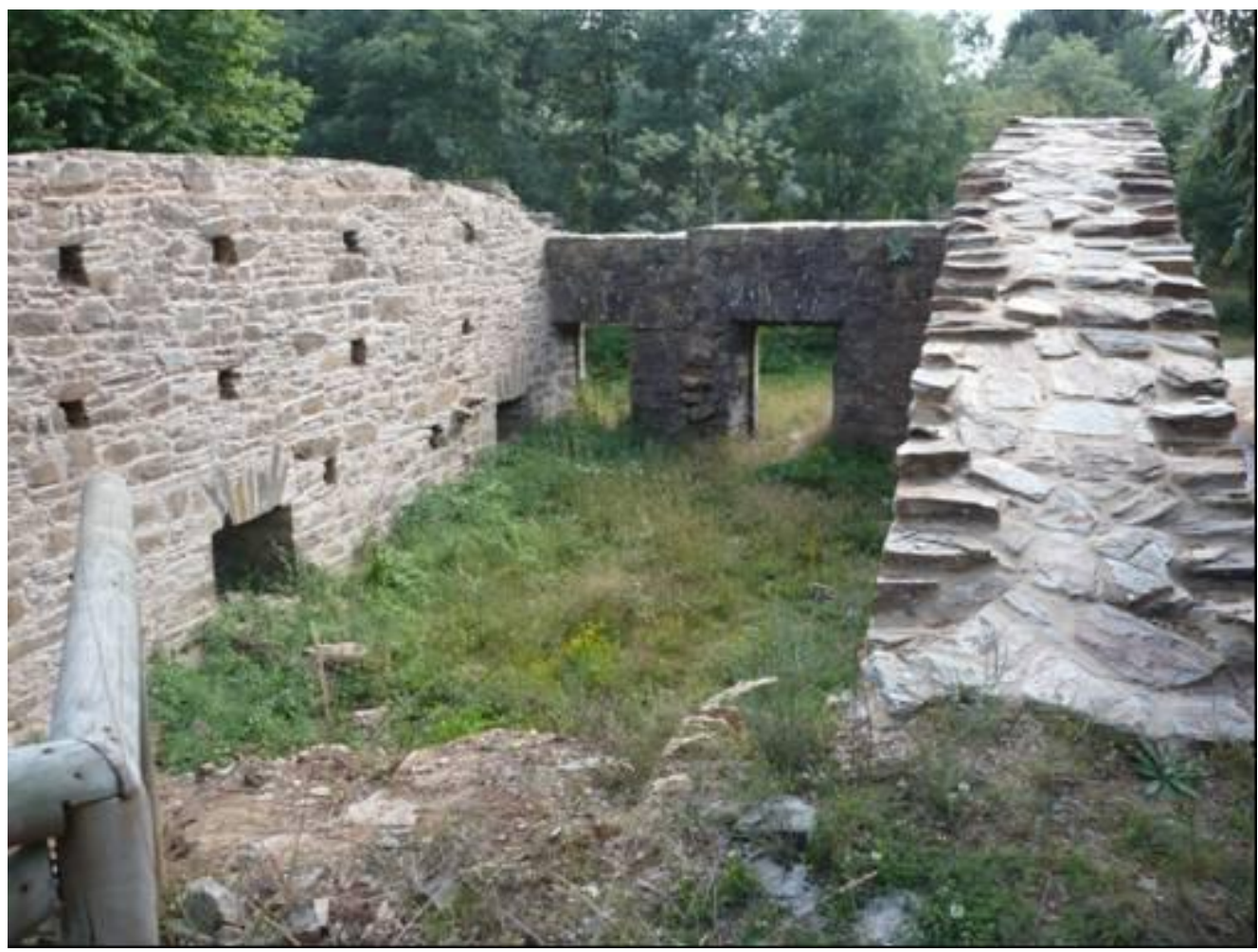

Ferrería de La Somoza

Las conclusiones de Datolí fueron desfavorables, aunque valoró positivamente el edificar una ferrería para surtir de este material a las fábricas de armas de Oviedo y Mieres; pues en Asturias no se conocían aún buenas 
minas de hierro y el de Somorrostro podía encontrar dificultades para su transporte en tiempos de guerra: "Mas si por cuenta de la Real Hacienda se construyera la herrería indicada en el partido de la Somoza, acerca de la qual trataré más adelante, produciría el hierro necesario para el surtido de la Fábrica, que podría salir en aquella a 25 maravedís la libra, y en los almacenes de la Fábrica a 32 maravedís; de lo qual resultaría un beneficio de $7^{1 / 2}$ reales en el precio de cada fusil, o de 90.000 rreales en cada año, con lo que resarciría el real Erario en 4 años el capital invertido en su construcción” ${ }^{552}$.

La rentabilidad de la operación parecía asegurada, así como su evidente interés para solucionar el abastecimiento de hierro a las fábricas de armas de Asturias. El autor, bien informado, señalaba incluso el lugar más adecuado para su construcción, en las cercanías de Vegueliña, en la jurisdicción de la Somoza; pues además de su mayor cercanía a Asturias, contaba con agua y madera abundantes, sin el peligro de otras ferrerías en los alrededores con las que tuviera que competir en materias primas y energía. Por último, Datoli adelantaba en su informe el coste de las obras de dicha fábrica que, según el maestro de obras villafranquino Pedro Landejuela, podría calcularse en unos 350.000 reales 1553 .

El informe de Datoli sería apoyado por el Director General de Artillería en un escrito de 8 de enero de 1798 al Secretario de Hacienda, don Juan Manuel Alvarez. Repite en él los mismos argumentos esgrimidos por Datoli, señala idéntico lugar de ubicación y coste de las obras; añadiendo además el interés que dicha ferrería tendría para la fábrica de armas, el Erario y para los propios habitantes del Bierzo. Por estas razones, "exige que se adopte el partido que resulta del reconocimiento ya expresado, y es el que se establezca por cuenta de S.M. la enunciada ferrería en el mencionado parage o en otro, si se halla más ventajoso y económico en las conducciones de materiales"1554. Solicita, al mismo tiempo, que se envíe nuevamente a Datoli para que complete, con un

1552 IBIDEM, p. 52

1553 IBIDEM. p. 60.

1554 IBIDEM, p. 82. 
estudio más exhaustivo, el proyecto, incluyendo cálculos exactos, planos de la ferrería y otras dependencias, y su coste.

Estas razones prendieron en el ánimo del gobierno que, pese a las dificultades financieras, aprobó el proyecto de construcción. Se encargó de ello el coronel Juan Manuel Munárriz que, desde junio de 1804, se encontraba en el Bierzo realizando una investigación para establecer una fábrica de pólvora en el Bierzo, en el pueblo de Quilós. Munárriz llegaría a ser un buen conocedor de esta tierra y de sus gentes. Fruto de sus estudios será un largo memorial, redactado años más tarde, que tiene un enorme interés para el conocimiento de la siderurgia berciana en el siglo XVIII ${ }^{1555}$. Era además un hombre de grandes conocimientos mineralógicos y químicos ${ }^{1556}$, de ahí la confianza del gobierno en su persona. Sin duda, este militar hubiera podido modernizar, como ocurriría más tarde con el general Elorza en Asturias, el obsoleto mundo de la siderurgia berciana, pero los avatares de la Guerra de la Independencia arruinaron también este proyecto.

De acuerdo con Datoli, Munárriz propuso como lugar más adecuado para la construcción de la nueva fábrica un terreno de enorme extensión, propiedad del cabildo de la colegiata de Villafranca, en la margen izquierda del río Burbia, a la altura del pueblo de Vegueliña, en el partido de la Somoza. La Somoza era una jurisdicción o merindad perteneciente al cabildo de Villafranca, en el curso alto del Burbia. Tenía entonces, según Munárriz, 370 vecinos repartidos en 10 lugares, de los que era capital Paradaseca; cifras que me parecen inexactas, pues según el Catastro de Ensenada de 1752, la merindad de la Somoza alcanzaba los 619 vecinos, es decir algo más de 2.000 habitantes. Pese a la crisis económica y demográfica de finales de siglo, en esos años la población no debía de bajar de los 2.000 habitantes ${ }^{1557}$. La pobreza de este valle, rodeado de ásperas montañas, nos ha sido dramáticamente descrita por este autor ${ }^{1558}$.

$1555 \mathrm{El}$ informe de Munárriz se perdió, pues no se encuentra en el expediente de la fábrica. Lo publicó en 1928 el general GÓMEZ NUÑEZ, S.: EL general de Artillería don Juan Manuel Munárriz y la siderurgia berciana en el siglo XVIII. Madrid, 1926. También lo publiqué en mi libro BALBOA, J. A. (1992): El Bierzo en la obra de dos militares del siglo XVIII: Datoli y Munárriz.

${ }^{1556}$ Para la vida y obra de Munárriz, ver las obras citadas en la nota anterior.

1557 BALBOA, J. A. (1994): “El antiguo Régimen”. En Historia del Bierzo. IEB, p. 86.

${ }^{1558}$ BALBOA, J. A. (1992): Ob. cit. p. 148-150. 
A las razones de Datoli, Munárriz añade otra de gran interés para la ubicación de la fábrica en la Somoza: la existencia de mineral de hierro. En el informe de Datoli, esta ferrería se abastecería del mineral de Formigueiros por ser el de mejor calidad y, pese a la distancia de nueve leguas, el más cercano relativamente. Por lo menos, decía este autor, hasta que no se encontrase otro más cercano. Munárriz lo halló en la misma Somoza, con la ayuda del mineralogista Thalacker, del Real Gabinete de Historia Natural de Madrid, que pasó seis meses en el Bierzo, hasta diciembre de 1807, estudiando diversos minerales de la zona. Fueron varios los lugares de la Somoza en los que hallaron yacimientos de hierro, pero sobre todo tenía interés el de la Mirandela, a media legua de la fábrica. Aunque las pruebas que se practicaron con él en la ferrería de Valcarce fracasaron, por un error de los carreteros que lo mezclaron con otro, Munárriz señala que era de buena calidad. La guerra impidió la realización de nuevas pruebas para saberlo con exactitud, pero posiblemente estaba en la cierto, pues este yacimiento es un afloramiento del actual coto minero de San José.

Para levantar el edificio se buscó una zona relativamente llana y espaciosa en aquel estrecho valle, que se encontró a los pies del soto de la Luctuosa o Leitosa, ingente explotación aurífera de época romana, a las orillas del río Burbia, a la altura del pueblo de Vegueliña o más exactamente de uno de sus barrios: Ribón, que se halla enfrente, pero al otro lado del río. Según Munárriz tenía 28.992 brazas de superficie, es decir, unos $50.000 \mathrm{~m}^{2}$, solar más que suficiente para levantar la ferrería y los edificios para vivienda y oficinas, aunque con algunos inconvenientes, al ser zona de frecuentes avenidas del río, sobre todo en años de lluvias abundantes.

El plano y el presupuesto de las obras fue encargado al arquitecto Fernando Domínguez. De acuerdo con el informe del teniente coronel Fernando Saravia, que la visitó en 1815, la fábrica se componía "de dos edificios o casas terreras, separadas como unos 20 pasos, formando martillo. El edificio principal, construido de cal, canto y cubierto de piedra de pizarra, tiene 32 varas de largo, 13 de ancho y 4 de altura; se divide en varias piezas o 
aposentos destinados al director y al pagador de la fábrica, taller de carpinteros y herreros y otros para el mejor servicio y comodidad de la fábrica (...). El segundo edificio, construido del mismo material que el anterior, forma un cuadrado de 20 varas de lado y $5^{1 / 2}$ de altura; está dividido en dos partes, una destinada para carbonera (...); y la otra, destinada para oficina de tirar hierro" ${ }^{1559}$. Todavía hoy es posible hacerse una idea del conjunto de sus construcciones por los restos conservados.

El 6 de abril de 1805 recibió Munárriz la orden del Director General de Artillería para que dieran comienzo las obras de la fábrica, al tiempo que le enviaba 28.000 reales para atender a los primeros gastos; adelantándose, de este modo, a la Real Orden de 3 de julio de ese año por la que se aprobaba la construcción de la fábrica de hierro de la Somoza, fecha en la que igualmente se le remitían a Munárriz 280.0oo reales que, por Real Orden de 4 de abril de 1804, provenían "de residuos del auxilo prestado por la Real Fábrica de paños de Guadalajara" 1560 .

Al mismo tiempo, se trasladaba la orden al Secretario de Despacho de Gracia y Justicia para que previniese al cabildo de la colegiata de Villafranca y a los pueblos de la Somoza "de lo infundado de su oposición a tan útiles establecimientos, y a que serán tenido por enemigos del bien de su país, y tibios en la obediencia del Soberano, siempre que no presten los auxilios convenientes a su creación y fomento" ${ }^{1561}$. Si a esta orden se añaden las reiteradas sugerencias hechas a Munárriz de que mostrase mucha moderación en su relación con los naturales de la zona, parece claro que entre éstos existe un evidente rechazo hacia su construcción. Este rechazo, como muy inteligentemente dirá años más tarde Saravia, no podía ser obra de los campesinos de la Somoza; porque, como antes los de Ancares (valle en el que se había construido una ferrería en 1788), sabían perfectamente el interés que para ellos suponía contar con una ferrería en su propia tierra, pues "estos aldeanos, aunque ignorantes y rudos, no suelen serlo en asuntos de intereses, debemos

1559 CARRASCO, A. (1889): "Fábricas artilleras de Villafranca del Bierzo". Memorial de Artillería, tomo XII, serie 4, p. 132

${ }^{1560}$ IBIDEM, p. 121

${ }^{1561}$ IBIDEM, p. 122 
creer que alguna mano oculta, interesada en arruinar este establecimiento, los dirige y hace obrar de modo contrario a sus verdaderos intereses" ${ }^{562}$.

El rechazo a la construcción de la fábrica venía, más que del cabildo, que aunque renuente al fin se avino a aforar el terreno en 100 reales de renta anual, de los propietarios de las otras ferrerías existentes en el Bierzo; pues en su lógica conservadora, la nueva ferrería se convertiría en un duro competidor, por su más adecuada tecnología y por sus precios inferiores, como con gran intuición había previsto Datoli: "La construcción de esta herrería sería siempre en beneficio del Real Erario porque en el caso que encontrando en este Principado de Asturias mineral a propósito, se construyera otra más inmediata para proveer la fábrica, se venderían en aquella (la de la Somoza) los hierros, que tendrían más estimación que los de las otras del país"1563. Entre los enemigos declarados de la fábrica, Munárriz nombra al marqués de Villagarcía, vecino de Villafranca e individuo perteneciente a la Junta Superior de Galicia en la Guerra de la Independencia. Este rechazo es comprensible si sabemos que este marqués era el dueño de una de las ferrerías cercanas, la de Visuña, establecida en el curso alto del Selmo, ya en el límite gallego.

En los días en que se llevaba a cabo la redacción del proyecto y los trámites con el cabildo de Villafranca, la Administración nombraba definitivamente los cargos directivos de la fábrica. La dirección era encomendada a Munárriz; al capitán Jesualdo López Sahajosa se le nombraba oficial al detall, cargo que en 1807 ocuparía el también capitán Francisco Macía y posteriormente el teniente Mateo Chardenoux; comisario de la fábrica a Antonio Unome y tras él a Francisco Manzano; por último, como pagador y guarda-almacén al sargento Bartolomé Maseras ${ }^{1564 .}$

Antes de iniciar las obras se realizaron varios estudios y consultas, con la intención de construir una ferrería de acuerdo con los adelantos técnicos de la época. Tanto los cálculos de Datoli como los de Munárriz nos muestran unas intenciones dirigidas a la construcción de un tipo de ferrería diferente a las

${ }^{1562}$ IBIDEM, 133

1563 BALBOA, J. A. (1992): Ob. cit. p. 53.

${ }^{1564}$ CARRASCO, A. (1889): Ob. cit., p. 135 
entonces existentes en el Bierzo. Datoli piensa en los modelos vascos: "Esta herrería, hecha de la magnitud de las de Vizcaya y Guipúzcoa y manejada por operarios hábiles, produciría un año con otro 1.500 quintales machos ó 9.300 arrobas de hierro, según resulta del cotejo del mineral de Formigueiros con el que tienen en dichas provincias; cuya cantidad no solo es suficiente para construir 12.0oo fusiles al año, sino también para fabricar el acero necesario para ellos, que podría fabricarse por cuenta de la misma fábrica, y para construir los instrumentos precisos para el uso de ellas"1565. Munárriz, a su vez, piensa que en una primera fase la fábrica ha de fundir 5.000 quintales de mineral de hierro con 12.000 cargas de carbón con los que elaborar 2.100 quintales de hierro, destinados a abastecer la fábrica de fusiles de Oviedo y la Maestranza de la Coruña ${ }^{1566}$. Estos quintales son casi el doble de los que producía una ferrería normal que, según el Catrasto de Ensenada o Datoli, se encontraba en torno a los 1200/1500 quintales de cinco arrobas ${ }^{1567}$.

Para realizar esos planes, Munárriz reune la más completa información de que es capaz, enviando a Pedro Nieva, cabo de carreteros de la Maestranza de Segovia, a inspeccionar varias ferrerías de Guipúzcoa; o solicitando informes sobre las ferrerías que el duque de Granada poseía en las provincias vascongadas. El mismo Munárriz se traslada en esos primeros meses a la fábrica de hierro de Sargadelos, fundada varios años antes por Raimundo Ibañez y que contaba entonces con gran renombre entre los metalúrgicos 1568 . Por último, solicita incluso a la Administración que se le envíe el modelo de la ferrería de Iraeta, llamada de Caquizano que, diseñado por la Real Fábrica de Placencia, se conservaba en el Museo de Artillería. A toda esta información oficial, Munárrriz añade la colaboración desinteresada de expertos en el tema, como la del villafranquino Carlos García Alvarez, que había sido director segundo de las

\footnotetext{
1565 BALBOA, J. A. (1992): Ob. cit., p. 60 y 61.

1566 CARRASCO, A. : Ob. cit. p. 121

${ }^{1567}$ BALBOA, J. A. (1992): Ferrerías bercianas. Madrid, p. 38 y ss.

1568 CASARIEGO, E. (1950): El marqués de Sargadelos o los comienzos del industrialismo capitalista en España. Instituto de Estudios Asturianos. Oviedo. P. 181 y ss.
} 


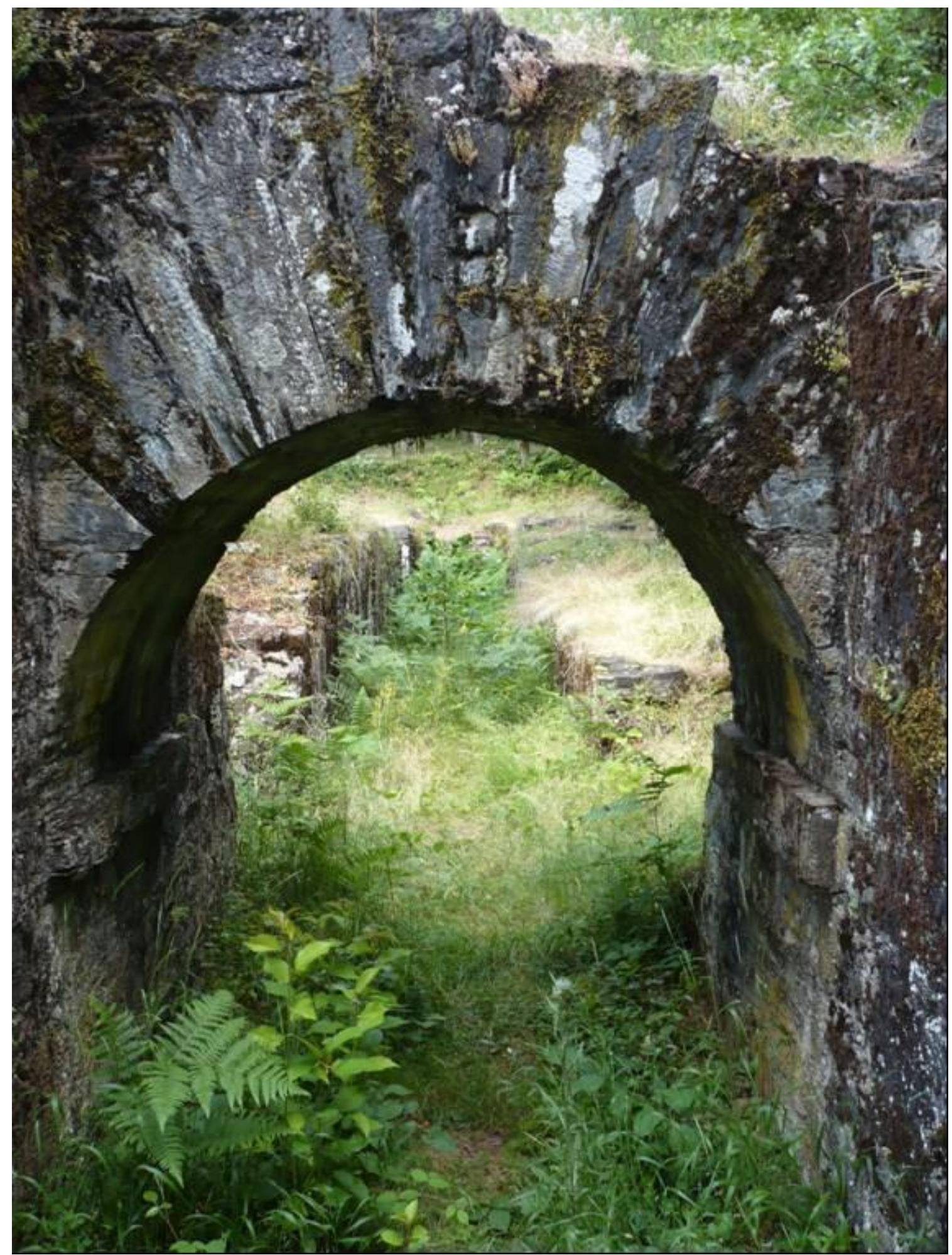

Banzadillo de la ferrería de La Somoza

minas gallegas de Monterrey o la de José Antonio Ojea, director de la ferrería de Iraeta que le aconseja sobre la utilización de trompas catalanas o barquines para 
inyectar aire al horno1569. Toda esta información y los restos del horno que todavía permanecen en pie son suficientes para afirmar que el objetivo de Munárriz no era construir una nueva ferrería, sino un horno alto. Esta puede ser la razón que explique la hostilidad concitada contra él por los dueños de las restantes ferrerías bercianas, tanto durante su construcción como posteriormente.

Las obras comenzaron en el mes de agosto de 1805, con casi cuatro meses de retraso sobre la fecha prevista, porque no se encontraban obreros capacitados para la ejecución de las mismas, pese a los edictos colocados en Lugo, Astorga, León y Ponferrada ofreciendo trabajo a dichos especialistas. En enero, cuando se llevaba una gran parte de la obra ya levantada, una violenta riada causó graves daños en la misma, evaluados en 14.000 reales. A estos daños se añadieron otros inconvenientes a causa del suelo poco firme en el que se asentaban los edificios y a la construcción de unos albergues provisionales para cobijar a los trabajadores en aquel descampado. Incluso para cumplir con el precepto religioso se instaló una capilla de campaña traída de Orbaiceta, solemnemente inagurada el día de San Fernando; nombre que Munárriz propuso para la fábrica, a lo que Godoy se opuso por razones obvias.

Se trabajó durante 1806 y 1807 con una lentitud exasperante, sucediéndose constantemente los problemas de todo tipo, humanos y técnicos. Canteros y carpinteros no llegaban al Bierzo hasta el mes de marzo, suspendiéndose los trabajos hacia noviembre o cuando las inclemencias del tiempo así lo aconsejaban. El terreno, como hemos señalado, era además poco firme. Para solucionar este problema tuvo que venir de Madrid un arquitecto, pero faltaba el aparejador capaz de llevar adelante el proyecto. Por fin, en julio de 1807, Raimundo Ibánez, propietario de Sargadelos, accedió a enviar uno de su propia fábrica para realizar los cimientos, cuyo coste ascendió a 20.000 reales, a los que hubo que añadir 18.000 más por el arreglo de la presa, que se había hundido con la riada de enero de 1806. En noviembre de 1807 se habían construido 36.048 pies cúbicos de mampostería, faltando todavía para su terminación otros 31.488 pies. En la primavera siguiente se reanudaron las

1569 CARRASCO, A: Ob. cit., p. 126 
obras y, cuando éstas estaban prácticamente ultimadas, se inició en Villafranca el levantamiento de 1808.

La Junta Local de Villafranca manda entonces suspender las obras, exigiendo la entrega de los fondos para adquirir armamento, a lo que el coronel Munárriz se niega hasta no recibir la orden de la Junta de Galicia. Poco después, el mismo Munárriz es destinado para llevar el mando de la Primera División de Artillería del Ejército de Blake, no sin antes hacer un inventario de los bienes, encargando al mismo tiempo trasladar la caja de caudales, con 18.000 reales, a la casa del Administrador de Rentas de Villafranca para su protección. En la fábrica quedarán el pagador, un peón, el guardabosques, y dos artilleros de la Comandancia de Vigo que, con otros dos y un cabo que residían en Villafranca para relevarles, constituirán el destacamento encargado de la vigilancia de la misma.

La Guerra de la Independencia llega al Bierzo en los meses finales de 1808 y en los primeros días de 1809, con su secuela de robos y devastaciones. En esto, ingleses y franceses compiten con igual salvajismo. Las tropas francesas en persecución del general Moore llegan al Bierzo en enero de 1809, entablando batalla el día 3 en el pueblo de Cacabelos, en la que moriría el general Colbert ${ }^{1570}$. El 4 están en Villafranca a la que saquean impunemente ${ }^{1571}$. En el saqueo son robadas la documentación y la caja de caudales de la fábrica. No son sólo ingleses y franceses. Aprovechando la confusión y el desorden, pueblos enteros o campesinos a título particular intentan romper sus vínculos ancestrales con señores y monasterios ${ }^{1572}$. La fábrica de hierro, protegida por las montañas, sufre desperfectos pero no excesivamente graves.

Cuando acabe la guerra, el teniente coronel Saravia informa a sus superiores, en 1815, sobre los desperfectos de la fábrica durante los años de aquélla, finalizando su informe en los siguientes términos: "Creo deber hacer la advertencia, que algunos de los naturales de este país y pueblos inmediatos a

\footnotetext{
1570 GONZÁLEZ, F. (1987): Retirada de Moore y batalla anglofrancesa de Cacabelos. Ay. Cacabelos, p. 38. ${ }^{1571}$ IBIDEM, p. 47-48.

${ }^{1572}$ BALBOA DE PAZ, J. A. (1997): El monasterio de Carracedo. León, p. 79 y 80.
} 
la fábrica han mirado con ojeriza el establecimiento, y desde su fundación, y particularmente durante la revolución, no han perdido ocasión de destruir todo cuanto era dependiente de este establecimiento, hasta tener los vecinos de un pueblo llamado Paradiña la osadía de imponer una contribución de vino al que no fuese a cortar leña en uno de los bosques inmediatos al establecimiento, creyendo de este modo podrían hacer que, careciendo de combustible, tendrían que abandonar la fábrica. También me han asegurado que el principal daño ocasionado a la presa ha dimanado de algunas piedras y maderos arrancados maliciosamente por algunos individuos, todo con el fin de destruir el establecimiento"1573. Sin embargo, Saravia no achacaba estos destrozos a los campesinos sino a manos ocultas que los instigaban, como anteriormente hemos dicho.

En su informe, Saravia hace una descripción de la fábrica que ya hemos citado. A excepción de la presa, con graves destrozos, el resto se hallaba en buen estado, por lo que el coste de sus reparaciones podía ser pequeño; por ello, terminaba diciendo: "Si este establecimiento lograse su perfección, parece sería el más ventajosamente situado para abastecer de hierro a la maestranza de la Coruña con una utilidad de los intereses del rey. En efecto, causa lástima que este edificio, después de hallarse casi al punto de ser concluido y estando en el día bien conservado, se abandonen las ventajas que, sin duda, se propuso su director cuando esta obra se planteó y puso en ejecución, haciendo infructuosos los crecidos gastos que indispensablemente debe haber tenido el rey para ponerlo en el estado en que se halla"1574. Nadie escuchó estas juiciosas recomendaciones. La fábrica y todos sus bienes fueron incautados por Hacienda, suponiendo erróneamente que eran parte de las propiedades de Godoy; pues como Director General de Artillería había firmado las órdenes para su construcción. En 1822, el Ministerio de la Guerra la reclamó al de Hacienda que, tras muchos expedientes, la devolvió el 28 de junio de ese mismo año. Empero, nada se hizo a excepción de un nuevo informe sobre su estado, firmado por José Villada, en el que da cuenta de la situación ruinosa de la misma1575.

\footnotetext{
1573 CARRASCO, A.: Ob. cit. p. 133

1574 IBIDEM: Ob.cit., p. 134-135

1575 IBIDEM: Ob. cit., p. 137
} 
En 1832, después de casi diez años de silencio absoluto, volvió nuevamente a plantearse el dilema sobre su propiedad, entre los ministerios de Hacienda y Guerra. Se hizo un último estudio por la Junta Económica de la Maestranza de La Coruña, sobre su posible viabilidad, pero se decidió que no tenía sentido una rehabilitación tan costosa para su escaso interés, proponiendo en su lugar la enajenación definitiva de la misma, lo que se hizo por Real Orden de 18 de mayo de 1833, sacándola a pública subasta y adjudicándosela al mejor postor, siempre que la oferta no bajase de los 2/3 del precio de tasación1576. A partir de entonces se pierden sus noticias, y con ellas, el lento desmoronamiento de toda la edificación.

ESTADO: De las viviendas solo hay algunos restos, pero se conserva bien la ferrería, especialmente el banzadillo y el conjunto, vacío y sin techumbre, de la forja y carboneras. Muy cerca hay un horno de calcinación en buen estado.

1576 IBIDEM: Ob. cit., p. 138. 


\section{PROVINCIA DE LUGO}




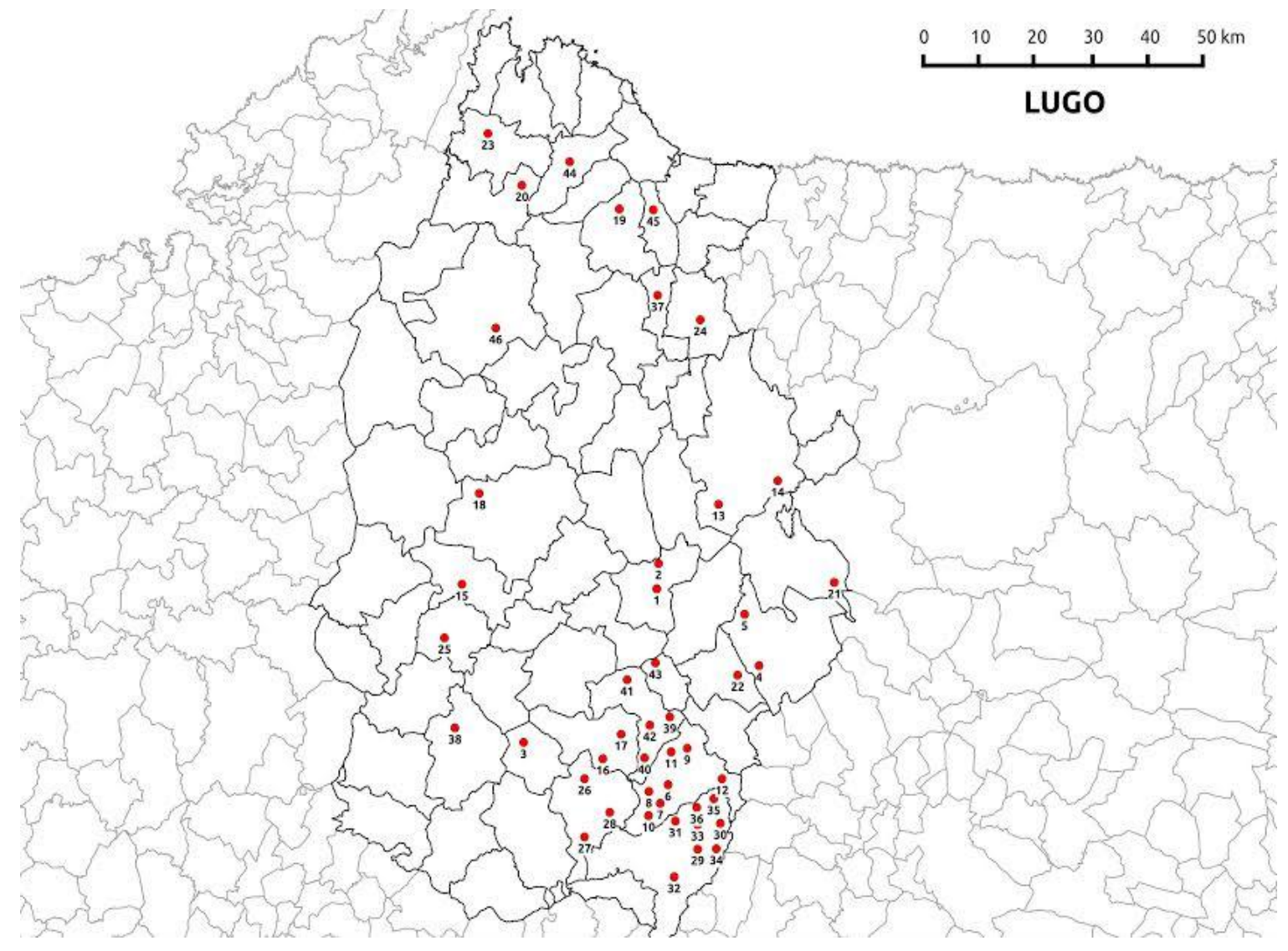

FERRERÍAS DE LUGO 


\title{
1. MUNICIPIO DE BARALLA
}

\section{FERRERÍA DE NEIRA DE REY}

\author{
LUGAR: Neira de Rey \\ MUNICIPIO: Baralla \\ RÍO: Neira \\ COORDENADAS: $42^{\circ} 55^{\prime} 45^{\prime \prime}$ N. y $7^{\circ} 17^{\prime} 4^{\prime \prime} \mathrm{W}$.
}

Se encontraba en la parroquia de San Martín de Neira de Rey, a orillas del Neira. A lo que aún resta de la ferrería se puede llegar desde Baralla, capital del municipio de Neira de Jusá, por la carretera que va a Meira: primero está San Miguel y luego San Martín, parroquias de Neira de Rey. Además de como "Ferrería de Neira de Rey" se la conocía también por el nombre de "Ferrería de Pereyriña"1577. Según Hernández Sampelayo, estaba construida sobre la roca, que es aquí una pizarra con organismos fósiles ${ }^{1578}$.

En la zona de Neira de Rey, enclavada en los criaderos de hierro de Cereixido ${ }^{1579}$, hubo actividades siderúrgicas desde la Edad Media'580; luego sabemos de la existencia de varios mazos ${ }^{1581}$, pero la ferrería no se construyó hasta finales del siglo XVIII, pese a que hubo proyectos anteriores. Según Eugenio Larruga, don José Quiroga y Armesto, vecino de la casa y granja de Otero, que poseía dos martinetes -en realidad eran de su mujer, $\mathrm{M}^{\mathrm{a}}$ Luisa Taboada y Gayoso- solicitó en el año 1752 facultad para descubrir minas de hierro con las que abastecer una nueva herrería que intentaba establecer en el valle de Neyra del Rey. "Suplicó también se le concedieran varias prerrogativas dirigidas al surtimiento de la mencionada herrería, y prohibición para otros

\footnotetext{
1577 AHPLU: 2377/1 (1847).

${ }^{1578}$ HERNÁNDEZ SAMPELAYO, P. (1935): Hierros de Galicia, t. II, p. 503

1579 IBIDEM, p. 494

${ }^{1580}$ En el siglo XII se menciona una ferrería en la cercana parroquia de Constantín, que pertenencía al monasterio de Sobrado. E. PORTELA y M.C. PALLARÉS (1979): "Os mosteiros, protagonistas da colonización e do proceso da señorialización na Galicia medieval: o exemplo do mosteiro de Sobrado". Estudis d'historia agraria, 2, p. 63: "Sobrado posuía e explotaba a mina de ferro de Pedrafita, e nas suas proximidades creou a granxa de Constantín, onde instalou una forxa para a fundición e transformación do metal, traballo para que o mosteiro contaba cun equipo de ferreiros entre os servos que posuía”. Esta Pedrafita que se menciona no es la del Cebrero sino la que está un poco más arriba de Neira de Rey por la carretera de Meira.

${ }^{1581}$ Según E. Larruga, desde muy antiguo, hubo aquí varios mazos: dos en la aldea de Bustos y uno en la vecina de los Mazos. Dos de ellos eran de don José Quiroga y Armesto.
} 
de los materiales de leñas, venas y demás. Pidió también se le diera libertad a la apertura de caminos, rompiendo tierras, granjas y montes... prohibiendo que otro alguno pudiese fabricar herrería ni martinete en dos leguas en contorno del valle de Neyra referido" ${ }^{1582}$. Se solicitó al gobierno y justicia de La Coruña información sobre varios extremos de dicho proyecto, el cual emitió sendos informes, cuyo resumen fue que se seguirían forzosamente graves perjuicios y ninguna ventaja al país, que ya contaba con suficientes ferrerías ${ }^{1583}$.

Estos informes coincidían, en cierto modo, con las denuncias de los vecinos del coto de Córneas, que pusieron pleito en $1755^{1584}$. Al parecer don José Quiroga, en el expediente, ocultó información a las autoridades, como por ejemplo que los vecinos del valle de Ouselle y Cancelada ya se habían opuesto anteriormente a la pretensión de don José Erbón de construir, en 1739, otra ferrería a media legua de distancia del lugar en el que pretendía levantar don José Quiroga la suya 1585. Las razones que alegan los vecinos de Córneas, coincidentes con los informes del gobierno de La Coruña, es que ya existen muchos artefactos en la zona, y no hay combustible para todos, siendo ellos los perjudicados por la falta de leñas ${ }^{1586}$.

\footnotetext{
${ }_{1582}$ E. LARRUGA (1800): Memorias políticas politicas y económicas sobre los frutos, fábricas, comercios y minas de España. Vol. XLV, Madrid, p. 333 y ss. 1583 IBIDEM

${ }_{1584}$ AHPLU: 6709/14 (1755). El 5 de abril de 1755, el procurador general, el juez y los vecinos del coto de Córneas, dijeron "haber llegado a su notizia que D. Joseph Quiroga, vecino de la casa de Neyro, jurisdicción del mismo nombre y de los cotos de Horbán y Chan de Lena, se transfirió su residencia a la que tiene en el valle de Neyra de Rey pretendiendo por este medio edificar una Herrería, para la que con siniestra relazión y amaño ganó zédula de Su Magestad, que Dios Guarde, ocultando la oposición que antes de aora han echo los vezinos y procurador general de la jurisdicción del valle de Ouselle y Canzelada de Abajo".

${ }_{1585}$ AHPLU: 6709/14 (1755): "Para la que con siniestra relazión y amaño ganó zédula de Su Magestad, que Dios Guarde, ocultando la oposición que antes de aora han echo los vezinos y procurador general de la jurisdicción del valle de Ouselle y Canzelada de Abajo a otra que en el mismo sitió yntentó fabricar D. Joseph de Erbón, vecino de la casa de Ribas, feligresía de San Pedro de Cadolla, a distanzia de media legua de la otra; por lo que consiguieran en primera ynstancia se recojiese la que a este fin se le despachó, y en segundo lugar se hallan opuesto de nuebo al Nuebo Recurso que el sobredicho yntentó por la sala y secretaría de la Real Junta de Comercio y Moneda en el pasado año de 1739, por seguirles grabe perjuizio en sus montes, arboles que produzen..."

1586 AHPLU: 6709/14 (1755). En los alrededores hay "dos mazos en la Borriqueyra yncluidos en el distrito de dicha jurisdicción de Ouselle, que son de D. Joseph de Erbón, otros quatro en la de Neyra de Rey, los dos y medio de D. Pedro de Santiso y D. Pedro Osorio, y el uno y medio de dicho Quiroga, los quales se contempla su consumo quasi el de las Herrerías". Por ello, la nueva ferrería causará daños a todos ellos y a las ferrerías "que ay en la zircunferencia en dicho distrito de la que pretende edificar el nominado D. Josep Quiroga y a legua y media la que intentó D. Josph Erbón se alla otra corriente nombrada de Bueis, que es de D. Luis de Ulloa...”.
} 
No sé si la protesta surtió efecto y si los vecinos consiguieron paralizar las obras, ya que no conozco ninguna mención a la existencia de la ferrería en el siglo XVIII. Sólo sé que en 1798 se intentó de nuevo levantar en el mismo sitio otra fábrica de hierro, pues "un cavallero poderoso del país y dueño de la casa de Basille, las de Frayán y Barbeitas" se proponía "abrir una zanja de considerable largo, ancho y profundidad en los términos del lugar de San Martín con el objeto de conducir desde el río Navia a la distancia de quatro o cinco mil varas de situación costanera, pedregosa e ynascesible que parece imposible su construcción con obgeto de hacer un famoso prado y herrería de considerable ynterés y aumento de su patrimonio"1587. Para llevar a cabo su proyecto "fixó además edictos públicos con las combocatorias mas formales ofreciendo a todos satisfazer su travajo por regulacion que se hiziese de él en los destajos que tomasen, o les abonaría sus jornales y herramientas"1588. Una vez realizada la obra, sin embargo, los trabajadores no recibieron la remuneración ofrecida, por lo que lo llevaron ante los tribunales ${ }^{1589}$.

Si lo llevaron a los tribunales hecha la obra de la zanja, hay que suponer que ésta se destinaba a la ferrería. Creo que en el texto debe haber un error, y que el canal se hizo desde el Neira o quizá desde alguna fuente pero no desde el Navia, porque eso no parece una obra practicable ${ }^{1590}$. Hacia 1804, Lucas Labrada aún no tiene noticia de esta ferrería ${ }^{1591}$; pero Madoz probablemente sí, ya que señala que en este concejo había dos ferrerías en Neira de Rey y tres martinetes y una ferrería en Neira de Jusá1592, lo que quiere decir que existía y que funcionaba hacia 1845. Como vamos a ver, era de don Juan María de Quiroga, dueño de las casa de Orbán, y por tanto heredero de aquel don José

\footnotetext{
${ }_{1587}$ AHRG. Vecinos: leg. 9214/ 43

1588 AHRG. Particulares: leg. 11837/14

${ }^{1589}$ SAURÍN, Ma R. (1983): Reforma y reacción en la Galicia del siglo XVIII (1764-1798). La Coruña, p. 43

1590 AHRG. Real Audiencia: 22.459/4. En el año 1803 se suscita un pleito de los vecinos de San Esteban de Neira de Jusá contra el señor de la casa de Basille, don José Manuel Gómez, por el uso de aguas que éste usaba para su "Prado da Coba". El agua provenía de dos fuentes la de la la Carbela y la de Ferreiros que llegaban hasta el mencionado prado, y él no quería dejársela usar. ${ }^{1591}$ LABRADA, L.: Ob. cit., p. 145 habla de los valles de Neira de Rei y Neira de Jusá, de los que solo nombra la existencia de 41 telares.

${ }^{1592}$ MADOZ, P: Ob. cit., t. XII, p. 152
} 
Quiroga. Este don Juan María en 1836 solicita explotar una mina de hierro en Vilares, en el valle de neira de rey, probablemente para esta ferrería ${ }^{1593 .}$

En 1847 este don Juan María, como dueño de la "Herrería de la Pereyriña, sita en el valle de Neyra de Rey", recuerda que "hace más de un año tiene conferido poder a D. Marco Vázquez de Triacastela para que le administrase, cuidase y reparase la fábrica de fierro mencionada de la Pereyriña, bienes y rentas de Neyra de Rey (...) ordenándole por separado varias veces (...) cuidase de los acopios de bena, carbón y más artículos indispensables con el objeto de que no cesase de trabajar un solo día la Herrería y prosperase todo lo posible"; pero como no lo hizo así, da ahora su poder a Alejandro Díaz Rosón para que en unión de José Parcero le tome cuentas del tiempo que administró la fábrica, además de nombrarle a él en dicho cargo, "para que pueda administrar la citada fábrica, bienes y rentas de Neyra de Rey, contratar oficiales, bena, carbón, etc.” 1594 .

Según Hernández Sampelayo, por referencias recogidas de campesinos de la zona, se llevó de Quintá de Pousada gran cantidad de mineral, entre 1850 y 1860, a las ferrerías de San Martín de Neira de Rey1595. Pero desde los años sesenta no se vuelve a mencionar.

ESTADO: No se conservan más que muros reaprovechados en construcciones posteriores.

1593 BOP de Lugo, ${ }^{0} 33$ de 24 de abril de 1836: "Don Guillermo Schulz (...) hago saber que por D. Juan María Quiroga, señor de las casas de Orbán, Basille y otras de Galicia, vecino de la ciudad de Lugo, se ha pedido la concesión legal de una mina de hierro descubierta por el mismo, y sita á orillas del arroyo Vilares inmediato al lugar de este nombre, en términos de San Martín del valle de de Neira de Rey, en esta provincia de Lugo". 1594 AHPLU: 2377/1 (1847).

1595 HERNANDEZ SAMPELAYO, P. (1931): Ob. cit. t. II, p. 494 


\title{
2. FERRERÍA DE PIAGO
}

\author{
LUGAR: Papín (Penarrubia) \\ MUNICIPIO: Baralla \\ RÍO: Neira \\ COORDENADAS: $42^{\circ} 55^{\prime} 27^{\prime \prime}$ N. y $7^{\circ} 12^{\prime} 3$ ” W.
}

Muy cerca de Neira de Rey, por la misma carretera de Baralla a Meira, se encuentra la parroquia de Penarrubia, en una de cuyas aldeas, la de Papín, se ubica la ferrería de Piago, también llamada de Penarrubia o Papín.

Como hemos visto al hablar de la ferrería de Neyra de Rey, hacia 1739 don José Erbón, vecino de la casa de Ribas en la feligresía de San Pedro de Cadoella (Becerreá), propietario de dos mazos ${ }^{1596}$, intentó construir una ferrería, a la que se opusieron los vecinos de la jurisdicción del valle de Ouselle y Cancelada1597, que lograron impedirla por dificultades en proveerla y abastecerse ellos de combustible. Por esa razón, en dicha parroquia el Catastro de Ensenada de 1753, sólo menciona "un mazo que sirve para estender hierro nombrado da Veiga, al sitio del mismo nombre, pertenece a Juan Fernández y consortes, trauaja con el agua del río Neira las dos terceras partes del año. Regulan de utilidad en cada uno ciento y sesenta y quatro reales de vellón"1598. No existía, por tanto, ninguna ferrería.

A finales del siglo XVIII, en una coyuntura diferente, un descendiente de don José Erbón tendría más suerte con sus vecinos y sí lograría levantar, por fin, una ferrería. En julio de 1797 los vecinos de varios lugares de la parroquia de Santiago de Fontaneira, en la jurisdicción de Neira de Rey, reconocieron ante notario que don Vicente María Pardo Erbón y Rivadeneyra, señor de la casa de Ribas, en el valle de Oselle, y su socio don Ramón de Ulloa y Valcarce, dueño de

\footnotetext{
${ }^{1596}$ Ver nota 398

${ }^{1597}$ AHPLU: 6709/14 (1755): Menciona la oposición que "antes de aora han echo los vezinos y procurador general de la jurisdicción del valle de Ouselle y Canzelada de Abajo a otra que en el mismo sitió yntentó fabricar D. Joseph de Erbón, vecino de la casa de Ribas, feligresía de San Pedro de Cadolla, a distanzia de media legua de la otra; por lo que consiguieran en primera ynstancia se recojiese la que a este fin se le despachó, y en segundo lugar se hallan opuesto de nuebo al Nuebo Recurso que el sobredicho yntentó por la sala y secretaría de la Real Junta de Comercio y Moneda en el pasado año de 1739, por seguirles grabe perjuizio en sus montes, arboles que produzen..."

1598 CATRASTRO DE ENSENADA: R. G.: Penarrubia.
} 
la casa de la Peña, en la jurisdicción de Neira de Rey, intentaban "construir de nuevo una Erraria en terreno suio propio, en el río Neira y sitio denominado da Retorta, términos del lugar de Papín, feligresía de Santa María de Peñarrubia inclusa en esta dicha jurisdición”. Por ello, añaden, les solicitaron permiso para erigirla "en atenzión a que el sitio referido da Retorta, su zircunferencia y a mucha distancia ay número crezido de montes poblados de Brezo, zepa o coza para su surtido, consumo reproduzible a pocos años de su arranque que no sirven para frutificar ni tienen otra utilidad". Permiso que ellos les conceden "para que puedan hazer y fabricar la mencionada Erraria disfrutando la leña o coza de los montes en que respectivamente son partizipes", porque así no tendrían que ir lejos a vender el carbón y tendrían hierro en abundancia ${ }^{1599}$.

La ferrería debió, por tanto, construirse y funcionar. Probablemente es a ella a la que se refiere Madoz ${ }^{1600}$, aunque esto no lo sabemos; pero Hernández Sampelayo, por referencias recogidas de campesinos de la zona, afirma que de Quintá de Pousada se llevó gran cantidad de mineral, entre 1850 y 1860, a las ferrerías de San Martín de Neira de Rey ${ }^{1601}$, lo que quiere decir que había más de una, es decir, la de Neira de Rey y la de Papín. Desde los años sesenta no se vuelve a mencionar.

ESTADO: No se conservan restos.

\footnotetext{
1599 AHPLU: 6792/2 (1797). Los vecinos de otros lugares de la misma parroquia añaden que si no tendrían que desplazarse muy lejos, por ejemplo llevando "a veneficiar (el carbón) semanalmente a la ziudad de Lugo distante más de zinco leguas, mazos de Orizón y otras partes".

${ }_{1600}$ MADOZ, P. : Ob. cit., t. XII, p. 152

${ }^{1601}$ HERNANDEZ SAMPELAYO, P. (1931): Ob. cit. t. II, p. 494
} 


\section{MUNICIPIO DE BÓVEDA}

\section{FERRERÍA DE PENACOVA}

LUGAR: Penacova, parroquia de San Juan de Remesar MUNICIPIO: Bóveda

RÍO: Penacova

COORDENADAS: $42^{\circ} 40^{\prime}$ o8” N. y $7^{\circ} 30^{\prime} 36^{\prime \prime} \mathrm{W}$.

La ferrería queda a orillas del Penacova, pequeño afluente del Mao, que a su vez lo es del Cabe. Se llega por la carretera de Monforte a Sarria, poco después de Bóveda, en Rubián, hay que desviarse hasta Teilán.

La ferrería se construyó hacia la mitad del siglo XVIII, aunque no la nombra el Catastro de Ensenada, lo que podría indicar que se hizo poco después de 1753. En torno a ese año don Juan Francisco Arias Quiroga y Losada, señor de la casa de Maside, "ganó en su vida foro y permiso de la excelentísima $D^{a}$ Rosa María de Castro, condesa de Lemus, terreno para fabricar una ferraria que en efectó erigió y fabricó en la situación de Penacoba términos de la parroquia de san Juan de Remesar, en la jurisdición de la Somoza Mayor de Lemus de su señorío, y en el mismo foro la referida señora otorgó a favor de D. Juan Francisco Arias la cesión, uso, goce y aprovechamiento esclusivo de las leñas y carbones que los montes del término de la expresada jurisdicción y la de Paradela su agregada del propioseñorío tuviesen"1602. Con este foro solicitó al Supremo Consejo de Castilla y a la Junta General de Comercio, Moneda y Minas licencia, que le concedió, para construir la citada ferrería, con lo que comenzó a trabajar.

Los problemas con el carbón debieron de ser una constante en esta ferrería, pues las querellas y los juicios se suceden desde 1769 en adelante. En ese año, don José Arias Enríquez, hijo del fundador, presentó una querella ante el corregidor de Monforte contra varios vecinos de la parroquia de San Juan de Remesar y de la Somoza, "carboneros de oficio", porque en lugar de vender sus

1602 AHRG. R. A.: 19.877/30 
carbones a ésta lo hacían a la de Viduedo y otras cercanas, por su mejor precio. Parece que la querella surtió efecto y no hubo más problemas hasta 1809 en que nuevamente ante el corregidor de Monforte, doña María Teresa Quiroga y Prado, viuda de don Antonio Arias Quiroga, nieto del fundador, hubo de poner una nueva querella, que por un par de años zanjó la cuestión; pues otra vez en 1811 tuvo que llevar a varios vecinos del coto de Acebedo y otras jurisdiciones cercanas por la misma causa ${ }^{1603}$.

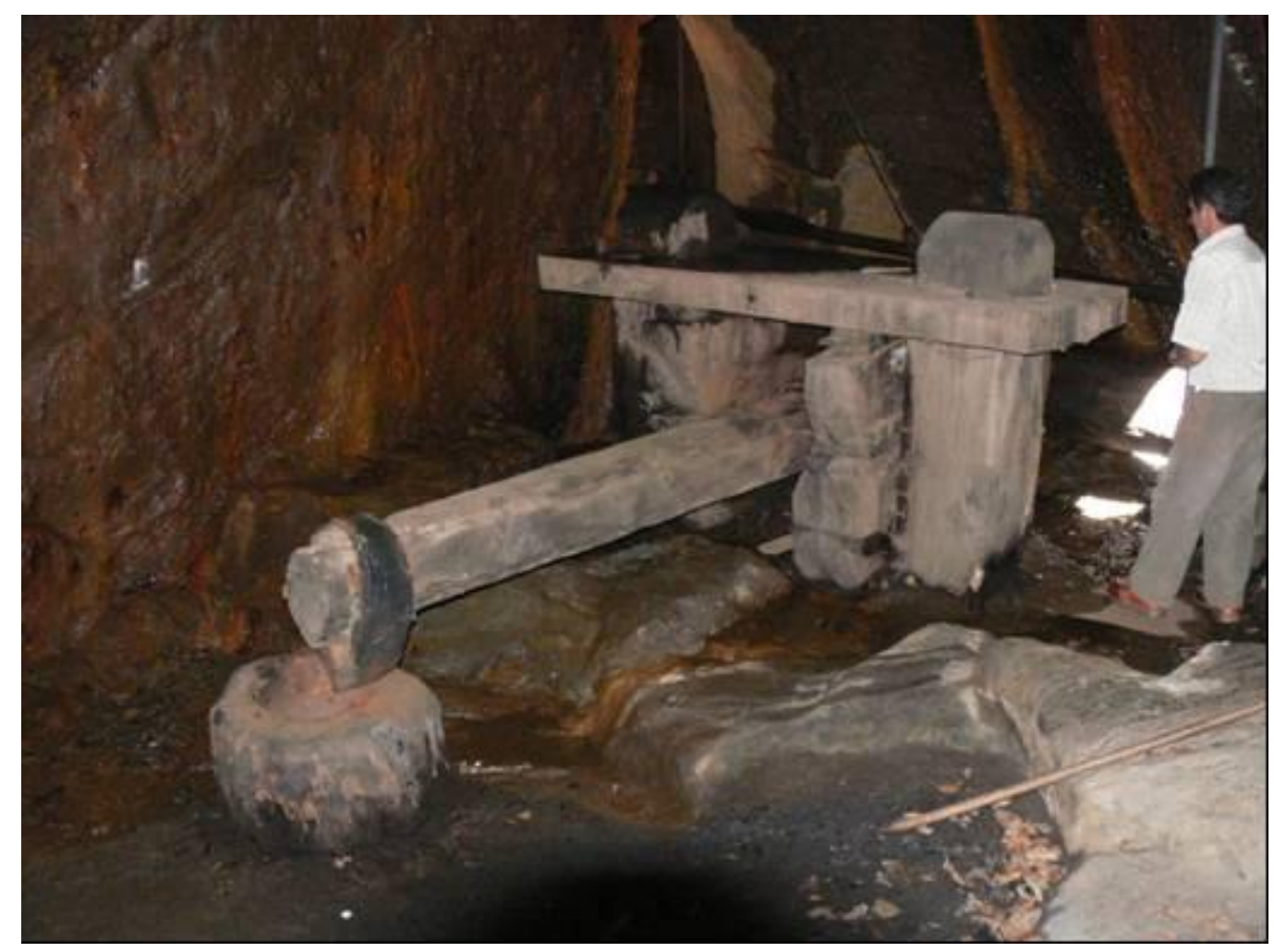

Mazo de la ferrería de Penacova

La ferrería parece que era llevada en arriendo. Antes de 1811 su arrendatario fue don Enrique Salcejama, y en ese año los hermanos Domingo y Juan Teijelo. Según Cornide Saavedra, que la ubica en Santa Eulalia de Teilán, la ferrería producía al año 550 quintales de hierro con vena del yacimiento de Rocas ${ }^{1604}$; pero al parecer utilizaba también mineral de la zona ${ }^{1605}$. Lucas Labrada menciona en la jurisdicción de la Somoza mayor "una herrería en la

1603 AHRG. R. A.: 19.877/30 1604 CORNIDE: ob. cit.

1605 AHRG. R. A.: 19.877/30 
que se benefician hasta 50 quintales de hierro al año"1606. Miñano dice que la ferrería pertenecía a la casa de Maside ${ }^{1607}$. Aunque Madoz años después solo habla de "herreros"1608, según José Villa-Amil, hacia 1866 seguía trabajando, con una producción aproximada de 600 arrobas anuales ${ }^{1609}$. Debió continuar como mazo hasta el siglo XX.

ESTADO: La ferrería, que forma parte de una acogedora Casa Rural, se ha reconstruido con ayuda de la Xunta de Galicia. Conserva una magnífica chapacuña de lajas de pizarra que elevan el agua casi seis metros sobre el cauce; éste está excavado en roca, lo mismo que el banzao. La ferrería también está excavada en la roca, de ahí su nombre; el banzadillo se ha reconstruido en madera; el mazo y los barquines, que mueven dos ruedas hidráulicas, son más pequeños que los originales. También se conservan las carboneras.

\section{MUNICIPIO DE CERVANTES}

\section{FERRERÍA DE FONQUENTE}

LUGAR: Vilarello de la Iglesia

MUNICIPIO: Cervantes

RÍO: Cales

COORDENADAS: $42^{\circ} 47^{\prime} 03^{\prime \prime}$ N. y $6^{\circ} 58^{\prime} 49^{\prime \prime} \mathrm{W}$.

Quedaba muy cerca del castillo de Doiras, en la parroquia de Vilarello de la Iglesia, lugar éste donde se encuentra la casa de los Saavedra.

La ferrería de Fonquente no existía en el siglo XVIII. Según el Catastro de Ensenada había en esta parroquia de Vilarello dos mazos: "ai dos mazos de hierro que baten con agua del río y dos ruedas todo el año, y el uno de ellos se halla al sitio referido dos Canzillós. Pertenece a Juana González y Agustín

1606 LABRADA, L. : Ob. cit., p. 148

1607 Citado por C. GONZÁLEZ (1994). Ob. cit., p. 143.

1608 MADOZ, P.: Ob. Cit., t. IV, p. 425

1609 J. VILLA-AMIL (1866): Crónica General de España. Provincia de Lugo. Madrid., p. 45 
Fernández, y el otro se alla al sitio de Doiras, bate todo el año, perteneze metad de el a Domingo López y la otra metad a Santiago Lombardía y Martín Freijo y regulan el producto de cada uno dellos e cada un año en mil reales de vellón"1610. Son los mazos de Doiras y Cancillós.

Carlos Antonio García Álvarez, vecino de esta parroquia, solicitó en 1802 permiso a la Junta de Comercio para construir una ferrería "en la jurisdicción y coto de Vilarello de la Yglesia en sitio inmediato a la puente de la Veiga del Seijo en terreno inculto, estéril y común”. Creía que siendo la tierra estéril, los vecinos pobres y el monte abundante en uz, la ferrería hecha "con los mayores ensanches que le sean posibles" sería un factor de desarrollo y mejora de las condiciones de la vida de los lugareños. Pensaba utilizar vena de Formigueiros y de minerales descubiertos por el solicitante en la Somoza, en el Bierzo ${ }^{1611}$. Sin embargo, hubo una fuerte oposición por don José María de Tineo, propietario de la cercana ferrería de Bueyes, pero no pudo conseguir su propósito pues la ferrería efectivamente se construyó, aunque son escasas las noticias sobre ella $^{1612}$.

Madoz menciona en Vilarello "ferrerías", pero no tenemos más datos ${ }^{1613 .}$

ESTADO: No hay restos.

\section{FERRERÍA DE SAN MARTÍN DE RIBERA}

LUGAR: San Martín de Ribera

MUNICIPIO: Cervantes

RIO: Navia

COORDENADAS: $42^{\circ} 53^{\prime} 42^{\prime \prime}$ N. y $7^{\circ}$ o3' $50^{\prime \prime} \mathrm{W}$.

\footnotetext{
1610 CATASTRO DE ENSENADA. R. G.: Vilarello

${ }^{1611}$ AGS. Junta de Comercio y moneda, leg. 295

${ }_{1612}$ C. GONZÁLEZ (1994): Ob. cit., p. 146. La Junta de Comercio y Moneda le concedió permiso para erigirla y le permitió beneficiarse de algunas ventajas ya concedidas antes a Antonio Andrés Bravo, como poder beneficiar hierro vasco y la licencia para importar maquinaria de fuera. Idem, p. 236.

1613 P. MADOZ.: Ob. Cit., t. XVI, p. 83
} 
Ignoro si se trata efectivamente de una ferrería o simplemente de un proyecto que no llegó a efectuarse, por más que en 1752, cuando don José Quiroga y Armesto pretendía construir una ferrería en Neyra de Rey, se citan otras dos ferrerías en San Miguel y San Martín. En el informe que se solicita al gobierno de La Coruña se pregunta "Si los dos martinetes que tenía y administraba por si en la jurisdicción de Neyra de Rey, provincia de Lugo, y si en una o en ambas de las dos ferrerías de San Miguel y San Martín, de dicha jurisdicción, don Josef Xavier de Quiroga, distaban quatro leguas de las ferrerías más inmediatas a los expresados martinetes"1614. Del texto se deduce que este José Quiroga era propietario -y lo era efectivamente por su mujer- de los dos martinetes de aquella jurisdicción, que estaban situados uno al lado del puente de Neyra del Rey y otro a unas 40 o 50 brazas más arriba, sobre el río Neira. Sin embargo, no está clara la propiedad de las dos ferrerías mencionadas, sin suda las de San Martín de Ribera y la de Pereyrúa, que tal vez no eran más que proyectos o simplemente eran igualmente mazucos.

Respecto a la de San Martín sabemos que en los últimos años del siglo XVIII don José Gómez Bermúdez, señor de la casa de Basille, proyectó construir una ferrería en San Martín de la Ribera, en la jurisdicción de Cervantes. Pretendía traer el agua del río Navia por un canal que tendría de 4.000 a 5.000 varas de longitud, entre 3,5 y 4 kilómetros aproximadamente, por un terreno escabroso y accidentado. Colocó carteles en las parroquias vecinas, como era usual, anunciando la obra para atraer interesados en su realización. Fueron muchos los lugareños que se presentaron para hacer un canal, que debió terminarse en unos meses del año 1798; pero el propietario, por razones que desconocemos, no se lo pagó.

En junio de 1798 varios de estos trabajadores presentaron una queralla ante la Audiencia de La Coruña, en la que estos operarios recuerdan cómo don José Gómez Bermúdez "entabló el proyectó de construir una dilatada, ancha y profunda zanja, por situación tan escabrosa, pendiente y peñascosa en término de dicho San Martín, que parecía poco menos que imposible su construcción, para por ella sacar un crecido caudal de agua, que con pretesto

${ }^{1614}$ E. LARRUGA: Ob. cit., t. XLV, p. 334 
de hacer un gran prado, oy demuestra, que además de ello yntenta construir una Herrería conduciendo el agua de la de el Río Navia a la distancia de más de quatro o cinco mil varas"1615. Al tiempo que lo acusan de deberle los destajos que habían realizado.

La zanja hecha por los denunciantes, en la zona más difícil y rocosa, tenía 474 varas de largo, por 3 ó 4 varas de ancho y otras tantas de profundidad. Durante varios años se siguió el pleito, por el que aquellos querían que se les pagase el mismo salario que entonces cobraban los que habían trabajado en las obras de la carretera de Madrid a La Coruña. Entre los peritos, a los que se solicitó su testimonio, se encontraba el ingeniero berciano Diego de Ochoa, que valoró aquellas 474 varas en 14.000 reales ${ }^{1616}$

ESTADO: Desconocido

\section{MUNICIPIO DE COUREL}

\section{FERRERÍA DE FERREIRÓS}

LUGAR: Ferreirós de Abajo (Parroquia de Santa María de Folgoso)

MUNICIPIO: Courel

RÍO: Arroyo de Ferreirós

COORDENADAS: $42^{\circ} 36^{\prime} 32^{\prime \prime}$ N. y $7^{\circ} 10^{\prime} 26^{\prime \prime} \mathrm{W}$.

La ferrería se encontraba en el pueblo de Ferreirós de Abajo, a la derecha de la carretera de Folgoso a Seoane, justamente por donde hoy pasa ésta, y a orillas del arroyo de Ferreirós, que es un afluente del Lor. Un documento de 1575 la denomina como ferrería "de las Cortellas de Ferreirós"1617.

La ferrería existía ya en el siglo XVI dado que conocemos una escritura de 9 de septiembre de 1564, que menciona a Juan Beltrán de Achega como rendero

\footnotetext{
1615 AHRG. R. A.: $11.837 / 14$

${ }^{1616}$ AHRG. R. A.: 11.837/ 14. Sobre Diego de Ochoa: V. FERNÁNDEZ (1999): Diego de Ochoa (1742-1805). Arquitecto y académico de San Fernando. Ponferrada.

1617 AHRG. R. A.: 26.179/54
} 
de ella, y de la que a su vez era administrador Juanes de Ibarreta ${ }^{1618}$. Este Juan Beltrán de Achega fue también rendero de la de Gondriz en los años setenta de ese siglo, y posteriormente en 1581 nuevamente lo encontramos como arrendatario de Ferreirós. Como arrendatario de Gondriz, en 1576, contrató con el venaquero vizcaíno Juan de Ormazábal que le arrancase 1.500 quintales de la venera de Rocas a precio de quince maravedís y medio el quintal. Al parecer no le pagó lo debido, por lo que cuando aquél, como rendero de Ferreirós, iba en 1581 con "quatro cargas de fierro y herrage a bender a la feria de Orense", Juan Ormazábal se lo impidió. En el pleito, los testigos admiten que el venaquero había cumplido su compromiso con los 1.500 quintales de vena, pero no debió ser así; porque cuando Juan Beltrán afirma que le pagará cuando termine de llevar la vena -ahora a la ferrería de Ferreirós-, Ormazábal contesta que ésta se encuentra muy lejos del venero de Rocas y que Ferreirós utiliza vena de Formigueiros y no de Rocas ${ }^{1619}$, dato cierto como veremos más adelante.

La ferrería era propiedad, probablemente por foro de la encomienda de la Barra, de Juan Pérez de Irazti, quien en junio de 1573 siendo rendero de las ferrerías de Valdomir y Ferreirós, arrienda esta última al vizcaíno Miguel Ortiz por cuatro años y renta de 120 quintales de hierro, la mitad grueso y la mitad delgado de vena de Formigueiros. Se la arrienda "corriente e moliente con todos sus aderezos e pertrechos de palancas e tinazas e martillos y herramientas buenas e malas (...) e con todas las casas a ella anexas e pertenescientes”. Como condiciones le impone el que la tenga, en los cuatro años, corriente y moliente, y que al cabo de ellos la deje libre y con todos sus pertrechos en buen estado; que si construyera un hórreo junto a la ferrería u otros edificios se los habría de pagar Juan Pérez o podría descontarlo de la renta; que dicho Pérez de Irazti debe arreglar por su cuenta el camino de la vena a Formigueiros, así como proporcionarle los veneros de dicho sitio ${ }^{1620}$. Unos meses más tarde, en octubre, muere Juan Pérez de Irazti quedando como propietaria su mujer Catalina de Armesto, como curadora de sus cuatro hijos: Pedro, Juan, Francisca y María.

1618 AHPL. PN.: caja 1488 (1564).

1619 AHRG. R. A.: 2.837/19

1620 AHRG. R. A.: 2.472/120 
El mencionado Miguel Ortiz "maestro de Errerias, rendero de la errería de feReiros que es en la tierra de Courel" se obliga a pagar en 1575 a don Iñigo de Cárdenas, comendador de la encomienda de la Barra, 1.200 reales por la compra de 70 anegas de centeno; y en 1576 el mismo Ortiz, pleitea con Pedro Vázquez de Allariz, vecino de Monforte, y con Virgilio da Costa, arrendatarios de los frutos de la encomienda de la Barra en los años 1563 a $1565^{1621}$. Como hemos dicho, probablemente la ferrería, al igual que otras de la zona, pertenecía a la encomienda de la Barra o al menos tenía en fuero el lugar y los montes de los que se abastecía ${ }^{1622}$.

Terminado el arriendo en 1577, Catalina de Armesto vuelve a arrendar la ferrería a su yerno Juan Beltrán de Achega (estaba casado con su hija Francisca) por otros cuatro años, aunque esto suscitará un pleito con Miguel Ortiz, el cual no quiere abandonar la ferrería alegando, como manifiestan algunos testigos, que Catalina no sacó dicho arrendamiento a pregón, como solía hacerse, sino que directamente la cedió al mencionado Juan Beltrán, cuando realmente había otros que pagarían diez o más ducados de renta que aquél1623. En 1578 seguía como rendero el vizcaíno Miguel Ortiz, quien estando en Ponferrada da poder a su yerno Juanes de Lasaca para que pueda cobrar en Cacabelos 100 quintales de hierro y 12.000 clavos $^{1624}$. Este Miguel Ortiz parece que fue también rendero de Valdomir y poco después, con su yerno, arrendarían al marqués de Villafranca, por cinco años, la ferrería de Valcarce ${ }^{1625}$. Pero la sentencia del juicio fue favorable a los Armesto; por eso, como hemos visto, en 1581 era arrendatario Juan Beltrán.

Entre 1582 y 1587 se menciona como rendero, probablemente como heredero del foro de su padre, a Pedro de Armesto de Yrazti, al que denuncia el

\footnotetext{
${ }^{1621}$ AHRG. R. A.: 26.179/54

1622 AHPL. PN.: caja 9113 (1868). Inventario de bienes de don Rafael Armesto y Arias: "Dicha Herrería de Ferreirós se halla grabada con la pensión anual de quinientos veinte y nueve reales, catorce maravedises, que antes perteneció a la Encomienda de la Barra, y habiendo comprado dicha pensión al Estado el difunto señor D. Rafael Armesto, pertenece hoy a este caudal, cuya pensión deben pagar todos los partícipes citados en dicha Herrería en proporción a la parte que cada uno representa"

1623 AHRG. R. A.: 2.472/120

1624 AHPL. PN.: caja 2849 (1578).

1625 AHPL. PN.: caja 2871 (1581).
} 
comendador de la encomienda de la Barra por entrometerse a labrar hierro en la ferrería de Valdomir, en la que también debía de tener una parte ${ }^{1626}$. En ese último año, Pedro de Armesto da su poder a Diego de Zuluaga, vecino de la ferrería de Loureiro, para que lo defienda en la partición de la mencionada ferrería de Valdomir ${ }^{1627}$. Este Pedro de Armesto debió morir hacia febrero de $1595^{1628}$ dejando tres hijos (María, Catalina y Pedro) y muchos acreedores, por lo que se realizó un concurso de acreedores, primero ante la justicia del Caurel y luego en la Real Audiencia de La Coruña. En 1597 se sentenció a pagar, de su herencia, algo más de 4.500 ducados a varios acreedores: 600 a Francisco López de Quiroga, 480 a Catalina de Armesto, 999 a Diego López del Valle, etc. ${ }^{1629}$. Hay varias documentos de obligación en relación con estas deudas que Juan Pérez y su hermana María Pérez, renderos de Ferreirós, se comprometen a pagar, una de estas obligaciones lo es por el fuero de la venera' ${ }^{1630}$.

Juan Pérez de Irazti, rendero de Ferreirós y hermano de Pedro de Armesto, como tutor de sus hijos, afirma en 1599 que Francisco López y Catalina de Armesto ya han cobrado, al tiempo que solicita al alcalde mayor de la Orden de Santiago que la deuda de 800 ducados (antes eran 999 ducados) "de los frutos que en arrendamiento cogió y gozó el dicho Pedro de Armesto" de los años 92, 93 y 94, que debe al licenciado Diego López del Valle, le rebaje 200 ducados y que el resto se lo pueda pagar en seis años "pues si se aze de los byenes que al presente ay de mis menores por ser en tyerra que al presente tyene la azienda poco valor" se le seguirán muchos perjuicios ${ }^{1631}$. El 8 de marzo de 1599 Gaspar

${ }_{1626}$ AHRG. R. A.: 2489/48

1627 AHRG. R. A.: 2489/48

${ }^{1628}$ AHPLU: 2407/9 (1596, enero). Gonzalo de Armesto dijo que Pedro de Armesto "cuya era la Eraria de Fereyrós se falleció podrá aber onze meses poco más o menos" y que lo dejó por albacea y tutor de sus tres hijos.

1629 AHPLU: 2547/1 (1599).

1630 AHPLU: 2407/9 (1596, 2 de diciembre). Ambos hermanos se obligan a pagar a don Antonio Nobo y Lemos "cuyo es el coto de Layosa" 143 ducados "los quales son por razón los mil e seiscientos reales dellos de resto de mayor cuantía (que exigió contra los bienes) que fincaron de Pedro de Armesto nuestro hermano por la renta atrasada de las beneras y ferrería de Ferreirós, en virtud de fuero que contamos el dicho don Antonio de la vena cruda questá frente de la dicha ferrería de Ferreirós tasada en los dichos 1600 reales, y los más reales a cumplimiento de los dichos 143 ducados son de renta desde presente año de noventa y seis de dichas beneras y ferrería y de otras quentas".

${ }^{1631}$ AHPLU: 2547/ 1. Esto lo corrobaron muchos testigos. Así Alvaro López, de Seoane, dice: "que sabe que en aberse de azer la entrega al presente se seguirá mucho daño a los dichos menores y sus bienes por ser la mayor parte de ellos raizes y baler a este tiempo muy poco por la gran aspereza y necesidad que ay en la tierra y aber muy pocos personas que los puedan 
de Salcedo, alcalde mayor de la Orden de Santiago en Castilla y León, Galicia y Asturias acepta la solicitud, y Juan Pérez se obliga a pagar en seis años los 600 ducados de la deuda ${ }^{1632}$. Por esos años se menciona también como rendero de esta ferrería a Juan de Arechaga ${ }^{1633}$, y entre 1600 y 1612 a Pedro Sánchez de Orozco "rendero de dicha ferrería de Ferreirós"1634, que era marido de María Pérez de Armesto, hija de Juan Pérez de Irazti y Catalina de Armesto "renderos que son de dicha ferrería y señores della"1635. En 1612 y en 1616 también lo era Antonio de Arechaga, hijo de Juan de Arechaga, e igualmente Juan Pérez de Irazti, todos miembros de la misma familia' ${ }^{1636}$.

Como vemos, en el siglo XVII la ferrería, como ocurrirá más tarde, estaba en varias manos, todos descendientes de Juan Pérez de Irazti y Catalina de Armesto1637. En 1641 conocemos a un Juan López "rendero en parte de la

comprar por cuya causa sabe el testigo lo abyan de tasar a muy baxo precio". Otro, Marcos López, también de Seoane, añade que "los byenes... no tienen el balor que solían".

${ }_{1632}$ AHPLU: 2547/1 (1599). Lo hace en unión de su hermana. Dicen que son hijos y herederos de Juan Pérez derrazti y de Catalina de Armesto "renderos que fueron de la dicha ferrería (de Ferreirós)", difuntos. Dijeron que quedaron herederos de todos sus bienes muebles y raíces, ferrerías, deudas y otras cosas, que asimismo Juan Pérez es tutor de las personas y bienes de los hijos de Pedro de Errazti y Armesto, rendero de dicha ferrería de Ferreirós "a los quales bienes ubo y ay pleito... por razón de que el dicho Juan Pérez y la dicha María Pérez deben pagar muchas deudas", por ello se conciertan entre ambos.

1633 AHPLU: 2047/9 (1596). Obligación de Juan de Arechaga "rendero de la ferrería de Ferreirós, como principal, y Juan Pérez derrazti, como fiador", con A. de Moldes clérigo capellán de San Vizenzo de Losada de 588 rs. por anegas de centeno. También AHPLU: 2407/9 (1596, 4 de mayo). Juan de Arechaga, rendero de la ferrería de Ferreirós, en nombre de Juliana López su sobrina y Pedro de Garabiso, rendero de la ferrería nueba de Orrios. La dicha Juliana se querelló contra Pedro Garabiso porque "le avía llevado su flor y birginidad siendo mujer hidalga".

${ }^{1634}$ AHPLU: 2408/1 (26 de junio). Como tal rendero se obliga apagar a Pedro López Somoza, cura de la iglesia parroquial de Santa María de Quintá (Quiroga), 116 reales que le prestó.

1635 AHPLU: 2408/2 (1612 (11 de mayo). Es un poder de María Pérez a su marido para el pleito contra Antonio de Arechaga "rendero asimesmo de la dicha ferrería de Ferreirós" "sobre la ragua mayor de la venera de Paradela que siendo suya se entró por fuerza a querer coger la vena en ella".

${ }_{1636}$ AHPLU: 2555/1 (1616, 21 de abril): Poder de Pedro Sánchez de Orozco "rendero de la ferrería de Ferreirós" para cobrar la renta de casas y bienes en Oencia; IDEM (1616, 9 de junio): Obligación de Juan Pérez derrazti y Armesto "rendero de la ferrería de Ferreirós" con el monasterio de Samos de 192 rs. por 24 fanegas de centeno; IDEM (1616, 12 de junio): Obligación de Pedro Sánchez de Orozco, "rendero de Ferreirós", su mujer María Pérez derrazti y Armesto y de Domingo de Zarauz, su yerno y arota en la ferrería, con el monasterio de Samos por 1.040 rs. de 130 fanegas de centeno que le vendió fr. López Vizcaíno, prior del convento a 8 rs./fanega; IDEM (1616, 25 de agosto): Obligación de Francisco González, ferramentero, de pagar a Antonio de Arechaga, "rendero de la ferrería de Ferreirós" 63 reales por hierro que le dio al fiado; IDEM (1616, 8 de sept.): Obligación de Pedro Sánchez de Orozco, rendero de Ferreirós, y su yerno Juanes de Lisasueta con Andrés de Albarriba de 88 reales de un rocín que les vendió en precio de 28 ducados; testigo Juan Pérez de Errazti, rendero de Ferreirós.

${ }^{1637}$ AHPLU: 2548/1 (1622, 21 de abril). Dice el escribano que ha llegado a su noticia cómo habrá seis días de la muerte de María Pérez de Armesto, viuda de Pedro Sánchez de Orozco, rendera de Ferreirós, de la de quedaron dos hijos, Catalina y María, por lo que se hace necesario hacer 
ferrería de Ferreirós", de la cual es aroza Blas de Zarauza ${ }^{1638}$. En 1669 Pedro de Alza era barquinero en esta ferrería, quien con su mujer Constanza de Losada y Armesto dan poder a don Lucas Fernández de los Ríos, residente en San Clodio de Ribas de Sil, para que pueda cobrar la herencia que les dejaron los padres de Constanza; como testigo firma su hijo Pedro de Alza y Armesto1639. Diez años después este Pedro de Alza se concierta con el contador del marquesado de Villafranca para hacer los barquines de la ferrería de Pontepetre, en precio de 4.063 reales ${ }^{1640}$. Vasco es también Antonio de Zarauza, vecino de la ferrería de Ferreirós, que adquiere numerosos bienes en este lugar en $1678^{1641}$.

La ferrería debía de ser de la encomienda de la Barra y como foreros la familia Pérez de Irazti y sus herederos. Como renta, la Encomienda cobraba anualmente 529 reales y 14 maravedís. En el siglo XVIII, por herencia o por venta la ferrería estaba en varias manos. Así, en 1700 doña Isabel de Quiroga, viuda de Juan de Ayra y nieta de Pedro Sánchez de Orozco, vende a don Carlos Manuel de Oca y Prada, dueño de la ferrería de Lousadela, "toda la parte y quiñón de herrería que a la otorgante le toca en la herrería de Ferreyrós ....que se compone de casas, fragua de hacer yerro, montes, veneras, según le toca y heredó de Christóbal de Lisasueta, su padre, aora difunto y dueño que fue de ella que son cuatro ágoas de las setenta y dos en que se reparte dicha herrería en cada un año entre los más herederos", en precio de 100 ducados, que es su precio real ${ }^{1642}$. Veremos que hay más propietarios.

Según el Catastro de Ensenada de 1753, la ferrería pertenecía a Francisco Robles y consorte. Trabajaban cinco oficiales ${ }^{1643}$ y se le regulaba solamente una

inventario de sus bienes, ante sus hijas y su cuñado Juanes de Ysasueta: "primeramente la parte y quinón de la ferrería de Ferreyrós ques la quarta parte della de que paga renta como constará de las escripturas" (....) "más la mytad del maçuco de Baldomill con dos fraguas", etc. ${ }_{1638}$ AHRG. R. A.: 19.816/8

1639 AHPL. PN.: caja 2936 (1669).

1640 AHPL. PN.: caja 3104 (1679).

${ }^{1641}$ AHPL. PN.: caja 2937 (1678). Estos Zarauza me parece que son nietos de Pedro Sánchez de Orozco y por tanto biznietos de Juan Pérez de Irazti.

${ }_{1642}$ AHPLU: 2566/10 (1700, 8 de marzo). Las cargas de la ferrería son 65 ducados "en cada un año entre todos los herederos" y por los montes y veneras otros 61 ducados.

${ }_{1643}$ CATASTRO DE ENSENADA. R. G.: Folgoso: "Los oficiales de la ferrería de Ferreirós de auajo que el aroza es Manuel de Quiñones al que se le consideran de utilidad por el tiempo que trauaja la ferrería al año seiscientos reales de vellón; el tirador es Mathias Valiña al que le consideran de utilidad (...) quinientos Rs. vn.; dos fundidores son Carlos de Neira y Francisco Arias, vezino de San Vicente de Villamor que a cada uno le consideran de utilidad (...) 
utilidad de 4.000 reales de vellón al año, pues solo trabajaba 4 meses por ser escasa el agua del arroyo que la abastecía; en realidad se trataba de una ferrería regatera ${ }^{1644}$. En aquella cantidad se incluía también el rendimiento de los montes de urz de los que se obtenía el carbón ${ }^{1645}$. Cornide en 1780 , por su parte, dice que su producción anual era de 900 quintales y que pertenecía a los marqueses de Viance ${ }^{1646}$. Varias escrituras de los años 1806 $1647,1819^{1648}$ y 1829 dicen que su dueño es Benito Barraganes. La última de esas escrituras nos aclara un tanto este lío de propietarios, al decir que lo es solamente de 22 ágoas de las 72 en que esta dividida la ferrería por acuerdo de sus propietarios ${ }^{1649}$.

La ferrería estaba dividida en 72 ágoas que pertenecían a varios propietarios, como consta en un documento de 1794, que nos explica además el funcionamiento de estos artefactos en los que había varios porcioneros: "Que la herraria nombrada de Ferreiros de auajo sita en el zitado lugar de este nombre es propia de la Excma. Sr ${ }^{a}$ Marquesa de Vianze, de D. Andrés Zalaya, vecino del lugar de Ferrerós de arriua, de D. Domingo Barraganes, del zitado Ferreiros de auajo, de D. Josep Armesto de Valdomir, de la expresada de Folgoso, de D. Nicolás de Páramo, dueño de la casa de la Hermida, en el balle de Quiroga, y de dicho D. Andrés (Alfaya)"1650. En 1811 don Andrés y don José Celaya, que poseían dos ágoas las venden a don Antonio Alfaya ${ }^{1651}$.

trescientos y sesenta rs. vn.; y el tazador es Joseph Aluarez hijo de Domingo Aluares al que le consideran de utilidad (...) dosciento y vente rs. vn.”.

${ }^{1644}$ AHPL. PN.: caja 9113 (1868). En el inventario de bienes de don Rafael de Armesto se dice que era una ferrería regatera.

1645 CATASTRO DE ENSENADA. R. G.: Folgoso.

1646 CORNIDE: ob. cit.

1647 AHPL. PN.: caja 3576 (1806) A don Benito Barraganes "dueño y vecino de la Herrería de Ferreirós en la jurisdicción de Caurel" se le rematan el diezmo de 15 parroquias de la zona de Triacastela y las del Caurel.

1648 AHPL. PN.: caja 3576 (1819): don Benito Barraganes, dueño y vecino de la Herrería de Ferreirós.

1649 AHPL. PN.: caja 3578 (1829). don Benito Barraganes arrienda a su cuñado Gregorio Martínez "las veinteydos Agoas que le pertenecen y corresponden hacer en cada temporada de las setenta y dos de arreglo echo entre los demás participantes, con las carvoneras, Herramientas, casa de Horno y más a ella pertenecientes se gún se halla, sus padres y mas de quien deriva la percibieron....".

${ }_{1650}$ AHRG. R. A.: 3.086/14. Continúa el texto: "entre todos los quales y en el termino de cada doze dias se allan repartidas las setenta y dos agoas que tanto quieren dezir como fundiciones de fierro, que da y produze dicha herraria que cada una saca un quintal, y de ellas corresponden (a Andrés Alfaya) primero y con preferenzia a los mas diez de aquellas que componen diez quintales; sigue D. Andrés Zalaya con dos, y despues de éstas otras seis como arrendatario de la parte perteneciente al D. Nicolás de Páramo; continúa dicha Excma. sra marquesa con veinte y una por si y treinta y tres por cuenta de D. Josep de Armesto y D. Domingo Barraganes, $y$ del mismo modo unos y otros interesados pagan a proporcion $y$ 
Años más tarde, en el testamento de Rafael Armesto de 1868 se vuelven a mencionar sus propietarios, que son los herederos del texto anterior: "en cuya herrería así descrita tiene este caudal (la herencia de Rafael Armesto) ocho ágoas de setenta y dos en que está dividida, o sea una novena parte, correspondiendo las otras ocho novenas partes a los Sr. D. Apolinar Suárez de Deza, de Villafranca ${ }^{1652}$, a D. José Alfaya y D. José Barraganes de Ferreirós, Sr. conde de Torre Penela y a D. Pedro Rodríguez del Valle del Mao"1653. Esa novena parte, más las rentas a que tiene derecho por los foros adquiridos (Encomienda de la Barra y Sabarey) por D. Rafael Armesto, vale 8.00o reales.

Desde 1788 hasta el principio del siglo XIX, las 21 ágoas de Ferreirós y la parte de la de Valdomir y Lousadela perteneciente a los marqueses de Viance las tuvo en arriendo don Juan Francisco Rivadeneira, sobrino de doña María Isabel Pardo Rivadeneira 1654. Primero hasta 1797 por arriendo de su tía, y posteriormente por arriendo de doña Ana Ramona Saavedra Pardo de Deza, nueva marquesa de Viance. Ésta se las arrendó nuevamente en 1797 por nueve años y 40.000 reales/año, y en 1806 las de Lousadela y Ferreirós por 3 años y 36.00o reales/año. De este último arriendo sabemos que 30.0oo eran por la de Losadela y 6.000 por las 21 ágoas de Ferreirós ${ }^{1655 .}$

En 1809, pasado el tiempo del arriendo, aquélla reclamó sus ferrerías, pero don Juan Francisco alegó que con “la inesperada invasión de los franceses” se había estancado la salida del hierro, hasta el punto de tener más de 6.000 quintales de hierro viejo sin vender, por eso pretendía que le prorrogara el arriendo. La marquesa le prorrogó otro año más, pero ni aún así quería aquél salir de la ferrería, alegando que estaba pagando 300 reales diarios, una de las

prorrata el coste de la Herraria, el de la reparación de sus escalabros y salarios de todos sus operarios y ofiziales...”.

${ }^{1651}$ Esta venta la denuncia don Lucas Flórez Somoza diciendo que tiene más derecho (AHPLU: 2406/1), pero al final, en 1813, se realizó la venta a aquél en 11.0oo reales (AHPLU: 2474/3).

${ }^{1652}$ AHPOU. Casa do Castro: caja 130 s/n. (1877): Inventario de bienes de don Apolinar Suárez de Deza: Ferrería de Ferreirós "que en unión de otros varios partícipes, fue del excelentísimo señor Suárez de Deza, y en que éste representaba tan solo veinte y una agoas por cada setenta y dos de las que confeccionan en dicha herrería". Su parte, con la casa habitación, plazas para la vena y otros derechos, valía 5.500 pesetas.

1653 AHPL. PN.: caja 9113 (1868).

1654 AHRG. R. A.: 25.291/28

1655 AHRG. R. A.: 25.291/28 
cláusulas del contrato, lo que suponía una renta de más de 90.00o reales anuales ${ }^{1656}$. Pese al juicio la ferrería siguió arrendada, primero a Juan Francisco Rivadeneira y luego a su mujer doña María Josefa Pardo Rivadeneira, propietarios también de la ferrería de Tejedo de Ancares ${ }^{1657}$. Igualmente tuvo en arriendo las 22 ágoas pertenecientes a don Benito Barraganes durante los años veinte, al menos hasta 1827 o $1829^{1658}$

En 1829 las 22 ágoas de don Benito Barraganes fueron arrendadas a su cuñado Gregorio Martínez ${ }^{1659}$ por espacio de 5 años (hasta mayo de 1834), con una renta de 5.000 reales año, pagada en dos veces, en julio y diciembre, y de la que no podría eximirse a no ser que la ferrería se arruinase totalmente. Debía reparar y conservar su parte en la fábrica para que ésta fuera en aumento y no en disminución ${ }^{1660}$. Este arriendo suscitó el enfrentamiento con doña María Josefa Rivadeneira, pues según declara ésta en 1829, ella llevaba "en arriendo sesenta y quatro ágoas o fundiciones de la Herrería del lugar de Ferreirós de Abajo, de las setenta y dos de que se compone", por diversos tipos de arriendo con sus propietarios, y que en 1828 cuando todavía le faltaban 28 ágoas por

${ }_{1656}$ AHRG. R. A.: 25.291/28. También AHPLU: 2455/2 (1809, 26 de agosto): Don Juan Francisco de Rivadeneira dice tener pleito con doña Ana Ramona Saavedra "sobre despojo y espelo que intenta de esta dicha casa fábrica de Herrería (de Lousadela), de la parte de la de Ferreirós, rentas y más bienes agregados".

${ }_{1657}$ AHPL. PN.: caja 3736 (1824 y 1825). AHRG. R. A.: 19.223/38. En 1825 dice un texto: "escede de treinta años que el caballero Maestrate D. Juan Francisco Rivadeneira estubo poseedor de la Herreria de Lousadela, de las Agoas que pertenecían a la marquesa de Biance en la de Ferreirós (...) y despues de la muerte de $D^{a}$ Ana Ramona Suárez de Deza y en virtud del arriendo otorgado por D. Bernardino Taboada, cura párroco del beneficio de San Julián de Meijente, como apoderado general de $D^{a}$ Antonia Caamaño siguió por el mismo orden y después del fallecimiento del citado caballero lo verificó la expuesta $D^{a} M^{a}$ Josefa como viuda y representante y en la actualidad detenta las explicadas agoas de la Herrería de Ferreirós, a consecuencia del arriendo otorgado por D. Alexo García apoderado general de D. Apolinar Suárez de Deza".

${ }^{1658}$ AHPLU: $2475 / 5$ (1825, 29 de julio). Don Benito Baraganes dice que terminado el arriendo de las 22 ágoas que le pertenecen en Ferreirós, le arrienda nuevamente, por dos años y 7.00o rs/año a doña María Josefa Rivadeneira.

1659 Este Gregorio Martínez ya tenía arrendada por seis años las dos ágoas de don Lucas Flórez Somoza, dueño de la casa de la Cuesta (San Clodio del Sil), que acaba de comprar a don Andrés Celaya, en 600 reales/año (AHPLU: 2474/3 (1813, 19 de julio). La compra de las ágoas las hizo ese mismo día 19 de julio de 1813 a D. Andrés Celaya y a su mujer Ana María Caneda. Le venden a D. Lucas "dos ágoas, parte de setenta y dos en temporada, que tienen y poseen en la fábrica de fierro esistente en la población de Ferreirós de Abajo, con todo lo a ellas pertenecientes" en precio de 11.000 reales, con las cargas que tienen:censo a don Josef Montenegro, fuero al conde de Maceda, y fuero al señor comendador de la Barra. El 29 de julio don Lucas da su poder a Gregorio Martínez para que ante la justicia de Caurel defienda su derecho de retracto, pues Andrés Celaya, su mujer y hermano han vendido otras dos ágoas que tenían a don Andrés Alfaya (AHPLU: 2406/1 (1813, 29 julio). ${ }^{1660}$ AHPL. PN.: caja 3578 (1829). 
labrar, Gregorio Martínez, su cuñado Benito Barraganes, que antes se las tenía arrendadas a ella, y otros entraron violentamente y le arrebataron la ferrería ${ }^{1661 .}$ En 1830 la justicia dio la razón a María Josefa Rivadeneira y condenó a don Benito Barraganes y a su hijo Ignacio a pagarle 36.000 reales. A causa de esta deuda, acordaron con Gregorio Martínez y su mujer Jerónima Robles el arriendo de las 22 ágoas en 4.000 rs/año, de los cuales 3.000 los pagarían a doña María Josefa de Rivadeneira hasta liquidar la deuda y los otros 1.00o rs. a ellos. Así fue hasta 30 de agosto de 1832 en que murió don Gregorio, aunque en realidad no habían pagado nada a doña María Josefa' ${ }^{1662}$.

Hechas cuentas con sus sobrinos quedaron alcanzados en 10.041 reales, 9.000 a aquélla por los tres años no pagados y 1.041 reales a ella. Doña Jerónima Robles acuerda con su sobrino Ignacio Barraganes dejarle el arriendo de la ferrería con la condición de que le pague 1.041 rs., quedando ella libre de los 9.000 rs. que se deben a la sra Rivadeneira, que habrá de pagar el sobrino. Además le subarrienda las 21 ágoas que le había arrendado en 1830 don Apolinar Suárez de Deza por cinco años y 3.000 rs/año, por los dos años que aún quedan y renta de 4.000 rs/año, más 3.900 rs. que debe al administrador de don Apolinar, don Alejo García; por último le cede también el subarriendo de ocho ágoas que su marido tenía en arriendo de don Lucas Flórez por el tiempo y precio del contrato. De todo esto sale fiador don Antonio Somoza, dueño de las ferrerías de Seoane ${ }^{1663}$. Años más tarde, por aquella deuda de 1830 con doña María Josefa Ribadeneira -en 1847 se dice que es de 31.578 rs.-, don Ignacio Barraganes cede a los Ribadeneira las 22 ágoas que les pertenecen, pasando así a esta familia ${ }^{1664 .}$

\footnotetext{
${ }^{1661}$ AHRG. R. A.:19.222/30. Don Benito Barraganes dice que María Josefa Rivadeneira lleva 22 meses aprovechándose fraudulentamente de sus 22 ágoas; pero el procurador de ésta dice que de esas ágoas es de lo que trata el pleito: "que la fábrica de la Herrería de Ferreirós se compone de setenta y dos fundiciones, de las cuales dos corresponden en propiedad al Gregorio Martínez, seis son de la casa de Baldomir y veinte y dos sobre que bersa la principal disputa pertenecen a D. Benito Barrafanes, lo que hace treinta, y son las que en el día trabaja el Gregorio, y las restantes, que ascienden a cuarenta y dos, mi parte, en esta forma: veinte $y$ una por arriendo de la casa de Láncara, trece por la de Alfaya y ocho por la de Flórez".

1662 AHPLU: 2376/3

1663 AHPLU: $2376 / 3$ (1833, 26 de octubre).

1664 AHPLuU 2377/1 (1847, 8 de nov.). Sin embargo en 14 de agosto de 1853 se dice que Vicente Martínez y Manuel Rodríguez, como depositarios de bienes embargados de don Ignacio Barraganes, arrienda las 19 ágoas de éste en la ferrería de Ferreirós a don Juan Ferreiros, vecino de Valdomir, en 3.100 rs/año (AHPLU: 2563/9); y en 23 de agosto de 1855, los mismos,
} 
También por esos años, al menos las suyas y las 8 ágoas de doña Clotilde Flórez, casada con el conde de Torre Penela, las trajeron en arriendo don Antonio Armesto, primero, y luego su hijo don Rafael Armesto y Arias, casado con la hija del industrial ferrero Nemesio Fernández de Ponferrada ${ }^{1665 . ~ E n ~} 1868$ las de todos los propietarios de la ferrería las tenía en arriendo Domingo Gallego ${ }^{1666}$. En el inventario de Bienes de don Apolinar Suárez de Deza, de 1877, se incluye "La herrería o forja catalana, denominda de Ferreirós, en Ferreirós de Abajo, parroquia de Santa María de Folgoso, que en unión de otros varios partícipes, fue del Excelentisimo señor Suárez de Deza, y en que éste representaba tan solo veinte y una agoa por cada setenta y dos de las que confeccionan en dicha herreria, con sus herramientas, moviliario, depósito de carbón, banzado o salto de agua, una sección de terreno destinado a plaza para el peso, hacinamiento y calcinación de la mena; una casa habitación y un pequeño terreno destinado a huerta (...) tasado en cinco mil quinientas pesetas. A lo que es anexo el derecho al carboneo y leñas en diferentes montes, mineral del monte de Formigueiros y otros derechos y regalías en diferentes localidades. Y aunque hasta ahora venía produciendo la renta anual de mil y quinientos reales, además de pagar el arrendatario las contribuciones, pensiones, obras y reparos menores (...) se aprecia todo (de esta parte de Suárez de Deza) en el capital líquido de quatro mil quinientas pesetas"1667.

Al parecer, según Hernández Sampelayo, la ferrería siguió trabajando hasta final del siglo XIX. Lo hizo en 1874 en que produjo 200 Qm. de yerro con 600 de vena de Formigueiros ${ }^{1668}$. De ese mismo lugar era el mineral que labraba la ferrería, como señalan Munárriz ${ }^{1669}$ y el inventario de don Rafael Armesto1670.

\footnotetext{
habiendo finalizado el arriendo, vuelven a arrendar las 19 ágoas a don Rodrigo Osorio, de la Ferreirúa, por un año, en 2.200 rs.

1665 AHRG. R. A.: 21.485/2: por esas 8 ágoas y cuarto y medio de ágoa en la de Valdomir, que le pertenecían, pagaban por ellas los Armesto 140 rs./año, desde 1833 a 1858, es decir, 26 años, más otro dinero por unas fanegas de centeno, que todo sumaba 6.440 rs. Como solo pagaron 3.600 están debiendo 2840 rs., que en 1859 dan origen a un pleito.

1666 AHPL. PN.: caja 9113 (1868)

1667 I. GARCÍA TATO (1999): Vilanova, Outarelo y San Francisco Blanco. Monografía histórica de una parroquia gallega. I.E.V. Cuaderno monográfico $\mathrm{n}^{\circ} 30, \mathrm{p} . .$.

1668 P. HERNÁNDEZ SAMPELAYO (1935): Hierros de Galicia, t. III, fasc. $1^{\circ}$, p. 40

1669 MUNÁRRIZ: Ob. cit. p. 135

1670 AHPL. PN.: caja 9113 (1868): "y el gravamen que por la venera de Formigueiros para sustento de esta y otras fábricas se paga al señor conde de Maceda".
} 
Según un documento de mediados del siglo XIX pagaba de foro 147 reales $^{1671}$. Todavía funcionó, unos tres meses, en $1880^{1672}$. Incluso en 1894 se anunciaba en el BOP de León el arriendo de las ferrerías de Pombriego, Bueyes y Ferreirós (21 ágoas), para lo que habría que dirigirse a don Pedro Seijo, en Madrid ${ }^{1673 .}$

ESTADO: Según el inventario de bienes de don Rafael Armesto, la ferrería se componía de "banzado, banzadillo y carbonera, que linda al Este casa de D. Apolinar Suárez de Deza, separada de la carbonera de la fábrica por un callejón servidumbre, Sur arroyo de Ferreyrós, Oeste plazuela en la cual hay dos castaños que pertenecen a Manuel Galán y D. José Alfaya y al Norte, o sea por arriba camino". En el inventario aparece además como propietario de carboneras (grande y pequeña), casas: "una casa de alto y bajo, cubierta de losa con un corredor a su lado norte; superfiecie doscientas cincuenta varas cuadradas, y además a su frente de poniente una plazuela para dos raguas y a continuación otra plazuela con tres castaños grandes para la vena cruda; lindando al Este huerta de este caudal, Sur casa de Manuel Galán, Oeste plaza de la vena de D. Apolinar Suárez de Deza y Norte o sea por abajo arroyo y pontón de sobre dicho arroyo" 1674 .

De todo esto no queda actualmente nada, a excepción del topónimo "Carboeira", con que se denomina el solar, que cruza hoy la carretera de Folgoso, que debió ocupar alguna carbonera ${ }^{1675 .}$

\section{FERRERÍA DE FOLGOSO}

LUGAR: Folgoso

MUNICIPIO: Courel

RÍO: Carballal

COORDENADAS: $42^{\circ} 35^{\prime} 10^{\prime \prime}$ N. y $7^{\circ} 11^{\prime} 57^{\prime \prime} \mathrm{W}$.

\footnotetext{
${ }^{1671}$ I. GARCÍA TATO (2000): "Las herrerías de Río Cabo y Pombriego en el siglo XIX". Revista Bierzo, p. 167.

${ }^{1672}$ P. HERNÁNDEZ SAMPELAYO (1935): Hierros de Galicia, t. III, fasc. $1^{\circ} \mathrm{p} .37$

1673 BOPL. de 2 de marzo de 1894.

1674 AHPL. PN.: caja 9113 (1868).

1675 C. GONZÁLEZ (1994): ob. cit. p. 154.
} 
Se encontraba en la parroquia de Santa María de Folgoso, en el mismo pueblo de Folgoso, en la parte de abajo, a pocos metros del puente que salva el río Carballal, que es un pequeño afluente del Lor.

Desde muy antiguo, probablemente desde mediados del siglo XVI hubo en este lugar de Folgoso un mazo ${ }^{1676}$. A su lado, aunque no sobre el mazo, se construyó en el siglo XIX una ferrería.

Del mazo conocemos algunas noticias en los siglos XVI y XVII, en los que su propiedad era, en parte, de Pedro Rodríguez y sus herederos; y en parte de los descendientes de Juan de Zuluaga. En 1612, Martín de Guizaburuaga, rendero de la ferrería de Santalla, pleiteó contra Antonio Rodríguez y Antonio Rodríguez Chantada, ferramenteros, "vecinos de dicho lugar de Folgoso sobre la mytad del maçuco de Folgoso y una fragua, barquines, yunque y más aderentes del con el derecho de mazerar" ante el alcalde ordinario de la Tierra de Caurel, quien sentenció que se diera "al dicho Martin de Guisaburuaga la posesión pro yndibiso de la mytad del dicho mazuco de Folgoso con la fragua y aderentes della" 1677 .

Al mismo tiempo este Guisaburuaga, tras tomar posesión del mazuco, aforó a aquellos Rodríguez "la mytad enteramente de el dicho maçuco de Folgoso con su presa y banzado y mazo de mazear con más una fragua con sus varquines, yunque y más aderentes a ella nezesarios", por el canón de ocho ducados de renta al año, pagados por el mes de septiembre, además de traerlo reparado, que no fuera en disminución sino en aumento, etc.1678. En realidad debió tratarse de un subforo, pues como declara el documento citado Martín de Guizaburuaga "mobio el pleyto como zesonario de Diego de Zuluaga, hijo y

\footnotetext{
1676 AHPLU: 2407/9 (1596). El 13 de enero de 1596 estando en el "machuco de Folgoso", Pedro Rodríguez probablemente herrero en dicho machuco, se obligó con Juan de Zuluaga, rendero de la ferrería de Loureiro, a pagarle 31 ducados "por razón de quinze quintales y medio de fierro". 1677 AHPLU: 2408/2. Unos años antes, en 1606 (AHPLU: 2555/1), estos dos hermanos ferramenteros, Rodríguez Chantada, arrendaban a Juan Fernández y su primo Julián Fernández, también ferramenteros, vecinos de Folgoso, "una fragua con el serbicio de maço y agua y yunque ... en el machuco que tienen en este lugar de Folgoso... por tiempo de tres años... y doze ducados en cada uno de los dichos tres años". Añaden que si hubiere escalabros en el machuco se obligan pagar a un carpintero para su arreglo.

1678 AHPLU: 2408/2
} 
heredero que quedó de Juan de Zuluaga, rendero que fue de la ferrería de Loureiro", los cuales seguramente eran los dueños del artefacto.

No volvemos a tener nuevos datos del mazo hasta principios del siglo XVIII. En el testamento de Carlos Manuel de Oca y Prada, de 26 de diciembre de 1719 , recuerda éste lo que le deben "los tratantes y erreros y las rexas que estan fabricadas en los mazos de Folgoso y Río Zereixa"1679. Una escritura de 1746, menciona una deuda de Pedro de Alza y su mujer, vecinos de Folgoso, con el mayordomo de la ferrería de Lousadela, se la pagarán con su casa "mas un día de mazo que les tocaba, de ocho en ocho días, en la fragua da estolda (roto) de dicho lugar de Folgoso"1680, que sin duda se está refierendo a una de las fraguas que solían trabajar en torno a estos artefactos. Estos datos, aunque parcos, parecen evidenciar que el artefacto estuvo en funcionamiento durante esos dos siglos.

A comienzos del siglo XIX, Munárriz escribe que las toberas de cobre que utilizan las ferrerías bercianas "las hacen en los mazos de Soldón y Folgoso, en Galicia"1681. El mazo probablemente era de varios propietarios, los Sánchez y los Arza, como deducimos de un documento de 1807, por el que Domingo Sánchez, Carlos Sánchez, Francisco Sánchez Pardín, Francisco de Arza y Andrés de Arza "partícipes y llebadores en las fraguas y artefacto de la oficina de mazo esistente en los terminos de esta vecindad (de Folgoso) y rio del do Mazo, cuyo artefacto se muebe con el agua que por aquel fluye" permiten a Manuel Sánchez Bullín abrir un cauce para regar un prado siempre que no perjudique su mazo ${ }^{1682}$.

En 1819, en la subasta de los bienes de don Manuel Antonio Sánchez, se afirma de éste que es propietario de un día de mazo en este de Folgoso ${ }^{1683}$.

1679 I. GARCÍA TATO (1999): Vilanova, Outarelo y San Francisco Blanco. Monografía histórica de una parroqia gallega. I.E.V. Cuaderno monográfico $\mathrm{n}^{\circ} 30$, p. 465.

1680 AHPL. PN.: caja 2126 (1646).

1681 J. A. BALBOA (1992): Ob. cit., p. 130

1682 AHPLU: 2454/7

${ }_{1683}$ AHRG. Real Audiencia: 12.446/45. En 1819 se pretendió subastar los bienes de don Manuel Antonio Sánchez, que había sido arrendatario de la ferrería de Soldón los años anteriores, a cuyo dueño quedó debiendo 166.952 reales. Entre sus bienes aparece "un día de fragua y mazo en el llamado de Folgoso y fragua da Porta", así como diferentes días en otras fraguas (la del Medio, la del Gorrión), que se encontraban al lado de dicho mazo. 
También miembros de esta familia, Andrés, Rosa y Domingo Sánchez se declaran en 1836 "participes en el mazo viejo sito en el arroyo del referido Folgoso, con sus respectivas fraguas para desfazer el fierro que compran y conducen de las Fábricas del país, distribuyéndole en diferentes clases de herrages que venefician hasta larga distancia de la circunferencia, como también para fundir cobre y hazer tuberas para arcas, trompas y barquines de todas las fábricas de Galicia"1684

Al lado de este "mazo viejo", en la parte de abajo del mismo arroyo, en 1836 Domingo Sánchez, vecino de Folgoso, construyó una nueva ferrería que suscitó una fuerte oposición de los propietarios de las de Ferreirós y Valdomir1685; y también de los del dicho "mazo viejo"1686. Primeramente les engañó a todos diciéndoles que lo que pretendía levantar era un mazo, pero luego se "quitó la mascarilla" y lo que construyó fue una ferrería, pese a sus protestas, como muestran documentos posteriores. Empezó a funcionar como tal poco después de ese año, pues Antonia Pol, viuda de Domingo Sánchez, su hija y su yerno Juan Arza llevaron a juicio de conciliación, en 1844, a Francisco Maceda, vecino de Santa María de Óutara, para que "les indemnizase de cantidad de reales de que es deudor por atrasos del arriendo de la Herrería que tienen los constituyentes en esta vecindad y que aquel administró desde junio del año pasado de 1839 asta igual fecha del de 43", cantidad que al parecer era de 3.051 reales y $17 \mathrm{mrs} .1687$

\footnotetext{
1684 AHPLU. 2377/2 (1836).

1685 AHPLU: 2377/2. Escritura de 6 de agosto de 1836 en la que don Antonio Alfaya y don Manuel Ignacio Barraganes dicen que con los demás propietarios de las ferrerías de Ferreirós y Valdomir denunciaron en mayo "la nueva fábrica de fundir y labrar fierro, que Domingo Sánchez vecino del pueblo de Folgoso, intenta construir, con el supuesto nombre por aora de Martinete a la parte de avajo del mazo viejo de dicho Folgoso". La denuncia es por los perjuicios que esa obra nueva causaría a las ferrerías en los aprovechamientos de carbón y leña. ${ }_{1686}$ AHPLU: 2377/2. Escritura de 7 de mayo en la que Andrés, Rosa y Domingo Sánchez, copropietarios del mazo viejo de Folgoso denuncian cómo " a principios del año presente Domingo Sánchez nuestro vecino dio principio a un nuevo artefacto edificándole vajo el sobre dicho mazuco viejo y en el mismo arroyo". Al principio les engañó diciendo que era para un nuevo mazo y pese a que les perjudicaba no se opusieron, pero luego "quitó la mascarilla y manifestó claramente la siniestra intención que tenía archibada en su imaginación, afirmando que la nueva obra hera con destino a una Fábrica o herrería de fundir y labrar fierro y no para martinete, que ya le permitía construir el D. Antonio Armesto según noticias por el bien de la paz". La denuncia la hacen porque la ferrería les perjudicaba enormemente, pues "es bien savido la abundancia de leñas que consumen las tales fábricas para raguas de cozer bena, carbón y más piezas que necesita".
}

1687 IBIDEM 
Los mismos dueños, en 1846, confiesan haber recibido de don Gregorio $\mathrm{M}^{\mathrm{a}}$ López, vecino y del comercio de la villa de Madrid, 15.000 reales el 25 de octubre de 1845, que se obligan a devolver en ocho años, más 900 reales de réditos al año. Para ello hipotecan "el artefacto de Herrería con sus casas y herramientas que los otorgantes tienen y posehen en la parte inferior de este pueblo"1688. Madoz también habla de ella, al señalar que en la parroquia de Folgoso hay dos Ferrerías, una en Valdomir y otra en Folgoso ${ }^{1689}$.

Según un documento de mediados del siglo XIX, la ferrería pertenecía por esa fecha a don Rafael Armesto, quien pagaba al marqués de Santa María del Villar, por el foro de la vena de Formigueiros, 200 reales ${ }^{1690}$. Desconocemos si fueron los Sánchez o don Gregorio $\mathrm{M}^{\mathrm{a}}$ López, que a su vez era propietario de la ferrería de la Rodela, quien la vendió a don Rafael Armesto, pero así consta también en su inventario de bienes del año 1868. Parece que don Rafael la adquirió para cerrarla y de eso modo no competir con la de Valdomir: "con cuyo obgeto y para mejor aumentar el valor a la de Valdomir, que es más caudalosa en aguas y reune mejor condiciones para la fabricación de fierro, fuera adquirida esta de Folgoso por el difunto D. Rafael Armesto"1691. En el inventario de 1868 ya estaba arruinada: "En el pueblo procsimo de Folgoso una Herrería con carbonera, plazuela de la vena, puente sobre el arroyo y presa que hoy se halla destruida asi como también el banzado del cual solo ecsisten las vigas del piso, arruinada dicha fábrica en su mayor parte ecsistiendo tan solamente las paredes cubiertas de losa y algunas maderas inservibles con algunos chopos a su frente; y al otro lado de dicha Herrería la casa para la administración de dicha fábrica"1692.

La razón de este abandono fue la dificultad para poder abastecerla de carbón al estar tan cerca la de Valdomir: "Se valora dicha Herrería y casa como un derecho de este caudal para que ninguna persona pueda construir o

1688 AHPLU: 2376/6 (1846)

1689 P. MADOZ: Ob. cit., t. VIII, p. 115

1690 GARCÍA TATO, I (2000): “Las herrerías de Río Cabo y Pombriego en el siglo XIX”. Revista Bierzo, p. 168.

${ }^{1691}$ AHPL. PN.: caja 9113 (1868).

${ }^{1692}$ AHPL. PN.: caja 9113 (1868). Después de describir la ferrería, ya arruinada en 1868, dice: "se valora pues esta Herrería arruinada de Folgoso con la casa de su frente y la caseta de junto al mazo destinada antiguamente a fragua de herreros con todas sus dependencias". 
edificar herrería en los términos de Folgoso, mediante que hallándose dicha fábrica de Folgoso tan procsima a la de Valdomir, se cree no conviene reedificarla, porque las dos fábricas no pueden subsistir sin grabe perjuicio la una de la otra a causa de la escasez de carbones; con cuyo obgeto y para mejor aumentar el valor a la de Valdomir, que es más caudalosa en aguas y reune mejor condiciones para la fabricación de fierro, fuera adquirida esta de Folgoso por el difunto D. Rafael Armesto, la cual en su adjudicación deberá precisamente ir unida a la repetida de Valdomir". Junto con la casa se valora en dos mil reales ${ }^{1693 .}$

El mazo, por su parte, seguía en manos de las dos familias -Sánchez y Arza$\mathrm{y}$ funcionando, probablemente hasta finales del siglo, como deducimos de un documento de 1862, por el que Francisco, Ana, Juan e Ignacio Arza y Luis y Benito Sánchez "llevadores y partícipes del Martinete que está situado en este mencionado pueblo" se conciertan, por mutua conveniencia, que "desde hoy día en adelante los que otorgan, sus hijos y herederos se priban de trabajar de noche en el citado Martinete por los perjuicios que se le ocasionan a causa de los escalabros que con tal motibo acaecen al dicho artefacto, imponiéndose la pena de doscientos reales al que contraviniere o falte a lo estipulado". Se obligan a trabajar sólo con luz del día, dejando libre y corriente para el que le toque trabajar a continuación; y si ocurriere algún descalabro lo reparará quien lo haya ocasionado, excepto los escalabros mayores que serán por cuenta de todos ${ }^{1694 .}$

ESTADO: No queda nada de la ferrería, que al parecer se la llevó una crecida del río en los años cincuenta del siglo XX. 


\section{FERRERÍA DE LOUSADELA}

LUGAR: Parroquia de Seceda

MUNICIPIO: Courel

RÍO: Lóuzara

COORDENADAS: $42^{\circ} 36^{\prime} 15^{\prime \prime}$ N. y $7^{\circ} 14^{\prime} 19^{\prime \prime} \mathrm{W}$.

Sus restos se hallan en el lugar de Lousadela, en la parroquia de San Silvestre de Seceda, a orillas del río Lóuzara, que nace en los montes del mismo nombre.

La ferrería de Lousadela debió de construirse en el siglo XVI, posiblemente en la segunda mitad, pues sólo conocemos referencias de ella en los años finales de ese siglo. Así sabemos que en 1596 Juanes de Ardana era "aroza de la ferrería de Lousadela"1695; en 1597 aparece como hombre bueno y liquidador de los bienes de Pedro Sánchez de Orozco, de la ferrería de Valdomir, un "Juanes de Fagoaga, aroça de la ferrería de Lousadela"1696, y en 1599 Gil González, tirador de herrerías, vecino de la ferrería de Incio, dice que residía en la de Lousadela ${ }^{1697}$. Por último, de ese mismo año conocemos un poder de García de Yribarri, aroza de la ferrería de Guadalupe, que antes, afirma, lo fue de la de Lousadela ${ }^{1698}$. Desconocemos quién la construyó, pero probablemente, como luego veremos, pudo ser el conde de Lemos. Sí sabemos que Francisco López de Quiroga, propietario en parte de las de Soldón y Valdomir, la tenía aforada, como se deduce de un escrito de 1612 en el que Pedro Martínez de Goicoechea dice que él y su mujer la aforaron (subaforaron) en 1606 a Jerónima de Villasur, viuda de aquél, "por las vidas y voces en que la tenía el dicho Francisco López"1699.

En 1604 doña Jerónima de Villasur, ya viuda, la dió en foro al licenciado Andrés Díaz do Piñeiro ${ }^{1700}$, rendero de la ferrería de Loureiro, aunque poco después, en 1606, la volvía a aforar Pedro Martínez Goicoechea y a su mujer

1695 AHPLU: 2407/9

${ }^{1696}$ AHRG. R.A.: 21.359/74

1697 AHPLU: 2547/1

1698 AHPLU: 2547/1. Está fechado en Seoane del Caurel, el 19 de abril de 1599, pero desconozco a que ferrería de Guadalupe se refiere.

1699 AHPLU: 2048/2

${ }_{1700}$ AHRG. R. A.: 19.816/8 
Lucía Díaz de Zuluaga, que era sobrina de aquél1701. A la muerte de este Pedro, y mientras su hijo de igual nombre era menor, fue rendero su hermano Juan Martínez de Goicoechea juntamente con Antonio de Achega, a quien Pedro Martínez le había arrendado antes de morir la mitad de la ferrería por tres años; pero en 1616 ambos se conciertan para que éste la deje libre el último de esos tres años ${ }^{1702}$. Desde ese año, y como tutor de su sobrino, vemos a este Juan Martínez como rendero hasta los años veinte1703. Más tarde, en 1630, Pedro Martínez Goicoechea, hizo fuero de su fuero, es decir subaforó, a don Diego de Valcarce Losada dicha ferrería, como conocemos por un pleito al que vamos a referirnos.

Por el pleito sabemos que "allandose poseedor de dicha erraria de Lousadela Pedro Martínez de Goicoechea en bertud del fuero echo por dona Jeronima de Uillasur, dexó a mi parte (a don Diego de Valcarce, dice su procurador) la dicha erraria el año de mill y seiscientos y treinta asta este presente año de quarenta y uno, asta el treinta y tres a medias que labrasen el hierro procedente por mitad, $y$ desde dicho año de treinta tres asta aora por arriendo que le hiço dicho Pedro Martínez en cada un año por trescientos

\footnotetext{
${ }^{1701}$ AHPLU: 2408/2. En 1612 muere Lucía Díaz de Zuluaga, hija y heredera de Juan de Zuluaga y de Catalina Díaz do Pineiro, renderos de Loureiro y Valdomir, hermana ésta de Andrés Díaz. En el inventario de sus bienes, se dice que deja un hijo de 9 años, Pedro Martínez de Goicoechea; aparece su tío Andrés Díaz do Piñeiro como rendero de Loureiro, a quien deben ella y su marido dinero y algunos quintales de hierro. Pedro Martínez de Goicoechea recuerda que sus suegros le dieron a su mujer, en 1606, 17.500 reales en cuenta y pago de la legítima y que con ese dinero aforaron a Jerónima de Villasur la ferrería de Lousadela. Pero que para seguridad y para poder trabajar en ella tuvieron que hacer una presa nueva, de canto y argamasa, que les costó 3.000 ducados.

${ }^{1702}$ AHPLU: 2555/1. 9 de junio de 1616, Ferrería de Lousadela: Antonio de Achega "rendero de la dicha ferrería" y Juan Martínez de Goycoechea "asimismo rendero de la dicha ferrería de Lousadela" dijeron que Pedro Martínez de Goicoechea, difunto, "rendero que fue de la dicha ferrería y hermano del dicho Juan Martínez ... abia arrendado la mytad de la dicha ferrería y lo que prozediere de yerro partiesen al medio dando carbon el dicho Antonio de Achega, pagando oficiales por tiempo y espacio de tres años ... y agora ambas dichas partes son conzertadas ... en esta manera, en que el dicho Antonio de Achega dexa y suelta al dicho Juan Martínez el postrer año de los tres de la dicha escriptura que comienza a correr y a contar desde el día de san Miguel de septiembre".

${ }^{1703}$ Así en 1616 (AHPLU: 2555/1) Juan Martínez, como tutor de su sobrino, da su poder a Martín de Goizueta y Juanes de Arriordona para que puedan cobrar deudas que le han quedado a su sobrino de ventas que hizo su padre; en 1620 (AHRG. R. A.: 12.476/2) acuerdo entre don Diego de Prada y los hermanos Celaya sobre la ferrería de Soldón. En nombre de éstos lo hace su primo Juan Martínez Goicoechea "rendero de la herraria de Lousadela"; en 1622 (AHPLU: 2548/1) Juan Martínez, rendero de Lousadela y tutor de su sobrino, dice que en el libro de cuentas de la ferrería hay un asiento por el que Juan Pérez de Arrebillaga debía a su hermano 58 ducados. Juan Martínez Goicoechea era primo de los hermanos Catalina y Juan Celaya, propietarios también de una parte de la ferrería de Soldón.
} 


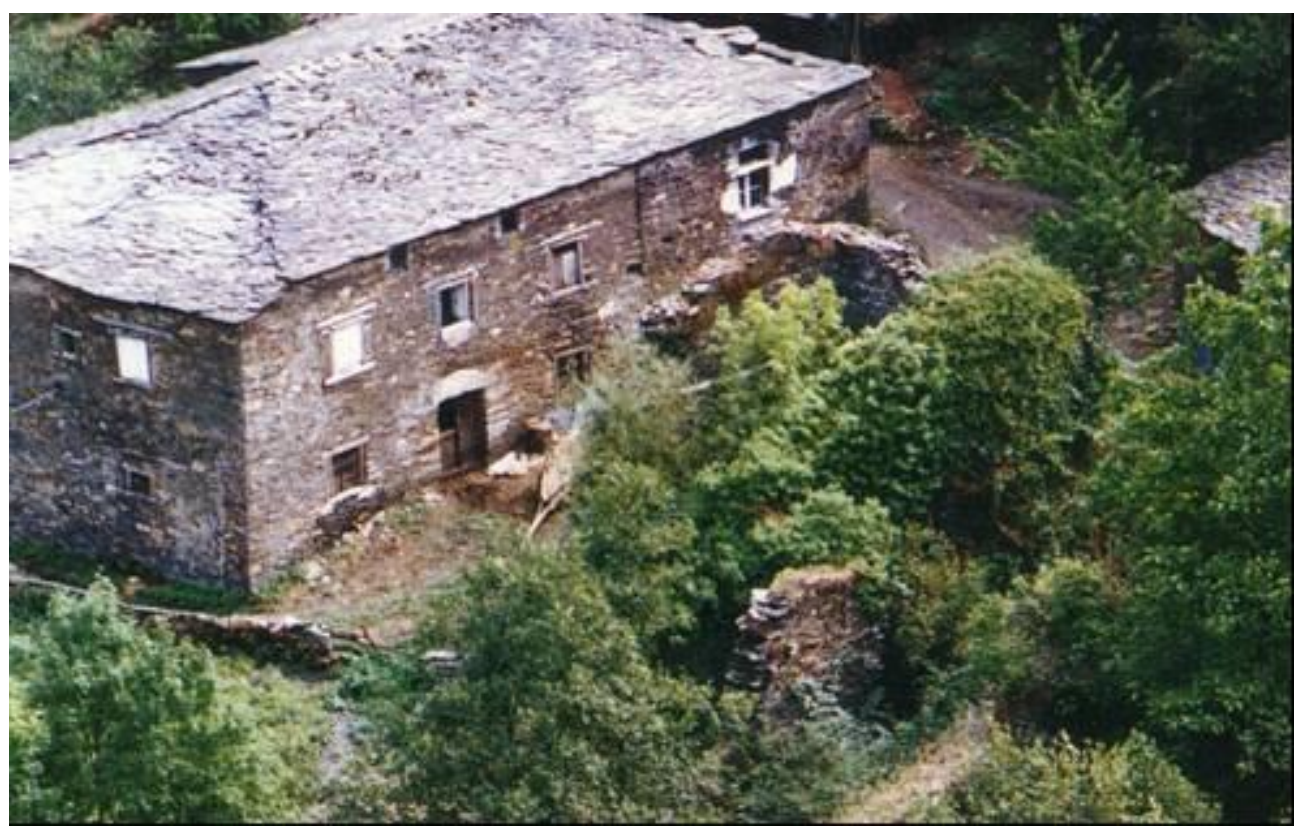

Vivienda de la ferrería de Lousadela

ducados y treinta canados de uino y sesenta anegas de pan y castañas, que dicha mi parte le pagaua y tiene pagos al dicho Pedro Martínez, pagando dellos a dicho Don Diego de Prada en cada un año cinquenta ducados de pension y diez y seis a la casa de Noseda (otro escrito del mismo pleito dice Maseda) y otros ocho al conde de Lemos como los tiene pagos"1704. Este texto ofrece datos que pueden explicar el origen de la ferrería, que con los del pleito que hemos mencionado aclararán otros puntos oscuros.

Que la ferrería pague ocho ducados al conde de Lemos pudiera explicar el que, de alguna manera, ésta estuviera relacionada con dichos condes, bien por que la hubieran construido, bien porque fuera suyo el terreno sobre el que se estableció. Ejemplos semejantes tenemos en sitios cercanos, como las ferrerías del Selmo leonés -Arnado y Pontepetre- y también la de Saltojo en La Coruña, erigidas por el conde viejo de Lemos, Pedro Álvarez Osorio. Los 16 ducados son, sin duda, el foro que la ferrería pagaba por la vena de Formigueiros al conde de Maceda. Por último, los cincuenta ducados de pensión a Diego de Prada es la renta del foro hecho por Jerónima de Villasur, pues aquél estuvo casado con la hija de ésta, doña Constanza de Losada Quiroga y Villasur, y por esa época

1704 AHRG. R. A.: 19.816/8 
aparece como tutor de su nieta doña María Antonia de Prada y Losada, por muerte de sus progenitores.

Pedro Martínez Goicoechea, forero de Jerónima de Villasur, debió de tener problemas con la ferrería por lo que en 1632 él y su mujer, doña María de Valcarce, se obligaron a pagar al capitan Diego de Valcarce "nuestro tío", vecino de Confaga, 233 ducados y medio que le deben por haberlos gastado "en acer la presa y bançado de la dicha herreria de Lousadela"; dinero que le pagarán la mitad a comienzos de 1633 y la otra mitad por Santiago del mismo año ${ }^{1705}$. En realidad según un testigo del juicio celebrado en 1641, el rendero de Ferreirós Juan López, "podrá hauer doce o trece años poco mas o menos tiempo que el dicho Diego de Valcarce y Losada antes que entrase a poseer dicha herreria hiço y edifico de nuebo la pressa della por la hauer llebado una avenida la que antes hestaua echa por donde hiua el agua para hacer andar dicha herreria"'; y la hizo trayendo muchos hombres, valiéndose de sus hermanos y deudos, alargándola más de lo que era, para lo que hubo de romper con picos de hierro un buen trozo de peña. Es decir, que dicho Diego Valcarce, un hidalgo potentado, hizo la presa por 233 ducados para sus sobrinos.

Un año después la mitad de la presa la volvió a llevar el río, por lo que la ferrería "estuvo otro año y medio sin trabajar" y por no tener el dicho Pedro Martínez "caudal para boluer a rredificar la presa por estar como hestaba pobre", por permanecer tanto tiempo sin trabajar, y viendo don Diego que sus sobrinos se arruinarían volvió a juntar gente, rehizo la presa " $y$ adereço las casas de la herreria, hiço las ruedas de nuebo y reedifico el uançado y erramientas" hasta poner todo en disposición de trabajar. Puso también a su costa "el arbole mayor en dicha herreria que costó ponerse mas de cien ducados" y arregló los caminos para bajar la vena y la leña pues estaban deshechos. Se gastó, dice el testigo, mucha hacienda dando de comer a los oficiales y trabajadores sin que en todo ello le ayudase su sobrino. En total pudo gastar, concluye, unos 2.000 ducados ${ }^{1706}$.

${ }_{1705}$ AHRG. R. A.: 19.816/8

${ }_{1706}$ AHRG. R. A.: 19.816/8 
No debieron estar tío y sobrinos totalmente de acuerdo, pues en 1637 Pedro Martínez de Goicoechea subaforó la ferrería a Andrés Díaz, tío de su madre, por la vida del rey Felipe IV y renta de 100 ducados al año ${ }^{1707}$. Esto fue lo que debió provocar el pleito de Diego de Valcarce y Diego de Prada, en nombre de su nieta, contra el licenciado Andrés Díaz. Aquel, de todos modos, recuerda en 1641, que gane quien gane el pleito, que es por el foro de la ferrería, a él le tienen que pagar de todos modos 4.000 ducados, porque en los once años que tuvo la ferrería "a gastado en su reparo y adreços mas de los dichos quatro mil ducados por hauer lleuado el rrío el bançado y pressa por estar en rrio muy caudaloso y la acostumbraba a lleuar cada un año con las abenidas"; y además hizo de nuebo la presa y el banzado "mudandola mucho trecho de lo que antes estaua y la hiço de canteria y aseguró para siempre y por mudar dicha presa rrompió mas de treçientas brazas de peña con mucho trauaxo". Y cuando la cogió la ferrería "estaua cayda y xamas trabajava" si él no la hubiera aderezado. Gastó más de lo dicho " $y$ hordinariamente dicha herraria aunque no fuese edificio que a echo necesita mas de quinientos ducados en cada un año"1708.

La ferrería era pues de la familia Losada Villasur, de quien pasaría en el siglo XVII, como herederos legítimos, a los Prada y Losada, y luego en el XVIII a los Oca y Prada, aunque probablemente siguieron manteniéndola en foro a miembros de la familia Valcarce, o mejor, Martínez de Goicoechea. Al menos en mayo de 1669, don Antonio de Valcarce y Martínez, que es hijo de Pedro Martínez y María de Valcarce, aparece como vecino y arrendatario de la ferrería. En esa fecha se obligaba con el mercader de Villafranca del Bierzo, Pedro de Sotogaioso, a proporcionarle "diez quintales de yerro delgado y picado puestos y pagados en dicha errería para el día fin de setiembre que biene deste dicho año", por el precio de 50 ducados de vellón. La escritura añade que también Bartolomé de Arce y Armesto, cuñado del anterior por estar casado con su hermana Inés, asimismo rendero de la misma ferrería, junto con Juan López, vecinos ambos de la feligresía de San Silvestre, en octubre de 1668 se habían comprometido con el citado mercader, a darle 40 quintales de hierro, 12 de ellos 
para diciembre de 1668 y otros 16 en febrero, cosa que a la fecha de 24 de mayo de 1669 habían incumplido por lo que pensaba ejecutar la obligación, acción que paralizó a ruego de don Antonio Valcarce ${ }^{1709}$.

A finales del siglo XVII y durante el XVIII la ferrería fue propiedad de la familia Oca y Prada, marqueses de Viance. En 1692 don Carlos Manuel de Oca y Prada arrienda la ferrería a Tomé Gómez Dares, de Quintanadona de Palacios, de la feligresía de San Román das Encobras (Coruña), por tres años y renta de 300 quintales de hierro "delgado y pesado de buena calidad" al año y 2000 reales ${ }^{1710}$. Durante el tiempo en que no está arrendada, el marqués de Viance tenía mayordomos, casi siempre licenciados o presbíteros, como Marcos Gómez Lodeiro en 1692 ${ }^{1711}$, Juan González Reymondez en $1704^{1712}$. En el testamento de Carlos Manuel de Oca y Prada, de diciembre de 1719, dice que "tengo por mayordomos en la herrería de Lousadela al licenciado D. Juan Reymundez de la Torre, $y$ en Otarelo a Domingo Antonio de la Carrera, uno y otro me han servido muchos años. Mando que de las quintas que tubieren que dar, no se les pida mas que el que ellos quisieren dar"1713. Por el texto parece deducirse que en este siglo, la ferrería ya no está aforada sino que se explota directamente por medio de administradores. Desconozco si fue este Carlos Manuel quien liberó el foro o simplemente se terminó el tiempo del mismo, aunque tengo la impresión, por su testamento, que la enorme deuda de 30.000 reales que mantiene con el casar de Layosa pudieran haberse aplicado a la redención del foro de la ferrería, a la que parecen estar también anexos los mazos de Folgoso y Río Cereixa1714. A

1709 AHPL. PN.: caja 2945 (1669).

${ }^{1710}$ AHPLU: 2566/2. Entre las condiciones del arriendo hay dos muy interesantes. Una dice que durante el arriendo no se quite a don Antonio Martínez y Bartolomé de Arce las casas en que viven en esta herrería ni las heredades que labran ni sotos, etc (este don Antonio Martínez parece heredero de los Martínez de Goicoechea); la otra dice "que si durante el tiempo de dicho arrendamiento dicho D. Carlos necesitare de hacer alguna herramienta mayor o menor o sacar los hierros necesarios para su nueva herrería que pretende fabricar avaxo del castro de Portela se aian de sacar y hacer sin llevarle por ello mas que el peso que tubieren descontándolo de lo que le a de pagar por el arriendo pagando al aroza y oficiales lo que con ellos se ajustase o según lo que se acostumbra a pagar por dichas herramientas". ¿Qué ferrería es ésta del Castro de Portela? La desconozco.

${ }^{1711}$ AHPLU: $2566 / 1$

1712 AHPLU: 2567/1

1713 AHPOU. Outarelo-genealogía: caja 77, $\mathrm{n}^{\circ} 18$.

${ }^{1714}$ AHPOU. Outarelo-genealogía: caja $77, \mathrm{n}^{\circ}$ 18: Dice que hace mejora de tercio y quinto de todos sus bienes en su hijo don Antonio Bernardo de Oca, pero con la condición de que éste "no entre a gozar ni perciuir cosa alguna de los vienes libres que yo tengo y he adquirido asta estar rredimido el zenso que pago al casar de Layosa, de treinta mil reales de prinzipal y solo le permito la labranza y prados de la herrería de Lousadela pero no el fierro que ay o hubiere 
diferencia de otros bienes, que están vinculados, de éstos dicen que son libres y adquiridos por él.

A la ferrería y a sus mayordomos los vuelve a mencionar el testamento de don Antonio Bernardo de Oca Prada, marqués de Viance, en $1740^{1715}$ y $1741^{1716}$ quien declara como su sucesor en el marquesado y en la propiedad de la ferrería de Lousadela a su nieto don Tomás Suárez de Deza Oca, nacido del matrimonio de su hija Tomasa de Oca Lamas con don Carlos Manuel Suárez de Deza, señor de Bóveda ${ }^{1717}$. En 1746 aparece como propietario don Manuel Carlos Suárez de Deza $^{1718}$ y como mayordomo el presbítero Antonio Roybas ${ }^{1719}$.

Según el Catastro de Ensenada de 1752, la ferrería era propiedad de don Carlos Suárez de Deza, marqués de Viance, quien la tiene arrendada en 325 quintales de hierro al año ${ }^{1720}$, lo que significa, si aceptamos como buenos los 950 quintales de producción anual que indica Cornide ${ }^{1721}$, un 34 por ciento de la producción, renta en la que que entra el pago de las quiebras mayores. El

en ella al tiempo de mi muerte, la qual deudas (sic) que me deuen los tratantes y erreros y las rexas que estan fabricadas en los mazos de Folgoso y Rio Zereixa todo lo qual y lo que me deuen de diferentes zensos ha de entrar en poder de mis testamentarios a quienes pido se apoderen de dichos vienes y deudas que ay al doble; y mas para pagar y rredimir dicho zenso..."

${ }^{1715}$ AHPOU. Outarelo-genealogía: caja 77, $\mathrm{n}^{\circ}$ 19. Copia simple del testamento de 9 de abril de 1740: "di orden a mis maiordomos de la herreria de Lousadela para que paguen la limosna (de misas) de ella a razón de dos reales cada una"

1716 IDEM: testamento de 15 de diciembre de 1741: “Domingo Pérez, administrador de la erraria de Lousadela"

1717 IDEM: Testamento de 15 de diciembre de 1741: "Declaro por suzcesor en el marquesado de Vianze, señorío de las villas de Rionegro,Mombuey y Carrapata y su maiorazgo el de la casa de Otarelo en el de esta ciudad partidos de Sarria, Goyan y Paramo y Herrería de Lousadela con sus jurisdiciones y presentaciones de Beneficios, etc. al motivado D. Thomas Santa Cathalina de Sena Suarez de Deza, Oca, Lamas y Caamaño, mi nieto".

${ }_{1718}$ AHPL. PN.: caja 2126 (1746). el 25 de noviembre de 1746 don Francisco de Armesto, mayordomo de la ferrería de Valdomir, vende a don Manuel Carlos Suárez de Deza, dueño de Lousadela, "todos los vienes que contiene una escritura de venta que le hicieron Pedro do rego y su mujer María Dabila, vecina de Valdomir, en 800 rs. vn”. Testigo don Antonio Roybas, presbítero, mayordomo de la ferrería de Lousadela.

${ }_{1719}$ AHPL. PN.: caja 2126 (1746). El 26 de noviembre de 1746 don Antonio Roybas, presbítero y mayordomo de la ferrería de Lousadela, dice que a causa de una deuda contraida por Pedro de Arza y Magdadela García, difuntos, vecinos de Folgoso, con don Domingo Antonio Pérez presbítero y anterior mayordomo de la ferrería de Lousadela, Francisco de Arza y su madre cedieron a dicho Domingo la casa que habitaban en Folgoso "mas un día de mazo que les tocaba, de ocho en ocho días en la fragua da estolda (roto)de dicho lugar de Folgoso".

${ }^{1720}$ CATASTRO DE ENSENADA. R. G.: Seceda

${ }^{1721}$ CORNIDE: Ob. cit. ff. 225. 
Catastro nombra también a los cinco oficiales que trabajan en la ferreríáa ${ }^{1722}$. Según Cornide, el mineral de hierro que consumía era del yacimiento de Rocas, pero también debía utilizar el de Formigueiros, pues sabemos que en el siglo XIX pagaba como foro al marqués de Santa María de Villar 88 reales ${ }^{1723 .}$

En el siglo XVIII la ferrería tuvo frecuentes pleitos por el carbón, que al parecer escaseaba. En un pleito de la ferrería de Valdomir, también de esta familia de los marqueses de Viance, con vecinos de lugares del Courel, hacia 1740, se dice que "es constante que hauiendo D. Antonio Bernardo de Oca, marqués de Biance (...) yntentado que los vecinos de Villamor, Leigasos, Vidallón, Froxán y otros no fabricasen carbón sino para sus errarias de Lousadela y Valdomir, y obtendio el efectivo despacho de dicha inquisición se obpuso a ello el real Monasterio de Samos y obtuvo despacho por el que los mismos inquisidores declararon ser libre en dichos vecinos el fabricar carbón y llevarlo a donde quisieren"1724. En 1792, nuevamente el monasterio de Samos pleiteó con el arrendatario de la ferrería de Lousadela por impedir éste que los carboneros del monasterio carboneasen en el monte del Lago en San Silvestre de Saceda ${ }^{1725}$.

Por lo que parece, según el Catastro, desde mediados de siglo la ferrería ya no se explotaba directamente por medio de administradores, sino que estaba arrendada. Desde $1788^{1726}$ la tuvo en arriendo, con 21 ágoas de la ferrería de Ferreirós, Juan Francisco Rivadeneira, vecino de Santa Eulalia de Teyllar, sobrino de la marquesa de Viance, doña María Isabel Pardo Rivadeneira. En

${ }^{1722}$ CATASTRO DE ENSENADA. R. G.: Seceda: “Ay cinco oficiales en la ferrería de Lousadela en esta feligresía el uno es Juan Marcos Aroza y director de dicha ferrería al que regulan de salario seis reales por día. Diego Galego tirador al que regulan de salario a cinco reales por día. Dos fundidores que son Pedro Seoane y Joseph Galego a los que se le regula a quatro reales por día. Esteban de Lago tazador al que se regula al año a tres reales por día".

${ }^{1723}$ I. GARCÍA TATO (2000): Ob. cit. p. 168.

1724 AHRG. R. A.: 7059/15

${ }^{1725}$ AHRG. R. A.: 103/4. También AHPLU: 2528/4. En 1792 los vecinos de San Silvestre de Seceda dan su poder a don Juan Francisco Ribadeneira, apoderado de la marquesa de Viance en la ferrería de Lousadela, para denunciar a los vecinos de la jurisdicción de Lózara, abadía de Samos, porque "armados de gruesos palos tumultuariamente con la maior probocación y violencia se entrometen a romper esta real jurisdicion del Caurel, talar y deszepar el monte denominado de Coto Lago y otros sitios ( ...) haciendo en ellos carbón estraiéndolo y beneficiándolo a las ferrerías de la jurisdición de Samos" en perjuicio de la de Lousadela.

${ }^{1726}$ AHRG. R. A.: 25.291/28. En un escrito de 1811 don Juan Francisco de Rivadeneira dice "hace mas de 23 años lleba en arrendamiento la Fábrica de hierro de Lousadela", lo que indice que, al menos, la tenía desde 1788. 
1797, la nueva marquesa, doña Ana Ramona Saavedra Suárez de Deza le volvió a arrendar ambas ferrerías por 9 años y 40.000 reales de renta anual ${ }^{1727}$; y en 1806 otro nuevo arriendo por 3 años y 36.000 reales, de los cuales 30.000 por la ferrería de Lousadela y 6.000 por las 21 ágoas, de 72 en que está dividida, la de Ferreirós ${ }^{1728}$.

En 1809, pasado el tiempo del arriendo, aquella reclamó sus ferrerías, pero aquel alegó que con "la inesperada invasión de los franceses" se había estancado la salida del hierro, hasta el punto de tener más de 6.00o quintales de hierro viejo sin vender, por eso pretendía que se le prorrogara el arriendo, por lo que la marquesa le prorrogó otro año, pero ni aún así quería salir de la ferrería, alegando que estaba pagando 300 reales diarios, una de las cláusulas del contrato y que suponía una renta de más de 90.000 reales anuales ${ }^{1729}$. Pese al juicio, la ferrería siguió arrendada primero a Juan Francisco Rivadeneira ${ }^{1730}$ y luego a su mujer doña María Josefa Rivadeneira, propietarios más tarde de la ferrería de Tejedo de Ancares ${ }^{1731}$.

En 1815, a la muerte sin hijos ni herederos directos de doña Ana Ramona y Saavedra, marquesa de Viance, doña Ana Caamaño y Pardo reclamó este título

1727 AHRG. R.A.: 21291/28. Esta nueva marquesa, casada con don Juan Benito Basandre, era prima de la anterior, que debió morir sin hijos. Un documento de 1797 dice de ella que "hállase lexitima subcesora en los vínculos y mayorazgos de que estubo poseedora la excma señora doña María Isabel Pardo Rivadeneira Suárez de Deza, su prima, marquesa que fue de Viance, a los quales entre otros vienes hes anexa y perteneciente la herrería de Lousadela sita en la feligresía de San Silvestre de Saceda en la jurisdicción de Laurel, la parte de otra en la que se nombra de Baldomir, la parte que también tiene en otra que se nombra de Ferreirós, y otras rentas...".

${ }^{1728}$ AHRG. R. A.: 2529/28. Entre las condiciones del arriendo de 1806, además de la renta, arreglo de escalabros, etc. se dice que como por algún accidente podía no desocupar aquella Herrería y parte de la otra en el término de los tres años se puso por condición, al parecer sin el consentimiento de la marquesa, el pagar 300 reales diarios por cada día natural que trabaje, es decir sin domingos ni festivos.

1729 AHRG. R. A.: 25.291/28

1730 AHPLU: 2474/3. En 1813 Andrés Celaya reconoce deber a don Juan F. Ribadeneira, administrador de la ferrería de Lousadela, 7.850 reales.

${ }^{1731}$ AHPL. PN.: caja 3736 (1824 y 1825). AHRG: R. A.: 19.223/38. En 1825 recuerda un texto que: "escede de treinta años que el caballero Maestrate D. Juan Francisco Rivadeneira estubo poseedor de la Herreria de Lousadela, de las Agoas que pertenecían a la marquesa de Biance en la de Ferreirós (...) y despues de la muerte de $D^{a}$ Ana Ramona Suárez de Deza y en virtud del arriendo otorgado por D. Bernardino Taboada, cura párroco del beneficio de San Julián de Meijente, como apoderado general de $D^{a}$ Antonia Caamaño siguió por el mismo orden y después del fallecimiento del citado caballero lo verificó la expuesta $D^{a} M^{a}$ Josefa como viuda y representante y en la actualidad detenta las explicadas agoas de la Herrería de Ferreirós, a consecuencia del arriendo otorgado por D. Alexo García apoderado general de D. Apolinar Suárez de Deza”. 
y su heredades a nombre de su hijo don Apolinar Suárez de Deza, dueño de los mayorazgos de Láncara, la Mezquita y otros; pues "han quedado bacantes el Mayorazgo que fundó el Comendador Don Andrés de Prada titulado Otarelo y el vínculo que hizo Don Carlos Manuel de Oca, entre otras de la Herrería y prados de Lousadela los quales corresponden legitimanente a dicho menor Don Apolinar"1732. En 1825 la arrendó a los hermanos Pedro y Andrés Iglesias, que la administraron hasta 1834 en que muerto Andrés, su mujer y cuñado hacen cuentas quedando alcanzada ésta en 24.000 reales ${ }^{1733}$. En sus manos se mantuvo a lo largo del siglo XIX ${ }^{1734}$, como podemos ver en su testamento de 1877 1735. En 1845 era mayordomo de la ferrería Pedro Pombo ${ }^{1736}$, de Valdefariña, y en 1862 lo era Pedro de Cela y Bolaño ${ }^{1737}$. En 1868 se publicó un anuncio en el Boletín Oficial de la provincia de León para su arriendo ${ }^{1738}$.

La ferrería trabajó hasta finales de siglo. En 1874 produjo 400 Qm. de hierro con 850 Qm. de vena, de la venera de Roques; en 1882 no trabajó por falta de combustible, pero si lo hizo en 1883 durante un mes ${ }^{1739}$.

ESTADO: Según el inventario de bienes de don Apolinar Suárez de Deza de 1877, la ferrería se "compone del artefacto, carbonera, banzado o salto de agua, herramientas y útiles necesarios, plaza para el peso, depósito y calcinamiento de la vena, molino harinero, casa habitación, capilla, cuadras de ganados, horno de cocer pan", sotos de castaños y montes, etc. ${ }^{1740}$. Actualmente de todo este complejo solo queda en pie la vivienda, aún habitada, y las ruinas de la ferrería, en las que son perceptibles los muros del banzao y banzadillo, con solera de madera.

\footnotetext{
${ }_{1732}$ AHOU. Outarelo-documentos generales: caja 79, $\mathrm{n}^{\circ} 97$.

1733 AHPLU: 5341/3

1734 C. GONZÁLEZ: ob. cit. p. 159: dice que a principios del siglo XIX la poseía Juan Francisco de Ribadeneira, pero es un error. Desconozco si éste fue arrendatario o administrador de don Apolinar Suárez de Deza.

${ }^{1735}$ AHPOU. Casa do Castro: caja 130 s/n: Inventario de bienes que dejó don Apolinar Suarez de Deza, 15 de julio de 1877: "Partido judicial de Quiroga. Término municipal de Caurel. Parroquia de San Silvestre de Seceda". 83: "la herrería o fábrica de fundición de hierro denominada de Lousadela". La ferrería, sotos y montes se valoró en un líquido de 20.000 pesetas.

1736 AHPLU: 2431/1

1737 AHPLU: $2431 / 6$

1738 BOPL. año $1868, \mathrm{n}^{\circ} 15$, p. 4

1739 P. HERNÁNDEZ SAMPELAYO (1935): Hierros de Galicia, t. III, fasc. 1, p. 38.

1740 AHPOU. Casa do Castro: caja 130, s/n.
} 


\title{
9. FERRERÍA DE SEOANE
}

\author{
LUGAR: Seoane \\ MUNICIPIO: Courel \\ RÍO: Lor \\ COORDENADAS: $42^{\circ} 38^{\prime} 9^{\prime \prime}$ N. y $7^{\circ} 14^{\prime} 19^{\prime \prime}$ W.
}

En Seoane del Caurel existieron dos ferrerías, una llamada Herrería Vieja o "Vella" y otra nueva o "Ferrería Nova", ambas a orillas del río Lor, en las inmediaciones del Pueblo de aquel nombre. Las ferrerías estuvieron ubicadas en la parroquia de Seoane, en la misma población y probablemente no muy lejos una de la otra. A su vez, lo que conocemos como Ferrería Nova fueron dos fábricas, prácticamente unidas, construidas ambas antes del primer tercio del siglo XIX.

La ferrería vieja pudo ser una construcción antigua, de la que no se conservaba en el siglo XVIII más que su topónimo. Probablemente tenga que ver con la que a principios del siglo XVII construyó doña Inés de Ribadeneira con el nombre de San Juan de Noceda, lugar muy cerca de Seoane ${ }^{1741}$, y que quizá a causa de la oposición del monasterio de Samos tuvo que cerrar. No la mencionan ni el Catastro de Ensenada ni Cornide Saavedra, pero sí existen algunas referencias al topónimo en la documentación. Así en 1772 se menciona a un Juan Vázquez, "vecino del lugar de la Herrería Vieja feligresía de esta dicha villa (de Seoane)" ${ }^{1742}$. En 1804 Josef de Fojo y María Díaz se declaran vecinos del "lugar de la Herrería Vieja inclusa en la parroquia de San Juan de Seoane"; y en ese mismo año se hace un foro a Manuel Fernández "vecino de la Ferrería viexa, inclusa en esta población (de Seoane)". Es decir que la tal ferrería estuvo situada en el mismo Seoane, aunque por entonces ya no era más que un simple topónimo.

La ferrería nueva la construyó, entre 1815 y 1817, don Antonio Somoza y Pardo, dueño y vecino de la Casa del Río, en San Martín del Río, en la

\footnotetext{
${ }^{1741}$ AHN. Clero: Libro 6495. Coto de Fisteus (de Samos): "Emplazamiento de demanda entablada por el monasterio (de Samos) en la Real Audiencia en 1634 contra Da Ynés de Ribadeneira sobre la Herraria nueba de San Juan de Noceda". ${ }^{1742}$ AHPLU: 2417/3 (1772).
} 
jurisdicción de Villauzán (La Somoza). El 19 de febrero de 1815, los vecinos de las parroquias de San Juan de Seoane y San Pedro de Esperante, arguyendo que viven en una zona de montaña muy escabrosa por lo "que la maior parte de las estaciones del año se ben precisados a no poder cultibar sus granjerías y por consiguiente carecen del forzoso y debido sustento", y que al mismo tiempo por ambas parroquias "gira el río que llaman Lor y que a las orillas de él se miran montes de mucha elevación de producción de leña de roble, cepa de ucedo y otros con bastante abundancia y que igualmente lo hacen de piedra de vena, materiales para fabricar fierro de superior calidad", por lo que es muy idóneo para construir una ferrería, dan su poder a Domingo García, como procurador síndico, para que negocie con alguien su construcción.

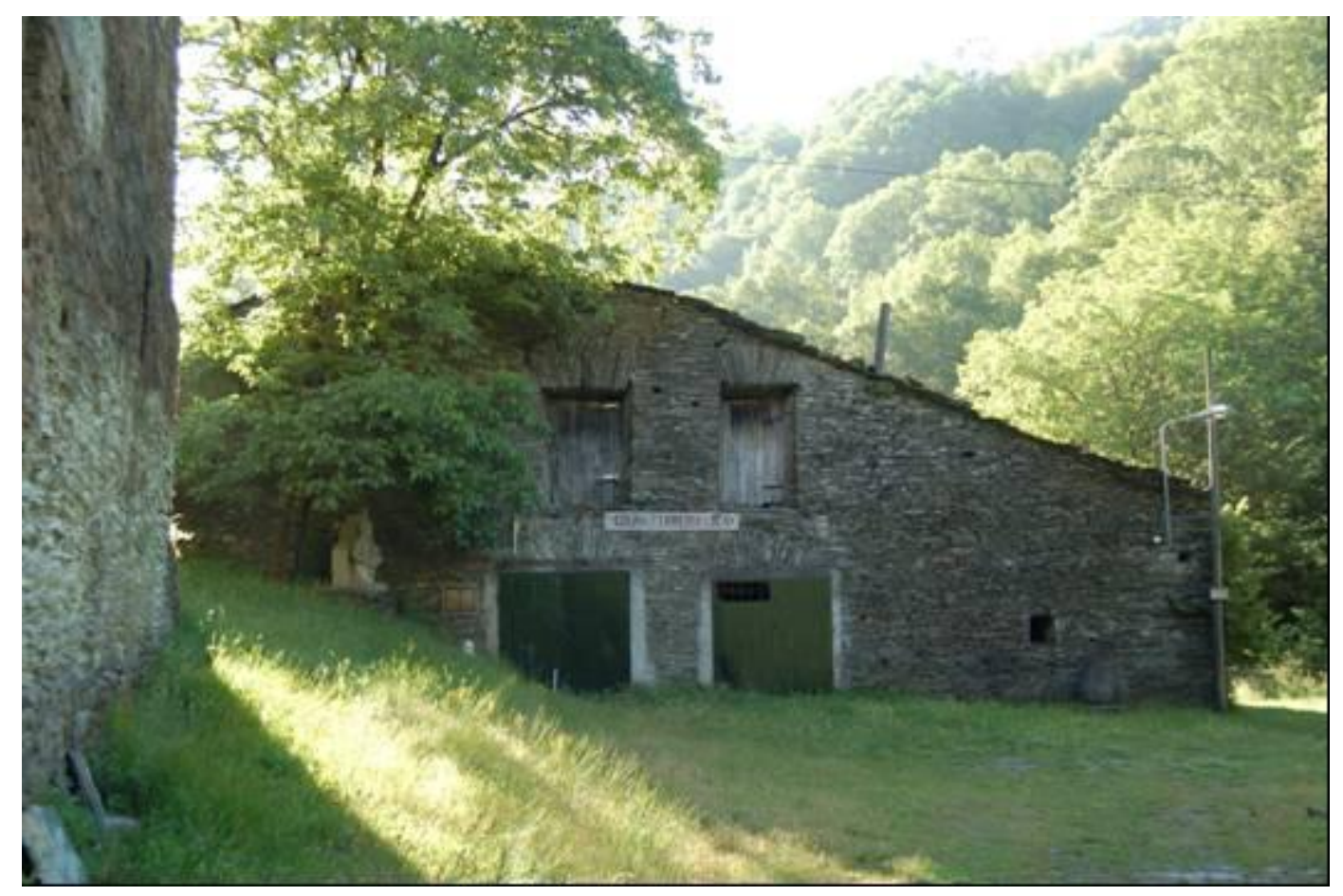

Ferrería de Seoane del Caurel

Haciendo uso de ese poder, el 21 de febrero de ese mismo año dicho Domingo García dice hallarse en tratos con don Antonio Somoza, el cual "intenta construir una Fábrica y Herrería de fierro en el río que llaman Lor y términos de las citadas dos parroquias, al sitio nombrado Puente de Seoane que dicen debajo de la motivada villa”. Por esa razón le cede a él y a sus descendientes todos los derechos que tienen ambos concejos en el "mencionado sitio y aguas del indicado río para que pueda inmediatamente y sin el menor 
impedimento construir dicha herrería". También le concede "el roze y corta de leña de roble y ucedo que produzcan los montes de las parroquias de Meiraos, Noceda, Seoane y Esperante que por la parte llaman Lomba de Parada encima del coto de la Seara", del que señalan detalladamente sus límites. Le ceden incluso la piedra y pizarra cercana al sitio de la ferrería para su construcción. Todo con la única condición de que los acarreos de piedra y materiales para la ferrería, roce de leña y fábrica de carbón "han de ser preferidos los naturales de estas dichas parroquias y más pueblos de la inmediación". Al día siguiente, los vecinos de Meiraos, Villasebil, Mirar, Paderne, Piedrafita, Noceda y Vilela ratifican en concejo el acuerdo anterior ${ }^{1743}$.

Clodio González recoge una tradición que cuentan los vecinos, de que la ferrería Nova fue construída por prisioneros franceses durante la guerra de la Independencia ${ }^{1744}$, cosa que no es cierta pero es probable que algún edificio de la casa vivienda sí pudiera ser de esa época, pues sobre la fachada de la capilla aparece el año 1810, de lo que podemos inferir que fue por esa época cuando se levantaron la casa y la capilla de los Somoza. El magnífico edificio de la ferrería se debió construir poco después del mencionado permiso, aunque en junio de 1816 aún no se había edificado, pues en esa fecha don Antonio Somoza compró al presbítero Domingo Balín y a su sobrino Carlos Balín, vecinos de Seoane, por 10.00o reales, un prado de seis ferrados de simiente junto al puente de Seoane, en el Lor, donde se erigiría la fábrica, y el uso del agua, con la que se riegan los prados, para las ferrerías que construyera en él1745. En julio vuelve a comprar en el mismo sitio otros dos pedazos de terreno a Pedro Bieiros, José Paiz y Francisco de la Fuente.

La ferrería estaba construida en 1817 , año en que su propietario dice haberla ya edificado y usado en ella mineral de Formigueiros, pero para no

\footnotetext{
1743 Todos estas escrituras en AHPLU: 2474/4 (1815).

1744 C. GONZÁLEZ (1994): Ob. Cit., p. 160.

1745 AHPLU: 2474/5 (1816). "Yten le venden el agua que necesite para cualquiera fábrica que quiera hacer y formar en el terreno referido, la que ha de conducir por el cauce con que fertiliza la pradería". Entre las condiciones señalan "que en caso no llegue el agua para regar los prados de los vendedores y para tener en ejercicio las fábricas a un mismo tiempo" tendrán preferencia los prados a las fábricas. También que la construcción de la chapacuña para extraer el agua del río Lor, asi como la conservación del cauce correrá por cuenta de don Antonio Somoza.
} 
perjudicar los derechos y regalías del conde de Maceda en ese yacimiento, da su poder a don Antonio Javier Álvarez, catedrático de la universidad de Santiago, para "que trate y convenga con él en razón de la cantidad con que se le haya de contribuir anualmente por el consumo que se haga del mineral de fierro de la referida venera en esta fábrica" ${ }^{1746}$. En otra escritura de ese año, don Antonio Somoza se declara "dueño de la Herrería de la Puente desta villa y vecino de la parroquia de San Martín del Río, en la jurisdicción de Villauzán”1747. En 1819 don José Somoza, vecino de Santiago de Freituje, "y al presente residente en la casa solar de la Erraria esistente en los términos de esta villa (de Seoane)", probablemente un pariente del dueño, afirma estar decidido a vivir con su mujer en la casa de la dicha ferrería como administradores seguramente, por lo que quiere poner como casero en la suya de Freituje a su criado Manuel Vázquez por seis años ${ }^{1748}$.

Hasta bien entrados los años veinte solo se habla de una ferrería en Seoane, pero al final de la década y posteriormente se mencionan siempre en plural: 1829, "Errerias de la villa de Seoane"1749, 1833 "dueño de las Herrerías de Seoane"1750, 1833 "dueño y vecino de las Fábricas de dicho Seoane"1751, etc. Don Antonio debió construir al lado, a finales de los años veinte, un nuevo artefacto pegado al otro, de ahí el nombre de "ferrerías" o "fábricas" de Seoane. Quizá por esa razón, debido al mayor consumo de carbón en esos años se van a suscitar, por los vecinos de las parroquias cercanas, querellas a causa del uso del bosque. Por ejemplo en 1837 se condenó a varios vecinos de Ferreirós y Campelo "como operarios jornaleros de D. Antonio Somoza y Pardo" por sustraer carbón y vena a Juan Antonio Montero y a su padre Santiago

\footnotetext{
1746 AHPLU: $5340 / 3$ (1817).

1747 AHPLU: 2474/6 (1817).

1748 AHPLU. 2474/8 (1819).

1749 AHPLU: 2528/10 (1829). Juan García Gallego se declara deudor de 6.179 reales a don Antonio Somoza, dueño "de las Errerías de Seoane". IDEM: Francisco González se obliga a pagar al mismo 6.000 rs. que le prestó.

${ }_{1750}$ AHPLU. 2458/14 (1833). Deuda de Pedro Jato de 2534 rs. a don Antonio Somoza "dueño de las Herrerías de Seoane". AHPLU: 5341/2 (1833). Reconocimiento de una deuda de José Carballo de 18.780 rs. al mismo "dueño de las ferrerías de Seoane" "procedidos de fierro que le vendió al fiado". Hipoteca una fragua de hacer herraduras, etc.

${ }^{1751}$ AHPLU: 2458/14. Reconimiento de una deuda de don Ignacio Barraganes de $12.215 \mathrm{rs}$. a don Antonio Somoza "dueño y vecino de las Fábricas de dicho Seoane". AHPLU: 5341/2 (1833). Don Antonio y su mujer dicen que "deseando solbentarse de una partida de dinero, que en bales reales deben pagar a la real Hacienda por atrasos a la encomienda de portomarín y para la que tienen hipotecada las fábricas de hierro que tienen... etc".
} 
Montero ${ }^{1752}$. Por entonces también los vecinos de Cereijido de la Sierra le conceden licencia para que pueda construir otra ferrería en ese lugar, que desconozco si efectivamente realizó ${ }^{1753}$.

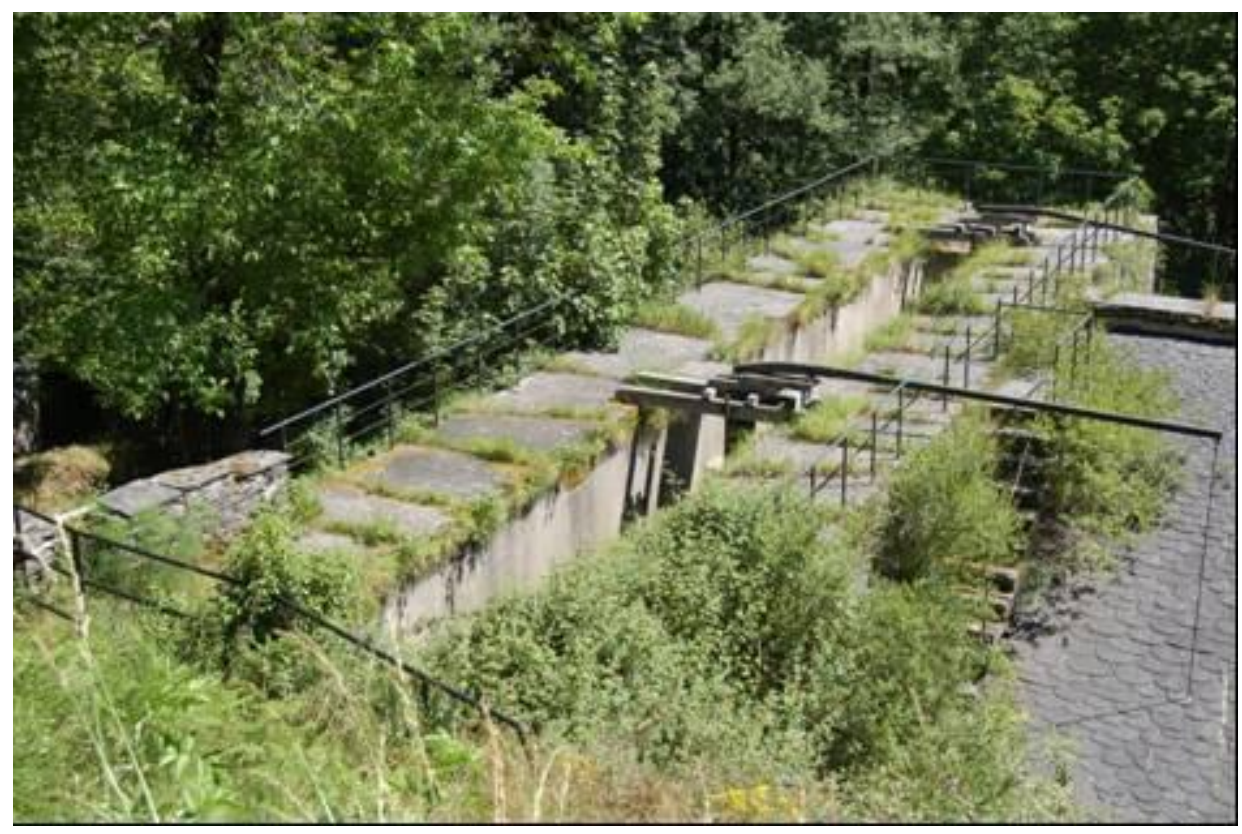

Banzadillo de la ferrería de Seoane

A partir de 1838 las ferrerías de Seoane aparecen como propias de su hijo primogénito don Juan Manuel Somoza ${ }^{1754}$. Madoz señala que en ese lugar hay dos herrerías ${ }^{1755}$. También el foro de la vena que se paga al marqués del Villar dice que paga 600 rs. "por las dos unidas de Seoane de don Juan Manuel Somoza", que es la cantidad más alta pagada de las diez y seis que se mencionan en un documento sin fecha, en relación con el pleito, en 1869, que con el conde de Maceda tuvo Apolinar Suárez de Deza por el uso de la vena de

\footnotetext{
1752 AHPLU: 6709/5 (1837). Este Santiago Montero fue uno de los promotores de la construcción de la ferrería berciana de San Vitul.

${ }^{1753}$ AHPLU: 5341/6 (1837). El 2 de abril de 1837 los vecinos de la parroquia de Nuestra Señora de la Encarnación del concejo de Cereijido de la Sierra, en Quiroga, señalan con don Antonio Somoza y otros "tienen concertado y acordado por el bien que a los primeros refluye, el que éste pueda libremente fabricar en los términos de esta parroquia y concejo las fábricas de hacer y desacer fierro que le acomoden, a cuyo efecto le franqueabn todas las facultades que en ellos residen, aguas, montes, dehesas, beneras y todo lo más conducente y anexo al ejercicio de dichas fábricas", con algunas obligaciones como no quitarles el agua de los prados, que nadie excepto ellos puedan carbonear en sus montes, etc.

1754 AHPLU: 5431/7 (1838). En ese año, como dueño de las ferrerías, adquiere varios bienes. Era el hijo mayor de don Antonio Somoza y Pardo y doña María Manuela Gayoso y Reymundez, matimonio que tuvo otros tres hijos: Ramón (canónigo en Lugo), José y Pedro; y cuatro hijas: María Concepción, Manuela, María del Carmen y Teresa.

1755 P. MADOZ: ob. cit., t. XIV, p. 183
} 
Formigueiros ${ }^{1756}$. Si pagaba por ambas quiere decir que las dos estaban por entonces en funcionamiento. Hay varios documentos de los años cuarenta y cincuenta en los que se menciona a don Antonio Somoza como propietario de ambas ferrerías ${ }^{1757}$, lo que quiere decir que aún vivía aunque las debía administrar su hijo. Probablemente él residía en la ferrería de La Mezquita, en Orense, que también era suya.

En 1856 los vecinos de San Pedro de Noceda demandan a don Juan Manuel Somoza por el uso de los montes bravos ${ }^{1758}$. El problema del combustible debió ser grave. En ese mismo año debe recordarles a los vecinos de Seoane -"con el obgeto de hevitar la estracción del carbón y leñas de los montes pertenecientes a las parroquias de Noceda, Esperante, Meiraos y Seoane"- la escritura de 1815 por la cual le cedieron a su padre el uso de las leñas. Por ello solicitó del gobernador de Lugo el deslinde y amojonamiento de los mencionados montes, licencia con la cual el comisionado don Félix Castillo pasó a realizarlo1759. Poco después, probablemente por falta de combustible, ya solo funcionaba una sola ferrería, que en 1874 aún benefició 300 Qm. de mineral de Formigueiros, que proporcionaron 100 Qm. de hierro; y así siguió algunos años más ${ }^{1760}$.

ESTADO: Además de la casa, capilla y otras dependencias, en buen estado y habitadas, la ferrería es una de las mejor conservadas y más monumentales de todo el Noroeste, especialmente por su elevado banzao, construido en sillares de pizarra.

1756 I. GARCIA TATO (2000): Ob. cit., p. 168

1757 AHPLU: 5431/1 (1845). Poder de don Antonio Somoza, dueño de las herrerías de Seoane, para cobrar deudas por hierro a varias personas de Orense y su partido judicial. AHPLU: 2377/1(1847). Foro de un prado que hace don Antonio Somoza, dueño de las herrerías de esta villa de San Juan de Seoane.

1758 AHPLU: 2563/6 (1856).

1759 AHPLU: 2409/1 (1856).

1760 P. HERNÁNDEZ SAMPELAYO: Ob. Cit., t.III, fsc. $1^{\circ}$, p. 40 y 36. 


\title{
10. FERRERÍA DE VALDOMIR
}

\author{
LUGAR: Santa Mariña de Folgoso \\ MUNICIPIO: Courel \\ RÍO: Río da Campa (Lor) \\ COORDENADAS: $42^{\circ} 34^{\prime} 29^{\prime \prime}$ N. y $7^{\circ} 13^{\prime} 10^{\prime \prime} \mathrm{W}$.
}

La ferrería de Valdomir -Baldomiro en algunos documentos- se encontraba en la parroquia de Santa Marina de Folgoso, a orillas de un pequeño afluente del Lor que allí mismo desagua, llamado río da Campa ${ }^{1761}$, justo cuando éste corta la carretera de Folgoso a Pobla de Brollón, muy cerca del lugar de Vilamor.

Era una ferrería relacionada con la encomienda de la Barra, probablemente del siglo XVI. Como en otros casos, el artefacto debió ser construido por vascos, aunque en terreno y montes aforados por dicha encomienda. Hacia la mitad de ese siglo parece tenerla en foro Juan Ortiz, casado con Marina de Zarauz, el cual cuando murió en 1558 era forero también de la de Soldón. En julio de 1574 sus hijos obligaron a su madre, que aún la traía arrendada, a tasar sus bienes, de los que eran herederos. Entre ellos: "tasaron los contadores y tasadores ante la dicha Marina de Sarauz los aRiendos que a Rentado la ferrería de baldomir con maçuco y casas -y palomar y huertas. Cada año setenta ducados por quince a esta parte que falleció el dicho Juan Ortiz hacen 1.100 ducados"1762.

Un año antes, en 1573, aparece como rendero de la ferrería, junto con la de Ferreirós, el vasco Juan Pérez de Arrazti casado con Catalina de Armesto, quien en junio de ese año arrienda esta última al vizcaíno Miguel Ortizi"163. En 1578, este Miguel Ortiz, rendero de la ferrería de Ferreirós, puso demanda a su compatriota Juanes de Lesaca por no pagarle 100 quintales de hierro que tiene depositado en Ponferrada, más todo el hierro que tenía en el lugar (¿் ${ }^{1764}$, que son cuatro quintales más 12.000 clavos de Valdomir y ocho quintales de hierro

\footnotetext{
${ }^{1761}$ AHPL. PN.: caja 3150 (1673) . De Pedro de Armesto dice un documento de 1673 que es "vecino del lugar de la Campa de Valdomiro, tierra de Courel".

1762 AHRG. R. A.: 19.768/32

${ }^{1763}$ AHRG. R. A.: 2472/120. .En el Indice Nuevo de Quiroga, del monasterio de Samos (AHN. Clero: Libro 6495, f. 4) se habla "del foro echo en 1573 a Juan Pérez de los montes y aguas de la Herraria de Valdomir". No me consta que esta ferrería fuera del monasterio de Samos, sino de la encomienda de la Barra, aunque es posible que Samos aforase algunos montes suyos. Nuevamente en 1610 se menciona una provisión Real para apear y aforar esos montes.

${ }_{1764}$ Ilegible en la escritura
} 
en la Hermida de Quiroga. Aunque no es muy explícito el documento, probablemente tenía en arriendo ambas ferrerías ${ }^{1765}$.

Lo cierto es que no está clara ni la propiedad ni el arriendo, que parecen llevar más de uno. Desde 1582 el comendador de la Barra, Diego del Valle, se querella con Juan de Zuluaga, rendero de la ferrería de Loureiro, y con Pedro de Armesto y Catalina de Armesto, mujer e hijo de Juan Pérez, vecinos de Valdomir; pues "teniendo como suya propia la quinta parte de la herraria de baldomir desta jurisdicion, con todo lo a ella anexo y perteneciente (...), los dichos acusados de dos meses a esta parte poco mas o menos se an entrometido por fuerça en su perjuicio a labrar y goçar la dicha erreria toda enteramente sin reconocerle ni acudir con la dicha su parte"1766. Entre los testigos, varios dicen que es cierto pero no saben qué parte corresponde a cada uno, aunque uno cree que la parte que pertenece a Diego del Valle es la que, desde hace años, llevaba en arriendo Lorenzo de Irigo; otro señala que tiene la novena parte y quiñón; y el tirador Juan Martín concluye que no sabe cuantos dueños tiene la ferrería de Valdomir ${ }^{1767 .}$

Creo que la ferrería estaba dividida en tres partes. Una pertenecía al comendador Diego del Valle, otra era propiedad de la familia de Juan Pérez de Arrazti, y la última parte a Juan de Zuluaga, rendero a la vez de la de Loureiro. En 1596 éste, que dice poseer la tercera parte de Valdomir, cede a Domingo de Arechaga, rendero que fue de la ferrería de Órreos, la mitad de aquélla ${ }^{1768}$. En ese mismo año Domingo de Arechega y su mujer María López aparecen como renderos de Valdomir, los cuales se obligan a pagar a Juan de Zuluaga 100

\footnotetext{
1765 AHPL. PN.: caja 2849 (1578)

${ }_{1766}$ AHRG. R. A.: 2489/48

1767 IBIDEM

${ }^{1768}$ AHPLU: 2407/9. Juan de Zuluaga "rendero de Loureiro y de la ferrería de Valdomyll" y Domingo de Arechega "rendero que fue de la ferrería nueba de Orrios" dijeron que "estan concertados ... en esta manera, en que el dicho Juan de Zuluaga, rendero susodicho, da al dicho Domingo de Arechega en conpanya y por mytad la parte y quynon que le toca $y$ perteneze de la dicha su ferreria de baldomyll ques de tercias partes a una y por otra de quarenta y cinco semanas una en esta manera, de que el dicho Juan de Zuluaga sea su cargo de poner la dicha su ferreria adrezada y reparada de barquines y tuberas arboles y ruedas $y$ mangos para el maço y el dicho Domingo de Arechega aya de poner y pagar los oficiales nezesarios de ferreria como son aroza, tirador y dos fundidores abiles y suficientes para el dicho oficio y carbón necesario de manera que por falta del no dexe de labrar la dicha ferrería y asi mismo aya de tener y pagar tazador para ella". La producción se ha de partir a partes iguales, la mitad delgado y la mitad grueso; y el acuerdo es por tres años.
} 
ducados que les prestó ${ }^{1769}$. Este Juan de Zuluaga se halla también ese mismo año como rendero de Loureiro y arrendatario de la encomienda de la Barra1770. En 1599 pasaría a su hijo Diego de Zuluaga al que citan numerosas escrituras como rendero de la misma ${ }^{1771}$; y luego a otro hijo, Pedro Díaz de Zuluaga.

En 1610 el comendador de Quiroga, Antonio de Leyba afora "los montes, aguas y pastos y mas vienes anexos y pertenecientes a la dicha Erraria de Valdomil y mazucos de Valdomir y Folgoso que solía poseer Juan de Zuluaga”, a Pedro Díaz de Zuluaga, hijo de éste Juan, por su vida y otras dos más, con la renta de 73 reales anuales y otras condiciones ${ }^{1772}$. Este Pedro Díaz denunció en 1619 a varios vecinos del lugar de Santa Eufemia por abrir una presa para regar sus prados, alegando que tenía "en fuero real la dicha ferrería de Valdomill, aguas, montes y beneras a ella anejo y pertenecientes para el uso y exercicio della de que paga fuero y rrenta al rey nuestro señor y al comendador de la Varra en su nombre", añadiendo que no solo él sino su padre, Juan de Zuluaga, "y mas antecesores están en la posesión quieta y pacífica de llebar a la dicha ferrería toda la agua del río de santa Eufemia para la labrança della”. Dice que el inicio de la querella es más antiguo, que se concertó con los tales vecinos en 1612 de que a cambio de no hacer la presa les daría 4 quintales de hierro al

\footnotetext{
1769 AHPLU: $2407 / 9$

1770 AHPLU: 2407/9. Como tal arrendatario arrienda el beneficio de la iglesia de Barja de Lor por tres años a Lope de Armesto y Valcarce, cura rector de dicha iglesia, en renta de 400 ducados al año.

${ }^{1771}$ AHPLU: 2547/1. Andrés Díez de Piñeiro, "rendero de la ferrería de Loureiro" en nombre y como tutor de los hijos menores que quedaron de Juan de Zuluaga "rendero de la dicha ferrería" por "esta carta dota e otorgaba e otorgo por pago y contento a boluntad de Diego de Zuluaga, rendero de la ferrería de baldomyll, hijo que fincó del dicho Juan de Zuluaga, es a saber una parte ciento y cinquenta y siete dozenas de herraje con su clabo a precio de a seis rs. que monta la dicha herraje nuevecientos y quarenta y dos rs., $y$ asimismo veynte y quatro quintales de yerro grueso a precio el quintal de a dos ducados ... los quales son por razon y (reparto?) de pago de la renta del arrendamyento que le hizo en nombre de los dichos menores de la ferrería de baldomyll...”. Este Andrés Díaz era cuñado de Juan de Zuluaga, el cual estaba casado con Catalina Díaz do Piñeiro. AHPLU: 2547/1. Año 1599. Diego de Zuluaga, rendero de Valdomir, da su poder a Rodrido Morán para que lo defienda del ferramentero Diego Sánchez por pegarle y otras afrentas.

${ }^{1772}$ AHRG. R. A.: 9090/4. Entre esas condiciones: que si no paga dos años seguidos pierda el fuero, que pague pese a cualquier suceso fortuito de la tierra o del cielo; "que no os aprobecharedes de los dichos montes aguas pastos y que no den fruto los mas vienes pertencientes a la dicha erreria y mazos de Baldomil"; traerlos bien labrados y que todo vaya en aumento y no en disminución, etc. Como fiador aparece Andrés Díaz do Piñeiro vecino de la ferrería de Loureiro y como testigo Martín de Gurriarán, vecino de la ferrería de Lousadela.
} 
año, pero que ellos no lo cumplieron ${ }^{1773}$. A este Pedro se le menciona por esos años en numerosas ocasiones ${ }^{1774}$.

Otra parte era de la familia de Juan Pérez de Errazti. En 1595 Catalina de Armesto, su viuda, madre y legítima heredera de Pedro de Armesto, difunto, da su poder a su hijo Juan Pérez de Arrazti para que pueda "regir y gobernar toda la hacienda, ferrerías, trato y caudal dellas .. que quedaron de su hijo Pedro de Armesto". Pedro de Armesto y Arrazti dejó numerosas deudas, entre ellas a su madre 480 ducados y a Diego López de Valle 999 ducados del arrendamiento de la ferrería de los años 1592 a $1594^{1775}$. También adeuda 600 ducados a Francisco López de Quiroga casado con Jerónima de Villasur, los cuales pusieron demanda por esa deuda a sus herederos ${ }^{1776}$. Según la querella le pertenecía: "la tercia parte de la herreria de Valdomir con todos sus pertrechos y adereços, excepto los barquines de fundir y tuberas y el entallo que sacó cabe la rueda barquinera, que esto es de los herederos que quedaron de Juan de Çuluaga, rendero de Loureiro, defunto, con mas la tercia parte de la casa que estaba caue la dicha ferraria y la tercia parte de otra casa y caballeriza que esta cabe la puente mayor de la dicha ferraria y la octaba parte del machuco de baldomill que al presente trahe el vecino de San Martino con mas la parte que le tocaba a Pedro de Armesto difunto en las huertas que están la una cabe la hermita de Santa Catalina y la otra junto al dicho maço con mas la parte de la casa que esta de la otra parte del rio". Bienes que los tasadores, de forma unánime, tasan en 650 ducados ${ }^{1777}$.

En el mes de diciembre de 1597 se ponen pregones con esos bienes, pero no hay nadie que dé por ellos los 650 ducados, así que el merino de la Tierra del Caurel, Macía Fernández Campelo entrega a Francisco López de Vesuña, en

\footnotetext{
1773 AHRG. R. A.: 5951/55

1774 En 1616 Pedro de Zuluaga, rendero de Valdomir, compra tres cuartales de centeno (AHPLU: 2555/1); y en 1622 Diego González vende a Pedro Díez de Zuluaga, rendero de Valdomir, 4 pies de castaños; en otra escritura de ese año se dice que el tal Pedro fue hijo de "juan de çuluaga rendero que fue de la ferrería de Loureiro".

1775 AHRG. R. A.: 21.359/74. También dejaba pequeñas deudas a otros muchas muchas personas. Así, a Juan de Arechaga 60 ducados, a Antonio L. Corujo 112 ducados, a Jerónimo Méndez 250 quintales de hierro, a Sebastián Macía, 71 quintales de hierro, etc.

${ }^{1776}$ Lo eran sus hermanos Juan, Francisca y María Pérez de Armesto. También tenía hijos, de los que aparece como tutor su hermano Juan.

1777 AHRG. R. A.: 5951/55
} 
nombre de Francisco López de Quiroga, la tercera parte de la ferrería de Valdomir, con todo lo a ella anexo. La adquisición de esa tercera parte por Francisco López de Quiroga sería luego objeto de disputas por los herederos de Pedro de Armesto. En 1615, Pedro Sánchez de Orozco, rendero de la ferrería de Ferreirós, como marido de María Pérez de Armesto se querella con Jerónima de Villasur, viuda de aquel Francisco López, "sobre la duodecima parte de la herrería, casa y guerta de baldomill"1778. Este mismo Pedro Sánchez, en agosto de 1616 apodera a su yerno Juanes de Lisasueta para el pleito con doña Jerónima sobre esa duodécima parte de Valdomir y para que requiera al señor don Fernando de los Infantes, gobernador de la encomienda de Quiroga, y al juez y justicia de ella1779.

La justicia del Caurel obliga a restituir esa duodécima parte, pero doña Jerónima apela, alegando que aquello ya era cosa pasada y juzgada anteriormente. La propiedad debió mantenerse dividida, pues en los años siguientes vemos como foreros y propietarios a Pedro Díaz de Zuluaga pero también a la familia Quiroga Villasur, de quien pasó, por matrimonio de Constanza Losada Quiroga, fallecida en 1614, con Diego de Prada, señor de Outarelo, a su hijo don Andrés de Prada y Losada, como recuerda éste en una carta de pago a su suegro, el marqués de Viance, de 1629, por la que hipoteca sus ferrerías de Soldón y Valdomir, al tiempo que nos dice que las heredó de su madre y abuela ${ }^{1780}$.

La ferrería de Valdomir, de la que dice que hipoteca la tercera parte, porque como hemos dicho no era toda completamente suya, la traía en arriendo el vasco Pedro Díaz Zuluaga ${ }^{1781}$, que a su vez tenía una parte en foro de la propia encomienda. En su testamento de 1632, con solo veintidós años, don Andrés de

\footnotetext{
${ }_{1778}$ AHPOU. Outarelo-genealogía: caja 77, $\mathrm{n}^{\circ} 14$

1779 AHPLU: 2555/1

${ }_{1780}$ AHPOU. Outarelo-genealogía: caja 77, $\mathrm{n}^{\circ}$ 14. Carta de pago de Andrés de Prada y Losada a favor de don Alvaro Pérez de Losada, marqués de Viance, de 3.00o ducados prometidos al tiempo de contraer matrimonio con su hija doña Constanza Antonia de Losada, según capitulaciones matrimoniales del 1 de noviembre de 1628: " $y$ particularmente me obligo $e$ ypoteco para mayor seguridad de lo que dicho es los vienes siguientes: la herreria de Soldón (...). Y asimesmo ipoteco la terçera parte de la herrería que llaman de Baldomir en tierra de Courel encomienda de la barra que tanvien trae de mi mano Pedro Díaz Yçuluaga Rendero della, los quales dichos vienes son propios de mi dicho Don Andrés de Prada y Lossada que los heredé de $D^{a}$ Constanza de Lossada y Quiroga mi madre y de $D^{a}$ Gerónima de Villasur mi abuela difuntas libres de vínculo y mayorazgo, obligaciones e ypotecas de toda restitución". ${ }^{1781}$ IBIDEM
} 
Prada, en agradecimiento a su padre y hermanas por los gastos de su familia cuando sirvió de paje en la corte y en las pruebas para ingresar en la orden de Santiago, les asignó las rentas libres de las ya citadas herrerías de Soldón y Valdomir, por un valor de cien ducados al año ${ }^{1782}$.

Este Diego de Prada, como tutor de su nieta doña Antonia de Losada, vende en 1640 la tercera parte de "la herraria de Valdomir, y el machuco, con todo lo a ella perteneciente en fauor de D. Venito Armesto $y$ Valcarce y de $D^{a}$ María de Valcarce, su mujer" en precio de 8.100 reales ${ }^{1783}$. Cuando Benito Armesto fue a tomar posesión de la tercera parte de la ferrería se opusieron a ello Juan de Lisasueta y otros por no estar hecha la escritura con las formalidades debidas, probablemente por afectar a bienes del mayorazgo de Andrés de Prada ${ }^{1784}$. Pero algunos testigos dicen que a doña Antonia Losada le interesa más la casa de Villafranca, que quiere comprar con ese dinero, que no la ferrería "por los escalabros que tiene y sucesos de abenidas y crecientes de los rios que suelen llevar las presas y hacer otros daños que cuestan mucho boluer a poner en perfección” ${ }^{1785}$. En 1641 se repite nuevamente la venta1786.

En manos de la familia Armesto, al menos una parte de la ferrería, permanecerá hasta el siglo XIX. En 1659 se menciona como propietario a don Antonio Díaz de Valcarce, con quien se obligan don Juan Díaz de Valcarce y doña María Ordoñez, sus tíos, vecinos de Villafranca, a pagarle "doce doblones de a quatro y diez y seis de a dos" por una parte y por otra $2.024 \mathrm{~ms}$. vn. "procedidos del balor de quarenta y quatro quintales de fierro picado que le a de entregar desde aquí a fin de agosto que biene de este presente año puestos

\footnotetext{
${ }^{1782}$ I. GARCÍA TATO (1999): Ob. cit., p. 454: "Y asi para descargo de mi conciencia quiero y es mi voluntad que de la renta que tengo libre en las herrerías de Soldón y Valdomiel, o en otra mas bien parada, se consignen dichos cien ducados en cada un año, en descuento de lo que gasté de dicha manera"

${ }_{1783}$ AHRG. R. A.: 21.359/74. Esos 8.100 debe pagarlos de la siguiente forma: 400 reales a Antonio Voto, vecino de la Ermida de Quiroga; y 7.700 reales a Juan Fernandez de Abuyn para acabar de pagar la casa de la yedra de Villafranca, adquirida para su nieta.

${ }_{1784}$ También porque Juanes de Lisasueta era yerno de Pedro Sánchez de Orozo y de su mujer María Pérez de Armesto, propietarios de otra tercera parte, como hemos visto por el pleito contra Jerónima de Villasur, y en este caso defendía los intereses de todos los herederos de Juan Pérez de Irazti y Catalina de Armesto.

1785 AHRG. R. A.: 21.359/74

1786 IBIDEM
} 
en esta villa a precio de quarenta y seis reales el quintal"1787. En 1711, don Bernardo Antonio de Armesto, dice que "hallándose en quieta y pacífica posesión de la erraria que llaman de baldomir y de lleuar caruon y mas necesario para dicha erraria en cauallerías por el camino que viene y pasa por el lugar de San Vicente”, el vecino de Vidallón, José Rodríguez, le impide el tránsito por un hoyo hecho ante su casa. Este vecino, dice en el pleito que aquel "aun no hace la tercia parte porque dicha erraria tiene dibersos renderos y porcioneros que trauajan y lleuan la maior parte del aprouechamiento y fabrica de dicha erraria trayendo el carbon y leña para el abasto della de los montes que llaman Vilar y Bidallón por el camino..."1788.

Es decir, que la ferrería tiene varios porcioneros y no solo a los Armesto, señores de Ferreirúa ${ }^{1789}$, porque en realidad pertenecía a la encomienda de la Barra ${ }^{1790}$, que la tenía aforada a varios propietarios. El Catastro de Ensenada dice que ésta pertenece a don Francisco Armesto y consortes ${ }^{1791}$; pero Cornide $^{1792}$ en 1780 matiza que la ferrería pertenecía al marqués de Viance y a don Antonio de Armesto, es decir que ambas familias la tenían igualmente aforada, o mejor ésta última tenía un subforo de aquélla, como se deduce de un documento posterior ${ }^{1793}$. Esta parece ser la realidad ${ }^{1794}$. Desde 1788 hasta el

\footnotetext{
1787 AHPL. PN.: caja 2698 (1659).

1788 AHRG. R. A.: 14.974/45

1789 AHN. Clero: Libro 6695. Escritura de venta: "Una de tres quartas de agoa y otra de quarto $y$ medio de agoa de yerro, con los materiales y pertrechos y porzion de montes correspondientes que hicieron al P. Fray Benito Cadagua, rendero de Quiroga, algunos vecinos de San Martiño de Quiroga y D. Josef de la Fuente vecino de Valdomir que les pertenecían en la herreria de Baldomir, jurisdiscción de Courel". AHPL. PN.: caja 2126 (1746). En 1746 se menciona a don Francisco de Armesto, vecino del lugar de Ferreirúa, como "residente y mayordomo de la ferrería de Valdomir", el cual vende a don Manuel Carlos Suárez de Deza, señor de Bóveda, "todos los vienes que contiene una escritura de venta que le hicieron Pedro de Rego y su mujer María Dabila, vecinos de Valdomir, en $80 o$ rs. vn.".

${ }^{1790}$ AHRG. R. A.: 15.167/24. En 1723 en un pleito de don Francisco de Armesto contra los vecinos de Vilamor, dice que "hallándose (él y sus padres y abuelos en la posesión) de aprouecharse de la coza y caruon que ay en los montes de dichas feligresías para el auasto de la erraria de Valdomir, los quales dichos montes (trae) en foro de la encomienda de la Barra" ${ }^{1791}$ CATASTRO DE ENSENADA. R. G: Folgoso

1792 J. CORNIDE: Ob. cit. ff. 225.

1793 AHPOU. Casa do Castro: caja 130 s/n. (1877) Inventario de bienes de don Apolinar Suárez de Deza: "El derecho real o pensión foral de tres mil cien reales anuales que graban a la herrería de Valdomir, situada en la misma parroquia de Folgoso, con que contribuyen los herederos de don Rafael Arias Armesto,vecinos de Villafranca y Ponferrada, según el foro otorgado en 5 de junio de 1800 por la señora marquesa de Viance, causante del señor Suárez de Deza ante don Juan Antonio Varela, escribano del numero de la Coruña". Seguramente este foro de 1800 fue simplemente una renovación de otro anterior.
} 
principio del siglo XIX, la parte perteneciente a los marqueses de Viance la tuvo en arriendo, con la de Losadela y 21 ágoas de Ferreirós, don Juan Francisco Rivadeneira, sobrino de doña María Isabel Pardo Rivadeneira1795. En 1797 la nueva marquesa de Viance (doña Ana Ramona de Saavedra Suárez de Deza, heredera de su prima doña $M^{\mathrm{a}}$ Isabel Pardo Rivadeneira Suárez de Deza) arrienda a dicho don Juan Francisco Francisco la ferrería por espacio de 9 años y 40.000 rs./año de renta ${ }^{1796 .}$

El Catastro de Ensenada dice que sólo trabaja tres meses y medio al año por ser pobre en agua, por lo que su utilidad, incluido el producto de los montes de urz para carbón es de solo 3.600 reales de vellón ${ }^{1797}$. Cornide le da una producción de 550 quintales ${ }^{1798}$. Además de pobre en agua, debía tener problema con el carbón, pues en a lo largo del siglo XVIII la ferrería hubo de enfrentarse con los vecinos de diversos lugares del Caurel por falta de suministro de carbón. Alega el derecho al bosque por foros concedidos a la ferrería por la encomienda de la Barra; pero aquellos vecinos los consideraban propios y por tanto con libertad de vender al mejor postor, que casi siempre es al monasterio de Samos ${ }^{1799}$. Según Munárriz esta ferrería utilizaba mineral de hierro de Formigueiros, aunque mezclado con el de Rocas ${ }^{1800}$. En el siglo XIX,

1794 AHPLU: 2417/2. Año 1771: Se menciona en la compra de una cortina por 44 ducados a don Gonzalo de Armesto, presbítero, "dueño y administrador de su erraria de dicho lugar de Baldomir", pero sabemos que sólo lo es de una parte.

${ }^{1795}$ AHRG. R. A.: 25.291/28

1796 IBIDEM

1797 IBIDEM

1798 J. CORNIDE: Ob. cit., ff. 225.

1799 AHRG. R. A.: 7059/15. En 1741 la ferrería de Valdomir intentó impedir "la condución del carbon a la herreria nombrada de Quiroga correspondiente al monasterio de Samos", cuyo administardor se opuso alegando "la posesion en que se hallaba de abastecerse del carbón fabricado en la jurisdicion de la encomienda de Quiroga como en la Real de Caurel". Nuevamente hubo problemas por la misma causa en 1774, alegando don José Armesto y el marqués de Viance, como dueños de Valdomir, que el monasterio utilizaba a los vecinos para abastecer sus propias ferrerías. En 1787 resurgieron los problemas, pero la justicia en esta ocasión falló a favor de Valdomir, pues como señalaba en un escrito "la encomienda de la Barra es dueño jurisdicional de la jurisdicion del Courel y también territorial de los montes en ella consistentes; que el aprovechamiento de estos ha sido siempre de la Herraria de Baldomir, y como tales se las aforó en el año de mil seiscientos diez la expresada encomienda al poseedor que era de aquella Pedro Díaz de Zuluaga", y que tanto él como sus sucesores han sido dueños del directo dominio. Añadiendo, José Armesto: "que yo gozo la mencionada Herrería por foro de la encomienda intitulada de la barra perteneciente a la militar orden de Santiago, cuyo foro se me concedió con el pribativo uso de montes y aguas"; y lo mismo dice D. Atonio Bernardo de Oca Prada, marques de Viance: "que son suias propias las Errerias de Lousadela y parte de la de Valdomir (...) y que a ellas son anexas los montes de cabeza de meda y otros" (AHRG. R. A.: 9090/4).

${ }_{1800}$ J. A. BALBOA (1992): Ob. cit., p. 135 
don Rafael Armesto pagaba de foro por la vena de aquel yacimiento consumida por la ferrería de Valdomir 50 reales ${ }^{1801}$.

En la primera mitad del siglo XIX la ferrería estuvo en manos de don Antonio Armesto y Robles ${ }^{1802}$ hasta su muerte en 1848, en que pasó a su hijo don Rafael Armesto Arias ${ }^{1803 . ~ U n a ~ p a r t e ~ e r a ~ d e ~ d o n ̃ a ~ C l o t i l d e ~ F l o ́ r e z, ~ d e ~ l a ~ q u e ~}$ una escritura de 1850 dice que es dueña "de cuarto y medio de ágoa en la herreria de Valdomir y de ocho ágoas en la de Ferreirós", añadiendo que su parte de Valdomir la llevó en arriendo desde 1832, don Antonio Armesto y luego su hijo Rafael hasta 1858, por 140 reales anuales ${ }^{1804}$. Este Rafael Armesto estuvo casado con una hija de Nemesio Fernández, propietario de cinco ferrerías en el Bierzo, de la que tuvo a su vez dos hijas, Agueda y Petra, las cuales, en 1868, heredaron, a partes iguales ${ }^{1805}$, las ferrerías gallegas de su padre, entre ellas esta de Valdomir, en cuyo inventario de bienes se valoraba en 58.000 reales ${ }^{1806}$.

Madoz habla de que en la feligresía de Santa Mariana (sic) de Folgoso hay dos ferrerías, una en Baldemir (sic) y otra en Folgoso1807. En 1874 benefició 600 Qm de vena de Formigueiros, de los que obtuvo 200 Qm. de hierro. Dos años después, entre ésta y la de Ferreirós de Abajo, en parte propiedad de los Armesto (ahora de sus yernos Adriano Quiñones y Francisco Soto) fundieron 900 Qm. de mineral de Roques, de los que obtuvieron 450 Qm. Aún trabajó en los años 1880 a 1885, aunque cada vez con menor producción, así en 1884 produjo 26 tn. de hierro con 80 de vena y en 1885,3 tn. con 10 tn. ${ }^{1808}$.

\footnotetext{
${ }^{1801}$ I. GARCÍA TATO, I (2000): Ob. cit. p. 168.

1802 Fue hijo de José Armesto, a quien escrituras de finales del siglo XVIII nombran como dueño de la ferrería, así en 1792 (AHPLU: 2528/4). A su muerte le quedaron varios hijos (Antonio, Ignacio, Salvador y Francisca), por lo que dejó como curadores a su mujer doña $\mathrm{M}^{\mathrm{a}}$ de Robles y a su hermano don Antonio de Armesto, presbítero, hasta aproximadamente el año 1820. Varias escrituras de los años 1834 (AHPLU 2458/15) y 1847 (AHPLU: 2377/1) mencionan como dueño a este don Antonio Armesto y Robles.

${ }_{1803}$ Una parte porque era suya y otra por foro, hecho en 1800, a los marqueses de Viance.

${ }_{1804}$ AHRG. R. A.: 21.485/2

1805 AHPL. PN.: caja 9113 (1869): Hijuelas de la herencia de don Rafael Armesto.

${ }_{1806}$ AHPL. PN.: caja 9113 (1868).

1807 P. MADOZ: Ob. cit., t. VIII, p. 115

1808 P. HERNÁNDEZ SAMPELAYO: Hierros de Galicia, t. III, fas. $1^{\circ}$, p. 37 y 38.
} 
ESTADO: En el inventario de 1868 se describía la ferrería de esta forma: "una herrería con banzadillo y banzado, con mazo y martinete para deshacer el fierro, con dos molinos harineros, uno a su parte superior y otro a la inferior, con carboneras, con todos los intrumentos y herramientas de fabricar hierro que a continuación se inventarían, con la casa habitación contigua a dicha herrería, cuadras, pageras, tinglados para leñas, plazuelas, puentes y pontones que dan paso a dicha fábrica, con los nogales, castaños y otros árboles de su frente"1809. De todo esto no se conserva más que la capilla, aún en uso, un pontón de madera y restos del banzao.

\section{FERRERÍA DE VILASIBIL}

LUGAR: Parroquia de Santa María de Meiraos

MUNICIPIO: Courel

RIO: Pequeno o Vilasibil

COORDENADAS: $42^{\circ} 39^{\prime} 26^{\prime \prime}$ N. y $7^{\circ} 10^{\prime} 4^{\prime \prime} \mathrm{W}$.

Desde Seoane por un camino que sigue el curso del río Pequeno, afluente del Lor, se llega hasta esta ferrería, que se encuentra en la parroquia de Meiraos, aunque algo alejada de la población.

Clodio González la considera una ferrería ${ }^{1810}$, pero los datos son tan parcos y tan imprecisos que es difícil saber si se trata de una verdadera ferrería o de un simple mazo. Lo construyó en 1813 Francisco Romero, vecino de Villasibil, como se deduce de un pleito entre éste y Domingo López. Al parecer aquél "intenta construir un artefacto de mazo para azer fierro en el molino do bao, términos de este dicho Meiraos"; para ello quiso levantar una "tapacuña y coro de agua", pero ésta al parecer "circunda la estolda o acequia de un molino harinero que (Domingo López) tiene a la parte superior de la espuesta 
tapacuña"; y para evitar juicios costosos acuerdan nombrar peritos agrimensores y no perjudicarse mutuamente ${ }^{1811}$.

El término mazo "para azer fierro" podría significar que no era únicamente un mazo, sino que también pretendía efectivamente fundir hierro, pero no lo sabemos con certeza, aunque es posible que así fuera durante un corto periodo de tiempo. Madoz, a mediados del siglo XIX, dice sencillamente que en este lugar hay "un martinete de hierro"1812. Creo que se trata de un mazo, aunque quizá transformado a partir de una anterior y precaria ferrería.

ESTADO: Hay restos de muros de la ferrería, el banzao y el canal.

\section{FERRERÍA DE VISUÑA}

LUGAR: San Pedro de Hórreos, feligresía de Santa Eufemia MUNICIPIO: Courel

RÍO: Visuña

COORDENADAS: $42^{\circ} 35^{\prime} 7^{\prime \prime}$ N. y $7^{\circ} 3^{\prime} 25^{\prime}$ W.

Con el nombre de Visuña -Visonia en los documentos medievales- se conoce el curso alto del río Selmo, que nace en la sierra del Caurel y desemboca en el Sil a la altura del pueblo berciano de Friera. Su curso discurre primero por territorio gallego, por el antiguo coto de Visuña, en la comarca del Caurel o Courel, en que a trechos es un río subterráneo; y luego por tierras del Bierzo, por la antigua merindad de Aguiar. Fue un río de una animada actividad siderúrgica, pues desde el siglo XV al XIX se construyeron en sus márgenes hasta seis ferrerías, cinco en el Bierzo, y una, la de Visuña u Órreos, en Galicia.

La ferrería se denominó indistintamente como de Visuña, por el río que movía sus ruedas, o como de Hórreos (Órreos en la documentación), por la parroquia de San Pedro de Hórreos en la que se sitúa. Frecuentemente también la documentación la nombra como "Ferrería Nueva". Quedaba a la derecha de 
la carretera que baja del pueblo de Visuña a Hórreos. El antiguo camino cruza el Visuña por un puente de madera justamente donde se situaba la ferrería, que se alzaba entre la vivienda, aún conservada, y el río.

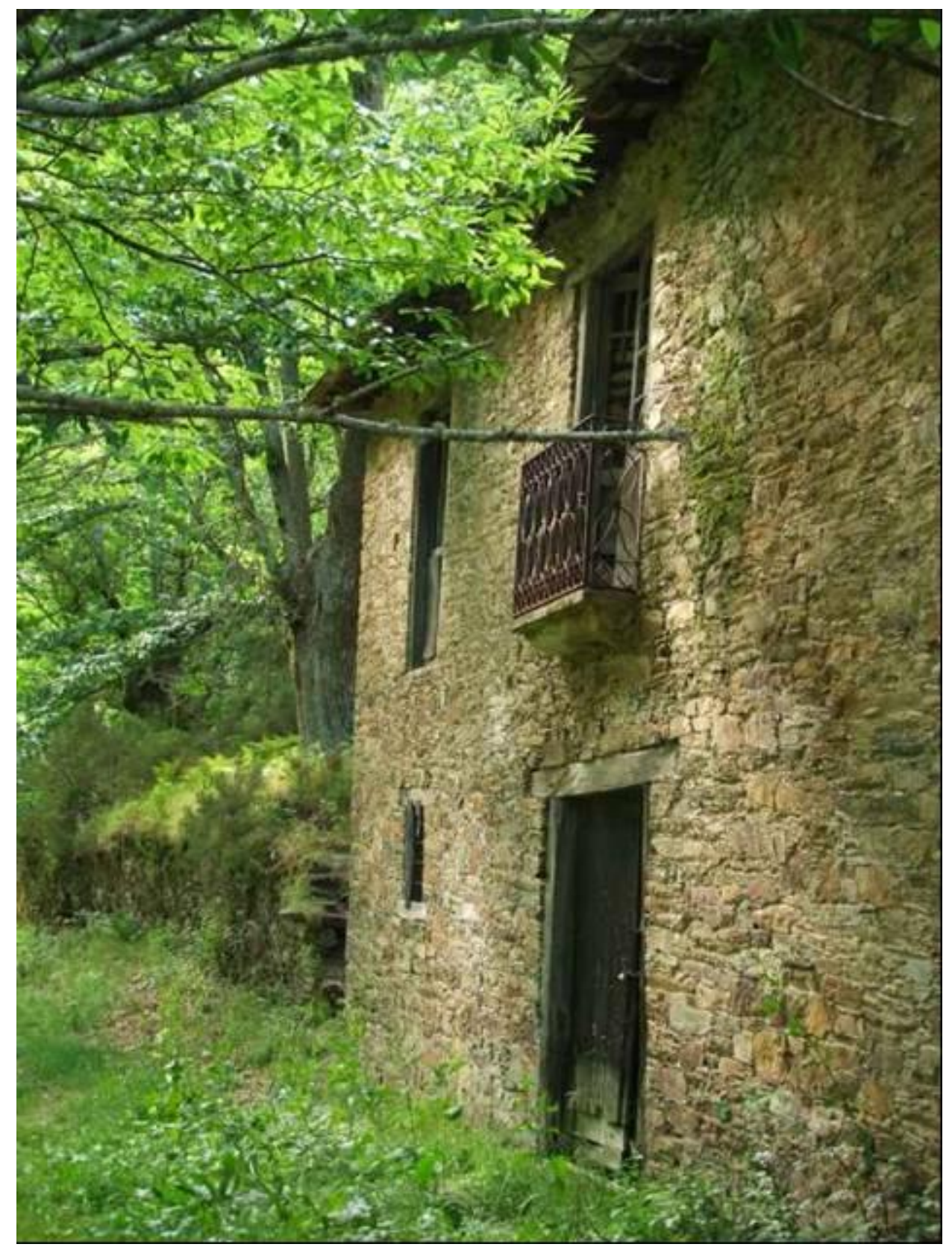

Vienda de la ferrería de Hórreos o Visuña

La denominación de Ferrería Nueva de Visuña puede entenderse como que la tal ferrería vino a sustituir a una Ferrería Vieja, probablemente de origen medieval o de los primeros años de la Edad Moderna. Clodio González dice que la primitiva ferrería estaba situada en la aldea de Céramo, tres kilómetros río 
arriba, lo que deduce por el nombre de los montes de los alrededores: Fornos de Céramo ${ }^{1813}$. Es posible que fuera así, y que la tal ferrería, en el monte, pudiera asemejarse a la que los vascos denominan "haizeolak" o ferrerías de viento1814; el tipo de escorias podría confirmarlo. Pero también el término "Nueva" podría referirse a que cuando se construyó en el siglo XVI era efectivamente nueva respecto a las bercianas de San Victor y Pontepetre, que están en el mismo río, o a las numerosas de las encomiendas de Quiroga y Caurel.

Desconozco la fecha en que se construyó, pero probablemente habría que situarla en la primera mitad del siglo XVI, pues en 1558 sabemos que era rendero Martín de Bergança, aunque solo se mencione la ferrería nueva ${ }^{1815}$. En enero de 1596 se dice de Domingo de Arechega que es "rendero que fue de la ferreria nueba de Orrios"1816; y en mayo de ese mismo año conocemos que Juan de Regil es "rendero de la ferreria nueba de Orrios"1817, lo que prueba que es una ferrería de este siglo, aunque más moderna que las otras de la zona (Soldón, Valdomir, Ferreirós, Arnado o Pontepetre) al denominársele como "nueva". Este Juan de Regil seguía siendo rendero en 1600, año en el que, por el mes de julio debió de morir ${ }^{1818}$, sucediéndole como renderos Pedro de Ordazcoyti y su mujer Juliana de Regil "renderos de la ferrería nueua de Orrios"1819, que eran yerno e hija de aquél respectivamente ${ }^{1820}$.

Poco después, en 1603, era rendero "Juanes de Celaya Rendero que soi de la herraria nueba de orrios partido tierra de courel encomienda de la

\footnotetext{
${ }_{1813}$ C. GONZÁLEZ (1994): Ob. cit., p. 155-156. También lo menciona Datoli (J. A. BALBOA (1992): Ob. cit., p. 59: "Monte llamado los Hornos de Céramo".

1814 I. ARBIDE y otros (1980): Ferrerías en Legazpi. Guipúzcoa, p. 19 y ss.

1815 Se trata del inventario de Juan Ortiz, rendero de Soldón, en el que aparece entre sus deudores un "Martín de Bergança, rendero de la ferrería nueba, veinte ducados y seis millares de clauo" (AHRG. R.A.: 19.768/32).

1816 AHPLU: $2407 / 9$

1817 AHPLU: $2407 / 9$

${ }^{1818}$ AHPLU: 2408/1. Ferrería de Órreos, 3 de septiembre de 160o. Inventario de bienes de Juan de Regil. Se dice que fue rendero de Órreos y que hará dos meses que se murió (es decir, en julio)

${ }_{1819}$ AHPLU: 2408/1. La Seara, 28 de julio de 160o. Pedro de Orozcoyti y Juana de Regil, su mujer, renderos de Órreos se obligan a pagar a Pedro Méndez, mercader de Villafranca, 30 ducados que les prestó antes de ahora.

1820 AHPLU: 2408/1. Poder hecho el 24 de noviembre de 1600 por "Pedro de Azcoyti, rendero de la ferrería nueua de Orreos, como marido de Juana de Regil, hija que quedó de Juan de Regil"
} 
Barra"1821; a quien se menciona nuevamente en 1604: "Juanes de Celaya, rendero de la herreria nueba de oreos"1822. Este Juanes de Celaya, de origen vasco, era medio hermano de Catalina de Celaya, hija de soltera de Catalina de Arburu y Beltrán de Celaya. Su madre estuvo casada con Juan Ortiz de Artinduaga (hijo de otro Juan de Ortiz que en 1550 reconstruyó la ferrería de Soldón), quien en 1603, viviendo con ella y su hermano en la ferrería de Órreos les cedió su parte en la ferrería de Soldón por los 4.800 reales que había recibido en dote al casarse con la mencionada Catalina de Arburu1823.

Probablemente la ferrería era de la encomienda de la Barra, o ésta había cedido en foro los montes de los alrededores de Órreos con la condición de hacer una ferrería, como fue el caso de otras cercanas. En 1616 Miguel de Licumberri "rendero de la ferrería nueua de Orrios" dice que "tiene en arrendamiento la dicha ferreria nueba de mano de Pedro de Urdazcoiti, señor de la dicha ferrería (...) por tiempo y espacio de nuebe meses"1824. Pedro de Urdazcoiti y Pedro de Orozcoiti ${ }^{1825}$ son la misma persona, que aparece primero como arrendatario y luego como señor de la ferrería; pienso que en este segundo caso lo es por foro, probablemente de la encomienda de La Barra, dueña del dominio directo de la zona y muy interesada en la promoción de ferrerías, como veremos en el caso de la de Quiroga. En la mencionada escritura de 1616, el rendero Miguel de Licumberri arrienda, a su vez, a Pedro García, vecino de Órreos, una semana de cada uno de los nueves meses de su arriendo, con la condición de ir a medias en el hierro producido en dicha semana, pagando a medias los oficiales, mientras que la vena, cocida y puesta en la ferrería, la ha de poner Miguel Licumberri y el carbón Pedro García ${ }^{1826}$.

\footnotetext{
${ }^{1821}$ AHRG. R. A.: 20441/70

${ }^{1822}$ AHRG. R. A.: 21468/32

${ }^{1823}$ AHRG. R. A.: 20441/70: "El caso digo que la dicha Catalina de Arburu fue casada con el dicho Juan Ortiz puede auer veinte y tres años mas o menos (es decir, hacia 1550), y al dicho tiempo llevó a su poder y reciuió bienes del valor de 4.800 rs. de que el dicho Juan Ortiz dio carta de pago" (julio de 1580)..

1824 AHPLU: 2555/1. Dice que esos 9 meses comenzaron a contar el día de San Miguel de Septiembre.

${ }_{1825} \mathrm{Si}$ no he leido mal, aparece de las dos maneras citadas, y en una ocasión como Pedro dordazcoyte, marido de Juana de Regil y rendero de Órreos.

${ }_{1826}$ AHPLU: 2555/1: " $y$ cada uno de ellos arrienda al dicho Pedro García una semana de cada uno de ellos de los dichos meses y en cada una de ellas partan el hierro (que se haze?) en la dicha ferrería tanto unocomo otro con condicion que lo que se adelgazare corra por quentaq de anbas partes el pagar los oficiales y brazeros de la dicha ferrería y para esto el dicho Pedro García sea obligadoa poner el carbón para la dicha semana de cada mes de (roto) para fundir
} 
Ignoro como pasó de estos Urdazcoiti a los Armestos, señores de Veyga de Forcas, pero parece que éstos la poseían a finales del siglo XVII o principios de siglo XVIII, aunque la tenían en arriendo, pues en 1682 Juan Fernández de Guzmán y su esposa Ana Fernández como arrendatarios de la ferrería Nueva de Visuña se obligan a pagar al comerciante de Villafranca Francisco Soto Gaioso, "quarenta y siete mil reales de moneda de vellón los cuales confiesan deverle por otra tanta cantidad que prestó a los otorgantes antes de aora en diferentes partidas", cantidad que han de pagar antes del 11 de agosto de $1682^{1827}$. Es posible que esa cantidad se la prestase dicho comerciante para pagar el arriendo y la puesta en marcha de la ferrería, como vemos que ocurre en otras ocasiones.

Como he dicho, a finales del siglo XVII la ferrería estaba en manos de la familia Armesto y Ron, señores de Veyga de Forcas (Lugo), en concreto en las de don Gonzalo de Armesto y Ron, que vivió en la segunda mitad de ese siglo, el cual la cedió a su hijo Matías de Armesto y Ron en $1723^{1828}$. En 1722 se menciona "la herraria de Ferramulin que corre de orden de D. Juan Triuijano vecino de la villa de Villafranca, Reino de León" ${ }^{1829}$, que podría ser un arrendatario. En 1729 don Matías de Armesto, vecino de Villafranca del Bierzo, la arrendó por tres años (1729-1733) a don Lorenso de Prada, vecino del monasterio de Jagoaza (Valdeorras), en precio de 250 ducados de vellón el primer año y 350 los otros dos ${ }^{1830}$. En los años 1733 y 1734 aparece como

la bena necesaria buen metal cozido y la ferraria sana y buena a su costa sin que corra por quenta del dicho Pedro García ezeto que los derechos de los oficiales de la dicha ferrería deban de pagar entrambos", como también los descalabros de aderezos y herramientas.

1827 AHPL. PN.: caja 2923 (1680). El documento está escriturado en "la Herrería Nueva, feligresía de Santa Eufemia del lugar de Vessuña, terra de Courel”; entre los testigos aparece su hijo Felipe de Guzmán.

${ }_{1828}$ AHPL. PN.: caja 3333 (1729): En el arriendo que de la ferrería hace su dueño don Matías de Armesto y Ron, vecino de Villafranca, el 16 de octubre de 1729, dice que le pertenece "por zesión que por vía de alimentos le hizo D. Gonzalo de Armesto y Ron, su padre, por escritura que pasó por testimonio de Phelipe García escribano de la jurisdicción de Toreno" en 1723.

${ }^{1829}$ AHN. Estado: leg. 1739, $\mathrm{n}^{\circ} 16$. No se trata de una ferrería nueva sino que la de Ferramulín es la de Visuña, que está al lado de dicho pueblo de Ferramulín sobre el río Visuña.

1830 AHPL. PN.: caja 3333 (1729). Entre las condiciones del arriendo figuran: 1) El otorgante da a don Lorenzo 40 anegas de centeno que pagan los colonos de Visuña, Ferramulín y otros; así como los censos que le deben en Villarrubín y el provecho de tres prados inmediatos a la ferrería; 2) el coste de las reparaciones del banzado y barquines son por cuenta de dicha renta; 3) los perfectos y mejoras que se hagan en la ferrería por cuenta de don Lorenzo se descontarán de la renta, si son realmente necesarias; 4) Si en los tres años hubiera desmejoras se han de pagar por el arrendatario; 5) si en el primer año del arriendo una venida arruinase la chapacuña, la ha de componer don Lorenzo y pagar la mitad; 6) otros descalabros mayores y menores todos 
arrendatario don Pedro Santín de Yrrasti, vecino de Portela de Aguiar1831; en 1746 se dice que es y fue arrendatario Francisco Alvarez, a quien por no pagar la renta, su dueño, don Matías Hernando de Armesto y Ordoñez, lo denuncia ante los tribunales ${ }^{1832}$.

Posiblemente estas dificultades en el cobro de la renta, llevaron a sus dueños, por algún tiempo, a administrar directamente la ferrería; pues en 1750 don Francisco Antonio de Losada aparece no como arrendatario sino como administrador, con quien se obligan los vecinos de Campazas, Josep Carlón y Félix Herrero, a pagarle 2.300 rs. vn., que "confiesan estarle debiendo de el balor de diferentes porciones de yerro que me ha remitido de dicha herrería por cuia cantidad y trescientos rs. más le tenía hecho bale en la villa de la Bañeza en los once de octubre del año pasado de mil setecientos cuarenta y nueve"1833. Este documento muestra el hinterland de esta ferrería por tierras leonesas, probablemente por la comercialización del hierro por arrieros maragatos, que tenían en La Bañeza su centro de distribución.

Según el Catastro de Ensenada, de 1752, la ferrería era propia de doña María Teresa Queipo de Llano, aunque en realidad no era más que curadora y madre de don Antonio de Armesto y Queipo, su verdadero dueño, ambos vecinos de Villafranca del Bierzo, localidad en la que residen frecuentemente estos y otros dueños de ferrerías gallegas. A la ferrería se le consideraba de útil sólo 4.000 rs. de vn. "por solo cuatro meses que trauaja al año por ser pobre de aguas" 1834 , lo que parece lógico al situarse en la cabecera del río. Cornide, en

por cuenta de don Lorenzo; Éste ha de recibir las caballerías que hay para el uso de la ferrería y tras el contrato las devolverá; 8) ha de recibir igualmente la vena y el carbón, tasando su precio; 9) si se originan pleitos por el monte, el coste se rebajará de la renta. Entre los testigos figura don Tomás de Armesto y Ron, rector de esta villa de Villafranca.

${ }^{1831}$ AHPL. PN.: 3341 (1733): Don Pedro Santín de Yrrasti "arrendatario de la Herrería Nueva en la jurisdición de Visuña Reyno de Galicia", da un poder a causa de una querella que presenta contra varios vecinos de Portela por robo en una panera suya; 1734, el mismo da un poder a don Francisco Antonio Guerra Donís, arrendatario de la ferrería de Soldón para que le defienda en un juicio.

${ }_{1832}$ AHPL. PN.: caja 3342 (1746). Es un poder de Bernardo de San Martín, del Mazo de Santigoso, pues también él está encausado por haber sido fiador del arrendatario moroso: "Francisco Alvarez arrendatario de la Herreria Nueba".

1833 AHPL. PN.: caja 616 (1750)

1834 CATASTRO DE ENSENADA. R. G.: Órreos. 
1780 , dirá que produce al año 600 quintales ${ }^{1835}$, cantidad que poco después Lucas Labrada reducirá a 200 quintales ${ }^{1836}$. En la pregunta 33 del interrogatorio se mencionan al aroza, el tirador, los dos fundidores y el tazador ${ }^{1837}$; cifra de oficiales semejante a la que señala Lucas Labrada en $1804^{1838}$.

Por lo general, los dueños de la ferrería son absentistas y no suelen explotarla directamente, sino que la tienen arrendada. En 1761 el arrendatario era don Gregorio Martínez Delgado, vecino de Benavides (León), que a su vez era administrador de la ferrería berciana de Pontepetre. Aquella se la administraba su hermano don Manuel Martínez Delgado. En un poder que aquél otorga al vecino de Astorga don Ventura Garcia Teixo, se mencionan los lugares en que tienen deudores ambas ferrerías, lo que nos indica la zona de hinterland del hierro: coto de Visuña, Jurisdicción de Valcarce, Barjas, Villafranca, Puebla de Sanabria, tierra de Frieras, Tabladillo, Combarros, Brazuelo, Villalibre y Laguna de Somozas; como indica al final el documento "tierra de maragatos", pues muchos de los lugares pertenecen a esa comarca leonesa, cuyos arrieros comercializaban frecuentemente el hierro gallego y berciano ${ }^{1839}$. Un nuevo arrendatario en 1793 fue don Juan Antonio Castrillón ${ }^{1840}$, a quien se la arrienda su nuevo dueño don Manuel de Armesto y Omaña ${ }^{1841}$.

1835 J. CORNIDE: Ob. cit. ff. 225. Este autor la incluye en el Reino de León, con la de Valcarce, Arnado y Oencia; pero es un error pues todos los documentos la mencionan siempre "en el Reino de Galicia”.

${ }^{1836}$ L. LABRADA: Ob. cit. p. 143

1837 CATASTRO DE ENSENADA. R. G.: Órreos: "que los que se ocupan en algunas artes Mecánicas son los cinco oficiales de la Ferrería que el Aroza es Francisco Fernández, vecino de San Vicente de Villamor, a quien por el tiempo que trauaja la Ferrería en cada un año le consideran de utilidad seiscientos rs. de vn. El Tirador es Crisóstomo Rodríguez vecino de la jurisdición de Quiroga al que le consideran de utilidad en cada un año por el teimpo que trauaja la Ferrería quatrocientos y cinquenta rs. vn. Los fundidores son Diego Baldonedo y Antonio Pais vecinos de San Mamed de Fisteus y a cada uno consideran de utilidad en cada un año por el tiempo que trauaja la Ferrería trescientos y cinquenta rs. vn. Y el tazador es Francisco Fernandez vecino de San Vizente de Villamor al que le consideran de utilidad por el tiempo que trauaja la Ferrería doscientos rs. vn."

${ }^{1838}$ L. LABRADA: $O b$. cit., p. 143.

1839 AHPL. PN.: caja 3341 (1761): Esos arrieros y vecinos de los pueblos mencionados "me estan debiendo varias cantidades de maravedis procedidos de hierro, que les he vendido al fiado ansi en dicha herrería (de Pontepetre) como en la Nueba, por medio de la persona de D. Manuel Martínez mi hermano que la administra; de dinero prestado, machos y otras caballerías que a algunos de dichas personas tengo vendido al fiado".

1840 AHPL. PN.: caja 3463 (1793).

${ }^{1841}$ AHPL. PN.: caja 3328 (1793). En ese año era dueño de la ferrería don Manuel de Armesto y Omaña. 
Este Manuel de Armesto y Omaña, a quien "le corresponde y posee como suya propia una Herrería llamada la Nueba, que se surte de la vena que producen los montes de Formigueiros, consistente en los términos jurisdicionales del lugar de Visuña”, pleitea en 1796 con don José María Tineo, dueño de la ferrería de Bueyes, porque siendo común el aprovechamiento del mineral "intentó apropiarse del sitio más pingüe y productivo (...) haciendo un voluntario amojonamiento del referido sitio e intentando perturbar este común aprovechamiento al esponente y demás interesados con igual título"1842. La querella, que se inició en 1790, se sustanció primero en la Real Audiencia de La Coruña, con sentencia favorable al dueño de la ferrería de Visuña; pero luego el de la de Bueyes apeló a la Chancillería de Valladolid.

En 1797 era administrador de la ferrería el presbítero don Juan Castrillón, con el que se obliga el herrero de Villafranca Antonio Blanco, alias Meixaus, a pagarle 1.518 reales y 12 mrs. que le debe de cuentas "dimanadas del yerro fiado que en diferentes ocasiones y porciones le he sacado de la dicha Herreria", y para lo que hipoteca diferentes bienes entre ellos "la casa fragua cubierta de losa con sus fuelles, yunque, martillos, tenazas y demás aperos de ella y necesarios al ejercio y oficio que este otorgante tiene de Herrero"1843

De don Manuel de Armesto ${ }^{1844}$, la ferrería y el mayorazgo pasó a principios del siglo XIX a Joaquín de Armesto y Tejeiro, abogado en Don Benito (Extremadura) quien en 1805 la tenía a cargo de un administrador llamado don Gregorio López Santalla, vecino de Córgomo (Valdeorras), desde "hace más de diez meses", es decir desde comienzos de ese año ${ }^{1845}$. Años antes, el

\footnotetext{
1842 AHPL. PN.: caja 3339 (1796).

1843 AHPL. PN.: caja 3337 (1797).

1844 AHPL. PN.: caja 3329 (1798). Todavía en febrero de 1798 era don Manuel de Armesto dueño de la ferrería, pues en ese año dio un poder a Fr. Onofre Rodríguez, prior de la ferrería de Rugando, para que inspeccionase las finanzas de don Rosendo Sánchez, vecino de Nobais (Quiroga), para la administración "de la herrería que poseo con lexítimos títulos en los términos y jurisdicción de Visuña, Reino de Galicia, y se titula la Nueba...”. Murió en 1801 y, al parecer de su matrimonio con doña Casilda Quintano y Valcarce no tuvieron hijos, por lo que el mayorazgo y la ferrería pasó a otra rama de la familia, a ese don Joaquín de Armesto Tjeiro, abogado en la villa de Don Benito, en Extremadura.

1845 AHPL. PN.: caja 3576 (1805). Dice que no acepta la curadoría de unos niños en el Castro de Valdeorras, pues no puede "desamparar la administración de la herrería que lleva relacionado, sin que experimente una total ruina en los vienes del otorgante, pues haviendo esparcido un gran número de caudales de su amo a los naturales de esta xurisdición para el
} 
administrador fue el presbítero, vecino de Soldón, don Pedro Fernández Rigueiro ${ }^{1846}$. Al menos, entre 1810 y 1833, tuvo como administrador y arrendatario ${ }^{1847}$ a Jacinto Fariñas, vecino de Lusío ${ }^{1848}$, en nombre de don Rodrigo Rodríguez de Campomanes, conde de Campomanes, a quien la ferrería pasó por su matrimonio con doña Rosa de Armesto Teijeiro y Cortés ${ }^{1849}$, aunque algún año, como 1824, se menciona como arrendatario a don Manuel A. Sánchez ${ }^{1850}$.

José de Ayra, administrador de la ferrería, denuncia en 1846 que Santiago Montero y su hijo le deben 1.289 rs. y Manuel Aira 275 rs. "procedentes una y otra partidas de fierro que llebaron al fiado de esta fábrica (de Órreos)”1851. En 1848, don Juan López, vecino de Cacabelos y apoderado de doña María de los Dolores Barrera y Freijo, como curadora de su hijo don Manuel Rodríguez de Campomanes y Armesto, arrienda a doña Estefanía Rivas, vecina de Villafranca,

acopio de materiales para la fábrica de que debe dar cuenta con el pago de alcances, no le es fácil verificarlo saliendo de ella".

${ }_{1846}$ AHPL. PN.: caja 3576 (1806). Dice este don Pedro Fernández, en un poder que otorga a Antonio Colinas,vecino de Bembibre, para que pueda cobrar a Domingo Alvarez, de Villar de las Traviesas, 1.100 rs. vn "procedidos de hierro que le dio al fiado en la Herrería Nueba propia del señor D. Joaquín Armesto y Tejeiro, vecino de esta villa (de Villafranca) en tiempo que su administración se hallaba a su cargo".

${ }_{1847}$ A veces no es posible distinguir si se trata de un administrador o de un arrendatario, aunque en este caso es efectivemnte un arerendatario. AHPL. PN.: caja 3677 (1829) Don Jacinto Fariñas y doña Antonia Sánchez, su mujer "residentes en esta casa (de la Herrería de Órreos) hace años" dice que "están convenidos con el sr. D. Rodrigo Rodríguez de Campomanes, conde de Campomanes, como marido de $D^{a}$ Rosa Cortes de Armesto, vecino de la ciudad de Lugo y residente actualmente en el palacio de Dompiñor en llebar en arriendo esta herreria o artefacto con los vienes y rentas y más a ella anexos", como consta de una carta de 4 de noviembre de 1829, y como no puede hacerlo personalmente encarga que firme el arriendo su hermano Juan Fariñas.

1848 AHPLU: 2455/4. (1810), testigo en la venta de una tierra: Jacinto Fariñas administrador de la ferrería de Órreos. AHPLU: 2406/3 (1815): Jacinto Fariñas, administrador de Órreos. AHPL. PN.: caja 3576 (1819): "D. Jacinto Fariñas, vecino de Lusío y administrador de la Herrería de Visuña"; AHPL. PN.: caja 3577 (1826) "D. Jacinto Fariñas, administrador de esta herrería (casa de la Herrería de Visuña). AHPL. PN.: caja 3577 (1828) Jacinto Fariñas, arrendatario de esta fábrica, de que es dueño el conde de Campomanes, dice "pasa de catorce años que Andrés Pérez, vecino del pueblo de Trabadelo (...), le adeuda diez mil y veinte y seis reales procedentes de fierro que le sacó al fiado de esta citada fábrica". AHPL. PN.: caja 3675 (1833) Todavía en este año de 1833 era arrendatario Jacinto Fariñas.

1849 AHPL. PN.: caja 3577 (1826) “D. Jacinto Fariñas, administrador de esta herrería (de San Pedro de Órreos) y vecino del lugar de Lusío en la merindad de Aguiar", dice que "se halla conbenido y ajustado con el señor D. Rodrigo Rodríguez de Campomanes, conde de Campomanes, como marido de la señora $D^{a}$ Rosa Armesto Teyjeiro y Cortes, vecinos de la ciudad de Lugo y dueños de esta expresada fábrica, en razón del arriendo de esta para lo que tiene arreglado el tiempo que a de durar, precio, plazos y condiciones..." y como no puede hacerlo directamente da su poder a su hermano "D. Juan Fariñas, administrador del Yncio" para que lo haga en su nombre.

${ }_{1850}$ AHPLU: 2406/11

${ }^{1851}$ AHPLU: 2576/6 
"por espacio de un año y los más que fuesen de la voluntad de su principal" la ferrería de Órreos en 12.500 reales de oro o plata de renta anual más el foro de la venera. En el contrato señala toda una serie de interesantes condiciones ${ }^{1852}$. Dos años después, seguía al frente de la ferrería la misma arrendataria ${ }^{1853 .}$

En 1853 doña Estefanía Rivas recuerda que como mayor postor, en 1847 había arrendado la ferrería de Órreos a la condesa de Campomanes por tres años, y que concluidos éstos siguió, de acuerdo con ella, en su arrendamiento, con la condición de avisarse con la antelación de medio año para rescindir el acuerdo; y sin hacerlo, " $y$ sin tener atrasos ni menos ir en disminución el artefacto" se entera ahora que la condesa se lo ha arrendado a otra persona; da por ello su poder a su hermano para que negocie o pleitee con ella. Tal vez por este problema, la citada Estefanía solicitó permiso para construir en Ferramulín, muy cerca de Órreos, una nueva ferrería. En mayo de 1855 Domingo Fernández le vende un prado en ese lugar "en atención a que $D^{a}$ Estefanía Rivas, vecina de Villafranca, quiere construir un artefacto o fábrica de hacer fierro donde llaman Caborca, términos de Ferramulín"1854; y en junio de ese año los vecinos de Ferramulín y Órreos, en concejo, dicen que esta mujer "trata de hacer una fábrica herraria de hacer fierro en los términos de esta parroquia y sitio que llaman a Caborca, cuya fábrica le consienten como igualmente a ella por vecina, por redundar en beneficio de todos los vecinos"; lo que hacen con varias condiciones referidas al uso de las aguas, carboneo y paga de $200 \mathrm{rs.}$ al año ${ }^{1855}$. Ignoro si efectivamente se llegó a hacer.

\footnotetext{
${ }_{1852}$ AHPL. PN.: caja 3582 (1848). Entre las condiciones: 1) “que si se diese la casualidad que la señora Condesa o los señoritos fuesen a la casa de la fábrica ha de estar a su disposición el gabinete y sala principal, usando del resto de la casa en unión con la doña Estefanía a escepción de la bodega del fierro, debiendo mantener las caballerías de los señores, no escediendo su permanencia de una semana"; 2) Idem respecto al apoderado; 3) "Todos los reparos de la casa, fábrica y bienes sean de cuenta de la arrendataria, a escepción del arbol de macear, banzado y de las trompas cuando sea necesario hacerlas de nuevo"; 4) conservar las regalias de la casa y ferrería; 5) conservar la casa y ferrería en el mismo estado en que se entrega; 6) pasar este arriendo por el oficio de hipotecas; y 7) avisar con antelación de medio año el cese del arriendo por ambas partes.

1853 AHPL. PN.: caja 3582 (1850). Dos escrituras de obligación con doña Estefanía Rivas: una de José Balboa, vecino de Oencia, por la que se compromete a pagar 336 rs. "procedentes de fierro que le sacó al fiado y deinero que le prestó sin ningún interés”; la segunda de Francisco Oulego, de Oencia, que también se obliga a pagale 1.342 rs. "procedido de fierro que le dio al fiado al precio corriente".

1854 AHPLU: $2563 / 7$

${ }^{1855}$ AHPLU: 2563/7
} 
La ferrería de Visuña la mencionan los diccionarios de Miñano ${ }^{1856} \mathrm{y}$ Madoz; un documento sin fecha, pero de esta época, dice que la ferrería, propia del conde de Campomanes, pagaba al señor marqués de Santa María de Villar por el foro de la vena, 396 rs. ${ }^{1857}$. En 1866 Villaamil y Castro dice que producía anualmente 800 arrobas de hierro ${ }^{1858}$, lo que, sino es un error, supone una cantidad exigua. Años más tarde, en 1874 durante los seis meses en que estuvo activa se beneficaron 500 Qm. de mena de Formigueiros, obteniendo 173 de metal. También trabajó en 1876, pero no muchos años más. ${ }^{1859}$

ESTADO: No hay restos

\section{MUNICIPIO DE FONSAGRADA}

\section{FERRERÍA DE PEREYRÚA}

LUGAR: Pereyrúa, feligresía de San Julián de Freixo MUNICIPIO: Fonsagrada

RIO: río de Piedra

COORDENADAS: $43^{\circ} 1^{\prime} 49^{\prime \prime}$ N. y $7^{\circ}$ 9' 2" W.

La ferrería se encontraba en el antiguo concejo de Burón, hoy Fonsagrada, pero desconocemos el lugar exacto en que se situaba, ni siquiera el río que movía sus ruedas, aunque es posible que lo fuera el Piedra (Pedra), afluente del Navia.

Su origen nos es desconocido, pero existía en el siglo XVII como propiedad de la familia Bolaño. En abril de 1677 se suscita un pleito entre miembros de esta familia por un altercado violento con robo de vena sufrido en la ferrería de Pereyrúa. Según la querella presentada por don Antonio Bolaño y Santiso y sus hermanos, vecinos del lugar de Pedra, en el concejo de Burón, eran propietarios

\footnotetext{
${ }^{1856}$ S. MINANO: ob. cit. II, p. 125: "Comprende este coto la feligresía de Órreos, y hay una ferrería en que trabajan como 200 quintales de fierro al año"; P. MADOZ: $o b$. cit., $p$. dice que hay "una fábrica de hierro". 1857 I. GARCÍA TATO, I (2000): Ob. cit. p. 167.

${ }_{1858}$ Cit. por C. GONZÁLEZ (1994): Ob. cit., p. 158.

1859 P. HERNÁNDEZ SAMPELAYO: Hierros de Galicia, t. III, fasc. $1^{\circ}$ p. 36.
} 
de "una ferraria que tienen a do llaman Pereyrúa sita en dicha feligresía de Freijo, y estando della en la quieta y pacifica posesión y de fabricar el fierro con la vena della por si, sus antecesores y causantes", don Antonio Bolaño y Saavedra, al amanecer del once de abril de ese año, con otras personas armadas y criados entraron en la ferrería en la que "quitaron mucha cantidad de fierro en cabalgaduras que llebaban para ello", que pretendían llevar para su casa de no impedírselo los Bolaño Santiso. No era, al parecer, el primer altercado, pues en otra ocasión ya se habían llevado 100 quintales de vena de la ferrería ${ }^{1860}$.

Por el pleito nos enteramos que las cosas no eran exactamente así; pues por las declaraciones de varios testigos sabemos que la mitad de la ferrería, con sus materiales y territorio propio, era de don Antonio Bolaño Saavedra, mientras que la otra mitad lo era de de los hermanos Bolaño Santiso y de su madre Inés de Miranda Buida ${ }^{1861}$. También se indica que había estado arruinada hasta hacía dos años, en que se restauró, y que desde los antecesores de unos y otros habían estado en su posesión "fabricando en ella el hierro por si y por personas y criados en su nombre con los materiales della". Por ejemplo en este momento, era Baltasar Méndez la "persona y maestro que corría con el abasto $y$ compostura de dicha ferraria"1862. En el pleito se habla de que era muy antigua, pues venía fabricando hierro desde hacía cincuenta años y más, por lo que habría que situar su construcción a principios del siglo XVII o finales del XVI.

Unos y otros se abastecían indistintamente de vena de los montes próximos, dando solo el nombre de "la uenera que llaman Da Pena Do ome"; y que era este monte de la vena y su acarreto lo que debía suscitar problemas entre ambas familias ${ }^{1863}$. Esta familia Santiso parece que contaba con otros artefactos, en concreto varios mazos no muy lejos; pues en las respuestas al informe para la licencia de construcción de la ferrería de Neyra de Rey, se dice

\footnotetext{
1860 AHRG. R.A.: 2149/35

${ }^{1861}$ El testigo Simón López dice que "saue y hes verdad que dicho don Antonio Bolaño Saavedra lleva y le pertenece la mitad enteramente de la ferrería de Pereyrúa, sita en esta feligresia de Freyxo, y sus materiales, y la otra mitad la poseen dicho don Antonio Bolaño Santiso, doña Juana Bolaño y más hermanos y doña Ynes de Miranda Buida, su madre de los susodichos". (IBIDEM). 1862 AHRG. R. A.: 2149/35

1863 AHRG. R.A.: 2149/35
} 
cómo a poca distancia de uno de los martinetes de don José Quiroga, en ese lugar, en un riachuelo que desagua en el Neira, posee otro don Pedro Santiso "con uxo y exercicio"; e igualmente un documento de 1755 menciona cuatro mazos en Neyra de Rey, dos y medio de los cuales eran de don Pedro Santiso y don Pedro Osorio ${ }^{1864}$.

La ferrería de Pereyrúa en el siglo XVIII no era ya más que un mazo, pues el Catastro de Ensenada habla de que en la feligresía de San Julián de Freixo hay un martinete o mazo en el río de Piedra, que pertenece a don Antonio Bernardo de Navia y Llamas, vecino de San Román de Cervantes, que trabaja ocho meses al año y renta 350 reales ${ }^{1865}$. Nada dice Madoz de la existencia de ferrería ni del mazo, por lo que hay que suponer que dejó de trabajar en esa primera mitad del siglo XIX ${ }^{1866}$.

ESTADO: Desconocido

\section{FERRERÍAS DE VILAR DE CUIÑA}

LUGAR: Vilar de Cuiña

MUNICIPIO: Fonsagrada

RÍO: Suarna

COORDENADAS: $43^{\circ} 4^{\prime} 9^{\prime \prime}$ N. y $7^{\circ} 57^{\prime} 11^{\prime \prime}$ W.

La ferrería de Vilar de Cuiña o del "Buen Retiro", única que se conserva de las dos que se construyeron en este lugar -la otra se llamó de "Buen Suceso"-, se encuentra en este lugar del antiguo concejo de Burón, hoy Fonsagrada, a orillas del río Suarna, afluente del Navia, y a la que se llega por una pista desde el mismo pueblo.

Las ferrerías de Vilar de Cuiña se construyeron en la última década del siglo XVIII, al socaire de la buena coyuntura económica de mediados del siglo,

\footnotetext{
1864 AHPLU: 6709/14

1865 CATASTRO DE ENSENADA. R. G.: Freixo

1866 P. MADOZ: Ob. cit., t. VIII, p. 180
} 
las exenciones fiscales a la fabricación de hierro ${ }^{1867}$ y la política proteccionistas de Carlos III. Fueron esos los factores que alentaron algunos proyectos de construcción de ferrerías, la mayoría fracasados pero de los que varios felizmente llegaron a cuajar.

Uno de ellos fue el proyectado por el asentista de la Maestranza de Artillería del Ferrol, Andrés Bravo Bermúdez, buen conocedor del mundo del hierro como natural de Santalla de Oscos y arrendatario de las ferrerías asturianas de Montealegre y Nafarea. Pretendía construir varias ferrerías y martinetes en zonas alejadas de la costa, ya muy desforestadas, en tierra de montaña en el límite entre Galicia y Asturias: los Oscos, Ibias, Grandas de Salime, Burón (Fonsafrada) y Navia de Suarna. En 1783 presentó al Consejo de Estado un memorial en el que se ofrecía a establecer en esa zona tres ferrerías, cuatro martinetes y cien casas, en un plazo de doce años ${ }^{1868}$. "Por ser materia tan grave" se solicitó información a la Diputación del Principado quien, a través del conde de Toreno, informó el proyecto desfavorablemente al considerar que el enorme consumo de madera por la Armada se incrementaría considerablemente, perjudicando de este modo a la agricultura. También se opusieron por diferentes motivos algunos particulares, como el dueño de la ferrería de Bullimeiro, don Juan Abello Castrillón, y varios vecinos de los concejos de San Martín y Villanueva de Oscos ${ }^{1869}$.

Aunque Gonzalo Anes y Joaquín Ocampo suponen fracasado este proyecto, lo cierto es que después de varios y costosos recursos, en 1788 don Andrés Bravo obtuvo licencia del Supremo Consejo de Castilla para construir tres ferrerías y cuatro martinetes en Vilar de Cuiña (Fonsagrada), Penalba (Ibias) y Rao (Navia de Suarna) que, con la excepción de Penalba, construiría a lo largo de la década siguiente. Pero dado lo costoso del proyecto, en 1789 obtuvo un nuevo permiso para constituir la "Compañía de la Vega de Ribadeo", integrada por diecinueve importantes accionistas y presidida por el marqués de Astorga. Este mismo año,

\footnotetext{
${ }^{1867}$ AHN. Ordenes Generales de Rentas: Libro 37, exp. 4939: “El rey (...) ha resuelto que las ventas de yerro que se hagan al pie de las ferrerías de las provincias de Castilla y León de labranzas de los mismos sean exentas por aora de Alcabalas y Cientos". 1868 G. ANES (1988): Economía y sociedad en la Asturias del Antiguo Régimen. Madrid, p. 114 1869 J. OCAMPO (1987). La economía asturiana al final del Antiguo Régimen. Las manufacturas, 1750-1850. Oviedo, p. 47.
} 
a Andrés Bravo y compañía le concedieron varios derechos y exenciones "para fomento de las Ferrerías y Martinetes que pusieran en Galicia y Asturias"1870.

La ferrería de Vilar de Cuiña se construyó entre 1792 y 1794 ${ }^{1871}$. En 1795 los vecinos de Monteseiro acuerdan con don Diego Munilla, "contador $e$ ynterventor de la Compañía de la Vega de Ribadeo" permitirle el uso de leñas y mineral de hierro para la ferrería del Buen Retiro que hay en esa feligresía ${ }^{1872}$. Al parecer también se explotó un venero en Sena, en el concejo de Ibias. Ante el escribano de Castropol se otorgó en abril de 1800 una escritura firmada por los vecinos de Sena y los apoderados del director de la Compañía de la Vega de Ribadeo, por la que aquéllos permitían a la ferrería de Vilar de Cuiña abastecerse del hierro, que el director de esta fábrica descubrió en el lugar de Formigueiro, con la condición de pagar a los vecinos cada año por razón de montazgo 400 reales en dinero y 200 libras de hierro de las que labrase la dicha ferrería ${ }^{1873}$. En 1803 se menciona como administrador a don Josep Benito Álvarez San Martín “administrador de la Erraria da Cuiña”1874.

\footnotetext{
1870 AGS. Junta de Comercio y Moneda: leg. 295.

${ }^{1871}$ J. LÓPEZ y A. GRAÑA (1998): Ferrerías, mazos y fraguas en Asturias. Oviedo, p. 27. Dicen estos autores que se construyó en 1792, pero aún estaba en obras en 1794 como se deduce de AHPLU: 1501/2 (1794, 1 de febrero). Domingo Marentes y otros vecinos de Penamayor y Castro, todos del concejo de Burón, dijeron: "que en el año próximo pasado de 1793, por D. Domingo Méndez del Busto, vecino de Monteseiro, de este propio concexo, y otros maestros que entendieron y aún continúan en la nueba fábrica de la Herraria que se haze de cuenta de la compañía de Ribadeo en la Vega da Barreira, feligresía de Santa María de Villabol de este mismo concexo, se ha cortado en los montes y términos de sus respectivas vecindades crecida porción de robles, quantos fueron nezesarios para todos los adornos de la madera que ha sido precisa....". Don Domingo Méndez les asegura que su importe se lo pagará don Antonio González Viexo como director de la citada compañía, "de cuia horden se hacía la Herraria que está para concluirse".

${ }^{1872}$ AHPLU: 1051/3 (1795, 12 de agosto). "En la casa de la Eraria titulada el buen retiro de la Cuiña conzejo de Burón”, don Andrés Valdés y más vecinos del lugar de San Bartolomé de Monteseiro, de una parte, y de la otra don Diego Munilla, dijeron "que en el precitado lugar y feligresía de Monteseiro existen algunos minerales que lo regular es, sea su qualidad yerro, el qual como neczesario para esta Erraria, y sauedor de ello D. Diego y más por quien haze, determinaron contratar en el particular con los otorgantes sobre su aprovechamiento". Acuerdan "que todos los precitados minerales de yerro u otro qualquiera mineral que produzcan los términos del dicho lugar y parroquia y sean nezesarios a la Erraria, ha de ser bisto aprobecharse esta de ellos a su arbitrio y boluntad". A cambio Diego Munilla y sucesores de la Compañía pagarán cada año, mientras exista la ferrería, 440 reales. "Asi mismo capitulan que mientras ésta dura se ha de poder aprobechar la nominada Erraria, su maiordomo y obperarios de la leña de robles, álamos y más árboles infructíferos que produzca el monte llamado Bol das trabas para raguas y cozer la vena de los tales minerales pagando por cada carro regular y por razón de montazgo a siete quartos y medio o treinta mrs.".

1873 J. LÓPEZ y A. GRAÑA (1998): Ob. cit., p. 15

1874 AHPLU: $1481 / 5$ (1803, 8 de abril).
} 


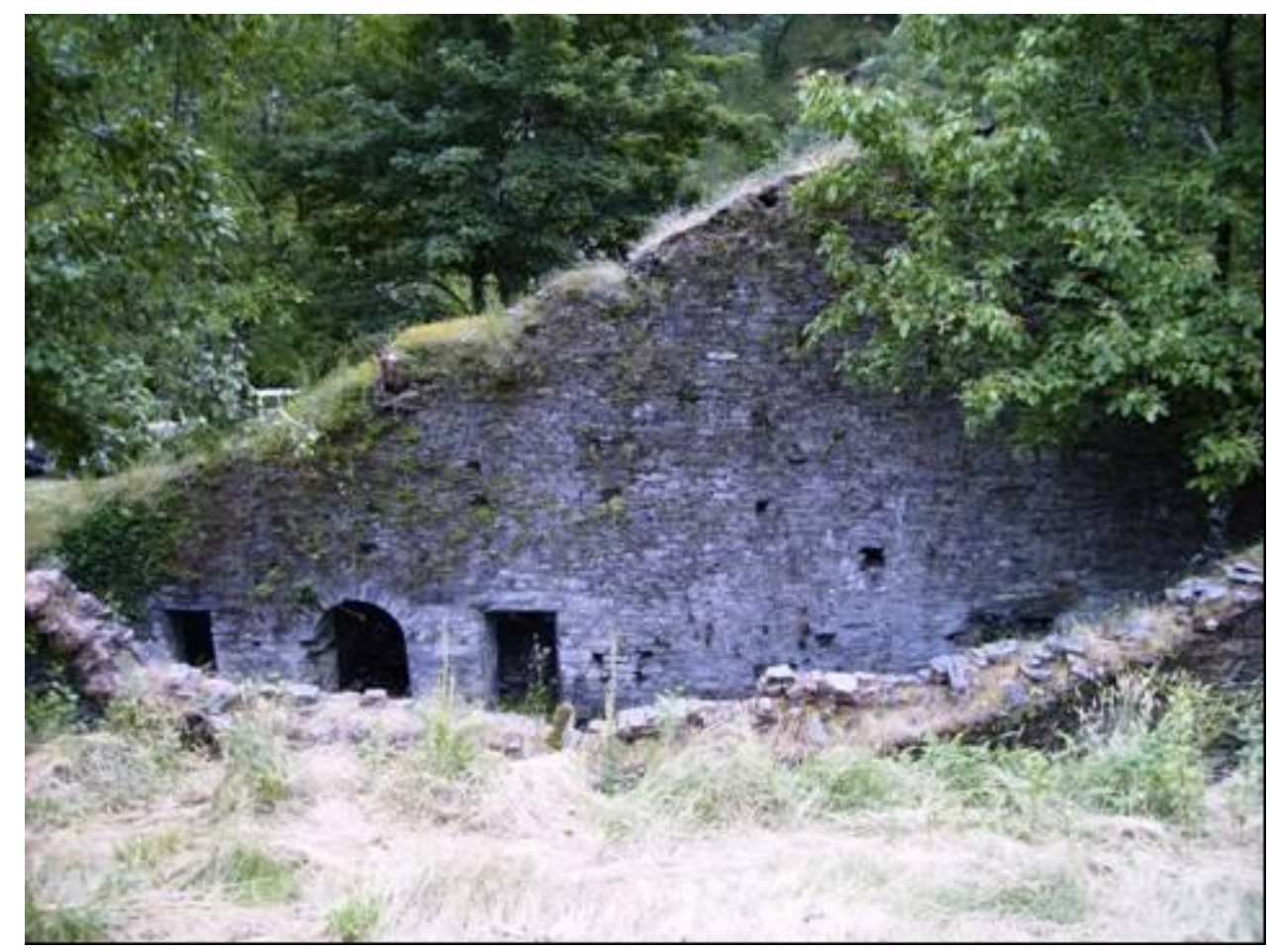

Ferrería de Vilar de Cuiña

Además de la ferrería se construyó al lado un mazo que, probablemente, poco después se transformó en una nueva ferrería. En el siglo XIX, al menos, se mencionan dos con los nombres de Buen Retiro y Buen Suceso. Ambas ferrerías, que estaban prácticamente abandonadas y medio derruidas, fueron aforadas en 1832 por Fernando Pérez Villamil, vecino de la ferrería de A Veguiña, y José María Bravo, nieto del fundador de la Compañía de la Vega de Ribadeo, que también llevaban en arriendo otras ferrerías asturianas ${ }^{1875}$.

Posiblemente hace referencia a estas dos etapas, Hernández Sampelayo, cuando afirma que "se trabajó en ella de modo intenso en dos épocas, terminándose hacia el año 1884" ${ }^{1876}$. Uno de sus problemas fue siempre el mineral de hierro, escaso en la zona, por lo que a veces estuvo paralizada, por ejemplo en 1873 y 1874. Aunque Sampelayo señala que debió ser el centro del consumo del mineral del país, fundiéndose las porciones que encontrasen más fáciles de explotar y reducir, reconoce por testimonios de vecinos que allí se 
fundió sobre todo mineral de Somorrostro1877. En 1870 se beneficiaron 520 Qm. de mineral vizcaino que produjeron $250 \mathrm{Qm}$. de hierro ${ }^{1878}$.

ESTADO: Según Hernández Sampelayo "la ferrería de Cuiña se encuentra en un bonito sitio poco al $\mathrm{O}$. de donde pasan las cuarcitas de la corrida principal; debió de ser una hermosa instalación para su tiempo" ${ }^{1879}$. Efectivamente así es, como aún puede comprobarse, pues se conserva, aunque algo deteriorados varios de los edificios que constituyeron este complejo con la forja, carboneras, capilla, etc.

\title{
6. MUNICIPIO DE GUNTÍN
}

\section{FERRERÍA DE PALLARES}

\author{
LUGAR: San Salvador de Guntín \\ MUNICIPIO: Guntín \\ RÍO: Ferreira \\ COORDENADAS: $42^{\circ} 52^{\prime} 43^{\prime \prime}$ N. y $7^{\circ} 41^{\prime} 41^{\prime \prime} \mathrm{W}$.
}

La ferrería se encontraba entre Guntín y Ferreira de Pallares, en la aldea de la Ferrería, a orillas del río Ferreira, que es un pequeño afluente del Miño.

La existencia de un monasterio medieval de nombre Ferreira de Pallares y un río con ese mismo nombre es un dato que permite suponer la existencia de algún tipo de ferrería hidráulica en el territorio de Pallares. Este monasterio, que en 1509 la congregación de Valladolid cedió al obispo de Lugo, volvió a Samos en 1517, que lo convirtió en un priorato gobernado por medio de priores $^{1880}$. De esta supuesta ferrería medieval no conocemos nada.

\footnotetext{
1877 P. HERNÁNDEZ SAMPELAYO (1931): Ob. cit. IV, t. II. p. 409. Dice que "el quintal que llamaban macho (124 libras gallegas de 20 onzas), de mineral de Bilbao pagaba 2,5 rs. por su transporte desde la Vega de Ribadeo (Vegadeo) y otro tanto por la carga de leña (8 quintales machos), que se ponía a 2,5 rs. en la fábrica; se utilizaba el carbón de leña para calcinar y el de brezo para reducir, pagándose a peseta la carga (40 kilos)".

1878 C. GONZÁLEZ (1994): Ob. Cit.p 167

1879 P. HERNÁNDEZ SAMPELAYO (1931): Ob. cit. IV, t. II. p 408

${ }^{1880}$ M. ARIAS CUENLLAS (1992): Ob. cit., p. 198 y 199.
} 
La ferrería de Pallares la construyó en 1635 el abad Mauro de Vega, beneficiando la vena existente entre Parga y Melide ${ }^{1881}$. Según Hernández Sampelayo, el criadero de Guntín, del que se abastecía esta ferrería y la de Ombreiro, está en una colina de unos 600 metros de altura, salpicada de numerosos y desordenados trabajos antiguos: grandes fosas cubiertas de vegetación desde 8 a 20 metros, en las que se sacaba una vena roja, dulce a la reducción en las forjas ${ }^{1882}$. Probablemente esta mina es la misma de la que habla el Catastro de Ensenada en la parroquia de Ferreira de Pallares: "ai asimesmo una mina de hierro propia de dicho monasterio de San Julián de Samos la que regulan le vendrá de utilidad al año quinientos reales de vellón"1883.

Según el Catastro de Ensenada, la ferrería, que estaba en la feligresía de Guntín, trabajaba muy poco tiempo al año, por lo que solo se le regula de utilidad 1.000 reales ${ }^{1884}$. En realidad, por entonces, la ferrería había prácticamente dejado de trabajar hasta que 1781 se la reedificó. El Estado de Cuentas del cuatrienio 1781-1785 dice: "reedificose, o hablando con propiedad, se hizo de nuevo la Herrería de Pallares, que desde el año 1753 no havia travajado, y algunos años antes, con ninguna o muy poca utilidad por haverse desgajado un pedazo de Monte sobre la Mina que surtía de vena a la Herrería. Considerando las utilidades que se seguirían al Monasterio en poner dicha oficina corriente y teniendo bien fundadas esperanzas de que en otras partes de su inmediación se hallaría la vena deseada, se practicaron exactas dilixencias para su descubrimiento y correspondió el suceso a la intención, a que resultó la Favrica de la Herrería sin poder aprovecharse de las piezas de la antigua, que después de tanto tiempo quedaron inutiles; y salió la nueva Favrica, aún en lo material, más mejorada que aquella"1885.

\footnotetext{
${ }^{1881}$ IBIDEM, p. 199 y 286. En el Catastro de Ensenada (R. G.: Ferreira de Pallares) dice que en la parroquia de Ferreira de Pallares "ai asimismo una mina de hierro propia de dicho monasterio de san Julián de Samos la que regulan le vendrá de utilidad al año quinientos reales de vellón al año".

1882 P. HERNANDEZ SAMPELAYO (1935): Ob. cit., t.III-2, p. 457

1883 CATASTRO DE ENSENADA. R.G.: Ferreira de Pallares

1884 CATASTRO DE ENSENADA. R. G.: Guntín: En realidad se refiere a un molino pues la ferrería estaba parada: " $y$ otro (molino) a dicho Real Monasterio de que hes propia una herrería que se alla en esta feligresía por lo que regulan de utilidad al año un mill reales por travajar mui poco tiempo al año".

${ }_{1885}$ A. M. SILOS: Archivo de la Congregación de Valladolid, libro XXII.
} 
Además de la ferrería se construyó el priorato: "Para maior servicio de la oficina, a su inmediación, se fabricó una grande porción de casa y con poco aumento quedará mas util que la presente, para havitación del Prior Rendero"1886. En el peritaje hecho en 1821, para su desamortización, la casa para la administración de la ferrería, distinta de la casa del priorato, constaba de cocina, capilla, varias habitaciones, panera, "bodega del fierro", bodega del vino, caballeriza ${ }^{1887}$.

Según Cornide, hacia 1780, es decir cuando todavía no estaba en pleno rendimiento, elaboraba 650 quintales de hierro, cantidad considerable, lo que confirma el mencionado Estado de Cuentas: "Por lo que respecta al producto del hierro, y a su utilidad es Herrería de las mejores del monasterio y ya comenzó a redituar una buena cantidad de su costo"1888. Pero los estados de cuentas no parecen confirmar esta afirmación:

$\begin{array}{lr}\text { Cuatrienio } & \text { Reales } \\ & \\ 1781-1785 & 11.803 \\ 1818-1821 & 19.170 \\ 1821-1824 & 9.170\end{array}$

Archivo de Silos

De hecho, parece que tenía problemas para el abastecimiento de vena y carbón. En enero de 1814, el alcalde constitucional de San Pedro de Villajuste, José Sendín, interpretando a su modo los decretos de las Cortes de Cádiz, probablemente los referidos a los señoríos, prohibió al administrador de la ferrería el uso de la vena y carbón de aquella jurisdicción. En marzo de ese año, el administrador de la ferrería fr. Gregorio Sarmiento redactó un largo y bien argumentado alegato, con referencias a la constitución de 1812 y otros decretos, contra la arbitraria decisión del alcalde, criticando además que la ferrería fuese la culpable de esquilmar los montes; al contrario, afirma que es muy beneficiosa para la zona, concluyendo que el alcalde lo que debería hacer es favorecer la industria y el comercio del municipio y no obstaculizarla. Pide por tanto que se

\footnotetext{
1886 IBIDEM

1887 AHPLU: Desamortización, 5 (1-2)

1888 A. M. SILOS: Archivo de la Congregación de Valladolid, libro XXII.
} 
le castigue por paralizar los trabajos, con lo que los venaqueros y carboneros "cesaron en el arranque de bena, fábrica de carbón y acarreo de ambas especies, y por consiguiente nunca podrá eximirse de ser responsable de los grabes perjuycios que se siguieron"1889.

El alcalde mayor de Lugo falló en julio a favor del monasterio, condenando a los vecinos a pagar las costas del juicio pero no los daños, por lo que el monasterio apeló a la Real Audiencia "porque todos han visto la Herrería parada por falta de materias para trabajar a causa del embargo". Los vecinos, en 1816, alegan que no es cierto, que pasa de doce años que el administrador compra el carbón en otras jurisdicciones, pues en Villajuste no hay ni para la ferrería ni para un mazo de tirar hierro que también existe en la parroquia. Respecto de la vena, arguyen que también el monasterio "tiene otro venero mas inmediato que el de Villajuste sito en los términos del lugar de Meijacoboy y del qual ha usado mucho"; mineral que pretendió utilizar la ferrería de Gonzar impidiéndoselo el monje administrador. Por último, respecto a los oficiales, concluyen que nada tuvieron que pagarles pues al estar parada la ferrería se fueron para sus casas sin cobrar nada, y que normalmente la ferrería paraba de julio a noviembre o diciembre ${ }^{1890}$.

En la desamortización del Trienio Liberal se tasaron los bienes del priorato, con la ferrería, en 476.750 reales, de los cuales 400.000 correspondían a la fábrica de hierro ${ }^{1891}$, a los que habría que añadir 8.000 reales de la casa administración de la ferrería. El resto lo constituía el valor de la casa del priorato, con el molino y prados, las huertas y cortinas, etc. Todos estos bienes salieron a subasta el 25 de mayo de 1822 en el mismo valor señalado por los peritos. La compró el marqués de Valladares, que tomó posesión de ella en julio

\footnotetext{
1889 AHRG. R. A.: $1.687 / 29$

1890 AHRG. R. A.: 1.687/29

${ }^{1891}$ C. GONZÁLEZ (1994): Ob. cit., p. 170: "la fabrica del fierro con puerta al naciente, la fragua al lado de poniente provista de barquines y rueda con el buelo y cruces rompidos, mas adelante la rueda del mazo y el banzado bastante deteriorado; la carbonera al lado del Norte con el techo muy desmejorado; la tazadera al sur con la puerta para entrar la vena junto a la de la fragua; pegada a esta otra de manos con la puerta para la tazadera; un pajar a la esquina de la carbonera con la puerta al Sur, y pegada una cavalleriza pequeña para marranos, la tasan con inclusión del monte de Villajuste en que se halla la vena, y de los de la estinguida Jurisdición de Ferreyra cuanto al uso de ella en doce mil reales vellón de renta anual y de principal cuatrocientos mil".
} 
de $1823^{1892}$. Sin embargo, estos bienes volvieron a poder del monasterio con la caída del gobierno liberal, ya que conocemos el nombre de algún prior hasta 1835, en que se produjo la exclaustración ${ }^{1893 .}$

Desconozco quien adquirió la ferrería de Pallarés, pero siguió trabajando pues Schulz en 1838, después de hablar de las minas de Formigueiros y Roques, afirma que "hay además las veneras de Lousadela y Piedrafita, de donde se surten las respectivas herrerías de Pallares y Ombreiro, cerca de la ciudad de Lugo, que consumen al año sobre seis mil quintales, empleando en su arranque quince obreros"1894. Sin embargo, Madoz ya no la cita ${ }^{1895}$, aunque es posible que trabajara hasta la segunda mitad del siglo XIX.

ESTADO: Sólo se conserva la vivienda; de la ferrería, todavía el P. Arias habla de que existía convertida en una serrería; hoy solo vestigios del banzado, que aprovecha un molino.

\title{
7. MUNICIPIO DE INCIO
}

\section{FERRERÍA DO BARREIRO}

\author{
LUGAR: Hospital \\ MUNICIPIO: Incio \\ RIO: Cabe \\ COORDENADAS: $42^{\circ} 38^{\prime} 42^{\prime \prime}$ N. y $7^{\circ} 20^{\prime} 48^{\prime \prime} \mathrm{W}$.
}

Aguas abajo de la ferrería de Incio, en el mismo río Cabe. Se menciona como Mazo da Pena o do Barreiro.

En 1550 el comendador de Incio y Quiroga, fr. Gonzalo Guiral, aforó al rendero de la ferrería de Incio, Domingo de Sarauz, y a su mujer, Inés Vázquez

\footnotetext{
1892 IBIDEM, p. 170

1893 AHN. Consejos: leg. 12.080, exp. 146, menciona a fray Ramón Fernández como prior de Pallares en el momento de la exclaustración.

1894 G. SHULZ (1838): "Ojeada sobre el estado actual de la minería en el distrito de Asturias y Galicia”. Anales de Minas, t. I, Madrid, p. 390

1895 P. MADOZ: Ob. cit., t. IX, p. 114
} 
de Armesto, "dicha herrería, según se hallaba hecha, con todos los términos y heredamientos a ella anexos y pertenecientes". Añadió además el permiso y "el sitio para otra casa y edificio a fin de que pudiera hacer $y$ edificar otra Herrería para fundir y hacer labrar hierro abajo de la otra, y en la Veiga de San Juan junto al río y Hospital, señalándole términos para ella de más allende de los que tenía la otra herrería". Todo ello lo aforó con la renta de 400 reales de 34 maravedís al año ${ }^{1896}$.

El texto dice "acabar de hacer", lo que indica que ya se estaba haciendo y que sin duda se terminó; pues en el testamento de Domingo de Sarauz y su mujer, de 1560, por el que ceden en vínculo estos bienes de Incio a su hijo Pedro de Armesto y Sarauz siempre hablan de herrerías y no de herrería: "mas le doy con las dichas herrarias demas de lo a ellas anejo e perteneciente que no es del dicho fuero las casa de las dichas Ferrarias y bodegas e mas los vienes que yo he hecho y comprado cerca de las dichas Ferrarias con todos las castañeras, soutos y otras heredades y arboles y otras cosas que estubieren dende Pena de Perra hasta las dichas herrarias que yo he comprado...". ${ }^{1897}$

Probablemente los problemas con el carbón obligaron a cerrar uno de los establecimientos, dejándolo como un mazo ${ }^{1898}$; por eso en documentos posteriores se le llama mazo da Pena o do Barreiro, aunque como la ferrería de Incio tenía derecho al carbón de los montes de esa jurisdicción. Era propiedad de los dueños de la ferrería.

En el pleito entre las ferrerías de Incio y Paredes, a comienzos del siglo XIX, se mencionan que en 1765 hubo un acuerdo con los vecinos de la jurisdicción de Incio de no usar los montes de aquella jurisdicción "sino en veneficio de la herrería del mismo nombre y mazo do Barreiro"; y en los libros del Catastro de Ensenada, feligresía de Santa Mariña de Incio, "declararon los peritos que la raiz que producen para carbón pertenecía el que así se fabricaba

1896 AHRG. R. A.: 23.088/72

1897 AHRG. R. A.: 23.088/72

1898 AHPLU: 2566/4 (1694). En 1694 se menciona a un Gregorio González do Olmo, fundidor, vecino del lugar del Varreiro, feligresía de San Miguel de Incio. Hablar de un fundidor en el Barreiro podría ser un indicio de que aún funcionaba como ferrería, pero creo que también puede ser simplemente que viva en ese lugar pero siendo fundidor de la ferrería de Incio, que es lo más probable. 
al mazo da Pena". Ambos términos eran el mismo, como aclara ese mismo documento: "el carbón que producen los montes de esta feligresía y son de calidad pertenecían al mazo da Pena y por otro nombre do Barreyro de la feligresía de san Miguel y dueño de él"1899.

ESTADO: Desconocido

\section{FERRERÍA DE INCIO}

LUGAR: Ferreira, en San Pedro de Incio

MUNICIPIO: Incio

RÍO: Cabe

COORDENADAS: $42^{\circ} 38^{\prime} 44^{\prime \prime}$ N. y $7^{\circ} 21^{\prime} 18^{\prime \prime} \mathrm{W}$.

Estaba en el lugar de la Ferrería frente al Balneario de Incio, en uno de los pequeños arroyos que forman el río Cabe.

Según Hernández Sampelayo el criadero de hierro del "Coto de Incio", continuación del de Caurel, se compone de diferentes yacimientos distibuidos sobre las laderas y alturas de la margen izquierda del Cabe, desde Monte Viduedo, frente a Óutara, hasta la Casela y Pena Redonda donde ya domina la vertiente del río Lor cara a los montes de Lózara. Los principales yacimientos son tres: la Cova de las Choyas, los crestones desde Mompedroso hasta Monte Redondelo y la venera de Roques. De todos ellos se surtió la ferrería de Incio, e incluso de Formigueiros ${ }^{1900}$.

La ferrería de Incio existía ya en el siglo XVI ${ }^{1901}$. Era propiedad, como toda la jurisdicción de Incio, de la encomienda de Quiroga de la orden de San Juan de Jerusalén. Toda esta comarca durante la guerra de las Comunidades tuvo problemas con la condesa de Lemos, de quien hubo de defenderla Alvaro

\footnotetext{
1899 AHRG. R. A.: 23.088/72

1900 P. HERNÁNDEZ SAMPELAYO (1935): Ob. cit., t.III, fasc., p.

${ }^{1901}$ AHN. Clero: libro 6695: "Escritura de venta a Samos de 1543 para que las herrerías de Yncio y otras no entren a hacer carbón en la jurisdicción de Lózara".
} 
Vázquez de Quiroga, por cuya gesta la encomienda aforaría a su hijo Francisco Vázquez de Quiroga una zona de Quiroga donde construiría la ferrería de este nombre ${ }^{1902}$.

En la primera mitad del siglo XVI era rendero de esta ferrería de Incio el vasco Domingo de Zarauz ${ }^{1903}$, a quien en 1550, el comendador de Incio y Quiroga fray Gonzalo Guiral aforaría también a su mujer Inés Vázquez de Armesto, "dicha herrería, según se hallaba hecha, con todos los términos y heredamientos a ella anexos y pertenecientes". Añadió además el sitio y el permiso para construir otra casa y herrería aguas abajo del río Cabe, junto a Hospital, que debió construir poco después, aunque más tarde se convertiría en un mazo. Todo ello lo afora con la renta de 400 reales, de 34 maravedís, al año ${ }^{1904}$. Por el foro de la ferrería pagaban a la encomienda 400 reales anuales ${ }^{1905 .}$

Ambos esposos, en su testamento de 1560, dejan como heredero en el foro a Pedro de Armesto y de Sarauz "mi hijo legítimo", a quien además mejoran "por via de tercio y quinto" en los otros bienes que han ido adquiriendo, y a sus otros hijos; "es a saver el lugar de Baldomar sito en la villa de Tiracastela (sic) y en el lugar do Pacio de Utonín y en el lugar de Trascastro de la Encomienda del Yncio que trae Gonzalo Paz e Alonso de Pumar y en el lugar de Don Piñor con los derechos e rentas eansi de pan, trigo, vollo y cabritos y otros presentes derechos" 1906 .

Este testamento hubo de traerse a colación en más de una ocasión por pleitos entre los herederos de los fundadores del foro, porque algunos también

\footnotetext{
1902 AHRG. R. A.: 1.662/4

1903 En 1504 el monasterio de Samos aforó a Diego Velón y Velasquida González una zona del valle del Lóuzara para hacer la ferrería de Santalla. Al morir Diego Velón, desconozco la fecha pero quizá antes de 1525, su mujer Velasquida se la vendió a Domingo de Zarauz, que por entonces era rendero de la ferrería de Incio; posteriormente el yerno de Diego Velón, Rui Sánchez de Orozco, que debió morir hacia 1550, la recobró. (AHRG. Real Audiencia: 931/44). 1904 AHRG. R. A.: 23.088/72

1905 Esta cantidad de 400 reales era la que pagaba, según las cuentas del administrador de la encomienda Juan Álvarez Ojea, aún en 1641 y 1642 esta ferrería. Cit. I. GARCÍA TATO y E. ÁLVAREZ (2012): Las Encomiendas gallegas de la orden de San Juan de Jerusalén. Estudio y edición documental. T. II-2 ${ }^{\circ}$. La Encomienda de Quiroga. Santiago de Compostela, p. 620 y 632.

${ }_{1906}$ AHRG. R. A.: 23.088/72
} 
querían su parte en la ferrería. Así, por ejemplo, en 1704, entre don Francisco Antonio de Orozco, sucesor en los vínculos de Domingo de Sarauz, y doña María de Balboa y Quiroga, viuda de don Andrés de Valcarce y Orozco ${ }^{1907}$; o en 1789 en el pleito entre doña Rosa Josefa Somoza Orozco Rivadeneira y su marido don Francisco de Miranda y Trelles contra doña Isabel $\mathrm{M}^{\mathrm{a}}$ de Orozco y Seijas "sobre la posesión de la mitad de la Ferrería de Yncio y otros vienes y efectos pertenecientes al vínculo fundado por Domingo de Sarauz e Inés Vázquez"1908.

La ferrería pasó de Pedro de Armesto a sus descendientes, entre ellos, en el siglo XVII, a otros dos Pedro de Armesto, padre e hijo y, por tanto hijo y nieto del primero1909; y luego a Domingo Antonio de Orozco, Francisco de Orozco y Somoza (casado con doña Josefa de Seijas), su hijo, y Manuel Francisco de Orozco Losada y Somoza (casado con doña Manuela de Quiroga y Somoza), su nieto ya en el siglo XVIII'1910. A este último le renovó el foro el comendador de Quiroga, don Diego Vélez de Guevara, el 11 de julio de 1722, por la vida de tres reyes o 300 años, a cien años por rey y con la renta de 402 reales, con las condiciones generales en este tipo de establecimientos: tener la ferrería en buen estado y funcionamiento, no venderla ni dividirla, obligación de reedificarla en caso de ruina, dejarla libre al final del foro, etc. ${ }^{1911}$.

\footnotetext{
1907 Esta María de Balboa y Quiroga, aparece como viuda de don Andrés de Valcarce (en realidad Orozco Valcarce) y rendera de la ferrería en 1681 (AHPLU: 2567/10. Año 1681, de 14 de mayo); también en 1693 en un acuerdo con el cura de San Pedro del Hospital de Incio (AHPLU: 2566/3. Año 1693, de 3 de febrero). En un foro de 1694 se dice que esta María de Balboa es "dueña en parte de dicha herraria (de Incio)" y también "actualmente dueña y poseedora de dicha herrería" (AHPLU: 2566/4. Año 1694, de 1 de marzo). En en otro foro de un casar, al año siguiente, se dice que "era del directo dominio de D. Pedro de Armesto y otro primero deste nombre renderos que fueron desta dicha herrería" y que reconoce como dueña de él a " $D^{a}$ María de Balboa y Quiroga y Armesto yxa y nieta de los arriba dichos Armestos asimismo rendera y vecina de dicha herreria" (AHPLU: 2566/4. Año 1695, de 6 de mayo). En 1698 seguía como "rendera de dicha herraria como yja y eredera de D. Pedro de Armesto y Balboa y de $D^{a}$ María de Ribadeneyra y Somoza, sus padres, asimismo renderos que fueron de dicha herraria, ahora difuntos" (AHPLU: 2566/8. Año 1698, 1 de mayo). Aún lo era en 1706 (AHPLU: 5088/9. Año 1706, 5 de mayo). En 1707 dejó como heredero a su nieto don Felipe Antonio Orozco y Ribadeneira (AHPLU: 5088/10. Año 1707).

1908 AHRG. R. A.: 23.088/72

1909 AHRG. R. A.: 3070/39. Un testigo en 1633 afirma haber oido a su padre, Juan del Olmo, muerto hacía más de 30 años y que tendría 90 años que sabe "que la ferraria del Yncio hes propia del dicho Pedro de Armesto y lo fue de sus antecesores". Entre estos antecesores nombra "a Diego de Armesto su hermano y Pedro de Armesto su padre y Pedro de Armesto su abuelo, y unos en pos de los otros". En AHRG. R.A.: 14.869/12 se menciona en 1627 a "Pedro de Armesto y Balboa rendero de la erreria de Incio".

1910 AHRG. R. A.: 23.088/72

1911 AHRG. R. A.: 23.088/72
} 
Probablemente la carencia de combustible explique la conversión en mazo de la ferrería construida por Domingo Sarauz en el siglo XVI, que luego se llamaría mazo da Pena o do Barreiro. Lo que si es seguro es que este problema fue causa de varios pleitos y querellas. Así en 1694 María de Balboa y Quiroga que se titula como "dueña en parte de dicha herrería", puso pleito a varios vecinos del Hospital de Incio y Foillebar por arrancar urz y hacer carbón en los montes de la ferrería ${ }^{1912}$. En 1762 y 1765 su dueño, Rodrigo Sánchez de Orozco, se querelló con don Lucas Somoza porque pretendía aprovecharse de las leñas y carbones de la jurisdicción de Incio para una ferrería que había construido en Viduedo, con sentencia favorable a los Orozco ${ }^{1913}$.

Otro pleito mantuvo en 1827 con doña Jacoba Gil Taboada, propietaria de la ferrería de Paredes o Portomarín, por haber construido un camino "desde el monte llamado Chao de Lamelas a la casa de San Miguel términos de esta feligresía de San Pedro y San Miguel de Incio y por él conducir la vena del mineral de Roques para depurarle de la primera escoria y cocer raguar junto a dicha casa de san Miguel, para el consumo de la Herraria de Paredes o de Puerto Marín, la que en la actualidad posee doña Jacoba"1914. La condesa alegaba el foro de 1722 de la encomienda.

Nada dice de ella el Catastro de Ensenada, aunque Cornide hacia 1780 señala que es propiedad de doña María Orozco y que producía al año $65^{\circ}$ quintales de hierro, lo que es una cantidad apreciable1915. Este autor indica que el mineral que utilizaba era de Rocas; y así era efectivamente. En 1633 Pedro de Armesto y Balboa, dueño de la ferrería de Incio, pleitea contra el merino de Pobla de Brollón y varios venaqueros de Rocas, porque teniendo la ferrería el derecho "de azer quebrantar y arrancar toda la bena de yerro que ay en ella para la dicha herraria arrancandolo y llevandolo y aprobechandose del (...) asta que podrá aber seis meses poco mas o menos que los dichos acusados por

\footnotetext{
1912 AHPLU: 2566/4 (1694). Porque "ellos y sus familias arrancaban cepa y della hacían carbon en los terminos y montes desta dicha herraria del Yncio que son los que hestan dentro de los limites y mojones de la dicha encomienda para llebar dicho carbon a otras herrarias de fuera desta en que conocen aver cometido delito". Por ello se allanan y le piden persón por hacerlo. 1913 AHRG. R.A.: 23.088/72 1914 AHRG. R. A.: 23.088/72 1915 CORNIDE: ob. cit.
} 
fuerça y contra boluntad de mi parte se an ydo a la dicha erraria y le an arrancado y llebado mucha cantidad de hierro". Pero lo más grave es que no quieren permitirle sacar vena de Rocas, pese a que "siempre hestubieron en (...) la posesión de quebrantar arrancar llebar y traer a ella toda la bena de yerro que hera necesaria de las beneras de rocas sin por razón dello pagar cosa ninguna a ninguna persona sino solamente la alcabala que se debe y paga en el partido del Yncio ... a su magestad"; se lo prohibieron. Un testigo dice que la ferrería además del hierro de la venera de Rocas tenía "una benera de yerro que era de la dicha ferraria en las dichas beneras de rocas donde ninguna podía arrancar genero de bena sino solamente los dichos renderos del Yncio o con su licencia" 1916 .

Doña María Isabel Orozco y Seijas, señora del pazo de Dompiñor ${ }^{1917}$, se casó en 1788 con Domingo Sabino Rodríguez de Campomanes, conde de Campomanes, en cuya familia encontramos la ferrería en el siglo XIX. En 1814 esta María Isabel dice que desde 1808 pleitea contra Alonso do Olmo y otros por la leña y carbón de los montes de Incio que eran privativos de la ferrería ${ }^{1918}$ y que aquéllos querían utilizar y vender; pleito que "con motivo de la guerra y hoy se halla retrasado el asumpto", por lo que solicita una provisión real para proseguirlo 1919 . También pleitea en 1827 , como ya hemos visto, con la propietaria de la ferrería de Paredes, pues quiere impedirle el uso de la leña y un camino desde Rocas para raguar en San Miguel de Incio la vena antes de llevarla a su ferrería de Gonzar en Portomarín ${ }^{1920}$. En 1824 y 1826 era administrador de esta ferrería don Juan Fariñas, de Lusío (León), hermano don Jacinto Fariñas, arrendatario de la ferrería de Órreos ${ }^{1921}$, que también era del conde de

\footnotetext{
1916 AHRG. R. A.: 3.070/39

1917 Está relacionada con los Sánchez de Orozco, que tuvieron la ferrería de Santalla.

1918 AHRG. R. A.: 12.331/27. Desde tiempo inmemorial "tenía (la posesión) de aprobecharse exclusivamente de la leña y carbón de los montes comunes y demás terrenos pertenecientes de la dicha jurisdición de Incio con destino a la Herrería del mismo nombre perteneciente a los mayorazgos que posehía".

1919 AHRG. R. A.: 12331/27

1920 AHRG. R. A.: 23.088/72. Alega en 1828 doña Isabel María Sánchez de Orozco, condesa de Campomanes, que esos montes de Incio son propios de su ferrería por el foro que el comendador de de Quiroga le hizo en 1722 a don Manuel Francisco Orozco Armesto y Zarauz y que los vecino de San Pedro y San Miguel por sentencia de 1765 no pueden usarlos sino a beneficio de su ferrería y del mazo del Barreiro, a excepción de los pastos para el ganado. ${ }^{1921}$ AHRG. R. A.: 22.758 y AHPL. PN.: caja 3577 (1826).
} 
Campomanes, ahora Rodrigo Rodríguez de Campomanes, por su mujer Rosa de Armesto Tejeiro y Cortés.

Madoz simplemente menciona en Incio "ferrerías"1922. Probablemente dejó de funcionar hacia la mitad del siglo XIX.

ESTADO: No hay restos

\title{
8. MUNICIPIO DE LUGO
}

\section{FERRERÍA DE OMBREIRO O GONDAI}

\author{
LUGAR: San Martín de Ombreiro \\ MUNICIPIO: Lugo \\ RÍO: Narla \\ COORDENADAS: $43^{\circ} 3$ ' 13 ” N. y $7^{\circ} 38^{\prime} 28^{\prime \prime} \mathrm{W}$.
}

En la N-VI, poco después de Lugo, desviación a Friol, queda Ombreiro, en cuyas inmediaciones, a orillas del Narla, afluente del Miño, se encontraba la ferrería de este nombre, hoy convertida en piscifactoría.

Ni Cornide ni Lucas Labrada ${ }^{1923}$ la mencionan. Sus orígenes parecen remontarse al primer cuarto del siglo XIX. Schulz en 1838 afirma que en Galicia, junto con los yacimientos de Formigueiros y Roques, "hay además las veneras de Lousadela y Piedrafita, de donde se surten las herrerías de Pallares y Ombreiro, cerca de la ciudad de Lugo, que consumen al año sobre seis mil quintales, empleando en su arranque quince obreros"1924. Madoz igualmente señala que esta ferrería utiliza mineral de Lousadela y Piedrafita, al tiempo que nos indica que era propiedad de don Buenaventura Plá1925. Éste Buenaventura

1922 P. MADOZ: Ob. Cit., t. IX, p. 428

1923 L. LABRADA: ob. cit., p. 149, dice que en el coto de Ombreiro hay solo 4 telares de lienzo 1924 G. SHULZ (1838): "Ojeada sobre el estado actual de la minería en el distrito de Asturias y Galicia”. Anales de Minas, t. I, Madrid, p. 390

1925 P. MADOZ: ob. cit., t. IX, p. 217 
Miguel Plá, natural del Ferrol, vecino y alcalde que fue de Lugo además de diputado en 1843, era un comerciante que adquirió muchos bienes desamortizados. Probablemente fue el promotor de esta ferrería, pues ya en 1834, según el BOP de Lugo, consta como propietario ${ }^{1926}$.

Hernández Sampelayo, al hablar de las minas de Vaamonde, dice que "estos antiguos trabajos (de Cabanarril) en la mina "Laura”, están extendidos en unos 500 metros de largo; la gran cantidad que se arrancó fue consumida en la herrería de San Martín, de Umbreiro, conocida por la de Gonday, cuya producción terminó hará unos sesenta años (1858-1860)”. En nota añade: "Como señal de la abundancia de arranque de mineral, en alguna de las épocas, se recuerda que cambiaban un saco de centeno por otro de mineral de hierro"1927.

ESTADO: Solo queda la vivienda de la ferrería.

\title{
9. MUNICIPIO DE MONDOÑEDO
}

\section{FERRERÍA DE VILOALLE}

\author{
LUGAR: A Ferrería (Santa María de Viloalle) \\ MUNICIPIO: Mondoñedo \\ RÍO: Agroalba \\ COORDENADAS: $43^{\circ} 27^{\prime} 45^{\prime \prime}$ N. y $7^{\circ} 22^{\prime} 17^{\prime \prime} \mathrm{W}$.
}

Se hallaba en la parroquia de Santa María de Viloalle, en el lugar de la Ferrería, a orillas del Agroalba, un pequeño arroyo que desagua en el Figueiras, afluente del Masma.

\footnotetext{
${ }^{1926}$ BOP de Lugo, $\mathrm{n}^{\circ} 25$ de 27 de julio de 1834: “D. Guillermo Schulz (...) hago saber: Que Don Buenaventura Miguel Plá, natural de la villa del Ferrol, vecino y del comercio de Lugo, y propietario de la herrería de Ombreiro" solicita permiso para explotar una mina de hierro en el lugar de Eirige, en la jurisdicción de Taboada.

1927 P. HERNÁNDEZ SAMPELAYO (1935): Ob. Cit., t. III-2 ${ }^{\circ}$, p. 391.
} 
Desconocemos si se trata de una ferrería medieval o del siglo XVI. Tampoco si se refiere a ella, aunque es probable, el testamento de Vasco López de Moscoso, vecino de San Martín de Mondoñedo, del 22 de febrero de 1531, en el que señala que "hizo diversas mandas entre ellas a los herederos de Pedro Miranda, tirador de su herrería, cuatro quintales de hierro"1928. Si fuera así éste solo sería su arrendatario o forero, pues poco después sabemos que pertenecía al obispo de Mondoñedo. En 1570 y 1571, los vecinos de varios lugares de la jurisdicción de Mondoñedo manifiestan que "habida cuenta de que los justicia y Regimiento de Mondoñedo y Cabildo del mismo lugar tratan con el prelado Fray Antonio de Luján de cerrar la ferrería de Viloalle, pagando al Prelado, de una o de otra forma, la renta que anualmente percibía de dicha herrería, dieron su poder (...) a fin de que pudiesen concertarse acerca de lo sobredicho y sobre lo que se debía dar al dicho Prelado, comprometiéndose a pagar cada uno lo que se le repartiese por este concepto, a fin de quitar a los vecinos comarcanos de la dicha ciudad que debían servir en la dicha herrería"1929. Los vecinos incluso sostenían en la Audiencia de la Coruña una querella contra el obispo por tener que prestar servicio con sus personas, bueyes y carros para reparar y conservar la ferrería de Viloalle, como vemos por un poder de $1570^{1930}$.

Seguramente el enorme consumo de madera, que esquilmaba los montes, así como los conflictos con los vecinos por los servicios a que estaban obligados, llevaron al obispo fray Antonio de Luján, representado por el canónigo Lope Martínez de Prabeo y el prior Bernardino de Salazar a negociar, el 6 de junio de 1571, una concordia con el regimiento de la ciudad y el cabildo para el cierre de la ferrería: "Viendo que era provechoso tanto para la Mesa Episcopal, como para la Capitular, como para la ciudad de Mondoñedo que cesase la actividad de la dicha herrería en la fundición de hierro, habida cuenta de que los montes cercanos, tanto por razón del carbón, como de fragas empleadas en la herrería, se veían muy perjudicados y de que la herrería estaba muy ruinosa (...) cerrar la herrería dejando el sitio y lugar al Cabildo y Ciudad de por

\footnotetext{
1928 E. CAL PARDO (1992): Mondoñedo. Catedral, ciudad, obispado en el siglo XVI. Catálogo de los documentos del archivo catedralicio. Lugo. Documentos sueltos. 1929 IBIDEM, $\mathrm{n}^{0}$ 1855, 1856, 1968. 1930 IBIDEM, $\mathrm{n}^{\circ} 3805$
} 
medio para siempre, en cuyo lugar podrían hacer éstos, Cabildo y Ciudad, un machuco o dos, dejándoles los pertrechos y materiales, con un molino y casas que estabn junto a la herrería". A cambio, el concejo y el cabildo entregaron al obispo 200 ducados, además de una renta de 4.000 maravedís al año, que se hipotecó sobre la herrería y sus bienes ${ }^{1931}$. Durante varios años (de 1595 a 1599) se mencionan en las actas capitulares la libranza de 2.000 maravedís al obispo, que es la parte que corresponde al cabildo ${ }^{1932}$; la otra mitad correspondía al Regimiento de la ciudad.

Desde los años setenta la fábrica no debió funcionar ya como ferrería pero si como mazo, como asegura Larruga: "en la feligresía de Santa Marta de Viloalles hay un mazo de tirar hierro de poca consideración"1933; aunque en 1845 Madoz dice que en esa parroquia hay "una ferrería"1934, lo que puede ser un error al confundirla con un mazo, o que efectivamente, como ocurrió en otros casos, en el XIX se adecuaron algunos para elaborar hierro. Las muchas escorias que se recogieron en los alrededores puede ser una prueba de su utilización como ferrería.

ESTADO: Hay algunos restos de la ferrería o machuco.

\section{MUNICIPIO DE MURAS}

\section{FERRERÍA DE SILÁN}

LUGAR: A Ferrería (San Esteban de Silán)

MUNICIPIO: Muras

RÍO: Rego de Vilariño

COORDENADAS: $43^{\circ} 32^{\prime}$ o" N. y $7^{\circ} 35^{\prime} 43^{\prime \prime}$ W.

\footnotetext{
${ }^{1931}$ IBIDEM, no 3819.

1932 IBIDEM, no 944, 1048, 1103, 1187, 1189, 1263.

1933 E. LARRUGA: Ob. cit. XLV, p. 362

1934 P. MADOZ: ob. cit. t. XVI, p. 92
} 
En el municipio de Muras, desde este lugar por una carretera secundaria hasta Silán; desde allí un camino llegaba hasta la ferrería, a orillas de un riachuelo o Rego de Vilariño, afluente del Landro. Hoy no hay nada.

Sus orígenes pueden ser medievales, aunque la primera referencia documental que conocemos data de 1553, en que Fernán Cao de Cordido, en nombre del señor Juan López de Prabeo, vecino y regidor de la ciudad de Mondoñedo, y el vizcaino San Juan de Aguirre, aroza de la ferrería de la Ponte da Nobal, se conciertan en que éste ha de servir durante un año en la ferrería de Silán, en la provincia de Mondoñedo, en el oficio de arota, haciendo "el dicho oficio de aroça en todo aquello que a el le sea posible y un aroça hes obligado de hazer en una herreria", por el precio de cincuenta ducados de oro y otros emolumentos propios de un aroza 1935 . Por la escritura no está clara la propiedad de la ferrería, pues parece que Juan López es su rendero, mientras que Fernán Cao solo actúa en su nombre, aunque son ambos los que hacen el acuerdo y los que se compromenten a pagar al aroza. Puede que sea una ferrería del siglo XVI y que, como otras, su puesta en funcionamiento se debiera a la presencia de ferrones vascos, como vemos en estos ejemplos. Igualmente en 1583 era rendero otro vasco, Juan de Lagún, a quien la justicia de Vivero procesó por vender hierro por pesas de piedra ${ }^{1936}$.

No hay datos posteriores, por lo que seguramente dejó de funcionar en el siglo XVII, convirtiéndose en un mazo. Como otras de la zona, la razón debió ser la falta de combustible. Sin embargo, en 1791 Antonio Raimundo Ibáñez y José de Andrés García, comerciante compostelano, pretendieron construir en Muras

1935 AHPLU: 3973/2 (1553): Vivero, 15 de julio de 1553, estando presentes "de la una parte Fernan Cao de Cordido en nombre del señor Juan López de Prabeo vezino e regidor de la ciudad de Mondoñedo, como rendero que es el dicho Juan Lopez de la ferreria de Silan e de la otra San Juan de Aguirre bizcayno de la probincia de bizcaya aroza que al presente hes de la ferrería de Ponte da nobal del condado de Santa Marta en que dixo el dicho San Juan daguyrre que concertaba con el dicho Fernand Cao como fautor del dicho Juan Lopez en esta manera, que el dicho San Juan de Aguyrre se obligó de estar e residir e servir de oficio de aroça en la dicha ferreria de Sylan por tiempo y espacio de un año conplido el qual corre e se a de contar desde el postrero día del mes de agosto deste año de mil e quinientos y cincuenta y tres años y fenescera por el mes de agosto que berná del año de mil e quinientos e cincuenta $e$ cuatro años, y que durante este año el dicho San Juan a de servir el dicho oficio de aroça en todo aquello que a el le sea posible y un aroça hes obligado de hazer en una herreria...". Por ese trabajo le pagarán cincuenta ducados de oro, en varias pagas, más los gajes de cada quintal de hierro y otros emolumentos que es costumbre pagar a un aroza.

1936P. SAAVEDRA: Ob. cit., p. 328, nota 82. Es posible que este data esté equivocada, pues ese año era rendero de la ferrería de Bravos, o quizá lo fuese de ambas. 
nuevas ferrerías, con dos martinetes, para lo que solicitaron permiso al rey Carlos IV, a "fin de tirar toda clase de herrajes, en los sitios que tengan mayor caida de aguas". En la solicitud no piden ningún derecho sobre el monte, pues piensan "pagar a sus dueños las leñas y carbones para el abasto de las fábricas a precios corrientes, según estimación de otras herrerías".

El Real Consejo pediría los pertinentes informes y en 1793, por medio de una Real Cédula, se concedía permiso a aquéllos para que pudiesen construir en la jurisdicción de Muras una o más ferrerías, con dos martinetes. Poco después, en marzo de 1795, la sociedad de Antonio Raimundo Ibáñez y José de Andrés García se disuelve, quedando el primero como propietario de Sargadelos y el segundo de las proyectadas ferrerías de Muras ${ }^{1937}$, además de fuertes desembolsos de dinero, que debilitaron el proyecto siderúrgico de Sargadelos ${ }^{1938}$. Desconozco si la proyectada ferrería de Muras llegó a construirse, pero cuando en 1799 muere José de Andrés entre su inmensa fortuna, de casi once millones de reales, se menciona la fábrica de Muras ${ }^{1939}$.

Igualmente ignoro si el proyecto de construcción de una nueva ferrería en Muras en 1857 se llevó a cabo. Se autorizó por Real Orden del 2 de agosto de ese año a don Isidoro de Bedia para construirla a orillas del Eume, en el lugar de Vilar, ayuntamiento de Muras ${ }^{1940}$.

\section{ESTADO: Sin restos}

1937 A. MEIJIDE PARDO: Documentos para la historia de las Reales Fábricas de Sargadelos, p. p.31-35 y doc. 12,13 y 14 .

${ }_{1938}$ J. CARMONA (1993): "Sargadelos en la historia de la siderurgia española". Revista de Historia Industrial, 3, p. 14 y 16

1939 X. R. BARREIRO (2000): “A burguesía compostelá (1760-1808). Una base de datos". Revista de Ciencias sociales y humanidades, v. 12, p. 38-39

1940 BOPA, 24 de agosto de $1857, n^{\circ} 135$, p. 2 


\section{MUNICIPIO DE NAVIA DE SUARNA}

\section{FERRERÍA DE RAO}

LUGAR: Rao

MUNICIPIO: Navia de Suarna

RÍO: Balouta

COORDENADAS: $42^{\circ} 55^{\prime} 40^{\prime \prime}$ N. y $6^{\circ} 51^{\prime} 47^{\prime \prime} \mathrm{W}$.

Se encontraba a orillas del río Balouta, a mano izquierda de la carretera que desde el pueblo de Balouta conduce a Rao, casi a la entrada de éste.

Hablando del yacimiento de Vieiro, Hérnández Sampelayo señala que su mineral se consumió en "la herrería de Murias y en una fábrica de potes que hubo próxima, en el trayecto de Murias a Rao, y de la que no quedan más que restos" ${ }^{1941}$. De estas palabras deberíamos deducir la existencia de una ferrería en Murias de Rao y una fábrica de potes como dos ingenios diferentes, aunque es difícil precisarlo; pues los datos que conocemos sobre ambas son bastante oscuros.

Lo que parece cierto respecto a la ferrería de Rao es que se trata de una de las que proyectaba construir don Andrés Bravo y que efectivamente el Consejo de Castilla le autorizó en 1788. La erigió a finales de la década de los noventa la Compañía de la Vega de Ribadeo, como afirma J. López ${ }^{1942}$ y como parece deducirse de las palabras de Datoli en 1797. Dice este militar hablando de la calidad de los minerales utilizados por la ferrería de Ancares: "finalmente que a la herrería de Ancares podrá aplicársele otro mineral que está a legua y media de ella, pasado el puerto de la Magdalena, jurisdicción de Galicia (...). Siendo así que la Compañía de la Vega de Ribadeo impidió a los dueños de la dicha herrería el que arrancasen aquel mineral que dice ser mejor, el qual es de infima calidad, como ya he reconocido y lo ha experimentado la citada compañía, por ensayo hecho en una de sus herrerías, lo qual obligará 
naturalmente a servirse para la herrería que está construyendo del mismo mineral que se sirve para las otras"1943.

Dado que de las tres ferrerías concedidas a Bravo, la de Vilar de Cuiña se había construido entre 1792 y 1794, y la de Penalba no se llegaría a realizar además del contexto que menciona Datoli, en la vertiente gallega del puerto de la Magdalena-, está claro que este autor está hablando de la ferrería de Rao, que por entonces, es decir hacia 1797, todavía se estaba edificando. Efectivamente, la construyó la Compañía de Ribadeo, y hacia 1801 ya estaba terminada, como se deduce del siguiente texto: "que haviéndose construido por cuenta de la referida compañía una fábrica de fierro o Herrería con su casa de administración y otras oficinas y Almazenes en esta situación les hera indispensable para su formal establecimiento, en observancia de la real facultad que para ello se les expidió, servirse de las materias primas que existen en los términos de dichos dos lugares de Murias y Robledo". Ese año los vecinos del concejo de Murias acuerdan con dicha Compañía el uso de los puentes por los que se conduce a ella la vena, el carbón y otros materiales ${ }^{1944}$.

Lucas Labrada, en 1803, menciona que "hay en este valle (de Rao) una fábrica de hierro, que habrá diez años se habrá establecido, a donde se ocupan

1943 Informe de Datoli, en J. A. BALBOA (1992): Ob. cit., p. 67

1944 AHPLU: 1377/2 (1801, 8 de febrero). Don Isidro Pérez LLano y Valdés, como apoderado de don Antonio González Vijeo, socio director tesorero y apoderado general de la Compañía de la Vega de Ribadeo, de una parte, y de la otra don Manuel Pérez Murias, presbítero, y más vecinos del concejo de Murias, parroquia de Santa María de Rao, dice: “que haviéndose construido por cuenta de la referida compañía una fábrica de fierro o Herrería con su casa de administración y otras oficinas y Almazenes en esta situación les hera indispensable para su formal establecimiento en observancia de la real facultad que para ello se les expidió servirse de las materias primas que existen en los términos de dichos dos lugares de Murias y Robledo para cuia condución y transporte a la citada fábrica hera tanvien preciso usar de los puentes y caminos reales y vecinales que oy existen", así como establecer otros pues se habían deteriorado por el mucho tránsito de los operarios a la fábrica. Para evitar pleitos acuerdan: 1) "que el puente colocado sobre el río Abeado con cuias aguas travaja dicha fábrica inmediato a ella, aunque siempre estuvo a cargo de los dos vecindarios de Murias y Robledo para construirlo por mitad de forma que sirviese para carro y ganado", es necesario hacerlo ahora más ancho, por lo que ellos dan la madera pero debe construirlo la Compañía; 2) que el otro puente situado en la "vajada de la sierra del Caroco inmediata a la mina que se travaja actualmente se ha de hacer para tránsito de carros y ganado". La Compañía, mientras se sirva de él, pagará las dos terceras partes de su coste y los vecinos la otra restante; 3) "el otro puente de a pie donde llaman el bao que sirve para conducir la maior parte de carbones lo han de hacer por mitad vecinos y Compañía, mientras se sirva de él para conducir el carbón"; 4) tambien "indemnizan (sic) a la Compañía del montazgo de leñas, maderas, etc. que les haya causado en la construcción del camino desde dicha sierra del Caroco para la extracción de sus venas". 
veinte operarios". "Pero en este año, sigue diciendo, se halla sin ejercicio por la falta de venta de hierro, aunque su clase nada ha desmerecido a los años anteriores"1945. No era el mineral, sino las ventas del hierro las que habían paralizado la actividad de la ferrería o las deudas, como recuerda en 1803 su administrador don Isidro Pérez Llano y Valdés, al decir "que barios sugetos de este domicilio le están adeudando por la citada Erraria distintas partidas de dinero procedente del Fierro" que le han llevado al fiado ${ }^{1946}$

La ferrería debió seguir funcionando hasta mediados del siglo XIX. Miñano en 1826 menciona la fábrica con parecidas palabras a las de Lucas Labrada. Según Hernández Sampelayo, hablando de los criaderos de hierro de Rao, dice que el mineral de Poso, fácilmente reducible "se ha beneficiado hacia 1835-1840 en la antigua herrería de Rao" 1947.

Respecto a la fábrica de ollas sólo nos consta la afirmación de Hérnández Sampelayo y el dato cierto de varios ejemplares de potes conservados con la inscripción "Rao" y un número ${ }^{1948}$, que se hicieron no con hierro forjado, que era lo que fabricaban las ferrerías, sino con hierro colado. A esta fábrica debe referirse Adaro, al señalar que los minerales de Rao fueron explotados en tiempos de Schulz por una campañía del país, que los beneficiaba en un alto horno al carbón vegetal, de cortas dimensiones, armado de una trompa, que existió entre los lugares de Robledo y Murias "y hubo de ser abandonado, sigue diciendo, entre otras causas, por la dificultad de efectuar económicamente los transportes en una comarca tan apartada y montuosa"1949.

Quizá esa fábrica de ollas, con un horno alto al carbón vegetal, fuera la proyectada por don José Alvarez de la Braña, vecino de La Coruña pero oriundo del concejo de Grandas, en el principado de Asturias, ya en 1784, cuando con su compañía solicitó licencia al Real y Supremo Consejo de Hacienda para "establecer una fábrica de ollas de hierro colado en los

\footnotetext{
1945 L. LABRADA: Ob. Cit., p. 141.

1946 AHPLU: 1503/2 (1803, 26 de marzo).

1947 P. HERNÁNDEZ SAMPELAYO (1931): Ob. Cit. IV, t. II, p. 489.

1948 Como el de la fotografía que incluye en su libro C. GONZÁLEZ (1994): Ob. Cit., p. 15

1949 ADARO (1916): Ob. cit., p. 194.
} 
concejos de Ybias, Navia de Suarna, LLan de Gaña o Burón, sitos en este Reyno, principado de Asturias y provincia del Bierzo"1950. Pese a la fuerte oposición de don Andrés Antonio Bravo y la Compañía de Ribadeo, que un año antes habían solicitado la construcción de tres ferrerías y cuatro mazos para la misma zona, con informes y contrainformes, en 1794 el rey concedía a Alvarez de la Braña la correspondiente facultad para establecer la fábrica de ollas de "fierro colado", en los términos y bajo las condiciones siguientes:

1. "Que el enunciado don Francisco Ygnacio Richter1951 pueda pasar a Asturias con el propio retiro que hoy goza para auxiliar a Braña en su establecimiento.

2. Que Braña pueda colocar su fábrica en cualquiera de los concejos de Ibias, Navia de Suarna, LLan de Gaña o Burón, existentes en Galicia, Asturias y provincia del Vierzo, o en otros sitios en que no cause perjuicio a la fábrica de igual clase y de herrages que estableció don Andrés Antonio Bravo y Bermúdez ni a otros

3. Que si el terreno que señalase Braña para la construcción de edificios así de la Fábrica como para habitaciones de los operarios y almacenaje fuese común, no se le pueda impedir por el concejo a quien corresponda, se mida y tase por peritos, pagando su importe principal si fuese de corta estimación, o el canón anual que se regule, lo qual ha de serbir para aumento de propios en uno y otro caso.

4. Que pueda usar de vena que necesite y del parage que le sea más conveniente, con tal que sacándola de los minerales señalados por el referido don Andrés Antonio Bravo quando trató de establecer sus fábricas, no perjudique a éste o a quien le suceda o haya sucedido en lo que igualmente fuere necesario.

5. Que ni Braña ni sus subcesores caso de balerse del carbón de piedra han de poder usar de más que el preciso a la misma fábrica.

6. Que tampoco han de poder usar de más leñas que las sobrantes surtido el vecindario, pagando su importe a tasación de peritos, reconociéndose

\footnotetext{
1950 AHRG. Protocolos: leg. 1.617, ff. 54

${ }^{1951}$ Francisco Iignacio Richter capitán retirado de Artillería e ingeniero de origen suizo había sido director de la Cavada y que en 1791 levantó el horno de Sargadelos para la elaboración de ollas; sería el director técnico del proyecto.
} 
antes por éstos la leña que se ha de cortar, guardándose siempre la ynstrucción de montes, cuyo importe y el de la que necesite Braña para construcción de la fábrica y edificios precisos ha de serbir también para aumentos de propios del concejo a quien pertenezcan y si las leñas fuesen de montes particulares se deberá entender con los dueños para su compra, reduciéndose éstos a equidad por medio de peritos quando pidieren precios excesivos.

7. Que si se construye algun camino para beneficio de la fábrica se dirija por terrenos abiertos e incultos y solo toque en tierra particular quando no hubiere otro arbitrio a juicio de inteligentes, pagando por tasacion de éstos el importe del terreno ocupado segun su calidad.

8. Que en punto a exenciones y regalías goze Braña para su fabrica los mismos que se concedieron a Bravo para las suyas, reducidas después de las que están acordadas por punto general a todas las de su especie, a la libertad de derechos de alcabalas y cientos en las primeras ventas al pie de la fábrica o para que señaladas como tal cobrándose en las demas ventas solo un dos por ciento por el precio de pie de fábrica, al libre tránsito del hierro que para dicha fábrica se conduzcan a las provincias exentas en solo la cantidad que se emplee en ynstrumentos y máquinas que faciliten los progresos de ella, con la circunstancia de que en cada ocasión que lo necesite de cuenta a la Dirección General de Rentas con expresión de la cantidad y calidad del hierro para que se disponga la introducción con precauciones que eviten todo fraude y la de que pueda introducir libremente de los Reynos extrangeros todas las máquinas e ynstrumentos que necesite para su fábrica.

9. Y que por lo resuelto a beneficio de las Fábricas de Bravo de comisión al regente de la Audiencia de Oviedo para el establecimiento de la de Braña en la conformidad expresada con facultad de subdelegar en un ministro de la misma Audiencia en caso de ocupación o quando conviniere pasar a territorios, oyendo la Audiencia a los ynteresados y al fiscal sobre la pertenencia de los terrenos que hubieren de ocupar quando haya dudas en quanto a ella o su legitima posesion, sin perjuicio de la execucion de las obras"1952.

${ }^{1952}$ AHN. Ordenes Generales de Rentas: libro 38, exp. 5.093 
Pese a la licencia, las dificultades para la construcción de la fábrica no se acabaron, pues Bravo y Cía acudieron poco después al Consejo de Castilla, donde al parecer aquél tenía valedores, alegando perjuicios a su fábrica de Cuiña. El Consejó mandó paralizar las obras y que se remitiesen a él los autos originales, como conocemos por un poder notarial, que en 1799 otorgó la viuda de Alvarez de la Braña, doña María Díaz y Ron, al madrileño don José Fernández encargado de negocios en aquella corte1953.

Desconocemos si la fábrica se llegó efectivamente a realizar, pero la existencia de potes con la marca RAO es un indicio de que así fue, aunque también es posible que estos se produjeran en la ferrería de Rao, lo que no creo, pues tales potes parecen de fundición. Probablemente el diccionario de Materia Mercantil, industrial y agrícola de Oriol Ronquillo nos de la clave de esta fábrica. Dice éste que no lejos de las fundiciones de Sargadelos se encuentra la del valle de Rao, al este de Navia de Suarna. La fábrica, anota, es "más reducida y susceptible de mayor desarrollo", pues cuenta con mineral propio y el combustible lo obtiene allí "con equidad", además "hay orden y economía en su administración". Sus trabajos, añade, se reducen hoy casi exclusivamente "a la fabricación de potería para el surtido de las montañas que la circundan"1954.

ESTADO: No hay restos

\footnotetext{
1953 AHRG. Protocolos: leg. 1.617, ff. 54-55

1954 J. CAVEDA (1851): Memoria presentada por el Excmo. Señor Ministro de Comercio, Instrucción y Obras Públicas por la Junta clasifiacadora de los productos de la industria española reunidos en la Exposición Pública der 1850. Madrid, p. 194; también en J. ORIOL RONQUILLO (1855): Diccionario de materia mercantil, industrial y agrícola. Barcelona, t. III, p. 168
} 


\section{MUNICIPIO DE LAS NOGALES}

\section{FERRERÍA DE BUEYES}

LUGAR: Bueyes (Parroquia de Noceda)

MUNICIPIO: Los Nogales

RÍO: Bois

COORDENADAS: $42^{\circ} 46^{\prime} 31^{\prime \prime}$ N. y $7^{\circ} 2^{\prime} 51^{\prime \prime} \mathrm{W}$.

La ferrería de Bueyes o Bois se encuentra en la parroquia de San Juan de Noceda, hoy en el municipio de As Nogais pero antiguamente, según el diccionario de Madoz, en el de Doncos, ${ }^{1955}$ a orillas del río Bueyes o Bois, que es un pequeño afluente del Navia, que baja de la Sierra de los Ancares. También fue conocida como ferrería de Noceda ${ }^{1956}$.

A la ferrería se puede llegar desde As Nogais, siguiendo un camino a la derecha, antes de cruzar el pequeño puente sobre el río Bois. Es una ruta en suave ascenso que nos lleva al barrio de Pandelo y O Couso, en Castelo, donde se abandona el camino principal para tomar un desvío a la izquierda. Se vadea un pequeño reguero hasta el manantial de "Augas Rubias"; luego se desciende hasta la ferrería.

Madoz dice que en Noceda hay "una fábrica de hierro de extraordinaria antiguedad"1957, apreciación cierta pese a que la ferrería que conocemos como de Bueyes algunos la datan en el siglo XVIII'1958. Su origen, sin embargo, es muy anterior, probablemente de la primera mitad del siglo XVI, aunque sólo en la segunda mitad conocemos a sus propietarios y los nombres de algunos de sus arrendatarios, presumiblemente vascos, como Miguel de Alduzin ${ }^{1959}$ y Lorenzo

1955 P. MADOZ: Ob. cit., t. XII, p. 168: Al hablar de la feligresía de Noceda ( San Juan), dice que está en el ayuntamiento de Doncos y que la integran "los lugares y casa de Brañas, Castelo, Casa de la Sierra, Dorna, Ferrerios, Herrería de Bueyes, Moral, Noceda, Pedriña, Pia, San Clodio, San Pedro, Silvela y Zizures”.

${ }^{1956}$ AHRG. R. A.: 680o/4. En un juicio de la ferrería de la Rodela, el testigo Juan Pol, dice que en 1751 fue tazador en la Rodela y al año siguiente se fue a la "Herraria de Noceda, que es de D. Pedro Luis Ulloa"

1957 P. MADOZ: Ob. cit., t. XII, p. 168

1958 C. GONZÁLEZ (1994): Ob. cit., p. 182, dice simplemente que ya existía en el siglo XVIII.

1959 AHRG. Familias: carp. 19 (documentación de la ferrería de Quintá, en cuya toma de posesión en 1566 se menciona, entre los presentes, a "Miguel de Alduzin, rendero de Boeys". En 
de Alza ${ }^{1960}$. Un hijo de Lorenzo de Alza y María Aldunzín, Miguel de Alza, rendero de la ferrería de Quiroga, pleitea en 1607 con don Pedro Bolaño Rivadeneira, dueño de la ferrería de Bueyes, por unos bienes propiedad de su padre que adquirió durante el tiempo en que fue rendero de Bueyes. Dice éste que su padre "fue rendero de la ferrería de Bueis por muchos años y asta el año de mil e quinientos ochenta y siete que se feneció (el contrato)"1961.

La ferrería de Bueyes era propiedad de don Pedro Bolaño Ribadeneira, señor de la casa y fortaleza de Torés, familia de rancio abolengo y estrechamente relacionada con la alta nobleza gallega. Desconocemos la fecha en que esta familia construyó la ferrería; pero, como hemos dicho, probablemente lo hizo en la primera mitad del siglo XVI. Este Pedro Bolaño pleiteó en 1611 con don Vasco Sánchez de Ulloa y Rivadeneira, señor de la casa de Noceda de Doncos, en cuya jurisdicción se encontraba la ferrería, porque éste pretendía hacer otra en el mismo río Bueyes (Bois), a distancia de media legua de la anterior ${ }^{1962}$. El señor de Noceda alega que el agua no perjudica a la primitiva ferrería de Bueyes, porque está por encima de la que él quiere construir; y que respecto al monte, tanto éste como la jurisdicción del lugar le pertenecen. Dice además "que de treinta años a esta parte no ay herraria en bueis por aberle faltado los montes y los que ay son de mi parte", por lo que la querella, sigue diciendo, no es sino

el mismo documento aparecen igualmente Juanes de Alduzín "rendero de la Erreria de la puente de Quiroga": Poco después, en 1587, Martín Alduzín vende la ferrería de Paleiras al dueño de la de Quintá. Es toda una familia de vascos arrendataria de ferrerías gallegas.

1960 AHPL. PN.: caja 2849 (1585): Lorenzo de Alza, rendero de la ferrería de Bueis concierta con un vecino de Quintanilla de Somoza que le traerá 300 quintales de hierro de la venera de Formigueiros.; este mismo "Lorenzo de Alça, rendero de la ferrería de Bueys" firma como testigo, en 1586, en el contrato entre Felipe Garbiso, rendero de la ferrería de Valcarce y varios arrieros el transporte de vena de Formigueiros (AHPL. PN.: caja 2874, año 1586).

${ }_{1961}$ AHRG. R. A.: 15.215/33. Dice: "que siendo el dicho Lorenzo dalça rendero de la ferraria de Bueis y auiendo dexado la dicha herraria despues de fenecido su arrendamiento que fue por el mes de julio del año de myll quinientos ochenta y siete dexó en dicha ferraria y casas della un horrio con seis aposentos y paneras, doze arcas de nogal y castaño, çinco cubas y tablas de barquines ferrados de fundir hierro y otros por ferrar, camas, sillas y otros axuares de balor y estimación todo ello de más de ducientos ducados". La sentencia, en 1608, fue favorable a Miguel de Alza; fue recurrida por el señor de Torés en 1609, pero nuevamente confirmada en 1610 en su favor.

1962 AHRG. R. A.: 21477/96: En 1611 dice: "que diz que teniendo él una herrería en el Río de bueis mi parte aze otra herrería en el dicho río con que le quita el agua y se aprobecha de sus montes"; otro escrito de 1612 añade: "debe declarar no se poder dar licencia al sobredicho para poder edificar la dicha erraria por todo lo general y lo otro porque la mitad del río en que se edifica la dicha erraria es de mi parte y el sobredicho saca la dicha agua de la madre del dicho rio siendo caudaloso y le quita su corriente y la agua que vaya para las molyendas y el regar los prados que están junto al dicho río". 
una venganza. Es posible que tras Lorenzo de Alza, en 1587, la ferrería estuviera parada por falta de carbón.

Esta nueva ferrería de Bueyes parece haberse erigido el año anterior, en 1610, pues "dende más de un año a esta parte (levantó) una herrería en su jurisdicción y dentro de sus propios montes y heredades rio abaxo distancia de media legua de la herrería de bueis sin que xamás dicho territorio y montes don Pedro aya tenido derecho ni posesión alguna”. La querella le perjudica porque "tiene muchos obreros que por su sueldo trabaxan en la dicha obra y por azerles pagar de bacio el tienpo que no trabaxaren por ser como son bescaynos". Entre éstos está "Lorenço Bordes Vizcaino rendero en la dicha herrería nueua que haçe el dicho Vasco Sanchez de Ulloa en bueis"1963. Aunque desconozco la sentencia, creo que esta ferrería fue la continuadora, con el mismo nombre, de la de Bueyes; pues a finales del siglo XVII ésta estaba en manos de la familia Sánchez de Ulloa, señores de Noceda1964, como ya veremos. La ferrería se hizo, al parecer, conculcando igualmente derechos de algunos vecinos ${ }^{1965}$.

Como a otras ferrerías gallegas, probablemente la crisis del siglo XVII le afectó directamente si no hasta paralizar la producción, sí a dificultarla. Un documento de finales del siglo XVII, sobre deudas por el foro de la vena de Formigueiros, puede ser una prueba de esto. Dicho texto señala que la ferrería de Noceda, propia de don Pedro de Ulloa, "deue desde dicho año de ochenta y dos hasta el de ochenta y siete, es decir desde 1682 a 1687, a rrazón de trescientos y cinquenta reales en cada uno de dichos años, dos mil y cien reales, $y$ el ajuste desde el año setenta hasta el de ochenta y uno"1966. Quiere decir que por esos años la ferrería estaba en funcionamiento, aunque sus

\footnotetext{
1963 AHRG. R. A.: 21477/96

1964 Por entonces, segunda mitad del siglo XVI, la jurisdicción de Noceda, con su palacio, pertenecía a Vasco Sánchez de Ulloa (L. LÓPEZ POMBO (2001): Hidalgos y casas señoriales de la provincia de Lugo, p. 210).

1965 AHRG. R.A.: 21477/56: Poder de Alonso García y su padre a varios procuradores para pleitear contra Vasco Sánchez de Ulloa y el vizcaíno Lorenzo Bordes, rendero de la nueva ferrería de Bueyes por que éstos han roto las medas de pan, les arrebataron un molino en el río de Bueyes contra su voluntad, se llevaron 400 carros de piedra de los cierres de las fincas, seguramente para la construcción de la ferrería, talaron el monte, les robaron el pan de las bouzas, etc.

1966 AHN. Estado: leg. 1739, nº 16 . También la ferrería de Valcarce debe el mismo foro por esos años.
} 
propietarios adeudaran el foro de la vena. También lo estaba en 1697, año en que las ferrerías de Bueyes y Valcarce pleitean contra varios carreteros por llevar vena a la de Arnado por el camino de Faro, que declaran ser suyo ${ }^{1967}$. A comienzos del siglo XVIII la poseía su hijo Pedro José de Ulloa ${ }^{1968}$; de quien la heredó Pedro Luis de Ulloa ${ }^{1969}$, hijo a su vez de aquél.

El Catastro de Ensenada proporciona una información extraordinaria sobre esta ferrería. Su propietario es el mencionado Pedro Luis de Ulloa, al que también pertenece la berciana de Herrerías de Valcarce. El arota Domingo del Val y el fundidor Fernando Chao, como peritos en el interrogatorio, desgranan toda una serie de datos: que la ferrería "trauaxa quatro meses y medio de ynuierno, con el agua de el Arroio de Aguas Rubias y con la de nieues y lluvias" (pero) "regulan que de los quatro meses y medio" solo trabaja unos 90 días, en los cuales cada 24 horas elabora "cinco agoas o masas de hierro cada una de peso de cien libras que hazen quintal", por lo que en los 90 días produce unos "quatrocientos cinquenta y cinco quintales de dicha especie, en bruto o vanda que llaman". Citan precios y coste de todas y cada una de las partes de la ferrería, salarios de los trabajadores y beneficios, a los que ya nos hemos referido en el cuadro XVIII y en el capítulo $5^{\circ}$. El total de los beneficios que deja anualmente la ferrería a su propietario es de unos 6.370 reales $^{1970}$, cantidad muy inferior a la de su ferrería berciana.

A la muerte de Pedro Luis Ulloa en 1787 sin herederos directos, la ferrerías de Bueyes y Valcarce (cedida ésta en foro por el marqués de Villafranca a don

\footnotetext{
1967 IBIDEM

1968 IBIDEM. En 1718 pleito de don Pedro de Ulloa Ribadeneira, señor de Noceda, dueño de la ferrería de Bueyes, contra varios vecinos de Visuña, de apellido Bailarín, por arrancar vena en Formigueiros, en un lugar en el que, con esfuerzo, ha descubierto tres o cuatro minerales, y se lo arrancaron. También se menciona en una relación que hace en 1722 el administrador de la Casa de Layosa de las ferrerías que pagan foro al conde de Maceda por la vena de Formigueiros. Este Pedro José Ulloa se casó con $\mathrm{D}^{\mathrm{a}}$ María Luisa Somoza y Saavedra, hija de los señores de la casa solar de los Somoza y su jurisdicción de Layosa (O Corgo).

1969 AHRG. R. A.: 680o/4. En un juicio de la ferrería de la Rodela, el testigo Juan Pol, dice que en 1751 fue tazador en la Rodela y al año siguiente se fue a la "Herraria de Noceda, que es de D. Pedro Luis Ulloa". En 1752 este Pedro Luis de Ulloa lleva a pleito al juez de la jurisdicción del Cebrero por no arreglar los caminos de su jurisdicción, por los que debe conducir la vena a su ferrería de Bueyes (AHPLU: 6709/11). L. LOPEZ POMBO (2001): Ob. cit., p. 216, dice que en 1764 Martín Osorio Santiso, en nombre de su mujer doña Juliana Vilariño y Baamonde, hipoteca la mitad de la aldea de O invernal en favor de D. Pedro Luis de Ulloa, señor de Noceda, por una deuda de 8.170 reales de hierro producido en sus ferrerías.

${ }_{1970}$ CATASTRO DE ENSENADA. R. G. Doncos (San Juan de Noceda).
} 
Pedro José de Ulloa), pasaron a su sobrino don José María Tineo y Ulloa1971, a quien también se la atribuye Cornide, diciendo que producía 500 quintales de hierro al año ${ }^{1972}$, lo que la hace una ferrería de poca producción; posiblemente porque en palabras de Datoli "escasea de agua en el verano en términos que solo anda ocho o nueve meses al año"1973. Este autor, por el contrario, dice que tiene montes de roble, "de cuya leña es el carbón que usa", lo que probablemente hacía algo agrio su hierro. La vena la traen de Formigueiros durante el verano, a causa de la nieve "que cae en el monte llamado los Fornos de Céramo"1974.

Como hemos visto, la ferrería de Bueyes utilizaba mineral de Formigueiros, por el que pagaba de foro al conde de Maceda 350 reales ${ }^{1975}$. De esta mina se abastecían varias ferrerías gallegas y bercianas, con las que el dueño de Bueyes sostuvo un sonado y prolongado pleito. Éste debió iniciarse hacia 1790 en la Real Audiencia de La Coruña ${ }^{1976}$. En escrito de 1791 se explicitan los motivos de la querella contra el presbítero don José Díaz, administrador de la ferrería de Soldón, porque éste con sus operarios se introdujo en una venera a extraer un mineral, que según don José María Tineo le pertenecía; pues él y sus antecesores siempre se hallaron "posehedores, cada uno en sus respectivos tiempos, de usar y aprovecharse de una venera situada en la montaña llamada de Formigueiros, a consecuencia de títulos lexítimos, arrancando de ella, con independencia de otro alguno, toda la vena necesaria para el

${ }^{1971}$ Además de Pedro Luis, que murió sin descendencia, don Pedro José de Ulloa tuvo una hija, María Joaquina que se casó don José Benito Tineo, señor de las cinco villas de las Regueras, de quienes fue hijo José María Tineo y Ulloa.

1972 CORNIDE (h. 1780): Ob. cit., ff. 225.

1973 J.A. BALBOA (1992): Ob. cit., p. 58; también en 1804 L. LABRADA (1971): Descripción económica del Reino de Galicia, p. 143 dice que "en las inmediaciones de Doncos hay una herrería llamada de Bueis, solo se trabaja en los ocho meses del año".

1974 J.A. BALBOA (1992): Ob. cit., p. 58 y 59. AHPLU: 6709/11. Don Pedro Luis Ulloa dice que él y sus antepasados están en la "quieta y pacífica posesión de transitar con bueis y carros para conduzir la bena de hierro desde el mineral llamado de Formigueiros para su erraria llamada de Bueis por el camino real".

1975 Esa era la cantidad que pagaba en el siglo XVII, como ya hemos visto; en el XIX sólo pagaba 330 reales (I. GARCÍA TATO, I (2000): "Las herrerías de Río Cabo y Pombriego en el siglo XIX”. Revista Bierzo, p. 168).

1976 AHN. Estado: leg. 1739, $\mathrm{n}^{\circ}$ 16. Escrito a la Audiencia de la Coruña: "que en junio de $1790 \mathrm{D}$. Diego García Pelagra, administrador de la Herraria de Bueys y apoderado del D. Joseph María Tineo dueño de ésta se querelló contra $D^{a} M^{a}$ Antonia Pardo y Quindós, como madre de D. Joseph Ygnacio Quiroga, dueño de la Herraria de Soldón, por decir le perturbaba en la posesión privativa de arrancar vena en una de las veneras del citado monte de Formigueiros" 
consumo de su herrería de Bueyes"1977. La sentencia debió de ser desfavorable al dueño de Bueyes, quien en 1792 recurrió a la Chancillería de Valladolid.

En el juicio, que se alargó hasta finales de siglo, pleitearon contra don José María Tineo los propietarios de la mayoría de las ferrerías de la zona, entre ellos el monasterio de Samos (La Rodela), José Quiroga Losada (Gorgueira), Manuel Armesto y Omaña (Órreos), José Alfonso Pertierra (Puentenuevo), Benito María de Prado (Quintá) y María Antonia Pardo (Soldón), a los que se añadieron después los de Paleiras, Pontepetre y Arnado1978. Como dice en 1796 el dueño de la ferrería de Órreos o Visuña, don Manuel de Armesto, porque siendo el aprovechamiento de Formigueiros común a todos las ferrerías de la zona, don José María Tineo “intentó aprovecharse del sitio más pingue y productivo (...) para surtir su Herrería llamada de Bueyes haciendo un voluntario amojonamiento del referido sitio e intentando perturbar este común aprovechamiento al esponente y demás interesados con igual título"1979. La Chancillería debió confirmar la sentencia de la Audiencia.

En la ferrería de Bueyes, según Lucas Labrada, trabajaban normalmente seis hombres, probablemente cinco oficiales y el administrador "a excepción de los días en que se calcina la vena, que entonces trabajarán 24"1980. Además habría que añadir los carboneros, venaqueros y transportistas de la vena. Unas veces, la ferrería aparece en manos de arrendatarios ${ }^{1981}$, y otras explotada directamente por los Ulloa, por medio de administradores ${ }^{1982}$, como hacían también con la de Valcarce.

La ferrería siguió funcionando en el siglo XIX, como vemos en los diccionarios de Miñano, Madoz, y en las Revistas Mineras. En 1833 era su administrador don Francisco Pablo Ruiz ${ }^{1983}$. En 1868 se anuncia en el Boletín

\footnotetext{
1977 AHPL. PN.: caja 3377 (1791).

1978 AHN. Estado.: leg. 1739, $\mathrm{n}^{\circ} 16$.

1979 AHPL. PN.: caja 3339 (1796).

1980 L.LABRADA: ob. cit. p. 143

${ }^{1981}$ AHPL. PN.: caja 3329 (1796) La tenía en arriedo don Benito Méndez Losada, de Cacabelos, juez en la jurisdicción de Valcarce "quien con motivo de tener alli sus bienes y llebar en arriendo una herrería llamada de Bueyes, no reside una décima parte del año en el juzgado". 1982 AHPL. PN.: caja 3377 (1791) Entre 1790 y 1796 aparece como administrador don Diego García Pelagra.

1983 AHPLU: 2376/3
} 
Oficial de la Provincia de León el arriendo de esta ferrería y la de Lousadela, propias del marqués de Láncara ${ }^{1984}$, a quien habían pasado por matrimonio de doña María Josefa Raimunda de Tineo con don Apolinar Suárez de Deza. En 1880 todavía trabajó tres meses ${ }^{1985}$; y en 1894 nuevamente se anuncia en el Boletín de la Provincia de León su arriendo, señalando que para ello se dirijan a don Pedro Seijo, en Madrid ${ }^{1986}$, que no sabemos si es su propietario o el apoderado de los señores de Noceda.

ESTADO: Se conservan algunos restos de la ferrería, como el lugar donde se encontraba el mazo. La casa y una pequeña capilla, ya sin uso, de magnífica construcción, se hallan en buen estado.

\section{MUNICIPIO DE OUROL}

\section{FERRERÍA DE BRAVOS}

LUGAR: A Ferrería (Santiago de Bravos)

MUNICIPIO: Ourol

RÍO: Bravos

COORDENADAS: $43^{\circ} 36^{\prime}$ 2" N. y $7^{\circ} 38^{\prime}$ o" W.

Se encontraba en la parroquia de Santiago de Bravos, a orillas de un arroyo de nombre Bravos, que es afluente del Landro.

Probablemente se trata de una ferrería medieval, o al menos del siglo XV, porque ya existía en 1478, año en el que los Reyes Católicos emiten un documento desde Sevilla por el que dan su amparo a favor de Fernando de Pomariño y Gonzalo Pérez de Bravos, vecinos de Vivero, sobre unas ferrerías que poseían en Bravos ${ }^{1987}$.

Sin saber si realmente se trata de la misma ferrería o de otra más moderna, en 1551 Pedro de Carnoza, como rendero de la ferrería de Bravos, se concierta

1984 BOPL., ${ }^{\circ} 15$ de 1868 , p. 4.

1985 P. HERNÁNDEZ SAMPELAYO (1935): Hierros de Galicia, t. III, fas. $1^{\circ}$, p. 37.

1986 BOPL., 2 de marzo de 1894.

1987 AGS: RGS.: t. II, f. 113 
con el mercader de Vivero, Fernán Díaz, a suministrarle 10 quintales de hierro ${ }^{1988}$. Dos años después el rendero era Juan de Salcedo, al que vemos como testigo en un documento de la ferrería de Silán1989; y en 1583 Juan de Lagún¹990. Desconozco quien era el propietario, pero probablemente ya lo fuera entonces la familia Pérez de Cora, posiblemente por foro del obispo de Mondoñedo ${ }^{1991}$, pues en 1600 y en 1614 se menciona como tal a un Gonzalo Pérez de Cora. En un documento del último año citado, el dicho Gonzalo dice que da todo su poder " $a$ todas las personas que sirban de hazer y caRetear carbon a la my feRaria de brabos para servicio della y labrar fierro" ${ }^{1992}$. En 1626 lo era su hijo Pedro Fernández de Cora, como dice el procurador de éste al hablar de un juicio: “ $a$ mas de doce años entre Gonzalo Pérez de Cora padre de mi parte señor que fue de la Erraria de brauos que ora es de mi parte"1993.

Como otras ferrerías de la cercana Asturias, próximas a la costa, esta de Bravos consumía vena de Vizcaya. En 1600 dos vecinos de San Julián de "Mosques" -Músquiz (Vizcaya)- afirman haber venido cargados de vena para la ferrería de Bravos, por acuerdo con su dueño, Gonzalo Pérez de Cora, quien "les dio en pago de su flete dos botas (una pipa) de vino a honce ducados cada una"1994. En 1641, Juan de Balderraín, residente en la ferrería de Bravos, acuerda con el vizcaino Juan de Montano que le traiga 1000 quintales de vena de la mejor que hallare, a precio de 3,17 reales ${ }^{1995}$. Este mismo arrendatario da

1988 AHPLU: 3573/1 (1551): Carta de obligación de Pedro de Carnoza, vecino de la feligresía de Brabos, "que es del quoncejo de bibero, que soy presente, que daré a Fernan Díaz, mercader vecino de la villa de bibero", diez quintales de hierro "labrado de banda las dos tercias e una tercia de bergallón, y que la banda sea de tres cavos, y a de ser bueno", hecho en la de ferrería de Bravos, a precio cada quintal de 14 reales.

1989 AHPLU: 3973/2

1990 AHPLU: 4026/2: Poder de Juan de Lagún "rendero de la ferrería de Brabos" para pleitear en la Chancillería de Valladolid y en la Audiencia de la Coruña.

1991 P. SAAVEDRA: Ob. cit., p.332. En 1758 se dice que don Francisco Jerónimo de Cora, señor por foro del obispo, del coto de Xerdiz, arrienda la ferrería de Bravos, propia de su vínculo al presbítero Diego de la Vega. Es decir que la ferrería estaba vinculada a los bienes del coto de Xerdiz, que disfrutaban por foro del obispo.

1992 AHRG. R.A.: $16.987 / 28$

1993 AHRG. R.A.: 25514/8

1994 P. SAAVEDRA (1985): Economía, política y sociedad en Galicia: La provincia de Mondoñedo, 1480-183o. Xunta de Galicia, p. 330.

1995 AHPLU: 4030/4 (1641). En Vivero a 18 de mayo de 1641: "Parecieron presentes Joannes de baldeRayn bizcayno Residente en la herreria de la feligresía de santiago de bravos de la una parte y de la otra joan de montano vezino de san julian de musquez de la encartazion de bizcaya e dixeron estauan conbenidos y conzertados el uno con el otro de quel dicho juan de montano le a de traer en su navio para en todo el mes de setiembre o del de octubre que viene deste presente año mil quintales de vena y la que pudiere venir en dos baxeles de los quel dicho 
igualmente su poder a Juan de Loperena, del valle de Oyarzún, para cobrar al vizcaíno Sebastián de Arburu 24 ducados que le prestó en 1640 ${ }^{1996}$.

Si la vena era una materia prima que había que traer de fuera, el carbón constituía una dificultad añadida para la ferrería. En 1614 el corregidor de Vivero manda castigar a dos carboneros, porque en las fragas de Bravos han cortado "por el pie mas de ducientos robles" para hacer carbón para la ferrería del lugar, contraviniendo las prohiciones de no cortar árboles por el pie1997. En 1640 una docena de vecinos de Ourol y San Pantaleón se enfrentan a los carboneros de la ferrería ${ }^{1998}$ y a su propietario, el capitán Pedro Fernández de Cora ${ }^{1999}$, pues mientras éste afirmaba que las "fragas" correspondían a la fábrica, los vecinos protestaban que eran suyas "anexas a sus lugares, se an vendido y venden con los mismos lugares y cuando se hace partixa de los vienes se parten entre los coherederos" ${ }^{2000}$. En dicho documento se menciona a "Juanes de Beldorrayn, rendero de la dicha erraria y sus oficiales $y$ carboneros", a los que acusan porque "dende nuebe o diez meses a esta parte usando officiales carboneros dieron en meterse en las fragas a cortar y talar en ellas y hacer oyas y fossas para carbón haciendo gran cantidad del para el servicio y fabrica de dicha herraria, con que les tienen a mis partes destruidas las dichas fragas" ${ }^{2001}$.

\footnotetext{
juan de montano tiene, puesta en el puerto desta dicha villa" por la que le ha de pagar a tres reales y medio el quintal.

1996 AHPLU: 4030/3 (1641): "Joanes de balderrayn vecino que resido al presente en la herreria de brabos" da su poder "a joanes de loperene vecino del balle de oyarzun y a joanes de alburu sapatero vecino del mismo valle que es en la provincia de guipuscua..." para que puedan cobrar de "sebastian de arburu, vizcaino vezino del dicho valle de oyarzun" 24 ducados "que le presté de que me hizo obligacion en honze dias del mes de junio del año proximo pasado de mill y seiscientos y quarenta".

1997 AHRG. R.A.: 16.987/28. Se trata de las fragas "que llaman da Penna da bona (...), fragas altas y crecidas a donde ay mucha cantidad de robles que tienen maderas para casas y nabios"; pero que como consecuencia del carboneo "tienen destruidas las dichas fragas".

1998 AHRG. R. A.: 21.708/6: poder de los vecinos para pleitear contra los "arrendatarios y carboneros de la erreria de Santiago de Brabos por nos aberen cortado y destruydo la fraga de Cauanas y Serra da Borra y otras más fragas para el carbón de la erraria”.

1999 AHRG. R. A.: 21.708/6: "Sepan quantos esta carta de poder vieren como yo el capitán Pedro Fernández de Cora y Aguiar, vecino de la feligresía de Santiago de Brabos, cuya es la erraria de la dicha feligresía que soi presente..."

${ }^{2000}$ AHRG. R. A.: 21.708/6

${ }^{2001}$ AHRG. R. A.: 21.708/6. Este Juan de Balderrayn, vizcaíno, rendero de Bravos, da su poder en 1641 a Juan de Loperena y al zapatero Juan de Alburu, vecinos del valle de Oyarzun, en Guipúzcoa, para poder cobrar de Sebastián de Alburu, también de Oyarzun, 24 ducados que le debe de un préstamo que le hizo en 1640 (AHPLU: 4030/4).
} 
Pero éste no era el único enfrentamiento con los vecinos de la jurisdicción de Bravos, también protestaban por la alcabala del hierro. Al parecer Gonzalo Pérez de Cora, en 1614, había logrado un privilegio real que le eximía de pagar alcabala de hierro o de otros mantenimientos que se vendiesen dentro de la ferrería, después de un largo pleito de más de doce años. En 1626 su hijo Pedro, con las protestas de los vecinos, exige que se le mantenga en el mismo privilegio "por concurrir las mismas calidades y por las mas causas que alegó ante el dicho corregidor"; pero éste no hizo el menor caso exigiéndole que pagase las alcabalas del hierro y le permitiese inspeccionar la ferrería, a lo que aquel no consintió, por lo que le presentó una querella ${ }^{2002}$.

Probablemente la falta de combustible fue la razón de su abandono durante la primera mitad del siglo XVIII2003, como recuerdan los informantes del Catastro de Ensenada, de 1753: "En la expresada feligresía ay una herrería correspondiente a dicho D. Francisco Gerónimo de Cora por hallarse deteriorada y sin exercicio a mas de treinta años incapaz de trabaxar a menos que sea con espendio de algún caudal para su reedificación, de cuio veneficio careze dicho don Francisco de Cora"; por ello no le regulan ningún beneficio ${ }^{2004}$. Pero esta situación cambió poco después, porque en $1758^{2005}$ este don Francisco Jerónimo de Cora la dió en arriendo al presbítero don Juan de la Vega y Río por 20 quintales de hierro al año, siendo las quiebras mayores por cuenta del dueño y las menores por la del arrendatario ${ }^{2006}$. Este don Juan de la Vega era miembro de una activa familia de comerciantes e hidalgos de San

${ }^{2002}$ AHRG. R.A.: 25.514/8: 1626 pleito entre los vecinos de la feligresía de Bravos y Pedro Fernández de Cora. Su procurador dice "que litigándose pleito contradictorio juicio a mas de doce años entre Gonzalo Pérez de Cora padre de mi parte, señor que fue de la Erraria de brauos que ora es de mi parte contra los vecinos de la dicha feligresia sobre la alcavala del fierro y otras cosas que pretendía pagase el dicho Gonzalo Pérez de Cora se dio auto en diez de julio de seiscientos y catorce por el corregidor que entonces era de la dicha villa de viuero por el qual mando en conformidad de un decreto de su magestad y su concejo (sic) de acienda que el dicho Gonzalo Pérez de Cora no pagase ninguna alcavala de fierro ni de otro mantenimiento que se vendiese dentro de la dicha Erraria y su distrito (...) y sucedió en la misma Erraria mi parte ques su hijo debiendo guardarsele el mismo previlegio que a su padre por concurrir en el las mismas calidades".

${ }_{2003}$ En 1722 se menciona la ferrería, pero no sabemos si estaba en funcionamiento (ARHG. R. A.: 21.859). En un pleito sobre la ferrería de Pesqueira se toma testimonio, el 12 de octubre de 1722, a Francisco Sanchéz de Vidarte, presbítero "en la feligresia de Santiago de Brabos y sitio de la erraria della".

2004 CATASTRO DE ENSENADA. R. G.: Bravos

2005 Por entonces la llevaba en arriendo el asturiano don Francisco de Navia.

2006 P. SAAVEDRA (1985): Ob. cit., p. 332, nota 102. 
Vicente de Lagoa. Fue tío de don Lorenzo de la Riba, que después de 1750 construyó una fábrica de sombreros en Mondoñedo, siendo el comerciante, en palabras de P. Saavedra, más emprendedor de la ciudad ${ }^{2007 .}$

Sin duda fue el acuerdo, que firmó en 1762 con las feligresías de Oriol, Muras y San Pantaleón, lo que le permitió a don Juan de la Vega y Río disponer de leña ${ }^{2008}$, y que por esa razón la ferrería pudiera trabajar desde esos años hasta 1781, en los que hicieron algunas piezas de hierro para los arsenales del Ferrol ${ }^{2009}$. Pero el combustible se convirtió en el problema más grave de esta ferrería hasta el punto de tener que cerrar, como reconocen en 1788 los vecinos de Rua, señalando que en la provincia de Mondoñedo, en la que se incluía esa parroquia, "había antes de ahora cuatro herrerías de labrar hierro: la una en el valle de Lorenzana, otra en Santa Marta, otra en el Valle de Oro y sitio de Pesqueira y otra en la feligresia de Bravos (...). Cuyas herrerías, por diferentes motivos, han quedado a hiermo y sin uso, imposibilitadas de jamás renovarse, efecto de la falta de leñas y carbón para su subistencia”2010.

Este problema del combustible lo vuelven a señalar varias parroquias de la jurisdicción de San Ciprián, en agosto de 1788, en su oposición a la fábrica de Sargadelos, porque al igual que los dueños de las anteriores fábricas, Ibáñez solo busca su enriquecimiento, destruyendo los montes y arruinando los pueblos: "de que tienen los exponentes dos ejemplares bien recientes, en las dos (herrerías) que se construyeron en los valles de Oro y Bravos, y en que después de que sus dueños asolaran los montes de la circunferencia llevándose las

\footnotetext{
2007 P. SAAVEDRA (1985): Ob. cit. p. 337

${ }^{2008}$ AHPLU: 2679/8 (1762): Los vecinos de San Vicente de Lagoa en el valle de Oro, de San Pataleón de Cabañas y Santa María de Orol dijeron que don Josep de la Vega y Río "arrendatario de la herraria de Santiago de Brauos representando ygual derecho de D. Josef Pertierra, en 28 de septiembre de este año acudió con memorial al comisario de Marina y Juez de Montes de esta provincia haziendo manifestación de la necesidad que tenía de carbones para el manejo de la herraria de donde salía partida de fierro para las reales obras de S.M. para cuyo cumplimiento tenía adquirido de algunos que se mostrarían partes interesadas en la fraga nombrada de Couso.." a lo que aquel le dió permiso pero los vecinos protesdtaron, pero como los pleitos son siempre costosos, le permiten utilizar la leña en una tercera parte de la fraga.

2009 P. SAAVEDRA (1985): Ob. cit. p. 332

${ }^{2010}$ A. MEIJIDE PARDO (1979): Ob. cit., p. 88, documento $\mathrm{n}^{\circ} 26$
} 
utilidades de ellos, desamparan las fábricas, actualmente abandonadas, y dejaron a los naturales del país en la mayor penuria de leñas y maderas” ${ }^{2011 .}$

Antonio Raimundo Ibáñez y José de Andrés García en su propuesta para levantar una ferrería en Muras, con argumentos contrarios a los de los vecinos, recuerdan en 1791 que la ferrería de Bravos ha cerrado recientemente "Una buena policía aumentaría aquellos bosques, las leñas serían inextinguibles, las fábricas perpetuas. En ello no hay ninguna incompatiblidad (....). El sistema contrario que la maledicencia querrá objetar de que las herrerías han destruido los montes, nada prueba, ni nada puede hallar protección sino en la ignoranciay en la barbarie; pues aunque es cierto que en la provincia de Mondoñedo han quedado a yermo algunas de aquellas fábricas por falta de leñas, y últimamente una en la jurisdicción de Bravos, distante tres leguas de la puente de Muras, no ha sido sino por el abuso y desorden de sus dueños, o más bien por el de sus arrendatarios, en cuya ambición no cabe otro interés que el de enriquecerse con avaricia"2012.

Por tanto, mucho antes de que se construyera la fábrica de Sargadelos estas dos ferrerías habían dejado de funcionar por problemas con el carbón y la madera. Nunca más volvieron a hacerlo.

ESTADO: No quedan restos de la ferrería, pero si de la casa señorial de los Cora, una buena casona deshabitada, con su capilla al lado.

${ }^{2011}$ IBIDEM, p. 104, $\mathrm{n}^{\circ} 33$

2012 IBIDEM, p. 39, $\mathrm{n}^{\circ} 12$ 


\title{
14. MUNICIPIO DE A PONTENOVA
}

\section{FERRERÍA DE SAN PEDRO DE BOGO}

\author{
LUGAR: Vilaboa (parroquia de San Pedro de Bogo) \\ MUNICIPIO: A Pontenova \\ RÍO: Reigadas \\ COORDENADAS: $43^{\circ} 18^{\prime} 31^{\prime \prime}$ N. y $7^{\circ}$ 9' o" W.
}

Desde A Pontenova por la carretera hasta Bogo, en el que hay que tomar un camino que baja al río de las Reigadas, afluente del Eo, en el que se encuentra la ferrería.

La ferrería de Vilaboa la construyó a principios del siglo XVI el hidalgo Pedro Miranda, de la casa de Ribadeneira, quien en 1537 la tenía arrendada al vasco Juan de Belastegui. Cien años después, en torno a 1637, otro vizcaíno, Juan de Lizalde, la tuvo igualmente arrendada por 20 quintales de hierro al año ${ }^{2013}$. Pero hacia 1700 la ferrería ya no funcionaba, por lo que hay que suponer que posiblemente estaba parada desde algún tiempo antes; y así siguió a lo largo del siglo XVIII, pues ni el Catastro de Ensenada ni Cornide la mencionan. Aquel sólo habla de la existencia de dos mazos, propiedad de Carlos de Oia y Rodrigo Caldaloba, situados en el lugar del Machuco 2014; uno de los cuales pudo ser la antigua ferrería, pues dicho Carlos de Oia es miembro de la familia Ribadeneira.

\footnotetext{
2013 SAAVEDRA, P. (1985): Economía, política y sociedad en Galicia: La provincia de Mondoñedo, 1480-183o. Xunta de Galicia, p. 327 y 328

2014 GONZALEZ, C. (1994): As grandes ferrerías da provincia de Lugo. Lugo, p. 194. Años más tarde, en 20 de abril de 1825 (AHPLU: 2071/6) Pedro Ramón de Oya y Pedro Méndez del Cancio dijeron "que el mazo o martinete de este repetido lugar propio en ambos dominios del primer otorgante siempre ha disfrutado sin el menor obstáculo para el movimiento y ejercicio de su máquinas todas las aguas del río que baja desde San Pedro de Bogo a este dicho lugar..." Ahora don Pedro ha hecho un poco más arriba un molino de dos ruedas, acuerdan: 1) "que como la Herrería de fierro de San Pedro de Bogo es también propia de dicho señor Oya y desde ella al citado mazo siempre hubo y se conserbó un camino husual y corriente para la condución de fierro, maderas y servicio respectivo de ambos artefactos, cuyo camino varió Méndez con motibo de hacer un prado". Éste no debe impedir el tránsito de fierro, madera, etc. 2) "que el expresado mazo o martinete siempre ha de llebar y disfrutar por su misma presa todas las mencionadas aguas sin minoración(por eso D. pedro solo utilizará el agua para el molino y que luego revierta en la presa". 3) si el molino se llegara a inundar, enharenarse, etc. sea la limpieza a costa de don Pedro o sus herederos.
} 


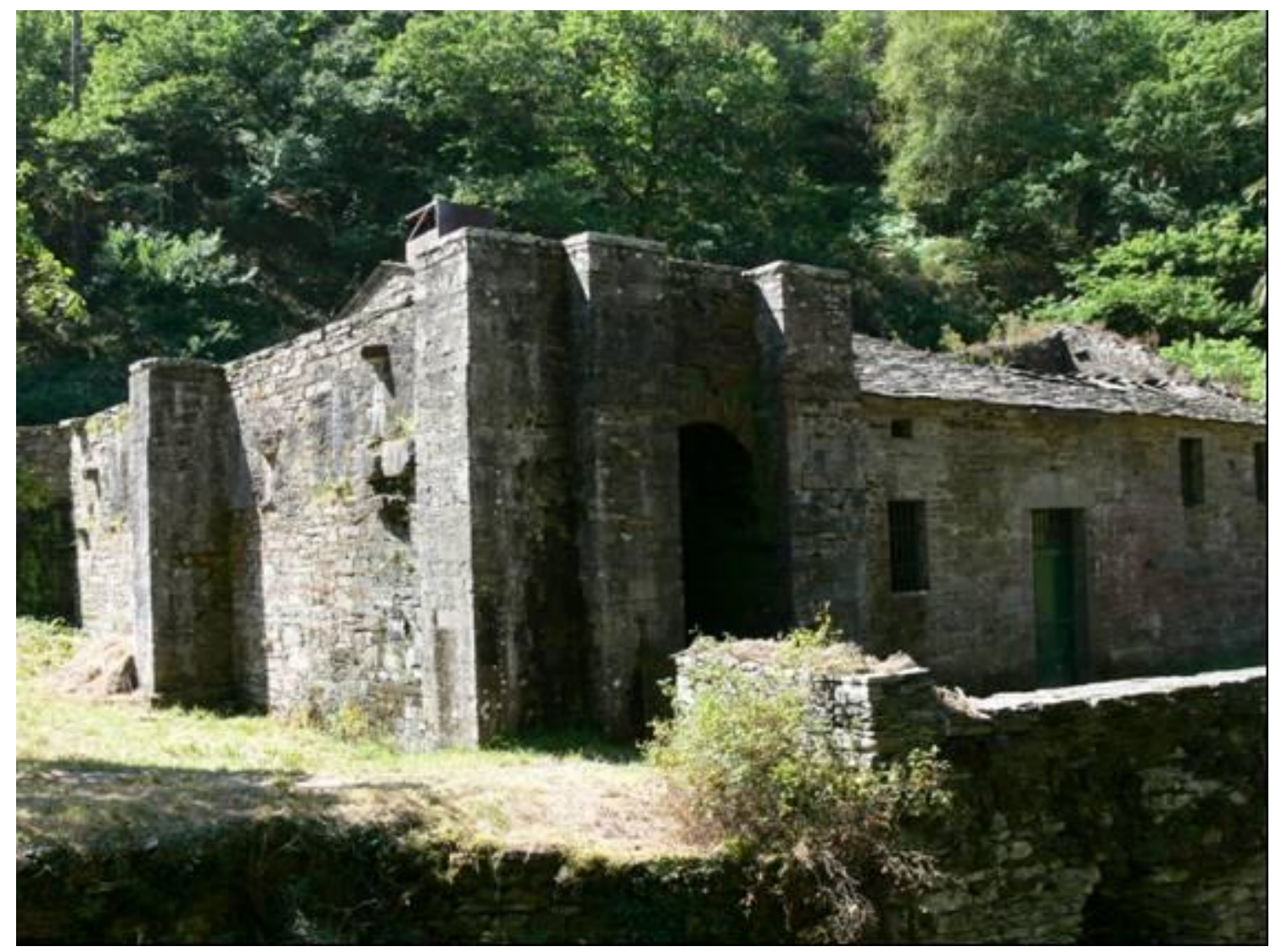

Ferrería de Bogo

La razón pudiera ser la falta de combustible; sin embargo, hacia 1800 vuelve a funcionar, pues dos años años antes, en 1798, el dueño de la casa de Miranda-Ribadeneira, don Pedro de Oya, forma "compañía" con Domingo Rodil y Antonio Bermúdez con el objetivo de reedificar -en realidad construir de nuevo- la ferrería, corriendo por mitad con los gastos don Pedro y los dos socios, a los que además afora los montes de la ferrería en 300 reales al año, que al parecer estaban entonces más poblados; es decir, que Domingo Rodil y Antonio Bermúdez serían los encargados de administrarla ${ }^{2015}$. Probablemente durante la Guerra de la Independencia la ferrería sufrió algún percance ya que en 1815 sería nuevamente restaurada.

La restauración corrió a cargo, en esta ocasión, de don Francisco Acevedo, subteniente graduado del Real Cuerpo de Artillería y administrador de las Reales Fábricas de Sargadelos ${ }^{2016}$. Éste el 24 de marzo de ese año dijo "que está a su cargo la construzión, reparo y complemento de la Herrería de San Pedro

2015 SAAVEDRA, P. (1985): Ob. cit. p. 333 ${ }^{2016}$ Era cuñado de Antonio Raiumundo Ibáñez, el fundador de Sargadelos, fábrica de la que Francisco Acevedo sería posteriormente director. 
de Bogo, sita en esta parroquia", para lo que necesita algún dinero, por lo que en este acto le presta don Benito Fernández Calbin 19.000 reales, que se compromete a devolver en un año. Como fiador está presente don Pedro Ramón de Oya, vecino de esta parroquia 2017. Es probable que la factura tan extraordinaria de esta ferrería sea obra de la restauración de finales del XVIII, aunque también podría deber mucho a Francisco Acevedo, seguramente hombre de botables conocimientos técnicos.

Este Pedro Ramón de Oya Méndez de Ribadeneira, capitán del Ejército e hijo de Pedro Roque de Oya, era, como recuerdan otras escrituras de esos años, el dueño de la ferrería. Como tal, en 1821, se la arrienda a don Manuel Álvarez Castrillón por tres años y renta anual de 10.640 reales ${ }^{2018}$. Finalizado el arriendo, la vuelve a arrendar en 1824 a Francisco Ibarbia y, por su ausencia de éste a "Martín Ibarbia, oriundo de la Vizcaya y provincia de Guipuzcoa", familiar probablemente de Francisco, en 54.000 reales, repartidos en seis semestres en esta forma: 8.000 reales los dos primeros, 9.000 rs. los dos siguientes y 10.000 los dos últimos ${ }^{2019}$.

Al lado de la ferrería siguió en funcionamiento el mazo, llamado en algunas escrituras como "Machuco viejo", como recuerda un acuerdo firmado en 1825 por don Pedro Ramón de Oya, su propietario, y don Pedro Méndez de Cancio, que construyó un molino sobre las aguas del río, con el permiso de aquél siempre y cuando no perjudique al machuco ni a la ferrería ${ }^{2020}$.

2017 AHPLU: 2070/4 (1815).

${ }^{2018}$ AHPLU: 2071/2 (1821). El 31 de enero de 1821 don Pedro Ramón de Oya Rivadeneira, capitán de infanterÍa retirado y dueño del pazo de Villacimil (Vilaboa) dice "que le corresponde en pleno dominio y como anexa a sus vínuclos y mayorazgos, con la porción de montes que tiene en los que nombran de Reygados, una Herrería titulada de San Pedro de Bogo en esta parroquia con sus correspondientes casa y oficinas, que se reducen a dos carboneras, almacén de fierro, un quarto con su cama para abitación de los oficiales, un comedor con su mesa de piedra y asientos, cinco cajones y una lacena con sus llabes correspondientes; unos fuelles de madera con su harbol, rueda y más aderentes con los aperos y pertrechos necesarios para el serbicio de dicha Errería", además de la casa, molino, prados, árboles, etc. Sigue diciendo que "como no le conbiene trabajar por su quenta la memorada Errería" se la arrienda a su actual mayordomo don Manuel Álvarez Castrillón, por tres años " $y$ sus tres labranzas". Entre las condiciones, además de los 10.640 reales/año dice "que para el surtido de carbón necesario para mil quintales gallegos de fierro poco más o menos señalará el señor otorgante al yndicado arrendatario los montes precisos", y si no le llega se entenderá con los dueños.

2019 AHPLU: 2071/6 (1824, 9 de enero).

2020 AHPLU: 2071/6: "que el expresado mazo o martinete siempre ha de llebar y disfrutar por su misma presa todas las aguas mencionadas sin minora (...) y que como la herrería de fierro de San Pedro de Bogo es también propia del dicho señor de Oya, y desde ella al citado mazo 


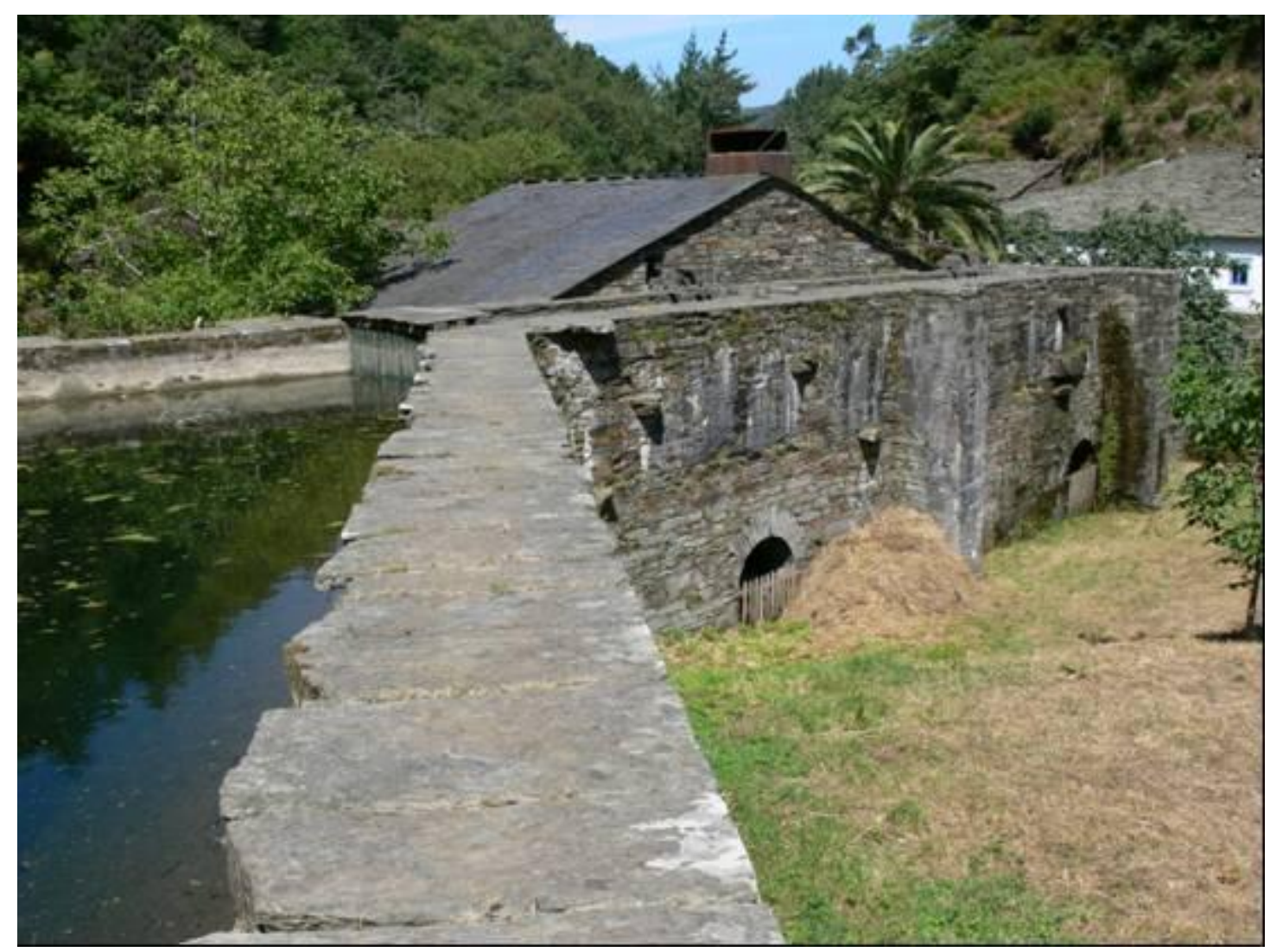

Banzao y banzadillo de la ferrería de Bogo

De don Pedro Ramón la ferrería paso a su hijo don Pedro Antonio de Oya, aunque desde 1829 hasta 1836 la administró su tío don Justo de Oya. El 9 de junio de 1836, tío y sobrino liquidan cuentas de los siete últimos años en que aquel la administró. En el texto se señala que la ferrería pertenece a los vínculos y mayorazgo que heredó, como primogénito, don Pedro tras la muerte repentina y sin testamento de su padre; y que para evitar juicios acuerdan que don Justo deje libre la ferrería a su sobrino, con el carbón que hay en las carboneras, que se valora en 10.000 reales, con lo que se da por satisfecho ${ }^{2021}$. Este don Pedro, días después, acuerda asociarse con don José Boan Martínez de la siguiente forma: éste pondrá el dinero para adquirir la vena y transportarla hasta la ferrería, por la que recibirá la tercera parte de los beneficios; las otras dos serán para don Pedro: una por el carbón que tiene en la carbonera y otra por el

siempre hubo y se conserbó un camino husado y corriente para la condución de fierro (...) debe dejarlo útil".

${ }^{2021}$ AHPLU: 2086/5 (1836). 
artefacto ${ }^{2022}$. El acuerdo es por un año y los quebrantos mayores correrán a cargo del dueño ("como son el cuerpo del árbol principal con su rueda, martillo, iunque de fierro, y lo principal del árbol, rueda de los barquines y barquines”), y las quiebras menores en proporción de una parte para José Boan y dos partes para don Pedro de Oya2023.

Según noticias recogidas de los vecinos por Clodio González, la ferrería desapareció como consecuencia de un incendio un día de San Pedro de un año que no saben precisar ${ }^{2024}$, aunque quizá lo que quiere decir es que dejó de funcionar.

ESTADO: La vivienda se conserva en buen estado y habitada. La ferrería ha sido recientemente restaurada por sus propietarios con ayudas de la Xunta. Puede verse los extraordinarios paramentos de la presa y el banzado. En la ferrería propiamente dicha se ha reconstruido el mazo y otras dependencias.

\section{MUNICIPIO DE PORTOMARÍN}

\section{FERRERÍA DE GONZAR}

LUGAR: A Ferrería, parroquia de Santa María de Gonzar MUNICIPIO: Portomarín

RÍO: Ferrería

COORDENADAS: $42^{\circ} 48^{\prime} 31^{\prime \prime}$ N. y $7^{\circ} 41^{\prime} 32^{\prime} \mathrm{W}$.

Por el Camino de Santiago, desde Portomarín a Gonzar, en el lugar de la Ferrería, y a orillas del arroyo de este último nombre. Se la conoció con los nombres de ferrería de Gonzar, Portomarín o Paredes. Se accede por una carretera, a la izquierda, antes de llegar a Gonzar, a menos de tres kilómetros.

\footnotetext{
2022 AHPLU: 2086/5 (1836, 15 de junio). 2023 IBIDEM 2024 GONZÁLEZ, C (1994): Ob. Cit., p 194.
} 
La solicitud para construir una ferrería en Gonzar fue tramitada en 1795 ante la Junta de Comercio, Moneda y Minas por las hermanas Jacoba y María del Carmen Gil de Taboada, vecinas de Santiago de Compostela, las cuales propusieron levantar una ferrería "o más, en el sitio llamado "el Molino viejo" $y$ río de la Ferreiroá, jurisdicción de Puertomarín, obispado de Lugo", con el propósito de fomentar la industria y aumentar la población en la zona. Dicha solicitud fue aprobada el 12 de octubre de ese mismo año, y la ferrería construida poco después, hasta el punto de que unos años más tarde estaba "corriente con toda la perfección del arte, que se halla en el día capaz de surtir de fierro a mucha parte de Galicia" 2025 .

Probablemente esta abundante producción, dificil de vender en la zona hasta el punto de almacenar un stok de 1.000 quintales de hierro, fue la que llevó a Jacoba Gil de Taboada en 1804, a solicitar que se le permitiera vender el hierro con los mismos derechos "como a pie de fábrica" en las almacenes que pretendía abrir en Ribadavia y Orense ${ }^{2026}$.

Pero la ferrería debía tener problemas para abastecerse de mineral de hierro. En 1816 los vecinos de Villajuste acusan al monje administrador de la ferrería de Pallares, con los que pleitea éste porque el alcalde le ha prohibido utilizar vena y carbón de esa parroquia, de impedir a la ferrería de Gonzar usar un venero situado en términos del lugar de Meijaboy²027, que debía estar muy cerca de esta última ferrería.

En 1824 el administrador de Incio, Juan Fariñas, pleitea contra don Bernardo de Prado Quiroga, administrador de la ferrería de Gonzar o Paredes por el uso de leñas y por abrir un camino para raguar la vena de Roques en San Miguel, en Incio, antes de llevarla a su ferrería ${ }^{2028}$; juicio con continúa en 1827 con la condesa de Campomanes, dueña de la ferrería de Incio, por el mismo

\footnotetext{
2025 AGS. Junta de Comercio y Moneda: leg. 295 2026 IBIDEM

${ }^{2027}$ AHRG. R. A.: 1.687/29. Los vecinos de Villajuste hablan de un venero del monasterio de Samos en Meijaboy "en el qual habiendo querido introducirse el mayordomo de la ferrería de Gonzar se lo impidió el Padre Administrador"; y que también tienen otro en tierra de Juan Pérez "en la que aunque quiso introducirse el prenotado Mayordomo de la de Gonzar se lo impidió dicho P. Administrador".

${ }^{2028}$ AHRG. R. A.: 22.758/41
} 
motivo; es decir, abrir un camino " $y$ por él conducir vena del mineral de Roques para depurarle de la primera escoria y cocer raguar junto a la dicha casa de San Miguel, para el consumo de la Herrería de Paredes o de Puerto marín”2029.

No era sólo el camino sino que el problema derivaba de utilizar el monte para raguar la vena. La Audiencia dió auto a la propietaria de Gonzar, doña Jacoba Gil Taboada, vecina de La Coruña, para que no se le impidese el paso ni el uso de la leña y carbón; pero aquella alega en 1828 que los montes "anexos y pertenecientes a la Herreria del Yncio con arreglo a la escritura foral de once de junio de mil setecientos veinte y dos echa por el comendador de Quiroga a D. Manuel Francisco Orozco Armesto de Sarauz" eran de su ferrería ${ }^{2030}$.

Hernández Sampelayo dice que la de Gonzar debió ser una gran ferrería, que consumió hierro de la zona de los altos de Donigos, en sus inmediaciones donde se aprecian vestigios de una gran serie de trabajo sobre filones poco potentes de hematites; por el contrario, aunque las gentes del país creen que el mineral de Lousadela, en la zona de Guntín de Pallares, se benefició en la ferrería de Gonzar, dice que está muy alejado y que habiendo otras más cercanas en ellas se debió de explotar en las más próximas ${ }^{2031}$.

Desconocemos hasta cuándo estuvo funcionando.

ESTADO: Se conserva la vivienda, un magnífico pazo con capilla, rodeado de una exuberante vegetación. Está por encima del río y de la ferrería; de ésta quedan algunos vestigios acondicionados como molino.

2029 AHRG. R.A.: 23.088/72

2030 AHRG. R. A.: 23.088/72

${ }^{2031}$ P. HERNÁNDEZ SAMPELAYO (1935): Ob. cit.t. III-2, p. 459-461 


\title{
16. MUNICIPIO DE PUEBLA DE BROLLÓN
}

\section{FERRERÍA DE BIDUEDO}

\author{
LUGAR: Biduedo (Santa María de Óutara) \\ MUNICIPIO: A Pobra de Brollón \\ RÍO: Cabe \\ COORDENADAS: $42^{\circ} 37^{\prime} 58^{\prime \prime}$ N. y $7^{\circ} 22^{\prime} 43^{\prime \prime} \mathrm{W}$.
}

Por la carretera de Pobra de Brollón a la Cruz de Incio se encuentra Óutara, parroquia en la que se localiza la aldea de Biduedo. La ferrería estaba a orillas del Cabe, poco antes de llegar a la vivienda y a la capilla, que aún perduran.

Fue una pequeña ferrería que debió construirse a mediados del siglo XVIII. No la menciona el Catastro de Ensenada, porque según Eugenio Larruga fue hacia 1752 cuando don Lucas Somoza y Losada solicitó permiso para la construcción de un artefacto para fundir hierro en la parroquia de Santa María de Óutara; iniciativa a la que, como en otros muchos casos, se le pusieron grandes obstáculos, entre ellos, según un jesuita de Monforte, también la Iglesia temía que por su causa disminuyeran los diezmos, pues "con la codicia del jornal que pillan al día (los trabajadores) muchos no cultivan ni media fanega de sembradura, y por consiguiente no tienen pan por Navidad; a que se sigue la decadencia en los diezmos, tributos y rentas de los dueños" ${ }^{2032}$. Pero probablemente la razón principal fue la escasez de combustible. Con todo, D. Lucas Somoza pudo al fin construirla.

Entre 1762 y 1767 este don Lucas mantuvo un pleito con la ferrería de Incio por la leña y el carbón ${ }^{2033}$. Un testigo del mismo, Javier Balboa, declaró que “oyó de publico que por D. Lucas Somoza estableciera una Herrería en las márgenes del río Cave, término de la aldea de Viduedo, feligresía de Santa

\footnotetext{
${ }^{2032}$ E. LARRUGA (1800): Memorias políticas políticas y económicas sobre los frutos, fábricas, comercios y minas de España. Vol. XLV, Madrid, p. 346.

2033 AHRG. R. A.: 23.088/72. El pleitó lo suscitó don Rodrigo Sánchez Orozco, dueño del pazo de Dompinor y de la ferrería de Incio, contra " $D$. Lucas Somoza dueño de la Herrería de Biduedo sobre el uso de los montes y aprobechamientos de sus producciones para sus respectivos artefactos".
} 
María de Óutara, jurisdición de la Puebla de Brollón, limítrofe con esta de Incio y parroquias de San Pedro y San Miguel, por lo que el año de mil sietecientos sesenta y cinco se quejara D. Rodrigo Orozco y Armesto padre de la que por quien depone, por extraer la leña y carbón de esta del Yncio para la citada nueba fábrica, ante la Real Junta de Comercio, Moneda y Minas, quien por comisión que diera al corregidor de Monforte, reciviera justificación sobre el particular y aunque D. Lucas tratara provar que los montes del Yncio eran concejiles, no lo consiguieron antes vien el $D$. Rodrigo justificara y acreditara con documentos ser del directo dominio de la Encomienda, por lo que al tiempo pagaba cada vecino quatro reales y el aprovechamiento de las leñas y el carbón, de antiquisimo e ynmemorial tiempo a la ferrería del Yncio".

La Junta de Comercio, Moneda y Minas en 1767 amparó a la ferrería de Incio, obligando a don Lucas Somoza a no perturbar la antigua posesión de ésta ${ }^{2034}$. A este don Lucas sucedió su hijo, otro don Lucas Somoza y Saavedra, “dueño de la casa solar de los Somoza sita en la villa de Layosa”, quien 1771 compraba en su herrería de Viduedo unos castañales a Juan Franco ${ }^{2035}$. Por esos años, Cornide escribe que beneficiaba unos 200 quintales de hierro, una de las cifras más pequeñas de todas las que menciona este autor ${ }^{2036}$. Quizá se trataba de una pequeña ferrería regatera.

A comienzos del siglo XIX la ferrería estaba en manos de don José Gabriel Somoza, probablemente hijo o heredero de don Lucas pero vecino de Lugo, como nos informa un pleito, en 1810, que se suscitó entre los propietarios de la ferrería de Penacoba y los vecinos del coto de Acebedo y otras jurisdicciones, a causa de la ferrería de Viduedo. Aquéllos decían que desde tiempo inmemorial se hallaban en la posesión "de hacer carbón, benderlo a todo xenero de personas y lo mismo la zepa de leña (...) y venderlo a la Herrería de Viduedo, villa de Monforte y a barios herreros del Balle de Lemos"; pues los montes son del colegio de Montederramo, al que ellos pagan foro 2037.

\footnotetext{
2034 AHRG. R. A.: 23.088/72

2035 AHPLU: 2467/7 (1771).

${ }^{2036}$ CORNIDE: Ob. cit, ff. 225.

2037 AHRG. R. A.: 19.877/30
} 
Los propietarios de Peñacoba, por su parte, alegaban que los montes eran del foro que el conde de Lemos había hecho a su ferrería y que desde 1769, en el que en una querella similar los tribunales le dieron la razón, no había habido problemas hasta 1809 en que varios vecinos de la Somoza volvieron a vender carbón a la ferrería "que llaman de Viduedo propia de D. Josef Gabriel Somoza, vecino de la ciudad de Lugo" ${ }^{2038}$; pero que desistieron ante la denuncia. En 1810 se suscitó el pleito ya aludido, pues "a solicitud de los ajentes del Somoza" han vuelto "a extraer y llevar a su ferrería de Viduedo en carros y cargas de Bestias masas de carbones que cuecen de intento para mantener aquella fábrica en perjuicio de la de los hijos de la otorgante y atrasos a su Patrimonio"2039. La razón no era otra sino su mayor estimación o precio más elevado.

No debió funcionar muchos años, pues aunque aún la nombra Miñano en $1826^{2040}$, poco después Madoz señala que estaba "paralizada por falta de

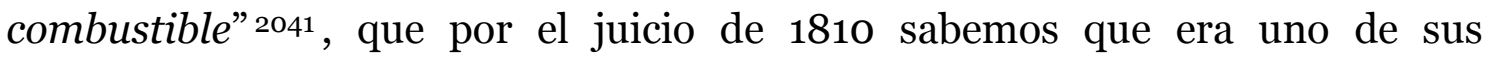
problemas más graves. Desconocemos si volvió a trabajar en la segunda mitad del XIX, aunque parece que lo hizo hasta mediados del siglo según Hernández Sampelayo ${ }^{2042}$.

ESTADO: Como testimonia Hernández Sampelayo, que la conoció en ruinas a principios del siglo $\mathrm{XX}$, era una construcción de una sorprendente amplitud y buena construcción, con vivienda, casas de obreros, capilla, y las dependencias propias de la ferrería. Actualmente no queda nada, a excepción de la vivienda reconstruida y la capilla2043.

\footnotetext{
${ }^{2038}$ AHRG. R. A.: 19.877/30

2039 AHRG. R. A.: 19.877/30

${ }^{2040}$ S. MIÑANO: Ob. Cit., t. VI, : “Al S. de Óutara, en lo bajo y a la izquierda del río, por cuya parte es la montaña muy elevada, está el lugar de Viduedo, y a la derecha la ferrería del mismo nombre".

${ }^{2041}$ P. MADOZ: Ob. Cit., t. XII, p. 416

2042 P. HERNÁNDEZ SAMPELAYO (1935): Ob. cit., III, p. 118 y 119.

2043 IBIDEM, p. 117.
} 


\section{FERRERÍA DE LOR}

LUGAR: Santa Mariña de Barxa de Lor MUNICIPIO: Pobra de Brollón

RÍO: Lor

COORDENADAS: $42^{\circ} 30^{\prime} 40^{\prime \prime}$ N. y $7^{\circ} 20^{\prime} 27^{\prime \prime} \mathrm{W}$.

Se encuentra en la parroquia de Barxa de Lor, a orillas del río de este nombre, en un lugar denominada Pena das Pombas ${ }^{2044}$, que según el Catastro de Ensenada quedaba como a un cuarto de legua poco más o menos de aquella parroquia. A veces se la nombra como "Ferrería Nueva de Lor".

La ferrería de Lor se construyó a comienzos del siglo XVIII en tierras propias de la encomienda de Quiroga. Bulas y decretos repetían constantemente a los comendadores que intentaran aumentar la riqueza de esa zona tan pobre; por lo que atendiendo a que en el coto de Lor "auia muchos montes propios (de $\mathrm{su}$ ) directo dominio, sin que estos sirviesen de utilidad alguna (para) el aprovechamiento de ellos, ni se cobraba renta por no residir en aquel paraje los comendadores y muchas personas sin titulo ni facultad se entrometían en ellos cortando y talando la leña", el 1 de julio de 1719 la encomienda aforó a don Joaquín Francisco Pardo Rivadeneira por la vida de tres reyes (de 33 años cada vida, es decir 99 años) los montes del mencionado coto para que construyera una ferrería " $y$ que éste pudiese usar de la leña de dichos montes, piedra, aguas del río Lor para la fábrica de casas y lo necesario para hacer dicha herrería en que se fabricase hierro" 2045.

El foro se lo hacen con las condiciones siguientes: pagar de renta anual, en el castillo de los Nobais de Quiroga, 4.00o maravedis al año; que no la puedan vender ni enagenar; que él y sus sucesores habrán de impedir que se entrometan las gentes en sus montes, pero ellos sí podrán hacerlo para "uso y abasto de las

\footnotetext{
2044 En 1733 se dice que don Joaquín Fco. Pardo de Rivadeneira es dueño "de la Erraria da pena das Pombas, sita en la feligresía de Santa Marina de Lor" (AHRG. R.A.: 3020/42). También CATASTRO DE ENSENADA. R. G.: Barxa de Lor: "Que asimismo se halla en dicha feligresía de Santa Marina de Varxa de Lor en el sitio que dicen Pena das Pombas, que dista del lugar de Varxa como medio quarto de legua poco más o menos".

2045 AHRG. R. A.: 3020/42
} 
fábricas de casas y herrería de hacer hierro y otras que les pareciese y le tubiere conveniencia". Por el contrario no les permiten el uso de los montes mansos, que la encomienda ya tiene aforados ${ }^{2046}$. El foro se firmó en Portomarín ante don Pedro Pardo Rivadeneira ${ }^{2047}$, prior de la colegiata de aquella villa, que pese a los apellidos no es su hermano sino su cuñado ${ }^{2048}$.

Dos años después, el 4 de mayo de 1721, ante el comendador de Quiroga, fray don Diego Vélez de Guevara, los vecinos de Barja de Lor conceden al mismo don Joaquín Pardo, del que ahora nos enteramos que es señor de los cotos de Val de Fariña, Portomeñe y otras jurisdicciones, miembro de la orden de San Juan,además de gobernador y administrador de las encomiendas de Quiroga y Portomarín, para que pueda "dentro de dichos términos y en la parte que juzgue mas a propósito fabricar y fabrique una herraria o más que le pareciere aprouechándose de los montes referidos para el gasto della y fábrica del hierro que labrare (...) aciendo para su abasto quemas y arranque el caruon necesario". Este permiso fue refrendado por la propia orden de Malta en Madrid en $1722^{2049}$.

Pero cuando en ese último año de 1722, don Joaquín Pardo comenzaba la construcción de la ferrería se presentó en las obras don Pedro Valcarce, vecino de Monforte y dueño de la ferrería de Loureiro, tratando de impedirlo por la fuerza, incluso con amenazas de golpes. Poco después presentaba una querella por "obra nueba contra D. Joachin Pardo y Riuadeneira, maestros y alarifes que fabrican una herreria". En otro escrito añade su procurador que denuncia al "yntitulado gobernador de la encomienda de Quiroga y contra los maestros

\footnotetext{
2046 AHRG. R. A.: 3020/42

2047 Joaquín Pardo de Rivadeneira era hijo de Francisco Pardo Rivadeneira e Isabel Pardo Teixeiro, y estuvo casado con Rosa Suárez de Deza

2048 Este Pedro Pardo Rivadeneira, del hábito de San Juan de Jerusalén, prior de la iglesia colegiata de San Nicolás de Portomarín fue nombrado en 1718, por su cuñado, vicario general, juez ordinario y de visita de toda la encomienda de Quiroga. Cit. I. GARCÍA TATO y E. ÁLVAREZ (2012): Las Encomiendas gallegas de la orden de San Juan de Jerusalén. Estudio y edición documental. T. II-2 ${ }^{\circ}$. La Encomienda de Quiroga. Santiago de Compostela, p. 838 .

, prior de la iglesia colegiata de San Nicolás de Portomarín fue nombrado en 1718, por su cuñado, vicario general, juez ordinario y de visita de toda la encomienda de Quiroga. Cit. I. GARCÍA TATO y E. ÁLVAREZ (2012): Las Encomiendas gallegas de la orden de San Juan de Jerusalén. Estudio y edición documental. T. II-2 ${ }^{\circ}$. La Encomienda de Quiroga. Santiago de Compostela, p. 838.

2049 AHRG. R. A.: 3020/42
} 
que trabajan y fabrican en la herreria en el rrio Lor cerca de la de mi parte por los agrauios que a unos y a otros hacía dicha herreria así en las tierras como en los sotos"2050. Por su parte, don Joaquín alega que el foro de 1719 ha sido nuevamente confirmado por el infante de Castilla, don Fernando de Borbón, gran maestre de San Juan en los reinos de Castilla y León ${ }^{2051}$.

La ferrería se construyó efectivamente en esos años, pero el pleito continuó hasta más allá de $1736^{2052}$. Como propiedad de aquella familia seguía a mediados de siglo; pues el Catastro de Ensenada, en 1753, señala que "es propia de D. Gregorio Pardo, vecino de el Caneyro Jurisdicción de Puertomarín", añadiendo que la administra por medio de un mayordomo ${ }^{2053}$. Utilizaba mineral de Rocas, distante unas tres leguas, que por su dureza no le permitía hacer más de cinco ágoas al día de cinco quintales cada una, por lo que, en los doscientos días que trabajaba, pues contaba con agua suficiente, producía aproximadamente unos mil quintales de hierro, que se vendían a 49 reales el quintal. Esto hace unos 49.000 reales, aunque debido a los crecidos gastos de producción el rendimiento lo estiman solamente en 1.100 reales de vellón ${ }^{2054}$.

\footnotetext{
2050 IBIDEM

2051 IBIDEM

2052 AHPLU: 2570/1 (1733). En 1733 sabemos que ya trabajaba y que se la denominaba "Herrería Nueba de Lor", como vemos en la compra que su dueño, don Joaquín Francisco Pardo Rivadeneira, hace de un pedazo de monte en 900 reales a Paula Sánchez Saco. En 1736 seguía el pleito como consta del escrito que hace ante la audiencia de La Coruña, en el que vuelve a relatar los pormenores del foro de los montes y el permiso para construir la ferrería (AHRG. R.A.: 3020/42)

2053 AHPLU: 2463/1 (1750). En 1750 aparece como administrador el presbítero don Francisco Pardo Rivadeneira, a quien don José Antonio Pardo Rivadeneira, dueño de la casa de Perrelas, gobernador y administrador de la encomienda de Quiroga, le arrienda por cinco años y 4.560 reales al año, el partido de Lor (rentas, diezmos, derechos, etc.). También sigue de administrador el mismo en 1752 (AHPLU: 2463/6, año 1752). En 1758 lo era don Marcos Díaz, con quien se obliga José do Mato, de Santa Marina de Lor, a pagarle 520 reales que le había prestado anteriormente (AHPLU: 2463/8, año 1758).

${ }^{2054}$ CATASTRO DE ENSENADA. R. G.: Barxa de Lor: “...y por quanto tiene agua suficiente para todo el año y trabaxa todos los días de el, a excepción de los festivos que se obserban todos, enteramente y los nezesarios al reparo de los frecuentes excalabros que padece por la rapidez y despeñado de dicho río y otros en que dexa de trabaxar ynundada de sus crecientes, contemplan que revaxados unos y otros, solo travaxe echo el computo por un quinquenio, y sin hacerlo de los excalabros mayores, ducientos días en cada un año, en cuyas vezes y quatro horas fabrica cinco quintales por ser más rudo y recio el mineral y no sacar por esta causa más de cinco hagoas en ellas; en cuya conformidad computan que fabrica en cada un año Mill quintales de yerro cada uno de los quales, atendiendo a los precios que tubo en este último quinquenio, computan a quarenta y nueve reales, como llevan expuesto, asi por el estado de dicha Herrería como por ser de ynferior calidad y menos estimación que en otras, y por quanto por la misma razón les consta que en dicha herrería no se fabrica herraxe alguno, contemplar que en las lícitas ynteligencias de que usa en el surtimiento de pan, vino y carne
} 
Esta producción, 1.000 quintales/año, es la misma que, treinta años después, declara José Cornide2055; cantidad que destaca sobre la media de las ferrerías gallegas.

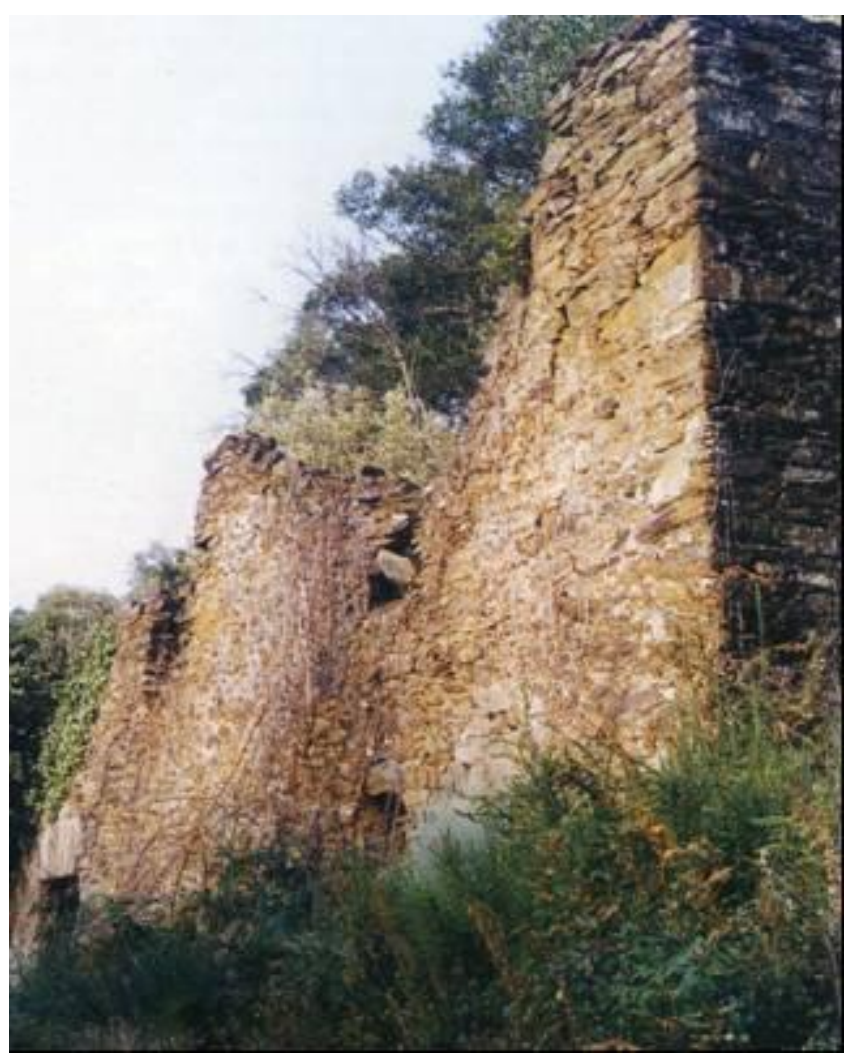

Ferrería de Lor

Según este autor, la ferrería era de don Pedro Ribadeneira, probablemente por cesión de doña $\mathrm{M}^{\mathrm{a}}$ Isabel Pardo de Deza, hija de don Joaquín Pardo Ribadeneira. Doña $M^{\mathrm{a}}$ Isabel había nacido en 1738; en 1753 ingresó en el monasterio benedictino de San Payo de Santiago de Compostela, en el que siguió gozando de sus rentas particulares, que según Colombás ascendían a 13.0oo reales de vellón, entre ellas, como ya veremos, la ferrería de Lor. En 1778 logró su secularización, después de un proceso eclesiástico en el que se anuló su profesión, alegando que había sido impelida por extraños a ingresar en el convento. Ese mismo año, por muerte sin sucesión de don Juan Francisco Suárez de Deza, se convirtió en la IX marquesa de Viance hasta su muerte,

para los oficiales de ella, le quedará a su dueño en cada un año el útil de mill y cien reales de vellón".

2055 CORNIDE: Ob. cit., ff. 225 
célibe, en $1797^{2056}$. Como tal marquesa fue propietaria de parte de las ferrerías de Valdomir, Lousadela y Ferreirós ${ }^{2057 .}$

Del año 1759 conocemos varias escrituras que mencionan a esta monja como propietaria de la ferrería de Lor, que la tenía arrendada a Marcos Díaz. Una de ellas, de 22 de julio, es un "reconocimiento y tasa del carbon, bena cocida y por cozer, escudos de ruedas, un gurrión, herraja de trauas, leñas de preuencion y un mango que todo se alla consistente en la herraria de Lor, cuios materiales son de Dn. Marcos Diaz arrendatario que acaua de ser de dicha herraria y los dexa por el prezio que se expresa a el real monasterio de San Payo de Ante Altares, y a Doña Maria Ysabel Pardo Suarez de Deza Monja del, dueña de dicha herraria y se entregan al Rmo.Padre Predicador Fr. Benito Pardo su vicario y confesor". Todo ello, según declaran los peritos encargados por ambas partes, importa 15.516 reales y 24 maravedís. Otra, de los días 23 y 24 de julio, es un nuevo reconocimiento y tasación, aún mucho más exhaustivo de la situación de la ferrería, sus partes, materiales, herramientas ${ }^{2058}$. Uno de los testigos es don Gregorio Pardo, residente en la feligresía de Saa, en la jurisidicción de la Puebla, quien por acuerdo con Fr. Benito Pardo, su hermano, se obliga a pagar a don Marcos Díaz la cantidad antes señalada de 15.516 reales y 24 maravedís 2059.

A la muerte de María Isabel Pardo, la ferrería no pasó a los marqueses de Viance, pues no pertenecía a ese vínculo y mayorazgo; por eso no se encuentra entre la documentación del marquesado. Debió seguir en manos de los Pardo Rivadeneira. En 1808 era dueño de la ferrería don Diego Antonio

\footnotetext{
2056 I. GARCÍA TATO (1999): Vilanova, Outarelo y San Francisco Blanco. Monografía histórica de una parroquia gallega. Instituto de Estudios Valdeorreses, $\mathrm{n}^{\circ}$ 30, p. 176 y ss.

2057 AHRG. R. A.: 25.291/28

2058 IBIDEM, p. 493-498

2059 IBIDEM, p. 598. Don Marcos Díaz pidió al P. Vicario que se le hiciese obligación por persona lega y abonada y ésta se la dió en la persona de "D. Gregorio Pardo y Guiza Vezino de la Casa de Mourillon en la Abbadia de Samos Dueño de la Jurisdiccion de Varrio y san Cosme, el qual estando presente Zierto y sabedor de lo que se auentura y haziendo de echo y deuda ajena suia propia dijo se obligaria y obligo con su persona y Vienes muebles y Raizes hauidos y por hauer de pagar por razon de lo que queda expresado al citado D. Marcos Diaz y Quien su poder huuiere los dichos quince mil quinientos y diez y seis reales y Veinte y quatro maravedís (...) y se da por entregado con el referido Padre Vicario de los expresados materiales". Este don Gregorio Pardo es hermano del tal padre Vicario. En la firma don Gregorio aparece con el apellido Pardo Ribadeneira, pero no hay otro así que todos los Gregorios han de ser el mismo, y por tanto ambos parientes de doña $\mathrm{M}^{\mathrm{a}}$ Isabel.
} 
Rivadeneira 2060, que la tenía bajo el cuidado de un administrador ${ }^{2061}$. Desconoco la relación de Juan Francisco Rivadeneira, que fue sobrino de doña $\mathrm{M}^{\mathrm{a}}$ Isabel Pardo, con esta ferrería de Lor, si es que tuvo alguna; pero sí sabemos que fue arrendatario durante muchos años de otras ferrerías y, desde los años veinte del siglo XIX propietario de la de Tejedo de Ancares.

Tanto Miñano como Madoz mencionan la ferrería de Barxa de Lor sin añadir otra cosa ${ }^{2062}$. Por el contrario no aparece citada en las revistas mineras desde los años cincuenta; probablemente dejó de trabajar hacia mediados del siglo XIX.

ESTADO: Aunque en ruinas, se conserva la vivienda y restos de la ferrería cubiertos de vegetación.

\section{FERRERÍA DE LOUREIRO}

LUGAR: San Pedro de Lamaiglesia

MUNICIPIO: Pobra de Brollón

RÍO: O Mazo

COORDENADAS: $42^{\circ} 33^{\prime} 28^{\prime \prime} \mathrm{N}$. y $7^{\circ} 18^{\prime} 15^{\prime \prime} \mathrm{W}$.

El Catastro de Ensenada y Madoz dicen que la ferrería de Loureiro se encontraba en la parroquia de San Pedro de Lamaiglesia. Cornide, por el contrario, la sitúa en San Pedro de Salcedo. La ferrería se hallaba en la carretera de Pobra de Brollón a Parada dos Montes, a la altura de Salcedo, a orillas de un arroyo afluente del Lor, llamado en los mapas como río do Mazo, y en Madoz como Loureiro ${ }^{2063 .}$

Para complicar aún más su situación, documentos del siglo XVIII mencionan un mazo del mismo nombre, pero en la feligresía de San Vicente de

\footnotetext{
2060 AHPLU: 2473/1 (1808).

${ }^{2061}$ AHPLU: 2468/4 (1809). Aparece en ese año de 1809 como administrador Pablo de Lago. 2062 Citado por C. GONZÁLEZ (1994): Ob. cit., p. 190

2063 P. MADOZ: Ob. cit., t. X, p. 48
} 
Villamor, que también se encuentra al lado ${ }^{2064}$. La solución nos la proporciona Madoz al precisar que "en el lugar de Loureiro hay una ferrería y un martinete, á cuyas máquinas da impulso un riachuelo que baja de Carballal y corre a unirse al Lor" ${ }^{2065}$. En otro sitio denomina a ese martinete con el nombre de Santiago ${ }^{2066 .}$

Había en Loureiro una ferrería en el siglo XVI, cuyo rendero era en 1582 Juan de Zuluaga ${ }^{2067}$ contra el que se querella don Diego del Valle, comendador de la Barra, porque este Juan de Zuluaga y Pedro de Armesto, rendero de la ferrería de Ferreirós, "de dos meses a esta parte poco más o menos se an entrometido por fuerça en su perjuicio a labrar y goçar la dicha errería" (de Valdomir) ${ }^{2068}$. No debía de ser el único vasco, pues un año antes, en 1581, en un pleito entre Juan Ormazábal, venaquero en el venero de Rocas, contra Juan Beltrán de Achega, rendero de Ferreirós y en 1576 en la de Gondriz, testifica un "Juan de Ybarreta vizcaino abitante en la ferraria de Loureiro" 2069 . Todo esto permite afirmar que esta ferrería, como otras de la zona, se debió levantar en el siglo XVI.

Diego de Zuluaga, hijo del anterior, aparece igualmente en 1587 como "vecino de la herraria de Loureiro, del condado de Lemos" quien recibe un poder de Pedro de Armesto y de Razti (creo que debe ser Irazti), rendero de Ferreirós, en tierra de Courel, para que lo defienda en la partición de la ferrería de Valdomir y sus anexos ${ }^{2070}$. A Juan de Zuluaga, como rendero de Loureiro y Valdomir, lo mencionan varios documentos de 1596. En uno de ellos se concierta con Domingo de Arechaga, "rendero que fue de la ferrería de Órreos", al que da "por mitad la parte y quiñón que le perteneze de la dicha su ferrería de Valdomill", aderezada con todo lo necesario, a cambio de la mitad del hierro

2064 I. GARCÍA TATO (1999): Ob. cit., p. 494. Entre los que hacen el reconocimiento y tasación de la ferrería de Lor, el 22 de julio de 1759, se encuentra Bernardo de San Martín "vecino del Mazo de Loureiro, Fra. de San Vicente de Villamor perito nombrado por el dicho D. Marcos".

2065 P. MADOZ : Ob. cit., t. X, p. 48

2066 P. MADOZ: Ob. cit., t. X, p. 392

${ }^{2067}$ AHPLU. 2408/2 (1612). Por un documento posterior, de 1612, sabemos que este Juan de Zuluaga estuvo casado con Catalina Díaz do Pineiro, hermana de Andrés Díaz do Pineiro; que tuvieron, al menos, dos hijos: Diego de Zuluaga y Lucía Díaz de Zuluaga, la que se casaría con Pero Martínez de Goicoechea, rendero de Lousadela.

2068 AHRG. R. A.: 2489/48

2069 AHRG. R. A.: 2837/19

${ }^{2070}$ AHRG. R. A.: 2489/48 
que labrare (que ha de ser por mitad delgado y grueso) durante tres años, que empezarán el día de Santiago de 1596²071; en otro arrienda a Bastián da Ribera, ferramentero vecino de Valdomir, "una fragua con sus barquines, yunques y más aderentes nezesarios que ella tiene en el dicho maçuco en la que al presente labra y travaxa el dicho Bastián da Ribeira” por diez ducados de renta ${ }^{2072}$; y por último, en otro Pedro Rodríguez, del mazo de Folgoso, se obliga a pagar 31 ducados por doce quintales y medio de hierro ${ }^{2073 .}$

Poco después sabemos que había muerto, pues una escritura de 1599 menciona a Andrés Díaz Piñeiro como "rendero de la ferrería de Loureiro, curador y tutor de los hijos que quedaron de Juan de Zuluaga rendero que fue de dicha ferrería” ${ }^{2074}$. Este Andrés Díaz Piñeiro (a veces do Pineiro) era tío de Juan de Zuluaga, en realidad Díaz de Zuluaga, de quien en 1610 se declara, además de rendero de la ferrería, "universal heredero que soy y finqué de Juan Díaz de Zuluaga mi sobrino defunto"2075. En ese mismo año sale sale como fiador de Pedro Díaz de Zuluaga, probablemente otro hijo de su sobrino ${ }^{2076}$.

Había, pues, una ferrería en el siglo XVI cuya propiedad nos es desconocida, pero que posiblemente fuera de la encomienda de la Barra y que la tuviera aforada, aunque aparezca como rendero, a Juan de Zuluaga, a quien sucedería en el foro alguno de sus hijos de quienes era tutor su tío Andrés Díaz ${ }^{2077}$, o probablemente los de éste; pues en 1616 se menciona a un Marco Díaz, hijo de Andrés ${ }^{2078}$, y en 1637 a Andrés Díaz de Noboa, con quien pleitea

${ }^{2071}$ AHPLU: 2407/9 (1596). A cargo de Juan de Zuloaga será "poner la dicha media ferreria adrezada y reparada de barquines, tubera, arboles y ruedas, mangos para el maço; y el dicho Domingo de Arechega a de poner y pagar los oficiales nezesarios de ferrería, como son aroza, tirador, dos fundidores ábiles y suficientes para el dicho oficio, y carbón nezesario de manera que por falta del no dexe de labrar la dicha ferrería, y asimismo a de tener y pagar tazador". Domingo ha de poner ese hierro en casa de Juan a precio de 19 rs. y medio/quinta.

2072 AHPLU: 2407/9 (1596)

2073 AHPLU. 2407/9 (1596)

2074 AHPLU. 2547/1 (1599)

2075 AHPLU: 2547/3 (1610). Andrés Díaz dice además que está casado con Isabel González Balboa y que su hijo, Alvaro Díaz de Balboa es estudiante y desea ser clérigo.

${ }^{2076}$ AHRG. R. A.: 9090/4

2077 AHPLU: 2408/2 (1612). En agosto de 1612 Martín de Guizaburuaga, rendero de la ferrería de Santalla, dice "que por quanto él mobio pleyto como zesonario de Diego de Zuluaga hijo y heredero que quedó de Juan de Zuluaga rendero que fue de la ferrería de Loureiro" contra unos ferramenteros por el mazo de Folgoso.

${ }^{2078}$ AHPLU: 2555/1 (1616). Se dice en esta escritura de obligación que su padre, Andrés Díaz de Pineiro había sido rendero "de la ferrería de Loureiro y arrendatario que fue de esta encomienda". 
don Diego de Prada, caballero de la orden de Santiago, por el tanteo de la ferrería de Lousadela. Al parecer, en 1604 esta última ferrería se la había aforado a aquél doña Jerónima de Villasur suegra de dicho don Diego; y ahora, en ese año de 1637 Andrés Díaz también subafora a Pedro Martínez Goicoechea, que era pariente suyo, la misma ferrería que éste tenía aforada a dicha señora ${ }^{2079}$.

Por el testamento de Pedro Díaz de Balboa, contador de los Estados del conde de Lemos y síndico del convento de madres descalzas de Monforte, del año 1682, nos enteramos de otros datos interesantes sobre la ferrería. Este Pedro Díaz, que ha logrado reunir un enorme patrimonio, resulta ser primo de Andrés Díaz de Noboa y que ambos poseen la ferrería de Loureiro. Con ese patrimonio aquél constituye un mayorazgo, en el que incluye "las siete partes de la herraria de Loureiro con sus montes, prados, guertas, sotos y lo demás della anejo y perteneciente como la solía llebar yo Don Pedro de Valboa y después por arriendo mio D. Francisco Valcarce mi cuñado, y la otra parte con lo a ella anexo y perteneciente toca a D. Mauro de Noboa y Cadórniga y a su hermana como hijos de D. Andrés Díaz de Noboa mi primo”"2080. Es decir, que estos Díaz de Balboa y Díaz de Noboa era los propietarios de esta ferrería, probablemente por herencia de Juan de Zuluaga o de Andrés Díaz do Pineiro que, como hemos dicho, la poseían seguramente por foro de la encomienda de la Barra.

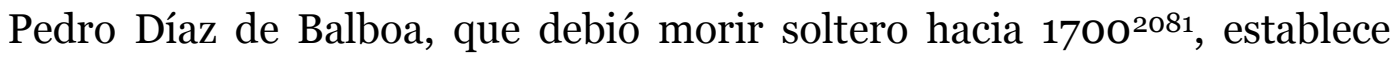
como cabeza de su mayorazgo a su sobrino Diego Antonio Valcarce ${ }^{2082}$, hijo del mencionado Francisco Valcarce, que como su padre regentó también la ferrería incluso en vida de su tío. Este Diego Antonio dejó como heredero a su primogénito Pedro Valcarce como dueño del mayorazgo y, por tanto, de la ferrería de Loureiro, que explotó directamente hasta $1723^{2083}$, en que al morir su

\footnotetext{
2079 AHRG. RA.: 19.816/8

2080 AHRG. R.A.: 14.119/58. Entre los bienes que dejó al morir hay mucha vajilla de plata con las armas de los Armestos, y alguna con la de los Somozas y Valcarce.

${ }^{2081}$ En 1699 Pedro Díaz de Balboa, que dice encontrarse muy enfermo, redacta un codicilo en que incluye su testamento de 1682, aunque sin modificarlo sustancialmente.

${ }_{2082}$ En 1704 aparece ya como propietario en un juicio por un peñasco de vena de Roques. A los testigos se les pregunta "si corrian vena a la Herreria del dicho D. Diego Balcarce", de quien recibían dinero por ser, añade el texto, persona poderosa (AHRG. R.A: 3176/59).

2083 AHRG. R.A.: 14.119/58. En el juicio entre los hermanos Pedro y Diego, en 1727, dice: "porque la herraria de Loureiro con todos sus vienes y rentas y casa de la Falangueira con sus
} 
primera esposa la cedió a su hermano Diego Ignacio Valcarce, comisario del Santo Oficio de la Inquisición del Reino de Galicia, a cambio de estudiar a sus dos hijos y dotar a sus tres hijas; pero por razones que desconocemos, en 1727, violentamente arrojó de la ferrería a su hermano y al presbítero que la administraba ${ }^{2084}$. Debía der hombre de armas tomar, ya que en 1722 trató de impedir por la fuerza, incluso con golpes a los operarios, que construían la ferrería de Lor, además de interponer una querella contra don Joaquín Pardo de Rivadeneira ${ }^{2085}$.

La ferrería pasó luego al hijo mayor de Pedro Valcarce, Francisco Valcarce, a quien menciona como propietario el Catastro de Ensenada en 1752, señalando que en la parroquia de Lamaigrexa hay una ferrería propia de don Francisco Valcarce, vecino de Monforte, a quien regulan que le dejará de utilidad al año siete mil reales de vellón ${ }^{2086}$. Por entonces también se menciona un martinete ${ }^{2087}$, probablemente el que luego Madoz denominará de Santiago. A finales de siglo, según Cornide su propietario era don Ramón Valcarce, que debe ser un hijo del anterior ${ }^{2088}$, que también aparece como tal en los primeros años del siglo XIX ${ }^{2089}$. Por esos años era administrador don Rosendo Francisco

pertenencias fue propio de D. Pedro Díaz Balboa quien de todo ello hizo vinculo y mayorazgo llamando por primer sucesor a D. Diego Antonio Balcarce y en segundo lugar a mi parte (D. Pedro Valcarce) como su hijo mayor que como tal ha recaydo por muerte de dicho su padre en el derecho de subcesion y en fuerça del lleuó, gozó y poseyó dicha casa y erraria con las Rentas (...) asta el año pasado de 1723 que de orden y permiso de mi parte pasó el querellante a correr con el manejo de dicha erraria".

${ }^{2084}$ AHRG. R.A.: 14.119/58. En julio de 1727 dice el procurador "que hallándose mi parte (don Diego Ignacio Valcarce) poseedor de la herraria de Loureiro con las rentas a ella anejas, como uno de los hijos que han quedado de D. Diego Antonio de Valcarce, como también en virtud de ajuste y zesión que de la parte que en ella hacía le hizo el dicho D. Pedro en octurbe del año pasado de veinte tres, $y$ con la condición de alimentarle mi parte cinco hijos que le quedaron del primer matrimonio, lo qual ha cumplido (...) (hasta) el día doce del presente mes el querellado de su propia autoridad se fue a dicha herraria, entró en ella y cogió las llaves que tenía el capellán, puesto por mi parte" (como administrador y los echó fuera ). Además le quitó 150 quintales de hierro, 18 arrobas de aceite, 100 cañadas de vino, los libros de acreedores, etc.; y añade que en lugar de vender el quintal de hierro a 60 y 66 reales, como se vendía, lo estaba haciendo a 50 reales.

${ }^{2085}$ AHRG. R.A.: 3020/42

${ }^{2086}$ CATASTRO DE ENSENADA. R. G.: Lamaigrexa.

2087 I. GARCÍA TATO (1999): Ob. cit. Entre los que hacen el reconocimiento y tasación de la ferrería de Lor, el 22 de julio de 1759, se encuentra Bernardo de San Martín "vecino del Mazo de Loureiro, Fra. de San Vicente de Villamor perito nombrado por el dicho D. Marcos".

2088 CORNIDE: ob. cit., ff. 225

${ }^{2089}$ AHPLU: 2473/1 (1807). "D. Ramón Valcarce, dueño de la herrería nombrada de Loureiro situada en términos de esta feligresía" (San Pedro de Lamaiglesia) se queja del reparto de tributos 
Sánchez, presbítero ${ }^{2090}$. En 1814 se menciona también como administrador a don Pedro González Valcarce ${ }^{2091}$, vecino de Vilela en la jurisdicción de Torés; y en 1818 como arrendatario a don Antonio Somoza y Pardo ${ }^{2092}$. En 1820 era su dueño don José María Valcarce con quien se concierta don Manuel A. Sánchez para "tomar en arrendamiento la fábrica de la Herrería nombrada de Loureiro"2093. Éste mismo propietario, en 1838, mantendrá un largo pleito con doña $\mathrm{M}^{\mathrm{a}}$ Josefa Monseo por el uso de la leña ${ }^{2094}$. Poco después la cita Madoz 2095. Hernández Sampelayo señala que funcionó hasta 1884, consumiendo vena de Roques ${ }^{2096}$.

No debía ser una ferrería muy pequeña a tenor de las cifras de producción que le atribuye Cornide, 550 quintales al año, pues no difieren mucho de las de las otras de la zona; pero sí es una ferrería que parece tener que buscar muy lejos el carbón. En un juicio del dueño de la ferrería de Valdomir, en 1724, contra vecinos de lugares del Caurel, se acusa a éstos de que el carbón que hacen en sus montes lo "conduzen a las herrerías de Loureiro, jurisdicción de la Puebla" y a otras ${ }^{2097}$; y en 1788 , en otro pleito por carbonear en montes del Caurel, el testigo Juan Rodríguez afirma "que no supo, bio ni oyo que del sitio llamado Barreiro se llebase carbon para la Erraria de Loureiro"2098.

Esta dificultad en el abastecimiento de carbón explica la oposición de don Pedro Valcarce, en 1722, a la construcción de una ferrería a orillas del Lor que lleva a cabo don Joaquín Pardo Rivadeneira 2099. Este mismo problema se suscitó en 1838, siendo dueño de la ferrería don José María Valcarce, que hubo de pleitear contra doña $\mathrm{M}^{\mathrm{a}}$ Josefa Monseo "por perturbar el uso $y$

\footnotetext{
2090 AHPLU: 2454/6 (1806). El 5 de octubre de 1806 éste afirma que "le están adeudando dibersos sujetos varias partidas de dinero $y$ en dibersas jurisdicciones procedidas de hierro, rejas y herrajes que le llebaron al fiado de las herrarias de Loureiro y Gurgueira, en tiempos en que las administró en clase de arriendos".

${ }^{2091}$ AHPLU: 2474/2 (1814)

2092 AHPLU: 2406/6 (1818)

2093 AHPLU: 2474/9 (1820)

2094 AHPLU: 2377/3 (1838)

2095 MADOZ: Ob. cit., t. X, p. 392

${ }^{2096}$ P. HERNÁNDEZ SAMPELAYO: (1935): Ob. cit., t. III, p. 88

2097 AHRG. R. A.: 15167/24

${ }^{2098}$ AHRG. R. A.: 9090/4

2099 AHRG. R. A.: 3020/42. Pone una querella contra don Joaquín Pardo y "contra los maestros que trabajan y fabrican en la herreria en el río Lor cerca de la de mi parte por los agrauios que a unos y a otros hacia dicha herreria así en las tierras como en los sotos".
} 
aprovechamiento del carvón de la sierra de Paramedela (Puebla de Brollón), con el que por medio de operarios se ha surtido privatibamente y deve surtir la su citada Herraria vieja de Loureiro en fuerza de los diversos foros y más documentos justificatibos que acreditan el lexítimo derecho que asiste al constituyente" 2100

ESTADO: Solo quedan restos de la vivienda, en bastante mal estado, la capilla y un molino.

\section{MUNICIPIO DE QUIROGA}

\section{FERRERÍA DE GORGUEIRA}

LUGAR: Paradaseca

MUNICIPIO: Quiroga

RÍO: Soldón

COORDENADAS: $42^{\circ} 27^{\prime} 29^{\prime \prime}$ N. y $7^{\circ} 12^{\prime} 25^{\prime \prime}$ W.

Por la N-120, varios kilómetros antes de Quiroga viniendo de Valdeorras, justo cuando el Soldón desagua en el Sil, hay una desviación que sigue el curso de este río hasta Paradaseca. Poco antes de entrar en el pueblo, a la altura de un letrero que pone "vedado de pesca", un camino a la derecha conduce a los restos de lo que fue la ferrería de Gorgueira.

Debe de ser una ferrería de la segunda mitad del siglo XVIII, pues no la menciona el Catastro de Ensenada, pero sí la nombra Cornide Saavedra, cuya propiedad atribuye a Juan Quiroga, de Reda, dándole una producción anual de 600 quintales de hierro²101, muy semejante a la de la mayoría de las ferrerías de la zona. 
Efectivamente así era, pues en el largo pleito que por el uso del mineral de Formigueiros se suscitó a finales del siglo XVIII entre don José María de Tineo, propietario de las ferrerías de Bueyes y Valcarce, contra otros propietarios de ferrerías aparece como dueño de ésta don Juan José Quiroga Losada Noguerol, señor de la jurisdicción de Reda y vecino de la granja de San Martín de Abajo (en la encomienda de Quiroga) ${ }^{2102}$. En 1797 dice éste "que él y sus antecesores, en los vínculos y mayorazgos que poseen, son propietarios de la Herrería de Gorgueira, y que para la fábrica de hierro están en posesión de usar libremente la vena de Formigueiros por foro del conde de Maceda", como otros muchos propietarios "cada uno en la parte que más le acomoda"2103. En 1791, durante el pleito, la ferrería estaba arrendada a don Francisco Facundo de los Santos González y Polanco 2104 y posteriormente lo estuvo a don Rosendo Francisco Sánchez Losada, presbítero ${ }^{2105}$. Munárriz la incluye entre las diez gallegas que consumían mineral de Formigueiros ${ }^{2106}$, y así era. Pagaba 300 reales al marqués de Santa María del Villar por dicho foro de la vena ${ }^{2107 .}$

De don Juan José, la ferrería pasó a comienzos del siglo XIX a su nieto, don Antonio $M^{a}$ Vázquez Quiroga ${ }^{2108}$, a quien sucedió posteriormente su hijo don Manuel María Vázquez Queipo, como vemos en el foro de la vena, hacia 18502109. Sin embargo durante algunos años debió disfrutar de sus rentas su hermano menor don Vicente María, mientras no lograra otras iguales o mayores

\footnotetext{
${ }^{2102}$ AHN. Estado: leg. 1739, $\mathrm{n}^{\circ} 16$ 2103 AHPLU: 2555/2 (1797).

2104 AHN. Estado: leg. 1739, ${ }^{\circ} 16$

2105 AHPLU: 2454/6 (1806). El 5 de octubre de 1806 éste afirma que "le están adeudando dibersos sujetos varias partidas de dinero y en dibersas jurisdicciones procedidas de hierro, rejas y herrajes que le llebaron al fiado de las herrarias de Loureiro y Gurgueira, en tiempos en que las administró en clase de arriendos".

${ }_{2106}$ J. A. BALBOA (1992): Ob. cit., p. 135

${ }^{2107}$ I. GARCÍA TATO (2000): "Las ferrerías de Río Cabo y Pombriego en el siglo XIX". Rev. Bierzo, p. 167.

${ }^{2108}$ AHPLU. 2468/2. Hay varias escrituras de los años 1811 y 1813 en que aparece éste como dueño, realizando compras de tierras o arrendando algún ferrado de tierra. En 1829 (AHPLU: 2398/2) dice "que como suia propia de sus vínculos y Maiorazgos es la Herrería titulada de Gorgueira situada en los términos de la feligresía de Santa Eulalia de Bendollo que trabaja en la misma jurisdicción con el agua del río del mismo nombre, en la fábrica de yerro, y teniendo como tiene una gran porción de quintales de éste afinado en la citada Herrería detenido y paralizada su venta, a fin de detenerla y poner en xiro su caudal, dispuso transportarlo con su propia recua a la ciudad de Astorga y como D. Patricio Alonso vecino de ella sea un sujeto que merece la confianza", le da poder para que pueda venderlo, ese y el que lleven otros conductores a los precios más ventajosos.

2109 I. GARCÍA TATO (2000): Ob. cit., p. 167
} 
de las que vivir en Madrid con el decoro exigido a su clase ${ }^{2110}$. Don Manuel María, conde de Torres Novaes y suegro de don José Alonso Quiroga, propietario de la ferrería orensana de A Pontenova, llevó hierro de esta ferrería de Gorgueira a la exposición gallega de 1858, celebrada en Santiago de Compostela211. También la cita Madoz diciendo que el agua del Soldón " $d a$ impulso a una fábrica de hierro llamada Gorgueira" sita en el término de Santa Eulalia de Bendollo, feligresía en la que se incluye el lugar de Paradaseca ${ }^{2112}$

Debió trabajar hasta finales de siglo. Hernández Sampelayo dice que las forjas de Gorgueira, del término de Quiroga, y otras "estuvieron, como el año anterior -es decir, 1873- paradas por falta de combustible" en $1874^{2113}$

ESTADO: Solo se conserva la vivienda, ahora abandonada, en medio de una lujuriante vegetación que a penas permite descubrirla; pero no hay restos de la ferrería, que se encontraba algo más abajo, al lado del río.

\title{
3O. FERRERÍA DE OUTEIRO
}

\author{
LUGAR: Outeiro (Parroquia de la Seara) \\ MUNICIPIO: Quiroga \\ RÍO: Soldón \\ COORDENADAS: $42^{\circ} 31^{\prime} 25^{\prime \prime}$ N. y $7^{\circ} 77^{\prime}$ ” W.
}

Se encuentra en la carretera de Quiroga a Hórreos, en el lugar de Outeiro, a orillas del río Soldón, justo a la altura del puente que cruza el río para tomar el camino de la ferrería de Soldón.

\footnotetext{
2110 AHPLU: 2406/23 (1836). El 25 de junio de 1836 don Antonio María Vázquez, "con la anuencia de su hijo primogénito D. Manuel María” cede a su otro hijo Vicente María, oficial primero de la sección de Instrucción Pública en el Ministerio de la Gobernación del Reino, mientras no tenga otras de igual o mayor cuantía, las rentas de la granja de Cabanelas, en Orense, y las de "la fábrica de hierro de Gorgueira sita en este partido de Quiroga", cuyo líquido supera los 12.000 reales. Le hace esta gracia porque está muy cara la vida en la corte y lo que gana no le permite vivir con el decoro correspondiente a su clase.

${ }^{2111}$ C. GONZÁLEZ (1994): Ob. cit., p. 198.

2112 P. MADOZ: Ob. cit., t. IV, p. 201

${ }^{2113}$ P. HERNÁNDEZ SAMPELAYO (1935): Ob. cit., t. III, fasc. $1^{\circ}$, p. 40.
} 
La ferrería de Outeiro la construyeron los hermanos José y Francisco Pérez, primero como un mazo, que más tarde transformaron en ferrería, como recuerdan sus hijos en 1846: "que halládose (los hermanos) matrimoniados y en una misma compañía construyeron un mazo o martinete de hacer rejas, batideras y otras herramientas en dicho lugar de Otero. Posteriormente, aunque separados y bajo la misma compañía, lo elebaron a Herrería de fundir y labrar fierro" 2114 .

La ferrería debió de construirse hacia 1825, pues en 1824 José Pérez, que entonces era arrendatario de la ferrería de Soldón, firmó un contrato de foro con la condesa de Maceda, doña Ramona Escolástica Pardo de Figueroa, por el que podía extraer vena de Formigueiros, pagando una renta de 400 reales ${ }^{2115}$. Clodio González supone que este contrato de foro era para la ferrería de Soldón, aunque lo dudo; pues dichos contratos los hacen los dueños de las ferrerías al construirlas, y esta de Soldón, de tanta antigüedad, lo tendría firmado en fecha muy anterior. Como veremos en el párrafo siguiente, esos 400 reales es lo que debe pagar de foro don Ignacio Fariñas como arrendatario de la ferrería, como se menciona en un documento posterior. En 1826 el dueño de la ferrería de Soldón, José Quiroga y Quindós, pleitea con los vecinos de Outeiro por vender carbón a la "Herrería que en el lugar de Outeiro tiene Josef Pérez" 2116 . Lo que quiere decir que ya estaba en funcionamiento.

Así seguía en 1835 cuando los hijos de José Pérez arriendan a su cuñado Ignacio Fariñas "la Herrería consistente en el pueblo de Outeyro que se halla pro indiviso entre todos los hijos de José Pérez", por espacio de dos años (desde 12 de diciembre de 1834 hasta el 12 de diciembre de 1836) y renta de dos mil reales, descontados ya los que le tocan por su mujer. $\mathrm{Y}$ "además ha de pagar en cada uno de dichos años 400 reales que por razón de venera se pagan a la

\footnotetext{
2114 AHPL. PN.: caja 3581 (1846).

2115 C. GONZÁLEZ (1994): Ob.cit. p. 209.

${ }^{2116}$ AHRG. R. A.: 7451/13. En 1828 acuerdan, por sentencia favorable a Soldón, no venderle carbón a la ferrería de Outeiro, que incumplen en 1829 por lo que habrá nuevo pleito.
} 
Excma. Sra. Condesa de Maceda", así como 30 quintales y cien reales de la renta que corresponden a los herederos de Francisco Pérez ${ }^{2117}$.

Sin embargo poco después debieron surgir problemas entre las dos familias, pues en 1837 los herederos de José Pérez, que fue administrador de la ferrería, dan su poder a Antonio Fariñas, administrador actual de la ferrería, porque los herederos de Francisco Pérez -una hija de éste, María, estaba casada con Benito del Valle, dueño de la ferrería de Valincarro- reclamaban "treinta quintales de fierro y cien reales en dynero que injustamente intentan reclamar cada un año de renta a los representados de los constituyentes por la Herrería sita en el precitado pueblo de Outeiro, siguiéndoles en el caso de haceder al pago de tan ilesa reclamación gravísimo perjuicio" ${ }^{2118}$. No sé si llegaron al juicio, pero en 1846 los herederos de ambos hermanos pactaban repartirse la ferrería. Dado que Lucía López, esposa de Francisco Pérez, no había aportado su dote a la compañía, a sus hijos le correspondían solo 3/7 de la ferrería. Por estas tres partes recibirían anualmente 4 quintales y medio de hierro ya acondicionado para su venta, más 40 reales en dinero. Los arreglos de la fábrica, como el árbol del mazo, etc. se repartirían en la misma proporción ${ }^{2119}$.

Poco después, hacia la década del cincuenta, la ferrería aparece en manos de don Juan José Vila, que era marido de Ramona Pérez, hija de José Pérez, y pagaba los 400 reales por el foro de la vena de Formigueiros ${ }^{2120}$. Debió continuar algunos años más, probablemente hasta los setenta, aunque en 1874 ya no la mencionan las revistas mineras ${ }^{2121}$.

ESTADO: Se conserva en muy buen estado, incluso habitada la vivienda.

\footnotetext{
${ }^{2117}$ AHPL. PN.: caja 3579 (1835). Además don Ignacio Fariñas debe hacerse cargo de todos los descalabros de la ferrería y al final del contrato dejar las existencias de vena y carbón que ahora le entregan o su valor, que se cifra en 10.452 reales.

2118 AHPLU: 2377/3

2119 AHPL. PN.: caja 3581 (1846).

${ }^{2120}$ GARCÍA TATO, I (2000): Ob. cit., p. 168. Pero una parte seguía siendo de la familia de Francisco Pérez, pues en el testamento de su mujer Lucía López, hecho en julio de 1860, deja a uno de sus cuatro hijos, Domingo, que vive con ella, además de la casa "quintal y medio de fierro del que me corresponde de la renta de Herrería" (AHPLU: 2528/11).

${ }^{2121}$ P. HERNÁNDEZ SAMPELAYO (1935): Ob. cit., t. III, fasc. $1^{\circ}$ p. 36 a 38.
} 


\section{FERRERÍA DE PALEIRAS}

LUGAR: Pacios da Serra

MUNICIPIO: Quiroga

RÍO: Pacios

COORDENADAS: $42^{\circ} 32^{\prime} 37^{\prime \prime}$ N. y $7^{\circ} 9^{\prime} 31^{\prime \prime} \mathrm{W}$.

En la carretera de Quiroga a Hórreos, desviación a Vilarbacú a la altura de la Cruz de Óutara. De Vilarbacú hay una pista que llega a Pacios da Serra, en la que se encontraba la ferrería, a casi un kilómetro de distancia, a orillas de un arroyo afluente del río Quiroga, de nombre Pacios.

La ferrería de Paleiras la construyó en el siglo XVI el vasco Martín de Aldoncín o Aldunzín"2122, en territorio propio de la Encomienda de la Barra: "que bien sabe cómo por el Rey nuestro señor me fue dado en fuero los montes, Aguas y pastos para la mi Erraria de las Paleras, que yo edifiqué de nuebo en término de dicha Encomienda" ${ }^{2123}$, fuero por el que paga una renta anual de 4.000 maravedís. A su vez este Martín de Aldoncín debía tenerla arrendada, pues en 1567 Beltrán de Celaya, "rendero de la ferrería de Paleras" acuerda con unos arrieros que le traigan de la venera de Formigueiros 300 quintales de vena de hierro, de 133 libras cada quintal, a precio de real y medio el quintal2124.

Martín Aldoncín, cansado de tantos años de vivir lejos de su país natal expresa en 1587 que "yo quiero hirme para mi tierra y disponer y bender la dicha Herreria con todo lo a ella anexo", y que además ya "tienen tratado y me da por ella Francisco Vázquez, vecino de la Encomienda de Quiroga, dos mil ducados". Pero dado que la encomienda, de acuerdo con una de las condiciones del fuero, tiene derecho de tanteo, y como "no la pudiere bender ni enagenar sin licencia de dicho comendador", solicita esa licencia. Juan López Pico, factor del comendador de la Barra, dice "que no tiene dinero de la dicha Encomienda

\footnotetext{
${ }^{2122}$ Este Aldoncín es el mismo apellido de Miguel Aldunzín, rendero de la ferrería de Bueyes y también de la del Puente de Quiroga, que está presentes en la toma de posesión de la ferrería de Quintá, en 1566. Esta ferrería del Puente de Quiroga es una ferrería nueva o es la de Paleiras. ${ }^{2123}$ AHRG. Hombreiro: leg. 19

2124 AHPL. PN.: caja 1487
} 
para la compra de la Erraria, ni la Encomienda tiene necesidad de ella", por lo que accede a la venta, pero en las mismas condiciones y tiempo por el que está aforada ${ }^{2125}$.

El 9 de junio de 1587, en Villafranca del Bierzo, se realiza el contrato de venta a Franscisco Vázquez, dueño de la ferrería de Quiroga: “otorgo e conozco que por esta presente carta que bendo, cedo y traspaso e doy en venta Real por juro de heredad para agora y para siempre jamás a vos Francisco Vázquez de Quiroga, vecino de la Encomienda de Quiroga, para vos y para vuestros hijos, herederos (...) la mi Herraria de las Paleiras sita en dicha Encomienda de la Barra con todas sus casas nuebas e viejas, molinos, heredades (...) con más los montes, pastos y Aguas". Se lo vende todo, con la pensión anual de $4.000 \mathrm{mrs}$. a la encomienda de la Barra, en 2.000 ducados que "suman y montan 750.000 maravedis" de los cuales “me distes y pagastes luego 150.000 mrs. que son 400 ducados, recibiéndoles en quenta y pago de otros 400 ducados que os debía y me alcanzaste de todo el tiempo y año que yo e mi ermano y mi padre difuntos trujimos en arrendamiento e gozamos de buestra herraria de Quiroga". Le da además cuatro años de plazo para pagar los 1.600 ducados restantes ${ }^{2126}$.

Poco después, Francisco Vázquez, al igual que con la ferrería de Quiroga, debió arrendar la de Paleiras; pues al menos en los años de 1592 al 1596 la tuvieron Juanes de Lesaca y Picabea y su mujer Graciana de Galarza. En 1596, don Alvaro de Quiroga y Somoza "cuya es la dicha ferrería”, hijo legítimo y heredero de Francisco Vázquez, vecino de Villafranca del Bierzo, puso pleito a Graciana de Galarza, "rendera de la dicha ferrería", ya viuda, ante la justicia de la tierra de Caurel "en virtud de una escriptura de arrendamiento de dicha ferrería por precio y quantía de dos mill reales". El 11 de octubre acuerdan, por el bien de ambos, que se haga revista de la ferrería, de las obras y descalabros, y que descontados cincuenta ducados por ellas, le pague Graciana en lo que resulte alcanzada ${ }^{2127}$.

${ }^{2125}$ AHRG. Hombreiro: leg. 19 ${ }^{2126}$ AHRG. Hombreiro: leg. 19

${ }^{2127}$ AHPLU: 2407/9 (1596) 
Ésta no debía de tener tanto dinero para saldar dicha deuda, por lo que el 17 de octubre prosigue la querella en la que varios testigos afirman que dicha Graciana se quiere ir de la ferrería a su tierra de Vizcaya, de donde era natural, pero que tiene muchos acreedores a los bienes que dejó su marido, que son de sus hijos menores, de los que es tutora. El juez en auto de 19 de octubre manda secuestrar los bienes de Graciana, entre los que se nombran el arriendo de la ferrería, algunas herramientas, ochenta cabras, cinco mulas, y otros bienes de domésticos. Como no es suficiente para pagar a sus muchos acreedores, el 21 de octubre se concierta con su cuñado Agustín de Yriarte, casado con su hermana Catalina Galarza, en el siguiente modo: les deja el arriendo de la ferrería, los bienes citados, las deudas que con ella y su marido tienen algunas personas en Galicia y en Castilla, a cambio de que ellos, a su vez, se hagan cargo de toda sus deudas ${ }^{2128}$.

El mencionado Alvaro de Quiroga compró en 1597 en 15 ducados a Juan de Vergara una casa aneja, en terreno propio de la ferrería, para así ampliar el espacio de ésta ${ }^{2129}$. En 1605 el mismo Alvaro de Quiroga le arrendó a Lorenzo de Alça ${ }^{2130}$, rendero de su ferrería de Quiroga, la de Paleras, por ocho años y 150 ducados de renta anual, más los 4.000 mrs. de pensión a la Encomienda ${ }^{2131}$. Entre las condiciones, como siempre, la de ir en aumento y dejarla corriente y moliente al final del arriendo. Pero no parece que fuera así como la dejaron los

\footnotetext{
${ }^{2128}$ AHPLU: 2407/9 (1596). Siguen varias escrituras de obligación de Agustín de Iriarte con algunos acreedores. Así el 22 de octubre, con "Don Antonio de Noboa y Lemos, cuyas son las beneiras de Formigueiros" con el que se obliga a pagarle 36 ducados "los quales son por razón de la vena que truxo Graciana de Galarze rendera de la dicha ferrería mi cuñada para la ferrería de las Paleras este presente año"; otra con don Alvaro de Quiroga y Somoza, dueño de la ferrería, "por la renta que le deuia de dicha ferrería conforme a la escritura de arrendamiento que en su favor y del dicho su marido otorgó por ante Juan de Armada, escribano de la tierra de Quiroga", de los años 92, 93, 94, 95 y 96, que asciende, por resto de cuentas, a 112 ducados y 5 reales, pues todo lo demás se lo da por pagado "por lo reparos y adreços que se gozó este berano... en la presa y banzado de la dicha ferrería”.

${ }^{2129}$ AHRG. Hombreiro: leg. 19: Juan de Vergara le vende "su casa de morada, que hizo ha y tiene junto a la dicha Ferraria de Paleras de la otra parte de la puente della con sus cámaras (...) porque el sitio y territorio de la dicha casa pertenece al dicho D. Albaro por ser del sitio de la dicha Herraria".

${ }^{2130}$ En 1586 hay un Lorenzo de Alça (Alza) rendero, con Miguel Alduncín, de la ferrería de Bueyes

${ }^{2131}$ AHRG. Hombreiro: leg. 19: Don Alvaro de Quiroga acuerda con Lorenzo Alza "de os arrendar la otra mi Herraria de Paleras que está en la jurisdición de Tierra de Courel moliente y corriente con sus casas y bodegas, cortes y corrales, erramientas, yunques $y$ banzado y aguas molientes y corrientes". Ferrería continúa que "por mi suele andar arrendada", y en las condiciones típicas de estos arriendos, respecto a los escalabros mayores y a dejarla corriente y moliente al final del arriendo.
} 
Alza. A Lorenzo de Alza sucedió en el arriendo de ambos ferrerías su hijo Miguel de Alza, del que en 1625 se dice que respecto a la de Paleiras la ha abandonado, "causa que al presente está damnificada y en ella no se puede trabajar y la casa de la dicha ferraria aunque es palacio principal le faltan muchas cosas de su gobierno" ${ }^{2132}$.

Álvaro de Quiroga se casó en primeras nupcias con Isabel de Sarmiento Solís con la que tuvo dos hijos: Francisco y Ana. El primero debió heredar las ferrerías de Quiroga y Paleiras, mientras que Ana recibía el tercio y quinto de la herencia. Así, en marzo de 1625 este Francisco de Quiroga Rivadeneira aparece como dueño de las ferrerías de Quiroga y Paleiras, y como tal propietario arrienda a Antonio da Chega, vecino de Ferreirós, y a Simón de Obide y Losada, aroza de ferrerías, la de Paleiras con sus montes, aguas, veneras y "con el derecho que tienen a que ninguno pueda cortar ni talar en el monte y dehesa que se dicen dos Pijos termino del lugar de Pacios anexo y perteneciente a dicha ferraria". Se la arrienda por cuatro años con la condición "primera $y$ principal que los dichos Antonio dachega y Simon de Obide sean tenidos y obligados a reparar, a aderezar y reidificar la dicha ferraria de Paleras, casa y palacio". Pasados esos cuatro años, en los que solo pagarán los $4.000 \mathrm{mrs}$. de pensión a la encomienda, se la vuelve a arrendar por otros cuatro años más y con la renta de 200 ducados anuales ${ }^{213}$. En 1640 Francisco moría sin hijos por lo que la herencia, en parte, pasó a su hermana Ana de Quiroga Rivadeneira casada con Sancho de Neira, con las ferrerías de Quiroga y Paleiras.

Sin embargo, poco después la ferrería de Paleiras pasaba a la familia Valcarce. La razón, creo, se debe al segundo matrimonio de Álvaro Vázquez de Quiroga con Ana Valcarce con la que tuvo, al menos, tres hijos: María, Marina y Diego Valcarce, que también recibieron parte de la herencia de aquél. Posteriormente estos Valcarce o Quiroga Valcarce en 1660 pleitearon con Sancho de Neyra por la tercera parte del coto de Fisteus ${ }^{2134}$, donde se situaba la ferrería de Quiroga. Creo que al final hubo un acuerdo por el que los Neira se quedaron con la ferrería de Quintá y los Valcarce con la de Paleiras. Por esta

${ }^{2132}$ AHRG. Hombreiro: leg. 19. 2133 AHRG. Hombreiro: leg. 19.

2134 AHRG. R. A.: 10.862/59 
razón en 1666 aparece como propietario don Gonzalo de Quiroga Valcarce, dueño del coto de Chan de Pena, a quien el ejecutor de la Real Chancillería de Valladolid presenta una ejecutaria de don Gaspar de Quiroga, caballero de Santiago, para que le pague 1.200 ducados "de perfectos en la erraria de Paleyras”. Este último parece un pariente además de su arrendatario. Aquél alega que él ya hizo "mil y quinientos ducados mas de perfectos en ella, utiles necesarios y permanentes, los quales justificó ante dicho executor pidiendole yçiese pago dellos juntamente con los dichos mill y ducientos que se le mandan pagar”. Exigió que se tasaran de nuevo los perfectos hechos por él ahora y antes "debiendo solamente cargar a mi parte los frutos que pudiera rentar dicha erraria antes de los perfectos no lo yço sino cargárselos a todo lo que pudo rentar después de los perfectos" 2135.

A finales de siglo, en el juicio por la construcción de la ferrería de Quintá, un testigo dice en 1692 que en el valle de Quiroga hay dos ferrería: la del convento de Samos (la de Quiroga o Rodela) "y la de Paleiras de D. Joseph de Quiroga vecino de Villar de Varrios" ${ }^{2136}$, que probablemente es un Quiroga Valcarce; pues es la primera mitad del siglo XVIII2137 la ferrería vuelve a estar en manos, primero de don Gaspar Valcarce y Quiroga ${ }^{2138}$ y posteriormente, según el Catastro de Ensenada, de don Diego Valcarce, de Valdeorras ${ }^{2139}$. Efectivamente en 1746 don Diego Valcarce Quiroga, como propietario arrienda "la herraria nombrada de Paleiras moliente y corriente y apertrechada de todo lo necesario" a don Diego Manuel de Quiroga y Losada por espacio de seis años y 5.00o reales de renta anual, más pagar las pensiones que debían de ser otros 1.00o reales, pues en otros documentos aparece como renta 6.000 reales. Pasados esos seis años, en 1752, se la vuelve a arrendar por otros seis años y

2135 AHRG. R. A.: $13.272 / 28$

${ }^{2136}$ AHRG. R. A.: 1.662/4. El Villar de los Barrios debe de ser la villa al lado de Ponferrada.

2137 AHN. Estado: leg. 1739, n ${ }^{\circ}$ 16. En 1722, en una relación que hace que hace don Froilán de Sobrado como administrador del conde de Maceda de las ferrerías que se abastecen de Formigueiros, se menciona la de Paleiras "que rige Miguel de Losada, vecino del dicho hospital de Quiroga”, pero no sabemos si es como dueño o como administrador.

2138 AHN. Clero: Libro 6495. Escritura de venta hecha al monasterio de Samos por don Gaspar Valcarce y Quiroga, dueño de la ferrería de Paleiras, de diferentes bienes y propiedades en la encomienda de Quiroga por 8.956 reales.

2139 CATASTRO DE ENSENADA. R. G.: Pacios: "Una ferrería al sitio Paleiras propia de don Diego Valcarce, vecino de Valdeorras a la que se regula de utilidad por seis meses y medio que trabaja al año por ser probre de agua en tres mill y quinientos rs. de vn. yncluyendo en esta regulación el producto de los montes de uz para carbón que el dueño de esta Ferrería tiene en la precitada feligresía como requisito preciso para esta fábrica”. 
otros 6.000 reales de renta ${ }^{2140}$. En ambos casos aparece como condición "que los escalabros mayores y menores habían de ser de quenta de dicho D. Diego Manuel Quiroga"2141.

En 1761 doña Angela Francisca de Neira Quiroga, viuda de don Diego Valcarce, se querella contra don Alvaro Manuel Quiroga, que puede ser el mismo del arriendo o su hijo, por no haberle pagado 18.000 reales, que son por tres años de renta. Éste alega, por su parte, que no le debe nada sino que, por el contrario, era ella la que le debía a él por los muchos gastos ocasionados por el arreglo de la ferrería, tanto en el primer arriendo -en que hubo de reparar los barquines, ${ }^{2142}$ ruedas, árboles mayores y cepos, etc-, como en el segundo, en el que una avenida en el año 1755 se había llevado el banzado y una pared de la ferrería; por lo que había un descargo de 5.00o reales gastados en "reedificar la estolda, banzado y pared principal de la Herrarias que se auia arruinado con la abendia en el año de cinquenta y cinco" ${ }^{2143 . ~ E l ~ p l e i t o ~ c o n t i n u o ́ ~ p o r q u e ~ s e g u ́ n ~}$ su propietaria en 1764 los arriendos se habían hecho "libres de toda carga", y que los escalabros mayores y menores "auian de ser de quenta de don Diego Manuel Quiroga"2144.

En 1791 la ferrería aparece como propia de doña Angela de Neira y Valcarce, vecina de la Vega del Cabo (Valdeorras) y como arrendatario don Juan Rafael Valcarce; pero ese mismo año la toma en arriendo don Manuel Sánchez, de Santa Marina de Folgoso, quien "para su surtido y manejo, por hallarse necesitado de algunos dineros", pide un préstamo de 20.000 reales al ponferradino don Francisco de Castro y Delgado, rendero de la ferrería de Arnado, que le devolverá en dos años y en los que le pagará "tres rs. vn por cada quintal de hierro que produzca y se fabrique en dicha fábrica" ${ }^{145}$, préstamo que le concede. Entre este Manuel Sánchez y su hijo Manuel Antonio Sánchez

\footnotetext{
2140 AHRG. R.A.: 14.147/12

${ }^{2141}$ IBIDEM

${ }^{2142}$ Sólo la composición del barquín por declaración del maestro "ymporta mill seiscientos y tantos reales" (IBIDEM).

2143 AHRG. R. A.: $14.147 / 12$

2144 IBIDEM

${ }^{2145}$ AHPLU. 2417/11 (1791)
} 
tendrán en arriendo la ferrería hasta $1820^{2146}$; también arrendarán, algunos años, las de Arnado y Loureiro, lo que les permitirá hacer un buen capital ${ }^{2147}$.

Según Cornide producía una media de 700 quintales de hierro anuales ${ }^{2148}$, con vena de Formigueiros ${ }^{2149}$, por la que pagaba de foro 400 rs. al año ${ }^{2150}$. A comienzos del siglo XIX, el propietario es ahora el mencionado anteriormente como arrendatario Juan Rafael Vázquez y Quiroga, y luego su mujer doña Teresa Gil Santiso, que tuvieron como administradores a los mencionados Manuel Sánchez y su hijo Manuel Antonio Sánchez ${ }^{2151}$. En 1824 era arrendatario Juan Fernández ${ }^{2152}$. Hacia la mitad del siglo XIX, su propietario era don José $M^{a}$ Pardo San Cibrián ${ }^{2153}$. En 1837, el presbítero don Manuel Domínguez, como administrador de la ferrería, adquiere varios prados ${ }^{2154}$. Don José $M^{a}$ Pardo San Cibrián pleitea en 1838 con don Antonio Rivadeneira porque intenta construir una ferrería en Villarbacú “inmediata a la Herrería de Paleiras", la cual "iba a arruinar todas las demás herrerías sitas en aquellas inmediaciones

\footnotetext{
2146 Algunos ejemplos: AHPLU 2454/3 (1804): Deuda de maravedís a Manuel Sánchez "residente y administrador de la herrería de Paleiras procedidos de hierro que llebó al fiado"; AHPLU: 2455/2 (1809): Manuel A. Sánchez afirma que la señora doña Teresa Gil y Santiso, viuda de D. Juan Rafael Vázquez y Quiroga, como tutora de su hija, en 8 de junio de 1809 le arrendó la ferrería de Paleiras por espacio de cinco años (hasta 1814) en la cantidad de 22.000 reales al año; AHPLU: 2474/7 (1818): Don Manuel A. Sánchez, administrador de la casa y herreria de Paleiras, es ejecutado por deudas de la ferrería de Soldón; AHPLU: 2474/9 (1820): En la herrería de Paleiras, poder de don Manuel A. Sánchez por no poder desplazarse a Monforte, para arrendar la ferrería de Loureiro; etc.

${ }_{2147}$ Muchas escrituras, que no puedo relacionar aquí, lo demuestran. Dos a título de ejemplo: AHPLU: 2474/7 (1818): Don Manuel A. Sánchez, administrador de Paleiras, dice que don Froilán Troche, apoderado general de don José Quiroga, dueño de la ferrería de Soldón, tiene pedido ejecución por la Audiencia como principal deudor en la cantidad de 44.615 reales ampliada en 41.000 reales más que vencen en diciembre y se quieren ejecutar sobre los bienes que posee en Santa María de Folgoso y en ganados, etc.; AHPLU: 2398/5 (1826): Poder de don Manuel A. Sánchez para poder cobrar deudas, pues "habiendo sido antes de haora administrador y arrendatario de las Herrerías de Paleyras y Soldón de la Seara dio al fiado y a varias personas tanto de este pais, del de Monte Rey, Caldelas y Maragatos del Reyno de León que comerciaban en aquellas diversas partidas asi de frutos y dinero como muchos quintales de fierro que producian..."

2148 CORNIDE: Ob. cit., ff. 225

2149 J. A. BALBOA (1992): Ob. cit., p. 135. Ya lo hemos visto en documentos de finales del siglo XVI. También en el pleito suscitado entre varias ferrerías y el dueño de la de Bueyes, en 1791, don Rafael Valcarce dice "que como dueño de la Herrería nombrada de Paleiras" (en realidad era arrendatario) "el y sus antepasados han usado vena de Formigueiros" (AHN. Estado: leg. $\left.1739, \mathrm{n}^{\circ} 16\right)$.

${ }^{2150}$ I. GARCÍA TATO (2000): Ob. cit., p. 167.

${ }^{2151}$ AHRG. R.A.: 12.446/45

2152 AHPLU: 2406/22 (1824)

2153 I. GARCÍA TATO (2000): Ob. cit., p. 167

2154 AHPLU: 2377/3
} 
pribándolas de la vena y más útiles necesarios para la fabricación”2155. Una nota original del siglo XIX en una carpeta de la documentación de San Martín de Hombreiro (cajón 49, mazo 37) dice que todos los documentos pertenecen a la ferrería de Paleiras "que no lleva la casa (de Hombreiro) y la posee el sr. de Mondriz" ${ }^{2156 .}$

Las Revistas mineras afirman que trabajó dos meses en 1874, en los que obtuvo 34 Qm. de hierro con 102 Qm de vena y cinco trabajadores²157. Debió continuar aún algunos años más.

ESTADO: Sólo permanecen en ruinas restos de la vivienda, pero no de la ferrería que estaba enfrente.

\title{
32. FERRERÍA DE QUINTÁ
}

\author{
LUGAR: Quintá (Hospital) \\ MUNICIPIO: Quiroga \\ RÍO: Quiroga \\ COORDENADAS: $42^{\circ} 30^{\prime} 11^{\prime \prime} \mathrm{N}$. y $7^{\circ} 12^{\prime} 25^{\prime \prime} \mathrm{W}$.
}

A doscientos metros de la ferrería de La Rodela, en la parroquia de Hospital. Hay que tomar la carretera de Quiroga a Hórreos, en el lugar de Barreiro, desviarse en dirección a Rebide. Desde aquí una pista llega a Quintá, que está aguas arriba de la de La Rodela, también a orillas del Quiroga. Se le conoció igualmente como Herrería Nueva de Quiroga.

La primitiva ferrería de Quintá o de Quiroga data del siglo XVI, cuando la encomienda de Quiroga, de los hospitalarios de San Juan, cede en foro a Francisco Vázquez en 1562 los lugares y montes de Campos de Vila, Carballo, Barxa, Arxubín, A Hermida, Vilanán, Campodola, Outeiro, Barxas y casa do Vello por una renta de 2.500 reales y 2 docenas de herraje de clavo. La ferrería, construida sobre terrenos del monasterio de Samos -el coto de Fisteus- se

2155 AHRG. R. A.: 5909/40

${ }^{2156}$ AHRG. Hombreiro: leg. 19.

${ }^{2157}$ P. HERNÁNDEZ SAMPELAYO (1935): Ob. cit., t. III, fasc. $1^{\circ}$, p. 39. 
inauguró en 1566. Hacia mediados del siglo XVII, el nieto de Francisco Vázquez se casa con Isabel de Sarmiento y Solís, cuya hija Ana de Quiroga y Solís se casaría a su vez con el hidalgo lucense Sancho de Neira, por lo que revertirían todos los bienes a esta familia de los Neira.

En el documento de fundación de la ferrería de Quiroga o primitiva de Quintá, de 1566, se menciona a "Juanes de Aldunçín, rendero de la errería de la Puente de Quiroga", pero también al señalar los límites de esa ferrería se habla del "termino y demarcaçion de la dicha otra erreria de avajo" y entre los presentes se mencionan a varios "vecinos de la dicha feligresia del ospital de Quiroga" ${ }^{2158}$. Es decir, que había en el río Quiroga, en la parroquia de Hospital dos ferrerías, una la primitiva de Quintá, luego llamada de A Rodela, y otra con el nombre de ferrería de la Puente de Quiroga, de la que no tenemos más noticias ${ }^{2159}$.

Al finalizar el foro de Fisteus, lugar en el que se asentaba la ferrería, los monjes de Samos pleitearon por la restitución de la propiedad, lo que, después de largos y costosos juicios, lograron en 1689 previo pago a los Neiras de 3.000 ducados ${ }^{2160}$. Años antes, en 1681 había quedado vaco el foro de 1562 "por auer fenecido por muerte de $D^{a}$ Antonia Quiroga Ribadeneira, madre de D. Antonio de Neira", la encomienda se lo volvió a renovar pues el mencionado don Antonio "ha gastado y esta gastando en Madrid mucho dinero en la defensa de dichos montes de la demanda que contra ellos tiene puesta el abad y monges de Samos", y porque además es muy util para la Encomienda. Por esa razón le aforan para su hijo don José Manuel de Neira, por la vida de tres reyes -el primero será Carlos II- todos los montes de la zona a excepción de los que pertenecen a la ferrería de Soldón y el coto de la Seara, por la renta de 2.300 maravedís y tres docenas de herrage con sus respectivos clavos, con la condición de que "en el sitio que llaman de Quintá y a donde antiguamente solía auer un machuco o mas arriba, el dicho D. Josef Manuel o sus subcesores hagan una herreria en nombre de dicha encomienda para que así todos los frutos y rentas de este partido y su contorno que son de dicha encomienda tengan mas valor $y$

${ }^{2158}$ AHRG. Hombreiro: leg. 19

2159 Podría ser el machuco de Quintá donde luego se hizo la ferrería

${ }^{2160}$ Ver lo dicho sobre esta ferrería en lo dedicado a la de La Rodela en las páginas siguientes. 
mejor renta”. Le obligan, so pena de perder el foro, a que la ferrería se construirá antes de veinte años ${ }^{2161}$.

Según algunos testigos hacia 1686, poco después de recibir en foro las antiguas propiedades, en el mismo lugar donde se situaba el antiguo machuco construido por Francisco Vázquez, entonces arruinado, volvió don Antonio de Neira a reconstruirlo primero y a edificar sobre él una nueva ferrería. Cuando ya estaba casi construída la fábrica, los monjes de Samos la denunciaron aduciendo supuesta privación de agua, pues la nueva ferrería se edificaba aguas arriba de la de la Rodela ${ }^{2162}$. En el juicio se nombraron dos peritos “maestros carpinteros de herrerías", uno por cada litigante. Ambos reconocieron que había ya muchas ferrerías, dieciséis en un radio de diez leguas. Respecto al agua uno testificó que no había para una ferrería y, por tanto, menos habría para dos; pero el otro matizó que el agua de la de arriba servía igualmente para la de abajo. Respecto a la vena uno no sabe nada, pero el otro dice que en Formigueiros hay vena para ambas y para otras muchas que se construyan. Por último, sobre lo de elevar el banzao es bueno para la de abajo, pero malo para la de arriba pues encorará sus aguas impidiendo el funcionamiento de las ruedas ${ }^{2163}$.

El pleito fue favorable a los Neira, en sentencia de 1693. El monasterio recurrió y los Neira editaron a imprenta un folleto justificando sus derechos. Al final ganaron los Neira, amparándose en que las leyes del Reino permitían la construcción de nuevos molinos cerca de los antiguos, siempre que el nuevo se hiciere en suelo propio o público. Un testigo en el juicio de 1721 contra vecinos de Campos de Vila y otros lugares recuerda que hacía unos treinta años que a don Antonio de Neira se le había renovado el foro que gozaban sus antepasados, con la condición "que dentro de veinte años auian de fabricar en el sitio de

\footnotetext{
${ }^{2161}$ AHRG. R. A.: 1.662/4

${ }^{2162}$ AHRG. R. A.: 1.662/4. Varios testigos, en 1692, afirman que hacia 1686 "alli auian visto una casa pequeña,que D. Antonio de Neira auia echo para un machuco y por el rairo que esta en medio de los dos que bienen a dicha fabrica auian visto llegar el agua asta junto el Bançado que para el se açia y dicha casa Bieron cubierta de losa y señalaron poco mas o menos por donde llegara y se midio y tenia quince baras de largo y ocho de ancho y despues se desyço y la alargo de la forma que al presente esta y que se quedo asi quando se la denuncio el conbento de Samos y quando los maestros trauajaban en la dicha nueba fabrica y la alargaban oyeron deçir que era para machuco (...) y oyeron decir que mas abajo de dicha nueba fabrica auia auido un mazuco y que el rairo viejo questa mas a la orilla del rio era el rairo por donde yba el agua a el".

2163 AHRG. R. A.: 1662/4
} 
quintá una erraria de fundir yerro por ser de utilidad para la encomienda y su comendador, y que cumpliendo con ello don Antonio de Neira auia principiado a fabricarla", con la oposición del monasterio, por lo que "oyó que el Real Tribunal le diera escritura a favor del don Antonio" ${ }^{2164 . ~ S i n ~ e m b a r g o, ~ l o s ~}$ pleitos, normalmente contra vecinos a los que apoya Samos, se sucederán entre 1721 y 1741 tanto por el problema del agua como por el uso de los montes y el carbón ${ }^{2165}$.

A principios del siglo XVIII la ferrería la tuvo en propiedad don Bernardo Neira y como administrador aparece en 1727 el presbítero don Francisco Rodríguez de Losada ${ }^{2166}$. El Catastro de Ensenada de 1753, señala que la ferrería de Quintá es propiedad del vecino de Lugo don Sancho de Neira; trabaja sólo seis meses, desde finales de diciembre hasta principios de julio, que descontados fiestas y días por descalabro y reparaciones quedan en unos 120 días, en cada uno de los cuales "fabrica cinco quintales y medio de hierro", lo que hace unos 660 quintales anuales. La vena que utiliza es de Formigueiros, distante unas cinco leguas ${ }^{2167}$. Cornide, por su parte, señala que produce 500 quintales de hierro al año y que es propia de don Sancho de Neira ${ }^{2168}$. Hasta entonces seguía pagando a la encomienda $2.300 \mathrm{mrs}$ y tres docenas de herraje de renta anual, pero en 1761 se la subieron a 175 reales (5.950 mrs.) ${ }^{2169}$. Estas

\footnotetext{
${ }^{2164}$ AHRG. R.A.: 26319/20

${ }^{2165}$ AHN. Clero: Libro 6495. Al hablar del coto de Fisteus, este libro de Samos menciona numerosos pleitos con esta ferrería. Así: 1738 pleito contra Francisco Rodríguez y Losada, administrador de la ferrería de Quintá, contra vecinos de Barxa y Arxubín por fabricar carbón en el monte Ferreiriño y venderlo a la Rodela; 1741, información del administrador de la Rodela sobre perturbación de carbón que hizo don Francisco Rodríguez, presbítero, como administrador de la ferrería de Quintá; etc. También en AHRG. R.A.: 26.319/20 encontramos en 1721 un pleito de los vecinos de Campo de Vila, Carballo, Barxa contra don Bernardo Neyra por impedirles hacer carbón en los montes cerrados de la ferrería.

${ }^{2166}$ AHPLU: 2576/2 (1727). En otro documento posterior (AHPLU: 2463/7), de diciembre de 1751, Don Sancho de Neira y Quiroga da un poder para que le defiendan de doña Ana Rodríguez, vecina de la Puente del Hospital, pues teniendo por su padre don Bernardo de Neira y Quiroga un pedazo de monte en el sitio que llaman de Quintá, cerca de la ferrería de este nombre, que es suya, dos criados de ésta lo rompieron y araron "cuando es suyo y muy util para su herreria", ya que se creía con derecho pues hasta 1745 un cuñado suyo, D. Francisco Rodríguez, había sido administrador de la ferrería.

${ }^{2167}$ CATASTRO DE ENSENADA. R. G.: Hospital. También AHN. Clero. Libro 6495. En 1743 los administradores de las ferrerías de La Rodela y Quintá compraron una venera. AHPLU: 2467/12 1813. E 1813 acuerdo entre ambas ferrerías para que la de Quintá pueda utilizar un camino carretal construido por el monasterio de Samos para que pueda conducir la vena de Formigueiros hasta la ferrería de Quintá.

2168 CORNIDE: Ob. cit., ff. 225

2169 V. MIGUÉS: Ob. cit., p. 225
} 
cifras no se ajustan a los datos de la contabilidad, pues la producción media de los años 1752 a 1792 fue de 733,71 quintales, es decir, un 46\% más ${ }^{2170}$.

A comienzos del siglo XIX la ferrería pasó a su hija doña $\mathrm{M}^{\mathrm{a}}$ Josefa de Neira y Ulloa casada con don Benito María de Prado y Lemos, caballero maestrante de Sevilla y alférez mayor y regidor perpetuo de Lugo ${ }^{2171}$. Éste, como padre y administrador de don José María de Prado y Lemos Neira pleiteó, desde 1796 a 1802, contra varios vecinos de la Ermida y San Vitorio "sobre perturbarle en el uso de los montes pertenecientes a la Herrería de Quintá (...y) que estos no le perturbasen la fabrica de el carbon para su Herreria de Quinta en los montes que siempre lo ha hecho y estan anexos a ella y sitio nombrado Campa de Eixe". Pleito que gana, lo que obliga a su mayordomo, don Melchor de la Riba a embargar a esos vecinos bienes para el pago de costas ${ }^{2172}$. De este Mechor de la Riba, en la documentación del marquesado de Hombreiro, hay varios estados de cuentas, en una de las cuales de 1805, se le hacen de cargo 185.325 reales y de data 158.334 reales, quedando alcanzado en 25.991 reales ${ }^{2173}$. Durante muchos años de principios del siglo XIX estuvo como administrador el presbítero don Pedro Fernández Rigueiro y luego, como arrendatarios sus hermanos Domingo ${ }^{2174}$ y Sebastián Fernández Rigueiro ${ }^{2175}$.

2170 AHRG. Hombreiro: Libro de cuentas de la ferrería de Quintá.

${ }^{2171}$ Este don Benito de Prado, en nombre de su hijo, dice en 1796 que su suegro, ya difunto, don Sancho de Neira y Ulloa pleiteó contra el dueño de la ferrería de Bueyes a causa de la vena de Formigueiros (AHN. Estado: Leg. $1739, \mathrm{n}^{\circ} 16$ ).

${ }^{2172}$ AHRG. R. A.: 7.215/3

${ }^{2173}$ AHRG. Hombreiro: leg. 13

2174 Este Domingo moriría asesinado en la ferrería por unos forajidos el 21 de agosto de 1826. Cf. C. GONZÁLEZ (1994): Ob. cit., p. 203. Según su hermano Antonio dejó al morir unos 300.000 reales en bienes, pero los que los inventariaron sólo los estirmaron en 82.000 reales, por lo que en 1827 los llevó a juicio (AHPLU: 2406/14)

2175 AHPLU: 2467/12 (1813) y 2406/2 (1814). En 1823 (AHPLU: 2406/10) firman un convenio los hermanos Domingo y Sebastián Fernandez Rigueiro, de la casa y mazo de Soldón, con su cuñado Juan Fernández. Éste, por acuerdo con sus cuñados el 15 de diciembre de 1822, había tomado a su cargo el arriendo de la ferrería de Quintá por el tiempo que la había arrendado su otro hermano el presbítero don Pedro. Ahora, octubre de 1823, deciden hacerse cargo ellos de la ferrería pero a cambio deben pagarle 39.169 reales y medio, de los cuales 20.000 por su trabajo y ganancias y los 19.169 y medio por la dote que dejó don Pedro a su mujer Ramona Fernández Rigueiro. En 1827 (AHPLU: 2406/14) Antonio Fernandez Rigueiro, otro hermano, dice que a la muerte de Domingo, en agosto de 1826, quedaron en la ferrería de Quintá, de la que aquel era arrendatario, "más de trescientos mil reales de caudal subsistente en fierro, bena, carbón, deudas y otros enseres", que no se inventariaron sino por personas inexpertas "por manera que todos los que conocían al difunto su hermano están escandalizados de sauer que su herencia no resulta hascender por dicho ynventario a más de ochenta y dos y pico reales quando debía constar de más de trescientos mil".; acusa a su cuñada, Dominga Macías, mujer joven que cuando se casó con su hermano era pobre se solemnindad y ya tenía dos hijos de soltera, a los que quiere mejorar con lo de su marido, perjudicando a sus sobrinos; etc. 
Según los monjes de Samos, durante el cuatrienio 1820-24 se continuó el pleito comenzado contra los venaqueros de la Seara, sobre conducir vena a la ferrería de Quintá. Pretendían que fuese conducida por el camino propio del monasterio y hecho a sus expensas para traer vena desde Formigueiros hasta la Rodela. Lo ganó Samos, siendo condenados aquellos a pagar las costas del juicio $^{2176}$. En 1829 los vecinos de la Ermida y San Vitorio se obligan con la ferrería, por la amenaza del arrendatario Antonio Fernández Rigueiro de llevarlo a juicio, de que ni ellos ni sus sucesores "arrancarán la coza o zepa de dichos montes vendidos no siendo para hacer carvon y conducirlo a la citada Erraria de Quintá”2177. Al año siguiente la ferrería pleiteó con los vecinos de Villañan y Framil, de la parroquia de San Salvador de Hospital, porque siendo la ferrería de don José María de Prado y Neira, dicho señor está en la posesión de “arrancar la coza de todos los montes de este Balle de Quiroga (en virtud de varios fueros) y azer carbon, dejando a los vecinos el uso libre de rozar la leña"; pero éstos hacen carbón y lo venden fuera. Nueva querella en 1841 por la misma razón con los vecinos de Paradepol ${ }^{2178}$. En 1838 en el juicio por la construcción de la ferrería de Villarbacú, el apoderado del marqués de San Martín de Ombreiro, dueño de la ferrería de Quintá, se opone por considerarla perjudicial para los intereses de su fábrica ${ }^{2179}$.

En manos de los Neira y sus descendientes los Prado, futuros marqueses de Hombreiro, permaneció la ferrería hasta 1844 en que fue vendida a Gregorio Antonio López, miembro de la burguesía madrileña ${ }^{2180}$. Debió trabajar hasta los años setenta.

ESTADO: Solo la vivienda, aún habitada, y el banzado que mueve un molino.

\footnotetext{
${ }_{2176}$ A. SILOS: Estado de Cuentas del monasterio de San Julián de Samos, 1824.

2177 AHPLU: 2406/16 (1829)

${ }^{2178}$ AHRG. Hombreiro: leg. 21

${ }^{2179}$ AHRG. R. A.: 5909/40

${ }^{2180}$ AHRG. Hombreiro: leg. 78/2
} 


\title{
33. FERRERÍA DE LA RODELA
}

\author{
LUGAR: Rodela (San Mamed de Fisteus) \\ MUNICIPIO: Quiroga \\ RÍO: Quiroga \\ COORDENADAS: $42^{\circ} 29^{\prime} 54^{\prime \prime}$ N. y $7^{\circ} 12^{\prime} 41^{\prime \prime} \mathrm{W}$.
}

A seis kilómetros de Quiroga, en la carretera que desde esta villa se dirige a Hórreos, sale una pista de tierra que termina en la ferrería, que antiguamente se encontraba en la parroquia de Hospital ${ }^{2181}$ y hoy pertenece a la de San Mamed de Fisteus, en la margen izquierda del río Quiroga.

La ferrería de La Rodela o de Quiroga, que fue de los monjes de Samos, se confunde en sus orígenes con la de Quintá; o mejor, la primitiva ferrería de Quintá, más frecuentemente llamada de Quiroga, construida en el siglo XVI por Francisco Vázquez, en tierras de la jurisdicción de la encomienda de Quiroga pero en una propiedad de Samos -el coto de Fisteus ${ }^{2182}$, pasaría en el siglo XVII a ese monasterio, modificando su antiguo nombre por el de La Rodela. Por su parte, los descendientes de Francisco Vázquez, la familia Neira, edificarían en dicha encomienda otra ferrería a la que denominarían también de Quintá, situada un poco más arriba de aquélla sobre las mismas aguas del río Quiroga.

La construcción de la ferrería de Quiroga o la Rodela -primitiva de Quintá 2183 - data del siglo XVI, cuando la encomienda de Quiroga, de los hospitalarios de San Juan, que tenían en el lugar de Hospital su castillo y capital del señorío, ceden en foro a Francisco Vázquez ${ }^{2184}$, en 1562, los lugares y

\footnotetext{
${ }^{2181}$ M. ARIAS CUENLLAS (1992): Historia del monasterio de San Julián de Samos, p. 287, dice que se encuentra en la parroquia de San Mamed de Fisteus pero está equivocado, pues él mismo cita a continuación el Catastro de Ensenada, que la localiza en San Salvador del Hospital. En este lugar se cita frecuentemente en escrituras del siglo XVIII: así en 1756 se dice que Samos es dueño de la ferrería de Rodela "en la feligresia de San Salvador del Hospital del valle de Quiroga" (AHRG. R.A. 190/33)

${ }_{2182}$ En realidad, según el documento de fundación de 1566, el coto de Fisteus era de Diego de Quiroga: "jurisdición que al presente possee el señor Diego de Quiroga por el su coto de San Christobo". Quizá lo era por foro de Samos o éste lo adquirió de aquél posteriormente. (AHRG. Hombreiro: leg. 19).

${ }_{2183}$ El documento de fundación dice de Francisco Vázquez "tenedor de la dicha errera da beyga de Quintá". A veces también se la denomina como ferrería nueva, así en 1566 se dice: "en la ferrería nueva de Quinta" (AHRG. Hombreiro: leg. 19).

2184 Francisco Vázquez era hijo de Alvaro de Quiroga, quien en tiempo de las Comunidades había defendido la fortaleza de O Incio, propia de la encomienda, frente a la condesa de Lemos, por lo
} 
montes de Campos de Vila, Carballo, Barxa, Arxubín, A Hermida, Vilanán, Campodola, Outeiro, Barxas y Casa do Vello por una renta de $\mathbf{2 . 5 0 0}$ maravedís ${ }^{2185}$ y dos docenas de herraje de clavo (mitad mular, mitad caballar). Este foro, con el que la encomienda de San Juan pretende fomentar la siderurgia en la zona ${ }^{2186}$, se suscribe cuando ya Francisco Vázquez ha invertido 800 ducados en una ferrería en la Campa do Muiño ${ }^{2187}$. El foro por la vida de Francisco Vázquez y otras tres personas se hace con las condiciones típicas de los mismos: ser vasallos fieles, que todo vaya en aumento y no en disminución, pueden traspasar el fuero pero con permiso de la encomienda, etc.. Sin embargo, excluye la jurisdicción civil y criminal, luctuosa, penas de cámara, veneras de oro y plata, así como el territorio sobre el que se ha construido la ferrería, el coto de Fisteus, cuyo directo dominio es de Samos, lo que luego tendrá consecuencias muy importantes sobre la propiedad de la ferrería ${ }^{2188}$.

que ésta le había usurpado parte de la hacienda que tenía en Castro Caldelas. De ahí las relaciones estrechas de esta familia con la orden de San Juan: En 1562 "recibió en fuero de esta encomienda la campa do moiño, los montes, aguas, yerbas en atención de que abía perdido mucha hacienda en tierra de Caldelas que le quitó la condesa de Lemos por auer su padre Alvaro Vázquez de Quiroga defendido de la dicha condesa la fortaleza y casa de el Yncio en tiempo de las Comunidades" (AHRG. R. A.: 1662/4)

${ }^{2185}$ De esos 2.500 maravedís, 2.000 por la vega del Campo do Moiño y montes, y los 500 restantes "por razon de un machuco que mas auajo de la dicha Herreria quereis hacer" (y aunque no lo hagan tendrán que pagarlos igualmente.

${ }^{2186}$ AHRG. R. A.: 26.319/20: "dicha ferreria e cassas que en ella y para ella han de acer donde siempre abrá quarenta o cinquenta ombres para el servicio y onrra de esta casa y encomienda y comendadores (...) e que hizo asimismo gran provecho e utilidad por razon de la dicha Herreria e xente que en ella abra las rentas de la dicha encomienda baldrán más".

${ }^{2187}$ AHRG. R. A.: 26.319/20: "Digo que por quanto Francisco Vazquez de Quiroga de mi consentimiento que en nombre del dicho comendador mi señor vos determinasteis e hicisteis una ferrería de fundir hierro mas arriua de el lugar de A Ponte donde dicen a campa de Moiño que es dentro de esta jurisdicion de quiroga porque en el dicho nombre bos prometí que de los montes e yerba e del sitio que esta cauo della os aria un fuero combenible y moderado y vos debajo de esta palabra ycisteis la dicha ferreria y aora me pedis os haga el dicho fuero e yo teniendo respecto a que en hacer la dicha ferrería aueis gastado mas de ochocientos ducados y aún para la acauar de açer haueis de gastar muchos mas Dineros y a que de auer echo la dicha ferrería se sigue gran utilidad y provecho a esta encomienda y acrecentamiento della".

${ }^{2188}$ AHRG. R. A.: 26319/20 


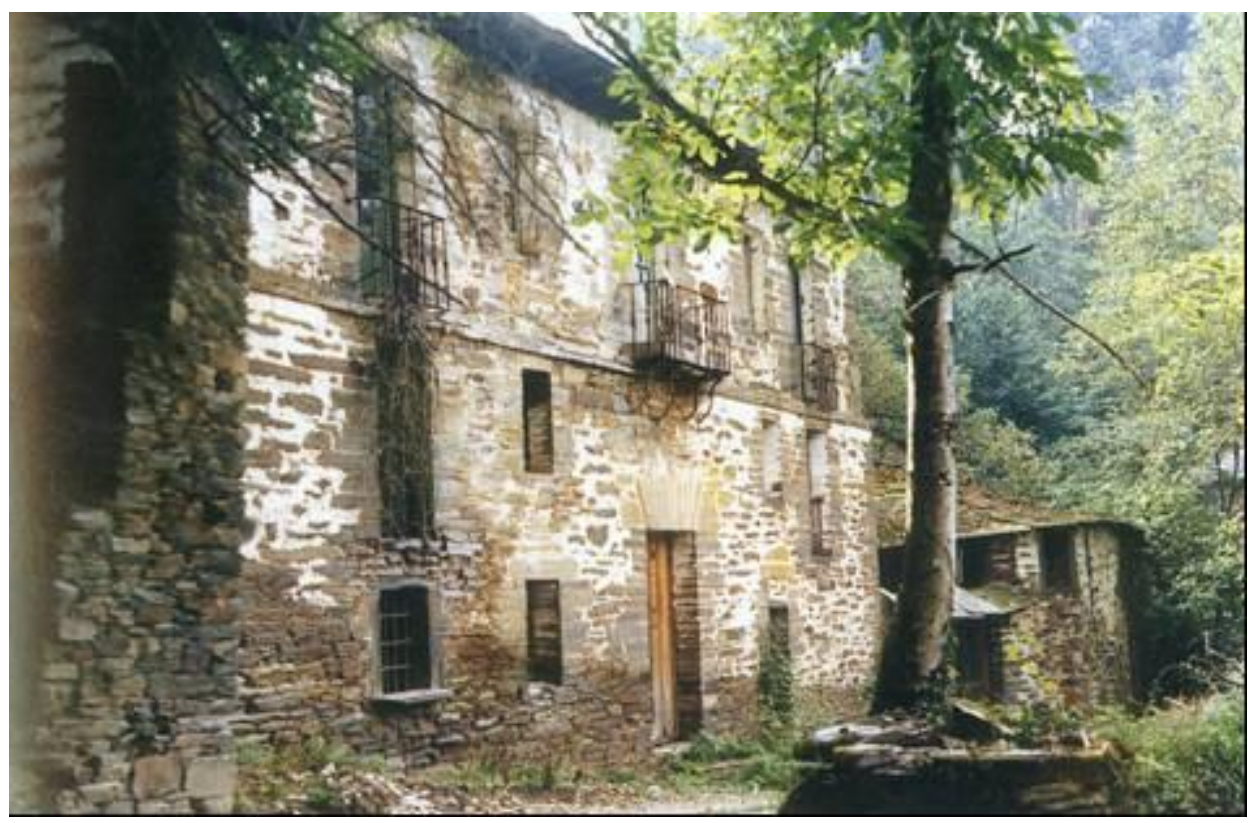

Vivienda de la ferrería de La Rodela

La ferrería se inaugura en 1566 mediante un minucioso ritual, en el que se sacrifica un toro al que, introducido atado en la ferrería, se le parte el cuello con el mazo al que dan agua sus dueños, y con cuya sangre se van marcando los marcos o límites de dicha propiedad. En opinión de Victor M. Migués, que reconoce las dificultades de explicar tan extraña ceremonia, tiene semejanza con prácticas rituales del mundo pagano grecolatino o con cultos relacionados con la fertilidad, aunque puede ser un simple ritual de posesión ${ }^{2189}$, como vemos en otras ferrerías cercanas. En el acto, que relacionado con prácticas semejantes en el País Vasco 2190 -era costumbre vizcaína ${ }^{2191}$-, hay numerosos ferrones vascos y algunos renderos de ferrerías cercanas ${ }^{2192}$.

${ }^{2189}$ AHRG. Hombreiro: leg. 19. Año 1566: “En la ferreria nueva de Quinta (...) paresio pressente francisco Basques de quiroga tenedor de la dicha erreria da veyga de quinta e dijo que el avia echo y edeficado la dicha erreria en su territorio para (...) fundir e labrar en ella fierro en la qual avia gastado muchos dineros y açienda asta ponerla como la pusso en los terminos para lo sobredicho y para que el y los renderos braseros y ofiçiales y biscaynos que en ella y en los terminos della estuvieren e vivieren (...) luego trageron y metieron dentro de la dicha erreria (...) un toro maron presso con dos sogas (luego lo sacaron y pasearon por los límites y marcos de la ferrería) echo lo suso dicho se bolvieron el y los ofiçiciales y perssonas a la dicha erreria con el dicho toro y le ataron las piernas y lo derrivaron sobre la junque teniendole por los cuernos y sogas y el dicho francisco basques e ysabel basques su muger tiraron por el palo de la tapadera del chifron y dieron agua a la rueda del maço el qual dio de golpes en el pescuesso del dicho toro (hasta cortarle la cabeza, co n la cual salieron y con su sangre mojaron los marcos,y luego hiceron una agoa de hierro y la pusieron sobre el mazo, etc.)

${ }^{2190}$ V.M. MIGUÉS (1996): "Em verbo do sorprendente ritual fundacional de umha ferraria quiroguesa no éculo XVI. Um apuntamento histórico-etnográfico". Brigantium, V. 9, p. 117-136. 
Poco después, en 1587, Francisco Vázquez compra al vasco Martín Aldonzín la ferrería de Paleiras en 2.000 ducados y 4.000 reales de foro a la encomienda de la Barra. Ambas ferrería las heredó su hijo Alvaro Vázquez de Quiroga ${ }^{2193}$, casado primeramente con Isabel de Sarmiento y Solís, cuya hija Ana de Quiroga y Solís se casaría a su vez con el hidalgo lucense don Sancho de Neira, por lo que revertirían todos los bienes a esta familia de los Neira ${ }^{2194}$. Antes de esto, la tuvo en propiedad su hijo primogénito, don Francisco de Quiroga Ribadeneira casado con Isabel Vázquez Caneda, que murieron sin descendencia (aunque habían tenido un hijo, Álvaro, que debió morir joven) por lo que pasó a su hermana Ana de Quiroga, a la que antes se la había mejorado con el tercio y quinto de su herencia ${ }^{2195}$. Álvaro Vázquez de Quiroga casó en segundas nupcias con Ana Valcarce con la que tuvo, al menos, tres hijos: María, Marina y Diego Valcarce, que también recibieron parte de la herencia. Posteriormente éstos, en 166o, pleitearon con Sancho de Neyra por la tercera parte del coto de Fisteus ${ }^{2196}$. Creo que al final hubo un acuerdo por el que los Neira quedaron con la ferrería de Quintá y los Valcarce con la de Paleiras.

${ }^{2191}$ Así lo afirma el autor del Libro Becerro de la casa de Lusío hablando de la ferrería del Rial. ARCHIVO DEL MONASTERIO DE SAMOS: Casa de Lusío, libro becerro (1715), p. 7v: “ y por que Lope Vazquez abía echo cortar un toro debajo del mazo, y rodear con el un pedazo de termino alrededor de la herraría (costumbre antigua de Vizcaya para adquirir algunas preeminenzias)".

${ }^{2192}$ Entre ellos "miguel de aurtiz biscayno y maestro que fue de la dicha erreria e miguel de aldunçin rendero de la erreria de la puente de quiroga y miguel de araburçe e julio mororro e sanjuan e lopo de espella maestros de ferraxe e miguel moran macheador e juancio biscayno e andres de bedia que son arossa tirador e fundidor y tassador y braseros y ofiçiales de la dicha erreria”. ¿Qué ferrería es esa de la Puente de Quiroga? No puede ser la de Paleiras, propiedad de otro Alduncín, Martín; pues según este mismo documento, al hablar de los límites de la ferrería de Quiroga, menciona entre ellos "la dicha otra ferrería de abajo". Pero Paleiras estaba más arriba de ésta y no debajo ¿Se trata de una ferrería diferente y desconocida?. Probablemente, pero no conozco más datos.

${ }_{2193}$ A quien sus padres, por testamento de 1573 reformado en 1590, mejoran en el tercio y quinto: 59.546 reales por su padre Francisco y 34.238 reales por su madre Isabel, haciéndose pago de la cantidad conforme a la elección de 77.000 rs. en que está tasada la herrería de Quiroga, con su molino, casas, arboleda etc.; y 7.700 rs. el machuco de Quintá, más una viña. (AHRG. Hombreiro: 57/39). Don Alvaro murió en Villafranca del Bierzo 1614, y dejó hijos de dos matrimonios.

${ }^{2194}$ AHRG. R. A.: 10.862. En 1666 don Sancho de Neira Montenegro dice tener "la posesión de las tres quartas partes de la jurisdicon de San Cristobal y de la erreria de Quiroga y de poner y quitar juez en ella quando le parece".

${ }_{2195}$ En 1640 al hacer las partijas de la herencia de Francisco Vázquez de Quiroga y su mujer Isabel Vázquez de Caneda, dejan éstos como heredero a su hijo Álvaro; pero de esta herencia "se a de sacar el tercio y quinto que se adjudica a Sancho de Neyra como marido de Ana de Quiroga heredera de don Álvaro de Quiroga, hijo de dicha Isabel Vázquez" (AHRG. Hombreiro: 57/39).

${ }^{2196}$ AHRG. R. A.: 10.862/59 
Durante la minoría de edad de Francisco de Quiroga, parece que fue su curador Miguel de Alza rendero de sus dos ferrerías²197, quien murió el 12 de julio de 1623 sin testar, por lo que el juez mandó hacer inventario de sus bienes, pues no había dado cuentas de su curadoría. Su hija María de Alduncín, probablemente nieta de Martín Alduncín, dueño de la ferrería de Paleiras, presentó una querella contra Francisco de Quiroga y su mujer Isabel de Solís así como contra don Diego de Valcarce, señor de la cuarta parte del coto San Cristóbal de Fisteus, porque sin contar con ella nombraron tasadores a un juez y un escribano, que "heran enemigos capitales del dicho difunto", y entraron a saco en sus bienes cuyo valor superaba los 30.000 ducados ${ }^{2198}$.

Pero en 1628 Gregorio Valerón, con comisión de la Real Chancillería de Valladolid, vino ante Francisco de Quiroga a hacerle entrega de las dos ferrerías $\mathrm{y}$ "de todos los vienes muebles y raices que quedaron a la fin y muerte de Miguel de Alça rendero que fue de ambas las dichas ferrerías y como curador de las personas y bienes de Francisco de Quiroga y Ribadeneira". Se puso pregón y aunque hubo varios postores, se remataron en Antonio Rodríguez Mosquera, rendero de la ferrería de Quiroga, como mayor postor en 930 ducados ${ }^{2199}$. En 1630 aparece como rendero un Andrés Mosquera, que antes lo había sido de la berciana de Pontepetre 2200 y en 1633 lo era Antonio de Achega con quien se querella el párroco de Fisteus, acusándolo de que no asiste a su parroquia como le corresponde, sino a la del Hospital de San Salvador ${ }^{2201}$. En

2197 AHRG. Hombreiro: leg. 19. Don Alvaro de Quiroga arrienda en 1605 la ferrería de Paleiras a Lorenzo de Alza, "rendero de la mi herreria de Quiroga" y AHRG. R. A.: 15.215/33: En 1607 "Sepan quantos esta carta de poder vieren como yo Miguel de Alça, rendero e vecino de la herraria de Quiroga hixo lexitimo y universal heredero que quedó de Lorenço de Alça y María Aldunzin". Esta María Alduncín era hija o hermana de Martín Alduncín, y ambos familiares de Miguel Alduncín, rendero que fue de Bueyes lo mismo que Lorenzo de Alza. AHRG. R. A.: 12.476: En 1620, en el pleito entre Lázaro de Celaya y Miguel de Alza por la ferrería de Soldón, se dice que "Miguel de Alça, rendero de la herraria de Quiroga".

${ }^{2198}$ AHRG. R. A.: 3636/77

2199 AHRG. Hombreiro: leg. 19

2200 AHPL. PN.: caja 2969 (1630): Alonso de Montes, contador mayor y juez de rentas del marquesado de Villafranca y Andrés Mosquera "rendero de la herrería de Quiroga y que lo fue de la de Pontepetre, que hes de dicho señor marqués" se conciertan por las deudas que éste ha dejado en la ferrería de Pontepetre.

${ }^{2201}$ AHRG. Real Audiencia: 20.866/2. Dice que la ferrería está en su feligresía (obispado de Astorga) y que "el y sus anteçesores ... desde tiempo inmemorial... (han de) acudir a oyr misa en la dicha mi yglesia por si y su jente todos los domingos y fiestas de guardar y por las pasquas confesar y comulgar y rezibir los santos sacramentos y pagar los diezmos y primiçias 
las cuantas del administrador de la encomienda de Quiroga de los años 1641 y 1642 se dice que el foro de la ferrería vale, como ya hemos visto en el siglo XVI, 2.500 mrs. y dos docenas de herraje ${ }^{2202}$. En 1663 era rendero Antonio González Felpete ${ }^{2203}$; sin embargo, en 1676 no hay rendero sino administrador, el presbítero Antonio Nuñez 2204.

Al finalizar el foro de Fisteus, en el que se asentaba la ferrería, los monjes de Samos pleitearon contra su poseedor don Antonio de Neira, hijo de Sancho de Neira y Ana de Quiroga, logrando aquéllos, después de un largo y costoso pleito ${ }^{2205}$, una sentencia favorable en 1689 , aunque se le permitía usar la ferrería hasta julio de 1690 para consumir la vena acumulada. Samos y don Antonio nombraron peritos que tasaron el valor de los bienes en 3.000 ducados: 800 ducados por el valor de la ferrería con sus materiales, a excepción de los barquines que estaban rotos; 200 ducados por el camino de carro recientemente hecho para traer vena de Formigueiros; y 2.00o ducados por las casas de junto a la ferrería, el palacio de arriba, molino, etc.; dinero que el monasterio tuvo que pagar a don Antonio Neira ${ }^{2206}$. De este modo pasó a Samos la ferrería de Quiroga, que a partir de entonces se denominaría de la Rodela ${ }^{2207}$. Sin embargo,

como tales feligreses"; pero desde hace algún tiempo no lo hacen sino en el "hospital que es de la orden de san Juan".

${ }^{2202}$ En 1641 se le toman de cargo: "la herreria de Quiroga balió en dicho año dos mill y quinientos maravedís en dinero y dos docenas de herraxe con su clavo, que esla renta que vale todos los años y haçen por todo ochenta y tres reales”. Cit. I. GARCÍA TATO y E. ÁLVAREZ (2012): Las Encomiendas gallegas de la orden de San Juan de Jerusalén. Estudio y edición documental. T. II-2 ${ }^{o}$. La Encomienda de Quiroga. Santiago de Compostela, p. 620

2203 AHPLU: 2386/3 /1663).

2204 AHRG. Hombreiro: 13/42

2205 AHN. Clero: Libro 6495. El pleito comenzó en la Audiencia de la Coruña en 1674 entre el monasterio de Samos y don Antonio Neira. En 1678 se absolvió a éste, por lo que el monasterio apeló a la Chancillería de Valladolid que condenó a los Neira dando el coto y la ferrería a Samos. Aquel presuntó recurso en la sala de 1.500 que sentenció a favor del monasterio en 1689 .

${ }^{2206}$ AHRG. R. A.: 1.662/4. Los monjes dicen que la ferrería "se fabricó en suelo y territorio foral propio del (monasterio".

${ }_{2207}$ Aunque algunos confunden Quintá con Rodela, no hay ninguna confusión. La primitiva ferrería se denomina de Quiroga, aunque estuviera construida en Quintá. Pasó luego al monasterio de Samos y comenzó a llamarse de la Rodela. Dicen en 1723 unos testigos que llevaron carbón "a la herreria de Quiroga y es del monasterio de Samos", la de Quiroga del monasterio es siempre la de Rodela, y más adelante "a la herrería vieja de Quiroga y a la que nuebamente se hizo en Quinta" (AHRG. R. A.: 15.167/24). En 1741 el corregidor de Ponferrada dice que no se impida a Samos la reedificación de la chapacuña "que sirbe a su Erreria llamada vieja consistente en este sitio de Rodela" (AHRG. R.A.: 9090/4). Otro de 1787 dice "a la Erraria de Quiroga y por otro nombre llamada vieja de Rodela" (AHRG. R. A.: 9090/4). En un documento del AHN. Clero: Libro 6495, hablando del coto de Fisteus, se dice que el monasterio de Samos "ejerce jurisdicción civil y criminal en este coto y en él tiene la Herraria llamada de Quiroga o de Rodela o la Herraria bieja". 
durante muchos años se mantendría una dura disputa entre ambos por la construcción de la ferrería de Quintá, como hemos visto.

Según Arias Cuenllas la ferrería de La Rodela fue construida en 1685 durante el abadiato del P. José Laguna ${ }^{208}$; pero el P. Arias y Arias, en consonancia con lo dicho anteriormente, señala que este abad ganó el pleito que el monasterio tenía sobre la hacienda y ferrería de Quiroga ${ }^{2209}$, lo que da a entender que ya existía (como así era), aunque por problemas estaba paralizada. No lo creo, se hizo el traspaso y la ferrería siguió funcionando, aunque con numerosos pleitos con los Neiras por la ferrería nueva de Quintá. Unos derivaban de la misma construcción y problemas sobre el agua, que duraron 29 años, de 1690 a 1719; otros por el carbón. De aquellos hablaremos en su momento, de los pleitos por carbón los hubo a todo lo largo del siglo XVIII. En 1721 el monasterio y los vecinos de Campos de Vila, Barxa, San Mamed de Fisteus y otros lugares pleitean contra don Bernardo de Neira porque "con la ocasion de hauer fabricado una Herreria nueua en dicha jurisdicion de quiroga pretenden ynpedir a mis partes y mas vecinos del uso $y$ aprovechamiento de dichos montes, su leña y carbon subponiendo tener a ello derecho y posesion", a lo que alega don Bernardo que no es cierto pues por foros sucesivos desde 1562 todos esos montes son suyos y no libres ni de Samos a quien venden el carbón ${ }^{2210}$.

Nuevamente pleitearon Samos y don Bernardo Neira en 1740 y 1741 por las obras que el monasterio hacía en su chapacuña, lo que llevó al corregidor de Ponferrada, don Juan Moreno Vallejo, a emitir en 1741 un auto para que "no se embaraze a la parte del Real Monasterio de Samos la reedificación que tiene intentada de la presa y tapacuña que sirbe a su Erraria llamada vieja consistente en este sitio de Rodela ni menos la conducion de carbón para su beneficio y fabrica de yerro", mandando al mismo tiempo colocar un edicto en las puertas de las iglesias. Don Bernardo dice que no es reedificación sino obra nueva, pero en la visita que hace el corregidor confirma que sí es reedificación pues se la llevó una avenida y manda al P. Juan Vázquez, maestro de obras y Fr.

${ }^{2208}$ M. ARIAS CUENLLAS (1992): Ob. cit., p. 287

2209 M. ARIAS y ARIAS (1950): Historia del Real Monasterio de Samos, p. 234-235.

2210 AHRG. R. A.: 26.319/20 
Benito Cadagua, administrador de la ferrería, que deje la obra tal como estaba anteriormente, cosa que más tarde certificarán don Pedro Díaz de Guitián y Francisco Antonio Iglesias, maestros arquitectos ${ }^{2211}$.

Pero quizá el pleito más largo y engorroso fue el mantenido con el cura de Fisteus, don Francisco Rodríguez de Losada, su hermana y los hijos de ésta por abrir éstos, por debajo de la ferrería, un cauce para regar un prado, cuya chapacuña encoraba el agua e impedía que las ruedas de la ferrería pudieran moverse. El pleito se inició en 1756 y pese a las sentencias favorables para el monasterio en 1759, aquéllos o sus herederos volvieron a reiniciarlo en 1763 y en 1799 e incluso en 1826 aunque siempre salió la ferrería ganadora de todos esos pleitos ${ }^{2212}$.

El problema del agua era fundamental para esta ferrería, pues según el Catastro de Ensenada de 1753, por falta de agua solo trabajaba seis meses, de los cuales por reparaciones, fiestas y domingos se quedaban reducidos a 120 días al año, en los cuales, regulando cinco quintales y medio al día, producía unos 660 quintales ${ }^{2213}$. Esta es aproximadamente la cantidad que recoge Cornide, 700 quintales anuales 2214 . La vena que consumía provenía, según el Catastro de Ensenada, de Formigueiros ${ }^{2215}$, al que en concepto de foro pagaba, según datos del siglo XIX, 400 reales ${ }^{2216}$.

La ferrería, como todas las de Samos, era administrada por un monje ${ }^{2217}$, que residía en la vivienda que había al lado. A cargo del prior rendero corría el

\footnotetext{
2211 AHRG. R. A.: 9090/4

${ }^{2212}$ AHRG. R. A.: 190/33, 680o/4, 13.895/2 y 7.199/6

2213 CATASTRO DE ENSENADA. R.G.: Hospital: "La otra que llaman de la Rodela propia del Real Monasterio de Samos distante de la referida (de Quintá) como dos tiros de vala, que asimismo trabaja con el agua de dicho río Quiroga y que por la misma causa de no tener agua más que para seis meses solo fabrica hierro otros ciento y veinte días naturales que a razón de otros cinco quintales y medio en cada uno se persuaden fabrica en el tiempo referido otros seizientos y sesenta quintales".

2214 CORNIDE: ob. cit., ff. 225

2215 CATASTRO DE ENSENADA. R. G.: Hospital: " $y$ asimismo conducese para dicha fábrica la Bena de el Mineral referido de Formigueiros". El monasterio fue uno de los que pleiteó a finales del siglo XVIII con el dueño de la ferreía de Bueyes por el uso de la vena de Formigueiros (AHN. Estado: leg. 1739, $\mathrm{n}^{\circ}$ 16).

${ }^{2216}$ I. GARCÍA TATO (2000): Ob. cit., p. 167

${ }^{2217}$ M. ARIAS CUENLLAS (1992): ob. cit., p. 203. En 1797 se menciona a fray Eufrasio Robles, prior de la herrería de la Rodela como concesonario de un préstamo de 1.200 reales a Francisco Fernández (AHPLU: 2555/2 (1797). En 1813 era administrador de la misma fray Bernardo de
} 
contrato con ferrones, venaqueros y carboneros, así como la venta del hierro, del que tenía que dar cuenta, como se recoje en los estados de cuentas del monasterio, y de los que a su vez el abad tenía que presentar al Capítulo General de la Congregación de Valladolid. Conocemos cuatro Estados de Cuentas de otros tantos cuatrienios, dos del siglo XVIII y dos del XIX. Los beneficios de esta ferrería fueron los siguientes:

$\begin{array}{ll}\text { Cuatrienio } & \text { reales } \\ 1777-1781 & 46.000 \\ 1781-1785 & 36.400 \\ 1814-1818 & 14.000 \\ 1818-1824 & 13.202\end{array}$

Fuente: Archivo de Silos

Como se ve, y esto es algo común a todas las ferrerías monásticas, el descenso en los beneficios durante el primer cuarto del siglo XIX es una señal evidente de sus dificultades económicas, provocadas por la inseguridad de la época, de la que algunos quisieron aprovecharse. Así ocurrió, por ejemplo, durante el cuatrienio 1820-24, en que sabemos que continuó un pleito comenzado contra los venaqueros de la Seara, sobre conducir vena a la ferrería de Quintá; pues pretendían que fuese trasladada por el camino propio del monasterio, hecho a sus expensas para traer vena desde Formigueiros hasta la Rodela. Lo ganó Samos, siendo condenados aquéllos a pagar las costas del juicio 2218 .

Incluso en los años del Trieno Liberal, hay que recordar que se produjo una temprana desamortización, que afectó a muchos bienes del monasterio de Samos, aunque desconocemos si entre ellos también se desamortizó, como en el

Carbajal, que firma un acuerdo con el administrador de la ferrería de Quintá por el uso de un camino de la vena a Formigueiros propio del monasterio (AHPLU: 2467/12 (1813).

${ }^{2218}$ A. SILOS: Estado de Cuentas del monasterio de San Julián de Samos, 1824. En 1813 los administradores de ambas ferrerías llegaron a un acuerdo para que la ferrería de Quintá pudiese usar un camino carretal construido por el monasteruio: "El padre prior de Rodela por hacer gracia y merced a D. Pedro Rigueiro (que es el administrador de Quintá) le concede permiso para que por si y sus carreteros de Bena pueda transitar por el citado camino del monasterio $y$ conducir desde primero de diciembre hasta el día quince de abril de cada año para la Erraria de Quintá, sin que él o sus subcesores, dueños de ella ni mandatarios lo puedan hacer en los meses restantes del año, y aún en los que ban capitulados quatro y medio puedan hacerlo sin expreso consentimiento y aprobacion del padre abad y más monjes" (AHPLU: 2467/12 (1813). 
monasterio de Montes, alguna de sus ferrerías. Esta desamortización se produjo a partir de 1836. En 1838 en el juicio por la construcción de la ferrería de Villarbacú, el Comisionado de Arbitrios de Amortización de la provincia de Lugo se opondrá a dicha construcción "con el fín de que la nación no se vea privada del crecido producto que le arrojan anualmente dichas Herrerías de Rodela y Rugando"2219. Lo que quiere decir, que durante unos años fueron administradas estas ferrerías del extinto monasterio de Samos por el Estado ${ }^{2220}$. Luego serían definitivamente desamortizadas, como ocurrió con esta de la Rodela que fue vendida en 1839 por 620.500 reales $^{2221}$, y con la de Rugando, adquiridas ambas por Gregorio $\mathrm{M}^{\mathrm{a}}$ López, un comerciante madrileño ${ }^{2222}$, que la explotó mediante apoderados, como don Juan Ma López, párroco de San Cosme de Nullán²223. Debió de trabajar hasta los años ochenta del siglo XIX. En 1874 trabajó dos meses solamente por falta de carbón, en los que benefició 450 Qm de vena de Formigueiros de los que obtuvo 150 de hierro, pero según Hernández Sampelayo "todavía funciona hoy (a comienzos del siglo XX) de un modo intermitente" 2224 .

ESTADO: Según Arias Cuenllas, la ferrería conserva las sólidas paredes de su fábrica, pero sin su maquinaria. Va camino de su ruina, al igual que la hermosa vivienda con su capilla2225. Ciertamente, ya hay partes ruinosas aunque mantiene todavía su antigua nobleza, al igual que la capilla. La ferrería se encuentra frente a la casa, en la que son visibles restos del banzado y de los muros perimetrales.

\footnotetext{
2219 AHRG. R. A.: 5909/40

2220 AHPLU: 5431/8 (1839). En 1839 era su administrador el escribano don Miguel Somoza, vecino de Santa María de Ruimil en la Somoza mayor de Lemos.

2221 AHPLU. Desamortización: leg. 10-2 (2)

2222 AHPLU: 2376/6 (1846). En mayo de 1846 los propietarios de la ferrería de Folgoso solicitan un préstamo de 15.000 reales a don Gregorio María López, vecino y del comercio de la villa de Madrid, a quien se lo devolverán en ocho años "en la mencionada casa de la Rodela como propia del señor emprestamista". También lo era en los años cincuenta (I. GARCÍA TATO (2000): Ob. cit., p. 167).

2223 El que propietario y administrador lleven el mismo apellido puede indicar parentesco, lo que explicaría que un comerciante madrileño, pero oriendo de Galicia, comprara unas ferrerías en esta región.

2224 H. SAMPELAYO------: Ob. cit., p. 39.

2225 M. ARIAS CUENLLAS (1992): Ob. cit., p. 292
} 


\title{
34. FERRERÍA DE RUGANDO
}

\author{
LUGAR: San Lorenzo de Villarmiel \\ MUNICIPIO: Quiroga \\ RÍO: Soldón \\ COORDENADAS: $42^{\circ} 29^{\prime} 5^{\prime \prime}$ N. y $7^{\circ} 9^{\prime} 14^{\prime \prime} \mathrm{W}$.
}

Se hallaba a orillas del río Soldón, en la parroquia de San Lorenzo de Villarmiel, un poco por encima de la de Gorgueira. Después de pasar Paradaseca y Paradepiñol, es el primer caserío con el que nos encontramos. El Catastro de Ensenada dice que se halla en la parroquia de San Mamed de Fisteus, pero debe de ser un error, que también comete Clodio González.

La ferrería se construyó a comienzos del siglo XVIII. Según el P. Arias Cuellas, a finales del siglo XVII, las ferrerías de Samos estaban pasando por un momento de crisis debido a la escasez de leñas y carbón; de ahí que sabedores de que en el coto de Villarmiel, en Quiroga, propio de la jurisdicción de Samos, había bosque, agua y un lugar apropiado para una nueva ferrería, la comunidad de Samos eligió, en 1698, a Fray Juan Pazos y Fray Plácido de Soldevilla, para que examinasen dicho lugar, y viesen si convenía edificarla allí; como resultado de la misión, se edificó en dicho lugar entre 1701 y $1705^{2226}$, en el abadiato de Fray José de Noboa, quien invirtió en ella más de 7.000 ducados $^{2227}$. Parece que hubo alguna oposición a esta construcción por parte del dueño de la ferrería de Soldón, así como por la apertura de un camino para su servicio ${ }^{2228}$.

La ferrería de Rugando comenzó a funcionar en 1707, como reconoce el abad Fray Diego de Ogea en 1708: "Que por quanto dicho Monasterio ha hecho y edificado de nuevo una Erraria en el sitio que llaman Rugando términos

\footnotetext{
2226 IBIDEM, p. 242 y 257.

2227 IDEM, p. 287.

${ }_{2228}$ AHN. Clero: Libro 6495: "Testimonio en relación dado por Juan García de Seixas en 1705 de la oposición no conseguida del Dueño de la Herraria de Soldón a la fábrica de nuestra ferrería de Rugando" ff. 91. IDEM: "Real auto dado en 1706 para los dueños de la ferrería de Soldón que no impidan el camino que hacía el monasterio (de Samos) para servicio de la ferrería de Rugando" ff 91.
} 
propios del dicho Real monasterio en tierra de Quiroga, la qual habrá cosa de un año muele y fabrica hierro; y parte de la vena que gastó havía benido de la venera que llaman Formigueros, que es y de que se halla poseedor su señoría dicho señor conde y para que desde oy dicho día (29 de mayo de 1708) en adelante dicha erraria pueda ser surtida y socorrida de toda la vena que le hiciese menester para su gasto y consumo así por tiempo de verano como de ynvierno..." acuerda con don Antonio Pimentel, en nombre del conde de Maceda, que pueda extraer dicha vena con la condición de pagar de canon 200 reales al año2229.

Años más tarde, en 1746, probablemente a causa de alguna avenida, Juan Bordel, maestro de cantería, "se retiró a la erraria de Rugando de dicho Real Monasterio a continuar en trabajar en otra presa que allí tenía principiado juntamente con dichos ofiziales" ${ }^{2230}$. El Catastro de Ensenada anota que trabajaba siete meses al año, de los cuales descontados arreglos, domingos y festivos, se reducían a 150 días. En ellos producía 825 quintales, a una media de cinco y medio quintales cada día, añadiendo que "tiene de coste en salarios, carbón, vena y otras expensas, cada quintal de hierro, en dicha herrería de Rugando, 37 reales de vellón". La vena la conduce "del referido mineral de Formigueiros que dista de dicha herrería poco más de tres leguas" ${ }^{2231}$. Por su parte Cornide Saavedra, hacia 1780, la considera la de mayor producción de la provincia de Lugo, en torno a 1.500 quintales, lo que indudablemente generaba a Samos unos beneficios muy cuantiosos. Según los Estados de Cuentas del Monasterio era, después de la de San Vicente de Leira, la más rentable, como podemos ver en el cuadro. La administración, como todas las de Samos, corría a cargo de un prior rendero ${ }^{2232}$.

INGRESOS DE LA F. DE RUGANDO

Cuatrienio reales

1777-1781

86.000

$1781-1785$ 96.000

2229 AHN. Clero: leg. 1739, $\mathrm{n}^{\circ} 16$.

${ }^{2230}$ AHRG. R. A.: 190/33

${ }^{2231}$ CATASTRO DE ENSENADA. R. G.: Fisteus

${ }^{2232}$ Así lo dice M. ARIAS CUENLLAS (1992): Ob. cit., p. 203. En 1798 lo era fray Onofre Rodríguez (AHPL. PN.: caja 3329 (1798); en 1828 fray Veremundo de la Peña, prior de la de San Vicente de Leira, dice haber sido antes de la de Rugando (AHPLU: 2406/15; y en 1835 fray Vicente Bousón (AHN. Consejos: leg. 12080, exp. 146.. 


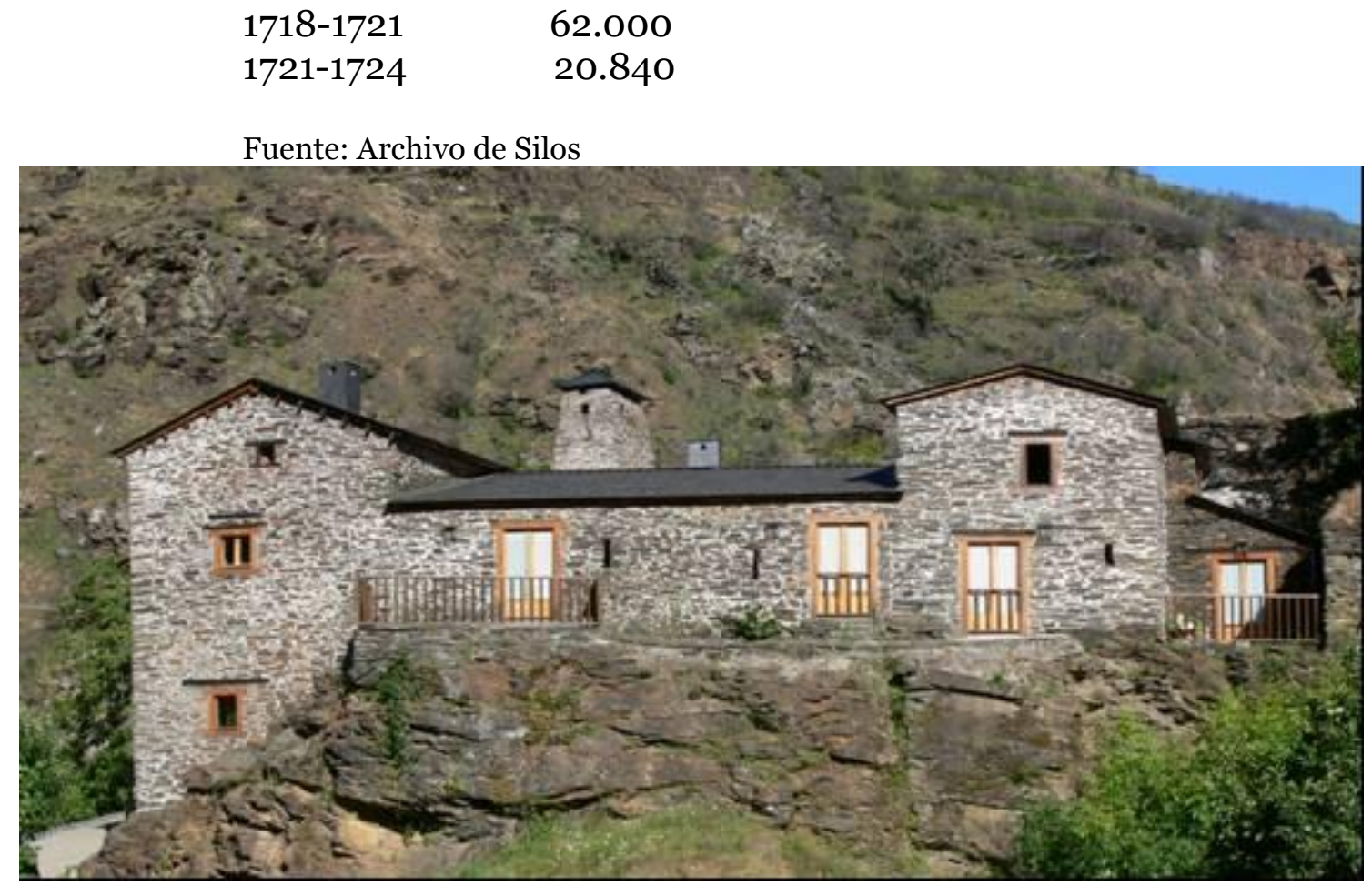

Ferrería de Rugando

Los datos del cuadro reflejan una caída de los rendimientos a principios del siglo XIX, muy acusada en los años del Trienio Constitucional, en el que el monasterio sufrió un intento de desamortización; pero también la ferrería tiene problemas en el abastecimiento de carbón. En el Estado General del monasterio de 1824 se habla de "la querella de fuerza que dio el monasterio en la audiencia de Galicia contra los vecinos de Villarmiel, porque impedían que el administrador de la Herrería de Rugando, embiase carboneros a arrancar y cocer carbón en los montes de aquella parroquia. Tubo el buen resultado de que dichos vecinos reconocieron la propiedad y uso que el Monasterio tiene sobre dichos montes y se allanaron por medio de escritura a no poner estorbo al administrador de la Herrería por el aprovechamiento del carbón, por medio de los peones que fuesen de su gusto, y pagaron los costas"2233.

Como otras ferrerías de Samos, tras la exclaustración, fueron incautadas por el Estado. En 1837 don Antonio Somoza y Pardo se declara "arrendatario de ella (de la ferrería de Rugando) por el crédito público”2234. Al año siguiente,

2233 A. SILOS: Estado general del Monasterio de San Julián de Samos, 1824. 2234 AHPLU: 5431/6 (1837). 
en el juicio por la construcción de la ferrería de Villarbacú, el Comisionado de Arbitrios de Amortización de la provincia de Lugo se opondrá a dicha construcción "con el fin de que la nación no se vea privada del crecido producto que le arrojan anualmente dichas Herrerías de Rodela y Rugando"2235. Estos datos indican que durante unos años ambas ferrerías del monasterio de Samos fueron administradas por el Estado. Luego, en tiempos de Mendizábal, serían desamortizadas, como ocurrió con esta de Rugando, que se subastó en 1.120.00o reales ${ }^{236}$. Debió adquirirla el mismo comprador que la de la Rodela, pues poco después ambas aparecen en manos de don Gregorio López, el cual pagaba de foro por la vena de Formigueiros al marqués de Santa María del Villar, 200 reales al año por esta ferrería de Rugando ${ }^{2237}$, como antes los monjes.

Por los datos de las Estadísticas Mineras vemos que la ferrería siguió trabajando durante todo el siglo XIX. En 1874, durante cinco meses, produjo 450 Qm. de hierro con 1.350 Qm. de vena de Formigueiros; diez años después benefició alrededor de $70 \mathrm{Tm}$. que produjeron $22 \mathrm{Tm}$ de hierro. Según Hernández Sampelayo, aunque intermintemente, siguió funcionando hasta $1925^{2238}$.

ESTADO: Hasta hace muy poco estaba todo abandonado, solo quedaban restos de la vivienda y la capilla, convertida en cuadra. Hoy está muy bien restaurada y convertida en una espléndida casa rural De la ferrería solo hay se conserva la chapacuña, la presa y algunos vestigios de la edificación.

2235 AHRG. R. A.: 5909/40

${ }^{2236}$ AHPLU. Desamortización, leg. 10, 2 (2)

2237 I. GARCÍA TATO (2000): Ob. cit., p. 167

${ }^{2238}$ HERNÁNDEZ SAMPELAYO (----): Ob. cit., p. 149. 


\section{FERRERÍA DE SOLDÓN}

LUGAR: Soldón (parroquia de la Seara)

MUNICIPIO: Courel

RÍO: Soldón

COORDENADAS: $42^{\circ} 32^{\prime} 22^{\prime \prime}$ N. y $7^{\circ} 6^{\prime} 6^{\prime \prime} \mathrm{W}$.

Se encuentra en una desviación de la carretera de Quiroga a Hórreos, a la altura de Outeiro. Aquí hay que tomar un camino que desciende por la margen izquierda del río Soldón, cuyas aguas movieron en otro tiempo las ruedas de esta ferrería. La fábrica se sitúa entre el camino, ya casi abandonado, y el río.

La ferrería de Soldón, propiedad de la Encomienda de Quiroga, existía en la primera mitad del siglo XVI, pero en 1550 fue reedificada por el vasco Juan Ortiz de Artunduaga. Años más tarde, en 1603, se les pregunta a los testigos del juicio al que luego nos referiremos si saben "que el sitio, montes y aguas de la dicha herreria de Soldon es de la encomienda de Quiroga y de sus comendadores de cuya mano el dicho Juan Ortiz (hijo del Juan Ortiz que la reconstruyó) y sus padres lo trahían en fuero, los quales dichos padres del dicho Juan Ortiz a quien como su heredero suçedió en la dicha herreria la hizieron e Edificaron y fundaron de nueba y para su fundamento y edificio rompieron peñas y montes, escaba y acequia muy onda y larga para dar toda la agua de la dicha herreria y mejorar la presa della como mejoraron en perpetuarla para siempre sin mas costa ni trauajo y ansi hizieron la casa de la dicha herreria con su carbonera y cabaña $i$ hizieron en ella mas perfectos y bien echuras"2239.

Efectivamente, el 18 de enero de 1550 fray Francisco Giral, comendador y señor de la encomienda de Quiroga, aforó a Juan Ortiz de Artunduaga la ferrería de Soldón por 29 años, que comenzaron a correr desde el día de Santiago de ese año, y en renta anual de $\mathbf{1 4 . 0 0 0}$ maravedís y siete docenas de herrage, la mitad caballar y la otra mitad mular. Dicho foro se lo hace por "los muchos e buenos e leales seruicios que bos Juan Ortiz (que por entonces debía ser también forero de la ferrería de Valdomir), que estades presente hasta aqui aveis fecho, ansi en fauorecer las cosas de mi religion como de las dichas mis encomiendas e que

2239 AHRG. R. A.: 20.441/70 
aveis hecho muchos buenos hedeficios en mejoramientos en la herreria de Soldon que es de la dicha mi encomienda de Quiroga estando como ella estaba para se yr a yermo e que aveis gastado mas de trescientos ducados, los quales aveis fecho por mi mandado e consentimiento e prometiendo bos de bos hazer fuero della". Añade además que tanto para él como para los comendadores que le sucedieran, pero sobre todo para la ferrería, es mejor "el hazer della fuero por años que no arrendarla de tres en tres años porque a causa de la tener por tan poco tiempo la dexaban ir a yermo e asolaban los montes necesarios para las maderas della"2240.

La ferrería era, pues, aún más antigua, probablemente de la primera mitad del siglo XVI, y hasta entonces se arrendaba de tres en tres años; pero los renderos no parece que hubieran tenido mucho interés en cuidarla ni en conservar los montes, sino sólo en lograr los mayores beneficios en el menor tiempo. Por eso, la encomienda busca remediar esa situación mediante su aforamiento a Juan Ortiz, que ya la traía en arrendamiento. En el foro se incluye el palacio nuevo y viejo, las casas, montes y aderezos de la ferrería; pero "no bos afuero jurisdicion civil ni criminal ni luctuosas ni penas de camara ni benero de oro ni plata ni otro metal alguno que sea saluo si fuere de yerro porque esto reservo para mi y para dicha encomienda"2241. Él y sus sucesores deben de pagar la renta, cuidar la ferrería y acrecentarla, y tras 29 años dejarla libre, corriente y moliente ${ }^{2242}$.

Este Juan Ortiz estuvo casado con Marina de Sarauz o Zarauz, de la que tuvo cuatro hijos: Julián, Juan, María e Isabel; pero debió morir joven, antes de 1558 en que se realiza el inventario de sus bienes, dejando a los niños de corta edad (el mayor tenía 12 años) ${ }^{2243}$. Tras su muerte siguió disfrutando el foro su

\footnotetext{
2240 AHRG. R. A.: 19.768/32

${ }^{2241}$ AHRG. R. A.: 19.768/32

2242 AHRG. R. A.: 19.768/32

${ }^{2243}$ AHRG. R. A.: 19.768/32. El inventario, hecho el 8 de noviembre de 1558, menciona "la ferreria con toda su monicion de palancas, maços, tenazas e todo lo más a ella nescesario en la qual declaro que avia tres varquines caudales e tres pares de barquines de las fraguas", la casa "que es el palacio de la dicha ferrería", un molino, "quinientos quintales de bena por cozer junto a la ragua de la dicha ferraria" y "otros quinientos quintales de bena cocida en los formigueiros donde se saca". Además se relaciona una larga cantidad de deudores, entre los que están el "aroça Estibariz", el tirador Martín de Sagarminada, "Martino aroça", Antonio mulatero, Domingo de Padria tirador, Martin de Berganza "rendero de la ferrería nueba", le debe Sebastian de Baldomir 500 rs. "por los quales le tiene penado el maçuco". También le
} 
mujer, que poco después se casaba en segundas nupcias con Ortuño Sánchez. A ambos, en 1560, cedió Juan de Solís, gobernador de la encomienda de Quiroga, el arriendo de las rentas y diezmos de dicha encomienda por 61.000 maravedís anuales $^{2244}$; pero al cumplirse el plazo de los tres años, en 1563, la encomienda los ejecuta por una deuda de 40.000 maravedís en las rentas de La Seara y 14.00o del fuero de la ferrería de Soldón del año 1561, por un valor por tanto de 54.0oo maravedís. Como no tienen otros bienes que el foro de la ferrería, se pregona por tres veces éste, hasta que en abril de 1563 adquiere dicho foro de la ferrería por la mencionada cantidad Pedro González, vecino de la villa del Castillo de Os Novaes.

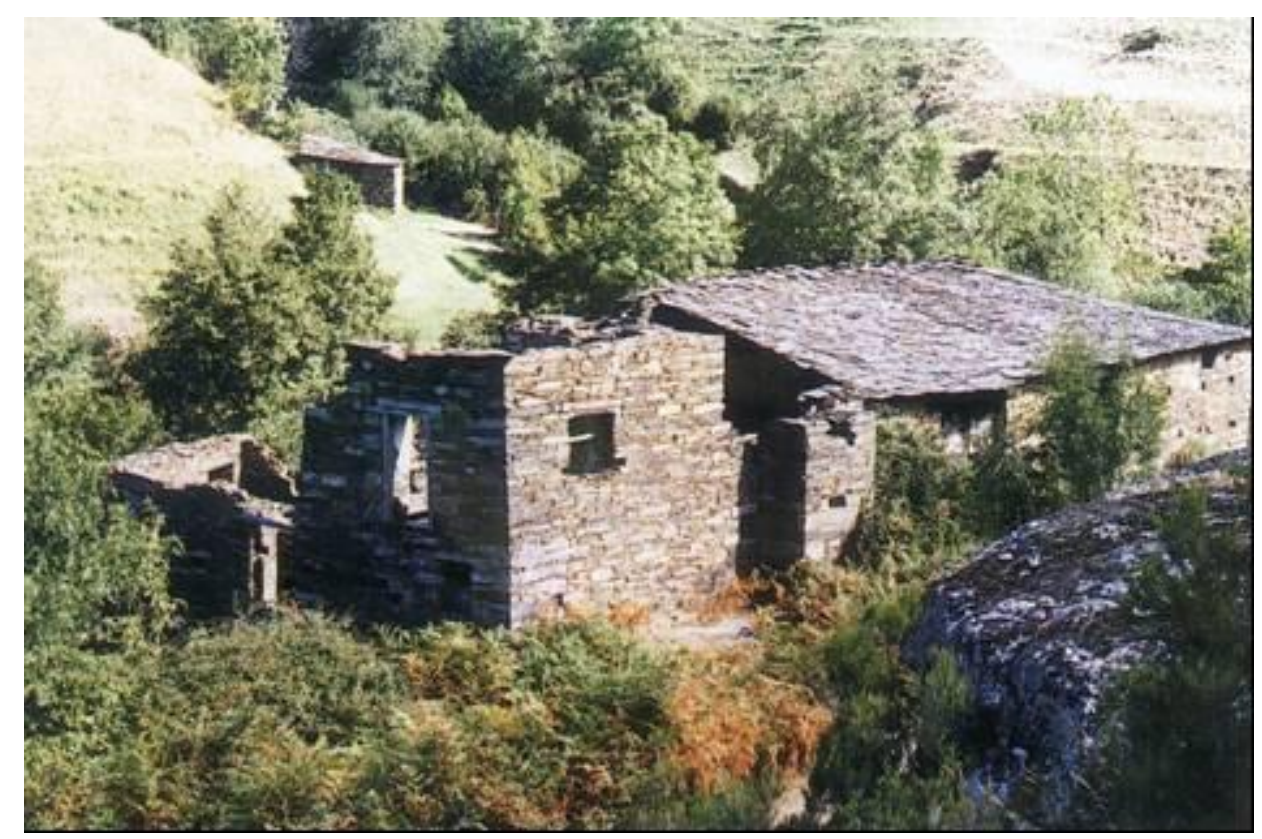

Ferrería de Soldón

La toma de posesión se hace con todo el ritual propio de estos actos. El alguacil llevó a Pedro González "e lo metio dentro de la dicha herraria e lo llebo al maço della la qual dicha herraria entrego con el dicho maço e rruedas e con sus palancas e tenezas e con todo lo demás a ella anexo (...) y el dicho Pedro

deben, de obligaciones en Vizcaya, seiscientos o setecientos ducados. Igualmente aparecen pequeñas cantidades que debe él: 14 ducados por un macho a Juan de Valcarce, de Villafranca del Bierzo, 48 reales por aderezar la herramienta de la ferrería, los barquines al barquinero Martín Santo, etc. En 1574, a partir del inventario de 1558, se tasan los bienes que dejó Juan Ortiz por demanda de sus hijos contra su madre. Se mencionan muchos bienes del oficio (fraguas, barquines, tenazas, mazos, etc.), años del arriendo de la ferrería de Soldón, deudas a su favor, etc. por valor de 57.054 rs., de los que la mitad son de la mujer, el resto 22.690 rs. es lo que debe a sus hijos.

2244AHRG. R. A.: 19.768/32 
Gonzalez se paseo por la dicha herraria e dio agua al maço e lo hizo andar...”. En el acto están presentes un buen número de oficiales, la mayoría vascos: Juan de Butrón, aroza, y Martín de Barrulaça "aroça de baldomir", e Juan de Çamudio e Pedro Lopez de Vesuña e Francisco de Mondelo de Vilar e Juan de Lasarte maestro de ferrage ${ }^{2245}$. Pero poco después, en ese mismo año, este Pedro González cedió la ferrería, en las mismas condiciones del foro primitivo, a Andrés López y Miguel Fernández de Villarrubín.

Hasta aquí todo parece normal, pero años después nos enteramos de que lo que debió subastarse en 54.000 maravedís fue sólo una parte de la ferrería y que otra parte seguía en manos de la familia Ortiz ${ }^{2246}$; pues Juan Ortiz de Artunduaga, hijo del otro Juan Ortiz, dirá en 1584 que antes de casarse con Catalina de Arburu, en 1580, él era propietario de la mitad de la ferrería de Soldón por la que había pagado 600 ducados 2247 . De hecho aquel año aparece el matrimonio como renderos de esta ferrería ${ }^{2248}$. Por esa razón en 1579, año en que se cumplía el tiempo del foro hecho a su padre en 1550, el comendador Alonso de Cotán se la volvió a aforar junto con los herederos de Miguel Fernández de Villarrubín, por la renta de 18.000 maravedís ${ }^{2249}$.

Como a su madre María de Sarauz, tampoco a este Juan Ortiz parecen irle muy bien las cosas, ya que en 1584 éste y su mujer reconocen deberle a Francisco López de Quiroga, vecino de la Granja de la Ermida, 570 ducados "los quales les prestó en reales por le hazer buena obra para adereçar el bançado y traer el arbol e bena e adereços de la dicha herraria y para pagar la renta que se debe al sr. comendador de Quiroga desta dicha herraria”. Para pagarlos se

2245 AHRG. R. A.: 19.768/32

${ }^{2246}$ AHRG. R. A.: 19. 768/32. En 1570 los hijos de Juan Ortiz pleitean con su madre, María de Sarauz, por la legítima. Presentan en el pleito el inventario de los bienes de su padre de 1558, la subasta de la ferrería de Soldón, etc. En julio de 1574 los tasadores evalúan los bienes dejados por Juan Ortiz en 57.054 reales, descargándosele a Marina de Sarauz 22.690, por lo que se condena a ésta a pagar a sus hijos 22.690 reales. Un testigo, en 1574 dice que hará unos catorce años más o menos "que Alonso de Solis comendador que fue de esta encomienda pedió hexecución en la mitad de la dicha herreria por çierta quantia de mrs". El documento de subasta de 1563 no dice que fuera la mitad, pero al parecer así fue.

2247 AHRG. R.A.: 20441/70

${ }^{2248}$ Esta Catalina de Arburu era hija de Miguel de Arburu "aroça de herrerías" y de María de Orbieta (AHRG. R.A.: 20441/70)

2249 AHRG. R. A.: 20.441/70. En 1586 dirá Juan Ortiz "que dicho sr. gobernador le avia echo fuero de la eRaria de Soldon con todo lo a ella perteneciente para si y los herederos de Miguel Fernández de Villarrubín por todos los días de la bida del dicho Juan Ortiz y otras tres vidas y personas después del". 
obligan a darle, por los 570 ducados, "cada semana diez quintales de hierro delgado y bueno a precio de a diez y nuebe reales quintal, ques el precio que comunmente agora vale" ${ }_{250}$. En 1586, probablemente porque no pueden pagar la deuda acuerdan "vender y traspasar (la ferrería) en el dicho Francisco Lopez de Quiroga que estaba presente por el tiempo y bozes que la tenía2251", con la renta de 18.000 maravedís a la encomienda, más 600 ducados para ellos. Más que una venta fue en realidad una ejecución por deudas, que posteriormente traería su cola. Este Francisco López no debió explotarla directamente, sino que la tenía arrendada pues en 1596 se menciona como rendero de la misma al vasco Juanes de Ezeolaza2252.

A comienzos del siglo XVII se entabló un doble pleito en relación con la propiedad de esta ferrería. Primero de Catalina de Celaya contra Juan Ortiz; posteriormente de aquélla contra doña Jerónima de Villasur, viuda de Francisco López de Quiroga, y sus hijos. El primer pleito se suscitó porque Catalina de Celaya, hija de soltera de Catalina de Arburu y su heredera universal, exigió a Juan Ortiz, marido de ésta, la dote de 4.800 reales que aquél había recibido cuando se casaron en 1580. Este Juan Ortiz, a su vez, afirma que por entonces él poseía la mitad de la ferrería de Soldón, pero que por deudas la justicia de Quiroga lo había ejecutado, obligándole a vender, en realidad a malvender, la citada ferrería a Francisco López de Quiroga, ya que su parte valía más de los 600 ducados que aquél le entregó. Por eso, en 1603 éste da su poder a Juan de Celaya, rendero de Órreos y hermano de Catalina, para que pleitee en su nombre contra Jerónima de Villasur y recobre parte del valor de la ferrería y así podrá cobrar ésta los 4.800 reales de la dote. De este modo unos y otros esgrimen razones sobre lo ocurrido y el valor del artefacto. Doña Jerónima dirá que su marido la adquirió legalmente por la deuda de 500 ducados, que era más de lo que valía, y por el contrario los otros dirán que no es cierto, que valía

${ }^{2250}$ AHRG. R. A.: 20.441/70

${ }^{2251}$ AHRG. R. A.: 20441/70. Con el permiso del comendador dice que "bendo y traspaso en el señor Francisco Lopez de Quiroga, becino de la hermida questa presente la media eRaria de Soldon con todas sus harboles, Rueda, barquines, yunque, cepos y con todo lo demas a la dicha eraria anexo y perteneciente y corriente y moliente como aora esta", por los 600 ducados "que por ella me dio y pago antes de aora de los quales me doi por entrego (...) por quanto confieso deberlos al dicho señor Francisco Lopez y abermelos su merced prestado y estar por ellos executado y deberselos yo realmente".

2252 AHPLU: 2407/9 
mucho más por ser una de las ferrerías mejores de la comarca, con una renta anual de 150 ducados, etc. ${ }^{2253}$. El pleito se alargó aún muchos años. Pero una parte siguió siendo de los herederos de Miguel Fernández Villarrubín²254.

En los primeros años del siglo XVII, como hemos dicho, una parte de la propiedad pertenecía a la familia Quiroga Villasur; por ejemplo, en 1603 doña Jerónima arrienda a Juan de Fagoaga la parte que le corresponde en la ferrería por tiempo de 4 años y 66 quintales de hierro de renta anual, puestos a su costa en su casa de la Ermida2255. De los Quiroga Villasur pasó, por el matrimonio de Constanza Losada Quiroga, fallecida en 1614, con Diego de Prada, señor de Outarelo, a su hijo don Andrés de Prada y Losada, como recuerda éste en una carta de pago a su suegro, el marqués de Viance, de 1629, por la que hipoteca sus ferrerías de Soldón y Valdomir, al tiempo que nos aclara que las heredó de su madre y abuela ${ }^{2256}$. Años antes, en 1620, el mencionado Diego de Prada, en nombre de su hijo, la subaforó al vasco Juan Martínez Goicoechea en nombre de

2253 AHRG. R. A.: 20.441/70. En 1603 se pregunta a los testigos si saben que cuando entró Francisco López a poseer la mitad de la ferrería "valía y vale al presente al gusto y común estimación más de dos mil ducados”, y si saben, además, que la mitad de la ferrería de Soldón vale de renta 150 ducados: "Porque está la dicha herreria en muy buena parte para comprar los vastimentos que a menester como para vender sus mercaderias a las ferias y mercados de quiroga, valdeores y Villafranca y Ponferrada, y Ansimismo tiene alrrededor muy grandes $y$ buenos montes para la leña de rragoas y carbon a quatro y cinco jornadas cada día y aún más y tiene tanbien la venera de Formigueiros a dos jornadas francas al día y es la mejor bena que ay en este reino y demás desto no tiene necesidad de presas, y tiene agua todo el año para labrar que estando bien aperceuida puede labrar ella mas de mill y nuebecientos quintales de hierro en cada año y aun dos mill y por eso saben los testigos que balia bien y bale la dicha mitad de la herreria de Soldon de Renta en cada un año los dichos ciento y cinquenta ducados". Jerónima Villasur dirá, a su vez, que no valía lo que pagó su marido "porque estaba perdida y asolada, sin bançado ni barquines"; lo que de acuerdo con el inventario, no era totalmente cierto.

2254 AHRG. R.A.: 20.441/70. En 1603 García de Vaamonde, en nombre de J. Villasur, dice "que la mitad de la herrería sobre la que hes el juicio no hera ni fue de Juan Ortiz, antes fue de los herederos de Miguel Fernández de Villarrubín, que la tenía arrendada de los comendadores de Quiroga, cuya es la propiedad y les pagaba por ello quince mill mrs. en cada un año".

2255 AHRG. R. A.: 20.441/70. Este Juan de Fagoaga se menciona como rendero de Soldón también en 1616, en un poder que da a María de Lindoso para que en su nombre cobre a Pedro, mulatero de Valdomir, 91 rs. de una carga de ferrage que le dió para comprar una recua (AHPLU: 2555/1).

${ }^{2256}$ AHPOU. Outarelo-genealogía: caja 77, $\mathrm{n}^{\circ}$ 14. Carta de pago de Andrés de Prada y Losada a favor de don Alvaro Pérez de Losada, marqués de Viance, de 3.00o ducados prometidos al tiempo de contraer matrimonio con su hija doña Constanza Antonia de Losada, según capitulaciones matrimoniales del 1 de noviembre de 1628: " $y$ particularmente me obligo $e$ ypoteco para mayor seguridad de lo que dicho es los vienes siguientes: la herreria de Soldón (...). Y asimesmo ipoteco la terçera parte de la herrería que llaman de Baldomir en tierra de Courel encomienda de la Barra que tanvien trae de mi mano Pedro Díaz Yçuluaga Rendero della los quales dichos vienes son propios de mi dicho Don Andrés de Prada y Lossada que los heredé de $D^{a}$ Constanza de Lossada y Quiroga mi madre y de $D^{a}$ Gerónima de Villasur mi abuela difuntas libres de vínculo y mayorazgo, obligaciones e ypotecas de toda restitución". 
los hermanos Lázaro de Celaya y Juan de Celaya, vecinos de la herrería de Soldón, por el tiempo y voces que la encomienda de Quiroga se la había aforado a su familia ${ }^{2257 .}$

La razón de este foro no fue otra que solucionar de una vez el viejo pleito. Unos y otros vuelven a esgrimir las razones ya conocidas, pero al fin reconocen que los pleitos son muy costosos y de final dudoso, por lo que se conciertan en que don Diego de Prada, en nombre de su hijo, "les haga fuero de la dicha media herraria sobre la que se litiga e de la mitad que yo y el dicho mi hixo poseemos la quieta y pacifica posesion con sus montes que solia tener toda la dicha herraria con mas otros montes que a ella añadio y compro el dicho Francisco Lopez de Quiroga mi suegro al dicho Laçaro de Celaya”. Se la afora por el tiempo que la tenían aforada "e por las mas voces que el fuero le fuere alargado". Entre las condiciones, además de la pensión a la encomienda de Quiroga y el foro de la venera, han de pagar cien ducados a su hijo y herederos de renta cada año, y por una vez, por atrasos y costas, 400 ducados: $200 \mathrm{al}$ contado y otros cien cada año de 1621 y $1622^{2258}$.

Sin embargo, en septiembre de ese mismo año en que se afora, es decir en 1620, Miguel de Alza, rendero de la ferrería de Quiroga, al enterarse de este subaforamiento a los Celaya se opone, porque según dice, doña Jerónima de Villasur, dos años antes, se la había arrendado a él por nueve años "e los mas que quisiese", por lo que no pueden disponer de ella en su perjuicio: "en virtud della yo puse de mi mano a Juanes de Fagoaga rendero que en ella asiste juntamente con el susodicho (Lázaro Celaya) el quel estubo y está en ella de mi mano y en mi nombre teniendo siempre la mitad a su disposicion labrando en ella y beneficiándola"; y añade, pagando la renta a dicha señora hasta su muerte y luego a don Diego ${ }^{259}$. Se inicia así un nuevo pleito en las que unos y otros

${ }^{2257}$ AHPOU. Láncara-Lousadela-Hacienda: caja 90, $\mathrm{n}^{\circ}$ 173: Foro de "esta dicha Herrería de Soldón con todos los montes adquiridos de los vecinos y los lugares de Soldón y la Seara, con todo lo más a ella anejo y perteneciente por el tiempo y voces que el dicho Don Diego como padre de su hijo tenían en foro que a sus antecesores hiciera el Comendador de la Encomienda de Quiroga; por renta y pensión cada un año de cien ducados pagos en dos plazos que son en fin de febrero y fin de agosto puestos en mano y poder de Don Diego, su hijo o quien los representare".

${ }^{2258}$ AHRG. R. A.: 12.476/2

2259 AHRG. R. A.: 12.476/2 
alegan sus razones. Lázaro de Celaya dice que Miguel de Alza no tiene razón y solo quiere enredar: "pues hes llano que qualquiera fuero o venta derogue los arriendos que son o fuesen echos de diez años auajo maiormente que el que alega la parte contraria quando fuera echo por mas tiempo de los diez años era nulo"2260.

En 1629 la ferrería seguía en manos de Juan de Celaya, aunque bajo el foro de Andrés de Prada2261. En su testamento, de 1632, con solo veintidós años, Andrés de Prada, en agradecimiento a su padre y hermanas por los gastos de su familia cuando sirvió de paje en la corte y en las pruebas para ingresar en la orden de Santiago, les asignó las rentas libres de las ya citadas herrerías de Soldón y Valdomir, por un valor de cien ducados al año ${ }^{2262}$.

El comendador de Quiroga, don Alvaro de Ulloa, poco después, en 1637, demandó a Juan de Celaya y a Juan Rodríguez, renderos de Soldón, para que dejasen libre la ferrería por haber finalizado el tiempo del foro. Estos alegan que la ferrería "hes nuestra por fuero que della nos hiço el dicho Don Diego de Prada y su hijo don Andres de Prada y Losada difunto". El comendador, por su parte, recuerda que es de la encomienda porque ha pasado el tiempo de las tres vidas y los 29 años más del foro ${ }^{263}$. Desde 1637 hasta 1641 fue rendero Antonio

\footnotetext{
2260 AHRG. R. A.: 12.476/2

${ }^{2261}$ AHPOU. Outarelo-genealogía: caja $77, \mathrm{n}^{\circ}$ 14. En la mencionada carta de pago dice Andrés de Prada que hipoteca "la herrería de Soldón que es mia propia, y esta sita en la encomienda de Quiroga segun que oy la trae de mi mano Juan de Celaya".

${ }^{2262}$ I. GARCÍA TATO (1999): Vilanova, Outarelo y San Francisco Blanco. Monografía histórica de una parroquia gallega. Instituto de Estudios Valdeorreses. Cuaderno monográfico $\mathrm{n}^{\circ} 30, \mathrm{p}$. 454: "Y asi para descargo de mi conciencia quiero y es mi voluntad que de la renta que tengo libre en las herrerías de Soldón y Valdomiel, o en otra mas bien parada, se consignen dichos cien ducados en cada un año, en descuento de lo que gasté de dicha manera"

${ }^{2263}$ AHRG. R. A.: 12.476/2. En 1639 Pedro de Soto en nombre del comendador dice que se condene a Juan Rodríguez y a Juan de Celaya a devolver la ferrería porque: "Resulta que dende el año pasado de quinientos y cinquenta Juan Ortiz el viejo y Juan Ortiz el moço su hijo, Francisco Lopez de Quiroga y dona Xeronima de Villasur su muger an lleuado los dichos uienes en birtud de los dichos aRiendos" (habla luego del contrato entre don Diego y Lázaro de Celaya, etc)... "Consta asimismo que dicho D. Diego de Prada hestubo casado con dona Constanza de Quiroga Losada hija legitima y heredera de los dichos Francisco Lopez de Quiroga y doña Jeronima de Villasur y que della ubo al dicho don Andres de Prada y que deste quedo por hija legitima la dicha dona María Antonia de Prada y Losada (...) a quien se via el último de dichos tres arrendamientos el año pasado de quinientos noventa y quatro por veinte $y$ nueve años que corrieron desde el año de mil y seiscientos $y$ ocho y fenescieron en treinta $y$ siete".
} 
de Achega 2264. Por esos años parece que la renta del fuero era de 18.00o maravedís anuales ${ }^{2265}$.

Quizá la ejecutoria citada en la nota precedente explique que años después el foro ya no parece estar en la familia de los Prada Losada; pues en 1669 aparecen como poseedores del foro de la ferrería por la encomienda de Quiroga doña Antonia de Losada y su marido, don Juan de Valcarce, aunque no sabemos si la citada Antonia de Losada era descendiente de aquéllos ${ }^{2266}$. En 1689 se menciona como rendero de las ferrerías de Quiroga y Soldón a don Francisco de Herrera y Cervera, juez de la encomienda de Quiroga ${ }^{2267 .}$

De comienzos del siglo XVIII conocemos a varios administradores de la ferrería, como Antonio Sánchez Somoza ${ }^{2268}$ y el presbítero Diego Testa ${ }^{2269}$; pero en 1727 la traía arrendada fray Juan Antonio Somoza y Quiroga, prior de San Salvador del Hospital ${ }^{2270}$. En 1728, terminado ese arriendo, don Josep Quiroga Lemus y Valcarce, señor de las jurisdicciones de Soñar, Anguerinos, Sésamo y Burela, dueño del útil de la ferrería de Soldón, "y del directo dominio de la Encomienda de Quiroga" la arrienda nuevamente al ponferradino don Francisco Guerra Donís, por cuatro años, con la renta de 4.200 reales al año más las cargas de $\mathbf{1 . 1 0 0}$ reales de foro a la encomienda, 400 reales al conde de Maceda por la vena de Formigueiros y seis ducados y medio de congrua al

2264 En las cuentas de Juan Álvarez Ojea, que fue administrador de las encomiendas de Quiroga, declara éste "que le pagó Antonio de Achega por don Diego de Prada, que los debía del fuero de la herrería de Soldón por tres años, desde 1637" 1.588 reales de plata; y también, sigue diciendo que se carga de 750 ducados de 11 reales cada uno "que recibí de D. Diego de Prada por mano del dicho Antonio de Achega, en los quales salió condenado por los frutos de la herrería de Soldón, conforme una executaria que ganó el dicho comendador en la Real Chancillería de Valladolid". Cit. I. GARCÍA TATO y E. ÁLVAREZ (2012): Las Encomiendas gallegas de la orden de San Juan de Jerusalén. Estudio y edición documental. T. II-2 ${ }^{\circ}$. La Encomienda de Quiroga. Santiago de Compostela, p. 640 y 641.

$2265 \mathrm{Al}$ administrador de los bienes de la encomienda de Quiroga, Juan Álvarez Ojea, se le toman de cargo en 1641 "quatro mill quinientos y ochenta y ocho reales y ocho maravedís de plata de los frutos de la herrería de Soldón, de ocho años, a raçon de diez y ocho mill maravedis de plata cada un año". Cit. I. GARCÍA TATO y E. ÁLVAREZ (2012): Las Encomiendas gallegas de la orden de San Juan de Jerusalén. Estudio y edición documental. T. II-2 ${ }^{\circ}$. La Encomienda de Quiroga. Santiago de Compostela, p. 633.

2266 B.N.: Ms. 13.338: Prioratos de Castilla de la Orden de San Juan de Jerusalen, fs. 303v-304r: "Paga don Juan de Valcarce por razón de la herrería de Soldón, casas, cavallerizas, huertas y prados a ella anexos que está inclusa dentro de este partido de la Seara y es uno de los fueros sueltos que no entran en partido. Paga don Juan de Valcarce y doña Antonia de Losada por fuero que tiene de la herrería de Soldón mil y cien reales de vellón".

2267 AHRG. R. A.: 1662/4

${ }^{2268}$ Lo era en septiembre de 1700 (AHPLU: 2514/5)

2269 Administrador en 1721 (AHPLU: 2570/6)

2270 AHN. Estado: leg. 1739, no 16 
vicario de Santa Magdalena de la Seara ${ }^{2271}$; arrendamiento que se debió renovar otra vez, pues años después seguía como rendero de ésta y de la de Arnado en el Bierzo 272 .

De don José Quiroga, la ferrería pasó a su hijo Pedro Carlos de Quiroga Lemos y Miranda, señor del pazo de Herbes ${ }^{2273}$, vecino de Betanzos según el Catastro de Ensenada, el cual nos informa que trabajaba sólo cuatro meses al año y dejaba un beneficio de 4.000 reales. A éste le sucedió otro don Josep Quiroga de Herbes, como señala Cornide hacia 1780, añadiendo que la ferrería producía 1.000 quintales al año 2274 , cantidad que Lucas Labrada rebaja a sólo 200 quintales 2275 . Por esos años, en 1790, el administrador de la ferrería de Bueyes se querelló contra doña María Antonia Pardo y Quindós, como madre de don José Ignacio Quiroga, dueño de la ferrería de Soldón, por decirle que le perturbaba en la posesión privativa de arrancar vena en una de las veneras de Formigueiros ${ }^{2276}$; querella que 1791 se extendió a su administrador don Jose Díaz de Castro, presbítero, acusado por don José María Tineo y Ulloa, dueño de las ferrerías de Bueyes y Valcarce, por arrancar vena de Formigueiros, en una venera que aquel consideraba propia de su ferrería ${ }^{2277}$. Dos años después, en 1793, este mismo hubo de pleitear con los vecinos de Outeiro por abrir una zanja en el río para regar sus prados, lo que perjudicaba a la ferrería ${ }^{2278}$.

\footnotetext{
2271 AHPLU: 2570/2

${ }^{2272}$ AHPL. PN.: caja 3341. En 1733 Úrsula Blanco vende una tierra en Friera, de 2 cuartales, en 156 rs. vn a don Francisco Guerra Donís "arrendatario de la Herrería de Soldón, en el Reyno de Galicia"; en 1734, Pedro Santín de Yrrasti, rendero de la ferrería de Visuña, da su poder a " $D$. Francisco Antonio Guerra Donís, arrendatario de la herrería de Soldón...”.

${ }^{2273}$ AHRG. R. A.: 7451/13. En 1747 el administrador de la encomienda de Quiroga hizo foro de los montes del coto de la Seara "a fabor de D. Pedro Carlos de Quiroga Lemos y Miranda, dueño de la casa de Erbes, como propietario de la ferrería de Soldón”.

2274 J. CORNIDE: $O b$. cit. ff. 225.

2275 L. LABRADA: Ob. cit., p. 143: "En el coto de Seara se halla una herrería a donde se trabaja al año como 200 quintales de hierro".

2276 AHN. Estado: leg. 1739, ${ }^{\circ} 16$.

2277 AHPL. PN.: caja 3377 (1791) Lo acusaba que con sus operarios se había introducido en su venera a extraer un mineral que, según don José María Tineo, le pertenecía; pues él y sus antecesores siempre se hallaron "posehedores, cada uno en sus respectivos tiempos, de usas y aprovecharse de una venera situada en la montaña llamada de Formigueiros, a consecuencia de títulos lexítimos, arrancando de ella, con idependencia de otro alguno, toda la vena necesaria para el consumo de su herrerfía de Bueyes"

${ }^{2278}$ AHRG. R. A.: 11.587/10. Dice don José Ignacio Quiroga Ulloa y Quindós que su ferrería de Soldón "trabaja con el agua del riachuelo a que da nombre aquella fábrica y se compone de los arroyos denominados de Montouto y Seara, de cuia agua ha usado siempre (...) y lo hicieron sus causantes (...) desde tiempo inmemorial".
} 
No muy lejos de esta ferrería había un mazo con el mismo nombre, en el que según Munárriz, al igual que en el de Folgoso, se hacían las toberas que utilizaban las ferrerías bercianas para inyectar aire al horno 2279 . Este autor distingue el mazo de la ferrería, de la que comenta que se abastece de la vena de Formigueiros 2280 , como ya sabíamos. En el mazo, además de las toberas de cobre, se hacían rejas y otros útiles ${ }^{2281}$. El mazo, que también nombra $M a_{0 z}^{2282}$, era de la familia Fernández Rigueiro, como vemos en 1807 en que se cita al presbítero don Pedro Fernández Rigueiro como propietario, y en 1842 Antonio Rigueiro ${ }^{2283}$. Esta familia fue también arrendataria de ferrerías, como por ejemplo Domingo Fernández Rigueiro que lo fue de la de Quintá en los años veinte del siglo XIX ${ }^{2284}$.

Durante la primera mitad del siglo XIX la ferrería siguió en manos de los señores del pazo de Herbes, que la explotan unas veces por medio de administradores, otras por arriendo. Entre 1808 y 1814 fue su administrador -en realidad arrendatario- don José Rodríguez Gallego 2285. En 1814 don Froilán Troche y Romero, administrador y apoderado del coronel don José Quiroga y Quindós, la arrienda por seis años a don Manuel Antonio Sánchez, en 41.00o reales $^{2286}$. Para la entrega del arriendo se hace un exhaustivo inventario ${ }^{2287}$. Este

\footnotetext{
2279 J. A. BALBOA (1992): Ob. cit., p. 130

2280 IBIDEM, p. 135.

${ }^{2281}$ AHPL.PN.: caja 3576 (1807). El 30 de agosto de 1807, en dos escrituras de obligación, dos vecinos de Combarros, se obligan a pagar a don Pedro Fernández Rigueiro, presbítero, del Mazo de Soldón, 1.015 y 850 rs. respectivamente "procedidos de yerro y rexas que les dio al fiado". 2282 MADOZ: ob. cit., t. XIV, p. 8.

2283 AHPL. PN.: caja 3580 (1842): Antonio Rigueiro, vecino del Mazo de Soldón se obliga a pagar a don Juan Fariñas, 85.530 reales de hierro que le vendió al fiado; para ello hipoteca las casas que habita en el Mazo de Soldón "con el mismo artefacto de mazo con sus fraguas, huerta y más aczesorio". Años antes, en 1826 (AHPLU: 2398/3), don Benito Sánchez, que había sido administrador y arrendatario de Soldón, reclama judicialmente a don Antonio Fernández Rigueiro 5.300 rs. "del importe de quintales de fierro que llevó... de la Herrería de Soldón”, y que en 1828 todavía no había pagado "de que provino la total ruina" de aquél.

2284 AHPLU: 2406/14

2285 AHPLU: 2406/11. En 1824 el administrador dice que en 1808 lo era don José Rodríguez Gallego. AHPLU: 2468/2. 15 de marzo de 1811; AHPLU: 2406/1. 11 de mayo de 1813. En este año, como administrador, y para evitar juicios siempre costosos, acuerda con Domingo Rodríguez, vecino de Soldón, que ha abierto una zanja en el arroyo de Rinan para regar un prado, que perjudica a la ferrería, el permitírsela pero con la condición de que cuando se necesite agua para la ferrería puedan sus administradores cortar el riego. AHPLU: 2406/2, en 1814 Juan Pérez dice en su testamento que está adeudando a José Rodríguez Gallego, administrador de Soldón 30 rs.

${ }^{2286}$ AHPLU: 2467/11. Le arrienda la ferrería con su casa, molino, bienes raíces, etc. desde 1814 a 1821 por la renta de 41.000 reales/año, más todas las pensiones a que está sujeta, así como costear todos los descalabros mayores y menores, etc.
} 
Manuel Antonio fue también arrendatario de la ferrería de Paleiras; era suegro de otros conocidos propietarios y renderos de la zona, como Benito Barraganes, Juan Fariñas y José de la Peña. En 1819 don José Quiroga se querelló con él por una deuda de 166.952 reales del arrendamiento de los años anteriores ${ }^{2288}$; de 1820 a 1822 la administró don Pedro Quiroga, vecino de San Mamed de Viana del Bollo, a quien hubo de separar "por justos motivos que mediaron", y con el que pleiteó en 1827 porque durante años le pidió cuentas, pero siempre alegaba que estaba enfermo 2289 .

En 1824 era arrendatario José Pérez ${ }^{2290}$, que por esos años construiría la ferrería de Outeiro, con la que ésta tendría problemas por uso del carbón, porque los vecinos de Outeiro se lo vendían a la nueva ferrería y no a la de Soldón²291. En 1830, don Jacinto Fariñas, arrendatario de la ferrería de Órreos, afianza a su hermano Juan Fariñas que "está decidido a recivir en arriendo la Herrería nombrada de Soldón en el coto de la Seara propia del señor Don José Quiroga y Quindós coronel de los Reales Ejércitos y vecino de Erbes"2292. Unos años antes, en 1824 el arrendatario era José Pérez, suegro de otro Ignacio Fariñas, hermano de los anteriores ${ }^{2293}$. Juan Fariñas debió administar la ferrería durante casi toda la década de los treinta ${ }^{2294}$ y parte de los cuarenta 2295.

\footnotetext{
${ }^{2287}$ AHPLU: 2406/3. 17 de enero de 1815. La fabrica corriente con todos sus pertrechos, "como son la tubera, barquines, rueda de estos, la de macear bastante vieja y espuesta a escalabros, el mazo yunque..." (luego cita todas las herramientas)... la fragua de manos corriente con su tubera de cobre... carbonera (con 9.600 reales en carbón), la plaza de la vena, (con 2.200 reales de vena cruda y 7.596 de vena cocida), la bodega del fierro (con pesas y balanzas), bodega del vino, casa de abajo, hórreo, cocina, molino, casa principal, prados, etc.

${ }^{2288}$ AHRG. R. A.: 12.446/45. Años más tarde, en 1826, su administrador dice que a don José Quiroga le fueron administrados diversos bienes en el Caurel que fueron de don Manuel A. Sánchez por la deuda de 160.000 y más reales; también en ese mismo año este Manuel Antonio dice que mucha gente "tanto del pais, del de Monte Rey, Caldelas y Maragatos del Reyno de León" le deben mucho dinero de partidas de hierro que les dió al fiado cuando era arrendatario de Soldón y Paleiras (AHPLU: 2398/5); quiza esas deudas fueron la causa de su ruina.

2289 AHRG. R. A.: 21.702/18

${ }^{2290}$ C. GONZALEZ (1994): ob. cit., p. 41. Sin embargo, en enero de ese año se menciona a don Manuel López Saco como administrador de Soldón (AHPLU: 2406/11). En 1826 era administrador el presbítero don José María Maceda (AHPLU: 2398/5).

${ }^{2291}$ AHRG. R. A.: 7451/13

2292 AHPL. PN.: caja 3578 (1830).

2293 C. GONZÁLEZ (1994): Ob. cit., p. 209

2294 AHPL. PN.: caja 3579 (1835): En una venta hecha en la Herrería de Soldón, aparecen como testigos Juan Fariñas y Francisco Sánchez, "residentes en la casa Herrería de Soldón”. AHPL. PN.: caja 3580 (1841): Don Juan Fariñas dijo "que con motivo de haver administrado algunos años la herrería de Soldón, diferentes sujetos del partido de Quiroga y otros le están adeudando partidas de maravedis procedentes de fierro que le sacaron al fiado". AHPL. PN.: caja 3580 (1842): Antonio Rigueiro, vecino del Mazo de Soldón, se obliga a pagar a Jacinto
} 


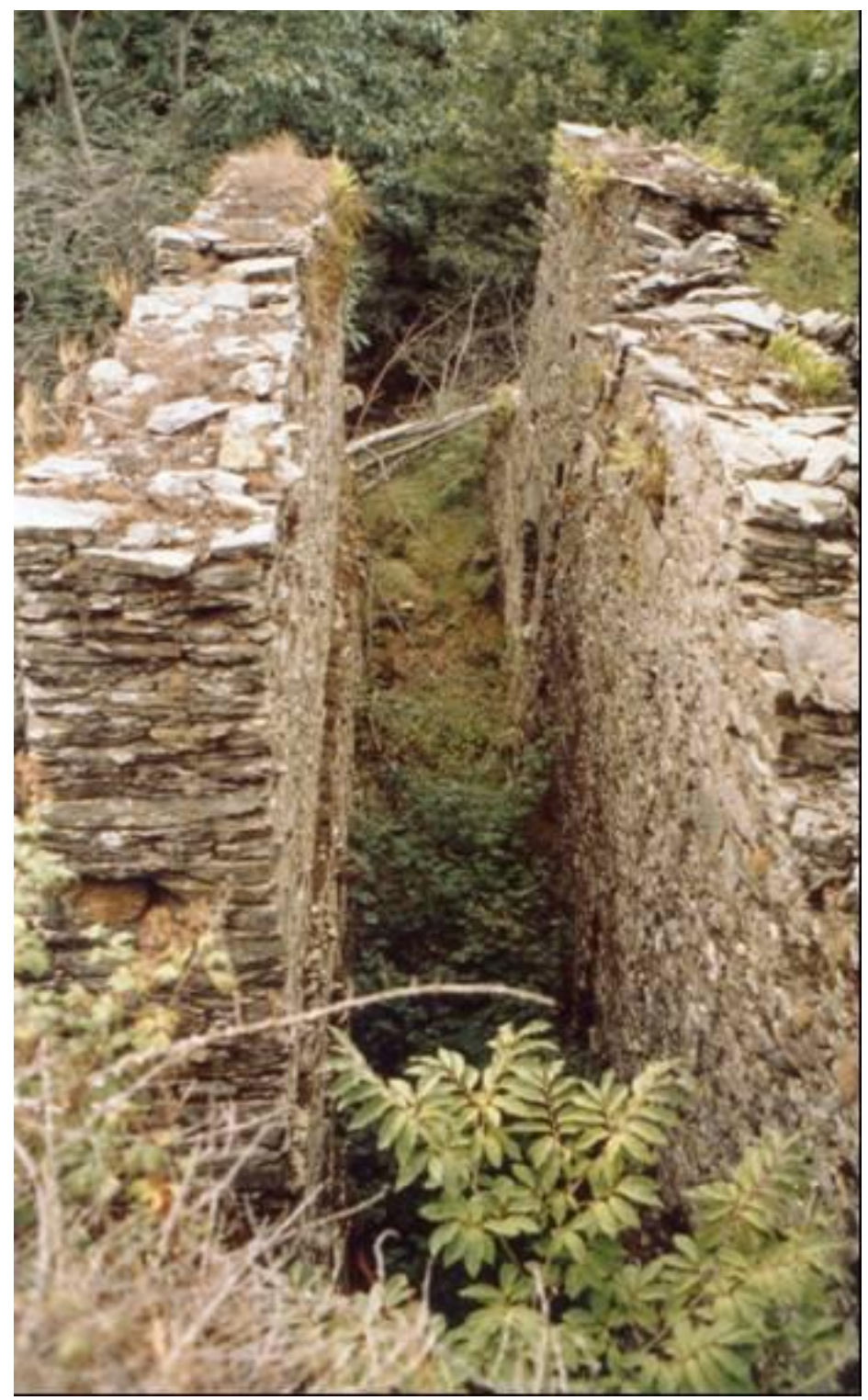

Ferrería de Soldón

Desde los años treinta hasta la segunda mitad del siglo fue propiedad de don Antonio Rivadeneira Acevedo, caballero del hábito de Santiago, dueño de las casas y pazos de Villaguirada, Quintanilla de Sollamas, etc., como marido de María Josefa Quiroga y Moscoso, hija y heredera de los vínculos y mayorazgos de don José Quiroga y Quindós, dueño del pazo de Herbes, propietarios

Fariñas 85.530 reales "que le está adeudando procedentes de fierro que le sacó al fiado en los nuebe años que administró la Erraria de Soldón y de dinero que le prestó sin ningún interés”. 2295 AHPL. PN.: caja 3581 (1845): Juan Fariñas, natural de Lusío y residente en el mazo de Soldón, vende a Benito Olmo, administrador de las ferrerías de Río Cabo, todo lo que tiene en Gestoso en 16.000 reales 
también de la de Villarbacú ${ }^{2296}$. La ferrería de Soldón pagaba, hacia el año cincuenta, al marqués de Santa María del Villar, 400 reales de foro de la vena de Formigueiros 2297. Madoz habla de que en La Seara hay una fábrica de hierro y un martinete ${ }^{2298}$. Poco después, hacia 1866, José Villamil y Castro estimaba que su producción anual era de unas 800 arrobas 2299 , cifra que muestra las dificultades de la ferrería, probablemente por falta de combustible, dado la competencia tan enorme por las muchas ferrerías de la zona. En 1874, en el que apenas trabajo tres meses, fundió 1719 Qm de los que obtuvo 573 Qm. Todavía trabajó hasta 1885 fundiendo 5 q.m. con 15 tn. de vena, aunque muchos años solo lo hizo uno o dos meses como máximo ${ }^{2300}$.

ESTADO: Todo está en ruinas, pero la vivienda aún conserva toda su estructura de sus muros, de buenos paramentos de pizarra, incluido el tejado también de pizarra. Al lado están los restos de la ferrería, de la que son visibles los muros del banzao y banzadillo, muy alabeados y a punto de arruinarse.

\title{
36. FERRERÍA DE VILARBACÚ
}

\author{
LUGAR: Vilarbacú (Parroquia de Seara) \\ MUNICIPIO: Quiroga \\ RÍO: de Vilarbacú \\ COORDENADAS: $42^{\circ} 32^{\prime} 58^{\prime \prime}$ N. y $7^{\circ} 8^{\prime} 12^{\prime \prime} \mathrm{W}$.
}

Los restos de la ferrería de Roxa Longa o de Vilarbacú se encuentran a unos tres kilómetros antes de llegar al lugar de Vilarbacú, al que se accede desde la Cruz de Outeiro (carretera de Quiroga a Hórreos), en el antiguo camino de Pacios da Serra. Sus ruedas las movía las aguas de un pequeño arroyo, el río de Vilarbacú, afluente del Quiroga.

\footnotetext{
${ }^{2296}$ AHRG. R. A.: 5909/40. También AHPLU: 2406/25: En 1838 don Juan Porto, como apoderado de don Antonio Rivadeneira, marido de doña $M^{a}$ Josefa Quiroga, dice que ésta es propietaria de la ferrería de Soldón, que lleva en arriendo don Juan Fariñas, y que en los mismos términos del foro que esa ferrería tiene de la encomienda de Quiroga este matrimonio va a construir otra ferrería, la de Vilarcabú.

2297 I. GARCÍA TATO, I (2000): Ob. Cit. p. 167.

2298 P. MADOZ: ob. cit., t. XIV, p. 8

2299 J. VILLAMIL y CASTRO: Ob. cit., p. 45

2300 P. HERNÁNDEZ SAMPELAYO: Hierros de Galicia, t. III, fas. $1^{\circ}$, p. 36 y 38.
} 
Los proyectos para la construcción de una ferrería en Vilarbacú se remontan a los años treinta del siglo XIX, en los que se suscitó un ruidoso pleito "por una errería en Villarbacú", entre sus promotores, don Antonio Rivadeneira y Acevedo y su esposa doña $\mathrm{M}^{\mathrm{a}}$ Josefa Quiroga y Moscoso, propietarios de la ferrería de Soldón, con el marqués de Hombreiro, propietario a su vez de la ferrería de Quintá y don José Ma Pardo San Cibrián, dueño de la de Paleiras. La denuncia fue presentada y admitida por la Audiencia de La Coruña en 1838, pese alegar el procurador de don Antonio Ribadeneira "que la fabrica de fierro que está lebantando mi parte en Villarbacú” ni está en terrenos del denunciante, ni "causaba perjuicios actuales a las ferrerías de Quintá y Paleiras, alegando por todo fundamento que la nueba fábrica se construhía en parage inmediato a las suyas ocasionándose grabísimos perjuicios por disminuirlas la leña y carbón que los vecinos les vendían y conducían y que era producto de los montes de la propiedad de Pardo San Cibrián y consorte”.

Al contrario, el procurador de don Antonio dice que la denuncia es maliciosa pues éste como dueño de la ferrería de Soldón cuenta con montes suficientes para abastecer a la nueva ferrería: "Mi parte dueño de la Herrería de Soldón y de los montes y derechos que le pertenecen adquiridos por foro de la Encomienda de Quiroga trató de construir otro artefacto dentro de los términos de la Carta foral, y adquirió terreno para el edificio en el sitio nombrado de la Ferbenza de Roja demarcación del lugar de Villarbacú, autorizando a su apoderado para proporcionarse además el suficiente surtido de bena por foro o en otra forma de los Montes de la Escelentisma Señora Condesa de Lemos" 2301.

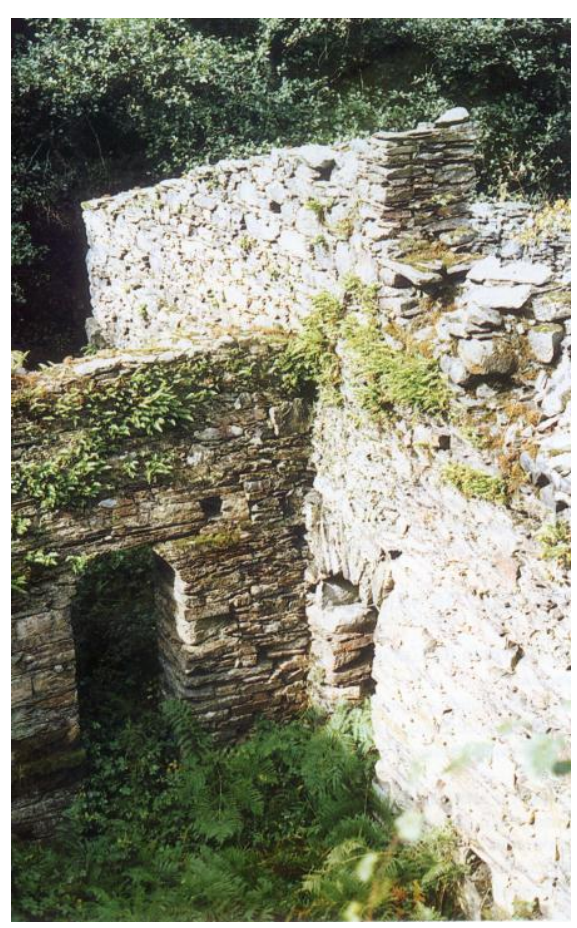


Sin embargo, el apoderado de don José $\mathrm{M}^{\mathrm{a}}$ Pardo San Cibrián se oponía porque dicha nueva ferrería "inmediata a la Herrería llamada de Paleiras" arruinaría "todas las demás herrerías sitas en aquellas inmediaciones pribándolas de la vena y más

útiles necesarios para la fabricación, sino que aprobechándose de sus fundos que no le pertenecen iba a producirse el aniquilamiento de la fábrica de la Herrería de Paleiras y de Quintá". No fue el único, porque el Comisionado de Arbitrios de Amortización de la provincia de Lugo se opondría igualmente alegando que perjudicaba a las ferrerías de Rodela y Rugando, expropiadas para su desamortización al monasterio de Samos: "con el fin de que la nación no se vea privada del crecido producto que le arrojan anualmente dichas Herrerías de Rodela y Rugando". La ferrería la construyen -el texto dice "no tenemos más que un edificio empezado"-, como administradores o arrendatarios, José Fariñas, natural de Lusío en el Bierzo, y José Porto; ambos ligados a esta industria del hierro2302.

El juicio debió retrasar unos años la puesta en funcionamientos, pues no comenzó a fabricar hierro hasta 1844, como consta en el acta de inauguración: "En el día diez y nuebe de Enero de 1844 principió ha dar yerro la Herrería nombrada de Roja Longa en los términos de Villar Bacú y a presencia del Alcalde Pedanio y los testigos que atodo se hallaron presentes en compañía del sr. alcalde que lo es Roque de Castro, Miguel y Juan Castro y José López y

${ }^{2302}$ AHRG. R. A.: 5909/ 40. Además del texto citado (AHPLU: 2406/25). 5 de junio de 1838: Don Juan Porto y Blanco, como apoderado de don Antonio Rivadeneira Acevedo, vecino de La Coruña, como marido de doña $\mathrm{M}^{\mathrm{a}}$ Josefa Quiroga y Moscoso dijo "que a la hacienda y fincabilidad que recayó en la sra $D^{a}$ María Josefa Quiroga corresponde la Herrería de Soldón, que actualmente lleva en arrendamiento D. Juan Fariñas, residente en la misma, con todos los montes y regalías de su anexión en la forma que se expresan y están demarcadas en la escritura foral de la Encomienda de Quiroga (...); y que habiendose determinado por los srs. sus principales la construcción de otro artefacto de igual naturaleza para hacer y dar fierro dentro de los términos de la carta foral (en un terreno comprado por el otorgante para sus señores al sitio denominado de la Fervenza de Roxa Longa términos del lugar de Villarbacú, parroquia de Santa María Magdalena de la Seara, para que haya sujeto que tanto en la construcción del artefacto, sus oficinas, y más a él perteneciente, con la solidez, perfección y firmeza indispensable llevando la cuenta y razón que para el cargo y sus datas pueda y deba ser abonada $y$ en orden al plan levantado, asi bien de mampostería como de carpintería; cuanto para adquirir el suficiente surtido de vena por foro o de otra forma en los montes de la Exma. Sra. Condesa de Lemos por la pensión o en el precio que más convenga; y no menos para la defensa de los derechos y regalías de los indicados montes, dentro de los cuales se halla sito el terreno y posición de la Fábrica vajo el nombre de la Fervenza de Roxa Longa... da su poder aD. Juan Fariñas, arrendatario de la ferrería de Soldón”. 
Pedro López entrambos Ermanos. No firman por no saber, a ruego del sr. Alcalde lo hace Francisco Rodríguez vecino de Otero de Soldón”2303.

Los propietarios eran Antonio Rivadeneira y Acebedo, caballero del hábito de Santiago, dueño de las casas y pazos de Villaguirada, Quintanilla de Sollamas, etc. y su mujer María Josefa Quiroga y Moscoso, heredera de los vínculos y mayorazgos de don José Quiroga y Quindós, dueño del pazo de Herbes, como hemos visto antes y se deduce del acta de toma de posesión de la ferrería: "En el día 9 de febrero (de 1844), tomó posesión el Sr. D. Antonio Riba de Neira de la Herrería de Roja Longa términos de Villarbacú en los Estados en que dicho día se encontraba aún no rematada la obra, por ante el escribano D. Bentura de el Quintanal residente y numerario en San Martín de Quiroga" 2304.

Utilizaba vena de Formigueiros, que se encuentra en sus inmediaciones, por cuyo foro pagaba don Antonio Ribadeneira 320 reales, y por la de Soldón, de la que también era propietario, 400 reales ${ }^{2305}$. Según Hernández Sampelayo aún trabajó en 1874 en una campaña de cuatro meses, en los que fundió 600 quintales de vena de Formigueiros de la que obtuvo 200 quintales de hierro, y en $1876^{2306}$.

ESTADO: Se conservan restos de muros de la ferrería, con el banzado y la fragua y carbonera; y de la vivienda del administrador.

${ }^{2303}$ C. GONZALEZ (1994): Ob. cit., p 210.

2304 IDEM, p. 211

2305 I. GARCÍA TATO (2000): Ob. cit., p. 168

${ }^{2306}$ P. HERNÁNDEZ SAMPELAYO (1935): Ob. cit., t. III, fasc. $1^{\circ}$, p. 39 y 36. En lugar de Vilarbacú, por error, la nombra Villabarcín. 


\section{MUNICIPIO DE RIOTORTO}

\section{FERRERÍA DE VILASECA}

LUGAR: Vilaseca (Parroquia de Santa Marta de Meilán)

MUNICIPIO: Riotorto

RÍO: Afluente del Eo

COORDENADAS: $43^{\circ} 21^{\prime} 30^{\prime \prime}$ N. y $7^{\circ} 16^{\prime} 34^{\prime \prime} \mathrm{W}$.

Desde Mondoñedo a Meilán y de allí a Vilaseca, en la parroquia de Santa Marta, a orillas de un pequeño afluente del Eo.

Según María Xosé Rodríguez Galdo, en la población de Vilaseca, dependiente del monasterio de Villanueva de Lorenzana, había en la Edad Media una herrería ${ }^{2307}$, que probablemente es la misma de la que tenemos noticia ya en el siglo XVI2308. En 1594, Francisco Pérez Monteseiro, de Riotorto, se obligaba a dar 16 quintales de "yerro de la tierra", de los fabricados en la ferrería de Vilaseca, al mercader mindoniense Diego de Cheilada2309.

Este Francisco Pérez Monteseiro era sin duda arrendatario de esta ferrería, que pertenecía a los Ulloa y Ribadeneira. En 1630 don Alonso de Ulloa y Ribadeneira, como propietario de la ferrería, acuerda con Bartolomé de Leibas la adquisición del carbón que éste vaya fabricando en un monte propio de don Alonso, en el lugar de Vilaouriz, pagándole por cada carga 1,2 reales, y por “dones" tres ducados. Para iniciar el trabajo le adelanta 28 reales en dos fanegas de centeno; en el mismo año y el mismo propietario se ajusta con dos vizcainos para que éstos le suministren 1.000 cargas de carbón para su ferrería ${ }^{2310}$.

2307 M.X. RODRÍGUEZ GALDO (1976): Señores y campesinos en Galicia: siglos XIV-XVI. Santiago, p. 82.

${ }_{2308}^{2}$ ¿Podría tener alguna relación esta ferrería con la llamada de la Ponte da Nobal en Santa Marta, que se menciona en 1553, al hablar de San Juan de Aguirre arota de dicha ferrería? AHPLU: 3973/2 (1553): Vivero, 15 de julio de 1553, estando presentes "de la una parte Fernan Cao de Cordido en nombre del señor Juan López de Prabeo vezino e regidor de la ciudad de Mondoñedo, como rendero que es el dicho Juan Lopez de la ferreria de Silan e de la otra San Juan de Aguirre bizcayno de la probincia de bizcaya aroza que al presente hes de de la ferrería de Ponte da nobal del condado de Santa Marta 2309 P. SAAVEDRA: Ob. cit., p. 330, nota 89. ${ }^{2310}$ P. SAAVEDRA: Ob. cit., p. 331, nota 94. 
En 1645, el curador de don Alonso Ulloa y Villamartín arrendó a los vizcainos Juan de Balderre y Martín de Celaya la ferrería con todos su bienes y derechos, entre los que entraban los diezmos, heredades, montes, rentas, luctuosa y todo lo que el propietario tenía en los cotos de Vilaseca y Moxoeira, así como los quintos de la vena del valle de Lorenzana, que como sabemos era propiedad del monasterio de Lorenzana. El arriendo se hace por cuatro años y renta cada uno de los vizcaínos de 1.100 reales y 44 quintales de hierro labrado 2311 .

Probablemente el dato sobre el quinto de la vena nos revela que la ferrería, como la del Saltejo, era también de este monasterio, quien pudo aforarla a la familia Ulloa, la cual a su vez la arrendaba a ferrones vascos. En 1671 Juan de Balderraín, administrador o rendero de la ferrería, se concierta con don Pedro López Villarino, vecino del valle de Lorenzana, para entregarla en la ferrería 50 quintales de hierro a 66 reales el quintal, por lo que ha de pagarle 200 ducados ${ }^{2312}$. Todavía a principios del siglo XVIII seguía en funcionamiento y pertenecía a Rodrigo Antonio Falcón de Ulloa, pero parece que tenía problemas con el combustible 2313 .

Posiblemente, como otras ferrerías vecinas, dejó de funcionar poco después a causa del combustible. El Catastro de Ensenada dice que en Santa Marta de Meilán no hay más que un mazo, evidencia de que la ferrería se había transformado en tal. La falta de combustible es lo que se alega en 1788 para la desaparición de todas las ferrerías de la provincia de Mondoñedo: "En la provincia de Mondoñedo (...) había antes de ahora cuatro herrerías de labrar hierro; la una en el valle de Lorenzana, otra en Santa Marta, otra en el Valle de Oro y sitio de Pesqueira y otra en la feligresia de Bravos (....).. Cuyas herrerías, por diferentes motivos, han quedado a hiermo y sin uso, imposibilitadas de jamás renovarse, efecto de la falta de leñas y carbón para su subistencia”"2314

${ }^{2311}$ P. SAAVEDRA: Ob. cit., p. 328 y nota 80.

2312 P. SAAVEDRA: Ob. cit., p. 328 , nota 81.

${ }^{2313}$ AHA. Caja 11249/09, doc. 28. Se cita una copia de una Real cédula, de 1716, sobre suministro de leña y carbón a esta ferrería, por estar su dueño en un pleito por esa causa con el prior del monasterio de Trabada.

${ }_{2314}$ A. MEIJIDE PARDO (1979): Ob. cit., p. 88, documento $n^{\circ} 26$ 
No hay noticias de que su reutilización posterior, como ocurrió en otros casos. Madoz no la menciona2315.

ESTADO: No hay restos.

\section{MUNICIPIO DE SAVIÑAO}

\section{FERRERÍA DE SARDIÑEIRA}

LUGAR: Santa Cruz de Rebordaos

MUNICIPIO: Saviñao

RIO: Sardineira

COORDENADAS: $42^{\circ} 37^{\prime} 35^{\prime \prime}$ N. y $7^{\circ} 40^{\prime} 59^{\prime \prime} \mathrm{W}$.

El Sardiñeira es un afluente del Miño, cuyas aguas movieron las ruedas de una ferrería, que se encontraba en las inmediaciones del lugar de Santa Cruz de Rebordaos, en el municipio de Saviñao, cerca de Monforte.

Desconocemos su origen pero probablemente haya que remontarla al siglo XVI. En 1628, Pedro López de Santa Cruz, vecino de Tierra de Saviñao, se querella contra Juan Marino y sus hijos Gregorio y Pedro Marino, porque teniendo aquel "en la Errería e machuco questá en el rrio de la Sardineira abaxo del lugar de la ciudad su parte e quiñón, y por razon dello los dichos acusados que trabaxan en el dicho machuco dende diez y seis años a esta parte, adreçaban a mi parte (al denunciante) sus logomes, açadones, fouces $y$ machados, hierros de arada y calderos y todas las demás herramientas y axuares sin por raçon de todo ello llebarle ningún derecho ni derechura ninguna y hestando ansi en posesion mi parte desde los dichos diez y seis años asta parte en bista y consetimiento de los acusados que lo consentín y adreçaban dichas herramientas (...) hasta haber quatro meses poco mas o 
menos que los susodichos por fuerça y contra boluntad de mi parte se sustraen de no quererlo hacer" ${ }^{2316}$.

Un testigo de Santa Cruz de Rebordaos, en 27 de mayo de 1628, dice que todo lo anterior es cierto, que desde hacía muchos años Pedro López les llevaba a la ferrería y machuco sus rejas y utensilios para arreglarlos, y que los Mariño siempre le trataron bien y que no le cobraban. El texto habla de una ferrería y un machuco que, al parecer, está dividido en partes o quiñones. Probablemente se trataba de una ferrería regatera y de un machuco con su fragua por el tipo de labores que realiza, pero es difícil precisarlo con esta única escritura. Si fuera una ferrería probablemente utilizaría hierro de Roques, pues no está lejos de este yacimiento.

Desconozco si la ferrería pervivió mucho tiempo y si tiene algo que ver con una "Herrería del Pez", que se menciona en un documento de 1850: "Domingo López del lugar de la Herrería titulada del Pez, parroquia de Santa María de Reyriz, distrito de Saviñao, partido de Monforte". No habla sólo de un lugar o topónimo sino claramente de una ferrería llamada del Pez, en el mismo municipio de Saviñao en el que se encontraba la otra, pero es probable que sea diferente y también una pequeña ferrería regatera.

ESTADO: Desconocido

${ }^{2316}$ AHRG. R.A 20527/ 41 


\section{MUNICIPIO DE SAMOS}

\section{FERRERÍA DE CARQUEIXEDA}

LUGAR: Parroquia de Santa Marina de Lózara

MUNICIPIO: Samos

RÍO: Lóuzara?

COORDENADAS: $42^{\circ} 37^{\prime} 35^{\prime \prime}$ N. y $7^{\circ} 40^{\prime} 59^{\prime \prime} \mathrm{W}$.

Se hallaba en el lugar de Santa Mariña, en la parroquia de Gundriz, por lo que a veces también se la nombra como ferrería de Santa Mariña.

No la mencionan ni el Catastro de Ensenada ni Cornide, por lo que hay que suponer que no existía en el siglo XVIII. Debió construirse hacia la mitad del siglo XIX, pues Madoz no la menciona2317. Hernández Sampelayo dice que del yacimiento de Rocas se surtieron dieciséis ferrerías gallegas, una de las cuales fue la de Carqueixeda2318; también se cita esta ferrería de "Carcajeda" en una relación privada de ferrerías de la provincia de Lugo, en un documento sin fecha de mediados del siglo XIX, de la Casa do Castro ${ }^{2319}$. Hay también algunas referencias en las Estadísticas mineras, por ellas sabemos que por falta de carbón no trabajó en 1873 ni en $1874^{2320}$.

Ignoro quien era el propietario de la ferrería, pero intuyo que debió tener algo que ver en ella Santiago Montero y su hijo Juan Antonio Montero. Aquél, natural de Santa Marina de Lózara y casado con Pascuala González, fue arrendatario con su mujer de varias ferrerías gallegas y bercianas de la zona del Selmo. Su hijo Juan Antonio Montero, en 1856, aparece como vecino de Carquejeda, en un juicio contra el dueño de la ferrería de Seoane, representando a los vecinos de San Pedro de Noceda por un problema en el amojonamiento de los montes bravos ${ }^{2321}$.

${ }^{2317}$ P. MADOZ: Ob. cit., t. X., p. 400 ${ }^{2318}$ HERNANDEZ SAMPELAYO (1935): Ob. cit., t. III, fasc. $1^{\circ}$, p. 112

2319 I. GARCÍA TATO (2000): Ob. cit., p. 167. Se trata de una relación de 38 ferrerías, de las cuales 20 son de Lugo "que tendrán que cerrarse si se les priva de surtir del carbón vegetal de los montes comunales y se les ponen trabas por los comisionados de los montes".

${ }^{2320}$ P. HERNÁNDEZ SAMPELAYO (1935): Ob. cit., t. III, fasc. $1^{\circ}$, p. 40

${ }^{2321}$ AHPLU: 2563/6 (1856). 
ESTADO: No hay ningún resto.

\title{
40. FERRERÍA DE GUNDRIZ
}

\author{
LUGAR: Gundriz \\ MUNICIPIO: Samos \\ RÍO: Lóuzara \\ COORDENADAS: $42^{\circ} 41^{\prime} 35^{\prime \prime}$ N. y $7^{\circ} 13^{\prime} 9^{\prime \prime} \mathrm{W}$.
}

Se encontraba en la parroquia de Gundriz, en el municipio de Samos, muy cerca de Lóuzara, en la orilla izquierda del río de este nombre. Desde Gundriz, a la derecha de la iglesia baja un camino en dirección al río, que conduce a la ferrería.

En la primera mitad del siglo XVI había en Gundriz un mazuco con seis fraguas que en 1546 fue vendido al monasterio de Samos en 300.000 maravedís ${ }^{2322}$. Según Arias Cuenllas la ferrería de Gundriz o Gondriz fue construida por el abad de Samos fr. Francisco de Parada en 1555, y desde sus orígenes tuvo problemas con la ferrería de Lusío, levantada sin permiso del monasterio en la misma jurisdicción de Samos por Lope Vázquez de Vilameixe, propietario del pazo de Lusío. ${ }^{2323}$.

En esa primera época, la ferrería estuvo arrendada a ferrones vascos. En 1576 la llevaba en arriendo Juan Beltrán de Achega con quien se concierta el venaquero Juan de Ormazábal para venderle 1.500 quintales de la venera de Rocas, a precio cada quintal de quince maravedís y medio ${ }^{2324}$. Juan Beltrán era

\footnotetext{
${ }^{2322}$ AHN. Clero: Libro 6695: "En este mismo número hai una venta antigua de el mazuco de seis fraguas de Gondriz en precio de 300.000 mrs. hecha a este convento en 1546", ff. 119v. Otro apunte de este libro habla de cómo "se entregó el machuco de Gondriz por orden del abad Fr. Lope de la Barrara en 11 de noviembre de 1557 a Martín de Urichaga".

${ }^{2323}$ M. ARIAS CUENLLAS (1992): Ob. cit. p. 291

${ }^{2324}$ AHRG. R. A.: 2837/19: Juan de Ormaçabal "se obligaba y obligó en su persona y bienes de quebrantar mill e quinientos quintales de bena (de la venera de Rocas) a Juan Beltrán de Achega rendero de Gundriz a precio cada quintal de quinze mrs. y medio que sea buena y limpia y buena para carretar en requa los quales los despedazará en esta manera, los quinientos quintales en el doce de este mes de abril y los mil quintales de oy hasta san Miguel
} 
probablemente familiar -padre o hermano- del vizcaíno Antonio de Achega, que poco después gozaba el arriendo de las dos ferrerías de Gondriz y Lusío o Rial. En 1583 este Antonio de Achega contrata con un arriero de Quintanilla que le traiga 300 quintales de vena de la venera de Rocas a las ferrerías de Rial y Gondriz en la abadía de Samos, a precio de un real y quartillo por quintal2325. Este mismo vizcaino, como rendero de la ferrería de Gondriz, en 1584 vende a Nicolás Valderas, vecino de Zamora, 200 quintales de hierro ${ }^{2326}$. Hasta principios del siglo XVII sabemos que siguió arrendada ${ }^{2327}$, pero a partir de 1615 parece que fue administrada por un monje dependiente del priorato de Lóuzara ${ }^{2328}$.

La existencia de varias ferrerías en el valle de Lóuzara suscitaba problemas en el abastecimiento de carbón, además del consumo propio de los campesinos. En 1650 el abad de Samos, Fr. Bernardo de Vozmediano, compró a los vecinos de San Juan de Padornelo, en el Cebrero, el carbón que habían hecho en los montes de Casarinos y de Fontaos, pertenecientes al señorío del conde Lemos, de quien eran vasallos. Protestó por ello don Lope Saco de Armesto, señor de Pacios, también en el Cebreiro, alegando que hacía más de cincuenta años que dicho monte lo habían comprado sus antepasados a un tal Cabana, y que en él hacían leña y carbón sin que nadie se lo impidiese hasta hacía nueve meses en que sucedió la venta del carbón a Samos. Fueron a pleito; en él se dice cómo los vecinos de Padornelos, Sabugo, Porfía y Pallarvello vendieron a Samos, para su ferrería de Gundriz, el carbón hecho en los montes de Casarinos y Fontaos; pero unos vasallos de don Lope, armados de lanzas y escopetas, subieron al monte y se llevaron el carbón y los cepos, por lo que la ferrería de Gundriz estuvo parada mucho tiempo, haciéndole perder más de 500 ducados. Exige que se le abonen esos ducados y las costas del juicio, pero no sabemos como terminó el asunto 2329 .

primero...(precio de la vena sin el transporte)”. Juan Ormazábal confiesa recibir por adelantado 24 ducados y 3 reales.

2325 AHPL. PN.: caja 1490 (1583)

${ }^{2326}$ AHPL. PN.: caja $2872(1584)$.

${ }^{2327}$ AHN. Clero: libro 6695: "Mas hai en este número una entrega y posesión de la herrería de Gondriz con el arriendo de dicha herrería", ff. 119v.

${ }^{2328}$ C. GONZALEZ (1994): Ob. cit., p. 215

2329 M. ARIAS CUENLLAS (1992): Ob.cit., p. 290 
Siendo administrador de la ferrería de Gundriz el P. Alonso Fernández Gotera, en 1674 los carboneros de esta ferrería fueron a hacer carbón al monte de Castelo, a lo que se opuso el señor de Lusío, don Pedro Valcarce, alegando que de ese monte y de los de Serrón y Dos Nogueiros se abastecía la ferrería de Rial, y que por tanto Gundriz nunca había utilizado aquel carbón. Se pleiteó en la Audiencia de La Coruña con sentencia favorable al monasterio ${ }^{2330}$. En 1719 la justicia de jurisdicción del Caurel, junto con don Carlos Manuel de Oca dueño de la ferrería de Lousadela, prendió a varios vecinos de Praducelo, del valle de Lózara, por quemar el monte y hacer carbón, a los que llevó a juicio junto con otros de Meiraos, Vilela, Mirás, Paderna y Pedrafita por vender carbón a la ferrería de Gundriz, fuera de la jurisdicción, por lo que fueron condenados ${ }^{2331}$.

No es extraño que el Catastro de Ensenada en 1753, dijera que aunque tiene agua suficiente para todo el año, "carece de carbón, bena y mas materiales de que se compone"; por ello se le regula de utilidad 11.0oo reales de vellón al año ${ }^{2332}$. Cornide dice que, con vena de Rocas, labraba unos 500 quintales al año ${ }^{2333}$. Según varios Estados de Cuentas de Samos, algo posteriores, no era de las más rentables del monasterio. Como todas las ferrerías monásticas estaba dirigida por un prior rendero, de los que conocemos algunos nombres 2334 .

\section{INGRESOS DE LA FERRERÍA DE GUNDRIZ \\ Cuatrienio Reales \\ $1777-1781 \quad 35.000$ \\ $1781-1785 \quad 19.600$ \\ 1818-1821 $\quad 20.225$ \\ 1821-1824 $\quad 14.337$}

Fuente: Archivo de Silos

${ }^{2330}$ IDEM, p. 291

${ }^{2331}$ AHRG. R. A.: 14.100/ 84

${ }^{2332}$ CATASTRO DE ENSENADA. R. G.: San Juan de Lózara

2333 CORNIDE: Ob. cit., ff. 225

${ }^{2334}$ AHPLU. 5088/2 (1700). Fray Bernardo Laguna "prior y rendero de la Herrería dicha de

Gundriz y administrador de sus bienes", en 31 de diciembre de 1700, da su poder a don Jacinto Faxardo y Osorio, canónigo de Astorga, para que pueda cobrar a Andrés Botas, de Santa Catalina, en la jurisdicción de Astorga, 1.954 rs. "procedidos de yerro de esta dicha herrería". 
Lucas Labrada 2335, Miñano ${ }^{2336}$ y Madoz 2337 la mencionan, pero la producción que ofrecen, por ejemplo Miñano, es muy pequeña, de tan solo 700 arrobas de hierro, cifra improbable aunque estuviese muy alicaída. Durante el Trienio Constitucional, como muestra el Cuadro, la ferrería bajó considerablemente la media de sus beneficios cuatrienales. En 1823, a consecuencia de haber "disminuido el número de monges y aún no reunidos todos por las críticas anteriores circunstancias", la comunidad de Samos, rompiendo con la costumbre de administrar directamente sus ferrerías, arrendó las dos del valle del Lózara, las de Gondriz y Santalla, a don Pedro Iglesias. Al año siguiente, sin contar con la comunidad, el abad fr. Manuel Iglesias, las volvió a arrendar, ahora por cuatro años, y como mejores postores, a don Pedro Antonio González Seijas, vecino del lugar de San Juan de Fabián, y a los hermanos Pedro y Andrés Iglesias, que a su vez eran hermanos del abad, vecinos del coto de la Balsa de Triacastela, por la cantidad anual de 18.000 reales, 24 jamones de 7 a 8 libras de peso cado uno y 12 cabritos. Con las ferrerías se incluían 180 fanegas de centeno, 91 fanegas a cada una, que pagaban los colonos del monasterio en sus alrededores. Entre las condiciones, además de componer y perfeccionar las fábricas y dejarlas libres al final del contrato, han de poner a su costa un sacerdote que diga misa los domingos y festivos ${ }^{2338}$. Luego se las repartieron: los hermanos Iglesias, en realidad Pedro Iglesias, se quedó con la ferrería de Santalla y Pedro Antonio González con la de Gondriz.

Pero al año siguiente, muerto el abad, la comunidad con el apoyo del General de la Congregación de Valladolid, se querelló contra los arrendatarios alegando que el contrato era ilegal porque los contratos de bienes del monasterio no puede hacerlos el abad "por si solo y contra la voluntad de la comunidad", y ésta no estaba de acuerdo porque consideraba que la renta era lesiva para el convento. No hubo muchos problemas con Pedro Iglesias, que renunció al contrato, aunque el convento, por medio de otra escritura de 14 de

${ }^{2335}$ L. LABRADA (1804): Ob. cit., p. 146: Samos "y hay en las feligresías de San Xoan de Lóuzara y San Cristóbal de Lóuzara dos herrerías y dos fraguas, en que se trabajan al año 1.500 arrobas de hierro".

${ }^{2336}$ S. MIÑANO: Ob. cit., t. 7, p. 432.

2337 P. MADOZ: Ob. cit., t. X, p. 400: "una ferreria en Gondriz"

${ }^{2338}$ AHRG. R. A.: 1.389/7 
marzo de 1825, le permitió seguir en la ferrería hasta el 25 de julio de ese año, con la renta de 7.000 reales, 12 jamones y 6 cabritos. Hubo más problemas con Pedro Antonio González Seijas, al que una escritura menciona como cirujano, pues éste alegaba que el contrato era legal, que cuando lo firmó ignoraba los estatutos de la orden y que ya había llevado sus cosas y familia para la vivienda de Gundriz. Al final, para no meterse en pleitos largos y costosos también aceptó, en el mes de junio, rescindir el contrato aunque permaneciendo en la ferrería hasta Nuestra Señora de septiembre, por una renta de 11.000 reales, 12 jamones y 6 cabritos 2339 .

Tras la exclaustración ${ }^{2340}$, fue desamortizada en 1839 y vendida al madrileño Antonio Santamarina en 455.133,12 reales ${ }^{2341}$, quien puso por administrador, según el P. Arias, al bisabuelo de los actuales propietarios ${ }^{2342}$. La menciona $\mathrm{Madoz}^{2343} \mathrm{y}$, aunque de forma intermitente, debió de trabajar hasta finales de siglo.

ESTADO: Se conserva la vivienda del monje administrador en buen estado y habitada, pero no la ferrería, aunque restos de la misma se utilizaron para construir un molino.

\section{FERRERÍA DE LUSÍO O RIAL}

LUGAR: San Cristóbal de Rial

MUNICIPIO: Samos

RÍO: Arroyo de la Ferrería

COORDENADAS: 42 $44^{\prime} 26^{\prime \prime}$ N. y $7^{\circ} 16^{\prime} 20^{\prime \prime} \mathrm{W}$.

En el tramo del Camino de Santiago desde Triacastela a Samos, en tierras de este municipio, se encuentra la parroquia de San Cristóbal del Real o Rial. A orillas del riachuelo denominado de la Ferrería, afluente del Oribio, frente al

\footnotetext{
2339 AHRG. R. A.: 1.389/7

${ }^{2340} \mathrm{Su}$ último administrador fue fray Gregorio Jara (AHN. Consejos: leg. 12.08o, exp. 146.

${ }^{2341}$ AHPLU: Desamortización: leg. 10, 2 (2)

2342 M. ARIAS CUENLLAS (1992): Ob. cit., p. 292. En realidad los actuales propietarios la compraron a los herederos de aquel, según C. GONZÁLEZ (1994): Ob. cit., p. 217

2343 P. MADOZ: Ob. cit., t. X, p. 400
} 
pazo de Lusío que allí fundara don Lope Vázquez de Vilameixe, que aún resiste sobre un altozano, están los restos de la ferrería de Lusío.

Don Lope Vázquez de Vilameixe, propietario del pazo de Lusío, con su mujer Leonor Alonso de Balboa levantaron en 1551 o simularon levantar un mazuco en un molino de su propiedad, que más tarde pretendieron transformar en ferrería, aunque sabían que no podían hacerlo; pues los monjes de Samos erigían no muy lejos de allí en 1555 su ferrería de Gondriz, con la que aquella podía competir por el combustible 2344 . Sin embargo, hacia 1575 aquel mazuco producía hierro, era por tanto una verdadera ferrería, sobre la que, al parecer, realizaron un ritual de posesión, de raigabre vasca, marcando con la sangre de un toro el espacio de la ferrería. Por eso, el abad fray Gabriel de la Puebla se querelló con ellos. Sin embargo el juez, basándose en que la ferrería estaba construida en terreno de su propiedad, sentenció a favor de don Lope y su esposa ${ }^{2345}$. Incluso unos años antes, en 1570, este don Lope suscribía un contrato con el canónigo fabriquero de la catedral de Lugo, junto con los rejeros Pedro Sobrado y Baltasar Ruz, por el que el "señor de la herrería del rrial de samos" se comprometía a entregar el hierro preciso para las rejas de la catedral, a precio de dos ducados quintal2346

\footnotetext{
2344 M. ARIAS CUELLAS (1992): Ob. cit., p. 291

2345 ARCHIVO DEL MONASTERIO DE SAMOS: Casa de Lusío, libro becerro (1715), p. 7v: "La herraría la hizo Lope Vazquez de Villameyxe el año de 1575, en cuyo sitio en tiempos de los antecesores del dicho Lope Vazquez estaba un molino de casa y hallándose Lope Vazquez con caudal con la herencia de su tio Pedro Vazquez, camarero de don Antonio Fonseca, discurrió en hazerla y rezelándose acaso u prebiniendo lo que le había de suzeder, y quien tiene enemigos no es bien que duerma, finjió que hazía un mazuco, con todo su finjimiento no dejaron los monjes de Samos de alterarse u fuese por embidia u por hazer daño (au que no es de presumir de religiosos tan sanctos) procuró Lope Vazquez alagarlos con la capa que era mazuco, y para este efecto por no meterse en quimeras por contentar sacó licencia del Abbad. $Y$ con el pretesto que hazía mazuco fue trabajando en la herraría asta que dio con ella echa y empezó a labrar hierro. Sabido esto por el convento lebantaron el grito y procuraron ympedirlo, y por que Lope Vazquez abía echo cortar un toro debajo del mazo, y rodear con el un pedazo de termino alrededor de la herraría (costumbre antigua de Vizcaya para adquirir algunas preeminenzias) se querelló el combento articulando le procuraba usurpar la jurisdizión, cuya querella desbanezió Lope Vazquez probando aberse echo en las errarias recien fabricadas y ser costumbre de dichas herrarías". En el pleito probó que la herrería estaba hecha sobre terreno propio: "finalmente el auto salió a favor de Lope Vazquez amparandole en la fábrica de la herraria antento abía probado ser el sitio de ella suyo propio y que pudiese aprovecharse de los montes uzedos para carbon como mas largo se verá en pleito cuya copia está en esta casa".
}

${ }^{2346}$ C. GONZALEZ (1994): Ob. cit. p. 218 
En esa primera época, la ferrería estuvo arrendada a ferrones vascos, y por lo que parece, el mismo rendero, el vizcaino Antonio de Arteaga, llevaba las dos ferrerías de Gondriz y del Rial. En 1583 este Antonio de Arteaga o de Achega contrata con un arriero de Quintanilla para que le traiga 300 quintales de vena de la venera de Rocas a las ferrerías de Rial y Gondriz, en la abadía de Samos, a precio de un real y quartillo por quintal ${ }^{2347}$. Este mismo vizcaíno, como rendero de la ferrería de Gondriz, en 1584, vende a Nicolás Valderas, vecino de Zamora, 200 quintales de hierro ${ }^{2348}$. En 1585 Antonio de Algesa, rendero de la ferrería del Rial, concierta con un arriero de Quintanilla, al lado de Astorga, que le traerá con su recua 150 quintales de vena del venero de Rocas y la llevará a descargar al Rial a precio de un real y quartillo por cada quintal ${ }^{2349}$. En 1612 se mencionan en el inventario de Lucía Díaz de Zuluaga, mujer del rendero de Lousadela, deudas con Martín de Azconeta "tirador que al presente es de la ferreria del rial" 100 ducados del tiempo que sirvió en Lousadela, y con Miguel de Salazar "fundidor que al presente es de la ferrería del rial", 36 ducados por lo mismo 2350

Después del pleito de Lope Vázquez, éste y sus sucesores usaron la madera de los montes "que caen desde Lózara aguas bertientes acá como públicos y conzejiles desta feligresía y partido, sin que la herraria de Gondriz nunca entrase a ellos a sacar carbón" ${ }^{2351}$; pero las disputas y pleitos fueron frecuentes con Samos por ese motivo. Así en 1674, siendo administrador de la ferrería de Gundriz el P. Alonso Fernández Gotera, los carboneros de esta ferrería fueron a hacer carbón al monte de Castelo, a lo que se opuso el señor de Lusío, don Pedro Valcarce 2352 , alegando que de ese monte y de los de Serrón y Dos Nogueiros se abastecía la ferrería de Rial, y que por tanto Gundriz nunca había utilizado aquel carbón. Se pleiteó en la audiencia de La Coruña, con sentencia favorable al monasterio ${ }^{2353}$. En 1704, el dueño de esta ferrería, don Pedro Andrés Valcarce Vázquez de Quiroga, compra a Francisco Ormazábal y a su cuñado Josef

2347 AHPL. PN.: caja 1490 (1583)

2348 AHPL. PN.: caja 2872 (1584).

2349 AHPL. PN.: caja 2849 (1585).

2350 AHPLU: 2408/2 (1612).

${ }^{2351}$ ARCHIVO DEL MONASTERIO DE SAMOS: Casa de Lusío, libro becerro (1715), p. 8 y 8v.

${ }^{2352}$ Lope Vázquez y Beatriz Alonso tuvieron varios hijos, uno de ellos fue Beatriz de Valcarce (AHRG. R. A.: 2793/8), probablemente de ella derive ese apellido Valcarce.

2353 IDEM, p. 291 
Valcarce un penedo en la venera de Rocas, que éstos tenían desde hacía 14 años, por 2.00o reales para explotar el hierro y consumirlo en su ferrería ${ }^{2354}$.

Entre 1730 y 1749, según P. Saavedra, esta ferrería de Lusío labró un promedio 20.753,3 kilogramos de media anual2355, cantidad baja respecto a las ferrerías bercianas o a la asturiana de Villanueva de Oscos, que la superan en más del doble. El Catastro de Ensenada, de 1753, dice que carece de agua y carbón por lo que no trabajaba todo el año, regulándose su beneficio anual en 4.00o reales ${ }^{2356}$. Su propietario era don Francisco Ignacio Valcarce. Cornide, años más tarde, afirma que su producción solo era de 150 quintales, lo que sin duda confirma su carácter de ferrería regatera ${ }^{2357}$. Con todo, como decía en 1715 su dueño Pedro Andrés de Valcarce Vázquez y Quiroga, con la ferrería Lope Vázquez les dejó "una alaja que les sirbe de recreo autoridad e ynterés por poco que sea y de mortificazión y rabia a los contrarios", pues gracias a los beneficios obtenidos por la venta del hierro habían acrecentado sus antepasados el patrimonio familiar ${ }^{2358}$.

A comienzos del siglo XIX, esta ferrería con la de Gorgueira eran propiedad de don Antonio María Vázquez Quiroga ${ }^{2359}$, heredero de la casa de Lusío. En 1808 hubo problemas por la construcción de un mazo en sus alrededores ${ }^{2360}$. En

2354 AHRG. R.A.: 3176/59

2355 P. SAAVEDRA (1982): "Un aspecto de la economía monástica: La producción de hierro. El ejemplo del monasterio de Villanueva de Oscos”. Semana de historia del monacato cántabroastur-leonés. Oviedo, p. 537

${ }^{2356}$ CATASTRO DE ENSENADA. R. G.: El Real

2357 CORNIDE: Ob. cit., ff. 225

${ }^{235^{8}}$ ARCHIVO DEL MONASTERIO DE SAMOS: Casa de Lusío, libro becerro (1715), p. 8. Se dice en este libro becerro, hablando de la ferrería, que Lope Vázquez de Villameixe "merece tener nombre eterno en esta casa no tanto por la fábrica de la herraría que hizo con que le dio el ser además de la hazienda que le adquirió; como por el balor, abilidad y destreza que hubo en defender su hecho con un enemigo tan fuerte y poderoso, y dentro de su porpia tierra y señorío y tan cerca de su casa, y tener amaño para fabricar la herraría primero qu el combento despertase, cuya aczion merece ser remunerada por sus subzesores en encomendarse continuamente a dios, pues les dejó debajo de las bentanas de su casa, a costa de su afán y trabajo, una alaja que les sirbe de recreo autoridad e ynterés por poco que sea y de mortificazión y rabia a los contrarios".

2359 En 1804 este don Antonio María Vázquez de Quiroga, dueño y vecino de la granja de Lusío dice que es apoderado de su madre María Gertrudis Arias Quiroga (AHRG. R. A.: 24.680/47 ${ }^{2360}$ AHPLU: 2468/2. Cristóbal Vilela, de la feligresía de San Cristóbal de Lózara, "se propasó ... a principiar la fabrica de un mazo en el monte y sitio de Castedo, aguas vertientes a su ferrería de Lusio, y habiendo sido contradicho el Cristobal", por lo que se querelló contra él. Pero, al parecer, éste pidió permiso a don Antonio $\mathrm{M}^{\mathrm{a}}$ Vázquez, que se lo dio el 5 de abril de 1808 "allanándose a no perjudicarle en el uso de los montes". Pero una vez construido el mazo hizo lo 
1838 la arrienda, por tres años, a Manuel Iglesias, de Triacastela, en 4.00o reales/año ${ }^{2361}$; en 1846 el mismo don Antonio la arrienda de nuevo por dos años a don José Vila, vecino de Gundriz en 3.300 reales/año ${ }^{2362}$. En 1848 aparece como dueño su hijo, don Manuel María Vázquez Quiroga, quien ese año da su poder a Manuel López para que en su nombre la vuelva a arrendar nuevamente a José Vila por otros dos años y $3.000 \mathrm{rs} / \mathrm{anno}^{2363}$. Este descenso continuado de la renta puede ser un indicio de su cada vez menor rentabilidad. En 1858 aquél expuso piezas de hierro elaborado en esta ferrería en la exposición de Santiago de Compostela. Siguió funcionando hasta finales de siglo 2364 .

ESTADO: Queda el pazo de Lusío, abandonado, y prácticamente nada de la ferrería.

\title{
42. FERRERÍA DE SANTALLA
}

\author{
LUGAR: San Xosé de Santalla \\ MUNICIPIO: Samos \\ RÍO: Fuente \\ COORDENADAS: $42^{\circ} 40^{\prime} 49^{\prime \prime}$ N. y $7^{\circ} 14^{\prime} 28^{\prime \prime} \mathrm{W}$.
}

Se hallaba aguas abajo de la ferrería de Gundriz aunque no en el río Lóuzara, en la actual parroquia de San Xosé de Santalla, antes en la de San Xoán de Lóuzara. La ferrería, que también perteneció al monasterio de Samos, estaba

\footnotetext{
que le vino en gana, carboneando en la coza de los montes, etc. por lo que aquel en 1811 se querelló nuevamente.

${ }^{2361}$ AHPLU: 2406/25 (1838). Entre las condiciones, además de que los descalabros mayores y menores correrán por cuenta del Iglesias, excepto el árbol mayor, se le exige el cuidado de los montes propios y que nadie haga carbón para otras ferrerías. Esta es una preocupación constante. Así en 1844, este don Antonio María Vázquez dice: “que a su Herraria de Lusío son pertenecientes para el carbón los montes inmediatos a ella, como son la Meda, San Jil do Carballo y otros desde tiempo inmemorial, y por haverse perturbado en su libre uso Domingo Montero del pueblo de San Jil dio querella contra él en el juzgado de primera instancia de Sarria en la que salió condenado en costas y a la satisfación de atrasos, daños y perjuicios causados a la Fábrica" (AHPLU: 2407/5 (1844). Cuatro años después, su hijo don Manuel María Vazquez, dirá que este Domingo Montero fue ejecutado y embargado en sus bienes "por el importe de los daños causados a la herrería de Lusío" (AHPLU: 2376/7 (1848).

2362 AHPLU: 2376/6 (1846). Le arrienda, del 25 de julio de 1846 a 25 de julio de 1848, "el artefacto de Herrería con sus casas y herramientas de que el señor otorgante es pribatibo dueño y se halla sita en el pueblo de Lusío en la parroquia de San Cristobal del Real en el distrito de Samos"; se la arrienda con el molino harinero, prados, huerta y leira de viña, en las condiciones normales en estos arriendos, incluidas todas las contribuciones y pensiones en que se halla gravada.

2363 AHPLU: 2376/7 (1848).

${ }^{2364}$ C. GONZÁLEZ (1994): Ob. cit., p. 219.
} 
frente a la iglesia parroquial. El agua provenía de una fuente bastante caudalosa durante la época de lluvias ${ }^{2365}$.

Según Arias Cuenllas, la ferrería de Santalla se construyó durante el segundo abadiato de Antonio Maseda (1665-1669)2366; pero esto es un error porque la ferrería se edificó a principios del siglo XVI. En 1504 fray Juan de Estella, presidente y reformador de Samos, aforó a Diego Velón y a su mujer Velasquida González de Cancelada, y a otras dos personas más "un sitio en el Rio o fontes de Loçara o en otro cabo qualquier que vos el dicho diego belon quisieres so el signo de Seoane de Loçara para que fagades una ferreria corriente y moliente, la qual os aforamos con todas sus aguas corrientes y estancas y manantes (...) con todos los montes y cosas pertenecientes a ferraria", y también con la justicia civil y criminal "alto e bajo e mero misto imperio". Se lo aforan con la renta anual de $750 \mathrm{mrs}$ y otras condiciones generales, entre ellas que al morir el forero, antes de treinta días, deberá presentarse ante el monasterio el nuevo so pena de quedar vaco el fuero" 2367 .

Por datos de un juicio de 1595, sabemos que la ferrería de Santalla (o de Seoane de Lózara) la gozaron dichos Velón y Velasquida hasta la muerte del primero, pues poco después la mujer "la traspasó y vendió a Domingo Zarauz, rendero de la herraria de Incio". Posteriormente, el yerno de Velón y Velasquida, Rui Sánchez de Orozco, casado con su hija Elena González de Balboa, recobró la ferrería y la tuvo hasta su muerte, que ocurrió hacia 1550. A Rui Sánchez de Orozo, segunda voz en el foro, sucedió su hijo Alvaro Sánchez de Orozco "el qual como hijo mayor de los dichos sus padres fue alçado por ultima voz del fuero de la dicha herreria y como tal la llebo y goço el tiempo que bibio". Estos Sánchez Orozco debieron explotar la ferrería por medio de

\footnotetext{
${ }^{2365}$ MIÑANO. ob. cit., t. XI: A la ferrería de Santalla "da aguas una famosa fuente que sale de una cueva en bóveda de peña, con tal abundancia y tan cerca del banzado de la ferrería, que ella sola da movimiento al artefacto. El espectáculo que ofrece es digno de admirar. Muchos opinan que es el renacimiento de un río sumido en la montaña superior, por cuanto suelen salir pajas y hojas de árbol entre las aguas. Estas son muy cristalinas y frescas, y al paladar no se presentan con el gusto de las del río".

${ }^{2366}$ M. ARIAS CUENLLAS (1992): Ob. cit., p. 286

${ }^{2367}$ AHRG. R. A.: 931/44
} 
renderos, como Antonio da Chega, que tuvo también las de Quiroga y Paleiras, María Dargandona y María de Guisaburuaga, su hija²368.

En 1595 el monasterio de Samos pleitea con Antonio Sánchez de Orozco pues con su padre habían finalizado las voces del foro de 1504; pero éste alega que su abuelo, Rui Sánchez había muerto antes de su suegra Velasquida, por lo que su padre Alvaro sería la segunda y él la tercera voz ${ }^{2369}$. La querella de Samos, con sentencia favorable al monasterio, debió terminar en arreglo, ya que en 1596 el convento volvía a aforar a Antonio Sánchez de Orozco, a su mujer y a dos vidas más la ferrería, con la justicia civil y criminal (aunque solo en primera instancia), con la renta de doce ducados anuales, además de las condiciones normales en estos foros: "que la herrería (la traigan) corriente y molinete (de manera) que mejore y no empeore”, etc. Si hay delitos de sangre los castigarán las justicias de la abadía 2370 .

Diego Sánchez de Orozco, merino y juez del valle de Incio y dueño de la granja de Dompiñor, y Alvaro González de Rivadeneira, su cuñado, en nombre de su mujer María de Quiroga y en el de su sobrina María de Losada, casada con Domingo Pérez de Robledo, hicieron a Martín de Guiçaburuaga en 1610 "fuero de su fuero de la dicha herraria con sus casas y jurisdicion civil y criminal como ellos lo tenian en fuero de dicho convento de Samos", por las voces del foro y con la obligación de pagar los 12 ducados al monasterio más 35 a ellos cada año, "y que cumpliese con todas las mas condiciones y grabamenes del dicho fuero" 2371 . Fuero que se modificó al año siguiente en el sentido siguiente: asegurando Martín de Guisaburuaga, mediante hipoteca, los 12 ducados al monasterio y eliminando la renta de los 35 ducados a los Orozco a cambio de

\footnotetext{
${ }^{2368}$ Como consta en AHRG. R. A.: 70/80: Foro a Antonio Sánchez de Orozco, de 15 de julio de 1596.

2369 AHRG. R. A.: 931/44

${ }^{2370}$ AHRG. R. A.: 70/80: Foro a Antonio Sánchez de Orozco, de 15 de julio de 1596: "que al presente en nuestro nombren traen maria dargandona y maria de guisaburuaga su hija con todas sus casas herramientas barquines y rraguas y todo lo demás a ella anejo y perteneziente segun nos perteneze y nos fue entregada y a este nuestro monasterio por mandando del señor don luys de molina oydor y alcalde mayor deste reyno y bisitador de los obispados de Lugo y Orense y Mondoñedo en ejecucion del auto y sentencia por el dado entre nos y bos el dicho Antonio Sánchez de Orozco (...) la qual dicha ferraria esta libre y baca por dejacion que oy dia della hiço antonio da chega del fuero della que le estaba hecho segun se contiene en la escritura que de ello hiço.."

${ }^{2371}$ AHRG. R. A.: 14.701/11
} 
500 ducados en dinero y 40 quintales de hierro, que valían otros 100 ducados 2372

Las vicisitudes de los subforeros no acabaron aquí. En 1621, los Orozco que no estaban muy contentos con la venta del fuero, se querellaron con Martín de Guisaburuaga exigiéndole más dinero. Éste alegaba que se había gastado más de 800 ducados en poner nuevos banzados y ruedas, más otros arreglos; pero por no pleitear acuerda pagarles 3.000 nuevos reales, 1.500 a cada cuñado 2373 . Sin embargo en 1627, Domingo Pérez y su mujer, sobrina de aquéllos, dicen no estar de acuerdo con el reparto, con lo que la nueva reclamación vuelve a afectar otra vez a Martín de Guisaburuaga, que debe pagarles otros 5.000 reales: 2.500 para Diego, 900 para Alvaro y 1.600 a Domingo Pérez. En total Martín Guisaburuaga pagó 14.000 reales por el fuero de la ferrería ${ }^{2374}$, aunque aún tendría que abonar al monasterio, por el traspaso de la misma, el quinto de esos 14.000 reales 1.800 reales-, que el monasterio le exigió en 1649 y que para evitar nuevos juicios pagó religiosamente 2375 .

Luego fue el monasterio el que se querelló en 1658 con el sobrino de Martín de Guisaburuaga, que lleva el mismo nombre de su tío, alegando que por esa fecha habían finalizado de nuevo las voces del fuero hecho a Antonio Sánchez de Orozco. Es aquí donde hay que entender los datos de Arias Cuenllas; es decir, que fue en el segundo abadiato de fray Antonio Maseda (1665-1669) ${ }^{2376}$ cuando se recuperó la ferrería, que durante pocos años el monasterio debió aún tener arrendada; pues al parecer en tiempos del abad Pedro Velázquez de León (1673-1677) pasó a ser administrada directamente por el convento, como perteneciente al mismo priorato que la de Gundriz. De este modo, los 12 ducados anuales que recibía el monasterio por el foro pasaron a 700, 800 e incluso 1.000 ducados al año de beneficios ${ }^{2377}$. En 1704 , en el juicio por un

\footnotetext{
2372 IBIDEM

2373 En realidad 2.00o reales a Diego y 1.000 a Alvaro

2374 AHRG. R. A.: 14.701/11

2375 AHRG. R. A.: 70/80

2376 M. ARIAS CUENLLAS (1992): Ob. cit., p. 286

2377 ARIAS (1950): Ob. cit. 231
} 
peñasco de vena de Roques, de la que se surtía la ferrería, se menciona a fray Anselmo de la Santa (roto), como rendero de Santalla ${ }^{2378 .}$

Según el Catastro de Ensenada en 1753, la ferrería tenía problemas de agua, al estar alimentada por una fuente, por lo que sus rendimientos eran escasos, sólo 3.400 reales de vellón al año, un tercio aproximadamente de la de Gundriz; pero eso no se corresponde con los Estados de Cuentas del monasterio, en los que, con excepción del cuatrienio 1821-1824, no hay grandes diferencias entre ellas. Tampoco los datos de producción de Cornide en 1780 coinciden con los del Catastro de Ensenada, pues la de Santalla elabora 700 quintales al año mientras que la de Gondriz sólo labra 500 quintales. La vena que consumía era también de Rocas ${ }^{2379}$. Al parecer tenía problemas de carbón, como se deduce del pleito del monasterio con la marquesa de Viance en 1792. Según el monasterio, los administradores de su ferrería "siempre han usado por medio de operarios del carbón necesario que produce el monte de Lago, sito en terminos de San Silbestre de Seceda", hasta que vecinos de la jurisdicción del Caurel, con el apoyo de la marquesa de Viance, se lo quiere impedir. Hubo acuerdo sobre los límites ${ }^{2380}$ pero no fueron respetados, por lo que nuevamente continuaron los juicios en 1795 y 1798.

\section{INGRESOS DE LA FERRERÍA \\ Cuatrienio reales \\ $1777-1781 \quad 28.720$ \\ 1781-1785 $\quad 37.500$ \\ 1818-1821 29.500 \\ $1821-1824 \quad 1.600$}

Fuente: Archivo de Silos

Como muestra el Cuadro, durante el Trienio Constitucional la ferrería bajó considerablemente la media de sus beneficios cuatrienales. En 1823, a

${ }^{2378}$ AHRG. R. A.: $3 \cdot 176 / 59$

2379 CORNIDE: Ob. cit., ff. 225

${ }^{2380}$ AHRG. R. A.: 103/4. Año 1792: “que los carboneros de la citada ferrería de Santalla (...) pudiesen fabricar carbon para ella en el referido monte de Lago hasta llegar a las demarcaciones que se expresan (y que nombra)" 
consecuencia de haber "disminuido el número de monges y aún no reunidos todos por las críticas anteriores circunstancias", la comunidad de Samos, rompiendo con la costumbre de administrar directamente sus ferrerías, arrendó las dos de Lózara, las de Gondriz y Santalla, a don Pedro Iglesias. Al año siguiente, sin contar con la comunidad, el abad Fr. Manuel Iglesias, las volvió a arrendar, ahora por cuatro años, y como mejores postores, a don Pedro Antonio González Seijas, vecino del lugar de San Juan de Fabián, y a los hermanos Pedro y Andrés Iglesias, que a su vez eran hermanos del abad, vecinos del coto de la Balsa de Triacastela, por la cantidad anual de 18.000 reales, 24 jamones de 7 a 8 libras de peso cado uno y 12 cabritos. Con las ferrerías se incluían 182 fanegas de centeno, 91 fanegas a cada una, que pagaban los colonos del monasterio en sus alrededores. Entre las condiciones, además de componer y perfeccionar las fábricas y dejarlas libres al final del contrato, han de poner a su costa un sacerdote que diga misa los domingos y festivos ${ }^{2381}$. Luego se las repartieron: los hermanos Iglesias, en realidad Pedro Iglesias se quedó con la ferrería de Santalla y Pedro Antonio González con la de Gondriz.

Pero al año siguiente, muerto al parecer el abad, la comunidad con el apoyo del general de la congregación de Valladolid, se querelló contra los arrendatarios alegando que el contrato era ilegal porque el contrato de bienes del monasterio no puede hacerlos el abad "por si solo y contra la voluntad de la comunidad", y ésta no estaba de acuerdo porque consideraba que la renta era lesiva para el convento. No hubo muchos problemas con Pedro Iglesias, que renunció al contrato, aunque el convento, por medio de otra escritura de 14 de marzo de 1825, le permitió seguir en la ferrería hasta el 25 de julio de ese año, con la renta de 7.000 reales, 12 jamones y 6 cabritos. Hubo más problemas con Pedro Antonio González Seijas, al que una escritura menciona como cirujano, pues éste alegaba que el contrato era legal, que cuando lo firmó ignoraba los estatutos de la orden y que ya había llevado sus cosas y familia para la vivienda de Gondriz. Al final y para no meterse en pleitos largos y costosos también aceptó, en el mes de junio, rescindir el contrato aunque permaneciendo en la

${ }^{2381}$ AHRG. R. A.: 1.389/7 
ferrería hasta Nuestra Señora de septiembre, por una renta de 11.000 reales, 12 jamones y 6 cabritos. ${ }^{2382}$

Además de las dos ferrerías del monasterio en San Xoán y San Cristóbal de Lóuzara había también, según Lucas Labrada, dos fraguas, "en las que trabajan al año 1.500 arrobas de hierro" 2383 . En los Estado de Cuentas se relacionan rendimientos de un mazo $^{2384}$.

Tras la exclaustración fue desamortizada y vendida en 599.000 reales a Modesto $\mathrm{M}^{\mathrm{a}}$ Arango Trabadelo, vecino de la ciudad de Lugo, a quien se la compró un antepasado de los actuales dueños ${ }^{2385}$. Funcionó hasta finales del siglo XIX.

ESTADO: No quedan restos de la ferrería, sólo la casa del administrador bastante reformada frente a la iglesia parroquial.

\section{MUNICIPIO DE TRIACASTELA}

\section{FERRERÍA DE FURCO}

LUGAR: San Juan de Furco

MUNICIPIO: Triacastela

RÍO: Desconocido

COORDENADAS: $42^{\circ} 55^{\prime} 45^{\prime \prime}$ N. y $7^{\circ} 14^{\prime} 28^{\prime \prime} \mathrm{W}$.

Según Clodio González, la ferrería de San Xoan de Furco estaba en el municipio de Becerreá, pero no encontró ni restos ni el recuerdo de dónde pudo ubicarse esta ferrería, aunque sí hay un topónimo Furco; yo tampoco porque, en mi opinión, no estuvo allí sino en la jurisdicción de Triacastela. Muy cerca de

\footnotetext{
2382 AHRG. R. A.: $1.389 / 7$

2383 L. LABRADA (1804): Ob. cit., p. 146

2384 A. M. SILOS: Archivo de la Congregación de Valladolid, libros XXIX y XXII.

2385 M. ARIAS CUENLLAS (1992): Ob. cit., p. 292
} 
este lugar existe también otro Furco, como puede verse en la Carta Geométrica de Galicia de Domingo Fontán, del año 1845, o en el mapa de Tomás López.

La única referencia a esta ferrería nos la ofrece Lucas Labrada, que la incluye en la jurisdicción de Triacastela, en la que además de 49 telares de lienzo hay, dice, "una herrería en la feligresía de San Xoán do Furco, de la misma jurisdicción, a donde se elaboran como unas 100 arrobas de hierro al año" 2386 . Probablemente se trata de una pequeña ferrería o de un simple mazo, dada la exigua producción que se le atribuye.

Miñano copia a Lucas Labrada por lo que no nos proporciona ninguna información y Madoz ni siquiera la menciona.

ESTADO: Desconocido.

\title{
22. MUNICIPIO DE VALADOURO
}

\section{FERRERÍA DE PESQUEIRA}

\author{
LUGAR: A Ferrería (Santa Cruz do Valadouro) \\ MUNICIPIO: Valadouro \\ RÍO: Rego da ferrería \\ COORDENADAS: $43^{\circ} 32^{\prime} 59^{\prime \prime}$ N. y $7^{\circ} 26^{\prime} 29^{\prime \prime} \mathrm{W}$.
}

Se encuentra a la salida de Santa Cruz de Valadouro en dirección a Vivero, en el lugar de A Ferrería, en el que actualmente no hay más que prados.

La ferrería de Pesqueira, con un machuco en sus aledaños, la construyó en el segundo cuarto del siglo XVI el hidalgo Pedro Maseda, probablemente como veremos después, en compañía de Pedro Pardo de Aguiar. Con la ferrería, el tal Pedro Maseda "pretendía exercer actos de jurisdición dentro de los términos de dicha ferrería, a que se opusieron los señores obispos y su alqalde maior". Pese a esa oposición, "por evitar pleitos”, el obispo de Mondoñedo, en 1544, "hizo

${ }^{2386}$ L. LABRADA (1804): Ob. cit., p. 146 
una concordia por la qual se le concedió alguna jurisdicción sobre los oficiales $y$ carboneros quanto a lo civil y criminal" 2387 . Es decir, que como en otros casos, y también en ese siglo XVI, con la ferrería, sus dueños pretendían tener como señores la jurisdicción civil y criminal sobre los trabajadores de la misma, cosa que al parecer lograron. Probablemente el terreno era del obispo de Mondoñedo, y aquellos la tenían en foro.

Pedro Pardo de Aguiar, señor del coto de Saramugo, y Pedro Maseda de Aguiar aforaron en 1571 al vizcaíno Francisco Sánchez Vidarte, rendero de la ferrería de Lorenzana, y a su mujer María Sánchez, ausente, "aquella nuestra herraria e machuco que se dize da Pisqueira que está sita en la dicha feligresía de Santa Cruz con todas sus casas, torre y molino, huertas, sotos y árboles que hestán entre las aguas de la dicha ferrería e con todos los aparatos e yngenios $e$ artifiçios y herramientas de la dicha ferraria", en precio y renta de 6.000 maravedís anuales, con varias condiciones. Entre ellas la de reparar a su costa y a la de sus sucesores la ferrería y machuco para que siempre funcione; que no la puedan vender, empeñar o traspasar salvo a persona llana; $y$, además, que si no pagan tres años seguidos la renta perderán los derechos del foro ${ }^{2388}$. Dicha renta ha de abonarse por mitad a cada uno de los dos propietarios y a sus respectivos descendientes.

La mitad de ese machuco de Pesqueira lo arrendó Francisco Sánchez de Vidarte probablemente al año siguiente, en 1572, a Juan Méndez, hijo de Alfonso Fernández, antiguo rendero de Lorenzana, y la otra mitad a Diego de Candeán, como conocemos por el juicio contra el fiador de este último Juan López Carpintero en 1573. Un testigo, el vizcaíno Juan Olazábal, dice saber que "el dicho Francisco Sánchez rendero tiene arrendado e aforado el dicho machuco de la ferrería de la Pesquera a Pero Maseda de la Pesquera e a Pero Pardo de Sanmarugo e como tal suyo propio lo lleba e tiene el dicho Francisco Sánchez rendero por fuero o arrendamiento de los sobredichos y trayéndolo allí sabe que tenya arrendado la mytad parte del dicho machuco a Juan Méndez hijo de Afonso Fernandez rendero y que lo tenía bien aderezado y que

2387 P. SAAVEDRA (1985): Economía, política y sociedad en Galicia: La provincia de Mondoñedo, 1480-183o. Xunta de Galicia, p. 327 2388 AHRG. R. A.: 21.859/104. 
lo arrendó en la otra mitad a Diego de Candean en el que el lo vió, pues entonces estaba él en la ferrería y machuco de la Pesquera" 2389 . Diego de Candeán, a quien arrendó por un año y diez ducados de renta la mitad del machuco, huyó dejándolo en mal estado, probablemente por la peste, aunque en el juicio se diga lo contrario 2390 .

Este Francisco Sánchez Vidarte aparece en años posteriores como rendero, con quien se concierta en 1583 el mercader de Vivero Juan García de Castrillón para que le suministre 30 quintales de hierro pletina ${ }^{2391}$. En 1627 lo era probablemente un descendiente suyo, de nombre Juan Andrés Vidarte, el cual como rendero de Pesqueira vende a Juan Díaz de Bao "treynta quintales de hierro labrado y sacado del maço de la ferrería"; cantidad de hierro que habrá de entregar en enero de 1628 pagando 33 reales por quintal, y como adelanto 500 reales 2392 .

Uno de los problemas de la ferrería, en competencia de las cercanas de Bravos y Lorenzana, fue encontrar combustible para reducir el mineral, lo que dió lugar a enfrentamientos con aquéllas y con los vecinos de los alrededores. En 1650 el monasterio de San Salvador de Lorenzana se querelló con el capitán Fernán Basanta de Saavedra porque éste "a secuestrado çierta cantidad de carbón y leña que mi parte tenía comprada a unos carboneros y a otras personas para una herrería y machuco donde labra hierro", con la intención de obligar a la ferrería de Lorenzana a cerrar, después de causarle, añaden los monjes, más de doscientos ducados de pérdida. A su vez el procurador del capitán recuerda que "en dicha jurisdición de Valle de oro está la herraria das Pesqueiras en que mi parte tiene parte y es util y prouechosa para los vezinos de el"; y por el contrario, que los montes de Picano donde carboneaban los carboneros de Lorenzana son de los vecinos de Adelán y Valle del Oro; y añade

\footnotetext{
${ }^{2389}$ AHRG. R. A.: $1140 / 65$

${ }^{2390}$ AHRG. R. A.: 1140/65. Dice " $y$ se fue antes que en el dicho machuco moriese ninguna persona ny obiese ningun mal de peste contaxioso... sabe (el testigo) que no ubo peste ninguna mas de averse falleçido el dicho Juan Mendez de enfermedad despues de hido y ausentado el dicho Diego de Candean".

${ }^{2391}$ P. SAAVEDRA (1985): Economía, política y sociedad en Galicia: La provincia de Mondoñedo, 1480-1830. Xunta de Galicia, p. 329. nota 87.

${ }^{2392}$ P. SAAVEDRA (1985): Economía, política y sociedad en Galicia: La provincia de Mondoñedo, 1480-183o. Xunta de Galicia, p. 329, nota 86.
} 
"porque en dicha jurisdición" están los dueños de la ferrería en posesión de llevar carbón de tales montes sin que se pueda vender en jurisdiciones foráneas 2393. Desconocemos que parte de la ferrería pertenecía al mencionado capitán Fernán Lasanta Saavedra; pero probablemente era suya la mitad, pues un Saavedra aparece en el siglo XVIII como dueño de la mitad de la ferrería, como veremos posteriormente.

Desde finales del siglo XVII o principios del XVIII debió dejar de funcionar como ferrería, probablemente por falta de combustible2394. En 1722 don Alvaro da Pedrosa y Saavedra, dueño de la mitad de la ferrería, denuncia a varias personas descendientes de Francisco Sánchez de Vidarte por impago de la renta foral de la ferrería y machuco de Pesqueira ${ }^{2395}$. Algunos de los encausados reconocen que es verdad, que desde hace algunos años -doce dice uno- no pagan la renta, de la que unos no saben ni siquiera la cantidad y otros creen que son ocho ducados ${ }^{2396}$. Sin embargo, don Antonio Villar Osorio, marido de doña María Pascuala Vidarte y curador de su cuñado Benito Vidarte, hijo otro Francisco Vidarte ${ }^{2397}$, señala que cuando se encargó de la curadoría, ocho años antes, "estaba la referida herraria totalmente deshecha e inutil para el trabajo sin thener materiales algunos, mas que las dos arboles maiores y lo demás se auía consumido con el dilatado tiempo de diez y ocho años que estaua de aquella suerte sin que ubiese fructificado emolumento alguno". Esto último

2393 AHRG. R. A.: 67/18

${ }^{2394}$ AHRG. R. A.: 67/18. En 1650 en el juicio entre Lorenzana y el capitan Fernán Basanta de Saavedra dice éste que "dicha herraria de Pisqueiras lo qual la maior parte del año no labra por falta de dicho carbón ni labró después de que dicho P. administrador lleuó dicho caruón y taló dichos montes".

2395 AHRG. R. A.: 21.859/104. Dice el tal don Alvaro da Pedrosa a los denunciantes. "llebadores y poseedores de la Erraria que se dice da Pisqueira, con sus casas, molino, guertas, sotos, machuco, eredades, edificios, aparejos, erramientas, montes y más anexo y perteneciente a dicha Erraria y machuco, según todo es bien conocido, y se alla sito en la feligresía de Santa Cruz deste balle y jurisdición, en que me toca y pertenece la mitad enteramente y por mi título de foro lleban los sobredichos, porque en cada un año me pagan y deuen pagar de canon, renta y pensión tres mil maravedís".

${ }^{2396}$ Así el presbítero Francisco Sánchez Vidarte sabe "que el dicho D. Albaro Antonio da Pedrosa y Saavedra vecino de la feligresía de Santiago de Adelán tenía y tiene parte en la erraria de la Pesqueira, con sus casas, molino, sotos, machuco y más a ella conducentes. No sabe fixamente lo que hes, solo saue que entre todos los hixos y erederos de D. Francisco Sánchez Vidarte y $D^{a}$ Mariana de Luaces su hermana lleuan en foro la dicha erraria de la Pesqueira toda la parte que tocaua a D. Alonso de Pedrosa al presente difunto padre del dicho don Albaro y que por ella le pagaban ocho ducados de renta y canon en cada un año entre todos los dichos herederos" (AHRG. R. A.: 21.859/104)

${ }^{2397}$ AHRG. R. A.: 21.859/104. Dice el texto que a este Benito Vidarte, en las partijas de sus padres, se le adjudicaron "las dos terceras partes enteramente de la herraria da Pisqueira". 
también lo confirman otros testigos al señalar que no pagaban renta porque nada producía; pero, añade aquél, que desde "el año pasado de setezientos y diez y nuebe (...) "a costa de sus mismos vienes la hizo y fabricó y puso a trabaxar, como oy esta auil para ello" ${ }^{2398}$.

Es decir, que durante años estuvo parada y fue este Antonio Villar el que la volvió a poner en funcionamiento en 1719. Durante años nadie pagó la renta, ni los dueños parece que se preocuparon en cobrarla; pero ahora que está nuevamente en funcionamiento vienen a reclamarla. Muchos de los herederos no tienen inconveniente en reconocer la deuda y comprometerse a pagar los atrasos porque quieren participar en los beneficios. En 1724 la justicia dio un auto a favor de don Alvaro, que don Antonio Villar apeló; pero en 1726 a la viuda de aquél, doña Baltasara de Aguiar, le reconoce la Real Audiencia el directo dominio de la mitad de la ferraría y el canon de 3.000 maravedís de renta al año.

La otra mitad debía de ser de los antiguos Maseda, ya que en 1733 un Josef Maseda y Río, vecino de la feligresía de Santa Cruz de Valle de Oro, administrador de la ferrería de Pesqueira, se queja del juez ordinario de la jurisdicción de dicho valle, porque dice su procurador "que necesitando mi parte bastimento de leña y caruon para dicha herraria compró a Diego Gonzalez ... unos castañales viejos e ynutiles ... y se hizo caruon con ellos (..). y desde el ocho de abril un carbonero natural del Principado de Asturias asta el 27 que en este concurrió mi parte en la noticia que se dio de estar en estado; con carros y bueis y otras personas para hauer de conducir dicho caruon a la citada ferrería y poder proseguir la fabrica de fierro que por falta de dicho Bastimento tenía parada con los oficiales y obreros que diariamente trauajan en ella y tambien porque el temporal amenaza ruina y sucedía caer agua y mojarse dicho carbón perdía la fuerza y se destruía sin quedar de prouecho para dicho ministerio y de llegado al referido soto hallaron la nouedad de que dicho juez hauía puesto en él coto y embargo a instancia de D. Andrés Louera Fajardo, vecino de la misma feligresía”, el cual vio realizar las labores durante

${ }^{2398}$ IBIDEM 
los diecinueve días que tardó la operación sin decir nada y luego lo denunció, causando un gran perjuicio a la ferrería ${ }^{2399}$.

No debió funcionar mucho tiempo, pues el Catastro de Ensenada no menciona la ferrería, sólo dice que en esta parroquia hay dos mazos arruinados, que sin duda son la ferrería y el machuco de la escritura de 1571. Tampoco la nombran Cornide ni Lucas Labrada. En febrero de 1788, en el permiso que los vecinos de Rúa otorgan a don Antonio Raimundo Ibáñez para construir una ferrería, recuerdan que "en la provincia de Mondoñedo, en que se incluía esta parroquia, había antes de ahora cuatro herrerías de labrar hierro; la una en el valle de Lorenzana, otra en Santa Marta, otra en el Valle de Oro y sitio de Pesqueira y otra en la feligresia de Bravos (...). Cuyas herrerías, por diferentes motivos, han quedado a hiermo y sin uso, imposibilitadas de jamás renovarse, efecto de la falta de leñas y carbón para su subistencia” ${ }^{2400 .}$

Este problema del combustible lo vuelven a señalar varias parroquias de la jurisdicción de San Ciprián en agosto de 1788, en su oposición a la fábrica de Sargadelos, porque al igual que los dueños de las anteriores fábricas, Ibáñez se enriquecerá destruyendo los montes y arruinando los pueblos: "de que tienen los exponentes dos ejemplares bien recientes, en las dos (herrerías) que se construyeron en los valles de Oro y Bravos, y en que después de que sus dueños asolaran los montes de la circunferencia llevándose las utilidades de ellos, desamparan las fábricas, actualmente abandonadas, y dejaron a los naturales del país en la mayor penuria de leñas y maderas" ${ }^{2401 .}$

Por tanto, mucho antes de que se construyera la fábrica de Sargadelos estas dos ferrerías habían dejado de funcionar por problemas con el carbón y la madera.

ESTADO: No queda sino el topónimo de la Ferrería.

\footnotetext{
2399 AHRG. R.A.: 8698/87

2400 A. MEIJIDE PARDO (1979): Documentos para la historia de las Reales Fábricas de Sargadelos. Ediciones do Castro, p. 88, documento ${ }^{\circ} 26$

${ }^{2401}$ IBIDEM, p. 104, $\mathrm{n}^{\circ} 33$
} 


\section{MUNICIPIO DE VILLANUEVA DE LORENZANA}

\section{FERRERÍA DE LORENZANA}

LUGAR: Vilanova

MUNICIPIO: Lorenzana

RÍO: Batán

COORDENADAS: $43^{\circ} 28^{\prime} 28^{\prime \prime}$ N. y $7^{\circ} 18^{\prime} 13^{\prime \prime} \mathrm{W}$.

Por la N-634 desde Mondoñedo a la costa, no lejos de Villanueva de Lorenzana sale una pista que llega hasta la Ferrería, que está debajo del puente de la autovÍa, a orillas del Batán, afluente del Masma.

Se trata de una ferrería medieval conocida con el nombre de "Ferrería de Saltejo", situada en las inmediaciones del monasterio de San Salvador de Villanueva de Lorenzana. De ella, al menos, se tienen noticias desde 1429, en el que un documento señala que el abad de dicho monasterio, don Fernando Suárez, llevaba su administración directa2402.

El abad fray Rodrigo Gumiel la aforó en 1519 a Fernando Rodríguez de Aguiar en 3.00o maravedís de renta anual: "vos aforamos la ferrería del casal de Saltejo cerca desta dita villa (...) con el palacio et casas del rendero de la dicha ferraria et entradas et salidad de la dicha ferraria et palacio et casas cuantas han et aver deben (...) aguas et presas et rio et montes et fontes plantados et por plantar mansos et bravos et con más el edificio, artificio, carpentarias (...) et con todas las mas suas cosas et censo et censos et deevicion et deviciones, rendaria, ferraria, mando et señorio çebil et criminal et con todo lo mas a la dicha ferraria debido (...) aveys de apostar et adobar los dichos palacios et casas que estan derrocados et mal adereçados et ansy mesmo aveys de apostar los vanzados, presas et represas et arboles et rodas et maço et toda la dita ferraria et buscar la madeira, piedra et fierro et ferraje et clavaje que

${ }^{2402}$ AHN. Clero: Lourenzá, códice 181/B, f. 47v. Cfr. Ma . X. RODRÍGUEZ GALDO: Señores y campesinos en Galicia. Siglos XIV-XVI, 1976, p. 83 
oviere menester et fuere necesario de se buscar" 2403 . Además el abad le faculta para "poner rendero, mayordomo, fundidores, carboneros, carreteros, y un juez que entienda en dicha ferrería en lo civil y criminal según era uso y costumbre"2404.

Del texto se pueden extraer varias conclusiones: que la ferrería probablemente estaba en malas condiciones y era poco rentable, por lo que se afora para su restauración y puesta en funcionamiento; que era ya una ferrería hidráulica con su banzao, ruedas y mazo; que el foro se hace no solo de la ferrería sino que con ésta se incluían un pazo, viviendas, carboneras, montes y dehesas, además del señorío civil y criminal sobre los territorios y gentes ligados a la ferrería. Otra conclusión es que los foreros podían arrendar la ferrería, como de hecho veremos en numerosas ocasiones.

El foro hecho por la vida de Fernando Rodríguez de Aguiar, debió finalizar al morir éste; pues en 1569 el abad y convento, después de poner anuncios en la puerta de la iglesia monástica, la vuelven a aforar, como mejor postor, al vizcaino Francisco Sánchez de Vidarte, vecino de Miranda, por tres vidas o voces, "la nuestra herrería desta dicha uilla con su casa e ferrería e lo a ella anexo y perteneciente (...) como la han llevado en arrendamiento los Renderos pasados". Entre las condiciones, se compromete a pagar $8.100 \mathrm{mrs}$. de renta anual (100 mrs. menos de su postura en la puja, que le rebajan a cambio de la reparación de la ferrería "que está algo desbaratada"). Debe conservarla siempre bien reparada y, al finalizar las tres vidas, dejarla corriente y moliente "de manera que labre fierro como agora". A la muerte del forero, su sucesor debe presentarse antes de 30 días al abad; no puede vender sin permiso del monasterio previo pago a éste de un quinto del precio de venta. Por último, es muy interesante la concesión de jurisdicción civil y criminal respecto a el término de la ferrería, y sus ferrones, carboneros, venaqueros y mulateros, así como las relaciones entre el rendero y los merinos del monasterio 2405 .

${ }^{2403}$ AHN. Clero: Lourenzá, códice 181/B, f. 47v. Cfr. Ma . X. RODRÍGUEZ GALDO: Señores y campesinos en Galicia. Siglos XIV-XVI, 1976, p. 83

2404 AHN. Clero: Lourenzá. Libro 6.622. Tabla de los pergaminos, t. I, ff. 326-327.

2405 AHRG. R.A.: $145 / 76$ 
Pedro Pardo de Aguiar, señor del coto de Saramugo, y Pedro Maseda de Aguiar aforaron en 1571 a este mismo Francisco Sánchez Vidarte, rendero de la ferrería de Lorenzana, y a su mujer María Sánchez, ausente, la ferrería de Pesqueiras ${ }^{2406}$, aunque siguió como rendero de aquella otra ${ }^{2407}$ al menos hasta 1588, en que vendió una cuarta parte de dicha ferrería a Pedro Pardo de Saavedra, el cual en 1597 solicita al convento permiso para venderla a Juan Sánchez de Durango, que la adquiere por 70 ducados, de los que debe pagar al monasterio un quinto, como constaba del foro de 1569 , es decir 14 ducados 2408 . Por esos años el mismo Sánchez de Vidarte debió vender otra cuarta parte a Pedro Díaz de Villapol, ya que en 1632 Domingo Díaz de Villapol recuerda que hará unos cuarenta años que "vio pagar el foro y pensión de un cuarto de dicha erreria a Pedro Diaz de Villapol su abuelo y a Pedro Díaz de Villapol su ijo y tio del testigo, que llebaban el dicho cuarto y pagaban por renta cada uno conforme llebaba la parte de dicha erreria al dicho monasterio y convento" 2409 .

En 1601 se concierta el abad de Lourenzana con Pedro Díaz Villapol y Juan de Durango para labrar 200 quintales de hierro en su ferrería, siendo por cuenta del abad la vena y el pago de los oficiales, que cobrarán en función de los quintales labrados o quintalaje, corriendo los renderos con el carbón. Cada sábado se dividiría por mitad entre monasterio y renderos el hierro labrado²410.

2406 AHRG. R. A.: 21.859/104

${ }^{2407}$ AHRG. R. A.: 1140/65. En el juicio contra Diego de Candeán, al que arrienda la mitad del machuco de Pesqueira, Francisco Sánchez de Vidarte se dice rendero de las ferrerías de Lorenzana y Pesqueiras.

${ }^{2408}$ AHRG. R.A.: 145/76. 1597, agosto, 29: Pedro Pardo de Saavedra vende a Juan Sánchez de Durango, "rendero e vecino de la aldea de negonze, morador en la ferrería della que estays presente para bos e para buestra muger maria yanes y para todos buestros hijos y herederos (...) la quarta parte enteramente de la ferreria de la dicha villa de Villanueva de Lorenzana, según y de la manera que al presente está con su banzado mazo varquines fragua ferramentas casas plaza y como la hube y compré por carta de venta rassa que en mi fauor otorgó francisco sanchez de vidarte rendero que fue de la dicha ferrería y según que hes de fuero del monasterio desta villa, hos bendo segun dicho hes y embirtud de la licencia que para la bender me fue dada por el padre prior del dicho monasterio de la dicha villa de villanueba".

2409 AHRG. R.A.: $145 / 76$

2410 AHPLU: 7011/1 (1601). 4 de diciembre, en Villanueva, parecieron presentes "de la una parte el padre frai Pedro de binuessa, abbad del dicho monasterio por lo que le toca y en nombre de su conbento, y de la otra Pedro Diaz de Villapol, vecino de la ciudad de Mondoñedo, y Joan de durango rrendero en la erreria del dicho monesterio de la otra e dixeron que por quanto entre ellos hestá tratado y concertado de que en la dicha erreria se an de azer venera ducientos quintales de yerro tirado y labrado y se a de azer el dicho yerro y comenzar a labrar el primero dia del mes de henero del año benidero de seiscientos y dos asta que se acabe de azer los dichos ducientos quintales de hierro y para se azerse el dicho abbad de su parte a de poner 
Esto quiere decir que a principios del siglo XVII, hacia 1613, aparecen como porcioneros los herederos de Francisco Sánchez de Vidarte (María Sánchez de Vidarte y su marido Juan Fernández Rivera), los de Pedro Díaz de Villapol (Antonio López de Villar y los capitanes Luis Cora Montenegro y Diego Teixeiro y Aguiar como maridos de sus tres hijas) y los de Juan Sánchez de Durango (varios hijos pequeños, cuyo curador es Domingo de Montouto). Posiblemente cada uno tenía un cuarto además de otro cuarto el propio monasterio quien llevaba igualmente la administración de la ferrería, o al menos de parte de ella ${ }^{2411}$, y además nombraba o contrataba a los renderos, venaqueros y carboneros. En 1620 fray Plácido Valdés, mayordomo del monasterio, demanda a Antonio López Villar, vecino de Mondoñedo, por una deuda de $31.029 \mathrm{mrs}$. como cabecero del foro de la ferrería, que no ha pagado. En el documento se habla de que la cobre de los hijos y herederos de Juan Sánchez de Durango y de Juan Fernández de Rivera, también porcioneros en el foro ${ }^{2412}$.

En 1632 el monasterio demanda a Andrés Sánchez de Vidarte, rendero de la ferrería como marido de Isabel Sánchez de Durango, y a otros herederos de Juan Sánchez de Durango, que según el documento "se fue a las Yndias y llebaba parte de la dicha Erraria". En el juicio se pregunta a los testigos "si saben que la Erreria caudal de Villanueba de Lorenzana, sita en el rio de la dicha villa, con su casa y banzado, arbol mayor y barquines y con todos los demás pertrechos y aderentes para hacer yerro con todo lo demas a la dicha Herreria anejos pertenecientes son bienes propios del dicho monasterio y como tales los han llebado y poseydo por sus foreros que han llebado la dicha Herrería y bienes". También si saben que Ana López, mujer de Antonio Sánchez de Villar e hija de Pedro Díaz de Villapol, es la tercera voz del fuero de la

toda la bena que fuere necesaria y pagar a su costa quatro reales a los oficiales por cada quintal de fierro tirado y labrado y los dichos quatro reales an de ser a su propia costa del dicho padre abbad y los dichos Pedro díaz de billapol y joanes de durango an de poner a su costa todo el carbon que fuere nezesario para hazer la dicha labranza tanto el uno como el otro a su costa sin quel dicho opadre abbad tenga de poner para el dicho carbon cosa alguna mas de la dicha bena y oficiales y si costase mas de hechura cada quintal de fierro de los quatro reales an de pagar el dicho apdre abbad la mitad y ellos la otra mitad de la demasia de los dichos quatro reales y todos los mas aderezos y quiebras que ubiere a de ser por mitad..."

${ }^{2411}$ Probablemente por compra, como dice en 1601 el pleito del monasterio contra los vecinos de Villanueva de Lorenzana y Masma: "dizen mi parte les conpele a que con sus carros lleuen leña, caruon y bena a una herraria que nuebamente dizen compró”. AHRG. R. A.: 18.201/13

${ }^{2412}$ AHRG. R.A.: 145/76 
ferrería ${ }^{2413}$. Parece que el monasterio, terminada la tercera voz del foro de 1569, pleitea por hacerse con el artefacto.

El hierro de esta ferrería debía tener buena calidad. En 1578 el rejero Juan Bautista de Celma da un poder a Domingo González para que acuerde "con el rentero o persona que tiene a su cargo la herrería de Villanueva de Lorenzana, por la cantidad de hierro labrado de que tengo necesidad para la rexa que tengo a mi cargo de hacer al Rmo. Sr. Obispo de Tuy y que me entregue todo el dicho hierro puesto a su costa en la ciudad de Betanzos y al precio de treinta reales el quintal, como ya está tratado entre mi y el dicho rentero" 2414 . En 1594 Pedro Fernández Sanjurjo, vecino de Villanueva de Lorenzana, se concierta con el mercader de Mondoñedo Jácome Folón para venderle "diez y ocho quintales de fierro de la herrería de Villanueva bien sacado de a cien libras gallegas el quintal", en precio cada quintal de 18 reales y medio; en total 33 ducados y 3 reales2415. En 1615 Pedro Fernández, de San Juan de Laje, se obliga a pagar diez ducados menos cuatro reales a Juan de Segastiberre "rendero" de la ferrería de Lorenzana, del resto de hierro que le había vendido ${ }^{2416}$. En 1679 Juan Mengoechea "el Viejo", residente en la ferrería de Lorenzana, acuerda con Sebastián Fernández das Coroas, de Ribadeo, enseñar durante cinco años el "oficio de zerraxero y ferramentero de obra blanca" a un hijo de éste2417.

Uno de los problemas de la ferrería fue el transporte de la vena y la fabricación del carbón. El monasterio era propietario de "todas las beneras que estaban dentro de su jurisdición”, por lo que, según el procurador del mismo en 1628, "ninguna persona, asi de los basallos de la jurisdición como en los que no lo son, pueda entrar a abrir ninguna de las dichas beneras, sino es con licencia de mi parte y pagándole el quinto de toda la bena que sacare"2418. Conocemos varios contratos de saca de vena tanto para esta ferrería como para la de

\footnotetext{
${ }^{2413}$ AHRG. R.A.: 145/76. El problema de las voces en el foro fue objeto de muchas disputas. Por ejemplo, sabemos que Juan Sánchez de Durango y su mujer Marina Oanes en 1603 era la $2^{\text {a }}$ voz, y en 1615 su hija $M^{\mathrm{a}}$ Sánchez de Durango y su marido Bernabé Garcia Cordido, la $3^{\mathrm{a}}$ voz; pero no eran los únicos y de ahí los pleitos.

2414 C. GONZÁLEZ (1994): Ob. cit. p. 174

2415 AHRG. R. A.: 21.130/75

2416 AHPLU: 7013/1 (1615).

2417 P. SAAVEDRA, p. 315

2418 AHRG. Monasterios, 54/67.
} 
Vilaseca, por ejemplo en 1609 varios vecinos de Ferreiravella se obligan a sacar para la ferrería del monasterio 1.774 quintales de vena en precio de 630 reales2419. En 1639, Bastián García, Pedro de Ron y otros, vecinos de Santa María la Mayor (Mondoñedo) se obligan a sacar para el monasterio "mil quintales de bena limpia y bien acondicionada para hacer dicho metal de yerro en la herrería de esta villa que es suya de dicho convento, los quales dichos mil quintales de bena darán puesta y sacada en las bocas de las Benas de dicho monasterio en su jurisdicción y territorio" ${ }^{2420}$.

Pero no estuvieron ausentes los conflictos por la obligación que el monasterio imponía a sus vasallos para el transporte de esa vena, como ocurrió en 1601, en que los vecinos de Lorenzana se querellaron ante la Real audiencia de que el abad, monjes y tenientes de merino les obligaban, como señores jurisdiccionales, a que transportasen en sus carros la vena y carbón para la ferrería ${ }^{2421}$. A ello replica el abad que está en posesión de obligarles a ello, pagándoselo: "Primero porque el dicho monasterio tiene la mitad de la dicha herraria en quanto al util $y$ directo dominio y la otra mitad en quanto al directo, y de tiempo ynmemorial a esta parte él y sus foreros siempre que an labrado hierro en la dicha Ferraria an conpelido a los vezinos de las dichas feligresías a que pagándoles su trauaxo traigan la dicha bena y carbón y pues mis partes les paga su trauaxo ninguna fuerza aze. Lo otro porque siendo como mi parte hes señor de la dicha jurisdicion, están obligados los sobredichos como sus uasallos a travaxar en sus lauores, pagándoles como le paga su trabaxo y en particular por pagarles más que otros les an pagado y pagan por su trauaxo pues por cada carro de leña carbón o bena que traigan les da dos reales, no pagándoles los otros más que a real y medio y a sesenta maravedís que es el justo precio de aquella probincia y tierra" ${ }^{2422}$.

\footnotetext{
2419 P. SAAVEDRA: Ob. cit., p. 330, nota 89.

${ }^{2420}$ Cfr. C. GONZÁLEZ (1994): Ob. cit. p. 174.

${ }^{2421}$ AHRG. R. A.: 18.201/13. Rodrigo García de Vaamonde, en nombre de los vecinos de Villanueva de Lorenza y Masma contra el monasterio de San Salvador, dice "siendo como mis partes son libres y exentos de pagar al dicho monasterio... y estando de tiempo ynmemorial a esta parte ..de no traer leña ni carbon ni bena a la herraria del dicho monasterio ni a otra ninguna el dicho abad y más culpados de dos a tres meses a esta parte an conpelido y conpelen a las dichas mis partes a que traigan y lleben leña, vena y carbon con sus carros y bueies a una herraria que el dicho abad ha comprado... molestandoles con carcel y prisiones..."

${ }^{2422}$ AHRG. Vecinos: 18.201/13.
} 
Con frecuencia el monasterio tenía que concertar con los campesinos de los alrededores la adquisición de carbón. En 1627 se concertó con los vecinos de Cedofeita para que en "fragas" propias de la comunidad, que ellos utilizaban como colonos, hiciesen 2.500 carros de carbón, a real cada uno ${ }^{2423}$; en 1671 un monje de Lorenzana aseguraba que los hermanos Díaz de la Rocha, de Sante, se habían obligado a darle "libres y seguros, el corte y montazgo en que pudieren fabricar quatro mil setecientos carros de carvon"2424; pero no siempre era tan fácil pues a veces surgían problemas con los concejos. Así ocurrió en 1626 en que Alonso Calbo, Simón Pérez y otros vecinos de Santiago de Adelán dan su poder a Alonso López, rendero de la ferrería de Lorenzana, para que los defienda en un pleito que tienen contra el alcalde mayor de Mondoñedo porque les prohibe hacer carbón, contra lo que alegan "que siendo de mis partes los montes y fragas de los dichos lugares y estando en posesión de cortar y azer carbón en ellos, las dichas justicias (de Mondoñedo), por odio y enemistad que tienen a mis partes" se lo quieren prohibir2425. En 1627 se firma una concordia entre el concejo de Mondoñedo y Pedro Valiña y Labrada en representación del monasterio porque "habia pleito pendiente en la Real Audiencia de Galicia entre el concejo y el abad y convento por haber éstos, sus factores, renderos y oficiciales de la herrería de Villanueva, pretendido hacer carbón en los montes y fragas de Couboeira, Andoriña, Paleira y otras partes, que eran de la ciudad y que los frailes decían compraran ellos al Capitán Pedro Saavedra Regidor del concejo mondoniense" 2426 .

Los problemas por el combustible dieron lugar a pleitos con los vecinos y con otras ferrerías, como ocurrió en 1650 con la de Pesqueira. El dueño de una parte de ésta, el capitán Fernán Basanta de Saavedra, según el monasterio, " $a$ secuestrado çierta cantidad de carbón y leña que mi parte tenía comprada a unos carboneros y a otras personas para una Herrería y machuco donde labra hierro, y lo tiene depositado en poder de algunas personas en donde se pierde y açe de menos mucha parte del por cuya causa a parado la Herrería por no tener carbón para trabajar en ella". Dicho capitán ha hecho que el monasterio

2423 AHN. Clero: libro 6.596, ff. 209-212

2424 P. SAAVEDRA: Ob. cit., p. 330, nota 93

2425 AHRG.Vecinos: 26.643/ 46

${ }^{2426}$ Cfr. C. GONZÁLEZ (1994): Ob. cit., p. 174 
"perdiese el dinero que tenía dado por dicho carbón y dicho capitán quererlo llebar para otras errarias suyas y porque cerrarse la mi parte y se le siguiese dello mucho daño como en effecto se le a seguido de más de ducientos ducados de todo el tiempo que a estado parada sin trabajar en ella por falta de dicho carbón”2427.

Como otras ferrerías de la zona debió dejar de funcionar a principios del siglo XVIII por falta de combustible. Ya en 1625 un vecino de Mondoñedo se quejaba a las autoridades de que el consumo de carbón en la ferrería de Lorenzana tenía arruinados los montes ${ }^{2428}$. De hecho ni el Catastro ni Cornide mencionan ya la existencia de esta ferrería. En un documento de 1788 se dice que "en la provincia de Mondoñedo, en que se incluía esta parroquia, había antes de ahora cuatro herrerías de labrar hierro; la una en el valle de Lorenzana, otra en Santa Marta, otra en el Valle de Oro y sitio de Pesqueira y otra en la feligresia de Bravos (...). Cuyas herrerías, por diferentes motivos, han quedado a hiermo y sin uso, imposibilitadas de jamás renovarse, efecto de la falta de leñas y carbón para su subistencia” ${ }^{2429}$. Nunca más volvió a funcionar.

ESTADO: No hay restos de interés.

2427 AHRG. R. A.: 67/18.

${ }^{2428}$ AHRG. R. A.: 26.643/46. Denuncia ante el alcalde mayor de Mondoñedo que vecinos de Adelán, San Martín, Couboeira, etc. "en las fragas de este obispado en ellas abian cortado muchos carballos por el pie y otras arboles para azer el dicho carbón y lo llebaban a bender a la erraria de Billanueba de Lorenzana con el qual dicho carbón tenían destruidas las dichas fragas".

2429 A. MEIJIDE PARDO (1979): Ob. cit., p. 88, documento $\mathrm{n}^{\circ} 26$ 


\title{
24. MUNICIPIO DE VILLALBA
}

\section{FERRERÍA DE SARAMUGO}

\author{
LUGAR: Saramugo \\ MUNICIPIO: Villalba \\ RIO: Támoga \\ COORDENADAS: $43^{\circ} 16^{\prime} 22^{\prime \prime}$ N. y $7^{\circ} 34^{\prime} 12^{\prime \prime} \mathrm{W}$.
}

En realidad debía estar situada en un pequeño afluente del Támoga, más que directamente en ese río.

Existía en el siglo XVI pero no nos es posible precisar la fecha exacta de su construcción. En 1590 se dice que "de veinte años a esta parte labró de dichos montes", lo que podría indicar que trabajaba desde 1570, pero es una cita muy ambigua, por lo que quizá haya que suponer una mayor antigüedad.

Sólo sabemos que en ese año de 1590 era rendero de esta ferrería de Saramugo Juan González de Romaña, al que pone pleito Pedro Voco, mayordomo del señor del condado de Saramugo, "sobre las beneras y montes donde se hace el carbon para la dicha ferrería", ordenándole que no "agan carbon de ninguna manera ni saquen bena para la dicha ferrería". Como es lógico, aquel denuncia "que sin dicho carbón y bena no puede labrar ni labra", añadiendo que "desde mas de veinte años a esta parte labró de los dichos montes que agora v.m. pretende impedirle, lo que le lleva a perder mucho dinero "que estimo la dicha perdida y daño es trescientos ducados cada un año mas otros cuarenta ducados que pago de renta y fuero por dicha ferreria cada año"2430.

Por esa época era señor del coto de Saramugo Pedro Pardo de Aguiar, propietario de la ferrería de Pesqueira con Pedro Maseda, los cuales la aforaron en 1571 al vasco Francisco Sánchez de Vidarte ${ }^{2431}$. Sin duda esta ferrería de Saramugo era igualmente de este Pedro Pardo de Aguiar. 
ESTADO: Desconocido

\section{MUNICIPIO DE CEDEIRA}

\section{FERRERÍA DE MONTOXO}

LUGAR: Montoxo

MUNICIPIO: Cedeira

RIO: Las Mestas

COORDENADAS: $43^{\circ} 38^{\prime} 32^{\prime \prime}$ N. y $7^{\circ} 59^{\prime} 58^{\prime \prime} \mathrm{W}$.

Montoxo no está en la provincia de Lugo, sino en la de La Coruña, en el municipio de Cedeira, muy cerca del mar. En el Antiguo Régimen perteneció a la provincia de Betanzos. Hay dos Montoxo, uno al lado del otro, San Xulian y San Román; desconocemos en cual de ellos estaba esta ferrería. Probablemente se situaba a orillas del río de las Mestas.

Se trata de una ferrería construida en los primeros años del siglo XVI, como deducimos de una escritura de foro: "En seys dias del mes hebrero del año pasado de quinientos y ochenta y cinco presentó una escritura de fuero censo perpetuo sinalada e firmada de Tomas Bernaldez notario segun della costa que parece fue hecha y otorgada por D. Rodrigo Enríquez Osorio, conde que fue de dicho condado (de Lemos) a Martín Basoa el biejo, abuelo de dicho Juan de Basoa y sus hermanos, del territorio llamado el Montoxo, para que en él hiçiesen y hedificasen una herraria en el sitio donde ya abia sido hedificada otra y por ello y por ello (sic) le abian de pagar en cada un año de pension tres mil mrs. con ciertas condiciones. Su fecha en la villa de Monforte de Lemos a quince dias de março del año pasado de quinientos diez y siete años”2432.

Del texto deducimos que en el lugar del Montoxo ya existía una ferrería anterior, probablemente del siglo XV o anterior. No está claro si la que ahora se permite construir es una ferrería diferente, con lo que tendríamos dos artefactos juntos, o es la reconstrucción de una anterior como parece más exacto. En todo

${ }^{2432}$ AHRG. R.A.: 5·772/33 
caso, lo evidente es que el conde de Lemos en 1517 aforó un terreno a un presumiblemente vasco para que construyera una ferrería, por la que ha de pagarle de foro 3.000 maravedís anuales. Como estaba muy cerca de la costa, hay que suponer que se abastecería de hierro vizcaíno, aunque no hay que descartar la utilización de alguna vena local, de los criaderos de Ortigueira 2433.

La ferrería debió funcionar durante buena parte del siglo XVI, durante las vidas de Martín de Basoa el viejo y el joven. Martín de Basoa el viejo todavía vivía en 1571, pues lo mencionan varias escrituras como vecino de la feligresía de Montojo y propietario de la mitad del lugar y casal de Sobrado ${ }^{2434}$. En ese mismo año lo encontramos junto con un Martin de Basoa, el Nuevo, pleiteando contra Lopez Díaz de Lago al que demanda por deudas del arriendo de los diezmos de Santa Marta, que los dos junto con Alvaro López de Serantes habían arrendado para los años 1564 a 1569, y de cuyo arriendo les había quedado a deber 52.500 maravedís ${ }^{2435}$. Por lo que se ve se trataba de personas con elevados ingresos y una alta posición social.

Sin embargo, en 1585 el mayordomo del conde de Lemos denunció a estos Basoa por impago de la renta del fuero de la ferrería de los años 1582 a 1584, que sumaba 8.000 mrs., porque 1.00o los había pagado Isabel Díaz, una de las hijas de Martín de Basoa el joven. Probablemente por entonces la ferrería había dejado de funcionar, como veremos. El mayordomo del conde llevó a juicio al escribano Juan de Basoa, hijo de Martín de Basoa el joven, como el miembro con más posibles de la familia; pleito que se sustanció con una sentencia favorable al conde. Para pagar la deuda y las costas del juicio se subastaron el molino, la casa de la ferrería y varias propiedades hasta un total de 9.800 maravedís (8.00o de la deuda más 1.800 de costas). Poco después, este Juan de Basoa pleiteaba a su vez contra sus hermanos Martín de Basoa e Isabel Díaz, casada con Pedro Sánchez, "sobre el fuero de la ferrería del Montoxo" porque él solo estaba obligado a acudir "a su parte con lo que tocaba que hera las dos

2433 P. HERNÁNDEZ SAMPELAYO (1935): Hierros de Galicia III, p. 548 2434 AHRG. R.A.: 24.837/43

2435 AHRG. R.A.: 23.716/6 
tercias partes" y no con todo, ya que la otra parte debían pagarla sus hermanos" 2436 .

Como deciamos antes, la ferrería debió dejar de funcionar por esos años finales del siglo XVI. Uno de los testigos del juicio, en 1595, "dixo que sabe y tiene noticia de la heredad que esta cerca donde tubo la ferreria questá en el rio e molino" y otro que "sabe la heredad questá junto donde tubo la herraria de Montoxo y está en el rio y molino". ${ }^{2437}$ Este “tubo la ferreria” puede indicarnos que la ferrería ya no existía.

ESTADO: Desconocido. 


\section{FERRERÍAS DE ORENSE}




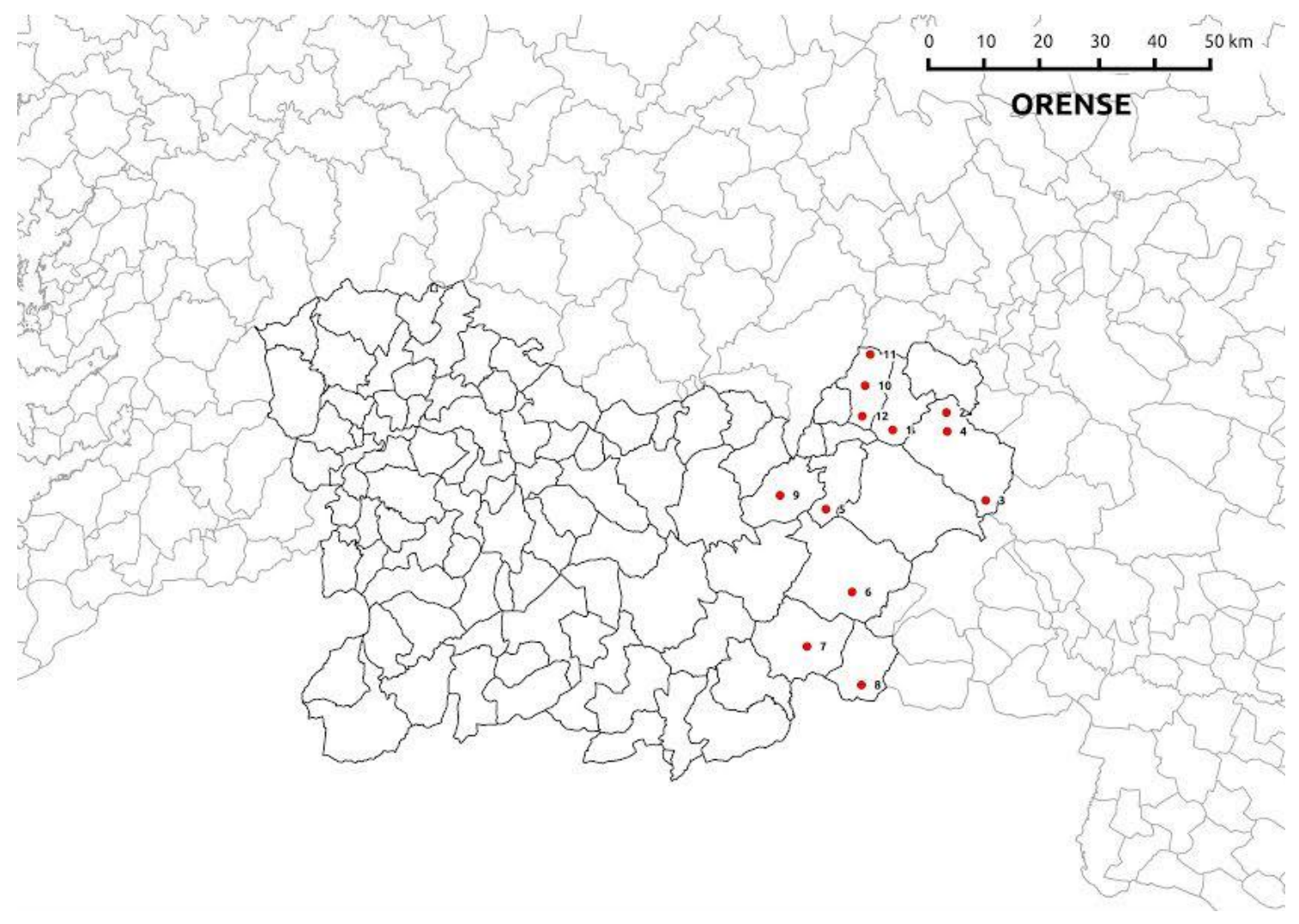

FERRERÍAS DE ORENSE 


\title{
1. MUNICIPIO DEL BARCO DE VALDEORRAS
}

\section{FERRERÍA DE FERVENZA}

\author{
LUGAR: El Encinal (Fervenza) \\ MUNICIPIO: Barco de Valdeorras \\ RÍO: Fervenza
}

COORDENADAS: $42^{\circ} 23^{\prime} 57^{\prime \prime}$ N. y $7^{\circ} 1^{\prime} 47^{\prime \prime} \mathrm{W}$.

La ferrería de la Fervenza (a veces Ferbenza) está situada a unos cinco kilómetros y medio del Barco de Valdeorras, en el lugar de Fervenza2438, al sitio del Encinal, en un pequeño arroyo afluente del Sil, denominado también río da Fervenza, que desemboca en las cercanías de Arnado.

La construyó en 1839 José I. de Prada Valcarce, persona según Ricardo Gurriarán, muy interesada en las prospecciones mineras, del que se conocen algunas denuncias de minas de hierro y oro ${ }^{2439}$. La ferrería se hizo en terreno comunal, pero siempre tuvo problemas de agua que por medio de una presa se traía desde Portomao, sin perjudicar a los vecinos, según acuerdo que hubo de hacer su propietario con ellos ${ }^{2440}$. Era probablemente una ferrería regatera.

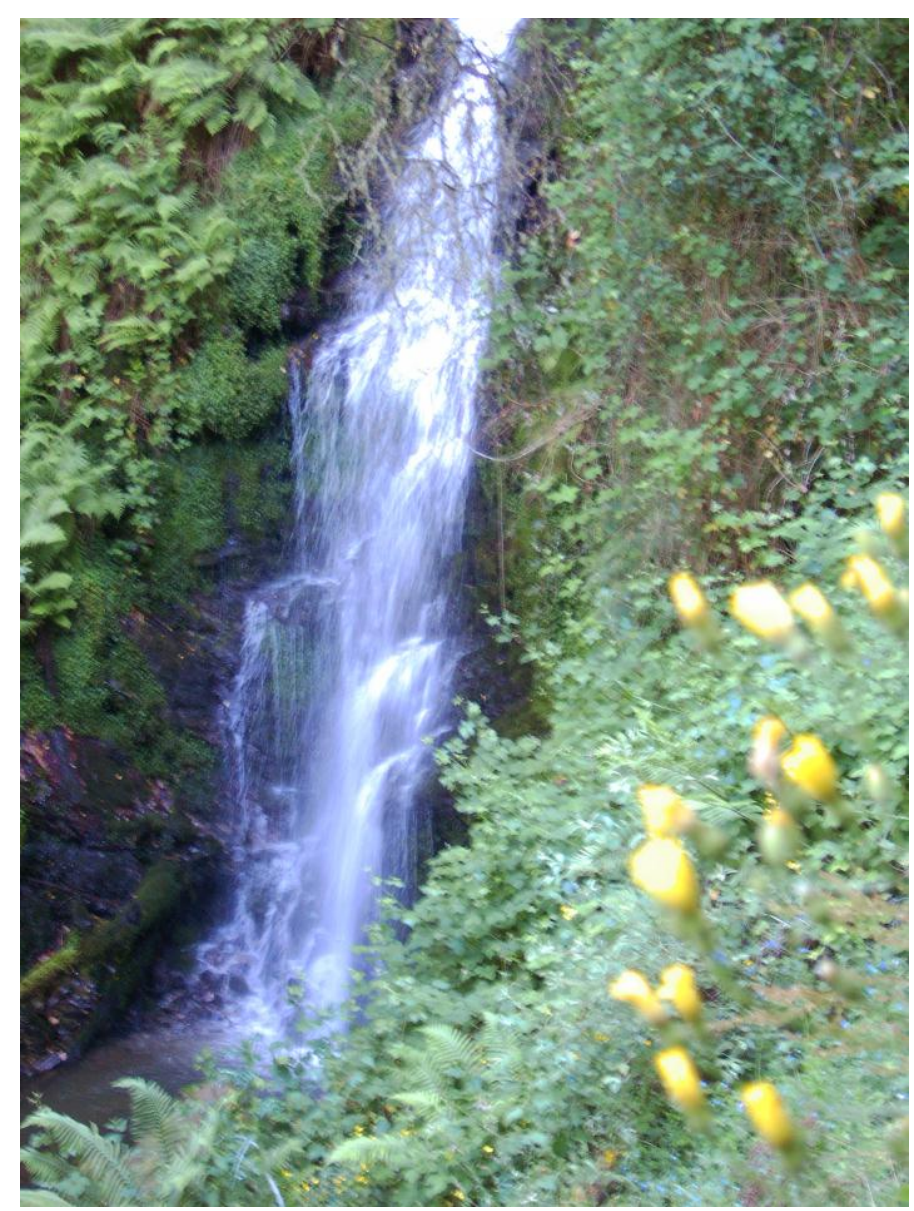

Arroyo de la ferrería de la Fervenza

${ }^{2438}$ Se trata de un lugar muy pequeño, que según un censo de 1766 contaba con 18 vecinos (68 habitantes). En A. CASTRO (1993): Valdeorras a mediados del siglo XVIII según el Catastro del marqués de la Ensenada. IEV. cuaderno mongráfico 15, p. 73.

2439 R. GURRIARÁN (2000): Ob. cit., p. 132.

2440 IBIDEM, p. 132 
El Nomenclator de la Provincia de Orense de 1863 la menciona: "Fábrica de Ferbenza. Fábrica de hierro, situada a 5,5 km. del Barco"2441, pero por entonces ya no trabajaba. Debió tener una vida efímera ${ }^{2442}$, aunque por la presencia de materiales de hierro que llevó José I. de Prada a la exposición Agrícola, Industrial y Artística de Galicia del año 1858, hay que presumir que en ese año aún estaba en funcionamiento. En 1866 la fábrica le fue embargada a su dueño por impago de alguna deuda contraída con Telesforo Alba, que era en dicho año alcalde del Barco de Valdeorras ${ }^{2443 .}$

ESTADO: Restos de muros.

\title{
2. MUNICIPIO DE CARBALLEDA
}

\section{FERRERÍA DE LA PONTENOVA}

\author{
LUGAR: A Pontenova (Sobradelo) \\ MUNICIPIO: Carballeda de Valdeorras \\ RÍO: Casayo \\ COORDENADAS: $42^{\circ} 24^{\prime} 45^{\prime \prime}$ N. y $6^{\circ} 50^{\prime} 36^{\prime \prime} \mathrm{W}$.
}

La Pontenova es un barrio de Sobradelo nacido a uno de los lados del puente sobre el río Sil, en la margen izquierda, justamente entre éste y el Casoyo que allí mismo desemboca. El barrio está, pues, entre el puente y ambos ríos ${ }^{2444}$. Hoy forma un núcleo de cierta consideración, surgido en gran parte alrededor de la ferrería que allí se construyó en el siglo XVIII.

\footnotetext{
${ }^{2441}$ F.FERNÁNDEZ FULGOSIO (1866): Crónica General de España. Provincia de Orense, p. 13. 2442 IBIDEM, p. 132

2443 IBIDEM, p. 132.

2444 M. MACIAS: El obispado de Astorga en el siglo XIX, p. 90 (manuscrito anónimo),: "Otro puente (después de hablar del de la Cigarrosa), llamado Puente Nuevo, hay dos leguas más arriba; inmediato a él entra en el Sil el río Casayo, con cuya agua anda una herrería que está en la confluencia de ambos ríos". J. A. BALBOA (1992): El Bierzo en la obra de dos militares del siglo XVIII: Datoli y Munárriz., p. 127. Dice Munárriz que está "a la entrada del valle de Valdeorras y en las aguas del riachuelo Casayo".
} 
La ferrería de la Pontenova debió construirse en la segunda mitad del siglo XVIII a orillas del Casayo, que desciende de Peña Trevinca ${ }^{2445}$, por su mayor caudal y regularidad que el arroyo de Domiz y por su relativa mayor cercanía a los yacimientos de hierro de Formigueiros. No la cita el Catastro de Ensenada; según Cornide, hacia 1780, la propiedad de esta ferrería pertenecía al señor de Viloria. En efecto, en 1792 sabemos que era propia de Diego Antonio de Quiroga y Nava, señor de dicha casa grande ${ }^{2446}$. Probablemente éstos compraron a sus parientes de la Casa del Castro el derecho que había conseguido para construir la ferrería de Robledo; pues según R. Gurriarán, en la portada del documento con la concesión de aquella ferrería, hecho posteriormente, se puso "Puentenuevo"2447. Pudiera ser, como indica este autor, que también hubiera problemas jurisdiccionales, pues alguno de los lugares de los que pensaba surtirse de vena, como Pardollán, pertenecían a la casa de Viloria.

En la cédula para la construcción de la ferrería de Robledo se hablaba de utilizar la vena de Biobra, Vilar de Silva, Pardollán y otros lugares de la provincia de León; pero como sabemos por el pleito de Formigueiros y por lo dicen Tomás López y Munárriz, la ferrería de la Pontenova usaba mineral de aquel venero lucense, pues el de aquellos lugares era de mala calidad ${ }^{2448}$; posteriormente también utilizó el de la Chana (Borrenes)2449. Según Tomás

\footnotetext{
2445 Un dato que confirma esto es que en la portada del documento que contiene la cédula con la licencia para la ferrería de Robledo de Domíz pone Pontenova, identificándolas.

${ }^{2446}$ AHN. Estado, leg. 1739, $\mathrm{n}^{\circ}$ 16: En el pleito por el uso de la vena de Formigueiros, año 1792, D. Blas Fernández, abad y cura párroco de San Miguel de Montefurado, como curador de D. Diego Antonio Quiroga y Nava, señor de Viloria, dice que el menor "es dueño de la herreria de el Puente nuebo, él y sus antecesores desde que tubo efecto su construcción siempre han usado de la Bena nezesaria para su uso y exercicio de la que produze el monte de Formigueiros en virtud de licencia y foro".

2447 R. GURRIARÁN (2000): Ob. cit., p. 73

2448 T. LÓPEZ: Diccionario. BNE. Secc. Manuscritos, 7304, f. 106: "Ay vena de fierro en los montes de Vila, Pumares y Pardollán, pero algo pobre por lo que una herrería que tiene $D$. Joseph Alfonso Pertierra, señor de Montefurado y vecino de Villoria, en el Puentenuevo trae la vena de los montes del Courel y sitio de Formigueiros". Cit. por I. García Tato: Valdeorras de cara al año 2000 , t. I, p. 609.

Munárriz dice que las ferrerías "de Valcarce, Arnado, Oencia, Puente Nuevo y San Vicente emplean el mineral de Formigueiros" en J.A. BALBOA (1992): El Bierzo en la obra de dos militares del siglo XVIII: Datoli y Munárriz, p. 127.

2449 HERNÁNDEZ SAMPELAYO: Ob. cit., p. 585 señala que en 1881-1882 funcionó con mineral de la Chana.
} 
López era una ferrería regatera, de escaso valor ${ }^{2450}$, y así parece a tenor de la producción anual que le señala Cornide: 550 quintales ${ }^{2451}$.

A finales del siglo XVIII, Tomás López afirma que el propietario de la Pontenova era don Joseph Alfonso Pertierra ${ }^{2452}$, dueño de la Torre y vecino de Cangas de Tineo; pero en realidad, como señala un documento de 1796, sólo lo era como administrador de los bienes de su hijo don Josef Xavier Alfonso Pertierra Quiroga, legítimo heredero del vínculo de la casa de Viloria, y por tanto de la ferrería, por su abuelo don Josef Nicolás de Quiroga y Nava; pues estaba casado con su hija doña María Francisca Xaviera Quiroga, Nava y Valcarce ${ }^{2453}$. En manos de éste seguía en 1819 , aunque arrendada al berciano Ramón Ovalle, que luego sería dueño de las ferrerías de Arnadelo y Valdelouro. En un documento de 1821 éste confiesa deberle, por atrasos en el arriendo de la ferrería, la cantidad de 36.192 reales, que el arrendatario se obliga a pagar2454. Parte de esta deuda, 8.191 reales, la paga Ramón Ovalle mediante el endoso en 1821 a don José Alfonso Quiroga, hijo de los dueños de la ferrería de La Pontenova, de una deuda por esa cantidad que le debía Juan Oulego, vecino de Oencia, de hierro sacado por su madre 2455 .

${ }^{2450}$ T. LÓPEZ: Ob. cit. f. 106: Dice de esta ferrería que trae el mineral de Formigueiros, "lo que, y ser regatera, le haze ser de poco valor". Cit. por I. García Tato (1996): Valdeorras de cara al año 2000 , t. I, p. 609.

2451 J. CORNIDE: Ob. cit.

${ }^{2452}$ T. LÓPEZ: Diccionario. BNE. Secc. Manuscritos, 7304, f. 106: “Ay vena de fierro en los montes de Vila, Pumares y Pardollán, pero algo pobre por lo que una herrería que tiene $D$. Joseph Alfonso Pertierra, señor de Montefurado y vecino de Villoria, en el Puentenuevo trae la vena de los montes del Courel y sitio de Formigueiros". Cit. por I. García tato: Valdeorras de cara al año 2000, t. I, p. 609.

${ }^{2453}$ AHN. Estado, leg. 1739, $\mathrm{n}^{\circ}$ 16. Escritura de 1796 en la que se dice que este Josef Alfonso Pertierra es legal administrador de los bienes de su hijo D. Josef Xavier Alfonso Pertierra Quiroga, heredero de los vínculos de la casa de Viloria y entre ellos "de la casa y Herraria del Puente nuebo de ella".

2454 AHPL.PN caja 2576 (1821). Poder de Ramón Ovalle a su hermano José, del 12 de mayo de 1821, para el cobro de ciertas deudas. Se incluye un memorial, en el que en 18 de noviembre de 1819, Da María Luisa Valdés y Sousa de Miramontes, mujer legítima de D. José Alfonso Pertierra, con poder de su marido "hizo transación por cierta escritura pública con D. Ramón Oballe cerca del arriendo que este tenía de la Herrería de Puentenuebo, propia de dicho su marido, y para cobro de deuda, que de los años que la disfrutaba el D. Ramón le estaba adeudando, se combinieron y ajustaron en que dicho D. Ramón la ha de dar la cantidad de treinta y seis mil ciento nobenta y dos rs. vn. y como le entregare (...) dicho D. Ramón por obligaciones y memoriales la cantidad de treinta y dos mil ciento ochenta y cinco según resultaron de dichas obligaciones y memorial(...) y el resto del alcance lo a de pagar al tiempo que entregue los efectos de dicha Herrería".

2455 AHPL. P.N.: 3576 
Además de Cornide, Tomás López y Lucas Labrada2456, a la ferrería la nombran Munárriz y Madoz. Este último al hablar de arroyo Casayo, dice de dicho río que impulsa "a una fábrica de hierro perteneciente a la casa grande de Viloria en el lugar de Puente-nueva"2457. En 1846 era su propietario don José Alfonso Quiroga y Valdés, cuyo suegro, don Manuel Ma Vázquez Queipo, señor de la casa grande de San Martín de Quiroga y propietario de varias ferrerías gallegas, como apoderado arrienda la de la Ponteneva a Enrique Celeiro, vecino del Puente de Lóuzara (Samos), por 9 años y 5.00o reales de renta anual2458. En 1868, junto con la de Riodolas, la tenía arrendada don Paulino Arias²59.

A finales del siglo XIX la revista Estadística Minera la menciona varios años, unas veces trabajando, otras parada: en 1881-1882 estuvo parada; en 1885 benefició 100 toneladas de mineral de hierro; en 1887-88 funcionó; en 1889-90 produjo 25 toneladas métricas de hierro ${ }^{2460}$. A principios del siglo XX era propiedad de los herederos de don Ignacio Morán²461.

ESTADO: A penas son visibles restos de la ferrería, a excepción del canal del agua de mampostería de pizarra, pero se intuye en medio de las edificaciones modernas, que en gran parte aprovechan las de la propia ferrería.

\footnotetext{
${ }^{2456}$ LUCAS LABRADA (1802): Ob. Cit. p. 117 dice: “Aquí (en Valdeorras) no hay más fábricas que una herrería en el lugar de Puentenuevo; pues aunque en las inmediaciones hay otras, no se comprenden en el distrito de esta jurisdicción, y si en el de Quiroga y merindad de Aguiar". 2457 J.A. BALBOA (1992): El Bierzo en la obra de dos militares del siglo XVIII: Datoli y Munárriz, p. 126, Munárriz dice: "La del Puente Nuevo, a la entrada del valle de Valdeorras y en las aguas del riachuelo Casayo"; y P. MADOZ (1845-1850): Diccionario geográficoestadístico-histórico de España y sus posesiones de ultramar. Madrid, t.VI, p. 57.

${ }^{2458}$ AHPLU:2376/6. Se la arrienda "andante y corriente" quedando de cuenta del arrendatario el pago de todas las contribuciones y demás pensiones "a que está sujeta la fábrica". Además todos los descalabros, a excepción del árbol mayor, rueda, banzado y chapacuña serán por cuenta del arrendatario. Este Enrique Celeiro había arrendado, en 1835, la ferrería de Mondón (AHPLU: 2406/27).

2459 BOPOU, 7 de enero de 1868.

2460 P. HERNÁNDEZ SAMPELAYO: Hierros de Galicia, t. III. $2^{\circ}$, p. 584 y 585.

${ }^{2461}$ I. GARCÍA TATO (1994): "A explotación louxeira no concello de Carballeda”.IEV. Cuaderno monográfico, 16, p. 222. Cita una escritura pública, de 1909, de constitución de la sociedad "Rogelio Limeres y Cía", que para explotar una cantera de pizarra, llamada "Troya", pretende hacer una vía férrea desde ella "hasta las inmediaciones de la herrería, que en el Puentenuevo poseen los herederos de Don Ignacio Morán"; con una estación que se establecerá "en las inmediaciones de las fraguas de la herrería de Puentenuevo, propia de los herederos de Don Ignacio Morán".
} 


\section{FERRERÍA DE RIODOLAS}

LUGAR: Riodolas

MUNICIPIO: Carballeda de Valdeorras

RÍO: Riodolas

COORDENADAS: $42^{\circ} 21^{\prime} 2^{\prime \prime}$ N. y $6^{\circ} 50^{\prime} 36^{\prime \prime} \mathrm{W}$.

Se encuentra en el lugar de Riodolas, al que se accede desde Sobradelo de Valdeorras por la carretera de Casoio. Al llegar al pueblo un camino que sale al pie de la iglesia baja hasta el río Riodolas, que es un pequeño afluente del Casoio. La ferrería está en la margen derecha del río, al otro lado del puente. También es posible acceder por el camino que a la entrada del pueblo y cerca de una pizarrera baja hasta el río.

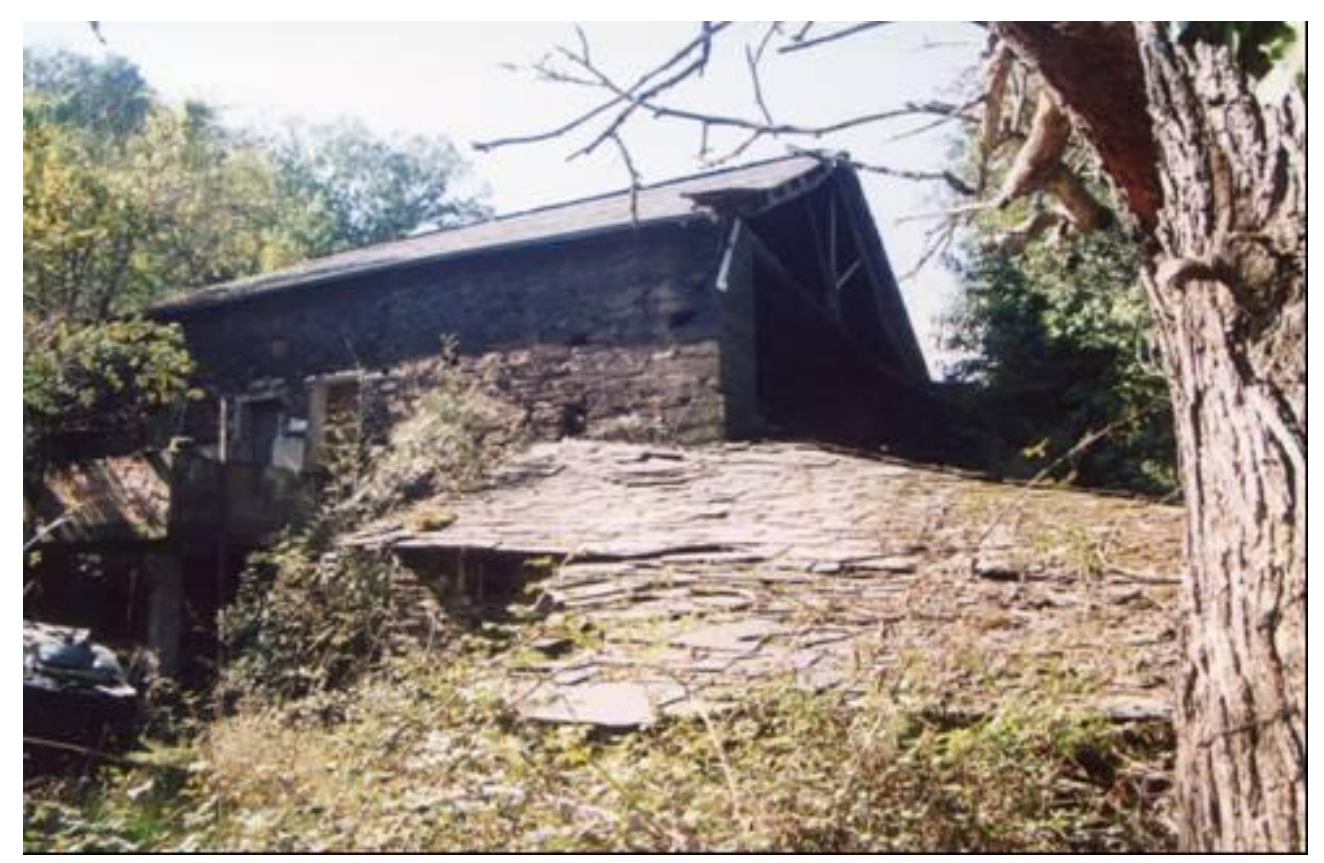

Ferrería de Riodolas

Aunque desconozco la fecha de construcción, debe tratarse de una ferrería del siglo XIX ${ }^{2462}$, probablemente de su segunda mitad, pues no la menciona Madoz. La primera referencia que conozco es de 1868, en la que su arrendatario,

${ }^{2462}$ R. GURRIARÁN (2000): Da prerromanización ao Wolfran: apuntamentos históricos das explotacións mineiras en Valdeorras. Edit. Cupire Padesa, El Barco de Valdeorras, p 77,. cree que puede ser del siglo XVIII; pero no la citan Cornide, Lucas Labrada, Munárriz. Ni siquiera la menciona F. Fulgosio, quien en la p. 13 de su Crónica General de España. Provincia de Orense, cita todas las que funcionan en la provincia cuando él escribe, en 1866. 
don Paulino Arias ${ }^{2463}$, que también lo era de la ferrería de A Pontenova, demandaba a varias personas por impago de la venta de hierro ${ }^{2464}$. Desde entonces hasta 1890 la mencionan las Estadísticas Mineras, señalando que utilizaba mineral de hierro de La Chana (Borrenes). Así, en 1871 produjo 230 quintales de hierro 2465 , recalcando aquella revista que la ferrería estaba bien dirigida; en 1881, 1882 y 1883, según Hernández Sampelayo aún seguía en funcionamiento 2466 .

ESTADO: La ferrería se enclava en un pequeño barrio, con varias edificaciones a ambos lados del puente, bastante bien conservadas, aunque con la amenaza de una cantera que se explota justamente encima de ella. La ferrería es el último edificio. Conserva el banzado, parte del banzadillo con restos de ruedas. Sobre lo que fue la forja, convertida en bodega, se ha construido una vivienda.

\title{
4. FERRERÍA DE ROBLEDO DE DOMIZ
}

\author{
LUGAR: Robledo de Domiz \\ MUNICIPIO: Carballeda de Valdeorras \\ RÍO: Casoyo \\ COORDENADAS: $42^{\circ} 23^{\prime} 30^{\prime \prime}$ N. y $6^{\circ} 54^{\prime} 1^{\prime \prime} \mathrm{W}$.
}

Los datos no son muy precisos, lo que ha llevado a algunos a identificar esta ferrería con la de la Pontenova ${ }^{2467}$; sin embargo, creo que se trata de dos diferentes: la de la Pontenova sobre el río Casoyo en los aledaños de su desembocadura en el Sil; y la de Robledo sobre el arroyo de este nombre, afluente del Casoyo, o más probablemente sobre este último, pero en las cercanías de aquel pueblo.

\footnotetext{
2463 DE 1872 a 1891 este Paulino Arias fue arrendatario de la ferrería de Pombriego 2464 BOPOU, 7 de enero de 1868 Cit. por R. GURRIARÁN: Ob. cit. p. 119, nota 254. 2465 IBIDEM, p. 120 2466 P. HERNÂNDEZ SAMPELAYO (1922-1935): Hierros de Galicia, t. III. $2^{\circ}$ p. 584 y 585 . ${ }^{2467}$ Así lo hacen R. GURRIARÁN (2000): Ob. cit. p 73; y I. G. TATO (2001): La casa de Outarelo de Valdeorras. Formación y desarrollo de su patrimonio (siglos XIV-XX). Santiago de Compostela, p. 79.
} 
Según Eugenio Larruga la licencia para la construcción de una ferrería en esta zona de Valdeorras fue solicitada al Consejo de Estado por don Antonio Tomás Flórez de Losada, señor del Castro de Valdeorras, en 1746, quien al parecer pretendía erigirla en Robledo de Domiz, en el monte virón ${ }^{2468}$, utilizando las aguas del arroyo de Robledo 2469. Argumentaba don Antonio Tomás que era un lugar muy a propósito por no haber ninguna otra en cuatro leguas a la redonda, con montes, sobre todo de brezo, y aguas abundantes, cuyo uso no perjudicaría a nadie por ser terreno inculto y de difícil acceso ${ }^{2470}$. El Consejo le concedió la licencia el 8 de julio de 1757 para construir la ferrería en Valdefuero, término del Castro de Valdeorras, "con los adherentes correspondientes a su uso y permanencia, abriendo la zanja combeniente para llebar a ella el agua desde el rio de Robledo de Domir (sic), que vaja de los montes de Casaio y Casoio y pasa inmediato a dicho sitio".

${ }^{2468}$ El término "virón" no creo que sea un topónimo como piensa R. GURRIARÁN (2000): Ob. cit., p. 73, sino un adjetivo con el significado de inculto, virgen, como cree I. G. TATO (2001): Ob. cit., p.79 . Por mi parte, he de decir que lo he visto con frecuencia para caracterizar montes en la zona de Caurel. Por ejemplo, en 1845 los vecinos de San Silvestre de Saceda venden en 800 rs. vn. a José Seoane, de la misma parroquia, "una porción de monte virón, que llaman monte de Conejeira y Trigareja" (AHPLu: 2431/1).

2469 E. LARRUGA (1794): Memorias políticas y económicas sobre los frutos, comercio, fábricas y minas de España. Madrid, t. XLV, p. 331-333

2470 A. DE SEGOVIA Y CORRALES (1895): Las producciones naturales de España. Estudios cientifico-económicos. Galicia, t. I, p. 38-40: "Después, en 1746, D. Antonio Tomás Flórez, dueño de la jurisdicción de Junquedo, dijo en un escrito que en el monte Virón, sito en el Robledo de Domir (sic), que era común, y que por su fragosidad y ser todo el término peñascoso no servía de utilidad a los vecinos, era sitio muy a propósito para fabricar una herrería donde fabricar hierro, en que no se siguiera perjuicio a vecino alguno por ser inculto, y no haber herrería donde fabricar hierro en más de cuatro leguas a distancia en los términos de dicha jurisdicción: que se podría sacar por zanja artificial el agua necesaria para la fábrica del río que llaman de Robledo de Domir (sic), que baja de los montes de Castayo (sic) y Casoyo y viene a parar al referido sitio, y después desagua en el Sil, en que a nadie se perjudicaba por no servir ni valerse de aquel sitio los naturales, así por su poca utilidad, como por ser fragoso y despeñado y ser el monte que tiene de brezo, que no puede sacarse para parte alguna por lo inaccesible del terreno; y hallándose con los caudales y disposición correspondiente para establecer dicha fábrica y herrería en dicho sitio y término, no habiendo en todo él minerales para el surtimiento de dicha herrería, era preciso buscarlos y traerlos de los términos de San Miguel de Oyobra (sic), lugares de Villar de Silva, Pordellán (sic) en el sitio de las Ferreiruscas, termino de los Fredesalas de la Rivera, sitio de Valdeforcadas, término de la feligresía de San Miguel de Pumares: todos en los antiguos reinos de Galicia y León, en los que se hallan los minerales de hierro y podrían sacarse sin que a nadie se siguiera perjuicio, así por ser sitios peñascosos y fragosos que no producen otro fruto ni utilidad, como por no haber herrería que pudiera servirse de ella a la referida distancia: que los caminos por donde se podría conducir el mineral a la premeditada herrería, unos estaban hechos y otros habría que abrir por lo áspero del terreno, en que a nadie tampoco le perjudicaba, por ser montes virones incultos. Y para poner en ejecución dicha herrería y fabricar hierro en ella, se suplicaba a S.M. se sirviera concederle Real Cédula y facultad correspondiente para poder hacer dicha herrería". (Cit. I. GARCÍA TATO (2001): La casa de Outarelo de Valdeorras. Formación y desarrrollo de su patrimonio (siglos XIV-XX), p. 76-77, nota 81). En realidad es el informe de Larruga. 
Posteriormente, en 11 de febrero de 1762, don Antonio Tomás Flórez, en un escrito al Consejo señalaba que ya estaba construida la ferrería y que no había tenido problemas con las autoridades del Reino de León respecto al uso de la vena en los lugares en los que la había solicitado, al no existir en los alrededores de la fábrica, es decir, en Salas de la Ribera y San Miguel de Pumares; pero que necesitaba una Real provisión, que el Consejo le concedería el 27 de mayo de ese año, para que las justicias valdeorresas dieran cumplimiento a lo contenido en la escritura de licencia, lo que seguramente se refiere al uso del mineral de Viobra, Villar de Silva y Pardollán, lugares de Valdeorras²471.

Creo que, aunque la ferrería se construyó, como claramente afirma el documento, no debió funcionar mucho tiempo como tal, si es que alguna vez lo hizo, probablemente por la dificultad para abastecerse de mineral de hierro; pues realmente los dos yacimientos explotados por aquellas fechas, Formigueiros y la Chana, estaban muy alejados, y el consumo de alguna de las menas locales solicitadas no debió de ser muy satisfactorio, como reconoce Tomás López refiriéndose a la de Pontenova2472. Posiblemente, como en otras ocasiones, la precaria ferrería se convirtió en un simple mazo. Madoz, en el siglo siguiente, menciona en este lugar de Robledo de Domiz la existencia de "una fábrica de clavazón”2473, que seguramente es la heredera de aquel machuco, y que en cierto modo confirma esta hipótesis.

ESTADO: Desconocido.

${ }^{2471}$ I. GARCÍA TATO (2001): Ob. cit., p. 77.

2472T. LÓPEZ: Diccionario. BNE. Secc. Manuscritos, 7304, f. 106: "Ay vena de fierro en los montes de Vila, Pumares y Pardollán, pero algo pobre por lo que una herrería que tiene $D$. Joseph Alfonso Pertierra, señor de Montefurado y vecino de Villoria, en el Puentenuevo trae la vena de los montes del Courel y sitio de Formigueiros". Cit. por I. G. TATO (1996): Valdeorras de cara al año 2000 , t. I, p. 609

2473 P. MADOZ (1845-1850): Diccionario geográfico-estadístico-histórico de España y sus posesiones de ultramar. Madrid, t.VII, p. 399. 


\title{
3. MUNICIPIO DE EL BOLLO
}

\section{FERRERÍA DE MONDÓN}

\author{
LUGAR: Mondón \\ MUNICIPIO: El Bollo \\ RÍO: Jares \\ COORDENADAS: $42^{\circ} 20^{\prime} 16^{\prime \prime}$ N. y $7^{\circ} 2^{\prime} 40^{\prime \prime} \mathrm{W}$.
}

A la ferrería de Mondón alude, en una breve referencia, Ricardo Gurriarán, que la toma de la Estadística Minera de $1871^{2474}$, pero son muy pocos los datos que se conocen de ella, excepto su existencia en el siglo XIX. La cita Fulgosio Fernández en 18662475 y algunos años antes, hacia 1845, el Diccionario de Pascual Madoz recuerda que en Mondón hubo "antiguamente una famosa fábrica de fundición de cobre, cuyas ruinas aún existen" ${ }^{2476}$, aunque no menciona que hubiera sido antes una ferrería, noticia que no hay que desdeñar pese a que no sea totalmente cierta. El mismo autor, en otro lugar del Diccionario escribe que, entre las cinco ferrerías de la provincia de Orense que supone que existen, había “otra en Mondón junto al río Jares” 2477 . Pocos y de escaso valor histórico son, por tanto, los datos reseñados.

La ferrería se encontraba en el municipio del Bollo, en el lugar de Mondón, aldea de tres o cuatro casas. Con este nombre existe un arroyo que desagua en Jares, afluente del Bibey, que probablemente toma su nombre del mencionado lugar al que se accede desde la Rúa de Petín por la carretera a Carballal y San Fiz, y luego por un camino que la vegetación ha cerrado casi completamente, al otro lado del río. La ferrería, aunque se llamaba de Mondón, no se hallaba sobre las aguas de ese pequeño arroyo, sino un poco más lejos del pueblo, a orillas del río Jares que como he dicho es un afluente del Bibey, ríos ambos con aguas

\footnotetext{
2474 R. GURRIARÁN (2000): Da prerromanización ao wolfram: apuntamentos históricos das explotacións mineiras en Valdeorras. Santiago de Compostela, p. 120. Escribe Gurriarán: En 1871 funcionaban en Valdeorras, según o informe estadístico, tres ferrerías: a do Mondón, no Bolo, pensamos que de vida efímera, xá que só aparece este ano”.

2475 F.FERNÁNDEZ FULGOSIO (1866): Crónica General de España. Provincia de Orense, p. 13 2476 P. MADOZ (1845-1850): Diccionario geográfico-estadístico-histórico de España y sus posesiones de ultramar. Madrid, t. IX, p. 585

2477 IBIDEM, t. XII, p. 310.
} 
abundantes para mover las ruedas de mazos y barquines. Todavía el mapa topográfico conserva el topónimo "Souto da Ferrería".

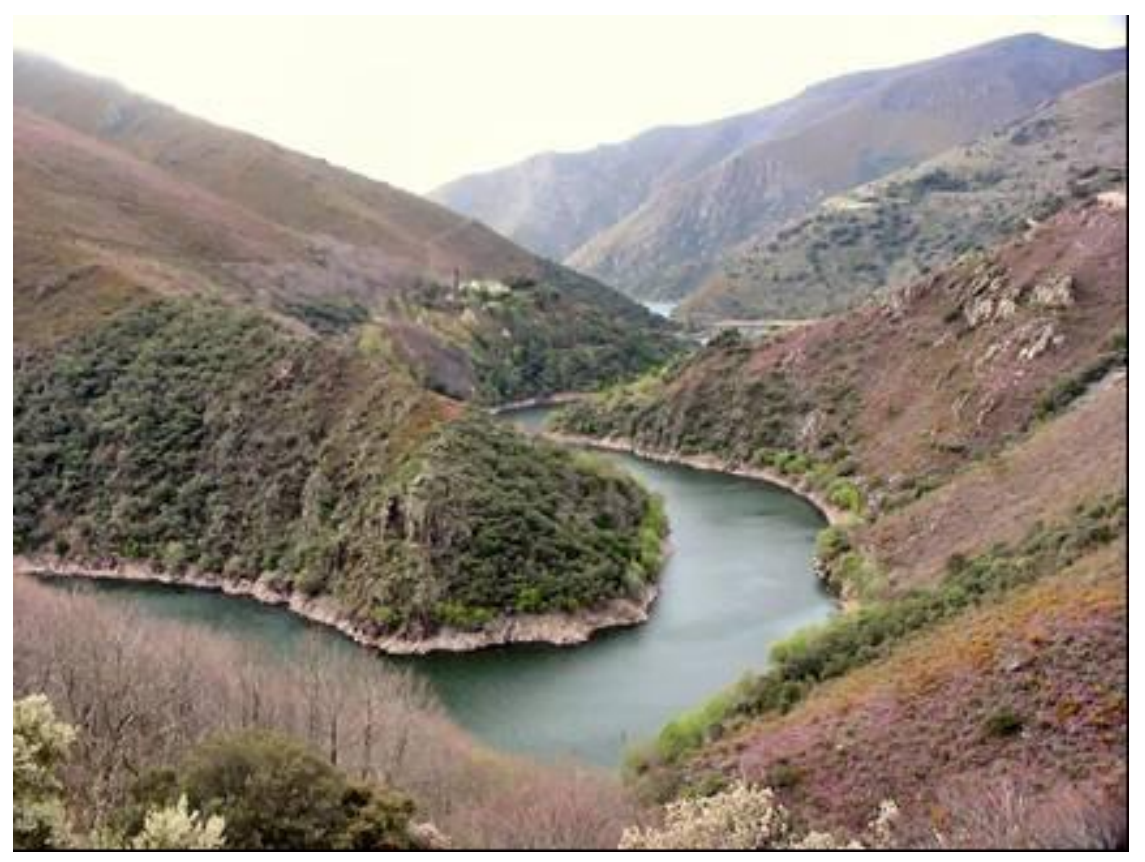

Río Jares, bajo cuyas aguas está la ferrería de Mondón

Como la cercana de Vegas de Camba, la ferrería de Mondón la debió construir hacia 1813 o quizá un poco después de esa fecha, don Juan Bernardo de Quiroga y Uría, dueño de la casa de Lamela, en la parroquia de San Salvador del Hospital (Quiroga). Por sus orígenes, los señores de la casa de Lamela, que también lo fueron del coto de Hivedo (Montefurado), no parece que hayan tenido nada que ver con el mundo del hierro, pues eran sobre todo propietarios de tierras, molinos y bosques. ¿Por qué construyen una ferrería en el siglo XIX?. Probablemente porque, como otros hidalgos, buscaron aumentar sus rentas con esta actividad, quizá también, como vamos a ver, por el matrimonio con una mujer que provenía de una familia propietaria de una ferrería, como la de Quintá, muy importante en el patrimonio de los Neira.

Ignoramos la fecha exacta de la construcción de la ferrería de Mondón, pero en 1828, en un poder que don Juan Bernardo Quiroga da a su hermano don José Ramón, abad de San Julián de Casoyo, para poder vender todas las propiedades que tiene en Sancedo, en el Bierzo, recuerda que "en el año de mil 
ochocientos trece obtubo facultad real para vender sus haciendas de la provincia del Vierzo, Reino de León, e invertir su importe en la construcción de la Herraria de Mondón, que en el día se halla corriente, aunque faltosa de algunos reparos necesarios para ponerla en estado de perfecta producción y para ello le es preciso acabar de realizar la venta de todas las comprendidas en dicha real facultad". ${ }^{2478}$ Años más tarde, nuevamente se mencionan ventas de propiedades en Villafranca y Vilela que se destinan al mismo fin, la ferrería ${ }^{2479}$. Todas estas ventas nos hablan de que esta familia tenía propiedades y rentas en el Bierzo, probablemente por herencia de algún antepasado.

El texto no aclara si la ferrería se construyó en 1813, sólo que en dicho año obtuvo el permiso para vender bienes y hacerla, pero sí que en 1828 ya funcionaba y con la venta de esas rentas pretendía mejorarla; por tanto hay que suponer que se construyó entre esas dos fechas extremas. La levantó, como hemos dicho, don Juan Bernardo de Quiroga y Uría, dueño de la casa de Lamela, en la parroquia de San Salvador del Hospital (Quiroga). Sin remontarnos al estudio de la casa grande o pazo de Lamela, que no es objeto de este estudio ${ }^{2480}$, sí debemos señalar que del matrimonio de don Joaquín Quiroga Losada, dueño de aquella casa, y doña Gertrudis Uría Queipo nacieron tres hijos, dos varones y una hembra. Esta, Joaquina Quiroga Uría, se casaría en 1795 con don Pedro Domínguez de Losada, de la casa grande de Trives; a su vez, los varones serían don Juan Bernardo, el primogénito y heredero del mayorazgo de la casa de Lamelas, y don José Ramón, el famoso abad de Casoyo, cabecilla audaz y arrojado en lucha guerrillera contra los franceses durante la Guerra de la Independencia, tanto en las comarcas gallegas de Valdeorras y Quiroga como en la del Bierzo ${ }^{2481}$.

\footnotetext{
${ }^{2478}$ AHPLU: 2406/14. En 1830 (AHPLU: 2406/17) vuelve a decir que "obtuvo Real cédula para disponer (de su bienes en el Bierzo) y emplear su importe como más ventajoso en la construcción de su Herrería de Mondón". Entre esos bienes dice que, por herencia de sus padres, tenía una casa en la colación de San Nicolás de Villafranca, que vendió a Julio Pombo y posteriormente éste a D. Ramón Ovalle, vecino de San Salvador, al que conocemos por sus ferrerías de Arnadelo y Valdelouro.

2479 AHPLU: 2406/17

${ }^{2480}$ Aunque con algunos errores, un somero estudio sobre esta casa puede verse en el artículo de Luis López Pombo: http://www.galiciadigital.com/opinion/opinion.416.php

${ }^{2481}$ Sobre este personaje proporciona abundantes datos R. LÓPEZ CANEDA (1989): Valdeorras en la Guerra de la Independencia. Instituto de Estudios Valdeorreses, cuaderno monográfico 8. Este abad fue el primero en ofrecer resistencia a los franceses poniéndose al frente de sus feligreses. Fue nombrado en enero de 1809 Comandante de los Valdeorreses, aunque su
} 
Acompañando a su hermano el abad de Casoyo, don Juan Bernardo fue igualmente otro destacado dirigente guerrillero, a la vez que abogado y vocal de la Junta Superior de Galicia. Posteriormente representó a la provincia de Orense en las Cortes de Cádiz e incluso fue vicepresidente de ellas durante un cierto tiempo ${ }^{2482}$. Don Juan Bernardo contrajo matrimonio con doña $\mathrm{M}^{\mathrm{a}}$ Manuela de Prado y Neira, hija de don Benito María de Prado y Lemos y de doña María Josefa de Neira y Ulloa, vecinos de la ciudad de Lugo y hermana del marqués de San Martín de Hombreiro, José María de Prado y Neira. Su mujer era, por tanto, nieta de Sancho de Neira, propietario de la lucense ferrería de Quintá2483, que luego heredarían los marques de Hombreiro, por lo que ahí puede estar una de las razones del interés de don Juan Bernardo por la siderurgia y la construcción de la ferrería de Mondón al acabar la guerra, como hemos visto por el documento citado de 1828 .

Que la ferrería ya funcionaba lo ratifica el que el año anterior, el 12 de julio de 1827 su propietario la arrienda a Felipe Fernández de Prada, de Portomourisco por cuatro años y 8.200 reales de renta anual; no siendo, por lo que dice el contrato, el primer arriendo ${ }^{2484}$, por lo que hay que presumir que ya funcionaba algunos años antes, aunque no estuviera totalmente terminada aún. La ferrería, como era corriente, se arrienda con casas, molino, huertas y prados, y con toda una serie de condiciones (referidas al arreglos de los "escalabros", la madera, herramientas, etc.), como podemos ver en el apéndice primero. Entre esas condiciones se habla de cómo "la Bodega principal del fierro queda por ahora reservada para Don Juan Bernardo, mientras no veneficie el que tiene

principal acción la llevó a cabo en junio cuando daba comienzo la retirada de Galicia del cuerpo de ejército del mariscal Soult, a quien se enfrentó en Montefurado, después en los codos de Larouco y Puente Bibey, aunque no pudo evitar que los franceses quemasen pueblos como San Clodio de Ribas de Sil y Castro Caldelas.

${ }^{2482}$ En 31 de mayo de 1813, el abad de Casoyo aparece como apoderado de su hermano don Juan Bernardo "actualmente Diputado en el Soberano Congreso de Cortes y residente con este destino en la ciudad de Cádiz”. En R. LÓPEZ CANEDA (1989): Ob. cit., p. 397.

2483 J. CORNIDE: Manuscrito de la Real Academia de la Historia.

${ }^{2484}$ AHPLU: 2406/14. Le arrienda, dice, "la Herrería de Mondón, con su casa y diestros, como son molino, soto, guerta y el prado del Bollo que acostumbra a disfrutar o andar unido con dicha Herrería", con varias condiciones relativas a escalabros, uso de la casa y bodega, fianzas, etc. 
almacenado en ella" 2485 , lo que es una prueba de que ya antes se había fundido hierro, probablemente por el propio dueño y tal vez mediante un administrador, gobierno de las ferrerías muy corriente en el siglo XIX junto con el arrendamiento.

Dos años después, en julio de 1829, el arrendatario, cargado de deudas con el propietario, le solicita rescindir el contrato, lo que aquel aceptó con el compromiso de que le pagara once mil reales que le adeudaba, en cuatro plazos $^{2486}$. Un mes más tarde, el primogénito de don Juan Bernardo, don José María Quiroga y Prado, como apoderado de su padre, arrienda de nuevo a Santiago Rodríguez, de San Pedro de Correjanes, como encargado de la fábrica, a Manuel Rodríguez, de Santalla de Lóuzara, y a Antonio Iglesias, de San Salvador de Ferreirós, la ferrería por un año y 4.800 reales de renta ${ }^{2487}$; cifra muy inferior al anterior arriendo, probablemente por la escasa producción de esta. Nuevamente, en agosto de 1830, dicho primogénito, vuelve a arrendar la ferrería, ahora a Tomás del Real, de San Pedro de Correjanes, por dos años y 5.200 reales de renta ${ }^{2488}$.

Desconocemos el origen de la vena que consumía la ferrería de Mondón, aunque no creemos que usara la de Formigueiros, en Lugo, que está excesivamente lejos; por otro lado, no aparece en la relación que conocemos de ferrerías que se abastecen de la aquella mina a mediados del siglo XIX. Quizá pudo usar el de alguna mina local, de hecho muy cerca hay una fuente ferruginosa, llamada "Fuente del Veto", que se utilizaría más tarde para un

\footnotetext{
2485 AHPLU: 2406/14

${ }^{2486}$ AHPLU: 2406/16. Felipe Fernández de Prada, vecino de Portomourisco, dijo: "que haviendo ajustado cuentas con el sr. D. Juan Bernardo Quiroga y Uría, dueño de la Herrería de Mondón, sobre el importe del arriendo de la misma y dos primeros y últimos años que concluien en viente y cinco del corriente mes; carbón entregado al tiempo de cargarse de aquella; abonarle el costo de los reparos y alguna que otra obra que hizo; tomándole en data lo recibido y haciéndole un perdón, resultó alcanzado en la cantidad de once mil reales, que por no tenerla para el apronto le suplicó se sirviese ponérselos a plazos y admintirle la Herrería por no contemplarse con medios para continuar en ella los dos años que le restan de arriendo; en que consistió dicho señor, con tal que le pague los once mil reales en quatro plazos". 
famoso balneario ${ }^{2489}$. Quizá esto explique las dificultades que la ferrería tuvo en el curso de su historia, porque el mineral de hierro en aquellos alrededores de la provincia de Orense era mal conocido y su uso muy escaso como reconoce Hernández Sampelayo ${ }^{2490}$. Sí sabemos, sin embargo, que su hierro se vendía por los alrededores, llegando a las zonas gallegas de Viana del Bollo y Frieras de la Mezquita, e incluso a Castromil ya en el límite con Zamora, por las deudas de “fierro que llevaron al fiado de su Herraria de Mondón”2491 gentes de esos lugares.

Estas dificultades pueden estar detrás del descenso continuado de la renta por la que se arrienda. Así en 1835 nuevamente su dueño, don Juan Bernardo Quiroga la vuelve a arrendar por tres años y 2.333 reales libres de toda contribución a Enrique Celeiro, de San Juan de Lózara (Samos)2492, persona que años más tarde, en 1846, arrendaría la de la Pontenova, también en Orense, en el municipio de Carballeda de Valdeorras ${ }^{2493}$, lo que nos indica que era un hombre relacionado con la industria del hierro. La disminución paulatina en el precio de la renta puede ser un dato de las dificultades de la ferrería, probablemente por el abastecimiento del mineral de hierro o por la mala calidad de las venas locales.

Madoz, como ya hemos dicho, dice que hubo en Mondón "antiguamente una famosa fábrica de fundición de cobre, cuyas ruinas aún existen” ${ }^{2494,}$ pero no menciona ninguna ferrería. Sin embargo, entre las cinco ferrerías de la provincia de Orense de las que habla, señala: "otra en Mondón junto al río Jares"2495. No es nada extraño esa utilización de los martinetes de las ferrerías para fabricar hierro y batir el cobre, como podemos comprobar en numerosos

\footnotetext{
2489 Este balneario se construyó a finales del siglo XIX o, quizá, en 1903, como indica una fecha grabadaa en la capilla. Lo construyeron Emilio López y su mujer. Contaba con tres pisos y más de 50 habitaciones. Dejó de funcionar hacia los años sesenta del siglo XX.

2490 P. HERNÁNDEZ SAMPELAYO (1931): Hierros de Galicia, t. II, p. 581-582

${ }^{2491}$ AHPLU: 2406/19. Así lo señala en 1832 D. Juan Bernardo Quiroga y Uría

2492 AHPLU: 2406/27. La arrienda con todos sus diestros, como son casa, huertos, molino, soto y prado del Bollo, "siendo por cuenta del Celeiro los escalabros maiores y menores, no siendo que llegase a arruinarse la dicha chapacuña y pared de la fábrica de hacia el río, ponerla corriente y dejarla también corriente con el molino y herramientas".

2493 AHPLU: 2376/6

2494 P. MADOZ (1845-1850): Diccionario geográfico-estadístico-histórico de España y sus posesiones de ultramar. Madrid, t. IX, p. 585

2495 IBIDEM, t. XII, p. 310.
} 
ejemplos gallegos y asturianos 2496 . Lo que llama la atención es que diga que por entonces, hacia la mitad del siglo, estaba arruinada, lo que puede ser cierto, por las razones aludidas; pero debió de restaurarse porque la cita posteriormente, en 1866, Fulgosio Fernández 2497, y en 1871 la Estadística Minera, nos confirma que aún trabajaba, pues durante tres meses, con cinco operarios, elaboró 138 quintales métricos de hierro ${ }^{2498}$. Aún existía en $1883^{2499}$.

ESTADO: Sus restos, si acaso se conservan, están bajo las aguas del embalse de Santa Eulalia.

\title{
6. FERRERÍA DE VEGAS DE CAMBA
}

\author{
LUGAR: Vegas de Camba \\ MUNICIPIO: Viana del Bollo \\ RÍO: Camba \\ COORDENADAS: $42^{\circ} 10^{\prime} 1^{\prime \prime}$ N. y $7^{\circ} 7^{\prime} 48^{\prime \prime} \mathrm{W}$.
}

Estuvo situada a orillas del río Camba, en el municipio de Viana del Bollo. El Camba nace en los montes llamados del Invernadero, cruza el municipio del Bollo y desemboca en el Bibey. La ferrería debió quedar anegada por las aguas del embalse do Bao.

El diccionario Madoz dice que "por los años de 1814 hasta 1816 hubo en sus márgenes (del río Camba) una herrería que se construyó a expensas de la casa de Láncara y que fue abandonada en 1830 por falta de mineral" 2500. Efectivamente se debió construir en los años veinte del siglo XIX por don Estanislao Peñafiel, curador y administrador de don Apolinar Suárez de Deza,

\footnotetext{
2496 Por no detenernos excesivamente en esta cuestión, podemos señalar que cuando Felipe Fernández solicita permiso para la construcción de la ferrería de Compludo por segunda vez (la primera fue en 28 de enero de 1856) el 23 de mayo de 1856 dice solicita el permiso para levantar "para una máquina de martinete para batir cobre y hierro aprovechando un salto de agua en terreno de su propiedad" (BOPL. 26 de mayo de 1856, ${ }^{\circ} 63$, p. 1).

${ }^{2497}$ F.FERNÁNDEZ FULGOSIO (1866): Crónica General de España. Provincia de Orense, p. 13 2498 R. GURRIARÁN (2000): Ob. cit. p. 120

2499 P. HERNÁNDEZ SAMPELAYO:Ob. cit., p. 585. En lugar de Mondón la menciona como Morindón o Monelón.

${ }^{2500}$ P. MADOZ (1845-1850): Diccionario geográfico-estadístico-histórico de España y sus posesiones de ultramar. Madrid, t. V, p. 331
} 
señor de Láncara y propietario de varias ferrerías en el Bierzo y Galicia. En 1824 aquél la cedió al señor de Láncara por alcance de 170.000 reales en las cuentas de la curadoría, "los cuales havía ymbertido dicho curador en la fabrica de la Erreria de Begas de Camba". No pudiendo pagarle esa deuda acordaron que Estanislao Peñafiel le traspasara "el dominio pleno de dicha fábrica con sus derechos de montes, aguas y más regalías para que dicho señor D. Apolinar la disfrute como suia propia. Y el referido señor la aceptó y recivió en pago y finiquito de las quentas de su curadoría" ${ }^{2501}$. Seguramente entonces ya estaba terminada.

Es probable que dejara de funcionar a causa de la dificultad de encontrar vena en las cercanías, por los años treinta como dice Madoz; pero este diccionario de los años 45-50, al hablar de la industria de Orense menciona, entre sus cinco ferrerías, una "en los montes de Camba"2502. Esto y su cita por Fernández Fulgosio en 18662503 no prueban nada respecto de su funcionamiento, sólo su existencia.

ESTADO: Desconocido.

\section{MUNICIPIO DE LA GUDIÑA}

\section{FERRERÍA DE MOAS}

LUGAR: San Mamed de Pentes

MUNICIPIO: Gudiña

RÍO: Arroyo da Ribeira

COORDENADAS: $42^{\circ}$ o' $46^{\prime \prime}$ N. y $7^{\circ} 10^{\prime} 9^{\prime \prime} \mathrm{W}$.

En la carretera de La Gudiña a Verín, una desviación a Pentes de San Mamede, a orillas de un pequeño arroyo llamado da Ribeira.

\footnotetext{
${ }^{2501}$ I. GARCíA TATO (2000): Ob. cit., apéndice 7, p. $113 .$.

${ }^{2502}$ P. MADOZ (1845-1850): Diccionario geográfico-estadístico-histórico de España y sus posesiones de ultramar. Madrid, t.XII, p. 310

2503 F.FERNÁNDEZ FULGOSIO (1866): Crónica General de España. Provincia de Orense, p. 13
} 
Dos escrituras de 17 de abril 1816 se encabezan de este modo: "En la casa de la Ferraria (Erraria dice otro) de Moas, parroquia de San Mamed de Pentes, xurisdición de la Gudiña" 2504. En ambas se menciona a don Juan Antonio González, presbítero "residente y administrador de esta dicha casa y Erraria”2505. Ambas escrituras son compras y permutas de fincas que hace dicho administrador.

Madoz dice que en este lugar hay "una herrería" 2506 . Pudiera ser una ferrería de los primeros años del siglo XIX, que explotaba algunas menas locales, al igual que las otras pequeñas ferrerías de las comarcas do Bolo y la Gudiña.

ESTADO: Desconocido

\section{MUNICIPIO DE LA MEZQUITA}

\section{FERRERÍA DE LA MEZQUITA}

LUGAR: Mezquita

MUNICIPIO: Mezquita

RÍO: As Veigas

COORDENADAS: $41^{\circ} 59^{\prime} 46^{\prime \prime}$ N. y $7^{\circ} 2^{\prime} 23^{\prime \prime} \mathrm{W}$.

En la carretera de La Gudiña a Lubián, desviación a la Mezquita, en el río de As Veigas.

Creo que se trata de una ferrería del siglo XIX, pues la única noticia que conozco es de 1833. No la mencionan ni el Catastro, ni Cornide ni Lucas Labrada. Pertenecía a don Antonio Díaz Somoza y Prado, dueño de la Casa del

2504 AHPLU: 5340/2

2505 IBIDEM

2506 P: MADOZ: Ob. cit., t.XII, p. 773 
Río y la de Castelo de Feituje de Lemos, y propietario también de la ferrería de Seone de Caurel2507.

ESTADO: Se conservan restos importantes.

\section{MUNICIPIO DE MANZANEDA}

\section{FERRERÍA DE SAN MIGUEL DE VIDUEIRA}

LUGAR: Requejo

MUNICIPIO: Manzaneda

RÍO: San Miguel

COORDENADAS: $42^{\circ} 15^{\prime} 44^{\prime \prime}$ N. y $7^{\circ} 10^{\prime} 59^{\prime \prime}$ W.

En la carretera de Puebla de Trives a La Gudiña, pasado Manzaneda, se encuentra Requejo. Allí en el arroyo San Miguel, afluente del Bibey, se construyó una ferrería en el siglo XIX, de la que no conozco más datos que los que proporciona Madoz. Hablando éste de las ferrerías de Orense menciona la primera en San Miguel de Vidueira ${ }^{2508}$, ferrería que en otro lugar denomina de Requejo: "una ferrería en Requejo"2509.

Con estos datos tan lacónicos no puedo asegurar si se trata de una ferrería, como dice Madoz, o un simple mazo.

ESTADO: desconocido

2507 AHPLU: 5341/2

2508 P. MADOZ (1845-1850): Diccionario geográfico-estadístico-histórico de España y sus posesiones de ultramar. Madrid, t. XII, p. 310

2509 IBIDEM, t. XVI, p. 38. 


\section{MUNICIPIO DE VILLAMARTÍN DE VALDEORRAS}

\section{FERRERÍA DE CERNEGO}

LUGAR: Cernego

MUNICIPIO: Villamartín de Valdeorras

RÍO: Leira

COORDENADAS: $42^{\circ} 26^{\prime} 26^{\prime \prime}$ N. y $7^{\circ} 3^{\prime} 46^{\prime \prime} \mathrm{W}$.

Situada en la parroquia de Cernego, ayuntamiento de Villamartín de Valdeorras, probablemente en las afueras, en el lugar llamado "Chao".

En este lugar se mencionan en 1611 a tres vecinos de apellido vasco: Martín, Cosme y Pedro Bizcaíno2510; pero probablemente tienen que ver con la cercana Herrería de Valdeorras, del siglo XVI, y no con una nueva ferrería de la que no hay noticias en Cernego hasta la segunda mitad del siglo XIX, ya que tampoco la menciona el diccionario de Madoz. Éste sólo habla del "carboneo" como ocupación de los vecinos de este pueblo.2511

El Nomenclator de la Provincia de Orense de 1863 afirma que en el lugar de Chao, en Cernego, hay una "fábrica de hierro"2512. Hernández Sampelayo nos confirma su existencia: "en la aldea de Cernego (Valdeorras) (640 m. de altitud) hay muchas manchas ferruginosas (...); en las proximidades de Cernego hay señales de una antigua ferrería" ${ }^{2513}$, que pudo utilizar el mineral de hierro de las cercanías: "Más arriba, sigue diciendo este autor, llegamos a Robledo (820 m. de altitud), desde donde se aprecia las minas que están comprendidas en la media ladera que va de Robledo a San Vicente”.

Probablemente se trata de una ferrería del siglo XIX, pero carecemos de datos para corroborarlo.

${ }^{2510}$ AHPOU.PN, caja 528 (1611)

${ }^{2511}$ P. MADOZ (1845-1850): Diccionario geográfico-estadístico-histórico de España y sus posesiones de ultramar. Madrid, t. VI.

${ }^{2512}$ Citado por R. GURRIARÁN (2000): Ob. cit. p. 78.

${ }^{2513}$ HERNÁNDEZ SAMPELAYO: Ob. cit. t.III-2 ${ }^{\circ}$, p. 600. 
Aguas abajo de Cernego, en el mismo río Leira, hay señales de un mazo, cuyo topónimo O Mazo (de san Antonio) aún se conserva.

ESTADO: No se conservan restos

\title{
11. FERRERÍA DE SAN VICENTE DE LEIRA
}

\author{
LUGAR: San Vicente de Leira \\ MUNICIPIO: Villamartín de Valdeorras \\ RÍO: Leira \\ COORDENADAS: $42^{\circ} 26^{\prime} 41^{\prime \prime}$ N. y $7^{\circ} 33^{\prime} 42^{\prime \prime} \mathrm{W}$.
}

La ferrería de San Vicente de Leira se encuentra a las afueras del pueblo de este nombre, en el municipio de Villamartín, hoy de la comarca de Valdeorras aunque durante siglos y hasta la división provincial de 1834 perteneció a la Merindad de Aguiar, juridicción berciana propia del marqués de Villafranca. La ferrería se construyó a orillas del Leira, en un paraje solitario protegido por las montañas.

En el río Leira, aguas abajo de San Vicente, hubo en los siglos XVI y XVII, como luego veremos, una ferrería propia de los condes de Ribadavia; por contra, la de San Vicente de Leira la construyeron los benedictinos de Samos a comienzos del XVIII, en terreno propio del monasterio pero de la jurisdicción del marqués de Villafranca. Estos monjes fueron propietarios de varias ferrerías antiguas en la provincia de Lugo (Rugando, Quiroga, Santalla, Gondriz, Pallarés); ferrerías que con la de Leira, según un “Estado de Cuentas” de 1785, le proporcionaban, por cuatrienio, unos ingresos netos de 309.803 Rs. Vn. ${ }^{2514}$. De todas esas ferrerías, la más moderna y la de mayores ingresos (108.500 Rs. Vn. en dicho cuatrienio) fue la de San Vicente de Leira, que, como otras de la zona, usó también mineral de Formigueiros ${ }^{2515}$.

\footnotetext{
${ }^{2514}$ ARCHIVO DE SILOS: Congregación de Valladolid, Estado de Cuentas de 1785 2515 MUNÁRRIZ: ob. cit. p. 127. En AHN, Secc. Clero, libro 6.495, ff. 87, hay un poder dado por los Condes de Maceda, a favor del monasterio, "para sacar la vena de los montes y término de Formigueiros, para el abasto de la Herraría de San Vicente, en la pensión anual de trescientos y cincuenta reales para dichos Exmos. Señores, pagos en dicha Herrería a la persona que se dispute para la cobranza. Licencia dada en 1722 ante Alejandro de Rivera”.
} 
La ferrería fue construida por el abad Antonio Sarmiento durante el cuatrienio de 1717 a $1721^{2516}$. De este abad, que llegaría poco después a ser general de la congregación de Valladolid, dijo un abadologio inédito del siglo XVIII que "con la excelente fábrica de una herrería que llaman de San Vicente (de Leira), la mejor sin duda de Hespaña, augmentó las rentas de este monasterio en mill y quinientos ducados"2517. Para la construcción de la ferrería el monasterio solicitó un empréstito de 6.000 ducados a un indiano de Layosa, que se fue redimiendo rápidamente con las ganancias obtenidas de la venta del hierro, como recuerdan varias actas de visita de los años 1720 y 1723 y otros documentos ${ }^{2518}$. En 1722 el abad de Samos y Francisco Tabeada, en nombre del conde de Maceda, acuerdan que Samos "pueda sacar y aprobecharse del abasto de la vena necesaria de los montes y términos de Formigueiros para el consumo y gasto de la erraria que este dicho monasterio tiene en San Vicente", bajo el canon de 350 rs./año. La primera paga se hará en septiembre de 1722 lo que podría indicar que fue ese año en el que empezó a labrar hierro 2519.

La ferrería era de una magnitud impresionante, con edificios para el prior, incluida una capilla u oratorio ${ }^{2520}$, molino ${ }^{2521}$, viviendas para los oficiales, la

${ }^{2516}$ AHN, sección Clero, libro 6.695, ff. 151-160, que dice: "Esta Herrería se fundó siendo Abbad el Yllmo Sarmiento, para cuio fin se tomaron a censo seis mill ducados, que se redimieron el año siguiente a su fundazión, que fue el 721", f. 158v; también en R. LÓPEZ CANEDA (1994): "Bienes eclesiásticos de regulares y desamortización en Valdeorras". Va Semana de $H^{a}$ de Valdeorras, I.E.V., p. 527.

${ }^{2517}$ M. ARIAS (1968): "un abadologio inédito de San Julián de Samos". Archivos Leoneses, 44, p. 200

2518 M. ARIAS (1992): Historia del monasterio de San Julián de Samos. Lugo, p. 288: en la visita de 1720, del general Benito Peñelles dice "para que este monasterio logre el beneficio de desempeñarse redimiendo el zenso de seys mill ducados que ha tomado para la fábrica de la herrería de San Vicente de Leyra al indiano de Layosa, mandamos en virtud de Santa obedienzia y so pena de excomunión mayor y de privazion de abbadia al P. Abad que al presente es o por tiempo fuere, que todo el producto de dicha herrería se emplee en la paga de réditos anuales de dicho zenso; y lo que se restare y sobrare pagados dichos réditos, se vaya depositando sin que se pueda divertir ni emplear en otra cosa más que en la redempzión del principal". Así debió hacerse, pues en AHN, clero, libro 6495, en 1721, se anota: "está aqui una escritura de redencion de seis mil ducados de censo que este monasterio tomó para fabricar la Herraria de san Vicente que pasó ante Pedro Fernández de Rego en 1721", f. 87. En la visita de 1723, del general Antonio Sarmiento, en cuyo abadiato se hizo la ferrería, se dice sin embargo, que los 6.00o ducados fueron prestados por diferentes monjes de la casa. Habrá que entender que con dinero propio de los monjes se quitó el prestamo del indiano de Layosa, pero luego el monasterio se lo debía a los monjes.

2519 AHN. Estado, leg. 1739, $\mathrm{n}^{\circ} 16$.

${ }^{2520}$ Mucho más tarde, ya desmortizada (AHPL.PN, caja 2724 (1860), en un contrato de arriendo se dice, entre las condiciones. "ninguna caballería permanecerá en el patio de entrada al oratorio y a la escalera principal de la casa". 
ferrería propiamente dicha con sus carboneras y caballerizas. No es extraño, aunque con evidente exageración, que el autor del abadologio digera que era "la mejor sin duda de Hespaña". Además ésta es una de las raras ferrerías del Noroeste en las que se construyó una chapacuña o presa de cantería, que aún alcanza los 15 metros de altura, realizada en sillares de granito; excavándose también en la roca un canal de casi 300 metros de longitud desde ésta a la ferrería. Las obras fueron dirigidas, en torno a 1721, por el P. Juan Vázquez, maestro de obras de la abadía, autor de uno de los extraordinarios claustros samonenses ${ }^{2522}$.

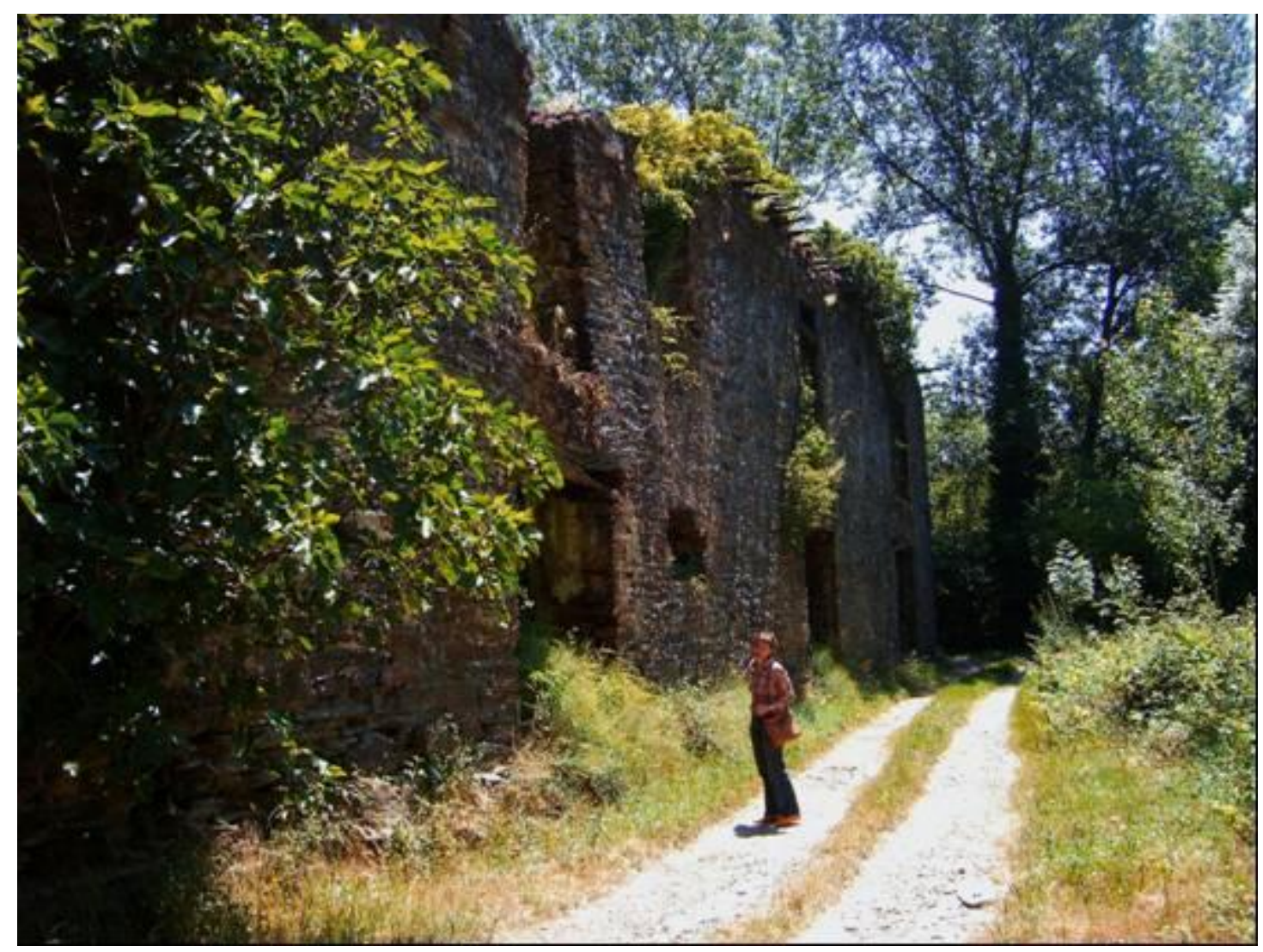

Ferrería de San Vicente de Leira

Según el Catastro de Ensenada, la ferrería funcionaba 250 días al año 2523 , en los que producía 6 quintales y medio al día, lo que supone una producción de

${ }^{2521}$ C. ENSENADA: " $Y$ el terzero (de los molinos es) propio del monasterio de San Julián de Samos, que solo muele para el consumo de los dependientes de la Herrería, y su utilidad regulan en seis quintales de zenteno".

2522 M.ARIAS (1992): Ob. cit., p. 329.

${ }^{2523}$ F.M. NIPHO: Correo general de España, $\mathrm{n}^{\circ} 27$ (1770): dice que "el arroyo de Rodeleyra (afluente del Sil), por baxar con agua abundante, después de hacer moler una Herrería del monasterio de Samos, le sangran beneficia una vega de una milla, poco más de larga, que 
1650 quintales al año, o $94.875 \mathrm{~kg} .{ }^{2524}$. Estos 1650 quintales no difieren mucho de los 1.500 que anota Cornide en 1780 como producción anual de la misma ${ }^{2525}$, siendo con las bercianas de Oencia y Arnado las de mayor producción de todo el Noroeste de España, en opinión de este autor. Contaba, según el Catastro, con cinco oficiales ${ }^{2526}$, además de criados y carboneros, y en ella, además del hierro en bruto, que en su mayor parte se vendía fuera, se fabricaban también clavos y herraduras ${ }^{2527}$. Al frente de la ferrería había un monje ${ }^{2528}$ con la obligación de administrarla 2529.

\section{INGRESOS DE LAS FERRERÍAS DE SAMOS}

Ferrería

San Vicente

Pallarés

Santalla

Rugando
1777-1781

$1781-1785$

$1818-1821$

1821-1824

$\begin{array}{cccc}90.480 & 108.500 & 47.000 & 31.023 \\ --- & 11.803 & 19.170 & 9.170 \\ 28.720 & 37.500 & 29.500 & 1.600 \\ 86.000 & 96.000 & 62.000 & 20.840\end{array}$

llaman Villamartín". Es decir, que el Leyra era un río, como dice el Catastro, caudaloso. Sin embargo, en 1775, en la consulta a Don José Moscoso y Prado "sobre si los vecinos de Zernego podían sacar aguas del arroyo del mismo lugar

para tierras inferiores a la Herrería, a lo que respondió que no" (AHN. S. Clero, libro 6.695, ff. 160)

${ }^{2524}$ CATASTRO DE ENSENADA. R. G. San Vicente de Leira: "Que también hay una herrería o artefacto de yerro propio de dicho monasterio, la que es caudalosa, y que regulan que trabaxa al año doszientos y zinquenta días, dando en cada uno seis quintales y medio de yerro, y que regulan por quinquenio a zinquenta y ocho reales por quintal".

2525 J. CORNIDE: Noticia de las ferrerías de Galicia (manuscrito). Real Academia de la Historia. ${ }^{2526}$ C. ENSENADA: "que en dicho artefacto de yerro hay zinco oficiales, que son Juan de Bergara, arota de dicha herrería, el que gana en doscientos zinquenta días que trabaxa dicha herrería, doce reales por día. Joseph López, tirador, ocho reales y veinticinco mrs. por día. Antonio Arias y Manuel Marcos, fundidores que ganan cada uno siete reales y medio y Fernando Sánchez su exercicio tazador, el que gana cuatro reales y cinco maravedís por día”. 2527 C. ENSENADA: "Que en el discurso del año deshazen setenta y zinco quintales en herraduras y que cada quintal produze diez y seis dozenas y que regularmente se vende la dozena a zinco reales. Que deshazen también quinze quintales en clavo de herraxe al año, y que cada quintal produce zinco millares y que el millar se vende a diez y seis reales". En 1821, Fr. Bernando Guerra, administrador que fue de esta ferrería, dice que "dispensó al fiado varias partidas de fierro, herraduras y clabos a Francisco Veyga, vecino del lugar de Fradelo, en la xurisdición de Viana”, por lo que le está adeudando 740 rs. (AHPLU:5340/5).

2528 C. ENSENADA: "Que hay un monxe Benito del combento de Samos a cuio cargo está la herrería"

2529 Algunos de estos administradores fueron, en 1752 Fr. Pablo de Castro (AHPLU: 2463/6); en 1800 Fr. Millán Bousón (AHPO, P.N., caja 547, fs. 10-10v); en 1818, Fr. José Noriega (AHPL. PN., caja 3576); antes de 1821 Fr. Bernardo Guerra (AHPLU: 5340/5) y entre 1820 y 1824 Fr. Veremundo Peña. Éste en 1820 otorga un poder para actuar judicialmente contra 27 vecinos de Santa María de Cereixido, pues adeudan a la ferrería 16.451 rs. y $24 \mathrm{mrs}$. de partidas de hierro (AHPO. PN. caja 550, fs. 150-151v); y en marzo de 1824 otorga otro poder para cobrar de D. Juan Martínez, de Cabarcos, diez quintales y medio y veintitrés libras de hierro "que en los últimos de octubre del año próximo pasado sacó de esta casa y herrería individualmente y sin legítima autoridad" (AHPL.PN. caja 3577). 


$\begin{array}{lllll}\text { Quiroga } & 42.000 & 36.000 & 14.000 & 13.202 \\ \text { Gondriz } & 35.000 & 19.600 & 20.225 & 14.357\end{array}$

Fuente: Archivo de Silos: Estados de Cuentas

Esa producción suponía al monasterio de Samos unos beneficios elevados, como podemos ver por diferentes Estados de Cuentas de los siglos XVIII y XIX. Por ellos conocemos, al margen de la caída de éstos en los difíciles años del Trienio Liberal, que los de San Vicente son los mayores de todas las ferrerías de Samos, porque también era la de mayor producción, según los datos de Cornide, a los que ya hemos aludido.

La ferrería, como hemos visto, tenía agua abundante pero no escasearon los problemas con los vecinos por el monte y el abastecimiento de carbón. Según el Catastro de Ensenada, el pueblo de San Vicente contaba en 1753 con 58 vecinos, es decir, algo menos de 250 habitantes que jurisdiccionalmente eran vasallos del marqués de Villafranca; pero cuyas propiedades eran solariegas del monasterio de Samos, quien se las había aforado2530 por la cantidad de 1.400 rs. anuales. Según los monjes, esa cantidad era muy inferior al valor real que deberían pagar -más de 4.000 reales, según ellos-, pero estaba así rebajada con la condición de "abastecer el artefacto de los suficientes materiales a los precios corrientes", así como conservar una parte del monte y no privar a la ferrería de las aguas necesarias para su funcionamiento. Los vecinos, al parecer, incumplieron dichas condiciones, por lo que el monasterio en 1818 los llevó ante los tribunales 2531 .

\footnotetext{
${ }^{2530}$ AHN. Sec. Clero, libro 6.695, ff. 86: El foro se hizo en 1752, modificando otro anterior de 1664. Deben pagar los vecinos 1.400 reales y en él "trae bien expresados los bienes y las propiedades que se dejaron a la herrería, por lo que debe pagar el rendero de la Herrería de san Vicente veinte y cinco libras de cera todos los años. Assi me lo dijo Nuestro Padre el Ministro Fray Helladio, Abbad en cuio tiempo se hizo el foro". Esas especificaciones están claras en el poder que el abad de Samos da al administrador, fr. Pablo de Castro, para firmar el foro: los vecinos no pueden "vender la coza o cepa que hay y huuiere dentro de los términos expresados ni el caruon que de ella se hiciere" sino a la ferrería del monasterio"; no pueden hacer bouzas en el monte del que se saca la coza, y que se reserve el agua del río para la ferrería "por el notable perxuicio que se sigue de el atraso en la fábrica de yerro por falta de agua" (AHPLU: 2463/6).

${ }^{2531}$ AHPL.PN, caja 3576 (1818): Poder del administrador de la ferrería, Fr. José Noriega, para llevar a los vecinos ante los tribunales, porque "bajo unas fribolas y supuestas protestas" se niegan a cumplir las condiciones del foro.
} 
Tras la exclaustración ${ }^{2532}$, la ferrería fue desamortizada. Según las actas de remate de 13 de noviembre de 1838, la adquirieron el marqués de Villagarcía, que era propietario de la de Visuña o de Órreos, y Manuel María Losada en 500.000 reales; sin embargo, en el Boletín de Orense de Venta de Bienes Nacionales de 28 de marzo de 1839 se dice "D. Juan Pérez, para ceder, remató la casa-fábrica-herrería de San Vicente de Leira de Villamartín de Valdeorras, de los Benedictinos de San Julián de Samos" en 550.000 reales ${ }^{2533}$. Probablemente esta mejor oferta fue la que se quedó con la ferrería. Poco después la menciona Madoz señalando que estaba a media legua de Villamartín²534.

El "para ceder" de la Venta de Bienes Nacionales nos indica que Juan Pérez la adquirió para otro; y así debió de ser pues poco después su dueño era el famoso maragato de Boisán, "Cuarentavacas"2535. En 1860 un hijo de éste, Andrés Martínez Criado, casado con una hija de Santiago Alonso Cordero, rico y emprendedor maragato, principal propietario de la ferrería de San Blas de Sabero, aparece como dueño de San Vicente de Leira junto con su hermano Francisco y su cuñado Juan Rodríguez de Cela, casado con Ramona Martínez Criado. Estos hermanos arriendan ese año la ferrería de Leira a Juan Manuel Alonso, vecino de San Vicente, por cuatro años y una renta de 27.00o reales, además de 350 reales del foro de la vena y 200 reales a un guarda para que cuide los montes y dehesas de la ferrería 2536 .

La ferrería debió de dejar de trabajar a finales del siglo XIX, pues la citan en ocasiones las Estadísticas Mineras, trabajando hasta $1883^{2537}$. Incluso puede referirse a ella un anuario de 1903, en el que se dice que "en la parroquia de San Vicente hay varias minas de hierro, una fábrica para laminación de cobre

\footnotetext{
2532 AHPLU: 2406/15. En 1828 era administrador Fr. Veremundo Peña.

2533 I. GARCíA TATO (1996): Valdeorras de cara al año 200o, t. II, p. 56.

2534 P. MADOZ (1845-1850): Diccionario geográfico-estadístico-histórico de España y sus posesiones de ultramar. Madrid, t. XII, p. 310.

2535 J. GARCÍA SÁNCHEZ: "La ferrería de San Blas de Sabero"en Filándón, p. 4 (Diario de León, 11-X-1998) dice que Cuarentevacas fue dueño de la ferrería de San Vicente de Leira.

${ }^{2536}$ AHPL.PN, caja2724 (1860). Este Alonso Martínez, en 1864 arrienda también la ferrería de Pontepetre por 4 años (AHPL.PN, caja 2729). En este escritura se dice que es el propietario de la de San Vicente, pero sólo era el arrendatario.

2537 P. HERNÁNDEZ SAMPELAYO: Hierros de Galicia, t. III, $2^{\circ}$, p. 58---. Menciona la ferrería trabajando en $1871,1873,1880$ y 1883 .
} 
y una importante herrería en El Mazo, propiedad del diputado a Cortes por Astorga y abogado D. Adolfo Rodríguez de Cela"2538. Este es sin duda un descendiente de Juan Rodríguez de Cela, y por tanto nieto de Cuarentavacas.

ESTADO: Se conservan en relativo buen estado la vivienda del priorato, pero de la ferrería solo restos de la canalización, además de la chapacuña.

\section{FERRERÍA DE VALDEORRAS}

LUGAR: El Mazo (Córgomo)

MUNICIPIO: Villamartín de Valdeorras

RÍO: Leira

COORDENADAS: $42^{\circ} 25^{\prime} 30^{\prime \prime}$ N. y $7^{\circ} 2^{\prime} 52^{\prime} \mathrm{W}$.

La documentación de los siglos XVI al XVIII menciona en el municipio de Villamartín de Valdeorras una herrería, que indistintamente se denomina como Herrería de Valdeorras o Herrería de Córgomo, pero siempre en la feligresía de San Antonio. En mi opinión es la misma, aunque algunos supongan que son dos diferentes ${ }^{2539}$. También se menciona un mazo que pervivió durante más largo tiempo, hasta el punto de sustituir el topónimo "La Herrería" por el de "El Mazo", que aún subsiste. Algunos creen que se trata de un ferrería y un mazo diferentes, como ocurre con otras muchas ferrerías que contaban con sus respectivos mazos anejos, así podría entenderse el texto de 1757 en que se menciona el foro del Mazo de la Herrería ${ }^{2540}$; pero también podría ser una ferrería transformada posteriormente en un mazo, aunque me parece más dudoso.

\footnotetext{
${ }^{2538}$ En 1903, un Anuario dice que "en la parroquia de San Vicente hay varias minas, una fabrica de laminación de cobre y una importante herrería en El Mazo, propiedad del diputado a Cortes por Astorga y abogado D. Adolfo Rodríguez de Cela, con una presa y salto de agua capaz para industrias más importantes”. Cit. Por R. GURRIARÄN. Ob. cit., p. 118, nota 252. 2539 Un documento de 1643 menciona a Francisco Xil Losada "vecino del lugar y de la feligresía de San Anton de la Herrería de Córgomo” (AHRG. R.A. 9.121/2)

2540 AHRG. R.A. 9.121/2
} 
La ferrería debió construirse en el siglo XVI, en relación con la presencia en la zona de numerosos vascos y navarros, como atestiguan sus apellidos ${ }^{2541}$; aunque hasta la segunda mitad no tenemos noticias de la ferrería. En 1586, primer documento conocido, Juan Gil o Xil el Viejo, vecino del lugar de la Herrería de Valdeorras ${ }^{2542}$, que tenía aforado "el maço y adreços de la herrería", arrienda ahora a cuatro vecinos "asientos de fragua"; y también "el maço y sus adreços" por tiempo de un año y en precio de diez ducados cada asiento, es decir 40 ducados, pagados cuatrimestralmente. Además le han de "ayudar a linpiar el vançado y rrepararlo siendo necesario, y si el maço e yunques o rruedas se quebrare le ayuden a adreçarlo cada vez que quebrare"2543 . Entre los testigos firma Martín de Gurriarán, tirador, uno de los oficios característicos de las ferrerías, aunque no sabemos de cual, seguramente de esta de Valdeorras, o de una de las bercianas. Como el documento habla del "mazo de la herreria", con las fraguas a su alrededor, como es frecuente en estos artilugios ${ }^{2544}$, creo que podemos hablar de la existencia de una ferrería de la que aquel mazo dependería.

La ferrería pertenecía al conde de Ribadavía, que la tenía aforada a la familia Xil (Gil). Por lo que sabemos debió haber varios foros sucesivos, el primero antes de 1586 en que lo tenía Juan Gil el Viejo; por tanto a sus antepasados, probablemente ya a principios del siglo XVI. El segundo en 1596,

${ }^{2541}$ R. GURRIARÁN:(2000): Da prerromanización ao Wolfran: apuntamentos históricos das explotacións mineiras en Valdeorras. Edit. Cupire Padesa, El Barco de Valdeorras, p. 49 y ss.: Juan de Aresta, Gaspar de Arístegui, Pedro Basco, Juan de Mondragón, Salvador de Zabaleta, Juan Darzechiga, Martín de Gurriarán, etc.

${ }^{2542}$ El documento está hecho el 19 de octubre de 1586 en Córgomo. Se distinguen claramente, pues, Córgomo de Herrería de Valdeorras, pero esto no significa que estén en lugares diferentes, como ocurre también con la ferrería berciana de Pontepetre, en Oencia, que unas veces se llama de Pontepetre y otras simplemente de Oencia.

2543 AHPOU. PN. caja 554 (1586).

2544Datos de fraguas: en 1669 se habla de la fragua de Lázaro Gurriarán; 1684, se mencionan fraguas en el acuerdo entre el cerrajero Pedro de Prada y su yerno Joseph de Gurriarán, vecinos de Córgomo, para el usufructo de una fragua que aquel había hecho con ayuda de éste: "y ahora por bia de paz (...) se ajustaron y estan conbenidos y conçertados en que dicho Pedro de Prada da a dicho Josep de Gurriarán su yerno la mitad de una fragua que al presente está açiendo para que puedan trabajar ambos juntos en ella mismamente açiendo otra de compañia, y sin embargo la mitad de dicha fragua siempre a de ser y estar por dicho Joseph de Gurriarán en satisfaçion de la otra mitad que le tocaba en la que había ayudado a açer".(AHPOU, PN, caj 605, año 1684). 
pues un documento de 1654, hecho en la Herrería de Valdeorras el 17 de mayo recuerda que don Alvaro de Sarmiento de Mendoza, conde de Rivadabia, "aforó -en dicho año- a Pedro Xil su abuelo la Herrería que al presente posehe en el dicho lugar por su vida y tres boçes despues del, en preçio cada año de ciento $y$ quarenta y tres reales"; esas tres voces acaban con el autor de este escrito, Pedro Gil de Losada, hijo a su vez de Francisco Gil de Losada y Francisca Díez 2545. En 1643 este Francisco confesó "ser lleuador y poseedor de la dicha herraria con su casa y pazo, Rueda, Banzado corriente de agua con la pesquera del Río desde donde viene el agua correspondiente (...) según fue aforada a Pedro Xil su padre", por la que paga "y deue pagar en cada un año de renta al dicho señor conde 13 ducados que hacen 143 rs. vn.”2546.

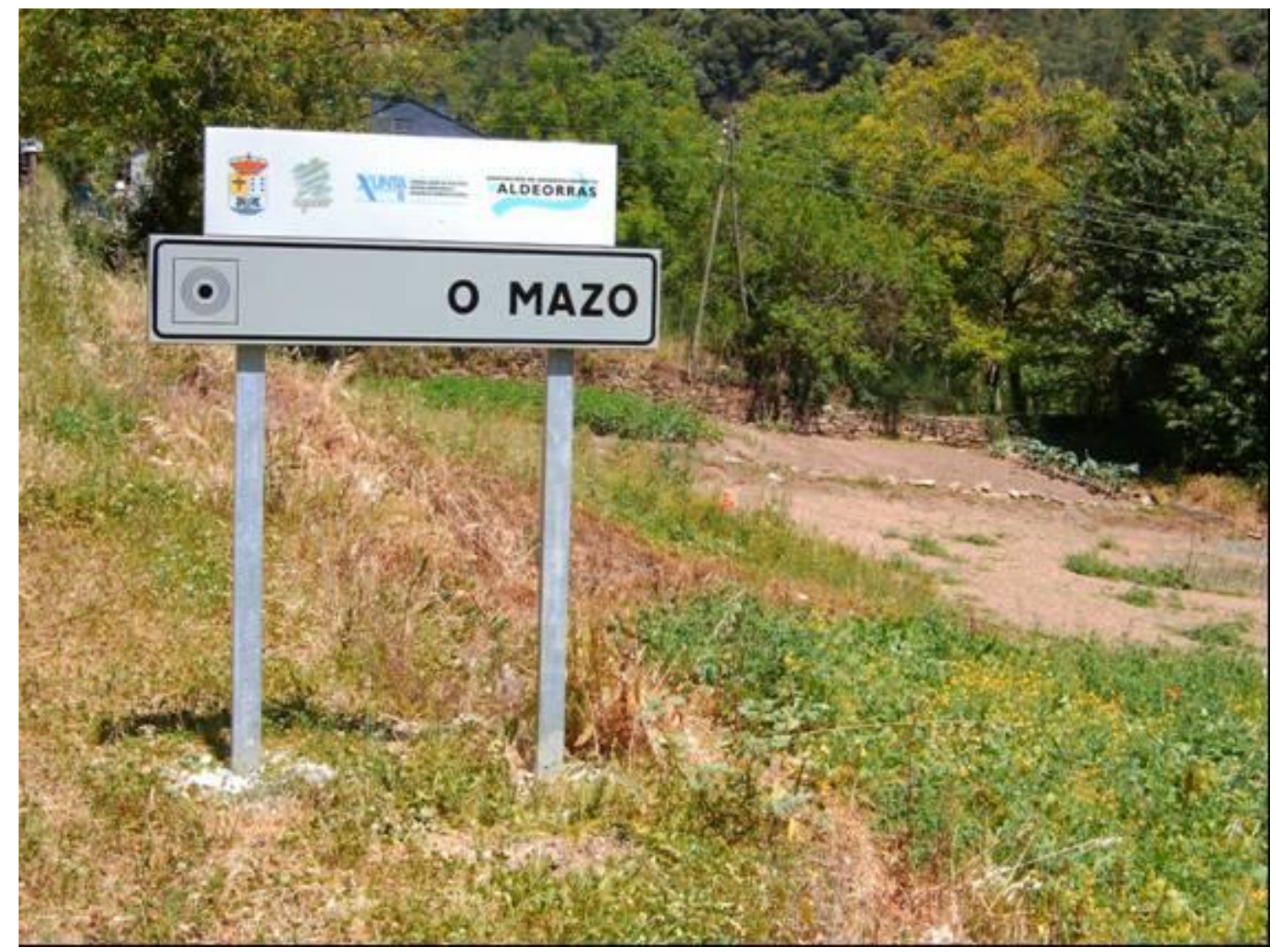

Topónimo “O Mazo", que alude a la ferrería de Valdeorras

2545 AHPOU.PN, caja 566 (1654). El primer Pedro Gil, el abuelo, sería demandao en 1604, por Juan de Celaya, rendero de Órreos, por los bienes de Juan Ortiz y su hermana Isabel Ortiz, por valor de más de 2.000 ducados, que reclaman Catalina de Celaya, hija de soltera de la mujer de Juan Ortiz, Catalina de Arburu y Francisco Rodríguez, entallador y vecino de Villamartín de Valdeorras, marido de Isabel Ortiz. Es probable que este Pedro Gil tuviera algún parentesco con esta gente.

${ }^{2546}$ AHRG. R.A. 9.121/2 
Terminado el foro parece que la familia Gil dejó la ferrería y el mazo en un completo abandono, como se deduce de un documento de 1669, por el que el gobernador de los estados del conde de Ribadavia recuerda que "por quanto se le ha dado notiçia que una herreria y maço con su guerta y molino sita donde dicen la Herrería que es propio lugar de su excelencia y trahia Francisco Xil de Losada, vecino de dicho lugar y feligresía de San Juan de Portela (...) de que se pagaba treçe ducados cada año de foro y pension annual y el sobredicho no pagó dicha renta a mas de seis años ni tiene vienes en que haçer el pago"; teniéndo todo además abandonado y sin trabajarlo, por lo que ahora la afora de nuevo "al capitan Bartolomé Rodríguez de Prada vecino de Córgomo que está absente como si estubiera presente" para él y sus hijos, "por tiempo y espacio de tres voçes de tres señores reyes de España”. Entre las condiciones se estipula traerlo bien labrado, pagar la renta de los trece ducados, no venderlo, etc. 2547.

Un apeo de 1695, por el contrario, nos informa que Francisco Gil traspasó el foro en la segunda mitad del XVII a Rodrigo de Prada, vecino de Villamartín, del que lo heredó su hijo Domingo Antonio de Prada. Años más tarde, en 1746 un testigo dice que el mazo del conde de Ribadavia "lo vio poseher a $D$. Domingo Antonio Losada, vecino de Villamartín, quien lo enagenó pasando a poder de D. Diego Santiso, vecino de Sobrado de Aguiar, y éste lo traspasó a D. Gaspar de Valcarce, que lo poseyó hasta su muerte" 2548 . Aunque Rodríguez de Prada y Rodrigo de Prada pueden ser la misma persona; también podría entenderse que lo que se afora a Bartolomé Rodríguez son los bienes de la ferrería, que ya no funcionaba, es decir las tierras anexas a ellas; mientras que el mazo, en manos de los Gil de Losada y aún en funcionamiento, lo aforan éstos a Rodrigo de Prada.

Así debió ocurrir pues en 1728, doña María Magdalena de Velasco y Losada, mujer de don Diego Cancelada, vecinos de Sobrado, en el Bierzo, subaforan a Domingo Antonio de Prada y Losada, vecino de Villamartín (Valdeorras), bienes que aquéllos tenían aforados al conde de Ribadavia, entre ellos: "Un mazo, molino, guerta y pesquera sito todo ello en el lugar de la 
Herrería de Córgomo, por lo que el susodicho paga de fuero en cada un año a la parte del Excmo. ciento y quarenta y tres Rs. vn.", cantidad por la que ahora se subafora" 2549 . El documento citado debe tratarse de la renovación del foro, pues en 1719 los vecinos de la Herrería de Valdeorras llegan a un acuerdo con este Domingo Antonio de Prada y Losada, con el que venían pleiteando porque querían sacar agua del arroyo para regar sus fincas; pero aquel se lo impidió "diciendo y articulando que sacando nosotros dicha agua se le perjudicaba al mazo y molino que el susodicho tiene en este lugar" por la probable escasez de agua en el verano, algo que niegan los vecinos, diciendo que es "abundante $y$ caudaloso en todo el tiempo del año". El acuerdo supone el que puedan hacer el cauce y regar pero "de manera que dicho su mazo y referido molino no tenga quiebra ni reciban daño ni perjuicio alguno por falta de dicha agua" $255^{\circ}$.

Es decir, que aquel ${ }^{2551}$ gozaba del mazo y el molino desde algunos años antes, pero ya no debía existir la ferrería, que ahora se nombra de Córgomo pero que indudablemente es la llamada Herrería de Valdeorras. No la nombran ni el Catastro de Ensenada hacia 1753, ni Cornide en 1780, lo que es signo de su desaparición. El mazo siguió funcionando hasta finales del siglo XIX o principios del XX.

ESTADO: No se conservan restos de la ferrería pero si del mazo.

\footnotetext{
2549 AHPL.PN. caja 3333, ff. 88.

2550 AHPOU, PN., caja 694 (1719).

${ }^{2551}$ Hay un D. Lorenzo de Prada, vecino del monasterio de Jagoaza, Valdeorras, que en 1729 arrienda la ferrería nueva de Visuña ces pariente? si así fuera se trataría de gente ligada a la explotación del hierro (AHPL. PN, caja 3333, año 1729).
} 


\section{FERRERÍAS DE ASTURIAS}



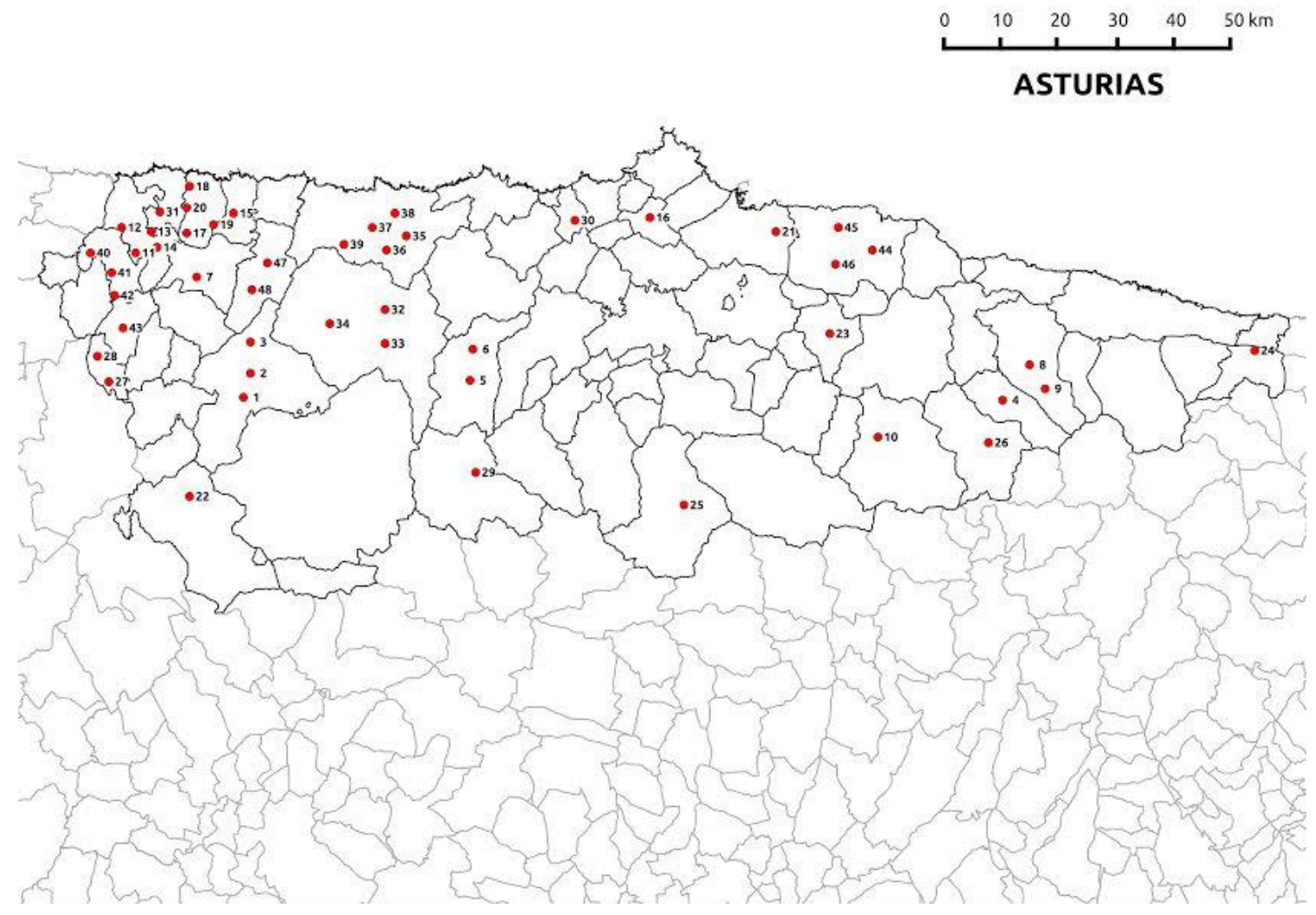

FERRERÍAS DE ASTURIAS 


\section{MUNICIPIO DE ALLANDE}

\section{FERRERÍA DE ARMENANDE}

LUGAR: Armenande, parroquia de Lago

MUNICIPIO: Allande

RÍO: Ourúa

COORDENADAS: $43^{\circ} 13^{\prime} 47^{\prime \prime}$ N. y $6^{\circ} 43^{\prime} 36^{\prime \prime} \mathrm{W}$.

En la carretera de Pola de Allande a Grandas de Salime, a la altura del pueblo de Lago una pista desciende hasta Armenande y la capilla de la Virgen de la O. La ferrería, denominada de abaxo, se encuentra en la margen izquierda del río Ourúa.

El 6 de julio de 1848, don Francisco Pérez de Barcia y compañía registraron un terreno para construir una fábrica de fundición de hierro en un paraje denominado Eiro del Ruido, en la parroquia de Lago, del concejo de Allande ${ }^{2552}$. Sin embargo, ésta y la de Villarín, registrada el mismo día, no se construirían hasta años después, pues en 1852 el gobernador de Oviedo dice que por manifestación de los interesados se admite el abandono de los registros de terrenos para "fábricas de fundición de hierro en los sitos de Veiga y Eiro del Ruido" en la parroquia de Lago, que tenía solicitados don José Lombardía y compañía 2553. Esta compañía la formaban varios accionistas: Francisco Cancio Cedrón, Faustino Lombán, José Lombardero, Gabriel José Bermúdez y Francisco Pérez de Barcia.

Dicha compañía debió de construirlas poco después, porque en 1854 vendieron a José María Bravo, Federico Guzmán y Antonio Osorio una octava parte "en las dos Herrerías de Ourúa denominadas de Villarín y Armenande (...) con todos sus derechos de presa, aguas, instrumentos, máquinas, casa de habitación, huertas, prados, monte, arbolado y todo lo a ellas perteneciente y accesorio" 2554 , lo que significa que por entonces ya estaban en marcha. Poco

\footnotetext{
$255^{2}$ BOPA, 14 de agosto de 1848 , no 97 , p. 4

2553 BOPA, 6 de agosto de 1852 , n ${ }^{\circ} 94$, p. 4

2554J. LÓPEZ y A. GRAÑA (1998): Ferrerías, mazos y fraguas en Asturias. Oviedo, p. 73.
} 
después, ambas ferrerías funcionaban bajo la razón social de "Bravo, Guzmán y Compañía de las herrerías de Armenande y Villarín”, cuyo administrador y director era José María Bravo, de Santalla de Oscos. En la fábrica había un representante de la sociedad encargado de la producción y venta del hierro, que en 1858 era José Antonio Lombardero, a quien Juan Ochoa y su mujer Ramona Rodríguez de Alva se obligan a pagar 5.203 reales "procedente del fierro" que les ha vendido 2555 .

Esta sociedad compró en 1859 "el aprovechamiento para carbón de todas las leñas que contienen la tercera parte de los términos del lugar de Probo" por un periodo de siete años y precio de 2.000 reales. En 1860 también adquiere los derechos para "lavorear cuatro mil quintales de carbón de roble y otros cuatro mil de cepa de uz moural (brezo) en los montes inmediatos a dichas herrerías de Ourúa y Armenande, desde donde nombran los Muraqueiros a la Balliba de Barraral (...) y las sierras altas de las mismas, y para asegurar el importe de los daños y perjuicios a los pueblos interesados, y después de reguladas las especies para dicho carbón en 2.000 reales y 30.000 el suelo del monte, hipotecaron dichas herrerías con sus pertenencias" 2556 .

La ferrería de Armenande cerró entre 1885 y 1890, después lo haría la de Villarín.

ESTADO: De la ferrería, bastante transformada por su utilización como molino, no se conservan más que ruinas. Sólo son visibles los restos del canal de agua, de unos 600 metros de largo, que en su parte final es un verdadero acueducto. 


\title{
2. FERRERÍA DE PENASEITA
}

\author{
LUGAR: El Mazo \\ MUNICIPIO: Allande \\ RÍO: Afluente del Narcea \\ COORDENADAS: $43^{\circ} 16^{\prime} 54^{\prime \prime}$ N. y $6^{\circ} 38^{\prime} 4^{\prime \prime}$ W.
}

Se hallaba en el lugar del Mazo, en la carretera de Pola de Allande a Grandas de Salime, en un pequeño afluente del Narcea.

La ferrería se construyó sobre el primitivo mazo de Peñaseita, que seguramente era el mismo que menciona el Catastro de Ensenada en Allande, como mazo de "abajo", perteneciente a los condes Marcel de Peñalba ${ }^{2557}$, señores de la casa de Allande. En 1860 don Manuel Pérez y don Juan Ochoa solicitaron permiso para transformar en forja catalana el martinete de Penaseita, que dicen ser de su propiedad, tal vez por compra. Como requería la Real orden de 1846, la solicitud fue expuesta a información pública durante veinte días y, al parecer, hubo cierta oposición por don Aquilino Suárez Bárcena en nombre de don Antonio Osorio. Sin embargo, visto el informe de la Junta Facultativa de Minería, el ministerio de Fomento la desestimó, dándoles permiso "para convertir el martinete en forja catalana". Ahora bien, tal concesión, añade la Junta, no afecta a los montes, cuyo aprovechamiento deben solicitar y obtener en cada caso de acuerdo con las leyes de montes 2558 .

Según J. López y A. Graña, aquellos solicitantes formaban en realidad parte de una sociedad integrada por ocho herreros de los mazos de Peñaseita, Colobrén y la Pola, en el concejo de Allande, junto con el industrial Rafael Uría, de Cangas de Narcea, que fue quien puso el capital necesario para el acopio de la vena y el carbón 2559 . Este Rafael Uría y Riego (1820-1901) fue alcalde de Cangas de Narcea entre 1856 y 1862 y diputado provincial en varias legislaturas; era

2557 CATASTRO DE ENSENADA. R. G.: Allande/3. "Quatro mazos que se denominan de arriua, de auajo, de Colobredo y la Puente, y sirven para fundir y hazer calderas de fierro, sartenes, cucharas, herraduras y otras herramientas, que sirben para las labores de el campo; $y$ corresponden a el conde Marzel de Peñalba, a quien reditúan de utilidad cada año un mill y seiszientos y seis reales de vellón".

${ }^{2558}$ BOPA, 20 de agosto de $1860, \mathrm{n}^{\circ} 131, \mathrm{p} .2$

2559 J. LÓPEZ y A. GRAÑA (1998): Ob. cit., p. 19 
hermano de José Francisco Uría y Riego, director de Obras Públicas en 1858. Como veremos, además, fue propietario de las ferrerías de Besullo y Vionga.

Según Fuertes Acevedo "en la actualidad solo funciona la de Peñaseita, que produjo en el año 1868, 200 quintales métricos de hierro forjado y 300 quintales en el de 1869. Esta ferrería en 1870 fabricó 260 q. m. de hierro forjado empleando solo hierros de Somorrostro y consumiendo 1.150 q. m. de carbón vegetal. En 1871, 200 q. m." ${ }^{2560}$. Adaro habla de ella como una ferrería que funcionaba en 1866 y afirma que en 1871 fue la única asturiana que trabajó ese año ${ }^{2561}$; también lo hizo en 1872 y en $1875^{2562}$.

ESTADO: Desconocido

\section{FERRERÍA DE VILLARÍN}

LUGAR: Armenande, parroquia de Lago

MUNICIPIO: Allande

RÍO: Ourúa

COORDENADAS: $43^{\circ} 15$ ' 33" N. y $6^{\circ} 41^{\prime} 22^{\prime \prime}$ W.

En la carretera de Pola de Allande a Grandas de Salime, a la altura de Montefurado baja un camino hasta los arroyos que forman el río Ourúa o del Oro. En sus orillas se encontraba la ferrería de Villarín también conocida como ferrería de arriba o ferrería vella.

Pese al nombre de Vella, con que se conoce, se construyó al mismo tiempo que la de Armenade. El mismo 6 de julio de 1848 don José Lombardero y compañía, integrada por los mismos que la de Armenade, solicitaron un paraje, denominado Veiga, término de la misma parroquia de Lago para levantar esta fábrica ${ }^{2563}$, que en 1852 aún no se había construido, como hemos visto. En 1854 sus socios vendieron una octava parte, como ya hemos visto, a Bravo, Guzmán y

2560 M. FUERTES ACEVEDO (1880): Mineralogía asturiana. Oviedo, p. 144.

${ }^{2561}$ L. ADARO (1916): Criaderos de hierro de Asturias. Madrid, p. 66

2562 IDEM, p. 63

${ }_{2563}$ BOPA, 14 de agosto de $1848, n^{\circ} 97$, p. 4. 
Cía. Según A. Quintana, entre 1850 y 1854 los mazos y fraguas de los Oscos se abastecían con hierro de esta ferrería ${ }^{2564}$.

Cerró antes de 1885

ESTADO: No hay ningún resto, excepto el prado donde se levantaba

\title{
2. MUNICIPIO DE AMIEBA
}

\section{FERRERÍA DE LA CENEYA}

\author{
LUGAR: La Ceneya \\ MUNICIPIO: Amieba \\ RÍO: Sella \\ COORDENADAS: $43^{\circ} 14^{\prime} 13^{\prime \prime}$ N. y $5^{\circ} 5^{\prime} 31^{\prime \prime} \mathrm{W}$.
}

Se encuentra en la carretera de Cangas de Onís a Oseja de Sajambre ( León), en el La Ceneya, municipio de Amieba, a orillas del Sella.

Según Angel Mato, en 1835 el arrendatario de la ferrería de Soto Rodrigo, el vasco Pedro López Llanos solicitó la construcción de una ferrería en La Ceneya, lo que le enfrentó al dueño de aquél establecimiento, que no le volvió a renovar el contrato de arrendamiento al finalizar éste en 1840, pues creía que una nuevo artefacto tan cerca acarrearía problemas de abastecimiento para ambos 2565. Pese a esto, según este autor, aquel vasco de Trucíos (Vizcaya) la puso en marcha e invirtió en ella un gran capital de dinero, amasado en los diez años que estuvo como arrendatario de la ferrería de Soto Rodrigo ${ }^{2566}$. Al parecer trabajaron en su construcción unos 40 obreros.

Entre 1835 y 1845, según A. Mato, logró una cierta expansión en su producción, pero luego entró en una grave crisis que provocó el cierre de la 2564 P. QUINTANA (2005): La labranza y transformación artesanal del hierro en Taramundi y los Oscos. Siglos XVI-XIX. Taramundi, p. 52, nota 23 2565 A. MATO (2010): La sociedad rural en el concejo de Ponga (1750-1930). Oviedo, p. 108. 2566 IBIDEM, p. 109 
instalación, probablemente por falta de combustible o quizá por problemas con la vena ${ }^{2567}$. No fue exactamente así. Lo que ocurrió es que, como se anuncia en el BOPA en agosto de 1843, fue subastada para pagar a los acreedores de Pedro López Llanos, "en virtud de acuerdo celebrado entre los mismos y el defensor del deudor". La ferrería, con sus casa habitación y fincas, fue tasada por peritos en la materia en 95.402 reales y medio de vellón, que deberían ser pagados antes de noventa días de aprobado el remate ${ }^{2568}$.

Madoz, que escribe poco después, afirma que la "herrería (a la catalana) establecida en Caneya desde 1838 funde hierro de Somorrostro, por no querer o no saber aprovechar el que con abundancia, aunque más duro, pudiera proporcionar el país". La razón, como señala el informante del diccionario, es que en el municipio de Amieva la actividad minera aún no se había iniciado2569; poco después parece que se empezó a trabajar en la mina de Buferrera, en el cercano municipio de Cangas de Onís.

La ferrería la debió comprar Antonio Vega Riestra, un indiano que había residido en Veracruz y que a su vuelta, en los primeros años del siglo XIX, edificó el palacio de Meré, cerca de Llanes. Aunque algunos afirman que fue éste quien la construyó en 1836, debió de ser solamente su comprador en la mencionada subasta de acreedores. Este indiano mantuvo su explotación hasta mediados de los años sesenta. En esta segunda época, según Mato, generaba unos 25.000 jornales anuales (entre trabajadores de la ferrería, carboneros, transportistas) con unas rentas para la zona superiores a los 100.000 reales ${ }^{2570}$. En 1849 José Vega Caso aparece como director de la ferrería ${ }^{2571}$, en nombre probablemente de un hijo de aquel Antonio, también llamado Antonio Vega, quien en 1851 adquiere 2.000 hayas para fabricar carbón y abastecer "la

2567 A. H. A. Fondo Histórico de la Diputación: caja 2911: "Sobre el año 35 se fundó la ferrería de Amieva nombrada Ceneya: debió calcular su dueño que no podía faltarle el combustible porque su arbolado no podía tener otra aplicación ni podía conducirse a donde más valiera; contaba por escritura con pagar 360 reales de pensión por el uso de los montes.... Calcularía igualmente el valor, flete y arrastre de las venas de Somorrostro hasta su establecimiento y como los cálculos suelen salir fallidos, por esta razón u otras no conocidas, no pudo prosperar". En A. MATO (2010): Ob. cit., p. 109.

${ }_{2568}$ BOPA, 22 de agosto de $1843, \mathrm{n}^{\circ} 67, \mathrm{p} .4$.

2569 P. MADOZ: Diccionario geográfico-estadístico-histórico de España y sus posesiones de ultramar. Madrid, 1845-1850. Ed. Facsímil. Asturias. Ed. Ámbito. Valladolid, 1985, p. 37.

2570 A. MATO (2010): Ob. cit., p. 105 y 276, nota 87.

${ }^{2571}$ IBIDEM, p. 276, nota 89 
herrería que tiene en el espresado concejo de Amieva"2572. En 1856 este Antonio vuelve a adquirir leñas suficientes pata fabricar 3.000 cargas de carbón para su ferrería 2573.

En 1866 la ferrería la adquirió Domingo Vázquez Villamil, propietario de la Cabanada, en el municipio de Castropol, al hijo del indiano comprador, Antonio Vega Vega, en 100.000 reales. La ferrería se componía de un edificio destinado a fábrica, con una plazuela, una carbonera, además de la vivienda "compuesta de piso, sala, desván; una panera de seis pies y un molino harinero de dos piedras"2574. Dejó de funcionar en el último cuarto del siglo XIX.

ESTADO: Desconocido

\section{MUNICIPIO DE BELMONTE}

\section{FERRERÍA DE AGÜERINA}

LUGAR: Agüerina (Parroquia de San Andrés de Agüera) MUNICIPIO: Belmonte

RÍO: Pigueña

COORDENADAS: $43^{\circ} 13^{\prime} 39^{\prime \prime}$ N. y $6^{\circ} 14^{\prime} 12^{\prime \prime} \mathrm{W}$.

Se encontraba en la carretera de Pola de Somiedo a Belmonte, en el lugar de Agüerina, en la parroquia de San Andrés de Agüera (concejo de Belmonte), a orillas del río Pigueña, afluente del Narcea.

La menciona el Catastro de Ensenada, que señala que era de don Álvaro Cienfuegos Miranda, regidor perpetuo de Pravia, y producía 1.200 quintales de hierro al año2575, lo que es una cifra muy alta, lo que podría ser un signo de su reciente construcción en ese siglo XVIII, aunque lo ignoramos.

\footnotetext{
${ }^{2572}$ BOPA, 14 de febrero de $1851, n^{\circ} 19$, p. 3.

2573 BOPA, 29 de febrero de $1856, \mathrm{n}^{0}$ 26, p. 1

${ }^{2574}$ J. LÓPEZ y A. GRAÑA (1998): Ob. cit., p. 19. A. Protocolos de Cangas de Onís. Escribano Francisco García Ceñal, 3 de julio de 1866, $\mathrm{n}^{\circ} 69$.

2575 J. OCAMPO (1987): La economía asturiana al final del Antiguo Régimen. Las manufacturas, 1750-1850. Oviedo, p. 42.
} 
Además de vena vizcaína, utilizaba mineral de hierro de Brueba, del que luego se surtiría la Real Fábrica de Trubia ${ }^{2576}$. Fernández Penedo afirma que era la única ferrería asturiana que mezclaba vena de Somorrostro con pequeñas cantidades de la del país ${ }^{2577}$, lo que no parece completamente cierto. Según un informe del brigadier Francisco Vallejo, director de la fábrica de Trubia, en 1796 se ensayó con hierro de esta ferrería para su utilización en la construcción de fusiles, pero "se soldaba con mucha dificultad y saltaron en pedazos al meterle la lima" 2578 .

Probablemente se refiere a esta ferrería una venta de un soto de castaños que, en 1818, realizan don Salvador Lombardía y su mujer a "D. Manuel Castrillón administrador de la Herrería de Miranda"2579. En un informe de la Sociedad Económica de Amigos del País de Asturias, de 1833, se menciona una ferrería en el concejo de Miranda ${ }^{2580}$, aunque poco después, Madoz habla de que en la feligresía de San Andrés de Agüera hay un lugar denominado "Herrería" y otro conocido como Agüerina, pero sin citar ferrería alguna. Sólo dice que en el concejo de Miranda existen "algunos martinetes de hierro" ${ }_{2581}$. Esta cita está en contradicción con otra en la que al hablar de un mineral de hierro cercano, que se utilizó en Sargadelos, el mismo Madoz alude a que éste "produce un corto rendimiento destinado a la herrería de Aguerina" ${ }^{2582}$, lo que resulta muy parecido a lo que Schulz afirmara unos años antes: "otra poca vena se extrae del concejo de Miranda para la herrería de Aguerina"2583, lo que indica que todavía trabajaba en los años cuarenta, lo que escierto.

${ }_{2576}$ BN. ms 7295, fs. 224-226. Cfr. G. ANES (1988): Economía y sociedad en la Asturias del Antiguo Régimen. Madrid, p. 113. Jovellanos cita en sus Diarios una mina de hierro que descubrió Álvaro Cienfuegos Miranda que "se cree excelente", aunque no se ha probado. En G. M. JOVELLANOS (1992): Diario. Ed. J.M. Caso. Barcelona, p. 206.

2577 S. FERNÁNDEZ PENEDO (1964): "Los primeros altos hornos al coque y la primera acería de España”. Revista del Instituto del Hierro y el Acero, $\mathrm{n}^{\circ}$ 93, p. 448

${ }^{2578}$ L. ADARO (1986): "Los comienzos de las Fábricas de Municiones Gruesas de Trubia y Oviedo, 1792-1799". BIDEA, no 118, p. 375

2579 AHPLU: $2070 / 7$ (1818, 7 de octubre).

${ }^{2580}$ Cfr, J. LÓPEZ y A. GRAÑA (1998): Ob. cit., p. 143. De las dos que había en este concejo, la de Belmonte debió desaparecer hacia 1790, así que la que ahora se menciona ha de ser esta de Agüerina.

${ }^{2581}$ P. MADOZ (1985): Ob. cit. p. 27 y 239

2582 P. MADOZ (1985): Ob. cit., p. 278

${ }_{2583}$ G. SCHULZ (1841): Estadística de la minería de Asturias y Galicia. Madrid, p. 5 
En 1845 su propietario, don Bartolomé Cienfuegos, puso un anuncio en el Bopa, publicitando su venta: "se vende una fábrica de labrar hierro, con martinete, molinos harineros y todos los utensilios que contiene, abundante en agua y en carbón vegetal, sita en términos del concejo de Miranda, parroquia de Agüera" ${ }^{2584}$. De acuerdo con este anuncio, la ferrería, que contaba con un martinete, debía de estar en buen uso y con materias primas abundantes, por lo que hay que suponer que trabajó algunos años más, aunque desconocemos quien la adquirió entonces.

ESTADO: Desconocido

\title{
6. FERRERÍA DE BELMONTE
}

\author{
LUGAR: Belmonte \\ MUNICIPIO: Belmonte \\ RÍO: Pigueña \\ COORDENADAS: $43^{\circ} 17^{\prime} 37^{\prime \prime}$ N. y $6^{\circ} 13^{\prime} 57^{\prime \prime} \mathrm{W}$.
}

Por la carretera de Pola de Somiedo a Belmonte, después de la ferrería de Agüerina, también en el río Pigueña del que Madoz dice "que nace en el puerto de Somiedo, baña por la derecha a Corias de abajo y por la izquierda a Alvariza y la Ferrería" 2585. En este lugar de La Ferrería, poco antes de Belmonte, se encontraba la ferrería de los monjes.

Desde antiguo hubo en la zona de Belmonte, en la que existen pequeños yacimientos de hierro, algún tipo de actividad siderúrgica. En 1581 el monasterio de Belmonte daba en foro, por tiempo de cincuenta años, al herrero Diego Dalba una fragua en Albariza, "que tiene unas varquias con su tubera, una incla, una vigornia con tubo de gruesas y otras de fesorias, una clavera con dos punzones para hacer erraduras, dos vergas para clavos, unos muelles, quatro martillos, tres tenazas, dos tajadoras". Como renta ha de pagar dicho herrero nueve reales. La fragua, construida por el monasterio anteriormente, le 
había costado a éste once reales de plata que hubo de pagar a Menendo Díaz de Silviella ${ }^{2586}$.

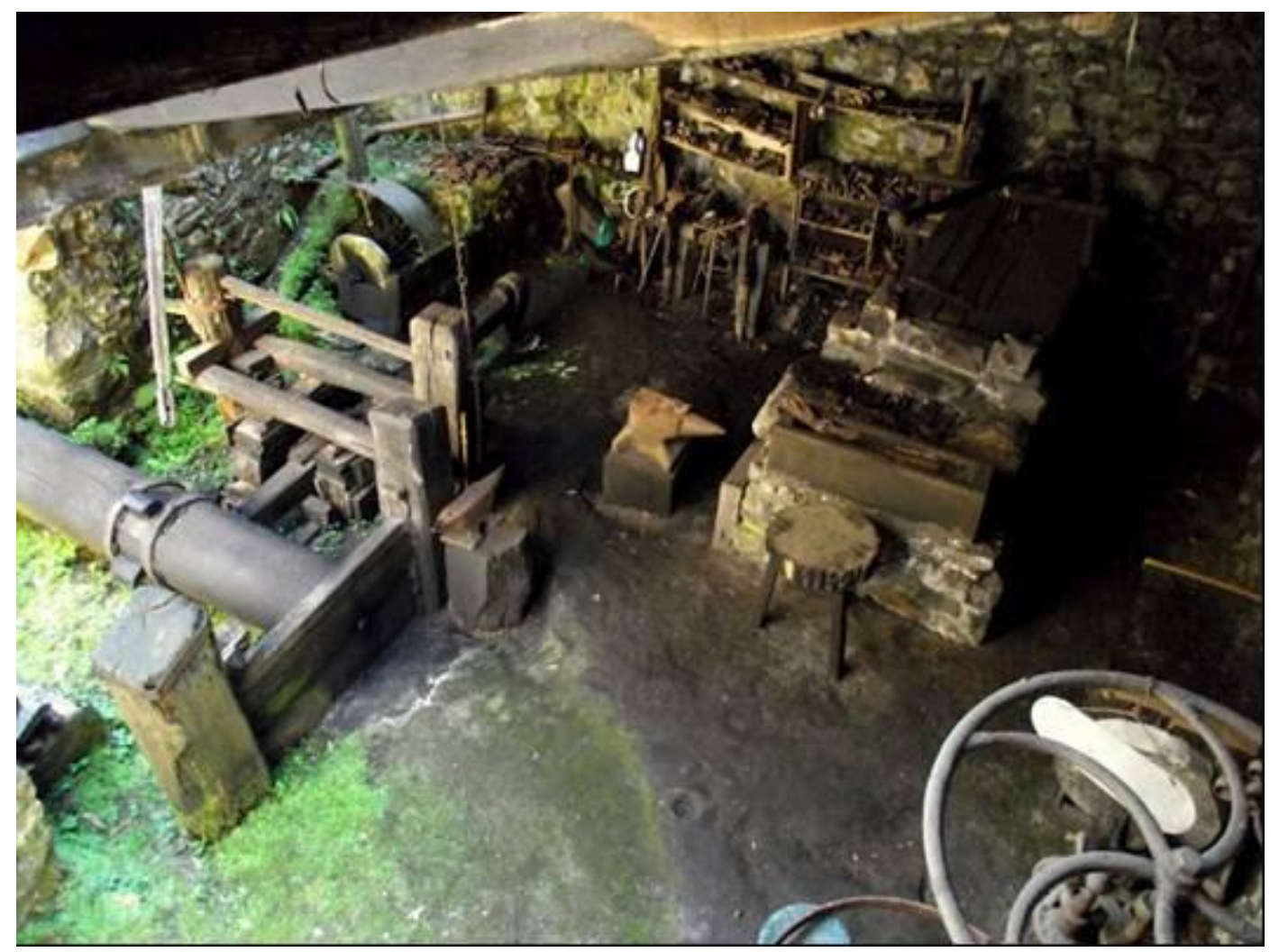

Mazo de Alvariza

En ese lugar debía existir probablemente un martinete del que se servían esa y otras fraguas. Jovellanos habla en 1792 de un machuco 2587 y Madoz hacia 1850 recuerda que en San Julián de Belmonte hay “un martinete de hierro en el pueblo de Alvariza" ${ }^{2588}$, es decir el mismo en que se mencionaba en 1581 la fragua de los monjes. Un documento de alrededor de 1805 señala que "el

${ }_{2586}$ AHN. Pap. Leg.133. Libro foral 1 ${ }^{\circ}$, f. 218. Cf. R. PRIETO BANCES (1976): “Apuntes para el estudio del señorío de Santa María de Belmonte en el siglo XVI”. En Obra Escrita, p. 102, nota 285bis.

${ }^{2587}$ G. M. JOVELLANOS (1992): Ob. cit., p. 103: "Casa de la Vega; más adelante se halla un buen machuco movido por las aguas del río o arroyo Pascual, que baja del monte Unombre por la derecha y sirve para tirar el hierro para varios usos, de flejes, clavazón, etc.; solo se hacen garfiellas (una especie de cazo con mango largo), porque no saben más; los herreros del país pagan al llevador (el dueño es don José Peláez, forista de Belmonte) seis ducados cada año por el uso de él para sus obras, poniendo ellos el carbón y el trabajo, y aún concurriendo a quiebras menores".

${ }_{2588}$ P. MADOZ (1985): Ob. cit., p. 76 . En la p. 79 dice también: "un martinete en Albariza". 
martinete está separado de la ferrería y con bastante abandono, mueben sus ruedas de paletas las aguas de un arroio que baja de la sierra contigua del Estopo" ${ }^{2589}$. Este martinete era diferente de la ferrería y aún existe en la actualidad como reliquia turística.

La ferrería de Belmonte la construyó en la segunda mitad del siglo XVII el abad fray Dionisio de Oñate. En 1684 los monjes protestan ante el ayuntamiento de Oviedo porque el administrador de la alcabala de esta ciudad quería cobrarles por ocho quintales de hierro que "fray Esteban de Llano, administrador de la ferrería", había remitido a un vecino de Oviedo, de nombre Carlos Pacheco. Por no pagar dicha alcabala le embargaron el hierro, lo que obligó al monasterio a acudir, primero al obispo y luego a la Chancillería de Valladolid, en defensa de un privilegio que tenía el convento de antaño. La Chancillería emitió en 1685 una sentencia favorable a los monjes, reconociendo el derecho de éstos a no pagar tributo por la venta del hierro en aquella ciudad $^{2590}$.

Durante un siglo no hay noticias de esta ferrería, de la que ni siquiera el Catastro de Ensenada hace mención. Probablemente estuvo parada en la primera mitad del siglo XVIII y volvió a ponerse en funcionamiento al elevarse el precio del hierro en la segunda mitad de ese siglo. Según Gonzalo Anes, la ferrería labraría unos 800 quintales "machos, cuando más, de hierro tirado", del que se servían los martinetes y herreros de las inmediaciones. Al parecer gastaba de cuatro partes, tres de mineral de Somorrostro y una del de la cercana mina de Brueba. Sus hierros eran de mediana calidad. El martinete, muy descuidado, estaba separado de la ferrería, movido por las aguas de un arroyo, como ya hemos dicho²591.

\footnotetext{
${ }_{2589}$ ACADEMA DE LA HISTORIA: Fondo Martínez Marina: ms. 9/6036, ${ }^{\circ} 15$ 2590 AHN. Pap. Leg. 136. Cfr. PRIETO BANCES (1976):Ob. cit., p. 102, nota 286. ${ }^{2591}$ BRAH.: 9/6.036, no 15: "Una de las fincas que tendría (el convento de Belmonte), a estar bien cuidada, sería la ferrería, que está en el mismo coto y a la distancia de doscientas diez toesas N.O. del escobio o estopo; mas dirigida por manos poco inteligentes solo produce anualmente ochocientos quintales machos, quando más, de hierro tirado, con lo que se probeen los herreros y cerrageros del entorno. Gasta tres partes de mena de Somorrostro y una de la Brueba y produce hierros de mediana calidad". Añade que las aguas del Pigueña mueven su máquina sopladora. Cfr.G. ANES: Historia de Asturias. Ayalga. t. III, p. 127
} 
Jovellanos, que la visitó en 1792, escribe que tiene una casa para el religioso, conocido como el prior de la ferrería. Ésta tenía camarado de madera y barquines. Cuando la visitó el ilustre polígrafo estaban poniendo un mango nuevo al mazo "formado por un robustísimo castaño cortado sobre el camino". Característica común a estas ferrerías del noroeste, a diferencia de las vascas, es lo poco aseado de sus oficinas. Dentro de la ferrería hay una fragua grande " $y$ en ella se formaba la última sortija para el gran dedo", dato que nos informa de una práctica corriente, como era la de reforzar con flejes de hierro el mango del mazo para darle una mayor consistencia ${ }^{2592}$.

Joaquín Ocampo cree que hacia 1790 se produce una grave crisis en la demanda interior y exterior de hierro, probablemente relacionada con las dificultades de la minería vizcaína. De esa fecha, o de un poco después, ya que Jovellanos aún la visita en 1792 como hemos dicho, data en su opinión el cierre de algunas ferrerías, entre ellas la del monasterio de Belmonte2593. Sin embargo, aún trabajaba en 1796 cuando el director de Trubia, Francisco Vallejo, pretendió que fabricara planchas para fusiles, a lo que se negaron sus dueños, aunque pudo hacerlo a un elevado precio en el martinete o machuco inmediato a ella2594. Después ya no se menciona más. Probablemente se convirtió en un simple mazo2595.

ESTADO: De la ferrería no se conserva ningún resto, pero sí del mazo de Alvariza, de titularidad privada, que fue declarado BIC en 1983. Se puede visitar.

\footnotetext{
${ }^{2592}$ G. M. JOVELLANOS (1992): Ob. cit., p. 103

2593 J. OCAMPO (1987): La economía asturiana al final del Antiguo Régimen, p. 46; aunque en otra obra: J. OCAMPO (1990): Campesinos y artesanos en la Asturias Preindustrial (17591850). Gijón, p. 241, dice que trabajó por última vez en 1815.

${ }^{2594}$ L. ADARO (1986): "Los comienzos de las Fábricas de Municiones Gruesas de Trubia y Oviedo, 1792-1799". BIDEA, $\mathrm{n}^{\circ} 118$, p. 376

2595 ACADEMA DE LA HISTORIA: Fondo Martínez Marina: ms. 9/6036. Un documento de principios del siglo XIX habla de un machuco del que se sirven los herreros del país, a cuyo dueño pagan seis ducados al año por el uso de él para sus obras, y añade "era una ferrería del monasterio de Belmonte con casa para un religioso residente siempre en ella".
} 


\section{MUNICIPIO DE BOAL}

\section{FERRERÍA DE FROSEIRA}

LUGAR: Froseira, parroquia de Doiras

MUNICIPIO: Boal

RÍO: Urubio

COORDENADAS: $43^{\circ} 23^{\prime} 26^{\prime \prime} \mathrm{N}$. y $6^{\circ} 50^{\prime} 42^{\prime \prime} \mathrm{W}$.

Se accede desde la carretera de Boal a Eilao por un desvío señalizado, que por una pista de tierra conduce hasta el lugar de Froseira, que está a unos tres kilómetros del cruce. La ferrería se encuentra en la margen izquierda del río Urubio.

$\mathrm{Su}$ construcción data probablemente de la mitad del siglo XVIII, concretamente del año 1751, según datos del Museo del Pueblo de Gijón. Un documento de finales de 1796, en el que se exponen las razones en contra de la construcción de la ferrería de Brieves, entre ellas que no bajaría el precio de hierro al aumentar la competencia, se señala que "esto se evidencia con el exemplo de otras herrerias que se han hecho de nuevo en aquel Principado y principalmente en la de Gullimoyro y la que llaman nueva del concejo de Boal en la que no obstante tener los montes muy cercanos no se despacha el yerro a precio mas moderado que en todas las demás antiguas"2596. La nueva del concejo de Boal no es otra que esta de Froseira. Si expresamente se menciona que "se han hecho de nuevo", no pueden ser muy antiguas, pero como ya veremos con la de Froseira, existía cuando se redactó el Catastro de Ensenada hacia 1753, por lo que probablemente hay que datarla un poco antes de esa fecha, en la primera mitad del XVIII.

El Catastro de Ensenada la menciona como una de las grandes ferrerías asturianas, indicio probable de su reciente construcción. Según sus datos, producía de 800 a 1.000 quintales de hierro al año, regulándosele un beneficio

${ }^{2596}$ A.H.N. Consejos: legajo. 28685, exp. 7-3, ff. $230 v$. 
de 16.000 reales anuales, cifra que contrasta con los más reducidos de otras ferrerías asturianas por esas fechas. No se indica su propietario sino su arrendatario, que era don Antonio Lombán2597. Sin embargo, sabemos que la ferrería perteneció siempre al vínculo y mayorazgo de la casa de Berdín, de la parroquia de Doiras (Asturias). Por ejemplo en 1795 su propietario era don Francisco Berdín ${ }^{2598}$, que la tenía arrendada al mencionado Antonio Lombán en 10.000 reales.

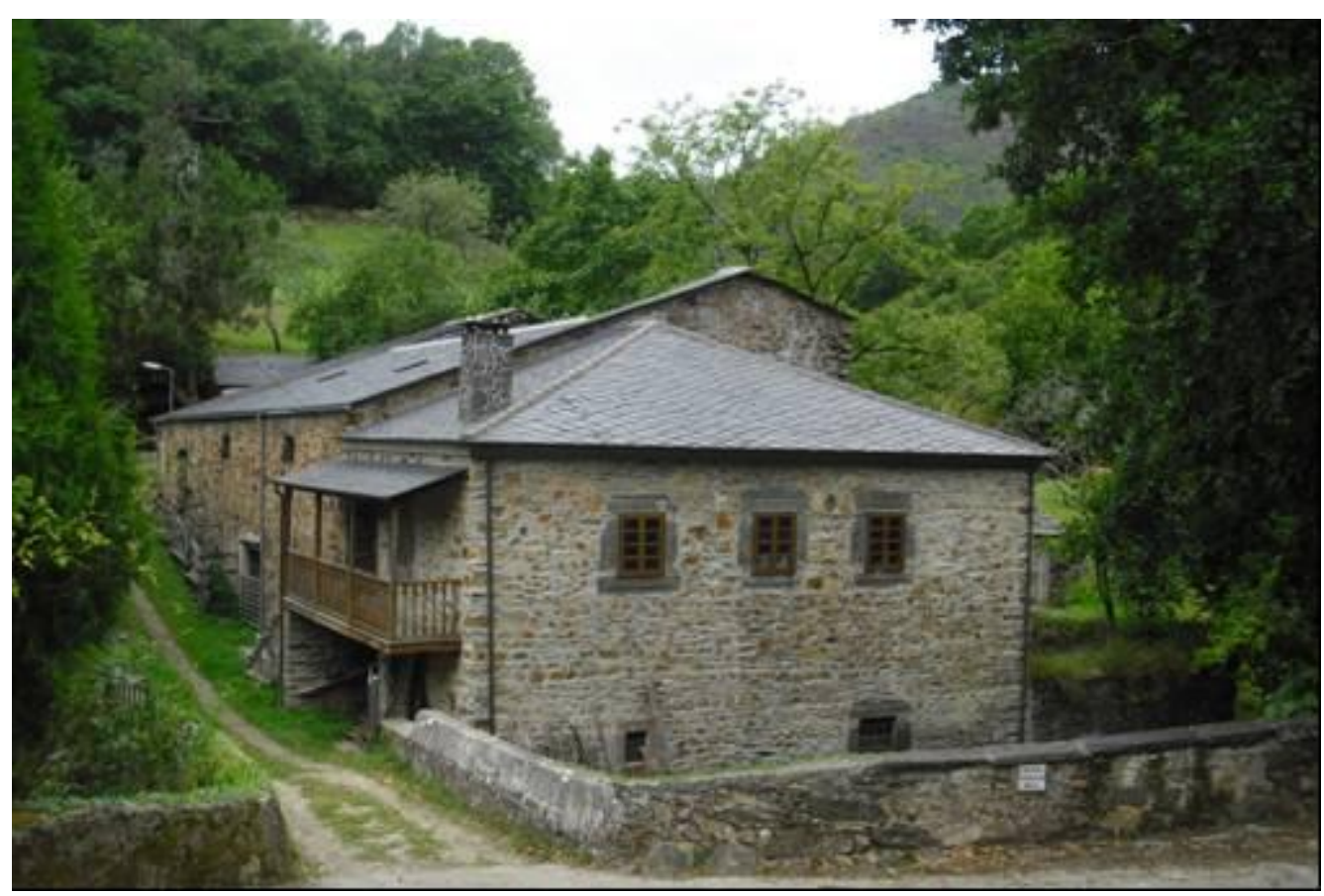

Ferrería de Froseira

A este Antonio Lombán sucedió Francisco Lombán y Castrillón, probablemente además propietario por compra a los Berdín de la ferrería, y del que en 1814 era su mayordomo otro Manuel Lombán o Manuel Díaz Lombán, que con ambos nombres se cita. Francisco Lombán y Castrillón era un hombre ligado al mundo del comercio y la siderurgia, pues estuvo casado con Gertrudis Ibáñez de Acebedo, hija de Antonio Raimundo Ibáñez, el fundador de la fábrica de Sargadelos. Manuel Lombardero se obligaba en 1817 a pagar a "D. Manuel Díaz Lombán, como apoderado y administrador de la Herrería de Froseira, de que es dueño el sr. D. Francisco Lombán”, 7.524 reales por la compra de 50 
quintales y 16 libras de "fierro fabricado en dicha Herrería" a precio de 150 rs/quintal2599.

Dicho administrador aún lo era en $1827^{2600}$. Francisco Lombán y Castrillón junto con don Juan Méndez Vigo, miembros de la Sociedad Económica de Amigos del País, elaboraron en 1833 un informe sobre el estado de las ferrerías asturianas ${ }^{2601}$. De éste pasaría más tarde al marqués de Gastañaga, pues una hija de Francisco Lombán, Amalia Lombán e Ibáñez, se casaría en 1834 con Miguel Nicolás Vereterra y Carreño, marqués de Gastañaga. Por eso, en $1844^{2602}$ y $1850^{2603}$ se menciona a éste como propietario de la ferrería, aunque en realidad era de su mujer. Por esos años su administrador era José Rodríguez ${ }^{2604 .}$

La ferrería beneficiaba vena casi exclusivamente del País Vasco, aunque también consumía la de alguna venera cercana. Según el libro de cuentas, con datos de numerosos años del siglo XIX, la vena de Vizcaya llegaba en barco hasta Navia, se llevaba luego por el río hasta los almacenes de Porto, en Coaña, y desde allí se transportaba hasta la ferrería en carros o caballerías. También consumía vena de la venera de Truitín ${ }^{2605}$. Madoz al hablar de aquel río dice que era navegable una legua más arriba del lugar de Navia, pudiendo fondear barcos de más de cien toneladas "las que conduce material para las herrerías de Bullimero en la feligresía de Parlero y para la de Frouseyra en el ayuntamiento limítrofe de Boal"'2606. De hecho, según este mismo autor en el puerto de Navia entraban todos los años una media de 7.382 quintales de mineral de hierro2607.

\footnotetext{
2599 AHPLU: 2070/6 (1817, 13 de agosto).

${ }^{2600}$ AHPLU: 2071/8 (1827, 12 de junio). Don Manuel y don Cayetano Martínez reconocen deber a don Manuel Díaz Lombán, administrador de la ferrería de Froseira, 640 rs. "procedente de fierro"

${ }^{2601}$ J. LÓPEZ y A. GRAÑA (1998): Ob. cit., p. 143

2602 Museo del Pueblo de Asturias: Archivo del marqués de Cienfuegos, leg. 21

2603 J. LÓPEZ y A. GRAÑA (1998): Ob. cit. p. 145, nº 8

2604 Este José Rodríguez exige a Antonio Villar, vecino del lugar de Pumares, que le pague 472 reales y 20 maravedís, resto de mayor cuantía procedente de 902 libras de hierro que le afianzó en la ferrería de Froseira, siendo el precio del hierro 130 rs./quintal. EN P. QUINTANA (2005): Ob. cit., t. I, p. 52, nota 23.

2605 IBIDEM, p. 139 a 143.

2606 P. MADOZ (1985): Ob. cit., p. 253

2607 IBIDEM, p. 254
} 
A través del libro de cuentas sabemos que entre 1850 y 1856, el 83 por ciento de las 224 toneladas métricas de hierro vendido por esta ferrería, que es el total de su producción (unos 750 quintales de cinco arrobas anuales) fue adquirido por solo ocho compradores o "tratantes de ferrería", algunos de los cuales eran también propietarios de martinetes ${ }^{2608}$, los cuales beneficiaban ese hierro para fabricar utensilios agrícolas y domésticos, y clavazón. En 1850 su propietario, el marqués de Gastañaga, presentó en la feria de muestras celebrada en Madrid algunos ejemplares de hierro dulce de esta ferrería “montada como las forjas catalanas"2609. Según La Revista Minera funcionaba en $1866^{2610}$, pero debió cerrar hacia $1868^{2611}$.

ESTADO: Se trata de un vasto complejo en el que junto a la ferrería hay un mazo, una capilla y la casa vivienda, todo ello en buen estado aunque muy modificado. La ferrería consta de dos grandes espacios: uno dedicado a forja, con dos compartimentos: el mazo y hogar en uno, y los barquines en otro; el segundo, también dividido en varios compartimentos, consta de dos carboneras y un almacén. Se conservan igualmente el canal, banzao y banzadillo con los huecos, cerrados con arcos de medio punto, para las ruedas hisráulicas.

\section{MUNICIPIO DE CANGAS DE ONÍS}

\section{FERRERÍA DE COVIELLA}

LUGAR: Coviella

MUNICIPIO: Cangas de Onís

RÍO: Sella

COORDENADAS: $43^{\circ} 23^{\prime} 1^{\prime \prime}$ N. y $5^{\circ}$ 10' $33^{\prime \prime}$ W.

Madoz dice que en Cangas de Onís hay "otra (fábrica) en el lugar de Cobiella construida por un particular con destino a la fundición de hierro"2612. Señala también que "aunque existen muchos y ricos veneros de hierro" la

2608 J. LÓPEZ y A. GRAÑA (1998): Ob. cit., p. 44

2609 BOPA, 28 de febrero de $1851, \mathrm{n}^{0} 25$, p. 3

${ }^{2610}$ REVISTA MINERA, t. XIX. 1868, p. 82. También en L. ADARO (1916): Criaderos de hierro de Asturias, p. 66

${ }^{2611}$ Según datos del Museo del Pueblo de Gijón

2612 P. MADOZ (1985): Ob. Cit., p. 109 
producción es nula. "Pocos años ha, continúa, se verificó un ensayo con vena sacada en Covadonga, pero resultó hierro muy quebradizo, lo que se atribuyó a la falta de conocimientos para la fundición”2613. Quizá por eso el experimento terminó en fracaso, pues no conozco ninguna otra mención.

Ignoro cuándo y quién construyó esta ferrería, probablemente en el primer tercio del siglo XIX. En el BOPA de 21 de diciembre de 1839 se menciona a un don Antonio María Faes Valdés "propietario de la Cobiella", el cual, añade el boletín, tomó posesión de una pertenencia de la mina de cobre de Peñacrespa, en términos de Villoria, del concejo de Laviana ${ }^{2614}$; pero no podemos asegurar que ese Cobiella se refiera a la ferrería o al lugar de ese nombre. Por su interés por la minería podría estar relacionado, además sabemos que este personaje, que nació en Carabanzo (Lena) en 1790, fue amigo del economista asturiano Álvaro Flórez Estrada, el promotor de la ferrería de Pola de Somiedo.

ESTADO: Desconocido

\section{FERRERÍA DE RIERA}

LUGAR: Coto de Riera

MUNICIPIO: Cangas de Onís

RÍO: Reinazo

COORDENADAS: $43^{\circ} 19^{\prime} 27^{\prime \prime}$ N. y $5^{\circ} 4^{\prime} 39^{\prime \prime}$ W.

Según el Catastro de Ensenada en el coto de Riera, en Covadonga, "don Ysidoro Antayo, marqués de Vista Alegre, vecino de Cádiz, está próximo a fabricar dentro de los términos del coto, una Herrería, para la qual se está ya conduciendo los materiales, si vien aún no han descuvierto el mineral que dicen estar en el concejo de Cangas de Onis" 2615 . En las respuestas de Cangas de Onís matiza esta noticia en estos términos: "declaran que en los puertos de este concejo se está trabajando por D. Ysidro de Antaio, Marqués de Bista Alegre, vecino de la ciudad de Cádiz, en descubrir un mineral de hierro, hallándose

2613 IBIDEM

2614 BOPA: 21 de diciembre de $1839, \mathrm{n}^{\circ}$ 102, p. 3

2615CATASTRO DE ENSENADA. R. G.: Cangas de Onís/Covadonga 
materiales prevenidos para hacer la herrería en el Coto de La Riera de Cobadonga incluso en este concejo" 2616 .

Este Isidoro o Isidro de Antayo y Bermúdez era el II $^{\circ}$ marqués de Vistalegre, título concedido a su padre, Antonio Agustín de Antayo y Monteverde, regidor perpetuo y alguacil mayor de Oviedo, por el rey Carlos III en 1755, al que nos referiremos en la siguiente monografía de Abantro; era también señor de la casa de Antayo y del coto de Viyao. Pero ignoro si realmente llegó a funcionar pues nada dice de ella Madoz, a no ser que se refiera a la fábrica de Coviella, en este mismo municipio, de la que dice: " $y$ otra (fábrica) en el lugar de Cobiella construida por un particular con destino á fundición de hierro"2617; pues está muy cerca de este lugar, aunque creo que se trata de dos diferentes.

ESTADO: Sumergida bajo las aguas del pantano de Tanes.

\section{MUNICIPIO DE CASO}

\section{FERRERÍA DE ABANTRO}

LUGAR: Abantro, feligresía de Santa María de Tanes MUNICIPIO: Caso

RÍO: Orlé

COORDENADAS: $43^{\circ} 12^{\prime} 10^{\prime \prime} \mathrm{N}$ y $5^{\circ} 22^{\prime} 42^{\prime \prime} \mathrm{W}$.

A mediados del siglo XVIII hubo en el concejo de Caso un proyecto para construir dos ferrerías. Lo promovieron don Antonio Agustín de Antayo, primer marqués de Vistalegre, y don Pedro Antonio de Peón Heredia, un ilustrado amigo del padre Feijóo, vecinos del Principado, que descubrieron en ese lugar "una copiosa vena de Fierro" que, en los ensayos, produjo una tercera parte de hierro de buena calidad. Argumentando que en el concejo de Caso había aguas abundantes " $y$ tanta leña de hayas que puede abastecer muchas Herrerías sin

2616 IBIDEM.

${ }^{2617}$ P. MADOZ (1985): Ob. cit., p. 109 
perjudicar a la construcción de bajeles" por la gran distancia al mar y ser los caminos intransitables, solicitaron se les concediese permiso para construir dos ferrerías en los sitios reales o concejiles que eligieren; pues redundarían en el mejor abastecimiento de hierro en Castilla y mejoraría las condiciones de vida de los habitantes de la zona ${ }^{2618}$.

Por orden del rey, don José de Colosia, que años después aparece como intendente de Marina de la villa de Avilés, envía un informe al marqués de la Ensenada, fechado el 29 de junio de 1749, en el que le dice haber visitado la zona y comprobado la abundancia de arbolado, pero también la dificultad de su transporte hasta el mar, por lo que concluye con un parecer favorable a la construcción de las dos pretendidas ferrerías ${ }^{2619}$. Por esa razón, el 23 de julio de 1749 el Consejo de Estado concede el permiso, aunque desconozco si realmente se construyeron o se hicieron en algún otro lugar cercano. De hecho, el Catastro de Ensenada no las menciona, sólo dice que en Caso hay varias fraguas ${ }^{2620}$.

La que conocemos como ferrería de Abantro se construyó en la segunda mitad del siglo XIX. Hubo, en realidad, dos solicitudes para construir en ese lugar una ferrería. La primera en 1859 por don Fernando Arias, vecino de Vegadeo $^{2621}$; la segunda por don Toribio Calvo en enero de $1860^{2622}$. Fue a éste a

\footnotetext{
2618 AGS. Secretaría de Marina: $\mathrm{n}^{\circ}$ 555. 24 de julio de 1749. Hablan de la utilidad para los vecinos pobres de aquel concejo, "asi por el mucho caudal que se distribuye entre ellos por el transporte de los materiales, como por el trabajo personal, que les escusa de salir por vecindad a talar las hayas para que penetrando el sol los montes puedan producir algún pasto para sus ganados y al interés que sigue a las dos Castillas abastecerse de hierro a menos distancia y por consecuencia a precios mas acomodados, y por el aprovecho que se sigue al Estado del aumento de sus favricas y que con el ejemplo de los exponentes se animarán otros a multiplicar estos edificios en aquellas montañas lo que podrá enriquecer todo el pais".

${ }_{2619}$ AGS. Secretaría de Marina: $\mathrm{n}^{\circ}$ 555. 24 de julio de 1749: "Tengo por conveniente que siendo S.M. servido puede conceder licencia para que usen de dichos montes para los carbones que necesiten para la provisión de las Herrerías en los quales siendo en abundancia las venas de fierro que se encuentran en aquel conzejo y de la calidad que se asegura especialmente en la Campa de escobalín, Buesomerón y govezanes que son inclusos en el enunciado concejo y asimismo en su inmediación y sitio de las Señales término de Maraña concejo de Baldeburón, rayando con el antecedente de Caso. Y también en el de Piloña y sitio de Espinaredo que confina con el sobredicho de Caso, y el de Ponga. Y consigue el Rey la utilidad de que se aprovechen aquellos materiales, que no pueden seguir para otros fines a su Real Hacienda". ${ }^{2620}$ CATASTRO DE ENSENADA. R. G.: Caso

${ }^{2621}$ BOPA, 2 de septiembre de $1859, \mathrm{n}^{\circ} 140$, p. 4. Dice en su solicitud que quiere hacerla en "el concejo de Caso, parroquia de Tanes, en el sitio llamado de Bañantes, junto al puente de Linares, aprovechando las aguas del río Nalón”. Este Fernando Arias solicitó al mes siguiente el permiso para otra ferrería en el concejo de Cabrales, en un lugar denominado "Huerta de Mistas, inmediato al lugar de Arenas" sobre el río Casaño (BOPA, 28 de octubre de 1859, $\mathrm{n}^{0}$ 170, p. 1); pero no tengo noticias de que ninguna de las dos se erigieran realmente.
} 
quien el ministerio de Fomento concedió permiso el 16 de junio de ese año para aprovechar las aguas del río Nalón "como fuerza motriz de una forja catalana que intenta establecer en el sitio llamado Llano de Bañante, término de Abantro, concejo de Caso, en provincia de Oviedo" ${ }^{2623}$. Entre las condiciones que se le imponen se mencionan: la altura de la presa no podrá exceder de dos metros sobre el nivel de las aguas ordinarias del río, el concesionario quedará obligado a construir las obras necesarias para dejar expeditos los caminos y demás servidumbres públicas en los puntos donde el nuevo cauce, que se ha de abrir, ocupe las existentes y las obras se realizarán con estricta sujeción al proyecto aprobado 2624 .

Todavía funcionaba en $1864^{2625}$ y $1866^{2626}$.

ESTADO: Desconocido, quizá bajo las aguas del pantano de Tanes.

\section{MUNICIPIO DE CASTROPOL}

\section{FERRERÍA DE LA CABANADA}

LUGAR: La Cabanada (Balmonte) parroquia de Santa Eulalia de Presno MUNICIPIO: Castropol

RÍO: Porcia

COORDENADAS: $43^{\circ} 25^{\prime} 25^{\prime \prime}$ N. y $6^{\circ} 55^{\prime} 44^{\prime \prime} \mathrm{W}$.

Se encuentra a orillas del Porcia en el lugar de La Cabanada, a $17 \mathrm{~km}$. de Castropol. Se llega a ella por un camino peatonal desde la campa de Couselo en la carretera de Penzol a Balmonte.

En 1859 Domingo Vázquez Villamil, natural de Brañatuille en el concejo de Castropol, solicitó una Real licencia para construir una forja a la catalana en la vega del Molino Viejo, en términos de su propiedad, en el río Porcia, a una legua

${ }^{2622}$ BOPA, 4 de enero de $1860, \mathrm{n}^{\circ}$ 2, p. 1. También en este caso la forja catalana se construiría "en el llano de Bañante, junto al postigo de Linares, término de Abantro, concejo de Caso, aprovechando las aguas del río Nalón”. A diferencia de Fernando Arias, este don Toribio añade que empleará como combustible las leñas de los montes comunes del concejo.

2623 BOPA, 27 de junio de $1860, \mathrm{n}^{\circ} 100$, p. 2

${ }^{2624}$ El Faro Nacional, 28 de junio de 1860 , época $5^{\mathrm{a}}, \mathrm{n}^{0} 74$, p. 869

2625 M. FUERTES ACEVEDO ((1880): Mineralogía asturiana. Oviedo, p. 144

${ }^{2626}$ REVISTA MINERA, t. XIX, 1868, p. 82. También en L. ADARO (1916): Ob. cit., p. 66 
del nacimiento del río ${ }^{2627}$. De acuerdo con lo dispuesto en la R. O. de 14 de marzo de 1846, el gobernador puso a información pública dicho proyecto, que suscitaría una enconada oposición por los dueños de las otras que había en los alrededores, entre ellos Fernando Villamil, Ramón Cancio Donlebún, Pedro Lastra, José Rodríguez Arango y Manuel Quintana. Éstos, alegando defectos de forma en la solicitud, enviaron un escrito al gobernador de Oviedo en el que exponían las razones de su oposición, que eran fundamentalmente la gran carestía de carbón, porque a distancia de menos de dos leguas existían nueve forjas a la catalana y otras siete hasta una distancia de seis leguas, todas las cuales se abastecían del mismo combustible 2628 .

Por su parte, Domingo Vázquez alegaba que aquellos se oponían por envidia, porque desde 1852, en que había arrendado la ferrería de La Veguiña, había subido los precios del carbón, que estaban muy bajos, elevando de ese modo el nivel de vida de los campesinos de la zona; por eso los dueños de las ferrerías, que se habían visto obligado a pagar más por la competencia, no le perdonaban su actitud: "pero como la envidia se desarrolla contra los buenos administradores, muy pronto llegó esta a la puerta de mis amos y les aconsejó que me despojasen; lo hicieron así y visto mis adversarios que no podían salir al mercado por no tener en donde consumir, volvieron a retirar un tanto los precios. A pesar de todo y contra el genio de mis adversarios en el periodo que se cuenta de ocho años el país sin ser visto otra cosecha de patatas, pagó las contribuciones atrasadas y ha vuelto a ponerse en el mejor estado que antes tuvo y nunca esperaba tener" 2629 .

Probablemente estas razones y el apoyo de los consejeros provinciales fueron suficientes para lograr el permiso de construcción, cuyo proyecto,

\footnotetext{
${ }^{2627}$ BOPA, 10 de agosto de $1859, \mathrm{n}^{\circ} 127$, p. 2

${ }^{2628}$ J. LÓPEZ y A. GRAÑA (1998): Ob. cit., p. 147: "En efecto, señor gobernador civil, a la distancia de una y dos leguas del sitio que designa Vázquez, existen nueve forjas catalanas y otras siete hasta la distancia de seis leguas, todas las que se alimentan con carbón vegetal. Trabajan con el mismo combustible una infinidad de martinetes y fraguas, que hay en el territorio que ocupan estas herrerías, viniendo a resultar un consumo inmenso, que no es bastante a sostener el estado de los montes del país, así es que por eso ha disminuido considerablemente en las herrerías de los exponentes, y en otras, la elaboración del fierro y muchos martinetes han cerrado"

2629 IBIDEM, p. 148
} 
redactado por el ingeniero don Salustio González Regueral (1829-1892)2630, fue aprobado el 30 de abril de $1860^{2631}$ Por Real Orden de 30 de abril, publicada en La Gaceta del 5 de mayo, se autorizaba a don Domingo Vázquez "para que, salvo el derecho de propiedad, y sin perjuicio de tercero, aproveche las aguas del río Porcia como fuerza motriz de una forja catalana que intenta establecer en el hilo (sic) Vega del Molino, termino de Valín de Balmonte, concejo Castropol, en provincia de Oviedo" ${ }^{2632}$. La ferrería funcionó hasta finales del siglo XIX, pues la cita la Estadística Minera como una de los dos que aún funcionaban ese año. Añade que era propiedad de Domingo Vázquez²633.

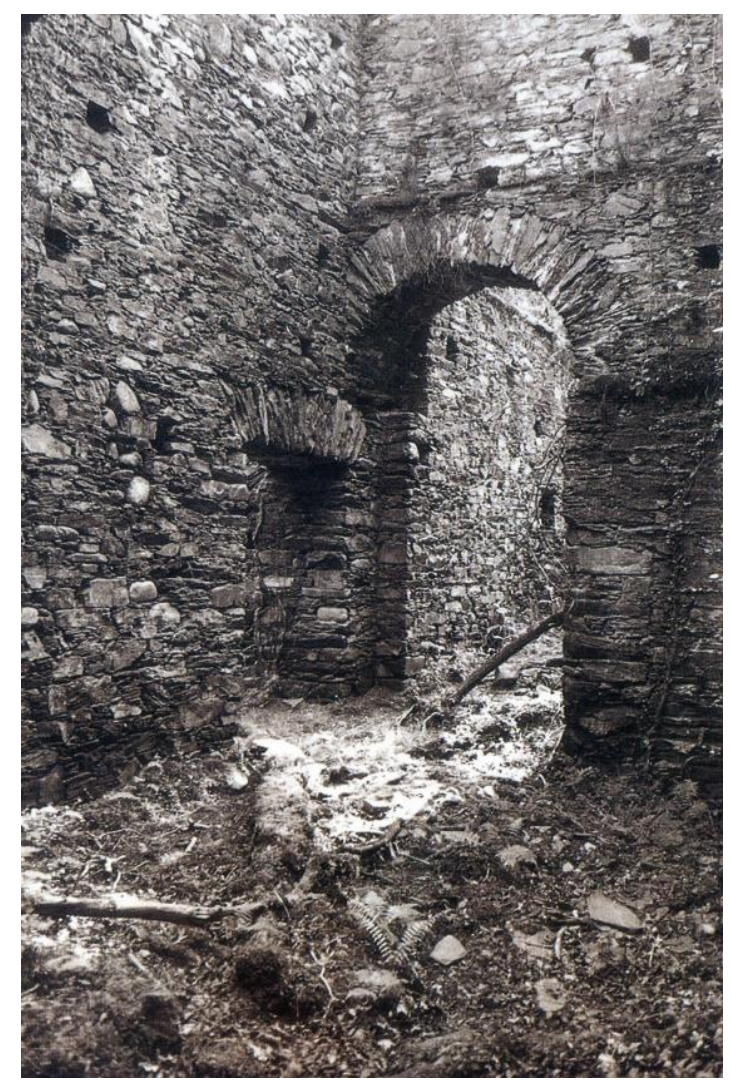

ESTADO: El edificio de la ferrería, que está en buen estado de conservación, no se atiene mucho al proyecto de González Regueral, pues fue muy modificado en su construcción. Su planta es irregular; el interior está dividido en cuatro grandes espacios: dos destinados a la forja (en uno estaba el martinete y el horno y en otro los barquines) y dos carboneras, todo ello protegido por una cubierta a dos aguas.

Carbonera de la ferrería de la Cabanada

${ }^{2630}$ Aunque nació en León en 1829 era oriundo de Asturias donde vivió y ejerció su profesión de ingeniero de Caminos, canales y puertos. Fue autor de numerosos proyectos de carreteras, ferrocarriles y puertos. Por lo que se ve también se interesó por los proyectos siderúrgicos. ${ }^{2631}$ Lo recoge El Faro Nacional. Revista de Jurisprudencia, administración, tribunales, notariado e instrucción pública. Madrid, de 15 de mayo de 1860, p. 638: "Por real orden de 30 de abril, publicada en La Gaceta del 5 de mayo, se autoriza a D. Domingo Vázquez para que, salvo el derecho de propiedad, y sin perjuicio de tercero, aproveche las aguas del río Porcia como fuerza motriz de una forja catalana que intenta establecer en el hilo (sic) Vega del Molino, termino de Valín de Balmonte, concejo Castropol, en provincia de Oviedo".

${ }^{2632}$ El Faro Nacional. Revista de Jurisprudencia, administración, tribunales, notariado e instrucción pública. Madrid, año X de 15 de mayo de 1860, p. 638.

2633 ESTADÍSTICA MINERA, 1883, p. 136 


\section{FERRERÍA DE LA CORREDOIRA}

LUGAR: Desconocido

MUNICIPIO: Castropol

RÍO: Desconocido

COORDENADAS: ¿ $43^{\circ} 27^{\prime} 28^{\prime \prime}$ N. y $7^{\circ}$ o' 40 " W.?

La menciona Pegerto Saavedra, aunque no la sitúa en un lugar concreto, sólo indica que estaba en el concejo de Castropol. Dice que en 1664 esta ferrería de la Corredoira se consideraba capaz de producir 25 quintales gallegos por semana, esto es, unos 40.60o kilogramos al año, suponiendo que trabajase, como la de Villanueva de Oscos, 28 semanas, desde mediados de noviembre hasta finales de mayo ${ }^{2634}$. No conozco ningún otro dato, a no ser que se confunda con alguna otra de este mismo municipio.

\section{FERRERÍA DE LAGAR}

LUGAR: Lagar (Balmonte), parroquia de Santa Eulalia de Presno MUNICIPIO: Castropol

RÍO: Porcia

COORDENADAS: $43^{\circ} 27^{\prime} 28^{\prime \prime}$ N. y $7^{\circ}$ o' $40^{\prime \prime} \mathrm{W}$.

Se hallaba en la margen izquierda del río Porcia o de las Herrerías, muy cerca de Balmonte, en el caserío de Lagar, en la carretera AS-24 (La RodaLagar).

Fernando Pérez Villamil, natural de Ouria, en el concejo de Boal, después de una vida dedicada a la milicia se retiró para dedicarse a las actividades siderúrgicas. En 1832, en que aparece como vecino de la ferrería de la Veiguiña probablemente era su arrendatario-, afora en compañía de José María Bravo las ferrerías gallegas de Buen Retiro y Buen Suceso, en Cuiña ${ }^{2635}$, al que ya hemos

2634P. SAAVEDRA (1982): "Un aspecto de la economía monástica: la producción de hierro. El ejemplo del monasterio de Villanueva de Oscos". En Semana de Historia de monacato cántabro-astur-leonés. Oviedo, p. 537

2635 J. LÓPEZ y A. GRAÑA (1998): Ob. cit., p. 95 
visto anteriormente como propietario de las ferrerías de Armenande y Villarín en los años cincuenta.

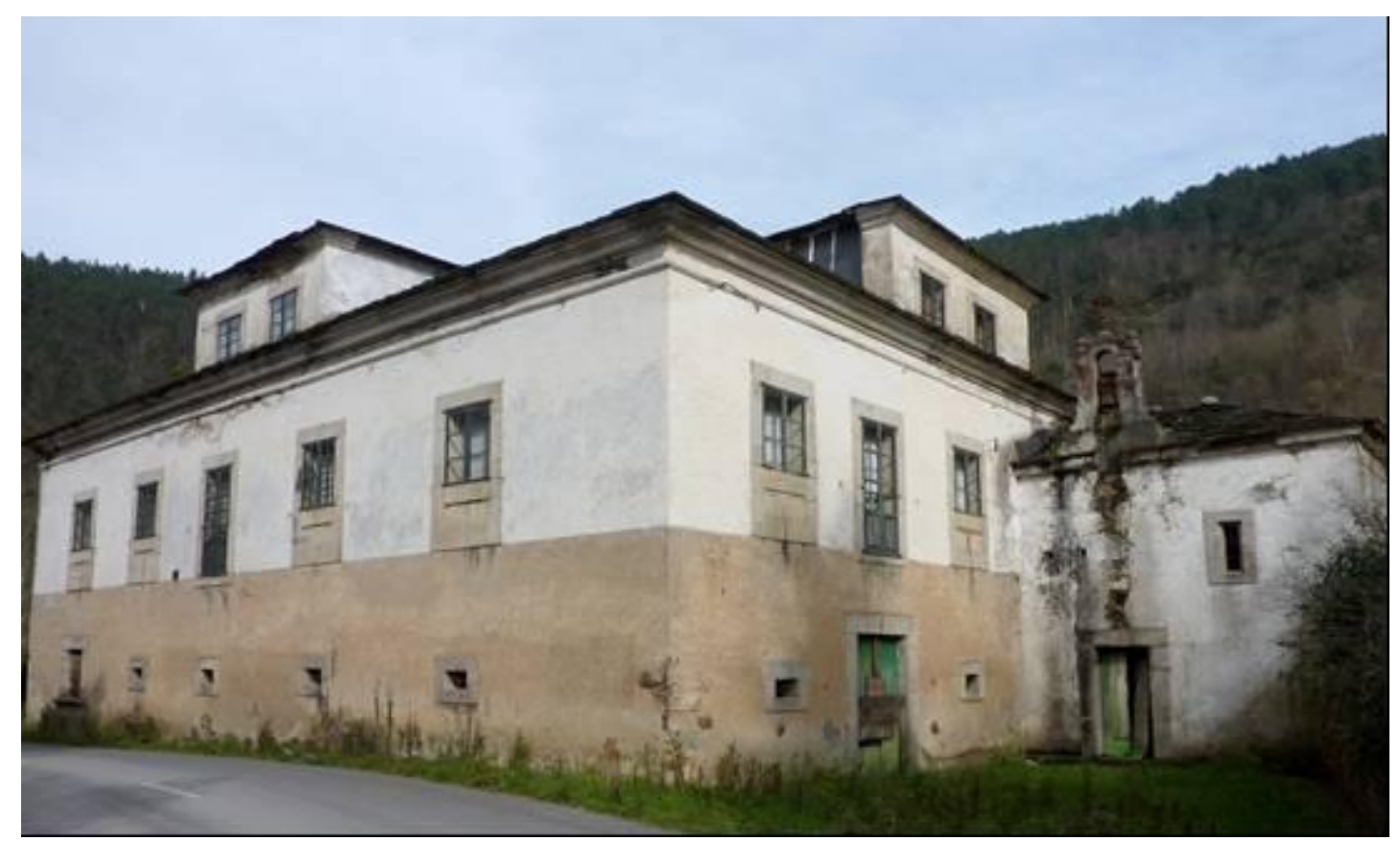

Vivienda de la ferrería de Lagar

Este Fernando Pérez Villamil construye en 1836 en el sitio de Lagar "dos fábricas de hierro, una tenería y la casa de su habitación ${ }^{2636}$. No la menciona Madoz aunque debía funcionar en los años cuarenta y cincuenta, porque aún se cita activa en un escrito de 1860 de Domingo Vázquez Villamil2637, el propietario de la ferrería de La Cabanada.

ESTADO: El complejo se encuentra a ambos lados del río Porcia, separados sus edificios por un puente. A la derecha la tenería y el molino; a la izquierda la ferrería y la casa del propietario. Pese a algunos pequeños derrumbes y $\sin$ cubierta, el conjunto de la ferrería está bien conservado: planta rectangular con sus carboneras, zona de barquines y mazo, banzadillo y un recinto para el martinete. 


\section{FERRERÍA DE MONTEALEGRE}

LUGAR: Venta de Montealegre, parroquia de Santa Eulalia de Presno MUNICIPIO: Castropol

RÍO: Suarón

COORDENADAS: $43^{\circ} 26^{\prime} 40^{\prime \prime}$ N. y $6^{\circ} 59^{\prime} 38^{\prime \prime} \mathrm{W}$.

Por la carretera de Vegadeo a Meredo, poco después de Samagán, en el lugar de la Venta, un camino que baja hasta el Suarón, a cuyas orillas se encuentra la ferrería, a unos doscientos metros de la carretera.

La ferrería funcionaba a principios del siglo XVI, por lo que es muy posible que la construyera en el siglo anterior el marqués de Astorga, quien la vendió a Pedro de Miranda ${ }^{2638}$. En 1531 este Pedro de Miranda, del concejo de Miranda, en la provincia de Lugo, la vendió a su vez a Juan Nuñez Pardo de Donlebún y Pero González de Abulí, de Castropol, en cuatrocientos ducados oro junto con la jurisdicción civil y criminal inherente a dicha propiedad; los cuales "en señal de posesión se pasearon por la dicha Herrería e términos della, tomando tierra e piedras e madera en las faldas de los sayos e fecieron dar al maço de la dicha herrería e dende allí se dieron por apoderados en todo ello e en los montes e plantados e en todo lo otro a la dicha herrería anexo" 2639 .

A finales del siglo XVI la ferrería pertenecía íntegramente a la casa de Presno, probablemente por compra de los Núñez Pardo de Donlebún a los González de Abulí, señalando aquéllos en 1571 que la tenían desde tiempo inmemorial, al parecer arrendada al vasco Pedro de Mindirichaga: "la qual yo la he dado en arrendamiento por (...) que ya son pasados a Pedro de Mindirichaga", quien para su buen funcionamiento, debió invertir una buena suma de dinero que, pese a la renta debida a su dueño en los años en que la disfrutó, este dueño quedó alcanzado en más de 300 ducados; pero aunque la ferrería estaba en buen estado para funcionar, eran necesarios muchos más de esos 300 ducados para ponerla en marcha ${ }^{2640}$.

${ }^{2638}$ Esta noticia de la venta del marqués de Astorga la proporciona el documento de la nota siguiente.

2639 J. LÓPEZ y GRINDA: Ob. cit. p. 25

${ }^{2640}$ IBIDEM, p. 25 
Fue esa deuda, así como el propio interés de la familia Presno en tener en buen funcionamiento la ferrería, lo que llevó a Ares Núñez, señor de la casa de Presno, a aforarla en 1571 al dicho Pedro de Mindirichaga y a su mujer María Ortiz de Bedia, y a otras dos personas más sucesivamente, con todo lo que a la ferrería pertenece, junto con la jurisdicción civil y criminal: "la dicha herrería de Montealegres e su coto e jurdiçion, e todo lo que en dicho coto e jurdiçión tengo e sus casas, presas, bançado e aguas, e heredades, e términos, e molinos, e ruedas, e edificios, e bienechos e plantados, según al presente están que es todo lo que para dicha herrería labrar hierro conbiene”2641.

Entre las condiciones que se estipulan están, en primer lugar, la condonaclos 300 ducados de deuda y la renta de 8.000 maravedís al año, pagada por Navidad, que en el caso de impago sucesivo durante tres años provocaría la perdida del foro. Ésta renta la han de pagar pese a las avenidas, guerras o pestes. La ferrería ha de ir en aumento: “abeis de tener bien adereçada e reparada la dicha herrería de todos los adereços y reparos que fueran menester, de manera que ella pueda labrar hierro liberalmente"; podrán utilizar la madera de los montes propios de la familia Presno, fuera del coto de la ferrería, pagando lo que normalmente se paga por la madera y el carbón. Por último, los señores de Presno están obligados a proporcionar la madera necesaria para "el arbol mayor o menor, çepos e dormientes, e puercas o maderas principales o mayores, ansi de la presa como de la herrería o camarado" 2642 . Se entiende en el foro, que la ferrería "esta adereçada de todos los adereços de piedra e madera e hierros e ruedas e arboles e bançadado $e$ camarado e otros edifiçios e aderentes que para labrar hierro conbiene”. E incluye, además la casa de la herrería y otra con horno, en donde vive Pedro de Mindirichaga, y dos más arriba y un molino "junto al camarado"2643.

Lo que no está claro es si toda la ferrería era de este Ares Núñez o de sus padres, Gonzalo Fuertes de Sierra y María Fernández; pues en 1581 se incoa un

\footnotetext{
${ }^{2641}$ LÓPEZ y GRINDA (1998): Ob. cit., p. 125-127

2642 IBIDEM p. 125-127

2643 IBIDEM, p. 125-127
} 
proceso en la Chancillería de Valladolid por la curadoría de los hijos de su hermana Sancha Álvarez de Sierra, Alfonso de Sierra y Aldonza Pérez, en el que se afirma que era de aquellos. En el pleito se habla de sus numerosos bienes en los concejos de Tineo y Castropol (brañas, viñas, rentas de aldeas, etc.), entre los cuales se citan además "la mytad de la aldea de Presno, ferrería de Montealegre y hacienda de Pineyro...”. En 1584 la justicia condenaba a Ares Núñez a restituir a sus sobrinos la mitad de todos esos bienes, entre ellos "dicha acienda y ferrerías de Montealegre y Presno"2644.

El Catastro de Ensenada de 1752 señala que su propietario era don Jacinto Pablo Valledor Presno y de su mujer doña Isabel Bermúdez, vecinos de Castropol, señores del coto de Montealegre, herederos de aquella familia.

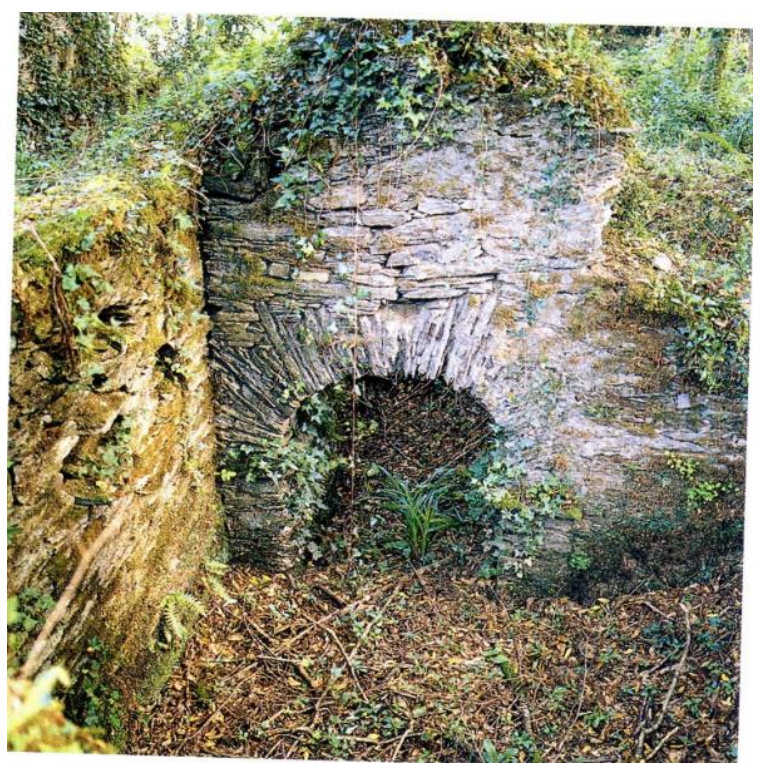

Restos de la ferrería de Montealegre Trabajaba cinco meses por la escasa cantidad de agua y las dificultades para abastecerse de leña; se regulaba a sus arrendatarios un beneficio anual de 2.500 reales 2645 . Aunque pertenecía a la familia Presno, en 1795 la tenía en arriendo la Compañía de la Vega de Ribadeo ${ }^{2646}$.

Como otras muchas ferrerías asturianas, en el siglo XIX funcionó intermitentemente por falta de combustible. A comienzo de siglo se menciona que en el coto de Montealegre "hay una herrería"2647. En 1808 y 1811 vemos a don Joaquín González de la Galea y Villamil como administrador de ella,

2644 A.Ch.V. R. E.: caja 1510,37

2645 CATASTRO DE ENSENADA. R. G.: Castropol (coto de Montealegre): "Que en el término de dicho coto ay una Herreria propia de D. Jacinto Pablo Valledor, dueño de él, cerca de la qual haviendo hecho varias consideraciones por la corta quantidad de agua de el rio con que trauaxa, la escasez de leña por hauer cortado los montes para reales fábricas y la conducción de venas para la fábrica del yerro de distintas prouincias regulan que puede trauaxar cinco meses del año y producir en ese tiempo dos mil y quinientos reales de vellón de utilidad al dueño".

${ }^{2646}$ MUSEO NAVAL: Colec. Guillén: Ms. 2175

2647 ACADEMIA DE LA HISTORIA: Fondo Martínez Marina: Ms 9/6034, nº 1 
también de la de Nafarea ${ }^{2648}$. Al parecer, en 1827 estuvo parada por falta de combustible. Madoz no la menciona pero en 1850 nuevamente conocemos que estaba en uso, siendo administrada por don Pedro Cotarelo2649. Por escasez de carbón, en 1859 sólo pudo trabajar la mitad del año. Su propietario era José Valledor Ribero.

ESTADO: Aunque arruinada, hay numerosos vestigios de sus instalaciones: canal, en parte excavado en la roca, banzao y bazadillo, carboneras, y algo separado un horno de calcinar la vena.

\title{
8. MUNICIPIO DE COAÑA
}

\section{FERRERÍA DE COAÑA}

\author{
LUGAR: Coaña \\ MUNICIPIO: Coaña \\ RIO: Meiro \\ COORDENADAS: ¿ $43^{\circ} 31^{\prime} 1^{\prime \prime}$ N. y $6^{\circ} 45^{\prime} 22^{\prime \prime}$ W.?
}

No la cita el Catastro de Ensenada. Pero Joaquín Ocampo asegura que en Coaña hay dos ferrerías propias del mayorazgo de la Casa Canel ${ }^{2650}$, lo que podría significar que eran ferrerías diociochescas. También la cita Schulz en su "Viaje por Asturias" y Adaro la menciona pero sin dar el menor dato sobre ella $^{2651}$. Según Ocampo dejó de funcionar en $1836^{2652}$.

\section{ESTADO: Desconocido}

\footnotetext{
2648 AHPLU: 2069/4 (1808, 11 de diciembre). Rosenda Fernández se obliga a pagar a don Joaquín González de la Galea y Villamil, administrador de la ferrería de Montealegre, 1360 reales y $10 \mathrm{mrs}$. de deudas de su hijo Manuel Castelao, por hierro que le dio a plazos. AHPLU: 2069/7 (1811, 21 de noviembre): Venancio Lombardero y su mujer Cayetana Rodil reconocen una deuda de 3.516 reales y 27 mrs. "que se hallan adeudando a D. joaquín González Villamil administrador de la Herrería de Montealegre (...) de fierro que sacaron al fiado de dicha Herrería y de la de Nafarea".

2649 J. ORIOL RONQUILLO (1855): Diccionario de materia mercantil, industrial y agrícola. Barcelona, t. III, p. 167.

2650 J. OCAMPO (1987): La economía asturiana al final del Antiguo Régimen. Las manufacturas, 1750-1850. Oviedo, p. 42

${ }^{2651}$ L. ADARO (1916): Ob. cit., p. 65

${ }^{2652}$ J. OCAMPO (1990): Campesinos y artesanos en la Asturias Preindustrial (1759-1850). Gijón, p. 241.
} 


\title{
9. MUNICIPIO DE CORVERA
}

\section{FERRERÍA DE TRASONA}

\author{
LUGAR: Trasona \\ MUNICIPIO: Corvera \\ RÍO: Trasona \\ COORDENADAS: $43^{\circ} 32^{\prime} 41^{\prime \prime}$ N. y $5^{\circ} 52^{\prime} 42^{\prime \prime} \mathrm{W}$.
}

En la parroquia de San Vicente de Trasona se encuentra la llamada Casa de Trasona. Se trata de un palacio que data del siglo XV, aunque con modificaciones posteriores, sobre todo del XVII. Perteneció a los Rodríguez de León, a los que expresamente se les llamaba "Señores de Trasona". En el siglo XVIII pasó a sus herederos los Trelles, y posteriormente a los Sierra y Argüelles.

Un documento de 1673 menciona a un Martín de Alzate "aroça que fue de la ferrería de La casa de Trasona" ${ }^{2653}$, que se encontraba a orillas del río Trasona, que nace en la una fuente de la parroquia de Ferreñes, y que en el lugar de aquel nombre se une al Tarín con el que desemboca en el mar muy cerca de Avilés 2654 . Según Miñano "se sabe que en el término de la feligresía de Trasona hubo ferrería, pues se conservan vestigios de ella, y se ve todavía el cauce y algunas paredes del edificio y grande porción de escoria" 2655 . Probablemente se trate de una ferrería del siglo XVII, aunque no habría que descartar una mayor antigüedad.

Sin embargo, cuando escribe Miñano hacía mucho que había dejado de funcionar. De hecho, en el Catastro de Ensenada ya no se menciona ferrería alguna en Corvera, pero sí "un artefacto de martinete de trauajar cobre". Era propiedad de don Pedro Valdés Solís al que le rentaba 800 reales anuales, aunque lo tenía arrendado; pues añade que lo administra don Francisco

2653 B. BARREIRO (1988). "Agricultura e industria en Asturias en el siglo XVIII". En E. FERNÁNDEZ DE PINEDO y J. L. HERNÁNDEZ (Ed.): La industrialización del norte de España. Barcelona, p. 52.

2654 S. MIÑANO (1826): Diccionario Geográfico-estadístico de España y Portugal. Madrid, t. I., p. 336.

2655 IDEM, t. III, p. 193 
Recagorri, al que le produce de beneficio 3.501 reales "después de pagados todos los maestros y oficiales" ${ }^{2656}$.

Por esos años del Catastro, don Manuel Mateo de Trelles León, dueño de la casa de Trasona construyó un nuevo martinete de cobre, como sabemos por la denuncia que de esta obra hizo el vecino de Avilés don Benito Diego Gutiérrez, alegando que este nuevo artefacto perjudicaba al que él había construido años antes, con licencia real, un cuarto de legua más abajo 2657 . Tanto la Audiencia de Oviedo en 1759, como la Chancillería de Valladolid en 1761, dieron la razón a don Manuel Mateo de Trelles, al entender el tribunal que lo que en realidad hacía éste era "rehedificar" en dicho lugar "una ferrería (derruida) que gozaron sus causantes". Es decir, por entonces, como ya sabíamos, la ferrería de Trasona estaba en ruinas; pero don Manuel Mateo pretendía construir sobre sus restos un martinete de cobre, como efectivamente hizo 2658 .

Por esa razón, Miñano habla de dos fábricas de cobre que aún funcionaban en su época, en las que se solían trabajar unas 50.000 libras de cobre para la fabricación de vasijas y otros utensilios domésticos, una de ellas más reciente 2659 .

ESTADO: desaparecida

\section{MUNICIPIO DEL FRANCO}

\section{FERRERÍA DE BOIMOURO}

LUGAR: Boimouro, parroquia de San Juan de Prendones MUNICIPIO: El Franco

RÍO: Bao o del Mazo

COORDENADAS: $43^{\circ} 30^{\prime} 40^{\prime \prime}$ N. y $6^{\circ} 50^{\prime} 38^{\prime \prime} \mathrm{W}$.

${ }^{265^{6}}$ CATASTRO DE ENSENADA. R. G.: Corvera.

${ }^{2657}$ Según un documento (AGS. Secretaría de Marina, 560), el permiso a Benito Diego Gutiérrez para la "construcción de un martinete de tirar cobre y hierro" se lo concedieron en 1754.

${ }_{2658}$ A.Ch.V.: R. E., caja 3272/4

2659 S. MIÑANO (1826): Ob. cit., t. III, p. 193-194 
Poco después de Arancedo, en la carretera FR-1 de La Caridad a Rozadas, se toma un desvío a la derecha que conduce a Boimouro. La ferrería estaba en la orilla derecha de río Bao o del Mazo, un pequeño afluente del Porcia.

La ferrería existía en el siglo XVI, en el que probablemente se construyó. Pertenecía a Ares de Omaña "El Rubio”. El 20 de abril de 1520, en La Coruña, el rey Carlos I concedía a éste y a su mujer, Mayor Bahamonde y Ribadeneira, licencia para vincular sus bienes y crear sobre ellos un mayorazgo ${ }^{2660}$. Años más tarde lo constituyen dejando como heredero en 1546 a su hijo Álvaro González de Omaña. En el documento de fundación señalan que incluyen en él "el nuestro lugar de Omañón y la casa de la puente de Omaña con todos sus términos e presentaciones e patronazgo e eredamientos en los concejos de Omaña y Laciana, anejos y dependientes de la casa de Omaña e ssosodicha, e mas ela nuestra casa de Villar e ferrería e coto de Voymouro con todos sus términos e todos los más vienes que nos avemos e tenemos e nos pertenesçen en todo el concexo de Castropol con mas nuestro concejo de padriñán con sus vasallos e rentas, y el poco o mucho todo quanto tenemos e posehemos en todo el rreyno de Galicia" 2661.

Por tanto, entre esos bienes aparece citada la ferrería de Boimouro que, como he dicho, pertenecía a Ares de Omaña, como señalaba el documento de 1520: "Yo Ares de Omaña cavallero señor de la casa e puente de Omaña e del lugar de Omañón e casas de Villar e coto de Prediñán e ferrerias de Vaymouro" 2662 . De acuerdo con esta fecha, la ferrería ya existía a principios del siglo; pero no sabemos si la construyó el propio Ares de Omaña o sus padres, Diego García de Omaña, a veces llamado también de Ribadeo, y Mayor Álvarez.

Los bienes, con la ferrería, pasaron a su hijo Álvaro González de Omaña tras la muerte de sus padres, pero éste murió sin hijos, por lo que en 1583 sus

2660 A.Ch.V. R. E.: caja 1633,50: "por quanto por parte de vos Ares de Omaña el de la Puente y de doña Mayor de Vramonde -sic- vuestra muger nos es hecha rrelaçion que vosotros teneys algunos vienes muebles rrayçes e semovientes 8...) de los que quereis azer mayorazgo en uno de vuestros ijos".

2661 IBIDEM

${ }^{2662}$ IBIDEM. Parece que el padre de Mayor Bahamonde la desheredó por casarse con un inferior, quizá por eso en el documento de creación del mayorazgo hablan de bienes y vasallos en Galicia, muchos o pocos, que quizá reivindican. 
sobrinos, hijos de sus tres hermanas y, por tanto, nietos de los fundadores del mayorazgo, se enfrentaron en un largo pleito por hacerse con él. No nos interesan las vicisitudes del mismo, sólo la sentencia que la Chancillería de Valladolid dictó en 1588 por la cual se declaraba heredero del mismo a Ares de Omaña y Ribadeneira, como hijo de Inés de Omaña y Ribadeneira, la mayor de las tres hermanas de Álvaro, a quien según las cláusulas del documento de fundación correspondía la herencia ${ }^{2663}$. En 1617 la ferrería estaba arrendada a Francisco Sánchez de Vidarte y a su hijo, pues sabemos que en ese año conciertan con Gonzalo Fernández Villanueva la venta de hierro 2664.

De Ares de Omaña descienden los marqueses del Villar2665 a los que el Catastro de Ensenada, en 1752, atribuye la propiedad de esta ferrería, en concreto a su titular don Pedro Miranda. Trabajaba, dice este documento, cuatro meses al año por falta de agua y se le regulaba al arrendatario un beneficio de 4.500 reales ${ }^{2666}$. Sabemos que años antes la ferrería estaba arrendada a Alonso de Miranda y Vivero, probablemente de la misma familia que el marqués ${ }^{2667}$. En el pleito contra la ferrería de Brieves de 1758 , se cita como una de las cercanas a ese lugar ${ }^{2668}$. En 1795 era propiedad del marqués de Campos $^{2669}$. No la cita Madoz, pero al parecer seguía funcionando en la segunda mitad del siglo XIX.

ESTADO: No se conservan más que el canal y restos de un muro, reaprovechado para construir un molino y serrería. También la casa de la ferrería, de buena construcción y habitable.

\footnotetext{
2663 IBIDEM

${ }^{2664}$ AHA. Caja 11249/o8

2665 Título concedido a D. José de Omaña pardo en 1705 por Felipe V. Su sobrina, que lo heredó, se casó con el III conde de San Román, D. Pedro de Miranda.

2666 CATASTRO DE ENSENADA. R. G.: El Franco. De las tres ferrerías que nombre el Catastro en este lugar "la una (está) en el coto de Boimoro, propia de D. Pedro Miranda marqués de Santa María del Villar, a la que regulan por quatro meses que solo trabaja por falta de agua en quatro mil y quinientos rs. vn. de utilidad".

${ }^{2667}$ En 1736 el marqués de Santa María del Villar libra un recibo a favor de dicho Alonso de Miranda, como rendero de la ferrería de Boimouro (AHA. Caja 11249/10)

${ }^{2668} \mathrm{M}^{\mathrm{a}}$ A. FAYA y l. ANES (2007): Nobleza y poder en la Asturias del Antiguo Régimen. Madrid, p. 249, nota 241.

2669 MUSEO NAVAL. Col. Gillén: Ms. 2175. Cfr. J. López, p. 17-18
} 


\section{FERRERÍA DEL FRANCO}

LUGAR: El Franco

MUNICIPIO: El Franco

RÍO: Porcia

COORDENADAS: ¿ $43^{\circ} 33^{\prime} 32^{\prime \prime}$ N. y $6^{\circ} 52^{\prime} 35^{\prime \prime}$ W.?

Según Adaro, en el concejo de El Franco se construyó a comienzos del siglo XIX, en torno a 1800, un horno alto, probablemente el primer horno alto del que se tiene noticia en Asturias, que funcionaba con carbón vegetal y se alimentaba con minerales que procedían de los yacimientos de Carozo, los Peñones y la Meda. La noticia parece que la toma del belga Carlos J. Bertrand, que vino a Asturias llamado por el general Elorza para ponerse al frente de la moldería de la Fábrica de Trubia, aunque éste no menciona concretamente a El Franco ${ }^{2670}$.

En un folleto publicado en 1882, Bertrand afirma que cuando desembarcó en Gijón el 28 de febrero de 1846 observó que, además de varias forjas en la zona, "había además un antiguo alto horno al carbón vegetal, que había sido construido por el gobierno para fundición de proyectiles de artillería y hacía ya más de 40 años que estaba apagado" ${ }^{2671}$. Adaro, que como ingeniero conocía bien la historia minera asturiana, dice que estaba en El Franco, lo que sin duda es cierto. De acuerdo con estos datos es probable que dejase de funcionar como consecuencia de la Guerra de la Independencia.

ESTADO: Desconocido

${ }^{2670}$ L. ADARO (1968): 175 años de la sidero-metalurgia asturiana. Ed. Cámara Oficial de Comercio, Industria y Navegación, p. 49

${ }^{2671}$ C. J. BERTRAND (1882): El verdadero librecambista. Estudio teórico-práctico de la industria metalúrgica y carbonera en Asturias. Oviedo, p. 5 


\title{
19. FERRERÍA DE SUEIRO (DE ARRIBA)
}

\author{
LUGAR: Sueiro \\ MUNICIPIO: El Franco \\ RÍO: Porcia \\ COORDENADAS: $43^{\circ} 31^{\prime} 43^{\prime \prime}$ N. y $6^{\circ} 52^{\prime} 32^{\prime \prime} \mathrm{W}$.
}

La ferrería de Sueiro, mejor las ferrerías de Sueiro pues eran dos, se encontraban muy cerca de Prendones, en el municipio de El Franco, a orillas del río Porcia. La ferrería de Arriba estaba como unos cincuenta pasos por encima de la de Abajo.

Parece una ferrería antigua, probablemente del siglo XV2672. Al menos existía en la primera mitad del siglo XVI, pues la menciona un documento de octubre de 1548, un juicio entre su propietario, Ares de Omaña el Rubio, y su arrendatario Martín San de Viana, el cual por mala fe o por imprudencia en la fabricación de carbón, en un día de invierno de ese mencionado año con mucho viento, quemó el monte y, al expandirse el fuego, arrasó con ella y las casas anexas. Según el documento, la ferrería, con las casas, el molino y batanes valían 1.00o ducados 2673 . Probablemente fue reconstruida tras el incendio.

\footnotetext{
${ }^{2672}$ En 1625 se dice que tenía más de doscientos años, es decir, que según eso se había levantado hacia 1425.

2673 AGS. RGS., 1548. Cfr. L. FERNÁNDEZ MARTÍN (1975): "Provisiones reales a favor de Asturias durante la regencia de los reyes de Bohemia (1541-1551)". BIDEA, 84-85, p. 268-269: "A los alcaldes ordinarios del concejo de Castropol que diz que es cámara del obispado de Oviedo. Alvar Lopez en nombre de Ares de Omaña el Rubio, vecino de dicho concejo por impetración que en el nuestro consejo presentó se querelló y acusó criminalmente a Martín Sanz de Viana, juez y arrendatario de las herrerías que dicen de Sueiro e a todos los demas (...) e dixo que el susodicho por él acusado en los meses de Henero y febrero pasados de este presente año usando de la enemiga que contra él tiene fue a unas hoyas de carbón que tenía junto a un monte del dicho su parte y en un día que hacía mucho viento y tormenta y mandó a ciertas personas que con él iban que pusiesen fuego, y ansi se le pusieron el qual quemó y abrasó mucha parte del campo y entre otras cosas se quemaron al dicho su parte unas herrerías con su casa y molinos y batanes con todos sus aparejos que estaban en ellas que valían más de 1.ooo ducados y ansi mismo se quemó seis casas que tenía hechas y hedificadas para el servicio de dichas azeñas y del dicho fuego se quemó también todo el monte y sotos de madera que estaban en mas de dos leguas de término alrededor de manera que del dicho fuego quedó todo destruido y asolado juntamente con ciertas heredades bravas y mansas que alli tenía y otras cosas suyas con 50 cabezas de cabras, cabritos, ovejas y corderos que él tenía dentro dellos que todo ello podría valer e rentar al dicho su parte en pan y dineros más de 50.000 mrs., demás que en el espacio de veinte años no se puede tener dél ningún aprovechamiento"
} 
A finales del siglo XVI, la ferrería debió pasar a otro Ares de Omaña, probablemente nieto de "el Rubio", propietario de la ferrería de Arganza, en Tineo. En 1625 aparecen como propietarios María de Omaña y su marido don Fernando de Sanjurjo y Montenegro, vecinos de Castropol 2674, los cuales mantendrían un largo pleito con Diego García de la Vega, porque este pretendía construir una nueva ferrería, la que hemos llamado de Abajo, en un molino que estaba muy cerca de la suya, lo que le perjudicaba por el retroceso de las aguas. Alegaban además que ese molino, llamado de la Lameyra, era la mitad suyo, del mayorazgo fundado por sus antepasado Andrés Marqués, y que Diego García usurpaba igualmente parte de un camino público. La sentencia de 1628 fue contraria, aunque obligó al propietario de la ferrería de Abajo a levantar un puente para no obstaculizar el paso 2675 .

El Catastro de Ensenada menciona en Sueiro las dos ferrerías. Una se encuentra en el coto de Sueiro y era propia del marqués de Santa María del Villar, descendiente de Ares de Omaña, a la que regula por cinco meses de trabajo, por falta de carbón, 4.900 reales de vellón de utilidad; y la otra en Sueiro de Abajo ${ }^{2676}$. Poco después, en 1783, en el escrito de don Juan Abello Castrillón, vecino de Navia, contra el proyecto de Andrés Bravo dice que en su entorno hay once ferrerías, una de las cuales es la de Suero o Sueiro ${ }^{2677}$, lo que quizá signifique que ya sólo funcionaba una; la otra debió cerrar poco después porque tampoco la menciona Madoz.

ESTADO: Desconocido

\footnotetext{
2674 A.Ch.V. R. E.: caja 2489,70. En 1628 señalan estos "que entre otros bienes del dicho mayorazgo tenían y poseían sus partes una herreria sita en el lugar de Sueiro en el rio de la beguiña, la qual abia más de doscientos años que se fabricó y continuamente la abian goçado he llebado los antecesores de la dicha doña María de Omaña".

2675 A.Ch.V. R. E.: caja 2489,47

${ }^{2676}$ CATASTRO DE ENSENADA. R. G.: El Franco.

2677 FAYA, Ma A. y ANES, L. (2007): Ob. cit., p. 252, nota 249.
} 


\section{FERRERÍA DE SUEIRO (DE ABAJO)}

LUGAR: Sueiro

MUNICIPIO: El Franco

RÍO: Porcia

COORDENADAS: $43^{\circ} 31^{\prime} 47^{\prime \prime}$ N. y $6^{\circ} 52^{\prime} 35^{\prime \prime} \mathrm{W}$.

La ferrería de Sueiro de Abajo se encontraba, como hemos dicho, a unos cincuenta pasos de la de Arriba, aguas abajo, en el río Porcia, que a veces aparece mencionado como de río de la Veguiña.

La construyó Diego García de la Vega y San Julián, vecino de El Franco, hacia 1625, pues en ese año le puso pleito ante la Chancillería de Valladolid Fernando de Sanjurjo y Montenegro y su mujer María de Omaña, propietarios de la de Arriba. Las razones que alegaban eran que el molino sobre el que la construía, llamado de la Lameyra, era la mitad suyo, y que Diego García "sin titulo ni fundamento ... se auía entrado en la mitad del molino de su autoridad y mala fe, sauiendo que es del dicho vinculo e que pertenecía a su parte”. Éste, a su vez, aseguraba que los molinos de la Lameyra eran de los "herederos de Men Suárez de la Vega difunto, mi ermano"2678, añadiendo que el pleito se lo ponía no tanto por esa propiedad como por "una herrería que pretendo azer e ago en el dicho sitio y lugar del molino que llaman de la alameyra".

Los Omaña alegaban que la nueva ferrería "estaua distante de la herrería del dicho mayorazgo como cincuenta pasos" y que el nuevo edificio vendría a "detener e rebalsar la corriente de dicho río" con lo que perjudicaría a la suya, por lo que "siendo mas antigua la suya no se podía fabricar otra en el sitio que la perxudicase"; además de que la nueva ferrería se pretendía edificar en un molino "cuya mitad perteneçía al dicho mayorazgo", como hemos dicho.

${ }^{2678}$ En otro escrito dirá que lo había heredado de su padre Lope Méndez de la Vega "el qual lo eredó de Alonso Mendez su abuelo e al tiempo que iço e fabricó la dicha erreria estaba en el mismo sitio un molino con dos ruedas propio del dicho Diego García y sus sobrinos, que se llamaba e tenía por nombre el molino de la lameyra, el qual solia estar en terminos e jurisdicion de la villa de Castropol que por aber sorredimido de esta jurisdiçion se llama aora del franco" (A.Ch.V. R. E.: caja: 2489,47). 
No parece que Diego García, alcalde del Franco, hiciese mucho caso a estas elegaciones, pues reunía maderas y materiales, y en junio de 1625 "escomençó a avrir las çangas e cimientos de la dicha erreria”, zanjas que había excavado sobre un camino público "por donde entravan las carretas de vena, maderas e mas materiales con que totalmente venía a ceçar ese exercio" en la suya, por lo que pedía que se demolieran las obras. Lo mismo decían los vecinos del Franco que veían sus caminos ocupados, pues de poco tiempo "a esta parte se abia echo una erreria junto al dicho coto" que con sus presas, camarado, etc. anegaba los caminos. Incluso denuncian "que las dos ruedas que tiene la dicha erreria tiene por cosa cierta que están en lo público y conçejil". Sin embargo, la sentencia en enero de 1628 dio la razón a Diego García de la Vega, que pudo terminar la ferrería y ponerla en marcha ${ }^{2679}$.

El Catastro de Ensenada menciona en Sueiro, como hemos dicho, dos ferrerías. La de Abajo, de la que hablamos pertenecía ahora por mitad a don Gómez de la Vega, residente en Andalucía, y a don Toribio de la Buelga, vecino del Franco. Trabajaba sólo tres meses por falta de carbón, con una utilidad de 3.700 rs. vn. ${ }^{2680}$. Poco después, en 1783, en el escrito de don Juan Abello Castrillón, vecino de Navia, contra el proyecto de Andrés Bravo dice que en su entorno hay once ferrerías, una de las cuales es la de Suero o Sueiro ${ }^{2681}$, lo que quizá signifique que ya sólo funcionaba una, aunque desconocemos cuál; la otra debió cerrar igualmente poco después porque tampoco la menciona Madoz.

\footnotetext{
2679 A.Ch.V. R. E.: caja: 2489,47 2680 CATASTRO DE ENSENADA. R. G.: El Franco.

${ }^{2681} \mathrm{M}^{\mathrm{a}}$ A. FAYA y L. ANES (2007): Ob. cit., p. 252, nota 249.
} 


\title{
11. MUNICIPIO DE GIJÓN
}

\section{FERRERÍA DE DEVA}

\author{
LUGAR: San Salvador de Deva \\ MUNICIPIO: Gijón \\ RIO: Peña de Francia \\ COORDENADAS: $43^{\circ} 30^{\prime} 18^{\prime \prime}$ N. y $5^{\circ} 35^{\prime} 54^{\prime \prime} \mathrm{W}$.
}

Se encuentra en el lugar de Deva, en la carretera de Gijón a Villaviciosa, a orillas del río llamado Peña de Francia (según el Catastro de Ensenada con agua de una fuente llamada de la Peña de Francia).

Probablemente se trata de una ferrería antigua, del siglo XV o principios de XVI. Creo que con las de Dueñes y Peón fue de Juan García de Jove. Estas dos pasaron al mayor de sus hijos del primer matrimonio con Aldonza Fernández de Lavandera, Gregorio García de Jove; la de Deva quedó en manos de Alonso Ramírez, que tuvo de su segunda mujer Isabel Ramírez de Alas y Miranda, descendiente de la Casa de las Alas de Avilés. La familia Ramírez de Jove consiguió en 1549 del obispo de Oviedo, en el coto de Natahoyo, algunos montes bravos, quizá para abastecer de leña a su herrería 2682 .

Isabel Ramírez de Alas, con licencia real, lograba fundar en 1552 el mayorazgo principal de la casa Ramírez, en el que incluía la ferrería, afectada siempre por problemas con el combustible. Así, en 1570 la justicia y regimiento de Gijón se quejaba ante el corregidor del Principado porque tres casas nobles del concejo, entre ellas los Ramírez de Jove, querían usurpar algunos montes en su propio beneficio. Hubo sentencia favorable en 1572 para los Ramírez de Jove y, posteriormente, en 1574, la chancillería de Valladolid reconoce a éstos la propiedad; pero amparando al concejo en el uso de cortar leña, pacer sus ganados, etc. La compra de tierras y los matrimonios serían una estrategia muy usada para aumentar el patrimonio y prestigiar la casa,

2682 IBIDEM, p. 191. 
La ferrería, en poder de dicho Alonso Ramírez, fue cedida por éste en 1588 como dote de su hija María Ramírez o María de Alas, como también se la conoce, al casarse con Fabián de Jove, nieto de Gregorio García de Jove, para que la pudieran gozar durante dos años ${ }^{2683}$. Parece que las relaciones entre ambas familias eran buenas, pues en el testamento de Gregorio de Jove "El Joven", que fue alférez mayor de la villa de Gijón, realizado el 5 de junio de 1599, manda que se devuelva a Alonso Ramírez los barquines y tobera que le prestó de su ferrería de Dueñas ${ }^{2684}$, lo que significa que mantenían estrechas relaciones, como familiares que eran descendientes de García de Jove "el Viejo".

A su vez María de Alas, viuda de Fabián de Jove, dejó a su hija doña Lucía de Jove, en 1619, como dote en su matrimonio con don Francisco de Llanos Tejera todos los bienes, casas, ferrerías, heredades y molinos pertenecientes al vínculo y mayorazgo de Gregorio García de Jove ${ }^{2685}$, herencia que había sido de su marido. Es decir, que Lucía recogía los bienes de ambas familias y por tanto se unían en una sola mano las ferrerías de Dueñes, Peón y Deva, aquellas vinculadas al mayorazgo creado por Gregorio García de Jove "el Viejo". Sin

2683 M. DE ABOL-BRASÓN (2011): Documentos escogidos de la Casa de Jovellanos en el Archivo de Mohias. Gijón, p. 89: "Constituyó de dote a la dicha Doña Maria su hija para según dicho es se casase por palabras de presente que agan verdadero matrimonio con el dicho Favian de Jove y mas y allende de lo susodicho que pueda llebar y lleve libremente la su herrería que tiene en la herrería de Deba según esta moliente y corriente con su presa y todo lo de mas a ella anexo y pertenesziente con mas la casa horrio questa junto a la dicha herrería según es del dicho Alonso Rramyrez para que lo pueda llebar y goçar durante dos años uno en pos de otro quescomyençan ha correr desde el dia de Santiago que primero biene del año de ochenta y nuebe hasta conplir y acabar los dichos dos años y despues de hacabados le dexara la dicha herrería al dicho Alonso Rramyrez según es suya y si por el dia de Santiago el dicho Alonso Ramyrez u otra persona en su nonbre tubiere algunos materiales bena y carbón rreguado o por rreguar quel dicho Fabian de Jove este obligado a lo tomar en preçio por mano de dos honbres nonbrados por las partes y los mas barquineros y toberas palancas tenaças y mas ferramentas y aparejos de herrería y a serbiçio della ansi mismo sea bisto por los dichos honbres buenos por ellos nonbrados para que la dimynuyçion acrecentamiento según costunbre de herrerías sean obligados a se lo pagar el uno al otro y el otro al otro ansi en lo que toca a la bena y carbón como en lo demas y se entiende que la bena y carbón se a de pagar luego que se apreçie y como mas se a de ver turante los dichos dos años y si el dicho Fabian de Jobe acabados los dichos dos años le sobraren bena y carbón por la misma orden el dicho Alonso Rramyrez se lo aya de pagar e pague por la orden arriba dicha y el dicho Fabian de Jove açeto y se contento con lo susodicho e todas partes por lo que les toca y atañe y atañer puede obligaron sus personas y vienes y dieron poder a las justicias del Rrey nuestro señor".

2684 M. DE ABOL-BRASÓN (2011): Ob. cit.: "Yten digo que el señor Alonso Rramirez me hizo merced de me prestar los barquines y tovera de su ferrería mando se le vuelva todo y si no se le pague lo que dijere el barquinero balian".

2685 IBIDEM, p. 98: "todos los bienes cassas ferrerías montes castañedos prados heredades $y$ caserias molinos duendo y bravo con todo lo a ello anejo y perteneciente contenido en el dicho binculo de mayorazgo del dicho Gregorio de Jove mayorazgo según y como en ellas suçedio la dicha Doña Luçia a entregarle el dia que se dixere missa de bendición con todos los abonos y mejoramientos que en ello hizo la dicha Doña Maria". 
embargo, unas y otras ferrerías pertenecían a vínculos diferentes y probablemente así siguieron estando durante el siglo XVII, aunque desconocemos si realmente esta de Deva estuvo funcionando todo el tiempo. Sabemos, eso sí, que hubo muchos pleitos y sentencias hasta bien entrado el siglo XVIII por problemas con los vecinos por el uso del monte 2686 .

En 1708 el rey Felipe V concedía a Carlos Miguel Ramírez de Jove el título de marqués de San Esteban del Mar2687. Éste mantuvo un nuevo pleito en 1725 con los concejos de Gijón y Villaviciosa por hacerse con los montes concejiles, sin duda, para abastecer a su ferrería de Deva. En el juicio se dice que esta casa noble, anteriormente solo tenía derecho al usufructo de los montes como un vecino más, y que debido a las necesidades de su ferrería le consintieron llevar leña y hacer carbón por lo que les pagaba dos reales de vellón al año. Los vecinos se quejan de que "es necesario mucha leña para su abasto... y se llegaron a destruir dichos montes cortando y talando por el pie el dicho marques y sus padres criados y carboneros". También le acusan de que en Deva muchos de sus vecinos emigraron, y que ahora hay herreros y carboneros de Guipúzcoa traídos por el marqués ${ }^{2688}$.

En el curso del juicio, en el año 1725 se dice que el marqués había reedificado la ferrería, por lo que hay que suponer que probablemente en el siglo XVII tuvo dificultades para abastecerse de leña o sencillamente alguna avenida pudo arruinarla. Su reconstrucción fue objeto nuevamente de polémica a causa de su consumo de madera, ya no muy abundante, porque además había otras tres ferrerías en sus cercanías. Un nuevo pleito en 1734 entablado por los vecinos de Peón, en el concejo de Villaviciosa, contra el marqués de San Esteban del Mar por idéntico motivo muestra las dificultades de la ferrería para abastecerse de madera y carbón ${ }^{2689}$. Quizá por eso siguieron los pleitos con el II ${ }^{\circ}$ marqués, Alonso Antonio Ramírez de Jove, el cual gastó unos 22.00o reales

\footnotetext{
${ }^{2686} \mathrm{M}^{\mathrm{a}}$ A. FAYA y L. ANES (2007): Ob. Cit, p. 214 y 223 yss.

2687 Parece que el título fue debido a las valerosas acciones de su tío Francisco Ramírez, muerto en acción de servicio en Milán en 1705.

${ }^{2688} \mathrm{M}^{\mathrm{a}}$ A. FAYA y L. ANES (2007): Ob. cit., p. 248.

2689 IBIDEM, p. 248.
} 
en pleitos sobre la jurisdicción de los montes e invirtió otros 30.00o reales para modernizarla "según el nuevo estilo de Vizcaya"2690.

El Catastro de Ensenada afirma que sólo trabajaba tres meses al año " $a$ causa de no tener agua suficiente a no ser que aya abenidas y crezientes". Es propia del marqués de San Esteban del Mar y se le da de utilidad al año 1750 reales de vellón ${ }^{2691}$, lo que probablemente oculte su verdadera rentabilidad; pues según I. González, esta ferrería proporcionaba a los Ramírez de Jove un $25 \%$ de las rentas vinculadas de la casa ${ }^{2692}$. Al igual que otras cercanas, como la de Dueñes, a finales del siglo XVIII contrataba con ferrones vascos la elaboración del hierro. A principios del siglo XIX se menciona que en Gijón "hay una herrería"2693, que seguramente es ésta. No la cita Madoz, por lo que hay que suponer que debió de dejar de funcionar antes de 1840, si no antes.

ESTADO: Inexistente

2690 AHPOV. P. N.: caja 1913 (año 1848), ff. 117-122. Citado por A. MENÉNDEZ (1992): Elite y poder: la Junta General del Principado de Asturias, 1594-1808. Oviedo, p. 688.

${ }^{2691}$ CATASTRO DE ENSENADA. R. G. Gijón, ff. 52-53

${ }^{2692}$ I. GONZÁLEZ (2004): "Patrimonio rústico del marqués de San Esteban del Mar en el Gijón del siglo XVIII". En F. J. ARANDA (cd.): El mundo rural en la España moderna. Cuenca. Universidad de Castilla-La Mancha, p. 495.

2693 ACADEMIA DE LA HISTORIA: Fondo Martínez Marina: Ms. 9/6034, nº 25 


\section{MUNICIPIO DE IBIAS}

\section{FERRERÍA DE VIONGA}

LUGAR: Folgueira de Avionga, parroquia de San Antolín MUNICIPIO: Ibias

RíO: Avionga

COORDENADAS: $43^{\circ} 4^{\prime} 11^{\prime \prime}$ N. y $6^{\circ} 50^{\prime} 48^{\prime \prime} \mathrm{W}$.

En 1859 Rafael Uría, vecino de Cangas de Tineo, solicitó autorización pata construir "dos forjas a la catalana en un solo local" en el pueblo de Piñeira, y sitio llamado de Vionga, sobre el río Valdebueyes ${ }^{2694}$. Expuesto el proyecto a información pública, la Gaceta de Madrid del 27 de marzo de 1860 autorizaba a aquel, "para que, salvo el derecho de propiedad, y sin perjuicio de tercero, aproveche las aguas del río de Valdebueyes como fuerza motriz de dos forjas a la catalana que intenta establecer en el sitio de Vionga, término de Piñeira, concejo de Ibias, provincia de Oviedo”2695. Poco después, en 1863, ya debía estar construida y en funcionamiento ${ }^{2696}$. De este Rafael Uría, que fue alcalde de Cangas de Narcea, ya hemos hablado como uno de los promotores de la ferrería de Penaseita.

Durante algunos años estuvo parada, probablemente por la falta de combustible; al menos La Estadística Minera de 1873 anuncia que la ferrería de Vionga, en Ibias, después de varios años de paralización, reanuda su trabajo ese año. Lo mismo dice en $1875^{2697}$.

ESTADO: Desconocido

\footnotetext{
2694 BOPA, 2 de septiembre de $1859, \mathrm{n}^{\circ}$ 140, p. 4

${ }^{2695}$ El Faro Nacional. Revista de Jurisprudencia, administración, tribunales, notariado $e$ instrucción pública. Madrid, año X, 3 de abril de 1860.

${ }^{2696}$ LÓPEZ y GRINDA (1998): Ob. cit., p., p. 27

${ }^{2697}$ L. ADARO (1916): Ob. cit., p. 66
} 


\section{MUNICIPIO DE LA NAVA}

\section{FERRERÍA DE LA NAVA}

LUGAR: Fuensanta

MUNICIPIO: La Nava

RÍO: Prada

COORDENADAS: $43^{\circ} 20^{\prime} 34^{\prime \prime}$ N. y $5^{\circ} 29^{\prime} 31^{\prime \prime} \mathrm{W}$.

Un manuscrito de la Academia de la Historia de los primeros años del siglo XIX, hablando de La Nava, dice que su valle lo atraviesa un río que toma el nombre de Prada; río que "al sur de la casa de la Ferrería recibe las aguas de la fuente de la Bobia para dos molinos y un batán que existen en el sitio de la antigua ferrería de los condes de Nava, y de una fábrica que hubo de buenas armas blancas, de que no queda vestigio" ${ }^{2698}$. Parece una ferrería antigua pero ignoro otros datos.

El lugar donde estuvo ubicada se encuentra en el municipio de La Nava, en el sitio de Fuensanta. Hay aquí un balneario de aguas famosas. Un camino conduce desde el balneario a la casa llamada La Ferrería. Se conserva una torre medieval a la que se añadieron en los siglos XVI y XVII otras edificaciones. El nombre que se le da al edificio -La Ferrería- creo que es indicio de que hubo aquí una ferrería, como he dicho, probablemente medieval o de los primeros siglos de la edad moderna. Perteneció a la familia de los Álvarez de las Asturias, luego a los condes de Nava.

El catastro de Ensenada no cita en La Nava ni ferrería ni mazo alguno, sólo que en ese lugar hay "diez maestros de herrería", probablemente herreros 2699 ; pero es significativa esa cantidad en un lugar tan pequeño. En el testamento de Francisco de Jovellanos, del año 1766, habla de que a su hija Catalina de Jovellanos y Ramírez de Jove casada con don José Alonso de Faes, vecino de La Nava, se le consigna de dote "dos mil ducados por consignación de mil y quinientos reales en cada un año de que por fin de el presente con algunas 
partidas de fierro que de mi horden cobró su marido, y tres años de el veneficio de la Nava que también precibió tiene rezibido algunos reales más de quinientos ducados" ${ }^{2700}$. El beneficio de La Nava podría ser de tierras y no de la ferrería, pero las partidas de hierro y el que haya diez herreros en ese lugar podría ser un indicio de que, si no una ferrería había un mazo, propio de José Alonso de Faes. Al fin y al cabo, la familia Jovellanos estaba muy ligada al negocio del hierro.

ESTADO: Inexistente

\section{MUNICIPIO DE PENAMELLERA}

\section{FERRERÍA DE PEÑAMELLERA}

LUGAR: Rales y Purón

MUNICIPIO: Penamellera

RÍO: Purón

COORDENADAS: $43^{\circ} 23^{\prime} 8^{\prime \prime}$ N. y $4^{\circ} 41^{\prime} 30^{\prime \prime} \mathrm{W}$.

Peñamellera es un municipio del oriente de Asturias, en el partido judicial de Llanes, integrado por numerosos lugares, que surcan los ríos Tielbe o Deva y su afluente el Cares. Entre estos lugares, Rales se encuentra cerca de Panes y Purón, al lado del pueblo del Mazo. Asiento probablemente de la ferrería de Penamellera.

En Penamellera había a comienzos del siglo XVI unas ferrerías²701. El 8 de julio de 1517 , la reina Juana emite una orden al juez de residencia de San Vicente de la Barquera para que consienta al comendador Diego de Rávago aprovecharse de las herrerías de Peñamellera (Asturias), que le pertenecen, y no le pongan impedimento en los caminos que a ellas conducen. Dicho comendador dice que las ferrerías de Penamellera eran herencia de sus difuntos

${ }^{2700}$ M. DE ABOL-BRASÓN (2011): Ob. Cit, p. 183

${ }^{2701}$ Las ferrerías de la zona reactivaron su producción como consecuencia de las guerras con Francis. En AGS.RGS., 1505. Cit. por C. CEBALLOS (2001): Arozas y ferrones. Las ferrerías de Cantabria en el Antiguo Régimen. Santander, p. 23 y 311. 
padres, Gutierre Rávago y Sancha de Turana: "y le son devidas algunas Rentas e tributos e perchas e derechos e ynfurçiones (...) estando en costumbre e posesyon e lo lleven e gozen (...) que le dexen libremente los heredamientos y caminos y cañadas" ${ }^{2702}$.

Carlos V concedió a Juan González de la Vega, hijo de Francisco de la Vega, propietario de la ferrería cántabra de Ibio, en 1554 el privilegio de cobrar la alcabala, diezmo viejo y "cinquisueldo", además de otros derechos pertenecientes a la Corona, sobre el hierro, coaya, acero y metales que se labrasen en las ferrerías de Rales, Ibio, Mazcuerras, Rucha, Quijano, de la Vega, Rábago, Purón y Movellán"; varias de las cuales son estas de Penamellera, que todavía lo pagaban en $1587^{2703}$. Desde ese siglo no se vuelven a citar, ni por supuesto en el Catastro de Ensenada ni en Madoz. Hay que suponer que debieron dejar de funcionar en el siglo XVII.

ESTADO: Inexistente.

\section{MUNICIPIO DE POLA DE LENA}

\section{FERRERÍA DE RENUEVA}

LUGAR: Renueva, feligresía de San Juan Malvedo MUNICIPIO: Pola de Lena

RÍO: Pajares

COORDENADAS: $43^{\circ} 5^{\prime} 27^{\prime \prime}$ N. y $5^{\circ} 47^{\prime} 19^{\prime \prime}$ W.

En mayo de 1857 don José Lombardero, vecino de Taramundi, solicitó una real licencia para aprovechar las aguas del río Pajares, "tomándolas junto a las peñas de Padrones, en un prado que actualmente posee María Antonia Fanjul”, vecina de Erías (Lena) para "establecer una fábrica de beneficio de hierro dulce con forjas catalanas y martinete en el término de Renueva, sobre el río Pajares, en dicha parroquia de Erías" ${ }^{2704}$. Después de la exposición pública del proyecto,

\footnotetext{
2702 AGS. RGS. 1517

2703 AGS. Expedientes de Hacienda, leg. 420 (1587).

2704 BOPA, 13 de mayo de $1857, n^{\circ} 76$, p. 2-3
} 
como exigían las leyes, la ferrería parece que se construyó en el curso del año siguiente. Además de José María Lombardero, anterior propietario de la ferrería de Pontigón, formaba compañía con él Pedro Cotarelo, vecino de la Vega de Ribadeo. Según el primero, "dio la desgracia de que al año siguiente de concluirse fueron dadas de baja esta clase de fábricas que antes eran conocidas por de mayor producto", por lo que su vida fue efímera ${ }^{2705}$.

La Revista Minera habla de una ferrería denominada de Renueva, en el concejo de Lena, que en 1866 estaba parada ${ }^{2706}$; pero según Adaro todavía funcionaba en 1878, pues la Estadística Minera afirma que en ese año "se encendió, en la ferrería de Renueva, un horno del sistema Thourangin, al carbón vegetal, después de cuatro años de paralización”2707. Quizá la antigua ferrería se modernizó con un horno Thourangin.

ESTADO: Desconocido

\section{MUNICIPIO DE PONGA}

\section{FERRERÍA DE SOTO RODRIGO}

LUGAR: San Juan de Beleño

MUNICIPIO: Ponga

RÍO: Ponga

COORDENADAS: $43^{\circ} 10^{\prime} 49^{\prime \prime}$ N. y $5^{\circ} 10^{\prime} 41^{\prime \prime} \mathrm{W}$.

La ferrería se halla en el pueblo de San Juan de Beleño, siguiendo la AS261 en dirección a Cadenaba. A un kilómetro hay que tomar un camino que baja al río Ponga, afluente del Sella.

La existencia de una importante masa forestal en el concejo de Ponga (unas 10.000 hectáreas de bosque comunal), agua y una cercanía relativa a la costa para importar mineral de hierro de Somorrostro, explican el interés de

\footnotetext{
${ }^{2705}$ Libro de Hesta Casa de Ferreirela. Cit. En P. QUINTANA (2005): Ob. Cit., t. I, p. 134. 2706 REVISTA MINERA, t. XIX, 1868, p. 82

2707 l. ADARO (1916): Ob. cit., p. 66 y 63
} 
Vicente Ignacio Argüelles, regidor perpetuo del concejo de Piloña ${ }^{2708}$, en solicitar en 1776 un permiso para construir una ferrería en los términos de Soto Rodrigo, en el que ya poseía dos molinos (por tanto, permiso para el uso del agua del río Ponga) y algunos montes colindantes de su propiedad. El permiso, que solicita tanto ante la justicia de San Juan de Beleño como ante el Consejo de Estado lo justifica en el beneficio que aquella tendría para los vecinos y la comarca, tanto por el trabajo directo en la fábrica como indirecto por el carboneo y la trajinería; en la abundancia de bosque cuyo uso, dada la distancia al mar, no proporcionaba a los naturales ninguna utilidad ${ }^{2709}$.

Tanto el Consejo de Estado como los vecinos de San Juan de Beleño le concedieron el permiso en ese mismo año ${ }^{2710}$, por lo que en los meses siguientes se inició la construcción de la ferrería, que estaba prácticamente terminada al año siguiente. Aunque no existen datos seguros, la presencia en la zona de numerosos apellidos vascos (Yarzábal, Amilleta, Eguía, Arresegor, Azuriaga, Michelena, Berasategui) habría que relacionar con la construcción, así como con los oficiales ferrones; igualmente es posible que los maestros carboneros fueran de aquella región, como ocurrió en el siglo XIX. El artefacto parece que trabajó desde ese año hasta la guerra de la Independencia, concretamente hasta 1812, luego permaneció cerrada durante 18 años, quizá por las dificultades económicas del momento. Aunque en principio se pensó utilizar mineral de Buferrera o el alguna mina cercana, en realidad se importaba del País Vasco.

En 1831 comienza una segunda fase que se alargaría hasta 1898, aunque con diferentes vicisitudes, porque hubo momentos en los que estuvo parada. El hijo del fundador, José Argüelles Campomanes firmó en diciembre de ese año con el vizcaíno Pedro López de Llanos, natural de Trucíos, un contrato de arriendo por nueve años y 3.640 reales de renta al año. En el arriendo se incluía, como era natural en este tipo de artefactos, otros bienes (prados, los dos

2708 Vicente Ignacio Argüelles se casó en 1767 con doña María Luisa de Campomanes y Valdés, dueña de la Casa de la Barrena.

${ }^{2709}$ La mayor parte de los datos sobre esta ferrería se encuentran en A. MATO (2010): La sociedad rural en el concejo de Ponga (1750-1930): labradores, pastores, madereros y arrieros. Oviedo. En las páginas 103-130, el autor hace un amplio estudio sobre la ferrería, el carboneo y la venta del hierro.

${ }^{2710}$ AHN. Consejo de Castilla: Consejos, 27197, exp. 4, y AHA: Fondo histórico de la Diputación, caja 2914. 
molinos, panera, casas, etc.) y el uso de los montes para abastecerla de carbón. El arrendatario se comprometía a la reedificación del edificio, lo que significa que por entonces estaba en mal estado, especialmente los árboles mayor y menor, la barquinera, etc.; cuyo coste de 18.000 reales se debería descontar de la renta anual, en la cantidad de 2.000 reales, por lo que la renta efectiva era de tan solo 1640 reales.

Un informe elaborado por miembros de la sociedad Económica de Amigos del País de Asturias de 1833 menciona que: "En la parte oriental del Principado en el concejo de Ponga hay una herrería" 2711. También Madoz al hablar de la feligresía de San Juan de Beleño se refiere a la "casa y ferrería de Soto-Rodrigo situada sobre el río Ponga"2712. El contrato con López de Llanos, que terminó en 1840, no le sería renovado al pretender el arrendatario construir en 1835 una nueva ferrería en La Ceneya, enfrentándolo al propietario de la de Soto Rodrigo, que pensaba que no habría combustible para ambas. Por otros nueve años, se la arrendó a Eustaquio de Santa Cruz y, al terminar este, por cinco más, al guipuzcoano Joaquín de Arsuaga. Por esos años conocemos contratos de compraventa de hierro de Soto Rodrigo por herreros de Sahagún y otros pueblos de León. En la exposición de 1850 se expuso una barra de hierro dulce "en extremo dúctil y de fácil elaboración”, de la ferrería de Sotorodrigo (Ponga), que pertenece a don José Arsuaga ${ }^{2713}$. Según este, la ferrería dejaba en la zona más de 90.000 reales anuales "en jornales que ordinariamente se ganan y en la elaboración de carbones ya en su conducción y en la de la vena".

Poco después, como consecuencia de la muerte de su propietario en 1848 , sus herederos la pusieron en venta, junto con el resto de propiedades en Ponga, como recoge un anuncio en el Boletín Oficial de la Provincia de Oviedo de 13 de marzo de 1848. La ferrería, dice el anuncio, que se haya trabajando "y está en buen estado; tiene un horno a la vizcaína y el correspondiente mazo y toda la herramienta necesaria; dos carboneras muy capaces, agua abundante y se surte

\footnotetext{
${ }^{2711}$ Cf. J. LÓPEZ y A. GRAÑA (1998): Ob. cit., p. 143

2712 P. MADOZ (1985): Ob. Cit. p. 76

2713 J. CAVEDA (1851): Memoria presentada por el Excmo. Señor Ministro de Comercio, Instrucción y Obras Públicas por la Junta clasifiacadora de los productos de la industria española reunidos en la Exposición Pública der 1850. Madrid, p. 193; también en J. ORIOL RONQUILLO (1855): Ob. cit., t. III, p. 167
} 
de carbones a precios muy ajustados". El conjunto de todos estos bienes se valora en 101.940 reales, pero añade que puede venderse sólo la ferrería, hórreo y molino y el terreno que tiene al lado para su servicio. También venden el carbón y la vena que hay en ella y en el puerto de Rivadesella y con las contratas de carbón para el año próximo, se las cederán al precio que tienen y con todo ello la ferrería puede seguir trabajando ${ }^{2714}$.

Ignoramos quien adquirió estos bienes o si solo se adquirió la ferrería, cosa más probable. Poco después, en 1851, se menciona como dueño a don Joaquín de Arsuaga ${ }^{2715}$, un vasco probablemente ligado a este mundo del hierro; aunque quizá sólo fuera su arrendatario. Lo cierto es que el 20 de abril de 1855 se vuelve a anunciar la venta la ferrería, que según el anuncio estaba en buen estado y producía 1.500 quintales machos de hierro al año ${ }^{2716}$. La adquirió en el mes de junio, José Pérez San Julián, un vecino de la Vega de Ribadeo, en 60.00o reales. Este trajo oficiales y trabajadores del occidente de Asturias, excepto a los administradores Miguel de Diego y Juan Fernández, ambos del lugar de Abiegos, en Ponga. Aunque al parecer trabajó hasta 1898, no debió de hacerlo todos los años, pues la Revista Minera, que la cita con el nombre de "Beloño en el Ponga" ${ }^{2717}$ señala en 1866 que estaba parada; pero sabemos, por recibos de venta de hierro para fraguas de León y de la propia zona de Ponga, que aún fabricaba hierro en 1877. Según Ángel Mato trabajó hasta $1898^{2718}$.

ESTADO: Se conservan restos del canal de agua de casi 900 metros y el camarado o banzado, así como algunas estructuras perimetrales de la propia fábrica, que se organiza en paralelo al camarado. Estos muros, de medio metro

${ }^{2714}$ BOPA, 13 de marzo de 1848, $\mathrm{n}^{0}$ 31, p. 4. Además de la ferrería se vende un hórreo de seis pies , un molino harinero, y la casería nombrada también de Soto Rodrigo, compuesta de casa y establo, un hórreo, una heredad de labrantío y un prado con árboles, todo de cabida de 53 días de bueyes, de mil ciento cincuenta y dos varas cuadras cada uno; además de otra pequeña heredad y un castañedo encima.

2715 BOPA, 28 de febrero de 1851, no 25, p. 3. Se trata de una información de los expositores que acuden a la fería celebrada en Madrid en noviembre de 1850: "Ejemplar de hierro dulce de la herrería de Soto Rodrigo (...) por su dueño don Joaquín de Arsuaga”.

${ }^{2716}$ BOPA: 20 de abril de $1855, \mathrm{n}^{\circ} 48, \mathrm{p}$. 4. "A voluntad de sus dueños se saca á pública subasta la Herrería de Sotorrodrigo, términos de San Juan de Beleño, capital del concejo de Ponga, provincia de Oviedo. La espresada fábrica está completa, bien habilitada y en ejercicio actualmente; tiene fuerza de agua hasta fines de junio, puede tomar cuanto carbón necesite al precio de cuatro y medio a cinco reales de vellón, y se elaboran en ella mil quinientos quintales machos de hierro".

2717 REVISTA MINERA, t. XIX, 1868, p. 82

${ }^{2718}$ A. MATO (2010): Ob. cit., p. 110. 
de espesor y en algún tramo con varios metros de altura, permiten reconstruir lo que fue esta ferrería: una primera zona, en la que se encontraban las salas del mazo y los barquines, con 73,5 y 58,1 $\mathrm{m}^{2}$ respectivamente, y a continuación, una detrás de otra, dos carboneras, de 175 y $87,7 \mathrm{~m}^{2}$ cada una, construidas en momentos diferentes.

\section{MUNICIPIO DE SANTALLA DE OSCOS}

\section{FERRERÍA DE FERREIRELA}

LUGAR: Santa Eulalia (Santalla) de Oscos

MUNICIPIO: Santa Eulalia (Santalla) de Oscos

RÍO: Santalla o Agueira

COORDENADAS: $43^{\circ} 14^{\prime} 46^{\prime \prime}$ N. y $7^{\circ}$ o $^{\prime} 41^{\prime} \mathrm{W}$.

Ferreirela, patria de Antonio Raimundo Ibáñez, marqués de Sargadelos, había en el siglo XVIII una ferrería ${ }^{2719}$, que no se cita en el Catastro de Ensenada. Según un texto de la Academia de la Historia en Santa Eulalia de Oscos, hacia 1800 sólo había "cuatro mazos de tirar hierro"2720. Por su parte, Madoz señala que en ese ayuntamiento "hay bastantes martinetes y herrerías", pero sin especificar en qué lugar del mismo. Adaro sí menciona una ferrería con el nombre de Ferreirela en Santa Eulalia de Oscos ${ }^{2721}$. En un escrito de Domingo Vázquez Villaamil de 1860 se cita igualmente la ferrería de Santalla de Oscos, que probablemente terminó siendo un simple mazo, quizá el que se conoce como Mazonovo, que aún se conserva.

Es posible que ésta fuera una de las que restauró o construyó de nuevo don Manuel Arango, que en 1829 adquirió en este concejo, en el lugar de Saceda, varias porciones de monte que los vecinos le venden, pues apoyan "su proyecto y ver aumentada la población, la industria y los brazos útiles al Estado”. Ese

\footnotetext{
2719 P. SAAVEDRA: Economía, política y sociedad en Galicia: La provincia de Mondoñedo, 1480-1830, p. 334.

${ }^{2720}$ ACADEMIA DE LA HISTORIA: Fondo Martínez Marina: Ms. 9/6034, nº 28

${ }^{2721}$ L. ADARO (1916): Ob. cit., p. 65
} 
proyecto consistía en erigir allí una población "que puede ser útil al público tanto por el acomodo de familias que proporciona como por el impulso que da a la industria y aprovechamiento de unos montes nulos y de ninguna utilidad hasta el día".

La idea era construir algunas ferrerías y martinetes para los que necesitaba montes para leña y carbón. Los montes bravos que adquiere en esta compra son los de la Folgairosa " $y$ toda la parte de la derecha del río que desciende de los montes de la Candeosa hasta confinar en los términos de los lugares de Nonide y Branabella" ${ }^{2722}$. Es cierto también que un año antes, este Manuel Arango había arrendado y restaurado la ferrería de Bullimeiro, y que estos bosques los podía haber adquirido para abastecerla, pero no lo creo.

ESTADO: Creo que sus restos corresponden a la llamada "Ferrería de Arriba", por oposición a la "Ferrería de Abajo", de la que hablaremos a continuación, que debían de estar muy cerca una de la otra.

\section{FERRERÍA DEL PONTIGÓN}

LUGAR: Pontigón, parroquia de Santalla de Oscos MUNICIPIO: Santalla de Oscos

RÍO: Santalla o Agüeira

COORDENADAS: $43^{\circ} 14^{\prime} 52^{\prime \prime}$ N. y $7^{\circ}$ o' $51^{\prime \prime} \mathrm{W}$.

Se encuentra a un kilómetro de Santalla de Oscos, en el límite de Asturias con Lugo, en la carretera de Santalla a Fonsagrada a orillas del río Santalla, curso alto del Agüeira, afluente del Navia. El Agüeira nace en la sierra de la Garganta junto al lugar de Peñacova y toma este nombre porque en el país llaman Augüeira a las zonas ribereñas fértiles por donde pasa2723. El lugar se conoce actualmente como "A Ferreiría de Abajo".

2722 AHPLU: 2071/10.

2723 P. MADOZ (1985): Ob. cit. p. 27. Algunos autores la sitúan en el río Santalla, nombre que también recibe el Agüeira en su curso bajo. 
Parece que la construyeron, probablemente sobre un antiguo mazo ${ }^{2724}$, hacia 1839-1840 Manuel Díaz Lombán, vecino del caserío de Pontigón²725, que anteriormente había sido administrador de la ferrería de Froseira; y su cuñado José Lombadero, vecino de Ferreirela. De Manuel Lombán dice un documento de 1843 que es "dueño y vecino de la ferrería de Santalla de Oscos", lo que significa que por esa época ya estaba construida y probablemente en funcionamiento, pues en dicho documento Antonio Prieto se obliga a pagar una deuda en "dinero y fierro" a favor de aquél, que saldaría "en dinero o carbón que hará de cachopos y raíces de castaño en el sitio de Sangunedo", y que entregaría en la ferrería a cambio de 32 cuartos por cada carga "de buen carbón", colocado en su carbonera "por la medida que tiene este ferrero" que es de "veinte y seis medidas por la del grano de Villanueva cada carga"

A mediados de siglo Madoz señala que las aguas del río Agüeira "hacen mover dos martinetes, una herrería y doce molinos"2727. La herrería, sin duda, es la de Pontigón, en manos de la sociedad de los mencionados cuñados, que se mantuvo hasta 1855 en que se disolvió, quedando la ferrería en manos de Manuel Díaz Lombán, el cual adquiría la parte de José Lombardero en 16.000 reales ${ }^{2728}$; probablemente porque poco después José Lombardero construía con Pedro Cotarelo la ferrería de Renueva en Pola de Lena ${ }^{2729}$. La ferrería continuó activa hasta mediados de la década siguiente. La Revista Minera escribe en 1866 que ya estaba parada 2730 .

\footnotetext{
2724 En un pleito de 1845 sobre la construcción del mazo en Os Penedois, se dice: “...para dar movimiento antes a un mazo y a un molino harinero y ahora al mismo molino y a una herrería que ha hecho del mazo en el mencionado sitio del Pontigón”. Cit. En P. QUINTANA (2005): Ob. cit., t. II, p. 211, nota 82

2725 CANELLA Y SECADES (1900): Asturias , t. III, Los Oscos, p. 366.

${ }^{2726}$ A.H.A. Fondos del juzgado de Grandas de Salime: caja 12709-7, año 1843. Cit. en P. QUINTANA (2005): Ob. cit., t. I, p. 72

2727 P. MADOZ (1985): Ob. cit. p. 27

${ }_{2728}$ P. QUINTANA (2005): Ob. cit., t. II, p. 206, nota 70

2729 IBIDEM, p. 206, nota 72

2730 REVISTA MINERA. t. XIX, 1868, p. 82.
} 


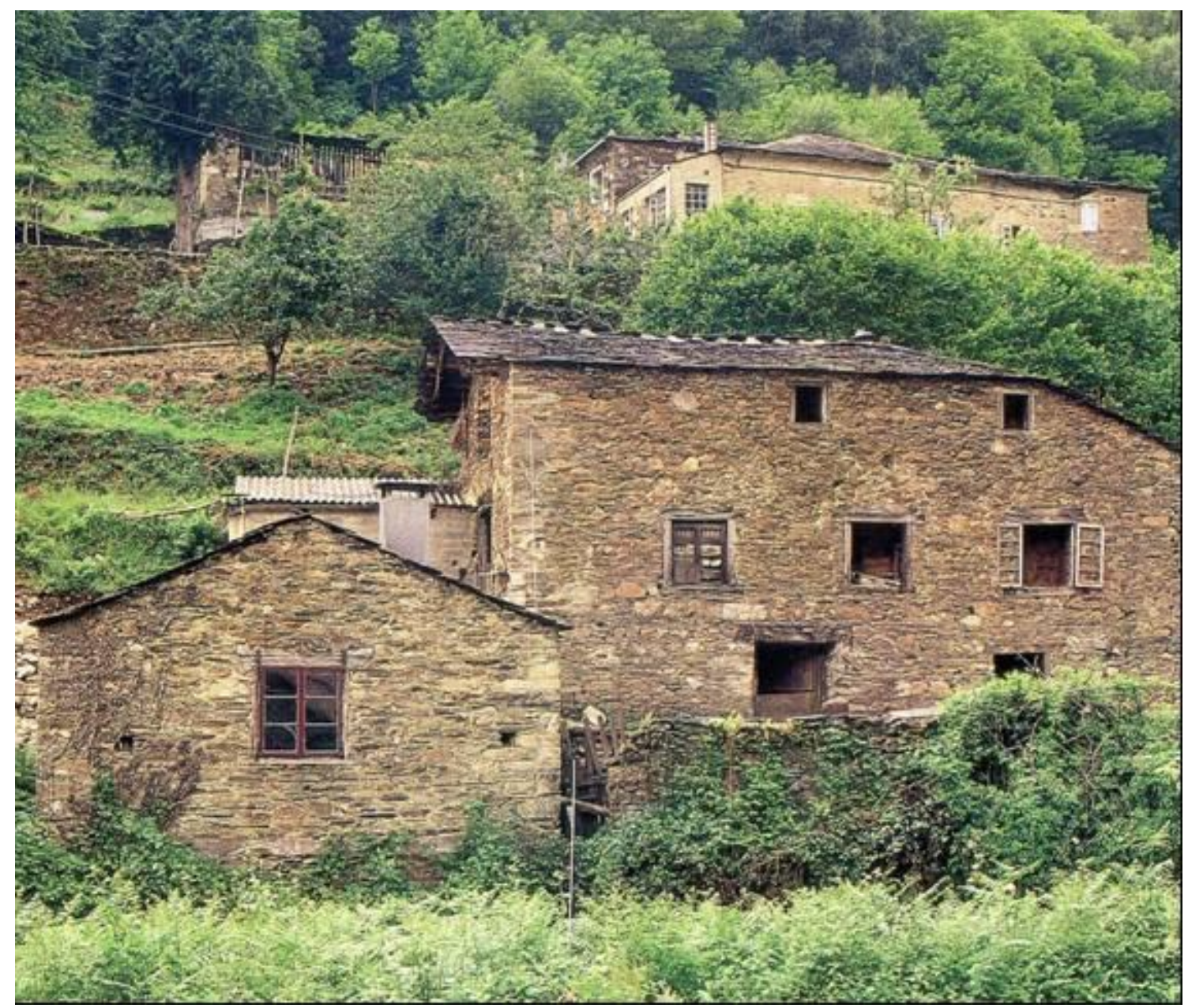

Ferrería de Pontigón

ESTADO: Se conservan aún dos espacios denominados "A Ferrería de Riba”, con la vivienda de los propietarios, corresponde a la de Ferreirela, y "A Ferrería de Baxo", a la de Pontigón, de la que se conserva parte de infraestructura hidráulica y las antiguas carboneras convertidas en cuadras

\section{MUNICIPIO DE SOMIEDO}

29. FERRERÍA DE POLA DE SOMIEDO

LUGAR: Pola de Somiedo

MUNICIPIO: Pola de Somiedo

RÍO: Caunedo

COORDENADAS: $43^{\circ} 5^{\prime} 5^{\prime \prime}$ N. y $6^{\circ} 15^{\prime} 29^{\prime}$ W. 
Se encontraba a menos de un kilómetro de Pola de Somiedo, en dirección norte, a orillas del río Caunedo poco antes de unirse al Saliencia, afluente del Pigueña.

La ferrería se construyó en 1805 para aprovechar el mineral de hierro de las minas de Capmayor, en la parroquia de Saliencia, en el mismo concejo de Somiedo; hierro cuya calidad se había previamente ensayado en otras ferrerías con muy buenos resultados2731: "A la distancia de mil varas N. de la Pola de Somiedo y en la ribera derecha del río que dibide a este pequeño pueblo en dos partes iguales, acaba de construir una magnífica y aun lujosa ferrería, la mexor de Asturias, y primera que probeerá al país de hierro tirado de superior calidad" ${ }^{2732}$. La zona ofrecía unas condiciones excelentes para un artefacto de esa naturaleza, especialmente por la abundacia de aguas: "Tiene esta ferrería abundancia de aguas y con la suficiente a dar potencia necesaria a las máquinas soplantes y al martinete para obtener producciones duplicadas que otras. No solamente en la temporada de llubias sino también en la abrasada canícula y ocasiones de sequía extraordinaria”2733.

La ferrería la construyó Álvaro Flórez Estrada (1766-1853), político y economista asturiano natural de Pola de Somiedo 2734 ; pero lo cierto es que no parece que llegara a funcionar. La razón pudieran ser los el difícil acceso y los altos costes del transporte, los problemas del combustible ${ }^{2735} \mathrm{o}$ bien que la Guerra de la Independencia paralizó su actividad e incluso pudo ser destruida,

${ }^{2731}$ ACADEMIA DE LA HISTORIA: Fondo Martínez Marina: Ms. 9/6033, ${ }^{\circ}$ 5. 15 de diciembre de 1805: "El mineral de Cacmayor de que va a usar y con que se hicieron en otras ferrerías, pero por quenta de ésta, ensaios y pruebas felices aún para hierros de cañón". Añade que se hicieron ocho cañones con ese mineral presentados a examen y prueba y con buen resultado "en este este año de 1805 ".

2732 ACADEMIA DE LA HISTORIA: Fondo Martínez Marina: Ms. 9/6033

2733 IBIDEM. Cf. G. ANES: Economía y sociedad en la Asturias del Antiguo Régimen, 1988, p. $113-114$.

2734 ACADEMIA DE LA HISTORIA: Fondo Martínez Marina. Ms. 9/6033: "Pertenece la ferrería a un hacendado de la Pola acreedor por esta empresa a todo elogio y reconocimiento".

2735 IBIDEM. Habla el texto de que se necesita para la ferrería un aroza instruido y práctico; pero sobre todo alerta de que "siendo el mineral de Cacmaior propio y peculiar de Saliencia, como los grandes bosques de Somiedo pribatibos de los lugares respectivos, o de otros posehedores posible es que con el tiempo se subsciten pleitos y disturbios capaces de arruinar este establecimiento metalúrgico". El autor del informe habla que deberían evitarse por el bien de todos. 
como afirma Javier Neira, por el incendio provocado por un hijo loco poco antes de esa guerra ${ }^{2736}$.

Flórez Estrada solicitó un nuevo permiso para su reconstrucción en plena guerra, que la Regencia del Reino le concedió el 6 de octubre de 1811 junto con un anticipo de 300.000 reales. Sin embargo, las dificultades de la guerra y de la posguerra debieron imposibilitar esa reconstrucción. En 1820 el rey Fernando VII amplió a 500.00o reales el mencionado anticipo, al tiempo que mandaba que el ministerio de la Guerra adelantara los primeros 300.000 reales, que Flórez Estrada debería devolver en un plazo de cuatro años, con hierro de la propia ferrería que habría de entregar al arma de Artillería ${ }^{2737}$.

Un año después la fábrica aún no funcionaba, como indica un documento del ministerio de la Guerra de 23 de septiembre de 1821: "S. M. ha resuelto que si no existe la fábrica de fierro, como indica el Director General de Artillería, tampoco existirá el fierro elaborado, y que en este concepto debe recogerse el dinero si se hubiese adelantado, pues el presupuesto de Artillería no puede sufrir este desfalco" ${ }^{2738}$. Debió hacerse en los años siguientes, aunque no estamos muy seguros porque un informe de 1833 señalaba que "en Somiedo hay otra (ferrería) a medio construir al estilo inglés, con martinetes y cilindros" ${ }^{2739 ;}$ lo que significa que todavía no estaba terminada. Schulz en 1841 dice que "continúa paralizada la nueva y magnífica herrería de Somiedo, que cuenta con excelente vena propia y bien cercana, y está rodeada de inmensos bosques aunque en país de difícil tránsito".

Quizá nunca llegó a trabajar por la razón expuesta por Schulz, su aislamiento y difícil acceso, lo que implicaba precios poco competitivos, como

${ }^{2736}$ J. NEIRA (2003): "Sesquicentenario de Álvaro Flórez Estrada”. El catoblepas, 22, p. 18 2737 L. ADARO (1916): Ob. cit., p. 56: Real Orden de 3 de noviembre de 1820: "Enterado el Rey N.S. de la solicitud que ha hecho D. Alvaro Flórez Estrada, refiriéndose a la Orden de la Regencia del Reino, expedida por este ministerio del cargo de V.E. en 6 de octubre de 1811 a efecto de que se verificase la anticipación en ella prevenida de 300.000 reales y que ahora amplía a 50o.ooo, para fomento de la Ferrería que hay en Asturias, en el concejo de Somiedo, se ha servido mandar Su Majestad que se lleve a efecto la anticipación de 3oo.ooo reales para fomento de la expresada finería, cargándose al presupuesto de Guerra y reintegrándolo Flórez de Estrada, en cuatro años, con fierro que entregará a la Artillería". Tomado de la Colección de Manuscritos de la Biblioteca del Instituto de Jovellanos. Gijón.

2738 IBIDEM, p. 56

2739 Cfr, J. LÓPEZ y A. GRAÑA (1998): Ob. cit., p. 143 
sostiene Velardo Fuertes ${ }^{2740}$. Madoz no la menciona por lo que hay que suponer que el proyecto, si realmente llegó a materializarse y funcionar, tuvo una corta duración probablemente porque ni el hierro era tan bueno ni se pudo superar el aislamiento. Este autor afirma que el río Caunedo, cuyas aguas movían la ferrería, era "de escaso caudal" ${ }^{741}$, lo que quizá fuese otro motivo para su fracaso. En 1850 cuando la visita el general Elorza la califica como "superior a otras de su clase que vio en países de Europa"2742, lo que no significa que por entonces trabajara, solo que era una ferrería con los adelantos de la época.

ESTADO: Desconocido

\title{
19. MUNICIPIO DE SOTO DEL BARCO
}

\section{FERRERÍA DE LABAYOS}

\author{
LUGAR: Labayos \\ MUNICIPIO: Soto del Barco \\ RÍO: Ferrería \\ COORDENADAS: $43^{\circ} 31^{\prime} 34^{\prime \prime}$ N. y $6^{\circ} 2^{\prime} 6^{\prime \prime} \mathrm{W}$.
}

Muy cerca de San Pedro de la Corrada fluye el río de la Ferrería que baja de la sierra de Candamo para verter sus aguas al Cantábrico por el puerto de Santa María del Mar, en el concejo de Avilés. No he encontrado en los mapas actuales el topónimo de Labayos en las inmediaciones de la Corrada, pero si existe en este lugar el de la Ferrería, vestigio sin duda de esa antigua fábrica.

Sebastián Miñano menciona en San Pedro de la Corrada, que incluye en el concejo de Pravia, un lugar denominado como Ferraría de Labayos, en el que "había antiguamente una ferrería propia de la Casa de las Alas, de Avilés, y más abajo en el mismo río de la Ferrería hubo otra, ambas hoy convertidas en

\footnotetext{
2740 J. VELARDE FUERTES (2011): "La búsqueda de una explicación de la ruptura con América desde la economía". Revista Hispanoamericana, 1, p. 4. ${ }^{2741}$ P. MADOZ (1985): Ob. cit. p. 130

2742 J. OCAMPO, J. (1990): Ob. cit., p. 242
} 
molinos"2743. No es el único que incluye el lugar en ese concejo de Pravia, como ya veremos; pero hoy pertenece al municipio de Soto del Barco.

Miñano habla de dos ferrerías, como también lo hace el Catastro de Ensenada, aunque por entonces ya no existían como tales sino como molinos. Dice el Catastro que en dicho San Pedro de la Corrada, que incluye igualmente Pravia, sobre el arroyo del Faedo (que sin duda es el mismo que el que luego Miñano y los mapas actuales denominan como de la Ferrería) "tiene el marqués de Camposagrado dos molinos: uno de la ferrería de arriba y otro de la ferrería de abajo". En esta de abajo también poseía un pisón²744.

Estos parcos datos no sólo hablan de la existencia de dos ferrerías cercanas, sino de sus propietarios: los Alas y los marqueses de Camposagrado, que fueron sus herederos. El primer marqués de Camposagrado, título concedido por Felipe IV en 1661 a Gutierre Bernaldo de Quirós de las Alas y Carreño, contrata en 1673 a Martín de Alzate, "aroça que fue en la ferrería de la Casa de Trasona", para trabajar en la suya de Labayos, en Pravia, durante un periodo de cuatro años. Este tendrá libertad para contratar al resto de los oficiales y se responsabilizará del transporte de la vena desde el puerto de San Esteban de Pravia, y del carbón desde los montes del propio marqués hasta la ferrería.

Por su parte, el marqués se compromete a traer de Somorrostro la vena necesaria hasta el puerto de San Esteban, así como de contratar a los carboneros para la fábrica de carbón en los montes de los alrededores. Tanto éstos como el aroza, que recibirá 9,5 reales por cada quintal fundido, cobrarán en dinero, hierro y pan2745. Martín de Alzate es sin duda un aroza de origen vasco, que ofrece sus servicios en las ferrerías asturianas.

${ }^{2743}$ S. MIÑANO (1835): Diccionario geográfico-estadístico de España y Portugal. Madrid, t. III, p. 196 2744 CATASTRO DE ENSENADA: R. G.: Pravia

2745 B. BARREIRO (1988). "Agricultura e industria en Asturias en el siglo XVIII". En E. FERNÁNDEZ DE PINEDO y J. L. HERNÁNDEZ (Ed.): La industrialización del norte de España. Barcelona, p. 52. 
Parece, por tanto, que en este concejo hubo dos ferrerías que, sin duda, habría que relacionar con las que a finales del siglo XV levantó Diego Quirós, como se desprende de una Real orden dada en 1494 a Fernando de Vega, contino y corregidor de Asturias, para que informase si tales ferrerías se habían hecho a costa de los vecinos ${ }^{2746}$, lo que nos indica que se habrían construido recientemente. Desconocemos quien era ese Diego Quirós. Años más tarde, en 1557, encontramos a otro Diego de Quirós, vecino de Avilés, que litiga contra su padre Lope de Omaña, vecino de Pravia, sobre la devolución 1.00o ducados, 210.00o maravedís en dinero y el resto en bienes raíces que le pertenecían por herencia de su abuelo Hernando de las Alas, situados en Pravia, Valdés y Oviedo, y sobre los bienes de su madre Francisca de las Alas, los cuales tenía y administraba el demandado 2747 . Como veremos, estos de las Alas, propietarios de la ferrería de Raicedo, probablemente emparentaron con los Quirós propietarios de estas otras de Labayos.

Las ferrerías de Labayos todavía existían en el siglo XVII y pertenecían a la misma familia Quirós de las Alas, marqueses de Camposagrado. El primer marqués de Camposagrado era hijo de Sebastián Bernaldo de Quirós y Miranda quien, en segundas nupcias, se casó con Eulalia de las Alas y Carreño. Esta Eulalia heredó los bienes de Martín de las Alas, que murió sin sucesión. En 1578 una Elvira de Valdés, viuda de Martín de las Alas, vecina de Avilés, pleitea contra Fernando de Arango, escribano del concejo de Pravia, por una escritura de obligación "de quantia de cincuenta ducados que un Juan Ortiz auia otorgado en fauor de su parte (es decir, de la mencionada Elvira) por rraçon de ciertas herrerias que le auia tomado en arrendamiento", pero que aquel no le había querido pagar ni entregar. Primero hubo pleito ante la audiencia de Oviedo y luego en la Chancillería de Valladolid que condenó en 1580 a Fernando de Arango en los cincuenta ducados y las costas del juicio ${ }^{2748}$.

Según esta escritura esta Elvira Valdés era, por tanto, propietaria de unas ferrerías, sin duda en el concejo de Valdés donde se firmó la escritura de obligación, las cuales tenía arrendadas al vasco Juan Ortiz. No sabemos si tales

2746 AGS. RGS.: leg. 149404/534.

2747 R.Ch.V. R. E: caja 900/13

2748 A.CH.V. R. E.: caja 1432, año 1580 
ferrerías eran suyas o de su marido, Martín de las Alas, ya fallecido. Lo cierto es que, posteriormente, las vemos como una propiedad de esta familia. Sin embargo, también podrían ser de Elvira Valdés y que de ésta pasarán a sus herederos, los Alas. De hecho, conocemos una carta ejecutoria de 1499 dictada por la Chancillería de Valladolid en el pleito entre Gonzalo de Argüelles, vecino de Oviedo, con Diego de Valdés y consortes, también de Oviedo, sobre el pago de las reparaciones hechas a unas ferrerías ${ }^{2749}$, que podrían ser éstas.

ESTADO: Inexistente

\section{MUNICIPIO DE TAPIA DE CASARIEGO}

\section{FERRERÍA DE A VEIGUIÑA}

LUGAR: La Veiguiña (Parroquia de Santa María del Monte) MUNICIPIO: Tapia de Casariego

RÍO: Porcia

COORDENADAS: $43^{\circ} 30^{\prime} 5^{\prime \prime}$ N. y $6^{\circ} 59^{\prime} 9^{\prime \prime} \mathrm{W}$.

Se encuentra en el lugar de La Veiguiña, en el concejo de Tapia de Casariego, (antiguamente, según el Catastro de Ensenada, al concejo de Castropol y en la parroquia de Serantes; según Madoz al del Franco), a 12 km. de Tapia, a orillas del río Porcia, también llamado de las Herrerías ${ }^{2750}$. Se accede por las carreteras AS-23 y AS-24, tomando un desvío antes de llegar a la aldea de Alfonsares.

La primera mención conocida de esta ferrería data de 1622, en un inventario de bienes de don Juan Núñez Pardo y doña María Valledor y Presno, probablemente hecho poco después de morir ésta en 1621. Según el inventario, su propiedad estaba dividida en tres partes: una pertenecía a los mencionados Juan Nuñez de Pardo y María Valledor, la cual se valoraba en 4.035 reales y 12 
maravedís ${ }^{2751}$; otra a Pedro Nuñez de la Beguina y a su hermano, y la última tercera parte a Domingo de Valderrendero. De acuerdo con el valor de la primera parte, es de suponer que el total alcanzara los 12.106 reales y 2 maravedís ${ }^{2752}$.

El apellido Valderrendero parece el mismo, aunque modificado, que los de Balderreña y Belderrein, que son apellidos vascos originarios de Aya (Guipúzcoa). Conocemos por un poder de Juan de Bengoechea a su mujer, para cobrar una deuda a los dueños de la ferrería de Dueñes del año 1649, que un tal Antonio de Balderreña era propietario de una ferrería en el concejo de Castropol en 1649, de la que el mencionado vizcaíno era aroza ${ }^{2753}$. También sabemos que un Juan de Balderraín, de la ferrería gallega de Bravos, en 1641, acuerda con el vizcaíno Juan de Montero que le traiga 1.00o quintales de vena a precio de 3,17 reales ${ }^{2754}$. Son todos probablemente miembros de una misma familia vasca relacionada con las ferrerías.

Juan Núñez de Pardo Montenegro, vecino de Castropol, fue un personaje muy interesante, que se dedicó al comercio con Portugal y Sevilla con barcos de su propiedad. Comerciaba con hierro y madera, y traía a Asturias vino, aceite y otras mercancías, como se deduce de las deudas que mantienen con él algunos comerciantes que se relacionan en su inventario de bienes, realizado cuatro años después de su muerte en 1633. Se casó dos veces, la primera con María Valledor Presno, con la que tendría cuatro hijos, dos varones y dos hembras; y en segundas nupcias con María de Cienfuegos de la que nacería Clara Pardo y Cienfuegos.

En su testamento de 1633 instituye, como había acordado con su primera mujer, mayorazgo en la persona de su hijo Pedro; pero muerto este en 1637, sus bienes pasaron al segundo, Mendo Alonso Pardo Montenegro. Sin embargo, la tercera parte de esta ferrería se atribuyó a la herencia de su hija María Pardo. Como ésta no tuvo hijos, esta ferrería y los bienes del mayorazgo, en los que se

${ }^{2751}$ Según un documento de 1637 esta parte se la habían comprado a Pedro Núñez de Presno en 4.037 reales (A.Ch.V. R.E.: caja 2682/2).

2752 J. LÓPEZ y A. GRAÑA (1998): Ob. cit., p. 109

2753 IBIDEM.

2754 IBIDEM. 
incluía una parte de la ferrería de Abres, cuando murió la hija sin descendencia de Mendo Alonso Pardo, Juana Pardo Sierra, pasaron a Antonio Ventura de Aguiar y Pardo, nieto de Ana Pardo, hermana de aquellos, que así reunió a finales del siglo XVII la herencia de sus bisabuelos 2755 .

De los otros herederos, sabemos que un Antonio Pérez de Belderrein se casa en 1639 con doña Antonia de Presno Villamil, por lo que pasaron a ser dueños y señores del coto y jurisdicción de la Veguiña, que pertenecía desde antiguo a la familia de ésta. Por eso ferrería, en sus dos terceras partes, pertenecía a los Belderrein-Presno. Quizá estos compraron a comienzos del siglo XVIII la parte de Antonio Ventura de Aguiar, vecino de Lorenzana; pues el Catastro de Ensenada, poco después, señala que la propiedad de toda ella era de Lorenzo Antonio Belderrein, al que se regulaba un beneficio de 2.600 reales. Al parecer sólo funcionaba tres meses al año "por falta de carbón y agua"2756. A finales de siglo, en 1795, la ferrería seguía en manos de la familia Belderrein de Castropol2757.

A principios del siglo XIX se menciona en la Veguiña “una herrería"2758, que por el matrimonio de doña Francisca Javiera Belderrein en 1805 con don José Lorenzo de Cancio Donlebún pasó a este nuevo apellido. En 1807 Domingo Díaz Rodil se obliga a pagar a don José González Infanzón, del coto de la Veguiña, 2.661 reales "procedentes de fierro que le compró al fiado"2759. Éste González Infanzón probablemente era el arrendatario de la ferrería. En 1832 la gozaba igualmente como arrendatario el capitán Fernando Pérez Villamil, quien después construiría la ferrería de Lagar2760.

En 1852 su propietario era don Ramón Cancio Donlebún, hijo de don José Lorenzo y doña Francisca, quien por esa fecha la arrienda, por cuatro años, a

\footnotetext{
2755 A.Ch.V. R. E.: caja 2682,2

${ }^{2756}$ CATASTRO DE ENSENADA. R. G.: Castropol/la Veguiña: “Ay una herrería propia de dicho D. Lorenzo Velderrein de fabricar fierro sobre el rio de la Veguina en dicho coto, que se compone de lo necesario para su exercicio y su carbonera y vodega y de cinco oficiales, etc.".. 2757 MUSEO NAVAL. Colección Guillén: Ms. 2175. Cfr. J. LOOPEZ y A. GRAÑA (1998): Ob. cit., p. 17-18

${ }^{2758}$ ACADEMIA DE LA HISTORIA: Fondo Martínez Marina. Ms 9/6034, ${ }^{\circ} 1$

2759 AHPLU: 2069/3 (1807, 11 de agosto).

2760 J. LÓPEZ y A. GRAÑA (1998): Ob. cit., p. 95
} 
Domingo Vázquez Villamil, posterior propietario de la ferrería de La Cabanada. Según el inventario hecho para ese arrendamiento, la ferrería contaba con tres ruedas para mover el árbol del mazo mayor, de siete quintales de peso, los barquines y un martinete; había además dos fraguas, una con un barquín de mano, y un molino. Todo ello en buen estado, aunque con las paredes algo deterioradas "pero serbibles sin esperanza de que fallezcan durante los cuatro años" 2761 .

No la menciona Madoz pero en 1860 todavía funcionaba, siendo su arrendatario Domingo Vázquez, pese a las presiones de los dueños de las ferrerías, descontentos con alguien que les hacía la competencia pagando más por el carbón que ellos ${ }^{2762}$. En $1864^{2763}$ y $1866^{2764}$ seguía elaborando hierro. Debió dejar de trabajar poco después.

ESTADO: Se conserva la vivienda en buen estado; de la ferrería hay restos del canal, el banzao y el banzadillo, con los arcos semienterrados por lo que pasaban los árbiles del mazo y barquines.

\section{MUNICIPIO DE TINEO}

\section{FERRERÍA DE ARGANZA}

LUGAR: Arganza

MUNICIPIO: Tineo

RÍO: Arganza

COORDENADAS: $43^{\circ} 15^{\prime} 48^{\prime \prime}$ N. y $6^{\circ} 29^{\prime} 28^{\prime \prime} \mathrm{W}$.

El Arganza es un afluente del Narcea, y Arganza una aldea del ayuntamiento de Tineo. Aquí hubo una ferrería cuya localización exacta desconocemos.

\footnotetext{
${ }^{2761}$ IBIDEM, p. 145-146

2762 IBIDEM, p. 148

2763 M. FUERTES ACEVEDO (1880): Mineralogía asturiana. Oviedo, p. 144

2764 REVISTA MINERA, t. XIX, 1868, p. 82. También en L. ADARO y JUNQUERA (1916): Ob. cit., p. 66
} 
La ferrería de Arganza la construyó a finales del siglo XVI Ares de Omaña, probablemente nieto de Ares de Omaña "El Rubio", a quien en 1585 denuncia el concejo de Tineo por construir dos edificios, una machuquera y una venta en término de Arganza; ya que el machuco o ferrería era muy perjudicial "porque ocupa los caminos publicos y con el continuo fuego que es necesario para la machuquera abrasa las binas y ansimismo no ay necesidad de la dicha hereria por aber tantas...”. La sentencia de la justicia ordinaria de Cangas y Tineo fue revocada en 1586 por la chancillería de Valladolid, que le absuelve y le da permiso para terminar la ferrería y venta que tiene comenzadas.

Ares de Omaña contradice al concejo denunciado que no son los vecinos, que saben de la utilidad y provecho de la misma, sino el odio que le tiene Diego García de Tineo y su hijo Juan, señores de la casa y mayorazgo de Tineo, los cuales quieren "que se pierdan los edificios, que ya suben a mil ducados" 2765 . No está claro si es un mazuco o una ferrería, aunque por el precio bien podría ser esto último. Desconozco otras menciones.

ESTADO: Inexistente

\section{FERRERÍA DE BESULLO}

LUGAR: Besullo

MUNICIPIO: Tineo

RÍO: Pumar

COORDENADAS:

De antiguo hubo en Besullo un mazo que el Catastro de Ensenada menciona como propio de don Pedro del Llano. Ignoro si es el mismo que el que en 1860 dice que tiene en ese lugar el industrial Rafael Uría, alcalde que fue de Cangas de Tineo. En ese año, éste solicita autorización para transformar "en

$2765 \mathrm{M}^{\mathrm{a}}$ A. FAYA y L. ANES (2007): Nobleza y poder en la Asturias del Antiguo Régimen. Madrid, p. 246-247. 
herrería o forja catalana" el martinete que posee en el sitio de los Pontones, sobre un riachuelo de nombre Pumar, en términos del lugar de Besullo ${ }^{2766}$.

Como no afectaba a nadie porque ya contaba con los derechos sobre el agua por la propiedad del mazo, probablemente logró la autorización. No hay que olvidar que la zona contaba entonces con abundantes bosques, por lo que podría abastecerse de carbón sin grandes dificultades. Es más, un mes más tarde, don Rafael solicitaba al juez de Grandas de Salime que le diese la posesión de los bosques comprados en "Baldebueyes, Pradias y Serodosio y Vallina de Abraedo" en el cercano concejo de Ibias, donde también había solicitado la construcción poco antes de la ferrería de Vionga. El juez, sin perjuicio de terceros, accedió a darle dicha posesión ${ }^{2767}$.

Conocemos que este don Rafael Uría prospectó por la zona la existencia de minas de hierro e incluso que registró algunas. Quizá fueron esos minerales los que fundió durante un periodo en la nueva ferrería que, más tarde, se volvió a convertir en el mazo que aún hoy existe.

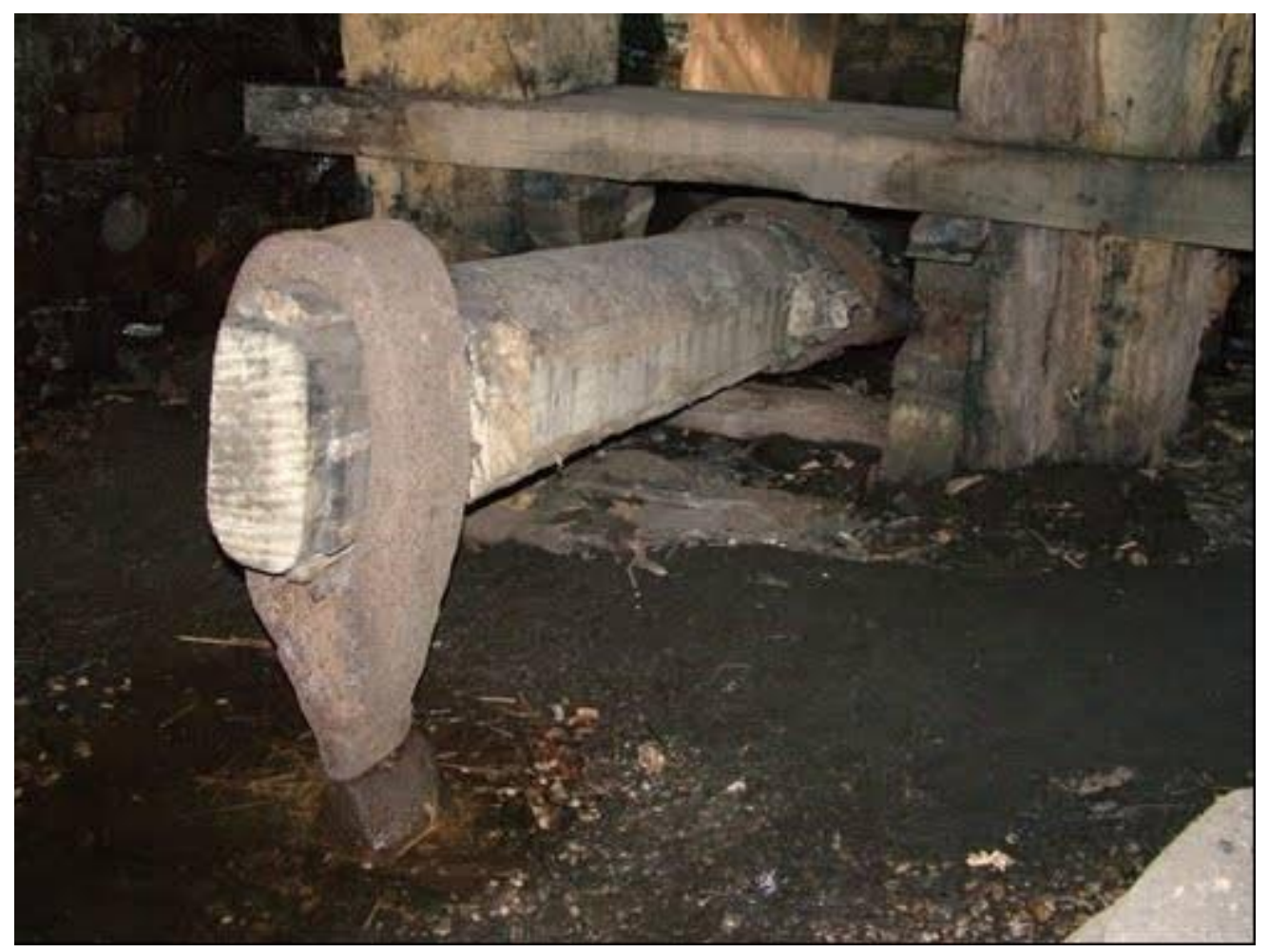

2766 BOPA, 20 de agosto de $1860, \mathrm{n}^{\circ} 131$, p. 2 2767 BOPA, 19 de septiembre de 1860 , p. 2 
También sobre las aguas del riachuelo Pumar, en la misma parroquia del Besullo pero en el lugar de Otriello y en el sitio de Navarín, don Rodrigo de Llano, vecinos de Cangas de Tineo, solicitó en 1859 construir "un martinete de estirar hierro" 2768 . Dado que el machuco de Besullo es llamado de "abaixu”, este quiza se construyó aguas arriba.

ESTADO: El mazo de Besullo, que aún se conserva, fue restaurado a finales del siglo XX.

\section{FERRERÍA DE LA FANOSA}

LUGAR: La Fanosa, feligresía Santiago de Cerredo MUNICIPIO: Tineo

RÍO: Bárcena

COORDENADAS: $43^{\circ} 20^{\prime} 44^{\prime \prime}$ N. y $6^{\circ} 34^{\prime} 11^{\prime}$ W.

En el lugar de La Fanosa, feligresía de Santiago de Cerredo que antiguamente perteneció a la jurisdicción de la Mortera, hoy una aldea de dicha feligresía, se construyó una ferrería en el siglo XVII a orillas del río Bárcena. Se llega desde la carretera de Pola de Allande a Luarca, muy cerca de la Mortera.

La construyó en 1664 don Francisco Antonio Maldonado, señor de la casa de Tineo, quien se concierta el 14 de marzo de ese año con Pedro Fernández de Fontouria, "maestre de carpinturias y herrerías", para "hacer y fabricar una ferrería en dicho sitio (de la Vega de la Fanosa). Dicho Pedro Fernández y sus oficiales la han de hacer "a su costa e mención hasta darla maçeando en lo que toca y perteneciere a la manefatura de carpinteria, maderando toda ella asi el cuerpo de la ferrería como el de la carbonera". Deben terminarla en un año o antes si pudieren.

Por su parte, don Francisco Antonio Maldonado pondrá todos los materiales al pie de la obra así mayores como menores " $y$ el cortar, serrar $y$ 
coxer dichas maderas, y açer la presa y las calçes, reples y estoldas y paredones y cassa de la ferrería y el traer el agua a la boca del camarado asta dar en el yugo y dar ayuda dicho sr. D. Francisco alçar las maderas y correrlas como son cepos, durmientes y los dos árboles y partes mayores $y$ cuatro coçines al dicho Pedro Fernández (...) y para la barquinera y cepotillos menores y los paraxes y poner la ferrería a de asestir el aroça para que sea de su gusto". Igualmente el propietario ha de dar un herrero a su costa para soldar los sellos y otras herramientas necesarias para la herrería. Además de la madera y otros materiales don Francisco pagará por esta obra 380 dineros y una pipa de vino tinto pagado en tres partes: al comienzo de la obra, a la mitad y al finalizarla ${ }^{2769}$.

No funcionaba ya a mediados del siglo XVIII2770, pues según el Catastro de Ensenada sólo había un mazo, llamado de La Fanosa, propio de la casa de Tineo, arrendado a Jerónimo Pérez, José Pérez, Domingo Antonio y Francico Pérez, vecinos del coto de las Morteras, los cuales mancomunadamente pagaban anualmente por él 440 reales ${ }^{2771}$; también Madoz escribe que en la feligresía de Santiago de Cerredo hay "dos mazos para estirar el hierro" pero no ferrería alguna ${ }^{2772}$. Es decir, que la ferrería se había convertido en un mazo.

ESTADO: Desconocido

\section{MUNICIPIO DE VALDÉS}

\footnotetext{
${ }^{2769}$ J. LÓPEZ y A. GRAÑA (1998): Ob. cit., p. 127-128

2770 ACADEMIA DE LA HISTORIA. Fondo Martínez Marina: Ms. 9/6034, $\mathrm{n}^{\circ} 14$.

${ }^{2771}$ CATASTRO DE ENSENADA. R. G.: En Tineo (Villarmilde), coto de las Morteras: “Asi mismo en dicho lugar de La Fanosa hay el artefacto de un mazo, con que se tira y bate el yerro, trabajando con las aguas del río de la Fanosa, el qual es propio de la referida casa de Tineo". 2772 P. MADOZ (1985): Ob. cit., p. 134
} 


\title{
35. FERRERÍA DE BRIEVES
}

\author{
LUGAR. Brieves \\ MUNICIPIO: Valdés \\ RÍO: Llorín o Orio \\ COORDENADAS: $43^{\circ} 29^{\prime} 8^{\prime \prime}$ N. y $6^{\circ} 25^{\prime} 49^{\prime \prime} \mathrm{W}$.
}

Se encuentra en el lugar de Brieves, parroquia de San Miguel de Trevías, a orillas del arroyo Llorín o Orio, que es un afluente del Esva o Canero

Don Jacinto Avella Fuertes, señor de la casa de Llamas (Canero) y regidor perpetuo del concejo de Valdés, solicitó en 1758 permiso para la construcción de una ferrería en el monte de Castro, en Brieves, en la parroquia de Trevías, a unas tres leguas de la villa de Luarca, en terreno propio, alegando que no había otras cercanas y por ello redundaría en bien de los vecinos, que podrían encontrar trabajo en ella y el hierro necesario para sus labores. El hierro se traería por mar desde Vizcaya y el carbón sería producido en sus montes o en otros de particulares que así se beneficiarían de ello.2773.

Don Juan Matías Menéndez y Luarca que poseía a dos leguas la ferrería de Setienes se opuso, porque consideraba que la nueva le haría competencia, bajaría el precio del hierro y subiría el de la madera debido a su escasez. Ambos eran parientes, pues Juan Matías Menéndez estaba casado con doña Juana María Avella Fuertes, pero había entre ellos enemistad y pleitos por cuestión de herencias y bienes. Dicha oposición y la de la justicia y regimiento de Luarca y el gremio de Mareantes a dicha construcción parece que surtió efecto2774.

\footnotetext{
2773 EXPÓSITO, D., ÁLVAREZ, V. y GONZÁLEZ, N. (2010 ): "La ferrería de Brieves: un ejemplo preindustrial de la manufactura del hierro en Asturias". En ÁLVAREZ ARECES, M. A.: Arquitecturas, ingenierías y culturas del agua. Gijón, p. 288-289: "cuias circunstancias se combenze la de no seguirse perjuizio alguno, antes vien mucho provecho al publico, en esta nueva fabrica, en especial porque unicamente en todo terreno inmediato solo se halla en la costa de la mar, y poniente otra herreria, y aun esta a distancia de mas de dos leguas, con tres rios caudalosos que las separan, y sin que a los mas lados de fábrica que pretendo establecer se halle otra alguna, en mas de doce leguas de distancia, lo que hace a los naturales penosa la condicion de el hierro para todas sus obras y las muchas herramientas que necesitan asi labradores como los que ejercen otros oficios".

${ }_{2774} \mathrm{M}^{\mathrm{a}}$ A. FAYA y L. ANES (2007): Ob. Cit., p. 349 y ss.: Hablan de ser perjudicial poner más ferrerías "por ser grande la escasez y carestía de leñas y maderas que esta experimentando especialmente en esta villa y sus cercanías y ser preciso suban a mayor precio con semejante motivo sin benefficio alguno de los vecinos de este concejo por no haver en el falta de yerro teniendo como tiene sobrado surtimiento de este genero con otra herreria que hai y las cinco o
} 
El pleito quedó en suspenso hasta que nuevamente a principios de los años noventa del siglo XVIII don Manuel Melchor Avella Fuertes, hijo de don Jacinto, intentó nuevamente que el Consejo de Castilla le permitiera la construcción de la ferrería. Aduce motivos semejantes a los de su padre, pero igualmente hay una fuerte oposición por don Juan Matías Menéndez, el propietario de la de Setienes, y por el marqués de Ferrera, dueño de la ferrería de Salientes. Uno y otros presentaron testigos a favor y en contra.

El regente de la Audiencia de Oviedo informó al Consejo de Castilla favorablemente, pues consideraba que haría "un beneficio conocido al pais y especialmente a los vecinos de aquellas cercanias que por su pobreza se emplearian en los trabajos de dicha fabrica". El gremio de mareantes y los propietarios de ferrerías alegaban el deterioro de los montes, que por las frecuentes sacas estaban esquilmados; la elevación de los precios del hierro por la lejanía de esta ferrería a la costa con lo que la vena vasca se encarecería con su transporte, e incluso se alega por el regimiento que la presa que habría de construirse en el río dificultaría la saca de madera y la subida de los salmones ${ }^{2775}$.

La ferrería, sin embargo, no se construiría hasta algunos años más tarde. En un documento de 1807 de don Manuel Avella Fuertes, hijo de don Jacinto Avella, declara haber construido la ferrería de Brieves en virtud de real Cédula de 1798, en el prado llamado del Castro, y que poco después, hacia 1803, ya estaba funcionando. Se abastecía de vena de Somorrostro, que desde Luarca se transportaba hasta la ferrería; para el carbón, al parecer por los años en que don jacinto Avella conseguía la real Cédula, adquiría en las parroquias próximas del concejo de Valdés la producción de leña de 34 montes por un periodo de ocho años, es decir preparó la reserva de carbón cinco años antes de que ésta comenzara funcionar, algo así como unas 5.000 cargas, lo que suscitaría

seis que se hallan en este contorno ademas del mucho que concurre por mar desde Vizcaya, cuyo comercio cesara estableciéndose mas herrerias y con el las utilidades y conveniencias que se siguen en el pais por surtirse al mismo tiempo y con este motivo de otros generos que necesita el abasto comun y le son indispensables por no los haver en este concejo".

2775 IBIDEM, p. 249 y ss. 
numerosos pleitos con los concejos, que alegaban no la compra sino la usurpación de sus montes, y con dueños de las ferrerías cercanas.

Parece que en esos primeros años producía unos 300 quintales de hierro al año. Posteriormente, en 1826, una avenida del río Llorín provocó graves daños, hasta el punto de que hay quien cree que fue en esa época cuando dejó de funcionar; pero debió restaurarse, porque en 1838 se anuncia en el BOPA su subasta pública para el día 10 de noviembre de ese año en Luarca, con su "maquinal y siete mil doscientas cargas de carbón almacenado", lo que sugiere que estaba en funcionamiento. La ferrería con el carbón se tasa en 96.648 reales, admitiéndose pujas en la escribanía de don Vicente Merás de Luarca ${ }^{2776}$. Poco después Schulz la cita por su nombre en su "Viaje por Asturias" y según la Revista Minera aún trabajaba en $1866^{2777}$.

ESTADO: Aunque la ferrería fue objeto de intervenciones y posteriores usos, por ejemplo como molino, aún se conservan partes del edificio donde se trabajaba el hierro, con muros y arcos de mampostería de cantos rodados y pizarra, que en algún caso sobrepasan los siete metros de altura, así como el canal que abastecía de agua.

\title{
36. FERRERÍA DE CARCEDO
}

\author{
LUGAR: San Pedro de Carcedo \\ MUNICIPIO: Valdés \\ RÍO: Esva o Canero \\ COORDENADAS: $43^{\circ} 29^{\prime} 20^{\prime \prime}$ N. y $6^{\circ} 25^{\prime} 36^{\prime \prime} \mathrm{W}$.
}

En la parroquia de San Pedro de Carcedo, que se encuentra en la carretera de Luarca al puerto de la Espina, menciona Madoz en el siglo XIX “una herrería donde se elabora el material conducido de Vizcaya"2778. No tengo más noticias de ella; incluso creo que podría ser un mazo sobre el río Esva, actualmente conocido como Canero.

\footnotetext{
2776 BOPA: 6 de octubre de 1838, p. 4.

2777 REVISTA MINERA, t. XIX, 1868, P. 82. También en L. ADARO (1916): Ob. cit., p. 66

2778 P. MADOZ (1985): Ob. cit., p. 50, 69, 246 y 115.
} 


\section{FERRERÍA DE RAICEDO}

LUGAR: Raicedo

MUNICIPIO: Valdés

RÍO: Negro

COORDENADAS: $43^{\circ} 31^{\prime} 58^{\prime \prime}$ N. y $6^{\circ} 32^{\prime} 7^{\prime \prime} \mathrm{W}$.

Raicedo se encuentra a orillas del río Negro, en la carretera de Luarca a la Espina. Antiguamente este lugar del municipio de Valdés pertenecía a la feligresía de Santiago de Arriba, como recuerdan, como veremos, documentos del siglo XVI al XVIII, aunque hoy se halla en la de Barcia. En algunos documentos se la denomina como "ferrería de abaixo, que llaman de Raycedo"2779; la de arriba podría ser la de Salientes.

Según un documento de la primera mitad del siglo XVI la ferrería de Raicedo pertenecía al avilesino Fernando de las Alas. En 1535 éste arrendó a Ruy Cabrón, ferramentero, vecino del concejo de Valdés, la ferrería de Raicedo "que está en el concejo de Valdés, en la feligresía de Santiago de Arriba", con sus montes, presa y herramientas "según oy día está moliente e corriente", con el molino, la huerta y casas por cuatro años "que corren desde el día de Nabidad primero que viene". La renta sería de 60 quintales de hierro al año "pesados por el quintal de la dicha ferrería a veynte y cinco onzas por libra e cien libras el quintal". Dicha renta la pagaría en tres veces: por Pascua florida, por san Juan de Junio y por Navidad. En el contrato se especifica que el propietario corre con los gastos del arreglo de la presa y el árbol mayor; el rentero la renta y arreglos menores. Asiste como testigo el aroza Juan Díez de Orozco 2780 .

Dos años después, por no pagar la renta, Fernando de las Alas denunció ante la justicia a Ruy Cabrón, por una deuda de 60 quintales de hierro, que al año siguiente subieron a 100 quintales. En el interrogatorio del juicio se mencionan, además del aroza citado, al tirador Martín Sánchez y al fundidor Pedro Díez, del que expresamente se dice que es vizcaíno, como probablemente 
lo era también el aroza ${ }^{2781}$. Ignoramos las razones del impago, pero es posible que tuviera dificultades en la producción y comercialización del hierro, aunque la coyuntura no era mala, como vemos en otras ferrerías de la zona. Como el arrendatario huyó de la cárcel, Fernando de las Alas demandó a Fernán González de Gozón, merino de Avilés y a otros por haberlo permitido; el juicio se alargó hasta $1543^{2782}$.

Un hijo de este Fernando o Hernando de las Alas fue Martín de las Alas, vástago de esa notable familia de marinos asturianos, uno de los cuales acompañó a su pariente Pedro Menéndez de Avilés en 1565 en su conquista de la Florida. Dicho Martín estuvo casado con Elvira de Valdés, igualmente de otra importante familia de la región. En 1580, ya como viuda, puso ésta una demanda a Fernando de Arango por 50 ducados que le debe del arrendamiento de una ferrerías, pero ignoramos si se refiera a ésta o a la de Labayos, que también era suya.

La segunda esposa de Hernando de las Alas fue Catalina Menéndez de Avilés, probablemente de este matrimonio desciendan los Menéndez que aparecen como propietarios de la ferrería de Raicedo a finales del siglo XVI. En 1595 se menciona como tal a María Méndez de Posada, viuda de Gaspar Menéndez de Luarca, y a su hijo el capitán Sancho Menéndez ${ }^{2783}$, aunque ignoramos si era de ella o de su marido. Lo cierto es que unos años más tarde, a comienzos del siglo XVII sabemos que la ferrería pertenecía a dos nietos de Gaspar Menéndez de Luarca y María Menéndez de Posada, uno de su hijo Sancho, Gaspar Menéndez de Luarca, y otro de su hija Melchor, Magdalena Menéndez. Ésta, casada con Alonso Menéndez Sierra, vende a su primo, y a la madre de éste Francisca de Tineo, en 1617 "la quarta parte que teníamos y era

\footnotetext{
${ }^{2781}$ IBIDEM

2782 ACh.V.: Pleitos civiles. Fernando Alonso (E). Caja 207,5

${ }^{2783}$ ACh.V. R. E. caja 1805,1. Se trata del pleito de estos Menéndez contra Pedro Fernández y Macías de Setienes por el hurto de un carro de leña en el monte de Tresmontes, propiedad de aquellos. En el curso del hurto hubo una pelea en la que Pedro Fernández hirió con un hacha en un brazo a Sancho Menéndez, por lo que fue condenado a destierro y una fuerte multa. En el texto se dice que Sancho les quitó el carro de leña y lo envió a una "errería de la dicha María Menéndez" que, aunque no se nombra debe de ser la de Raicedo.
} 
nuestra propia de la herrería de Raycedo" por 500 ducados, cuatro bueyes y seis quintales de hierro 2784 .

Sin embargo, en 1625 se entabla un pleito por el incumplimiento del contrato, en el que Alonso y Magdalena piden la ejecución de su primo por deudas. Gaspar Menéndez alega que cuando compró la ferrería "no balía quatrocientos ducados, ni la quarta parte balía ziento y si algo mas bale al presente es por los nuebos gastos y mejoramientos que mi parte en ella hiço y tiene hechos"; además en otro escrito del pleito añade que la venta no fue por 500 ducados sino por $35^{2785}$. No está claro si es cierto que la ferrería estaba en tan mal estado, pues algunos testigos saben que don Alonso y doña Magdalena percibían por esa cuarta parte 10 quintales de hierro como renta de los arrendatarios, los cuales valían 40 ducados, lo que significa que se trabajaba en ella, aunque otros afirman "que tiene nuebos reparos y hedeficios" construidos a costa de don Gaspar2786.

Por la compra, el mencionado Gaspar Menéndez poseía la mitad de la ferrería, pero a causa de las deudas, la justicia ordenó su subasta. No hubo postor, así que estas dos partes se las adjudicó a Alonso Menéndez de Sierra y su esposa "según solia llebar Melchor Menéndez de Luarca, suegro del dicho Alonso Menéndez". En señal de posesión, el alguacil, el 21 de noviembre de 1626, "tomó por la mano al dicho Alonso Menéndez y le metió dentro de la dicha herrería y truó con la mano en algunas de las piedras de la pared della e dixo daba posesión real... de la mitad de la ferrería y le entregó un martillo de yerro en señal de posesión”. Además se sacaron a los ferrones que trabajaban en ella, añadiendo que "se aga notificación a Martín Barbachano, rendero de la dicha ferrería, para que no contravenga a lo que en ella a contenydo".

\footnotetext{
2784 ACh.V. Sala de Vizcaya, caja 3089,8

2785 En un texto se alude a que por la venta don Gaspar pagó de alcabala diez ducados y medio " $a$ rrazón de tres por ciento de la cantidad en que vendió dicho quarto", lo que da una cantidad de 350 ducados.

${ }^{2786}$ IBIDEM. En el interrogatorio se pregunta, además, si saben "que la dicha ferrería de raycedo y bienes a ella anexos no son libres, antes se debe sobre ellos tributo en cada año seis carros de leña y una manta de sayal nueba al ospital de la villa de Luarca que dexó al dicho ospital Juan Rayón de Luarca". Parece que una parte de la ferrería se la vendió a este Juan rayón el licenciado Alonso Ramírez, vecino de Oviedo, con otros bienes en las aldeas de Carcedo y San Cristóbal
} 
De las protestas de este Martín Barbachano, vizcaíno, que alega que él no lleva en arrendamiento nada de Gaspar Menéndez, sino de los hermanos Pereira, nos enteramos de que la otra parte era propiedad de Simón y Lorenzo Pereira, hijos de Diego Pereira "el qual en sus días y vida le aforó estando como estaba demolida y desconzertada sin presas ni calces ni árboles ni otro pertrecho para poder labrar". Añade, además, que no fue Gaspar sino su madre, doña Francisca de Tineo, la que la había dado la otra parte, "por tiempo y espacio de diecisiete años". Pero para poder labrar tuvo que gastar más de 2.00o ducados, aunque en otro escrito dice que son 1.500: "es propia mia y de mis partes por aberla edificado y puesto en ella los pertrechos necesarios y aber gastado en ella mil quinientos ducados (...) porque antes no avía herrería ni rentaba cosa alguna asta que mis partes la hicieron y fabricaron".

Por ello, Marín Barbachano exige que a los Pereira, que residen en Madrid, se les debe notificar la toma de posesión de don Alonso, por ser aquellos “dueños y señores de dicha ferrería”2787. ¿Por qué son dueños? ¿quiénes eran estos Pereira?. Diego Pereira es un comerciante portugués, con actividades por toda la cornisa cantábrica. Unas veces lo vemos residiendo en Bilbao, donde comercia con vascos, cántabros, franceses, flamencos, etc., con telas, vinos pero también hierro y herraje ${ }^{2788}$. En otras ocasiones, hacia 1607-1609, administra las salinas del Reino de Galicia y las del Principado de Asturias ${ }^{2789}$. Se trata, probablemente, de un converso adinerado dedicado al comercio. Quizá adquirió parte de la ferrería de Raicedo a los Menéndez, financiando su reparación que, por lo que hemos visto, pudo ascender a 1.500 o 2.000 ducados.

Esa parte pasó a sus hijos Simón y Lorenzo, a los que en los años veinte vemos como residentes en Madrid; pero también pudo ser un préstamo hipotecario, un censo, porque en el siglo XVIII la ferrería aparece como propia nuevamente de la familia Menéndez, como recuerda el Catastro de Ensenada, al

\footnotetext{
${ }^{2787}$ A.Ch.V. Sala de Vizcaya, caja 3089,8

${ }^{2788}$ ACh.V. Sala de Vizcaya (sin signatura). Pleito en 1603 de Diego Pereira y Simón baz de reina contra Adan Jibas, de Francia, por ejecución de dos navíos cargados de hierro por valor de $72.000 \mathrm{mrs}$.

${ }_{2789}$ a.Ch.V. Pleitos civiles, Pérez Alonso, caja 1400,1 y R. E., caja 2027,52
} 
decir que pertenece a don Lope Matías Menéndez 2790. Según esta fuente, la ferrería trabajaba cinco meses al año y producía cien quintales al mes, con una producción total de 500 quintales, que se vendían a 60 reales el quintal. La ferrería estaba arrendada a don Juan basilio Álvarez²791. En 1796 en que se suscitó un pleito por el nuevo intento de construir la ferrería de Brieves por un hijo de don Jacinto Avella, su dueño, Juan Matías Menéndez, afirma que solo puede trabajar seis meses al año, pero se sentía amenazada por las dificultades en abastecerse de carbón ${ }^{2792}$. Debió de trabajar poco después porque ni Miñano ni Madoz la mencionan.

\title{
ESTADO: No existe
}

\section{FERRERÍA DE SALIENTES}

\author{
LUGAR: Salientes \\ MUNICIPIO: Valdés \\ RÍO: Negro \\ COORDENADAS: $43^{\circ} 30^{\prime} 21^{\prime \prime}$ N. y $6^{\circ} 32^{\prime} 32^{\prime \prime} \mathrm{W}$.
}

Se halla al lado del pueblo de Salientes. En el mapa topográfico aún se menciona como topónimo una "ferrería de arriba".

$\mathrm{Si}$ a la ferrería de Raicedo se la nombra a principios del siglo XVII como "ferrería de abaixo", quiere decir que por entonces ya existía otra ferrería denominada "de arriba", que no puede ser otra que la de Salientes, como así la nombra el topográfico. Entre ambas, en el mismo río, se construyó la de Setienes, al que un documento del siglo XVIII, que mencionaremos al tratar de esta ferrería, data como "de tiempo inmemorial".

En el pleito entablado por el dueño de la ferrería de Setienes contra la pretensión de don Manuel Melchor Avella Fuertes de construir una ferrería en

${ }^{2790}$ CATASTRO DE ENSENADA. R. G.: Valdés (parroquia de Santiago de Arriba): Asi mismo hay en la parroquia nominada de Santiago de Arriba una herrería, que sirue para fábrica de yerro, propia de Don Lope Matías Menéndez, vecino del lugar de Setienes, construida sobre el río Negro de la montaña". 2791 IBIDEM

$2792 \mathrm{M}^{\mathrm{a}}$ A. FAYA y L. ANES (2007): Ob. cit., p. 249 
Brieves, en 1796, se habla de una ferrería propia del marqués de Ferrera, de Avilés. El documento recuerda las dificultades para el abastecimiento de la ferrería de Setienes, que si se le da permiso a Avella Fuertes para la suya tendrá que cerrar, "como cesó antes de ahora por la misma razón la que el Marques de Ferrera tenía en el mismo concejo de Valdés"2793. Según Faya y Anes se trata de la ferrería de Salientes (Luarca), que se menciona en 1758, cuando ya el padre de Manuel Melchor, don Jacinto Avella, quiso construir la ferrería de Brieves. Al parecer dejó de funcionar por su escasa rentabilidad2794.

ESTADO: Desconocido

\title{
39. FERRERÍA DE SETIENES
}

\author{
LUGAR: Setienes \\ MUNICIPIO: Valdés \\ RÍO: Negro de las Montañas \\ COORDENADAS: $43^{\circ} 31^{\prime} 5$ " N. y $6^{\circ} 32^{\prime} 30^{\prime \prime} \mathrm{W}$.
}

Setienes en una aldea del municipio de Valdés, en la que aún se conserva el topónimo Herrería-Setienes.

Se trata probablemente de una ferrería antigua, ya que en el pleito suscitado en el siglo XVIII por su dueño contra la construcción de la ferrería de Briebes, se dice que don Juan Matías Menéndez, regidor perpetuo del concejo de Valdés, y sus antecesores "desde tiempo inmemorial han tenido la herreria que está sita junto al rio de la villa de Luarca, y a las inmediaciones de esta, y la han poseído y aprovechándose de ella pacíficamente y de los montes comunes y particulares de aquel Concejo de Valdes, como son los de la Braña de Caborno, los de la de Businde, el del rio de la Vieja en la parroquia de Paredes, el de Silbouta en la misma parroquia que dista legua y media de la referida herreria, y los otros dos leguas poco mas o menos". Poco después, en el mismo documento, vuelve a hablar de "su antiquísima herreria" 2795.

\footnotetext{
2793 AHN. Consejos: Leg. 28685, exp. 7-3, ff. 229. 2794 M $^{\text {a }}$ A. FAYA y L. ANES (2007): Ob. cit., p. 249, nota 241. 2795 IBIDEM, p. 356-357.
} 
Como hemos visto, en 1758 don Jacinto Avella Fuertes solicitó permiso para la construcción de una ferrería en Brieves, a unas tres leguas de la villa de Luarca. Don Juan Matías Menéndez y Luarca que poseía a dos leguas la ferrería de Setienes se opuso, porque consideraba que la nueva le haría la competencia, bajaría el precio del hierro y subiría el de la madera debido a su escasez. Ambos eran parientes, pues Juan Matías Menéndez Luarca y Tineo estaba casado con doña Juana María Avella Fuertes, pero había entre ellos enemistad y pleitos por cuestión de bienes. Dicha oposición y la de la justicia y regimiento de Luarca y el gremio de Mareantes a dicha construcción parece que surtió efecto ${ }^{2796}$.

La ferrería de Setienes, que estaba al lado del mar, se nutría de mineral de hierro vasco, pero debía de ser cierto que tenía problemas para el abastecimiento de leñas y carbón. No la cita el Catastro de Ensenada, aunque por las protestas de su propietario por la nueva ferrería de Brieves, aún trabajaba. Madoz dice que en el concejo de Valdés hay "ferrerías"2797. La de Setienes la menciona Schulz en su "Viaje por Asturias". Funcionaba todavía en $1866^{2798}$.

ESTADO: Desconocido

\section{MUNICIPIO DE VEGADEO}

\section{FERRERÍA DE ABRES}

LUGAR: Abres

MUNICIPIO: Vegadeo

RÍO: Ouría

COORDENADAS: $43^{\circ} 25^{\prime} 22^{\prime \prime}$ N. y $7^{\circ} 6^{\prime} 7^{\prime \prime}$ W.

En el lugar de Abres, en la carretera de Vegadeo a Lugo, a orillas del Reguero dos Moynos, afluente del Ouria.

\footnotetext{
2796 IBIDEM, p. 349 y ss.

2797 P. MADOZ (1985): Ob. cit., p. 421

2798 REVISTA MINERA, t. XIX, 1868, p. 82. También en L. ADARO y JUNQUERA (1916): $O b$. cit., p. 66
} 
En 1623 se solicitó la construcción de una ferrería de obra nueva en el lugar de Pumar de Veiga, en Santiago de Abres"2799, argumentando que "con la dicha obra y herrería no hacemos daño ninguno ni perjuicio a la dicha feligresía ni a otra persona ninguna ni a los concejos de Santiago ni Santiso ni Taremunde ni en el dicho rio que jamás ningún paso ni hacemos presa". Además de no hacer daño en el agua tampoco lo haría en el monte, pues los dueños de la ferrería "tienen mucha cantidad de montes propios por mas de cincuenta años". Los vecinos parece que no estaban de acuerdo con estos argumentos por lo que iniciaron un pleito que, sin embargo, no interrumpió la construcción de la ferrería ${ }^{2800}$, que aún estaba en obras en 1627.

En el pleito por la construcción de la ferrería de Sueiro (la de abajo), un testigo vizcaíno, del valle de Oyarzún, que dijo ser maestro "de hacer e fabricar herrerias", y que “al presente reside en el lugar de Abres, ques dos leguas de la uilla y $q^{o}$ de Castropol”, afirmó en ese año de 1627 "que esta açiendo una herreria que fabrican en el dicho lugar Fernando Miranda y consortes"2801. Entre esos consortes parece que estaban además del citado Fernando de Miranda y Osorio, Álvaro González de Miranda y Juan Nuñez de Pardo y Montenegro ${ }^{2802}$. En el testamento de Juan Núñez de Pardo de 1633 dice que el 13 de diciembre de 1627 aseguró con las benditas cofradías del Santísimo Sacramento y de la Virgen del Buen Suceso "la ferrería de Abres para que el pleyto se acabase y lo tuviésemos bueno" ${ }^{2803}$, lo que confirma que por entonces aún estaban en pleitos.

Entre loss consortes quizá también se hallaba Pedro García de Presno, al que Juan Núñez de Pardo, casado con María Valledor y Presno, paga de foro 1.650 reales, probablemente por la ferrería o por el suelo en el que se construía, como recuerda en su inventario de bienes de 1637. De acuerdo con él, a su hijo

2799 Probablemente se hizo sobre, o cerca, de una antigua forja, que se cita en 1557 como Forja de Abres. Se trata de la venta de una casa que hace María Fernández a favor de Gonzalo Méndez de Miranda (AHA. Caja 11250/63, $\mathrm{n}^{0} 79$ )

2800 A.D.O. Parroquia de Santiago de Castropol: caja 14.3.218.

${ }^{2801}$ A.Ch.V. R. E.: caja 2489,47

${ }^{2802}$ AHA. Caja 11249/o2, doc. 82, se menciona una concordia de 1626 entre estos tres personajes sobre "la fábrica de una herrería en el río Abres".

2803 IBIDEM 
Mendo Alonso Pardo y Montenegro le corresponden 92.533 reales y por ellos, entre otros bienes, "la quarta parte de la ferrería de las Mestas de Ouría de la feligresía de Abres, con lo ha ella perteneciente y cargas que tiene del fierro que paga a Pedro García de Presno en mill y seiscientos y cinquenta reales"2804. En otro lugar dice que esa cantidad es por derechos de foro. La ferrería tenía una bodega en la que tenían unos "cuarenta quintales de bena cocida" que valen 140 reales.

La parte de la ferrería que pertenecía a este Mendo Pardo la heredó su hija Juana Pardo Sierra y Osorio, que se casó con Antonio del Riego del que no tuvo herederos. Este en 1663, en nombre de su mujer, vendió su parte al capitán Pedro de Miranda y Acevedo ${ }^{2805}$, quien debió tenerla arrendada, pues en 1675 pleiteó con Pedro López de Espesande por impago de la renta ${ }^{2806}$. Sin embargo, muerto Antonio del Riego, su mujer pleiteó en 1685 con los hermanos de su marido para que le devolvieran "mas de dos mil y quinientos reales en que el dicho D. Antonio del Riego auía empeñado la quarta parte de la errería de Abres, que era de la dicha $D^{a}$ Juana Bernarda, al capitán de Abres"2807. A finales del siglo, esta parte pasó a un nieto de su tía Ana Pardo, Antonio Ventura de Aguiar y Pardo.

Aunque en 1741 se habla de la venta de la mitad de esta ferrería que hace Alonso Antonio Castrillón a Alonso Vivero y Miranda 2808, el Catastro de Ensenada en 1753, menciona a tres propietarios. Dice este que en las parroquias de Piantón, Abres y Paramio menciona que "hay tres herrerías de sacar hierro (...) otra en el Reguero que se dice de Moynos (afluente del río Ouria) de la parroquia de Abres, que por trabajar de represa cuatro meses de cada año y hallarse en terreno muy escaso de carbón y leña, consideran produce de útil anual, un mil quinientos reales de vellón a dicho Don Jacinto (Pablo Valledor),

\footnotetext{
2804 IBIDEM En otra ocasión se dice que "se bajan setenta y cinco reales que pareze debia el defunto del foro de la ferraria de Abres de dos años a razón de quintal y quarto cada año a Pedro García de Presno y consortes".

2805 AHA. Caja 11249/07, doc. 94

2806 AHA. Caja 11249/14.

2807 IBIDEM

${ }^{2808}$ AHA. Caja 11249/12
} 
a Don Alonso Miranda y a Don Juan Raimúndez, a quienes pertenece"2809. En 1759 María Pardo Pimentel, viuda de Manuel Rodríguez de Cancio, libra varios recibos a favor de Fernando Miranda, como arrendatario de la ferrería de Abres ${ }^{2810}$.

Según Joaquín Ocampo a finales del siglo XVIII el precio tan elevado de la vena vasca motivó que se cerraran las herrerías de la zona de San Tirso de Abres ${ }^{2811}$, entre ellas ésta.

ESTADO: Desconocido

\section{FERRERÍA DE MEREDO}

LUGAR: Herrería de Meredo

MUNICIPIO: Vegadeo

RÍO: Suarón

COORDENADAS: $43^{\circ} 25^{\prime} 33^{\prime \prime}$ N. y $6^{\circ} 59^{\prime} 58^{\prime \prime} \mathrm{W}$.

En el lugar de la Herrería de Meredo, en la parroquia de Santa María, al que se llega desde Vegadeo a Presno y de allí por otra secundaria hasta Meredo.

El Catastro de Ensenada de 1753 señala que en la parroquia de Piantón, Abres y Paramio "hay tres herrerías de sacar hierro, la una situada en el río Meredo, perteneciente a D. Juan de Cancio, y Pedro Pérez de la Ferrería, y a Don Gaspar Castrillón vecino del concejo de Boal, que trabaja ocho meses de cada año, cuyo útil anual consideran en dos y quinientos reales de vellón contemplando el crecido gasto de bena, carbón y leña; y el de las quiebras que tiene"2812. En 1795 esta ferrería pertenecía a don Benito Lastra ${ }^{2813 .}$

\footnotetext{
2809 J.L. PÉREZ CASTRO (1976): “Piantón, Paramio y Abres (actual concejo de Vegadeo), según el Catastro de Ensenada”. BIDEA 88-89, p. 590-591 2810 AHA. Caja 11249/11

${ }^{2811}$ AHN. Fomento: Leg. 2928, n ${ }^{\circ} 28$ y 58. Cfr. J. OCAMPO (1987): Ob. cit., p. 38

2812 J.L. PÉREZ CASTRO (1976): Ob. cit., p. 590-591

2813 MUSEO NAVAL. Col. Guillén: Ms. 2175
} 


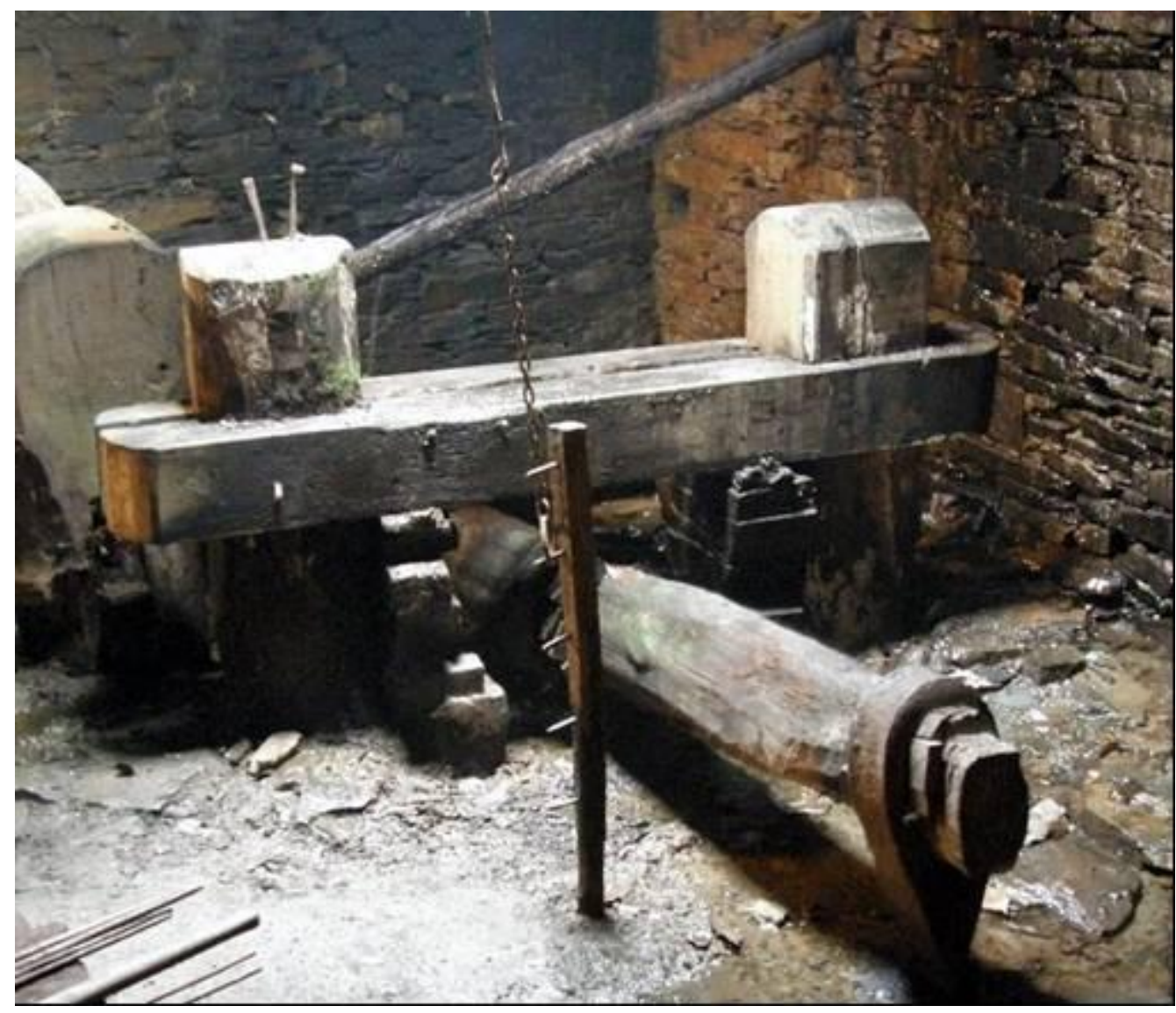

Mazo de Meredo

Madoz simplemente menciona en la feligresía de Santa María de Meredo “ferrerías"2814, pero existía porque en 1850 don Benito Rodríguez Arango, de la Vega de Ribadeo, presentó en la Exposición Pública Madrid de ese año varios ejemplares de hierro de ferrerías asturianas, uno de ellos -acero en banda- de la de Meredo con vena de Somorrostro, fabricado por don Jacinto Miranda ${ }^{2815}$; también aparece citada en un escrito de Domingo Vázquez Villamil de $\mathbf{1 8 6 0}^{2816}$. Por los años cincuenta se nombra al lado, también con el nombre de Meredo, un mazo propiedad de don Francisco Arias ${ }^{2817}$.

ESTADO: Desconocido

2814 P. MADOZ (1985): Ob. cit., p. 236

2815 J. CAVEDA (1851): Memoria presentada por el Excmo. Señor Ministro de Comercio, Instrucción y Obras Públicas por la Junta clasificadora de los productos de la industria española reunidos en la Exposición Pública de 1850. Madrid, p. 192; también en J. ORIOL RONQUILLO (1855): Diccionario de materia mercantil, industrial y agrícola. Barcelona, t. III, p. 167.

2816 J. LÓPEZ y A. GRAÑA (1998): Ob. cit., p. 148

2817 J. ORIOL RONQUILLO (1855): Ob. cit., t. III, p. 167. 


\section{FERRERÍA DE NAFAREA}

LUGAR: Nafarea, parroquia de Santa María de Meredo MUNICIPIO: Vegadeo

RÍO: Suarón

COORDENADAS: $43^{\circ} 24^{\prime}$ 2" N. y $6^{\circ} 59^{\prime} 49^{\prime \prime} \mathrm{W}$.

La ferrería de Nafarea, antiguamente en Piantón, Madoz la ubica en la parroquia de Santa María de Meredo. Debía de estar más cerca de Piantón, al que se llega desde Vegadeo.

Según el Catastro de Ensenada, 1753, en la parroquia de Piantón, Abres y Paramio "hay tres herrerías de sacar hierro (...) Otra en el río Nafarea propia de Don Jacinto Pablo Valledor, vecino de la villa de Castropol, y de Doña Isabel Bermúdez, viuda, que por falta de agua trabaja solo seis meses cada año, por cuya consideración y las de la antecedente, le regulan de útil en cada uno dos mil reales vellón" ${ }^{2818}$. Además de parte de la ferrería de Abres, don Jacinto Pablo Vallador era dueño también de la ferrería de Montealegre. En 1795 esta ferrería estaba arrendada a la Compañía de la Vega de Ribadeo ${ }^{2819}$.

Madoz menciona el mazo de Nafarea dentro de la feligresía de Santa María de Meredo. En ésta simplemente habla de la existencia de "ferrerías" 2820 , sin especificar más; pero la ferrería de Nafarea existía en 1850 como propia de don Pedro de Lastra, pues se cita como una de las que en la exposición de 1850 presentó un lingote de hierro ${ }^{2821}$; este mismo, en 1860, aparece en una protesta que envían al gobernador de Oviedo los dueños de varias ferrerías contra la pretensión de Domingo Vázquez Villamil de construir una nueva en la Cabanada2822.

ESTADO: Desconocido

\footnotetext{
2818 J. L. PÉREZ CASTRO (1976): Ob. cit., p. 590-591

${ }_{2819}$ MUSEO NAVAL. Col. Guillén: Ms. 2175. Dice que se hallaba en el coto de Castropol ${ }^{2820}$ P. MADOZ (1985): Ob. cit. 236

${ }^{2821}$ J. CAVEDA (1851): Ob. cit., p. 192; también J. ORIOL RONQUILLO (1855): Ob. cit., t. III, p. 167.

${ }^{2822}$ J. LÓPEZ y A. GRAÑA (1998): Ob. cit., p. 146, nº 10
} 


\title{
24. MUNICIPIO DE VILLANUEVA DE OSCOS
}

\section{FERRERÍA DE VILLANUEVA DE OSCOS}

\author{
LUGAR: Santa Eufemia \\ MUNICIPIO: Villanueva de Oscos \\ RÍO: Vilanova \\ COORDENADAS: $43^{\circ} 18^{\prime}$ o" N. y $6^{\circ} 59^{\prime} 47^{\prime \prime} \mathrm{W}$.
}

Sus escasos restos se encuentran a unos 500 metros al sur de Santa Eufemia, en el término de Candaedo ${ }^{2823}$, en la carretera de Villanueva a Santalla de Oscos (AS-33). Lo único que se conserva es la casa de administración; la ferrería se situaba entre ésta y el río.

La tradición herrera de la zona, que cuenta con aguas abundantes y madera; el ejemplo de otros monasterios gallegos y asturianos, como Lorenzana, Samos o Belmonte; y la necesidad imperiosa de incrementar las rentas del cenobio, que le permitieran aumentar el número de monjes de doce a veinte como quieren las definiciones cistercienses para evitar convertirse en un simple priorato, obligaron al monasterio de Villanueva de Oscos, integrado en la renovada observancia de la congregación de Castilla del Císter en 1511, a buscar nuevos recursos en la actividad siderúrgica, pese a las dificultades económicas de la empresa y la oposición de los colonos y campesinos que, aunque conscientes de los bienes que les podría generar, la rechazan por la competencia en el uso del monte.

La idea de construir una ferrería contó con una experiencia previa entre 1606 y 1658 , tiempo en que fue madurando la idea en la comunidad, una vez superados los muchos pleitos que hubo de sostener a finales del siglo XVI y principios del XVII con los colonos y campesinos. Antes de la ferrería hubo en el mismo lugar un mazo construido por la familia vasca Ochoa y Salazar, la cual a principios del siglo XVII había comprado una parte del foro de Pedro de Lastra, en Santa Eufemia, para establecer junto al río un machuco. La licencia del abad

${ }_{2823}$ "La herrería de que oy goza este monasterio está sita en el término de Candaedo" 
para esta obra parece una contraprestación por el censo de 300 ducados que los Ochoa han hecho al convento en momentos difíciles. En su parte del foro, Juan y Pedro de Ochoa construyen hacia 1606 una casa, molino y mazo ${ }^{2824}$.

Poco después los Ochoa, ante los buenos resultados en el trabajo del hierro, pretendieron transformar aquel mazo en una verdadera ferrería "porque viendo que sus intereses podían aumentar, si este artefacto, en vez de mazo, fuese herrería" solicitan licencia al abad para construirla, lo que obtienen "con la capa de que querían probar cierta vena de hierro que había cerca del mazo". El mazo, como en otras ocasiones, se transforma en ferrería previo las necesarias obras de remodelación. Pero antes de que éstas terminaran, los campesinos, temerosos de la deforestación del bosque por el uso abusivo de leñas y el carboneo, protestan al abad quien en 1658 decide paralizar las obras de la ferrería, aunque "no se le oculta la utilidad que al monasterio le resultaría, si tuviera una"2825. No hay que olvidar que en esos años finales del siglo XVII se produce una evidente demanda de hierro, lo que explica la construcción de varias ferrerías en todo el noroeste ${ }^{2826}$.

\footnotetext{
2824 D. PAZ (1991): El monasterio de Santa María de Villanueva de Oscos: De la reforma a la exclaustración. Oviedo, p. 146-147.

2825 IBIDEM, p. 147

${ }^{2826}$ P. SAAVEDRA (1982): "Un aspecto de la economía monástica: la producción de hierro. El ejemplo del monasterio de Villanueva de Oscos". En Semana de Historia de monacato cántabro-astur-leonés. Oviedo, p. 535.
} 


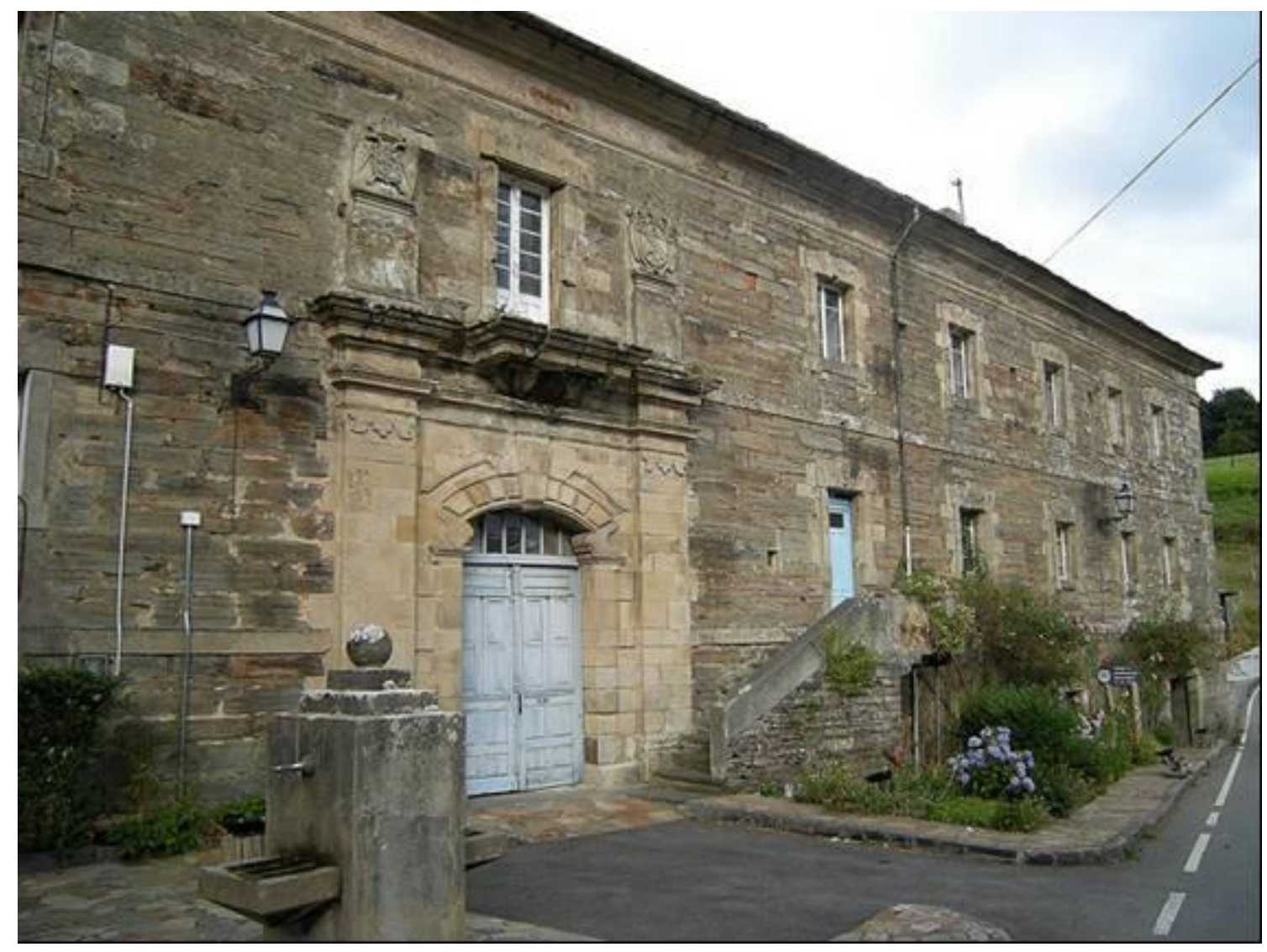

Monasterio de Villanueva de Oscos

Esto último llevó a al abad Lucas de Arboleda, ya en los años sesenta, a iniciar las gestiones ante el gobernador del Principado "para fundar una herrería en los montes de San Cristóbal", con madera abundante y menos conflictos campesinos. Este permiso lo logra en $1666^{2827}$; pero como veremos, la ferrería no se construiría en dicho lugar sino en el de Santa Eufemia, probablemente por la presión de los Ochoa, medio arruinados por el fracaso de su proyecto anterior, quienes logran del abad Lucas de Arboleda que se edifique, lo que por otra parte era más racional, sobre las instalaciones del antiguo mazo. De este modo los monjes asocian a la empresa a los Ochoa, a quienes arriendan la ferrería por 16 años en contratos de cuatro años, por la cuarta parte del beneficio pero con la condición de sufragar igualmente la cuarta parte de los gastos de construcción y también, en lo sucesivo, la cuarta parte de las

${ }^{2827}$ AHN. Clero: Libro 9437: "La licencia para fundarse la Herrería la concedió el sr. Don Carlos de Villamayor y Vivero del Consejo de su Magestad, su oydor en la Real Chancillería de Valladolid". 
reparaciones y quiebras ${ }^{2828}$. Dicho convenio se firmó en 1674 siendo abad Fr. Gabriel de Estrada, al que tradicionalmente se le atribuye como el fundador de la ferrería ${ }^{2829}$.

La obra se hizo en un tiempo breve pues en febrero de 1677 la fábrica iniciaba su funcionamiento, haciéndose en tal fecha un requerimiento a los Ochoa para que entrasen a labrar hierro en ella. Para las obras de construcción de la ferrería los monjes de Villanueva tuvieron que pedir un censo de 4.000 ducados al monasterio de Lorenzana, con un interés del 5\%; dinero que, sin embargo, no fue suficiente a tenor del estado de cuentas del abad Estrada, quien en la apertura de caminos, salarios de carpinteros, acarreo de maderas, jornales de oficiales, porteo de la vena, barquines, etc. gastó 51.823 reales. A éstos habría que añadir otros derivados de algunos fallos en las obras "porque los barquines, mazo, ingle y fragua son muy diminutos" 2830.

Estas contrariedades, lejos de desanimar a los monjes fueron un acicate, porque como muestra el acta de visita del General Reformador en 1678, la ferrería se consideraba ya como una base imprescindible para el futuro económico del monasterio: "pues es una de las principales raíces y de que más fruto a de perciuir esta casa para su conservacion y augmento" 2831 . Para hacer frente a estas primeras dificultades manda el reformador no redimir los censos tomados para construir la ferrería, hasta que ésta no cuente con 66.00o reales para la adquisición de vena, carbón y todo lo demás necesario para su funcionamiento; además ordena que el útil de la ferrería se guarde en el Arca de la comunidad con destino a gastos de la ferrería, y que los administradores

2828 D. PAZ (1991): Ob. cit., p. 148

${ }^{2829}$ AHN. Clero: Libro 9437. 22 de noviembre de 1674. Acuerdo entre el monasterio (abad Fr. Gabriel de Estrada y los hermanos Juan y Pedro de Ochoa, vecinos del mazo de Santa Eufemia: "Ceden a fauor del dicho monasterio el derecho, boz y aczión que tienen al dicho fuero y lo dan baco para que dicho P. Abbad, prior y mas monjes hagan del a su boluntad como bien bisto les fuere..." (y para utilidad y aumento del monasterio). "Quieren edificar y açer una ferreria en el dicho sitio del maço para en ella labrar fierro y para que tenga efecto y se aga y que dichos Pedro y Juan de Ochoa tengsn algun lucro de la çesion y bacante que açen se a de açer dicha ferrería en la forma siguiente": 1) los monjes han de poner tres partes de lo que costare la fábrica y 2) los Ochoa otra parte (la cuarta parte). "Asta estar hecha y perficionada la dicha ferrería y a punto de labrar fierro". Para ello arriendan esa cuarta parte a los Ochoa por 16 años, de cuatro en cuatro. Los monjes llevarán de cada cuatro semanas tres continuas y los Ochoas una, poniendo para ello los materiales y pagando a los oficiales en dicha semana.

2830 D. PAZ (1991): Ob. cit., p. 149

${ }^{2831}$ AHN. Clero: Libro 9437, año 1678. 
repueblen todos los montes en los que se hubiere cortado árboles para el abasto de la fábrica ${ }^{2832}$.

Durante años la ferrería siguió exigiendo nuevas inversiones. Así el abad Juan Cerrato (1677-1680) tuvo que reedificar el canal de la ferrería tres veces en dos años, gastando en esa obra 16.000 reales y otros 40.000 en la propia ferrería sin percibir ingreso alguno. A partir de 1697, trascurridos no 16 sino 23 años del contrato con los Ochoa, el capítulo del monasterio decidió no prorrogar más éste, pese a las protestas y calumnias de los Ochoa que decían que el monasterio los había expoliado y arruinado ${ }^{2833}$. De este modo el monasterio pasa a su explotación directa transformando la ferrería en un priorato, al que se dota de capilla, cuarto del prior, habitaciones para oficiales y criados, horno, taberna, bodega de hierro; obras que debieron hacerse en tiempos del abad Benito Barreda, encargándose de su ejecución fray Alonso Pol, monje de Oseira, que luego sería abad ${ }^{2834}$. Desde entonces y hasta la exclaustración la ferrería la dirigirá un prior rendero como en otras instituciones monásticas.

Como en todas las ferrerías, las obras fueron frecuentes. Durante el abadiato de Luis Bernardo (1721-1724) se quebró el árbol mayor en el mejor tiempo para la labranza. Se dice que recorrió todos los montes de la jurisdicción hasta hallar uno apropiado en los más intrincado del bosque, que solo con la ayuda de muchos campesinos de los alrededores fue posible llevarlo hasta la ferrería: "es alaja verdaderamente que no se hallará mejor en muchas leguas en contorno, tan firme y bueno, que aseguran los que lo entienden durará mas de setenta años"2835. También fue preciso echar el árbol de la barquinera "con lo que dejó compuesta la ferrería por muchos años". No debieron ser tantos, pues en 1744 el abad Lorenso Soto "se gastó mucho dinero en reparar la ferrería, por estar toda ella arruinada y caida, hizo de nuevo el vanzado, casa de fragua, carbonera nueva y de la vieja que hay levantó el tejado que se hallaba

${ }^{2832}$ D. PAZ (1991): Ob. cit., p. 149

2833 IBIDEM, p. 150: Por el libro de la Herrería, sabemos que los beneficios de la ferrería alcanzaron en los 20 años de funcionamiento 83.120 reales, de los que 20.780 rs. correspondía a los Ochoa, lo que significa unos ingresos anuales de 1.039 rs. , cifra muy superior a la obtenida por los mazos o herreros de la zona.

${ }^{2834}$ Fr. D. YAÑEZ (1973): “El monasterio de Villanueva de Oscos y sus abades”. BIDEA, nº 8o, p. 697

2835 IBIDEM, p. 700 
caido, pudo herramientas dobles, según lo acordado en la visita, así como dos cepos e introdujo en ella muchas mejoras"2836. Un nuevo banzado y los dos cepos mayores hizo también el abad Isidoro Meruendano (1753-1756)2837.

Según el Catastro de Ensenada, la ferrería trabajaba desde mediados de noviembre hasta finales de mayo ${ }^{2838}$. Su producción, según las cifras de Pegerto Saavedra, que estudió las cuentas del Liobro de la ferrería desde 1680 a 1835 , fue en todos esos años de 91.546 quintales de 100 libras gallegas, lo que viene a dar unos 5.264.278 kg, que divididos por 155 años suponen una media anual de $33.963 \mathrm{~kg}$., media aceptable e incluso superior a otras muchas ferrerías gallegas ${ }^{2839}$. El mineral que utilizaba era el de Somorrostro, además de pequeñas cantidades de vena local.

La ferrería abastecía de hierro a los siete mazos cercanos y a más de 150 fraguas de los alrededores. Entre esos siete mazos, dos se encontraban en el siglo XVIII en el coto de Villanueva ${ }^{2840}$. El mazo del Angel fue construido por el abad fray Angel de Mercado entre 1668 y 1671 en sustitución del de Ochoa; pero en tiempos de Manuel Herráez (763-1767) se "hizo de nuevo a fundamentis el Mazo que llaman del Angel"; pues hubo de ponerle de nuevo banzado, zepos, barquines y todas las demás herramientas para su servicio". El otro mazo, erigido en San Mamed, lo construyó, con permiso del monasterio, don Manuel Lombardía a mediados del XVIII ${ }^{2841}$.

El interés de estos artefacto parece que llevó a los monjes a pensar en la construcción de una nueva ferrería en una zona mejor situada, no tan lejos para

\footnotetext{
${ }^{2836}$ IBIDEM, p. 703

2837 IBIDEM, p. 704

${ }^{2838}$ CATASTRO DE ENSENADA. R. G.: Villanueva de Oscos, ff. 9: "La herrería, que es perteneziente a dicho real monasterio, que la administra de casa, trabaxa sobre el río que llaman de Villanueva, desde mediados de noviembre hasta todo el mes de mayo, y consideran que dejara de utilidad a dicho Monasterio quatro mil reales libres cada año computando bueno con malo".

2839 P. SAAVEDRA (1982): Ob. cit., p. 536-537

${ }^{2840} \mathrm{El}$ Catastro de Ensenada (Ob. cit., ff. 9) sólo menciona uno: "El machuco perteneze a Ignacio y Juan Lopez, vecinos de dicha parroquia de Santa Eufemia, quienes le lleuan en foro vitalicio de mano de dicho monasterio a quien pagan annualmente doscientos setenta y cinco reales de vellón. Trabaja la terzera parte del año sobre el rio de Pasaron, por su mal sitio y falta de agua, y le consideran sacara de utilidad en el moro de este machuco doscientos reales libres cada año".

${ }^{2841}$ D. PAZ (1991): ob. cit., p. 151
} 
avituallarse de vena y con menos conflictos con sus vasallos respecto al monte. Se eligió para ello el priorato de Presno, pero la falta de liquidez, los gastos en la primitiva ferrería y otras razones lo desaconsejaron, pese a haber creado una especie de montepío o depósito para reunir los caudales necesarios para la obra $^{2842}$.

Las obras en la ferrería fueron numerosas. El abad Herráez, que construyó el mazo del Ángel, también puso nuevos los barquines de la ferrería; Benito Araujo (1767-1771), levantó un nuevo banzado y Eusebio Fernández (1771-1775) puso el árbol de la barquinera y los barquines ${ }^{2843}$. Pese a todas estas obras, la ferrería proporcionó al monasterio pingües ingresos que le permitieron, a partir de 1776, un ambicioso programa de reforma del monasterio, que desde unos años antes amenazaba ruina, hasta el punto que el colegio que había en el monasterio hubo de trasladarse a Azibeiro. Desde 1776 hasta 1799, la comunidad invirtió en obras en el nuevo edificio monástico la nada despreciable cantidad de 592.718 reales $^{2844}$.

A comienzos del siglo XIX, el abad Arsenio Mosquera reconstruyó parte de la vivienda de la ferrería ${ }^{2845}$, como todavía puede verse en la fecha -“Año de 180o"- del dintel de una puerta; pero por esos años se evidenciaron problemas para abastecerse de carbón e incluso de mineral de hierro, por lo que para abaratar los costes de éste con venas locales firmó el abad Mariano Gutiérrez en 1805 un convenio con Raimundo Ibáñez, para la explotación de una mina que se encontraba en terrenos del monasterio, en Ouroso, tanto para su fábrica de Sargadelos como para la ferrería de Villanueva.

A partir de 1810 la producción de hierro baja casi a la mitad, siendo numerosas las causas: encarecimiento de la vena y el carbón, desastres de la Guerra de la Independencia ${ }^{2846}$. Durante el Trienio permaneció cerrada y tras la exclaustración de 1835, la ferrería fue desamortizada en 1839 y adquirida por Gabriel José Álvarez Bermúdez, Manuel Quintana Mon y José Pérez de Barcia,

2842 IBIDEM, p. 162-163

2843 Fr. D. YAÑEZ (1973): Ob. cit., p.705, 707.

2844 IBIDEM, p. 709

2845 IBIDEM, p. 707

${ }^{2846}$ D. PAZ (1991): Ob. cit., p. 168 
vecinos de Santalla de Oscos, en 441.50o reales, al que se añadió poco después Francisco Fernández Villanueva ${ }^{2847}$. Probablemente como en otras ferrerías monásticas, desde la exclaustración hasta su venta, el Estado la debió administrar por medio de don Manuel Lombán, al que años antes vemos como mayordomo de Froseira y posteriormente como propietario de la de Pontigón. Todavía funcionaba en 1866, en que la menciona la Estadística Minera ${ }^{2848}$.

ESTADO: Sólo se conserva la casa de la ferrería y el canal de agua

\title{
25. MUNICIPIO DE VILLAVICIOSA
}

\section{FERRERÍA DE AMANDI}

\author{
LUGAR: Amandi \\ MUNICIPIO: Villaviciosa \\ RIO: Amandi \\ COORDENADAS: $43^{\circ} 28^{\prime} 15^{\prime \prime}$ N. y $5^{\circ} 26^{\prime} 29^{\prime \prime} \mathrm{W}$.
}

Amandi se encuentra al inicio de la carretera de Villaviciosa, a cuyo municipio pertenece. Uno de las aldeas de la feligresía de San Juan de Amandi se llama justamente La Herrería, que está a orillas del Amandi, río que nace de la unión de varios arroyos que bajan de Cabranes y de Sietes, y que según Madoz era “de poca agua en verano"2849. Aquí se encontraba la ferrería.

Al parecer la construyó el regidor de Villaviciosa Gutierre de Hevia hacia 1549. El 3 de octubre de ese año, en una provisión real, se dice que Gutierre de Hevia "en una heredad cerca de la dicha villa (de Villaviciosa) quiere hacer una herrería e para ello tiene necesidad de traer agua de un arroyo que por allí cerca pasa e por razón de que se atraviese una o dos sendas o caminos le quieren impedir el dicho aprovechamiento e porque dello le viene mucho daño e a la republica porque las herrerías son en ella muy necesarias, y en estos nuestros reinos nos suplicó (...)". Y la suplica surtió efecto pues se concede lo

2847 P. QUINTANA (2005): Ob. cit., t. II, p. 200. En esa cantidad se incluía con la ferrería algunas fincas, tres fanegas de monte, un molino y la casa.

2848 J. LÓPEZ y A. GRANA (1998): Ob. cit., p.109

2849 P. MADOZ (1985): Ob. cit., p. 34 
que aquel pide "aunque se atraviesen los dichos dos caminos pues de ello ningún daño y perjuicio sigue a persona alguna" 2850 .

Este Gutierre de Hevia parece una persona decidida y sin demasiados escrúpulos. En ese mismo año de 1549 el también regidor de Villaviciosa, Juan de Valdés Noriega, le denunció por daños y agravios al concejo y vecinos de aquel lugar, porque "de ocho o diez años a esta parte so color que dize ser mayorazgo de Pernús se avía entrado en los propios términos de dicha villa e concejo e avía ocupado y tomado dellos más de un tercio de legua de tierras y montes y los avía incorporado en el dicho coto y echo en ella una casa y un orrio (...)", y otros agravios ${ }^{2851}$. Gutierre de Hevia estuvo relacionado con los García de Jove, pues se casó en segundas nupcias con Isabel García de Miranda, hija de Juan García de Jove en su segundo matrimonio con Isabel Ramírez de Alas y Miranda. Por tanto todos ellos eran propietarios de las ferrerías de Dueñes, Peón, Deva y Amandi.

La ferrería se construyó efectivamente en ese siglo XVI y funcionó hasta finales del siglo XVIII. Según el Catastro de Ensenada pertenecía a don Diego de Hevia, es decir, a la misma familia de su fundador, cuyo beneficio regulaba en 1.800 reales; su arrendatario eran don Pedro Ortiz Mieres con un beneficio de 4.00o reales, que todo hacía 5.800 reales ${ }^{2852}$. Sin embargo, por lo que parece seguía teniendo muchos problemas en el abastecimiento de combustible, como comprobamos en el pleito que se suscitó en 1759 entre los vecinos de la parroquia de Santa María del Arroyo, concejo de Piloña, a causa de un monte. Francisco Antonio de Llano, propietario de la ferrería de Dueñes y apoderado de los vecinos, dice que la ferrería la traía arrendada Pedro Ortiz, vecino de Villaviciosa pero probablemente de origen vasco, quien intentaba cortar el monte vecinal pese a que, según la denuncia, tenía montes propios ${ }^{2853}$

\footnotetext{
${ }^{2850}$ AGS. RGS. 3 octubre de 1549. Cfr. FERNÁNDEZ MARTÍN: "Provisiones reales a favor de Asturias". BIDEA, $\mathrm{n}^{\circ} 84-85$, p. 322.

${ }^{2851}$ IBIDEM, p. 321.

${ }^{2852}$ CATASTRO DE ENSENADA. R. G.: Villaviciosa, ff. 17 y 54

2853 AGS. Sección Marina: $\mathrm{n}^{\circ}$ 561. 31 de julio de 1759: "con motibo de tener arrendado D. Pedro de Hortiz, vecino de la villa y conzejo de Villaviciosa del mismo prinzipado, una errería llamada de Amandi ynmediato a dicha villa, propia dicha errería de D. Diego de Ebia, no obstante tener el Dueño de dicha Erreria otros montes más ynmediatos a ella y otros montes de particulares también ynmediatos a dicha errería y que sin perjuizio de terzero podía fabricar el carbón nezesario para ella, balido de ser un vezino de crecido caudal y por
} 
El tal Pedro Ortiz Mieres ayudado de don Francisco del Canto, cura párroco de San Martín de Balles, del mismo concejo, pasó "a cortar en dicho monte por el pie todos los arboles que le parezió sin reserbar arbol alguno marcado ni por marcar" (porque al parecer esos árboles estaban destinados a la Real Fábrica de Navíos). Por ello se le puso demanda, pero para evitar que la ferrería parara se obligó al arrendatario a pagar una fianza de 1.000 reales "en razón de la sentencia final", y que de este modo pudiera aprovecharse de la madera de haya cortada ${ }^{2854}$.

Según Joaco López, la ferrería de Amandi, que se abastecía de mineral de hierro vizcaíno, dejó de funcionar a finales del siglo XVIII por falta de combustible, por la deforestación de los concejos de la costa 2855 .

ESTADO: Desconocido

\section{FERRERÍA DE DUEÑES}

LUGAR: Parroquia de Arroes

MUNICIPIO: Villaviciosa

RÍO: España

COORDENADAS: $43^{\circ} 31^{\prime} 21^{\prime \prime}$ N. y $5^{\circ} 32^{\prime} 20^{\prime \prime} \mathrm{W}$.

Probablemente se encontraba en el lugar de Ferreira, en la parroquia de Arroes, a orillas del río España, en una desviación hacia el sur de la carretera de Gijón a Villaviciosa, a cuyo municipio pertenece.

Madoz dice que por la parroquia de Arroes pasa el río Arroes o España sobre el cual hay "un castillo o torreón llamado la Herrería". Tiene, sigue diciendo, "una sola puerta pequeña, una ventana reducida y varias troneras, hubo en este edificio a fines del siglo pasado una fábrica de hierro, que aún recuerdan haber visto algunos ancianos de esta feligresía y de las inmediatas;

consiguiente los muchos empeños que tiene a su fabor y por esto mismo tener de su parte las justicias de aquellos pueblos ausiliado de este poderío intenta cortar el monte de los suplicantes".

2854 AGS. Sección Marina, $\mathrm{n}^{\circ}$ 561. 31 de julio de 1759.

2855 J. LÓPEZ y A. GRAÑA (1998): Ob. cit., p. 25 
hoy no ofrece utilidad alguna, y es de propiedad de los herederos del sr. Jovellanos" ${ }^{2856}$. Los datos de Madoz nos hablan de una ferrería de indudable antigüedad en la que, como en otros muchos casos, existe una torre como signo de la jurisdicción que sus dueños tenían sobre el conjunto de sus propiedades: ferrería, monte, aguas.

La ferrería existía en los primeros años del siglo XVI. En 1512 doña Isabel de Valdés vendió la sexta parte de la misma a Juan García de Jove. De éste pasó a su mujer Isabel Ramírez y a su hijo Gregorio García de Jove, en cuyas manos estaba en 1528, aunque probablemente no toda. $\mathrm{Al}$ año siguiente sabemos que una avenida el 9 de octubre la arruinó. Quizá la reconstrucción por estos Jove, comerciantes adinerados, fue lo que les permitió hacerse completamente con ella. De hecho, unos años más tarde, Gregorio García de Jove "El Viejo" y su mujer María González de Bandujo, cuando en 1548 crean su mayorazgo, entre los bienes que vinculan incluyen "mas las nuestras tres hererias que tenemos en el rio de Peon, e Dueñas, es a saber la herreria de Dueñas con su torre y edefiçios (...) las quales dichas tres fererias vinculamos en el dicho mayorazgo"2857. Es decir, que por entonces no sólo poseían esta de Dueñes sino también las de Peón.

Gregorio García de Jove fue escribano del ayuntamiento de Gijón y, a tenor de un escrito de hacia 1544, persona muy poderosa de la que dice dicho escrito que "tracta en vino y en otras mercaderias y tiene tres herrerias que labran hierro $y$ vende al fiado el dho vino y hierro $y$ otras mercaderias a los vecinos de del dicho concejo la tercia parte mas de lo que vale lo qual haze por tener todos losoficios del dicho concejo de su mano y como es escribano de ayuntamiento y dello los vecinos del dicho concejo lo compran por hazerle plazer sin tener necessidad de ello"2858. Dos de esas ferrerías eran las de Peón, la otra la de Dueñes. A estas ferrerías de García de Jove se refiere un pleito de

${ }^{2856}$ P. MADOZ (1985): Ob. cit., p. 51

2857 M. DE ABOL-BRASÓN (2011): Documentos escogidos de la Casa de Jovellanos en el Archivo de Mohias. Gijón, p. ...Continúa el texto: "con sus torres, casas, orrios, y edeficios, y heredades, y arboledas, e montes que tenemos, e tubieremos al tiempo de nuestra muerte y nos pertenecieren asi por raçon de propiedad, como al dicho fuero de Val de Dios en todos los terminos de Peon e según ban las vertientes del dicho rio de Dueñas hasta la mar, e ansi mesmo con todas herramientas, instrumentos, pertenecientes a las dichas herrerías".

${ }^{2858} \mathrm{M}^{\mathrm{a}}$ A. FAYA y L. ANES (2007): Ob. cit., p. 344. 
1557 que menciona la venta de 200 quintales por 380 ducados, que el mercader Pedro de Bueres hace a Gonzalo de Tineo, regidor de Gijón ${ }^{2859}$.

La ferrería siguió en manos de esta familia durante el siglo XVI. A finales del siglo la heredó su biznieto, Fabián de Jove, que se casaría con su prima María Ramírez o de Alas, propietaria de la de Deva. Ésta, en su testamento de octubre de 1621, recuerda cómo arregló la ferrería de Dueñes para lo que tuvo tratos con un vizcaíno al que le quedó a deber cien reales ${ }^{2860}$. Dos años antes, en 1619, ya viuda de Fabián de Jove, dejaba a su hija doña Lucía de Jove como dote por su matrimonio con don Francisco de Llanos Tejera, todos los bienes, casas, ferrerías, heredades y molinos pertenecientes al vínculo y mayorazgo de Gregorio García de Jove ${ }^{2861}$, herencia de su marido. Es decir, que Lucía recogía los bienes de ambas familias y por tanto se unían en una sola mano las ferrerías de Dueñes, Peón y Deva.

Un hijo de este matrimonio, Francisco de Llano Jove en 1649 reconoce deber al vizcaíno Juan de Bengoechea "cien ducado del salario del tiempo que fue tal aroça en la ferrería de Dueñes” ${ }^{2862}$. Este Francisco mantuvo en 1681 un pleito con los vecinos del valle de Peón, Rozadas, Niévares, Candanal, Sariego y San Justo (Villaviciosa) por el uso y aprovechamiento de los montes de Osil, Veguellina, La Pescar, Pelepotros y otros del citado concejo, con sentencia favorable ante el gobernador del Principado, por lo que los vecinos apelaron a la chancillería de Valladolid en 1684. Éstos alegaban que los montes eran

${ }_{2859}$ A.Ch.V. R. E.: caja 900,7. El pleito lo suscita Pedro de Bueres contra Gonzalo de Tineo, vecino y regidor de Gijón, porque éste se negaba a pagar 170 ducados, resto de los 300, arguyendo que se los habían robado. Por otros datos sabemos que este Pedro de Bueres debía de ser comerciante, pues años más tarde sabemos que había fletado un navío para llevar a Irlanda mercancías, que fue apresado por corsarios ingleses (A.Ch.V. R. E.: caja 1617,50).

${ }^{2860}$ M. DE ABOL-BRASÓN (2011): Ob. cit., p. 112: "Yten digo que yo hiçe un trato con un honbre vizcaino de que se encargava de adereçar la ferrería de Dueñes el nombre y beçindad del qual estará en una escritura que conmigo otorgo que piensso esta ante Gonçalo Garcia de Jove u Torivio de Llanos scribanos de el numero deste concejo al qual dicho bizcayno soy en cargo de çien rreales del dicho trato y de la madera que dexo que yo bendi y assi mando que se por quien es y a el y a sus hijos muger u herederos se le den çien rreales luego y se paguen de mis bienes sin falta alguna y no pareciendo se los digan de missas en San Franzisco de Avilles con ellos".

${ }^{2861}$ IBIDEM, p. 98: "todos los bienes cassas ferrerías montes castañedos prados heredades y caserias molinos duendo y bravo con todo lo a ello anejo y perteneciente contenido en el dicho binculo de mayorazgo del dicho Gregorio de Jove mayorazgo según y como en ellas suçedio la dicha Doña Luçia a entregarle el dia que se dixere missa de bendición con todos los abonos y mejoramientos que en ello hizo la dicha Doña Maria”.

${ }^{2862}$ J. LÓPEZ y A. GRAÑA (1998): Ob. cit., p. 31 
realengos y concejiles, mientras que Francisco sostenía que eran parte del foro que, para abastecer la ferrería de Dueñes, tenía con los monjes de Valdediós. Los testigos de los vecinos aseguran que don Francisco taló por el pie más de seis mil árboles, que valen más de diez mil ducados para alimentar su ferrería. La sentencia en 1689 fue favorable a Francisco de Llanos, y le permitía cortar la leña que necesitara para la ferrería en los montes, aunque declara al concejo de Villaviciosa como propietario de los mismos, y que sus vecinos tenían derecho a los aprovechamientos 2863 .

Cuando muera en 1691 recordará en su testamento que gastó diez mil ducados de la dote de su hijo en obras de sus casas y en la reparación de la ferrería de Dueñes, "que a la saçon estava con gran necesidad y remedio" 2864. Desde el siglo XVIII estos Llano Jove serían más conocidos por el apellido Jovellanos, a los que seguía perteneciendo la ferrería. Un descendiente de aquel Francisco, Francisco Gregorio de Jovellanos contraería matrimonio en 1731 con doña Francisca Apolinara Ramírez de Jove, hija del primer marqués de San Esteban del Mar, propietario de la ferrería de Deva, como ya sabemos. En 1748 este Francisco Gregorio Jovellanos arrienda Dueñes por 9 años a Cipriano Menéndez Valdés, quien se concierta con los vecinos del lugar para que le entreguen 4.500 cargas de leña que le han de dar en los cinco primeros años. Contrata a algunos vecinos la elaboración de carbón de castaño "bien hecho y cribado", que elaborarían desde marzo a San Miguel, corriendo a cargo de los carboneros "el montazgo, hechura y acarreto" 2865.

El Catastro de Ensenada dice que es de este don Francisco y le da de utilidad 1.800 reales de renta al dueño y 4.000 al arrendatario, todo lo cual suma 5.800 reales 2866 . La ferrería, como otras de la costa, utilizaba vena de Somorrostro y es frecuente encontrar ferrones vascos como oficiales de la

\footnotetext{
${ }^{2863} \mathrm{M}^{\mathrm{a}}$ A. FAYA y L. ANES (2007): Ob. cit., p. 247-248.

2864 M. DE ABOL-BRASÓN (2011): Ob. cit. p. 156: "Yten declaro que ademas de lo en lo que llebo mencionado distribuy los dichos diez mill ducados de la dote del dicho mi hijo en los desempeños y mas cosas declaradas distribuy de ellos una porcion considerable del dicho capital en los reparos perfectos y mejoras de las haçiendas reedificios de cassas y obras y en la herreria de Dueñes que a la saçon estava con gran necesidad de remedio y en las exsequias y funerales de la dicha señora Doña Juana Jacinta mi muger".

2865 AHA. P.N. V. Prendes, leg. 1945 (años 1745-56).

${ }^{2866}$ CATASTRO DE ENSENADA. R. G.: Villaviciosa, f. 17 y 54
} 
misma. Ya hemos visto al aroza Juan de Bengechea en 1649. En 1755 el arrendatario Cipriano Menéndez ajusta la labranza del hierro con el aroza Pedro Apasteguía, vecino de Amandi, y el tirador Pedro Martínez, vecino de San Juan de Prendones (El Franco), obligándose éstos a comenzar el trabajo "para las primeras lluvias y aguas que sobrevienen después de San Miguel de septiembre y luego que vengan otros dos oficiales que se esperan de la provincia de Guipúzcoa, a quienes así el dicho aroza y el referido D. Cipriano los tienen encargados”2867. La ferrería trabajaba, aproximadamente, desde esa fecha hasta Santiago apóstol, a finales de julio.

En el testamento de Francisco de Jovellanos, de 17 de noviembre de 1766, refiere muchas cosas interesantes sobre la ferrería. Que la labranza del hierro estaba a punto de comenzar (estamos a mediados de noviembre), que para ello ya tiene vena y carbón para fabricar 600 quintales de hierro que, al precio regular a que se vende, pueden valer 50.000 reales, dinero que quiere que una vez pagados los oficiales se utilice para desempeñar todas sus deudas. Recuerda que la ferrería la lleva un mayordomo, al que le paga 360 reales al año y que desde 1757 lo es Luis de la Rionda y antes Cipriano Menéndez hasta su fallecimiento en ese año, quien dejó la ferrería con todas las herramientas necesarias para su funcionamiento ${ }^{2868}$.

\footnotetext{
${ }^{2867}$ AHA. P.N. Ambrosio del Busto Paredes, 8 de julio de 1755

2868 M. DE ABOL-BRASÓN (2011): Ob. cit. p..... "Yten digo que la herrería esta para empezar la labranza y ay prevenciones de carvon y vena para 600 quintales aunque parte de la vena aun esta aquí, es mi volumptad que todo este fierro, que vendido a un prezio rregular puede valer mas de zinquenta mil rreales pagados que sean los ofiziales se aplique todo al desempeño de las deudas según la necesidad de los acredores, la que deven atender mis testamentarios pagando primero lo que se debiese a caravineros y ofiziales de la herrería, que se pondrá en el memorial: Y por lo correspondiente al mayordomo que es Luis de la Rionda no se le haga cargo alguno por los años anteriores asta el dia 25 de Diciembre de este año de 1766 cuyas quentas y cargos doy por fenezidas asta dicho dia sin embargo de haver suplido muchas cantidades en el pleito de las capillas, en el gasto de estudios de su hixo y últimamente para haviarle en un dia viaje y embarco a Yndias, que se hizo desde el Ferrol y otros 476 rreales que en varias partidas le he dado a dicho Luis y su muger y 194 y medio que pague de rropa que devian cuyas cantidades estoy cierto cubren bastantemente los tres mil y seiscientos rreales que importan los 360 rreales que le señale en cada un año desde el mes de Jullio de 1757 que entro a servirme digo que la herrería se me entrego por por el difunto Don Zipriano Menendez en 26 de Jullio de el año de 56 con todos sus instrumentos de toveras, barquines, palancas mayores y menores corricas pequeñas y grandes y quantos instrumentos son nezesarios para el trabajo de una herrería de que debe rresponder dicho Luis a quien condono cualesquiera cargos que se le podían hazer por muchos quintales de fierro no entregados en algunos años y las crezes de todos de que se aprovecho sin embargo de lo qual todo se lo condono con tal que no reclame cosa alguna que de todo esta bien pagado; advirtiendo que esta condonazion no se entiende mas que por los años pasados, porque de la presente libranza que esta para hacerse, se le debe tomar quenta puntual; y asi de las demas si la hereria continuase pagándole al fin
} 
Jovellanos la cita en sus diarios en 1795-1796, al hablar del hierro que pensaba utilizarse en la fábrica de Trubia: “ ¿No se sabe que las descubiertas por Vallejo en Castañedo del Monte, y fueron ensayadas en la ferrería de mi hermano, son malas, agrias, sin liga, y de escasísimo producto?”. Quiere decir que la ferrería aún funcionaba y era propiedad de su hermano, Francisco de Paula. De hecho en 1796 el mencionado Francisco Vallejo, director de Trubia, se refiere a ella en un informe con el que pretendía conocer la calidad de los hierros y la posibilidad de usarlos para la fábrica de fusiles ${ }^{2869}$. Poco después, probablemente por la muerte de su hermano en 1798, pasó a ser de propiedad de don Gaspar de Jovellanos; pues en abril de 1799 habla de una proposición a los Rodríguez de las mesadas "sobre 400 fanegas de grano que tengo entrojadas y la labranza próxima de fierro, que llegará probablemente a 300 quintales" ${ }^{2870}$. Esa producción es la mitad de la de cuarenta años antes, quizá por falta de combustible. Por esa razón dejó de funcionar probablemente a principios del siglo XIX, como recuerda Madoz 2871 .

ESTADO: Hay restos del torreón, que conserva dos fachadas incompletas; de la ferrería solo algunos trozos de muros

de ella los 360 rreales si entregase todo el fierro que hiziese, de que se devera tener cuydado y de que semanariamente avise quantas zamarras y quantos quintales cada semana".

${ }^{2869}$ L. ADARO (1986): "Los comienzos de las Fábricas de Municiones Gruesas de Trubia y Oviedo, 1792-1799". BIDEA, $\mathrm{n}^{0} 118$, p. 376: Dice que efectivamente se construyeron en la ferrería 175 planchas de 81 arrobas de peso y que por cada libra de a 20 onzas se ajustó a 18 cuartos, pero "no se ha podido construir más por haberse concluido los carbones", que era sin duda uno de sus mayores problemas. De hecho, según Vallejo, mientras el quintal de 155 libras de hierro costaba en Vizcaya 158 reales, en Dueñes salía a 238 reales.

2870 G.M. JOVELLANOS (1992): Diarios. Barcelona, p. 199 y 399.

${ }^{2871}$ Este dice a finales del siglo XVIII, pero como vemos aún funcionaba en ese siglo. 


\section{FERRERÍA DE PEÓN}

LUGAR: Parroquia de Santiago de Peón

MUNICIPIO: Villaviciosa

RÍO: Arroes

COORDENADAS: $43^{\circ} 29^{\prime} 8^{\prime \prime}$ N. y $5^{\circ} 32^{\prime} 33^{\prime \prime} \mathrm{W}$.

Se encontraba a orillas del río Arroes o España, en la feligresía de Santiago de Peón, en el municipio de Villaviciosa. Se accede por una desviación hacia el sur en la carretera de Gijón a Villaviciosa.

El origen de la ferrería de Peón se remonta a la Edad Media, probablemente al siglo XV. La construyeron los monjes del cercano monasterio de Valdediós, quienes en 1538 la aforaron a perpetuidad a Gregorio García de Jove, por una renta de 5.000 maravedís ${ }^{2872}$. Sin embargo en 1548 , cuando éste y su mujer establecen su mayorazgo, dicen que vinculan "las nuestras tres hererias que tenemos en el rio de Peon, e Dueñas, es a saber la herreria de Dueñas con su torre y edefiçios (...) las quales dichas tres fererias vinculamos en el dicho mayorazgo", declarando que las de Peón las tenían por fuero del monasterio de Valdediós ${ }^{2873}$. Es decir, no era una sino dos las ferrerías que había en Peón. También se refiere a éstas un documento de 1544, que habla de este Gregorio como persona muy poderosa, que "tracta en vino y en otras mercaderias y tiene tres herrerias que labran hierro"2874. Dos de éstas son las dos de Peón, la otra la de Dueñes. De hecho, en varias ocasiones se habla del “foro perpetuo de las herrerías del Valle de Peón”, en plural.

Una de estas ferrerías de Peón era conocida como "ferrería de ¿Epinas?.". Esta ferrería sabemos que en los años sesenta del siglo XVI estaba arrendada al vizcaíno Martín de Beitia y a su socio Pedro del Viso, de Noreña. En 1564 aquel

\footnotetext{
${ }_{2872}$ Así consta en varios documentos de los años 1641, 1655 y 1799. Siempre son cinco mil maravedís. En M. DE ABOL-BRASÓN (2011): Ob. cit., p. ..

2873 IBIDEM, p. ...Continúa el texto: "con sus torres, casas, orrios, y edeficios, $y$ heredades, $y$ arboledas, e montes que tenemos, e tubieremos al tiempo de nuestra muerte y nos pertenecieren asi por raçon de propiedad, como al dicho fuero de Val de Dios en todos los terminos de Peon e según ban las vertientes del dicho rio de Dueñas hasta la mar, e ansi mesmo con todas herramientas, instrumentos, pertenecientes a las dchas herrerías".

$2874 \mathrm{M}^{\mathrm{a}}$ A. FAYA y L. ANES: Ob. cit., p. 344.
} 
denunció a Pedro del Viso por no pagarle parte de la renta de la ferrería y por deudas en el comercio del hierro, en concreto 15 quintales de hierro. Parece que este Pedro del Viso se había concertado con Martín de Beitia para transportar el hierro desde la ferrería hasta la ciudad de León y ponerlo en manos de un tal licenciado Rodríguez. Cada vez debía transportar cinco o seis cargas de hierro "de a quintal y medio asturiano" cada carga, por lo que le pagaría 11 reales por carga, y así mismo debería traer de León, como retorno, las mercancías que le ordenara, como pan, vino, etc. Por todo, es decir por las cargas de ida y vuelta le pagaría 15 reales. En 1566 la Chancillería de Valladolid emitió una Real Ejecutoria sobre el pleito2875.

Durante los siglos XVII y XVIII los monjes siguieron aforando estas ferrerías a la familia Jove (más tarde Jovellanos), lo pudiera hacernos creer que todavía funcionaban; pero no lo creo así. Lo que hacían estos Jovellanos era utilizar sus tierras para el cultivo y la madera de los montes que comprendía el foro para su ferrería de Dueñes, pero las de Peón estaban parada probablemente desde finales del siglo XVII ${ }^{2876}$. El Catastro de Ensenada ya no las nombra.

ESTADO: Sin restos

\section{MUNICIPIO DE VILLAYÓN}

\section{FERRERÍA DE ARBÓN}

LUGAR: Parroquia de San Pedro de Villayón MUNICIPIO: Navia

RÍO: Arbón

COORDENADAS: $43^{\circ} 28^{\prime} 1^{\prime \prime}$ N. y $6^{\circ} 41^{\prime} 52^{\prime \prime}$ W.

En la carretera que, siguiendo el curso del Navia, va desde Navia a Villayón se encuentra Arbón, en cuyas inmediaciones corre el río de este nombre, afluente del Navia; en sus orilla se se levantaba la ferrería. Unas veces aparece 
citada como ferrería de Arbón y otras como ferrería de Villayón, también como ferrería de Oneta, pues en realidad está entre estos tres lugares.

La cita el Catastro de Ensenada en 1753, diciendo que "ay asimismo en la parroquia de Villallón (jurisdicción de Navia) una herrería para la fábrica de yerro propia del marqués de Santa Cruz construida sobre el río Arbón, que trabaja quatro meses al año por lo que les consideran de utilidad en cada uno mill y cien reales de vellón" ${ }^{2877}$. Joaquín Ocampo dice que producía 800 quintales de hierro por temporada con un rendimiento de 2.000 reales ${ }^{2878}$. A su lado había también un mazo. El marquesado de Santa Cruz de Mercenado, título concedido en 1679 por Carlos II a Sebastián Vigil de Quiñones, pertenecía a mediados del siglo XVIII a los Navia Osorio, cuya importancia social y económica en la vida asturiana era muy importante.

Con el nombre de Arbón, y en propiedad del marqués de Santa Cruz se cita en un informe elaborado por el ingeniero Pedro Delgado en $1795^{2879}$. Otro informe hacia 1800 señala que "hay una herrería propia del marqués de Santa Cruz de Mercenado, que reditúa 1.100 rs. año; y un mazo de tirar yerro" 2880. No la menciona Madoz ni nadie la cita en el siglo XIX, lo que nos lleva a pensar que, como otras cercanas a la costa, debió cerrarse por falta de combustible en los primeros años de ese siglo.

ESTADO: Desconocido

2877 J. MARTÍNEZ: "Navia en el siglo XVIII". BIDEA, no 81, p. 194

2878 J. OCAMPO (1987): Ob. cit., p. 42. No cita de donde extrae este dato.

2879 MUSEO NAVAL. Col. Guillén: Ms. 2175

2880 ACADEMIA DE LA HISTORIA: Fondo Martínez Marina: Ms. 9/6034, ${ }^{\circ} 31$. 


\section{FERRERÍA DE BULLIMEIRO}

LUGAR: San Bartolomé de Parlero

MUNICIPIO: Navia

RÍO: A Polea (fluente del Navia)

COORDENADAS: $43^{\circ} 24^{\prime} 19^{\prime \prime}$ N. y $6^{\circ} 41^{\prime} 18^{\prime \prime} \mathrm{W}$.

San Bartolomé de Parlero se encuentra por encima de Villayón, en la carretera que sigue hasta la sierra de Muniellos. En este lugar, a orillas de un afluente del Navia, se halla la ferrería de Bullimeiro.

Su construcción data probablemente de la primera mitad del siglo XVIII. Un documento de finales de 1796, en el que se exponen las razones en contra de la construcción de la ferrería de Brieves, entre ellas que no bajará el precio de hierro, señala que "esto se evidencia con el exemplo de otras herrerias que se han hecho de nuevo en aquel Principado y principalmente en la de Gullimoyro y la que llaman nueva del concejo de Boal en la que no obstante tener los montes muy cercanos no se despacha el yerro a precio mas moderado que en todas las demás antiguas" 2881 . La de Gullimoyro no es otra que esta de Bullimeiro. Si expresamente se menciona que "se han hecho de nuevo", no pueden ser muy antiguas, pero como veremos ésta ya existía cuando se redactó el Catastro de Ensenada hacia 1753, por lo que probablemente hay que datarla antes de esa fecha, quizá en la primera mitad del XVIII.

El Catastro de Ensenada cita una ferrería en Parlero propia de la casa de los Sierra de Andes, de Navia, que la tienen arrendada a don Pedro Arango 2882 . En 1795 su propietario era el marqués de Santa Cruz del Mercenado ${ }^{2883}$, pero igualmente por esas fechas, en 1783 , aparece como propietario J. F. Abello Castrillón quien se opone a los proyectos de Andrés Bravo y Bermúdez, que pretende construir en los confines de Asturias y Galicia tres ferrerías y cuatro mazos ${ }^{284}$. Este último es solamente el arrendatario o la ferrería era propiedad

\footnotetext{
${ }^{2881}$ A.H.N. Consejos: legajo. 28685, exp. 7-3, ff. $230 v$.

2882 J. OCAMPO (1987): Ob. cit., p. 42

2883MUSEO NAVAL. Col. Guillén: Ms. 2175

2884 J. LÓPEZ y A. GRAÑA (1998): Ob. cit., p. 27
} 
de varios socios, cosa por otro lado relativamente frecuente, sobre todo con las construidas en los siglos XVIII y XIX.

Funcionaba a finales del siglo XVIII, aunque parece que durante los primeros años del siglo XIX estuvo parada, porque se hallaba en estado ruinoso. Según Joaco López se abrió nuevamente en 1828 cuando su propietario, don Francisco Julián de la Sierra, hijo del regidor perpetuo de Cangas de Tineo, Francisco José Sierra y de $\mathrm{M}^{\mathrm{a}}$ del Carmen Abello Fuertes de Castrillón, contrató con don Manuel (Rodríguez) Arango reedificarla o hacerla de nuevo con el premio de disfrutarla durante diez años ${ }^{2885}$; pero en realidad ya lo estaba al menos desde algunos años antes. En 1824 don Manuel Rodríguez Arango, vecino de la Vega de Ribadeo, adquirió de don Manuel José Rodríguez, de la Leirosa, en el concejo de Tineo, una porción de monte para hacer carbón y así "dar surtido a la Erreria de Bullimero que tiene en arrendamiento". Para ello se concertó con Antonio Álvarez de Lamesa, para que éste reedificara un viejo camino desde el Valle de las Hayas hasta la ferrería por lo que le pagaría 2.000 reales 2886 .

\footnotetext{
2885 AHN. Ministerio de Hacienda, leg. 1479. 1 (26) 1828: "hallándose arruinada esta ferrería, propia de D. Francisco Julián Sierra, contrató con él D. Manuel Arango para reedificarla o hacer de nuevo con el premio de disfrutarla diez años". Este Manuel Arango, escribano de Santalla de Oscos, estaba por esa época proyectando la construcción de una población en la que pensaba levantar varias ferrerías. En 1829 don Manuel Pereiro, vecino de Sarceda, le vende su parte en un monte propiedad de varios porcioneros, en la Folgueirosa, "para que forme la población proyectada cualquiera fábrica o establecimiento que le acomode" (AHPLU. 2071/10. 22 de enero de 1829).

2886 AHPLU: 2071/5 (1824, 19 de diciembre). Convienen en "que dicho Lamesa ha de romper, redificar y reparar dicho camino con toda solidez y según arte a su corta y espensas en el preciso término de dos meses (...) desde el valle de las Jayas, estremo del citado monte, hasta la errería, dirigiendolo por donde se alla roto para la condución de la madera que salió del mismo monte hace algunos años, hasta el campo de tablero de las Cruces, en donde se deja y toma por la izquierda al lugar de Parlero, en donde también se alla roto y muy arruinado y luego desde Parlero a la errería (...)". Se ha de hacer "para uso de los carros", a excepción "del que hay debajo de la sierra desde el vado del arroyo de Bullimeiro inclusive, hasta introducirse en la carbonera, pues que esta corta porción queda a cargo del Arango". Todo ello por 2000 reales y le ha de "dar cuatro picones, cuatro rodos, una madarria y un palo de fierro por via de empréstito", que devolverá concluida la obra.
} 


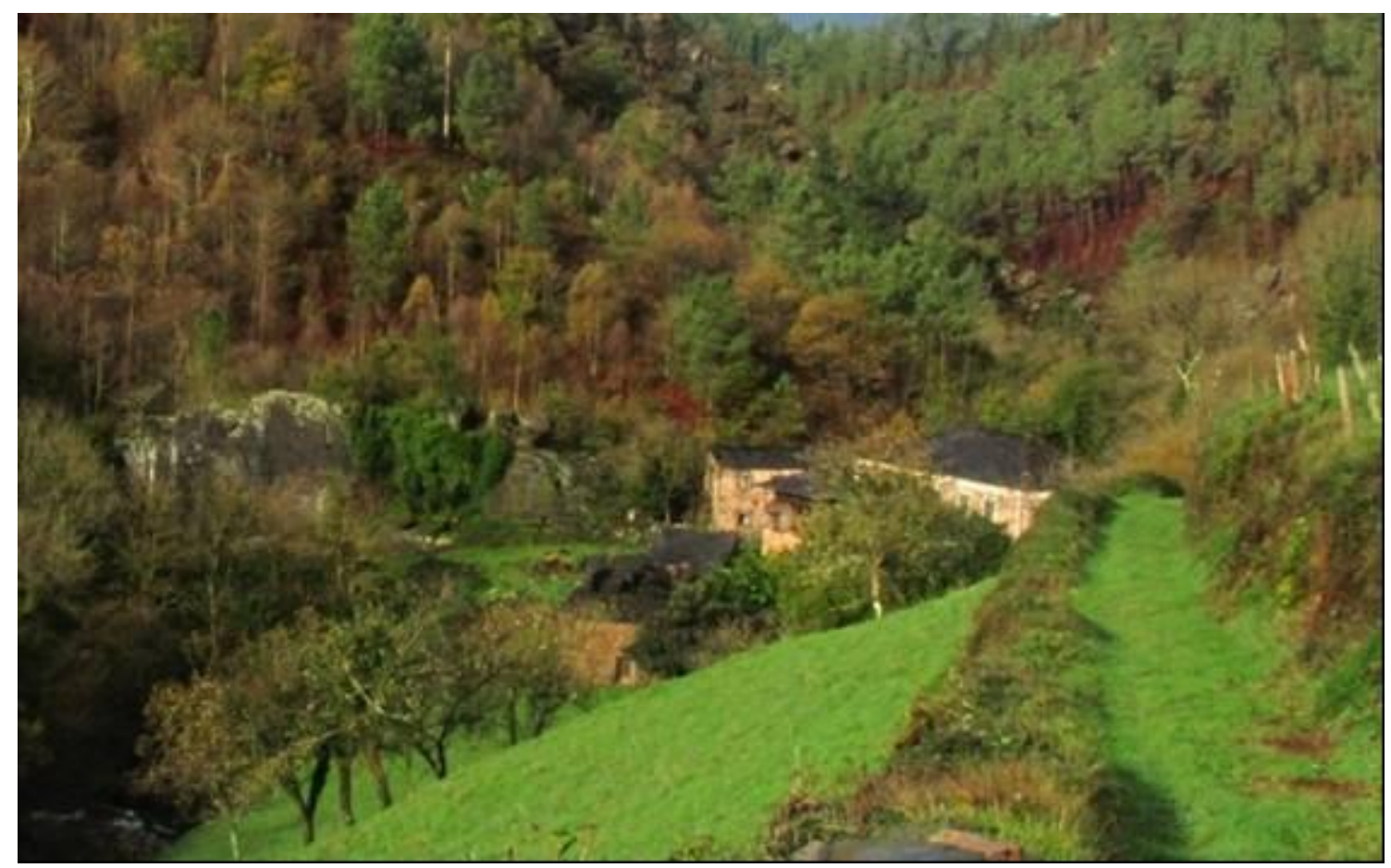

Casa de la Ferrería de Bullimeiro

Madoz menciona en Bullimero una ferrería2887; y hablando del Navia dice que es navegable una legua más arriba de Navia, pudiendo fondear barcos de más de 100 toneladas, por cuyas aguas se “conduce material para las herrerías de Bullimero en la feligresía de Parlero y para la de Frouseyra en el ayuntamiento limítrofe de Boal"2888. De hecho, según este mismo autor en el puerto de Navia entraban todos los años una media de 7.382 quintales de mineral de hierro ${ }^{2889}$. La ferrería, como hemos dicho, fue de don Manuel Arango, aunque en los años cincuenta la tuvo en arriendo José González. En 1857 don Cándido Arango y Bravo, vecino de la ferrería de Villanueva de Oscos, solicitó ante el juzgado de Luarca la propiedad de esta ferrería, compuesta "de dos casas, capilla, algunas fincas rústicas y otras dependencias”, como legítimo heredero de Manuel Arango contra el mencionado arrendatario. El juez, vistos los títulos de propiedad, por auto del 7 de abril de 1857, le entregó la propiedad de la ferrería ${ }^{2890}$.

\footnotetext{
2887 P. MADOZ (1985): Ob. cit., p. 346

2888 IBIDEM, p. 253

2889 IBIDEM, p. 254

2890 BOPA, 27 de mayo de $1857, n^{\circ} 84$, p. 4.
} 
La Estadística Minera la menciona como una ferrería en funcionamiento en 1882 y 1883, siendo la última ferrería asturiana en cerrar sus puertas ${ }^{2891}$. En 1883 aquella revista menciona además el nombre de su propietario, "Cándido Arango, de la Vega de Rivadeo, término de Villayón”2892, que como vemos es un descendiente de los Arango, que primero la tuvieron arrendada y luego la reedificaron, probablemente a medias, y luego la debieron comprar.

ESTADO: Se conserva una casa con el nombre de La Ferrería 